\title{
NUCLEAR, RADIOLOGICAL AND CHEMICAL WEAPONS, RADIATION AND CHEMICAL ACCIDENTS
}
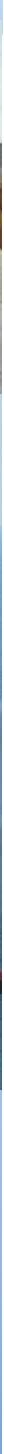


\title{
NUCLEAR, RADIOLOGICAL AND CHEMICAL WEAPONS, RADIATION AND CHEMICAL ACCIDENTS
}

\section{MONOGRAPH}

\author{
VIČAR Dušan \\ PRINC Ivan \\ MAŠEK Ivan \\ MIKA Otakar Jiř́i
}

\section{Z L Í $\mathbf{N}$}

2021 
KATALOGIZACE V KNIZE - NÁRODNÍ KNIHOVNA ČR

Vičar, Dušan, 1953-

Nuclear, radiological and chemical weapons, radiation and chemical accidents : monograph / Vičar Dušan, Princ Ivan, Mašek Ivan, Mika Otakar Jiří. -- Order of issue: first, issued electronically. Zlín : Tomas Bata University in Zlín, 2021. -- 1 online zdroj

Obsahuje bibliografii

ISBN 978-80-7678-053-8 (online ; pdf)

* 623.454.8*623.45*623.459*621.039.586* 504.61:62*(048.8:082)

- jaderné zbraně

- zbraně hromadného ničení

- chemické zbraně

- jaderné havárie

- technické havárie

- kolektivní monografie

623 - Vojenská technika [19] 
Reviewers:

prof. Ing. Ján Kurucz, Ph.D.

prof. MUDr. Leoš Navrátil, CSc., MBA, dr. h. c.

(C) Dušan VIČAR, Ivan PRINC, Ivan MAŠEK a Otakar J. MIKA, 2021

Translation: Alena LANGEROVÁ

ISBN 978-80-7678-053-8

DOI: https://doi.org/10.7441/978-80-7678-053-8 
"Saddam had previously used nerve gas, mustard gas and poisons affecting the blood in combat. Although he did not resort to the use of chemical ammunition on Ras al-Khafji, I still expected him to do so when we launch the offensive. Admittedly, we equipped the soldiers with chemical protection equipment and trained them for combat in the event of a chemical attack, but there was still a danger that they would start running around disordered, and worst of all, they would panic. Since World War I, the US troops have not fought against an enemy who used chemical weapons."

\section{General Norman Schwarzkopf Commander of Operations Desert Shield and Desert Storm in the Persian Gulf War}

In addition to a technical description relating to the history of the development and use of nuclear, radiological and chemical weapons, and the cases of radiation and chemical accidents, their destructive effects and principles of protection against them, the monograph will also include original case studies. These case studies are concerned with the consequences of nuclear accidents and incidents such as Three Mile Island (USA, 1979), Chernobyl (Ukraine, 1986), Fukushima (Japan, 2011) and also with hitherto known and potential scenarios of the so-called CBRN terrorism using radioactive materials.

These issues are intended for the students of the bachelor's study program entitled Population Protection and the follow up master's study program entitled Security of Society. This title will be followed by another monograph dealing with the issues of biological warfare agents and toxins. The Faculty does not yet have a comprehensive publication relating to this field and its English version will allow this course to be offered to foreign students.

\section{Cover pictures:}

Top left: Accident of an alumina refining plant in Devecser, Hungary. Date: October 13, 2010. Author: Ministry of Public Administration and Justice, International Communications Office. Licence: CC0. cs.wikipedia.org

Bottom left: English chemical bomb from World War I. Author: Benjamin Hirschfeld. Posted by: Christoph Herrmann. Licence: Attribution-Share Alike 3.0. cs.wikipedia.org

Top centre: World map with the symbols of danger of mass destruction. Author: Fastfission. Source: Figure: BlankMap-World gray.svg (Licence: CC-BY-SA / GFDL by Simon Eugster and user Vardion), Figure: Radiation warning symbol.svg (PD-self), Figure: WMD-biological.svg (Licence: CC-BY-SA / GFDL by user Andux) and Figure: Skull and crossbones.svg (PD-self). cs.wikipedia.org

Bottom centre: A nuclear explosion is capable of carrying large amounts of material to considerable heights in the atmosphere. "Operation Ivy, nuclear ammunition fired on November 15, 1952 at Enewetak Atoll." Licence: CC0. cs.wikipedia.org

Top right: Agent Orange barrels stored on Johnston Atoll in about 1976. Author and source: US Government photograph. Licence: CC0. cs.wikipedia.org

Bottom right: Fire-fighting vessels are trying to put out a fire on the Deepwater Horizon oil rig on April 21, 2010. Author: unknown. Source: US Coast Guard - 100421-G-XXXXL - Deepwater Horizon fire, April $20,2010$. Licence: CC0. cs.wikipedia.org 
1. INTRODUCTION

2. SPECIFICATION AND VOCATION OF THE PUBLICATION .................................................... 11

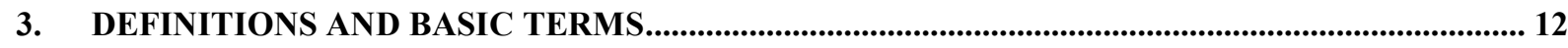

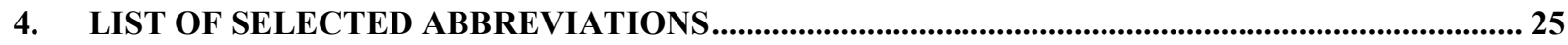

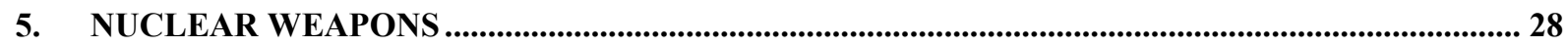

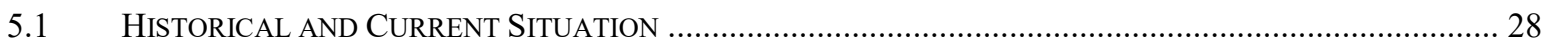

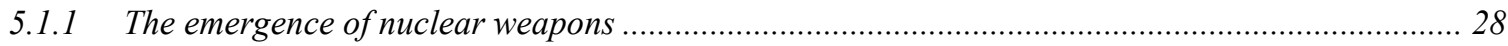

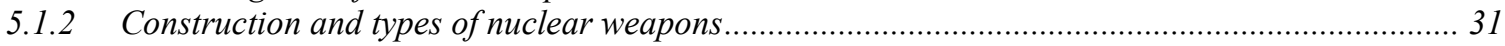

5.1.3 Use of nuclear weapons - Japan bombing....................................................................... 35

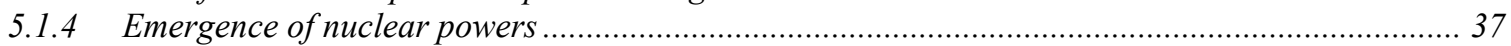

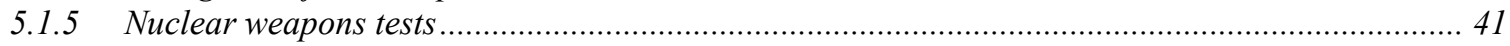

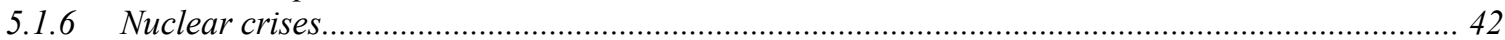

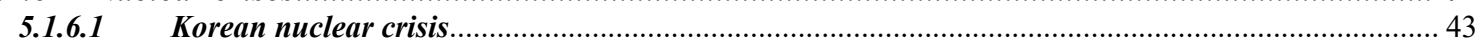

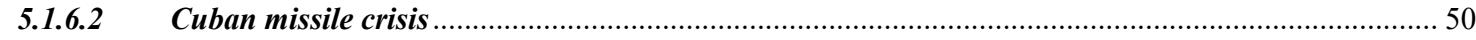

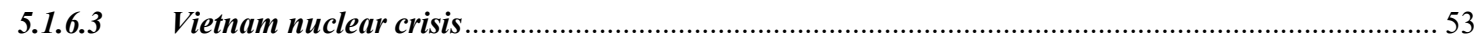

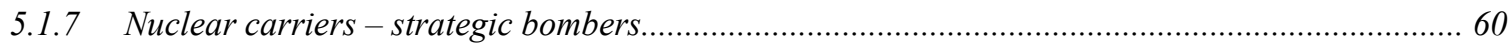

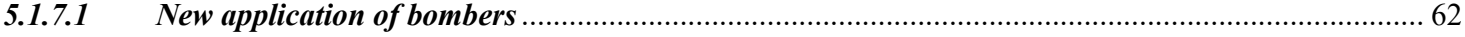

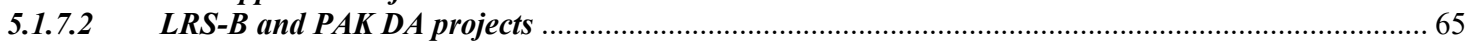

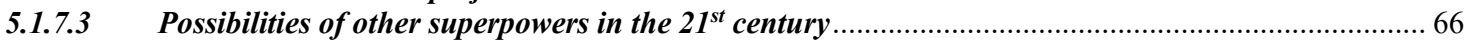

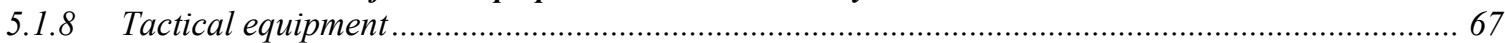

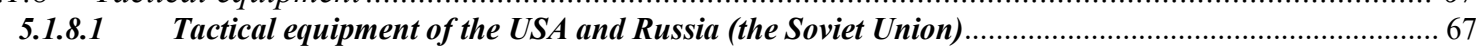

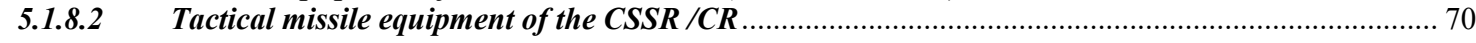

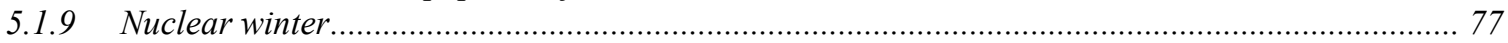

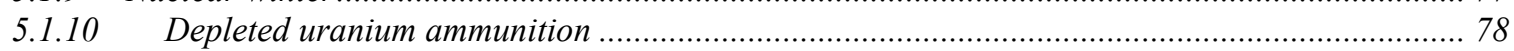

5.1.10.1 Uranium and depleted uranium properties ................................................................................. 79

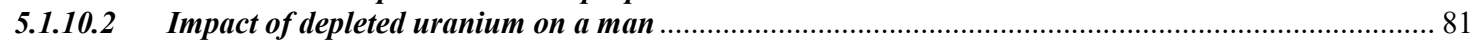

5.1.11 Prohibition of nuclear weapons .................................................................................... 83

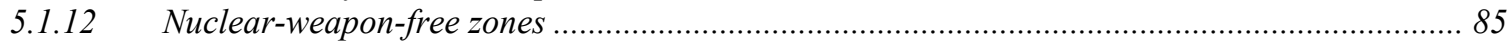

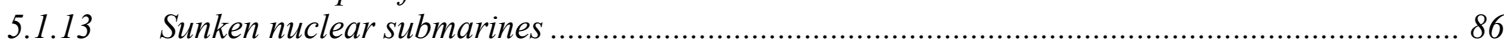

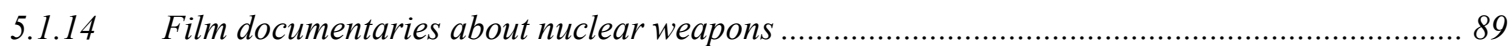

5.1.15 Smuggling of nuclear materials ................................................................................... 89

5.1.16 The present state of nuclear weapons in the world ......................................................... 90

5.2 BASIC TERMS IN THE AREA OF NUCLEAR WEAPONS .................................................................. 91

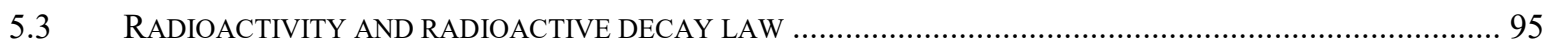

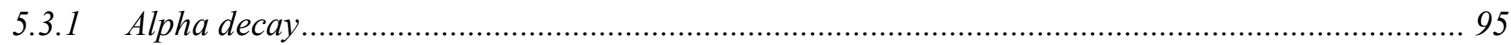

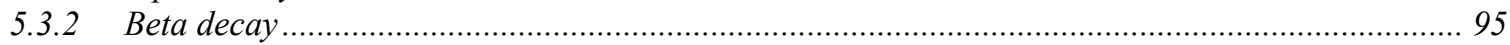

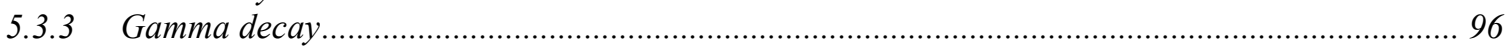

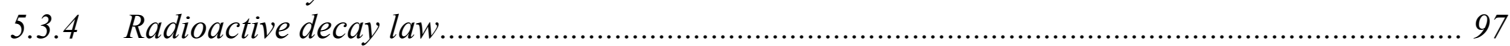

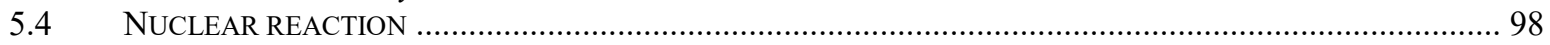

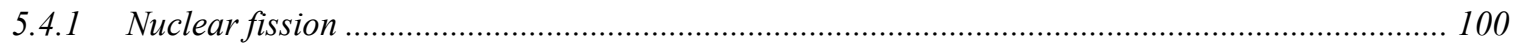

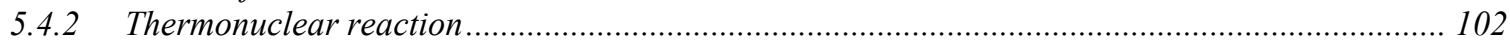

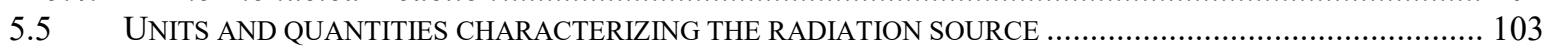

5.6 UNITS AND QUANTITIES CHARACTERIZING THE RADIATION FIELD ................................................ 104

5.6.1 Relationship of exposure to dose and kerma and some problems with the use of quantities ........ 105

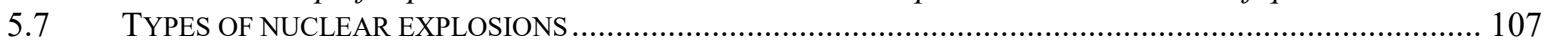

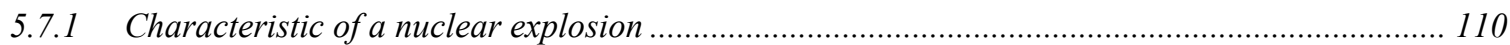

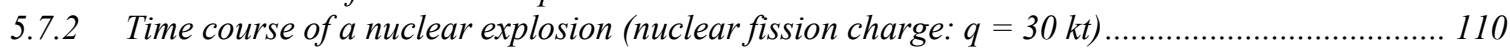

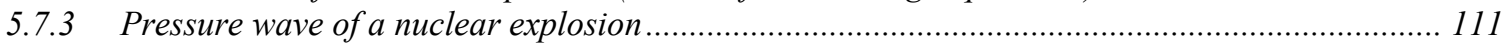

5.7.3.1 The destructive effects of a pressure wave ...................................................................................... 113

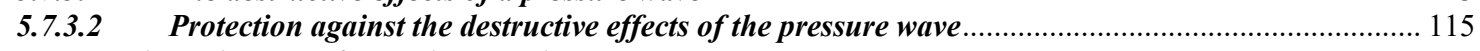

5.7.4 Light radiation of a nuclear explosion ................................................................................ 115

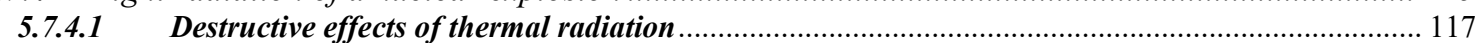

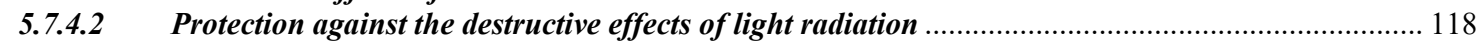

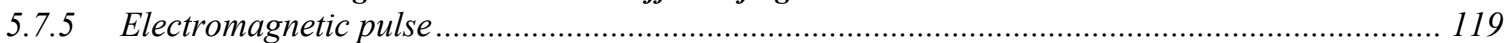

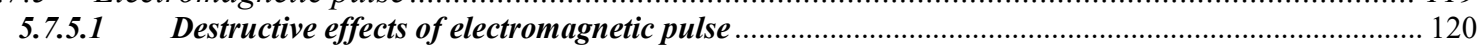

5.7.5.2 Protection against the effects of electromagnetic pulse ........................................................... 122

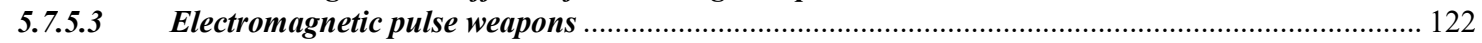

5.7.6 Initial radiation of a nuclear explosion ............................................................................. 127

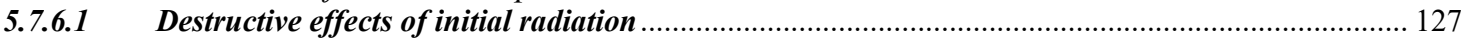

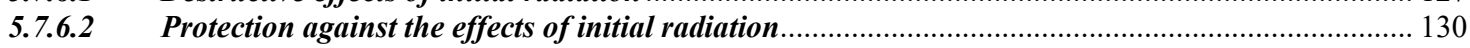




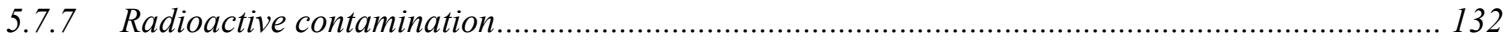

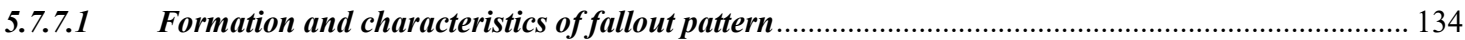

5.7.7.2 Destructive effects of ionizing radiation ..................................................................................... 137

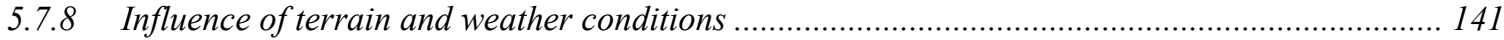

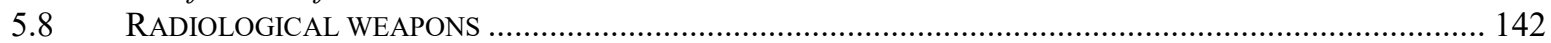

5.8.1 Shelters - effective protection against the effects of nuclear and radiological weapons ............. 147

5.8.2 Protection against the effects of non-explosive radiological weapons - case study................... 154

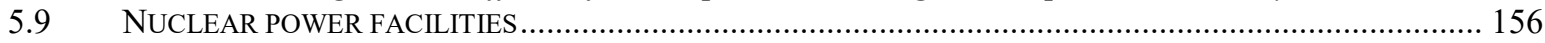

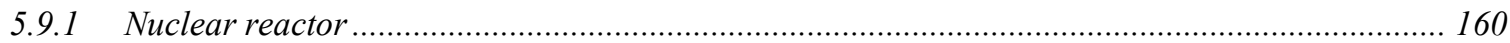

5.9.2 Nuclear reactors in the Czech Republic - PWR and VVER ............................................... 164

5.9.3 Deep repository of nuclear waste and its anatomy ............................................................ 167

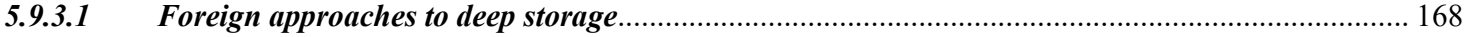

5.9.3.2 Current near-surface repositories in the Czech Republic ......................................................... 174

5.9.3.3 The concept of a deep geological repository in the Czech Republic............................................... 179

5.9.4 Radiation incidents and radiation accidents ................................................................ 185

5.9.4.1 The A-1 nuclear power plant accident at Jaslovské Bohunice (Czechoslovakia 1976 and 1977) ...... 188

5.9.4.2 The Three Mile Island nuclear power plant accident (USA 1979) ............................................ 190

5.9.4.3 The Chernobyl nuclear power plant accident (the Soviet Union, Ukraine 1986) ............................. 191

5.9.4.4 The accident of the Fukushima I nuclear power plant (Japan 2011) ........................................... 204

5.9.4.5 Radiation incidents caused by ionizing radiation sources........................................................... 207

5.9.4.6 Recommendations and conclusions when dealing with radiation incidents ..................................... 210

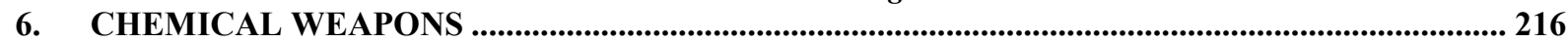

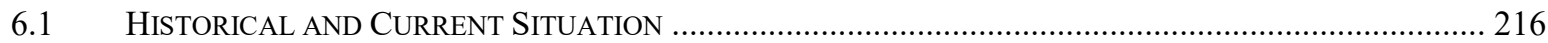

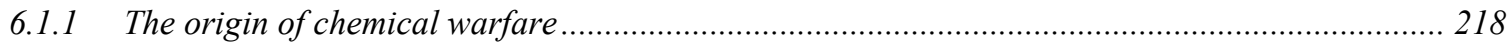

6.1.1.1 What preceded the first massive chemical attack?.........................................................................2 219

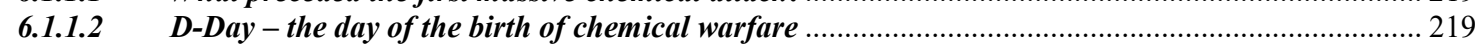

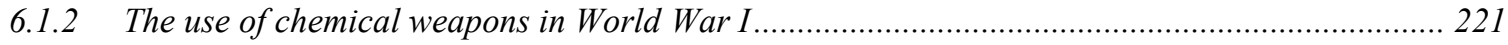

6.1 .3 Use of chemical weapons after World War I.................................................................... 222

6.1.4 Use of chemical weapons in World War II........................................................................... 223

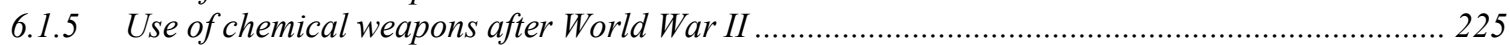

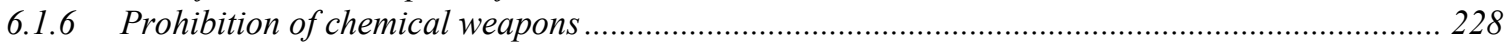

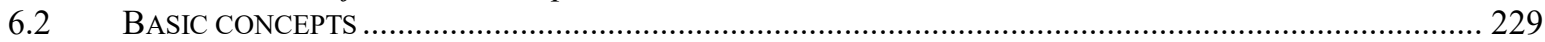

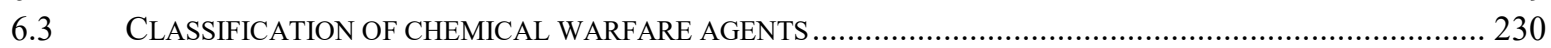

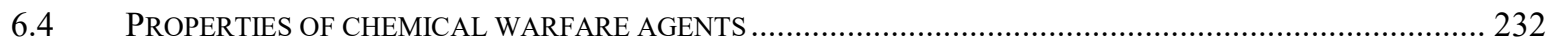

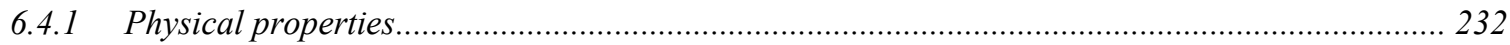

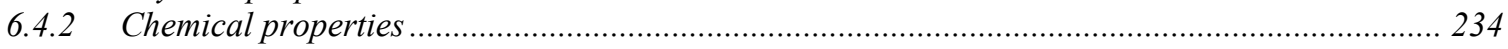

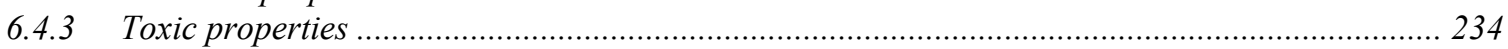

6.4.4 Properties of chemical warfare agents used in combat ......................................................... 235

6.5 SYMPTOMS OF EXPOSURE AND THE FIRST AID AFTER THE EXPOSURE TO CHEMICAL WARFARE AGENTS 238

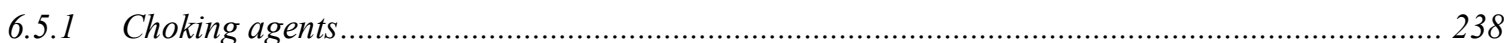

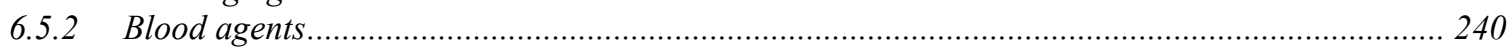

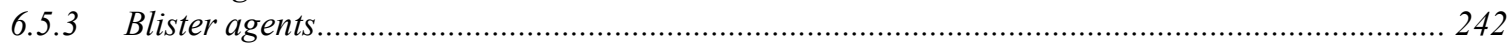

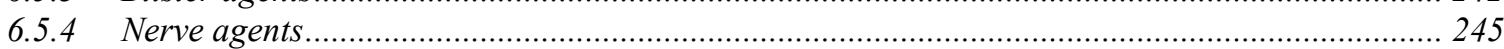

6.5.4.1 The FOLIANT Program - Novichoks and their properties, structure, reactivity …............................ 249

6.5.4.2 Novichoks and control measures under the Convention on the Prohibition of Chemical Weapons 256

6.5.4.3 Cases of using the agents of the Novichok group, developed under a Soviet programme codenamed

FOLIANT 258

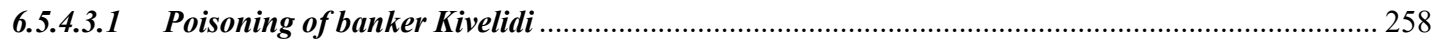

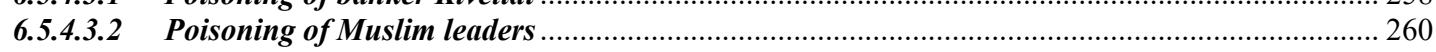

6.5.4.4 Case study dealing with the poisoning of Sergei Skripal and his daughter Yulia Skripalova ........... 260

6.5.4.4.1 Sequence of events from March 4, 2018 to February 14, 2019 ............................................... 261

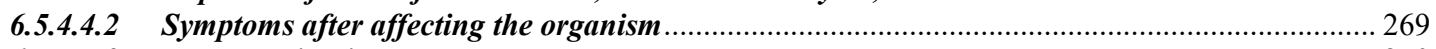

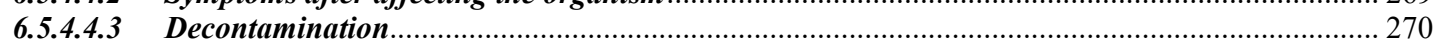

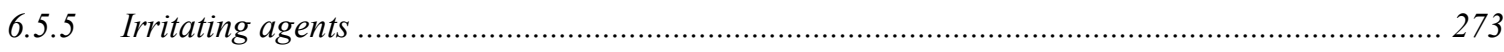

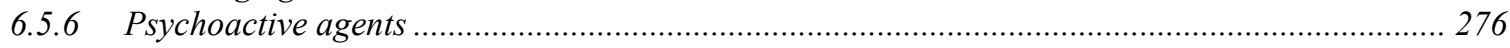

7. INDUSTRIAL CHEMICALS - A SECONDARY CHEMICAL WEAPON ................................... 278

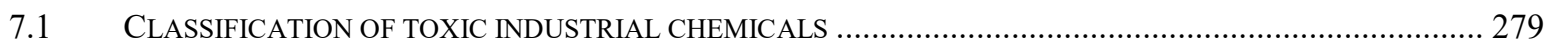

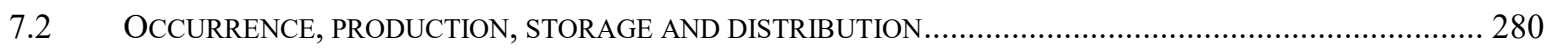

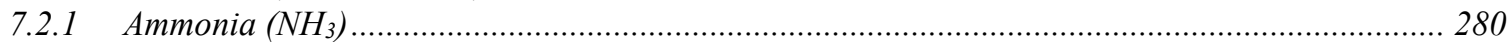

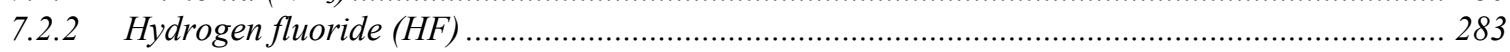

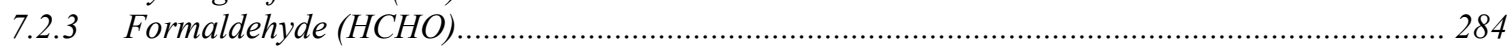




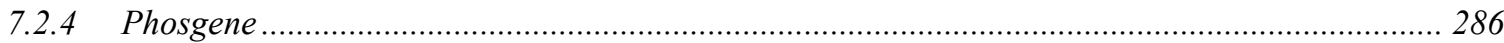

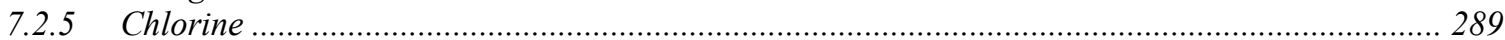

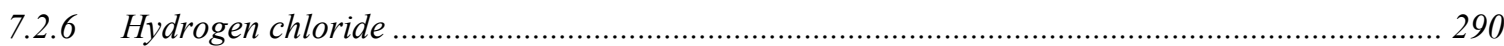

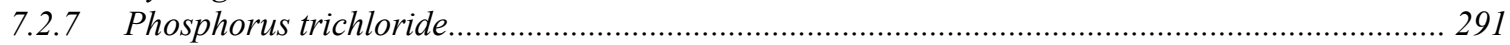

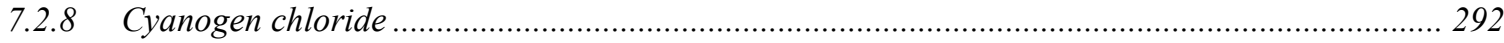

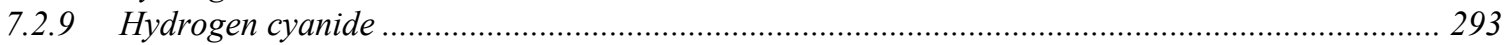

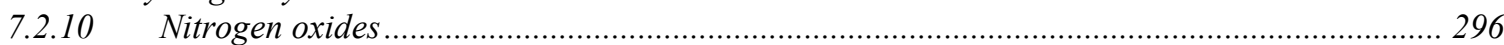

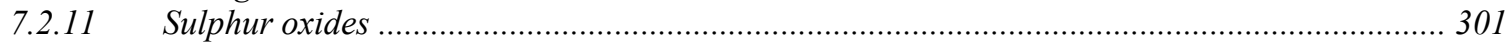

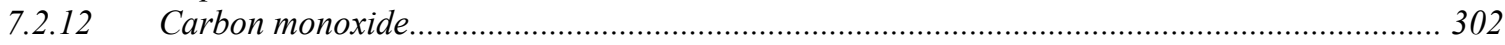

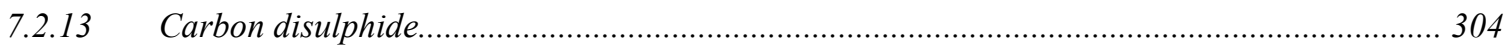

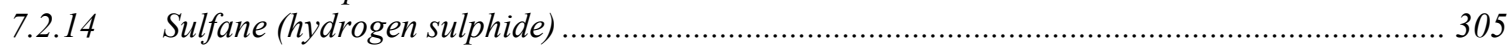

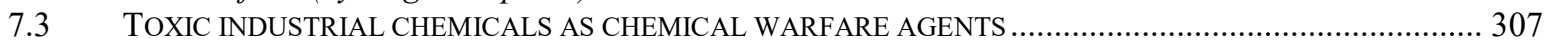

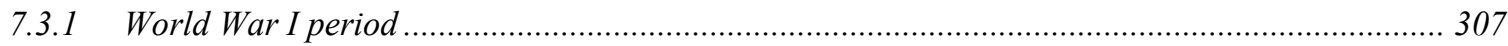

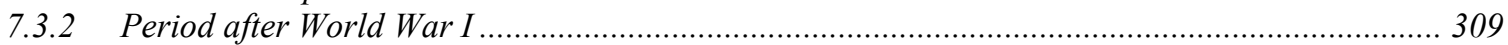

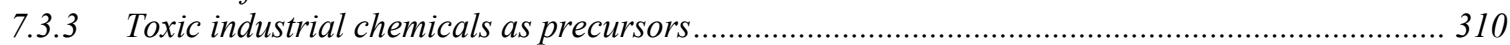

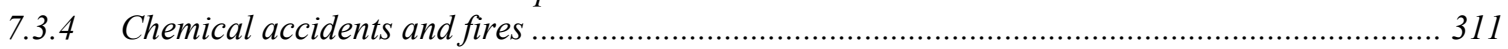

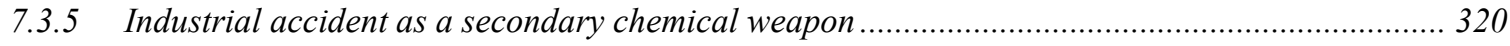

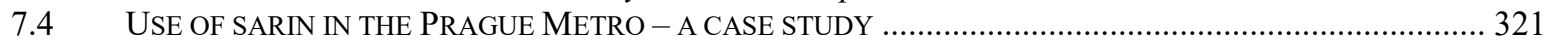

7.5 IMPACTS OF PESTICIDES ON HUMAN HEALTH AND THE ENVIRONMENT - A CASE STUDY ......................3 325

7.5.1 Adverse effects of pesticides on food and health ..................................................................... 325

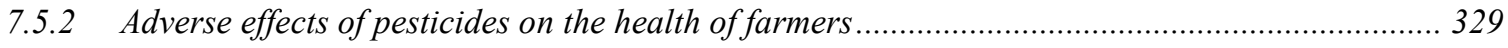

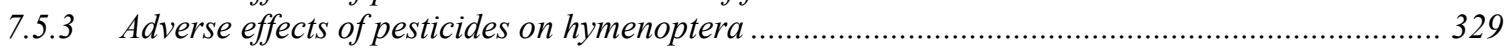

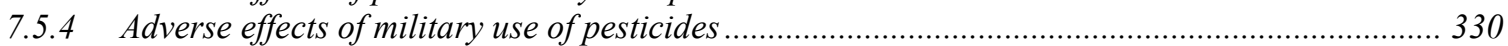

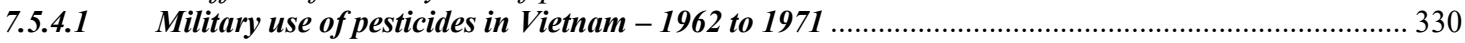

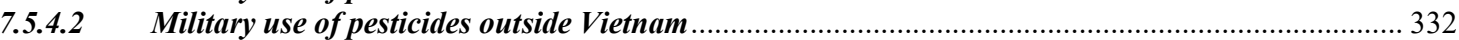

7.5.5 Chemical accident with mustard gas in the port of Bari-weapons in the sea - a case study..... 335

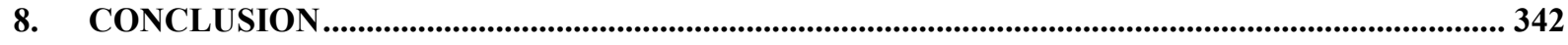

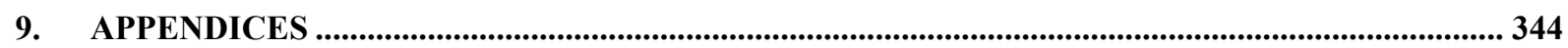

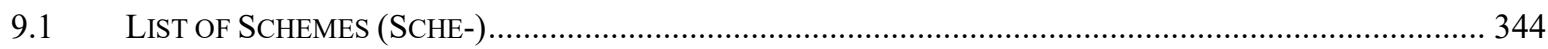

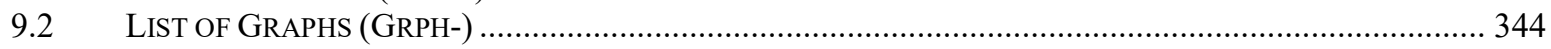

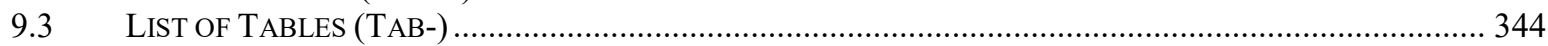

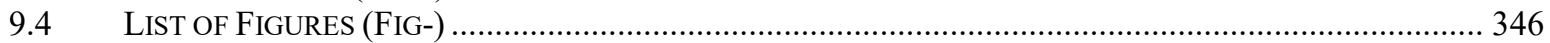

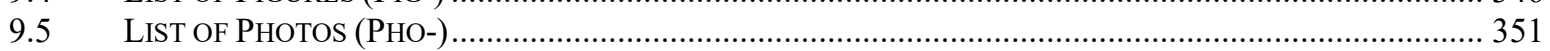

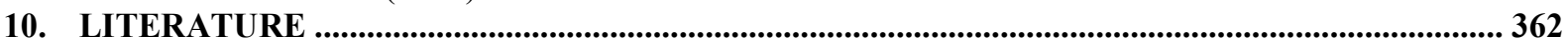

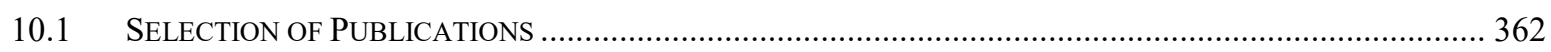

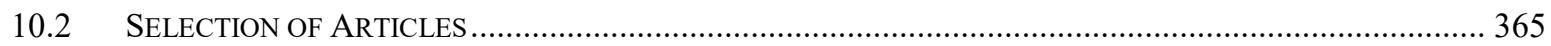

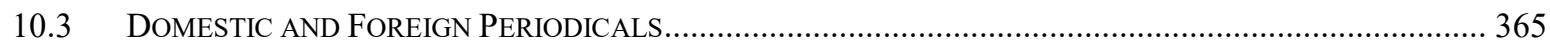

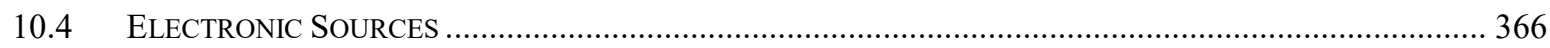

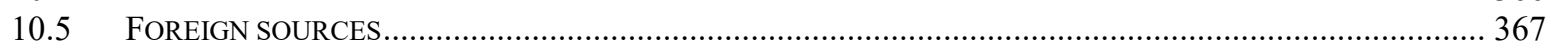

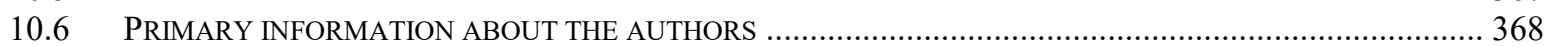




\section{Introduction}

The current society, which has gone through the stages of the industrial revolution and the scientific and technological revolution and is entering the postmodern stage, is subjected to numerous serious threats. However, some new, very dangerous and serious security threats and risks did not emerge until after 1990, which is mainly associated with the disintegration of the bipolar world of the East and the West. The causes are as follows: the uneven development of individual regions, the widening gap between the rich North and the poor South, ongoing wars and armed conflicts, the asymmetric use of non-renewable natural resources, the increasing indebtedness in many developed countries, rising poverty, malnutrition, hunger, diseases, the lack of safe water in an increasing part of the population, overpopulation and the unhealthy development of large settlement agglomerations, the growth of serious and organized crime, the migration of inhabitants, the pollution of all components of the environment and threats to biodiversity. The abovementioned and other world problems accompany mankind and the biosphere, when entering the third millennium.

The current world is totally interconnected by a series of relationships. The interconnection of the basic components of the environment, the complete division of the world, the economic links as well as the transport and communication infrastructure have led to current globalization that brings new challenges for all humanity, society, individual states, regions, communities and individual inhabitants of the planet. The only comprehensive strategic concept of the postmodern society, which has no rational alternative and is the only one to adequately address these threats and challenges, is a sustainable development strategy that is global in nature and implies all aspects of preserving the bare existence and the future development of human society, the biosphere and the Earth.

Sustainable development is not conceivable without sustainable security, both internal and external, which is interconnected with other segments of the all-society development. One of the threats to the contemporary society is organized crime and its most considerable form - terrorism. Namely, group terrorism is a serious social threat as it has an international to global character as a result of the globalized world.

The tragic events of September 11, 2001 clearly and convincingly showed that even a rich, high-tech democratic society with established protective and security structures is not prepared sufficiently for the threats of current terrorism. Terrorism becomes extremely brutal and can even use the most effective means, i.e. weapons of mass destruction (WMD) and their devastating components.

Science will continue to develop at high speed, even revolutionary leaps. Improvements in information technology, the benefits of nanotechnology, new innovations in biotechnology, and continued investment in science and technology will provide both opportunities and threats to infiltrate knowledge towards agents with hostile intentions. As a result, the proliferation of WMD will become a much more serious problem. In the areas of defence and protection, information technology will contribute to the acceleration of decision cycles. Space and cyberspace will be interconnected and more widespread through military applications than ever before. Nanotechnology will enable not only the military, but also various terrorist and extremist groups to use miniaturized, remote-controlled or even robotic systems, while biotechnology will increase the level of personal protection and the accuracy of sensors for targeting biological elements. Ultra-terrorism, sometimes called super-terrorism, i.e. chemical, biological, radiological and nuclear terrorism, represents not only future, but, unfortunately, also contemporary security threats, as demonstrated by the use of super toxic lethal sarin by the Aum Shinrikyo doomsday cult in 1994 and 1995. 
In view of the above-mentioned globalization and development in all existing and new branches of science, no part of the world community is immune from terrorist attacks. Therefore, also in our conditions, it is necessary to assess the possibilities of threatening the population of the Czech Republic, the biosphere, the areas of social activities and relevant infrastructures on the basis of an analysis of the threats of contemporary terrorism.

This specialized publication has been prepared only on the basis of the so-called "open information sources." 


\section{Specification and vocation of the publication}

Chemical, biological, radiological and nuclear terrorism ranks among new threats of terrorism. These professional issues have already been explored thoroughly before, but after the terrorist attacks on the World Trade Center buildings in New York and the Pentagon in Washington on September 11, 2001, they have received a new strong impetus. The content of the monograph aims at the area of chemical, biological, radiological and nuclear terrorism. Naturally, it tries to find the ways of a fast and reliable reaction and response to new threats, especially from the viewpoint of protecting the population of the Czech Republic and the critical infrastructure of our country.

The issue of new terrorism threats is relatively new, but very significant. Although the possibility of the abovementioned terrorism is still (probably temporarily) relatively low, the consequences of such an assault may be catastrophic. Generally, it is believed that the number of victims can reach the value of several tens of thousands. Moreover, it is currently widely accepted that the possibility of such terrorist attacks is slowly but unequivocally increasing. Therefore, experts and specialists should pay appropriate attention to these issues. Based on the scientific research in the given area, they should discuss and search for ways of fast and reliable response and recovery after such large-scale terrorist attacks.

The monograph is intended both for the general public and especially for the needs of the students in the study program entitled Population Protection. It is also usable for other university students as a supplementary study material. Appropriately, the monograph can also be used to educate particular basic and other components of the Integrated Rescue System of the Czech Republic.

The aim of this monograph is to acquaint students and other interested persons from a number of the expert and lay public with the issues of chemical, biological, radiological and nuclear terrorism; they should also become familiar with the description of a possible conceptual plan for the prevention, repression, protection and elimination of the consequences of chemical, biological, radiological and nuclear terrorism in the Czech Republic with the focus on the Population Protection. The monograph is divided into three parts. The first part deals with the issues of nuclear, radiological and chemical weapons, and toxic industrial chemical agents and radioactive agents. The second part discusses the issues of bacteriological (biological) and toxin weapons, and incendiary and thermobaric weapons. In this part, the issues of protection against the use / misuse of weapons of mass destruction are discussed. The last part is focused on the issues of chemical, biological, radiological and nuclear terrorism.

When developing this monograph, a large number of publications, professional periodicals and other open domestic and foreign sources of information have been used, especially from the issues of weapons of mass destruction and the protection against them. Moreover, the rich professional experience of all authors of the publication has been used as they regularly participate in both domestic and international conferences, workshops and symposia with a focus on the CBRN issues. For the sake of completeness, it should be added that the published material has been developed only on the basis of open information sources. The most valuable information about the field of CBRN is published in the intelligence and security papers and analyses.

For the purpose of greater clarity, the publication is supplemented by a rich appendix, including extensive case studies of sarin misuse in Matsumoto (1994) and Tokyo (Tokyo, 1995). 


\section{Definitions and Basic Terms}

Basic definitions and terms have been borrowed from the NN 300101 official terminology norm of the Chemical Corps (Ladislav Trtílek), Praha 2002. Some definitions and terms have been borrowed from the Czech legislation (e.g. Major Accident Prevention Act, etc.). A few basic definitions and terms have been borrowed from the professional handbook entitled Preparedness for emergency situations (Kejval, J., 2004) and from the publication entitled Dictionary of Emergency Management (Richter, R., 2010) published by the Ministry of the Interior - the General Directorate of Fire Rescue Service of CR in Prague, ISBN: 978-80-86640-54-9.

Further, the Czech Encyclopaedic Dictionary or, if need be, other encyclopaedic resources have been used.

In some frequent cases, definitions and basic terms have been effectively modified or shortened. The abridgement has been done only to the extent so that the reader may understand the content and context and not to be burdened by great technical details. On the other hand, in other cases, the main definitions and basic terms have been slightly extended and supplemented with the latest available scientific information.

The main definitions and basic terms are arranged alphabetically for easier searching and quick orientation of students and other users of this professional publication. This part has been included intentionally since the following text comprises some technical expressions. The reader may also return to this part of the text at any time during the study of individual parts of this professional publication.

\section{Accident}

An undesirable extraordinary, partly or completely uncontrolled, temporally and spatially bounded event that has occurred or its occurrence is imminent in conjunction with the operation of engineering facilities, production, use, storage, disposal or transport of hazardous substances leading to the loss of life, impairment or hazard to human health, living organisms or the environment or to the demonstrable damage to property.

\section{Auto-injector}

A device designed for antidote administration by injection as a first aid (buddy-aid or selfaid) in the event of exposure to nerve agents. The device can also be used for administrating other medical drugs, e.g. analgesics.

\section{Bacteria}

Bacteria are single-celled microorganisms that may cause diseases in humans and animals. They are a part of biological weapons. They reproduce by cell division and are not dependent on host cells. Some of them, e.g. anthrax may survive even very adverse conditions in the form of resistant spores. The diseases caused by bacteria are often treated with antibiotics.

\section{Bacteriological (biological) weapons}

A type of weapons of mass destruction. They use the detrimental effects of biological warfare agents most often on the human or any other living organism or, if need be, even on selected species of animals or plants. They consist of biological warfare agents and their means of delivery. They also include the use of infected rodents, insects, etc.

\section{Beyond design basis accident}

An accident of a nuclear power facility, which by its nature exceeds the criteria of the maximum design basis accident. 


\section{Binary chemical munitions}

Munitions, in which chemical substances, held in separate containers, react when mixed or combined as a result of being fired, launched or otherwise initiated to produce a chemical warfare agent when delivering munitions to an intended target. The initial substances used are in principle non-toxic and are called precursors. Some information about possible "binary biological ammunition" has also appeared in the professional "western literature".

\section{Biological warfare agents (BWA)}

Pathogenic microorganisms (bacteria, rickettsia, viruses, fungi and moulds). They cause diseases of people, plants, animals, possibly they cause material damage and deterioration. "Western sources" also mention toxins (see poison gases) as biological warfare agents.

\section{Chemical accident}

An accident (destruction) of infrastructure facilities associated with the release of industrial toxicants into the surroundings in a quantity, which seriously endanger humans and the environment. The Major Accident Prevention Act defines in more detail the so-called major accident that may cause emergency consequences, such as fire, explosion or leakage of toxicants.

\section{Chemical agents (CA), formerly also combat chemical agents (CCA), now chemical warfare agents (CWA)}

Chemical compounds and their mixtures, the effects of which, when used in combat, can kill, seriously injure or incapacitate humans, contaminate the environment, humans, military hardware, structures and other material. They rank among toxic chemicals. They are a part of chemical weapons. Depending on their effects, they are divided into nerve agents, blister agents, choking agents, blood agents, irritants and psychotomimetic agents. In accordance with the Czech military standards, toxins are also included. They do not include riot control agents, herbicides, smoke-producing agents and incendiary agents.

\section{Chemical weapons}

A type of weapons of mass destruction. They use the highly toxic effects of chemical warfare agents that affect the human organism. They include chemical warfare agents and their means of delivery.

\section{Clearance operations}

Clearance operations mean activities to remove the consequences caused by an emergency event.

\section{Collective protection}

A set of organizational and material measures, the aim of which is to protect groups of humans against the external irradiation using ionizing radiation and against the effects of radioactive agents, biological warfare agents or toxic chemicals. The collective protection equipment also protects against the effects of conventional weapons. The self-protection is provided by collective protection equipment.

\section{Collective protection equipment}

Facilities (shelters, buildings, vehicles, etc.) designed to protect groups of humans against the effects of radioactive, chemical warfare and biological warfare agents or toxic chemicals, against the destructive factors of a nuclear burst and incendiary agents. Their usual part is a filtering and ventilating equipment. 


\section{Common Emergency Communication and Information System (CECIS)}

The Common Emergency Communication and Information System abbreviated as CECIS is one of the elements of a European Community mechanism for civil protection to promote enhanced cooperation between the European Community and its Member States in civil protection assistance interventions. The aim of CECIS is to enable communication and information sharing between the European Community Monitoring and Information Centre (MIC) and the operational contact points of Member States.

\section{Contamination}

Storage, absorption and presence of radioactive agents, industrial toxicants and chemical warfare and biological warfare agents in quantities and concentrations that are considered harmful to the lives and health of humans and against which protective measures are taken.

\section{Crisis communication}

Crisis communication means the transfer of information between state bodies, territorial self-governing bodies and the Integrated Rescue System components using the means of voice and data transmission of information of the public telecommunications network and selected parts of non-public telecommunications networks.

\section{Critical infrastructure}

Critical infrastructure includes means, systems and their parts located in a Member State, which are essential for the maintenance of the most important social functions, health, safety, security or good economic or social conditions of the population, the disruption or destruction of which would have a serious impact due to the failure of these functions.

\section{Critical infrastructure protection}

Critical infrastructure protection means all the activities focused on ensuring the functionality, continuity and integrity of critical infrastructure with the aim to prevent, mitigate and neutralize threats, risks or vulnerabilities.

\section{Danger zone}

The whole space, or set of spaces, in which a dangerous substance is located in one or more installations, including common or related infrastructures and activities, owned or used by an operator.

\section{Design basis accident}

A postulated accident that a nuclear facility must be designed and built for. The operator of the facility has machines and other necessary material at his disposal to eliminate this accident, after which the defective parts can be repaired.

\section{Detection}

Processes by which the presence of biological warfare agents or toxic chemicals and radioactive agents is detected or monitored.

\section{Detector}

A device intended for detecting or monitoring the presence of different harmful agents. The decisive properties of the detector are the response speed (time of detection of the substance presence) and sensitivity (possibility of detecting the required concentration). Detectors can detect harmful agents in their immediate area, can be positioned at a certain distance or can detect distant harmful agents. 


\section{Domino effects}

An increased risk of the occurrence of a major accident and the severity of its consequences due to the vicinity of another structure or facility, in which a dangerous substance is located.

\section{Economic measures for crisis states}

Organizational, material or financial measures taken by an administrative authority in crisis states to ensure the necessary supplies of products, works and services, without which it is not possible to overcome crisis states (in the law as a necessary supply). They are designed to meet the basic needs of individuals on the territory of the Czech Republic to enable the survival of crisis states without actual bodily harm (in the law as basic necessities of life), further, to support the activities of the armed forces, armed security corps, fire rescue brigades, emergency services and to support the performance of state administration.

\section{Emergency/Crisis situation}

Emergency means an extraordinary event/emergency when the state of danger, state of emergency, state of peril to the country or the state of war are declared (in the lawas crisis states).

\section{Emergency (event)/Extraordinary event}

An emergency is the harmful effects of forces and phenomena caused by human activities, natural forces and influences, as well as accidents that endanger the lives or health of people and animals, the environment and property and require rescue and clearance operations work.

\section{Emergency management}

Emergency management is a set of managerial activities of competent authorities focused on the analysis and assessment of security risks, planning, organizing, the implementation and control of activities related to coping with an emergency.

\section{Emergency plan}

The emergency plan contains a set of measures and policies to cope with emergencies. The comprehensive update of the emergency plan is performed in three-year cycles after its approval. The Ministries and other administrative authorities, the Czech State Bank, Regional Fire Rescue Services, and Offices of the Chamber of Deputies, the Senate and the President of the Republic, the Office of the Government, the Supreme Audit Office and the Czech Intelligence Agency are responsible for developing an emergency plan.

\section{Emergency plan of the region}

In the exercise of state administration, for the purpose of preparing for emergencies, the Regional Authority develops a plan for carrying out rescue and clearance operations and protecting the population in the territory of the region, which is referred to as the Regional Emergency Plan.

\section{Emergency planning zone}

A territory in the vicinity of the structure or facility, in which the regional authority, in the territorial district of which the structure or facility where a hazardous substance is located, applies the requirements of emergency planning in the form of an external emergency plan and in which it ensures public hearing related to specified documents.

\section{Emergency preparedness plan}

Emergency preparedness plan means a plan, in which the preparation of a relevant legal entity or a self-employed physical entity for dealing with emergencies is regulated. 


\section{Emergency preparedness}

If there is a suspicion that an industrial disaster will occur, emergency preparedness means a set of measures taken to ensure that activities can be conducted to reduce its enlargement and consequences. It includes the elimination of the consequences of the disaster.

\section{End elements of warning and notification}

The end elements of the warning are technical devices capable of issuing a warning signal, e.g. sirens; the end elements of the notification are technical devices capable of transmitting information to emergency management authorities, e.g. mobile phones.

\section{Epidemic}

Mass occurrence of a disease in a certain region and in a certain time period that considerably exceeds the usually expected values of such a disease.

\section{Evacuation}

One of the basic methods of population protection. It is a summary of special measures ensuring the relocation (displacement) of people and property (as selected valuable material) in a given order of priorities from the places of threat to assembly points or, if need be, to safe places.

\section{Evacuation plan}

A document containing a summary of organizational, material and technical special measures aimed at the organized relocation of humans and designated valuable material from the areas where an event leading to the danger to lives and health of the population or the damage to property occurs or has occurred.

\section{European critical infrastructure}

Critical infrastructure located in Member States, the disruption or destruction of which would have a significant impact on at least two Member States.

\section{External border}

The external borders of the Czech Republic are the borders of the Czech Republic with a state other than the state, for which the provisions of the Schengen Agreement are binding (hereinafter referred to as the Contracting State). External borders also mean an international airport in the territory of the Czech Republic intended for flights, the places of departure, stopover or arrival of which are not in the territory of a Contracting State.

\section{Facility}

A technical or technological unit, in which a hazardous substance is manufactured, processed, used, transported or stored.

\section{Fire Rescue Service of the Czech Republic (FRS CR)}

The Fire Rescue Service is a rescue service, the basic mission of which is to protect the lives, health and property of the population against fire and to provide effective help in emergencies. The Fire Rescue Service is the main component of the Integrated Rescue System (see below).

\section{First aid}

Immediate, but temporary on-site care provided to victims of an accident, disaster or sudden illness to avert complications, relieve pain and save life until expert assistance is provided by an emergency medical service or a medical doctor. 


\section{Fundamental obligations of the state}

The fundamental obligations of the state include ensuring the sovereignty and territorial integrity of the Czech Republic, protecting the democratic foundations of the Czech Republic and protecting lives, health and asset values.

\section{Hazardous chemical substance}

A selected hazardous chemical substance or a chemical mixture that exhibits one or more hazardous properties, classified based on the Act on Chemical Substances and Chemical Mixtures. Earlier legislation used the word preparation instead of the word mixture.

\section{Hazardous substance location}

The planned quantity of a hazardous substance that is or will be manufactured, processed, used, transported or stored in an object or a facility or that may accumulate in an object or a facility in the event of a major accident.

\section{Humanitarian aid}

Measures taken in order to assist the population stricken with an emergency, in which human and material resources are used.

\section{Humanitarian aid reserves}

Humanitarian aid reserves are selected basic materials and products to be provided free of charge to a physical person affected seriously by the loss of property after the declaration of the state of emergency. The regional governor, the mayor of a municipality with extended powers or the mayor of a designated municipality to whom humanitarian aid reserves have been provided are responsible for allocating the reserves to private individuals. The reserves are a part of the emergency management system and are created by the Administration of State Material Reserves in the state material reserve system.

\section{Incubation period}

The time elapsed between the entry of pathogenic organisms into the body and the manifestations of the first signs and symptoms of the disease. In addition to the type of a causal agent it depends on the method of penetration into the body and on the number of microorganisms that have entered the body.

\section{Incident}

An undesirable extraordinary and, for a short time, uncontrolled event that has occurred and passed in a very short period of time and affected a part of operation or facility without endangering the health of humans, living organisms or the environment or a demonstrable loss of property.

\section{Individual protective equipment}

Equipment intended for protecting the respiratory tract, eyes and body surface of humans against exposure to radioactive, chemical warfare and biological warfare agents or toxic chemicals and against light and thermal radiation of a nuclear explosion. It can partially protect against incendiary substances. It includes respiratory protective equipment (protective mask, self-contained breathing apparatus), protective goggles and various types of body surface protection items including protective ointments.

\section{Infection}

Penetration of pathogenic organisms into the body, their multiplication and causing a disease. 


\section{Informing legal and physical entities of the threat and measures}

Informing legal and physical entities of the character of a potential threat, planned measures and the manner of their implementation is provided by the municipal office and the employer. To do this, they use information provided mainly by the Fire Rescue Service of the region. The information is usually provided through mass media, leaflets and information brochures, examples of the activities of the Integrated Rescue System or discussions with the population.

\section{Inspection}

Systematic examination, the aim of which is to determine whether the activities in the selected area of the management system and the related results are in accordance with the planned intentions and whether these intentions are implemented effectively and are suitable for achieving the set goals. The term inspection is usually understood as an examination carried out by a trained employee of the operator.

\section{Integrated Rescue System (IRS)}

The IRS is a system to ensure coordinated action of the IRS components in the preparation for emergencies and in the implementation of rescue and clearance operations (see details in the monograph text).

\section{Internal border}

The internal borders of the Czech Republic are the borders of the Czech Republic with states, for which the Schengen Agreement provisions are binding (hereinafter referred to as Contracting State). The internal borders also mean the airport in the territory of the Czech Republic designed exclusively for flights among Contracting States. The internal borders are not protected and can be crossed at any point.

\section{International Nuclear Event Scale - INES}

The International Atomic Energy Agency (IAEA) classifies nuclear events into seven levels based on the threat to humans and the environment, the damage to a nuclear power plant equipment and the violation of the security system as follows: 1 . Anomaly (deviation from the limits of prescribed functional parameters), 2. Incident (failure with potential for safety consequences), 3. Serious incident, 4. Accident without significant off-site risk, 5. Accident with significant off-site risk, 6. Serious accident, 7. Major accident.

\section{Intervention}

Intervention means carrying out a fire intervention, carrying out rescue or clearance operations within the Integrated Rescue System.

\section{Intervention site}

The coordination of rescue and clearance operations in the place of deployment of the Integrated Rescue System components and in the area of the anticipated effects of the emergency is indicated as the intervention site. The intervention commander divides the intervention site based on the extent of an emergency and the needs of rescue and clearance operations coordination into the external zone for closing the intervention site, the danger zone, the assembly point, the rear area, the decontamination area, the area for providing health care, the evacuee collection point, the area for an alternative housing of evacuated or rescued animals (veterinary care), the area for placing and identifying casualties, the area of anticipated spread of the emergency and into the sectors and sections where the components carry out rescue and clearance operations. 


\section{Major accident}

An emergency, partly or completely uncontrolled, temporally and spatially bounded event that has occurred in connection with using a structure or a facility where a dangerous substance is produced, processed, used, transported or stored and that leads to an immediate or successive serious damage or danger to lives and health of citizens, livestock, the environment or a damage to property and exceeds the restrictions mentioned in the Annex of the Major Accident Prevention Act.

\section{Major accident risk}

Probability of the occurrence of a major accident and its potential consequences that could happen in the course of a certain period or under certain circumstances.

\section{Major emergency}

A major emergency means any situation which has or may have an adverse impact on humans, the environment or property and that may lead to a request for assistance under the European Community mechanism to facilitate reinforced cooperation in assistance interventions in the area of civil protection.

\section{Material assistance}

Material assistance means providing material assets during rescue and clearance operations and exercises at the call of the intervention commander, regional governor or mayor of a municipality. Material assistance can also be provided voluntarily without a call, but with the consent or awareness of the intervention commander, regional governor or mayor of a municipality.

\section{Material resources to cope with emergencies (crisis situations)}

Material resources mean movable and immovable assets in the possession of the state, territorial self-governing units, legal entities and self-employed physical entities, or the services provided by them that can be exploited for coping with an emergency (crisis situation).

\section{Meteorological data}

Important data concerning atmospheric movements and atmospheric phenomena. The data are important for the evaluation of the radiation, chemical and biological situation after the use of WMD after a radiation or chemical accident. These are mainly the direction and speed of ground and high-altitude winds, air and soil temperature, sky coverage with clouds, air humidity, etc.

\section{Miosis}

Miosis means excessive constriction (shrinking) of the pupil of the eye. It is one of the basic and typical symptoms of people being affected by nerve agents. Subjectively, miosis is manifested by impaired vision even in good light conditions.

\section{Monitoring and Information Centre of the European Community}

The abbreviation MIC - Monitoring and Information Centre is also used. It is one element of the Community mechanism to facilitate reinforced cooperation between the Community and the Member States in civil protection assistance interventions.

\section{Notification of the Integrated Rescue System (IRS) components}

A summary of organizational and technical measures ensuring the timely transmission of information on an impending or occurring emergency to emergency management authorities based on the set sequence. 


\section{NBC defence}

It is a package of organizational and technical measures taken, the aim of which is to reduce the influence and eliminate the consequences of NBC weapons destructive effects. The parts of NBC defence are special measures, e.g. detection and monitoring of hazardous substances radioactive, chemical and biological warfare agents; warning; protection of humans and materials; health measures; decontamination; clearance of the consequences of the attack, etc.

\section{NBC weapons / Weapons of mass destruction}

A collective term for nuclear weapons, chemical weapons and bacteriological (biological) weapons. Their use causes mass casualties, the destruction of material and extensive damage to infrastructure. However, the destructive effects of particular NBC weapons differ significantly (see particular types of NBC weapons in detail: nuclear weapons, chemical weapons, bacteriological [biological] weapons, radiological weapons).

\section{Nuclear facility}

A nuclear facility means a structure and an operating unit, the part of which is a nuclear reactor using fission chain reactions, a facility for the production, processing, storage and disposal of nuclear materials, excluding uranium ore processing plants and radioactive waste repositories.

\section{Nuclear safety}

Nuclear safety means the condition and capability of a nuclear facility and its personnel to prevent an uncontrolled development of fission chain reaction or unallowable escape of radioactive agents or ionizing radiation to the environment and to eliminate the consequences of accidents.

\section{Nuclear weapons}

The type of weapons falling into the category of mass destruction weapons. Their destructive effects are caused by a large amount of energy released during a nuclear explosion in form of the so-called nuclear explosion destructive factors (see details in the technical publication text).

\section{External emergency plan}

If an emergency planning zone covers the territory of more than one administrative district of a municipality with extended powers of its own region or covers the territory of a region from the territory of another region, the regional authority, in cooperation with relevant municipal offices with extended powers, develops a plan to carry out rescue and clearance operations in the vicinity of the source of risk. It is called External Emergency Plan.

\section{Operator}

Any legal entity or a self-employed physical entity that, as of the effective date of the Atomic Act and the Act on the Prevention of Major Accidents uses or will use a structure or a facility, in which a hazardous substance is or will be placed in the same or sizable quantity than the quantity specified in the Act on the Prevention of Major Accidents, or uses and handles the sources of ionizing radiation in accordance with the Atomic Act.

\section{Optimization of radiation protection}

The optimization of radiation protection means the procedures to achieve and maintain such a level of radiation protection that the risk of danger to lives and health of people and the endangering of the environment is as low as can reasonably be achieved, taking into account economic and social factors. 


\section{Population protection}

Protection of the population means the fulfilment of civil protection tasks, in particular warning, evacuation, shelter, emergency survival of the population and other measures to ensure the protection of their lives, health and property (according to "Additional Protocol I to the Geneva Conventions").

\section{Preparedness}

Preparedness means the state of readiness and capability of human and material resources achieved as a result of a pre-arranged action, enabling them to ensure an effective and rapid response to an emergency.

\section{Prevention}

Organizational and technical measures or activities, the aim of which is to prevent an adverse events (emergencies), and to create conditions for ensuring emergency preparedness.

\section{Protective measure in the event of a radiation emergency}

The limitation of exposure of humans and the environment in the event of a radiation emergency is carried out through protective measures, which are urgent protective measures including shelters, iodine prophylaxis, evacuation and subsequent protective measures including the relocation, the control of ingestion of food and water contaminated with radionuclides and the control of ingestion of animal feed contaminated with radionuclides.

\section{Protective mask respirator}

Basic individual protective equipment designed for protecting an individual. It provides the protection of air passages, eyes and face against the exposure to radioactive agents, biological warfare agents and toxic chemicals. A protective mask respirator is usually formed by a set consisted of a face mask, filter, carrying bag and other parts.

\section{Provision and acceptance of humanitarian aid}

Humanitarian aid can be accepted and provided to satisfy the bare necessities of life of the population and to restore the territories affected by an emergency in the form of material and financial resources, services or special works. It is provided free of charge by the state administration authorities, bodies of territorial self-governing units, legal entities, self-employed physical entities, non-governmental organizations, non-profit organizations and associations of citizens, groups of people and individuals at the request or on their own initiative in the form of offers.

\section{Public information in the emergency planning zone}

It is information intended for the public. It contains the data on hazardous agents and the nature of a major accident risk in a simple and understandable way, including the estimate of the consequences and their impacts on lives and health of people, livestock, the environment and property in the emergency planning zone. The data on the method of warning the people and the people's behaviour desired are a part of the information.

\section{Public opinion}

It is a written statement of each individual, self-employed physical entity or legal entity relating to the security programme for preventing major accidents, the safety report, the external emergency plan or their updating in the course of their public hearing. 


\section{Quarantine}

A set of anti-epidemics (sanitary) and anti-epizootic (veterinary) measures, the purpose of which is to isolate the focus of infection caused by biological weapons and eliminate contagious diseases. It is usually a temporary isolation of a group of people or livestock suspected of being infected over the time corresponding to the longest duration of the incubation period.

\section{Radiation accident}

A higher level of a nuclear event (accident) that threatens the lives and health of personnel and requires protective and environmental measures.

\section{Radiation incident}

An event, in which people were irradiated with the doses greater than normal or permitted values are, or radioactive substances exceeding specified limits were released.

\section{Radiation accident classification}

Radiation accidents in nuclear power plants are classified based on the extent and consequences into design basis accidents, maximum credible accidents and beyond design basis accidents.

\section{Radiation protection}

Radiation protection means a system of technical and organizational measures to limit the exposure of individuals and to protect the environment.

\section{Radioactive agents}

Isotopes of elements or their compounds and mixtures containing radionuclides. They are formed during a nuclear explosion or in the nuclear reactors of nuclear power plants. They can escape into the environment in the event of a major radiation accident.

\section{Radiation contamination (Radioactive contamination)}

Contamination of personnel, military hardware, other material, air, terrain, water and structures caused by radioactive agents that occurred as a result of a nuclear explosion, in a radiation accident or due to the leakage of industrial radioactive agents.

\section{Radioactivity}

A spontaneous natural transformation of a radionuclide (radioactive element) to another substance, which is associated with emitted ionizing radiation. This phenomenon proceeds independently on ambient conditions, i.e. the temperature, pressure, air humidity, etc.

\section{Radiological weapons}

Weapons of mass destruction with the harmful effects of ionizing radiation on humans and the environment.

\section{Regulatory measure}

Regulatory measures within the economic measures for crisis states are intended for reducing the consumption of scarce raw materials, products and energies or for coordinating the consumption in compliance with contingency plans in cases when an emergency is so extensive that routine economic tools are not effective enough for ensuring indispensable deliveries.

\section{Rescue operations}

Rescue operations are activities to avert or reduce the immediate impact of risks arising from an emergency, especially in relation to the threats to life, health, property or the environment and leading to the interruption of their causes. 


\section{Response}

Response means any action taken on the basis of the Community mechanism to support the strengthening of cooperation in civil protection assistance interventions during or after a major emergency, in order to address its direct consequences.

\section{Risk}

An imminent event or probability of the occurrence of a potentially destructive phenomenon in a given period and at a certain place.

\section{Risk analysis and risk assessment of a major accident}

It is performed and documented within the range corresponding to the accident risk, i.e. to the probability of its occurrence and severity of its impacts using qualitative and quantitative analytical methods. It includes identifying risk sources, defining potential scenarios of events and causes that may result in an accident, estimating the impacts of these scenarios on people's lives and health, on livestock, the environment and property, determining the risk level of these scenarios and assessing the acceptability of major accident risks.

\section{Routes of entry into an organism}

The ways, through which biological warfare agents, radioactive agents or toxic chemicals may enter the human body. From the general viewpoint, four basic routes of entry are important: respiratory system (inhalation), through the skin and eyes (absorption), ingestion (swallowing) and injection (injury caused by a sharp object).

\section{Scenario in the system of major accident prevention}

In the major accident prevention system, a scenario means a variant description of the development of a major accident, a description of the development of causal and consecutive and sequential events, either spontaneously or as activities of people to manage a major accident.

\section{Source of ionizing radiation}

A source of ionizing radiation means a substance, an apparatus or a device that may emit ionizing radiation or release radioactive agents.

\section{Source of risk}

The source of risk (danger) in the system of major accident prevention means the property of a hazardous substance or a physical situation that may cause the occurrence of a major accident.

\section{Special facts}

Special facts are information in the field of emergency management, which, in the case of misuse, could lead to danger of life, health, property, the environment or the business interest of a legal entity or a physical entity carrying out a business activity according to special legal regulations.

\section{Terrorism}

Terrorism is a phenomenon injurious to the public that manifests itself at the national and international levels. It is a pre-arranged, deliberate use of violence or a threat of violence, usually directed against often uninvolved people with the aim to evoke fear, through which the political, ideological or religious requirements are to be achieved. 


\section{Financing of terrorism}

Financing of terrorism means the provision or collection of funds, in any way, directly or indirectly, with the intent or knowledge that they will be used in whole or in part to commit any of the offenses within the meaning of the Directive of the European Parliament and of the Council on combating terrorism.

\section{Toxic dose}

The amount of a toxic chemical that causes the symptoms of poisoning after it enters the body. The toxic doses are as follows: threshold (TD), effective (ED), incapacitating (ID) and lethal (LD). The percentage of affected individuals out of the whole number is indicated by an index. The toxic dose is expressed in grams or milligrams per unit weight or per person weight $(70 \mathrm{~kg})$.

\section{Toxicity}

The property of substances to cause pathological changes or death after penetration into the organism.

\section{Toxins}

Substances produced by living organisms (plants, microorganisms, fungi) or acquired synthetically, which are characterized by high toxicity.

\section{Vaccine}

An inoculant, after the administration of which an organism creates antibodies.

Virulence

It is defined as the degree of pathogenicity of a pathogen and is determined by its ability to invade and multiply within the host. Relative ability of some microorganisms to cause infectious diseases (also the degree of pathogenicity).

\section{Viruses}

Submicroscopic organisms that infect animals and plants and cause diseases. They need a host cell for their replication. They do not respond to antibiotics.

\section{Warning}

Announcing and disseminating messages that warn of imminent danger. It may also contain information on protective measures. As a rule, all available means such as local radio, radio cars, radio and television are used for warning. Currently, only one warning signal is used in the Czech Republic.

\section{Warning signal}

A warning signal is an appointed method of acoustic activation of the end elements of warning the population against an imminent or occurring emergency. 


\section{List of Selected Abbreviations}

The abbreviations listed are used directly in this technical text or are commonly used in the Anglo-Saxon technical literature related to the issues of chemical, biological, radiological and nuclear terrorism and protection against it.

On the other hand, English abbreviations nowadays are widely used, namely, even their English versions. The CBRN abbreviation, which means Chemical, Biological, Radiological and Nuclear, can serve as an example.

Therefore, the overview of English-written abbreviations in Table 1 is broader than the abbreviations and English terms used in the instructional text. In view of the fact that the Czech and English nomenclatures are not fully equivalent, in necessary cases an explanatory note is indicated in the brackets to clarify a term. For fast orientation, the alphabetical order of particular abbreviations has been selected regardless of the language.

Table 1: List of English abbreviations. [Source: Tab-1]

\begin{tabular}{|c|c|c|}
\hline Abbreviation & Name in English & Name in Czech \\
\hline $\mathrm{ABM}$ & Anti-Ballistic Missile & $\begin{array}{c}\text { Smlouva o omezení systémů protiraketové } \\
\text { obrany (zkrácená verze) }\end{array}$ \\
\hline AČR & Army of the Czech Republic & Armáda České republiky \\
\hline $\mathrm{AG}$ & Australian Group & Australská skupina \\
\hline AIDS & $\begin{array}{l}\text { Acquired immunity deficiency } \\
\text { syndrome }\end{array}$ & Syndrom získané ztráty imunity (AIDS) \\
\hline $\mathrm{BDM}$ & Ballistic Missile Defence & Obrana proti balistickým řízeným střelám \\
\hline BCHL & Chemical warfare agents & Bojové chemické látky \\
\hline BTWC & $\begin{array}{l}\text { Bacteriological (Biological) and } \\
\text { Toxin Weapons Convention }\end{array}$ & $\begin{array}{c}\text { Úmluva o zákazu bakteriologických } \\
\text { (biologických) a toxinových zbraní } \\
\text { (zkrácená verze) }\end{array}$ \\
\hline $\mathrm{CD}$ & Conference on Disarmament & Konference o odzbrojení \\
\hline CIA & Central Intelligence Agency & Ústřední zpravodajská služba (USA) \\
\hline CICP & $\begin{array}{l}\text { (UN) Centre for International Crime } \\
\text { Prevention (since } 2002 \text { renamed } \\
\text { to UNODC Crime Programme) } \\
\text { [see UNODC] }\end{array}$ & $\begin{array}{c}\text { Centrum (OSN) pro prevenci mezinárodního } \\
\text { zločinu (od r. } 2002 \text { přejmenováno na } \\
\text { Program proti zločinu Úřadu OSN pro drogy } \\
\text { a zločin) }\end{array}$ \\
\hline CBRN & $\begin{array}{c}\text { Chemical, biological, radiological and } \\
\text { nuclear... }\end{array}$ & $\begin{array}{c}\text { Chemické, biologické, radiologické } \\
\text { a jaderné... }\end{array}$ \\
\hline CTBT & $\begin{array}{c}\text { Comprehensive Nuclear-Test-Ban } \\
\text { Treaty }\end{array}$ & $\begin{array}{c}\text { Smlouva o všeobecném zákazu i jaderných } \\
\text { zkoušek }\end{array}$ \\
\hline $\mathrm{CWC}$ & Chemical Weapons Convention & $\begin{array}{l}\text { Zkrácená verze Úmluvy o zákazu } \\
\text { chemických zbraní }\end{array}$ \\
\hline DPI & Department of Public Information & Odbor pro poskytování informací veřejnosti \\
\hline EU & European Union & Evropská unie \\
\hline FBI & Federal Bureau of Investigation & Federální úřad pro vyšetřování (USA) \\
\hline
\end{tabular}


Table 1: List of English abbreviations (continued).

\begin{tabular}{|c|c|c|}
\hline Abbreviation & Title in English & Title in Czech \\
\hline FAO & $\begin{array}{c}\text { Food and Agriculture Organization } \\
\text { of the United Nations }\end{array}$ & Organizace OSN pro potraviny a zemědělství \\
\hline FMCT & Fissile Material Cut-off Treaty & $\begin{array}{c}\text { Smlouva o zákazu výroby štěpných materiálů } \\
\text { (zkrácený název pro Smlouvu zakazující } \\
\text { výrobu štěpných materiálů pro jaderné zbraně } \\
\text { nebo jiná jaderná výbušná zařízení) }\end{array}$ \\
\hline FRS & Fire Rescue Service & Hasičský záchranný sbor \\
\hline HEU & Highly Enriched Uranium & Vysoce obohacený uran \\
\hline IAEA & International Atomic Energy Agency & $\begin{array}{l}\text { Mezinárodní agentura pro atomovou energii } \\
\text { (MAAE) }\end{array}$ \\
\hline ICAN & $\begin{array}{l}\text { International Campaign to Abolish } \\
\text { Nuclear Weapons }\end{array}$ & $\begin{array}{l}\text { Mezinárodní kampaň za zrušení jaderných } \\
\text { zbraní }\end{array}$ \\
\hline ICBM & Intercontinental Ballistic Missile & Mezikontinentální balistická střela \\
\hline ICAO & $\begin{array}{c}\text { International Civil Aviation } \\
\text { Organization }\end{array}$ & Mezinárodní organizace pro civilní letectví \\
\hline ICJ & International Court of Justice & Mezinárodní soudní dvůr \\
\hline ICRC & $\begin{array}{l}\text { International Committee of the Red } \\
\text { Cross }\end{array}$ & Mezinárodní výbor Červeného kř́íže \\
\hline ILO & International Labour Organisation & Mezinárodní organizace práce \\
\hline IMF & Intermediate (Nuclear) Force & $\begin{array}{l}\text { (Jaderné) střely středního a kratšího dosahu } \\
\qquad(500-5500 \mathrm{~km})\end{array}$ \\
\hline IES & Integrated Emergency System & Integrovaný záchranný systém \\
\hline IRS & Integrated Rescue System & Integrovaný záchranný systém \\
\hline MIRV & $\begin{array}{l}\text { Multiple Independently Targetable } \\
\text { Re-entry Vehicle }\end{array}$ & $\begin{array}{l}\text { Mezikontinentální balistická střela s více } \\
\text { (až 10) nezávisle naváděnými hlavicemi }\end{array}$ \\
\hline $\mathrm{MoD}$ & Ministry of Defence & Ministerstvo obrany \\
\hline MFA & Ministry of Foreign Affairs & Ministerstvo zahraničních věcí \\
\hline MH & Ministry of Health & Ministerstvo zdravotnictví \\
\hline MA & Ministry of Agriculture & Ministerstvo zemědělství \\
\hline NPT & Non-Proliferation Treaty & Smlouva o nešíření jaderných zbraní \\
\hline NAP & $\begin{array}{l}\text { National Action Plan } \\
\text { (fight against terrorism) }\end{array}$ & Národní akční plán (boje proti terorismu) \\
\hline NBC weapons & $\begin{array}{l}\text { Nuclear, Biological and Chemical } \\
\text { weapons }\end{array}$ & $\begin{array}{l}\text { Jaderné, biologické a chemické zbraně } \\
\text { (zbraně hromadného ničení) }\end{array}$ \\
\hline NATO & North Atlantic Treaty Organisation & Severoatlantická aliance \\
\hline ODCCP & $\begin{array}{l}\text { Office for Drug Control and Crime } \\
\text { Prevention (now UNODC) }\end{array}$ & $\begin{array}{l}\text { Úřad (OSN) pro kontrolu drog a prevenci } \\
\text { zločinu (viz UNODC) }\end{array}$ \\
\hline OSN & The United Nations & Organizace spojených národů \\
\hline
\end{tabular}


Table 1: List of English abbreviations (continued).

\begin{tabular}{|c|c|c|}
\hline Abbreviation & Title in English & Title in Czech \\
\hline PCR & Police of the Czech Republic & Policie České republiky \\
\hline SALT & Strategic Arms Limitation Talks & Jednání o omezení strategické výzbroje \\
\hline SLBM & Submarine-launched ballistic missile & Balistická střela odpalovaná z ponorky \\
\hline SONS & State Office for Nuclear Safety & Státní úřad pro jadernou bezpečnost \\
\hline TNT & Trinitrotoluene & Trinitrotoluen - tritol \\
\hline UNEP & $\begin{array}{c}\text { United Nations Environment } \\
\text { Programme }\end{array}$ & Program OSN pro životní prostředí \\
\hline UNIDIR & $\begin{array}{l}\text { United Nations Institute for } \\
\text { Disarmament Research }\end{array}$ & Ústav OSN pro výzkum odzbrojení \\
\hline UNDCP & $\begin{array}{c}\text { United Nations Drug Control } \\
\text { Programme }\end{array}$ & Program OSN pro kontrolu drog \\
\hline UNAIDS & $\begin{array}{c}\text { Joint United Nations Programme } \\
\text { on HIV/AIDS }\end{array}$ & Společný program OSN proti HIV/AIDS \\
\hline UNICEF & United Nations Children's Fund & Dětský fond OSN \\
\hline UNCTAD & $\begin{array}{l}\text { United Nations Conference on Trade } \\
\text { and Development }\end{array}$ & Konference OSN pro obchod a rozvoj \\
\hline UNDP & $\begin{array}{l}\text { United Nations Development } \\
\text { Programme }\end{array}$ & Program OSN pro rozvoj \\
\hline UNESCO & $\begin{array}{c}\text { United Nations Educational, Scientific } \\
\text { and Cultural Organisation }\end{array}$ & Organizace OSN pro výchovu, vědu a kulturu \\
\hline UNHCR & $\begin{array}{l}\text { United Nations High Commissioner } \\
\text { for Refugees }\end{array}$ & Vysoký komisař OSN pro uprchlíky \\
\hline UNICRI & $\begin{array}{l}\text { United Nations Interregional Crime } \\
\text { and Justice Research Institute }\end{array}$ & $\begin{array}{c}\text { Meziregionální ústav pro výzkum zločinu } \\
\text { a práva }\end{array}$ \\
\hline UNIDO & $\begin{array}{l}\text { United Nations Industrial } \\
\text { Development Organisation }\end{array}$ & Organizace OSN pro průmyslový rozvoj \\
\hline UNODC & $\begin{array}{l}\text { United Nations Office on Drugs } \\
\text { and Crime }\end{array}$ & Úřad OSN pro drogy a zločin \\
\hline VIC & Vienna International Centre & Vídeňské mezinárodní centrum \\
\hline WCO & World Customs Organisation & Světová celní organizace \\
\hline WFP & World Food Programme & Světový potravinový program \\
\hline WHO & World Health Organisation & Světová zdravotnická organizace \\
\hline WMD & Weapons of mass destruction & Zbraně hromadného ničení \\
\hline WTC & World Trade Center & Světové obchodní centrum \\
\hline
\end{tabular}




\section{Nuclear Weapons}

\subsection{Historical and Current Situation}

The history of the emergence of nuclear weapons is relatively long and undoubtedly quite dramatic as well. Even before the research and development of nuclear weapons, a number of important fundamental discoveries were made, especially in the field of nuclear physics. These gradually culminated in the mid-1940s, which led to the construction, testing and practical use of nuclear weapons during World War II. These most destructive weapons were used by the American Army only against Japan at the end of World War II. Many significant discoveries also date back to the end of the 19th century. The discoveries in the sphere of nuclear physics were a result of systematic and careful work and research of great scientists of the world. Just as in the sphere of chemistry German scientists were also in the leading place in nuclear physics. A number of Nobel Prizes awarded show the evidence of that.

However, in 1939, the evidence of fission neutrons was carried out and the possibility of nuclear fission chain reaction was confirmed. This initiated extensive work in the sphere of nuclear research with the aim to produce a nuclear weapon. Scientific and research programs focused on the production of nuclear weapons have been running since 1939 and later in many leading developed countries: in Germany, Great Britain, France, the USA, the Soviet Union, Japan and Canada. For obvious reasons, the nuclear research was kept under wraps and well financed in all the countries mentioned.

The aggressive regime of Nazi Germany, led for several years by Adolf Hitler, based on very advanced scientific, technical, technological and economic potential, was diligently seeking effective means to achieve world domination. Since 1939 the informed scientific personalities had been clearly conscious that Nazi Germany had necessary conditions and main prerequisites for nuclear weapon production (production capacity of chemical, electrotechnical and engineering industries, non-ferrous metallurgy, basic and raw materials, top scientists, knowledge of nuclear physics, modern research institutes and facilities and financial resources.

It is no secret that German nuclear physicists were the first to start developing nuclear weapons in 1939. Up to 22 research institutes in Germany were gradually involved in this secret research. Originally, the German scientists led by W. Heisenberg studied the chain reaction of uranium using graphite as a moderator. An essential mistake in determining the quantity of graphite caused that the German scientists began to use scarce heavy water as a moderator. The German scientists made some other crucial mistakes both in the research itself and in scientific conclusions done. Finally, the experiments in Germany were nearly stopped as they were not considered to be important.

Most of nuclear physicists and chemists from the whole Europe emigrated to the United States of America before or during World War II and thus a considerable intellectual scientific potential to deal with the issues of development and production of a new destructive nuclear weapon was created.

\subsubsection{The emergence of nuclear weapons}

In 1941, the American National Academy of Sciences called for the accelerated construction of a nuclear weapon to ensure security of the state and the free world. Following this request, in which one of the greatest scientists of the last century, Albert Einstein, was personally engaged, then US President Franklin D. Roosevelt provided sufficient human, financial and other necessary resources for further extensive research and work on the construction of a new nuclear weapon. 
It is generally known that, in those days, even three cities were actually built in the USA, which dealt exclusively with the individual stages of nuclear weapon research and development. Another important and little-known fact is that between 1943 and 1944 after top-secret US-British negotiations and talks, about 50 top British nuclear scientists left for the United States. They also brought with them very advanced results of the British nuclear research. Thus, the effective combination of the British and American nuclear programs took place. The excellent results of the British nuclear military research, which was much more advanced than the American one, were placed at the disposal of the scientific teams in the USA.

After that, an intensive and, finally, a very successful nuclear military secret research and development took place in the USA. And so, it happened that Americans were the most successful in the research, development and construction of nuclear weapons. This is despite the fact that the work of nuclear scientists in the USA was directed to the military sphere as late as September 1942. They focused on the research of nuclear fission of uranium 235 and plutonium 239 using graphite as a moderator.

Since 1942, whole new cities have sprung up in the United States that have systematically dealt with the various stages in the production of nuclear weapons. In Oak Ridge, one of the three US secret cities, uranium 235 was obtained from the uranium ore. In Hanford, uranium was converted to plutonium 239. In Los Alamos, new central military laboratories and a control centre were built and the greatest scientists from all over the USA were called to work there.

On December 2, 1942, Enrico Fermi, the American physicist of Italian origin, succeeded in inducing the first nuclear chain reaction, which was performed under the west stands of the University of Chicago. After this significant experiment it was clear that the nuclear weapon manufacture was feasible. All professional work in Los Alamos was carried out under strict secrecy. The code name of the nuclear weapon project itself was Manhattan. Less than three years after Fermi's first chain nuclear reaction, Americans succeeded in preparing the first nuclear explosion test in the world.

During the predawn hours of July 16, 1945, the first nuclear plutonium bomb with a yield of approximately 20 kilotons of trinitrotoluene (TNT) was detonated in the Alamogordo area, New Mexico. This nuclear explosion test (nuclear test) is, in general, considered to be an essential milestone in the emergence of nuclear weapons. Led by Julius R. Oppenheimer, the distinguished American physicist, the Trinity bomb, 1.5 metre in diameter weighing 2.5 tonnes, was hauled up the 30-metre steel tower. After that, the first nuclear explosion test in the world was executed. The mushroom cloud caused by this nuclear explosion test rose to a height of up to 12 kilometres.

The main work on the construction of the nuclear bomb rested on the work team of the American physicist Julius R. Oppenheimer at Los Alamos, New Mexico. In literature, Julius R. Oppenheimer and Leo Szilard (American of Hungarian origin) are considered to be masterminds of nuclear weapons.

Since the Japanese completely rejected the Potsdam Declaration, US President Harry S. Truman ordered the use of a nuclear weapon and informed his allies, Great Britain and the Soviet Union, about that in Potsdam. On July 30, 1945, the USS Indianapolis cruiser delivered nuclear bombs and a number of American experts to the island of Tinian in the Mariana Islands where the last preparations for the use of nuclear bombs against the Japanese enemy took place. The nuclear bombs called Little Boy and Fat Man were ready for the first combat employment.

An important question is why exactly the USA constructed the first nuclear weapon in the course of World War II when this research had been started initially in Germany (since 1939). 
Photo 1: The course of the TRINITY nuclear test. [Source: Pho-1]

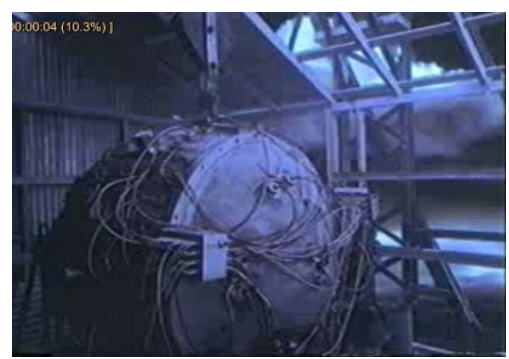

Photo 1-1: 2 seconds before the explosion

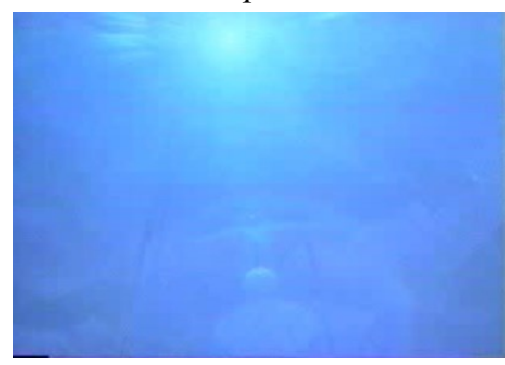

Photo 1-4: The $1^{\text {st }}$ second-flash, explosion

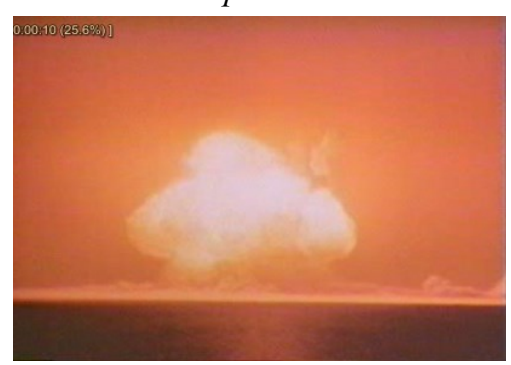

Photo 1-7: The $4^{\text {th }}$ second after the explosion

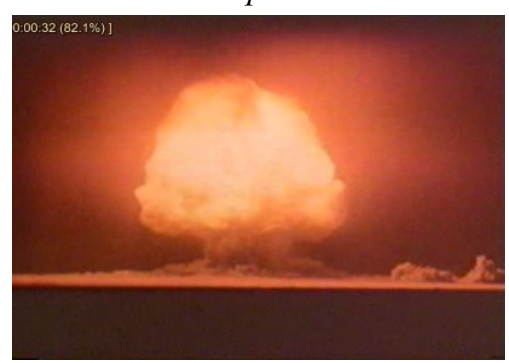

Photo 1-10: The $7^{\text {th }}$ second after the explosion

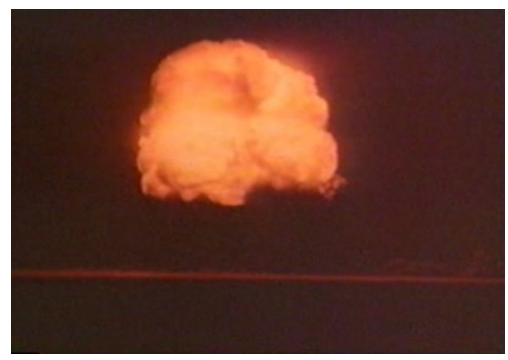

Photo 1-13: The $10^{\text {th }}$ second after the explosion

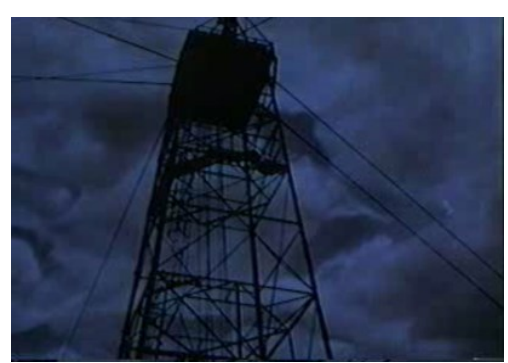

Photo 1-2: 1 second before the explosion

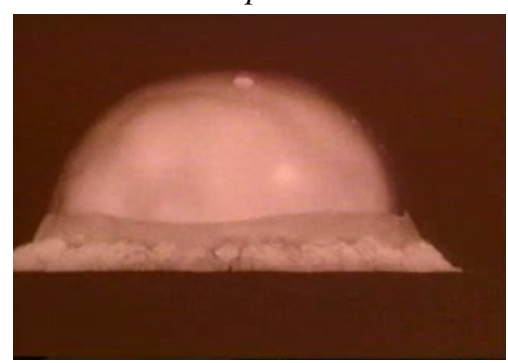

Photo 1-5: The $2^{\text {nd }}$ second after the explosion

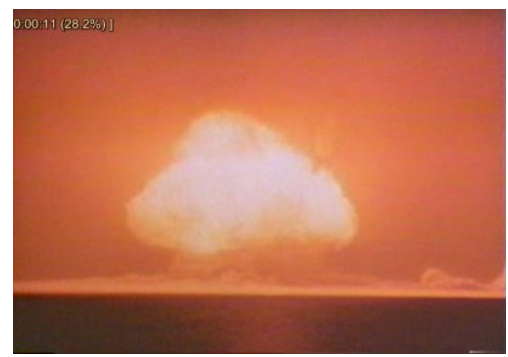

Photo 1-8: The $5^{\text {th }}$ second after the explosion

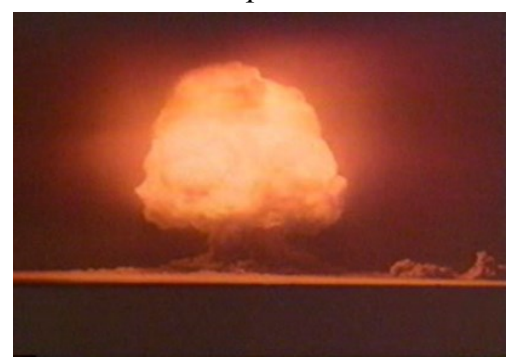

Photo 1-11: The $8^{\text {th }}$ second after the explosion

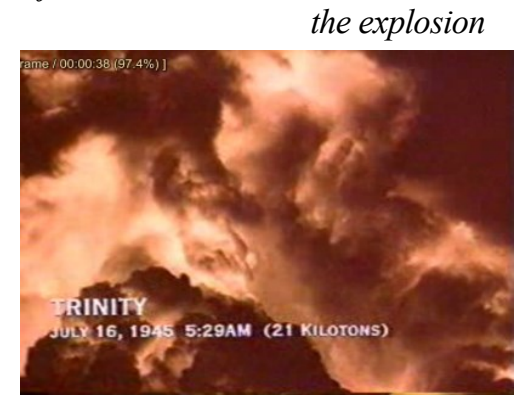

Photo 1-14: The $30^{\text {th }}$ second after the explosion

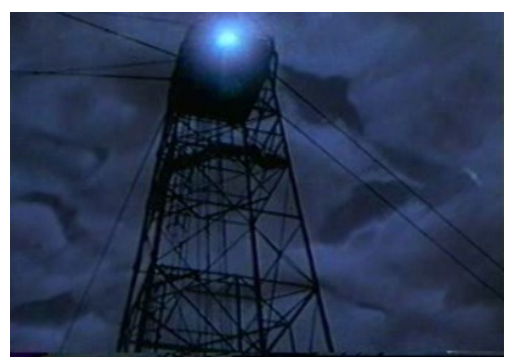

Photo 1-3: 0 second -flash, explosion

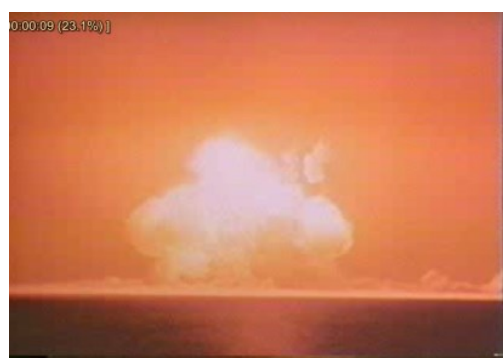

Photo 1-6: The $3^{\text {rd }}$ second after the explosion

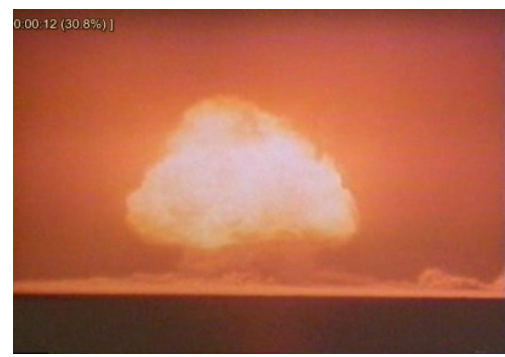

Photo 1-9: The $6^{\text {th }}$ second after the explosion

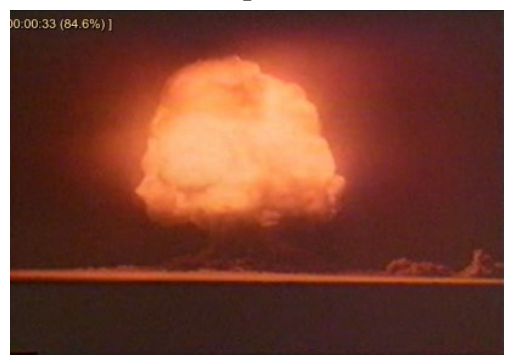

Photo 1-12: The $9^{\text {th }}$ second after the explosion 
A lot of significant facts contributed to this situation, as follows:

1. Scientific assumptions: a number of top scientists in various disciplines emigrated from Europe to the USA due to fascism and after combining the British and American research efforts many British top scientists also left for the USA and there they shared in the research and development of a nuclear weapon.

2. Political assumptions: serious concern of the USA that Germany as the first will acquire a nuclear weapon and will use it for its aggressive goals.

3. Economic assumptions: in the USA there were strong economic resources and capacities for financing the extensive research and development of nuclear weapons.

4. Technical and technological preconditions: in the USA there were excellent technological conditions and high technology for the extensive research and development of nuclear weapons.

\subsubsection{Construction and types of nuclear weapons}

Each explosive nuclear device must contain the following:

- A particular nuclear charge - nuclear fission explosive, neutron reflector, neutron source, neutron absorber or, if need be, another device to ensure explosion;

- A device to create supercritical amount of fissile material;

- Priming device - e.g. time fuse, signal receiver, power supply units, controlling and self-destroying equipment.

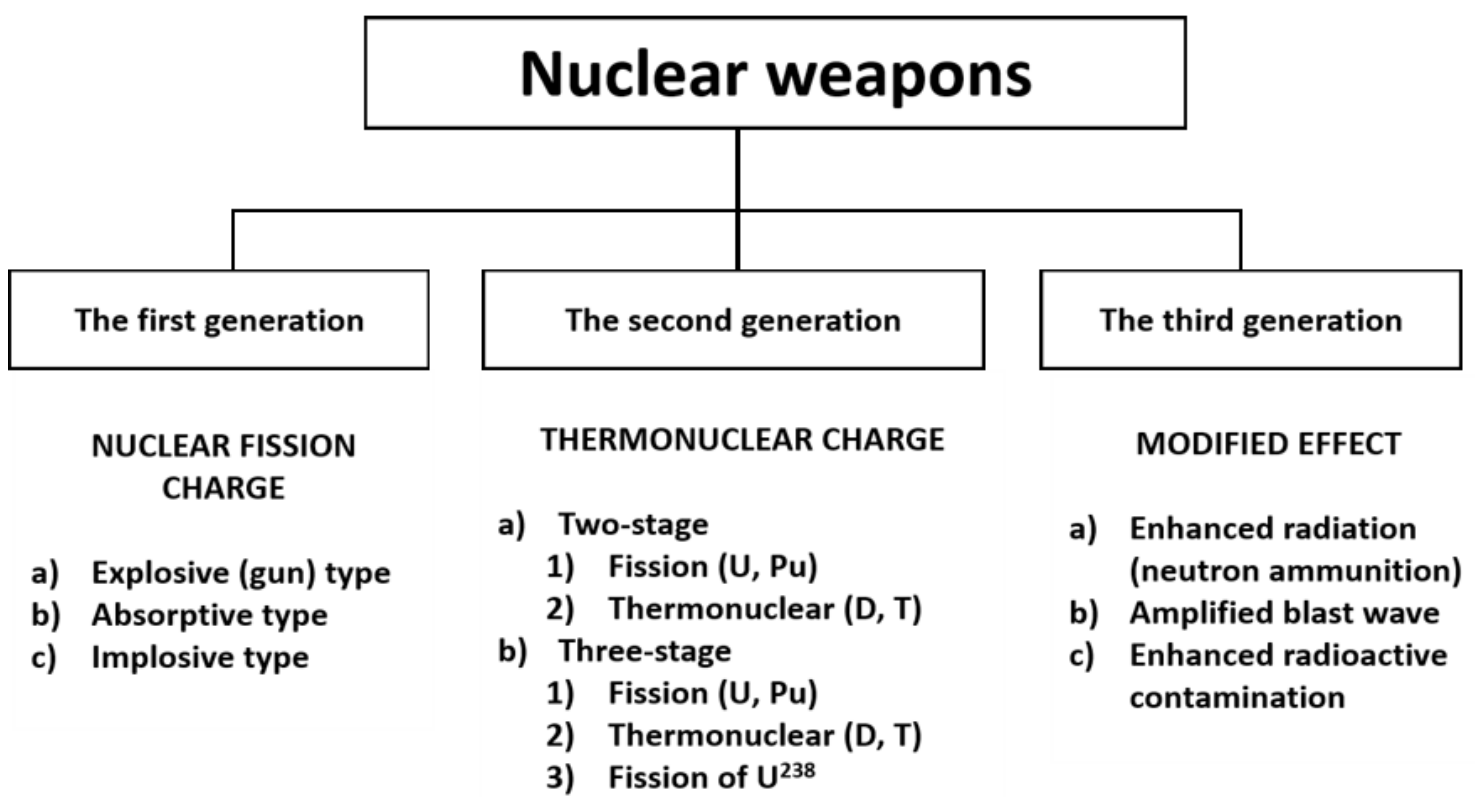

Figure 1: Designs types of nuclear weapons. [Source: Fig-1]

The effect of nuclear weapons is based on the energy utilization that releases during nuclear reactions. The energy release happens either by nuclear fission of heavy element nuclei or nuclear fusion of light element nuclei. In the case of fission of heavy element nuclei, it is a nuclear fission reaction, in the case of fusion of light element nuclei, it is thermonuclear reaction.

Initializing the reaction of a nuclear charge (nuclear fission reaction) happens when the nuclear charge is in such an energy state that enables the course of a given nuclear reaction. The high energy state of a nuclear charge induces an uncontrolled chain nuclear reaction and subsequent release of nuclear energy. Nuclear weapons containing nuclear fission charges are the first-generation nuclear weapons. 
The design principles of nuclear fission ammunition are divided according to the method of creating a supercritical amount:

a) Explosive (gun) type of nuclear ammunition:

The total amount of fissile material in ammunition is supercritical, but is divided into two (or even more) subcritical parts. At the moment of initiation, the explosion of a conventional explosive material takes place, which sharply throws subcritical parts against each other to create supercritical quantities.

To increase the value of the multiplication factor $(k)$, the whole reactive region is momentarily surrounded by a neutron reflector, the task of which is to return the diffusing (escaping) prompt neutrons back to the reactive region (Fig. 2).

b) Absorptive type of nuclear ammunition:

A substance that absorbs neutrons is located in an explosive of supercritical weight as well as shape. In this way the decrease in multiplication factor $(k)$ of the fissile reaction development takes place. Initiating the nuclear explosion happens through the removal of this neutron absorber (Figure 3).

Figure 2: Scheme of nuclear fission ammunition of explosive (gun) type. [Source: Fig-2]

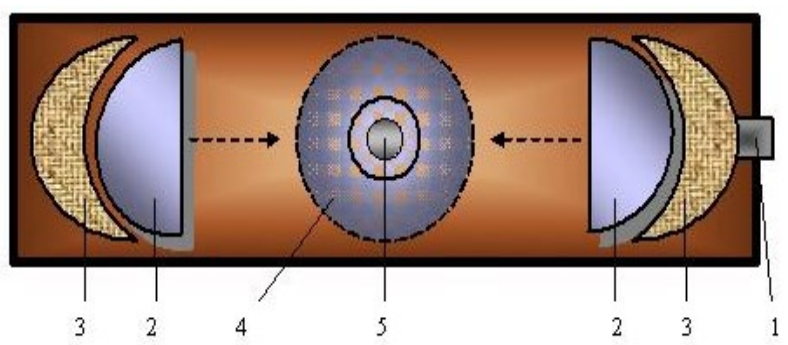

1 - initiator, 2 - fissile material divided into two subcritical quantities, 3 - conventional explosive, 4 - arising supercritical amount after the initiation of a conventional explosive, 5 - neutron source
Figure 3: Scheme of nuclear fission ammunition of absorptive type.

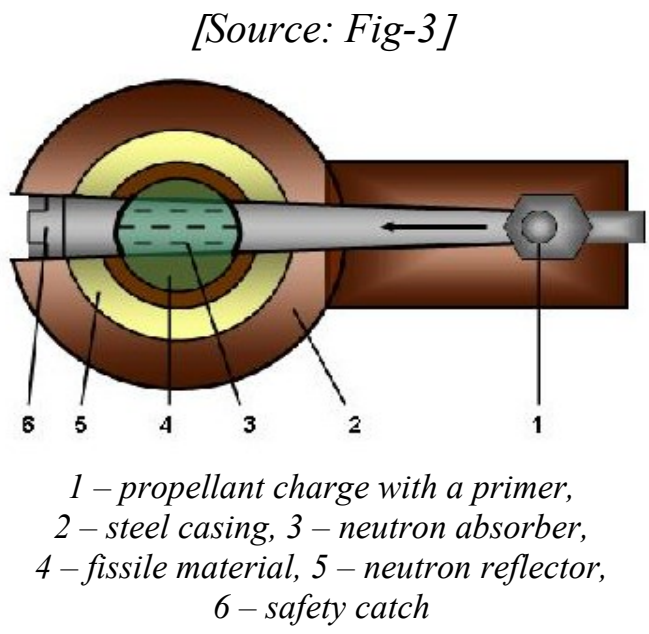

c) Implosive type of nuclear ammunition:

The supercritical amount in ammunition is modified to a subcritical amount through the decrease in its density. The explosion of the conventional charge compresses the fissile material and thus sharply increases its density required for the course of the fission reaction (Fig. 4). This modification enables the explosion power to be changed when a relatively small amount of a nuclear explosive is used.

\section{1) Single-stage thermonuclear ammunition}

The high temperatures necessary for the initiation of thermonuclear reactions of deuterium and tritium are achieved through the effect of shaped charges of a conventional explosive. The effect of the individual cumulative charges is directed so that the detonation waves collide at the same time in one place. The thermonuclear explosive is heated to the initiation temperature by this compression, while the reaction between deuterium and tritium begins (Fig. 5). The single-stage thermonuclear ammunition does not contain a fissile priming charge, so it was called a clean weapon in the past. When it explodes, a strong flux of neutrons causes extensive induced radioactivity in the air and in the field. 
Figure 4: Scheme of the implosive type of nuclear ammunition. [Source: Fig-4]

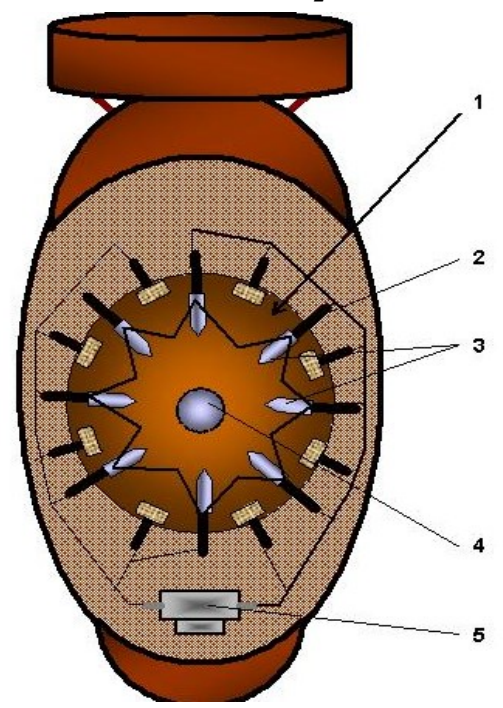

1 - conventional explosive, 2 - detonators, 3 - subcritical amounts of fissile material with normal density, 4 - emerging supercritical amounts of fissile material with increased density, 5 - initiator
Figure 5: Diagrammatic section of one-stage thermonuclear ammunition. [Source: Fig-5]

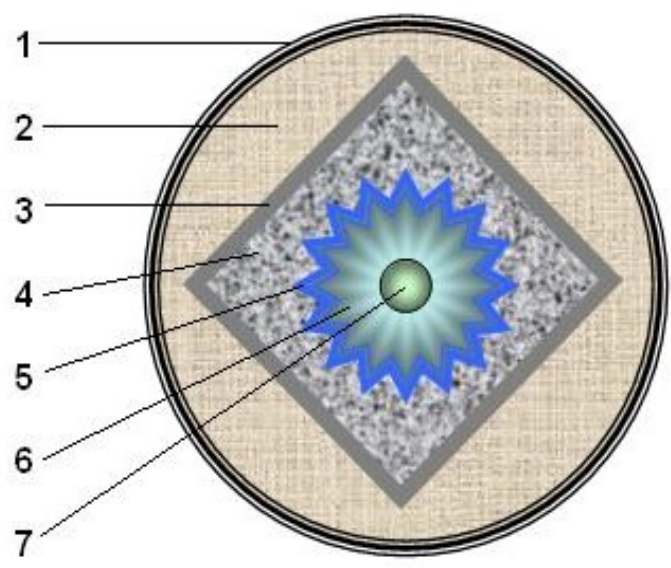

1 - outer casing, 2 - conventional explosive, 3 - steel casing of the shaped charge 4 -shaped charge of a conventional explosive and deuterium lithium, 5 - liner of the shaped charge and lithium, 6-deuterium and tritium thermonuclear charge, 7-vacuum

Figure 6: Diagrammatic section of two-stage thermonuclear ammunition.

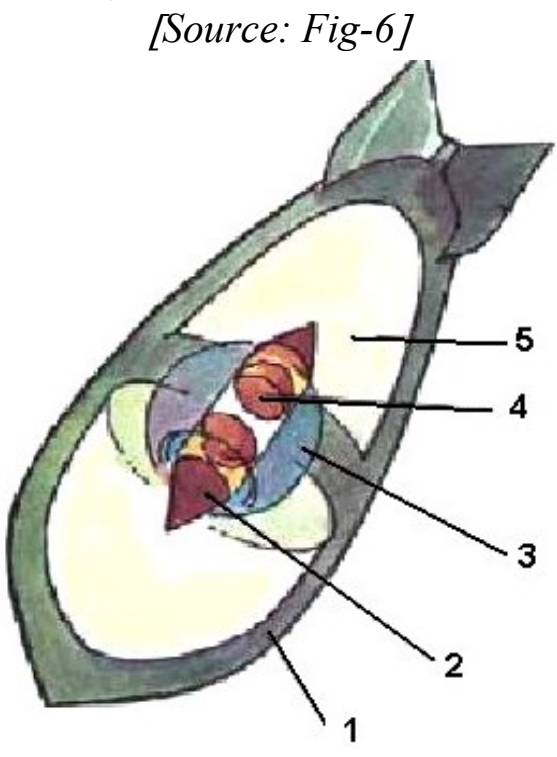

1 - outer casing, 2 - delay fuse and a conventional explosive, 3 - thermonuclear tritium detonator, 4 -nuclear fission charge,

5 - thermonuclear deuterium charge, lithium deuteride cause significantly less terrain contamination at the same TNT equivalent than the use of nuclear weapons with a fissile nuclear charge. 
The course of processes in a two-stage thermonuclear reaction is as follows:

\section{The first stage}

- First of all, the initiation of a conventional charge takes place in the initiator;

- Due to these explosions, the subcritical amounts of a nuclear fission charge are thrown against each other;

- By creating the supercritical amount in an explosive or implosive manner, supported by a neutron reflector and additional neutron sources, an avalanche fission reaction takes place in the initiator and the required temperature, pressure and strong flow of prompt neutrons are created.

\section{The second stage}

- The resulting neutrons react with lithium hydride, further increasing the temperature and pressure;

- This initiates the fusion of deuterium and tritium and raises the temperature to hundreds of millions of Kelvins.

The production and storage of tritium presents certain problems. Its production is too complicated and, therefore, expensive. The storage of tritium is complicated due to its radioactivity (half-life is 12.3 years) and its instability.

Figure 7: Diagrammatic section of three-stage thermonuclear ammunition. [Source: Fig-7]

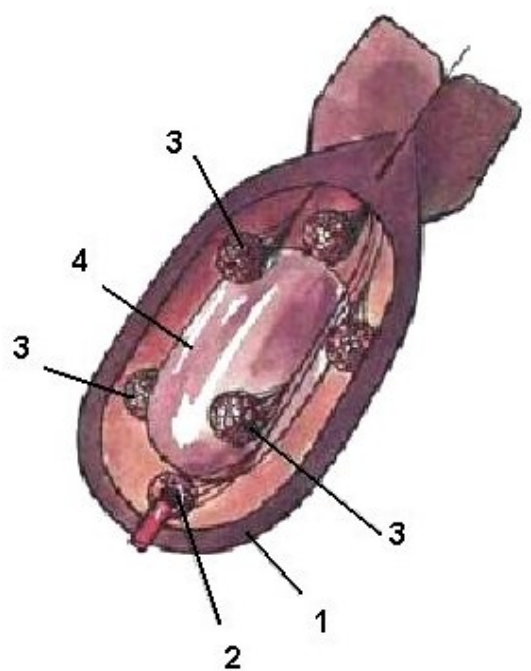

1 - metal casing with an inner layer of uranium, 2 - additional neutron source, 3 - plutonium charges, 4 - lithium deuteride
The starting point was the use of some hydrogen compounds, especially lithium deuteride (hybrid). It is a chemically very active white and crystalline substance that can be manufactured in large quantities at a low price. The sufficient amount of tritium can be obtained through the reaction of lithium deuteride with neutrons arising in the first stage of the thermonuclear explosion:

$$
{ }_{3}^{6} \mathrm{Li}+{ }_{0}^{1} \mathrm{n} \rightarrow{ }_{2}^{4} \mathrm{He}+{ }_{1}^{3} \mathrm{~T}
$$

This eliminates the problem of tritium production and storage, as it arises directly in the thermonuclear charge. Tritium, formed in this way, subsequently reacts with deuterium, which is obtained, for example, from sea water (the deuterium content in sea water is about $0.15 \%$ ):

$$
{ }_{1}^{2} \mathrm{D}+{ }_{1}^{3} \mathrm{~T} \rightarrow{ }_{2}^{4} \mathrm{He}+{ }_{0}^{1} \mathrm{n}+16.7 \mathrm{MeV}
$$

\section{3) Three-stage thermonuclear ammunition}

In three-stage thermonuclear explosions, the course of the first two stages is similar to that in the two-stage thermonuclear ammunition. However, if we surround the thermonuclear charge with relatively cheap uranium ${ }^{238} \mathrm{U}$, the third stage of thermonuclear explosion will occur. Fast neutrons arising in the reaction of deuterium and tritium will begin to fission ${ }^{238} \mathrm{U}$ nuclei, by which means additional energy will be released and the proportion of radioactive contamination will increase (Figure 7).

That means that the use of nuclear weapons with the three-stage thermonuclear charge can cause considerably higher terrain contamination at the same TNT equivalent. Thermonuclear charges are used for constructing the second-generation nuclear weapons. 
The so-called cobalt charge is a specific three-stage thermonuclear ammunition. Fast neutrons arising during the thermonuclear explosion react with the cobalt casing according to the equation:

$$
{ }_{27}^{59} \mathrm{Co}+{ }_{0}^{1} \mathrm{n} \rightarrow{ }_{27}^{60} \mathrm{Co}+\gamma
$$

The resulting cobalt isotope is a hard gamma-beta emitter with a half-life of 5.3 years and during surface bursts it contaminates the ground on a long-term basis.

The third-generation nuclear weapons include the weapons with modified characteristics, i.e. with the suppressed or amplified effects of individual destructive factors of nuclear weapons. They are as follows:

- Small nuclear weapons with an enhanced effect of initial radiation, often called neutron weapons, are designed mainly for eliminating the personnel, while the material, combat and transportation equipment are kept in a usable condition.

- Nuclear weapons with an enhanced effect of a blast wave are designed to destroy fixed structures, namely shelters and underground command posts.

- Nuclear weapons with an enhanced effect of radioactive agent contamination. On the basis of using different materials with different half-lives, which, due to induced radioactivity, become radioactive, the contamination of the ground can last several hours up to several years.

The damage rate and extent of threat caused by a nuclear weapon depends on the weapon type, nuclear yield and height of burst, the distance from the blast scene, weather conditions and target vulnerability or, if need be, the target resistance.

\subsubsection{Use of nuclear weapons - Japan bombing}

We do not have to view the past in its own context, otherwise we will not understand it. It is not possible to conceive why the decision to use a nuclear weapon was adopted when we do not consider the possibilities the Allies had at their disposal at that time. It is worth recalling that in one B-29 bomber attack on Tokyo on the night of March 9-10, 1945, 100,000 people died. If only half of civilians had been killed in this night air raid, then 1.5 million Japanese would have been killed in a month, not to mention material losses.

Based on the records from June 30, 1945, there were a sufficiency of ammunition for 12 divisions, food supplies for 2.1 million men for a month and monthly medical supplies for 11.6 million cases. According to plans, $90 \%$ of units from Korea and Manchuria arrived by the end of June. The material was stored on the island of Kyushu $-50 \%$ in caverns, $50 \%$ in schools, households, etc.

During the bloody military operation lasting 82 days when the Japanese island of Okinawa was being conquered, the US Armed Forces suffered 12,000 casualties. American President Harry S. Truman offered capitulation to the Japanese; however, it was not accepted. The US analysts estimated that the US Armed Forces could lose up to 1 million lives during the invasion of Japan. Therefore, the American president decided to use a nuclear bomb with the aim to speed up the end of the war.

At the end of World War II, two American nuclear bombs were used, of which one was code-named Little Boy and was dropped on the Japanese city of Hiroshima in the early hours of the morning ( 8 hours 15 minutes of local time) on August 6, 1945. The explosion of a nuclear bomb occurred after it was dropped from an aircraft at an altitude of about 580 meters above the city. This nuclear bomb was the so-called gun-type bomb (explosive type) and uranium 235 was used as a nuclear explosive. Non-uniform literature sources state that the nuclear yield ranged from $12.5 \mathrm{kt}$ to $20 \mathrm{kt}$ of TNT (trinitrotoluene). 
After the use of the first nuclear bomb, the Japanese government did not want to surrender and, therefore, Americans dropped a second bomb on the harbour city of Nagasaki.

Photo 2: Drop of the nuclear bomb on Hiroshima. [Source: Pho-2]

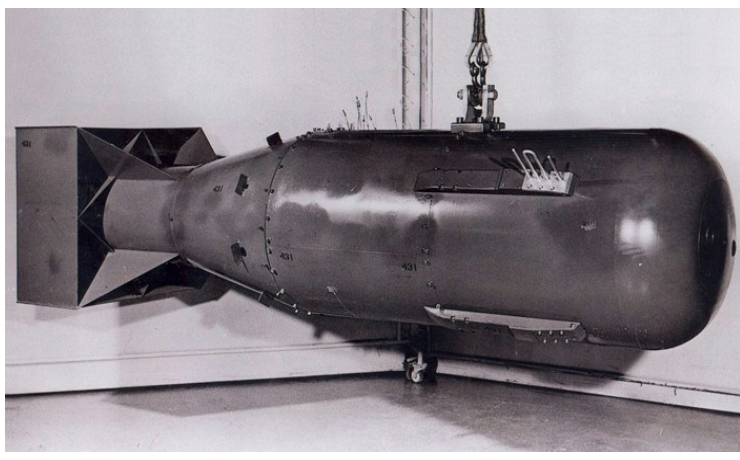

Photo 2-1: The USAF Little Boy nuclear bomb.

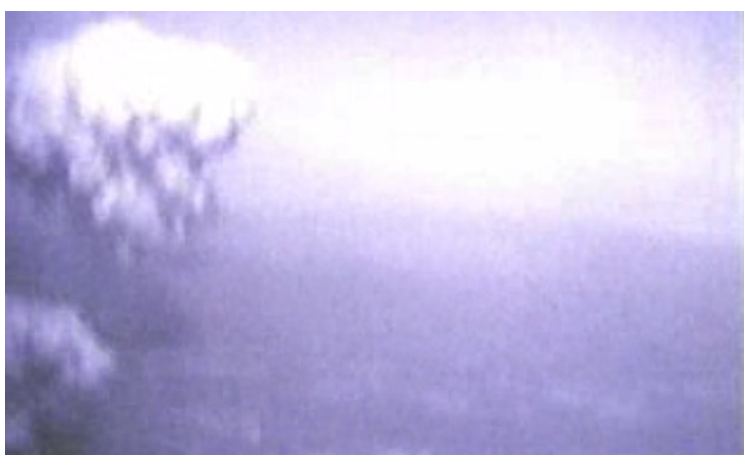

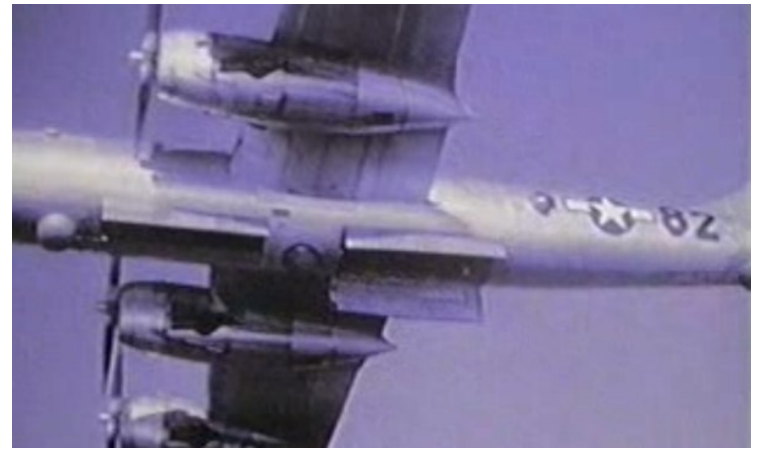

Photo 2-2: The B-29 Superfortress Bomber Enola Gay)

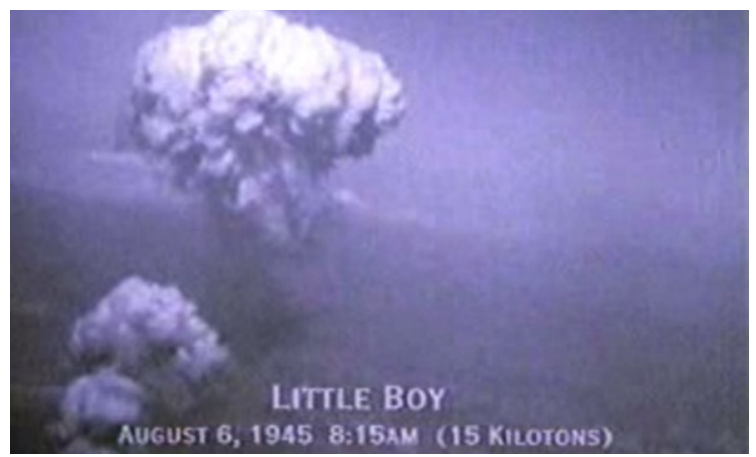

Photo 2-3 and 2-4: Hiroshima - the drop of a nuclear bomb by Major Thomas W. Ferebee from the B-29 Enola Gay.

On August 9, 1945 around 11:00 am local time, the second American nuclear bomb codenamed Fat Man was dropped on Nagasaki. The bomb was named in honour of W. Churchill, the then British Prime Minister. It was a plutonium bomb (plutonium 239 was used as a nuclear explosive) with an implosive design principle. The nuclear yield was approximately $20 \mathrm{kt}$ up to $22 \mathrm{kt}$ of TNT.

Both nuclear explosions had strong and completely devastating effects on both cities and resulted in a considerable number of casualties. In Hiroshima there were 150,000 up to 200,000 casualties and in Nagasaki 30,000 casualties (these data differ considerably according to the sources of information; the values mentioned here are stated in the publication entitled Chronicle of the $20^{\text {th }}$ Century). Other data related to the casualties in Hiroshima vary according to the American and Japanese sources. According to the American sources, 70,000 humans were killed or vanished without a trace in Hiroshima and the same number of humans were injured.

Based on the Japanese sources 78,150 people were killed, 13,983 people were missing, 37,424 people were injured and 235,656 people were handicapped differently. Out of the number of 24,158 soldiers in Hiroshima 6,769 were killed.

Only after the nuclear bombing of the Japanese city of Nagasaki the Japanese officials agreed to the unconditional surrender. It means that the nuclear bombing of the Japanese cities of Hiroshima and Nagasaki in August 1945 significantly helped to bring about the rapid end of World War II. Despite of this matter of fact, impassioned expert and lay debates over the necessity to use nuclear weapons have been still held either among politicians or soldiers or, if need be, the public. 
However, the prevailing view in American public opinion is that the nuclear bombing of Japanese cities at the end of World War II was justified because Japan then capitulated. On the $50^{\text {th }}$ anniversary of dropping the atomic bombs on Hiroshima and Nagasaki, Bill Clinton, the then American President, expressed his opinion that "the United States owed Japan no apology for dropping atomic bombs on Hiroshima and Nagasaki at the end of World War II, and it was the right decision to use the bombs."

\section{Photo 3: Drop of the nuclear bomb on Nagasaki. [Source: Pho-3]}

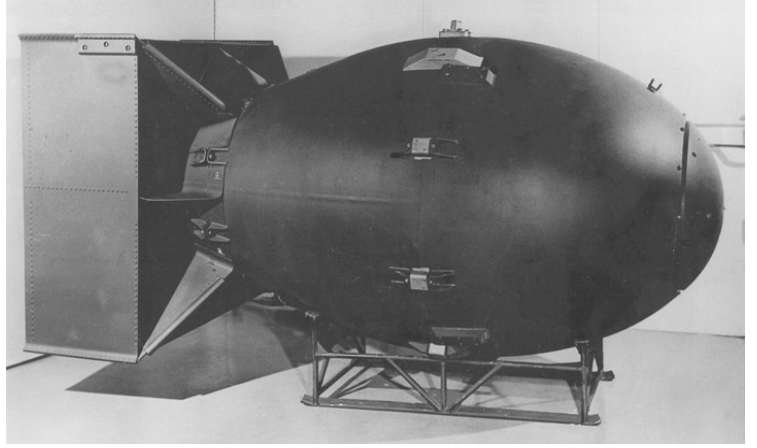

Photo 3-1: The USAF Fat Man nuclear bomb.

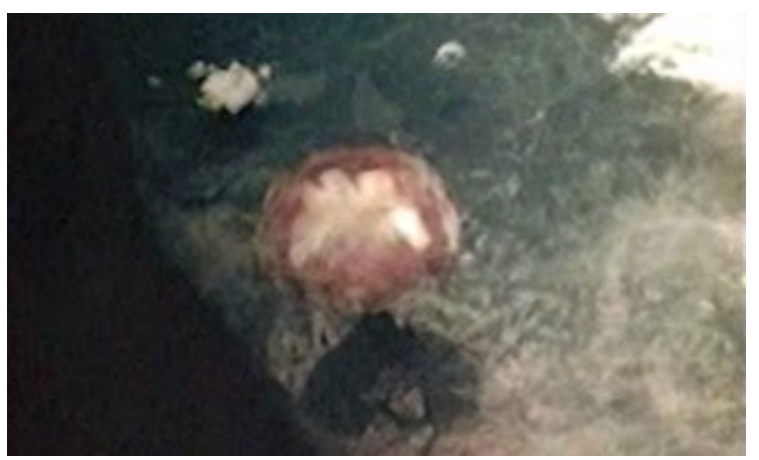

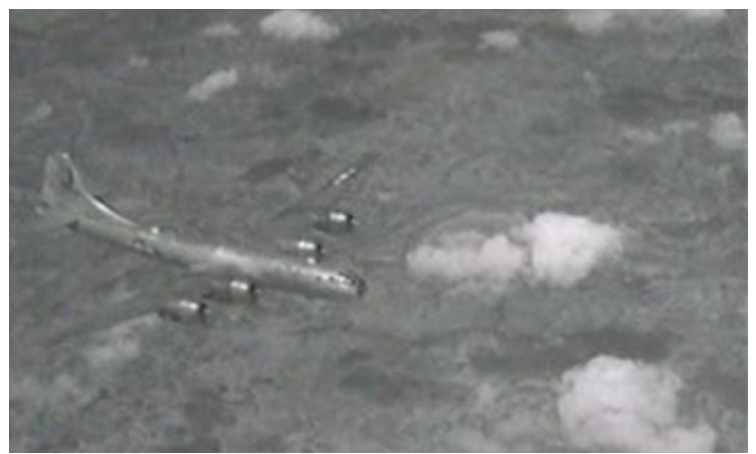

Photo 3-2: The B-29 Superfortress bomber (Bock's Car)

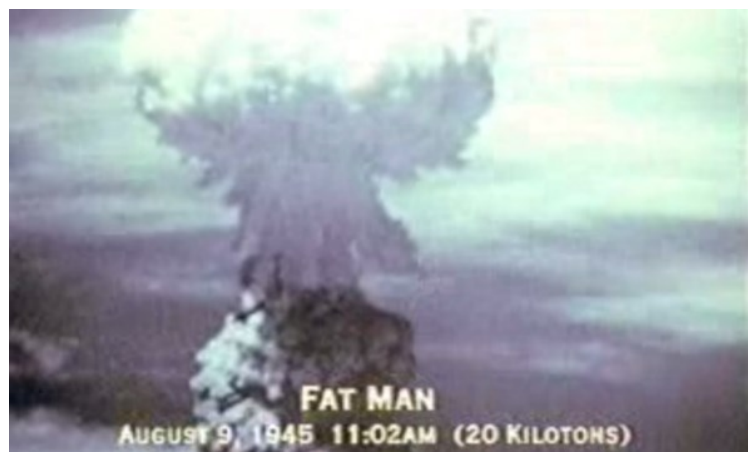

Photo 3-3 and 3-4: Nagasaki - the drop of a nuclear bomb by Captain Kermit K. Beahan from the Bock's Car aircraft.

\subsubsection{Emergence of nuclear powers}

At the end of World War II, only the United States of America owned nuclear weapons. Thus, it became the first nuclear power. In the Soviet Union, the work on research, development and construction of nuclear weapons led by I. Kurchatov were started on a large scale in 1943. In spite of many problems, which existed in the country destroyed by the war, the results appeared relatively soon. It was also caused by the broad, well-organized and carefully controlled intelligence network of the Soviet Union that operated in the secret nuclear weapon laboratories of the United States and Britain during World War II, but also after that.

The espionage cases of Alan Nunn May, Kim Philby, Klaus Fuchs, and Julius and Ethel Rosenberg are well known. Mostly, the exposed spies were punished severely, e.g. Julius and Ethel Rosenberg were put to death in an electric chair at Sing Sing Prison on June 19, 1953. The Rosenbergs were executed despite many demonstrations against the sentence. They were arrested in May 1950 and accused of nuclear espionage for the benefit of the Soviet Union. In April 1951, despite of the absence of direct evidence, they were sentenced to death for passing the secret information on the nuclear bomb production to the Soviet Union. The Rosenbergs were the first Americans to be executed for high treason in peacetime. Both of them denied their guilt until the last moment. 
It is surprising that the espionage for the benefit of the Soviet Union (the USSR) was the work of left-wing intellectuals instructed by the Committee for State Security (KGB) workers from the Soviet consulates. The construction of the first Soviet atomic bomb was based on the detailed description of the American atomic bomb that Klaus Fuchs handed over to the Soviet spies in the second half of 1945. According to the testimony of J. Chariton, the chief designer of the Soviet atomic bomb, the Soviet team worked on its own bomb concept in 1945, but the procedure according to the American documentation shortened the development and production time of the Soviet bomb by approximately two years.

Here, it is necessary to recall a well-known principle that fortune favours the prepared mind. Even the best information stolen may be worth only for a person who is able to interpret and use it competently. Undoubtedly, in 1945, the USSR had a sufficient number of experts who would, sooner or later, produce an atomic bomb by themselves. The first Soviet atomic bomb exploded in August 1949 and the period of 4 years, which the USSR needed for its production, is comparable with the period Americans needed. Undoubtedly, the totalitarian system of the Soviet Union, the deployment of a large number of people and the disregard for environmental and security principles played a part in this rapid progress, which surprised even the American intelligence services.

\section{Photo 4: The first Soviet atomic bomb test. [Source: Pho-4]}
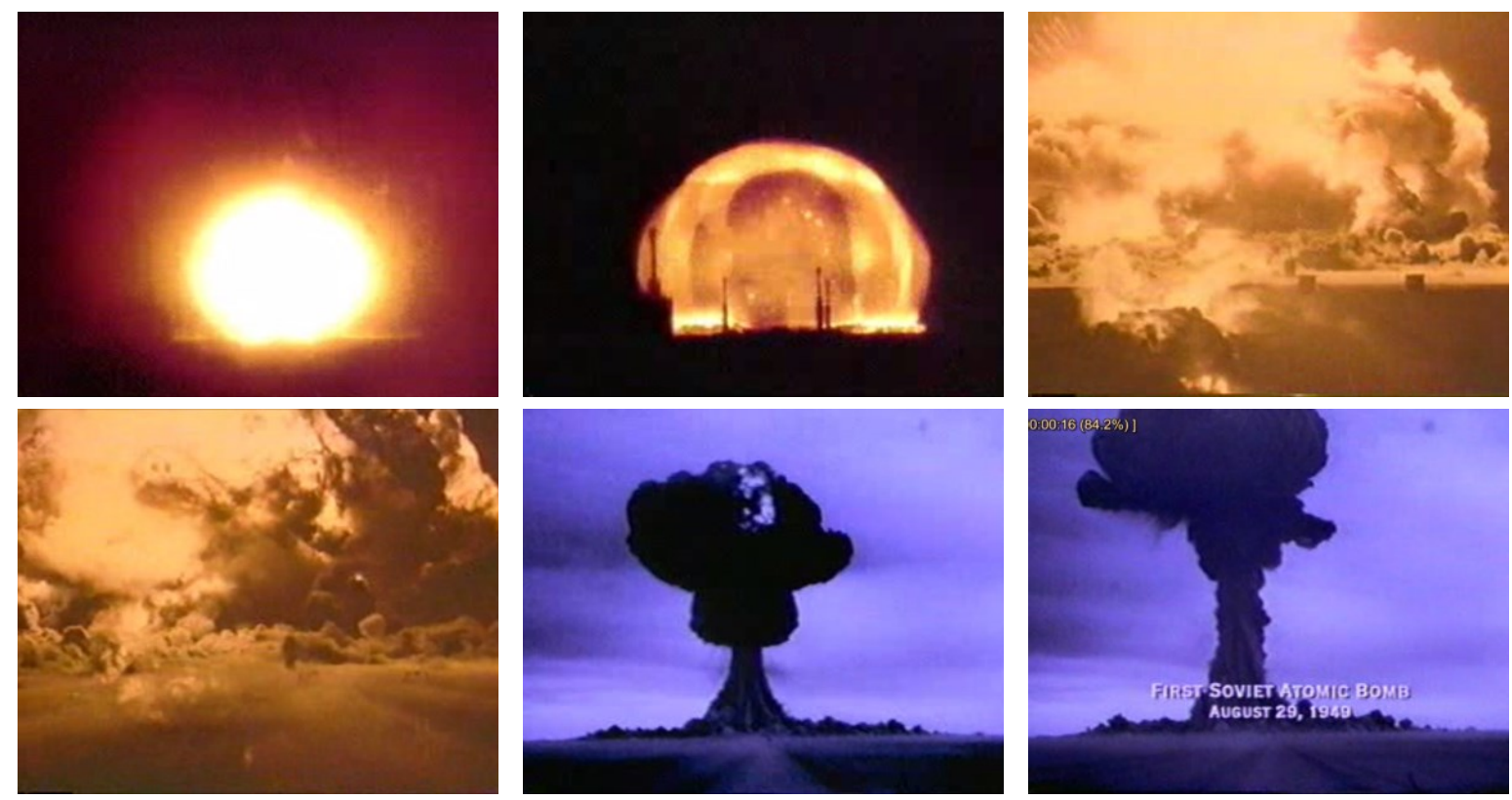

Photo 4-1 up to 4-6: The explosion phase of the first Soviet nuclear bomb.

In 1949, the then Soviet Union announced that it had also executed a successful nuclear explosion test and thus ended the American monopoly of the possession of nuclear weapons (see Photo 4-1 up to 4-6). At that time both powers (the USA and the USSR) possessed the first-generation fission nuclear weapons. Gradually, additional three powers entered the official Nuclear Club, i.e. Great Britain as the first one, France a bit later and the People's Republic of China as the last one. Nuclear weapons are based on the nuclear fission reaction or thermonuclear reaction. In all the above-mentioned states simpler nuclear fission weapons were developed first and then thermonuclear weapons were developed several years later (about one decade). In general, the India's and Pakistan's possession of nuclear weapons is considered to be very dangerous since these states came into several nuclear-free serious armed conflicts with each other in the second half of the last century. The considerable hostility towards each other and permanent political and military tension between them still persists. 
It is also interesting that Israel's military nuclear arsenal is currently greater than Britain's military nuclear potential.

The S.A.R. (South African Republic) renounced its nuclear weapons in 1991; it is the only country to voluntarily relinquish its right to possess nuclear weapons. Although it possessed a few atomic warheads, it voluntarily abandoned, dismantled and destroyed them. The exact dates when particular countries joined the Nuclear Club are indicated in Table 2.

All the official nuclear powers (see Table 2 the first 5 indicated countries only) are signatories of the Nuclear Non-Proliferation Treaty adopted in 1968. In 1995, the term of the treaty was extended without time constraint. Israel, India and Pakistan are not signatories of this significant international treaty. Although North Korea signed the Nuclear Non-Proliferation Treaty, it withdrew from it in 2003.

Israel, India and Pakistan refused to sign the international Nuclear Non-Proliferation Treaty; however, each of them produced and stockpiled

Table 2: The emergence of nuclear powers. [Source: Tab-2]

\begin{tabular}{|c|c|}
\hline Country Name & Date \\
\hline the USA & July 16, 1945 \\
\hline the USSR & August 29,1949 \\
\hline Great Britain & October 3,1952 \\
\hline France & February 13, 1960 \\
\hline China (P.R.C.) & October 16, 1964 \\
\hline Israel & $1969-70 ?$ \\
\hline India & May 11, 1998 \\
\hline Pakistan & May 28, 1998 \\
\hline North Korea (D.P.R.K.) & October 9, 2006 \\
\hline
\end{tabular}
nuclear weapons in secrecy. Neither the USA nor the International Atomic Energy Agency (IAEA) punishes any of these countries. The USA are even providing a comprehensive all-round assistance to the governments of Israel and Pakistan in value of milliards of dollars including military assistance. For instance, the United States, among other things, sold the Israeli Air Force even the most modern aircraft capable of carrying nuclear weapons. Former American President George W. Bush did not comment on the step of Pakistan that, a few years ago, it had tested its own attack cruise missile capable of carrying a nuclear warhead and hitting the largest Indian cities. The American administration even did not impose any punishment on Pakistan when it was confirmed that Pakistan had traded in nuclear weapons illegally. Probably also criticized Iran acquired part of the special information and technology for uranium enrichment in Pakistan.

Former American President George W. Bush and his experts certainly knew a lot about the nuclear weapons programs of Israel, India, Pakistan, North Korea and other states due to spy satellites and the work of intelligence services.

Nevertheless, the USA intimidates Iran with the military power, on the one hand, and provides finances and delivers weapons to other sinners, on the other hand, without requiring the disposal of their atomic arsenals. This dual irresponsible approach complies with the American power-political interests not only in the region of the Near East and the Middle East.

In 2006 and 2007, a grave suspicion arose in the international community that Iran strove for acquiring nuclear weapons. The International Atomic Energy Agency (IAEA) was also involved in the process of controls and negotiations. All the indications are that Iran may have its own nuclear weapons in the near future. This important fact would have a profound impact on the security situation in the Middle East.

Current American President Barack Obama commented on the Iranian nuclear program at his first press conference (on November 07, 2008). According to Obama the development of nuclear weapons is unacceptable under the regime of Iranian President Mahmoud Ahmadinejad. The American President said that the international community had to prevent the Iranian regime from developing the nuclear program and obtaining nuclear capability, especially the construction of nuclear warheads. 
Figure 8: A map illustrating the development in nuclear weapons possession. [Source: Fig-8]

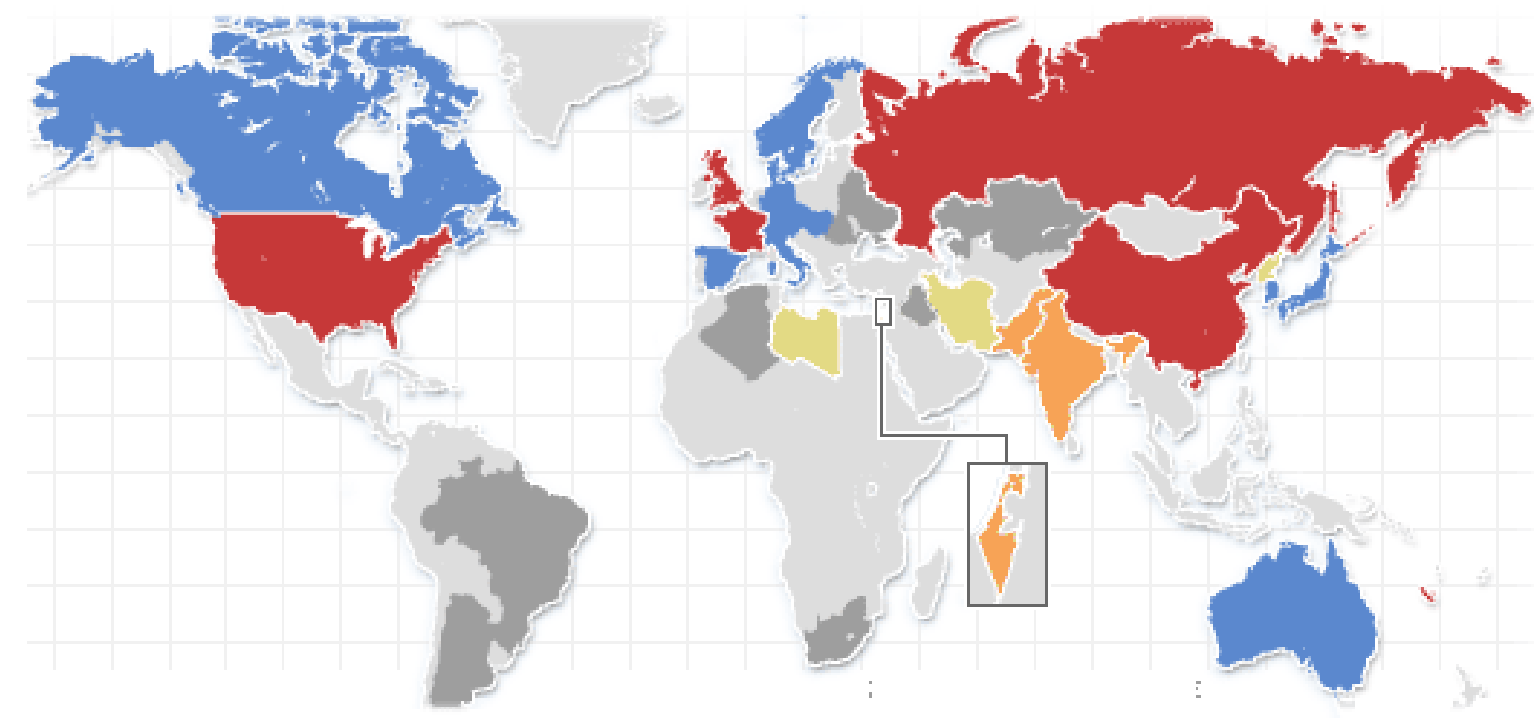

Note:

Countries possessing nuclear weapons.

Countries possessing nuclear arsenal (non-members of the Nuclear Non-Proliferation Treaty).

"High risk" countries.

Countries that abandoned the development of nuclear weapons.

Countries that possessed nuclear weapons or a nuclear program in the past.

Obama also criticized supporting the terrorist groups by Ahmadinejad's administration. At the press conference in Chicago, the American President said: "Iran's support of terrorist organizations, I think is something that has to cease".

The data related to the acquisition of thermonuclear weapons by particular nuclear powers are very interesting. It is generally believed that it took several years of research, development and design work before the nuclear powers (which only own a fissile nuclear weapon) managed to acquire a higher degree of nuclear weapons. It is indicated in Table 3. It is probable that only the nuclear weapon states of the Nuclear Club possess thermonuclear weapons as indicated in Table 3 , not the new nuclear weapon states.

The use of thermonuclear synthesis of light elements for the construction of a thermonuclear weapon (inaccurately called a hydrogen bomb) was considered in the Table 3: The year of the acquisition of thermonuclear weapons.

[Source: Tab-3]

USA by E. Fermi and E. Teller as early as 1941. In the USA this idea was then monitored and developed during as well as after the war.

The decisive impulse to start the development of a thermonuclear weapon in the USA was the first Soviet nuclear explosion in 1949. In January 1950, President Harry S. Truman ordered to produce a thermonuclear weapon. In autumn 1952, the USA tested the first thermonuclear bomb, code-named Ivy Mike, which took place at Enewetak Atoll in the Pacific Ocean and achieved a yield equivalent to 10 megatons. In the USSR the works on a thermonuclear bomb led by I. J. Tamm started already in 1948 and the first nuclear bomb explosion of a megaton yield was carried out in autumn 1955. 
Photo 5: The test of the first thermonuclear bomb IVY MIKE (USA), 10 Mt. [Source: Pho-5]
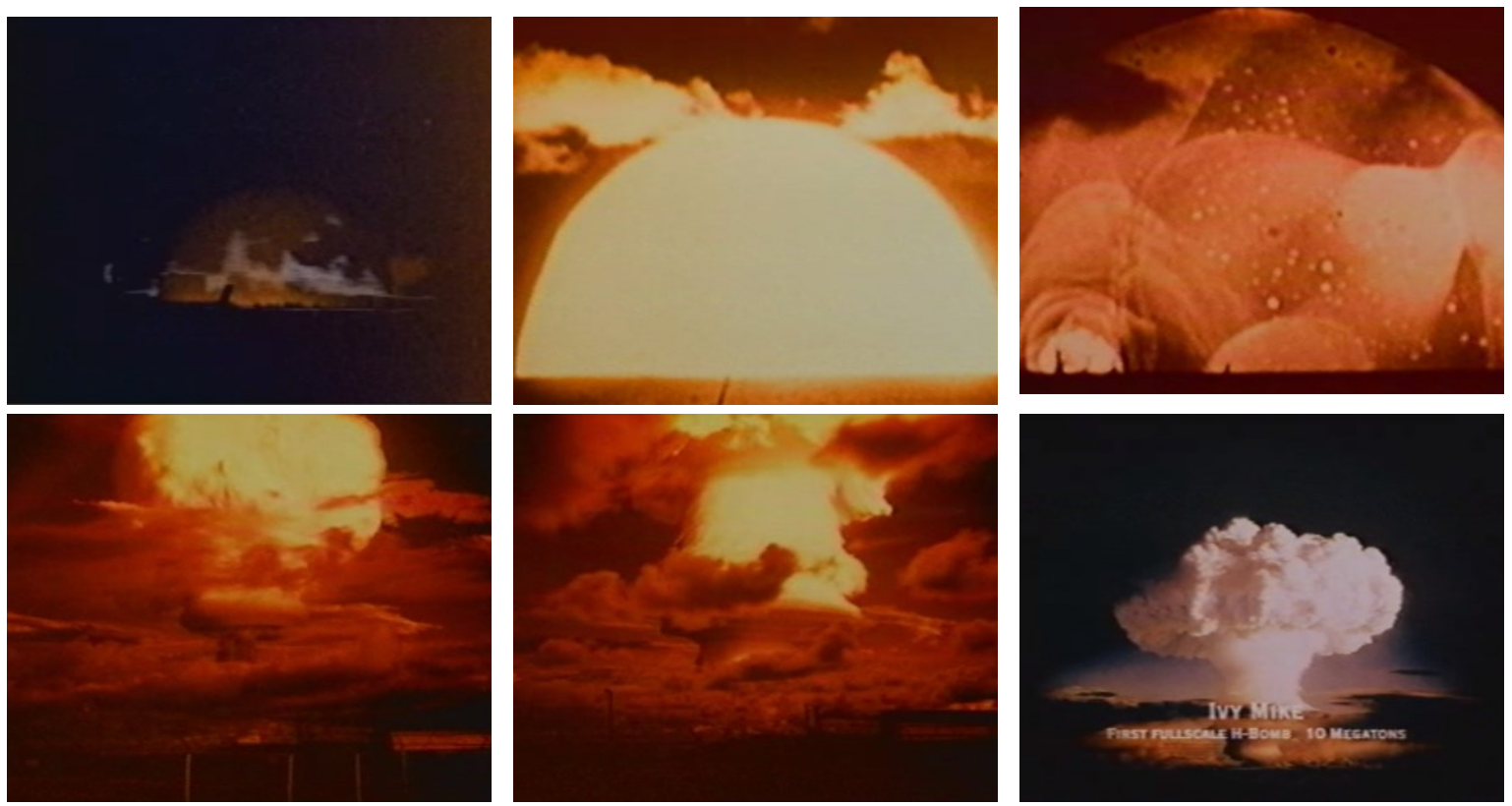

Photo 5-1 up to 5-6: Explosion Phases of the First American Nuclear Bomb.

\subsubsection{Nuclear weapons tests}

Experiments with nuclear weapons took place relatively intensively in the second half of the last century. From the beginning of the nuclear weapons development (1945) the tests represented a significant activity of nuclear powers that not only tested the results of their nuclear weapons in practice, but they also searched for effective methods for their construction and other improvement. In a practical way, the first nuclear explosion tests meant the emergence of individual nuclear powers as stated in Table 2 above.

The Soviet Union reached the greatest power of a nuclear test explosion on October 30, 1961, when it detonated the strongest 58-megaton TNT nuclear charge ever.

The development of both types of nuclear weapons (fission and thermonuclear) and their gradual improvement required tens of nuclear explosion tests. All nuclear powers were conscious of considerable risks connected with nuclear weapons testing; therefore, they conducted their nuclear weapons tests in remote places where they had built missile firing ranges for this purpose. While the United States, the Soviet Union and the People's Republic of China conducted their nuclear tests on their own territories, Great Britain and France conducted them on the territories of foreign states.

Atmospheric tests of nuclear weapons have been carried out since 1945, as it can be seen in Table 4. They were very intense especially from 1954 up to 1958 and from 1961 up to 1962. After 1964, they were carried out only sporadically.

Strong radioactive contamination of the environment brought the representatives of particular nuclear powers to the negotiating table in the mid-50s of the last century. After long negotiations and the adoption of several treaties (the first one as late as 1963) nuclear tests in the atmosphere, in outer space and under water were gradually restricted or banned. Finally, after long and complicated international negotiations, particularly within the UNO, the international Comprehensive Nuclear Weapon Test Ban Treaty was adopted in 1996. However, this international treaty has not still been valid as it has not been ratified by the required number of countries including nuclear powers. 
The last of the five official nuclear weapon states that carried out nuclear explosion tests was France despite of the strong resistance of the world peace public and many national and international institutions, non-governmental organizations, etc. The last French nuclear tests were conducted in the Pacific Ocean (again away of the French state territory) from 1995 up to 1996.

Table 4: Experimental nuclear explosions. [Source: Tab-4]

\begin{tabular}{|c|c|c|c|c|}
\hline Date & Name & $\begin{array}{c}\text { Power } \\
\text { (kt TNT) }\end{array}$ & Country & Note \\
\hline Jul 16, 1945 & Trinity & 19 & the USA & The first successful atomic bomb test \\
\hline Aug 6, 1945 & Little Boy & 15 & the USA & Atomic bomb dropped on Hiroshima \\
\hline Aug 9, 1945 & Fat Man & 21 & the USA & Atomic bomb dropped on Nagasaki \\
\hline Aug 29,1949 & RDS-1 & 22 & the USSR & The first atomic bomb test in the USSR \\
\hline Oct 3, 1952 & Hurricane & 25 & Britain & The first British atomic bomb test in Australia \\
\hline Nov 1, 1952 & Ivy Mike & 10,400 & the USA & $\begin{array}{c}\text { The first hydrogen bomb explosion on an atoll } \\
\text { in the Pacific Ocean }\end{array}$ \\
\hline Aug 12,1953 & RDS-4 & 400 & the USSR & The first hydrogen bomb explosion in the USSR \\
\hline Mar 1, 1954 & Bravo & 15,000 & the USA & $\begin{array}{c}\text { The explosion of the most powerful American } \\
\text { hydrogen bomb on Bikini Atoll in Micronesia }\end{array}$ \\
\hline May 15,1957 & Grapple & 1,800 & Britain & $\begin{array}{c}\text { The first British hydrogen bomb explosion } \\
\text { in the Pacific Ocean }\end{array}$ \\
\hline Feb 13, 1960 & Gerboise & 70 & France & $\begin{array}{c}\text { The first French atomic bomb test in the Sahara } \\
\text { Desert }\end{array}$ \\
\hline Oct 31,1961 & Tsar-bomb & 50,000 & the USSR & The most powerful atomic bomb explosion \\
\hline Oct 16, 1964 & 596 & 22 & China & The first atomic bomb explosion in China \\
\hline Jun 17, 1967 & Test No. 6 & 3,300 & China & The first hydrogen bomb explosion in China \\
\hline Aug 24, 1968 & Canopus & 2,600 & France & The first French hydrogen bomb explosion \\
\hline May 18, 1974 & $\begin{array}{c}\text { Smiling } \\
\text { Buddha }\end{array}$ & 12 & India & The first atomic bomb explosion in India \\
\hline May 28, 1998 & Chagai-I & $9-12$ & Pakistan & The first atomic bomb explosion in Pakistan \\
\hline Oct 9, 2006 & & to 1 & D.P.R.K. & The first atomic bomb explosion in North Korea \\
\hline May 25, 2009 & & up to 20 & D.P.R.K. & Allegedly, the second explosion in North Korea \\
\hline
\end{tabular}

No data on Israel's nuclear weapons testing have been known. In 1998, India and Pakistan carried out their nuclear weapons tests. Further, it is stated that North Korea also carried out a nuclear test successfully in 2006 and acquired its own nuclear weapons.

\subsubsection{Nuclear crises}

The concept of nuclear crises means severe events when the use of nuclear weapons was considered and the world found itself close to the brink of a world nuclear disaster. After the end of World War II, several short-term nuclear crises happened. An overview of them is given below:

- The first Berlin nuclear crisis in 1949;

- Korean nuclear crisis in 1950;

- The second Berlin nuclear crisis in 1961 (connected with the Berlin Wall construction);

- Cuban nuclear crisis in 1962;

- Vietnam nuclear crisis in 1966 and 1970; and

- Egyptian-Israeli War in 1973.

The Korean nuclear crisis, the Cuban nuclear crisis, the Vietnam nuclear crisis and the Egyptian-Israeli War are considered to be the most significant nuclear crises. They are briefly described below. 


\subsubsection{Korean nuclear crisis}

Since the end of World War II, the Korean Peninsula has remained a focal point of tensions. While conflicts have ended in other places, the Korean War, the first hot conflict of the Cold War even half a century after the ceasefire between both parties, still has been affecting the international course of events and current strategic doctrines due to its consequences.

The ceasefire from July 1953 ended the fighting, however, a peace agreement has not been signed up to the present. The Democratic People's Republic of Korea (North Korea) situated in the northern part of the Korean Peninsula and the Republic of Korea (South Korea) situated in the South are "de iure" in the state of war. At the same time, the war, which threatened to grow into a nuclear one, defined another form of conflict between the two blocs. Instead of direct conflicts, limited and non-nuclear wars happened on the territories of the third states where Washington and Moscow supported the warring parties. Soldiers of both countries often took part directly in the conflicts

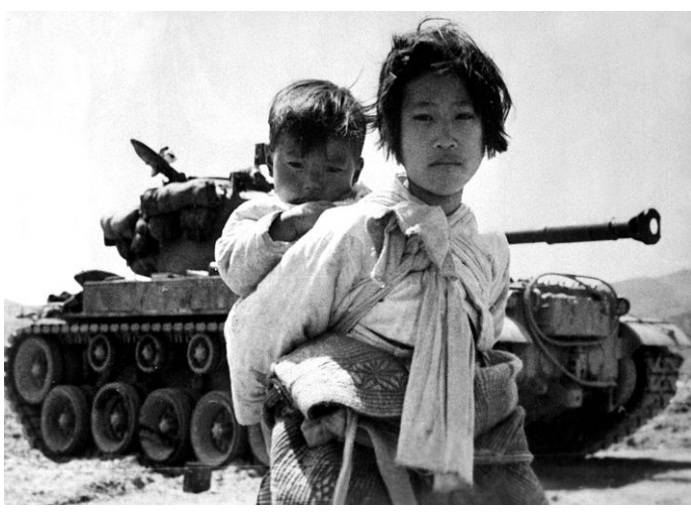

Photo 6: A Korean girl carrying her brother on her back in Haengju, Korea. M-26 tank in the background. [Source: Pho-6] or as advisers.

Finally, the conflict, which broke out between the two Koreas, grew into the conflict of the USA and its allies with China supported by the USSR. The conflict was not only a result of the increasing tension on the Korean Peninsula where North Korea was communist and South Korea was anti-communist. It also reflected the existing political situation at the beginning of the Cold War when the both superpowers possessing nuclear weapons weighed up their own positions and, at the same time, tried to expand their spheres of influence. On the Korean Peninsula, the Western Block as well as the Block of People's Democracies verified their positions in the divided world.

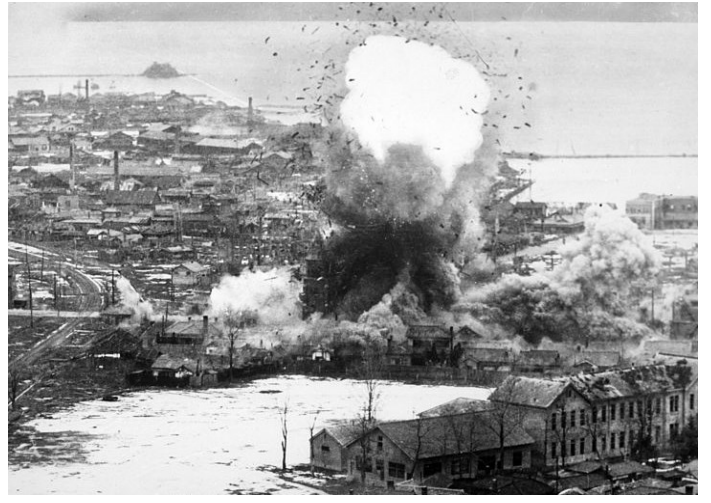

Photo 7: Bombing of supply depots and facilities in the port of Wonsan by Air Force B-26 Invader North Korea, 1951. [Source: Pho-7]

Unlike European states that knew, which sphere of influence they rank among, in the rest of the world it was different. The pre-war order could no longer be restored, the colonial system disintegrated, and India gained its independence. In Asia, the fight against the Japanese occupiers during the war was mostly led by nationalist groups which did not want to return to colonial rule and longed for independence, looking for Allies in Moscow and Beijing. However, the Americans did not intend to abandon their positions, so the USA pursued a policy of detaining communism.

The situation was further complicated due to the course of events in China, where Chiang Kai-shek and Mao Tse-tung were unable to reach an agreement, and in 1946 the civil war broke out in the country, in which Maoists supported by North Korean units dislodged the Kuomintang, which evacuated its government to Taiwan. Initially, it was not even clear what nature this conflict determining all the successive similar conflicts would take, whether it would not escalate into World War III because US General Douglas MacArthur repeatedly considered the use of nuclear weapons. 
At first, he wanted to isolate the Korean Peninsula using nuclear weapons so that the Chinese could not send more troops, but then he also considered attacking Beijing.

The Korean War broke out as a result of the situation that developed on the Korean Peninsula after World War II. Korea, which had been under rule of the Japanese Empire since August 22, 1910, gained freedom after World War II, however, it was divided into two parts - the North was liberated by the Red Army and the South by Americans. Two days after the nuclear bomb was dropped on Hiroshima, the Soviet Union declared war on Japan and on the day of the nuclear attack on Nagasaki, on August 9, 1945, the Red Army launched Operation August Storm.

On August 15, Japanese Emperor Hirohito announced the surrender, however, fighting with the Cantonese Army continued until August 19. The first Far Eastern Front advanced on Korea and undertook several amphibious operations in its north to cut off supply routes. The Soviet units landed in Wonsan on August 21, and three days later the Red Army reached Pyongyang. The Soviet Union accepted and adhered to the plan for partitioning Korea, during its liberation, along the 38th parallel of latitude and stopped advancing.

The Americans landed at Incheon on September 8, i.e. six days after Japan signed the surrender, and established their own occupation administration in the south. The division of the country was confirmed by the Moscow Conference of Foreign

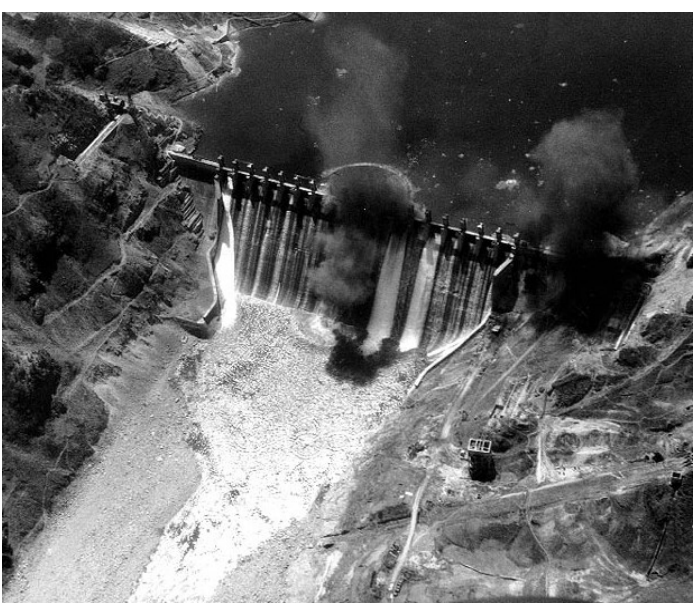

Photo 8: Aerial bombing of the HWACHEON Dam in South Korea - a picture from F4U Corsair, May 1, 1951. [Source: Pho-8] Ministers of the USSR, the USA and Great Britain in December 1945 with the result that the interim administration would last five years. Neither party took into account the emergence of two states. However, the development after WW II and the onset of the Cold War changed that. In both countries, governments were established that met the requirements of the countries that administered both halves of Korea.

In February 1946, Kim Il-Sung became a leader of the Interim People's Committee in North Korea; in the same year, Yee Sung-man (Syngman Rhee, for historical reasons, will continue to be listed as Yee Sung-man) became a leader in the South and headed the government in exile during WW II. The USA submitted the issue of Korea to the United Nations where the UN Temporary Commission on Korea was created. Its task was to supervise the national elections in 1948, however, Pyongyang refused the elections to be held on its territory.

In the South, Yee Sung-man won the elections on May 10 and declared the Republic $\mathrm{f}$ Korea on August 15, which was recognized by the UNO. Pyongyang reacted immediately, on August 25, the elections were held in the North and, on September 9, the Democratic People's Republic of Korea (D.P.R.K.) with the Prime Minister Kim Il-Sung at the head was declared. On October 11, Moscow recognized the Democratic People's Republic of Korea and, on October 21, Moscow also recognized People's Democracies including Czechoslovakia. After the Proclamation of Independence in both countries both Americans and Soviets withdrew from the Korean Peninsula. The leaders of both Koreas sought to unify the country under their rule.

Finally, the increasing tension on the Korean Peninsula resulted in a war that broke out on June 25, 1950 and till the ceasefire on July 27, 1953 it claimed up to four million victims. After the war, the command of the UN forces published its casualties, the casualties in North Korea are only estimates. The precise numbers have never been released. 
Up to the present, there have been disputes on who provoked the war, whether it was a unilateral aggression of North Korea or the reaction to provocations on the part of South Korea.

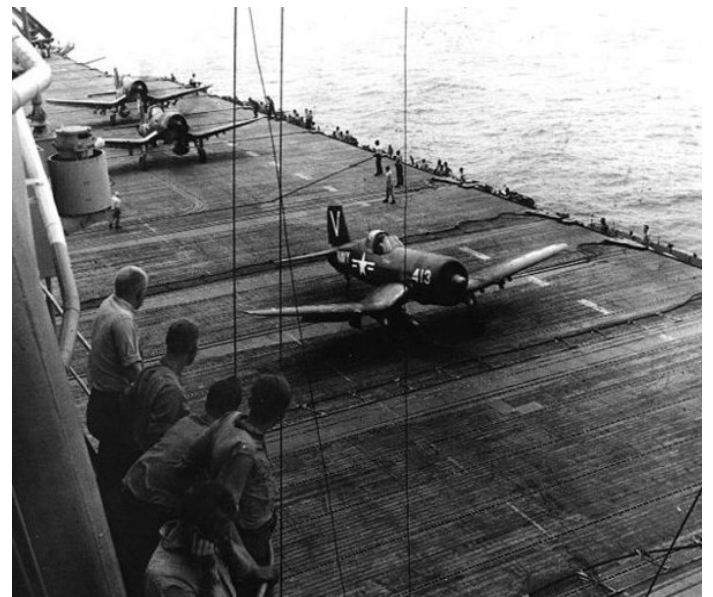

Photo 9: The F4U-4B Corsair pilots of VF-114 fighter squadron known as Executioners taking off from the USS Philippine Sea (CV-47) aircraft carrier, October 1950. [Source: Pho-9]

In 1949, Kim Il Sung submitted a plan for the occupation of South Korea to Stalin; however, Moscow did not approve it due to the fear of extension of the conflict. In further negotiations, Stalin advised the North Korean leader to consult everything with Mao Tse-tung. When Kim Il Sung agreed, Stalin said he would not oppose the attack. Pyongyang was ready for the conflict, fighting began on June 25 and three days later North Korean soldiers were in Seoul and advanced. Kim Il Sung's assumption that he would be welcomed as a liberator did not come true.

On the day of the attack itself, the Security Council (hereinafter referred to as SC) denounced the North Korean aggression and called on Pyongyang to withdraw beyond the $38^{\text {th }}$ parallel. At the same time, the SC agreed to provide South Korea with assistance. Nine out of eleven members agreed, one abstained and the Soviet Union, which could veto the resolution, was absent at the meeting since it boycotted its negotiations in protest against the UN Secretary General Trygve Lie who opposed the proposal that China will be represented by Mao Tse-Tung and not by Chiang Kai-shek in the SC. This implies that Moscow did not have to anticipate the attack and, definitely, it did not expect such a quick reaction. All Moscow could do was to designate the SC resolution as unlawful on June 29.

Two days after the attack, on June 27, American President Harry Truman issued an order to the American units in the Far East to support and protect South Korean units. American General Douglas MacArthur was appointed the Supreme Commander of international forces in Korea. The first American units arrived in South Korea on July 01, however, they did not prevent the North Korean units from advancing. At the end of the summer they reached a distance of 150 kilometres from $\mathrm{Pu}-$ san (also spelled Busan). Nevertheless, its conquest was beyond the strength of North Korean troops. The supply routes were long and the UN forces had air superiority, which they used for permanent disrupting. The North Korean offensive stopped and the UN forces launched a counterof-

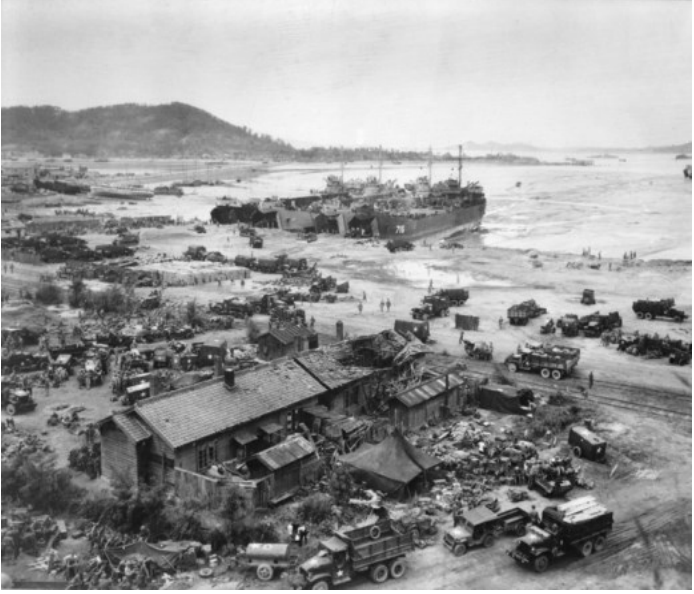

Photo 10: Landing of US units at the port of Incheon one day after the Battle of Incheon in September 15, 1950. [Source: Pho-10] fensive.

On September 15, 1950, MacArthur landed unexpectedly at Incheon, interrupted supply routes and advanced to Seoul, which he conquered on September 26. At the end of September, the North Korean troops were already expelled from South Korea, and the UNO approved an attack on the North Korean territory on October 07, despite of the protests from the People's Democracies. 
At the same time, China threatened, on September 27, to join the war in that case, but the USA considered it a trick. Already on October 16, Pyongyang was occupied. On October 19, the Chinese units were given the order to advance. When, on October 25, the United Nations Command forces approached the Yalu river (on the border between North Korea and China), they encountered the Chinese units that routed three South Korean divisions a day later.

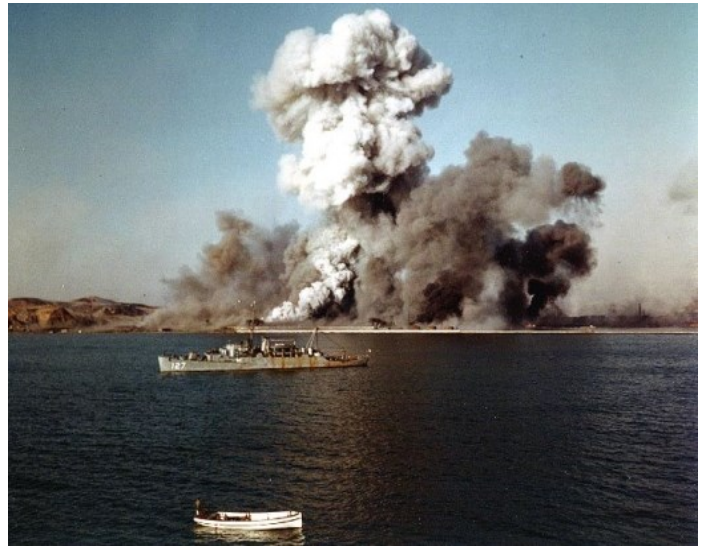

Photo 11: Smoke from the dock and the city during the Gangnam evacuation, October 1950. [Source: Pho-11]

MacArthur decided on carpet bombing the border area. In November, China had to explain why its soldiers were in the Democratic People's Republic of Korea. Pyongyang stated that it was a spontaneous action of volunteers. MacArthur intended to end the war by Christmas and scheduled the date of the offensive on November 24. One day later, the Chinese units defeated their enemy during the counteroffensive. A total of 150,000 American, South Korean and other soldiers were encircled and trapped. The startled President Harry Truman considered the deployment of nuclear weapons for the first time, but realized that he would also need the consent of concerned Allies. On November 28, MacArthur gave the order to retreat, which meant breaking through the siege in the cold to the port of Gangnam, and asked for reinforcements. MacArthur considered attacking China and bombing access routes from Manchuria. Nuclear weapons were also considered as their use could block the access from China to Korea. Under the pressure of the circumstances, Truman spoke publicly about the possibility of nuclear bombing: "The military commander in the field will have charge of the use of the weapons, as he always has."

In the meantime, on December 06, the forces of the Korean People's Army (KPA) and Chinese People's Volunteers (CPV) liberated Pyongyang and moved forward. They managed to push the Americans out, but not to kill them. Another offensive by Chinese and North Korean troops aimed at conquering South Korea began on the night of New Year and January 4. The units of KPA and CPV conquered Seoul. However, the Chinese, who were identified by the UN as aggressors in another Security Council resolution, were pushed out of it on March 05, 1951, and the warfare became static, with the front running along the $38^{\text {th }}$ parallel.

In March, MacArthur again thought of a plan for the reconquest of the North and the advance to China even at the price of a nuclear war, in which

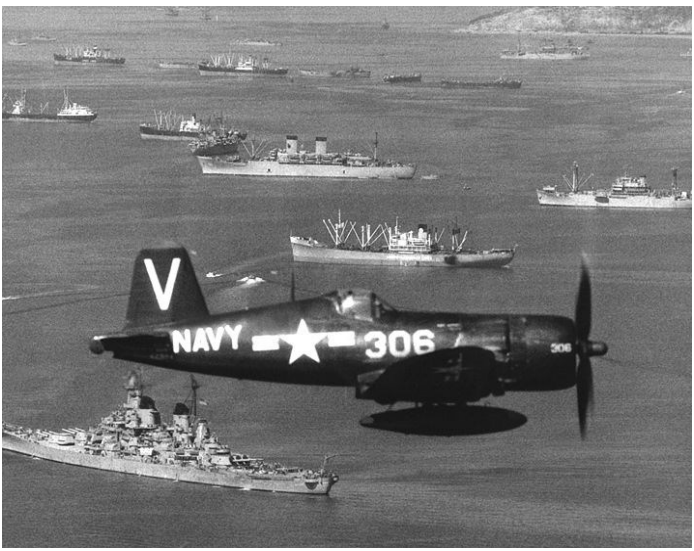

Photo 12: F4U-4B Corsair fighter of VF-113 fighter squadron also known as the Stingers from USS Philippine Sea (CV-47) aircraft carrier is flying over vessels in Incheon, Korea, September 15, 1950. [Source: Pho-12] the Soviet Union being under the contract with China could also be involved. However, instead of that President Harry Truman withdrew MacArthur on April 11. The war continued for other two years, although, on May 22, 1951, US Senator Johnson proposed a return to the pre-war status. Kim Il Sung agreed on the offer for direct negotiations from June 29, so the talks at Kaesong between Admiral Joy and Generals Nam Il and Hsieh Fang started on July 10. The negotiations reached a deadlock, both parties blamed each other, so in August the negotiations were interrupted and then continued at Panmunjom from October 25. 
Some progress was achieved at the beginning of 1952. Both parties made concessions. Americans agreed on the airport in the D.P.R.K. and its reconstruction. Korea and China again stopped insisting that the Soviet Union oversee peace, and nominated Czechoslovakia and Poland for the Neutral Nations Supervisory Commission (NNSC); the opposing party appointed Sweden and Switzerland. In April 1952, the negotiations reached a deadlock when the UN Command announced that only 70,000 Koreans and 5,100 Chinese out of the captured soldiers of the Korean People's Army (KPA) and Chinese People's Volunteers (CPV) wanted to return to their homeland.

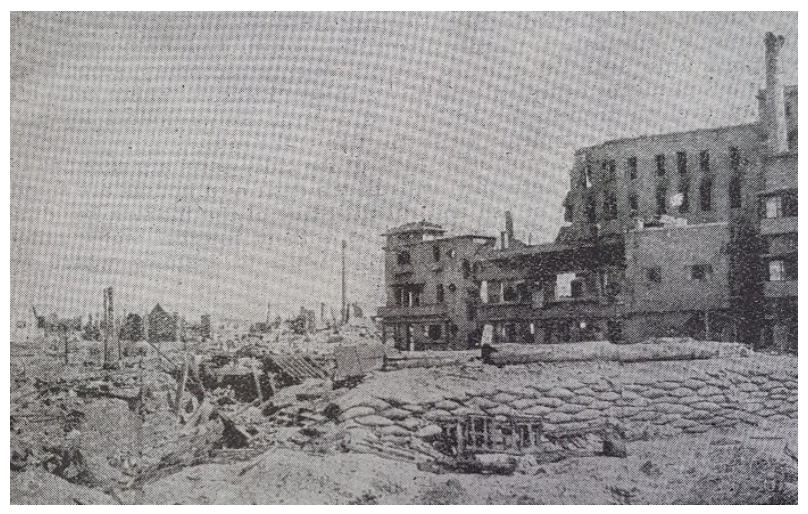

Photo 13: Pyongyang in May 1951. [Source: Pho-13]

That was unacceptable for Pyongyang and Beijing. It was the fate of the prisoners that was the problem, and both sides refused to make concessions. The Americans attempted an offensive in the autumn of 1952, but without success. The Korean-Chinese side was preparing for another American accession at the beginning of 1953, and the US again considered blocking China. In the end, a breakthrough was achieved at the negotiating table when the following Indian proposal was adopted: the prisoners will be transferred to a demilitarized zone with international control and will decide for themselves whether they want to be repatriated or not. Based on the proposal, the Chinese and North Korean soldiers detained in the South should not have been returned directly to their homeland as demanded by the North representatives, but they should not have been liberated in the country of imprisonment. They were to be given the opportunity to decide freely in front of the Neutral Nations Repatriation Commission (NNRC) whether to return home or remain on the other side.

In the spring of 1953, China proposed that those prisoners who did not want to be repatriated be transferred to third countries. Negotiations were commenced at Panmunjom in April 1953. As details could not be fine-tuned and negotiations did not appear to lead to an Armistice Agreement, the Americans resumed bombing of power plants, railroads and cities in May 1953 to put Beijing and Pyongyang under pressure. It was not until June 08 the agreement was signed at Panmunjom. The Neutral Nations Repatriation Commission (NNRC)

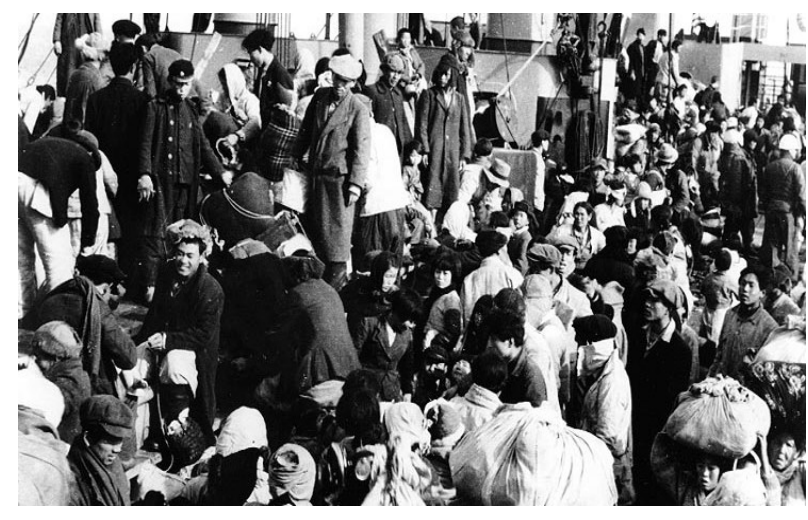

Photo14: Korean escapees on the deck of the SS Meredith Victory, December 1950. [Source: Pho-14] should have decided on the prisoners' fate. The Commission consisted of the representatives of India, Poland, Czechoslovakia, Sweden and Switzerland. Difficulties occurred between June 18 and June 20 when South Korea released 27,000 prisoners of war who avoided repatriation.

The Chinese could leave for Taiwan and strengthen Chiang Kai-shek's weakened troops. It threatened that the ceasefire negotiations in Korea will not be successful. The Swiss and the Swedish cancelled their participation in the NNRC, and Czechoslovakia threatened to take the same step. Yee Sung-man said he would not allow the Czechoslovak and Polish members of the Neutral Nations Supervisory Commission (NNSC) to work on the territory of South Korea as stated in the agreement. 
India convened an extraordinary session of the United Nations. The USA stated that released prisoners could not be detained again, but it guarantees that Seoul will abide by the Armistice Agreement. On July 10, negotiations were resumed and on July 20, 1953, the demarcation line was set out a few kilometres north of the $38^{\text {th }}$ parallel. Seven days later the UNO and the representatives of North Korea and China signed the Armistice Agreement and fire was stopped. The agreement also included the necessity for establishing the bodies to supervise its observance and to deal with the problems incurred.

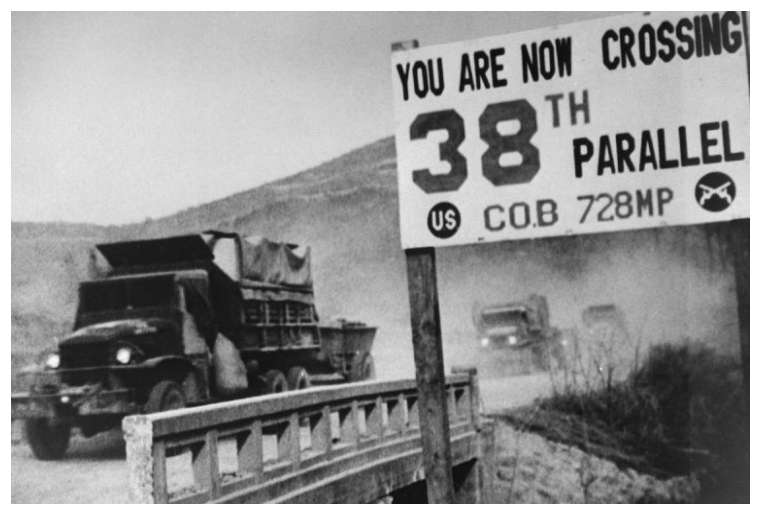

Photo 15: UN forces' transport vehicles re-crossing the 38th Parallel as they withdraw from Pyongyang in 1950. [Source: Pho-15]

The observance of the agreement, removal and exchange of soldiers as well as weapons should have been supervised by the Neutral Nations Supervisory Commission, to which two countries - Poland and Czechoslovakia were proposed by the North and two countries Sweden and Switzerland were proposed by the South. The commission presented its findings to the Military Commission, which consisted of the commanders of the warring parties, the American, Chinese and North Korean generals. At the time of the Korean War, the commanding American General McArthur demanded the use of nuclear weapons. His concern for their use was so great that, finally, the acting President Harry S. Truman decided to remove the military commander from the post of commander-in-chief of the US Armed Forces in Korea.

\section{Crimes against the civilian population}

In July 1950, the South Korean Military Police carried out mass executions of political prisoners whom it suspected of being communist sympathizers. Approximately 3,0007,000 political prisoners were executed near the city of Daejeon and at least 1,800 political prisoners near Seoul. In total, it is estimated that approximately 100,000 political prisoners were mostly executed without trial in the mid-1950s.

Military police and right-wing paramilitary units executed thousands of left-wing political prisoners and peasants in 1950. Americans knew about the crimes; however, they did not

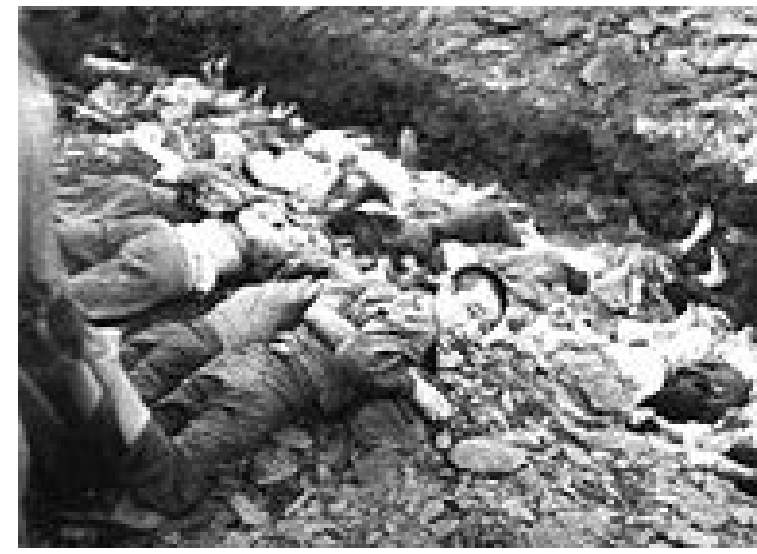

Photo 16: One of the prisoners of war on the eve of the execution near the city of Daejeon in South Korea. [Source: Pho-16] intervene. General MacArthur sought to curb the mass killings and passed the information to the Pentagon and the US Consulate in South Korea. The Pentagon kept information secret for more than half a century. John J. Muccio, the US ambassador to South Korea, later wrote that he forced the South Korean authorities to carry out the executions in a humane and lawful manner.

The diplomat for the USA, Gregory Henderson, got records after the war about the mass massacres of more than 100,000 pro-northern political prisoners. Forces sent to Korea from the United States used the "Shoot first, then ask" tactic for some time against any civilian refugee approaching U.S. combat positions. This tactic led to the massacre on July 26, 1950, in the village of No Gun Ri, where the U.S. forces slaughtered, based on estimates, up to 400 civilians suspected of hiding guerrillas. 


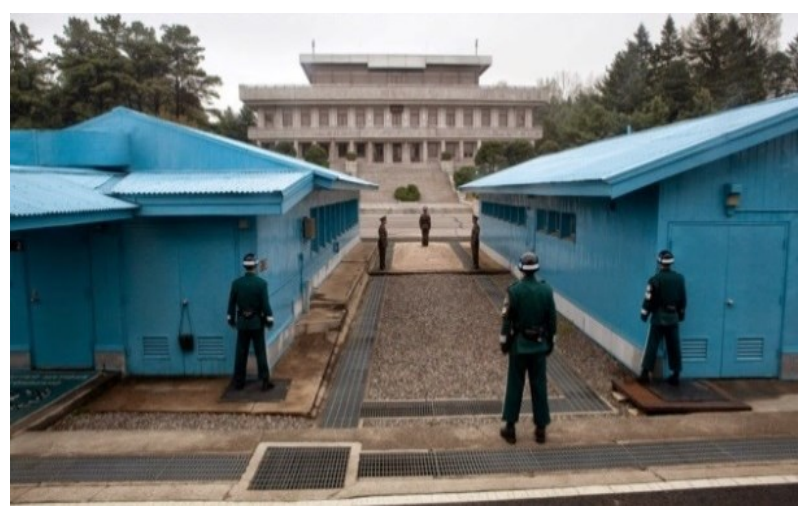

Photo 17: The border in demilitarized zone. [Source: Pho-17]

\section{Post-war development}

The military actions were terminated in 1953 only on the basis of the Armistice Agreement, and the peace treaty has not been concluded to this day, so that formally both states are still in the state of war. The demilitarized zone surrounded by a barbed wire fence was built between Koreas. Around this zone, the troops of North and South Korea stand constant guard. This demilitarized zone is often referred to as the most guarded border in the world.

There are often border incidents, namely on the sea since the Armistice Agreement defines the border between Koreas in coastal waters rather vaguely. On May 27, 2009, North Korea announced that it no longer felt bound by the ceasefire and was not responsible for the safety of foreign vessels in North Korea's part of the Yellow Sea. The South Korean corvette sinking on March 26, 2010 attracted international attention. It was caused by a North Korean torpedo according to the International Commission of Enquiry. North Korea denies involvement in the sinking of the ship.

Table 5: Survey of the Korean War 1950-1953. [Source: Tab-5]

\begin{tabular}{|c|c|c|}
\hline Parties concerned & Engaged forces & Casualties \\
\hline $\begin{array}{l}\text { UNO coalition: } \\
\text { South Korea } \\
\text { the USA } \\
\text { Medical support: } \\
\text { Denmark } \\
\text { Italy } \\
\text { Ine United Kingdom } \\
\text { Norway } \\
\text { - India } \\
\text { - Sweden }\end{array}$ & $\begin{array}{l}\text { South Korea 590,911 } \\
\text { the USA 302,483-480,000 } \\
\text { The United Kingdom } 14,198 \\
\text { Philippines } 7,000 \\
\text { Canada } 6,146-26,791 \\
\text { Turkey 5,190 } \\
\text { the Netherlands } 3,972 \\
\text { Australia } 2,282 \\
\text { New Zealand } 1,389 \\
\text { Thailand } 1,294 \\
\text { Ethiopia } 1,271 \\
\text { Greece } 1,263 \\
\text { France } 1,119 \\
\text { Columbia } 1,068 \\
\text { Belgium } 900 \\
\text { the South African Republic } 826 \\
\text { Luxemburg } 44 \\
\text { Total 941,356-1,139,518 } \\
\end{array}$ & $\begin{array}{l}118,515 \text { killed } \\
264,591 \text { wounded } \\
92,987 \text { captured (most of prisoners } \\
\text { of war died) } \\
\\
150,000 \text { wounded } \\
80,000 \text { captured } \\
3,000,000 \text { dead civilians }\end{array}$ \\
\hline $\begin{array}{l}\text { Communists: } \\
\text { North Korea } \\
\text { the CPR } \\
\text { the USSR } \\
\text { Medical support: } \\
\text { the CSR } \\
\text { the PPR } \\
\text { the HPR } \\
\text { the BPR } \\
\text { Romania }\end{array}$ & $\begin{array}{l}\text { North Korea 260,000 } \\
\text { the CPR 2,300,000 } \\
\text { the USSR 26,000 } \\
\text { Total 2,586,000 }\end{array}$ & $\begin{array}{l}\text { - } 215,000 \text { killed in action, } 303,000 \\
\text { wounded and } 120,000 \text { captured and } \\
\text { missing } \\
\text { Officially } 148,000 \text { killed in ac- } \\
\text { tion, } 380,000 \text { wounded and } 21,400 \\
\text { captured } \\
\text { Based on estimates - the USA more } \\
\text { than } 400,000 \text { killed in action, } 486,000 \\
\text { wounded and } 21,000 \text { captured } \\
282 \text { killed in action }\end{array}$ \\
\hline
\end{tabular}


The North Korean development of nuclear weapons is another source of tension. All the inter-Korean non-aggression agreements were unilaterally denounced by North Korea on March 08, 2013 after the UN Security Council had imposed further sanctions on North Korea due to its third nuclear test. For long years, the Korean War has been forgotten. In the 1970's, the comic, but quite realistic American series entitled M.A.S.H. evoked memories of that war.

\subsubsection{Cuban missile crisis}

On October 10, 1962, American President J. F. Kennedy received the satellite images of launch pads under construction in the western part of Cuba. Immediately afterwards, U-2 reconnaissance aircraft were flying over the Island of Freedom, which provided detailed images of nuclear missile launch sites being built by the Soviets - see Photo18.

On October 16, 1962, Washington was sure: Forty-two Soviet nuclear missiles with a range of 1,800 kilometres are in Cuba, and next twenty-four missiles with a range of 3,500 kilometres are on the way. Cuba is located 144 kilometres far from the USA mainland. While the travel of a missile launched from the Soviet Union would take about half an hour, the travel of a missile launched from Cuba would take a few tens of seconds only. Moreover, the US alert system did not cover this Caribbean area at all.

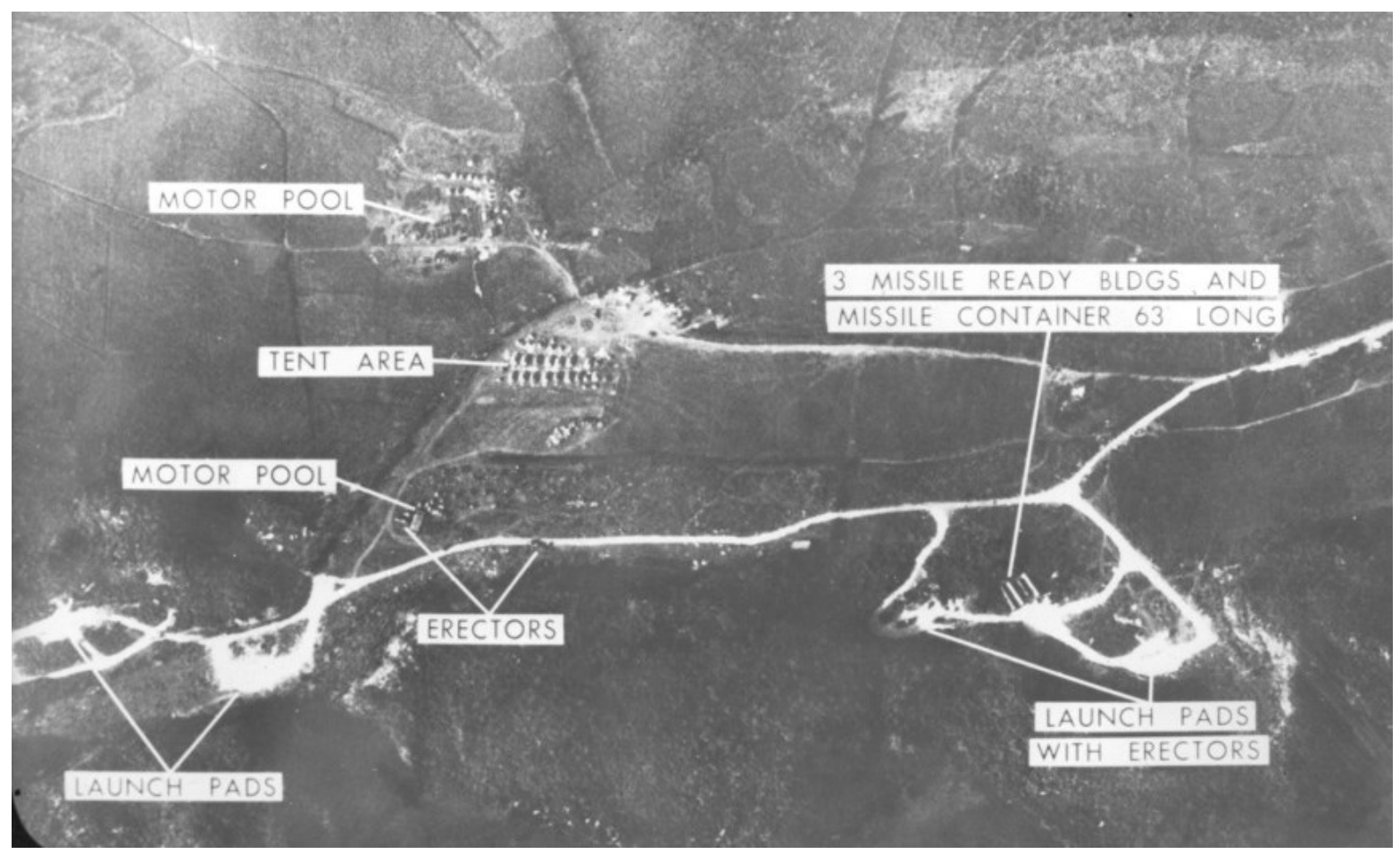

Photo 18: Photographs of a missile base in Cuba. [Source: Pho-18]

The declassified records of the meeting in the White House showed that since the very beginning, Kennedy had been faced increasing pressure from his military advisors and some politicians to respond to the missile threat with force. Despite of the threat of a total nuclear war, Dean Acheson, the US Secretary of State, proposed a radical solution through massive aerial bombing, military invasion, and subsequent total blockade. At that time, the missile superiority of the Americans was 8:1; however, the doves in the American administration helped change the situation.

Defence Minister McNamara and mainly the President's brother Robert Kennedy claimed that such plans were un-American. The US planners had to take into account the response of the USSR that would have certainly arrived. 


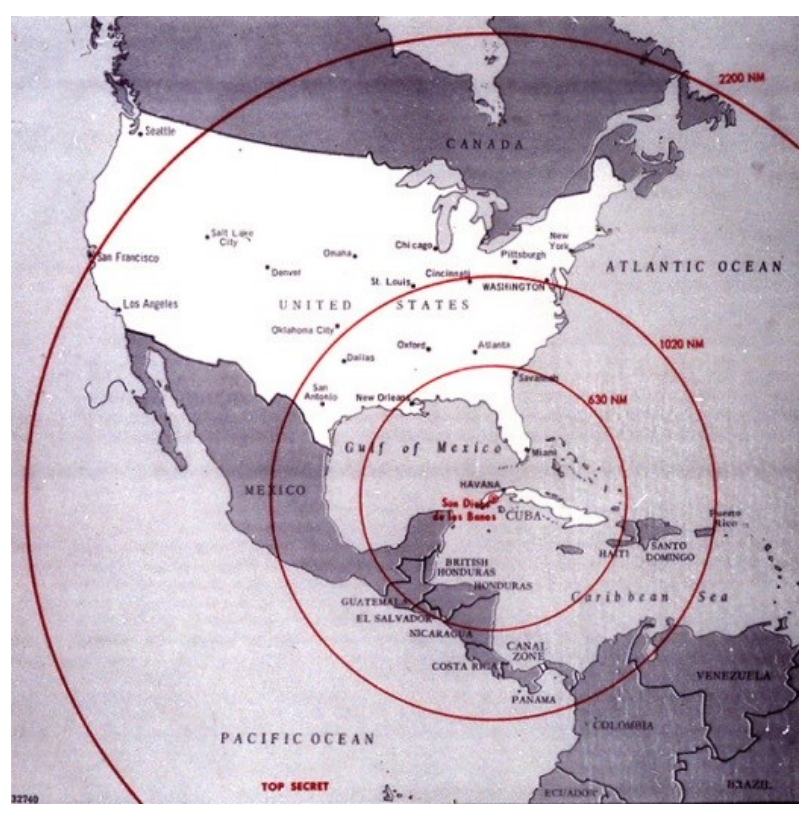

Photo 19: Cuban crisis - a map.

[Source: Pho-19]

It could be an attack on US bases in Europe or the occupation of West Berlin. The confrontation could get out of control and World War III would become a reality.

On October 24, 1962, the US naval blockade of Cuba to prevent the further shipments of Soviet weapons from entering Cuba started. These were especially Soviet missiles delivering nuclear warheads, both short-range guided missiles capable of striking Washington, D. C. and medium-range guided missiles ranging as far north as Hudson Bay, Canada.

President J. F. Kennedy addressed the world public and announced that the USA could prove the presence of the Soviet medium-range missiles and the existence of launch pads in Cuba. He explained the U.S. Navy had imposed a quarantine or naval blockade around Cuba (as international law considered a blockade an act of war, the Kennedy administration chose to use the term quarantine instead) with the support of the Organization of American States (OAS). Khrushchev announced that he wouldn't be intimated with threats and the Soviet ships steering for Cuba would ignore the quarantine.

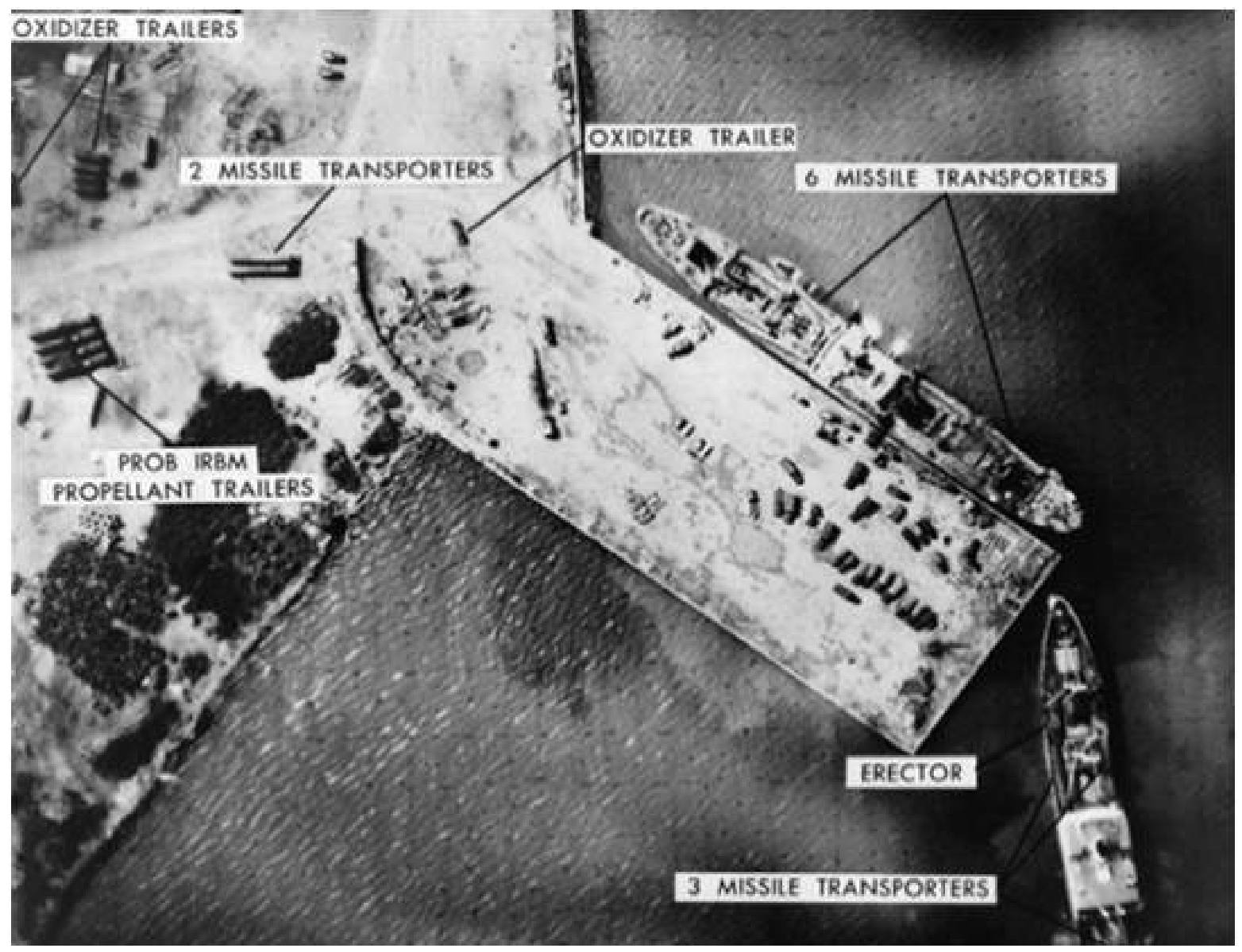

Photo 20: Spy plane images. [Source: Pho-20] 
On the night from October 24 to 25, the world was on the brink of nuclear apocalypse. For the first time in history, the DEFCON 2 (Defense Readiness Condition) readiness level was announced for the Strategic Air Force.

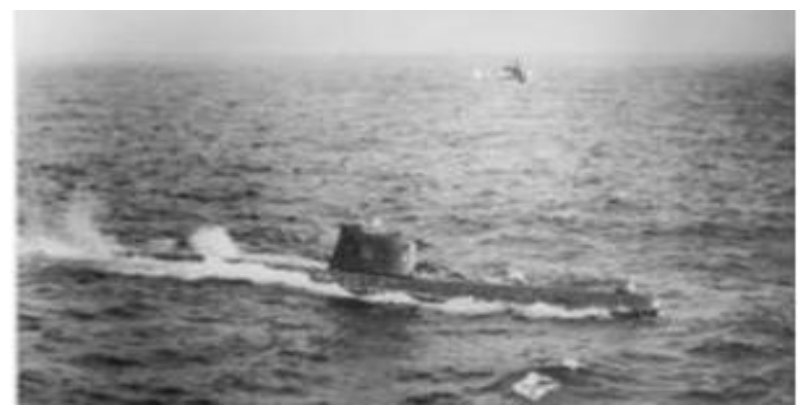

DEFCON 2 ordered units a heightened state of alert, but less than maximum readiness.

DEFCON 1 means maximum force readiness. i.e. war. A total of 12,000 members of the US Marine Corps were in full combat alert; other forces were prepared at military bases. $20 \%$ of US B-52 bombers Photo 21: The Soviet submarine B-59. [Source: Pho-21] armed with nuclear weapons aboard took off.

The crews of eleven hundred B-52, B-47 and B-58 bombers slept aboard planes to be ready for an operation. Missile silos were open and warheads were activated; nuclear submarines were approaching the coast of the enemy and were ready to launch missiles. Naval large formations, foreign bases and allied forces, all had the highest level of combat readiness. The armies slept in boots. After the exchange of a few sharp diplomatic notes, the situation calmed down thanks to the UNO Secretary General's efforts. Soviets promised to withdraw their missiles and rockets with nuclear warheads back to the Soviet Union. Is war coming? The entire world asked this question.

It was not just the Americans and their allies who were preparing. East of the Iron Curtain armoured divisions were waiting for an order to attack and the soldiers stood at the Soviet missile launchers and were ready to press the red button. At that time, Kennedy expected immediate death of sixty million Americans and the same number of Russians. Khrushchev saw the nuclear conflict more realistically - he expected that half a milliard people would die immediately and the rest of humanity would live a miserable existence on the destroyed and contaminated planet. Finally, the Soviet leader made a concession. After all, he did not want to be responsible for starting this apocalyptic war.

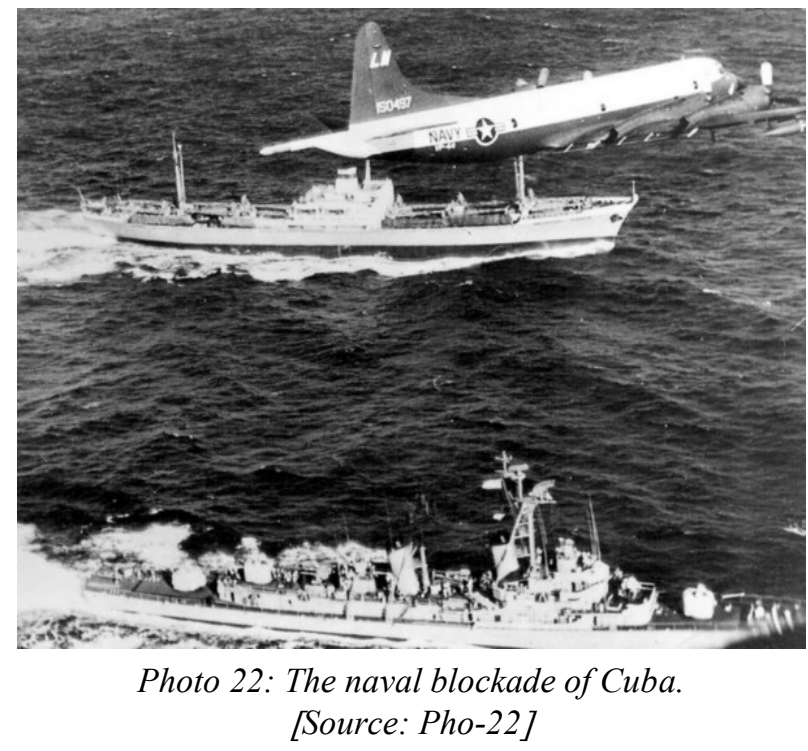
Five minutes before half past ten in the morning, the message arrived announcing that the Soviet ships had either slowed down or changed course.

Two days later, both sides started diplomatic talks. The Soviet side submitted a proposal: "Promise that you will not invade Cuba and we will remove our missiles from Cuba". The Americans sent their approval via Dean Rusk, the Secretary of State. However, Khrushchev wanted more, not to look like a coward in front of their Central Committee. He "bartered" an additional secret understanding relating to the removal of the US ballistic nuclear missiles from Turkey. Nevertheless, the world had not won yet. On Saturday, on October 27, the White House received a message on the bringing-down of an American U-2 reconnaissance aircraft over Cuba, which exacerbated the crisis. The Joint Chiefs of Staff (the supreme authority of the US Armed Forces) considered this to be a trick of the Kremlin before the direct attack on the United States. Thus, generals proposed an immediate blow. 
In the middle of the escalating tensions, an American destroyer, the USS Beale, began to drop depth charges on the B-59, a Soviet submarine, one of four at the quarantine line, each carrying nuclear-tipped torpedoes. According to the National Security Archive director Thomas Blanton, the US Navy "did not have a clue that the submarine had a nuclear weapon on board." The submarine's signals intelligence officer Vadim Orlov said: "It felt like you were sitting in a metal barrel, which somebody is constantly blasting with a sledgehammer." A Soviet submarine could fire a nuclear missile and begin a nuclear hell on earth. Instead of that, the sailors surfaced and made the last dramatic end to the hustle and bustle of recent days. Kennedy approved the agreement proposed by the Soviets. The Cuban missile crisis ended and the entire world took a breath again.

\subsubsection{Vietnam nuclear crisis}

The Vietnam War was a part of one of the longest conflicts of the Divided World Era. The fighting on the territory of today's Vietnam, Laos and Cambodia lasted from 1946 to 1975 and claimed 2.3 up to 3.8 million casualties in total. The conflict had several phases. The Vietnam War itself took place from 1964 to 1973. Two years later, Saigon fell, and in 1976, Vietnam was reunited under the rule of the communist North.

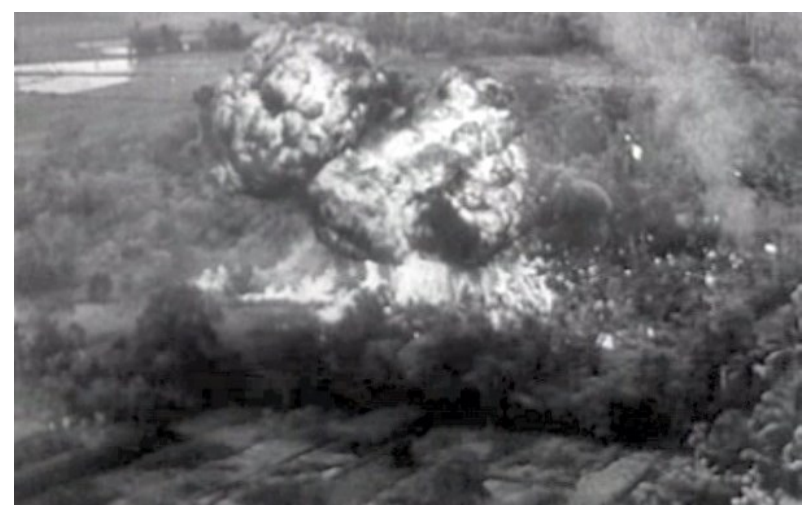

Photo 23: Napalm used by the French Army in the Indochina War, 1953. [Source: Pho-23]

From 1946 to 1954, the Indochinese War between France, which sought to maintain colonial rule over the region, and the liberation movement took place. After the defeat of Japan, France tried to reclaim the territory of its former colony; however, the North had already been controlled by the Viet Minh led by Ho Chi Minh. In November, the French Navy attacked Haiphong and Ho Chi Minh was expelled from Hanoi. The Viet Minh retreated to the mountains and, in the following year, it suffered casualties when attacked by the French units. In 1947, France established the State of Vietnam, the capital of which was Saigon. At its head was Emperor Bao Dai.

In 1949, the conflict grew into a regular war. France was supported by the United States, which supplied it with weapons. The Viet Minh was supported by the People's Republic of China, which enabled the guerrilla forces to be transformed into regular units, and General Vo Nguyen Giap could launch his offensive from the Chinese border. He captured Lai Khe at the Gulf of Tonkin. During the next offensive launched in September, he gradually captured Dong Khe, Cao Bang and Lang Son. France lost 4,800 of its men.

In 1953, Giap changed his tactics and, instead of direct attacks on the French, which failed, he launched an invasion of Laos. France that knew that it did not stand a chance of succeeding in a long-term conflict wanted to defeat the Viet Minh in a decisive battle at the end of 1953. This battle ended in cruel defeat of France at Dien Bien Phu.

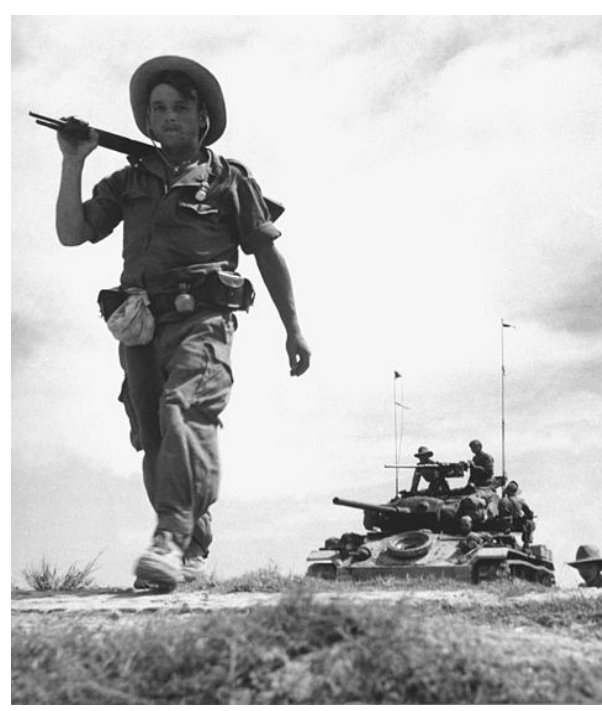

Photo 24: Units of the French Foreign Legion and M24 Chafee tank. [Source: Pho-24] 
Laos and Cambodia were proclaimed independent states and Vietnam itself was divided at the $17^{\text {th }}$ parallel into North (Communist) Vietnam and South (pro-Western) Vietnam. The exact number of victims of the war is unknown. Based on some estimates, there were a million casualties. France had 75,581 soldiers killed in action, the Vietnam State more than 400,000 soldiers killed in action, wounded or captured. By estimation, the Viet Minh had 300,000 deaths. The conflict also claimed some 150,000 civilian casualties. In 1956, when the Chinese withdrew from the North and the French left the South, elections were to be held under the Geneva Conventions to decide on the reunification of Vietnam. However, the USA and South Vietnam that became a republic in 1955 refused to sign.

In 1956, South Vietnamese President Ngo Dinh Diem launched a campaign against the communists, killing thousands of opponents and imprisoning some 40,000 others. Therefore, the support of the Viet Cong guerrillas increased. Many people in South Vietnam were upset that President Ngo Dinh Diem is a Catholic because most people are Buddhists. The situation escalated in 1959 when Ho Chi Minh changed his tactics and decided to support the armed struggle in the south of the country. The Viet Cong, therefore, launched larger-scale operations. This year is considered to be the beginning of the Second Indochina War. In 1960, the National Liberation Front was established in the South. The Americans, therefore, began to send their soldiers to the South; in 1963, there were already 16,500 of them.

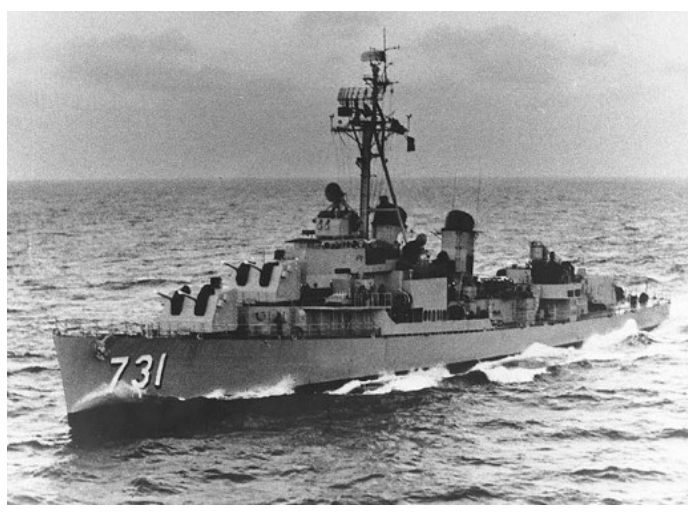

Photo 25: USS Maddox (DD-731).

[Source: Pho-25]

In 1964, the conflict between the USA and the Democratic Republic of Vietnam escalated into a war after the incidents in the Gulf of Tonkin. The destroyer USS Maddox who was on a secret mission off the Vietnamese coast, announced on August 2 that North Vietnamese speedboats had fired a torpedo at her and she responded with fire. She called for air help and a machine from the aircraft carrier USS Ticonderoga sank one of the North Vietnamese boats.

Two days later, the USS Maddox announced that she had been attacked again in the storm, but not hit. She fired at the ships she saw on the radar. It was claimed that two boats had sunk, but no wreckage was found. For the United States, this second incident, which was controversial, served to launch retaliatory raids on North Vietnamese cities. On August 07, 1964, the Congress approved the Southeast Asia Resolution, which provided the justification for further U.S. escalation of the conflict in Vietnam.

The United States fought on two fronts, bombed the North, and at the same time waged an antiguerrilla war in the South, where there were 150,000 guerrillas in 1965. The conflict, therefore, escalated and grew. A three-stage bombing campaign against North Vietnam was open. The goal of Operation Flaming Dart, Operation Rolling Thunder and Operation Arc Light was to prevent the North from supporting guerrillas in the South.

After the attacks on American bases in the South, it was decided in March 1965 to dispatch 3,500 US Marines to the South to protect them because the South Vietnamese military seemed incapable of providing security. This step is considered to be the beginning of the Ground War in Vietnam. At the end of the year, there were 200,000 American soldiers in Southern Vietnam. The South Vietnamese military was unable to face not only guerrilla attacks, but also the usual tactics of combat. Its forces suffered heavy losses at the Battle of Binh Gia; they were again defeated at the Battle of Dong Xoai. South Vietnam was completely divided politically, with coups taking place every year, which strengthened the guerrillas. 
In 1966, the Pentagon specialists recommended American President Lyndon Baines Johnson to use nuclear weapons to end the war in Vietnam. They proved, using their computer modelling that a nuclear attack would save lives of American soldiers. L. B. Johnson pointed to a window, behind which a number of people demonstrated and said: "I have one more problem for your computer - will you feed into it how long it will take five hundred thousand angry Americans to climb that White House wall out there and lynch their President if he does something like that?" The President refused that.

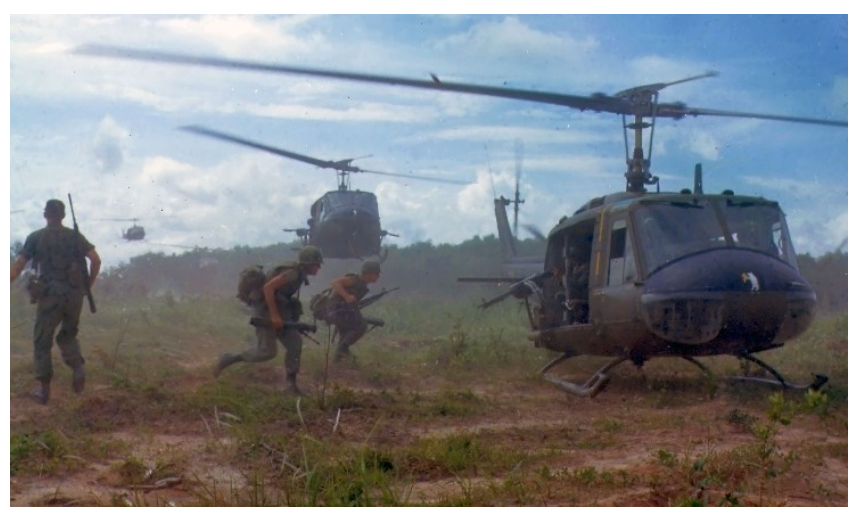

Photo 27: American units when searching for guerrillas. [Source: Pho-27]

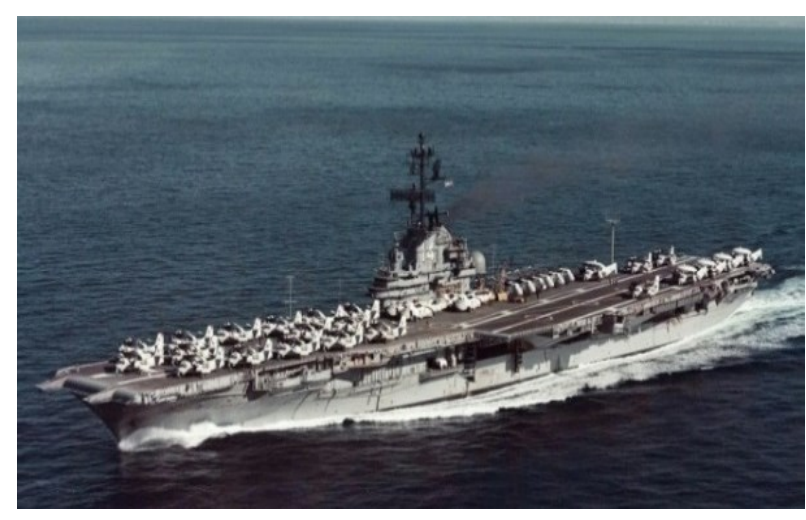

Photo 26: Aircraft Carrier USS Ticonderoga (CVS-14) Essex class in 1972. [Source: Pho-26]

As in Korea, the United States sought to gain Allied support from the SEATO Pact. Australia, New Zealand, the Republic of Korea, Thailand and the Philippines agreed, but Great Britain and Canada refused. Nevertheless, the strategy failed. In 1968, the liberation forces launched the surprise Tet Offensive (derives its name from the Vietnamese New Year holiday called Tet). Over 100 cities were attacked, with assaults on the Westmoreland headquarters and the U.S. embassy in Saigon.

During the counterattack, the city of Hue was razed to the ground and seized; the battle left 80 percent of the historic city in ruins. Although the offensive, from the military point of view, was a disaster for the liberation forces, it changed public opinion and the Americans began to protest massively against the war. The carpet bombing claimed considerable civilian victims of war and large numbers of seriously wounded people, burnt by napalm or poisoned by defoliants (defoliation was supposed to strip trees of leaves so that the guerrillas would have nowhere to hide).

Resistance to the war intensified after the My-lai massacre in March 1968, when American soldiers brutally raped, tortured and murdered about 500 residents of the village of the same name.

In 1970, the Pentagon again proposed the use of nuclear weapons in Vietnam, this time, to President Richard Milhous Nixon. Nowadays, we know from declassified documents that R. M. Nixon was afraid to do so also due to huge protests in American streets. At that time, demonstrators thought they had failed to achieve anything. However, thanks to their protests they prevented a destructive nuclear war.

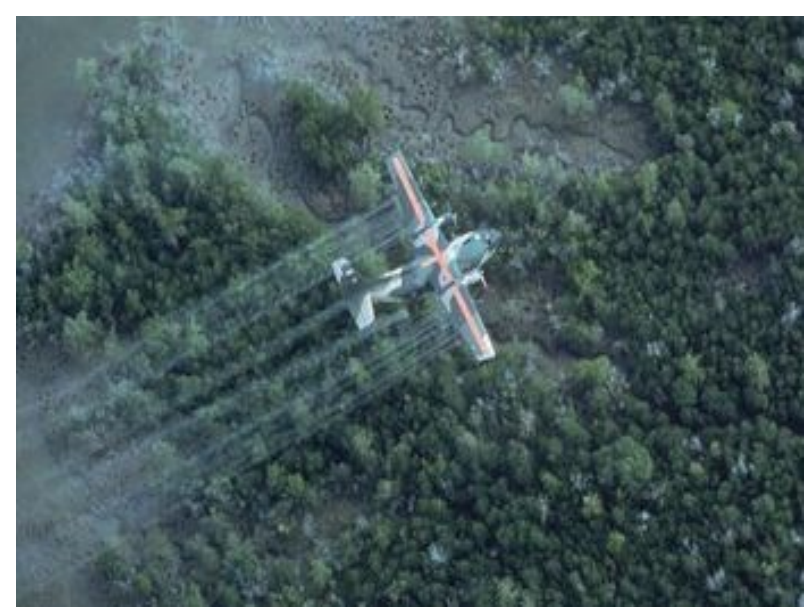

Photo 28: USAF aircraft - the spraying of Agent Orange. [Source: Pho-28] 
In 1972, American politicians proposed a new strategy called Vietnamization of the war when only the North Vietnamese and the South Vietnamese soldiers would face each other. The South, however, has never been strong enough. This led to reducing the American involvement in the Vietnam War from 543,000 to 265,000 soldiers. New president Richard Nixon also insisted on negotiating. He wanted China and the USSR to stop supporting North Vietnam and guerrillas. However, he did not succeed.

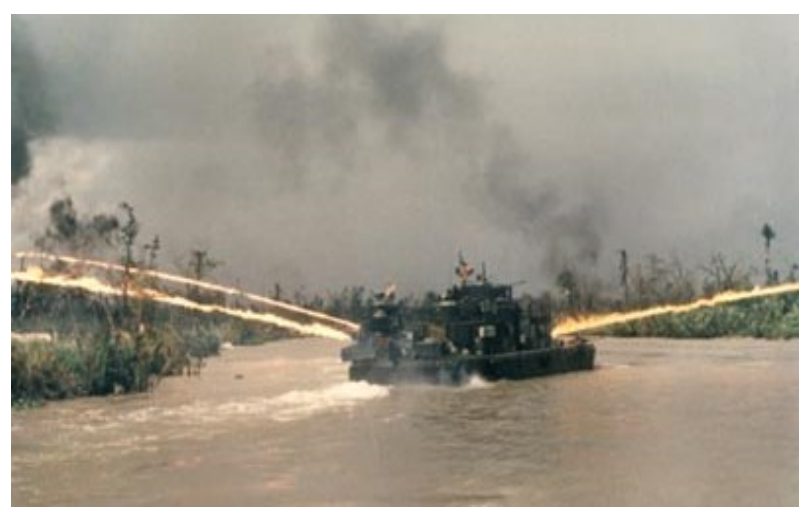

Photo 29: „Zippo” boat equipped with a flamethrower could fire compressed napalm up to 200 yards.

[Source: Pho-29]

Since the supplies were delivered along the Ho Chi Minh trail through Cambodia and Laos, at the beginning of the 1970s, the USA launched air attacks on both countries. In Cambodia, Prince Norodom Sihanouk was overthrown by a coup led by Lon Nol who set up a military government. The idea of Vietnamization failed as soon as the South Vietnamese soldiers met with resistance. They fled, leaving their vehicles and asking for evacuation by helicopters. This was also shown during the South Vietnam Easter Offensive of 1972. They were defeated again on the head and the situation was saved only by another air offensive called Operation Linebacker. Even so, the American withdrawal continued. As early as 1971, the number of American soldiers in the war dropped below 200,000 and by the spring next 45,000 were withdrawn. Australians and New Zealanders also left.

Washington was willing to start negotiations. The North launched another bombing offensive and, in 1973, the United States, South Vietnam, the Viet Cong, and North Vietnam formally signed an Agreement on Ending the War and Restoring Peace in Vietnam.

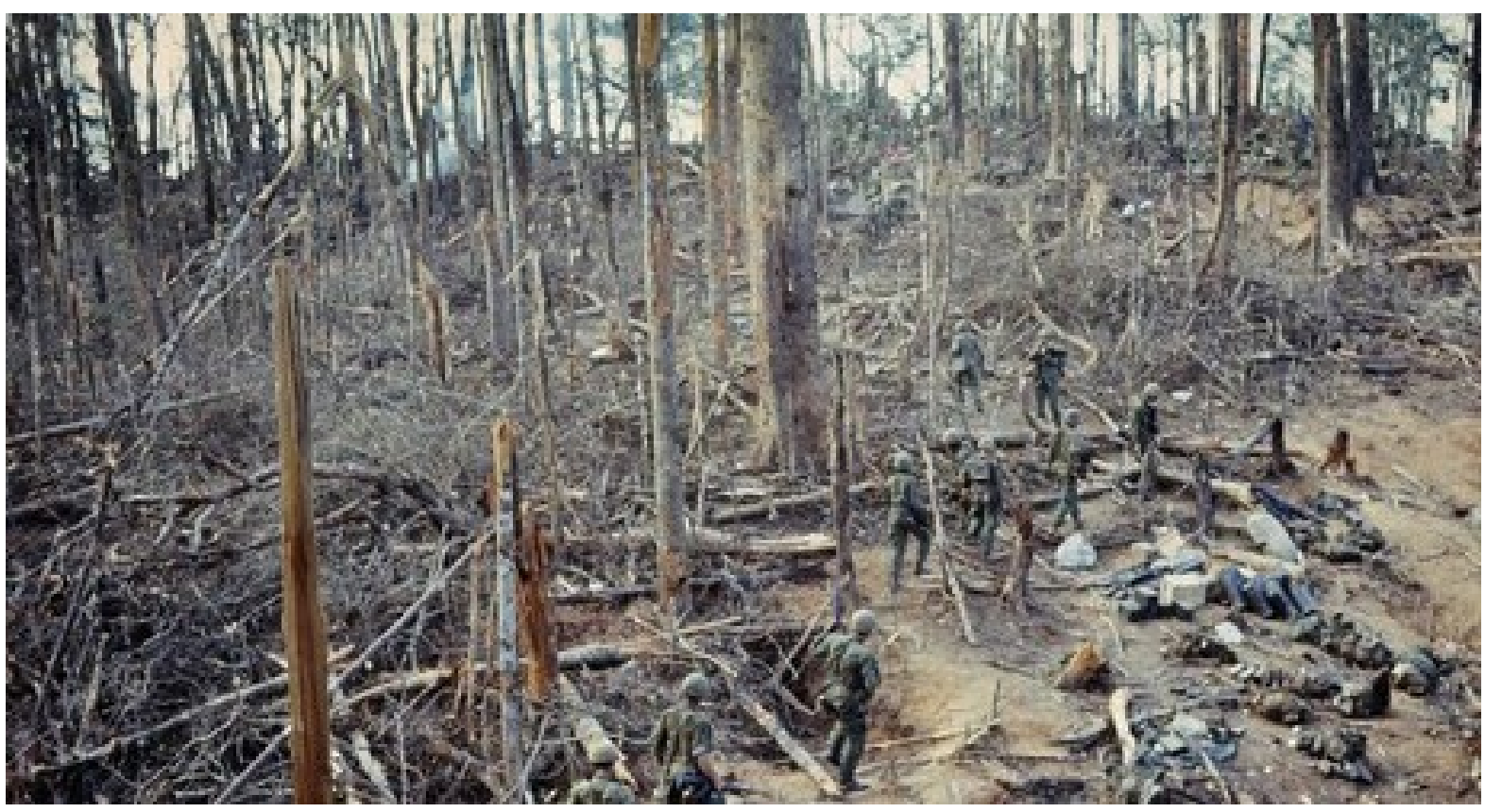

Photo 30: Devastated nature after pesticide-spraying. [Source: Pho-30]

North Vietnam did not relinquish its plans for the unification of the country and launched an offensive in 1975. On April 30, 1975, a Soviet T-54 medium tank used by the People's Army of Vietnam, entered the gate of the Presidential Palace in the South Vietnamese capital, Saigon. 
Since most of the soldiers of the Army of the Republic of Vietnam preferred looting to defending the capitol, the fall of Saigon (known today as Ho Chi Minh City) avoided greater bloodshed. On July 02, 1976, the unified Socialist Republic of Vietnam was proclaimed.

The opinion of experts drawing the attention to the withdrawal of the USA forces from Vietnam was confirmed. After signing the Agreement on Ending the War and Restoring Peace in Vietnam in January 1973, the USA left the corrupt, but pro-American and sharply anti-communist regime of the Republic of Vietnam at the mercy of the communists. The ceasefire was often violated. The official data of Saigon states that there were 136,971 battle deaths (killed in action and died of wounds in action) of the Viet Cong and the People's Army of Vietnam since the ceasefire was negotiated not until April 12, 1975.

About 2,644,000 American, 372,853 South Korean, 47,424 Australian and 3,890 New Zealand soldiers were involved in the Vietnam War. More than 3,000 (according to another estimate even 12,000) Canadians, out of which 56 were killed in action (according to an alternative source 126 were killed in action), served in the American units. Due to colossal losses, the Democratic Republic of Vietnam was forced to engage 3,000,000 of its own soldiers in the conflict. Out of nearly 1,000,000 soldiers of the Viet Cong, 200,000 were women.

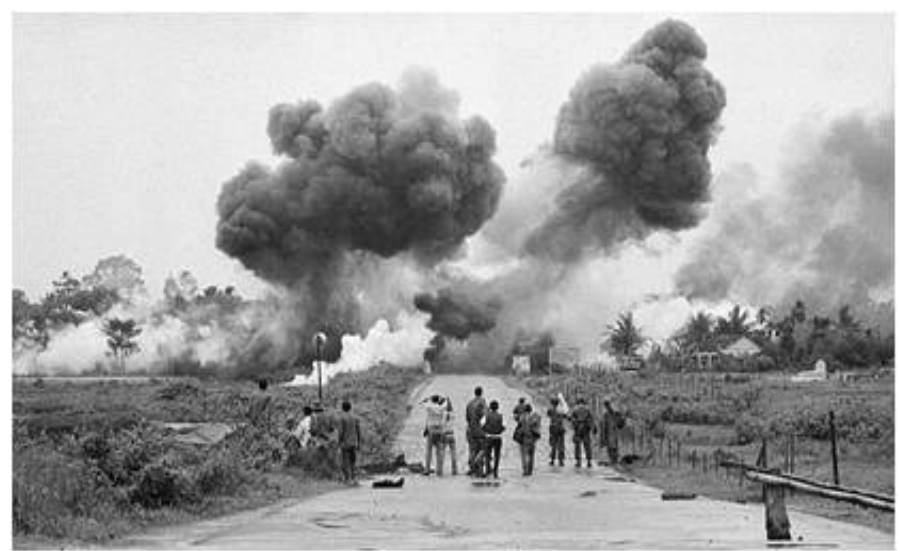

Photo 31: Burning houses at Trang Bang in 1972. [Source: Pho-31]
During the Vietnam War, which officially lasted from August 04, 1964 to January 27, 1973 according to the Americans (but, previously, American advisers were already dying here), a total of $8,752,000$ people served in the United States Armed Forces. It claimed the lives of 58,193 American soldiers $(38,209$ in the Army, 14,838 in the Marine Corps, for which it became even the second bloodiest war after World War II, 2,584 in the Air Force, 2,555 in the Navy and 7 in the Coast Guard); a total of 303,695

American soldiers were wounded (the data comes from 2004). Of these, 47,393 were battle deaths and 10,800 were non-battle deaths.

According to the number of battle deaths, most victims were from California $(4,547)$. 1968 and 1969 became the bloodiest years for the Americans as well as the People's Army of Vietnam and the Viet Cong. The battle deaths of the United States included, among other things, 4 majors, 3 brigadier generals and 160 colonels.

According to Saigon and American sources, there were 196,863 soldiers killed in action and 502,383 wounded in the Armed Forces of the Republic of Vietnam. After adding non-battle deaths, this number rose to

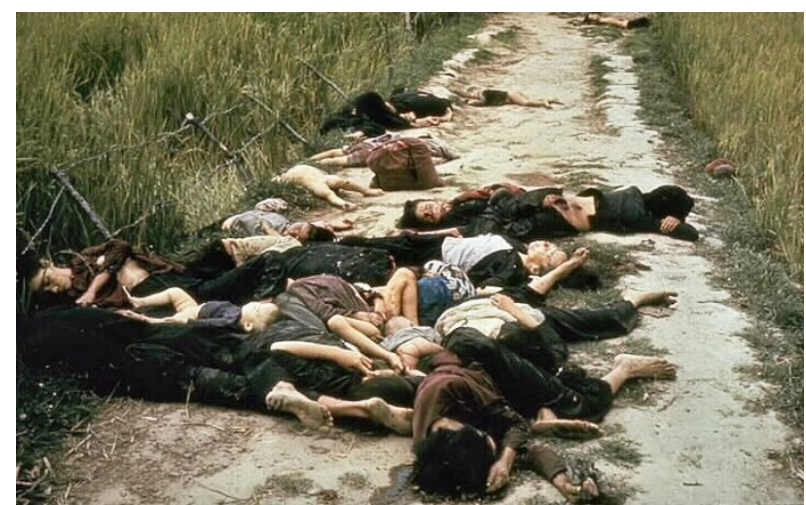

Photo 32: Civilian victims of the Vietnam War. [Source: Pho-32] 220,357 and after including the losses incurred after signing the Agreement on Ending the War and Restoring Peace in Vietnam, this number rose to 254,257 deceased and 783,602 wounded. 
Alongside the United States, soldiers from five countries fought, which the Americans collectively called the free world. Australia lost 3,372 people (out of which 426 were killed in action), the Philippines 9 (7 killed in action), the Republic of Korea 16,335 (5,099 killed in action), New Zealand 267 (55 killed in action) and Thailand 1,709 (351 killed in action), i.e. 21,692 (5,938 killed in action) in total. These are not negligible numbers. It is impossible to determine the exact number of victims on the part of the Democratic Republic of Vietnam and the Vietcong. According to official US and South Vietnamese data, the battle deaths in the Vietnamese People's Army and the Vietcong from 1961 to 1975 were up to 1,027,085 people. Some experts claimed that this figure also included a considerable number of civilians, and the number of battle deaths was reduced to 731,000 .

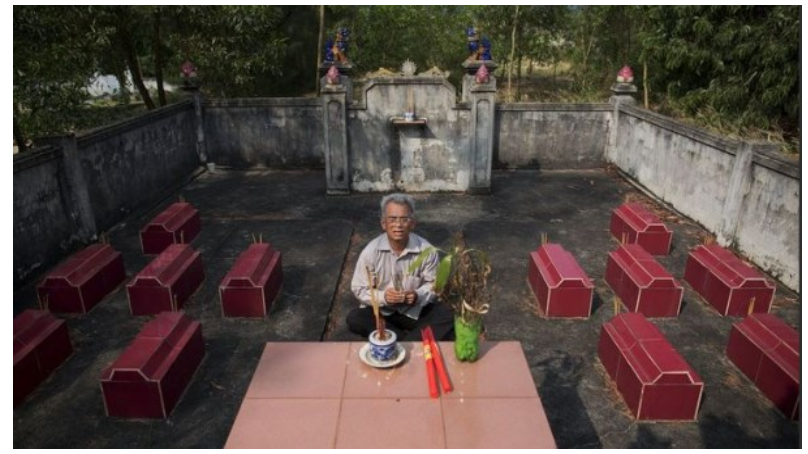

Photo 33: Ex-serviceman Do Duc Diu spent more than twenty years trying for a baby. The children always died and their parents didn't know why. After the birth of the fifteenth child they found out it was caused by a chemical agent in the father's body. All their deceased children are in the coffins. [Source: Pho-33]

It was not until April 03, 1995, twenty years after the end of the war, the Vietnamese news agency (VNA), with reference to the Ministry of Labour and Social Affairs disclosed the top-secret figures for disabled ex-servicemen for the first time. According to these figures, the communist forces lost 1.1 million soldiers in the conflict (lasting twenty-one years), which broke out in 1954, shortly after the Geneva Conventions entered into force. Surprisingly, this corresponds to the American body count so much criticized at that time.

There were also 600,000 wounded soldiers. It is strange that the number of deaths is nearly double although it is usually opposite; that is to say, thousands of people died due to diseases.

In both Vietnams, a total of 2,000,000 civilians died, and the same number of civilians were injured. As a result of pesticide spraying, 50,000 children were born deformed. Army General Vo Nguyen Giap, the Defence Minister of the Democratic Republic of Vietnam, later the Socialist Republic of Vietnam, admitted 330,000 missing people in the People's Army of Vietnam and the Viet Cong. No one dealt with their fate as thoroughly as with the fate of the missing Americans. From July 11, 1965 to December 31,1974 , a total of 6,359 generals and officers of the Soviet Armed Forces took part in the Vietnam War. They had a decisive share in the building of very strong air defence, trained the Vietnamese crews of anti-aircraft

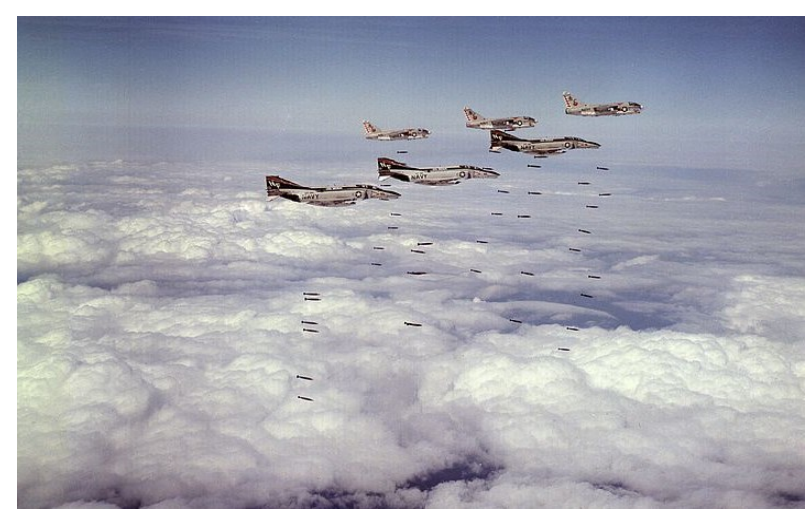

Photo 34: Three fighter-bombers McDonnell Douglas F-4B Phantom II of fighter squadron VF-161 Chargers from the aircraft carrier USS Midway (CVA-41) and three aircraft LTV-7C Corsair II in the attack of air squadron VA-86 Sidewinders from the ship USS America (CVA -66), March, 1973, Vietnam. [Source: Pho-34] missile systems and guns, and trained fighter pilots. Fifteen officers and one private were killed.

As for the People's Republic of China, out of 327,000 members of the Chinese People's Liberation Army (providing logistic support and air defence to the Democratic Republic of Vietnam), a total of 1,446 were killed and 4,200 were wounded. 
The Democratic People's Republic of Korea, which had offered a military contingent to the Democratic Republic of Vietnam as early as 1966 in response to the involvement of opposing South Korea, sent more than 200 pilots to North Vietnam to defend the capital, Hanoi. A total of 14 pilots were killed.

After World War II, the Vietnam conflict, also referred to as the Helicopter War, became the second most expensive conflict for the USA as for the aircraft losses. The USA lost 2,561 aircraft and 2,857 helicopters in combat and 1,158 aircraft and 2,282 helicopters in accidents, i.e. 8,588 in total. According to another source, the USA lost even 8,612 (3,270 aircraft and 4,892 helicopters). Only over the territory of the Democratic Republic of Vietnam, the USA admitted the loss of 1,095 aircraft and 11 helicopters (however, according to the Democratic Republic of Vietnam the loss of aircraft was 4,498).

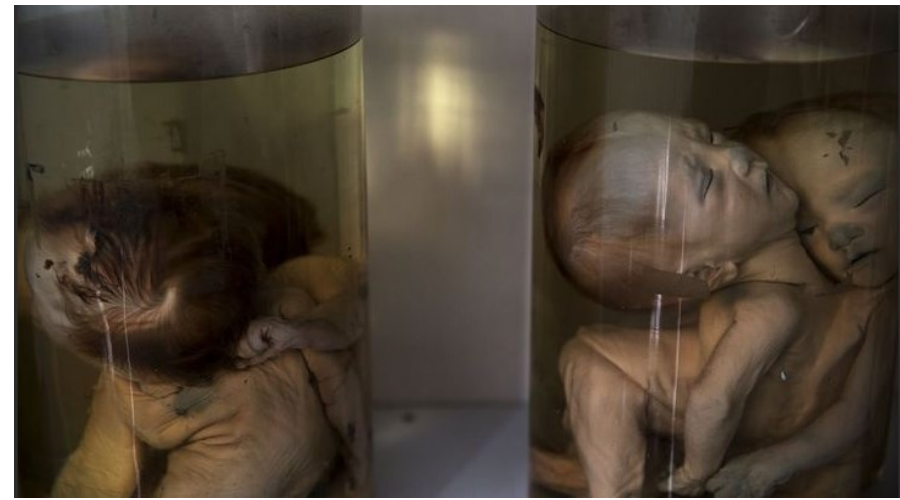

Photo 35: Agent Orange continues to kill even 40 years after the war. About 5,000,000 people were exposed to its effects; more than 3,000,000 of them suffered or still have been suffering from killer diseases. [Source: Pho-35]
From 1966 to 1972 , the US aircraft dropped 7,508,884 tonnes of explosives in Indochina, while during World War II it was only 2,057,244 tonnes on all battlefields. An American general threatened that the United States should bomb North Vietnamese back into the Stone Age. By 1970, US Army Ground Forces fired 5,759,933 tonnes of explosives in Vietnam. The amount of ammunition used by the United States from 1965 to 1971 in Indochina was $213 \%$ of the ammunition used by the Americans during World War II on a much larger territory. From 1965

to 1971 , a total of $274 \mathrm{~kg}$ of bombs, rounds and other ammunition per capita were used in Vietnam. That is about as much as the annual consumption of steel per capita in Finland, and twenty-five times the consumption per capita in Vietnam.

The massacre committed by American soldiers in My Lai, in which 567 people lost their lives, children crippled after the US Air Force bombing, the South Vietnamese Police Chief executing a detained member of the Viet Cong in a Saigon street, a shocking treatment of prisoners in the South Vietnam tiger cages, sadistic interrogations of prisoners of war and civilians - all these photographs circled the world and certainly did not gain affection for the USA and its Asian ally.

During Operation Phoenix focused on eliminating political and military cadres of the Viet Cong, a total of 26,369 Vietnamese was slaughtered in the course of five years. Many of them represented only small fry in the insurgent movement. Informing became commonplace. The atrocities

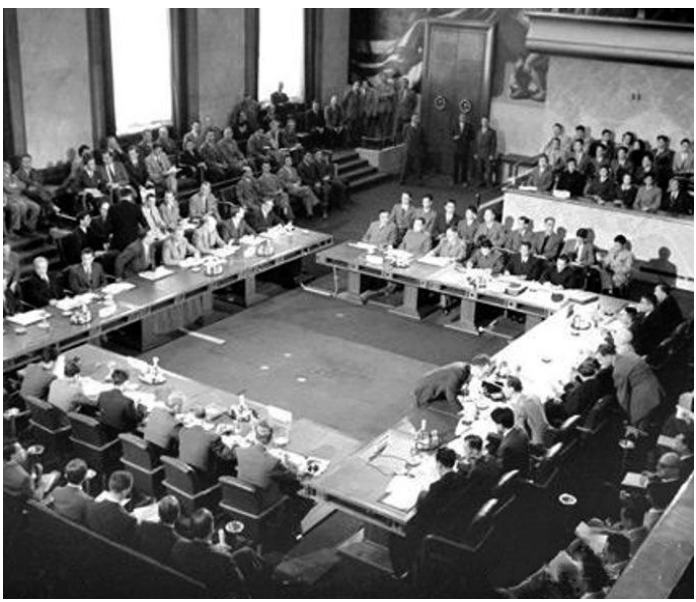

Photo 36: The Geneva conference where the fate of Vietnam was negotiated.

[Source: Pho-36] were committed by the Americans, by the South Vietnamese government forces on their own people, but also by their allies. On February 12, 1968, the $2^{\text {nd }}$ Marine Brigade of the Republic of Korea Marines massacred 80 civilians in the village of Phong Nhi. 
On our side of the Iron Curtain, it was concealed that, from 1957 to 1972, the Viet Cong and the People's Army of Vietnam massacred up to 36,725 people, often teachers and chairmen of municipal councils, who were guilty of a mere loyalty to the Saigon government, and kidnapped other 58,499 people. After the liberation of Hue, a total of 2,800 bodies of people killed by the Viet Cong during the Tet Offensive in 1968 were found. Of these, 1,892 were administrative staff, 38 police officers and 790 other civilians. On December 05, 1967, 600 soldiers of the Viet Cong equipped with 60 flamethrowers destroyed the village of Dak Son, inhabited by mountain dwellers cooperating with the Saigon government, and burned 252 people alive. A total of 50,000 young Americans preferred an exile to the service in Vietnam and 12,000 Americans deserted, which is nothing when compared with the Armed Forces of the Republic of Vietnam; from 1968 to 1971, 490,936 Vietnamese deserted. The destinations of Americans who avoided military service became Canada where 30,000 Americans found asylum, and Sweden with 1,000 asylum seekers. During the presidency of Bill Clinton, in 1995, the United States and the Socialist Republic of Vietnam, after years of hostility, declared the normalization of diplomatic relations. However, it does not mean a definite end of the unfortunate conflict. By June 01, 2006, the Americans still registered 1,805 missing people in Indochina and 1,376 in Vietnam. They continue searching intensely for their fates.

The Vietnam War was also a disaster for Cambodia where guerrillas opposed the military junta. Finally, the brutal Khmer Rouge captured Phnom Penh on April 16, 1975. Their tyranny, when they were introducing Maoist agricultural communism, claimed up to 3,000,000 lives before Pol Pot was overthrown by Vietnam in 1979. During the Egyptian-Israeli war of October 1973, the then Soviet Union and the USA threatened each other with the use of nuclear weapons (USSR on the side of Egypt, USA on the side of Israel).

\subsubsection{Nuclear carriers - strategic bombers}

In 1946, the US Air Force created the Strategic Air Command (SAC), i.e. a special headquarters responsible for the deployment of strategic bombers, mainly carrying nuclear weapons. However, the Soviet Union was not idle either - only two weeks later, the Long-Range Aviation Headquarters (Komandirovanije dalněj aviacii - KDA) was established. The Russians understood well the great importance of bombers, which were (as in the USA) perceived as the main nuclear delivery system. However, this lasted only a short time, as the main carrier of nuclear

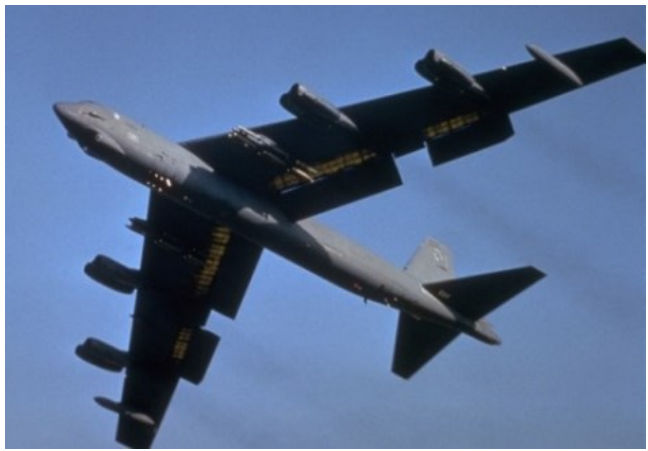

Photo 37: B-52 Stratofortress US strategic bomber is flying to bomb Iraq during Operation Desert Storm. [Source: Pho-37] warheads soon became inter-continental ballistic missiles (in the US were included under the SAC, in the Soviet Union created a special component - RVSN, missile forces of strategic deployment).However, this did not take long as intercontinental ballistic missiles soon became main nuclear carriers (in the USA they came under the SAC, in the Soviet Union they formed a special component, i.e. the Strategic Missile Forces).

After introducing the first nuclear bombs into the inventory of the USA and the USSR intended for strategic aerial delivery systems, military planners raised requests for the development of this equipment to be used in the Navy, Army and Air Defence. In the ground forces, the intention was to use mass destruction devices from the level of divisions, brigades and in some cases even regiments. It was based on the philosophy of nuclear weapon deployment at that time, which should have been identical with conventional ammunition deployment, with the only difference being that these were weapons of very high efficiency. 


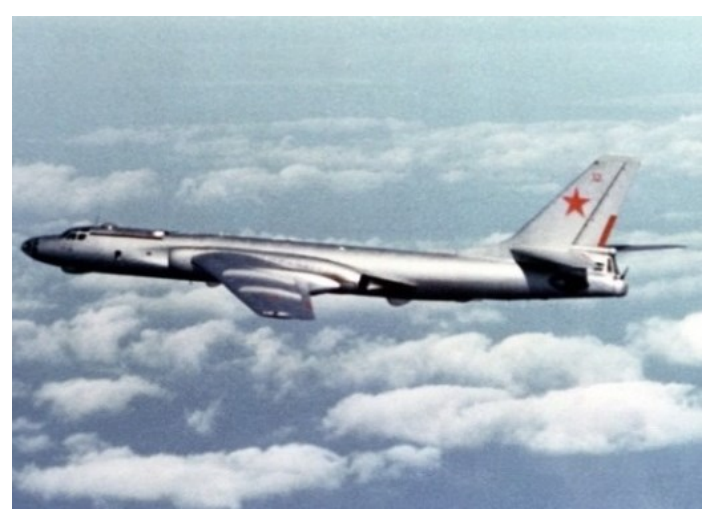

Photo 38: The Tupolev Tu-16 (NATO codename: Badger) was a Soviet or Russian long-range bomber. [Source: Pho-38]

To fulfil this intention, appropriate nuclear weapon delivery systems together with the development were sought so that they could be used with the existing conventional means. It concerned reducing their weight and size while maintaining or even increasing the effects of weapons and later also their miniaturization. The emphasis was laid on their resistance when in use under field conditions and the possibility of sustained storage without the frequent exchange of components with a limited service life.

For the delivery of these weapons, the systems of barrel artillery and missile artillery were being developed or, if need be, modified. At the same time, a discussion was held whether to use tracked or wheeled vehicles as a chassis for tactical missile systems and how to ensure sufficient mobility of barrel artillery systems of high yield and whether to produce them in self-propelled or towed versions. Last but not least, it was necessary to develop means of preparation, maintenance and security of these nuclear weapons so that they could be used under field conditions.

After that, in the 1960s, intercontinental ballistic missiles carrying nuclear warheads appeared. As both the USA and the USSR could hit the entire state territory of an enemy easily, further feverish nuclear arms race became meaningless. Although initially the intercontinental ballistic missiles were only stationary and were positioned in launch silos (where they were easily vulnerable), later, these important combat means became mobile and thus hardly detectable and vulnerable.

Bombers played only a supporting role and, in a hypothetical nuclear war, their task was to clean the targets, which had not been

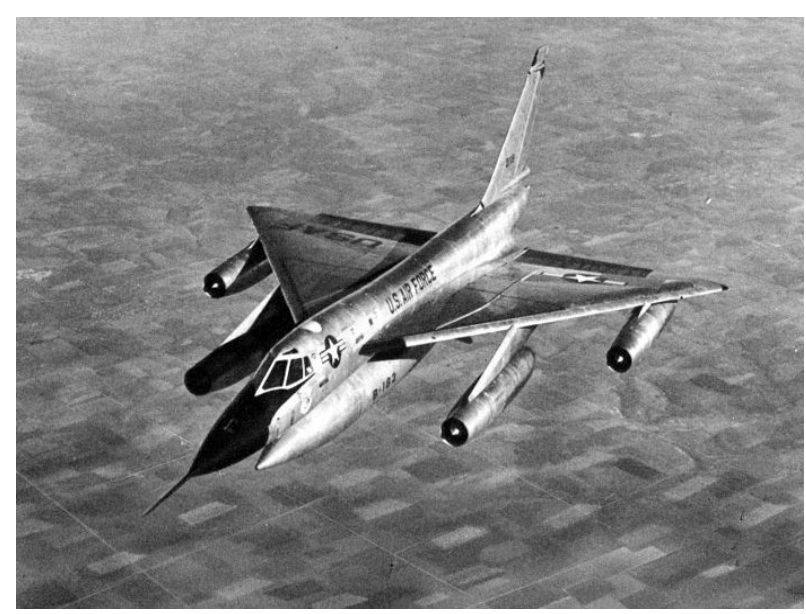

Photo 39: The US Bomber Convair B-58 Hustler. [Source: Pho-39] destroyed during the first missile nuclear attack. Unguided nuclear bombs were standard armament of bombers. In the 1960s, guided nuclear air-to-surface missiles (American AGM-69 SRAM or Soviet Ch-22) and in the 1980s, Air-Launched Cruise Missiles (American AGM-86 ALCM or Soviet Ch-55) were produced. It can be said that the long-range bombers in the Soviet Union fulfilled another specific task - in addition to the Air Force they were also used in the Navy where they served as carriers of heavy anti-ship missiles that should have been a silver bullet that would overcome the defence of US aircraft carriers.

The Soviets also exported their bombers (namely Tu-16 and Tu-22), i.e. a number of thirdworld countries also had a certain quasi-strategic Air Force (although non-nuclear, with the exception of China). Large jet bombers were developed by other countries, namely England (types: Valiant, Victor and Vulcan) and France (Mirage IV), as well as in both superpowers, however, the primary means of transporting nuclear warheads are ground or submarine ballistic missiles. 


\subsubsection{New application of bombers}

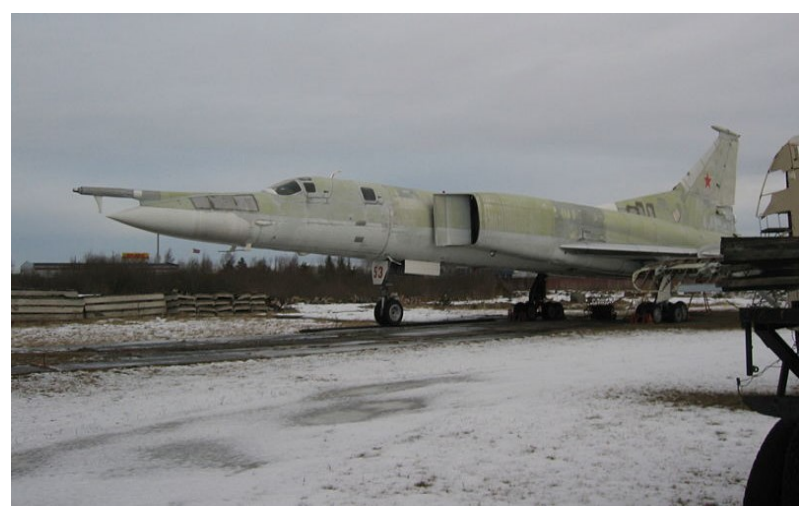

Photo 40: The Soviet bomber Tu-22M.

[Source: Pho-40]

Of course, the aircraft of the American Strategic Air Command (SAC) and the Soviet Long-Range Aviation Headquarters were on call and carried out long patrol flights with live munitions on board so that they could attack the enemy immediately in case of the outbreak of a conflict. Fortunately, this fateful command never came. And if we ignore this deployment, then the heavy bombers played only a limited role. Apparently, the use of American B-52 bombers in Vietnam was the most significant, the raid of the British Vulcans on the airport in the occupied Falklands in 1982 was a very interesting episode.

Soviet bombers were used in Afghanistan and were also sent to combat by a few foreign owners (e.g. the Iraqi Tu-22 operation against Iran). Strategic bombers might have seemed to be a very expensive weapon used to a limited extent only, the capabilities of which would be even smaller in the new world after the collapse of the Soviet Bloc. The opposite was true. It soon became clear that this new world order could fit the bombers more than well. This happened soon, already in 1991, when an international coalition took action against the Iraqi occupation of Kuwait. In this operation (i.e. in the Persian Gulf War) American B-52 bombers were also engaged and dropped approximately $40 \%$ of entire air armament used by the coalition. Further operations against Iraq came in 1998 when B-1B supersonic bombers were used for the first time. And, in 1999, hypermodern B-2A spirit stealth bombers (difficult to be detected), during Operation NATO Allied Force launched in response to Serbian President Slobodan Milosevic, were also used for the first time. All the three types of American bombers played a significant role in the post-September $11^{\text {th }}, 2001$ conflicts in Afghanistan and Iraq.

Generally, it was clear that a strategic bomber is very efficient as a platform for delivering many precision-guided conventional weapons against an enemy with a weak (or decommissioned) air defence. In particular, the operation against Yugoslavia revived the view that the air force is capable of winning the war in itself. With reference to the specificity of that conflict as well as other factors, such a statement is very controversial; however, it is true that the American strategic bombers have found their position and role even in the new world order.

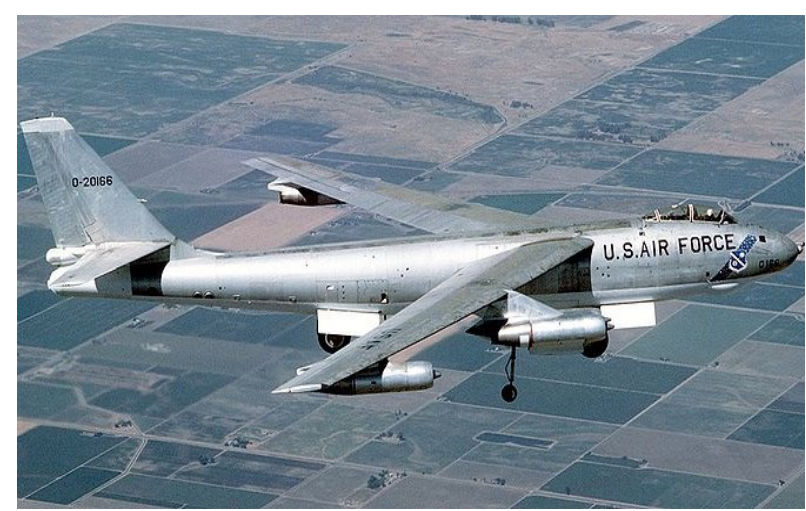

Photo 41: The US Boeing B-47 Stratojet Bomber. [Source: Pho-41]

This change is also reflected in the new organizational structure of the US Air Force. The legendary SAC was dissolved in 1992 and all its combat aircraft and ballistic missiles were moved under the ACC (Air Combat Command). Then in 2009, the extensive capability of bombers in their new role was important for the establishment of the new Air Force Global Strike Command (AFGSC), which practically represents a direct SAC successor. Minuteman III intercontinental missiles and B-52H and B-2A bombers were moved from the ACC to subordination of the new AFGSC. 


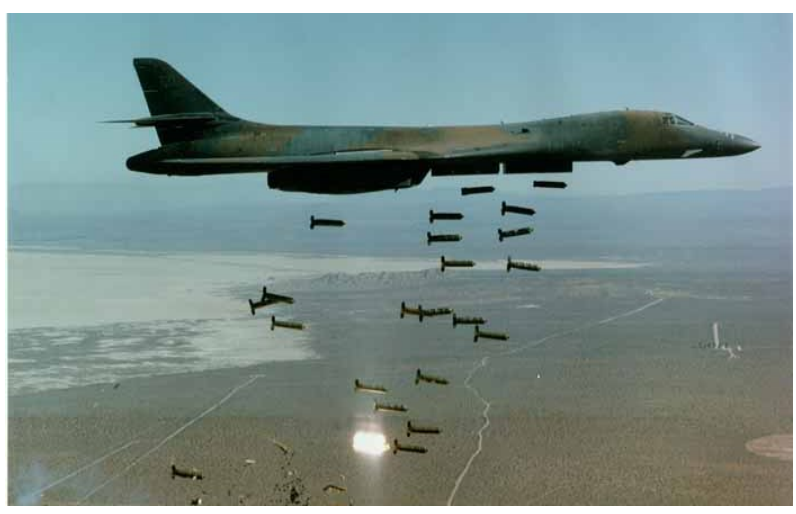

Photo 42: The US B-1B Lancer Bomber. [Source: Pho-42]
The mission of the AFGSC is to ensure nuclear deterrence and carry out (also nonnuclear) global attacks. However, the B-1B supersonic bombers remained in the ACC structures because they were in fact denuclearized and essentially no longer expected to carry nuclear weapons. Their role was taken over by the B-52H bombers. Admittedly, they are still capable of it technically, but now the mission of B-1B supersonic bombers is exclusively conventional. If we look at the AFGSC current aerial potential, we see that the most numerous types are the obso-

lete Boeing B-52H Stratofortress bomber. A total of 85 aircraft are included in active service and 9 aircraft are in reserve.

Despite of its age, the B-52 (nicknamed BUFF, Big Ugly Fat F**** $\mathrm{r}$ ) is still a very effective weapon, mainly due to its huge load-carrying capacity (about 30 tonnes) and a huge range (over 7,000 km). All of them are constantly being modernized, especially in the field of electronics, but there is also a lot of talk about replacing engines, because the current units are simply inefficient. The blended-wing-body Northrop Grumman B-2A Spirit represents an opposite pole of the spectrum. Generally, a total of 21 pieces have been produced and 19 pieces should be in service. The B2-A is capable of transporting slightly fewer weapons (23 tonnes only); however, it makes the detection by radar difficult, which is its principal advantage. Nowadays, it is unstoppable for air defence of most countries. The B2-A is a unique aircraft which, by contrast with the B-52 and B-1B, has no counterpart outside the United States.

The American B-52H, B-1B and B-2A bombers began to be used more for transporting precision-guided conventional weapons. In addition to the USA, the Soviet Union also built extensive strategic bomber aviation and most of this force was inherited by present-day Russia, which also faced the task of how best to deal with it and use it.

The Boeing (earlier Rockwell) B-1B Lancer strategic bombers that, theoretically, can transport more weapons than any other aircraft in history (approx. 60 tonnes) and have a maximum speed equivalent to Mach 1.25 at higher altitudes come under the ACC. Just as the $\mathrm{B}-52 \mathrm{H}$, the $\mathrm{B}-2 \mathrm{~A}$ and the $\mathrm{B}-1 \mathrm{~B}$ are also improving and their arsenal is expanding. So far, the latest development is the GBU-57/B Massive Ordnance Penetrator (MOP), which is a powerful bunker-busting bomb that could penetrate underground nuclear facilities. For a long time to come, the

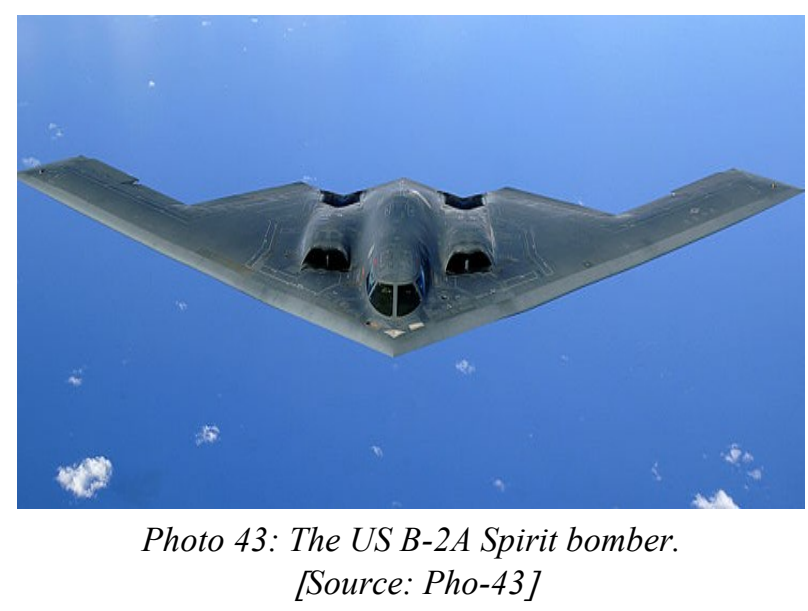
B-52 is expected to play an active role in the field of cyber-space security, which was until recently nearly an inconceivable idea for these bombers. Nowadays, Russia as well as the USA own three types of bombers, although their structure is noticeably different. The Tupolev Tu-95MS (NATO code name: Bear-H) that, due to turboprop engines, looks more archaically than the B-52H but analogous to its American counterpart it distinguishes itself by a large mission capability. 


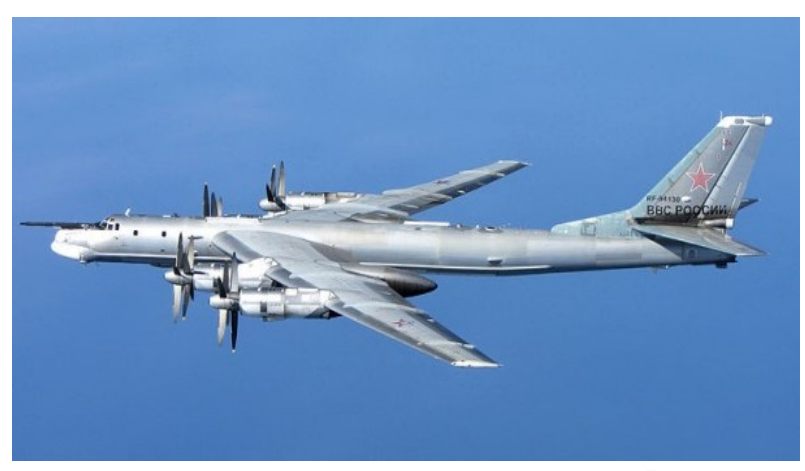

Photo 44: The Russian Tupolev Tu-95 Bear bomber. [Source: Pho-44]

The Tu-160 (NATO code name: Blackjack) is the most efficient Russian bomber, which at an altitude reaches a speed of Mach 1.87 and can travel $15,000 \mathrm{~km}$ without refuelling. It is larger than the American B-1B and is considered to be the largest bomber in the world. Nowadays, the Russian LongRange Aviation Command operates more than 30 Tu-95MS bombers (approx. 60 bombers are in reserve) and $16 \mathrm{Tu}-160$ bombers (a few bombers are in the process of construction and they are expected to be

introduced gradually into inventory).

The last bomber is the Tu-22M (NATO code name: Backfire) that is often a discussion topic since it occurs at the bottom of the strategic bombers category and is also used in this way, although it does not rank among them formally. Russia owns about $150 \mathrm{Tu}-22 \mathrm{M}$ bombers of different versions, considerably fewer, about 40 bombers, are in operation (the newest is Tu-22M3). Doubtlessly, the results of the deployment of American bombers in the 1990s impressed Russia, especially the fact itself that these aircraft gained ground.

It can be seen most due to the ongoing modernization of all three types of Russian bombers - the Tu-95MSM, Tu-160M and Tu-22M3M. The main change is to improve the quality of electronics and expand the armament with guided conventional anti-ground weapons. Russia has also resumed patrol flights of nuclear bombers and is using its aircraft, even as a demonstration of strength, especially in the form of violating some Western countries' airspace. The pilots of the Czech JAS-39 Gripen fighters patrolling over the Baltics could also regularly meet the Russian bombers during their missions.

The current methods of deploying strategic bombers prove that it is a category of equipment with an extensive capability. Just versatility and flexibility are the properties that the proponents of bombers mention most often when high acquisition and operation costs of these bombers are criticized. Except for nuclear deterrence and transport of plenty of conventional munitions, there is a varied spectrum of roles resulting from especially the maximum load capacity, radius of action and speed of bombers.

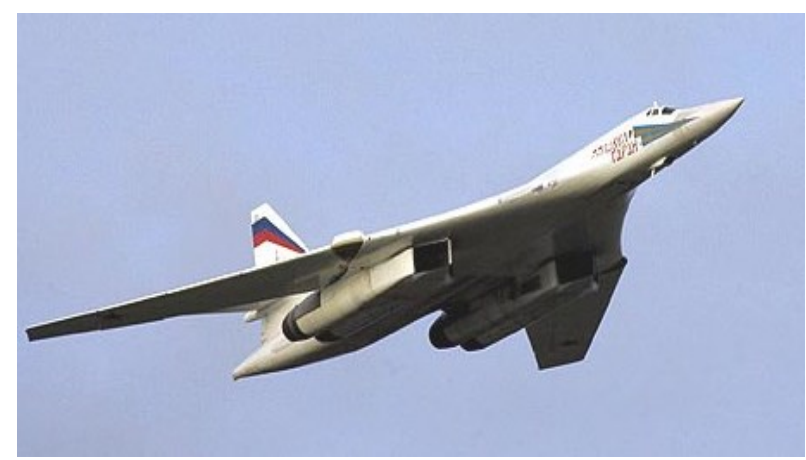

Photo 45: The Russian Tupolev Tu-160 Blackjack long-range strategic bomber. [Source: Pho-45]

For instance, it is possible to adapt them for reconnaissance, electronic warfare or suppression of the enemy air defence (Russia has even developed special versions of the Tu-22M3 aircraft for these purposes). From time to time, an interesting idea to equip bombers with anti-aircraft guided missiles also appears. In the USA, they also speak about the possibility that bombers could carry AIM-120 AMRAAM (Advanced Medium Range Air to Air Missile).

Such aircraft would have not only a better possibility of their own defence, but they could also operate actively as a kind of airborne launch platforms with a large number of air-to-air missiles, using which the numerical superiority of the enemy Air Force would be eliminated from a safe distance. Some sources state that the B-1B aircraft can carry missiles AMRAAM suspended externally. 
The speed and carrying capacity of bombers were also in the studies, according to which they could be ideal platforms for anti-missile defence (in reality, the concept of air-launched Patriot PAC-3 missile modification has already been published) or for launching anti-satellite missiles.

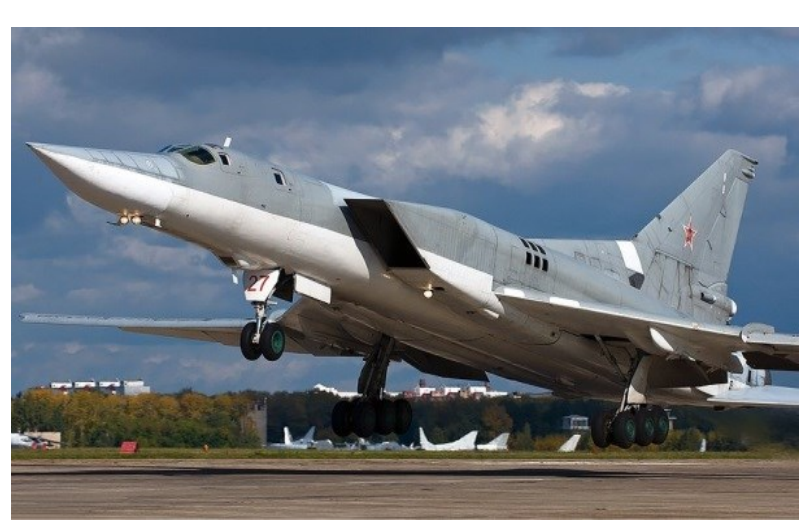

Photo 46: The Russian Tupolev

Tu-22M3 Backfire bomber. [Source: Pho-46]

There is also a possibility to launch small launch vehicles from them - it is known that the Burlak air-launched satellite launcher was developed for the Tu-160 and is capable of carrying about a tonne of cargo into low Earth orbit. The enormous power of bomber engines may also serve as a power source of electric generators that would feed energy-directed weapons, e.g. lasers, microwave emitters or plasma projectors. Finally, an airborne aircraft carrier alternative can also be mentioned, i.e. an aircraft launching unmanned air vehicles for various purposes.

The B-52 has already been operated in this role. The extensive potential of bombers is, therefore, one of the main reasons why new types of this category are being developed.

\subsubsection{LRS-B and PAK DA projects}

Apart from the modernization of existing bombers and the expansion of their arsenals, the Air Forces of the USA as well as Russia count on new aircraft. Based on current plans, the oldest B-52H and Tu-95MS aircraft should be taken out of service after 2030, however, experts have already started to work on qualitatively new types of strategic bombers. In the USA, a few projects of aircraft have been started (and ended again) and presently there is an LRS (Long Range Strike) program. However, it is necessary to emphasize that the LRS will be a system of systems for attacks at longer distances, in which the new strategic bomber (LRS-B) will be only one of the elements, although probably the main one.

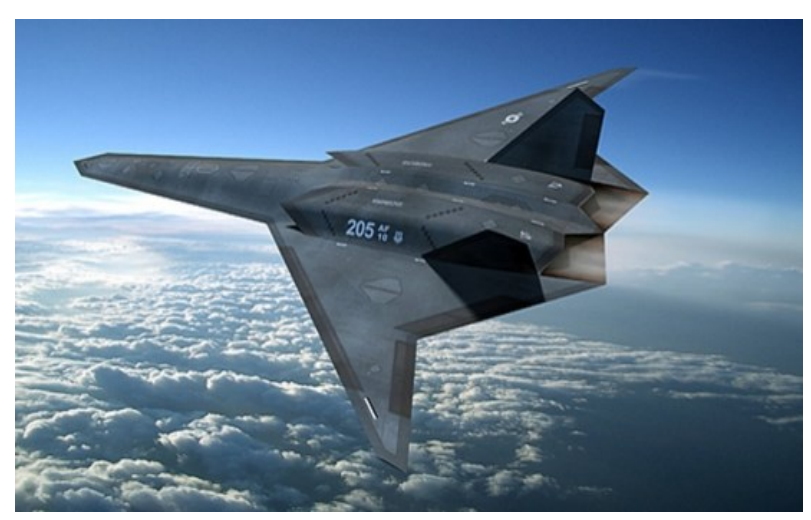

Photo 47: Lockheed Martin's Long-Range Strike Bomber (LRSB) concept. [Source: Pho-47]

There is only a little specific information about this aircraft. Actually, it is not known whether it will have a human crew on board. At a certain time, unmanned aircraft were planned, but according to the last information the new bomber seems to have a human crew after all (or there will be an optional possibility to operate without it). Whereas the stress will also be laid on cost efficiency, the LRS-B will be most likely a subsonic aircraft since the supersonic speed would require much more expensive construction. The US Air Force would like to put the new aircraft into operation before 2030, however, in view of the Pentagon budget cuts it is not sure whether it succeeds.

Russia has been working on a bomber denoted PAK DA (Perspektivnyj aviacionnyj kompleks dalněj aviacii) since 2007. In summer 2012, the basic design suggested by the Tupolev Design Bureau was confirmed and the optimistic estimates claim that the prototype could already fly in 2020 . 
Little is also known about the Russian aircraft, although the unmanned aircraft has never been mentioned. According to a few statements, it should be a hypersonic aircraft (flying at speeds above Mach 3), however, it was obviously misleading. The bomber itself will probably be only supersonic and the guided missiles carried will reach hypersonic speeds (up to Mach 12). The USA also counts on this feature of future air-launched guided missiles for bombers.

Russia has been inspired by the American adaptation even if, in its case, the transformation is slower. All the more it employs

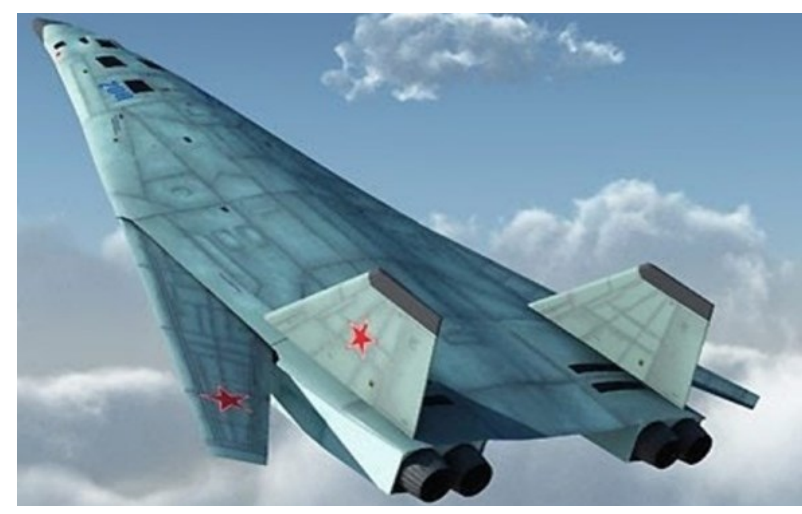

Photo 48: One of possible PAK DA variations, which has appeared on the internet forums

/www.anti-teror.ucoz.ual. [Source: Pho-48] its bombers as symbolic means to notify: "We are still here; you have to count on us". It is clear that strategic bombers continue to represent an important and efficient weapon that offers an exceptional potential for air forces of the great powers. Thus, we can expect they will retain their role and efficiency in the future as well.

\subsubsection{Possibilities of other superpowers in the $21^{\text {st }}$ century}

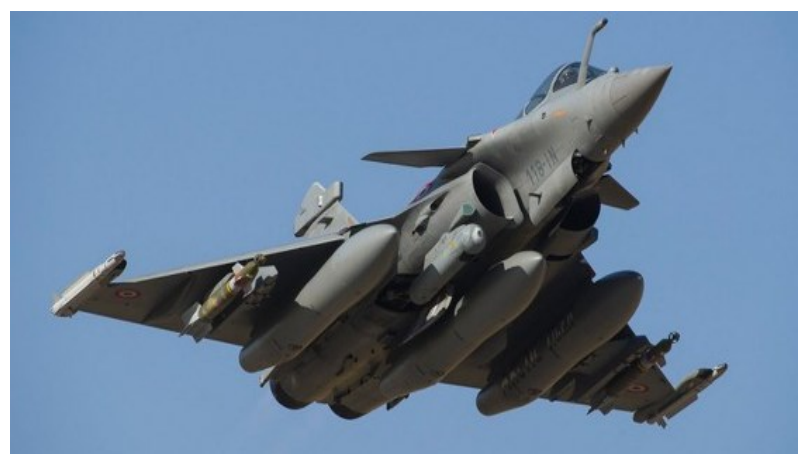

Photo 49: The French Rafale aircraft. [Source: Pho-49]

Great Britain has abandoned the airborne component of its nuclear deterrent force completely while the French Air Force bets on guided missiles for Mirage 2000 and Rafale fighters. The People's Republic of China remains the only other country possessing strategic bombers in service.

Its Air Force and Navy use more than 120 Xian H-6 aircraft, which are improved copies of the Soviet Tu-16 (NATO code name: Badger). The last versions, such as the $\mathrm{H}-6 \mathrm{M}$ and the H-6K, differ considerably from the original Soviet type and serve as cruise missile carriers.

Generally, it is assumed that China has also been preparing a new type of strategic bomber. According to some sources, it will be a comprehensive development of the H-6, while according to other sources it will be a completely different design (probably a blended-wing-body). It is also known that China intended to buy the Tu-22M3 bombers from Russia in 1998, but this did not happen. India has a similar intention and this possibility cannot be excluded in the future. India has already been using the Tu-142M long-range maritime patrol aircraft, which is a variant of the Tu-95 bomber. However, it is not known that India would

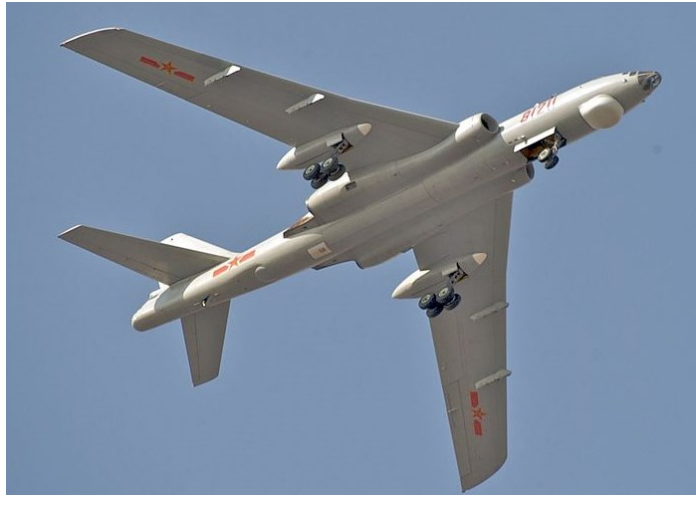

Photo 50: The Chinese Xian H-6 bomber. [Source: Pho-50] take any interest in developing its own strategic bomber as it relies especially upon cruise missiles carried by tactical combat aircraft. A possible Chinese bomber is probably a future affair; it means that the US and Russian Air Forces will continue to play a key role in the future. 
In the case of the USA, it is apparent that the bomber aviation has fully mastered the adaptation to the new world. The two of three types are all the time the significant nuclear deterrent force and all three can serve as efficient platforms for the transport of a considerable quantity of guided conventional weapons and be engaged in a broad spectrum of conflicts.

\subsubsection{Tactical equipment}

\subsubsection{Tactical equipment of the USA and Russia (the Soviet Union)}

The first American unguided solid-propellant tactical artillery rocket introduced into the US and later NATO armament, was the HONEST JOHN rocket. Its development began in the time of war and the first tests took place in 1951. The actual introduction of this device took place in 1953. During the gradual improvement of the rocket, the range of fire was extended from the original approx. 27 up to 37 kilometres. Since 1956, its smaller version Little John was being developed and after 1961 it was introduced into the armament. It was designed for transport by aircraft (W-45, Mod. 1, 2, 3 with the tonnage from 0.5 to $15 \mathrm{kt}$ ).

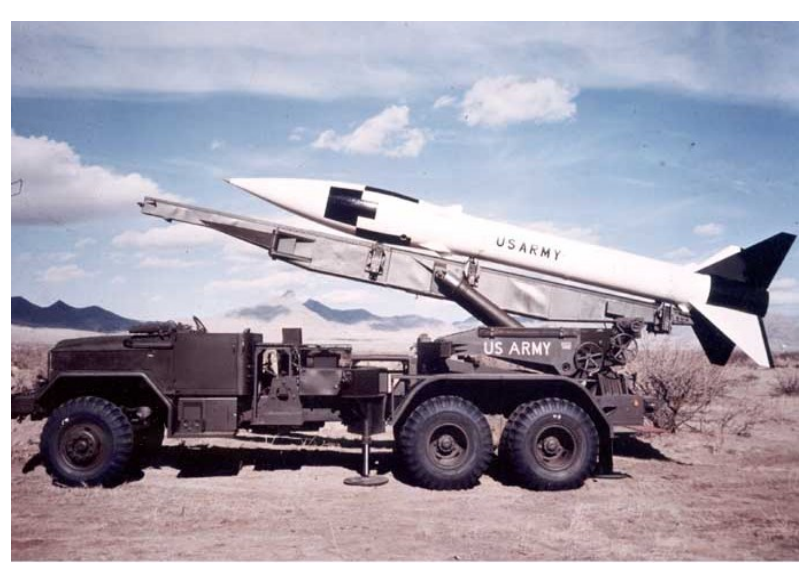

Photo 51: The MGR-1A Honest John artillery rocket. [Source: Pho-51]

The first American tactical guided missile was the LACROSS-M4E2 missile renamed to MGM-18A in 1963. The batch production took place between 1957 and 1960. The LACROSS carried a warhead weighing 181 up to $244 \mathrm{~kg}$ with the range of fire from 8 to $34 \mathrm{~km}$. The missile was equipped with the W-40 nuclear warhead with yield up to 10 kilotons (from 1959 to 1962400 nuclear warheads were made).

It was a hybrid between ballistic and cruise missiles. The OKB-52 attempt to design a Russian LACROSSE - a system of $B A B Y$, orig. Малютка, has failed. In response to the American "MATADOR" and "MACE" tactical surface-launched missiles, the USSR created the KS-7 and S-5 (FKR-1,2) cruise missiles. In 1972, the LANCE tactical missile with the range of fire of 110 up to $120 \mathrm{~km}$ with nuclear combat part XM234 was introduced into the armaments.

In the late 1950s and early 1960s, only a few dozens of solid-propellant tactical rockets were produced in the USSR, such as MARS-3R1 (NATO designation - Frog-2), calibre: $324 \mathrm{~mm}$, and FILIN-3R2 (NATO designation - Frog-1), calibre: $612 \mathrm{~mm}$ (originally, 3P-1 Марс and 3P-2 Филин), tested since 1955, with the over-calibre nuclear warhead $600 \mathrm{~mm}$ in diameter - weight $565 \mathrm{~kg}$ and $850 \mathrm{~mm}$ - weight $1200 \mathrm{~kg}$, range of fire 17.5 and $25.7 \mathrm{~km}, 2 \mathrm{P} 4 \mathrm{TEL}, 2 \mathrm{P} 3$ transporter, on the PT-76 chassis with two

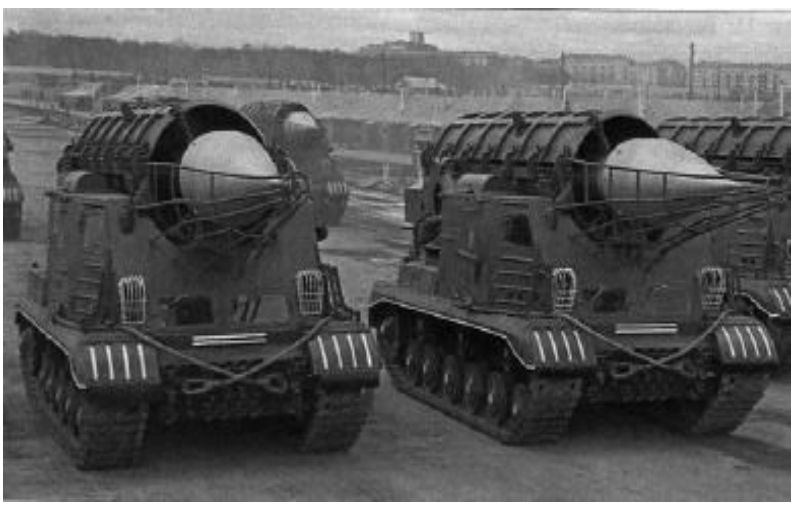

Photo 52: FILIN-3R2 (Frog-1). [Source: Pho-52] rockets and crane).

Only the LUNA tactical missile system (according to NATO - Frog-3) and later the LUNA-M (according to NATO - Frog-7) became mass-produced unguided tactical missiles. 


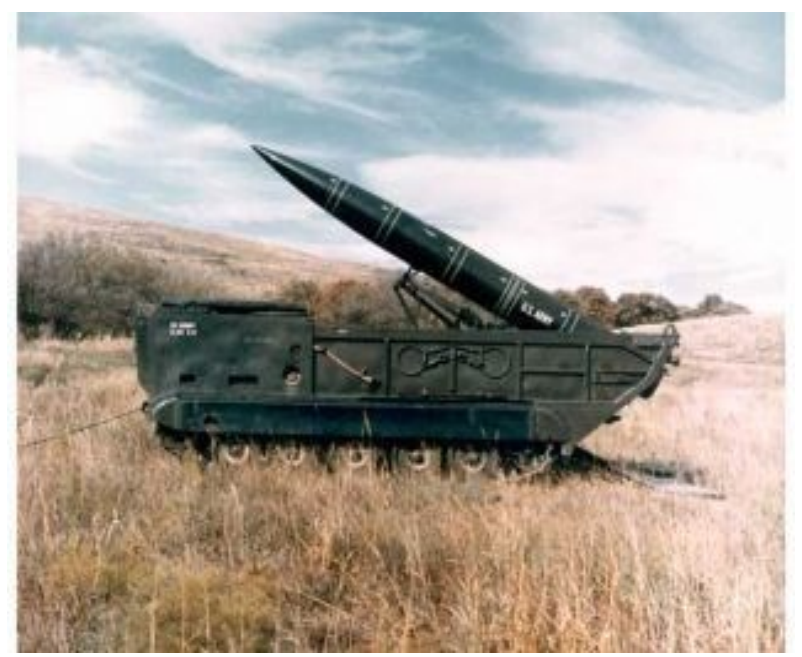

Photo 53: The MGM-52 LANCE (SS-21) tactical guided missile. [Source: Pho-53]

As a nuclear weapons delivery system, the system of mobile missile-technical bases (MMTB) called POLE was introduced, which was designed as a multipurpose system for a nuclear grenade - calibre $406.4 \mathrm{~mm}$, a nuclear mine - calibre $420 \mathrm{~mm}$ and a nuclear warhead for the FILIN missile on the chassis of the ZIL vehicle.

In 1959, the intention to introduce tactical missiles in the ground forces of the USSR was changed; therefore, the STEP system of mobile-missile technical bases for $2 \mathrm{~K} 6$ was developed. The STEP systems of mobile-missile technical bases were also used for tactical missiles stationed in Cuba (see the Cuban missile crisis).

The response to LANCE came in 1971 when the Soviets began to work on the first tactical guided missile of the TOCHKA system modification, variant $R$ that had a passive homing system $(R L S)$. In comparison with the original Tochka only the part of the missile head was exchanged. The hit accuracy in the case of continuously moving targets was 45 metres. This TOCHKA modification was introduced in the armament of the USSR in 1983.

In 1984, the modernization of the TOCHKA system to the TOCHKA-U modification took place. The aim was to increase the range of the device and the accuracy of hit. This was achieved through modifying the software of the guidance system, whereas the experience acquired from the introduced antiaircraft system (the $V-611$ missile and the M-11 system) was used. The TOCHKA and TOCHKA-R systems had a range of 15 up to $70 \mathrm{~km}$. According to the type of combat part, the missile is designated as $9 \mathrm{M} 79 \mathrm{~F} / \mathrm{F}-1$ (fragmentation type), $9 \mathrm{M} 79 \mathrm{~K}$ (cluster type), AA-60 (nuclear type), etc.

The TOCHKA-U short-range ballistic missile had a range of 20 up to $120 \mathrm{~km}$, with $C E P$ at a maximum range of fire, 200 up to $300 \mathrm{~m}$. The warhead component was nuclear (AA-60), fragmentation (OF) $9 \mathrm{~N} 123 \mathrm{~F}$ and 9N123F-1 (passive homing system), cassette 9N123K (9N24 fragmentation submunitions), etc. The missile is guided during all its flight time. The system was introduced in the armament in 1989.

The transporter was intended for missile transportation, loading/unloading and the attachment of missiles and warheads. It was possible to place 2 missiles with combat

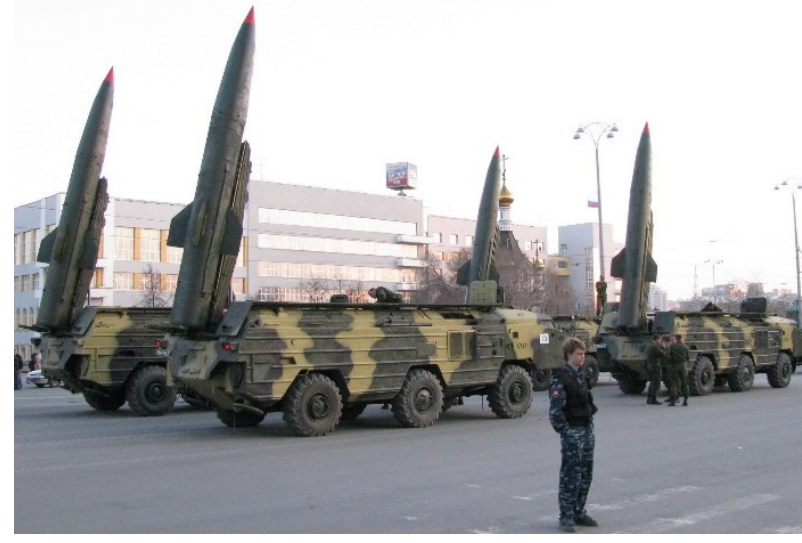

Photo 54: The 9M79K TOCHKA-U (SS-21 Scarab) tactical guided missile. [Source: Pho-54] components or 4 containers of warheads in it. The triad of offensive nuclear weapons of destruction also includes nuclear submarines with nuclear weapons aboard.

They are highly mobile and identifiable with difficulty, and thus little vulnerable, which causes that these combat means are nearly absolute weapons. 


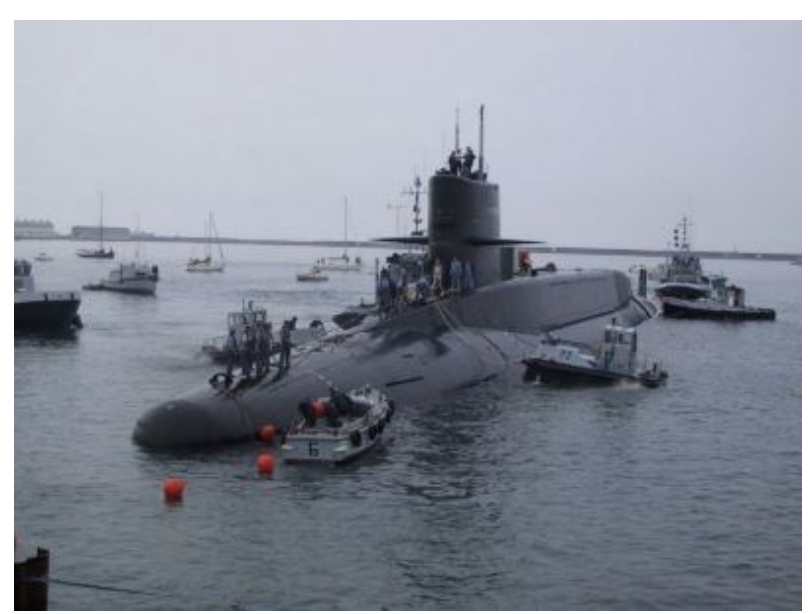

Photo 55: Le Redoutable S611 ballistic missile submarine. [Source: Pho-55]

It can be stated that in the early 1970s the then USSR achieved relative nuclear parity with the USA in the power and quality of nuclear weapons of both countries. It refers especially to a global view because the representation of individual nuclear weapon delivery systems (carriers) in both countries (today the Russian Federation as a successor of the former Soviet Union) is considerably different. At the end of the bipolar era, the strategic nuclear forces of the Soviet Union had 300,000 soldiers, more than 1,400 intercontinental missiles and 300 nuclear carriers deployed at 28 bases. After the dissolution of the Soviet Union and the reduction taking place in the first half of the 1990s the numerical strength fell to 100,000 personnel in 1996, out of which conscripts formed a half.

The reorganization of the Russian Armed Forces also concerned this component, and in 1997 it was merged with the forces intended for operations in space, which was identical to the merger of the air defence forces with the air forces in the following year. The full autonomy that the strategic forces (i.e. Raketnyje vojska strategičeskogo naznačenyja) lost within the Ministry of Defence in the first half of the 1990s is to be restored in 2015. From 2001 to 2003, the number of Earth satellite vehicles increased (by $350 \%$ ). Today, about 100 Earth satellite vehicles operate in orbit and anti-ballistic defence is to be their priority.

The numerical strength of strategic forces is 60,000 personnel, mostly professionals. The reform of the armed forces then presupposes an extensive modernization of armaments. The acquisition of modern weapons has been significantly above average for this type of troops in recent years.

Obsolete SS-18, SS-20 and SS-22 systems are to be fully replaced by the modern Topol-M (SS-27) system by 2016, which is currently being introduced into armaments and can also be placed on nuclear submarines. In 2006, the new Iskander-M opera-

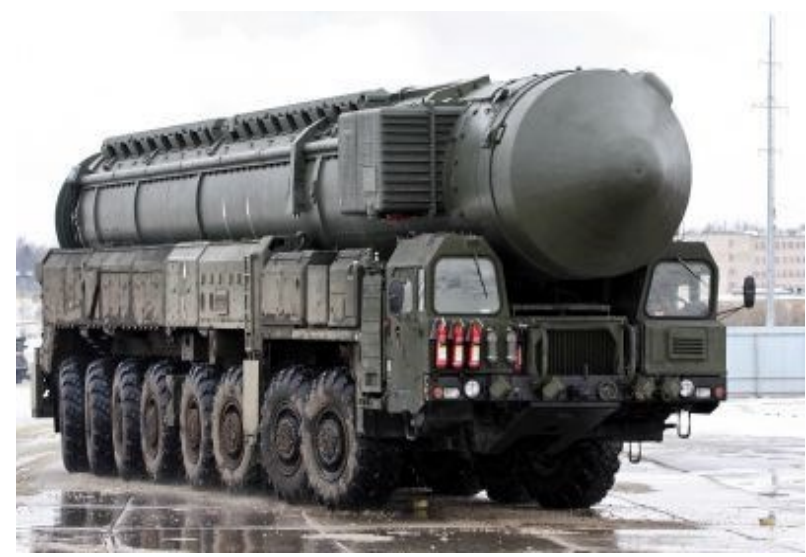

Photo 56: RT-2UTTKh Topol-M. [Source: Pho-56] tional tactical missile system was introduced. In 2012, Russia owned, in accordance with the START 1 treaty (expired in 2009), 1,700 up to 2,200 nuclear warheads, as compared with 3,115 nuclear warheads of the ground-based launching systems, 1,744 nuclear warheads of the navy guided missile launching systems and 624 nuclear warheads of the Air Force as compared with 2002.

In addition to the Topol-M and Iskander-M systems, a new generation of Earth satellite vehicles is to increase the capabilities of strategic forces, together with now developed communication satellites (Meteor, Dialog and Condor), the life cycle of which is 5 to 10 years. They will be launched to orbit from the Cosmodromes in Baikonur and Plesetsk. The modernization of early warning systems at the bases in Baranovichi (Belorus) and Nurk (Tajikistan) is to support anti-missile defence of Russia. 
The anti-missile defence system at the Sofrino base in the Moscow region also achieved operational capabilities.

Table 6: Missile carriers of nuclear weapons in the Third World countries. [Source: Tab-6]

\begin{tabular}{|c|c|c|c|}
\hline Country & Carrier & Country & Carrier \\
\hline Argentina & CONDOR 1, 2 TABANO & Israel & Jericho 1,2 \\
\hline \multirow{2}{*}{ Brazil } & $\begin{array}{c}\text { MB/EE-SS 300, 600; SS 1000; } \\
\text { SONDA 4 }\end{array}$ & Pakistan & HATF 1, 2 \\
\hline Egypt & SCUD-B; CONDOR 2 & Syria & SCUD-B; SS-21; SCUD-C; M-9 \\
\hline Algeria & SCUD-B & China & M-1B; M-9, 11, 12; CSS-1, 2, 3, 4 \\
\hline Libya & SCUD-B; AL-FATAH; SCUD-C & India & AGNI; PRITHVI \\
\hline S.A.R. & RIHA 2, 3 & D.P.R.K. & SCUD-B, C; NO DONGH \\
\hline \multirow{2}{*}{ Iraq } & SCUD-B; AL-HUSSEIN; & $\begin{array}{c}\text { South } \\
\text { Korea }\end{array}$ & HYONMU; NHK-1 \\
\cline { 2 - 4 } & AL-ABBAS & Taiwan & CHING FENG \\
\hline Iran & SCUD-B, C & Vietnam & SCUD-B \\
\hline
\end{tabular}

\subsubsection{Tactical missile equipment of the CSSR /CR}

After World War II, post-war Central Europe wanted to be a gateway between East and West. Instead of that it became a buffer zone of the both powers. In the event of a nuclear war, the territory of Czechoslovakia would thus become a nuclear battlefield. The nuclear holocaust could become a reality. The first mention of plans to place nuclear weapons in Czechoslovakia comes from 1961, when, based on the intention of the Ministry of National Defence, but in reality, on the basis of long-term pressure from Moscow, an agreement was reached on August 30, 1961 to introduce operational tactical missiles into the armament of the Czechoslovak People's Army.

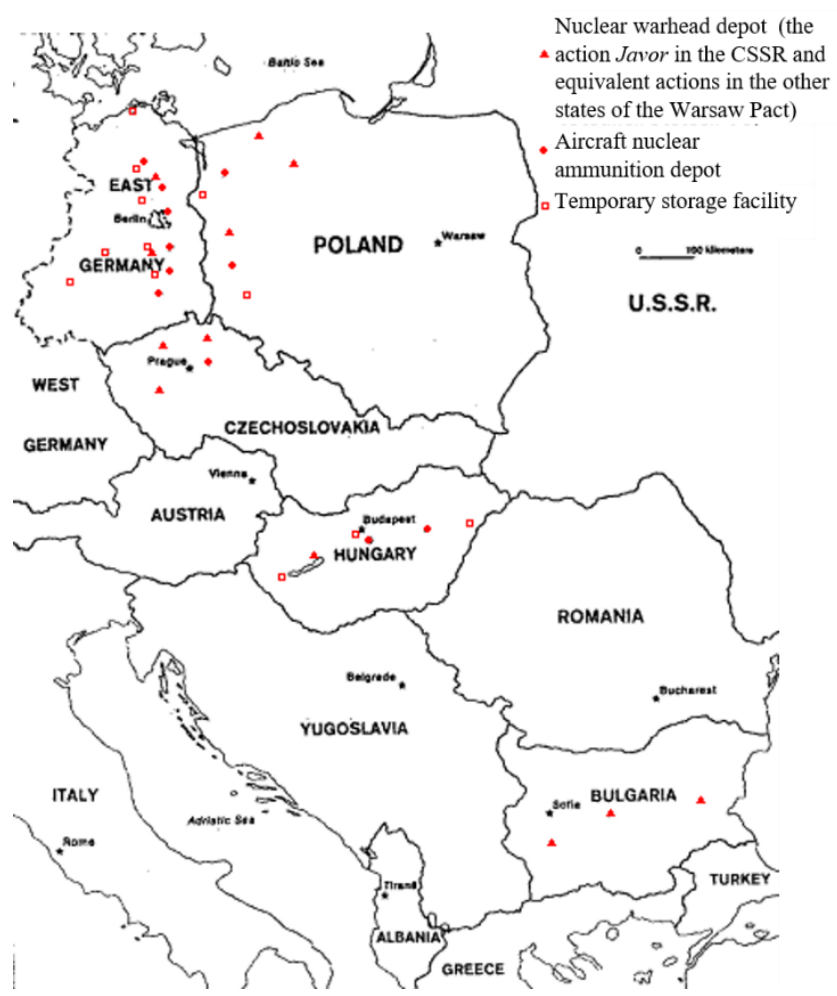

Figure 9: Nuclear ammunition depots in Europe. [Source: Fig-9]
In the same year, the first two heavy artillery brigades were built up. They were $311^{\text {th }}$ and $321^{\text {st }}$ heavy artillery brigades. The build-up of the third brigade began in 1963 . It was the $331^{\text {st }}$ heavy artillery brigade. Every three years, each of the brigades took part in firing live ammunition outside the territory of the republic.

Thus, in the early 1960s, although the Czechoslovak People's Army had carriers capable of carrying nuclear material, it did not have nuclear warheads at its disposal. These would be delivered from the USSR at the moment of declaration of a given state of readiness. It soon became clear that just transporting the warheads would take up to 22 hours. This meant that the Czechoslovak Front would have to launch an attack without the means of nuclear attack. Therefore, Moscow urged the Czechoslovak side for a long time, and on December 15, 1965, the Treaty between the Governments of the USSR and

the CSSR on Measures to Increase the Combat Readiness of Missile Forces was signed. 
The subject of the Treaty was the construction of three special underground depots on Czechoslovak territory as part of actions called Javor 50, Javor 51 and Javor 52. The depots were also known under the code name Ćáslav. Due to these depots, the time of nuclear weapons delivery was reduced to the required 3 hours.

The depots fell under the $12^{\text {th }}$ Main Directorate of the Ministry of Defence (or the $12^{\text {th }}$ GUMO) and their service was provided by the Soviet garrison that was not subordinated to the Central Group of Forces. There were about 200 such special objects throughout the

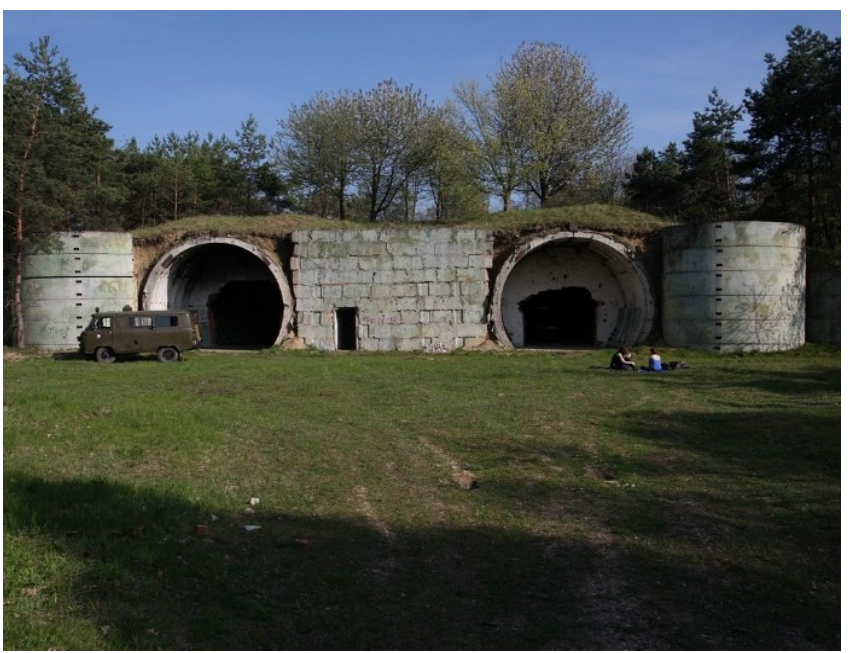

Photo 57: Special ammunition depot - Boži Dar u Milovic airport. [Source: Pho-57] USSR.

Three sites were selected for the construction of depots: Bělá pod Bezdězem, $10 \mathrm{~km}$ far from Mladá Boleslav, Míšov (Borovno), $30 \mathrm{~km}$ far from Pilsen and Bílina, located $25 \mathrm{~km}$ far from Ústí nad Labem. The construction of depots that should have been finished until December 31, 1967 was delayed as compared with the plan. Thus, the Czechoslovak side did not hand over the first two nuclear depots to the Soviet Special Forces until April 1969, and the third depot in Bílina only in December 1969.

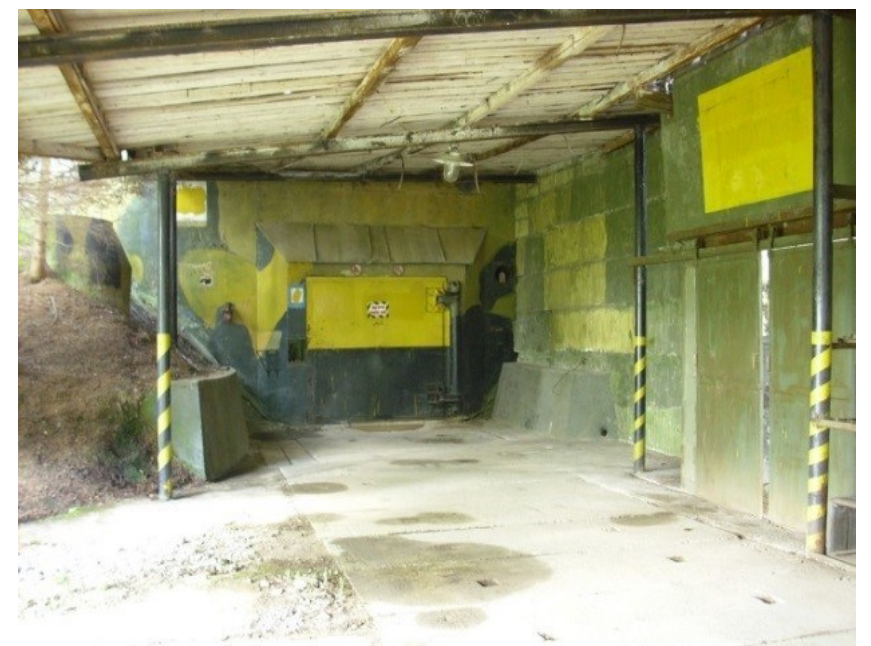

Photo 58: The JAVOR 51 nuclear ammunition depot in Mišov (Borovno). [Source: Pho-58]
The fourth structure was a special ammunition depot Na Vinici u Milovic - Boží Dar airport. The local depots were most probably designed for the storage of nuclear ammunition, which would serve for the liquidation of urban complexes. These were probably less effective tactical warheads, which were designed to destroy military targets of the size of one battalion.

This may be one of the explanations of the difference as compared with the nuclear ammunition depots built within the Javor action; those were probably intended for the storage of more efficient warheads. On the other hand,

we must not forget that the Javor depots were built in the second half of the 1960s. That means that they were older and, due to their parameters, corresponding to the then level of nuclear weapon development and the then war plans.

Initially, the aircraft nuclear ammunition was to be stored most likely in the Javor depots and their utilisation could change gradually with regard to new requirements. The $\mathrm{Na}$ Vinici depot belonged to a new type of depots for nuclear ammunition that Soviets started building in the territory of their satellites in the 1980s. 
Table 7: Modification and types of systems in the Czechoslovak People's Army (CPA).

[Source: Tab-7]

\begin{tabular}{|c|c|c|c|}
\hline Russian name & Code name in NATO & Rocket type & Note \\
\hline Filin & Frog-1 & $3 \mathrm{R} 2$ & \multirow{2}{*}{ Was not introduced } \\
\hline Mars & Frog-2 & $3 \mathrm{R} 1$ & \\
\hline 2K6 Luna & Frog-3 & 3R9 & \multirow{2}{*}{ Introduced into the CPA } \\
\hline 2K6 Luna-2 & Frog-5 & $3 \mathrm{R} 10$ & \\
\hline 9K52 Luna-M & Frog-7 (A, B) & 3R11,9M21, 9M52 & \multirow{3}{*}{$\begin{array}{c}\text { Introduced into the } \mathrm{CPA} / \mathrm{ACR} \\
\text { as R-65, R-70 }\end{array}$} \\
\hline $\begin{array}{l}\text { 9K79 Tochka } \\
\text { (OTR-21) }\end{array}$ & \multirow{2}{*}{$\begin{array}{c}\text { SS-21 } \\
\text { Scarab-A, B }\end{array}$} & $\begin{array}{l}\text { 9M79F, 9M79K, } \\
\text { 9M79B }\end{array}$ & \\
\hline 9K79-1 Tochka-U & & 9M79-1 & \\
\hline \multirow{2}{*}{ 9K72 Elbrus } & $\begin{array}{c}\text { SS-1a } \\
\text { SCUD-A }\end{array}$ & $\begin{array}{l}\text { 8K11(R-11M), 8A61 } \\
\text { (R-11 Zemlja) }\end{array}$ & $\begin{array}{c}\text { Introduced into the CPA/ACR } \\
\text { as R-170 }\end{array}$ \\
\hline & $\begin{array}{c}\text { SS-1b } \\
\text { SCUD-B }\end{array}$ & $\begin{array}{c}8 \mathrm{~K} 14 \\
\text { (R-17 Elbrus) }\end{array}$ & $\begin{array}{c}\text { Introduced into the CPA/ACR } \\
\text { as R-300 }\end{array}$ \\
\hline $\begin{array}{l}\text { 9K714 OKA } \\
\text { (OTR 23) }\end{array}$ & SS-23 SPIDER & $\begin{array}{l}\text { 9M714B (nuclear) } \\
\text { 9M714K (cassette) }\end{array}$ & $\begin{array}{c}\text { Introduced into the CPA/ACR } \\
\text { as R-400 }\end{array}$ \\
\hline
\end{tabular}

The 2K6 Luna (Luna-2) tactical rocket system with 3R9 missiles (with a highly explosive warhead) and 3R10 missiles (with a nuclear warhead) is designed for the destruction of manpower, the destruction of firing devices, combat equipment and means of nuclear attack of the enemy in the tactical depth. The $3 R 10$ version, $10,600 \mathrm{~mm}$ long, carries one of the two possible over-calibre nuclear warheads of the $2^{\text {nd }}$ generation (3N14 or 3N74) with a 901 A4 nuclear warhead component (strength: 3, 10, $20 \mathrm{kt}$, warhead total weight: $503 \mathrm{~kg}$, diameter: $540 \mathrm{~mm}$ ).

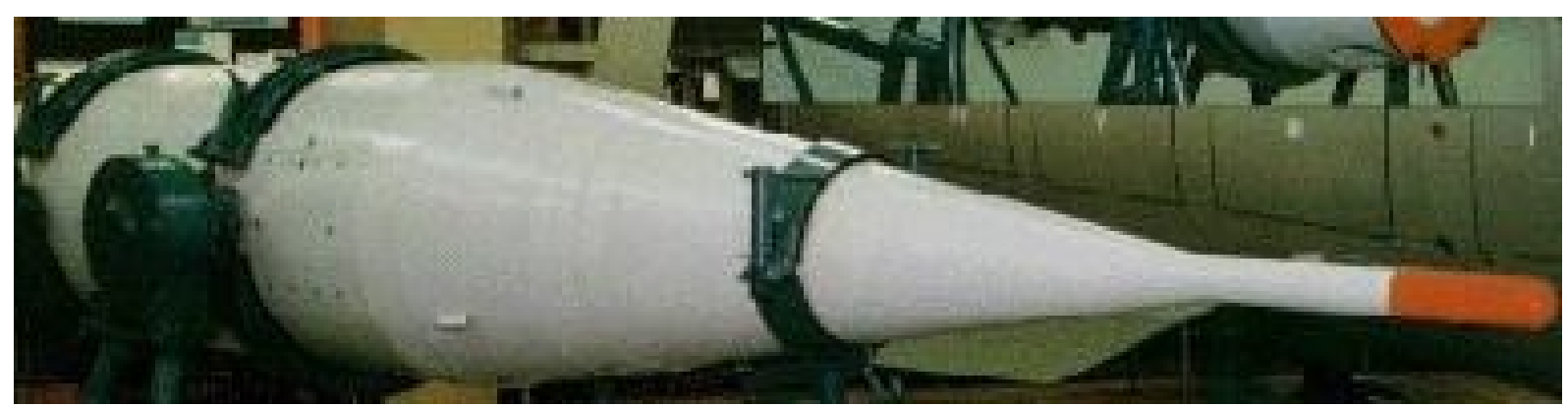

Photo 59: The 3R10-3N14-901A4 nuclear warhead. [Source: Pho-59]

The rocket is a standard unguided missile consisting of a warhead and a bicameral engine. The version of the $3 Z 6$ rocket engine: rocket weight $2,155 \mathrm{~kg}$, span of tail: 1,000 mm, length: $9,000 \mathrm{~mm}-3 \mathrm{R} 9$ with 3N15 calibre warhead.

In flight the missile is spin-stabilized using stabilizer wings misaligned by $1^{\circ}$ from the missile axis. The rotation pulse is initiated by a rotary engine ( $48 \mathrm{~kg}$ of gunpowder) with tangential nozzles. The engine is located in a transition cone. The missile engine (bicameral) consists of the $3 Z 6$ main engine only (burning time: 4.3 seconds). For initiating the warhead of $3 R 9$ the safety and percussion initiation mechanism (nose fuse and base detonating fuse) is used. As to $3 R 10$ the radar fuse with adjustable height of explo-

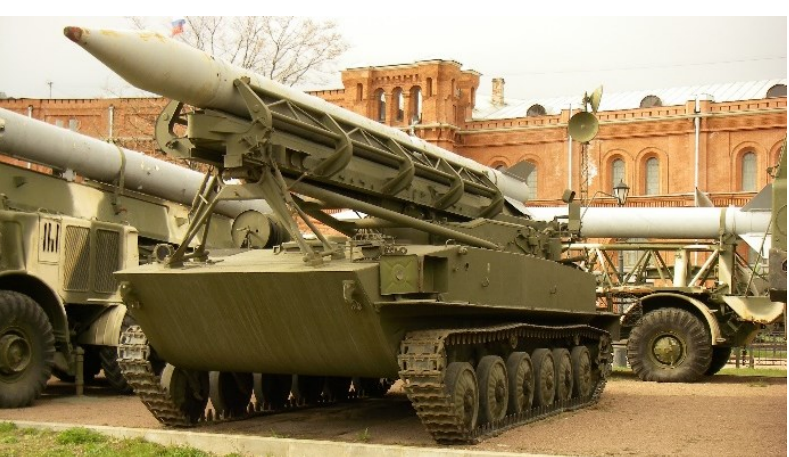

Photo 60: 2K6 LUNA (Frog-3). [Source: Pho-60] sion is used. 
The 2K6 Luna-2 (NATO code name FROG 5) tactical missile system consists of:

- Mobile command post;

- 2P16 launch platform, PT 76 chassis;

- 3R9, 3R10 rocket (with the same 2P16 launch platform);

- 2U 663 missile transporter;

- Zil-157 vehicle and 2U659;

- T-138 AD crane;

- technological equipment;

- RVZ 1 meteorological radar;

- AD-10-T/230 power units;

- Topographic tagger.

The 9 K52 Luna-M (Frog 7) tactical artillery rocket system with $9 M 21$ rockets is designed for the destruction of the enemy, destruction of firing devices, combat equipment and means of nuclear attack of the enemy in the tactical depth. The modernized 9K52 LUNA-M (Frog-7) version was introduced into the armament in 1965. Besides the USSR the system was introduced into the armaments of the other states of the Warsaw Pact, among others, Bulgaria, Poland, Czechoslovakia (in 1966), the German Democratic Republic, Hungary, Yugoslavia and exported to Afghanistan, Algeria, Egypt, Iraq, Kuwait, North Korea, Libya, Syria, Yemen and Cuba since the 1970s. In 1995, it was put out of service of the Army of the Czech Republic.

The 9K52 LUNA-M system (Frog-7) consists of the following components:

- The mobile command post of the 9S445M fire battery is positioned in the GAZ-66 truck with a superstructure including the $9 \mathrm{~V} 57 \mathrm{M}-1$ or VM-3M1 fire control computer;

- The MALACHIT or RMS-1 meteorological radar;

- 9P113M launch platform on the ZIL-135LM chassis;

- The 9T29 transporter on the ZIL-135LM chassis;

- 9V822 set - technological equipment;

- The 9M21 rocket.

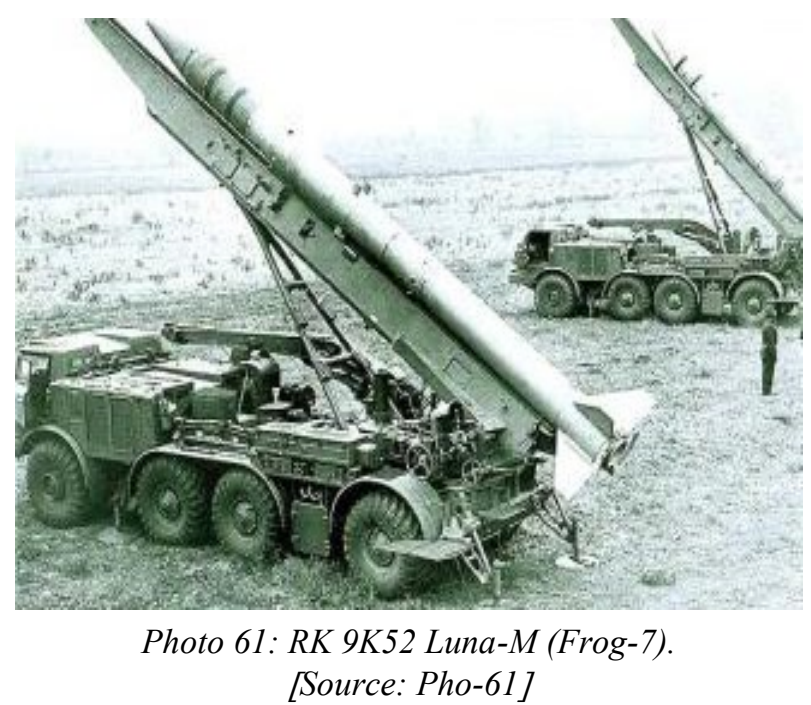

The rocket $9 M 21$ is a standard unguided rocket composed of a warhead and an engine. The $9 \mathrm{M} 21 \mathrm{~F}$ rocket version can carry multipurpose submunitions of various designs. The $9 M 21 B$ version can be equipped with one of three types of tactical nuclear warheads of the $3^{\text {rd }}$ generation $A A-22$, $A A-38$ or AA-52 with yields of 3 up to $200 \mathrm{kt}$. In flight the rocket is spin-stabilized using stabilizer wings and at the initial segment of the flight path using the rotary engine. The rocket engine consists of a flight engine, booster and rotary engine. When firing up to $29 \mathrm{~km}$, brake segments are used. A safety and initiation mechanism is used to initiate the warhead. The weight of a special charge is $420 \mathrm{~kg}$ and the detonation height of the warhead is 1,200 to $1,740 \mathrm{~m}$. The $9 \mathrm{Ja} 26$ container is used for transport. Heating the warheads is provided by three Sb39/119 heaters (manual or automatic mode) for the rocket with 9M21B warhead in the range of 15 to $35^{\circ} \mathrm{C}$, the $\mathrm{AB}-1 \mathrm{P} / 30$ power supply system, the control device for measuring the temperature of the PKTZ $1 \mathrm{M}$ warhead with the $9 \mathrm{~W} 268$ adapter for measuring the temperature of powder charges and the device for setting the lighter for 9M21F. 
Types of rockets: 9M21B - rocket with a nuclear warhead, 9M21D - rocket with a warhead for psychological war with propaganda leaflets, $9 \mathrm{M} 21 \mathrm{E}$ - rocket with a high explosive warhead, $9 \mathrm{M} 21 \mathrm{~F}$ - rocket with a fragmentation warhead, $9 \mathrm{M} 21 \mathrm{TF}$ - rocket with a fragmentation combat warhead, 9M21G and 9M21Ch - rockets with chemical warheads, 9M21K rocket with a cassette warhead and 9M21U - rocket for training purposes.

Types of warheads:

- 9N32 AA-22 - nuclear (TNT equivalent $10 \mathrm{kt}$; length 2,870 mm; calibre $884 \mathrm{~mm}$; total weight $989 \mathrm{~kg}$, out of which charge $278.3 \mathrm{~kg}$ );

- 9N38 AA-38 - nuclear; storage and transport in the 9Ja224M container;

- 9N32M AA-52 - nuclear; storage and transport in the $9 \mathrm{Ja} 224 \mathrm{M}$ container;

- 9N18 OF - high explosive warhead (E training ammunition),

- $9 \mathrm{~N} 18 \mathrm{~F}$ - high explosive warhead with a directed effect;

- $9 \mathrm{~N} 18 \mathrm{G}$ - chemical warhead (216 kg of VX nerve agent);

- $9 \mathrm{~N} 18 \mathrm{~K}$ - cassette warhead (42 pieces of submunition); and

- $9 \mathrm{~N} 18 \mathrm{~A}$ - leaflet warhead (with propaganda leaflets).

The development of the 9 K 79 TOCHKA tactical ballistic missile system took place in the 1970s. The first tests were carried out in 1976. It was introduced into the armament in 1981 as a substitution of the LUNA system. In 1986, in the course of modernization the version 9K79-1 Tochka-U (Scarab-B) and, in 1989, Scarab-C arose. The difference between them is in increasing the range up to $120 \mathrm{~km}$ in Scarab-B and $185 \mathrm{~km}$ in Scarab-C. This was

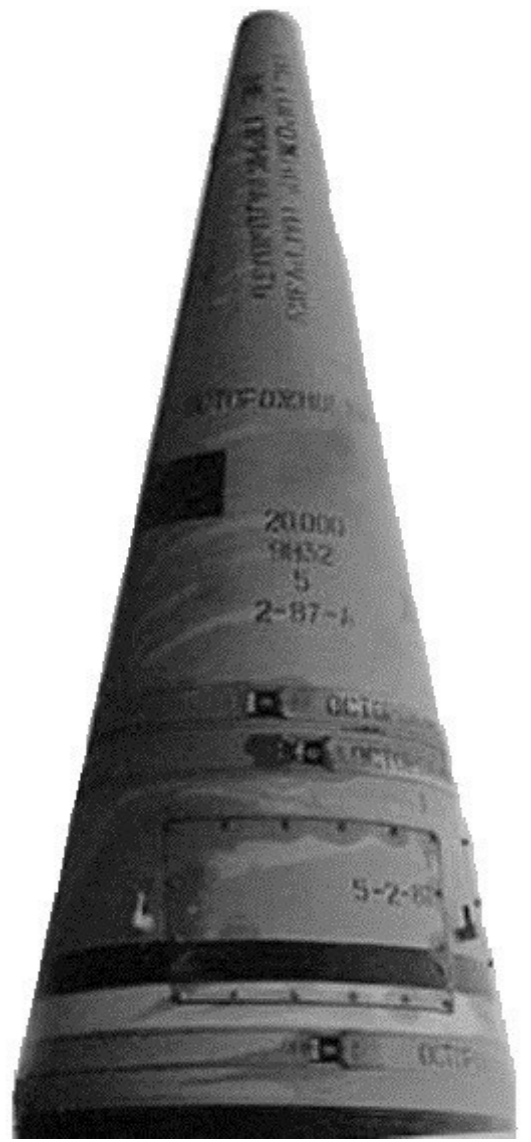

Photo 62: Nuclear warhead 9 N32 AA-22. [Source: Pho-62] achieved through the change in the composition of solid fuel of the engine. The system was introduced into the armaments of Belarus, Czechoslovakia, the German Democratic Republic, Hungary, Kazakhstan, Poland, Syria and Ukraine. The system was put out of service of the Army of the Czech Republic in 2000.

The 9K79 tactical ballistic missile system with highly accurate 9M79 missiles is designed for the destruction of combat formations, pinpoint and small area targets in the tactical depth using the $9 \mathrm{~N} 123 \mathrm{~F}$ high explosive warheads or the $9 \mathrm{~N} 123 \mathrm{~K}$ cassette warheads. In the case of extra important targets, the missiles with AA60 nuclear warheads are used to destroy missile launchers, nuclear artillery, the stationary structures of air defence, aerodromes, strong points, communications centres and command posts in the tactical depth, all with high efficiency.

The components of the 9K79 TOCHKA (SS-21) system are as follows:

- The 9P129 missile launcher on the BAZ 5921 vehicle;

- The 9T218 transporter-loader on the BAZ 5921 vehicle;

- The 9T222 (9T238) transport vehicle;

- 9M79B, 9M79B1,9M79K, 9M79F missiles;

- The 9V818 (9V819/9V820) automated control and testing machine with the ESB-12VS/400-M1U1 electric generator; and

- The 9V84 maintenance vehicle. 


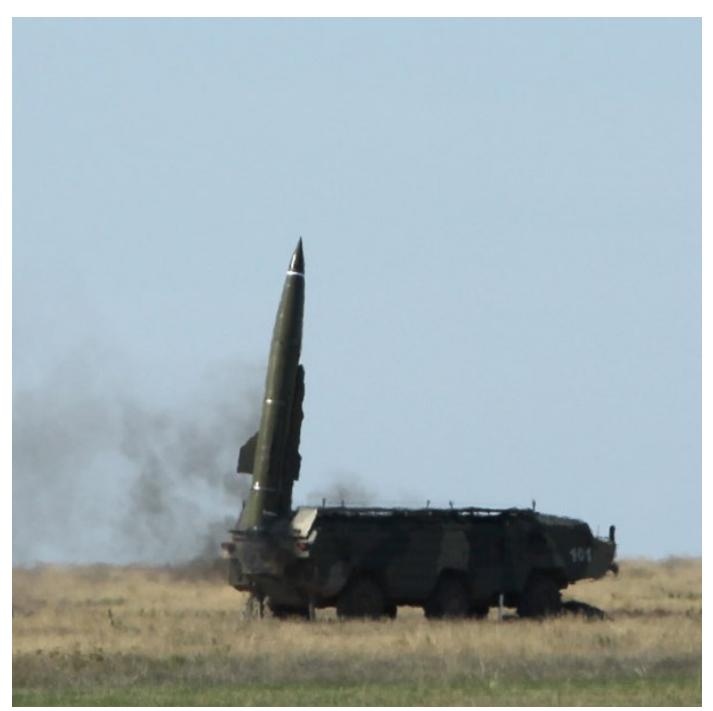

Photo 63: The 9M79 TOCHKA missile on the 9P129 missile launcher. [Source: Pho-63]

The 9 M79 missile is aerodynamically shaped. It is a solid-propellant missile of the single-stage type. The missile flight is controlled using an inertial guidance system enabling the missile control along the active segment of the flight path. The flight control method rests in the program control of the rocket flight according to the angle of longitudinal inclination and in the attitude control to the centre of gravity (along the final segment of the flight path). The flight control elements are four aerodynamic and four gas rudders with servomechanisms. Gas rudders provide control along the active segment of the flight path where the efficiency of aerodynamic rudders is small. The safety and initiation mechanism provide initiating the combat component with directional effect (two grades of protection), which is activated through a pulse from the contactless radar and a laser sensor or contact sensors.

The 8K11 operational-tactical missile system on the 8U218 missile launcher was introduced into our Army as the first. In NATO classification it was designated as $S S-1 A$, $S C U D-A$. According to its range it was indicated as R-170. The missile could carry a nuclear warhead with a yield of 20 up to $100 \mathrm{kt}$ with the maximum range of $170 \mathrm{~km}$.

- The length of the missile was more than $10.5 \mathrm{~m}$;

- The diameter of the warhead was up to $0.88 \mathrm{~m}$; and

- The take-off weight was $4,400 \mathrm{~kg}$.

The tracked missile launcher had a modified chassis of the ISU-152K gun, the speed of which was $50 \mathrm{~km} / \mathrm{h}$ on paved roads and $25 \mathrm{~km} / \mathrm{h}$ in the field. This type was modified to the $8 \mathrm{~K} 14$ type on an extended missile launcher; its range was $270 \mathrm{~km}$. Both variants used a tracked chassis, the second one used an extended chassis due to a longer missile.

From 1961 to 1963 , altogether sixteen $8 \mathrm{~K} 11$ systems were delivered and introduced into the armaments of the $311^{\text {th }}$ and $321^{\text {st }}$

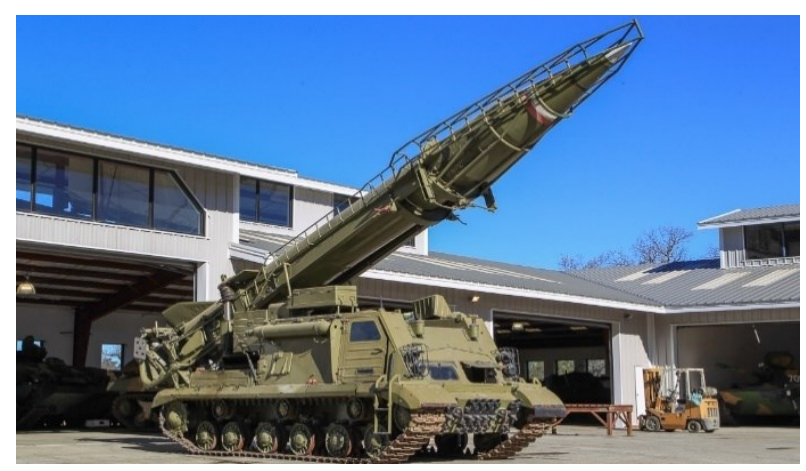

Photo 64: The 8K11 system on the $8 U 218$ missile launcher (SCUD-A). [Source: Pho-64] heavy artillery brigades. The first one obtained 9 systems, the second one 6 systems and 1 system was intended for the Artillery Training Centre. From 1963 to 1965, the Czechoslovak Army obtained 7 systems in an improved version. A total of 6 of them were allocated to the $331^{\text {st }}$ heavy artillery brigade and 1 to the Artillery Training Centre. The above-mentioned missiles were sensitive to shocks. Therefore, it was decided to update them put them on a wheeled chassis. The new version was designated as an operational-tactical missile system with the 9P117 missile launcher. At the beginning of the 1970s, Army brigades were rearmed to the wheeled version, i.e. the $311^{\text {th }}$ heavy artillery brigade in 1971 and the $321^{\text {st }}$ heavy artillery brigade in 1972. One battalion of the $331^{\text {st }}$ heavy artillery brigade was rearmed as late as 1982 and the second battalion in 1985. The rearmament continued and the enhanced 8K14 missile with the range of $300 \mathrm{~km}$ was, according to NATO, designated as SCUD B. 


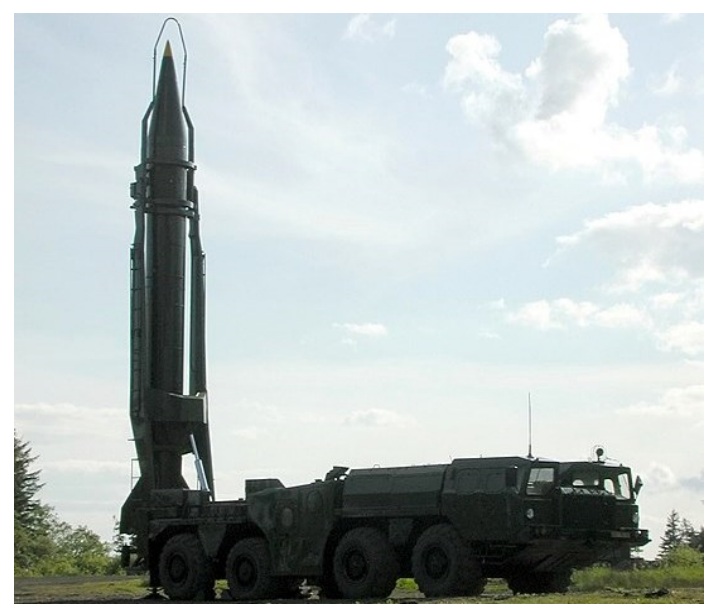

Photo 65: The 8K14 system (SCUD-B). [Source: Pho-65]
Basic data on the $8 \mathrm{~K} 14$ missile:

- Length: 11,164 mm;

- Missile body diameter: $880 \mathrm{~mm}$;

- The take-off weight: $5,862 \mathrm{~kg}$;

- Minimum range: $50 \mathrm{~km}$;

- Maximum range: $300 \mathrm{~km}$;

- Maximum speed: $1,430 \mathrm{~m} / \mathrm{s}$;

- Running time of the missile engine: $70 \mathrm{~s}$;

- Accuracy: circular error probability $610 \mathrm{~m}$;

and

- 9N33 nuclear warhead with an adjustable effect of 10, 20, 40 or $100 \mathrm{kt}$.

The introduction of the 9 K714 OKA (NATO code name SS-23 SPIDER) operational-tactical

missile system into the armaments of the Warsaw Pact armies was criticized harshly as the violation of the agreements already made. In particular, these were the treaties between the USA and the USSR related to medium- and short-range missiles. The Czechoslovak $311^{\text {th }}$ heavy artillery battalion was considered able to be employed in combat after carrying out fire with live ammunition in Kapustin Jar in 1986. The 9M714B missile was used as a nuclear rocket. It was a very sophisticated system with a very fast missile and high accuracy. Its introduction caused great anxiety among NATO members.

The Czechoslovak People's Army received 4 missile launchers, modified vehicle BAZ 6944, 4 transporter-loaders, vehicle BAZ 6944 again, 4 prime movers (ZIL131), 18 missile carriers and 18 cassette warheads.

Basic data on the 9M714B missile:

- Length: 7,516 mm;

- Missile body diameter: $974 \mathrm{~mm}$;

- Take-off weight: 4,400 kg;

- Minimum range: $50 \mathrm{~km}$;

- Maximum range: $400 \mathrm{~km}$;

- Maximum speed: Mach 4;

- Running time of the missile engine: $70 \mathrm{~s}$;

- Accuracy: circular error probability $160 \mathrm{~m}$; and

- Nuclear warhead: 100 kt.

The Czechoslovak People's Army had the following types of systems:

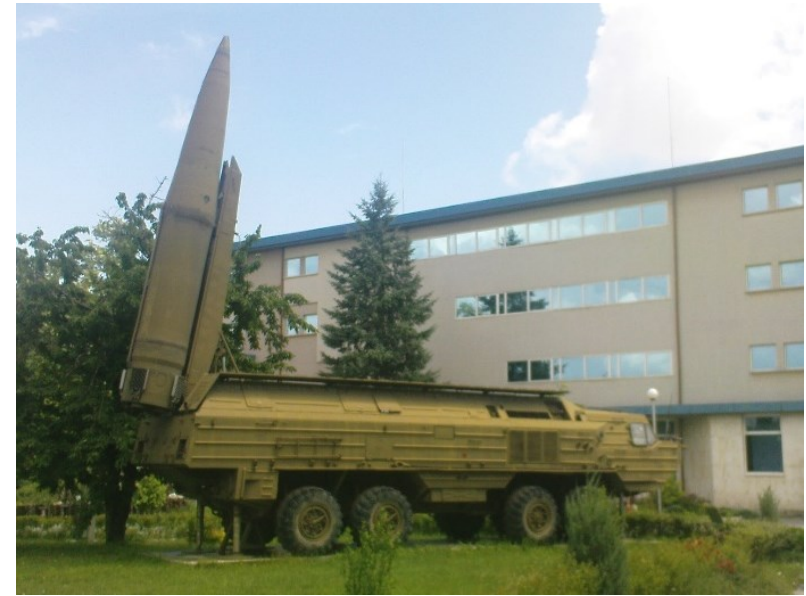

Photo 66: The 9K714 OKA system (SS-23 SPIDER). [Source: Pho-66]

- In 1969, the $311^{\text {th }}$ heavy artillery brigade had the SCUD A missiles in three battalions, three batteries in each and one missile launcher. In 1972, it was rearmed to a wheeled version with the same number of missile launchers. In 1981, the brigade was reorganized to the binary system, each battalion had three batteries with two missile launchers each and thus the total number of missile launchers increased to 18 . In 1985, one battalion was rearmed to a completely new weapon system type, i.e. the 9K714 OKA, based on NATO code name SS-23 SPIDER, sometimes designated as R-400, missile system of the $2^{\text {nd }}$ generation. A total of 4 pieces of this weapon system were delivered. In 1988, the brigade owned 12 SCUD B missile launchers and 4 SPIDER missile launchers (OKA). 
- In 1969 , the $321^{\text {st }}$ heavy artillery brigade had SCUD A missiles, in two battalions, three batteries in each, where each battery had 1 missile launcher. Altogether, it had 6 missile launchers. In 1971, it was rearmed to a wheeled version to SCUD B. In 1981, the brigade was reorganized to the binary system and thus the total number of missile launchers increased to 8 . In 1985, there was another reorganization when it had three battalions, three batteries in each where each battery had 2 missile launchers. Thus, the number of missile launchers increased to 18 . This state continued by 1988 . It was armed with SCUD B missiles.

- In 1969, the $331^{\text {st }}$ heavy artillery brigade had SCUD B missiles. In 1988, it had SCUD B in two battalions, three batteries in each, where each battery had 1 missile launcher. Altogether, it had 6 missile launchers. In 1971, it was rearmed to a wheeled version (SCUD B again). In 1981, it was reorganized to the binary system and thus the number missile launchers increased to 8. In 1982, this brigade rearmed to a wheeled version of missile launchers.

With regard to possible aggressiveness of our Army and its capability of attacking its enemies, it is possible to mention the following:

In 1964, when we were supposed to attack Western Europe based on the directives of the USSR, our friendly nuclear forces consisted of:

- 21 tactical missile systems, 21 operational-tactical missiles and no gun-type weapon.

The enemy had the following:

- 43 self-contained units and 10 division units intended for conducting strikes using nuclear weapons against our state. Thus, it was, altogether, 282 barrels and missile launchers.

\subsubsection{Nuclear winter}

According to the special expert report of the UN World Health Organization, in 1987 (i.e. towards the end of the Cold War) the world nuclear arsenal was alarming. It was estimated to be about 15,000 megatons of TNT. The destructive power of these bombs was enormous. If only one percent were used in attacks on an urban area, during a few hours it would kill more people than throughout World War II.

In the 1980s, such scenarios were considered realistic and were designated as a total nuclear war or, if need be, an unlimited nuclear war. To prepare the scenarios the modelling of nuclear war consequences for selected world capitals, such as London, New York, Moscow and others, was used. The above-mentioned expert report is a research study, which a lot of experts, specialists and security analysts all over the world participated in.

Apart from the immediate effects of a shock wave and thermal radiation, the radioactive fallout caused by nuclear explosions would have both short-term and long-term destructive effects. Numerous fires caused by heat after many nuclear explosions would end in blazes that would spread in all affected large and small cities. Under such conditions it wouldn't be possible to survive not even in the first-class dugouts.

Enormous amount of smoke, soot and other gaseous products, but also radioactive particles would shade the sun that a long-term drop in the air temperature would occur. Towards the end of the 1980s, it was estimated through modelling and computer evaluation that the nuclear winter would take place, which would have catastrophic consequences for people, but also for fauna and flora on the Earth, in principle for the entire ecosystem of the Earth. Towards the end of the Cold War, just the climatic changes caused by the total nuclear war effects were the centre of considerable attention of especially scientists. It emerged that the reduction in temperature by a few degrees would affect the nature on the Earth seriously. The technical term nuclear winter became accepted usage and was included in vocabularies of both experts and politicians in the 1980s. 
Based on the UNO scientific papers, it was expected that in the course of the total nuclear war, the total collapse of health services would have taken place. No medical system in the world would be able to deal satisfactorily with the enormous number of slightly and seriously injured people. After the total nuclear war, hunger and diseases would become a widespread phenomenon and social, communications and economic systems would be disrupted seriously. Alongside with classical destructive factors of the nuclear explosion, the destructive effects of the total nuclear war would also include considerable atmospheric changes that would affect adversely agriculture, industry and economy in not only belligerent states, but also in those that didn't participate in the conflict.

It was also difficult to anticipate social impacts of such a total nuclear war. The surviving population would probably divide into small separate groups, which would be caused by the destruction of or damage to communications and transport.

With regard to the lack of resources and the vast country destruction and devastation, such groups would struggle for food and other sources; essentially, they would fight for mere survival. It was difficult to predict the interrelations of such groups, but it is probable that their attitudes and expectations would be defensive and competitive. Worldwide, it was expected that a relentless and atrocious fight for scarce and uncontaminated resources would develop. The collapse of international and national relations would introduce terror, violence and fight for survival instead of cooperation.

Nowadays, it seems to us as if these were parts of a science fiction movie. Unfortunately, even before quarter of a century the world, due to its division into East and West, stood on the brink of a nuclear devastating apocalypse. The Cold War was accompanied by a frantic nuclear armaments race, which pushed humanity to the brink of a nuclear disaster.

The research, development, construction and production of nuclear weapons represented, especially for the main owners, i.e. the USA and the USSR, heavy expenditure that undoubtedly blocked the scientific, technical, technological and economic potential devoted to nuclear weapons not only in the above-mentioned countries. It is possible to imagine that these resources and possibilities could be used much more sensibly for building educational facilities, hospitals, cultural facilities and other infrastructures of the modern highly-developed society.

\subsubsection{Depleted uranium ammunition}

Depleted uranium (hereinafter referred to as DU) is used in ammunition as metallic material, i.e. metal with high specific gravity. High specific gravity is advantageous for working parts of the ammunition types when the penetration effect in the target is required (in armourpiercing shells by kinetic energy of their armour-piercing part, in high explosive anti-tank projectiles by kinetic energy of cumulative jet).

Other reasons for using DU in ammunition are technological and economic. From the viewpoint of technology, DU is metallic material and its required ammunition usable properties can be provided using common metallurgical and engineering technologies, namely through acceptable requirements for ensuring the hygienic, radiological and fire safety. The economic reasons rest in the fact that primary raw material to produce DU is essentially industrial waste, which must be kept in protective storage until fully depleted due to its radiation degree of risk, which demands to spend considerable financial assets on a long-term basis. Therefore, the processing of these types of nuclear wastes into usable material is attractive for economic reasons, especially for each owner of waste who has technological possibilities for its reprocessing.

However, there are a lot of discussions related to possible health consequences caused by DU ammunition used by the US Armed Forces in the course of wars not only in the Balkans, Iraq and Afghanistan, but also in the whole series of other armed conflicts all over the world. 
This discussion was initiated by Italian Prime Minister Giuliano Amato who asked NATO to explain deaths of already six Italian soldiers who served in the Balkans and then died of cancer. In mass media, a lot of considerably different opinions emerge - from serious scientific analyses, comparisons of this ammunition effects with nuclear weapons effects up to the disparagement of these problems. Mass media denote many completely unexplained oncological diseases of soldiers who took part in NATO SFOR in Bosnia and KFOR in Kosovo as a Balkan syndrome, which is related to the use ammunition with DU.

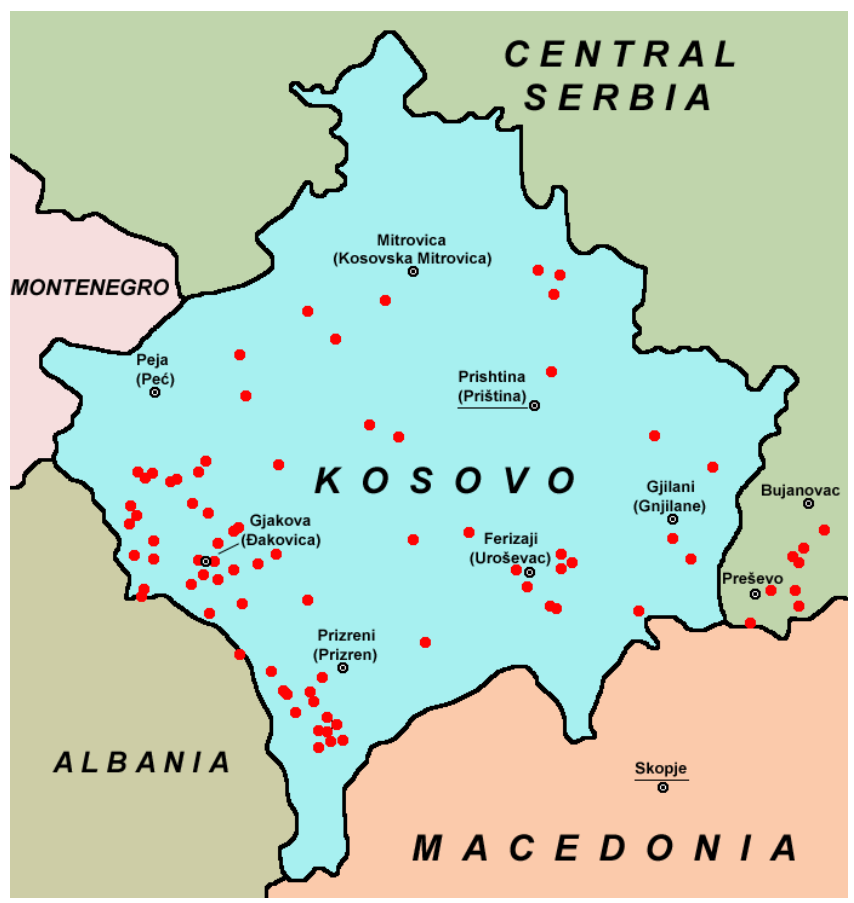

Figure 10: Places in Kosovo and in the south of Central Serbia where depleted uranium ammunition was used by the NATO Air Forces in the bombardment in 1999. [Source: Fig-10]
In 1991, the DU ammunition was used for the first time during the Persian Gulf War where the US aircraft and tanks allegedly fired 860,000 pieces of ammunition containing 290 tonnes of DU and the British tanks 100 pieces of ammunition with 1 tonne of DU. After this war unexplained illnesses and deaths also occurred and the term Gulf War syndrome, which is also known as Desert Storm Disease started to be used. During the war in Bosnia and Herzegovina (from 1994 to 1995) the US troops used 10,800 pieces of DU ammunition. In 1999, in the course of the bombing campaign conducted by NATO against the Yugoslav troops in Kosovo more than 31,000 pieces of ammunition containing approximately 10 tonnes of DU were used. The weapon systems containing DU are developed and produced by the USA, the Russian Federation and some successor states of the former USSR, by Great Britain, Turkey,

Saudi Arabia, Pakistan, Israel and France. Based on some information, the USA and France delivered charges with DU for $105 \mathrm{~mm}$ and $120 \mathrm{~mm}$ tank guns to other countries as well.

Many ex-servicemen of the Peace Forces in the Balkans have died or have fallen ill with cancer. The numbers of the affected mentioned in various sources differ. Portugal reported 1 death and 3 illnesses, Spain 2 deaths and 7 illnesses, France 5 illnesses, Belgium 5 deaths and 4 illnesses, the Netherlands 4 deaths, Switzerland 1 death, Italy 8 deaths and 10 illnesses, Germany, Denmark, Greece and Great Britain each 1 illness. The Czech Republic registers 1 death and the Slovak Republic 2 deaths of veterans who served in the peace missions in the Balkans and after the return they died of cancer. The fundamental question - whether and in what extent DU contributes to bringing on these illnesses and deaths - hasn't still been answered.

\subsubsection{Uranium and depleted uranium properties}

Uranium (U) is a chemical element with nucleon number 92. It is a silver-grey metal with an average occurrence in the Earth's crust of 4 grams per a tonne (the topmost 30-cm layer of Earth contains about $1,500 \mathrm{~kg}$ of uranium per $1 \mathrm{~km}^{2}$ ). It is more abundant than elements such as mercury, silver, or gold. Natural uranium consists of three different isotopes: $99.2836 \%$ of ${ }^{238} \mathrm{U}, 0.7110 \%$ of ${ }^{235} \mathrm{U}$, and $0.0054 \%$ of ${ }^{234} \mathrm{U}$. Isotopes are chemically barely distinguishable atoms of one and the same element, having the same number of protons in the atomic nucleus. 
However, the isotopes differ in the number of neutrons and correspondingly in their mass and nuclear properties. Uranium has a very high density $\left(19.07 \mathrm{~g} / \mathrm{cm}^{3}\right)$, only slightly lower than tungsten $\left(19.3 \mathrm{~g} / \mathrm{cm}^{3}\right)$ and considerably higher than lead $\left(11.35 \mathrm{~g} / \mathrm{cm}^{3}\right)$. It is sufficiently ductile and forging, it can be tooled mechanically and it creates alloys with other metals. The uranium metal is chemically very reactive; in the open air it is subject to gradual oxidation. In a powdered form it can ignite spontaneously.

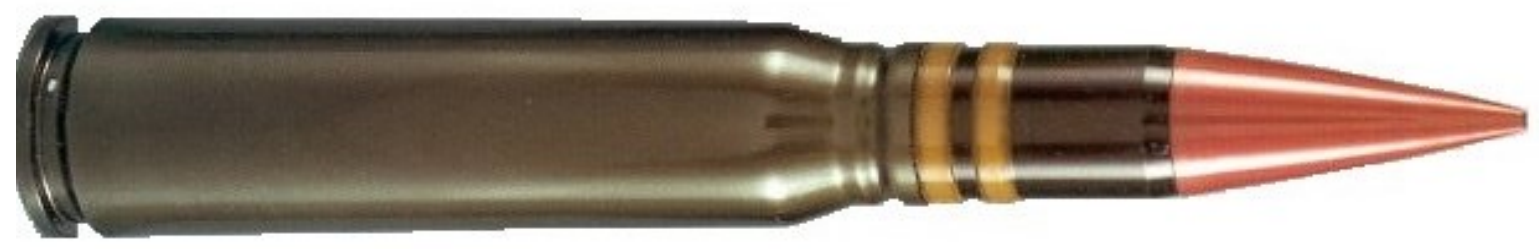

Figure 11: The 30mm x 173 GAU-8 the most efficient ammunition used in Operation Desert Storm (1991) against all targets including tanks, armoured and light vehicles. The $30 \mathrm{~mm}$ ammunition was developed to optimize the air-surface missile on the US Army AH-64 Apache helicopters. [Source: Fig-11]

All three uranium isotopes are radioactive, which means that their nuclei are unstable. Enriched uranium has more than $2 \%$ of ${ }^{235} \mathrm{U}$ and is used in the civil and military field. For most applications in nuclear technology, the comparatively small fraction of $0.711 \%$ of ${ }^{235} \mathrm{U}$ in natural uranium is not sufficient and must be increased. This process is called uranium enrichment, in which the atoms of natural uranium are separated into a mixture containing more ${ }^{235} \mathrm{U}$ (enriched mixture) and to another one containing less than $0.711 \%$ of ${ }^{235} \mathrm{U}$ (leaned mixture or depleted uranium). Natural uranium is usually depleted to a remaining content of approximately 0.2 up to $0.3 \%$ of ${ }^{235} \mathrm{U}$.

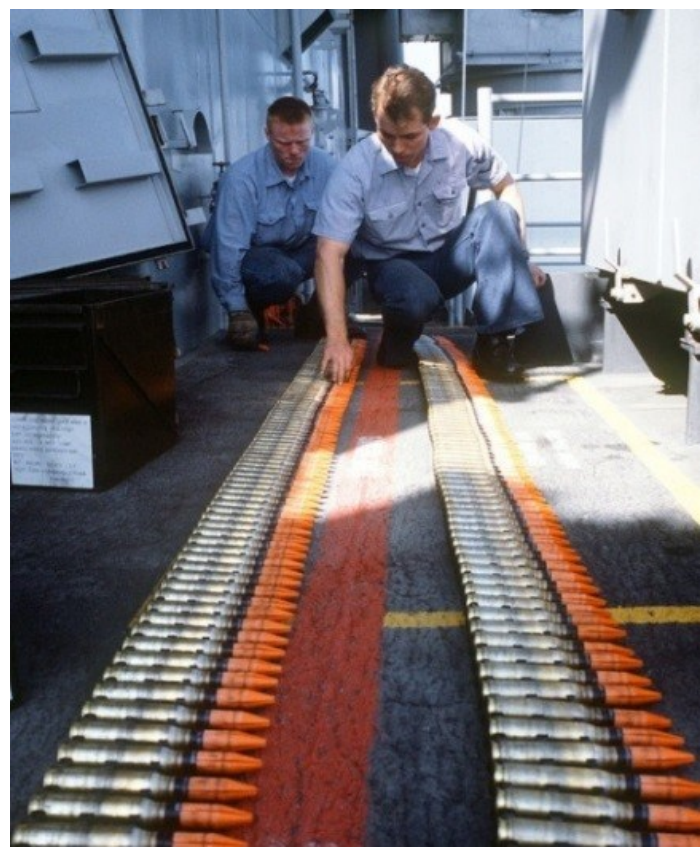

Photo 67: The belts of Mark 149 Mod 2 with $20 \mathrm{~mm}$ DU ammunition on the battleship (USS Missouri). [Source: Pho-67]

The civil use of DU lies in its high specific weight, low cost and excellent shielding properties for gamma radiation. Therefore, it is used where maximum mass in a limited volume is required, e.g. in stabilizers in aircraft and ships, in space exploration to load satellites, in the mining industry for the production of drilling rigs to exploit petroleum. Also, because of its excellent shielding properties for gamma radiation, it can be used in containers for spent fuel rods from nuclear power plants and for the production of shields protecting against radioactive radiation in the health service.

In the military field, DU is used in armour-plating and armour-piercing ammunition. By alloying with $2 \%$ molybdenum or $0.75 \%$ titanium and after a special heat treatment, DU achieves the hardness of hardened tool steel. Combined with its high density, it is a material well-suited for the construction of ammunition because the shells made of DU may be smaller, achieve a higher speed, have a longer range and penetrate armoured walls easily due to the kinetic energy only without any blasting charge. Further, uranium has an excellent mechanical cohesion, which is maintained even at a high temperature and pressure at the impact of a shell on the target and when penetrating its surface. 
Even the so-called self-sharpening ability was found, i.e. that the bodies formed by uranium under these extreme state conditions spontaneously form into an optimal shape, ensuring the penetration of an obstacle with the least possible energy loss. This property excels especially in comparison with tungsten, another similarly usable construction material.

All three uranium isotopes emit alpha particles. The alpha activity of natural uranium is about $25,000 \mathrm{~Bq} \cdot \mathrm{g}^{-1}$; that of DU is about $15,000 \mathrm{~Bq} \cdot \mathrm{g}^{-1}$. Thus, the alpha activity of DU is about $40 \%$ less than that of natural uranium. The newly formed nuclei resulting from the alpha decay of uranium (the so-called daughter products) are not stable, but continue to decay, mostly by emitting beta particles. The activity of its daughter products must be added to that of uranium.

Beta radiation of the daughter products of natural uranium and DU have practically the same intensity equal to about $25,000 \mathrm{~Bq} \cdot \mathrm{g}^{-1}$. Together with its daughter products, DU has an activity of approximately $40,000 \mathrm{~Bq} \cdot \mathrm{g}^{-1}$. This means that about 40,000 decays take place per gram and per second. Only about 100 of these are accompanied by high energy gamma radiation.

\subsubsection{Impact of depleted uranium on a man}

DU hazards lie in its chemical toxicity analogous to other heavy metals (e.g. lead and mercury) and in its radioactivity (all uranium isotopes are radioactive, i.e. they emit ionizing radiation). However, it is necessary to emphasize that uranium is less toxic than cadmium, lead and mercury. From the viewpoint of radioactivity, $D U$ is by $40 \%$ less radioactive than natural uranium. DU outside the body acts through irradiation only. There are various paths, through which DU can get into the human organism - the lungs (inhalation), digestive organs (ingestion) through water and food or the contamination of open wounds by fragments of ammunition containing DU. In all these cases, it will affect the body from inside (internally) and its chemical and radiological effects must be taken into account.

In the industrial processing of DU as well as in accidents, the formation and emissions of fine dust particles (aerosol) of DU play a decisive role. In fires, e.g. in the DU ammunition depots, uranium burns to form very poorly soluble uranium oxides. They contaminate the site of fire and partly they also enter the air in the form of fine aerosol. When a missile with DU penetrates armour, the crewmen may be wounded by flying DU fragments.

The damaging effect of ionizing radiation is essentially a result of the energy absorption by the body tissues, called a radiation dose. When exposed to external influences, the effect of DU is manifested exclusively by the gamma and beta radiation emitted, because alpha-radiation is absorbed by the upper layers of the skin and, therefore, does not act on body tissues.

The dose of external radiation received near the DU is very low. One $\mathrm{kg}$ of DU, at a distance of $1 \mathrm{~m}$, produces a dose lower than $1 \mathrm{mSv}$ per year. In comparison, an average year dose a person accumulates from natural radioactive sources per year is about $3 \mathrm{mSv}$. According to some American

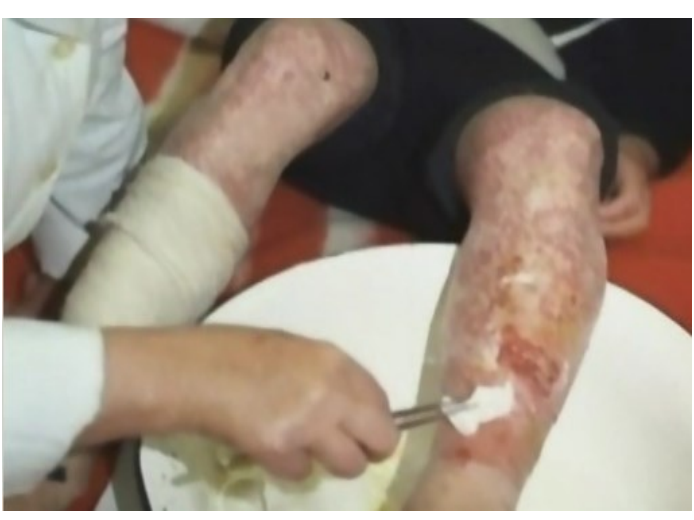

Photo 68: Radiation burns - the consequence of the radiation accident in the Chernobyl atomic power plant. [Source: Pho-68] sources, if a DU surface is touched by the bare skin, the result is a localized dermal dose of about $2 \mathrm{mSv}$ per hour. A considerable dermal dose would be achieved in the case of a direct contact of DU with an unprotected part of the skin taking several days, which is very improbable. 
In the form of a fine aerosol, which is formed, for example, in the uranium industry during uranium ore mining, after the impact of DU-containing missiles on armour or during uranium burning, DU can enter the lungs by inhalation. The solubility of the inhaled DU in the body fluids is a decisive factor. American investigations have shown that after the impact of DU projectiles on heavy armour, about $17 \%$ of the DU aerosol produced, is found in an easily soluble form. If uranium is in a chemically soluble form, its main part is excreted through the kidneys within a few days. Due to its toxicity, uranium may cause temporary kidney damage or even complete kidney failure.

For temporary renal impairment, the limit value is a single inhalation of $8 \mathrm{mg}$ of uranium in soluble form and $40 \mathrm{mg}$ of uranium in soluble form leads to permanent renal impairment. If uranium is in a poorly soluble form, it can remain in the lungs for a long time (years). In this case the kidneys are not nearly affected since the liberated quantity of uranium is very small. However, the DU radioactivity affects the lungs. The International Commission on Radiological Protection (ICRP) calculates a dose factor of $0.1 \mathrm{mSv} / \mathrm{mg}$ for the inhalation of poorly soluble ${ }^{238} \mathrm{U}$. Therefore, with the exception of extremely high uranium concentrations, acute radiation damage to an organism in this way is not expected.

Only about 2 to $5 \%$ of DU in an easily soluble form is absorbed into the bloodstream through the intestinal mucosa as other heavy metals and is excreted through the kidneys. Thus, the threshold value for the occurrence of reversible or permanent kidney damage after a single exposure is comparable to the amount of DU received through the inhalation pathway. Uranium in the form of uranium oxides, which are poorly soluble in the body fluids, is practically not absorbed by the digestive tract and, therefore, even in gram quantities it has no chemically toxic effect. When DU is brought directly into the body through open wounds, the toxicological effect is also determined by the DU solubility. Soluble uranium is eliminated by the kidneys and can damage them when the threshold dose is exceeded. Insoluble DU remains in the tissues for a long time, causing a relatively high, locally limited radiation dose, leading to a slight increase in the long-term risk of cancer. In the United States, a group of about 30 Gulf War veterans live with fragments of DU in their bodies. They are the victims of the so-called friendly-fire incidents (i.e. they were accidentally hit by the friendly troops).

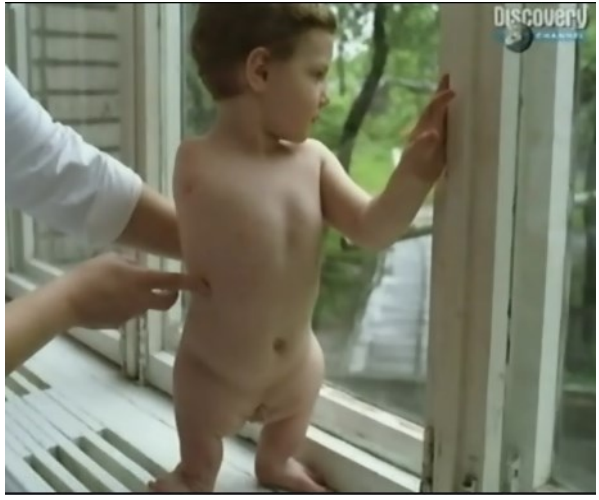

Photo 69: Fetal genetic disorders consequence of a radiation accident at the Chernobyl nuclear power plant on April 26, 1986. [Source: 9.5.69]

Medical examinations of a group of about 100 soldiers exposed to DU aerosol in their own tanks in the friendly-fire incidents in the Gulf War have not yet revealed any damage to health that could be attributed to DU. The long-term prognoses of adverse health effects for those injured by DU fragments are somewhat less certain. Up to now, in this whole group of approximately 30 people there is also no evidence of negative effects. Additional and much larger groups of Gulf veterans stayed near the destroyed tanks and the exploded ammunition, or later entered such places. In these cases, only rough estimates can be given, as no measured data on DU emissions or dose size calculations have been published yet.

The well-known health problems that were later observed in many Gulf War veterans, called Gulf War Syndrome cannot be explained by exposure to uranium, and, therefore, must be attributed to the combination of all risk factors (stress, burning oil fields, chemical agents and heavy metals in the battlefield, unsuitable vaccination). Information on the occurrence of DU contamination during and after the fighting is not available for the Persian Gulf or the Balkans. 
In the vicinity of the impact of DU ammunition, it is possible that the individuals who were not warned against the possibility of contamination (i.e. children playing with the pieces of ammunition or tank wreckage) and those who stayed there for a longer time could accumulate a radiation dose or accept the amount of DU exceeding the internationally recognized limits. However, the probability that this amount and doses would lead to acute diseases is negligible. Namely, the ingestion pathway is less dangerous as uranium is only poorly transferred into the biological cycle soil $\rightarrow$ plants $\rightarrow$ animals $\rightarrow$ man. Damage to genetic material by increasing neonatal abnormalities is not expected from very small doses of DU. The problem with the use of DU ammunition probably lies mainly in the fact that after the end of the fighting in more contaminated places the residual local contamination of the environment with uranium and its radiation exceeds the internationally recommended standards.

\subsubsection{Prohibition of nuclear weapons}

While other weapons of mass destruction, such as chemical, bacteriological (biological) and toxin weapons, are prohibited by international conventions (including the complete destruction of stockpile of these weapons and facilities for their production), in the case of nuclear weapons the attempts to come to an agreement failed although nuclear weapons are the most devastating weapons of the contemporary complex and contradictory world. Their development or use is not prohibited.

The Treaty of Non-Proliferation of Nuclear Weapons (NPT) that picks up on the control system of peaceful nuclear facilities under the supervision of the International Atomic Energy Agency (IAEA) was accepted as

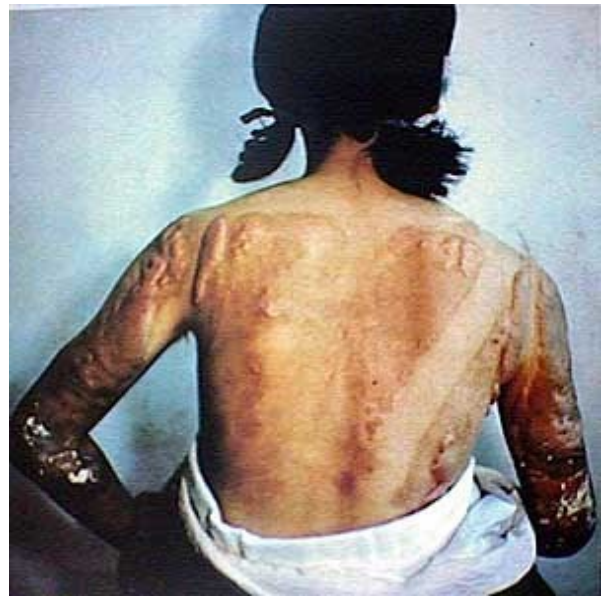

Photo 70: Radiation burns of a girl after the nuclear explosion in Hiroshima on August, 6, 1945. [Source: Pho-70] the first. Since 1968 up to now, 189 countries, out of which 5 possess their own nuclear weapons officially (the USA, France, Great Britain, Russia and China), have signed it.

Only India, Pakistan and Israel have not signed the treaty and the D.P.R.K. withdrew from it in 2003. The treaty came into force on March 05, 1970. Even if the concept of three pillars does not appear directly in the treaty, the treaty is often interpreted through them. They are the non-proliferation of nuclear weapons, disarmament and the right to peaceful use of nuclear energy.

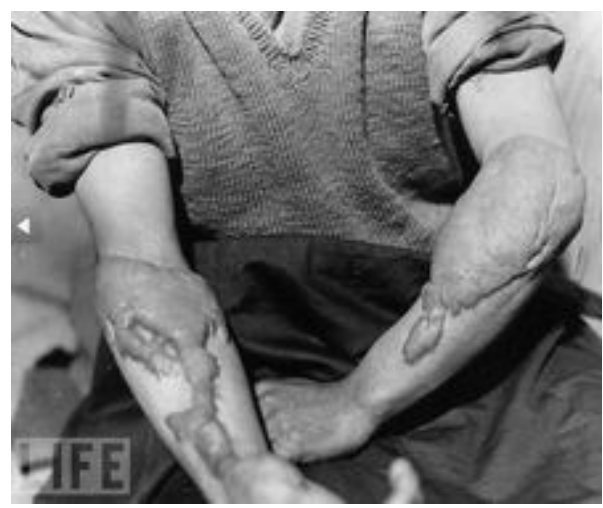

Photo 71: Keloid scars (hypertrophic scars) - the consequence of the nuclear explosion in Hiroshima on August, 6 , 1945. [Source: Pho-71]
The General Assembly agenda, which aims to force those Member States that have not ratified the Comprehensive Nuclear-Test-Ban Treaty (CTBT), which bans all nuclear tests for both military and civilian purposes, is never missing from the General Assembly agenda.

The treaty was accepted by the General Assembly in 1996, but, unfortunately, it has not come into force up to now. This will not happen until 180 days after ratification by the forty-four states listed in the instrument annexed to the treaty. Six states have not yet ratified the treaty (the United States, Israel, Iran, China, Egypt and Indonesia, which have already begun the ratification process), and India, Pakistan and the D.P.R.K. have not even signed the treaty. 
The CTBT includes measures to ensure its observance. If it came into force, the devices for monitoring soil, water and atmosphere to capture any nuclear explosion could be used in the territory of the Contracting States. More than 300 such devices are positioned all over the world. They record the captured data and then they send it to the International Data Centre in Vienna, Austria, where the CTBT office has its seat. If this treaty enters into force, all Contracting States will be obliged not to carry out or support nuclear tests on their territory, which is also a very important point in the treaty.

The Strategic Arms Limitation Talks (SALT) took place between the USA and the USSR during the Cold War. The aim of both powers was to limit the number of nuclear missiles in their arsenals. In 1969, the negotiations started in Helsinki, Finland. The first agreement (SALT I) was signed in 1972 and caused the freeze of the number of strategic missile bases.

The Anti-Ballistic Missile Treaty (ABM) was another agreement. This treaty ordered both states to reduce the number of anti-ballistic defence systems to one for each state. Within the SALT II the negotiations between the American and Soviet Presidents proceeded from 1977 to 1979. It was an attempt to curtail the production of strategic nuclear weapons and thus to pick up on the success of the prior agreement (SALT I).

They agreed to ban new missile programs. The USA retained its Trident program and the USSR could retain 308 missile launchers of heavy Intercontinental Ballistic Missiles (ICBMs) of the SS-18 type. Although both presidents signed the treaty, the American Congress refused to ratify it in response to the Soviet invasion to Afghanistan, even if the treaty was observed in practice.

In 1986, the USA withdrew from the treaty completely. After that, the Intermediate-Range Nuclear Forces (INF) Treaty was signed in 1987. Both countries bound themselves to destroy all intermediate-range and shorter-range missiles ( 500 up to $5,000 \mathrm{~km}$ ) and cruise missiles. The treaty came into

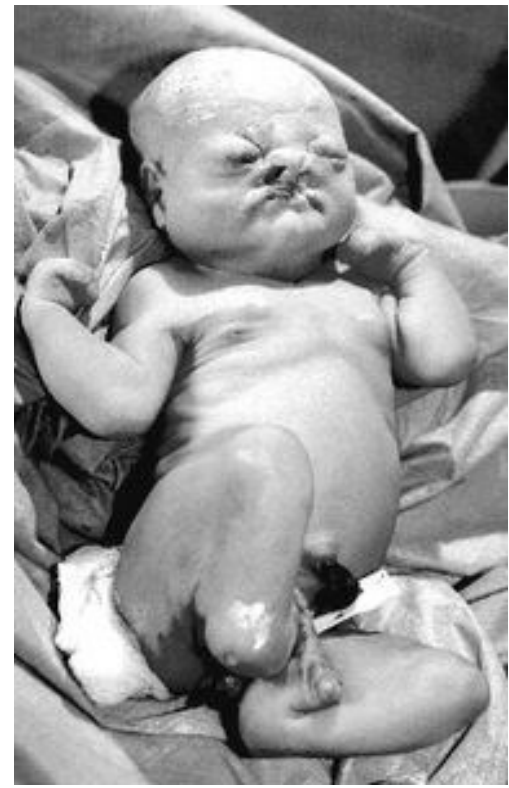

Photo 72: Genetic disorders of the fetus - the result of a nuclear explosion in Hiroshima.

[Source: Pho-72] force in 1988 and eight years later all weapons were liquidated.

In 1982, next talks between the USA and the USSR started and were aimed at reducing strategic weapons. The Strategic Arms Reduction Treaty (START I) was signed on July 31, 1991 and entered into force on December 05, 1994. Ten years later the treaty was implemented, which meant the removal of approximately $80 \%$ of all strategic nuclear weapons. After the end of START I negotiations, new talks over the START II Treaty started. This treaty should have followed the START I Treaty. The signing took place between the American and Russian presidents on January 03, 1993. Although ratified, it never came into force.

The Russian Federation withdrew from the treaty on July 14, 2002. It responded to the termination of the Anti-Ballistic Missile Treaty (ABM Treaty) by the US government. Officially, the START II Treaty was replaced by the Strategic Offensive Reductions Treaty (SORT), upon which President George W. Bush and President Vladimir Putin agreed at the summit in November 2001. Half a year later, it was signed in Moscow and both states bound themselves to reduce the number of nuclear warheads from 2,200 to 1,700. During the $1990 \mathrm{~s}$, the START III draft treaty was created, however, it has never been signed. It would mean a drastic reduction of nuclear arsenals of both countries, but after the entrance of the new Bush administration all START III negotiations ended. 
In April 2009, American President Barack Obama, in his Prague speech, indicated his ambitions in the issue of stopping the spread of nuclear weapons and set his goal to build the world without them. One year later, on April 08, 2010, together with Russian President Dmitry Medvedev he concluded the most important disarmament agreement since the day of the START I Treaty (new START), which terminated at the end of 2009. Thus, both states bound themselves to reduce the number of strategic nuclear warheads to 1,550 for each state.

\subsubsection{Nuclear-weapon-free zones}

Nuclear-weapon-free zones are currently established in some parts of the world, but the use of nuclear weapons is not prohibited. Why couldn't a nuclear-weapon-free zone also be in the entire Europe or any of its part? Currently, the US nuclear weapons are located in Europe in five NATO member states. Extreme pressure on their transfer back to the United States of America is applied in Germany and Italy.

The Nuclear-Weapon-Free Zones (NWFZs) in contrast with the Treaty on the Non-Proliferation of Nuclear Weapons (NPT) aim at the problem of nuclear weapon proliferation at a regional level. They represent a territory completely without nuclear weapons. They are established by a multilateral treaty, in which states undertake not to produce, acquire, test, own or control nuclear weapons.

The possibility for establishing such a zone is specified in the Non-Proliferation of Nuclear Weapons Treaty (NPT), Article VII. However, in contrast to the

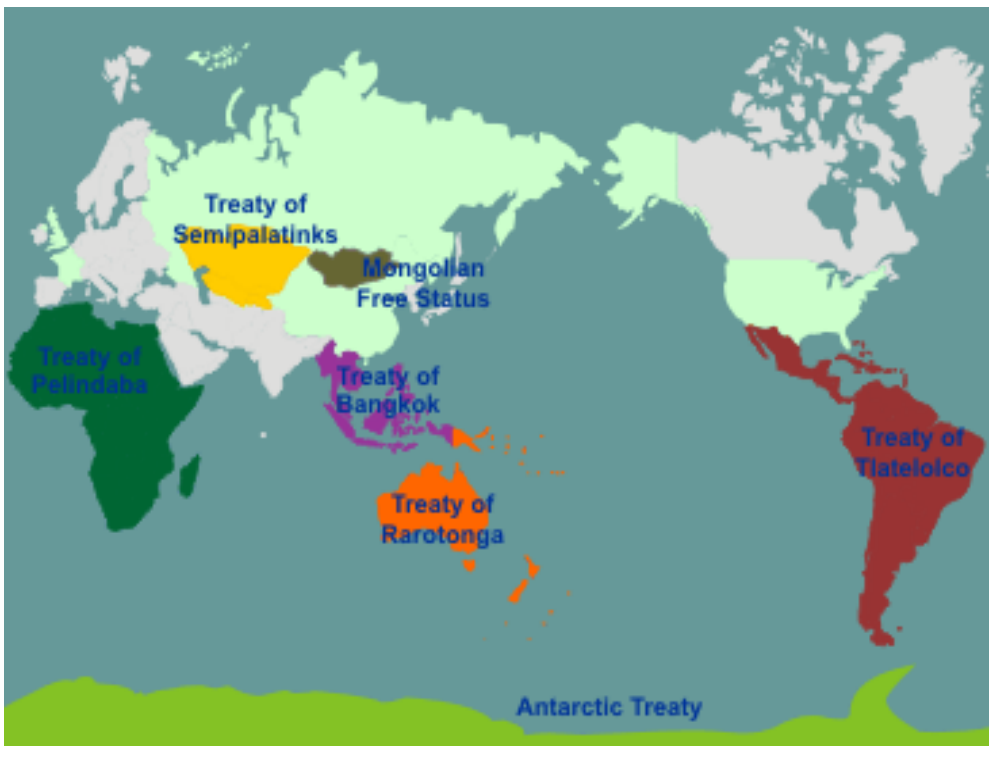

Figure 12: The present state of declared nuclear-weapon-free zones (NWFZs) in the world. [Source: Fig-12] NPT, the countries enter into greater obligations by establishing a nuclear-free zone. That is to say that the treaties establishing NWFZs are based on the principle of the comprehensive nuclear weapon ban within the zone. On the other hand, the NPT enables the arsenal of a nuclear state to exist on the territory of a non-nuclear state, provided that it will operate it.

Since 1967, when the first nuclear-weapon-free zone was established, four next NWFZs have been established. Currently, there are the following nuclear-weapon-free zones:

- NWFZ in Latin America and the Caribbean region (Treaty of Tlatelolco, 1967);

- NWFZ in the South Pacific (Treaty of Rarotonga, 1985);

- NWFZ in Southeast Asia (Treaty of Bangkok, 1995);

- NWFZ in Africa (Treaty of Pelindaba, 1996); and

- NWFZ in Central Asia (Treaty of Semipalatinsk, 2006).

Some states declared themselves nuclear-weapon-free zone, however, only Mongolia won the international recognition. It is currently proposed to create zones in South Asia, Northeast Asia, Central and Eastern Europe, the Middle East and the entire Southern Hemisphere. Nuclear-weapon-free zones may play a positive role in the process of the complete nuclear disarmament. 


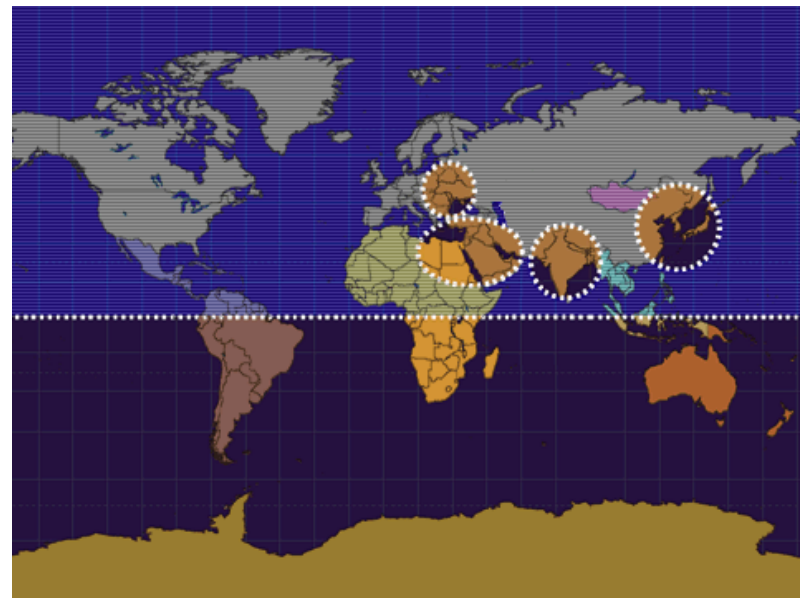

Figure 13: Proposed nuclear-weapon-free zones (NWFZs) in the world. [Source: Fig-13]
It is clear that establishing such zones is the first and fundamental step to the gradual nuclear disarmament. Thus, mankind is faced with an urgent task to prepare and accept an international treaty related to the comprehensive nuclear weapon ban and the complete destruction of their stockpile under effective international control. However, currently, there is no sufficient political will to prepare and accept such a complex international treaty, especially in the official owners of nuclear weapons. And so, all of us, the population of planet Earth, remain in a nuclear capture even at the beginning of the $21^{\text {st }}$ century.

\subsubsection{Sunken nuclear submarines}

For several decades, everything related to nuclear missile submarines was shrouded in the strictest secrets. Sometimes, this weapon system has been and is called exaggeratedly an absolute weapon for its terrifying power, efficiency and very difficult vulnerability. However, it is also a special item from the viewpoint of the environmental damage due to nuclear weapons in the cases of sunken and lost nuclear submarines or submarines with nuclear weapons onboard. From 1963 up to 1989, 7 Soviet and 2 American nuclear submarines or submarines with nuclear weapons onboard disappeared in the sea. We can call these emergencies the environmental tax of the Cold War. The radioactive material at the bottoms of seas became an ecological ticking time bomb. It is only a matter of time before the corrosion caused by salt sea water releases them. This radioactive material will then spread freely and without any control to the environment.

Let's start with warheads. In addition to them, there are also nuclear bombs in the seas, which the American and Soviet Air Forces lost in the past. There is no danger of a nuclear explosion. The basis of detonation of a nuclear weapon is that two or more smaller (subcritical) quantities of fission material will get together at an appropriate angle and the chain reaction may take place in them. In weapons, this is ensured by the mechanism and its construction should be secured so that the fissile material does not get together spontaneously. A nuclear weapon cannot explode without enough neutrons from outside to start a reaction. They must be supplied by e.g. the neutron accelerator, which does not switch itself on in the sea. Similarly, there is no need to be afraid of the explosion of a nuclear reactor, which cannot work as a bomb. On the other hand, the reactor could melt down similarly as it happened in Chernobyl. Theoretically, the reactor should shut down itself in the accident. However,

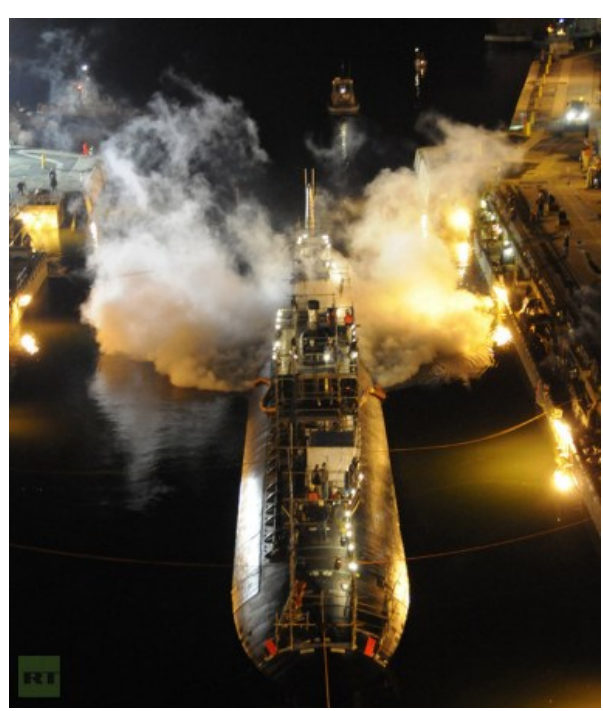

Photo 73: The fire on the SSN-755 nuclear submarine caused \$440 million in damage. [Source: Pho-73] if it did not happen, the reaction would continue proceeding in it without any control. The surface of the reactor would not melt down so easily as on dry land because water cools it down undersea. 
Water would also stop the fission reaction if the protective layers melted down. Radioactivity would then penetrate to the sea. After that, it would spread to the surrounding area. The situation could not be repeated as in Chernobyl, where after the packaging melted in a fire, the high temperature created an air chimney, which pulled the fission products high into the atmosphere, where they dispersed over Europe.

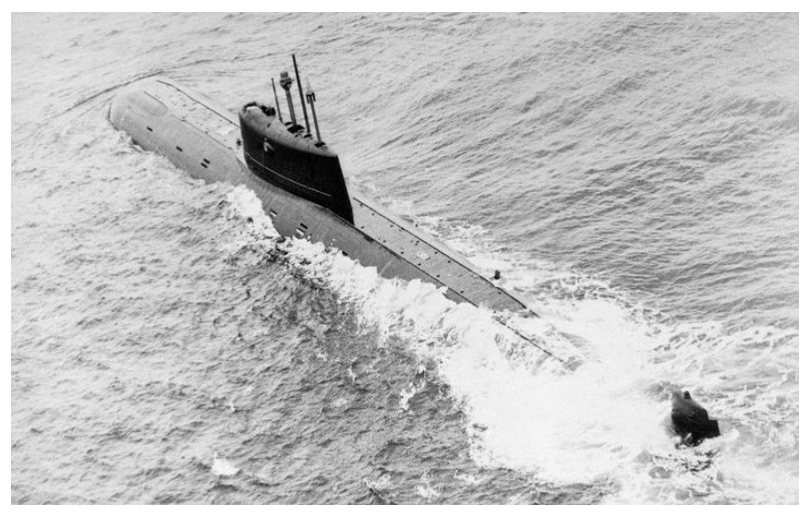

Photo 74: The Soviet K-278 Komsomolets nuclear submarine, which sank in the Norwegian Sea on April 07, 1989, 42 dead. [Source: Pho-74]

Radioactive contamination in the sea would be influenced noticeably by the local surroundings only. The fact is, however, that to this day, remnants of radioactivity from submarine nuclear tests, which lasted until the early 1960 s, are found in seawater around the globe. However, representative papers on how they affected the life in the sea are not at disposal.

Contamination of the place of accident threatens also due to unexploded warheads and unmelted reactors. Warheads usually contain 20 up to $30 \mathrm{~kg}$ of plutonium, which is a toxic and radioactive element with a halflife of nearly 25,000 years. In organisms, plutonium settles in bones and from there it destroys them through radiation. After some time, even if it is not quite certain after how many years it will be, the salt water will corrode the protective covers and plutonium will be released. Then, it will depend on how fast it will escape and how fast it will dilute and spread in the sea. It is not possible to predetermine and, therefore, it would be better if states pulled their warheads out from the bottom.

Table 8. Nuclear submarine accidents (since 1960). [Source: Tab-8]

\begin{tabular}{|c|c|c|}
\hline Date of accident & State & Type of submarine, type of accident and consequences \\
\hline October 13,1960 & USSR & K-8 Kit - leaky steam generator (13 irradiated). \\
\hline April 10, 1963 & USA & $\begin{array}{l}\text { USS Thresher ( } S S N-593) \text { - during the deep-diving tests. The cause } \\
\text { of catastrophe has not been clarified sufficiently; it was probably caused } \\
\text { by a crack in a welded seam of the piping system ( } 129 \text { dead). }\end{array}$ \\
\hline February 12,1965 & USSR & $\begin{array}{l}\text { K-11 / November - unplanned activation of the reactor during } \\
\text { the exchange of fuel rods (part of the crew irradiated). }\end{array}$ \\
\hline September 8, 1967 & USSR & $\begin{array}{l}\text { K-3 Leninskij Komsomol / November - a fire in the } 1^{\text {st }} \text { and } 2^{\text {nd }} \text { sections } \\
\text { when patrolling ( } 39 \mathrm{dead}) .\end{array}$ \\
\hline March 8, 1968 & USSR & $\begin{array}{l}\text { K-129 Rudá hvězda / Golf - the submarine sank when patrolling near } \\
\text { the Island of Guam. The Americans raised it in May, } 1974 .\end{array}$ \\
\hline May 22, 1968 & USA & $\begin{array}{l}\text { USS Scorpion (SSN-589) - the causes have not been clarified up to now } \\
\text { (99 dead). }\end{array}$ \\
\hline April 17, 1970 & USSR & $\begin{array}{l}\text { K- } 8 \text { / November }- \text { a fire during patrolling in the Bay of Biscay. } \\
\text { The submarine sank to a depth of } 4,680 \text { metres }(52 \mathrm{dead}) \text {. }\end{array}$ \\
\hline $\begin{array}{l}\text { September 23, } \\
1972\end{array}$ & USSR & K-19 / Hotel - a fire when patrolling in the North Atlantic (28 dead). \\
\hline June 24,1983 & SSR & $K-429$ - the submarine sank near the coast of Kamchatka ( 16 dead). \\
\hline August 10, 1985 & USSR & $\begin{array}{l}\text { Explosion during the refuelling of the nuclear submarine at Chazhma } \\
\text { in the Far East. In the centre of burst, the radiation reached } 90,000 \mathrm{r} / \mathrm{h} \text {. } \\
\text { The wide surroundings were contaminated ( } 10 \text { people immediately dead, } \\
\text { later additional tens of people died due to radiation injuries). }\end{array}$ \\
\hline
\end{tabular}


Table 8. Nuclear submarine accidents (since 1960) - continued.

\begin{tabular}{|c|c|c|}
\hline Date of accident & State & Type of submarine, type of accident and consequences \\
\hline October 3, 1986 & USSR & $\begin{array}{l}K-219 \text { - an explosion in the launching shaft. The submarine sank three } \\
\text { days later to a depth of about } 5,000 \text { metres ( } 4 \text { dead). }\end{array}$ \\
\hline April 7, 1989 & USSR & $\begin{array}{l}\text { A fire on the submarine Komsomolets, which sank with two nuclear } \\
\text { torpedoes onboard in the international waters in the Norwegian Sea } \\
\text { (out of } 69 \text { crew members } 42 \text { died). }\end{array}$ \\
\hline March 20, 1993 & $\begin{array}{l}\text { Russia } \\
\text { USA }\end{array}$ & $\begin{array}{l}\text { The USS Grayling nuclear submarine collided with a Russian ballis- } \\
\text { tic missile submarine in the Barents Sea about } 160 \mathrm{~km} \text { far from } \\
\text { the Kola Peninsula; submarines were slightly damaged. }\end{array}$ \\
\hline August 12, 2000 & Russia & $\begin{array}{l}\text { K-141Kursk / Oscar } 2 \text { - an explosion in the torpedo tube was probably } \\
\text { the cause of an accident and sinking of the submarine in the Barents Sea } \\
(108 \text { dead). }\end{array}$ \\
\hline February 9, 2001 & USA & $\begin{array}{l}\text { USS Greenville (SSN 772) - in a collision it sank Ehime Maru, a fishery } \\
\text { high school training ship ( } 9 \text { dead fishermen). }\end{array}$ \\
\hline August 30, 2003 & Russia & $\begin{array}{l}K-159-\text { a decommissioned submarine heading for the Shkval dock sank } \\
\text { in the Barents Sea. The submarine disconnected from the tugboat } \\
\text { in a strong storm, overturned and went to the bottom ( } 10 \mathrm{dead}) \text {. }\end{array}$ \\
\hline October 25,2003 & USA & $\begin{array}{l}\text { The USS Hartford (SSN 768) - ran aground and damaged its hull, rudder } \\
\text { and sonar (no injuries). }\end{array}$ \\
\hline January & USA & $\begin{array}{l}\text { The USS San Francisco (SSN 711) - an impact at a depth of more than } \\
150 \text { metres on an underwater mountain off the island of Guam (1 dead, } \\
23 \text { wounded). }\end{array}$ \\
\hline March 21, 2007 & England & $\begin{array}{l}\text { HMS Tireless (S117) - an explosion onboard during the exercise in the } \\
\text { Arctic ( } 2 \text { dead). }\end{array}$ \\
\hline November 8, 2008 & Russia & $\begin{array}{l}K-152 \text { - after an unexpected start of the fire extinguishing system } \\
(20 \text { people died and other } 21 \text { were poisoned partially). }\end{array}$ \\
\hline $\begin{array}{l}\text { February } 3,(4) \\
2009\end{array}$ & $\begin{array}{l}\text { England } \\
\text { France }\end{array}$ & $\begin{array}{l}\text { The British HMS Vanguard and the French Le Triomphant (S616) -col- } \\
\text { lided in the Atlantic (no injuries). }\end{array}$ \\
\hline March 20, 2009 & USA & $\begin{array}{l}\text { USS Hartford (SSN 768) - a collision with the USS New Orleans } \\
\text { amphibious landing craft (15 injured). }\end{array}$ \\
\hline December 30, 2011 & Russia & $\begin{array}{l}\text { K-84 Yekaterinburg - a fire during repair works in the dock } \\
\text { ( } 9 \text { injured). }\end{array}$ \\
\hline May 23, 2012 & USA & $\begin{array}{l}\text { USS Miami (SSN 755) - a fire during repair works in the dock } \\
\text { (7 injured). }\end{array}$ \\
\hline September 6, 2013 & Russia & K-132 Irkutsk - a fire during repair works in the dock (no injuries). \\
\hline & England & HMS Talent (S92) - a hole in the to \\
\hline April 7, 2015 & Russia & $K$-266 Orel - a fire during repair works in the dock (no injuries). \\
\hline
\end{tabular}

The fuel in nuclear reactors is usually uranium in tablets made of metal and zirconium alloys. It is enriched more than usually in power plants to give more energy. As long as uranium is not used in a reactor, it does not represent a big problem since it is not too radioactive. In the sea, the radioisotopes from fuel tablets would leach slowly and water would dilute them. Then water flows would spread them in mild concentrations.

On the other hand, after the utilization, uranium converts to depleted fuel, to the mixture of highly radioactive agents that are mortal for about one hundred thousand years. The advantage of high enrichment of nuclear fuel for submarines is at least that less dangerous plutonium arises than in a regular reactor. Nevertheless, radioactivity would get into fish and then maybe on plates. The risk would be dependent on the distance of the contaminated area from fishing locations. 
For the time being, Americans only monitor their sunken submarines. As for the USS Thresher submarine that sank in 1963 near the East Coast of the USA and the USS Scorpion submarine that wrecked in 1968 near the Azores Islands, survey instruments detect mild radioactivity. However, it seems to come from the cooling medium of reactors, not from their fuel. Thus, the multi-barrier protection system has prevented water from getting into reactors for the time being.

\subsubsection{Film documentaries about nuclear weapons}

In addition to a number of professional books, publications, research reports, information studies, secret intelligence analyses and various manuals, a number of film materials have been produced, which can now be partially viewed on the Internet. Most of them are various shots of the nuclear bombing of Hiroshima and Nagasaki at the end of World War II. It is worth mentioning the American movie, which was released by the American Broadcasting Company (ABC) in 1983 and shocked the whole of America. The movie represents the escalation of political and military tension between East and West and shows the catastrophic situation after the use of Soviet nuclear weapons in the attack on American cities. The movie entitled Holocaust (complete destruction, complete doom) that was prepared in 1988 as a scientific forecast for a possible nuclear war of large extent deserves special attention. Apart from other things, it includes computer animations and other simulations of nuclear attacks on the largest metropolises. It shows a catastrophic damage to the modern society critical infrastructure. The preparation and production of the half-hour movie was led by the world nuclear physicist Frank Barnaby from Great Britain who, at that time, worked as a prominent leading personality of the science world in the Stockholm International Peace Research Institute (SIPRI).

The 45-minute US document from 2009 entitled Lost Bombs: Nuclear Weapons, made by the studio of Douglas Keeney and Mickey Youmans Production, is a very interesting documentary. It shows how ten aircrews faced terrible accidents in bombers armed with nuclear ammunition. The results are utterly startling and surprising, nevertheless, absolutely true. The movie can be viewed at http://dokumenty.tv/utajene-nehody-nuklearnich-zbrani-dokument/.

Another US document, which the Czech TV broadcasted in 2012, is entitled Nukes in Space. The document describes the end of the Hot War in 1945 and the subsequent period of the Cold War. They inseparably included atomic and later space races between the two Great Powers. Scientists and soldiers wanted to gain as much information as possible about the effects of nuclear weapons. Politicians then tested cold-bloodedness of the opposite party through these tests in critical moments. During the 1950s and the 1960s, hundreds of experimental nuclear explosions happened. Nowadays, it seems to be incredible, however, most of these tests were carried out by the USA and the USSR in the atmosphere of our planet. Great Britain and France also entered the Nuclear Club in the same way. In 1963, the Test Ban Treaty was signed, which banned nuclear tests in the atmosphere; however, one year later China, which did not sign and follow it, entered the Nuclear Club. The movie can be viewed at http://dokumenty.tv/pokusyv-ovzdusi-dokument/.

Obviously, there are a lot of other documentaries, which record the course of World War II also with a detailed nuclear bombardment of both Japanese cities, Hiroshima and Nagasaki.

\subsubsection{Smuggling of nuclear materials}

After 1990, the cases of smuggled nuclear materials increased sharply. It was caused especially by the high price of nuclear materials even in small quantities. There are dozens of cases of detected nuclear material smuggling and the question is how many nuclear explosives ${ }^{235} \mathrm{U}$ and ${ }^{239} \mathrm{Pu}$ used for weapons) were sold illegally into dangerous hands. 
It is currently acknowledged that the International Atomic Energy Agency (IAEA) in Vienna does not perform its control functions or, if need be, it performs them only insufficiently. In general, it is deemed that the lost nuclear fissile material would be enough for a few small nuclear charges. In this context, the proliferation of nuclear weapons and also much more dangerous interconnection of terrorism and nuclear weapons are most often mentioned. The critical amounts of nuclear explosives are about $5 \mathrm{~kg}$ only for ${ }^{235} \mathrm{U}$, while $4.5 \mathrm{~kg}$ only for ${ }^{239} \mathrm{Pu}$.

On the basis of numerous media reports, it is difficult to assess the severity of smuggling from the viewpoint of the risk of proliferation. A more reliable source for this assessment is the "Illicit Trafficking Database" established by the IAEA (International Atomic Energy Agency) in 1995. Currently, this database is called "Incident and Trafficking Database (ITDB)" and can be found on the IAEA website: https://www.iaea.org/resources/databases/itdb. This database provides an overview of the incidents involving the smuggling of nuclear materials and incidental discoveries of unguarded material. For example, the Agency recorded 650 confirmed cases during the period 1993-2004. Most cases (more than $60 \%$ ) involve non-fissile radioactive materials, such as caesium ${ }^{137} \mathrm{Cs}$, strontium ${ }^{90} \mathrm{Sr}$, cobalt ${ }^{60} \mathrm{Co}$ or americium ${ }^{241} \mathrm{Am}$. These materials can be dangerous because of their usefulness in constructing a dirty bomb by a criminal or terrorist group. Other $30 \%$ of the cases concern nuclear materials such as natural uranium, depleted uranium, thorium and low-enriched uranium. By the end of 2004, the IAEA reported 63 cases of smuggling low-enriched uranium. From the viewpoint of proliferation, in the eighteen most important cases, the material suitable for producing nuclear weapons was seized. In seven cases it was plutonium, of which six times the quantity did not exceed 10 grams. In the seventh incident, in August 1994, 360 grams of plutonium were seized at the Munich airport, thanks to the cooperation of the German Secret Service and the Russian authorities. The smuggling of highly enriched uranium in the quantity from 1 gram to $2.5 \mathrm{~kg}$ was detected in eleven cases. The investigation of most incidents shows that the seizure of contraband was a success in preventing further attempts at smuggling. In general terms, it can be said that the IAEA data confirm the trends in proliferation indicated by the non-state actors in the previous text.

\subsubsection{The present state of nuclear weapons in the world}

Table 9 represents the present state of nuclear weapons. The presented estimates (the actual states of armament are, in principle, kept secret and the declarations of the owners may be inaccurate and misleading) are usually based on well-known information sources, which is in this case a Yearbook of the Stockholm International Peace Research Institute (SIPRI). All estimates are approximate and as of January 2021. https://www.sipri.org/yearbook/2021

Table 9: The present state of nuclear weapons in the world (January 2021). [Source: Tab-9]

\begin{tabular}{|c|c|c|c|c|}
\hline Country & $\begin{array}{c}\text { Deployed } \\
\text { warheads }^{a}\end{array}$ & $\begin{array}{c}\text { Stored } \\
\text { warheads }\end{array}$ & $\begin{array}{c}\text { Other } \\
\text { warheads }\end{array}$ & $\begin{array}{c}\text { Total } \\
\text { inventory }\end{array}$ \\
\hline The USA & $1800^{c}$ & $2000^{d}$ & $1750^{e}$ & 5500 \\
\hline The USSR & $1625^{f}$ & $2870^{g}$ & $1760^{e}$ & 6255 \\
\hline Great Britain & 120 & 105 & - & $225^{h}$ \\
\hline France & 280 & $10^{i}$ & .. & 290 \\
\hline China & - & 350 & - & 350 \\
\hline India & - & 156 & .. & 156 \\
\hline Pakistan & - & 165 & .. & 165 \\
\hline Israel & - & 90 & .. & 90 \\
\hline North Korea (D.P.R.K.) & - & .. & [40-50] & {$[40-50]^{j}$} \\
\hline Total $^{k}$ & 3825 & 5745 & 3510 & 13080 \\
\hline
\end{tabular}

= not applicable or not available; $-=$ nil or a negligible value; [ ] = uncertain figure. 


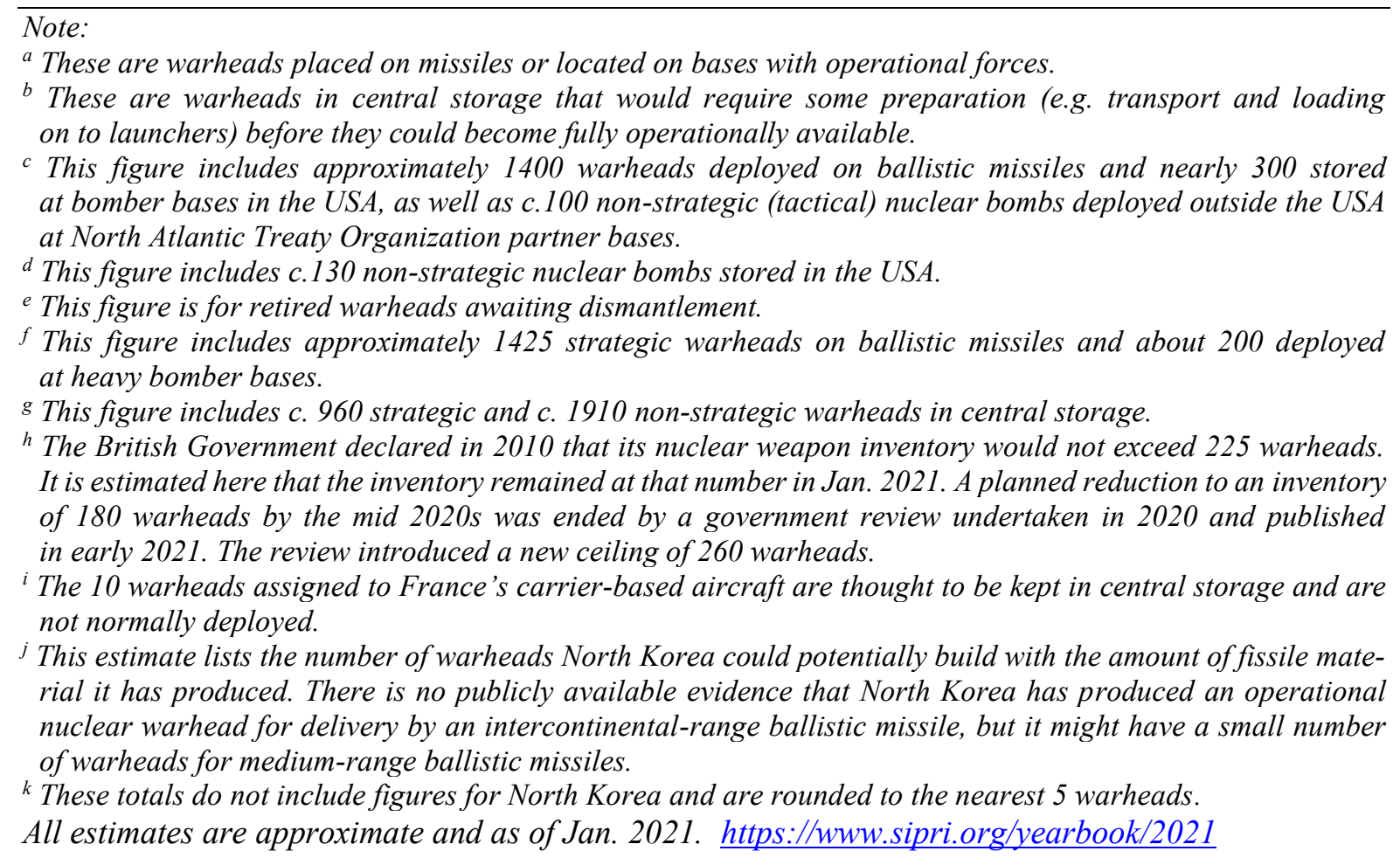

In conclusion of the chapter on nuclear weapons, the present state of nuclear weapons is mentioned in brief. Even at present, it can be stated that the state of nuclear weapons is a legacy of the Cold War. Even though nuclear arsenals stagnate in the owners of nuclear weapons (Great Britain, France and the People's Republic of China) or, let us say, increase (in such countries as Pakistan, India and North Korea), the main owners of nuclear weapons reduce their nuclear military capacities. These are only nuclear weapons of the USA and the Russian Federation. It is generally estimated that US and Russian nuclear weapons account for as much as $95 \%$ of the world nuclear potential.

\subsection{Basic Terms in the Area of Nuclear Weapons}

Nuclear weapons are the most effective means of mass destruction of troops, logistics structures and the facilities of the state economic infrastructure. They are intended to annihilate personnel, destroy combat and transport equipment, structures and to create the zones of natural barriers, floods and contaminated terrain. Nuclear weapon is a weapon based on the military use of energy yield, which is released during a nuclear reaction. The source of energy is an atomic nucleus. It includes nuclear ammunition and nuclear delivery means.

A nuclear weapon is an explosive device that derives its destructive force from nuclear reactions, either fission (fission bomb) or from a combination of fission and fusion reactions (thermonuclear bomb). Both bomb types release large quantities of energy from relatively small amounts of matter. It may be fissile $\left({ }^{233} \mathrm{U},{ }^{235} \mathrm{U},{ }^{239} \mathrm{Pu}\right.$, etc.) or thermonuclear (hydrogen or lithium isotopes). The first test of a fission (,, atomic”) bomb released an amount of energy approximately equal to 20,000 tons of TNT (84 TJ).

The first thermonuclear (,,hydrogen”) bomb test released energy approximately equal to 10 million tons of TNT (42 PJ). A thermonuclear weapon weighing little more than 2,400 pounds $(1,100 \mathrm{~kg})$ can release energy equal to more than 1.2 million tons of TNT (5.0 PJ). A nuclear device no larger than traditional bombs can devastate an entire city by blast, fire, and radiation. Since they are weapons of mass destruction, the proliferation of nuclear weapons is a focus of international relations policy. 
Nuclear charge is a nuclear explosive along with a device that initiates nuclear reaction (a system actuating a nuclear explosive). Based on the type of nuclear explosive it is divided into fission and thermonuclear. Thermonuclear explosives may be two-phase or three-phase.

Nuclear cartridge is made of a nuclear charge along with a casing, in which it is delivered to the target (nuclear bomb, nuclear guided missile, nuclear shell, nuclear mine, etc.). The term nuclear ammunition is also used for nuclear cartridges. For nuclear ammunition delivery especially missiles, the Air Force and the Artillery are used.

Atom - an atom is the smallest constituent unit of ordinary matter that has the properties of a chemical element. Every solid, liquid, gas, and plasma is composed of neutral or ionized atoms. Atoms are very small; typical sizes are around 100 picometers (a ten-billionth of a meter, in the short scale). Every atom is composed of a nucleus and one or more electrons bound to the nucleus. The nucleus is made of one or more protons and typically a similar number of neutrons. Protons and neutrons are called nucleons. More than $99.94 \%$ of an atom's mass is in the nucleus. The protons have a positive electric charge, the electrons have a negative electric charge, and the neutrons have no electric charge. If the number of protons and electrons are equal, that atom is electrically neutral. If an atom has more or fewer electrons than protons, then it has an overall negative or positive charge, respectively, and it is called an ion.

Atomic nucleus - the atomic nucleus is the small, dense region consisting of protons and neutrons at the centre of an atom. The diameter of the nucleus is in the range of $1.75 \mathrm{fm}$ $\left(1.75 \times 10^{-15} \mathrm{~m}\right)$ for hydrogen (the diameter of a single proton) to about $15 \mathrm{fm}$ for the heaviest atoms, such as uranium. These dimensions are much smaller than the diameter of the atom itself (nucleus + electron cloud), by a factor of about 23,000 (uranium) to about 145,000 (hydrogen).

Mass unit - the unified atomic mass unit or Dalton (symbol: $\mathrm{u}$, or Da) is a standard unit of mass that quantifies mass on an atomic or molecular scale (atomic mass). One unified atomic mass unit is approximately the mass of one nucleon (either a single proton or neutron) and is numerically equivalent to $1 \mathrm{~g} \cdot \mathrm{mol}^{-1}$. It is defined as one twelfth of the mass of an unbound neutral atom of carbon-12 in its nuclear and electronic ground state and at rest, and has a value of $1.660539040(20) \times 10^{-27} \mathrm{~kg}$, or approximately 1.66 yoctograms.

Atomic (proton) number - the atomic number or proton number (symbol Z) of a chemical element is the number of protons found in the nucleus of an atom. It is identical to the charge number of the nucleus. The atomic number uniquely identifies a chemical element. In an uncharged atom, the atomic number is also equal to the number of electrons. The sum of the atomic number $Z$ and the number of neutrons, $N$, gives the mass number $A$ of an atom. Since protons and neutrons have approximately the same mass (and the mass of the electrons is negligible for many purposes) and the mass defect of nucleon binding is always small compared to the nucleon mass, the atomic mass of any atom, when expressed in unified atomic mass units (making a quantity called the "relative isotopic mass"), is within $1 \%$ of the whole number $A$. Atoms with the same atomic number $Z$ but different neutron numbers $N$, and hence different atomic masses, are known as isotopes.

Nucleon (mass) number - the mass number (symbol A), also called atomic mass number or nucleon number, is the total number of protons and neutrons (together known as nucleons) in an atomic nucleus. It determines the atomic mass of atoms. Because protons and neutrons both are baryons, the mass number A is identical with the baryon number B as of the nucleus as of the whole atom or ion. The mass number is different for each different isotope of a chemical element. This is not the same as the atomic number $(Z)$ which denotes the number of protons in a nucleus, and thus uniquely identifies an element. Hence, the difference between the mass number and the atomic number gives the number of neutrons $(N)$ in a given nucleus:

$$
N=A-Z
$$


Nucleons - In chemistry and physics, a nucleon is either a proton or a neutron, considered in its role as a component of an atomic nucleus. The number of nucleons in a nucleus defines an isotope's mass number (nucleon number). The proton and neutron are both baryons and both fermions. One carries a positive net charge and the other carries a zero-net charge; the proton's mass is only $0.1 \%$ less than the neutrons. Thus, they can be viewed as two states of the same nucleon, and together form an isospin doublet $(I=1 / 2)$.

Isospin - in nuclear physics and particle physics, isospin (isotopic spin, isobaric spin) is a quantum number related to the strong interaction. Particles that are affected equally by the strong force but have different charges (e.g. protons and neutrons) can be treated as being different states of the same particle with isospin values related to the number of charge states.

Proton - a proton is a subatomic particle, symbol $p$ or $p^{+}$, with a positive electric charge of $+1 e$ elementary charge and mass slightly less than that of a neutron. Protons and neutrons, each with masses of approximately one atomic mass unit, are collectively referred to as "nucleons". One or more protons are present in the nucleus of every atom; they are a necessary part of the nucleus. The number of protons in the nucleus is the defining property of an element, and is referred to as the atomic number (represented by the symbol Z). Since each element has a unique number of protons, each element has its own unique atomic number. Because protons are not fundamental particles, they possess a physical size, though not a definite one; the root mean square charge radius of a proton is about $0.84-0.87 \mathrm{fm}$ or $0.84 \times 10^{-15}$ to $0.87 \times 10^{-15} \mathrm{~m}$. Mass is $1.672621898(21) \times 10^{-27} \mathrm{~kg}$ or $1.007276466879(91) \mathrm{u}$ (unified atomic mass unit).

Neutron - the neutron is a subatomic particle, symbol $n$ or $n^{0}$, with no net electric charge and a mass slightly larger than that of a proton. Protons and neutrons constitute the nuclei of atoms. The free neutron has a mass of about $1.675 \times 10^{-27} \mathrm{~kg}$ or $1.0087 \mathrm{u}$ (unified atomic mass unit). The neutron has a mean square radius of about $0.8 \times 10^{-15} \mathrm{~m}$, or $0.8 \mathrm{fm}$, and it is a spin- $1 / 2$ fermion. The neutron has no measurable electric charge. With its positive electric charge, the proton is directly influenced by electric fields, whereas the neutron is unaffected by electric fields. The neutron has a magnetic moment, however, so the neutron is influenced by magnetic fields. The neutron's magnetic moment has a negative value, because its orientation is opposite to the neutron's spin.

Electron - he electron is a subatomic particle, symbol $e^{-}$or $\beta^{-}$, with a negative elementary electric charge. Electrons belong to the first generation of the lepton particle family, and are generally thought to be elementary particles because they have no known components or substructure. The electron has a mass that is approximately 1/1836 that of the proton. Quantum mechanical properties of the electron include an intrinsic angular momentum (spin) of a halfinteger value, expressed in units of the reduced Planck constant, $\hbar$. As it is a fermion, no two electrons can occupy the same quantum state, in accordance with the Pauli Exclusion Principle.

Isotope - isotopes are variants of a particular chemical element which differ in neutron number. All isotopes of a given element have the same number of protons in each atom. The

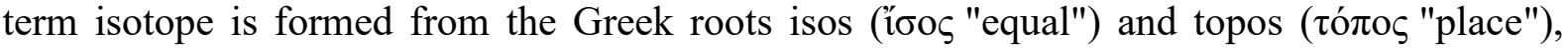
meaning "the same place"; thus, the meaning behind the name is that different isotopes of a single element occupy the same position on the periodic table. The number of protons within the atom's nucleus is called atomic number and is equal to the number of electrons in the neutral (non-ionized) atom. Each atomic number identifies a specific element, but not the isotope; an atom of a given element may have a wide range in its number of neutrons. The number of nucleons (both protons and neutrons) in the nucleus is the atom's mass number, and each isotope of a given element has a different mass number. For example, carbon-12, carbon-13 and carbon-14 are three isotopes of the element carbon with mass numbers 12,13 and 14 respectively $\left({ }^{12} \mathrm{C},{ }^{13} \mathrm{C}\right.$ and $\left.{ }^{14} \mathrm{C}\right)$. The atomic number of carbons is 6 , which means that every carbon atom has 6 protons, so that the neutron numbers of these isotopes are 6,7 and 8 respectively. 
Nuclide - a nuclide (from nucleus) is an atomic species characterized by the specific constitution of its nucleus, i.e., by its number of protons $Z$, its number of neutrons $N$, and its nuclear energy state.

Radionuclide - a radionuclide (radioactive nuclide, radioisotope or radioactive isotope) is an atom that has excess nuclear energy, making it unstable. This excess energy can be either emitted from the nucleus as gamma radiation, or create and emit from the nucleus a new particle (alpha particle or beta particle), or transfer this excess energy to one of its electrons, causing that electron to be ejected as a conversion electron. During those processes, the radionuclide is said to undergo radioactive decay. These emissions constitute ionizing radiation. The unstable nucleus is more stable following the emission, but will sometimes undergo further decay. Radioactive decay is a random process at the level of single atoms: it is impossible to predict when one particular atom will decay. However, for a collection of atoms of a single element the decay rate, and thus the half-life $\left(t_{1 / 2}\right)$ for that collection can be calculated from their measured decay constants. The ranges of the half-lives of radioactive atoms have no known limits and span a time range of over 55 orders of magnitude.

Ionisation - is the process by which an atom or a molecule acquires a negative or positive charge by gaining or losing electrons to form ions, often in conjunction with other chemical changes. Ionization can result from the loss of an electron after collisions with subatomic particles, collisions with other atoms, molecules and ions, or through the interaction with light. Heterolytic bond cleavage and heterolytic substitution reactions can result in the formation of ion pairs. Ionization can occur through radioactive decay by the internal conversion process, in which an excited nucleus transfers its energy to one of the inner-shell electrons causing it to be ejected.

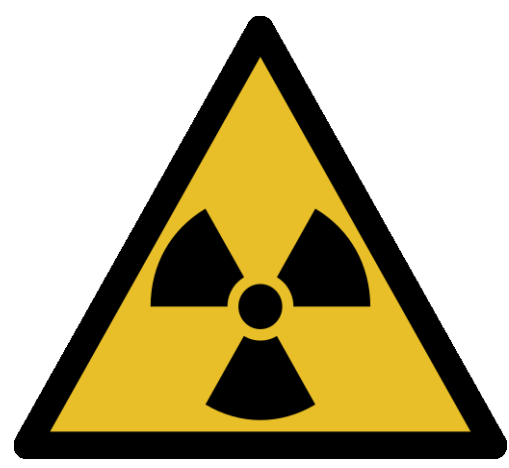

Figure 14: Ionizing radiation hazard symbol. [Source: Fig-14]

Ionizing radiation (ionising radiation) - is radiation that carries enough energy to liberate electrons from atoms or molecules, thereby ionizing them. Ionizing radiation is made up of energetic subatomic particles, ions or atoms moving at high speeds (usually greater than $1 \%$ of the speed of light), and electromagnetic waves on the high-energy end of the electromagnetic spectrum. Gamma rays, X-rays, and the higher ultraviolet part of the electromagnetic spectrum are ionizing, whereas the lower ultraviolet part of the electromagnetic spectrum, and also the lower part of the spectrum below UV, including visible light (including nearly all types of laser light), infrared, microwaves, and radio waves are all considered non-ionizing radiation. The boundary between ionizing and non-ionizing electromagnetic radiation that occurs in the ultraviolet is not sharply defined, since different molecules and atoms ionize at different energies. Conventional definition places the boundary at photon energy between $10 \mathrm{eV}$ and $33 \mathrm{eV}$ in the ultraviolet (see definition boundary section below). Typical ionizing subatomic particles from radioactivity include alpha particles, beta particles and neutrons. Almost all products of radioactive decay are ionizing because the energy of radioactive decay is typically far higher than that required to ionize.

Other subatomic ionizing particles which occur naturally are muons, mesons, positrons, and other particles that constitute the secondary cosmic rays that are produced after primary cosmic rays interact with Earth's atmosphere. Cosmic rays are generated by stars and certain celestial events such as supernova explosions. Cosmic rays may also produce radioisotopes on Earth (for example, carbon-14, ${ }^{14} \mathrm{C}$ ), which in turn decay and produce ionizing radiation. Cosmic rays and the decay of radioactive isotopes are the primary sources of natural ionizing radiation on Earth referred to as background radiation. 
Ionizing radiation can also be generated artificially using X-ray tubes, particle accelerators, and any of the various methods that produce radioisotopes artificially.

TNT equivalent is a convention for expressing energy, Table 10: Nuclear yields. typically used to describe the energy released in an explosion. The "ton of TNT" is a unit of energy defined by that convention to be 4.184 gigajoules, which is the approximate energy released in the detonation of a metric ton (1,000 kilograms or one megagram) of TNT.

The convention intends to compare the destructiveness of an event with that of conventional explosive materials, of which TNT is a typical example, although other conventional explosives such as dynamite contain [Source: Tab-10] more energy (Table 10). The "kiloton (of TNT)" is a unit of energy equal to 4.184 terajoules.

The "megaton (of TNT)" is a unit of energy equal to 4.184 petajoules. The kiloton and megaton of TNT has traditionally been used to describe the energy output, and hence the destructive power, of a nuclear weapon. The TNT equivalent appears in various nuclear weapon control treaties, and has been used to characterize the energy released in such other highly destructive events as an asteroid impact.

\subsection{Radioactivity and radioactive decay law}

Radioactivity is a spontaneous disintegration of atomic nuclei that proceeds independently on external conditions. It was first discovered in 1896 by H. Becquerel (radioactivity of uranium). In 1898, Marie and Pierre Curie discovered polonium and radium and conducted the first studies of radioactivity in these elements.

Radioactive agents cause gas ionization, blackening of lithographic emulsion, luminescence of some fluorescent substances, and they release energy (a higher temperature of a radioactive agent considering the neighbourhood). All these properties are caused by radiation that is emitted by a radioactive agent, i.e. alpha, beta and gamma radiation and in rare cases (in some fission products) they are also emitted by neutrons.

\subsubsection{Alpha decay}

The radioactive nucleus emits alpha particles - helium nuclei. The original atom changes into another one and has 2 fewer protons in its nucleus. Its mass is about 4 units smaller.

in general: ${ }_{\mathrm{Z}-2}^{\mathrm{A}-4} \mathrm{X} \rightarrow{ }_{\mathrm{Z}-2}^{\mathrm{A}-4} \mathrm{Y}+{ }_{2}^{4} \mathrm{He} \quad$ example: $\quad{ }_{94}^{239} \mathrm{Pu} \rightarrow{ }_{92}^{235} \mathrm{U}+{ }_{2}^{4} \mathrm{He}$

The energy of alpha particles of different radionuclides is about 2 up to $8 \mathrm{MeV}$, whereas the alpha particles have a certain amount of energy. At an energy of e.g. $5 \mathrm{MeV}$, they move at a speed of $15,000 \mathrm{~m} \cdot \mathrm{s}^{-1}$. As they move in matter, their energy decreases rapidly until they equal the energy of the thermal motion of the particles in matter. The distance that an alpha particle travels - a range - is a few centimetres in the air, even less in other substances. A moderated alpha particle will attract two electrons and will turn into a helium atom. Due to the positive charge, alpha particles cause dense ionization along their track.

\subsubsection{Beta decay}

It is the most common type of artificial radioactivity. Most of the radionuclides currently known is beta - active, as well as most of the products arising from a nuclear explosion. 
Types of beta decay:

1) $\beta$ decay - an electron (megatron) with an antineutrino (the most frequent phenomenon) is emitted from the nucleus:

$$
\begin{aligned}
& { }_{\mathrm{Z}}^{\mathrm{A}} \mathrm{X} \rightarrow{ }_{\mathrm{Z}+1}^{\mathrm{A}} \mathrm{Y}+{ }_{-1}^{0} \mathrm{e}+v \\
& { }_{\mathrm{Z}}^{\mathrm{A}} \mathrm{X} \rightarrow{ }_{\mathrm{Z}-1}^{\mathrm{A}} \mathrm{Y}+{ }_{+1}^{0} \mathrm{e}+v
\end{aligned}
$$

2) Electron capture by a nucleus from its own electron shell to produce an electron neutrino (K conversion):

$$
{ }_{\mathrm{Z}}^{\mathrm{A}} \mathrm{X}+{ }_{-1}^{0} \mathrm{e} \rightarrow{ }_{\mathrm{Z}-1}^{\mathrm{A}} \mathrm{Y}+\mathrm{v}
$$

Beta decay is always accompanied by neutrino (v) radiation. Neutrinos fall into a category called leptons (elementary particles) with zero rest mass. Neutrinos are absorbed by matter negligibly and most of neutrinos produced by beta decay leave the Earth.

When passing through the medium, beta particles interact with the atoms of the medium. The most specific result of the interaction between beta particles and the atoms of the medium is ionization of these atoms. The electron ejected from the atom by the beta particle further ionizes the atoms, which it encounters during its pathway. Ionization caused by these electrons is called secondary ionization. Due to primary and secondary ionization beta particles create thousands of ions.

When penetrating into the depth of matter, the

Table 11: The range of beta particles in different materials.

[Source: Tab-11]

\begin{tabular}{|c|c|c|c|}
\hline \multirow{2}{*}{$\begin{array}{c}\text { Matter } \\
\text { (medium) }\end{array}$} & \multicolumn{3}{|c|}{ Particle energy [MeV] } \\
\cline { 2 - 4 } & 0.5 & 1.0 & 2.0 \\
\hline Air & $0.9 \mathrm{~m}$ & $3 \mathrm{~m}$ & $7 \mathrm{~m}$ \\
\hline $\begin{array}{c}\text { Leather, rubber, } \\
\text { tissue }\end{array}$ & $1.2 \mathrm{~mm}$ & $4 \mathrm{~mm}$ & $8 \mathrm{~mm}$ \\
\hline $\begin{array}{c}\text { Glass, } \\
\text { aluminium }\end{array}$ & $0.4 \mathrm{~mm}$ & $1.6 \mathrm{~mm}$ & $3.3 \mathrm{~mm}$ \\
\hline
\end{tabular}
beta particle gradually loses its energy; finally, its energy changes to the mean energy level of particles creating the medium and the beta particle will become an electron. The higher the initial energy of the particle, the greater range in a given matter (see Tab. 11).

The stream of beta particles emitted by a certain radionuclide is not attenuated suddenly, but gradually. The distance, at which they are absorbed by a medium completely, is called the maximum range of a beta particle. Beta particle energy produced by nuclear fission is 0.8 up to $2.4 \mathrm{MeV}$; this implies that beta radiation is almost completely absorbed by the leather of boots, window glass or windshields and metal plates of at least several millimetres thick.

\subsubsection{Gamma decay}

It is a process, in which an atomic nucleus emits gamma-ray photons during the transition from the excited state to the ground state. The emission of gamma radiation may also be accompanied by alpha or beta decay.

Photon is a spatially concentrated energy quantum of electromagnetic radiation of the size as follows:

$$
\begin{array}{ll}
\multicolumn{2}{l}{\mathbf{E}=\mathbf{h} \times \mathbf{v}} \\
\mathrm{h} \ldots & 6.625 \times 10^{-34} \mathrm{~J} . \mathrm{s}^{-1} \text { (Planck constant); } \\
\mathrm{v} \ldots & \text { frequency of radiation. }
\end{array}
$$

Gamma radiation differs from luminous radiation by the wavelength and thus higher energy as well. Unlike light, it also penetrates opaque materials. It is very penetrating; the higher the penetrating power, the higher its energy. Gamma quanta have virtually no charge. 
It has been demonstrated experimentally that common changes of external conditions do not affect the rate of radioactive transformations. The radioactive decay is a property of the nucleus itself and is dependent on its internal state.

\subsubsection{Radioactive decay law}

The radioactive decay law is a basic physical rule related to radioactive decay.

$$
\mathbf{N}=\mathbf{N}_{0} \times \mathbf{e}^{-\lambda . t} \text {, }
$$

where: $\mathrm{N}_{0}$...the number of atoms of a given isotope at the initial time $\mathrm{t}=0$;

$\mathrm{N}$... the number of atoms of this isotope after the lapse

Scheme 1: Illustration of gamma decay. [Source: Sche-1]

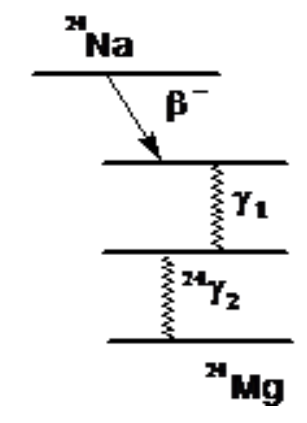
of time t;

e ... the base of a natural logarithm;

$\lambda \ldots$ the disintegration constant indicates the number of atoms of a given isotope that are subject to radioactive decay after time $t$; and

t... the time unit dependent on the total number of atoms at a given moment and on disintegration constant $\lambda$. It is specific for every radioactive transformation.

However, radioactive decay is of a statistical character. Therefore, the correct calculation of the number of decays taking place during a definite period of time is possible only then if the number of atoms is sufficiently large. Thus, it is clear that there is a close relationship between the disintegration constant and the half-life required to halve the original number of radioactive atoms.

When we substitute $\mathrm{N}_{0} / 2$ instead of $\mathrm{N}$ in the equation and $\mathrm{t}$ is equal to $\mathrm{T}_{1 / 2}$ (half-life of disintegration), then:

$$
\begin{gathered}
\frac{\mathrm{N}_{0}}{2}=\mathrm{N}_{0} \times \mathrm{e}^{-\lambda . \mathrm{t}} \quad \text { hence it follows } \quad \mathrm{T}_{1 / 2}=\frac{\ln 2}{\lambda}, \lambda=\frac{\ln 2}{\mathrm{~T}_{1 / 2}} \\
\text { and } \mathrm{T}_{1 / 2}=\frac{0.693}{\lambda}, \quad \lambda=\frac{0.693}{\mathrm{~T}_{1 / 2}}
\end{gathered}
$$

Both disintegration constant $\lambda$ and half-life $\mathrm{T}$ are characteristic of a given radionuclide. If we know the half-life or the disintegration constant, we can look up in the tables, which radionuclides are concerned. The half-life is usually expressed in different, for a given case, the most appropriate units (seconds, hours, days, years).

The atoms of some radioactive isotopes may be also subject to a double type of radioactive transformations. For example, potassium ${ }^{40} \mathrm{~K}$, in which $90 \%$ out of the number of atoms subject to the radioactive transformation per a time unit undergoes the transformation of $\beta^{-}$and $10 \%$ undergoes the transformation of $\mathrm{K}$. Each of these transformations has its disintegration constant $\lambda$; the total constant for the transformation of radioactive ${ }^{40} \mathrm{~K}$ is $\boldsymbol{\lambda}=\boldsymbol{\lambda}_{\mathbf{1}}+\boldsymbol{\lambda}_{\mathbf{2}}$.

A stable (non-radioactive) nuclide may be a product of one radioactive nuclide transformation. However, there may be a case that a product may be another unstable radioactive nuclide that continues disintegrating into another radioactive nuclide and so the entire disintegration series arises. The final product of the disintegration series is a stable isotope that does not undergo the radioactive transformation.

\section{Activity}

An important quantity that is related to the half-life and the disintegration constant is activity A (radioactivity). It indicates the proportion of atoms that decay per a unit of time. It is dependent on the number of radioactive atoms. 
It is equal to:

$$
\mathbf{A}=\boldsymbol{\lambda} \times \mathbf{N}
$$

The activity drops with time (Fig. 15) as well as the number of radioactive atoms:

$\mathbf{A}=\mathbf{A}_{\mathbf{0}} \times \mathbf{e}^{-\boldsymbol{\lambda} \times \mathbf{t}}$ where:

$\mathrm{A}_{0} \ldots$ the activity of a radionuclide in time $\mathrm{t}=0$,

A ... the activity in time $t$.

$A$ unit of activity $A$ is becquerel.

1 becquerel $=1 \mathrm{~Bq}=(1$ reciprocal second $=1 \mathrm{~s}^{-1}$ )

With an activity of $1 \mathrm{~Bq}$, one process of disintegration per second takes place in a radionuclide. The former activity unit was curie (ci). 1 ci corresponded to $3.7 \times 10^{10}$ of processes of disintegration per second.

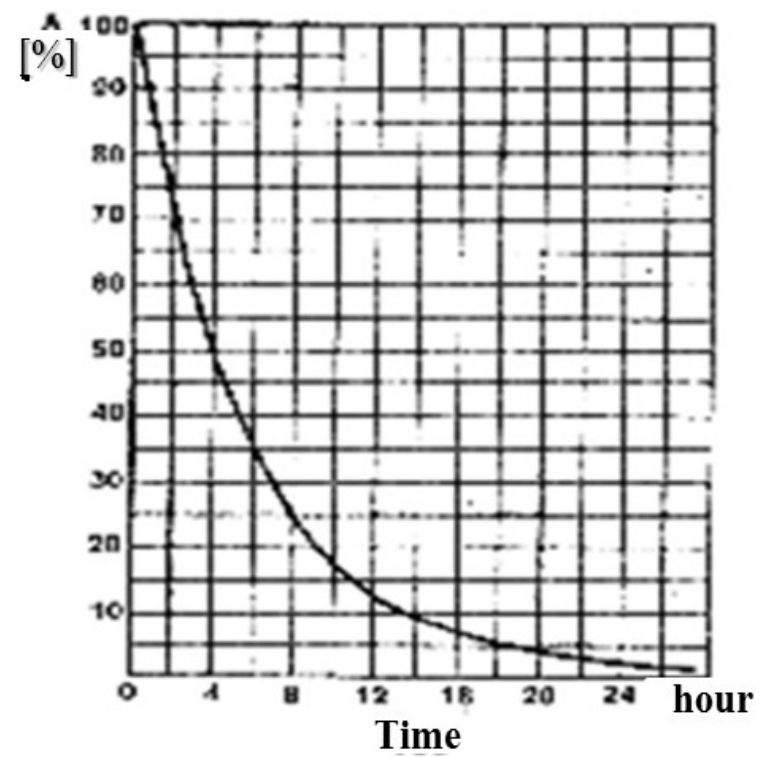

Figure 15: The decrease in the activity with time. [Source: Fig-15]

\subsection{Nuclear reaction}

Nuclear reactions are processes, in which, as a result of the bombardment of a nucleus (target) by a fast particle, a new nucleus and a new particle are formed:

generally: $\mathbf{A}+\mathbf{p} \rightarrow \mathbf{B}+\mathbf{q} \quad$ where:

A ... an arbitrary nucleus;

p ... an accelerated particle - nuclear missile (proton, neutron, alpha particle, electron, deuteron or photon;

B ... a new nucleus produced as a product of radioactive transformation; and

q ... a new fast particle (proton, neutron, alpha particle, electron or photon).

With a high energy of the accelerated particle (nuclear missile) a few particles $\mathrm{q}_{1}, \mathrm{q}_{2}, \ldots$ may be released instead of one fast particle $\mathrm{q}$, as a result of the nuclear reaction.

We record nuclear reactions either in a full form:

$$
{ }_{7}^{14} \mathrm{~N}+{ }_{2}^{4} \mathrm{He} \rightarrow{ }_{8}^{17} \mathrm{O}+{ }_{1}^{1} \mathrm{H} \text { or in a short form: }{ }_{7}^{14} \mathrm{~N}(\alpha, \mathrm{p}){ }_{8}^{17} \mathrm{O}
$$

In this case, the target is nitrogen, the missile is an alpha particle and the result of the reaction is oxygen and hydrogen (proton). The given reaction was the first nuclear reaction that was observed and artificially induced (Rutherford 1919).

\section{Nuclear reactions proceed in two stages:}

1. The fusion of a nuclear missile (a bombarding particle) with a nucleus (target) and the formation of the so-called compound nucleus that has not only kinetic energy, but also the binding energy of this particle. The binding energy is about $8 \mathrm{MeV}$ per one nucleon.

2. The following disintegration of the compound nucleus to form reaction products.

In the second stage, the nucleus loses a great deal of excess energy, the remaining portion is released during the disintegration of reaction products or is bound in stable end products of the reaction. 
In nuclear reactions as well as in chemical reactions, some energy is released and some energy is consumed. The reactions of the first type are called exothermic and the reactions of the second type are called endothermic. In the first case, reaction energy $Q$ is positive, in the second case, the energy is negative. However, the value of energy in nuclear reactions is much higher than the value of energy in chemical reactions.

Nuclear reactions can be classified according to the particles inducing the reaction (neutrons, deuterons, protons, alpha particles, photons, etc.).

1) Neutron-induced nuclear reactions are very numerous and different. Neutrons do not have a charge and their penetration into the nucleus is not prevented by a potential barrier (potential wall). Therefore, they are of the greatest importance during a nuclear explosion. Their interaction with matter creates the most significant component, the so-called induced radioactivity of a nuclear explosion. The main neutron reactions are: $(\mathrm{n}, \gamma) ;(\mathrm{n}, \mathrm{p}) ;(\mathrm{n}, \alpha) ;(\mathrm{n}, 2 \mathrm{n})$; (n, 3n); (n, pn); (n, f). All stable nuclides (with the exception of ${ }_{2}^{4} \mathrm{He}$ ) react with neutrons. These processes are the most abundant out of all nuclear reactions.

Proton-induced nuclear reactions need higher energy of particles to overcome the strong Coulomb field of a nucleus. In the reactions with light nuclei this energy may be decreased significantly. Protons may cause reactions of $(p, \gamma),(p, n)$ and $(p, \alpha)$ type.

- Deuteron-induced nuclear reactions are of great practical importance. At the same velocity, deuterons have twice higher energy than protons; hence it follows their advantage in carrying out their nuclear transformations by deuterons. The reactions of $(d, p),(d, n)$ and $(\mathrm{d}, 2 \mathrm{n})$ type are the most significant deuteron reactions. The reaction $(\mathrm{d}, \gamma)$ is unlikely.

- Nuclear reactions of alpha particles. The most significant reactions are especially $(\alpha, p)$ and $(\alpha, n)$.

${ }^{9} \mathrm{Be}+{ }^{4} \mathrm{He} \rightarrow{ }^{18} \mathrm{C}+{ }^{12} \mathrm{C}+{ }^{1} \mathrm{n}$

The above-mentioned reaction was studied by J. Chadwick in 1932 and neutrons were discovered. It has still been used as the simplest source of neutrons.

- Photodisintegration of nuclei. Gamma radiation of sufficient energy causes photonuclear reactions. It is a sort of photochemical nuclear reactions. They are especially $(\gamma, n)$ and $(\gamma, p)$ reactions. With gamma energies up to $20 \mathrm{MeV}$, the liberation of neutrons is observed, i.e. reactions $(\gamma, \mathrm{n})$. With higher energies, the liberation of protons $(\gamma, \mathrm{p})$ also occurs. The simplest reaction $(\gamma, n)$ is the photodisintegration of deuterons ${ }^{2} \mathrm{D}(\gamma, n),{ }^{1} \mathrm{H}$. Currently, we can release energy from a nucleus by two methods - on the one hand, by splitting the nuclei of heavy elements, on the other hand, by combining the nuclei of light elements.

For peaceful purposes (the gradual release of energy for the power industry), unfortunately, only the first method is mastered. This happens in nuclear reactors (e.g. of the VVER type which, as we know, are installed in Temelin and Dukovany nuclear power plants). However, both processes are fully mastered for military purposes - the instantaneous release of nuclear energy during a nuclear explosion. 


\subsubsection{Nuclear fission}

Neutrons of all velocities, including the thermal ones, disintegrate the nuclei of ${ }^{235} \mathrm{U},{ }^{238} \mathrm{U}$, ${ }^{239} \mathrm{Pu}$ and also transuranium isotopes (e.g. ${ }^{249} \mathrm{Cf}$ ). ${ }^{238} \mathrm{U}$ and ${ }^{232} \mathrm{Th}$ also disintegrate using fast neutrons with the energy over $1 \mathrm{MeV}$. The fission reaction of e.g. ${ }^{235} \mathrm{U}$ can be expressed as:

${ }^{235} \mathrm{U}(\mathrm{n}, \gamma){ }_{92}^{236} \mathrm{U} \rightarrow{ }_{\mathrm{Z}_{1}}^{\mathrm{A}_{1}} \mathrm{Y}_{1}+{ }_{\mathrm{Z}_{2}}^{\mathrm{A}_{2}} \mathrm{Y}_{2}+\mathrm{v} \times \mathrm{n}+\mathrm{Q}$ where:

${ }_{92}^{236} \mathrm{U} \ldots \ldots \ldots$ a compound nucleus (see nuclear reaction stages);

$\mathrm{Y}_{1}$ and $\mathrm{Y}_{2} \ldots$ fission products (new nuclei produced by fission);

$v \times n \ldots . . .$. the number of prompt neutrons; and

Q ............. energy.

In the process, the target nucleus disintegrates into different pairs mostly asymmetrically so that there are mostly one lighter nucleus and one heavier nucleus.

$$
\begin{array}{r}
{ }_{92}^{236} \mathrm{U}+{ }_{0}^{1} \mathrm{n} \rightarrow{ }_{37}^{93} \mathrm{Rb}+{ }_{55}^{141} \mathrm{Cs}+2{ }_{0}^{1} \mathrm{n} \\
{ }_{36}^{94} \mathrm{Kr}+{ }_{56}^{140} \mathrm{Ba}+2{ }_{0}^{1} \mathrm{n} \\
{ }_{38}^{101} \mathrm{Sr}+{ }_{54}^{133} \mathrm{Xe}+2{ }_{0}^{1} \mathrm{n}
\end{array}
$$

These pairs are created with different, but certain probability. The fission takes place in about 40 different ways, so that about 80 primary fragments - fission products - are formed. These fission products have an excess of neutrons, i.e. they are neutron emitters. Fission is also accompanied by gamma radiation. It is not of practical importance for the release of nuclear energy. Besides fission caused by a nuclear missile, spontaneous fission also happens in the nuclei of heavy elements. This process is little useful and, for example, for ${ }^{238} \mathrm{U}$ spontaneous fission has a half-life of $10^{16}$ years.

When a nucleus with a large atomic number is split, two nuclear fragments - fission products are formed with more or less different weights. The proton/neutron ratio in these nuclei corresponds to the ratio of these nucleons in the nucleus of a heavy element (target). Both nuclei - nuclear fragments, belong to the elements in the centre of the periodic system and will, therefore, have too many neutrons to be stable. The nuclear fragments can become stable due to the emission of one or several neutrons or due to the transformation (repeated transformations) of a neutron into a proton when a beta particle is emitted. Beta decay is accompanied by gamma radiation. Fission neutrons are divided into two groups:

Prompt neutrons are emitted within a very short time of about $10^{-14} \mathrm{~s}$ (also earlier) after fission and are produced directly during the fission reaction. During one fission, 2 to 3 neutrons are released. The excited nucleus formed by the absorption of fissile neutrons (nuclear missiles) is first divided into two nuclear fragments, each of which has an excess of neutrons. They also have some excess (excitation) energy of 6 to $8 \mathrm{MeV}$ that is necessary for ejecting a neutron. Then, the excited nuclear fragment will eject one or more prompt neutrons in a very short time. The prompt gamma quanta accompanying fission are emitted at the same time.

Delayed neutrons are emitted from the generated nuclear fragments with a delay of the nuclear fragment half-life (0.43 to $55.6 \mathrm{~s})$. Of the total number of neutrons released, $99.25 \%$ are fast and only $0.75 \%$ are delayed neutrons. Nevertheless, delayed neutrons create a relatively considerable part of initial neutron radiation during a nuclear explosion.

Nuclear fission is also accompanied by gamma radiation. This radiation as well as the emission of neutrons are divided into prompt radiation and delayed radiation. A part of prompt gamma radiation is emitted along with prompt neutrons and the rest is emitted by those fission products, which have very short processes. Delayed gamma radiation is emitted for a longer time by numerous fission products with longer half-lives. 
Fission neutrons are formed every time a heavy nucleus is split in a number of 2 to 3 . If we count with two neutrons in the first fission (the $1^{\text {st }}$ generation), which would disintegrate 2 other nuclei to form 4 neutrons (the $2^{\text {nd }}$ generation), then in the $3^{\text {rd }}$ generation, 8 neutrons and 4 fission nuclei would be produced, etc. This phenomenon is called fission chain reaction.

Certainly, this would be an ideal case that, in fact, cannot happen since not every neutron is destined for a fission reaction $(\mathrm{n}, \mathrm{f})$. In the real system, the fate of neutrons produced by fission is as follows:

- Neutron absorption by a nucleus leading to its own fission reaction (n, $\mathrm{f}$ );

- Neutron capture by a nucleus not leading to fission, but to another reaction, such as $(n, \gamma)$

- Neutron absorption in nuclei of other substances (contaminants) in the reaction system, in fission products and other materials (constructional); and

- Neutron diffusion and their escape from the reaction system through the surface.

So, if the number of neutrons, when considering all four possibilities, is higher in each successive generation than in previous generations, the reaction will be divergent and the nuclear explosion will take place. Then we talk about the so-called supercritical amount of fissile material.

\section{Energy released during fission}

Some nuclei of heavy elements $\left({ }^{238} \mathrm{U},{ }^{235} \mathrm{U},{ }^{242} \mathrm{Am}\right.$, etc. $)$ are unstable. Therefore, it is sufficient for some fast particles (nuclear missile) to bring some energy into such a nucleus (target) to produce a compound nucleus, which is in an excited state and which then splits into smaller nuclei (fragments) or is stabilized through the emission of excess energy (e.g. in the form of gamma radiation).

Thus, we consider the reaction:

${ }_{0}^{1} \mathrm{n}+{ }_{\mathrm{Z}}^{\mathrm{A} X} \rightarrow{ }_{\mathrm{Z}}^{\mathrm{A}+1} \mathrm{X}^{\times} \rightarrow{ }_{\mathrm{Z} 1}^{\mathrm{A} 1} \mathrm{Y}+{ }_{\mathrm{Z} 2}^{\mathrm{A}} \mathrm{Y}+(2-3){ }_{0}^{1} \mathrm{n}$

The released energy, i.e. the reaction energy, is equal to:

$E_{r}=\left[m_{n}+m(Z, A)-m\left(Z_{1}, A_{1}\right)-\left(Z_{2}, A_{2}\right)-2 m_{n}\right] \times c^{2} \quad$ where:

- $m_{\mathrm{n}} \ldots$ rest mass of the neutron;

- $\mathrm{m}(Z, \mathrm{~A})$.....nuclear mass, characterized by mass number $A$ and atomic number $Z$;

- $\mathrm{m}\left(\mathrm{Z}_{1}, \mathrm{~A}_{1}\right) \ldots$ mass of the first nuclear fragment;

- $\mathrm{m}\left(\mathrm{Z}_{2}, \mathrm{~A}_{2}\right)$...mass of the second nuclear fragment;

- c ...speed of light.

Mean binding energy $\varepsilon$ of a nucleon in the nucleus is energy that will release when the nucleon and the nucleus are combined. In heavy nuclei, such as a uranium nucleus, mean binding energy $\varepsilon_{\mathrm{t}}=7.6 \mathrm{MeV}$. In medium-sized nuclei (with mean mass number A) binding energy $\varepsilon_{\mathrm{s}}=8.5 \mathrm{MeV}$. So, we find out $\varepsilon_{\mathrm{s}}>\varepsilon_{\mathrm{t}}$ that medium-heavy nuclei are more stable than the heavy ones. During fission, therefore, excess energy is released in the form of the kinetic energy of nuclear fragments, neutrons and other arising particles.

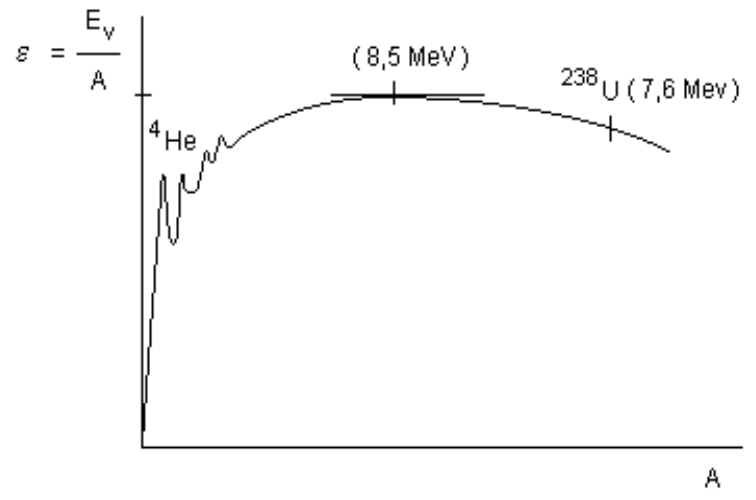

Figure 16: The dependence of mean energy on mass number A. [Source: Fig-16] Compound nucleus ${ }_{\mathrm{Z}}^{\mathrm{A}+1} \mathrm{X}^{\mathrm{x}}$ contains a total of $\mathrm{A}+1$ nucleon. 
Thus, for energy $E_{\mathrm{r}}$ released from the nucleus it applies:

$\mathrm{E}_{\mathrm{r}}=\left(\varepsilon_{\mathrm{s}}-\varepsilon_{\mathrm{t}}\right) \times(\mathrm{A}+1)=0.9 \times(\mathrm{A}+1)$

Let's suppose that e.g. ${ }_{\mathrm{Z}}^{\mathrm{A} X}$ is ${ }_{92}^{235} \mathrm{U}$. Then, $\mathrm{E}_{\mathrm{r}}=0.9 \times 236=212 \mathrm{MeV}$.

During the fission of one nucleus of ${ }_{92}^{235} \mathrm{U}$ about $210 \mathrm{MeV}$ of energy will be released.

This energy is distributed roughly as follows:

- $170 \mathrm{MeV}$ the kinetic energy of fission fragments;

- $5 \mathrm{MeV}$ the prompt neutron energy;

- $5 \mathrm{MeV}$ the gamma radiation energy;

- $7 \mathrm{MeV}$ the energy of $\beta$ particles emitted by fission products; and

- $10 \mathrm{MeV}$ the energy of antineutrinos emitted by fission products.

\subsubsection{Thermonuclear reaction}

As it has already been mentioned, the most stable nuclei are medium-heavy nuclei with mean mass number A. Their mean binding energy is about $8.5 \mathrm{MeV}$. On the contrary, the binding energy of heavy nuclei as well as light nuclei is smaller, i.e. they are less stable. In principle, energy can be obtained in two different ways: by the fission of heavy element nuclei or by the synthesis of light element nuclei, the so-called thermonuclear reaction.

There is a considerable disproportion between the mean binding energies of light element nuclei. While, for example, a nucleus of ${ }_{1}^{2} \mathrm{D}$ has its mean binding energy $\varepsilon=1.1 \mathrm{MeV}$, the mean binding energy of ${ }_{2}^{4} \mathrm{He}$ is substantially higher, i.e. $\varepsilon=70 \mathrm{MeV}$. By the synthesis of the nuclei of elements with the low mass number (e.g. hydrogen isotopes) and helium nuclei a high energy yield can be obtained.

$$
\text { e.g.: } \quad{ }_{1}^{2} \mathrm{D}+{ }_{1}^{3} \mathrm{~T} \rightarrow{ }_{2}^{4} \mathrm{He}+{ }_{0}^{1} \mathrm{n}+16.7 \mathrm{MeV}
$$

The above-mentioned reaction can take place, but only provided that the Coulomb repulsive forces between deuterium and lithium nuclei (they contain positively charged protons) are overcome. For the attractive nuclear forces to prevail over these repulsive forces, the nuclei must approach at a distance of approximately $10^{-15} \mathrm{~m}$. To do this, they must be given considerable energy. The nuclei must be accelerated as they must gain energy, which is higher than the Coulomb barrier (about $0.3 \mathrm{MeV}$ ). This can be achieved, for example, by supplying a considerable amount of thermal energy. Therefore, we talk about the thermonuclear reaction.

However, when selecting the thermonuclear reaction, it is necessary to proceed from the following assumptions:

- It is necessary to select such isotopes of light elements that are, with regard to their Coulomb barrier, capable of a combination (synthesis) reaction at a temperature of $10^{7}$ to $10^{8} \mathrm{~K}$. These isotopes are ${ }_{1}^{1} \mathrm{H},{ }_{1}^{2} \mathrm{D},{ }_{1}^{3} \mathrm{~T},{ }_{2}^{3} \mathrm{He},{ }_{3}^{6} \mathrm{Li}$ and ${ }_{3}^{7} \mathrm{Li}$.

- The reaction must proceed fast enough in the area of achievable temperatures. The maximum temperature is reached in a time of the order of $10^{-6} \mathrm{~s}$.

- It is necessary to select such a reaction that has the greatest possible energy yield.

The reaction between the heavy forms of hydrogen (deuterium and tritium) proceeds fastest at a given temperature. It is also a basic reaction of all thermonuclear charges. The temperature of the order of $10^{7} \mathrm{~K}$, which is required as a suitable reaction medium to overcome the Coulomb repulsive forces necessary for combining hydrogen isotopes, can be achieved through a nuclear fission.

The use of deuterium and tritium causes some difficulties. One of them is a complicated production as well as a considerable price of tritium. In addition to that, tritium cannot be stored on a long-term basis $\left(T_{1 / 2}=12\right.$ years $)$. 
Another problem is to achieve the necessary density of a thermonuclear explosive and to place it into a small space. The use of heavy water $\left(\mathrm{D}_{2} \mathrm{O}\right)$ is inappropriate due to the presence of oxygen. Liquid hydrogen (the density of $0.07 \mathrm{~g} . \mathrm{cm}^{-3}$ ) requires a complex cooling device. The starting point is the use of some hydrogen compounds, such as lithium hydride $\mathrm{LiH}$.

Table 13: Characteristics of other thermonuclear reactions. [Source: Tab-13]

\begin{tabular}{|c|c|c|c|c|}
\hline \multirow{2}{*}{ Reaction } & \multicolumn{2}{|c|}{ Energy yield } & \multicolumn{2}{c|}{ Mean reaction time (s) } \\
\cline { 2 - 5 } & $\begin{array}{c}\text { Per 1 nucleus } \\
(\mathrm{MeV})\end{array}$ & Per $1 \mathrm{~kg}(\mathrm{~J})$ & At $10^{7} \mathrm{~K}$ & At $10^{8} \mathrm{~K}$ \\
\hline${ }_{1}^{2} \mathrm{D}+{ }_{1}^{3} \mathrm{~T} \rightarrow{ }_{2}^{4} \mathrm{He}+{ }_{0}^{1} \mathrm{n}$ & 17.60 & $33,9 \times 10^{13}$ & $3,9 \times 10^{-5}$ & $2,4 \times 10^{-7}$ \\
\hline${ }_{1}^{2} \mathrm{D}+{ }_{1}^{2} \mathrm{D} \rightarrow{ }_{1}^{1} \mathrm{H}+{ }_{1}^{3} \mathrm{~T}$ & 4.03 & $9,6 \times 10^{13}$ & $1,9 \times 10^{-3}$ & $1,9 \times 10^{-6}$ \\
\hline${ }_{1}^{2} \mathrm{D}+{ }_{1}^{2} \mathrm{D} \rightarrow{ }_{2}^{3} \mathrm{He}+{ }_{0}^{1} \mathrm{n}$ & 3.26 & $7,9 \times 10^{13}$ & $1,9 \times 10^{-3}$ & $1,9 \times 10^{-6}$ \\
\hline${ }_{3}^{7} \mathrm{Li}+{ }_{1}^{2} \mathrm{D} \rightarrow 2{ }_{2}^{4} \mathrm{He}+{ }_{0}^{1} \mathrm{n}$ & 14.9 & $15,9 \times 10^{13}$ & $2,4 \times 10^{3}$ & $2,4 \times 10^{-5}$ \\
\hline${ }_{3}^{6} \mathrm{Li}+{ }_{1}^{2} \mathrm{D} \rightarrow 2{ }_{2}^{4} \mathrm{He}$ & 22.40 & $27,2 \times 10^{13}$ & $7,5 \times 10^{3}$ & $7,5 \times 10^{-5}$ \\
\hline${ }_{3}^{7} \mathrm{Li}+{ }_{1}^{1} \mathrm{H} \rightarrow 2{ }_{2}^{4} \mathrm{He}$ & 17.30 & $20,9 \times 10^{13}$ & $1,8 \times 10^{3}$ & $4,5 \times 10^{-5}$ \\
\hline${ }_{3}^{6} \mathrm{Li}+{ }_{1}^{1} \mathrm{H} \rightarrow{ }_{2}^{3} \mathrm{He}+{ }_{2}^{4} \mathrm{He}$ & 4.02 & $5,5 \times 10^{13}$ & $1,8 \times 10^{2}$ & $4,5 \times 10^{-5}$ \\
\hline
\end{tabular}

The use of lithium- 6 deuteride ${ }^{6} \mathrm{Li}^{2} \mathrm{D}$ is the most advantageous for the following reasons: neutrons liberate during the explosion of a fission charge and may react with ${ }^{6} \mathrm{Li}$ :

${ }^{6} \mathrm{Li}+{ }^{1} \mathrm{n} \rightarrow{ }^{4} \mathrm{He}+{ }^{3} \mathrm{~T}$

In this way, tritium is produced directly in the thermonuclear charge and there is no problem with its production and storage. Tritium reacts with deuterium as follows:

${ }^{2} \mathrm{D}+{ }^{3} \mathrm{~T} \rightarrow{ }^{4} \mathrm{He}+{ }^{1} \mathrm{n}$

More energy will be released, the temperature will increase and then additional thermonuclear reactions can proceed. Therefore, lithium deuteride is used as a main component of the so-called thermonuclear explosive.

\subsection{Units and quantities characterizing the radiation source}

The concept source of ionizing radiation means any radiation or radionuclides producing ionizing radiation.

Activity $[A]$ - the body of a radioactive element (nuclide), in which one transformation process will take place per one second, has the activity equal to $1 \mathrm{~Bq}$. In British-American literature, this unit is also called transmutation per second (tps). It expresses a quotient of the mean number of radioactive transformations $\Delta \mathrm{N}$ and time interval $\Delta \mathrm{t}$, in which these transformations in a specific quantity of radionuclide happen: $\quad \mathbf{A}=\frac{\Delta \mathbf{N}}{\Delta \mathbf{t}}$

Surface activity $\left[a_{s}\right]$ - the surface activity of $1 \mathrm{~Bq} \cdot \mathrm{m}^{-2}$ pertains to a homogeneous material evenly distributed on the surface, the activity of which is $1 \mathrm{~Bq}$ on the surface of $1 \mathrm{~m}^{2}$. Therefore, it is a quotient of activity $A$ and surface $S$, in which the activity is distributed: $\mathbf{a}_{\mathbf{s}}=\frac{\mathbf{A}}{\mathbf{S}}$

Specific activity $\left[a_{m}\right]$ - the specific activity of $1 \mathrm{~Bq} \cdot \mathrm{kg}^{-1}$ pertains to a homogenous material, which has the activity equal to $1 \mathrm{~Bq}$ in the mass of $1 \mathrm{~kg}$. Therefore, it is a quotient of activity $A$ and mass $m$, in which the activity is distributed: $\quad \mathbf{a}_{\mathbf{m}}=\frac{\mathbf{A}}{\mathbf{m}}$

Volume activity $\left[a_{v}\right]$ - the volume activity of $1 \mathrm{~Bq} \cdot \mathrm{m}^{-3}$ pertains to a homogeneous material, which has the activity equal to $1 \mathrm{~Bq}$ in the volume of $1 \mathrm{~m}^{3}$. Therefore, it is a quotient of activity $A$ and volume $V$, in which the activity is distributed: $\quad \mathbf{a}_{\mathbf{v}}=\frac{\mathbf{A}}{\mathbf{V}}$ 
Source strength $\left[\Phi_{p}\right]-$ is a mean number of particles emitted from the source per a time unit. The unit of the source strength is a reciprocal second $\left(\mathrm{s}^{-1}\right)$ or one per second $(1 / \mathrm{s})$ without a separate title. In some literature, the source strength is indicated as external radiation:

$$
\Phi_{p}=\frac{d N}{d t}
$$

A radionuclide, an X-ray tube or an accelerator and particles emitted from the source may originate directly from the radioactive transformation or may be accelerated in the source or may be secondary particles produced through the interactions with a material medium. It is necessary to specify the emitted particles in more detail and then the quantity name will read as follows: the emission of electrons, the emission of fast neutrons the emission of photons with certain energy. The source strength is, therefore, a total particle flux passing through a closed (i.e. precisely defined) surface formed by the source surface.

Table 14: Conversion relationships between units and quantities. [Source: Tab-14]

\begin{tabular}{|c|c|c|c|}
\hline $\begin{array}{l}\text { Quantity name according } \\
\text { to the Czech technical stand- } \\
\text { ards (ČSN), other names, } \\
\text { military terms }\end{array}$ & $\begin{array}{l}\text { Unit in the SI sys- } \\
\text { tem (International } \\
\text { System of Units) }\end{array}$ & Subsidiary units & Conversion relationships \\
\hline $\begin{array}{c}\text { Activity } \\
{[\mathrm{A}]}\end{array}$ & $\begin{array}{c}\text { becquerel } \\
(\mathrm{Bq})\end{array}$ & $\begin{array}{c}\mathrm{Ci} \\
\text { decay.s } \mathrm{s}^{-1} \\
\text { decay.min } \\
\end{array}$ & $\begin{array}{c}1 \mathrm{Ci}=3.7 \times 10^{10} \mathrm{~Bq} \\
1 \text { decay. } \mathrm{s}^{-1}=1 \mathrm{~Bq} \\
1 \text { decay.min }{ }^{-1}=60^{-1} \mathrm{~Bq}\end{array}$ \\
\hline $\begin{array}{c}\text { Surface activity } \\
\text { Surface contamination level } \\
{[\alpha]} \\
\end{array}$ & $\begin{array}{l}\text { becquerel per } \\
\text { square meter } \\
\left(\mathrm{Bq} \cdot \mathrm{m}^{-2}\right)\end{array}$ & $\begin{array}{c}\text { Ci.m. } \\
\text { decay } \cdot \mathrm{s}^{-1} \cdot \mathrm{cm}^{-2} \\
\text { decay.min } \mathrm{min}^{-1} \cdot \mathrm{cm}^{-2}\end{array}$ & $\begin{array}{l}1 \mathrm{Ci} \cdot \mathrm{m}^{-2}=3.7 \times 10^{10} \text { Bq.m } \mathrm{m}^{-2} \\
1 \text { decay } \cdot \mathrm{s}^{-1} \cdot \mathrm{cm}^{-2}=10^{4} \text { Bq.m } \mathrm{m}^{-2}\end{array}$ \\
\hline $\begin{array}{c}\text { Specific activity } \\
\text { Contamination level of food, } \\
\text { water }\left[\mathrm{a}_{\mathrm{m}}\right]\end{array}$ & $\begin{array}{c}\text { becquerel per } \\
\text { kilogram } \\
\left(\mathrm{Bq} \cdot \mathrm{kg}^{-1}\right) \\
\end{array}$ & $\begin{array}{c}\text { Ci.g } \mathrm{g}^{-1} \\
\text { decay.s } \mathrm{s}^{-1} \cdot \mathrm{g}^{-1} \\
\text { decay } \mathrm{min}^{-1} \cdot \mathrm{g}^{-1}\end{array}$ & $\begin{array}{l}1 \text { decay } . \mathrm{s}^{-1} \mathrm{~g}^{-1}=10^{-3} \mathrm{~Bq} \cdot \mathrm{kg}^{-1} \\
1 \mathrm{Ci} \cdot \mathrm{g}^{-1}=3.7 \times 10^{13} \mathrm{~Bq} \cdot \mathrm{kg}^{-1}\end{array}$ \\
\hline $\begin{array}{c}\text { Volume activity } \\
\text { Contamination level of food, } \\
\text { water }\left[\mathrm{a}_{\mathrm{v}}\right]\end{array}$ & $\begin{array}{l}\text { becquerel per } \\
\text { cubic meter } \\
\left(\mathrm{Bq} \cdot \mathrm{m}^{-3}\right) \\
\end{array}$ & $\begin{array}{c}\text { Ci.1 } \\
\text { decay.s } \text { s }^{-1} \cdot 1^{-1} \\
\text { decay.min }{ }^{-1} \cdot 1^{-1} \\
\end{array}$ & \begin{tabular}{|c|}
1 decay $. \mathrm{s}^{-1} \cdot \mathrm{l}^{-1}=10^{3}$ Bq. $\mathrm{m}^{-3}$ \\
1 decay. $\mathrm{s}^{-1} \cdot \mathrm{cm}^{-3}=10^{6}$ Bq. $\mathrm{m}^{-3}$ \\
1 Ci. $\mathrm{l}^{-1}=3.7 \times 10^{13}$ Bq. $\mathrm{m}^{-3}$ \\
\end{tabular} \\
\hline
\end{tabular}

\subsection{Units and quantities characterizing the radiation field}

In most cases a radiation field is described according to radiation effects passing through a material of a given volume in a certain place. Quantities that are based on this principle are called dosimetric.

Absorbed dose $[D]$ is a ratio of mean absorbed energy $\mathrm{d} \varepsilon$ of ionizing radiation in a volume element of the material and mass $\mathrm{d}_{\mathrm{m}}$ of this volume element: $\quad \mathbf{D}=\frac{\mathbf{d} \boldsymbol{\varepsilon}}{\mathbf{d m}}$

One gray represents the absorption of 1 joule of energy in 1 kilogram of mass, i.e. the absorption of 100 rads (radiation absorbed doses) in 1 gram of mass. That is only an approximation, namely assuming that an absorbing medium is air.

Dose rate $\left[D^{\bullet}\right]$ is defined by the relation as a time increment (time variation) of absorbed dose dD: $\mathbf{D}^{\mathbf{\prime}}=\frac{\mathbf{d D}}{\mathbf{d T}} \quad$ (the quantity of radiation absorbed per unit time)

Kerma $[K]$ is the quotient of the sum of initial kinetic energies $\mathrm{dE}_{\mathrm{k}}$ of all charged particles liberated by indirectly ionizing radiation (namely gamma and neutrons) in a volume element of the material of mass $d_{m}$ in this volume element: $\quad K=\frac{\mathbf{d E}_{\mathbf{k}}}{\mathbf{d m}}$ 
Kerma rate $\left[\mathrm{K}^{\bullet}\right]$ analogous to the dose rate, it is defined as the time increment of kerma according to the following relation: $\quad \mathbf{K}^{\mathbf{*}}=\frac{\mathbf{d K}}{\mathbf{d t}}$

Exposure $[X]$ is defined using the ionizing effects of gamma photon rays on air as the quotient of the mean sum of electric charges dQ of all ions having one sign, produced in an air volume element with mass $d_{m}$ when all electrons (megatrons and positrons) liberated by photons in this volume element and its mass $\mathrm{d}_{\mathrm{m}}$ are completely decelerated, according to the following relation: $\quad \mathbf{X}=\frac{\mathbf{d Q}}{\mathbf{d m}}$

Exposure rate $\left[\mathrm{X}^{\bullet}\right]$ is defined as the time increment of exposure $\mathrm{dX}$ :

$$
X^{\cdot}=\frac{d X}{d t}
$$

Dose equivalent $[\mathrm{H}]$ characterizes the relation between the absorbed dose of ionizing radiation and radiobiological damage to a living organism (to humans) by different types of ionizing radiation:

$$
\boldsymbol{H}=\boldsymbol{D} \times \boldsymbol{Q} \times \boldsymbol{N} \quad \text { whereas }
$$

Q ... quality factor expressing various levels of radiobiological damage to an organism caused by different types of ionizing radiation when absorbed dose $\mathrm{D}$ is the same:

- for photons, electrons and gamma rays it is equal to 1 ;

- for thermal neutrons it is equal to 2,3;

- for neutrons, protons and particles with one charge it is equal to 10 ;

- for alpha particles with more than one charge it is equal to 20 ;

$\mathrm{N}$... the coefficient of a series of modifying factors that characterizes the so-called dose quality, especially its time-and-space distribution in an organism and the sensitivity of different types of tissue.

\subsubsection{Relationship of exposure to dose and kerma and some problems with the use of quan- tities}

To understand the physical meaning of established dosimetric quantities of dose, kerma, absorbed dose rate and kerma rate, it is necessary to realize the way of energy transfer to matter by directly as well as indirectly ionizing particles. The directly ionizing particles (particles carrying an electric charge) transfer their energy along the path in manifold interactions with atoms or molecules of the medium. The processes of ionization and excitation of the medium and other processes, such as the dissociation of molecules, etc. are the result of interaction. In principle, it is a direct loss of energy of charged particles. From this it follows that mean energy $\varepsilon$ conveyed to matter and caused by charged particles characterizes the process of the direct transfer of energy of these particles to matter in the process of primary interaction with matter. Indirectly ionizing particles or uncharged particles (neutrons, gamma quanta, etc.) cannot ionize the medium directly, i.e. cannot transfer energy directly in view of the fact that they do not have an electric charge.

The way of energy transfer EK to matter by indirectly ionizing radiation proceeds in the secondary or, if need be, tertiary interaction processes. Although the exposure is not conceptually identical even with one of the quantities of absorbed dose and kerma, the properties of both of these quantities are included in it; the difference is that the absorption matter (medium) is the air. In the military practice, the unit of roentgen $(R)$ is still used to express the absorbed dose. Roentgen $(R)$ is an older unit to measure radiation intensity. This is an exposure, in which the photons of electromagnetic radiation (gamma and $\mathrm{x}$-ray) induce corpuscular radiation (megatrons, positrons) in $1 \mathrm{~kg}$ of air. After the complete braking in this amount of air, corpuscular radiation produces ion pairs resulting in a charge of $2.58 \times 10^{-4}$ coulombs of air under standard conditions. 
Table 15: Used units and quantities characterizing the source of radiation.

[Source: Tab-15]

\begin{tabular}{|c|c|c|c|c|}
\hline \multicolumn{2}{|c|}{$\begin{array}{l}\text { Quantity name according } \\
\text { to the Czech technical } \\
\text { standards (ČSN), other } \\
\text { names, military terms }\end{array}$} & $\begin{array}{l}\text { Main derived unit } \\
\text { in the SI system } \\
\text { (International } \\
\text { System of Units) }\end{array}$ & $\begin{array}{l}\text { Some } \\
\text { subsidiary } \\
\text { units }\end{array}$ & Conversion relationships \\
\hline $\begin{array}{l}\text { Absorbed dose } \\
\text { Dose } \\
\text { Radiation dose }\end{array}$ & {$[\mathrm{D}]$} & \multirow[t]{2}{*}{ gray (Gy) } & $\begin{array}{c}\mathrm{J}^{\mathrm{kg} \mathrm{kg}^{-1}} \\
\mathrm{rad}\end{array}$ & $\begin{array}{c}1 \mathrm{rad}=10^{-2} \mathrm{~J} \cdot \mathrm{kg}-1=10^{-2} \mathrm{~Gy} \\
10^{2} \mathrm{rad}=1 \mathrm{~J}^{-k g^{-1}}=1 \mathrm{~Gy} \\
1 \mathrm{~Gy}=1 \mathrm{~J}^{-1} \mathrm{~kg}^{-1}=10^{2} \mathrm{rad} \\
1 \mathrm{R}=8.69 \mathrm{mGy}=0.869 \mathrm{rad}^{*}\end{array}$ \\
\hline Kerma & {$[\mathrm{K}]$} & & J.kg-1 & $1 \mathrm{~Gy}=1 \mathrm{~J} \cdot \mathrm{kg}^{-1}$ \\
\hline $\begin{array}{c}\text { Dose rate } \\
\text { Absorbed dose rate } \\
\text { Radiation level } \\
\end{array}$ & {$\left[\mathrm{D}^{\bullet}\right]$} & \multirow[t]{2}{*}{$\begin{array}{l}\text { gray per second } \\
\left(\text { Gy.s } \mathrm{s}^{-1}\right)\end{array}$} & $\begin{array}{l}\text { Gy.h } \mathrm{h}^{-1} \\
\text { W.kg } \\
\text { rad.h }\end{array}$ & $\begin{array}{c}1 \mathrm{rad} . \mathrm{s}^{-1}=10^{-2} \mathrm{~W} \cdot \mathrm{kg}^{-1}=10^{-2} \mathrm{~Gy} \cdot \mathrm{s}^{-1} \\
10^{2} \mathrm{rad} \cdot \mathrm{s}^{-1}=1 \mathrm{~W} \cdot \mathrm{kg}^{-1}=1 \mathrm{~Gy} \cdot \mathrm{s}^{-1} \\
1 \mathrm{rad} . \mathrm{s}^{-1}=10^{-2} \mathrm{~Gy} \cdot \mathrm{s}^{-1}=36 \mathrm{~Gy} \cdot \mathrm{h}^{-1}\end{array}$ \\
\hline Kerma rate & {$\left[\mathrm{K}^{\bullet}\right]$} & & $\mathrm{W} \cdot \mathrm{kg}^{-1} \cdot \mathrm{s}^{-1}$ & $1 \mathrm{~Gy} \cdot \mathrm{s}^{-1}=1 \mathrm{~W} \cdot \mathrm{kg}^{-1} \cdot \mathrm{s}^{-1}$ \\
\hline $\begin{array}{l}\text { Exposure } \\
\text { Irradiation } \\
\text { Dose }\end{array}$ & {$[\mathrm{X}]$} & $\begin{array}{l}\text { coulomb per } \\
\text { kilogram } \\
\left(\mathrm{C} . \mathrm{kg}^{-1}\right)\end{array}$ & $\mathrm{R}$ & $\begin{array}{c}1 \mathrm{R}=2.580 \times 10^{-4} \mathrm{C} . \mathrm{kg}^{-1} \\
3.87597 \times 10^{3} \mathrm{R} . \mathrm{s}^{-1}=1 \mathrm{C} . \mathrm{kg}^{-1} \\
1 \mathrm{C} . \mathrm{kg}^{-1}=3875.97 \mathrm{R}\end{array}$ \\
\hline $\begin{array}{c}\text { Radiation dose rate } \\
\text { Exposure rate } \\
\text { Radiation level }\end{array}$ & {$\left[\mathrm{X}^{\bullet}\right]$} & $\begin{array}{l}\text { ampere per } \\
\text { kilogram } \\
\left(\mathrm{A} \cdot \mathrm{kg}^{-1}\right)\end{array}$ & $\begin{array}{l}\text { R.s.- } \\
\text { R.h }\end{array}$ & $\begin{array}{c}1 \mathrm{R} \cdot \mathrm{s}^{-1}=2.580 \times 10^{-4} \mathrm{~A} \cdot \mathrm{kg}^{-1} \\
3.87597 \times 10^{3} \mathrm{R} \cdot \mathrm{s}^{-1}=1 \mathrm{~A} \cdot \mathrm{kg}^{-1} \\
1 \mathrm{R} \cdot \mathrm{h}^{-1}=7.16 \times 10^{-8} \mathrm{~A} \cdot \mathrm{kg}^{-1} \\
1 \mathrm{~A} \cdot \mathrm{kg}^{-1}=1.39 \times 107 \mathrm{R} \cdot \mathrm{h}^{-1}\end{array}$ \\
\hline Dose equivalent & {$[\mathrm{H}]$} & sievert (Sv) & rem & $\begin{array}{l}1 \mathrm{rem}=10^{-2} \mathrm{~Sv} \\
1 \mathrm{~Sv}=102 \mathrm{rem}\end{array}$ \\
\hline Dose equivalent rate & {$\left[\mathrm{H}^{\bullet}\right]$} & $\begin{array}{c}\text { sievert per } \\
\text { second }\left(\mathrm{Sv}^{-1}{ }^{-1}\right)\end{array}$ & $\begin{array}{l}\text { rem. } s^{-1} \\
\text { rem. }\end{array}$ & $1 \mathrm{rem} . \mathrm{s}^{-1}=10^{-2} \mathrm{~Sv} \cdot \mathrm{s}^{-1}=36 \mathrm{~Sv} \cdot \mathrm{h}^{-1}$ \\
\hline
\end{tabular}

A basic condition for converting exposure to a dose is to attain the electron equilibrium, whereas at a distance equal to the range of liberated megatrons and positrons the energy flux density (i.e. energy fluence) must change markedly. In the air, the values of exposure and its corresponding absorbed doses differ by approximately $13 \%$ only. The absorbed dose in X-rays can be expressed only in cases of external irradiation by gamma products of radioactive contamination, or components of gamma radiation initial radiation. The unit of absorbed dose is the gray or the rad and can be expressed in all cases of external as well as internal irradiation by directly as well as indirectly ionizing radiation. Then, for the conversion of exposure to an absorbed dose (or kerma) in the air the following equation can be used: $\mathbf{D}=\mathbf{k} \times \mathbf{X}$

where: $\quad \mathrm{k} \ldots$ the conversion coefficient;

$\mathrm{X}$... exposure;

whereas it applies:

$\mathrm{k}=33.7$ for the conversion from the units of $\left(\mathrm{C} \cdot \mathrm{kg}^{-1}\right)$ to the units of $\left(\mathrm{J}^{\mathrm{kg}} \mathrm{kg}^{-1}\right)$, or to gray $(\mathrm{Gy})$;

$\mathrm{k}=8.69 \times 10^{-3}$ for the conversion from the units of roentgen $(\mathrm{R})$ to the units of $\left(\mathrm{J}_{\mathrm{kg}}{ }^{-1}\right)$, or to gray (Gy);

$\mathrm{k}=8.69$ for the conversion from the units of roentgen $(\mathrm{R})$ to milligray (mGy);

then it is obvious:

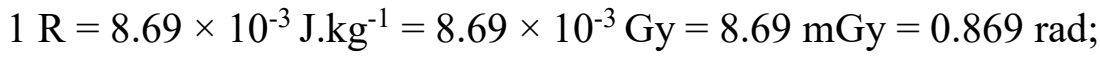

$115.1 \mathrm{R}=1 \mathrm{~Gy}=100 \mathrm{rad}$. 
For the conversion of exposure rate (radiation level) to dose (kerma) rate, then it applies:

$1 \mathrm{R} . \mathrm{s}^{-1}=8.69 \times 10^{-3} \mathrm{~Gy} . \mathrm{s}^{-1}=8.69 \mathrm{mGy} . \mathrm{s}^{-1}=0.869 \mathrm{rad} . \mathrm{s}^{-1}$;

115.1 R.s $\mathrm{s}^{-1}=1 \mathrm{~Gy} \cdot \mathrm{h}^{-1}=100 \mathrm{rad} . \mathrm{s}^{-1}$;

$1 \mathrm{R} \cdot \mathrm{h}^{-1}=8.69 \times 10^{-3} \mathrm{~Gy} \cdot \mathrm{h}^{-1}=8.69 \mathrm{mGy} \cdot \mathrm{h}^{-1}=0.869 \mathrm{rad} \cdot \mathrm{h}^{-1}$;

$115.1 \mathrm{R} \cdot \mathrm{h}^{-1}=1 \mathrm{~Gy} \cdot \mathrm{h}^{-1}=100 \mathrm{rad} \cdot \mathrm{h}^{-1}$.

\subsection{Types of nuclear explosions}

According to the height and environment of the explosion, nuclear explosions are divided into:

- High-altitude bursts;

- Airbursts;

- Surface bursts (bursts on water surface);

- Sub-surface bursts (underwater bursts).

The knowledge of the type of explosion is crucial for assessing the effects of a nuclear explosion. Therefore, a more detailed division that considers the nuclear yield is used. The following empirical formula applies to the height of burst $\mathrm{H}$ or, if need be, the depth of burst D (during
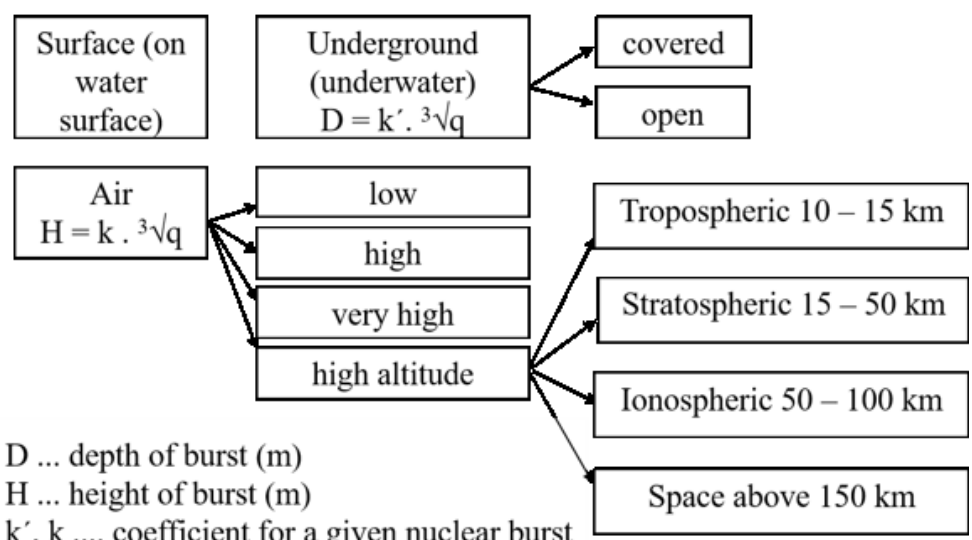

$\mathrm{k}^{\prime}, \mathrm{k} \ldots$. coefficient for a given nuclear burst

$\begin{array}{lrl}\text { covered } & \mathrm{k}^{\prime}>12 \\ \text { open } & \mathrm{k}^{\prime}<12 \\ \text { low } & 4<\mathrm{k}<10 \\ \text { high } & 10<\mathrm{k}<15 \\ \text { very high } & 15<\mathrm{k}<20 \\ \text { high altitude } \quad \mathrm{k}>>2\end{array}$

Figure 17: Division of nuclear bursts according to coefficient $\boldsymbol{k}$ (or $\left.\boldsymbol{k}^{\prime}\right)$. [Source: Fig-17] an underground burst):

$\mathbf{H}=\mathbf{k} \times \sqrt[3]{\mathbf{q}} \quad$ or $\quad \mathbf{D}=\mathbf{k}^{\prime} \times \sqrt[3]{\mathbf{q}}$ where:

$\mathrm{k}$ (or $\mathrm{k}^{\prime}$ ) ... the coefficient characterizing the type of burst;

$\mathrm{q}$... the yield $(\mathrm{kt})$.

In a nuclear explosion, we recognize the burst centre (actual ground zero and epicentre). In an underground burst we sometimes talk about hypocentre.

The epicentre is a point on the ground that we obtain by dropping or drawing a perpendicular to the centre of a planned or actual nuclear detonation. In a surface burst, the ground zero is identical with the epicentre. Using an external image of a nuclear explosion, a good observer can determine the type of nuclear explosion, or even estimate its yield. It is also possible to get an almost immediate idea of the effects of individual destructive factors.

\section{Types of nuclear bursts:}

a) Nuclear airburst:

- The luminous area has a shape of a sphere (an incomplete sphere with a low altitude nuclear explosion) and does not touch the surface of the terrain;

- Between the dust column and the head of the mushroom cloud there is a gap shortly after the blast (the dust column is not connected with the head of a mushroom cloud);

- The cloud is not too dark;

- Practically, no crater arises on the ground; and

- Weak radioactive contamination of the ground is in the vicinity of the epicentre only. 
b) Nuclear surface burst:

- At first, the luminous area has the shape of a hemisphere lying on the Earth's surface, later the shape deforms;

- The resulting column of dust is connected to mushroom cloud from the beginning, the colour of the cloud is significantly darker than in the case of the nuclear airburst;

- A heavily contaminated crater is formed on the ground; and

- In the direction of the cloud movement, highly radioactive contamination is created.

c) Nuclear underground burst:

- The luminous area is not visible;

- The cloud lacks its mushroom shape, is very dark and thick;

- The cloud ceiling is smaller in comparison with an airburst or a surface burst;

- A large, highly contaminated crater is formed in the burst centre; and

- Contamination in the fallout pattern is roughly twice higher than in the case of a surface burst.

Nuclear surface burst is an explosion, during which the luminous sphere touches the Earth's surface. The destructive factors of a nuclear surface burst are light and thermal radiation, initial radiation, electromagnetic pulse, pressure wave and the contamination of the ground by radioactive agents. Nuclear surface burst speciality is the contamination of the terrain by radioactive agents (radioactive contamination) both in the area of explosion and in the direction of radioactive cloud movement.

During massive surface bursts, extensive areas of radioactive contamination are created, which may cause the massive elimination of personnel from action, make the combat

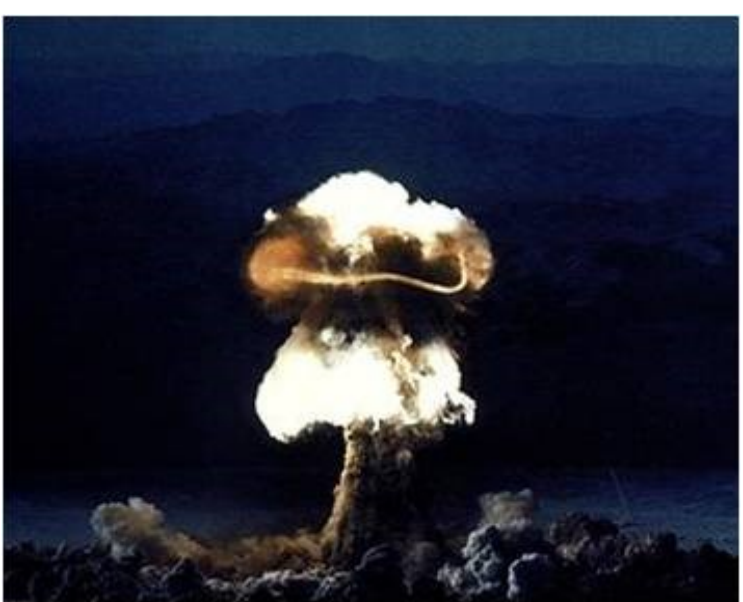

Figure 18: Surface nuclear explosion.

[Source: Fig-18] activity of troops more difficult and cause considerable losses of civil population in cities.

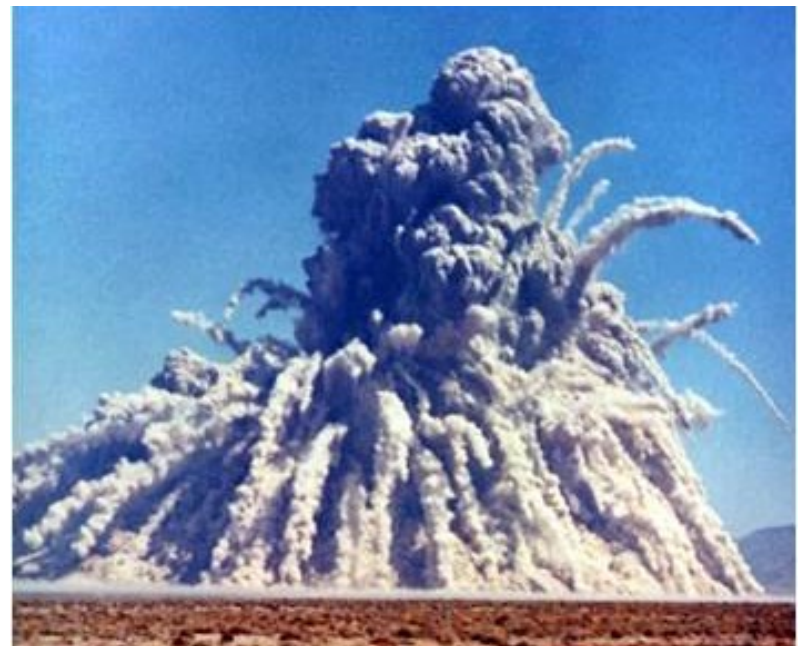

Figure 19: Sub-surface nuclear explosion. [Source: Fig-19]
In the epicentre of explosion, a crater is formed, the dimensions of which are dependent on the nuclear yield and the type of subsoil.

Nuclear underground burst is an explosion carried out under the Earth's surface. The nuclear underground burst creates a crater, the diameter of which is 2 up to 2.5 times larger than the diameter of the crater caused by a nuclear surface burst of the same yield. The destructive effects of an underground burst are radioactive contamination and a seismic pressure wave. Light and thermal radiation, initial radiation and electromagnetic pulse are completely absorbed by the soil. 
Nuclear airburst is an explosion, during which the luminous area does not touch the terrain surface (water surface). It may be low and high. The destructive effects of a nuclear airburst are light and thermal radiation, initial radiation, electromagnetic pulse and a pressure wave.

In the epicentre of a low nuclear airburst (or in its vicinity), radioactive contamination of the terrain occurs. Contamination of the terrain in the direction of the radioactive cloud movement is not produced or is negligible and has no substantial effect on the activity. The electromagnetic pulse is a significant factor of this burst. It causes physical changes in the atmosphere, which complicates the operation or even leads to disabling the communication equipment.

High-altitude nuclear burst is an explosion

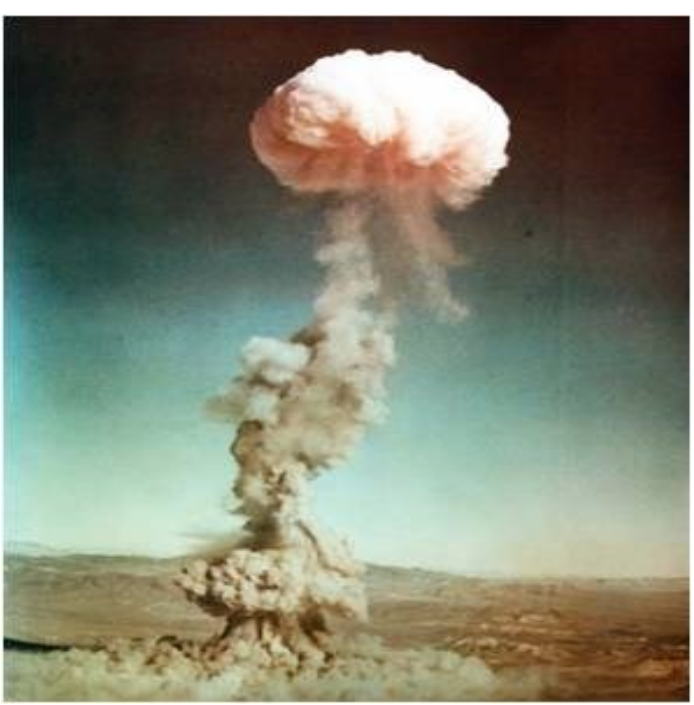

Figure 20: Nuclear airburst.

[Source: Fig-20] carried out with the aim to destroy air targets during the flight at a height safe for ground structures or, if need be, to disrupt communication. The destructive factors of a high-altitude nuclear explosion (at a height up to 25 to $30 \mathrm{~km}$ ) are a pressure wave, light and thermal radiation and initial radiation. In the high-altitude explosion, no contamination of the terrain caused by radioactive agents takes place.

When attacking air targets, the pressure wave is a determining destructive factor. As the height of the explosion increases, the radius of the pressure wave impact zone decreases, and light and heat radiation increase. The radius of the zone affected by initial radiation increases up to a height of 20 to $30 \mathrm{~km}$ and then it does not change. An electromagnetic pulse is another determining destructive factor. It causes significant physical changes in the high layers of the atmosphere, which results in the temporary elimination or restriction of the operation of the appropriate means of communication.

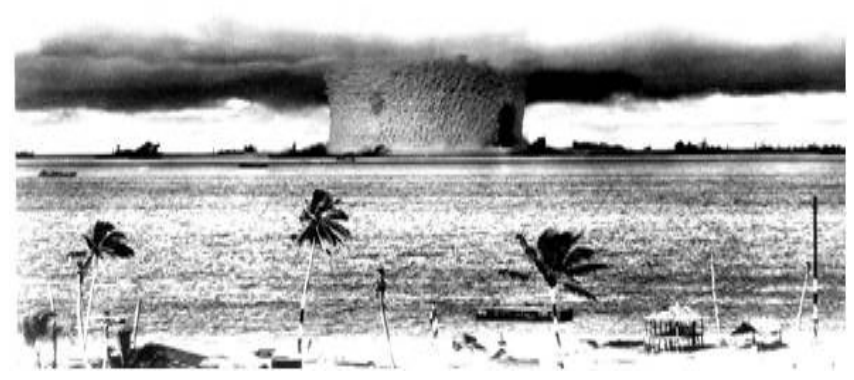

Figure 21: Nuclear burst above the water surface. [Source: Fig-21]
A nuclear burst above the water surface is an explosion, in which the luminous area touches the water surface. The main destructive factors of this burst are an air pressure wave and a pressure wave in water that is dangerous namely for hydrotechnical facilities and other objects under as well as on the water surface. The effects of light and thermal radiation and initial radiation are considerably reduced by a large amount of water vapours. Strong radioactive contamination of water happens both in the area of burst and in the direction of cloud movement. For a nuclear explosion above the water surface and a ground nuclear explosion a term of contact nuclear explosion can also be used.

Underwater nuclear burst is an explosion carried out under the water surface. A characteristic phenomenon of an underwater explosion is the formation of a column of water spray and a foundation wave. 
On the top of the water column there is a big mushroom cloud composed of radioactive vapours and gases. As a result of the disruption of the water column, a foundation wave is created, which propagates from the centre of the explosion and rises to a height until it joins the cloud of the water column.

The basic destructive factor of an underwater explosion is the foundation and pressure wave, which is dangerous for vessels and hydrotechnical equipment. Light and thermal radiation and initial radiation are almost completely absorbed by water and water vapours. Underwater explosions can lead to strong contamination of water or vessels and the coastal zone with radioactive agents.

\subsubsection{Characteristic of a nuclear explosion}

A nuclear explosion is characterized by the instantaneous release of large amounts of energy

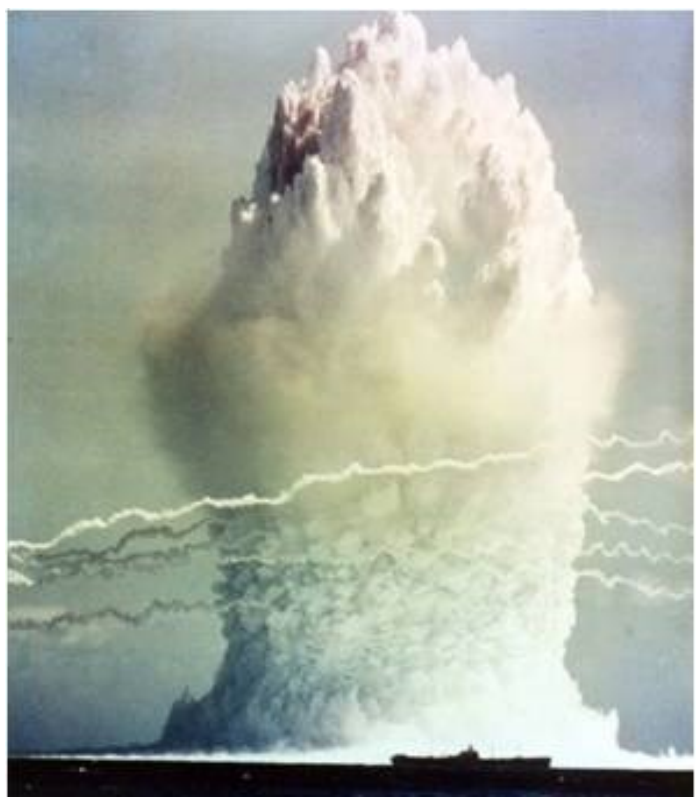

Figure 22: Underwater nuclear burst. [Source: Fig-22] due to a fission or thermonuclear reaction. Due to its destructive ability, this released energy is used for military purposes. Therefore, we speak about the destructive effects (factors) of nuclear weapons. In total, there are five destructive effects as follows:

- Pressure wave of a nuclear explosion;

- Initial radiation;

- Electromagnetic pulse;

- Light radiation of a nuclear explosion; and

- Radioactive contamination.

The yield of a nuclear explosion is dependent on the amount of energy released during the detonation of a nuclear weapon, on the so-called trinitrotoluene equivalent. In a nuclear explosion, only $85 \%$ of energy is released in the form of kinetic (thermal) energy. Of this, some part of energy is used to generate a pressure wave (soil compression wave). The rest of energy is consumed to produce light radiation. The portion of energy emitted in the form of light radiation depends on the type of nuclear charge and the conditions of the explosion. For instance, for a nuclear airburst at a height of up to $30 \mathrm{~km}$ this portion ranges from $30 \%$ up to $40 \%$. The distribution of energy corresponds to this explosion according to graph 1 . The development time of a fission nuclear reaction up to an explosion is $10^{-6} \mathrm{~s}$. The majority of energy (approx. $90 \%$ ) is released during $10^{-7} \mathrm{~s}$.

The initial concentration of this energy is, therefore, extremely high. If we assume a fission charge with a density of about $2 \times 10^{4} \mathrm{~kg} \cdot \mathrm{m}^{-3}$, the initial energy will be equal to about $3.2 \times 10^{17} \mathrm{~J}^{-\mathrm{m}^{-3}}$ (by seven orders higher than in the TNT explosion). The maximum temperature in the reaction region increases with the total energy released and decreases with the increase in the charge surface and with the increase in the reaction time. The values of this temperature are around $3 \times 10^{7} \mathrm{~K}$.

\subsubsection{Time course of a nuclear explosion (nuclear fission charge: $q=30 \mathrm{kt}$ )}

Time $t \leq 10^{-6} s$ (since the moment of release of up to $90 \%$ of the explosion energy) - the evaporation of the fission charge and nuclear charge casing occur. The arising vapours are heated to a temperature of approx. $10^{6} \mathrm{~K}$. Strong gamma rays and neutron radiation (initial radiation) are emitted from the reaction region. 
Time $10^{-6} s \leq t \leq 10^{-4} s-$ a hot (luminous) area and a pressure wave are created. The surface temperature of the hot area increases to $50,000 \mathrm{~K}$ and its radius to approx. $20 \mathrm{~m}$ towards the end of this stage.

Time $10^{-4} \mathrm{~s} \leq t \leq 2 \times 10^{-2} \mathrm{~s}-$ the surface of the hot area is the shock front. The surface temperature of the hot area drops to $3,500 \mathrm{~K}$, its radius increases to $120 \mathrm{~m}$. The shock front pressure decreases from $1,000 \mathrm{MPa}$ to $5 \mathrm{MPa}$. The pressure wave stops glowing.

Time $2 \times 10^{-2} s \leq t \leq 2.10^{-1} \mathrm{~s}-$ the temperature of the hot area increases to $8,000 \mathrm{~K}$ and the radius increases to $200 \mathrm{~m}$. The radius of the shock front increases to $300 \mathrm{~m}$, the pressure at the shock front decreases to $1 \mathrm{MPa}$. Towards the end

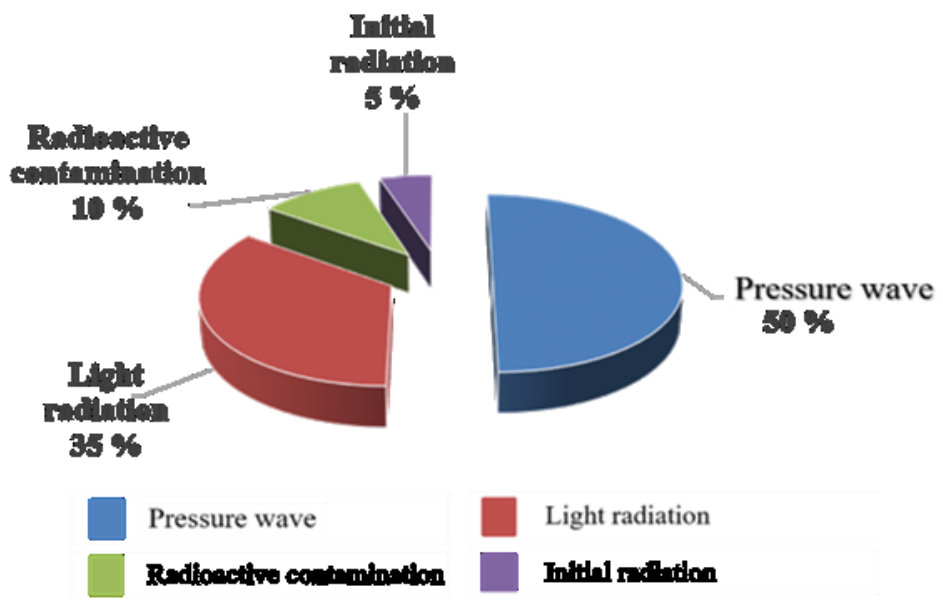

Graph 1: The distribution of nuclear explosion energy in a nuclear airburst $H=$ up to $30 \mathrm{~km}$. [Source: Grph-1] of this stage the action of neutron radiation is over.

Time $2 \times 10^{-1} s \leq t \leq 3 s$ - the surface temperature of the hot area drops to $1,500 \mathrm{~K}$, the radius increases to $300 \mathrm{~m}$. Towards the end of this stage, the action of light radiation is over and the formation and rise of the explosion cloud begins. The radius of the shock front achieves a height of $1,700 \mathrm{~m}$, the pressure at the shock front drops to $0.03 \mathrm{MPa}$. The dose due to gamma radiation is about $95 \%$ of the total dose at the end of the period.

Time $3 s \leq t \leq 60 s$ - the height of the upper part of the cloud reaches $3,000 \mathrm{~m}$ and its diameter $2,000 \mathrm{~m}$. The pressure wave reaches a distance of approx. $20 \mathrm{~km}$ and its destructive effects diminish.

Time $1 \mathrm{~min} . \leq t \leq 10 \mathrm{~min}$. - the rise and development of the explosion ends. The main part of the cloud reaches a height of 10 to $13 \mathrm{~km}$, the diameter of the cloud is 5 to $6 \mathrm{~km}$.

Time $t>10 \mathrm{~min}$. - radioactive products of the explosion fall out of the cloud to the Earth's surface. The nuclear cloud disperses.

For more massive explosions, the range of individual phenomena (cloud height and diameter, range and energy of the blast wave, etc.) will be greater. The time required for the development of phenomena will also be longer. However, their chronological arrangement will remain the same.

\subsubsection{Pressure wave of a nuclear explosion}

The expanding luminous area sharply compresses the ambient air layers and their vibration takes place. This air spreads from the explosion centre to all directions as a pressure wave. The maximum pressure is at the shock front and decreases towards the centre (see Graph 2). In an instant when the pressure wave separates from the hot area, the pressure at its shock front is equal to approximately twice the pressure in the centre of the hot area.

At small distances from the explosion centre, the air at the shock front is compressed considerably and heated, so it glows. As the pressure wave moves away, the overpressure at the front gradually decreases. From a certain distance, the pressure behind the shock front gradually decreases until it falls below the value of atmospheric pressure - a dilution area is created. The pressure wave has the strongest destructive effect in the compression phase. During the dilution phase the destructive effects are negligible. 


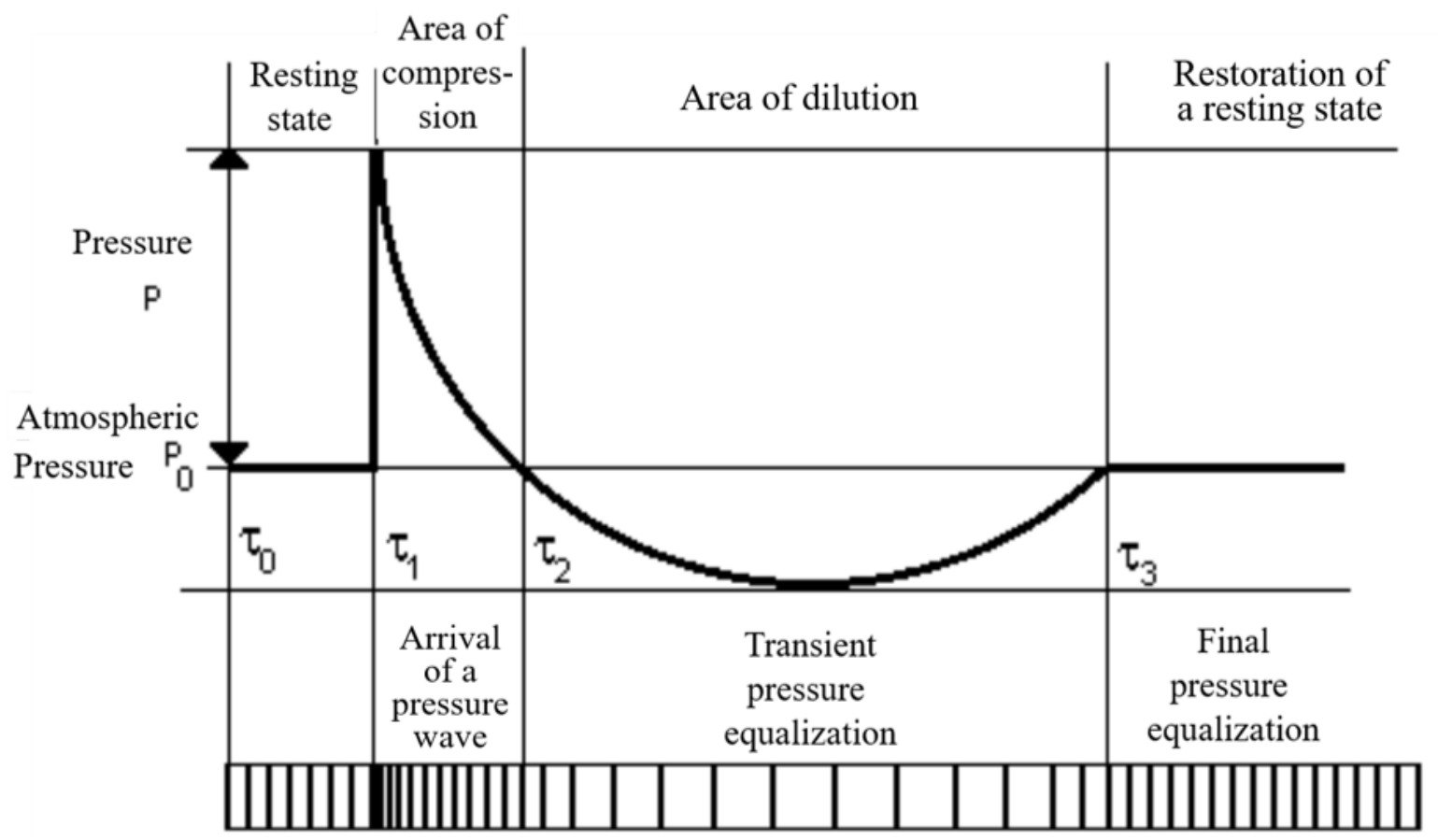

Graph 2: The course of the pressure wave of a nuclear explosion depending on time and distance. [Source: Grph-2]

Besides the overpressure at the shock front, it is necessary, in some cases, to consider another effect of the pressure wave, i.e. drag loading. The air masses of considerable kinetic energy advance behind the shock front. This air acts on obstacles (it is braked) and thus increases the effect of the pressure wave. The drag loading is a function of the velocity and density of the air behind the shock front Both these quantities are dependent on overpressure at the shock front. The drag loading value exceeds the overpressure value in the case of massive blast waves. For overpressures at the shock front higher than $0.35 \mathrm{MPa}$, the drag loading predominates, for overpressures lower than $0.35 \mathrm{MPa}$, the overpressure predominates. The maximum drag loading decreases with the distance from the explosion centre.

This process is faster than in the case of overpressure at the shock front. If the shock front arrives at a certain point, the overpressure as well as the drag loading increase sharply; then they decrease. The values of both parameters decrease to zero approximately at the same time. In the dilution phase, the drag loading has an opposite direction; however, its value is negligible.

The speed of the shock front movement as well as the time of its arrival is dependent on the yield and on the distance from the explosion centre. In the first moments of an explosion, the speed of the shock front movement exceeds the speed of sound transmission many times. However, with the

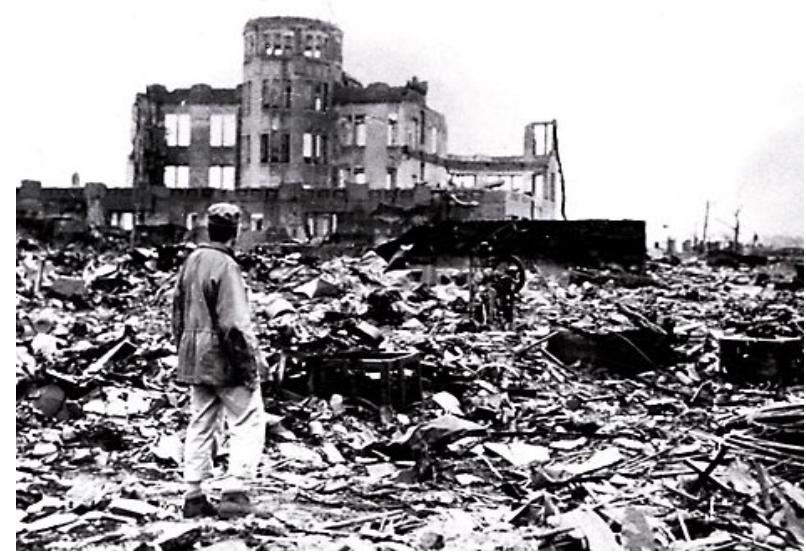

Photo 75: Nuclear explosion effects, Hiroshima 1945. The ruin was later named the Hiroshima Peace Memorial. [Source: Pho-75] increasing distance from the explosion centre, the speed of the shock front movement decreases until the wave moves approximately at a speed of sound (about $344 \mathrm{~m} \cdot \mathrm{s}^{-1}$, at the air temperature $\left.\mathrm{t}=20^{\circ} \mathrm{C}\right)$. 
Thus, the speed of the shock front movement is always higher or equal to the speed of sound. On the contrary, the speed of the air mass movement behind the shock front exceeds the speed of sound in the first moments after the explosion only.

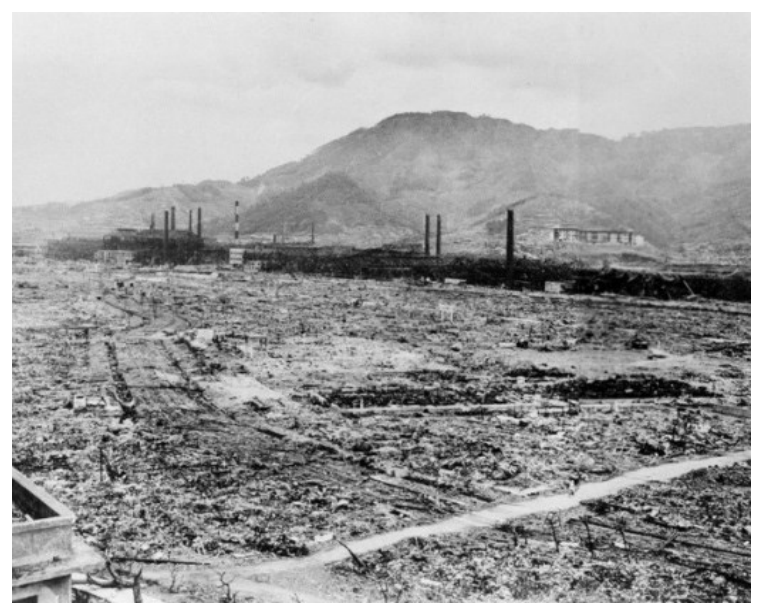

Photo 76: Nuclear explosion effects, Nagasaki 1945. [Source: Pho-76]

The air can be considered to be a homogeneous medium. Let's assume a nuclear airburst. The pressure wave propagating from the explosion centre is called incident wave. If it hits the Earth's surface or another obstacle, it reflects and moves along as a reflected wave. The reflection of the pressure wave occurs instantaneously and, therefore, the objects located at the ground level are exposed to a single impact. Therefore, the value of overpressure on the Earth's surface can be considered to be only the value of overpressure in a reflected wave.

In the area of explosion centre, the value of overpressure at the front of the reflected wave will exceed the value of overpressure at the front of the incident wave more than twice. The intensity of overpressure in the reflected wave is dependent on the incident wave energy and the angle of arrival.

The change in overpressure with time in a certain point on the Earth's surface in the vicinity of the epicentre is similar to the change in overpressure in a certain point in the air. An object located at a certain height above the Earth's surface will, in fact, be subject to two collisions, i.e. one from the incident wave and the other from the reflected wave. Thus, the curve of the change in overpressure with time will have two maximums.

The incident and reflected waves do not move at the same rate. The reflected wave moves in the air heated and compressed by the incident wave, the overpressure at its front is higher and, therefore, the reflected wave moves faster than the incident wave. Under these conditions, the reflected wave catches the incident wave and they fuse to form a third wave. The so-called frontal pressure wave is created. The region, in which this phenomenon occurs is called the more distant region of the pressure wave propagation (the region of irregular reflection). In the closer region of the pressure wave propagation (the region of regular reflection), no coalescence of waves takes place. With the increasing distance from the epicentre, the tri-

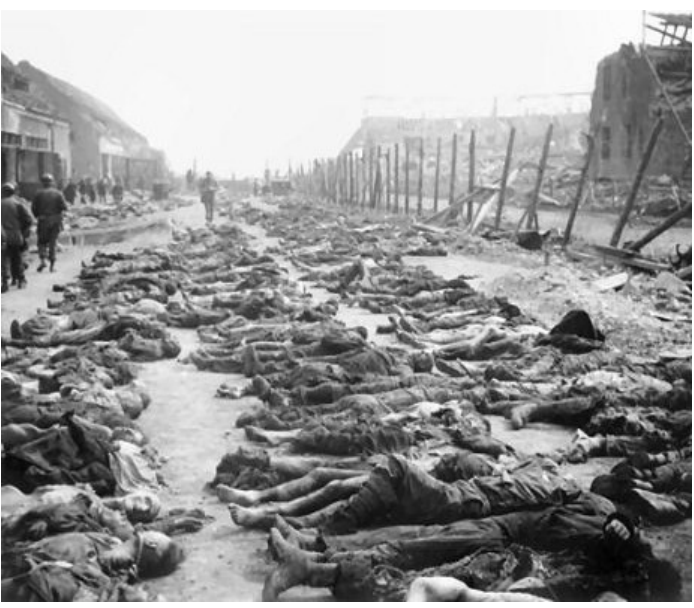

Photo 77: Victims of the nuclear explosion, Nagasaki 1945. [Source: Pho-77] ple point at an ever-increasing height is located. The overpressure at the shock front of the frontal pressure wave is the summary of values of overpressures at the front of both waves.

\subsubsection{The destructive effects of a pressure wave}

The damage to structures subject to the pressure wave effects of a nuclear explosion depends on the structural strength, the nuclear yield, the type of nuclear explosion, the distance from the explosion site and other factors (topography, terrain coverage, etc.). However, ordinary structures are damaged and destroyed even due to small overpressures at the shock front. 
Timber buildings are least resistant. The radii of destroying brick buildings are approximately 1.5 up to 2 times smaller in dependence on the number of storeys. Such structures can survive a nuclear explosion without a more severe damage even in the vicinity of explosion site (epicentre). At different distances from the epicentre, the impact of a pressure wave on objects differs. In a closer area, the buildings towering over the Earth's surface are subject to the impact of the incident and reflected pressure waves. In the first moments, the structures are subject to a smash caused by the incident wave (roof, etc.).

With the reflection of the incident wave from the ground, the structure occurs in the area of the compressed air and is subject to the pressure from all directions.

For the nuclear surface burst or for a more distant area of a nuclear airburst, it applies that the pressure wave propagates along the Earth's surface. The individual parts of the objects occurring in the area of the pressure wave will be loaded differently in unequal instants. The front wall will be loaded the most and at the first moment. It is subject to the overpressure as well as the drag loading. In the area of overpressure, the side walls and the cover of the building and finally the rear wall gradually find themselves. Behind the buildings, however, there is an area where drag loading does not occur. In this area, the ac-

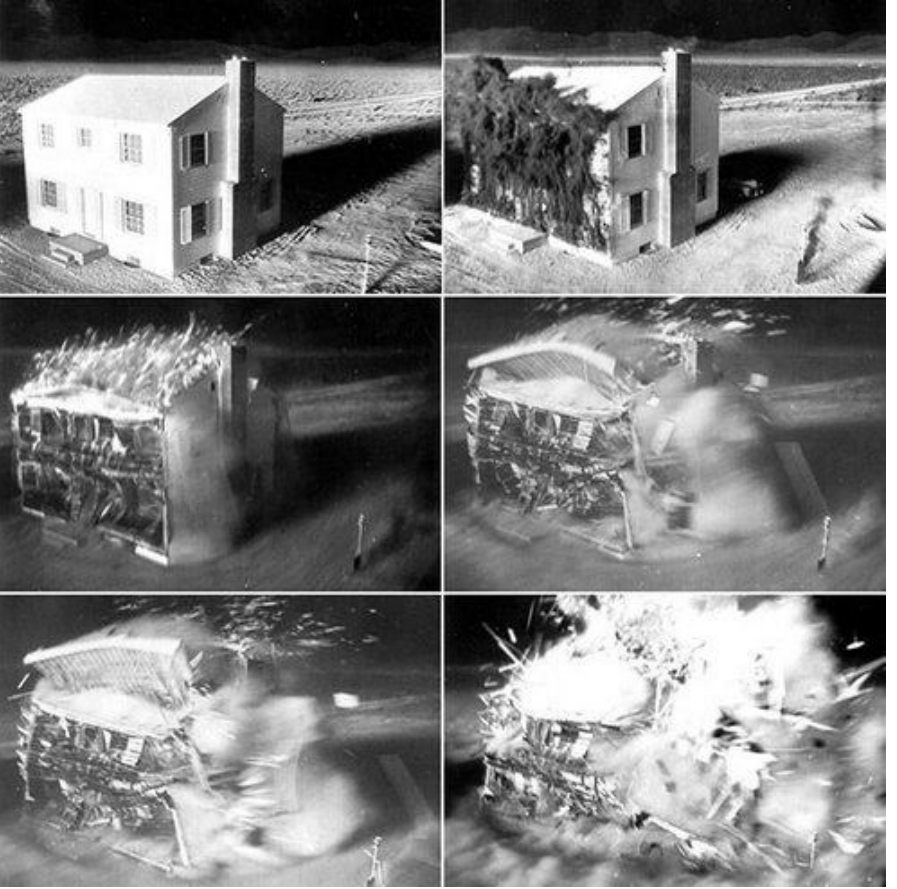

Photo 78: The effect of light (thermal) radiation and the pressure wave of a nuclear explosion. A test in the USA. [Source: Pho-78]

tion of the pressure wave is then weaker (roughly one-third, in comparison with the direct effect of the pressure wave on a perpendicular obstacle). This is used for the protection against the pressure wave action.

The action of the pressure wave on the objects that do not tower over the Earth's surface (in-ground) is considerably smaller than on the objects towering over the Earth's surface. The drag loading does not affect these objects. The increase in the pressure wave action does not occur due to the reflection of the pressure wave.

Approximately the same rules mentioned above apply to the direct action of the pressure wave on humans. The pressure wave can cause serious injuries to humans (it also acts indirectly) due to the fragments of various things, flying rocks, splinters of roof covering, windows, etc.

These secondary effects of the pressure wave cannot be predicted. The pressure wave action is dangerous especially in inhabited areas.
Table 16: The values of coefficient " $k$ ". [Source: Tab-16]

\begin{tabular}{|c|c|c|}
\hline \multirow{2}{*}{$\begin{array}{c}\text { Type of combat equipment } \\
\text { (type of a building) }\end{array}$} & \multicolumn{2}{|c|}{$\begin{array}{c}\text { Dependence of the } \\
\text { coefficient on the } \\
\text { type of explosion }\end{array}$} \\
\cline { 2 - 3 } & Surface & Air \\
\hline Trucks & 0.43 & 0.51 \\
Armoured personnel carriers & 0.25 & 0.32 \\
Anti-aircraft guns & 0.3 & 0.3 \\
Towed artillery, missiles & 0.25 & 0.25 \\
Medium tanks & 0.2 & 0.2 \\
\hline Timber constructions & 1.1 & 1.4 \\
Brick dwelling houses & 0.7 & 0.75 \\
Emergency shelters & 0.22 & 0.2 \\
Shelters to relax - light type & 0.18 & 0.16 \\
Shelters to relax - heavy type & 0.11 & 0.06 \\
Trenches without lining & 0.35 & 0.35 \\
\hline
\end{tabular}


The injuries caused by flying things may occur at much greater distances than the injuries caused by the pressure wave. For the calculation of distance (a), at which combat equipment and objects are put out of operation, the approximate formula applies as follows:

$$
\mathbf{a}=\mathbf{k} \times \sqrt[3]{\mathbf{q}} \quad \text { where: }
$$

$\mathrm{q}$... TNT equivalent $[\mathrm{kt}]$;

$\mathrm{k}$... the coefficient for different types of structures and combat equipment (see Tab. 16);

a ... elimination radius $[\mathrm{km}]$.

\subsubsection{Protection against the destructive effects of the pressure wave}

In principle, the protection against the pressure wave destructive effects is the same as the protection against the pressure waves caused by conventional explosives. However, it is necessary to realize some facts as follows:

- The radius of destruction is naturally several times larger in the case of a nuclear explosion pressure wave;

- The effect of the pressure wave of a nuclear explosion is longer than that of a conventional explosive; and

- Both the overpressure at the shock front and the drag loading are taken into account.

As mentioned above, the protection against the pressure wave destructive effects will also depend on other factors, such as the distance of the position from the explosion centre, the type of nuclear burst, the yield, the relief, the terrain coverage, etc. However, all the findings mentioned can be summarized into the following principle: The larger the exposed surface, the more the pressure wave affects objects. If, at the time of explosion, people are present in the field where it is difficult to use undulations or other obstacles (however, it is always necessary to consider the indirect action of the pressure wave), the simplest way of protection is as follows: to lie down on the ground, face down, to point the legs toward the explosion, bring the heels together, and arms and personal weapons must be folded under the body, tip-toes to the ground. In this way, the area exposed to the pressure wave (especially to the drag loading) can be diminished approximately 6 times.

If it is possible with regard to time, it is advantageous to use a suitable terrain unevenness (a rear slope, hill, ravine, fold, crater after the impact of ammunition, structurally strong combat equipment, etc.) and to hide behind it, and thus to diminish the effect of especially drag loading.

Reliable protection against the effects of the pressure wave is provided primarily by armoured vehicles. The tank armour is able

Table 17: Levels of personal injuries in dependence on overpressure at the shock front.

[Source: Tab-17]

\begin{tabular}{|c|c|}
\hline Degree of impact & $\begin{array}{c}\text { Value of overpressure } \\
\text { [MPa] }\end{array}$ \\
\hline Scattered overpressure & below 0.01 \\
Light degree of impact & 0.01 up to 0.02 \\
Moderate degree of impact & 0.03 up to 0.06 \\
Severe degree of impact & 0.06 up to 0.1 \\
Very severe degree of impact & 0.1 \\
\hline
\end{tabular}
to withstand an overpressure of about 0.04 up to $0.05 \mathrm{MPa}$ and the armour of an infantry combat vehicle about $0.025 \mathrm{MPa}$. The protection level of people, military equipment and material against the effects of the pressure wave is increased through the engineer works in the terrain.

\subsubsection{Light radiation of a nuclear explosion}

In the nuclear explosion, $1 / 3$ of total energy releases in the form of electromagnetic radiation with wavelengths from $10^{-2}$ up to $10^{5} \mu \mathrm{m}$. This radiation is called light radiation of a nuclear explosion. Light radiation with wavelengths of 0.38 up to $0.76 \mu \mathrm{m}$ is visible. The wavelengths shorter than $0.38 \mu \mathrm{m}$ correspond to ultraviolet radiation; the wavelengths greater than $0.76 \mu \mathrm{m}$ correspond to infrared radiation. 
During the transition of electrons in shells of atoms from a higher energy level to a lower one, the emission of electromagnetic radiation takes place. These transitions occur in excited atoms, i.e. atoms, in which the action of energy has led to the transition of shell electrons to higher energy levels. The spectral composition of emitted electromagnetic radiation as well as the total amount of radiated energy is dependent on the temperature of the radiating body in the case of light radiation.

The fireball surface temperaTable 18: Distribution of ultraviolet radiation. ture produced during a nuclear explosion does not change continuously. The temperature attains two maximums. The first maximum (millions of degrees) happens in an instant of explosion. The air around the hot area gradually heats up and its transparency decreases. The hot area temperature drops down sharply until [Source: Tab-18]

\begin{tabular}{|c|c|c|}
\hline Name & Abbreviation & Wave length \\
\hline Near & NUV & $400 \mathrm{~nm}$ to $200 \mathrm{~nm}$ \\
\hline UVA, long-wave, black light & UVA & $400 \mathrm{~nm}$ to $320 \mathrm{~nm}$ \\
\hline UVB, medium-wave & UVB & $320 \mathrm{~nm}$ to $280 \mathrm{~nm}$ \\
\hline UVC, short-wave, germicidal & UVC & below $280 \mathrm{~nm}$ \\
\hline DUV, deep ultraviolet & DUV & below $300 \mathrm{~nm}$ \\
\hline Far or vacuum & FUV, VUV & $200 \mathrm{~nm}$ to $10 \mathrm{~nm}$ \\
\hline Extreme or deep & EUV, XUV & $31 \mathrm{~nm}$ to $1 \mathrm{~nm}$ \\
\hline
\end{tabular}
it attains the first minimum. Then this heated and glowing air expands as a pressure wave into the surroundings, its temperature decreases and the transparency increases. The surface temperature of the hot area rises sharply again and reaches the second maximum.

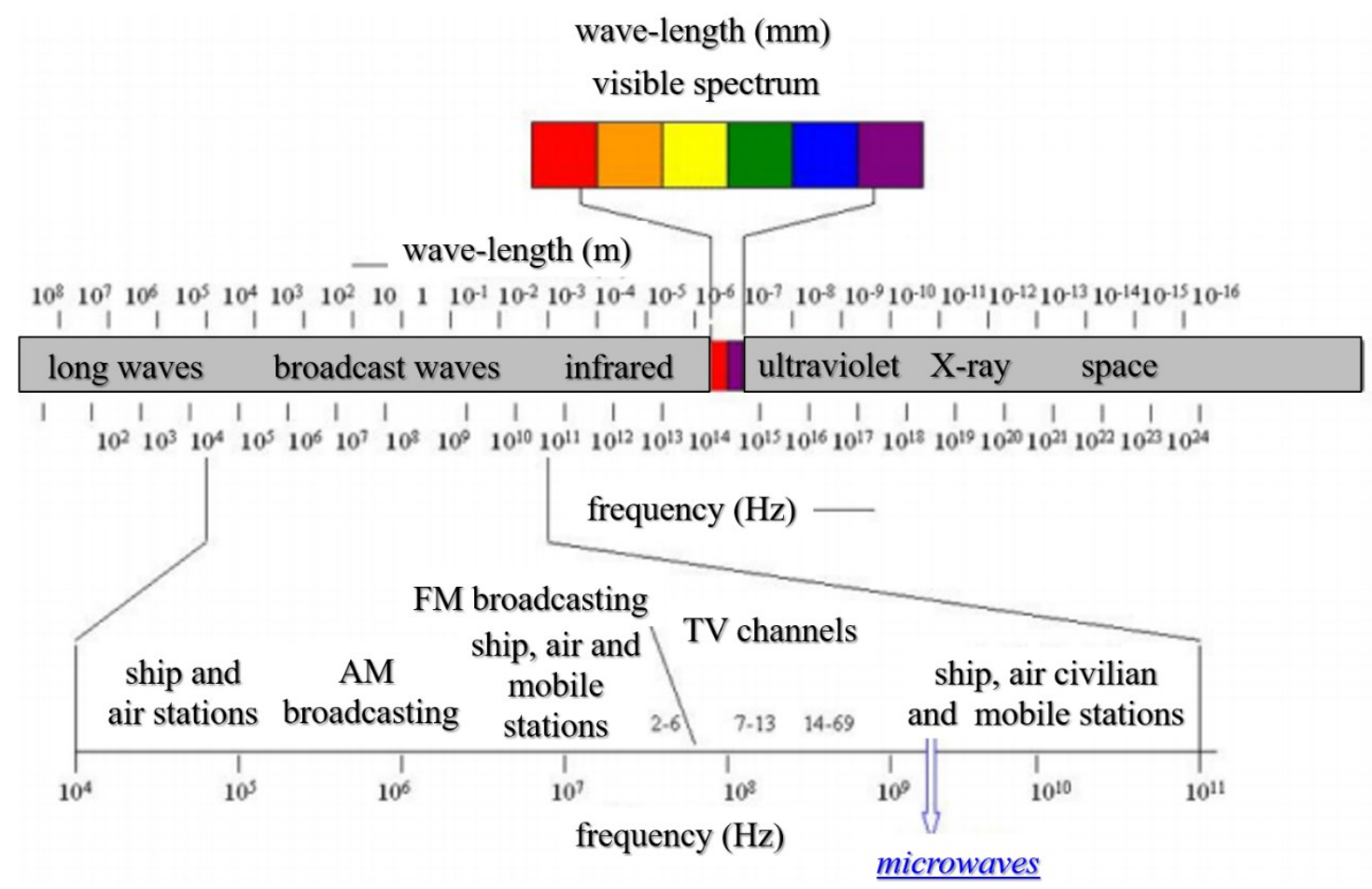

Figure 23: Radiation distribution. [Source: Fig-23]

The maximum energy density of light radiation falls on the visible region of the spectrum at a temperature of about $7,000 \mathrm{~K}$. This temperature is approximately equal to the maximum temperature of the fireball surface at the second maximum, which does not exceed 7,600 K too much. Therefore, the considerable part of energy is represented by visible and infrared radiation. Only a small part falls on ultraviolet radiation. The light radiation of a nuclear explosion is emitted in two periods. The first period (to the first minimum) takes fractions of a second. During this period only about $1 \%$ of total energy of light radiation is emitted. The second period (from the first minimum to the end of the radiation) usually lasts a few seconds. 
The quantity of the light emitted through the surface of a radiating body per time unit is called the total intensity of light radiation and is dependent on the yield of the explosion. The amount of light energy incident throughout the radiation per $1 \mathrm{~m}^{2}$ of surface, which is perpendicular to the direction of the incident rays of light, is called light pulse.

The light pulse is measured in $\mathrm{J}^{\mathrm{m}} \mathrm{m}^{-2}$ or in ${\mathrm{J} . \mathrm{cm}^{-2}}^{-}$. The magnitude of the light pulse depends on the total intensity of light radiation, on the distance from the explosion Table 19: Distribution of infrared radiation (IR). [Source: Tab-19] site and on the air quality. The magnitude decreases with a square of distance from the explosion site. In the atmosphere, it is attenuated proportionately by the distance depending on its magnitude, shape, etc. Light radiation incident on any surface is partly reflected from the surface, partly absorbed and partly passed through the body.

The absorbed part of the energy is converted into the thermal energy and causes the heating of the body. The temperature, to which the body is heated, is dependent on the quantity of absorbed energy, temperature, thermal conductivity, specific heat of material, its dimensions, shape, etc. The total energy of light radiation absorbed by $1 \mathrm{~m}^{2}$ of surface throughout the entire time of illumination is called heat burst.

\subsubsection{Destructive effects of thermal radiation}

As have been stated, when a body is illumi- Table 20: The magnitude of the light pulse nated, it is usually heated strongly, which causes during a nuclear explosion (the light pulse damage to or destruction of material. Flammable materials ignite, non-flammable materials lose strength, deform, melt and crack. At first sight, the military equipment appears to be relatively resistant against the light radiation effects. It is mostly composed of rather robust structural parts, mostly made of non-combustible, refractory metals. Non-uniformity in the strength of individual parts, the use of non-homogeneous material, is in $10^{-3} \mathrm{~J}^{2} \mathrm{~m}^{2}$. [Source: Tab-20] the local heating and others are causes of the stress in the construction and the development of deformations, which depreciate it.

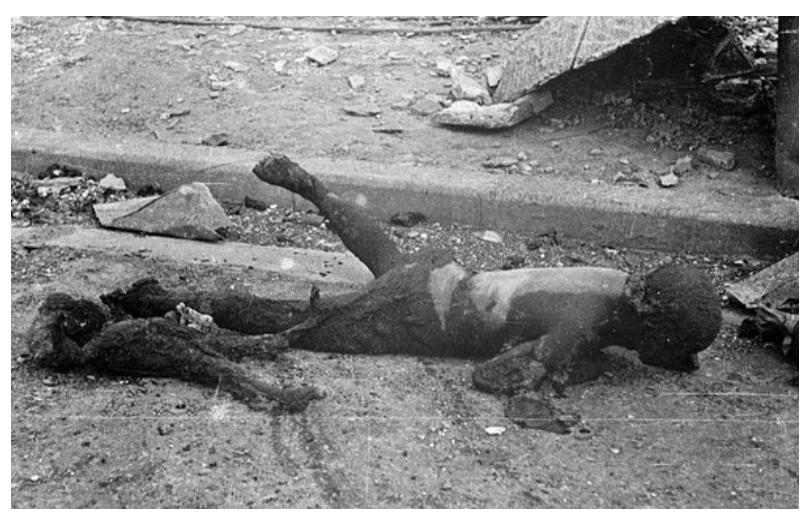

Photo 79: Victims. Hiroshima 1945. [Source: Pho-79]

Most of the military equipment used contains elements that are little resistant to the effects of light radiation caused by a nuclear explosion. These are especially rubber tyres, fuel distribution systems, compressed-gas bombs, wiring, optical parts, canvas, parts made of wood and plastics, and others. Fuel containers and namely the presence of ammunition may lead to explosions connected with the spread of fires as well as the total destruction of combat equipment. 
Compared to the above-mentioned equipment, the situation related to structures is more favourable. As to the materials used, they are of superior quality and more resistant to the effects of light radiation. However, it is necessary to realize that building materials are not indestructible from the viewpoint of high-temperature resistance.

Bricks are made at a temperature of 1,000 up to $1,200{ }^{\circ} \mathrm{C}$, glass at a temperature of 500 up to $600{ }^{\circ} \mathrm{C}$, steel softens by heat at a temperature of 1,300 up to $1,500{ }^{\circ} \mathrm{C}$, but it loses a half of its hardness when heated up to $500{ }^{\circ} \mathrm{C}$ and the concrete cracks due to heat, etc. If light radiation of a nuclear explosion falls on a structure and ignites its combustible construction, a primary fire will occur. If there are conditions for further spreading of fire (combustible material, flammable buildings) in the vicinity and the fire spreads there, we speak about a second-

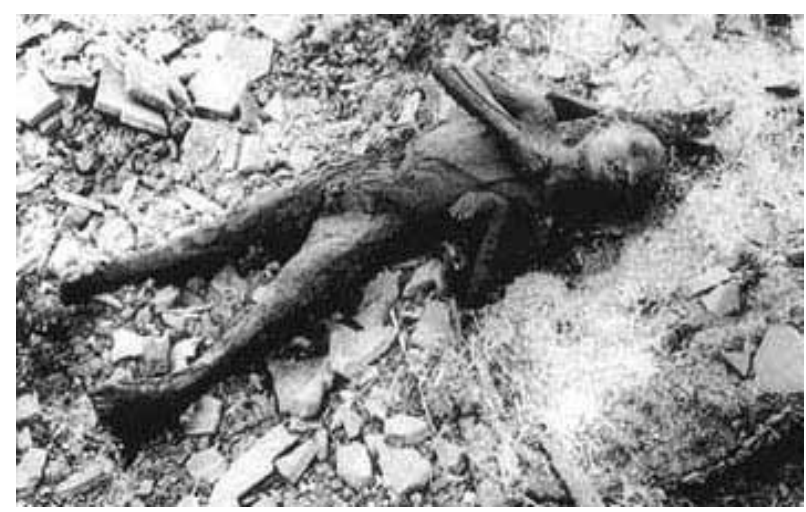

Photo 80: One of the victims. Hiroshima. [Source: Pho-80] ary fire. Its characteristic features are considerable dimensions and intensity. If there are a few secondary fires at a time, they connect gradually to produce a tertiary fire also called firestorm. It does not destroy through the contact of blazes only, but also through the radiation heat and demolition effect of air masses drawn to the centre of the focus from the neighbourhood achieving a speed of $60 \mathrm{~m} \cdot \mathrm{s}^{-1}$. This may cause the massive destruction of urban districts.

Table 21: Degrees of burn injuries. [Source: Tab-21]

\begin{tabular}{|c|c|c|c|}
\hline \multirow{2}{*}{ Degree } & \multirow{2}{*}{ Accompanying symptom and prognosis } & \multicolumn{2}{|c|}{ Light pulse $\left[\mathrm{J} . \mathrm{m}^{2}\right]$} \\
\hline & & Exposed skin & Covered skin \\
\hline $1^{\text {st }}$ & $\begin{array}{l}\text { Skin redness (erythema) reminiscent of overexposure to sun- } \\
\text { light, combat readiness preserved to a great extent }\end{array}$ & $15 \times 10^{-3}$ & $50 \times 10^{-3}$ \\
\hline $2^{\text {nd }}$ & $\begin{array}{l}\text { Skin pain and redness with blisters, damage to dermal tissue, } \\
\text { special long treatment necessary, combat readiness lost }\end{array}$ & $20 \times 10^{-3}$ & $75 \times 10^{-3}$ \\
\hline $3^{\text {rd }}$ & $\begin{array}{l}\text { The whole layer of the skin is affected in depth, due to the } \\
\text { destruction of the sensory nerve endings, the burn is not } \\
\text { painful in the first days of the impact, subsequent shock } \\
\text { and direct threat to life }\end{array}$ & $25 \times 10^{-3}$ & \\
\hline
\end{tabular}

The immediate effect of light radiation on humans is given by the body surface affected by burns and the degree of visual impairment. In addition to direct burn injuries, light radiation can also act indirectly by fast heating or burning clothes. Then we speak about the so-called contact burns. Especially the body surface where the clothes cling to the body is affected most. It also depends on the colour of clothes. Contact burns occur on the body surface covered by black textiles. According to the causes, the extent and the depth of injuries, there are altogether three categories of burn injuries (see Table 21). Burn injuries occur especially on the exposed parts of the body (face, hands, neck) near the explosion. Radiation spreads directly. In addition to the above-mentioned skin injuries in people, serious visual impairment may occur.

\subsubsection{Protection against the destructive effects of light radiation}

Light radiation spreads at the speed of light and lasts a few seconds depending on the nuclear yield. The protection against fires caused by the effect of light radiation is identical to the principles of fire protection. 
All the measures to protect people against destructive effects, if they were not taken before the explosion, must be carried out immediately after the flash of the nuclear explosion. Protecting the skin from burns is basically no problem. Any non-transparent obstacle placed between the radiation source and a person serves as protection against its effects.

The people unprotected from the explosion must decide immediately, i.e. to hide immediately behind an obstacle that provides a shade (not against the sun, but against the nuclear explosion). The obstacle must be sturdy and resistant against the light pulse. If there is no shelter in the vicinity, it is necessary to lie down on the ground immediately (see the protection against the destructive effects of a pressure wave). Eye protection consists of closing the eyes immediately after a flash and placing the arms on the eyes.

\subsubsection{Electromagnetic pulse}

Electromagnetic pulse is one of the nuclear burst destructive effects. Nuclear electromagnetic pulse (NEMP or also EMP) is a term usually used for electromagnetic signals, which are a consequence of a nuclear burst. The aim of this part is to simply describe the emergence of NEMP/EMP, its basic characteristics and methods, using which these signals penetrate platforms and systems. The term of electromagnetic pulse (EMP) has the following meanings:

- Electromagnetic radiation originating from an explosion (mostly nuclear) or from an electromagnetic bomb (e-bomb).

- Highly intensive, broad-band emission of electromagnetic energy taking a very short time.

The EMP can cause a short-term, but also a long-term indisposition and is able to cause temporary or long-term breakdowns of electronic and electrical systems in all the geographic regions of the world. Stationary equipment, mobile ground equipment, aircraft, satellites, missile guidance systems and marine equipment may be affected and, therefore, it is necessary to adjust them for a trouble-free operation in a dangerous electromagnetic environment.

Since the character, the altitude of an explosion, the location and distance of the equipment from the explosion site affect the signal strength and wave form, it is appropriate to differentiate the electromagnetic pulse at high altitude (HEMP), the source region electromagnetic pulse (SREMP) and the system-generated electromagnetic pulse (SGEMP).

On the other hand, SGEMP will not appear until the equipment is present and is a consequence of the explosion products, which affect this equipment directly. Since SGEMP signals are strongly dependent on the topology of devices, no SGEMP voltage and current criteria are specified in the North Atlantic Treaty Organization (NATO). On the basis of available information, a particular state has to define these values for its devices, aircraft, vessels, satellites or vehicles.

$\boldsymbol{E M P}$. First of all, it is necessary to define what happens in the centre of an explosion. Kinetic energy occurs in a chemical (i.e. a massive explosion) and nuclear form. Subatomic particles (neutrons) and a form of electromagnetic energy (X-ray and gamma radiation) carry a large part of this energy. Nuclear particles move radially from the centre of the explosion at high speed and act on surrounding substances, such as the Earth's atmosphere, the Earth itself, or specific devices. The action is mutual, and when it takes place in the atmosphere, free charges and positively charged ions are formed, which are referred to as the source region. If the interaction occurs on Earth or in a device, currents and voltages are generated.

EMP is thus a general term that denotes the resulting electromagnetic field caused by the deceleration of electrons (referred to as Compton electrons) by the Earth's geomagnetic field (in the case of HEMP) or by various recombination processes of electrons in electromagnetic fields (HEMP), SREMP and SGEMP). 
HEMP. In the case of HEMP, the interaction between gamma rays and the upper layers of the Earth's atmosphere in the source region at a height of approximately 20 up to $40 \mathrm{~km}$ above the Earth will take place. The Compton electrons produced move directly until they encounter the flux lines of the geomagnetic field and then they continue moving in their direction until their recombination in the atmosphere takes place. During this time, electrons create an in-phase electromagnetic pulse. When viewed from the Earth (along the tangential radius $\mathrm{Rt}$ ) it is a simply radiated field which can be described by the intensity of the electric field in $\mathrm{V} / \mathrm{m}$. For a typical explosion, it can be calculated that the available average HEMP energy density is between 0.1 and $0.9 \mathrm{~J} . \mathrm{m}^{-2}$. For a device, the surface of which is several square metres, the energy bound to its surface may be of the value up to several joules. It results from the previous tests when some components of devices were damaged that the energy of a few microjoules brought to the input/output of an electronic device is sufficient to cause damage or errors in the operation due to a thermal breakdown.

SREMP. If the fireball of a nuclear explosion touches the Earth's surface, then the signal outside this fireball produces a source region and is referred to as SREMP. In such a case, the electric field and the magnetic field do not have the same course and thus it is necessary to identify the electric field strength in units of volts per metre $(\mathrm{V} / \mathrm{m})$ and the magnetic field strength in units of amperes per metre $(\mathrm{A} / \mathrm{m})$. Due to the detonation caused by a surface nuclear burst, free electrons are forced out of air molecules, which move radially from the Earth's surface and create a source region in the shape of a hemisphere, which is highly conductive. In this region, the electron flow moves vertically upwards from the surface burst. The electron flow creates a vertically polarized electric field with respect to the Earth. As the distance from the Earth extends, the electron trajectory bends and electrons return to the Earth. The free electrons that remained in the air recombine with positively-charged air molecules and the impedance of the air returns to a usual value (it is $377 \Omega$ for the free space). The dominant field in this extent reduces to small amplitude radiated in a distant field. Electromagnetic signals are characterized by an initial electric and magnetic field with fast rises, a high amplitude peak and a significant energy level.

SGEMP. SGEMP is different from SREMP. It is a pulse caused by the interaction of X-rays, gamma and neutron radiation, and a specific system, when electrons are excited and released. The charge of the electrons forming the current is transformed into a flux through the surface of the system, creating an EMP. If a device is in the vicinity of an explosion, the direct interaction with the system is very significant. The interaction of a device that is placed on the Earth, neutron radiation and gamma radiation will produce SGEMP, the effect of which increases with the dimensions of the device. In this case, X-ray radiation is not applied because it is absorbed in the ambient atmosphere and contributes to the thermal and pressure pulse spreading radially. X-rays are significant only in the external atmosphere, where they interact directly with the device located in free space (with satellites) and where SGEMP occurs. SGEMP for satellites was originally referred to as internal EMP (IEMP).

\subsubsection{Destructive effects of electromagnetic pulse}

The destructive effect is caused by the fact that during nuclear explosions, electromagnetic fields are created in the surrounding environment, which cause electromagnetic fluxes and voltages in wires and cables of air and ground line communication, in navigation of command and control systems, signalling, radio antennas, etc. In the case of a nuclear explosion or an asteroid, the electromagnetic pulse consists of a continuous frequency spectrum. Most of the energy is in the form of lower frequencies between $3 \mathrm{~Hz}$ and $30 \mathrm{kHz}$. Gamma rays of a nuclear explosion produce high-energy electrons through Compton scattering. These electrons are captured in the Earth's magnetic field, at altitudes between 20 up to $40 \mathrm{~km}$ where they resonate. 
An oscillating electric current produces a coherent electromagnetic pulse (EMP) that takes approximately 1 millisecond up to 1 microsecond. The side effects of EMP may take more than one second.

With regard to the short duration of electromagnetic fields of a nuclear explosion, it is a custom to call it electromagnetic pulse. The pulse is very strong and long metal objects (pipes, cables) work like antennas, on which high voltage is induced if the pulse cannot be grounded in any way. These voltages and the associated high currents are capable of destroying unprotected electronics, such as electrical appliances that are not in a metal, magnetically conductive, grounded box. In particular, it is devastating for semiconductors and absolutely the worst for field-effect transistors (FET). As for EMP, no effects on biological organisms have been observed. At the same time, radio waves, which propagate at large distances from the explosion site, are emitted. These waves are received by an electronic device as a short-term fault, analogous to a distant lightning fault.

In high-altitude explosions, significant voltages and currents are induced in wires and cables at distances of up to several hundred kilometres from the site of an explosion. Their value may be sufficient to disrupt line function, regardless of lightning arresters that respond late to such a short intense pulse. The effect is evident especially when the explosions happen high enough above the surface as both the then superpowers ascertained in the early 1960s. For the first time, during Operation Starfish Prime (high-altitude nuclear test) in July 1962, a nuclear weapon of a yield of $1.44 \mathrm{Mt}$ was launched at a height of 250 miles (approx. $400 \mathrm{~km}$ ) above the Earth's surface in the Pacific Ocean; it caused extensive damages to the electric equipment in Hawaii situated 898 miles (approx. 1,445 km) far from the site of the test.

Induced currents and voltages achieve the highest values in surface nuclear bursts and low airbursts. In the area with a radius of several kilometres from the explosion site, the voltages in connections of power transmission lines occur. They may cause the puncture of insulation among individual conductors, the puncture of insulation of installation and device elements connected to the air and ground lines, puncture of linear connection transformers, carbon dischargers, damage to moving parts of small capacity electromagnetic relays, damage to semiconductor devices as well as fuse protection used to protect lines from overload.

The communication, signalling lines and lines of command and control systems are most exposed to the effects of the electromagnetic pulse. Cables and equipment usually have an electrical resistance of no more than 2 to $4 \mathrm{kV}$ direct current voltage. Since the electromagnetic pulse acts for a short time, the ultimate strength of these connections can be considered to be 8 to $10 \mathrm{kV}$. If common protection elements are used on the connecting lines, they are standardized up to $10 \mathrm{~V} / \mathrm{m}$ for lightning protection in military installations, the dangerous voltage is $50 \mathrm{kV}$. Induced voltage in air lines and cables in low and surface explosions from $1 \mathrm{kt}$ up to $1 \mathrm{Mt}$ arises at distances of 2 to $3.3 \mathrm{~km}(10 \mathrm{kV})$ from the explosion site and 1 to $1.7 \mathrm{~km}(50 \mathrm{kV})$ from the explosion site.

For a typical explosion, it can be calculated that the available average HEMP energy density is between 0.1 and $0.9 \mathrm{~J}_{\mathrm{m}} \mathrm{m}^{-2}$. For a device with a surface area of several square meters, the energy bound to its surface can be as high as a few joules. It results from previous tests when some components of devices were damaged that the energy of a few micro-joules brought to the input/output of an electronic device is sufficient to cause damage or errors in the operation due to the thermal breakdown.

In microelectronics, unwanted currents are also induced in connections, inside the devices themselves and their elements. Integrated circuits, transistors and thyristors are particularly sensitive. On the contrary, thermionic devices are the most resistant. 


\subsubsection{Protection against the effects of electromagnetic pulse}

The protection against the effects of electromagnetic pulse includes a number of technical and organizational measures in addition to the measures of a technical character (special protection of inputs of the whole communication systems by over-voltage elements and filters).

They are as follows:

- Periodic inspection of conductor insulations and leads to devices; and

- Readiness of operators and technical personnel to detect and remove defects relating to the electromagnetic pulse.

However, the most ordinary and also the simplest method of protection is immediate disconnection of all unnecessary appliances from power supplies.

As mentioned above, electrical devices can be protected by placing them in a grounded metal box or in a Faraday cage. In this way they are protected against the EMP electrical component; however, to protect them against the EMP magnetic component, it is necessary to put them into a magnetically conductive box (iron, ferrite). If an appliance is connected to the electricity network $(230 \mathrm{~V}, \mathrm{LAN}$, etc.), it is appropriate to protect the appliance at these inputs using the Transil or Trisil. Antenna inputs can also be protected by these components. Of course, screened radio sets cannot work properly; however, older devices based on vacuum tubes are not so susceptible to the effects of EMP. Therefore, the Soviet aircraft were equipped with electronic systems based on vacuum tubes during the Cold War. However, even the best shielding will not help if a device is connected to an antenna.

\subsubsection{Electromagnetic pulse weapons}

Electromagnetic pulse (EMP) weapons have long been considered to be a slightly fantastic spectacle in the arsenal of movie super villains. However, as it turns out, fantasy quickly becomes a reality. The EMP weapons must be taken into account. Probably everyone who has watched any thriller knows it. For instance, in the three-dimensional thriller called Godzilla, helicopters fall on the ground like flies after being hit by electromagnetic discharge. It seems simple and effective in a movie. The recent Russian tests of an electromagnetic pulse weapon developed by the research teams in Moscow, Tomsk, Nizhny Novgorod and Yekaterinburg looked the same or similar. The first tests of EMP weapons were launched in the 1960s.

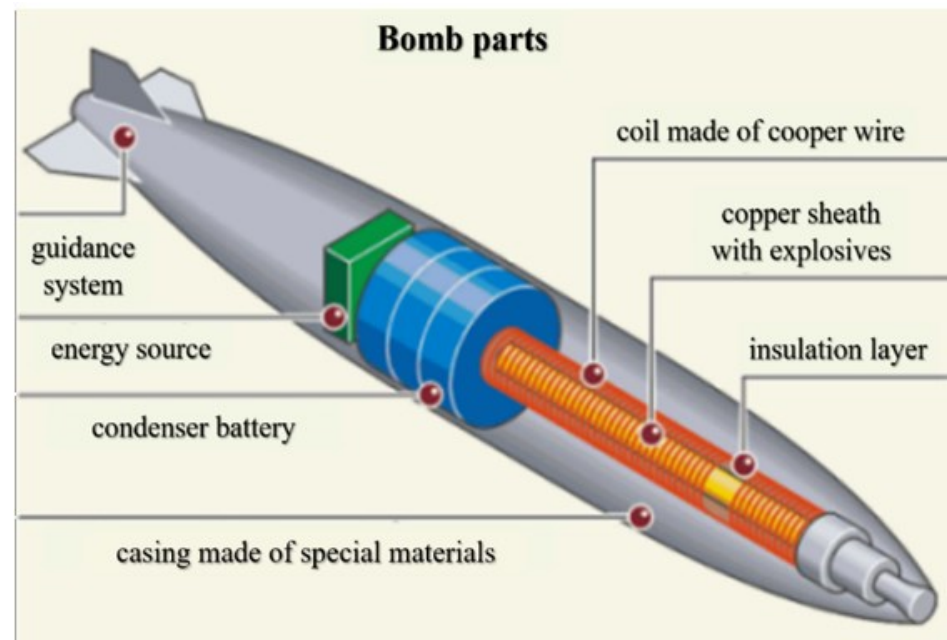

Figure 24: Description of the electromagnetic pulse bomb. [Source: Fig-24]
EMP weapons or radio-frequency (RF) weapons are weapons affecting a target by emitted electromagnetic waves. The waves of high frequencies damage electronics and microwave frequencies may also affect brain functions in humans. Electromagnetic weapons are a category of non-lethal weapons (Non-Lethal Weapons). Their purpose is to disable a selected group of people for a certain time without a direct threat to their lives or to put selected types of military equipment out of action or, if need be, to make combat action impossible. 
High-frequency weapons emit electromagnetic energy in part of the electromagnetic spectrum of radio waves. The mechanism of action of high-frequency weapons on the human body can be divided into energy and information. The thermal action of strong high-frequency energy fluxes is the most investigated.

High-frequency electromagnetic radiation depending on the carrier frequency and power interferes with the brain and central nervous system functions and limits a person in activities temporarily. It may cause perceptual disorders, fatigue and drowsiness or restlessness and stress, feeling of hunger, sensation of thirst, fever or cold, itching and sometimes other minor sensations as well. At the same time, the effect is perceived by an individual as an excruciatingly painful feeling of intense noise and whistling accompanied by anxiety and nausea depending on the specific conditions and parameters of the signal.

However, all direct and indirect effects of high-frequency weapons on a living organism are not yet known. Most medical doctors are not clearly convinced of their complete harmlessness. Doubts were heightened in connection with the Gulf War.

One of the possible causes of the disease could be the exposure to the effects of radio-frequency radiation during the cross-country flights of aircraft equipped with activated radar jammers over the friendly troops. It is known as the effect of the so-called audibility of broadcast by an affected

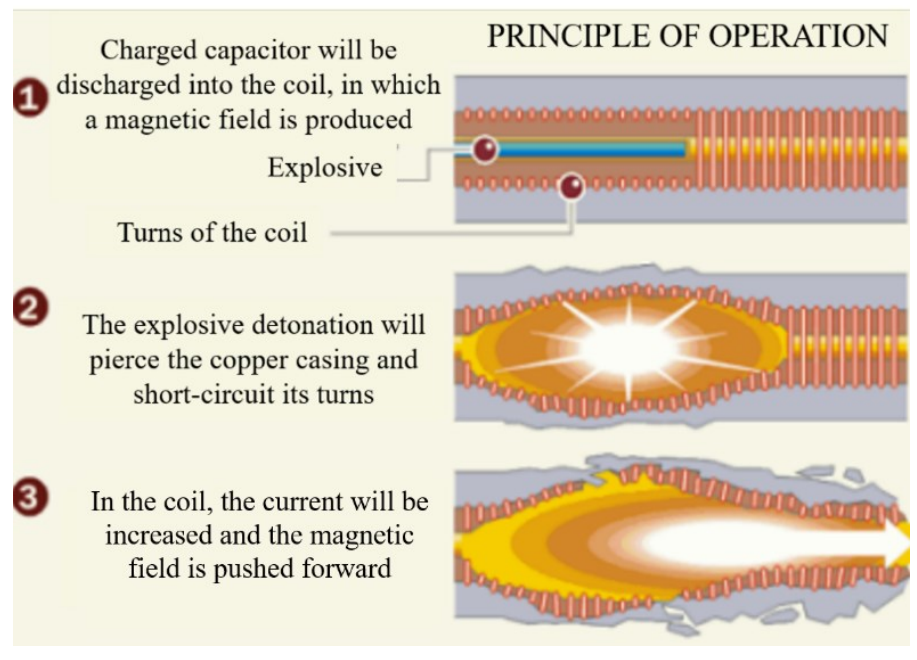

Figure 25: Principle of operation of an electromagnetic pulse bomb. [Source: Fig-25] person, which means that people present in the strong field of a radio transmitter can hear the so-called inner voices and music.

Experts in the field explain the nature of this phenomenon as follows: some individuals are able to detect the carrier frequency modulated by the non-linear internal environment of a human organism with the subsequent transformation into signals perceptible by the auditory nerve. A secondary result may be quite distinguishable hissing in the ears accompanied by sleep disorders, loss of appetite and excessive fatigue persisting for several days.

Some types of EMP weapons are included in the arsenal of modern armies and have been used in local conflicts. Some types are in the phase of laboratory tests and field tests. These are especially the following weapons:

- Laser and microwave weapons (DEW - Directed Energy Weapons);

- Electromagnetic pulse bombs (E - bomb, EMP - Electromagnetic Pulse, HPM - High Powered Microwave); and

- Microwave weapons (ADT - Active Denial Technology, ADS - Active Denial System, HPM - High Power Microwaves), e.g. with a thermal effect.

In connection with a constant tension on the Western Russian border, more and more people began to ask whether Russia did not own a super weapon, against which there is no effective method of defence, i.e. a weapon, which will disable enemy electronic equipment by a single short strike. That is exactly what EMP can do. 


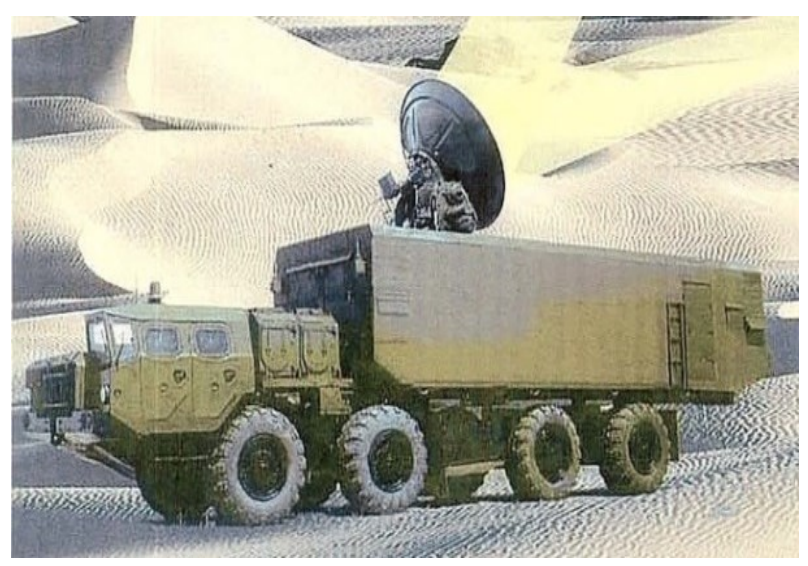

Figure 26: The Russian MMPS Ranets-E High Power Microwave (HPM) weapon system on the MZKT-7930 chassis. [Source: Fig-26]

Initially, EMP was observed especially as a secondary effect of a nuclear explosion. During the Cold War, it was planned that nuclear explosions at high altitudes would generate EMP, which would damage the opponent's interests seriously. But then it has been found out that it is possible to create EMP by conventional methods.

In a simplified fashion, it can be said that there is a conventional detonating charge in EMP warheads. It explodes, after which the energy of the explosion of special electrical components, such as suitably arranged coils and capacitors, is converted into electromagnetic energy. It is emitted by the antenna in the form of a short but extremely intense pulse. This is a time in the order of just picoseconds, but we calculate performances in gigawatts.

The resulting EMP has a devastating effect against devices that use semiconductors, because the EMP seems to burn through semiconductor junctions or turn them into conductors, which eliminates the device.

On October 22, 2012, the test EMP missile denoted as Champ exploded over the desert in Utah. The results of the weapon test of the Boeing Company were impressive also due to its dramatic course. Keith Coleman, the Champ project manager for Boeing Phantom Works, said that the video camera

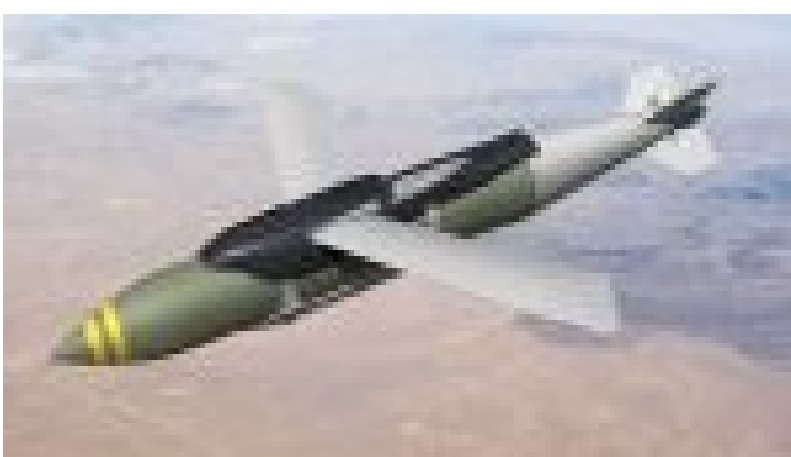

Figure 27: The Champ test EMP missile. [Source: Fig-27] had recorded the pictures of running desk computers and a sudden breakdown of all followed by rapid blackening of the camera itself. He also said: We'll hit any target we'll want, we'll reach every target. Today, we have turned scientific fiction into a scientific reality.

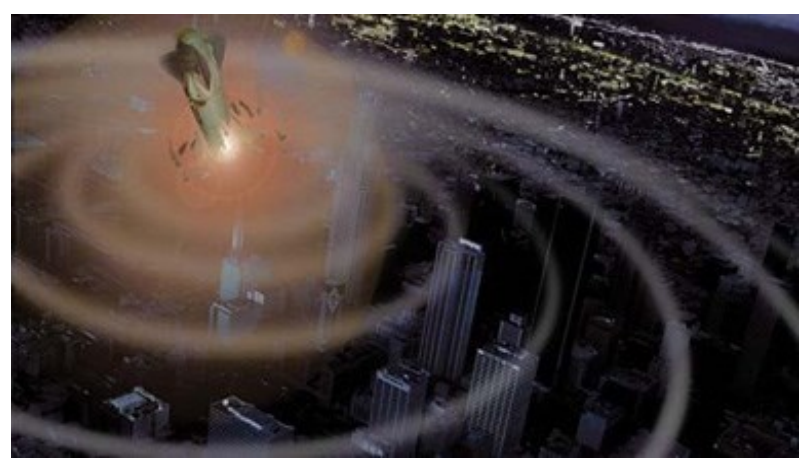

Figure 28: The explosion of the EMP bomb will disable technologies and will blind the enemy. [Source: Fig-28]
During the test, the Champ missile sent a dose of very strong energy, which effectively knocked out the data and electronic subsystems, against which it struck. The Boeing Company said that Champ allowed it to strike against a number of selected targets during a single mission. This technology represents a new era in warfare. In the near future, this technology may be used to render an enemy's electronic and data systems useless even before the first troops or aircraft arrive. It is not known, which aircraft instruments would be endangered by the use of an electromagnetic pulse weapon and what damage would such a weapon cause because it depends on the type of an aircraft, whether it is a sports, passenger or combat aircraft and also on the systems, which the aircraft is equipped with. 
In general, the more electronic systems a machine is equipped with, the more vulnerable it is to electromagnetic pulses. It seems that the more outdated the aircraft, the more protected against the EMP. Russia still uses vacuum tubes. It is often the laughing stock because of this, but the fact is that in the case of the tactical employment of electromagnetic pulse weapons, its machines could be more durable than the futuristic war machines of the Western world.

With regard to the fact that nowadays computer or, more precisely, electronic systems are used to control almost everything, the havoc that the EMP weapons could cause can hardly be underestimated. Aircraft could crash, cars would stop and most of electrical appliances would stop

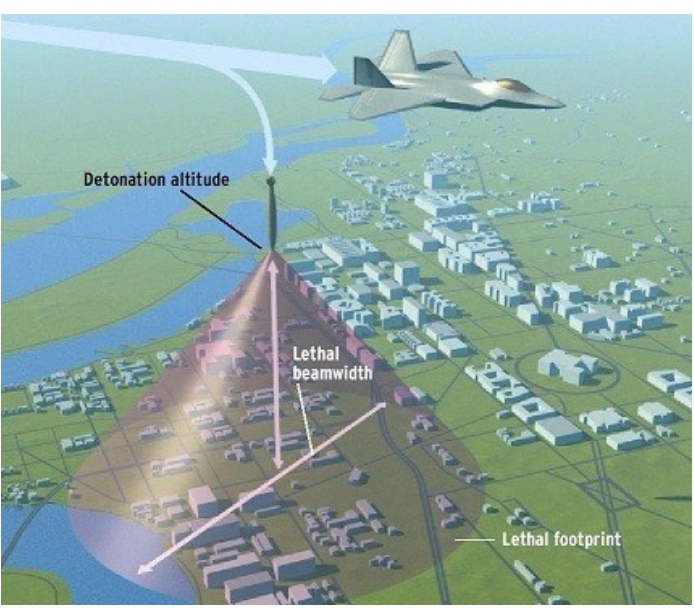

Figure 29: The EMP weapon will explode at a high altitude and will hit the region.

[Source: Fig-29] working. Communication would be paralyzed and people with pacemakers would probably die. In this respect, the western technical civilization is vulnerable and it can be assumed that the EMP weapons could become very interesting for some terrorist organizations.

As references to electromagnetic pulse weapons have begun to increase in recent years, military analysts have embarked on scenarios of an armed conflict, in which EMP weapons would play a major role. They have something to build on. We know that the United States used the weapon at the latest in the operation against Iraq in 2003, although it was already speculated in that during the raids on Serbia in 1999. A number of other states, at least Russia and major European powers, also possess the EMP warheads.

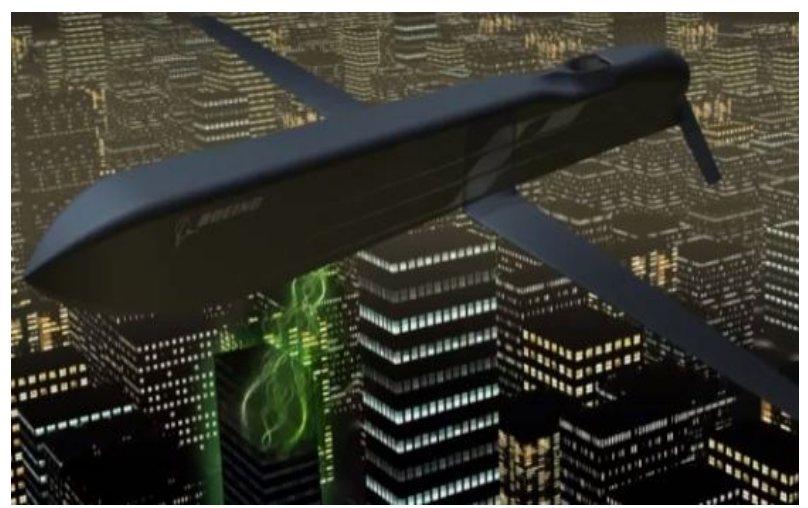

Figure 30: EMP may be a bomb, a missile or a ballistic rocket. [Source: Fig-30]

Their size may vary; thus, they also have a wide range of applications. Americans use them in the form of aerial bombs or warheads for the Tomahawk cruise missiles. In the case of Russia and China, there may be mainly warheads for short-range and intermediate-range ballistic missiles, however, there are much more possibilities. Among others, there has been some information about the development of warheads for antiaircraft guided missiles or even about EMP hand grenades.

At one time, even the researchers of the Military Research Institute at Vyškov worked on EMP warheads. In the Communist Era in Czechoslovakia, an interesting project occurred, which could be described as EMP shouldermounted. It was a modification of a non-reusable anti-tank weapon, type RPG-75 (known as Kobylka). In a standard weapon design, there is an armour-piercing grenade; however, this variant should have included a compact EMP warhead, which could destroy even the entire position of an enemy unit by its pulse, e.g. of an artillery battery or anti-aircraft battery. With regard to a small size any infantryman could carry and use it.

In November 2013, a report appeared in the media that the totalitarian regime of North Korea had obtained the electromagnetic pulse technology from Russia or from China. 
According to the snippets of information of the South Korean communications intelligence, the Democratic People's Republic of Korea could use this technology within a cyber-attack on its southern neighbour. The use of EMP is also possible via the BM-25 Musadan intermediate-range ballistic missiles.

Electromagnetic pulse discharges with epicentres on the South Korean territory could have a devastating impact on the defence capability of the state. Currently, there is no possibility of defence against EMP if we do not consider secret technologies, which undoubtedly are being developed. There may be EMP jammers, which e.g. the Air Force One (the American aircraft carrying the President) is equipped with.

For the present, it is true that EMP can be considered a cannon, against which there is no armour. For the time being, all the defensive possibilities are in the stage of development and research. However, protection can be provided

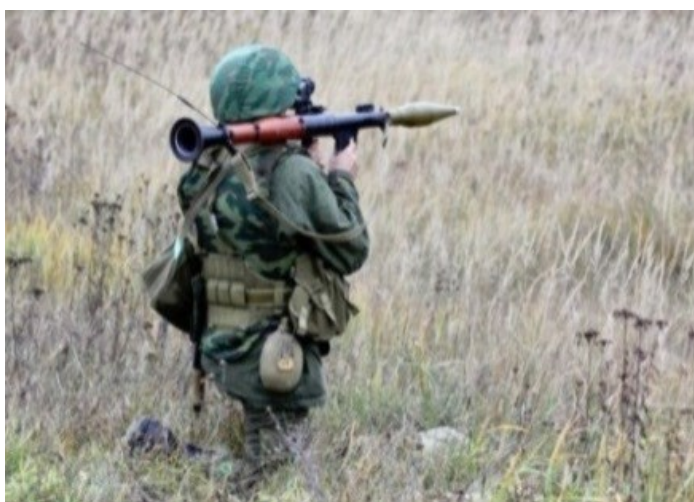

Figure 31: The CSSR was developing an EMP missile on the basis of the RPG rocket launcher. [Source: Fig-31] especially through shielding, which actually means closing the entire device into a conductive box, the so-called Faraday cage; however, it is a problem in some types of equipment.

Another possibility is to modify the front-end circuits of devices, e.g. radars to be able to withstand an EMP, which is difficult, but possible. That shielding could be the right way to go in the search for EMP protection is not a completely accurate comparison, but the electromagnetic pulse is an extremely strong lightning in effect. And if it hits a flying aircraft, this will work as a Faraday cage. An electric discharge will flow round the aircraft body and will move on. Depending on the strength of the lightning and the place of its strike, devices and electric systems are affected, their operation is at risk, and they may even be destroyed.

It is not unrealistic that a counter-weapon will be found, which will be universally applicable and, above all, will be used on a mass scale. In the past, e.g. researchers managed to eliminate the danger of magnetic mines using demagnetization loops, even if not definitely. Until such a weapon against EMP is introduced, EMP weapons remain a great danger.

It is necessary to pay great attention to EMP weapons as they could cause great damage if used by terrorists. It is practically impossible to effectively prevent the manufacture of these weapons. Admittedly, it demands exceptional precision, but the theoretical principle is known well and most components can be purchased on the civilian market. So, it is only a question of time when EMP weapons will also spread outside the most advanced countries of the world or, more precisely, when some technologically advanced non-governmental groups will include them into their inventory.

Everything seems to indicate that at least the United States realizes to what degree the expansion of EMP weapons could shuffle the cards thoroughly in the endless battle of different tactics. In 2014, the former CIA director James Woolsey stated in the memorandum intended for higher military representatives: If it is a weapon, the efficiency of which we can specify and, at the same time, we know that it is the technology, which even the backward economy of North Korea may handle in the foreseeable future, it is our primary duty to eliminate and overcome this weapon. 


\subsubsection{Initial radiation of a nuclear explosion}

During a nuclear explosion, strong ionizing radiation is produced. It is formed by gamma radiation, neutron radiation, alpha radiation and beta radiation. A part of ionizing radiation is emitted during a fission or fusion nuclear reaction. The rest of radiation is emitted after the completion of the reaction for ages and is caused by the decay of fission products.

However, the radiation that is emitted during the fission or fusion reaction until the time of 10 up to 15 seconds after its completion is included in initial radiation. After the time limit of 10 up to 15 seconds, the luminous area of hot gases rises up and the distance between the radiation source and the Earth's surface increases, which causes the attenuation of radiation falling on the Earth's surface. The reach of beta and alpha particles in the air is small (see radioactivity, the radioactive decay law), therefore, we do not consider it in initial radiation. We include only gamma radiation and neutron radiation, which are penetrating.

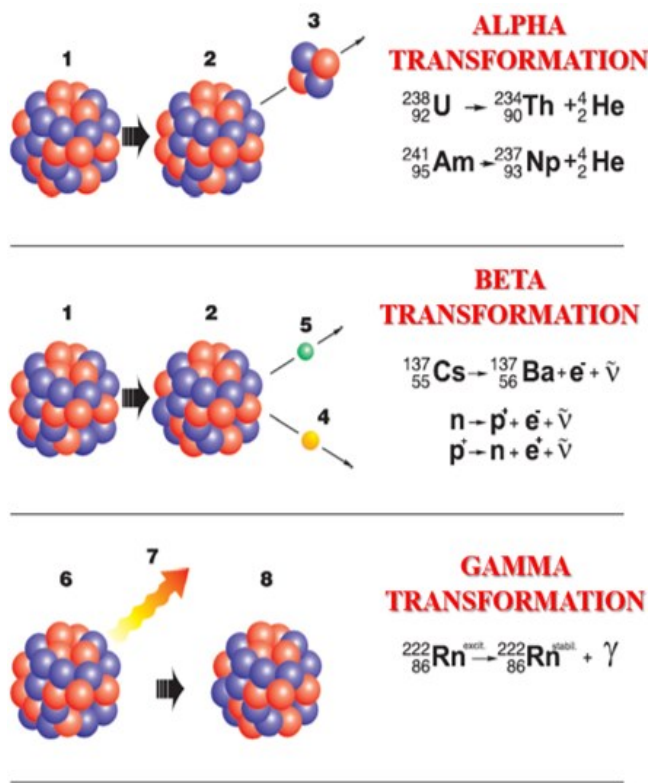
1. Parent nucleus
5. Antineutrino
2. Daughter nucleus
6. Excited nucleus
3. Alpha particle
7. Gamma radiation (photons)
4. Electron
8. Stabilized nucleus
Figure 32: Basic notions of radioactive transformation. [Source: Fig-32]

\subsubsection{Destructive effects of initial radiation}

\section{Initial gamma rays}

is released until the nuclear charge is completely dissipated. The prompt gamma radiation also arises during the inelastic scattering of neutrons on atomic nuclei in the vicinity of the explosion centre and during the neutron radioactive capture in the nuclear charge material. According to the radiation time we can divide initial gamma radiation into the following:

- Prompt (initial) - acts from 0 to $10^{-5} \mathrm{~s}$. The source is fission and fusion reactions. This radiation is released until the nuclear charge is completely dissipated. The instantaneous gamma radiation also occurs during the inelastic scattering of neutrons on the nuclei of atoms around the center of the explosion and during the radiative capture of neutrons in the material of the nuclear charge.

- Short-term - acts from $10^{-5} \mathrm{~s}$ to $3 \cdot 10^{-1} \mathrm{~s}$ after the explosion. This arises as a consequence of the neutron capture by nitrogen nuclei in the air. This also includes gamma rays produced by the decay of fragments.

- Second - acts from $3 \cdot 10^{-1}$ to $15 \mathrm{~s}$ (the emission time depends on the nuclear yield). It arises especially by the decay of fragments.

- Residual - emitted after $15 \mathrm{~s}$ as a consequence of the decay of fission products. We do not include this radiation in initial radiation.

According to the origin (source) we can divide gamma rays into 3 groups as follows:

1) Gamma ray induced fission is usually divided into gamma rays accompanying the fission itself and gamma rays of fission products. The radiation accompanying the fission corresponds to the course of a fission reaction with regard to time. The radiation of fission products is accompanied by their decay. Therefore, it takes a long time after the completion of the fission reaction itself (depending on the half-lives).

2) Product of reactions of neutrons with nuclei - the radiation of inelastic scattering of neutrons in a nuclear charge material, in the soil, in the air, etc. This radiation is prompt. 
3) Gamma radiation produced by neutron capture:

- It arises from the neutron capture in the nuclear charge material. It is prompt radiation.

- It arises from the neutron capture by atmospheric nitrogen (reaction $\left.{ }^{14} \mathrm{~N}(\mathrm{n}, \gamma){ }^{15} \mathrm{~N}\right)$. It is short-term radiation.

- It arises from neutron radiation in the soil. This division belongs to the group of shortterm radiation.

Interaction of gamma radiation with matter - during the passage of initial gamma radiation through matter a lot of processes take place. As a consequence of these processes secondary corpuscular radiation is produced (the formation of particles with non-zero mass, e.g. electron, alpha, etc.), which causes the ionization of other atoms of the medium. At the same time, radiation attenuation takes place. These types of interactions of gamma rays with matter are as follows:

1) Photoelectric effect - during the passage of gamma quantum through matter, the release of an electron from the atom shell (usually K or L) happens. A gamma-ray photon transfers all its energy to the electron of an affected atom. Part of this energy is consumed to separate an electron from an atom (ionization energy); the residue is converted

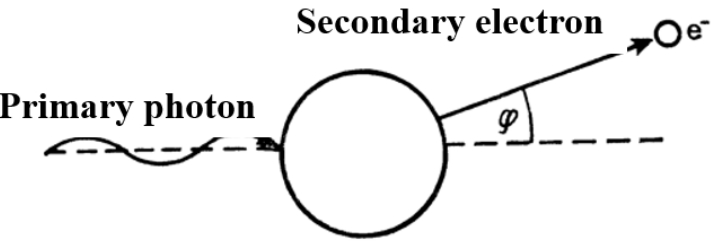

Figure 33: Photoelectric effect. [Source: Fig-33] to the kinetic energy of this electron. However, the condition of the photoelectric effect is that the photon energy of gamma rays is greater than the ionization potential of a given shell. The probability of the photoelectric effect increases with a growing atomic number of the target and decreases with a growing energy of a nuclear missile. The places in the atomic shell, vacated due to the photoelectric effect are filled up with electrons from outer shells, and this leads to the emission of X-ray radiation (Auger-electron emission).

2) Scattering (Compton) - photon scattering of gamma quantum, which occurs on free electrons or very weakly bound electrons of the outer atomic shell. Here, the gamma quantum pulls an electron out of the electron shell and transfers part of its energy to it. The quantum moves further with less energy and in a changed direction.

3) Electron-positron pair production is characteristic of the photons of gamma quanta with energies greater than $1.022 \mathrm{MeV}$. The quantum is decelerated in the field of atomic nucleus and is converted into an electron-positron pair.

Initial neutron radiation - in a nuclear fission reaction of a nuclear explosion prompt and delayed neutrons are produced.

Prompt neutrons are produced directly in a fission reaction. Their energy ranges from $0.025 \mathrm{eV}$ to $17 \mathrm{MeV}$. The majority of prompt neutrons are absorbed by the envelope of a nuclear charge to very low energies. These neutrons have a relatively small range $\left(\approx 10^{2} \mathrm{~m}\right)$. There is,

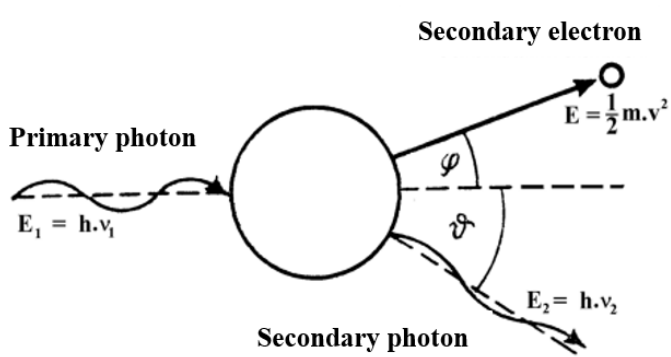

Figure 34: Compton scattering. [Source: Fig-34] therefore, an area with a high concentration of neutrons at the explosion site. A smaller part of the neutrons passes through the envelope without much loss of energy. These neutrons spread to considerable distances from the explosion site.

Delayed neutrons are emitted from produced fragments. Their energy ranges from 0.25 to $0.67 \mathrm{MeV}$. Therefore, they are not slowed down by the envelope of a nuclear charge (they are emitted from a fission product). 
Thermal neutrons are absorbed by the medium easily. They cause (artificial) induced radioactivity only in the immediate vicinity of the explosion centre and in the air by the ${ }^{14} \mathrm{~N}(\mathrm{n}, \mathrm{p})$ ${ }^{14} \mathrm{C}$ reaction.

Fast neutrons are the most dangerous. They have high hardness. Due to the radioactive capture, they cause induced radioactivity in the soil and various materials.

\section{Neutron interaction with matter:}

a) Elastic scattering - during a collision with a nucleus, a neutron transmits a part of its kinetic energy and moves further in a changed direction:

$$
{ }_{\mathrm{Z}}^{\mathrm{A} X}+{ }_{0}^{1} \mathrm{n} \rightarrow{ }_{\mathrm{Z}}^{\mathrm{A} X}+{ }_{0}^{1} \mathrm{n}
$$

Elastic scattering for light nuclei is of high importance. The portion of the transferred kinetic energy increases with the decrease in the nuclear mass. The greatest transfer of kinetic energy of neutrons takes place in the collisions with hydrogen nuclei, when during one collision a neutron can transfer up to the half of all its energy. Mate-

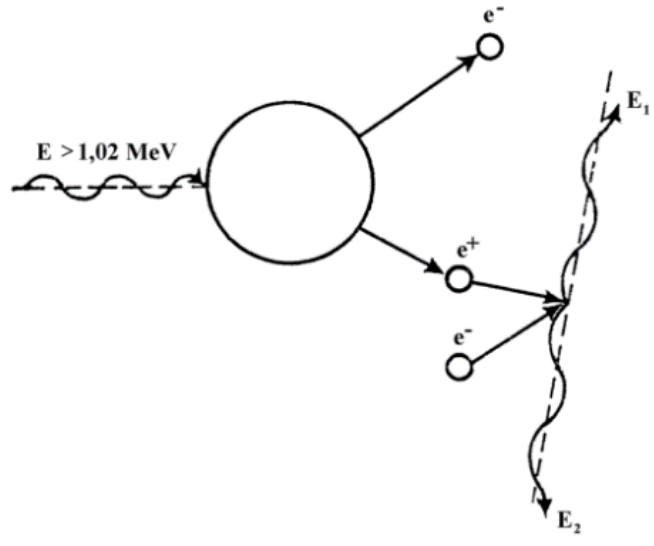

Figure 35: Pair production. [Source: Fig-35] rials with high hydrogen content are, therefore, used for the slowing-down of neutrons. In light nuclei, elastic scattering happens when the kinetic energy of neutrons is lower than $1 \mathrm{MeV}$.

b) Inelastic scattering - after the collision with a neutron, the scattering nucleus absorbs the neutron energy in the form of kinetic energy, on the one hand, and in the form of excitation energy, on the other hand. Thus, an excited nucleus arises and passes back to the ground state by photon emission as follows:

$$
\begin{aligned}
{ }_{\mathrm{Z}}^{\mathrm{A}} \mathrm{X}+{ }_{0}^{1} \mathrm{n} \rightarrow{ }_{\mathrm{Z}}^{\mathrm{A}} \mathrm{X}^{\times}+{ }_{0}^{1} \mathrm{n} \\
\longleftrightarrow{ }_{\mathrm{Z}}^{\mathrm{A} X+\gamma}
\end{aligned}
$$

Heavy nuclei have the largest effective cross-section for the inelastic scattering of neutrons with the energy of $1 \mathrm{MeV}$. The loss of neutron energy in inelastic collision is even greater than in elastic scattering. Therefore, the inelastic scattering is very important for the deceleration (moderation) of neutrons.

\section{c) Neutron capture (absorption) by a nucleus:}

$\left.c_{1}\right)$ neutron reaction $(n, \gamma)$ is the most frequent of all types of nuclear reactions.

$$
\begin{aligned}
{ }_{\mathrm{Z}}^{\mathrm{A}} \mathrm{X}+{ }_{0}^{1} \mathrm{n} \rightarrow{ }_{\mathrm{Z}}^{\mathrm{A}+1} \mathrm{X}^{\times}+\gamma \\
\qquad{ }_{\mathrm{Z}+1}^{\mathrm{A}+1} \mathrm{Y}+\mathrm{e}^{-}+\mathrm{v}
\end{aligned}
$$

In the reaction, radioactive nuclei, which further disintegrate by $\beta^{-}$decay, are produced. This reaction has a high effective cross-section for thermal neutrons.

$\left.c_{2}\right)$ neutron reaction $(n, p)$ :

$$
\begin{array}{r}
{ }_{\mathrm{Z}}^{\mathrm{A}} \mathrm{X}+{ }_{0}^{1} \mathrm{n} \rightarrow{ }_{\mathrm{Z}-1}^{\mathrm{A}} \mathrm{Y}+{ }_{1}^{1} \mathrm{p} \\
\longrightarrow{ }_{\mathrm{Z}}^{\mathrm{A}} \mathrm{X}+\mathrm{e}^{-}+\nabla
\end{array}
$$

The reaction has the highest effective cross-section for neutrons with the energy higher than $1 \mathrm{MeV}$ (fast neutrons) for the nuclei of light elements.

$\left.c_{3}\right)$ neutron reaction $(n, \alpha)$ :

$$
{ }_{\mathrm{Z}}^{\mathrm{A}} \mathrm{X}+{ }_{0}^{1} \mathrm{n} \rightarrow{ }_{\mathrm{Z}-2}^{\mathrm{A}-3} \mathrm{Y}+{ }_{2}^{4} \mathrm{He}
$$


This reaction proceeds in the nuclei of light elements only. The resulting nucleus is subject to $\beta^{-}$decay again.

$\left.c_{4}\right)$ neutron reactions $(n, 2 n) ;(n, 3 n) ;(n, p n)$. They usually take place in neutrons with the energies higher than $10 \mathrm{MeV}$.

${ }_{\mathrm{Z}}^{\mathrm{A}} \mathrm{X}+{ }_{0}^{1} \mathrm{n} \rightarrow{ }_{\mathrm{Z}}^{\mathrm{A}-1} \mathrm{X}^{\mathrm{x}}+2{ }_{0}^{1} \mathrm{n}$

$\left.c_{5}\right)$ neutron reaction $(n, f)$ :

$$
\begin{aligned}
&{ }_{\mathrm{Z}}^{\mathrm{A}}+{ }_{0}^{1} \mathrm{n} \rightarrow{ }_{\mathrm{Z}}^{\mathrm{A}} \mathrm{X}^{\mathrm{x}}+\gamma \\
& \longrightarrow{ }_{\mathrm{Z}}^{\mathrm{A}} \mathrm{Y}+{ }_{\mathrm{Z}}^{\mathrm{A} 2} \mathrm{Y}+(2-3){ }_{0}^{1} \mathrm{n}
\end{aligned}
$$

It is, therefore, a nuclear fission reaction (see nuclear fission reaction).

\subsubsection{Protection against the effects of initial radiation}

During the passage of initial radiation through matter, its interaction with the particles, of which the matter is composed, takes place. As soon as their energy drops to a value corresponding to the thermal motion, they thermalize to lose their original identity - they cease to be the particles of radiation. This process is called absorption of radiation.

Radiation penetrating the matter not only loses its energy, but it can also change its original direction due to the effect of the electric field of the nucleus or

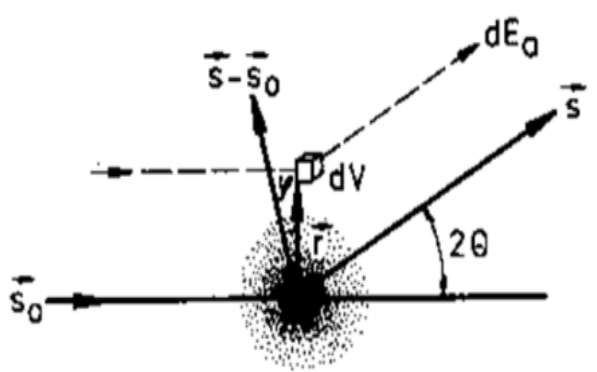

Figure 36: Radiation scattering on an atom. [Source: Fig-36] the electron shell of an atom. This phenomenon is called radiation scattering.

Thus, the absorption and scattering of radiation penetrating the matter form the basis of protection against the effects of initial radiation.

The beam intensity of light radiation (beta, gamma) during its passage through matter decreases gradually. The attenuation of light radiation, as it passes through matter, takes place exponentially in an ideal case and is expressed by the Beer-Lambert Law:

$$
\mathbf{I}=\mathbf{I}_{\mathbf{0}} \times \mathbf{e}^{-\mu_{m} \times \mu_{\mathbf{s}}}=\mathbf{I}_{\mathbf{0}} \times \mathbf{e}^{-\mu \times \mathbf{e}}
$$

I $\quad \ldots$ intensity after the adoption by an absorbent;

$\mathrm{I}_{0} \quad \ldots$ original intensity;

$\mu_{\mathrm{m}} \quad$... mass attenuation coefficient;

$\mu_{\mathrm{s}} \quad \ldots$ surface mass $\left(\mathrm{kg} \cdot \mathrm{m}^{-2}\right)$;

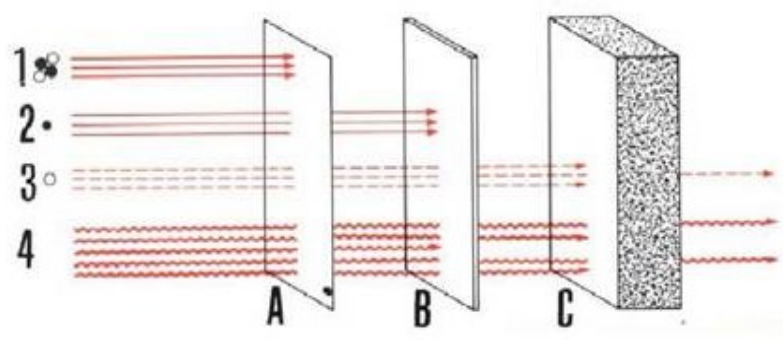

Figure 37: The shielding effect of different types of material for particular types of radiation. [Source: Fig-37] Note:

1 - alpha radiation, 2 - beta radiation,

3 - neutron flux, 4-gamma radiation

$A$-sheet of paper, $B$-steel plate, $C$-concrete wall

$\mu \quad \ldots$ linear attenuation coefficient $\left(\mathrm{m}^{-1}\right)$; and

e $\quad \ldots$ weakening material thickness $(\mathrm{cm})$.

It should be noted that the equations mentioned apply exactly to a parallel bundle of monochromatic rays only. The linear attenuation coefficient is characteristic for a given radiation energy and a given type of material. In addition to the above-mentioned coefficients, another quantity, the so-called half value layer (half-thickness), is used for the radiation hardness in matter and is linear. It is such a layer of material, which attenuates the radiation flux density to the half (see Tab. 22). 
However, gamma rays and neutron radiation attenuate differently. Gamma radiation is best attenuated by heavy materials, while neutron radiation is attenuated especially by light materials. However, this rule applies only roughly. The absorption of both gamma rays and neutrons also depends on their energy. Calculating with half value layers is simple. It applies approximately that one half value layer attenuates radiation twice, two half value layers 4 times, 4 half value layers 8 times, etc. up to 10 half value layers 1,024 times, 20 half value layers approximately $10^{6}$ times, 30 half value layers approximately $10^{9}$ times.

Table 22: Half value layers in cm for materials and the mean value of the energy of gamma rays and neutron radiation in a nuclear explosion. [Source: Tab-22]

\begin{tabular}{|c|c|c|c|c|c|}
\hline \multirow{2}{*}{ Material } & \multirow{2}{*}{$\begin{array}{c}\text { Density } \\
{\left[{\mathrm{g} . \mathrm{cm}^{-3}}^{-3}\right.}\end{array}$} & \multicolumn{2}{|c|}{ Fission explosion } & \multicolumn{2}{c|}{ Thermonuclear explosion } \\
\cline { 3 - 6 } & 0.7 & gamma & neutrons & gamma & neutrons \\
\hline Wood & 30 & 10 & 40 & 14 \\
\hline Polyethylene & 0.9 & 22 & 3 & 30 & 5 \\
\hline Water & 1.0 & 21 & 3 & 30 & 5 \\
\hline Soil & 1.6 & 13 & 9 & 20 & 11 \\
\hline Bricks & 1.6 & 13 & 10 & 20 & 14 \\
\hline Concrete & 2.3 & 10 & 9 & 12 & 10 \\
\hline Steel & 7.8 & 3.5 & 11 & 3.5 & 12 \\
\hline
\end{tabular}

The following relationship applies to accurate calculations:

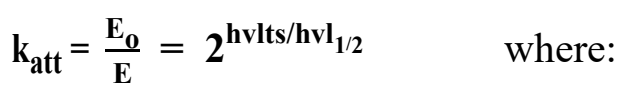

$k_{\text {att }}$... attenuation coefficient indicative of how many times radiation will be attenuated;

$\mathrm{E}_{0} \ldots$...exposure (exposure rate) measured by a dosimeter in the radiation field without any shielding;

E ... exposure (exposure rate) measured by the same dosimeter in the same place of the radiation field in the shielding object;

hvlts ... half value layer thickness of the shielding material $(\mathrm{cm})$; and

$\mathrm{hvl}_{1 / 2} \ldots$ half value layer $(\mathrm{cm})$.

Based on the above-mentioned formula, another formula can be derived for calculating a necessary material layer and a desired attenuation coefficient:

\section{$\mathbf{k}_{\mathrm{att}}=3.3 \times \mathrm{hvl}_{1 / 2} \times \log$ hvlts}

It can be seen that for calculating the attenuation $\mathrm{k}$, we raise 2 to a multiple of the half value layers. If it is the attenuation by different materials in different thicknesses at the same time, we first calculate a total number of half value layers hvlts $1 / \mathrm{hvl}_{1 / 2}+\mathrm{hvlts}_{2} / \mathrm{hvl}_{1 / 2}+\mathrm{hvlts}_{3} / \mathrm{hvl}_{1 / 2}+\ldots$ etc. and then we raise 2 to the total number of half value layers.

Example: Calculate the attenuation of neutron radiation of a thermonuclear explosion for $8 \mathrm{~cm}$-thick steel and $5 \mathrm{~cm}$-thick polyethylene.

Procedure: From Table 22 for a thermonuclear explosion we subtract:

$$
\text { for: } \begin{aligned}
& \text { hvlts }_{\text {steel }}=8 / \mathbf{1 2}=0.66 \\
& \text { hvlts } \\
& 1+0.66=1.66 \text { and further } 2^{1.66}=3.16
\end{aligned}
$$

The attenuation coefficient $k$ for $8 \mathrm{~cm}$-thick steel and $5 \mathrm{~cm}$-thick polyethylene is $\underline{\underline{\mathbf{3 . 1 6}}}$

In the calculation, it is necessary to calculate the attenuation for gamma radiation and separately the attenuation for neutrons. The total attenuation of initial radiation can be calculated only if we know the mutual radius of both types of radiation. 


\subsubsection{Radioactive contamination}

Unlike other factors of a nuclear explosion, radioactive contamination has a long-term effect. Strong radioactive contamination of the terrain (temporarily also the air) occurs after surface nuclear bursts and nuclear airbursts. In airbursts, there is little or quite negligible radioactive contamination. We speak about radioactive contamination when the initial radiation effects cease, i.e. about 10 up to 15 seconds after the explosion.

Radioactive contamination has three sources as follows:

- The fission products of a nuclear reaction;

- A non-reacted nuclear explosive material;

- Induced (artificial) radioactivity of previously inactive matter.

Fission products of a nuclear reaction - as it has been mentioned in the previous part (see nuclear fission reaction), there are about forty different ways of nuclear fission. Fission products are a mixture of more than 200 radionuclides, which were created from approximately 80 original fragments. The decay of a primary fragment to a stable isotope may proceed according to the scheme, e.g.:

${ }_{54}^{140} \mathrm{Xe} \longrightarrow \mathrm{T=16} \mathrm{s}{ }_{55}^{140} \mathrm{Cs} \underset{\mathrm{T}=66 \mathrm{~s}}{\longrightarrow}{ }_{56}^{140} \mathrm{Ba} \mathrm{T}=12.8$ days ${ }_{57}^{140} \mathrm{La} \underset{\mathrm{T}=40 \mathrm{~h}}{\longrightarrow}{ }_{58}^{140} \mathrm{Ce}$ (stab.)

On average, each primary fragment undergoes three transformations, during which it emits 3 beta particles and 1 up to 2 gamma quanta. The fission products of a nuclear reaction create nuclides predominantly from the centre of the periodic system and their mass numbers (symbol: A) range from 72 to 160 . The primary proportion of a certain nuclide in the mixture of fission products is expressed by the so-called absolute yield. The thermal neutron fission, as it has been mentioned, proceeds asymmetrically. In ${ }^{235} \mathrm{U}$ fission, the fragments with mass numbers of ${ }^{94} \mathrm{Kr}$ and ${ }^{133} \mathrm{Xe}$ have the greatest absolute yield (about $6.4 \%$ ). The probability of fission by another method decreases. The absolute yield of fission mentioned is also similar in the case of other fission explosives $\left({ }^{233} \mathrm{U}\right.$ and $\left.{ }^{239} \mathrm{Pu}\right)$. With the increasing time after an explosion, the uneven decrease in the activity of fission products takes place. In the first moments after the explosion, the radionuclides produced by the decay of primary fragments increase in the mixture. However, at the same time, the radionuclides with short half-lives disappear.

About $50 \mathrm{~g}$ of fission products fall on each kiloton of fission yield. Their activity reaches significant values. For example, when the nuclear yield is $1 \mathrm{Mt}$, the activity after 1 hour is about $2.10^{22} \mathrm{~Bq}$, which is equivalent to the activity of about $7 \times 10^{5}$ tonnes of radium. Actinoids ${ }^{239} \mathrm{~Np}$ and ${ }^{237} \mathrm{U}$ that arise from ${ }^{238} \mathrm{U}$ by the effects of neutrons are also assigned to fission products. They usually occur in thermonuclear charges. In a thermonuclear explosion, the content of actinides can be so high that at certain time intervals there is a certain violation of the rules on the activity, type and energy of radiation of the products of the explosion.

Non-reacted nuclear explosive material - in an instant of blowing a nuclear charge, a certain part of a fission explosive (more than $50 \%$ ) that failed to participate in the fission reaction always remains. It is mainly ${ }^{233} \mathrm{U},{ }^{235} \mathrm{U}$ and ${ }^{239} \mathrm{Pu}$. This non-reacted explosive material also contributes to radioactive contamination. Radionuclides forming a nuclear explosive emit alpha radiation. Their half-lives are long, so their activity in comparison with the activity of fission products is almost negligible.

Induced radioactivity - a large number of neutrons arise in the fission reaction. A part of them, the neutrons of initial radiation, are involved in the fission reaction itself. These neutrons interact with the nuclei of inactive elements of the envelope of a nuclear charge, air, soil, objects in the field, etc. and cause the artificial formation of radionuclides. We talk about the so-called induced radioactivity. 
Radioactivity induced in nuclear charge material - radionuclides formed by the action of neutrons, together with fission products, are contained in a fireball formed after an explosion. Together with the fission products, they fall to the ground in the fallout pattern. The radioactive isotopes of iron, chromium, manganese and nickel arise mainly due to the effect of neutrons in the envelope of a nuclear charge. With regard to the activity of the fission products and actinides, their activity is negligible.

Radioactivity induced in air - it is of practical importance from the viewpoint of global air contamination. Oxygen absorbs fast neutrons to form radioactive ${ }^{16} \mathrm{~N}$. The effective cross-section of this reaction is small. Moreover, the resulting radionuclide has a half-life of only $7.3 \mathrm{~s}$. Neutrons react with nitrogen in two different ways as follows:

$$
\begin{aligned}
& { }^{14} \mathrm{~N}+\mathrm{n} \rightarrow{ }^{15} \mathrm{~N} \text { (stab.) }+\mathrm{p} \\
& { }^{14} \mathrm{~N}+\mathrm{n} \rightarrow{ }^{15} \mathrm{C}+\mathrm{p}
\end{aligned}
$$

The first reaction has a small effective cross-section. The arising ${ }^{15} \mathrm{~N}$ is stable. However, the cross-section of the second reaction is about 16 times larger than that of the first reaction. The arising ${ }^{14} \mathrm{C}$ is beta radioactive. Its half-life, however, is 5,760 years. Radioactive carbon in the form of $\mathrm{CO}_{2}$ enters living organisms and becomes a part of them. That is its main danger.

Radioactivity induced in soil, water and field objects - the formation of radionuclides by the action of neutrons on inactive elements contained in soil, water and objects in the field depends on the type, energy of the explosion and the composition of the material. The action of neutrons on elements in the soil most often produces radionuclides - see Table 23. The reaction ${ }^{23} \mathrm{Na}(\mathrm{n}, \gamma){ }^{24} \mathrm{Na}$ is of the greatest importance. The content of ${ }^{25} \mathrm{Na}$ in the soil is relatively small; however, this reaction has a large effective cross-section. This, together with the relatively short half-life, causes considerable activity.

In contrast, manganese is present nearly in all soil types. The ${ }^{56} \mathrm{Mn}$ formed by absorption has a shorter half-life than ${ }^{24} \mathrm{Na}$, therefore, its activity decreases faster. However, shortly after the explosion it poses a greater danger than ${ }^{24} \mathrm{Na}$.

Aluminium is an essential component of the soil. The action of neutrons produces ${ }^{28} \mathrm{Al}$. It contributes to the ini-

Table 23: Characteristic of radionuclides (radioactivity induced in the soil). [Source: Tab-23]

\begin{tabular}{|c|c|c|c|c|c|}
\hline $\begin{array}{c}\text { Stable } \\
\text { nuclide }\end{array}$ & $\begin{array}{c}\text { Arising } \\
\text { radionuclide }\end{array}$ & $\mathrm{T}$ & $\begin{array}{c}\text { Type } \\
\text { of radiation }\end{array}$ & $\begin{array}{c}\mathrm{E}_{\beta} \\
(\mathrm{MeV})\end{array}$ & $\begin{array}{c}\mathrm{E}_{\gamma} \\
(\mathrm{MeV})\end{array}$ \\
\hline${ }^{23} \mathrm{Na}$ & ${ }^{24} \mathrm{Na}$ & $14.9 \mathrm{~h}$ & beta - gamma & 1.48 & 1.4 \\
\hline${ }^{27} \mathrm{Al}$ & ${ }^{28} \mathrm{Al}$ & $2.3 \mathrm{~min}$ & beta - gamma & 2.8 & 1.8 \\
\hline${ }^{30} \mathrm{Si}$ & ${ }^{31} \mathrm{Si}$ & $2.7 \mathrm{~h}$ & beta & 1.5 & - \\
\hline${ }^{41} \mathrm{~K}$ & ${ }^{42} \mathrm{~K}$ & $12.5 \mathrm{~h}$ & beta - gamma & 3.6 & 1.5 \\
\hline${ }^{55} \mathrm{Mn}$ & ${ }^{56} \mathrm{Mn}$ & $2.59 \mathrm{~h}$ & beta - gamma & 2.8 & 1.2 \\
\hline
\end{tabular}
tial contamination of the soil significantly owing to its short half-life. One hour after an explosion, its activity is almost neutral. Radioactive ${ }^{31} \mathrm{Si}$ is a beta emitter; therefore, it is not too dangerous.

In pure water, induced radioactivity is practically absent. A stable ${ }^{2} \mathrm{H}$ is formed from ${ }^{1} \mathrm{H}$ nuclei. We have already mentioned the capture of neutrons by oxygen nuclei. Induced radioactivity, however, arises in the substances dissolved in water. This mainly concerns the radionuclides arising from sodium, potassium, chlorine and magnesium (see Tab. 24).
Table 24: Characteristic of radionuclides (radioactivity induced in water). [Source: Tab-24]

\begin{tabular}{|c|c|c|c|c|c|}
\hline $\begin{array}{c}\text { Stable } \\
\text { nuclide }\end{array}$ & $\begin{array}{c}\text { Arising } \\
\text { radionuclide }\end{array}$ & $\mathrm{T}$ & $\begin{array}{c}\text { Type } \\
\text { of radiation }\end{array}$ & $\begin{array}{c}\mathrm{E}_{\beta} \\
(\mathrm{MeV})\end{array}$ & $\begin{array}{c}\mathrm{E}_{\gamma} \\
(\mathrm{MeV})\end{array}$ \\
\hline${ }^{41} \mathrm{~K}$ & ${ }^{42} \mathrm{~K}$ & $12.5 \mathrm{~h}$ & beta - gamma & 3.6 & 1.5 \\
\hline${ }^{23} \mathrm{Na}$ & ${ }^{24} \mathrm{Na}$ & $14.9 \mathrm{~h}$ & beta - gamma & 1.48 & 1.4 \\
\hline${ }^{26} \mathrm{Mg}$ & ${ }^{27} \mathrm{Mg}$ & $9.4 \mathrm{~min}$ & beta - gamma & 1.7 & 1.05 \\
\hline${ }^{37} \mathrm{Cl}$ & ${ }^{38} \mathrm{Cl}$ & $37.3 \mathrm{~min}$ & beta - gamma & 4.8 & 1.5 \\
\hline
\end{tabular}


Shortly after an explosion, particularly radionuclides ${ }^{42} \mathrm{~K}$ and ${ }^{38} \mathrm{Cl}$ cause contamination; later on, predominantly ${ }^{24} \mathrm{Na}$ and ${ }^{42} \mathrm{~K}$ cause contamination. In terms of the hazardous effects of ionizing radiation on the human body, the radioactivity induced by the effects of neutrons on objects and especially on combat equipment is of the greatest importance. The armours of tanks, combat vehicles, armoured personnel carriers and special vehicles are made of alloy steel. Therefore, the formation of radionuclides ${ }^{59} \mathrm{Fe}$ and ${ }^{60} \mathrm{Co}$ with very long half-lives will be of the greatest practical importance for the further stay of personnel in the combat equipment (see Tab. 25).

As for food, especially sodium, chlorine, magnesium and potassium come into question. The radioactivity of glass objects is caused by a large content of potassium and sodium. The occurrence of dangerous induced radioactivity takes place in the vicinity of the explosion centre, where sufficiently large neutron fluxes occur.

Table 25: Characteristic of radionuclides (radioactivity induced in objects and combat equipment).

[Source: Tab-25]

\begin{tabular}{|c|c|c|c|c|c|}
\hline $\begin{array}{c}\text { Stable } \\
\text { nuclide }\end{array}$ & $\begin{array}{c}\text { Arising } \\
\text { radionuclide }\end{array}$ & $\mathrm{T}$ & $\begin{array}{c}\text { Type } \\
\text { of radiation }\end{array}$ & $\begin{array}{c}\mathrm{E}_{\beta} \\
(\mathrm{MeV})\end{array}$ & $\begin{array}{c}\mathrm{E}_{\gamma} \\
(\mathrm{MeV})\end{array}$ \\
\hline${ }^{55} \mathrm{Mn}$ & ${ }^{56} \mathrm{Mn}$ & $2.59 \mathrm{~h}$ & beta - gamma & 2.8 & 1.2 \\
\hline${ }^{58} \mathrm{Fe}$ & ${ }^{59} \mathrm{Fe}$ & 45.3 days & beta - gamma & 2.4 & 2.1 \\
\hline${ }^{59} \mathrm{Co}$ & ${ }^{60} \mathrm{Co}$ & $5.24 \mathrm{~h}$ & beta - gamma & 1,8 & 2,5 \\
\hline${ }^{63} \mathrm{Cu}$ & ${ }^{64} \mathrm{Cu}$ & $12.8 \mathrm{~h}$ & beta - gamma & 2.7 & 1.8 \\
\hline
\end{tabular}

At these distances, however, the destruction of objects by the effect of the pressure wave and light radiation happens.

\subsubsection{Formation and characteristics of fallout pattern}

Radioactive contamination of the terrain in a nuclear explosion occurs in two ways. In the vicinity of the epicentre, induced radioactivity caused by the action of neutrons takes place. Further, radioactive particles fall out of the nuclear cloud gradually; it is the so-called radioactive fallout. The radioactive fallout occurs in the area of epicentre as well as along the path of the cloud propagation due to the effects of wind. The so-called fallout pattern arises. The formation of the fallout pattern occurs in all types of nuclear bursts (even in radiation accidents in Chernobyl and Fukushima). With the increasing height of a burst, contamination in the fallout pattern becomes negligible. In surface and underground bursts, the concentration of radioactive agents in the fallout pat-

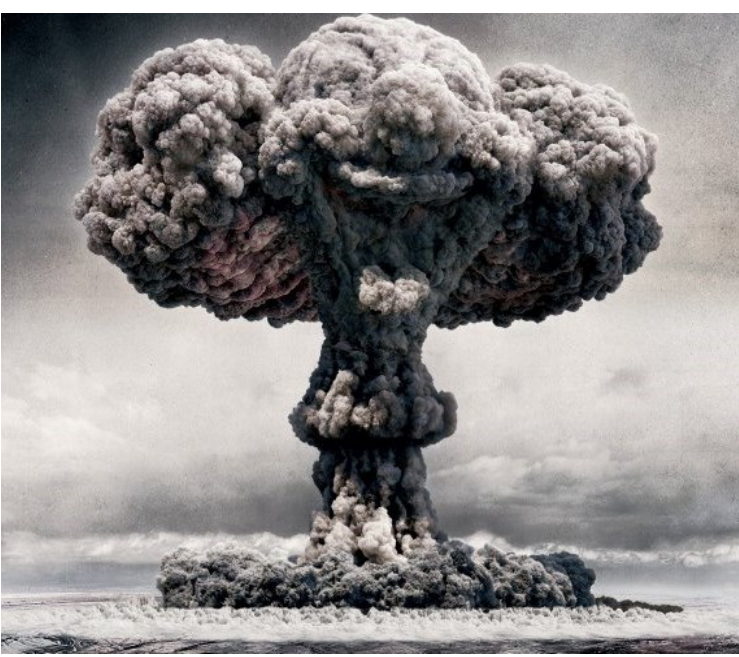

Figure 38: The characteristic mushroom after a nuclear burst - the source of radioactive particles. [Source: Fig-38] tern reaches very high values.

Radioactive fallout can be divided into two groups as follows:

- The early (local) fallout consisting of radioactive particles that fall on the Earth's surface within 24 hours after the explosion;

- The delayed (global) fallout is formed by radioactive particles falling on the Earth's surface after 24 hours. It can affect virtually any place on the globe. From the military point of view, however, it is of no practical significance.

When the fireball cools, fission products and other vapours condense on the soil, etc. These particles are sucked up from the Earth's surface during the rise of the fireball. This process involves the fractionation of fission products and produced actinoids. 
From this viewpoint, we can divide radionuclides arising in a nuclear explosion into three groups:

1) Radionuclides evenly distributed in the fallout pattern and in the cloud. The fission products with mass numbers A 141, 143, 144 and further ${ }^{239} \mathrm{~Np}$ fall into this group;

2) Radionuclides contained in the radioactive slag in the area of the crater as well as in the vicinity of the epicentre. The fission products with mass numbers A 95 and $99,{ }^{237} \mathrm{U}$ and ${ }^{239} \mathrm{Pu}$ fall into this group. Moreover, the area of the epicentre includes radionuclides produced by the effects of neutrons on the ground, water resources and structures on the ground (induced radioactivity); and

3) Radionuclides that enrich the fallout pattern at great distances from the epicentre and the radioactive cloud. Fission products with mass numbers A 89, 111, 115 and 140 falls into this group.

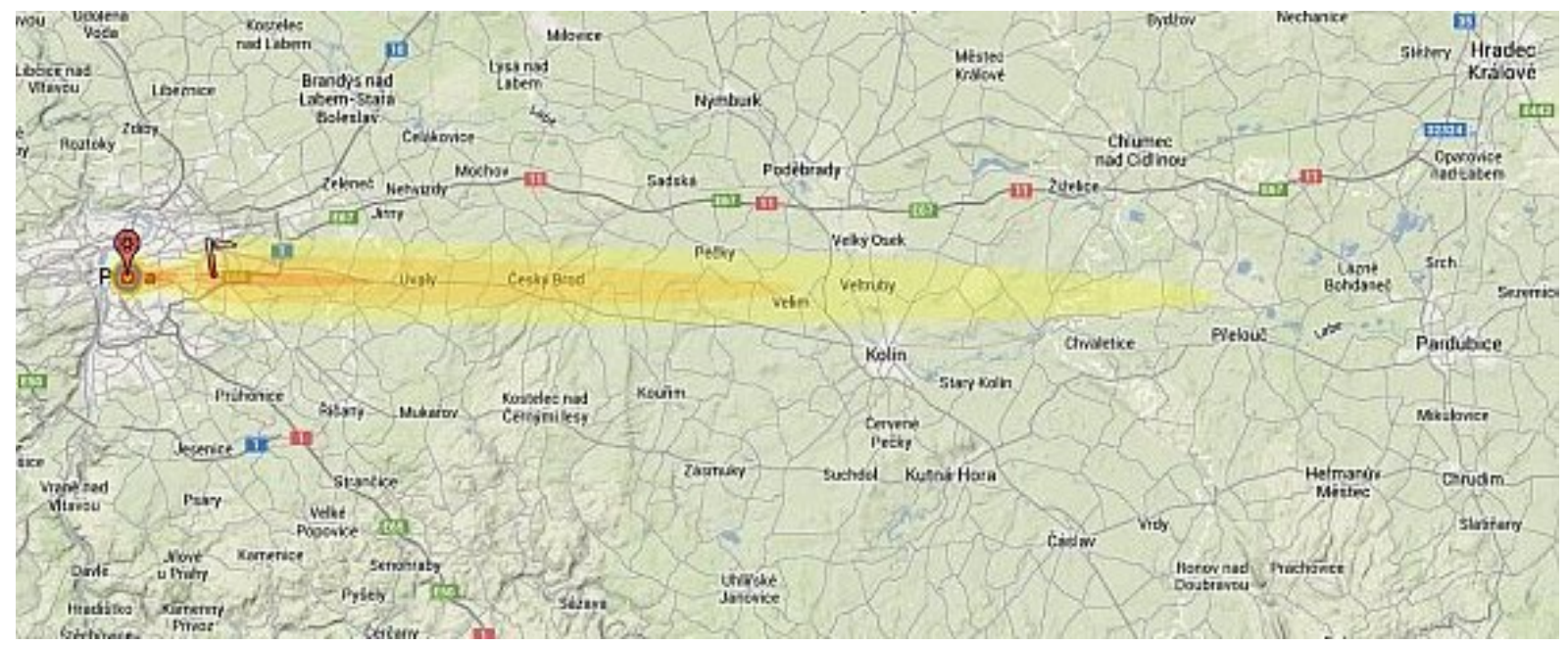

Figure 39: The direction of nuclear fallout after the detonation of a 5 kt nuclear bomb in Prague-

the west wind speed of $24 \mathrm{~km} / \mathrm{h}$. [Source: Fig-39]

The fallout pattern is formed on the Earth's surface due to the evaporation of radioactive particles from the nuclear cloud. The density of radioactive contamination in the fallout pattern is dependent on the type of nuclear reaction, the explosion energy, the height of burst, terrain features and weather conditions. In low airbursts, surface and especially underground bursts, larger soil particles get into the atmosphere. They fall out from the radioactive cloud and create a local fallout. The smallest particles remain in the atmosphere and cause delayed (global) fallout. It has been found out that 20 up to 30 tons of soil are drawn up into the area of the fireball due to the nuclear yield of approximately $1 \mathrm{kt}$. The size of radioactive particles in the nuclear cloud ranges from fractions of micrometres to several millimetres. The time of fallout of these particles depends on the size, the density and weather conditions.

The share of the activity of particles that fall out as a local fallout in the total cloud activity is variable. We can assume that during a surface burst the local fallout is approximately 50 up to $70 \%$ of the total activity of the cloud. During 24 hours at a distance of up to several hundreds of kilometres, the falling particles represent approximately $60 \%$ of the total cloud activity. The remaining $40 \%$ of particles fall out at even greater distances. In the case of an underground burst, the share of local fallout is even higher. In the case of a burst above the water level, the share of local fallout is lower (by $30 \%$ at an average). The precise distribution of the total cloud activity is not known. It is assumed that the cloud head in a surface burst contains particles representing about $90 \%$ of the total activity. The rest is in the stem of the mushroom cloud. In the case of a burst on the water surface, the ratio of activity in the stem of the mushroom cloud compared to the activity in the mushroom head is even lower. 
As to an airburst, the activity in the stem of the mushroom cloud is almost zero. The longer the particles remain in the air, the more their activity decreases due to the different half-lives; this leads to their gradual extinction and loss. At the same time, they disperse, their concentration decreases per unit area of the Earth's surface. The radioactive cloud ceases to be visible after a few hours. It is scattered by the wind. The shape and size of the fallout pattern and the density of radioactive contamination in it are mainly determined by the direction and speed of the high-altitude wind from the Earth's surface up to the maximum height of the cloud. The shape of the terrain and precipitation also have an effect.

The combination of these influences, the uneven distribution of the activity in the cloud, the nature of the soil in the vicinity of the epicentre, the yield of the explosion, etc. cause an irregular shape of the fallout pattern and an irregular dispersion of the activity of radioactive particles in the fallout pattern. There are usually the so-called hot spots in the fallout pattern, i.e. the places where the level of radiation (exposure or dose rate) on the ground is much higher than in the places significantly closer to the epicentre of the explosion. The occurrence of these hot spots can be also caused by rain in a given region. Based on the above-mentioned statement it is evident that a perfect prediction of shape, size and density of radioactive contamination of the fallout pattern is almost impossible.

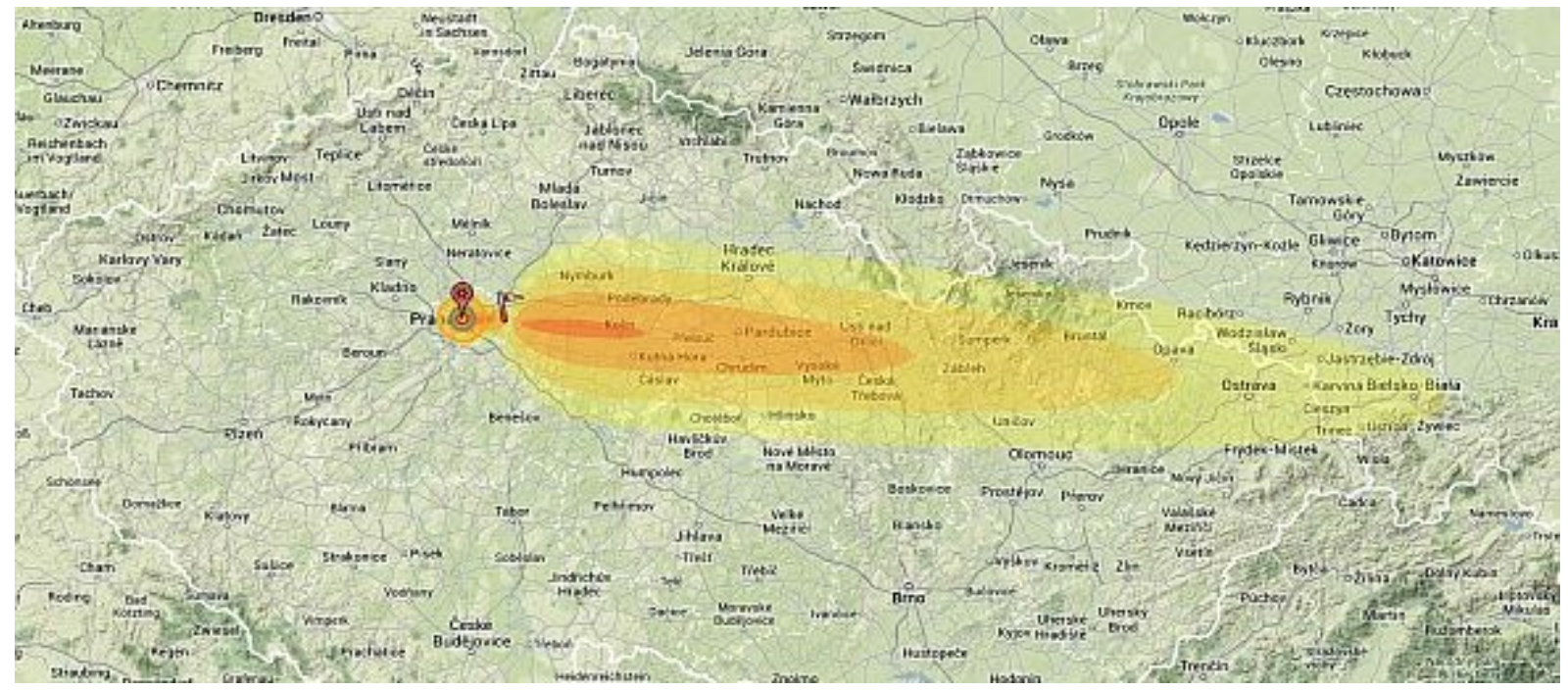

Figure 40: The direction of nuclear fallout after the detonation of a $550 \mathrm{kt}$ nuclear bomb in Praguethe west wind speed of $24 \mathrm{~km} / \mathrm{h}$. [Source: Fig-40]

If we assume a flat, uncovered terrain, the same direction and speed of high-altitude wind in all layers, no side effects (rain, fog, etc.), then the resulting fallout pattern will be in the shape of an ellipse, the maximum width of which will be 1/6 up to 1/10 of length. The fallout pattern will be formed by a circle around the explosion centre (the radius of contamination due to induced radioactivity and the dispersal of radioactive slag after the explosion) and further, more or less by an elliptical shape. The level of radiation (exposure or dose rate) in the fallout pattern decreases with the distance from the explosion centre. The fallout pattern has the highest level of radiation (exposure rate) in its axis, decreasing rapidly in the direction of the sides.

Particles fall out of the cloud gradually. The time, during which all radioactive particles will fall out of the cloud in a given place, is determined by the atmospheric conditions and the scattering of particle size. The smaller the mean particle size, the longer the time period. As the distance from the epicentre increases, so does the time of particle fall out. With the increasing time of particle falling out, radiation (exposure or dose rate) at a certain point of the fallout pattern increases to a maximum value and then gradually decreases. 
There are two contradictory phenomena here. As a result of fallout, the activity in a given place increases, and at the same time it decreases due to radioactive decay. At first, the first phenomenon prevails when the activity increases, however, later the second phenomenon prevails when the activity decreases due to the radioactive decay.

\subsubsection{Destructive effects of ionizing radiation}

The effect of ionizing radiation on combat equipment and material - the surface of solids is usually damaged due to external irradiation. Radiation causes considerable surface defects, which manifest themselves as submicroscopic traces caused by incident particles and the so-called radiation corrosion occurs.

The surface at the place of these microscopic defects is then more susceptible to chemical agents than the surrounding intact matter. The action of these agents may increase the incurred defects and, therefore, the gradual degradation of the material takes place. This may be topical, especially because of the further application of decontamination mixtures on such a damaged material. Most of decontamination formulas are very aggressive.

Moreover, due to the effect of ionizing radiation on solids, the lattice defects caused by the changes in the positions of atoms or ions may occur. Therefore, the original arrangement of the crystalline structure is disrupted. These changes, when extensive, may exhibit a change in mechanical properties (hardness, density, brittleness) or in physical properties (electrical conductivity, specific heat capacity, etc.). The exposure to ionizing radiation can occur in certain materials and change their colour or luminescence.

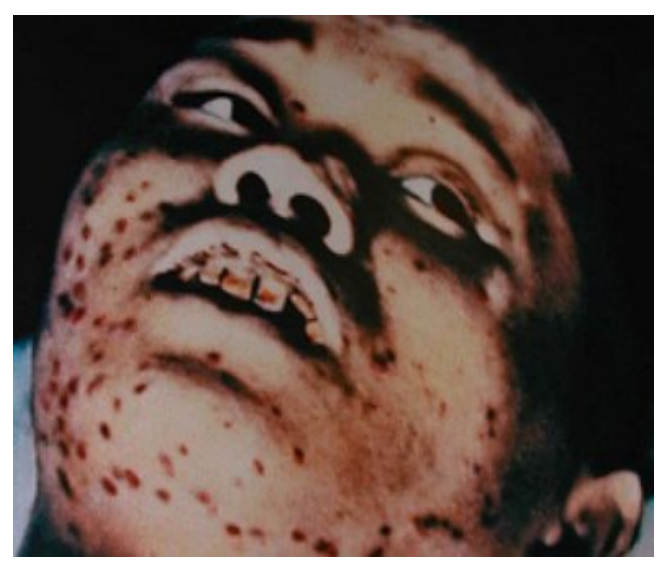

Photo 81: Acute radiation syndrome, Hiroshima. [Source: Pho-81]

The most considerable destructive effect is the occurrence of radioactivity induced in material, especially in the equipment that is then unusable for its original purpose up to the complete extinction of man-made radionuclides (technology graveyards 30 years after the Chernobyl nuclear power plant disaster.

The effect of ionizing radiation on humans - the effects of ionizing radiation on humans and other living organisms comply with the same laws as the interaction between radiation and matter. The difference is that biological organisms have a high degree of hierarchical organization, i.e. their uniform volumes have functionally quite different positions, so the consequences of this or that unit volume may differ. Another specificity of living biological systems is the ability to repair, i.e. to repair damage depending on the nature of a given individual. To understand the issues of radiation hazards to people, it is useful to know the biological effects of radiation and the health consequences of radiation.

The transfer of ionizing radiation energy to an animal cell and the damage to deoxyribonucleic acid (DNA) macromolecule may cause the following types of damage to the body:

- Acute radiation syndrome;

- Acute localized damage (radiation dermatitis, hair loss, ulceration);

- Fetal damage in pregnancy, infertility;

- Irreversible late damage (cataract, chronic radiation dermatitis, shortening of life); and

- Genetic changes. 
The most significant symptom of the early effect of ionizing radiation is an acute radiation_syndrome, which develops after irradiating the body or part of it with a higher dose. Depending on the level of irradiation, the symptoms of the damage to the hematopoietic organs, the digestive tract, and the central nervous system dominate the clinical picture. Table 26 shows that the injuries to health resulting from irradiation can be divided into three aspects:

- Somatic after-effects (manifested directly in irradiated individuals) and genetic after-effects (manifested in future generations);

- Early after-effects (manifested over days, weeks

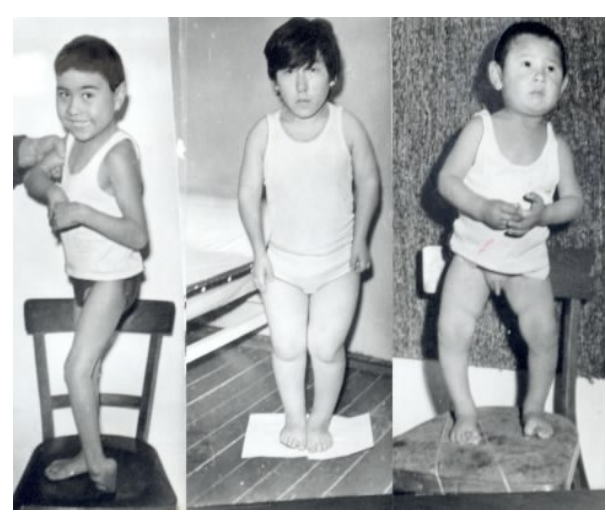

Photo 82: The damage to fetus after irradiation, Hiroshima. [Source: Pho-82] or months) and late after-effects (manifested only after years); and

- Effects:

- Deterministic (regular, non-stochastic, non-random) always manifested, but only when a certain threshold dose is exceeded, in all irradiated individuals. The value of the threshold dose for a given effect decreases individually, depending on irradiation conditions. From this threshold dose, the effects on an individual are proportional to the size of a dose. The first four items of damage to the body correspond to the effects of non-stochastic character.

- Stochastic (random, statistical) have no threshold dose and are of a statistical (probabilistic) nature. Stochastic damages manifest themselves only in a part of people (individuals) from a significant statistical set, i.e. they have only a certain probability coefficient for individuals. As for stochastic effects, it is never possible to determine precisely whether a concrete person gets ill or not due to irradiation.

In relation to the consequences of deterministic damages, e.g. the threshold dose of the whole-body irradiation for the acute post-radiation syndrome has a value of about $1 \mathrm{~Sv}$. If this value is not exceeded, it is impossible for an irradiated person to get ill with a classic radiation sickness.

The assessment of stochastic effects is based on the following risk factors:

- The risk coefficient of nonfatal cancer is estimated at approximately $10 \times 10^{-6} \mathrm{mSv}^{-1}$, the risk coefficient of genetic after-effects for the first two generations is estimated at approximately $13 \times 10^{-6} \mathrm{mSv}^{-1}$.

- The risk coefficient of radiation-induced fatal cancer is currently estimated at $50 \times 10^{-6} \mathrm{mSv}^{-1}$, i.e. when one million people are irradiated, each by the dose of $1 \mathrm{mSv}^{-1}$, about 50 people die of cancer due to irradiation. Cancer does not arise immediately, but after several years of latency (e.g. in lung tumours after 10 up to 40 years). In each generation of people in the Czech Republic (10 million people), there are about 100,000 radiation-induced cases of fatal cancer caused by irradiation from all natural and artificial sources. The total incidence of cancer of any origin is about twenty times higher, about 2 million people, i.e. every fifth person will die of cancer of various origin. Some authors state that this number is even higher.

The biological effect of ionizing radiation on humans, or any other living organism in general, rests in the ionization and excitation of atoms and molecules of animal and plant origin. Due to this phenomenon, the chemical changes in a living organism take place; they are induced mainly by the products of water radiolysis, the content of which in the body is considerable. 
Table 26: Processes taking place in the cell after irradiation, biological effects of irradiation and health consequences. [Source: Tab-26]

\begin{tabular}{|c|c|c|c|c|c|}
\hline Stage & \multicolumn{4}{|c|}{ Processes } & Duration \\
\hline Physical & \multicolumn{4}{|c|}{ Absorption of ionizing radiation energy, ionization of water } & $10^{-16} \mathrm{~s}$ \\
\hline $\begin{array}{l}\text { Physico- } \\
\text { chemical }\end{array}$ & \multicolumn{4}{|c|}{ Interaction of ions with molecules, formation of free radicals } & $10^{-6} \mathrm{~s}$ \\
\hline Chemical & \multicolumn{2}{|c|}{$\begin{array}{l}\text { Denaturation of important cell } \\
\text { components and fragments }\end{array}$} & \multicolumn{2}{|c|}{ Interaction with dna } & Seconds \\
\hline \multirow{2}{*}{ Biological } & \multicolumn{2}{|c|}{ Cell death } & \multicolumn{2}{|c|}{$\begin{array}{c}\text { Change in genetic information } \\
\text { of a cell, mutation }\end{array}$} & \multirow{2}{*}{$\begin{array}{c}\text { Tens of } \\
\text { minutes } \\
\text { up to tens } \\
\text { of years }\end{array}$} \\
\hline & $\begin{array}{l}\text { Killing at a rest } \\
\text { state }\end{array}$ & \begin{tabular}{|l} 
Extinction linked \\
to cell division
\end{tabular} & Somatic & genetic & \\
\hline \multirow{3}{*}{$\begin{array}{l}\text { Radiation } \\
\text { effects }\end{array}$} & \multicolumn{2}{|c|}{ Deterministic (non-stochastic) } & \multicolumn{2}{|c|}{ Stochastic } & \\
\hline & Early & \multicolumn{3}{|c|}{ Late } & \\
\hline & \multicolumn{3}{|c|}{ Somatic } & genetic & \\
\hline \multirow{3}{*}{$\begin{array}{c}\text { Health } \\
\text { consequences } \\
\text { caused } \\
\text { by irradiation }\end{array}$} & $\begin{array}{c}\text { Acute post-radia- } \\
\text { tion syndrome } \\
\text { (radiation sickness) }\end{array}$ & $\begin{array}{c}\text { Chronic } \\
\text { suppression of } \\
\text { haematopoiesis }\end{array}$ & Leukaemia & \multirow{3}{*}{$\begin{array}{c}\text { consequences } \\
\text { in } \\
\text { descendants }\end{array}$} & \\
\hline & $\begin{array}{c}\text { Acute local } \\
\text { changes } \\
\text { non-tumour organ } \\
\text { damage }\end{array}$ & $\begin{array}{l}\text { Chronic } \\
\text { dermatitis }\end{array}$ & \multirow{2}{*}{$\begin{array}{l}\text { Tumour dam- } \\
\text { age to organs } \\
\text { (cancer) }\end{array}$} & & \\
\hline & $\begin{array}{l}\text { Damage to the } \\
\text { development of the } \\
\text { embryo or fetus }\end{array}$ & Cataract & & & \\
\hline
\end{tabular}

The water radiolysis products mediate (through other chemical reactions) peroxidic changes to functionally important macromolecules in a cell, the change to its biological integrity and the damage to a macromolecule of deoxyribonucleic acid (DNA). This has consequences for the genetically determined regulation of the cell and its progeny.

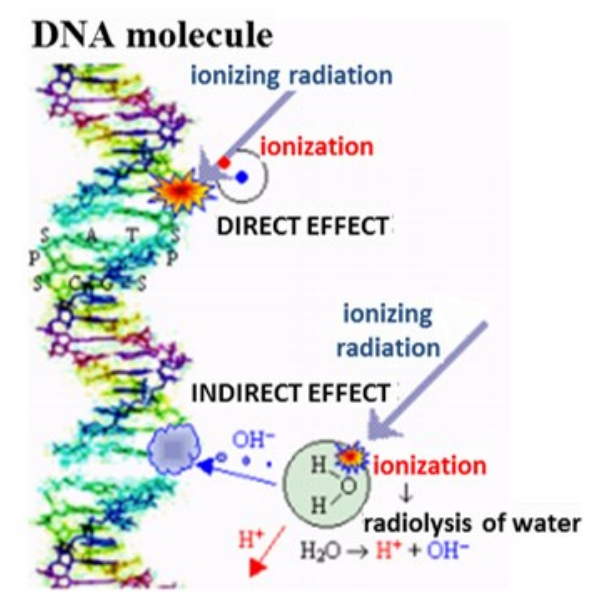

Figure 41: The effect of ionizing radiation on organisms. [Source: Fig-41]
The quantitative degree of effects of directly and indirectly ionizing radiation on the human body is expressed by the so-called dose $D$ (also absorbed dose, or radiation dose). Dose is defined as the mean energy transmitted by ionizing radiation to a substance per unit mass of the substance to which the energy was transmitted. The unit of dose is the joule per kilogram $\left(\mathrm{J}^{\mathrm{kg}} \mathrm{kg}^{-1}\right)$ with a special name gray (Gy) and the size of $\mathrm{m}^{2} \cdot \mathrm{s}^{-2}$. The unit used earlier was rad.

The biological effect of radiation is expressed by the so-called dose equivalent $H$, which is given by the length coefficient, the biological efficiency factor Q (i.e. the quality factor), and other modifications of the $\mathrm{N}$ factors.

$$
\boldsymbol{H}=\boldsymbol{D} \times \boldsymbol{Q} \times \boldsymbol{N}
$$

The unit of dose equivalent is the sievert ( $S v)$, the previously used unit was rem (derived from the English name roentgen equivalent man - biological human X-ray equivalent). The values of quality factor $Q$ for various types of radiation are given in Table 27. For the product of all modifying factors, $\mathrm{N}=1$ is currently taken by convention in all cases. 
Moreover, in military dosimetry, the X-ray unit $(\mathrm{R})$ is used to express the quantitative measure of the effects of ionizing radiation on the human body, but this is incorrect since X-rays are a secondary unit of exposure that determines the amount of radiation by the ionizing effect on air.

Conversion relationships:

- $1 \mathrm{rad}=10^{-2} \mathrm{~J}_{\mathrm{kg}}{ }^{-1}$

- $1 \mathrm{~J}_{\mathrm{kg}}{ }^{-1}=1 \mathrm{~Gy}$

- $1 \mathrm{~Gy}=100 \mathrm{R}$

- $1 \mathrm{rad}=10 \mathrm{mGy}$

- $1 \mathrm{rad}=1 \mathrm{R}$ (approximately only during the passage of radiation through air.

Dose calculations in a contaminated area - in some cases, we are not able to measure the dose by a dosimeter, and since we need to calculate the dose at least roughly to be able to assess the hazard rating of external radiation from people, we can use the following method:

The case when the contamination is very old and does not change significantly over time:

then it applies: $\mathbf{D}=\mathbf{P} \times \mathbf{t}$

where: $\mathrm{D}$ is a dose in $\mathrm{cGy}$

$\mathrm{P}$ is the radiation level in $\mathrm{cGy} \cdot \mathrm{h}^{-1}$

$\mathrm{t}$ is the length of stay in a contaminated area

The case when the contamination is younger and the level of radiation changes significantly during the stay:

then it applies: $\mathbf{D}=\frac{\mathbf{P}_{1}+\mathbf{P}_{2}}{\mathbf{2}} \times \mathbf{t}$

where: $\mathrm{P}_{1}$ is the radiation level at the beginning of irradiation in $\mathrm{cGy} \cdot \mathrm{h}^{-1}$

$\mathrm{P}_{2}$ is the radiation level at the end of irradiation in $\mathrm{cGy} \cdot \mathrm{h}^{-1}$

Protection against the effects of radioactive contamination - the protection against the effects of radioactive contamination does not differ virtually from the protection against the effects of initial radiation, the principles of which have been clarified. Contamination of clothing or the surface of the body can be practically eliminated by appropriate and timely use of personal protective equipment, or by the use of equipment and shelters. Internal contamination can be prevented by using the protective properties of combat equipment and shelters. When working outside of them, it is possible to use a protective face mask, which prevents the penetration of radioactive particles into the body.

When radionuclides fall out of the nuclear cloud, the humans in a contaminated area are endangered by three types of danger as follows:

- External irradiation by radionuclides fallen out of the nuclear cloud on the ground and arising due to induced radioactivity;

- Contamination of clothing, possibly the body surface by radioactive material during operations in a contaminated field (external contamination); and

- Internal contamination when radionuclides enters the body.

The zones of radioactive contamination after nuclear surface bursts or after the activation of nuclear barriers are mostly overcome in directions with the lowest levels of radiation or after the decrease in high radiation levels. Landslides, fires and flooded areas are bypassed. Before crossing the zones of radioactive contamination, radioprotective substances are administered to soldiers to increase their resistance to the effects of ionizing radiation. 
Table 28: Permissible standards for contamination of surfaces with radioactive agents.

[Source: Tab-28]

\begin{tabular}{|c|c|}
\hline Surface of items & $\begin{array}{c}\text { Degree of contamination } \\
\text { in mGy. } \mathrm{h}^{-1}\end{array}$ \\
\hline $\begin{array}{c}\text { Underwear, face pieces of a protective mask, footgear, individual } \\
\text { protective equipment, personal weapons, first aid supplies }\end{array}$ & 0.5 \\
\hline $\begin{array}{c}\text { Food packaging, kitchen equipment, equipment for canteens, bakeries } \\
\text { and food warehouses }\end{array}$ & 0.5 \\
\hline Surface of animal bodies & 1.0 \\
\hline $\begin{array}{c}\text { Military equipment, vehicles, aircraft, special vehicles, cannons, } \\
\text { mortars, rocket launchers and accessories }\end{array}$ & 2.0 \\
\hline
\end{tabular}

Note:

- The data are valid for the age of radioactive material 1 day (24 hours).

- If the contamination is caused by the products of a nuclear explosion less than 12 hours old, the stated values are increased 4 times (less than 12 hours have passed since the nuclear explosion).

- If the contamination is caused by the products of a nuclear explosion between 12 and 24 hours old, the stated values are increased 2 times (12 to 24 hours have passed since the nuclear explosion).

- When measuring, the distance between the instrument probe and the surface of the object must be 1 to $1.5 \mathrm{~cm}$.

- In contaminated zones with the radiation level of up to $5 c G y \cdot h^{-1}$, protective masks can be taken off up to 4 times per 24 hours based on the regulation. In total, however, not more than 3 hours per day.

\subsubsection{Influence of terrain and weather conditions}

On the pressure wave - the pressure increases on the forward slopes of hills, the angle of which exceeds $10^{\circ}$ to $15^{\circ}$. The steeper the slope, the greater the increase in pressure. The coefficient of increase in pressure at the shock front, e.g. for the positive pressure of $0.05 \mathrm{MPa}$ is at the angles of forward slopes as follows: for $15^{\circ}=1.31$; for $30^{\circ}=1.65$; for $45^{\circ}=2.3$ and for $60^{\circ}=2.5$. On the reverse slopes the pressure decreases. In the valleys, the direction of which corresponds to the direction of the pressure wave propagation, the pressure decreases with the distance more slowly than in the open space.

In valleys, ravines and trenches situated perpendicularly to the propagation of the wave, the pressure is approximately the same as in the open space, but the mechanical action of the pressure wave is considerably smaller. This explains their protective effect. The decrease in pressure in the pressure wave on the reverse slopes of hills is according to the angle of the reverse slope as follows: for $15^{\circ}=0.93$; for $30^{\circ}=0.86$; for $45^{\circ}=0.77$ and for $60^{\circ}=0.67 \%$ of the pressure on the flat ground. In gorges and ravines, the direction of which is parallel to the direction of the pressure wave propagation, the so-called blowing-through occurs (the effect of the pressure wave intensifies), which can cause extensive injuries to people, destruction of buildings, military equipment etc. The influence of forest stands on the parameters of the pressure wave is given by the resistance caused by trees against the movement of air masses. The maximum overpressure at the shock front within the forest area is higher by 10 to $15 \%$ than in an open area; however, the speed of air masses with the shock front will decrease and the effect will be 2 to 3 times smaller. The pressure wave with overpressure of 0.03 to $0.05 \mathrm{MPa}$ breaks trees and creates landslides. Falling trees can hurt and kill people and damage combat equipment. For instance, the radius of the forest landslide area is at a nuclear yield of $1 \mathrm{kt}$ about $0.5 \mathrm{~km}$; at $10 \mathrm{kt}$ about $1.1 \mathrm{~km}$; at $100 \mathrm{kt}$ about $2.3 \mathrm{~km}$ and at $1 \mathrm{MT}$ about $5 \mathrm{~km}$. 
On light radiation - in fog, rain and snow light radiation weakens so much that its role as an independent destructive factor is close to zero. With low humidity and air pollution, light radiation is weakened little. Attenuation of light radiation can also be achieved by shielding with atmospheric clouds (in airbursts), clouds of vapours rising from the ground, uneven terrain, vegetation, local objects, etc. Attenuation of light radiation in the forest depends on the nature of trees, the density of their tree-tops, the age of the forest and also on the season of the year. Dense forest attenuates light radiation according to the nature of trees 10 to 15 times, sparse forest 2 to 5 times.

On radioactive contamination - rain, fog, snowfall increase the amount of fallen radioactive material and thus increase the degree of contamination in the precipitation area.

On initial radiation and electromagnetic pulse - basically, they have no effect. With the increasing distance from the nuclear explosion site, the effects of destructive factors decrease, with the increasing yield they increase, with the increasing altitude the effect of the pressure wave and radioactive contamination decreases.

\subsection{Radiological weapons}

A radiological weapon is defined as any device, including a nuclear weapon or armament other than a nuclear explosive, which is specially designed to scatter radioactive material to cause destruction, damage or injury through ionizing radiation resulting from the radioactive decay of such material. It is sometimes called a device to disperse radionuclides. Its source is radioactive agents, which together with delivery systems form a complex of radiological weapons. Radiological weapons, i.e. the deliberate dispersion of radioactive material in armed conflicts, are not covered by any international convention. During the negotiations at the Conference on Disarmament in Geneva, this problem was withdrawn from the agenda in 1984, or a group of independent and non-aligned countries wanted to unreasonably link this problem to nuclear disarmament. Even from a military point of view, such weapons were not considered current in terms of effectiveness because the use does not bring either a rapid effect (such as chemical weapons) or a delayed effect (such as bacteriological weapons). It is deemed that such weapons, therefore, do not exist in the military arsenals, although, after the Gulf War, the team of UN inspectors found out that Iraq had tried to develop these weapons.

A war waged with radiological weapons is defined as the use of radioactive agents or equipment that emits ionizing radiation to cause casualties or restrict the use of the terrain. It includes the intentional exploitation of radioactive fallout of a nuclear weapon. Sources of radiological weapons include nuclear technical equipment, radiochemical development, large-scale production and use of radionuclides. Radioactive agents are divided according to the type of radiation, the time of existence, origin, consistency, usability, suitability for deployment and the expected effect. The common long-lived fission products of irradiation are cobalt $\left({ }^{60} \mathrm{Co}\right)$, caesium $\left({ }^{137} \mathrm{Cs}\right)$ and tritium $\left({ }^{3} \mathrm{~T}\right)$.

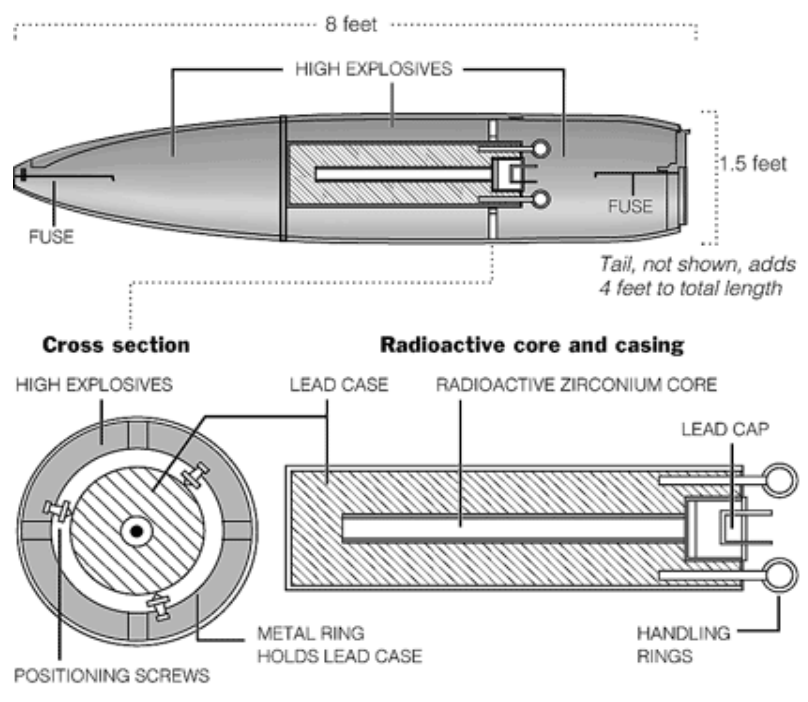

Figure 42: Saddam's Dirty Bomb - Iraq manufactured and tested a radiological bomb in 1987. [Source: Fig-42] 
The short-lived radionuclides can be produced artificially in irradiation channels and they can be used for several hours to days after irradiation. It is probable that irradiation products can be used in three states - solid, gaseous and liquid.

\section{Dirty bomb}

Although the term of dirty bomb implies an explosion, it is not possible to include this weapon in the group of explosive nuclear weapons. This group comprises atomic, hydrogen (thermonuclear) as well as neutron bombs, which use intranuclear energy as a primary destructive moment. Intranuclear energy is released in the course of explosive nuclear reactions during the fission of nuclei of heavy elements (uranium, plutonium) or the joining of nuclei of light elements (isotopes of hydrogen, lithium).

During the explosion, these bombs cause a destructive pressure wave, heat and, in the case of a ground or underground explosion, earthquakes, all accompanied by initial radiation and subsequent long-term contamination and induced radioactivity, which arose in the vicinity by the impact of neutrons on atomic nuclei.

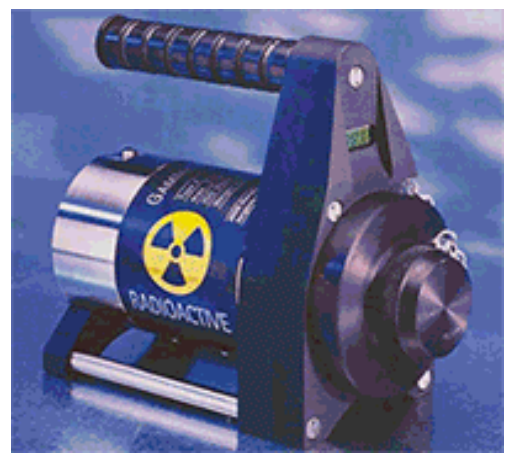

Figure 43: Gammamat SE Type A gamma ray projector using ${ }^{75} \mathrm{Se}$ for defectoscopy. [Source: Fig-43]

On the contrary, a dirty bomb can use a charge with a conventional filler (e.g. trinitrotoluene) to scatter radioactive materials and its immediate destructive effect is negligible when compared to the bombs previously mentioned. Its action (except psychological aspects) rests in contamination of a certain territory by nuclear radiation, whereas the most discussed materials for this purpose are gamma radiation producing cobalt ${ }^{60} \mathrm{Co}$, caesium ${ }^{137} \mathrm{Cs}$, iridium ${ }^{192} \mathrm{Ir}$ or alpha particles emitting americium ${ }^{241} \mathrm{Am}$ and plutonium ${ }^{238} \mathrm{Pu}$.

However, in order to effectively disperse radioactive materials, it is not enough just to wrap them in dynamite stolen from the quarry, even if such a charge explodes in the air, for example after being dropped from a small sports plane or in a balloon (scattering would be negligible and radioactive agents would be relatively easy to detect and neutralize, but on the other hand, such an action could cause panic and have a psychological effect). For a stronger effect of a dirty bomb it is important to create a substance, on the basis of which a radioactive cloud distributing radiation throughout a wide area would be produced. Mainly aerosol is suitable. During the Cold War. the diluted solutions of radioactive agents were used for producing the contents of a contemporary dirty bombs.

These diluted solutions of radioactive agents included a high content of inactive salts, which were rid of inactive ingredients and concentrated, whereas individual groups of radioactive isotopes with certain radiation properties separated. The concentrates obtained were used for preparing radioactive materials.

Other products used for the preparation of these materials were artificial radioactive isotopes obtained in a nuclear reactor by irradiation of certain stable elements. Contemporary terrorists either try to get these materials in an existing form (particularly from the sources located on the territory of the former Soviet Union), or they try to produce them, which also applies to rogue states.

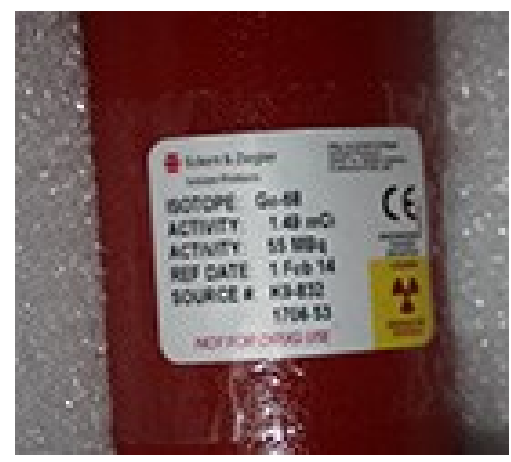

Figure 44: Industrial radiator using ${ }^{58}$ Co for defectoscopy. [Source: Fig-44] 
In this context, it should be emphasized that contemporary terrorists preparing or at least transporting radioactive materials in hazardous conditions are subject to a considerable risk of irradiation as distinct from the protected experts of the nuclear weapon states. The concept of suicide terrorism also acquires a new dimension, which no longer has to be defined only in view of the final phase of a terrorist attack, but also in terms of its long-term preparation.

The pilot of a pulverizing aircraft that would spray a radioactive substance would also be exposed to the danger of radiation (which is sometimes discussed as an alternative to a dirty bomb, another alternative is an attack on a nuclear power plant or another nuclear facility). In this case a stricken reactor itself transforms into a radiological weapon of an extraordinary destructive force. In the accidents of nuclear reactors, no nuclear explosion happens. The contaminated area is smaller than in the case of a nuclear weapon explosion, however, the time of contamination is longer.

When a nuclear reactor is hit by a nuclear weapon, in the first week, the dynamics of contamination in the surrounding area will not differ too much from the course of this process during the explosion of a nuclear weapon itself. However, the time of radioactive contamination will be considerably longer.

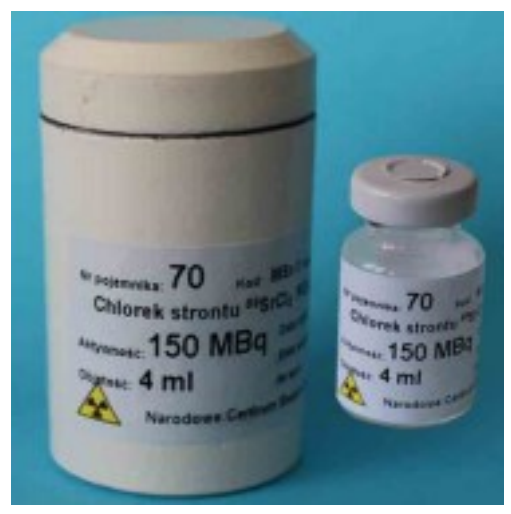

Figure 45: Radioactive strontium in the form of chloride salt $\left({ }^{89} \mathrm{SrCl}_{2}\right)$ for chemotherapy. [Source: Fig-45]

In general, the use of weapons of mass destruction (WMD) is preferred by Islamist terrorists or a Japanese doomsday cult (Aum Shinrikyo) and is related to their not very selective choice of victims.

The strategy of contemporary Islamists envisages harming as many infidels as possible and stirring the panic and chaos needed to facilitate Muslim expansion. The sectarian attempts are characterized by an effort to bring about the destruction of a corrupt world.

Ultra-leftist or ethno-separatist terrorists (apart from various Islamic separatists, of course) are maybe more selective in choosing specific victims (this does not mean that they do not condescend to the mass massacres of civilians), however, the contaminated territory, on which their class and ethnically pure state would exist, is not in their interest.

This also applies to the most dangerous Al Qaeda terrorist network, which also other organizations start competing with in terms of the degree of risk. In May 2002, Jose Padilla, an American citizen, who had converted to Islam and adopted the name Abdullah al-Muhajir was detained in the USA. He had very close ties to Al Qaeda and planned to detonate a radioactive dirty bomb on the American territory. However, even according to American investigators, he was not at the stage when he had set a specific goal. He was only trained in Pakistan in handling explosives and, apparently, he tried to procure radioactive materials in the former USSR. Plans for a dirty bomb were also secured in several actions against bin Laden's network, with the units in Afghanistan apparently furthest in its development.

After the American warning, Narong Penanam was arrested in Thailand in June 2003. He tried to smuggle $30 \mathrm{~kg}$ of caesium of Russian origin $\left({ }^{137} \mathrm{Cs}\right)$ from Laos. In the same week, the members of Jamaa Islamiya were arrested (they fight for establishing a fundamentalist Muslim state in Southeast Asia and are responsible for the terrorist attacks in Bali on October 12, 2002).

They planned attacks against embassies and tourist districts, especially against the summit meeting of the Council for Asia-Pacific Economic Cooperation (on October 20 and 21, 2003, US President G. Bush was supposed to attend). 
At the nuclear summit in 2010, US President Barack Obama won a pledge of nearly fifty countries that, within four years, they would ensure the control of all fissile material they have at their disposal and help prevent it from getting into unauthorized hands. But according to nuclear experts, the world should be much more afraid of terrorists using the so-called dirty bomb (i.e. a conventional charge with a fissile material) than of attacking by nuclear weapons. It is not easy to steal uranium or plutonium in the concentration needed to make a bomb, although, in the past, there were attempts to smuggle radioactive material originating from

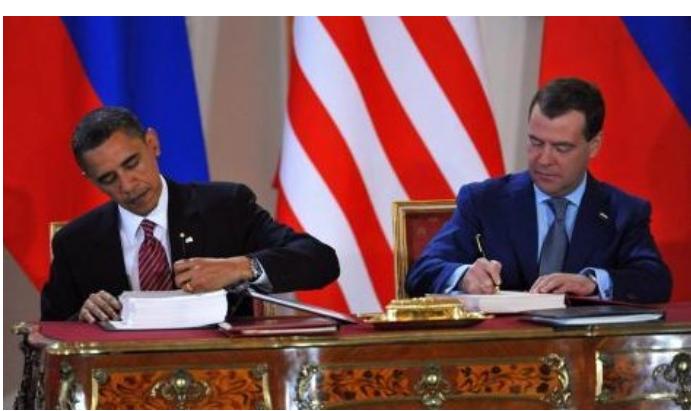

Photo 83: Presidents of the USA and Russia (Obama a Medvedev) signing the major Nuclear Arms Control Agreement on April 8, 2010 in Prague. [Source: Pho-83] the countries of the former Soviet Union. The emitters used in hospitals or some devices to measure the quality of materials pose a much greater risk.

Table 29: Radionuclides. [Source: Tab-29]

\begin{tabular}{|c|c|c|c|c|c|c|c|}
\hline Radionuclide & $\begin{array}{c}\text { Half-life } \\
\mathrm{T}_{1 / 2}\end{array}$ & $\begin{array}{l}\text { Disintegra- } \\
\text { tion method }\end{array}$ & Use & Radionuclide & $\begin{array}{c}\text { Half-life } \\
\mathrm{T}_{1 / 2}\end{array}$ & $\begin{array}{l}\text { Disintegra- } \\
\text { tion method }\end{array}$ & Use \\
\hline${ }_{0}^{1} \mathbf{n}$ & 13 min. & $\beta^{-}$ & $\begin{array}{c}\text { nuclear } \\
\text { analysis }\end{array}$ & $\begin{array}{r}123 \\
53\end{array}$ & $\begin{array}{c}13.2 \\
\text { hours }\end{array}$ & EC & $\begin{array}{l}\text { nuclear } \\
\text { medicine }\end{array}$ \\
\hline${ }_{1}^{3} \mathbf{H}$ & 12.3 years & $\beta^{-}$ & biology & $\begin{array}{r}125 \\
53\end{array}$ & 60 days & EC & $\begin{array}{c}\text { nuclear } \\
\text { medicine }\end{array}$ \\
\hline${ }_{6}^{14} \mathrm{C}$ & $\begin{array}{l}5,730 \\
\text { years }\end{array}$ & $\beta^{-}$ & \begin{tabular}{|l|} 
biology \\
analysis
\end{tabular} & $\begin{array}{r}131 \\
53\end{array}$ & 8.04 days & $\beta^{-}$ & $\begin{array}{l}\text { nuclear } \\
\text { medicine }\end{array}$ \\
\hline${ }_{9}^{18} \mathbf{F}$ & 110 min. & $\begin{array}{l}\beta^{+}(97 \%) \\
\operatorname{EC~}(3 \%)\end{array}$ & $\begin{array}{c}\text { nuclear } \\
\text { medicine }\end{array}$ & ${ }_{54}^{133} \mathbf{X e}$ & 5.3 days & $\beta^{-}$ & $\begin{array}{c}\text { nuclear } \\
\text { medicine }\end{array}$ \\
\hline${ }_{15}^{32} \mathbf{P}$ & 14.3 days & $\beta^{-}$ & $\begin{array}{c}\text { nuclear } \\
\text { medicine }\end{array}$ & ${ }_{55}^{137} \mathrm{Cs}$ & 30 years & $\beta^{-}$ & $\begin{array}{l}\text { gamma } \\
\text { source }\end{array}$ \\
\hline${ }_{19}^{40} \mathbf{K}$ & $\begin{array}{c}1.28 \times 10^{9} \\
\text { years }\end{array}$ & $\begin{array}{c}\beta^{-}(89 \%) \\
\operatorname{EC~}(11 \%)\end{array}$ & $\begin{array}{l}\text { isotope } \\
\text { dating }\end{array}$ & ${ }_{77}^{192} \mathbf{I r}$ & 74.2 days & $\begin{array}{l}\beta^{-}(95 \%) \\
\operatorname{EC}(5 \%)\end{array}$ & $\begin{array}{l}\text { gamma } \\
\text { source }\end{array}$ \\
\hline${ }_{24}^{51} \mathrm{Cr}$ & 27.7 days & $\mathrm{EC}$ & $\begin{array}{c}\text { nuclear } \\
\text { medicine }\end{array}$ & ${ }_{81}^{201} \mathbf{T l}$ & 73 hours & $\mathrm{EC}$ & $\begin{array}{c}\text { nuclear } \\
\text { medicine }\end{array}$ \\
\hline${ }_{27}^{57} \mathrm{Co}$ & 271 days & $\mathrm{EC}$ & \begin{tabular}{|l|} 
gamma \\
source
\end{tabular} & ${ }_{88}^{226} \mathbf{R a}$ & $\begin{array}{l}1,602 \\
\text { years }\end{array}$ & $\alpha$ & $\begin{array}{l}\text { alpha } \\
\text { source }\end{array}$ \\
\hline${ }_{27}^{58} \mathrm{Co}$ & 70.8 days & $\beta^{+}, \mathrm{EC}$ & $\begin{array}{c}\text { biology, } \\
\text { nuclear } \\
\text { medicine }\end{array}$ & ${ }_{90}^{232} \mathrm{Th}$ & $\begin{array}{l}1.41 \times \\
10^{10} \\
\text { year }\end{array}$ & $\alpha$ & $\begin{array}{c}\text { potential } \\
\text { nuclear } \\
\text { fuel }\end{array}$ \\
\hline${ }_{27}^{60} \mathrm{Co}$ & $\begin{array}{l}5.271 \\
\text { years }\end{array}$ & $\beta^{-}$ & \begin{tabular}{|l|}
$\begin{array}{l}\text { gamma } \\
\text { source }\end{array}$ \\
\end{tabular} & ${ }_{92}^{235} \mathbf{U}$ & $\begin{array}{c}7.1 \times 10^{8} \\
\text { years }\end{array}$ & $\alpha$ & $\begin{array}{c}\text { fissile } \\
\text { material }\end{array}$ \\
\hline${ }_{31}^{67} \mathbf{G a}$ & 3.26 days & $\mathrm{EC}$ & $\begin{array}{c}\text { nuclear } \\
\text { medicine }\end{array}$ & ${ }_{92}^{238} \mathbf{U}$ & $\begin{array}{c}4.51 \times 10^{9} \\
\text { years }\end{array}$ & $\alpha$ & $\begin{array}{l}\text { nuclear } \\
\text { reactor }\end{array}$ \\
\hline${ }_{31}^{68} \mathbf{G a}$ & $68 \mathrm{~min}$. & $\begin{array}{c}\beta^{+}(89 \%) \\
\text { EC }(11 \%)\end{array}$ & $\begin{array}{c}\text { nuclear } \\
\text { medicine }\end{array}$ & ${ }_{94}^{239} \mathrm{Pu}$ & $\begin{array}{c}2.44 \times 10^{4} \\
\text { years }\end{array}$ & $\alpha$ & $\begin{array}{c}\text { fissile } \\
\text { material }\end{array}$ \\
\hline${ }_{38}^{90} \mathrm{Sr}$ & 28.8 years & $\beta^{-}$ & & ${ }_{95}^{241} \mathrm{Am}$ & 458 years & $\alpha$ & $\begin{array}{l}\text { alpha, } \\
\text { gamma } \\
\text { source }\end{array}$ \\
\hline${ }_{39}^{90} \mathrm{Y}$ & 64 hours & $\beta^{-}$ & $\begin{array}{c}\text { nuclear } \\
\text { medicine }\end{array}$ & \multirow{2}{*}{${ }_{98}^{252} \mathbf{C f}$} & \multirow{2}{*}{2.65 years } & \multirow{2}{*}{$\begin{array}{c}\alpha(97 \%) \\
\text { spontaneous } \\
\text { fission } \\
(3 \%) \rightarrow \mathrm{n}\end{array}$} & \multirow{2}{*}{$\begin{array}{c}\text { neutron } \\
\text { source }\end{array}$} \\
\hline${ }_{53}^{111} \mathbf{I}$ & 2.8 days & $\mathrm{EC}$ & $\begin{array}{l}\text { nuclear } \\
\text { medicine }\end{array}$ & & & & \\
\hline
\end{tabular}

Note: EC-Electron Capture of beta radioactivity 
In 1987, two men stole a radiation therapy device from the clinic in Goiania, Brazil that had ceased its operation. They dismantled it and sold it to a junkyard owner. The robbers showed their relatives and friends a powdered substance glowing blue in the dark, which they found inside the device. At that time, four people died of radioactive caesium and 250 other people were found to have significant levels of radioactive material in or on their bodies.

To build a nuclear bomb, despite of guaranteed manuals on the Internet, is also very difficult. It requires not only an expert knowledge, but also approximately $25 \mathrm{~kg}$ of fissile material. Terrorists can get radioactive material for a dirty bomb from a range of devices containing emitters such as cobalt, iridium, krypton or strontium.

In March 2002, customs officers in the Altai Mountains searched a touring bus and found $10 \mathrm{~kg}$ of highly radioactive thorium $\left({ }^{232} \mathrm{Th}\right)$ in one luggage, from which it is possible to create uranium $\left({ }^{233} \mathrm{U}\right)$ (fissile material for nuclear reactors). The bus provided connection between Kamenogorsk in Kazakhstan, which became one of the largest owners of nuclear arsenal after the collapse of the USSR, and the Russian city of Barnaul.

In September 2002, a Russian who tried to sell 400 grams of uranium was detained in Ukraine. A week before this case, another Russian was detained in Ukraine as he tried to sell radioactive strontium $\left({ }^{90} \mathrm{Sr}\right)$, which is used for making a dirty bomb.

In 2006, a man who offered 100 grams of highly enriched uranium for one million dollars was arrested in Georgia. Two years later, a similar case occurred in Cherkasy in Ukraine.

In April 2009, a couple of entrepreneurs and a member of the Regional Parliament who tried to sell nearly $4 \mathrm{~kg}$ of fissile material, reportedly plutonium, were arrested near Ternopil in West Ukraine. They demanded ten million dollars for them. It turned out that the special containers they had, contained only americium, an element exceeding a normal level of radioactivity approximately 250 times.

In 2002, the chief of the Russia's nuclear security system was forced to admit that the control over the Russian nuclear arsenal would have to be improved because their stock control is carried out (in his own words) once in a while by a babushka that ticks off the entries carelessly in a greasy memo book. Putin's Minister for Atomic Energy Alexander Rumyantsev confessed the same in Vienna. Once, he said at the IAEA meeting that Russia had lost control over its radioactive sources after the collapse of the USSR.

The West feared that these tremors of Russian sincerity were to get more financial aid to Russia; Russia just as other post-Soviet republics has been the centre of the international finance program to destroy weapons of mass destruction since the early 1990s not to become a logistic base of international terrorists or directly terrorist states. Over ten years (from 2002 to 2012), the G8 released 20 milliard dollars to Russia for these purposes. This money was intended not only to destroy nuclear arsenals, but also to prevent Russian scientists from selling themselves to terrorists. Therefore, the Americans devised a program of fidelization (fidelity for Russian and post-

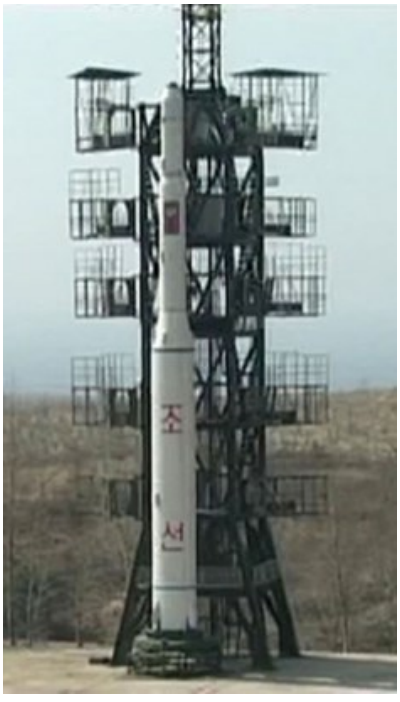

Figure 46: North Korean missile - Taepodong-2.

[Source: Fig-46]

Soviet scientists, but it did not work much. Nuclear depots are situated between Russia in the north and Iran and Iraq in the south in the so-called transit zone. The Stockholm International Peace Research Institute (SIPRI) reports that after the collapse of the USSR, the Russian and post-Soviet scientists who found themselves without work took care of the proliferation of nuclear weapons most. 
According to the International Atomic Energy Agency (IAEA), more than a thousand incidents in connection with the attempts to find someone to buy stolen radioactive materials on the black market were recorded from 1993 to 2008. In 463 cases, these were cobalt and strontium emitters stolen from hospitals and research institutes. In other 754 cases, the radioactive agent was lost, but there was no proof that it was an attempt to steal it. However, according to Vyacheslav Turkin who is in charge of the safety of nuclear materials at the IAEA, the number of such incidents has remained stable since the mid-1990s and is not growing. Fortunately, only two or three cases involved highly enriched uranium or plutonium. Moreover, the stolen nuclear material was traced in all cases. It does not apply to weaker emitters. According to the IAEA, there are hundreds of thousands of them in the USA itself, moreover, they are insufficiently secured.

The Russian authorities warn that Chechen terrorists may own a dirty bomb (they might pass it to other Islamists, although they would rather use it primarily to attack Russia). Already during the first war in Chechnya in 1995 , a container with radioactive caesium $\left({ }^{137} \mathrm{Cs}\right)$ was discovered in a Moscow park and it is believed that Shamil Basayev, one of the Chechen field commanders, buried it there. However, the radioactivity of this material was low and did not endanger human health. However, the fears that Chechens are responsible for at least some of a series of losses and thefts of radioactive materials in Russia and post-Soviet territories persist. In addition to the possibility of using dirty bombs against Russian targets and the abovementioned transfer of radioactive materials to the worldwide Islamist networks, a possible illegal trade in these materials, realized by Chechen (or Caucasian) organized crime is a big problem. Some states possess components for producing a minimally effective dirty bomb. The source of material is nuclear reactors including reactors in nuclear power plants. However, it is questionable whether they would be willing to use or pass a dirty bomb to terrorists because they would incur the threat of reprisal from the USA.

In any case, a state, which has recently declared ownership of dirty bombs and from which a high risk of their use in a possible attack comes, is the Democratic People's Republic of Korea. It also owns the equipment for hitting targets without the risky smuggling of nuclear material, the concealing of a bomb during transportation and the threat to carriers to be irradiated. These are ballistic missiles, including the Taepodong-1 with a range of up to 2,500 kilometres (tested in August 1998) and a planned three-stage missile Taepodong- 2 with a range of about $15,000 \mathrm{~km}$, which raises the greatest concern of the USA (between 2012 and 2013, North Korea conducted launching satellites into the space).

\subsubsection{Shelters - effective protection against the effects of nuclear and radiological weapons}

The overall consequences of a nuclear explosion are dependent on many factors. These are especially the nuclear yield, weather conditions, type of explosion, surrounding build-up area, etc. For the basic survival needs of the population, it is necessary to provide protection especially against the consequences of primary effects (except the electromagnetic pulse) and the secondary radioactive fallout. For this, the protective properties of special buildings shelters - are used. They are divided into:

- Permanent shelters - they are permanent buildings of civil protection used to shelter people from the effects of WMD and their consequences.

- Improvised shelters - their construction occurs only with an increased risk of using WMD. Their use is similar to permanent shelters.

Due to the reduction in the risk of using WMD and the need to save funds spent on the protection of the population, permanent shelters are being closed down and replaced by improvised shelters. 
The mutual comparison of permanent and improvised shelters is shown in Table 30 . In theory, this method seems appropriate and quite realistic. However, the problem is its practical implementation.

Table 30: Comparison of properties of permanent and improvised shelters. [Source: Tab-30]

\begin{tabular}{|c|c|c|c|c|}
\hline \multirow{2}{*}{ State } & \multicolumn{2}{|c|}{ Permanent shelters } & \multicolumn{2}{|c|}{ Improvised shelters } \\
\hline & Advantages & Disadvantages & Advantages & Disadvantages \\
\hline \multirow{3}{*}{ Peace } & $\begin{array}{c}\text { Use for } \\
\text { emergency } \\
\text { accommodation }\end{array}$ & $\begin{array}{l}\text { Financially } \\
\text { demanding }\end{array}$ & Financially undemanding & \\
\hline & \multirow{2}{*}{$\begin{array}{l}\text { Possibility } \\
\text { of education } \\
\text { and training } \\
\text { of personnel }\end{array}$} & $\begin{array}{l}\text { Necessity of } \\
\text { maintenance }\end{array}$ & $\begin{array}{c}\text { Utilization for peaceful } \\
\text { purposes (garages, storages) }\end{array}$ & \\
\hline & & $\begin{array}{c}\text { Necessity of } \\
\text { inspections }\end{array}$ & $\begin{array}{l}\text { Minimum requirements } \\
\text { for maintenance }\end{array}$ & \\
\hline \multirow{7}{*}{$\begin{array}{c}\text { State of } \\
\text { threat to } \\
\text { the state, } \\
\text { state of } \\
\text { war }\end{array}$} & $\begin{array}{l}\text { Fast putting them } \\
\text { on standby }\end{array}$ & \multirow{7}{*}{ Minimum } & Large number of objects & $\begin{array}{l}\text { Absence of equipment } \\
\text { (sanitary installations, }\end{array}$ \\
\hline & $\begin{array}{l}\text { Guaranteed } \\
\text { parameters }\end{array}$ & & \multirow{6}{*}{$\begin{array}{l}\text { Relatively continuous } \\
\text { geographical distribution }\end{array}$} & $\begin{array}{l}\text { filtering and ventilation } \\
\text { equipment) }\end{array}$ \\
\hline & $\begin{array}{l}\text { Higher level } \\
\text { of protection }\end{array}$ & & & $\begin{array}{c}\text { Necessity of transporting } \\
\text { material and equipment }\end{array}$ \\
\hline & $\begin{array}{l}\text { Verification } \\
\text { of functionality }\end{array}$ & & & Unverified functionality \\
\hline & $\begin{array}{c}\text { Arrangement } \\
\text { of inner spaces }\end{array}$ & & & $\begin{array}{l}\text { Limited distribution } \\
\text { of inner spaces }\end{array}$ \\
\hline & Number of people & & & Unguaranteed parameters \\
\hline & - attendants & & & Need for renovation \\
\hline
\end{tabular}

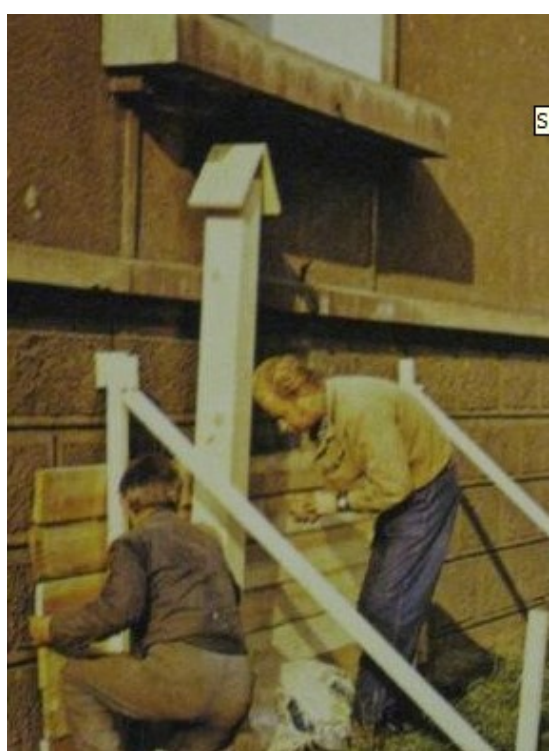

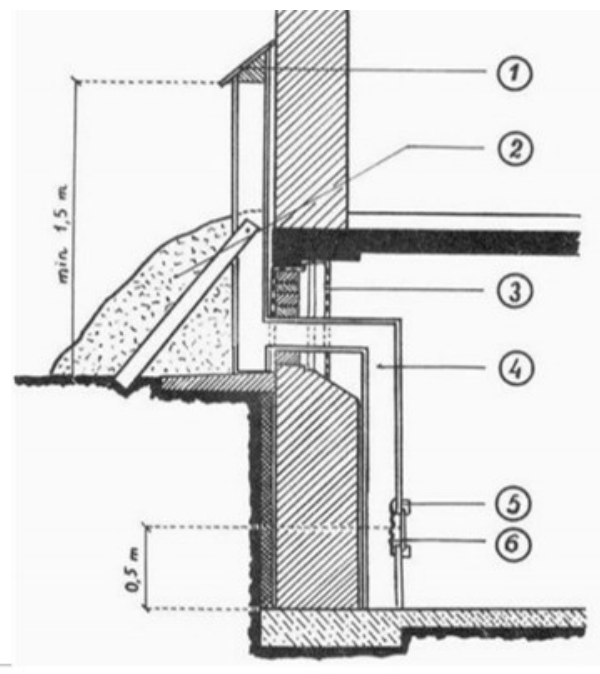

1 - roof, 2 - earth, 3 - sealing foil, 4 - little chimney, 5 - shut-off flap, 6 - dust collector, 7 - small net

Figure 47: The construction of a chimney for an improvised shelter for up to 50 people (principle of gravity ventilation). [Source: Fig-47]

Many municipalities lack adequate capacities or expertise to implement projects of improvised shelters and to carry out the activities associated with them. A possible solution is to develop a methodology for designing improvised shelters, their registration and scheduling. To create a similar methodology, it is necessary to process many aspects and then interconnect them. One of the fundamental aspects that affect the protective properties of the proposed shelters is the type of material used in the building modification and the construction of shelters. 
Other aspects influencing the choice of material are mainly its availability in the vicinity of improvised shelters and the complexity of their processing - the implementation of construction work.

Improvised shelters must provide protection against the primary effects of a nuclear explosion, and especially against the effects of radioactive fallout. It should be remembered that the structure and materials of improvised shelters must meet the basic requirements for the protection against the primary effects of a nuclear explosion. The protective properties of buildings against the effects of initial radiation are measured using the so-called protective coefficient of the building. This indicates how many times dose $D_{u}$ (radiation level $P_{u}$ ) of nuclear radiation in a shelter is lower than dose $D_{0}$ (radiation level $P_{0}$ ) of radiation at a height of $1 \mathrm{~m}$ above the exposed terrain surrounding the shelter. Equations 2, 3 and 4 are used to calculate the protective coefficient of the building for shelters partially buried beneath the ground or not buried beneath the ground (2), buried shelters with superstructures (3) and completely buried shelters without superstructures (4). To determine a protective coefficient of the building $\mathrm{K}_{0}$, it is necessary to know the data about the building construction. It is especially the surface density of walls and structures, the areas of openings, room dimensions, the depth of the buried floor and the information about the surrounding build-up area.

$$
\begin{aligned}
& \mathrm{K}=\frac{\mathrm{D}_{\mathrm{O}}}{\mathrm{D}_{\mathrm{u}}} ; \mathrm{K}=\frac{\mathrm{P}_{\mathrm{O}}}{\mathrm{P}_{\mathrm{u}}} \\
& \mathrm{K}=\frac{0.65 \times \mathrm{K}_{1} \times \mathrm{K}_{\mathrm{raw}}}{\left(1-\mathrm{V}_{2}\right) \times\left(\mathrm{K}_{\mathrm{r}} \times \mathrm{K}_{\mathrm{raw}}+1\right) \times \mathrm{K}_{\mathrm{ss}}} \\
& \mathrm{K}=\frac{0.77 \times \mathrm{K}_{1} \times \mathrm{K}_{\mathrm{raw}} \times \mathrm{K}_{\mathrm{ci}}}{\left(1-\mathrm{V}_{2}\right) \times\left(\mathrm{K}_{\mathrm{r}} \times \mathrm{K}_{\mathrm{raw}}+1\right) \times\left(\mathrm{K}_{\mathrm{ci}}+1\right) \times \mathrm{K}_{\mathrm{ss}}} \\
& \mathrm{K}=\frac{0.77 \times \mathrm{K}_{\mathrm{cis}}}{\mathrm{V}_{2}+\mathrm{K}_{\mathrm{rpe}} \times \mathrm{K}_{\mathrm{cis}}} \\
& \mathrm{K}_{1}-\text { coefficient of exterior wall influence; } \\
& \mathrm{K}_{\text {raw }}-\text { coefficient of radiation attenuation through an exterior wall; } \\
& \mathrm{V}_{2}-\text { coefficient of the construction width; } \\
& \mathrm{K}_{\mathrm{r}}-\text { coefficient of radiation penetration through openings; } \\
& \mathrm{K}_{\mathrm{ss}}-\text { coefficient of influence of surrounding structures; } \\
& \mathrm{K}_{\mathrm{ci}}-\text { coefficient of floor construction influence; } \\
& \mathrm{K}_{\mathrm{cis}}-\text { coefficient of floor construction influence (for shelters with superstructures); } \\
& \mathrm{K}_{\mathrm{rpe}}-\text { coefficient of radiation penetration through the entrance. }
\end{aligned}
$$

The areal density of walls and structures of the building - this is one of the most important aspects affecting the protective properties of the building It affects protection against all the effects of nuclear weapons. When protected against initial radiation, it represents an obstacle that directly shields radioactive radiation. When dealing with the fire safety of buildings within the protection against light and thermal radiation, it is necessary to know the values of fire resistance of construction products and structures and to design structures, that meet the required values of fire resistance. The areal density is used for the purposes of protective properties of buildings; it indicates the density of a specific construction in relation to its thickness. The area density is determined according to equation 5 .

$$
\begin{aligned}
& \rho_{\mathbf{a}}=\mathbf{H} \times \mathbf{x}\left[\mathrm{kg} \cdot \mathrm{m}^{-2}\right] \\
& \text { where: } \rho_{\mathrm{a}}-\text { area density; } \\
& \mathrm{H}- \text { density; } \\
& \mathrm{x}- \text { wall thickness. }
\end{aligned}
$$


The equation shows a direct relationship between the density of the material and the areal density. It is the most advisable to use materials with higher density. Due to the planned implementation of construction work in the time of a higher risk of using WMD, it is necessary to count on chaos and panic. Therefore, when selecting materials, it is necessary to consider their availability in the vicinity of shelters and their properties when performing construction work. The availability of materials is important and represents the primary evaluation aspect. It should be noted that the adjustment of the improvised shelter may take place during a state of war, when it will not be possible to secure supplies of material. Therefore, it is necessary to use materials from local sources (Tab. 31).

\section{Example:}

The spaces intended for building a shelter are shown in Figure 48. The thickness of the ceiling is $0.4 \mathrm{~m}$; the thickness of outside walls is $0.5 \mathrm{~m}$. The material of outside walls and the floor construction is reinforced concrete tamped manually. The spaces have one entrance, the size of which is $2 \times 1 \mathrm{~m}$. The entrance is direct, then twice curved at an angle of $90^{\circ}$. The construction work improves protective properties that represent particular materialization of the entrance. It is a completely buried building, so we use equation [4].

$$
\mathrm{K}=\frac{0.77 \times \mathrm{K}_{\mathrm{cis}}}{\mathrm{v}_{2}+\mathrm{K}_{\mathrm{rpe}} \times \mathrm{K}_{\mathrm{cis}}}
$$

For the calculation of the protective coefficient of the building, it is necessary to determine coefficients $\mathrm{K}_{\text {cis }}$ (coefficient of floor construction influence - for shelters with superstructures), $\mathrm{K}_{\text {rpe }}$ (coefficient of radiation penetration through the entrance) and $V_{2}$ (coefficient of the building width). First of all, it is necessary to determine the areal density of the floor construction according to equation [5].

$$
\boldsymbol{\rho}_{\mathbf{a}}=\mathbf{H} \times \mathbf{x} ; \quad\left[\mathrm{kg} \cdot \mathrm{m}^{-2}\right]
$$

The floor construction is made of reinforced concrete tamped manually and its width is $0.4 \mathrm{~m}$. We will find out the density value of this material $\left(2,400 \mathrm{~kg} \cdot \mathrm{m}^{-3}\right)$ from Table 31 and substitute it into the equation:

$$
\rho_{\mathrm{a}}=2,400 \times 0.4=960 \mathrm{~kg} \cdot \mathrm{m}^{-2}
$$

Table 31: Comparison of the density of building materials and their availability in crises. [Source: Tab-31]

\begin{tabular}{|c|c|c|}
\hline Material type & $\begin{array}{c}\text { Density } \\
\left(\mathrm{kg} \cdot \mathrm{m}^{-3}\right)\end{array}$ & Availability \\
\hline brick chippings & 1,200 & $\begin{array}{c}\text { medium, } \\
\text { import }\end{array}$ \\
\hline stone chips & 1,800 & easy, import \\
\hline crushed stone & 1,700 & easy, import \\
\hline fireclay bricks & 1,900 & $\begin{array}{c}\text { medium, } \\
\text { import }\end{array}$ \\
\hline foam concrete blocks & 800 & $\begin{array}{c}\text { medium, } \\
\text { import }\end{array}$ \\
\hline stone block pavement & 2,600 & easy, import \\
\hline softwood & 650 & easy, import \\
\hline hardwood & 850 & easy, import \\
\hline steel - iron & 7,850 & $\begin{array}{c}\text { medium, } \\
\text { import }\end{array}$ \\
\hline sand, clayey sand, gravel sand & 2,000 & easy, local \\
\hline clay, silty clay, loam & 2,000 & easy, local \\
\hline solid burnt brick masonry & 1,800 & easy, local \\
\hline $\begin{array}{c}\text { plain concrete } \\
\text { (tamped manually) }\end{array}$ & 2,200 & easy, import \\
\hline $\begin{array}{c}\text { reinforced concrete } \\
\text { (tamped manually) }\end{array}$ & 2,400 & $\begin{array}{c}\text { medium, } \\
\text { import }\end{array}$ \\
\hline $\begin{array}{c}\text { lightweight concrete } \\
\text { (foamed concrete) }\end{array}$ & 300 & $\begin{array}{c}\text { medium, } \\
\text { import }\end{array}$ \\
\hline $\begin{array}{c}\text { cement mortar } \\
\text { lime mortar }\end{array}$ & 2,000 & easy, import \\
\hline & 1,700 & easy, import \\
\hline
\end{tabular}

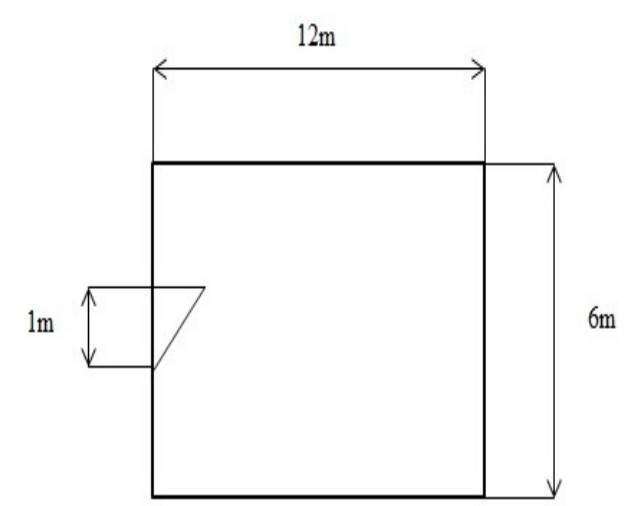

Figure 48: Basic dimensions of a shelter. [Source: Fig-48] 
We will read coefficient $\mathrm{K}_{\text {cis }}$ from Graph 3 based on the areal density of the floor construction: $\mathrm{K}_{\mathrm{cis}}=300$.

The last necessary information is coefficient $K_{r p e}$, which we determine from the equation: $\quad \mathbf{K}_{\mathbf{r p e}}=\mathbf{K}_{\text {epp }} \times \mathbf{P} ; \quad[6]$ where:

- $\mathrm{K}_{\text {epp }}$ is the coefficient characterizing the disposition location of the entrance and its protective properties (see Table 32).

- $\mathrm{P}$ is the type and character of the entrance (see Table 33).

The height of the shelter door is $2 \mathrm{~m}$ and its width $1 \mathrm{~m}$. From Figure 48 we can also determine the distance of the entrance from the centre, which is $6 \mathrm{~m}$. Thus, the value of coefficient $\mathrm{K}_{\text {epp }}$ is 0.015 .

The type of the entrance is direct, twice curved at an angle of $90^{\circ}$, thus coefficient $\mathrm{P}$ is 0.2 . After the substitution into equation 6 , we will calculate the value of coefficient $\mathrm{K}_{\text {rpe: }}$

$$
\mathrm{K}_{\text {rpe }}=0.015 \times 0.2 \Rightarrow \mathrm{K}_{\mathrm{rpe}}=0.003
$$

The last unknown is $V_{2}$, i.e. the coefficient of the building width, which we determine from Tab. 34. If the exact value cannot be determined from the table, we will find it using the interpolation of values in the table. The building width, in which the shelter occurs, is $12 \mathrm{~m}$.

The value of coefficient $\mathrm{V}_{2}$ is 0.24 . After the substitution in the equation for calculating the protective coefficient of the building, we get the final value:

$$
\mathrm{K}=\frac{0.77 \times 300}{0.24+0.003 \times 300}=\underline{\underline{\mathbf{2 0 2}}}
$$

The value of the protective coefficient of the building is 202 without the construction work. The construction work will represent the materialization of the entrance using a layer of bricks and the building of an entrance alcove (with the same areal density as in the outside walls and floor constructions). After performing construction work, coefficient $\mathrm{K}_{\mathrm{rpe}}$ will be equal to 0 .

If we substitute it again into the equation for calculating the protective coefficient of the building, we will obtain a protective coefficient of the building after the construction work.

$$
\mathrm{K}=\frac{0.77 \times 300}{0.24+0}=\underline{\underline{\mathbf{9 6 2}}}
$$

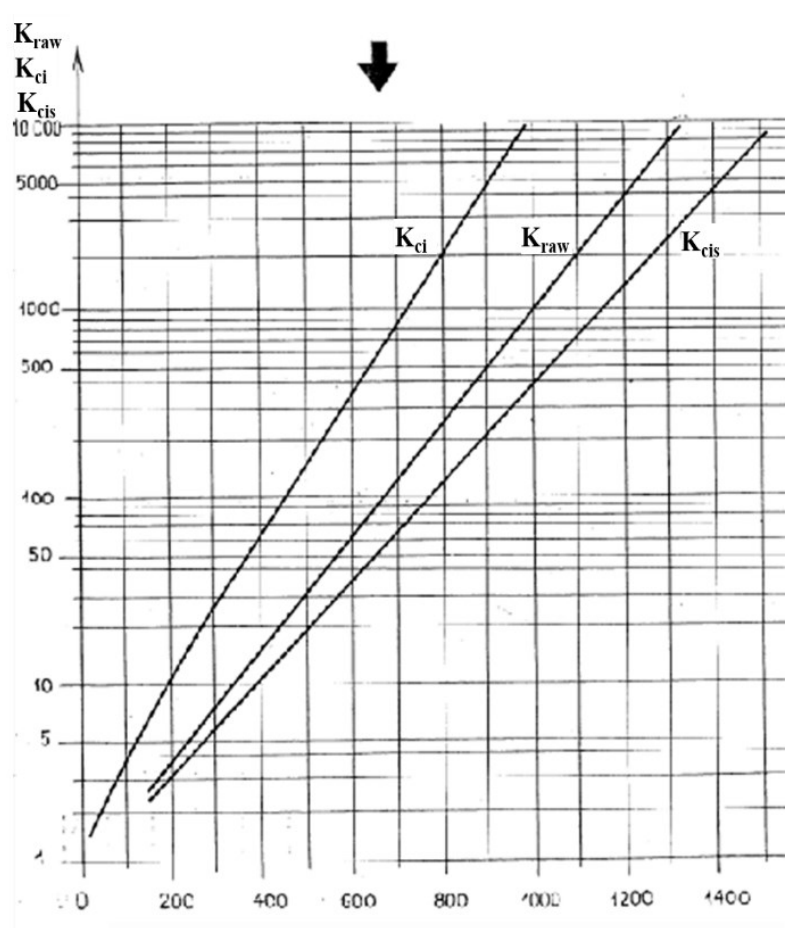

Area density of the floor construction $\left(\mathrm{kg}^{\mathrm{m}} \mathrm{m}^{-3}\right)$

Graph 3. Values of coefficients $K_{r a w}, K_{c i}$ and $K_{c i s}$ and the area density of the floor construction. [Source: Grph-3] Note:

$K_{\text {raw }}-$ coefficient of radiation attenuation through an outside wall.

$K_{c i}$ - coefficient of floor construction influence.

$K_{\text {cis }}$ - coefficient of floor construction influence (for shelters with superstructures).

Improvised shelters can be divided into materialization of the entrance, the value of the protective coefficient of the building will increase to 962 .

ventilated and unventilated shelters according to the method of ensuring the air for people in shelters. 
Gasproof shelters are designed primarily for command posts, first aid posts, communications nodes and alternating rest of troops. A gasproof shelter must provide the protection against the infiltration of the contaminated air and the delivery of air suitable for breathing.

Unventilated shelters are usually simple protective buildings without filtering and ventilation equipment. In these shelters all openings, through which the contaminated air could penetrate inside, are sealed and entrances are provided with hermetic curtains. It is possible to stay in unventilated shelters as long as there is enough air to breathe. One person needs 1 to $2 \mathrm{~m}^{3} \cdot \mathrm{h}^{-1}$ of air. If the air is contaminated in the outside environment, it is not possible to enter such a shelter or leave it.

Table 32: Values of coefficient $K_{\text {epp }}$ for different widths of the entrance $2 \mathrm{~m}$ high. [Source: 9.3.31]

\begin{tabular}{|c|c|c|c|}
\hline \multirow{2}{*}{$\begin{array}{l}\text { Distance } \\
\text { of entrances } \\
\text { from the } \\
\text { centre of the } \\
\text { shelter }(\mathrm{m})\end{array}$} & \multicolumn{3}{|c|}{$\begin{array}{l}\text { Width of the entrance } \\
(\mathrm{m})\end{array}$} \\
\hline & 1 & 2 & 4 \\
\hline 1.5 & 0.1 & 0.17 & 0.22 \\
\hline 3 & 0.045 & 0.08 & 0.12 \\
\hline 6 & 0.015 & 0.03 & 0.045 \\
\hline 12 & 0.007 & 0.015 & 0.018 \\
\hline 24 & 0.004 & 0.005 & 0.007 \\
\hline
\end{tabular}

Table 33: Values of coefficient P. [Source: 9.3.32]'

\begin{tabular}{|c|c|}
\hline Type of entrance & Coefficient P \\
\hline Staircase directly from the ground surface & 1 \\
\hline Direct entrance curved at an angle of $90^{\circ}$ & 0.5 \\
\hline $\begin{array}{c}\text { Direct entrance curved 2x at an angle } \\
\text { of } 90^{\circ}\end{array}$ & 0.2 \\
\hline Vertical entrance with a trap door & 0.5 \\
\hline Vertical entrance with a corridor & 0.2 \\
\hline
\end{tabular}

Table 34: Values of coefficient V2. [Source: 9.3.33]

\begin{tabular}{|c|c|c|c|c|c|c|}
\hline $\begin{array}{c}\text { Width of the build- } \\
\text { ing (m) }\end{array}$ & 3 & 6 & 12 & 18 & 24 & 48 \\
\hline${\text { Coefficient } V_{2}}^{2}$ & 0.06 & 0.16 & 0.24 & 0.33 & 0.38 & 0.5 \\
\hline
\end{tabular}

Calculating the time of a possible stay_in closed unventilated shelters or combat equipment is based on the following requirements:

- The oxygen content must not fall below $17 \%$;

- Carbon dioxide $\left(\mathrm{CO}_{2}\right)$ content must not exceed $2.5 \%$;

- The air temperature must not be higher than 27 up to $30^{\circ} \mathrm{C}$;

- The air humidity must not exceed $70 \%$.

Per capita it is calculated $2 \mathrm{~m}^{3}$ of the air per 1 hour sitting, a quiet activity. To achieve the overpressure, it must be counted on the air supply in about the fivefold capacity of the shelter in an hour; otherwise, sooner

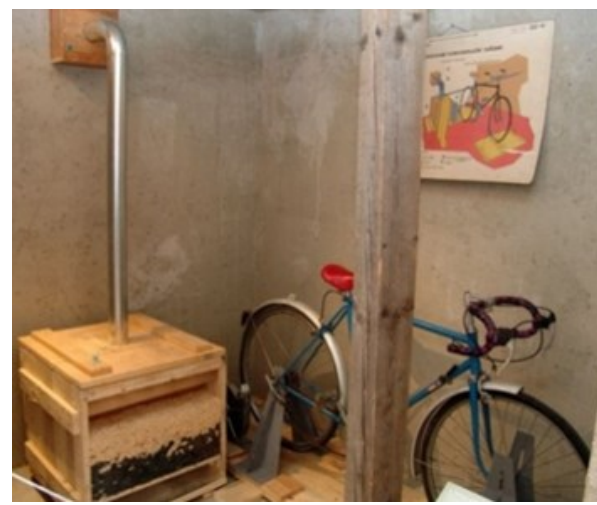

Figure 49: Example of an improvised shelter with air filtering equipment. [Source: Fig-49] or later the external contaminated air will enter the shelter.

The permissible period of sealing is calculated as follows:

$$
\mathbf{f}=\frac{\mathbf{k} \times \mathbf{W}}{\mathbf{n}}
$$

where: $f=$ permissible period of sealing;

$\mathrm{W}=$ internal volume of the shelter space in $\mathrm{m}^{3}$;

$\mathrm{n}=$ number of people present in the shelter;

$\mathrm{k}=$ coefficient, the value of which is: 1.2 for relaxation;

0.66 for work;

0.33 for medical shelters. 
After the lapse of the calculated time, it is necessary to ventilate the shelter well, otherwise the environment for work and relaxation will start to deteriorate sharply.

$A$ ventilated shelter protects against the effects of a pressure wave, light radiation and initial radiation at a certain distance from the explosion site. The length of stay in a ventilated shelter without a protective mask depends on:

- The degree of sealing doors, chimneys, inlets, etc;

- The amount of the suction fresh air; and

- The number of people who live in the shelter, enter it and leave it.

The chemical and climatic changes, which take place in a shelter due to exhaling carbon dioxide and releasing heat and moisture, should be kept in mind.

At higher temperatures and concentrations of carbon dioxide and lower oxygen content the people's health may be damaged. The reliability of a shelter depends on compliance with the rules for its use. After the announcement of a radiation or chemical alarm or after a nuclear explosion in the vicinity of the shelter, the filtration and ventilation equipment is switched off for 20 to 30 minutes and the insulation operation is switched on. During this period, it is prohibited to enter or leave the shelter. The hidden people must be at

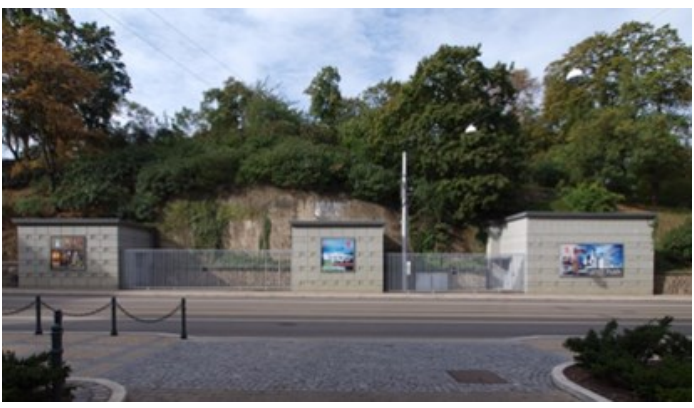

Photo 84: The civil protection shelters below the Spilberk Castle in Brno. [Source: Pho-84] rest to consume as little air as possible. During the action of the filtering and ventilation equipment, the shelter supervisor is obliged to check the purity of the air coming out of the filter using radiation and chemical survey devices.

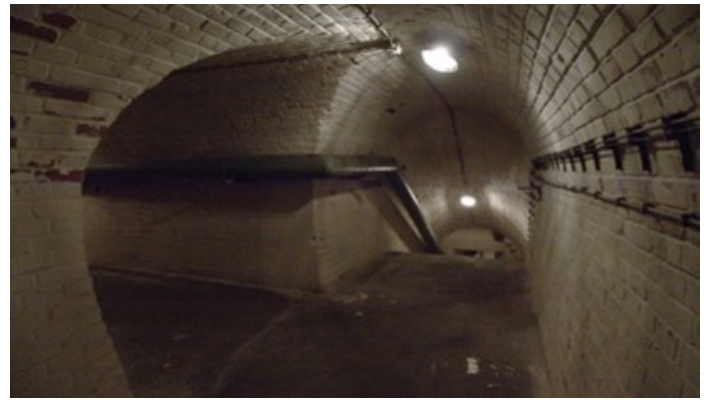

Photo 85: The civil protection shelters below the Spilberk Castle in Brno. [Source: Pho-85]

The entry and exit from the shelter take place with the consent of the shelter commander. It is necessary to observe strict rules when entering and leaving the shelter. The shelter has two hermetic doors and an external protective door (counterpressure - protecting against the pressure wave of a nuclear explosion). Only one door can be open at a time when leaving (or entering). People entering the shelter take off personal protective equipment or other contaminated parts in front of the entrance to the hall. If the outside air is contaminated with radioactive agents, the incoming people do not have to stay in the halls, but they must carefully shake off the radioactive dust from their clothing before entering the first hall. If the outside air is contaminated by chemical agents, the incoming people are obliged to stay in the first hall for 3 to 5 minutes, then they go to the second hall and there they stay again for 3 to 5 minutes before they can enter the shelter itself.
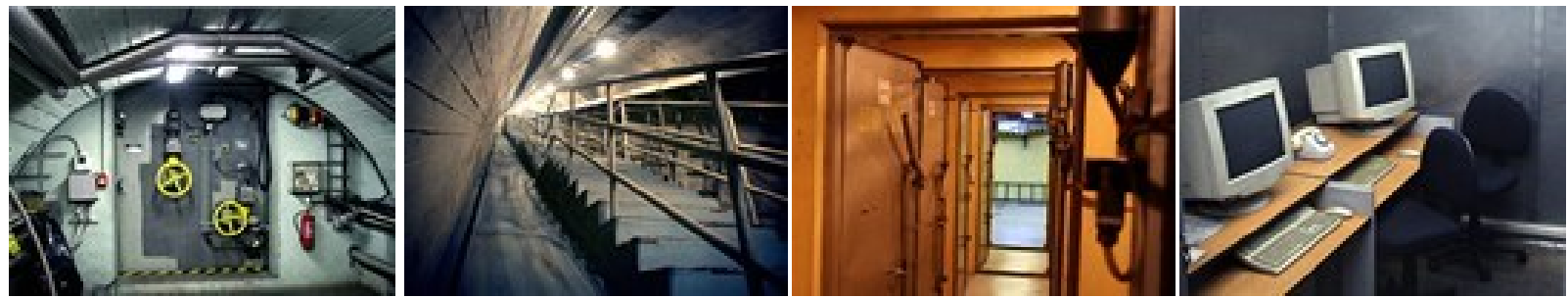

Photo 86-1 to 86-4: The civil protection shelters under the Strahov tunnel. [Source: Pho-86] 
All the people in a shelter must wear protective masks (respirators) in the standby position. It is forbidden to smoke in the shelter. It is necessary to leave the shelter in groups wearing protective masks or respirators without any delay in halls. In each shelter, a shelter supervisor and his/her assistant are determined. They ensure that order is maintained. When a chemical agent is detected in the shelter, a chemical alarm is sounded. The door is checked from time to time, especially after an explosion near the shelter. The entry and exit are permitted only with the consent of the commander of the shelter while observing the established rules. The last person closes all doors. When operating fans, the designated personnel take turns. When operating an electrically-driven device, the control valve may be opened so that the air meter indicator could show at the most $100 \mathrm{~m}^{3}$ on the filtering ventilation device, type FVZ-100 and at the most $150 \mathrm{~m}^{3}$ on the filtering ventilation device, type FVZ-150. The higher fan delivery is prohibited; there is a danger of electric motor destruction.

After building a shelter as well as during its operation, its tightness must be tested. Leaks in the shelter can be identified according to the penetration of light, the escape of smoke from the smoke pot lit inside the shelter and the rapid drop in overpressure created in the shelter. The shelter tightness tests must be always repeated after explosions in the vicinity of the shelter.

\subsubsection{Protection against the effects of non-explosive radiological weapons - case study}

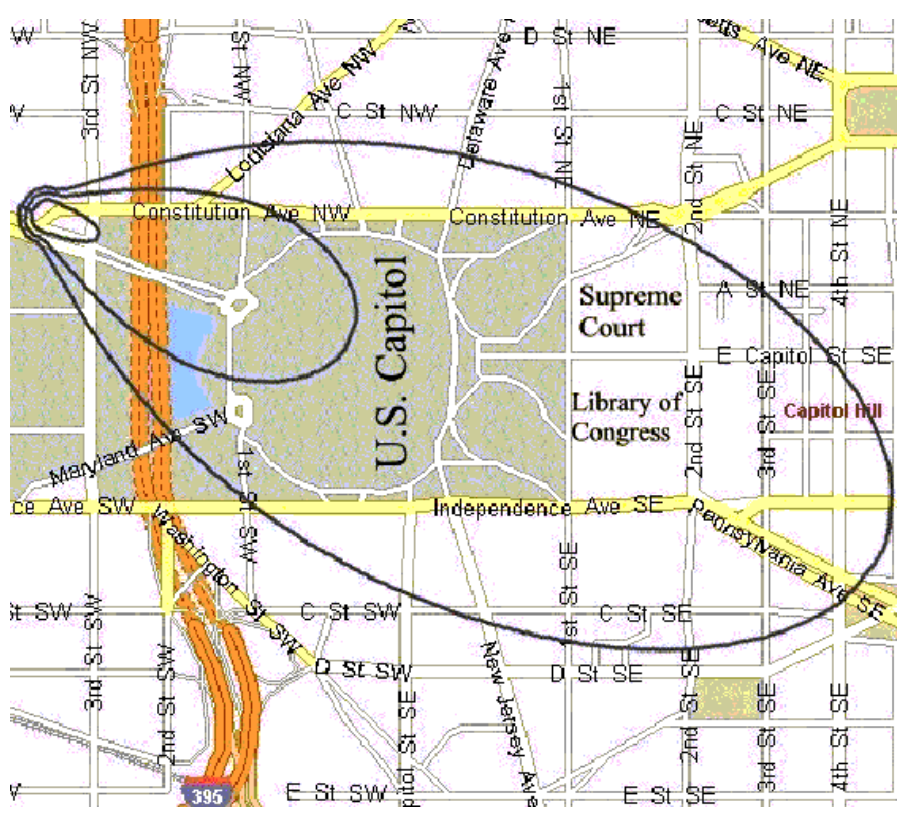

Figure 50: Long-term contamination when using a dirty bomb (caesium ${ }^{137} \mathrm{Cs}$ ) in Washington, D. C. [Source: Fig-50] Notes:

a) Inner zone: one death from cancer per 100 people due to residual radiation.

b) Medium zone: one death from cancer per 1,000 people due to residual radiation.

c) Outer zone: one death from cancer per 10,000 people due to residual radiation.

The Environmental Protection Agency (EPA) recommends decontamination. of wind, etc.) or the building materials used in the area (some radioactive agents are chemically combined with the materials, such as concrete, glass and asphalt).
The protection against the effects of non-explosive radiological weapons is basically the same as in the explosive nuclear weapons. The intensity of radiation is weakened by the barriers placed between the radiation source and the human body. The protection against gamma and neutron radiation is difficult. The intensity of radiation may be reduced depending on the type of material and its thickness. The basic rules of protection against the effects of radiological weapons are active defence or preventing their use, performing continuous radiological survey, implementing the measures to ensure radiation safety and minimizing the residence time in the contaminated area.

The effects of the so-called dirty bomb depend mainly on the type, duration and intensity of radiation and on the amount of the material used. Other influencing factors are the population density in the area of use, weather conditions during and after the explosion (rain, direction and force
some radioactive agents are chemically 
In November 2002, the Scientific American magazine considered the consequences of the explosive use of caesium $\left({ }^{137} \mathrm{Cs}\right.$ ), with an activity of $1.3 \times 10^{14} \mathrm{~Bq}$ (a material that terrorists could obtain in the former USSR) southeast of Manhattan. The catastrophe would be smaller than at Chernobyl; nevertheless, the area of $800 \mathrm{~km}^{2}$ would be contaminated more than the standards (even if strict) admit. In the area of about twenty streets, the residents (if decontamination did not occur) would be subject to a highly increased risk of cancer for thirty years. The area of about $15 \mathrm{~km}^{2}$ would have to be evacuated according to the recommendation of the International Commission on Radiological Protection (ICRP). Even if the permissible limits fell to a level used around Chernobyl, a hundred residential blocks would still be uninhabitable. Material damages would amount to milliards of US dollars and there would be no precedent for decontaminating such a large area in a densely populated city.

Experience would only be drawn from relatively small decontamination of company premises and from studies carried out during the Cold War on the consequences of nuclear war (or from contemporary exercises of armies and civil protection units).

Deployed units would first have to remove radioactive dust from external surfaces and from cracks and fissures, which could still be done at relatively low cost, as well as suction. However, where radioactivity would penetrate porous materials, the outer surfaces would have to be sandblasted or removed in another costly manner.

In many cases, the surface of roads and pavements would have to be removed as well as the top layers of the soil in parks and gardens. A large part of vegetation would be destroyed. Rust and mineral deposits, with which radioactive particles would mix, would have to be removed using acids and other chemicals.

It would be necessary to reassess the directives on the values of radiation developed for peacetime. If all districts were not evacuated, their citizens would have to bear a higher risk of cancer. Besides these direct effects of radiation, the psychological effects of using a radiological bomb (chaos, panic, stampede out of the city accompanied by congestions, mob mentality, etc.) would play an extremely important role.

In the case of more frequent or repeated use of the bomb, the unforeseen reactions

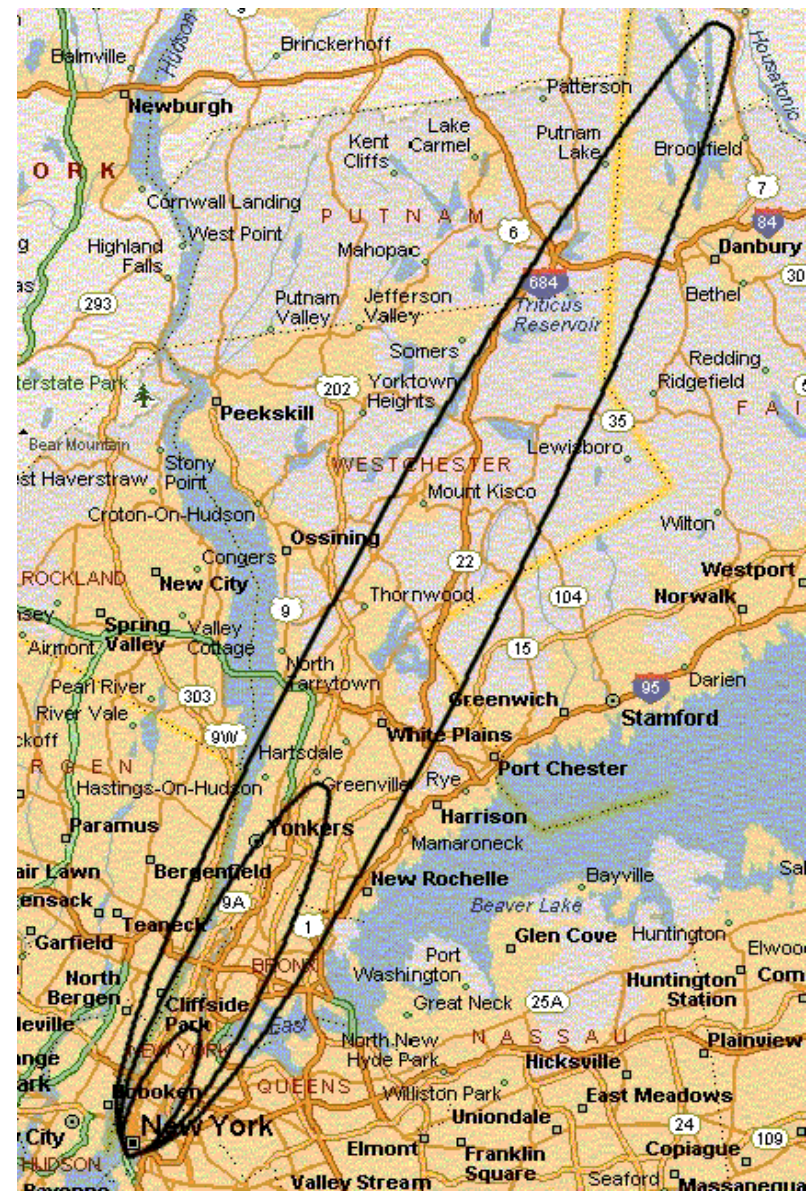

Figure 51: Long-term contamination when using a dirty bomb (cobalt $\left.{ }^{60} \mathrm{Co}\right)$ in Washington, D. C. [Source: Fig-51]

Notes:

a) Inner zone: one death from cancer per 100 people due to residual radiation.

b) Medium zone: one death from cancer per 1,000 people due to residual radiation.

c) Outer zone: one death from cancer per 10,000 people due to residual radiation.

Environmental Protection Agency (EPA) recommends decontamination of the population in affected countries or regions could occur in relation to the national representation, the political regime, etc. The above-mentioned effect of the bomb is, of course, a lure for numerous terrorist groups, particularly the Islamist ones. 
The fight against a dirty bomb used by terrorists or rogue states must, therefore, focus primarily on the prevention because, after the explosion, the above-mentioned adverse effects will occur, which will require a considerable and costly number of deployed units and equipment for decontamination. In the case of an attack, it is necessary to train relevant military and civilian components and to prepare residents for the desired behaviour, at least in the main features. It is extremely important to prevent panic, which may have, under certain circumstances, more tragic consequences than the effects of the bomb itself.

\subsection{Nuclear power facilities}

Today, the human population in the world exploits fossil fuels (coal $23 \%$, oil $35 \%$ and natural gas $21 \%$ ), uranium (7\%) and renewable energy sources (water $2 \%$, biomass $11 \%$ and the others $1 \%$ ). These resources are then used in the power engineering, heating plant industry, transport, industry, households and services. The world production of electric power is provided by coal-fired power plants $(39 \%)$, gas power plants $(18 \%)$, atomic power plants $(16 \%)$, hydroelectric power plants (17\%), oil-burning plants $(8 \%)$ and the others $(1 \%)$.

The first successful experiment with nuclear fission was carried out by Otto Hahn, Lise Meitner and Fritz Strassmann in Berlin in 1938. During World War II, a nuclear program got under way in a number of countries. On December 2, 1942, the first controlled chain fission reaction took place in the CP-1 reactor built by Enrico Fermi under the west stands of old University of Chicago's Stagg Field football stadium. The motivation for the experiments was both scientific and military - the reactors based on the results of Fermi's research were then used to produce plutonium for use in a nuclear weapon. After the dropping of atomic bombs on Hiroshima and Nagasaki, the construction of reactors for producing plutonium was also started in other countries. On December 20, 1951, the nuclear reactor was first used for power generation at the EBR-I research station near Arco (Idaho). The plant, based on a fast breeding reactor, initially supplied an output of around $100 \mathrm{~kW}$.

The nuclear power plant in Obninsk in the Soviet Union is often referred to as the first nuclear power plant. It was connected to the grid on June 27, 1954. Graphite as a moderator and water as a coolant were used in a $5 \mathrm{MW}$ reactor. However, the Calder Hall nuclear power plant in Great Britain, which came into operation on October 17, 1956, is considered to be the world's first power station; it began generating electricity on August 27, 1956. The use of nuclear energy then developed rapidly. In 1960, the installed capacity was less than 1 gigawatt $(\mathrm{GW})$, in the late 1970s, it was $100 \mathrm{GW}$ and in the 1980s, it was $300 \mathrm{GW}$. Since the late $1980 \mathrm{~s}$, the increase has been much slower, largely due to the construction of nuclear power plants in China. In 2005, the installed nuclear capacity was $366 \mathrm{GW}$. A wave of resistance against the use of nuclear energy has risen in many countries. It was based on fears of an accident such as the Chernobyl accident (1986) and fear of radiation. Austria (1978), Sweden (1980) and Italy (1987) even held referendums, which resulted in the abandonment of the use of nuclear energy; however, Sweden later re-evaluated its decision.

Other reasons for slowing down the construction of nuclear resources were economic. Nuclear energy is very cheap in terms of the production itself; however, the investment costs in the construction and decommissioning of nuclear power plants are very high, while the cost of fossil fuels is relatively low. But the industry, despite of the fact that new nuclear resources in the vast majority of countries were not being built and the electricity consumption was growing, managed to maintain its percentage share of production. This was achieved through numerous technical improvements, which enhanced the installed capacity above the original design limit by improving production efficiency and by shortening necessary maintenance shutdowns (some power plants run as much as $90 \%$ of the time). 
The condition was to maintain the security level. The economic benefits have also increased after it has been shown that the individual nuclear power plants can be operated safely for a significantly longer period of time than it was planned originally. Currently, the nuclear energy industry is able to produce the cheapest electricity.

At present, a nuclear power renaissance occurs - in Romania, a new nuclear power unit of the nuclear power plant in Cerna Vodă has been launched, a new nuclear power plant unit is also being built in Finland (Olkiluoto) and in France. France has decided on the construction of other new nuclear power plant units, which should replace the older ones.

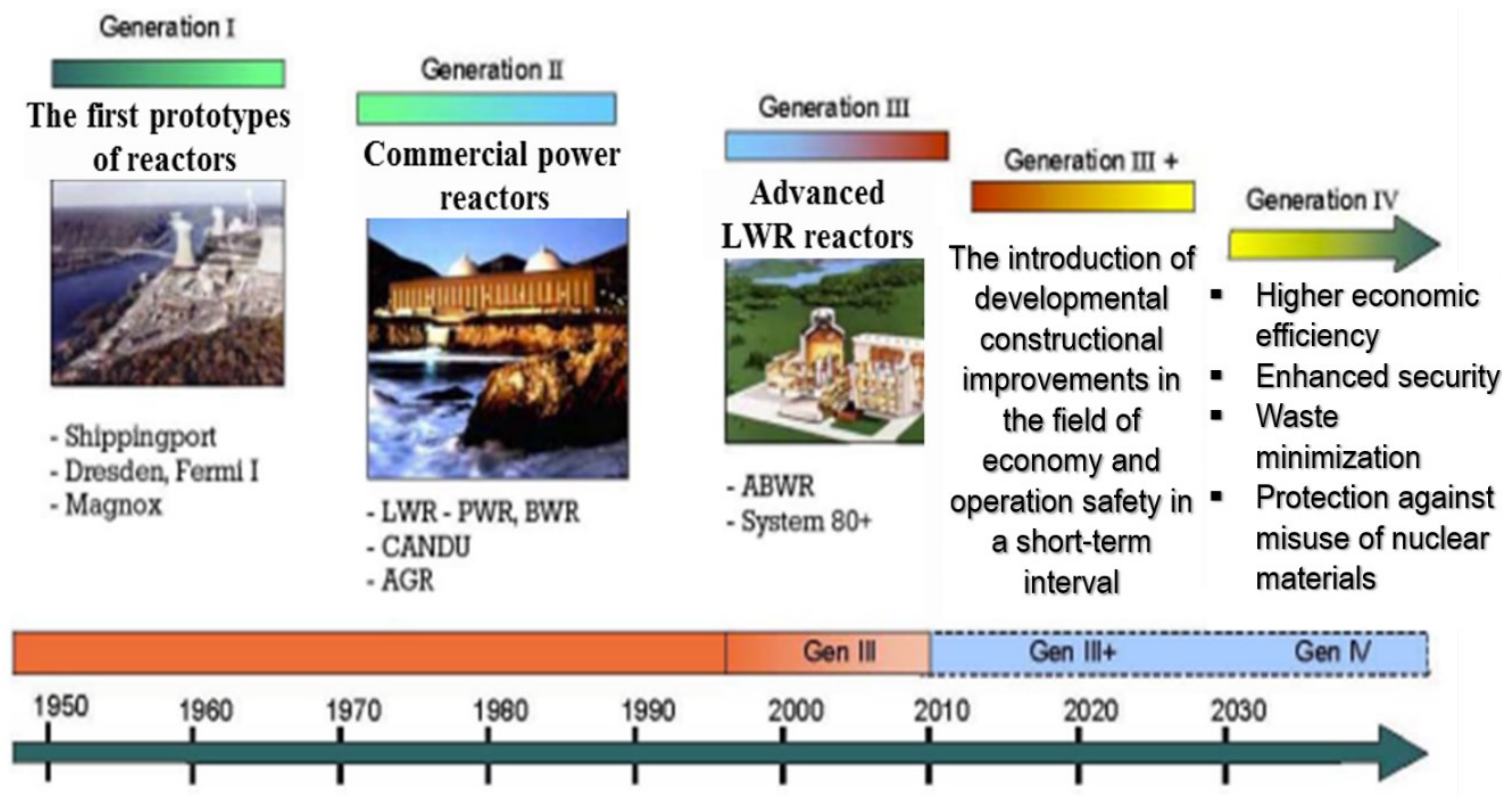

Figure 52: Development of nuclear reactors. [Source: Fig-52]

For instance, Bulgaria, Lithuania (a joint project with Latvia, Estonia and initially also with Poland) and Slovakia have decided to build new units, which should replace the units decommissioned for a low security level after joining the EU. Asian nations, especially China, India and Japan, have been developing nuclear energy industry. Russia and Ukraine also want to substantially increase the share of nuclear energy production. Great Britain has also decided for the construction of new nuclear power plants. Preparations for the construction of a nuclear power plant in the new location have also begun in Switzerland. Turkey, the United Arab Emirates and Egypt have also decided on the construction of new nuclear power plants. Other states, which intend to develop the nuclear energy industry or even have decided on it, are e.g. South Africa, Slovenia, Albania, Poland, the Netherlands, Jordan, Brazil and many others.

Although the accidents at Chernobyl (in 1986) and in Japan's Fukushima Daiichi (in 2011) inflicted a heavy blow to the nuclear energy industry, China and India, the countries planning to build the largest number of new power plants, have confirmed their orientation to the nuclear energy industry. However, Germany has decided to shut down its nuclear plants by 2022.

An American documentary featured on TV Nova in 2006 (CME 21 Ltd.) within the Seconds from Disaster series describes the Chernobyl accident. The strength of an atom is to become an unlimited source of cheap energy for the Soviet Union. At Chernobyl, there is the latest triumph of the Soviet science, but it soon will not be true. In just an hour and twenty-four minutes, the routine safety test will get out of control. Thirty-one people will die. Hundreds of others will be affected and the toxic cloud will get above Asia and the United States. The document can be viewed at http://dokumenty.tv/cernobyl-vteriny-pred-katastrofou-dokument/. 
An American documentary featured on the National Geographic Channel in 2012 (NGC Network International, LLC) within the Seconds from Disaster series describes the accident in the Japanese Fukushima on March 11, 2011. The nuclear power plant was first hit by a destructive earthquake that devastated the entire north-eastern part of the country. Experts designated it as the greatest earthquake in history that struck Japan. With regard to the fact that the epicentre was located in the sea $130 \mathrm{~km}$ from the coast, a series of large tsunami waves devastated many coastal areas and instigated the major nuclear accident at the Fukushima power plant. The forty-five-minute documentary can be viewed at http://dokumenty.tv/fukusimavteriny-pred-katastrofou-dokument/.

As of April 01, 2015, in 30 countries of the world, 437 nuclear reactors with a total installed capacity of 380,770 MWe were in operation according to the statistics of the World Nuclear Association (WNA). A total of 65 of them is being under construction in 14 countries. The construction of 165 reactors is planned. Next 316 reactors, the installed capacity of which would reach about $363,000 \mathrm{MW}$, are considered preliminarily. They produce about $16 \%$ of the world's electricity worldwide. Most nuclear sources are in the USA, France, Japan, Great Britain and Russia.

In Asia, a number of new nuclear power plants, especially in China, India, South Korea and Japan, are under construction. In Europe, Olkiluoto 3 in Finland and Flamanville in France, both with European pressurized water reactors (EPRs), are under construction as well as two units on the site of the former village of Mochovce in Slovakia. In the USA, new types of reactors are licensed, preliminary building permissions are issued and the life of many existing reactors is extended. After thirty years, when the existing power plants were modernized only, the new Virgil C. Summer Nuclear Station, Unit 2 in South Carolina has been under construction.

The most common types are so-called light water reactors. They represent $80 \%$ of all reactors in operation in the world (of which pressurized water reactors $-59 \%$ and boiling water reactors $-21 \%$ ), and conceptually they are quite different from the RBMK-type that caused the Chernobyl accident in 1986 due to a failure of the human factor. Currently, the offered projects of the so-called Generation III+ are the AP 600 and AP 1000 pressurized water reactors (Westinghouse), the EPR (Framatome ANP), the VVER 1000 (Atomstroyexport) and the boiling water reactors (BWR) SWR 1000 (Framatome ANP - Siemens), the ABWR (General Electric) and the BWR 90+ (Westinghouse Atom). The 1,600 MWe Franco-German EPR reactor became a winner for the construction of the $5^{\text {th }}$ Unit in Finland. The Generation IV International Forum was initiated in 2000 when the USA convened the leaders of nuclear technology (the USA, France, Japan, South Korea, Great Britain, the EU and others).

The aim of this initiative is to develop technologies of the six selected types of reactors to be employed after 2025 (gas-, lead- and sodium-cooled fast reactors, high temperature gascooled reactors, supercritical water-cooled reactors and molten salt reactors). Great attention is paid to those types that, due to the high temperature, allow hydrogen production in addition to electricity production. Hydrogen is a fuel of the future, especially in transport, where it will replace petroleum products. Reactor safety is one of the main conditions of the development.

In the Czech Republic, a number of anti-nuclear movements set themselves against nuclear energy, e.g. the South Bohemian Mothers Association or the Czech branch of multinational Greenpeace; however, the majority of the population supports the development of nuclear energy. According to the National Energy Policy approved by the Government of the Czech Republic on March 10, 2004 by Resolution No. 211, the operation of the $7^{\text {th }}$ nuclear unit is planned for the period between 2020 and 2025 and the operation of the $8^{\text {th }}$ nuclear unit for the period between 2025 and 2030. 


\section{Deployment of nuclear reactors in Europe}

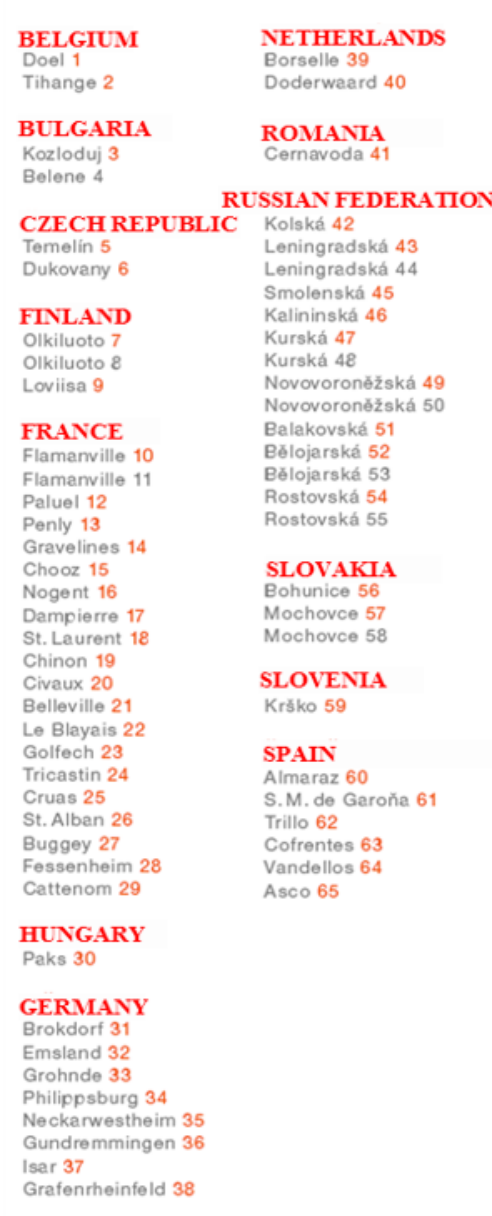

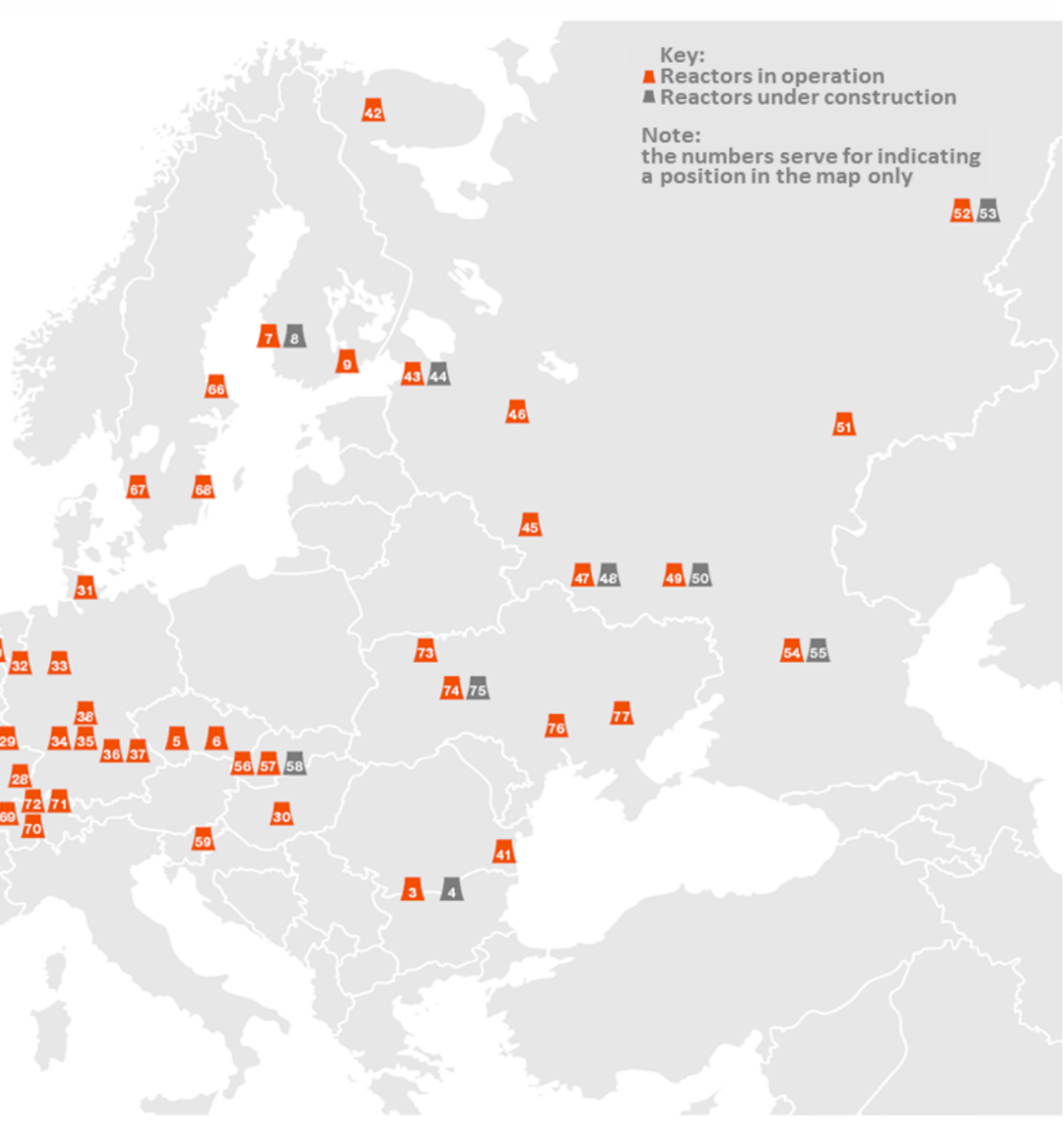

Figure 53: Deployment of nuclear reactors in Europe. [Source: Fig-53] 
In 2006, under pressure of the Green Party, the coalition government, in its programmatic statement, promised not to support further construction of nuclear units. In 2008, the so-called Pačes Commission recommended the development of the nuclear energy industry in the Czech Republic. The current government is supporting the development of nuclear power engineering again. It considers finishing the $3^{\text {rd }}$ and $4^{\text {th }}$ units at the Temelín nuclear power plant.

\subsubsection{Nuclear reactor}

A nuclear reactor is a device, in which the energy released during nuclear fission converts into thermal energy, which is then used in a classical power plant to produce electricity. Reactors have various constructions, the principles of operation as well as the area of use.

\section{Boiling Water Reactor (BWR)}

The BWR boiling reactor is the second most common type. The fuel is slightly enriched uranium in the form of uranium dioxide cylinders arranged in

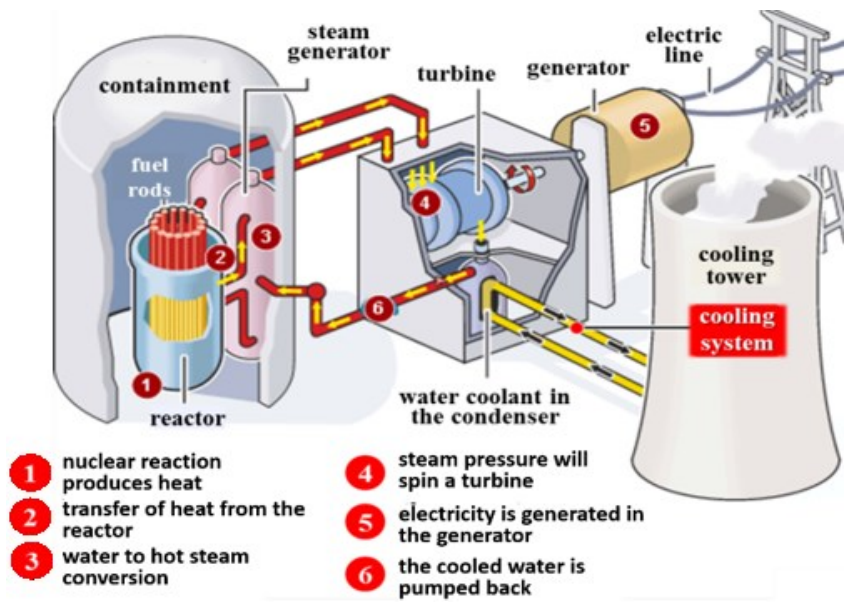

Figure 54: Nuclear boiling water reactor. [Source: Fig-54]

fuel rods. The fuel is changed as frequently as in the case of pressurized water reactors (PWR). The core and plain water as a coolant and moderator are similar. The water is heated to boiling directly in the pressure vessel and the steam accumulates in the upper part of the reactor.

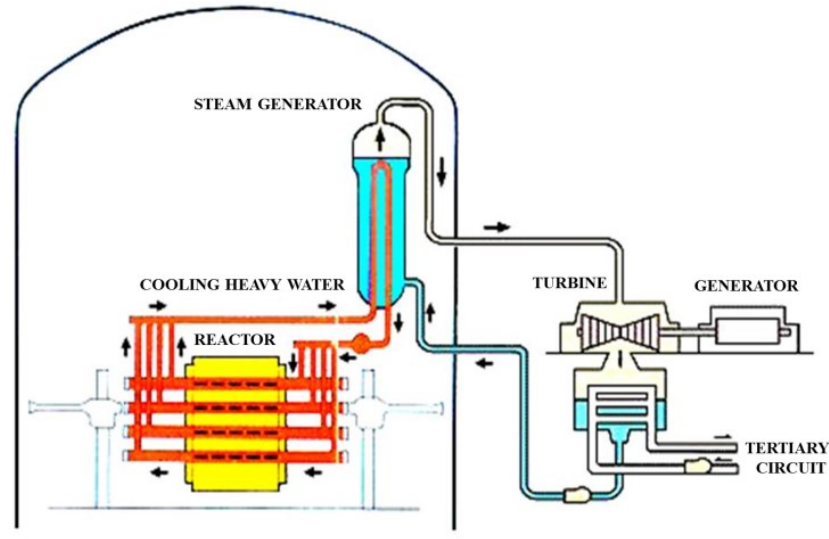

Figure 55: CANDU 6 nuclear reactor. [Source: Fig-55]
The BWR parameters (1,000 MW): $2.6 \%$

- Isotope ${ }^{235} \mathrm{U}$ is enriched to 2.1 up to

- The dimensions of the core $-4.5 \mathrm{~m}$ in diameter and $3.7 \mathrm{~m}$ in height; and

- The temperature of steam at the reactor outlet $-286^{\circ} \mathrm{C}$ and the water pressure $-7 \mathrm{MPa}$.

\section{CANDU heavy water reactor}

The CANDU heavy water reactor was developed in Canada and exported to India, Pakistan, Argentina, Korea and

Romania. The fuel is natural uranium in the form of uranium dioxide; the coolant is heavy water $\left(\mathrm{D}_{2} \mathrm{O}\right)$, which also acts as a moderator. The reactor core is placed in a horizontal vessel in the shape of a lying cylinder. It is provided with horizontal vents for pressure pipes. The moderator in the vessel must be cooled, as the moderating ability decreases with increasing temperature. $\mathrm{D}_{2} \mathrm{O}$ from the first cooling circuit transfers its heat to the plain water in the steam generator where the steam is conducted to the turbine.

The CANDU reactor parameters (600 MW):

- The dimensions of the core $-7 \mathrm{~m}$ in diameter and $5.9 \mathrm{~m}$ in height;

- The pressure of heavy water in the reactor $-9.3 \mathrm{MPa}$; and

- The heavy water temperature at the reactor outlet $-305^{\circ} \mathrm{C}$. 


\section{Gas Cooled Graphite Moderated Reactor (Magnox GCR)}

The Magnox Gas Cooled Reactor (GCR) is used in the UK. The fuel is natural uranium metal in the form of rods covered with magnesium oxide. The core consists of graphite blocks (moderator), through which a few thousands of channels pass, in each of which several fuel rods are placed. The core is enclosed in a spherical steel pressure vessel with concrete shielding. The fuel is exchanged during operation. The coolant is carbon dioxide, which, after heating, is conducted to the steam generator where it transfers heat to the water of the second-

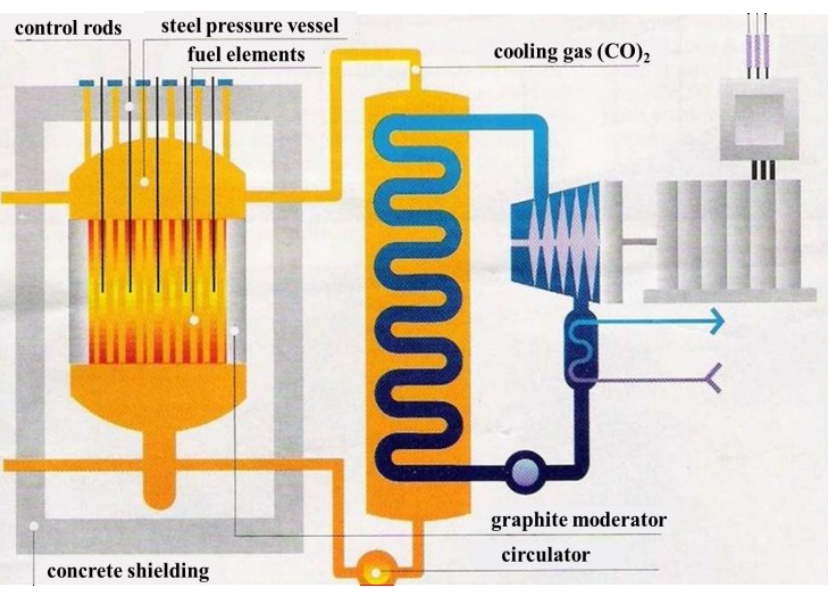

Figure 56: Magnox nuclear reactor. [Source: Fig-56] ary circuit.

The Magnox reactor parameters (600 MW):

- Isotope ${ }^{235} \mathrm{U}$ is enriched to $0.7 \%$;

- The dimensions of the core - $14 \mathrm{~m}$ in diameter and $8 \mathrm{~m}$ in height;

- The pressure of $\mathrm{CO}_{2}-2.75 \mathrm{MPa}$; and

- The temperature of $\mathrm{CO}_{2}$ at the reactor outlet $-400{ }^{\circ} \mathrm{C}$.

\section{Advanced Gas Cooled (Graphite) Reactor (AGR)}

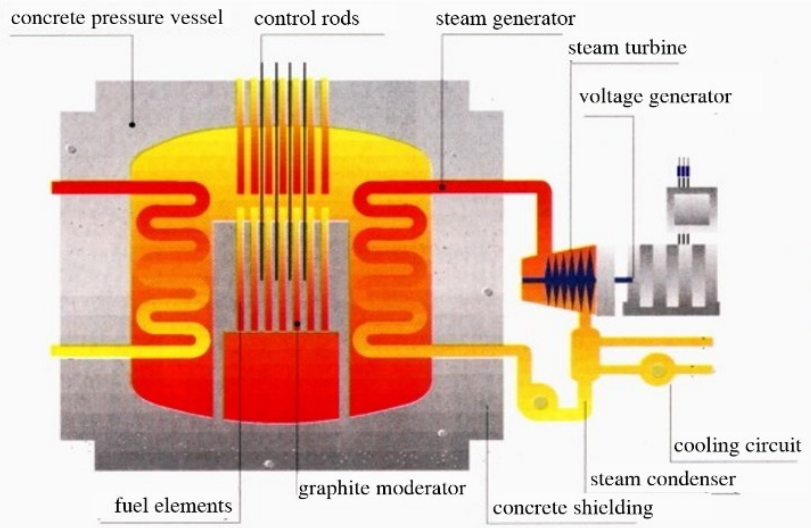

Figure 57: Nuclear advanced gas cooled reactor (AGR). [Source: Fig-57]

The Advanced Gas Cooled Reactor (AGR) is used exclusively in the UK. The fuel is uranium enriched with isotope ${ }^{235} \mathrm{U}$ in the form of uranium dioxide, the moderator is graphite, and the coolant is carbon dioxide. The power plant is two-circuit.

The AGR parameters (600 MW):

- Isotope ${ }^{235} \mathrm{U}$ is enriched to $2.3 \%$;

- The dimensions of the core $-9.1 \mathrm{~m}$ in diameter and $8.5 \mathrm{~m}$ in height; and

- The temperature of $\mathrm{CO}_{2}$ at the reactor outlet $-650{ }^{\circ} \mathrm{C}$ and the pressure

of $\mathrm{CO}_{2}-5.5 \mathrm{MPa}$.

\section{RBMK (Reactor Bolšoj Moščnosti Kanalnyj) High Power Channel Reactor}

The reactor of the Soviet type (the abbreviation of LWGR is also known) is used exclusively on the territory of the former USSR. The reactor of this type was at the first nuclear power plant in Obninsk as well as at Chernobyl.

Other reactors of this type have not been already built. The fuel is natural or slightly enriched uranium in the form of uranium dioxide. The fuel rods are placed in the channels, through which the coolant (plain water) flows. The water vapour is produced directly in pressure channels. It drives the turbine after the separation of moisture. The power plant is twocircuit. The moderator is graphite, which surrounds the channels. 
The RBMK parameters (1,000 MW):

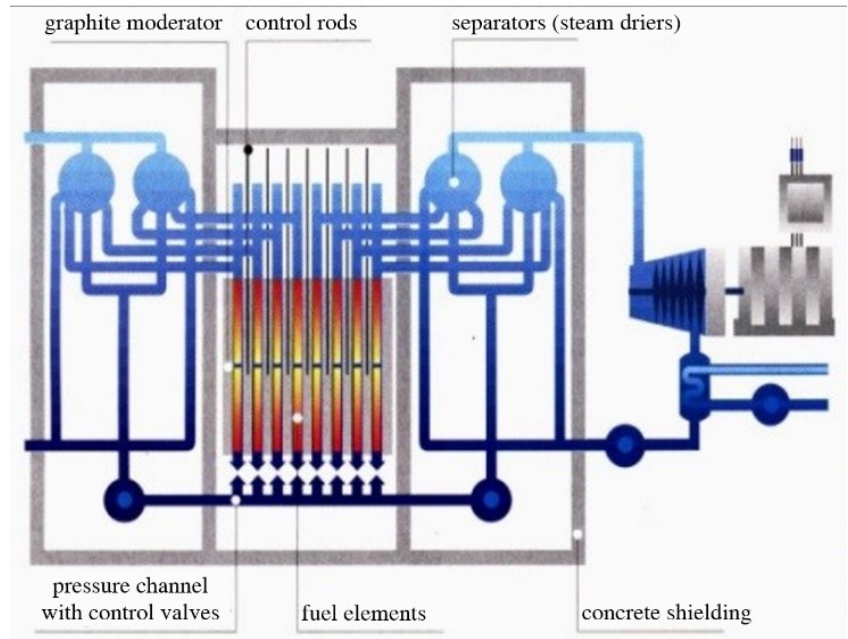

- Isotope ${ }^{235} \mathrm{U}$ is enriched to $1.8 \%$;

- The dimensions of the core $11.8 \mathrm{~m}$ in diameter and $7 \mathrm{~m}$ in height, the number of channels - 1,693; and

- The temperature of the steam-andwater mixture at the reactor outlet $284{ }^{\circ} \mathrm{C}$ and the saturated vapour pressure $-6.9 \mathrm{MPa}$.

\section{High Temperature Gas-Cooled Re- actor (HTGR)}

The High Temperature Gas-Cooled Reactor (HTGR) ranks among very perspective types of nuclear reactors. The se-

Figure 58: RBMK nuclear reactor. [Source: Fig-58]

curity of this type is at a high level, the reactor provides a very high temperature at the outlet. Therefore, it has a very high efficiency of electricity generation (up to 40\%). The heat can be used not only for generating electricity, but also directly in various industrial processes, e.g. in metallurgical processes or in coal gasification. So far, high-temperature reactors have only been developed experimentally in Germany, the USA and the United Kingdom. The fuel is highly enriched uranium in the form of small pellets of uranium dioxide.

The pellets coated with three layers of silicon carbide and carbon are dispersed in graphite pellets of roughly the size of a tennis ball. Graphite serves as a solid, heat-resistant shell of uranium as well as emerging radioactive residues and also as a moderator. The fuel pellets are freely poured into the core; at the bottom they are gradually removed. The coolant is helium circulated through the core.

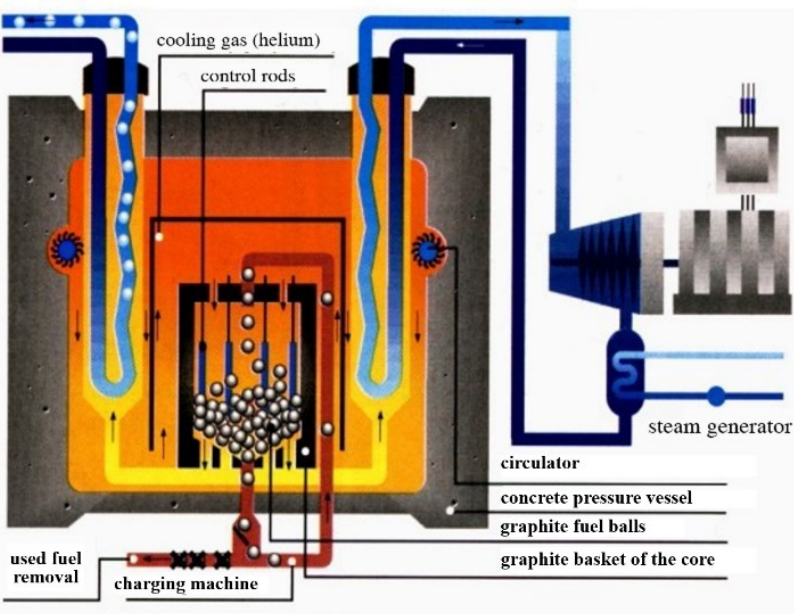

Figure 59: HTGR nuclear reactor. [Source: Fig-59]

The typical parameters of the RBMK (1,000 MW):

- Isotope ${ }^{235} \mathrm{U}$ is enriched to $93 \%$;

- The dimensions of the core $-5.6 \mathrm{~m}$ in diameter and $6 \mathrm{~m}$ in height;

- The temperature of helium at the reactor outlet $-284{ }^{\circ} \mathrm{C}$ and the pressure of helium - $4 \mathrm{MPa}$.

\section{Fast Breeder Reactor (FBR)}

The Fast Breeder Reactor (FBR) is in operation in Russia (BN-600 at Beloyarsk). It has operated in France (Superphoenix) and the UK. There are demonstration power plants of this type in the USA, Germany and Japan. New demonstration power plants are being built in Russia, Japan and India. In a long-term perspective, great importance is attached to these reactors.

The fuel is plutonium in the mixture of plutonium dioxide and uranium dioxide. During the operation it produces more new plutonium fuel than it burns it itself. The reactor has no moderator, the controlled fission reaction proceeds due to the action of fast neutrons. The core consisting of bundles of fuel rods is surrounded by the reactor blanket of uranium. 
Up to ten times more heat is released in each litre of the FBR volume than in conventional slow reactors. The coolant is sodium, which flows from the secondary circuit to the steam generator where it heats water in the third circuit and turns it into steam.

The FBR parameters (1,300 MW):

- Isotope ${ }^{235} \mathrm{U}$ is enriched to $5 \%$;

- The dimensions of the core $3.1 \mathrm{~m}$ in diameter and $2.1 \mathrm{~m}$ in height;

- The temperature of sodium at the reactor outlet $-620{ }^{\circ} \mathrm{C}$ and the pressure of sodium $-0.25 \mathrm{MPa}$.

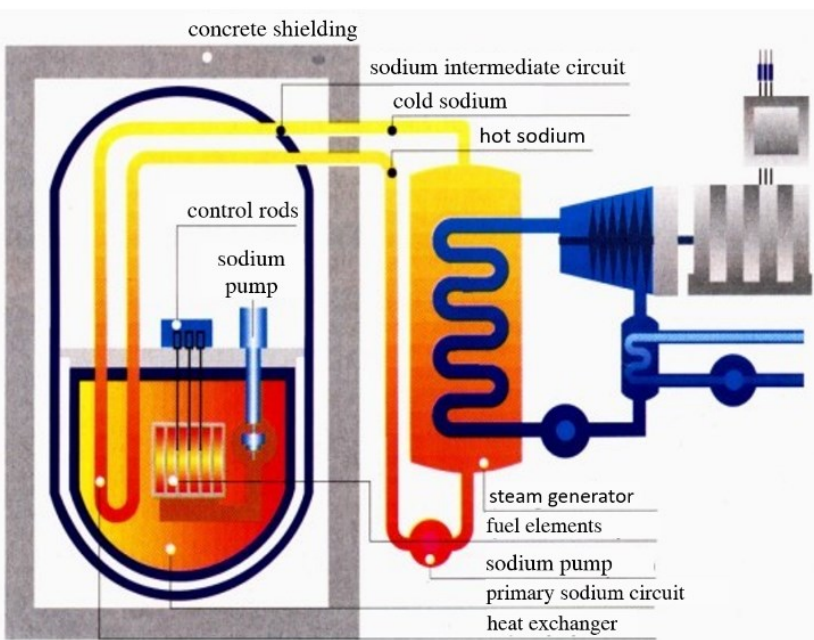

Figure 60: Nuclear reactor (FBR). [Source: Fig-60]

\section{European Pressurised Water Reactor (EPR ${ }^{\mathrm{TM}}$ )}

The European Pressurised Water Reactor $\left(\mathrm{EPR}^{\mathrm{TM}}\right)$ of the $3^{\text {rd }}$ generation is a significant project not only for future Europe. This reactor with an expected output of more than 1,500 MW is based on the experience of German and French nuclear power plants. In 1989, the German Siemens Company and the French Framatome founded a joint venture called Nuclear Power International to develop the $\mathrm{EPR}^{\mathrm{TM}}$ reactor. The $\mathrm{EPR}^{\mathrm{TM}}$ supplier for Olkiluoto 3 in Finland is the Areva-Siemens consortium. The project is designed as a turnkey contract for a fixed price. Due to the delay caused by various organizational reasons, it is also taken into account that its activation, originally planned for 2014, may be delayed up to two more years.

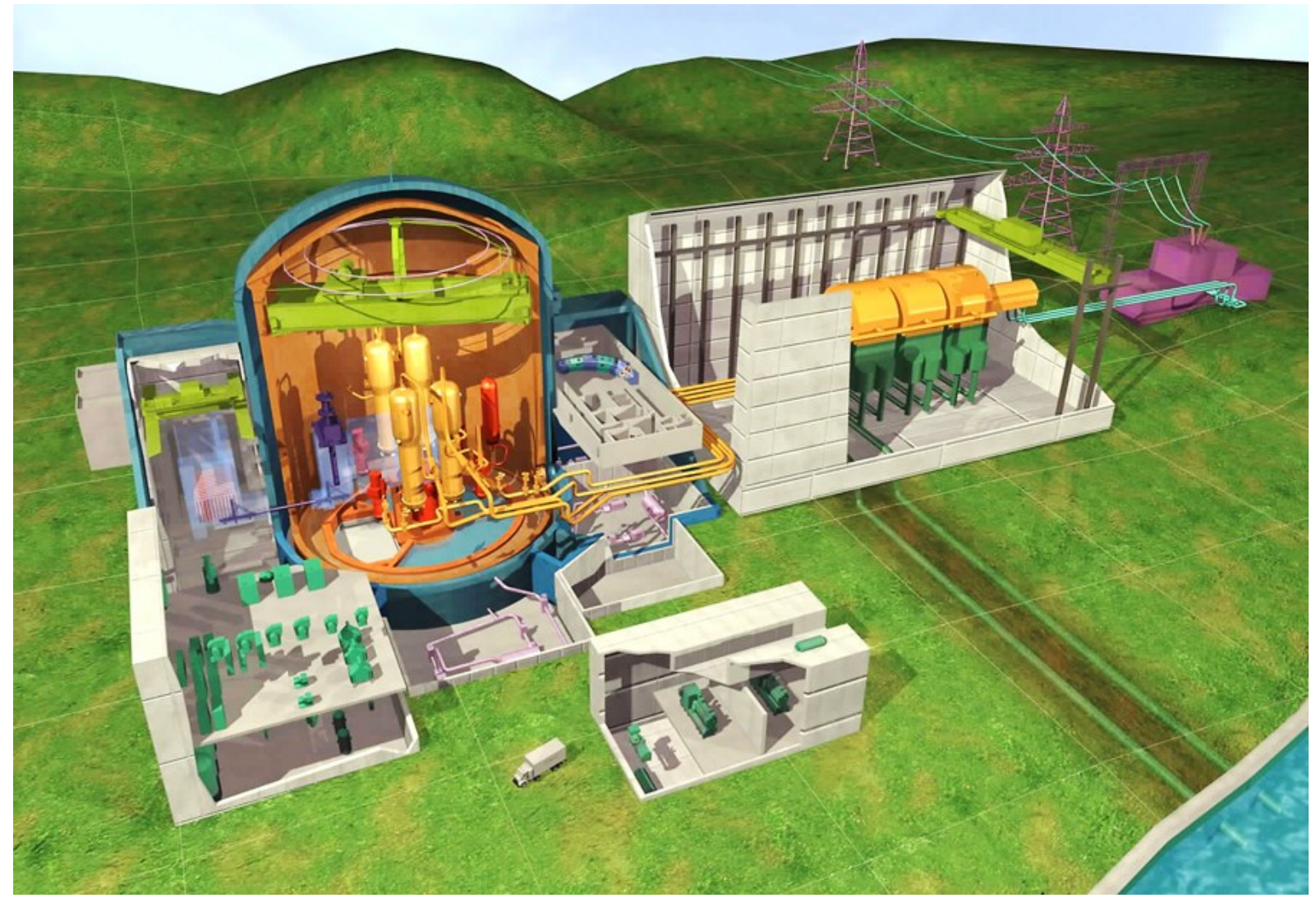

Figure 61: A virtual model of the section view through the unit with the EPR ${ }^{T M}$ reactor. [Source: Fig-61] 
The European pressurized water reactor has optimal safety characteristics. It is equipped with quadruple redundant safety systems, a double-walled containment and the so-called passive device (i.e. without intervention of the control technology) for the case there would be a core meltdown. The project focused on simplifying key structural elements, which brings both the increase in efficiency and safety and the price reduction. The first units are being built in Finland and France.

The nuclear unit with the EPR ${ }^{\mathrm{TM}}$ pressurized water reactor at Olkiluoto, Finland has been under construction since 2005. Several necessary adjustments have been identified that need to be made before the expected start-up in 2018. The construction work on the unit with an output of 1,650 MWe began in Normandy in France in December 2007. The designer of the project is the EDF Group, while Areva is responsible for the steam supply system and the Bouygues Construction Company leads a consortium of construction companies.

The dome of the reactor building was built in mid-July 2013 and the reactor vessel was installed in January 2014. The unit was originally expected to start commercial operation in 2013, but due to delays, it is now expected to start in 2017. Two more units with the EPR ${ }^{\mathrm{TM}}$ reactors are now under construction at the Taishan nuclear power plant in China. The first unit of the Taiwan NPP has been under construction since 2009 and is expected to be launched in 2016, while the second unit of the Taiwan NPP is expected to start one year later.

Typical parameters of the EPR $(1,650+\mathrm{MW})$ :

- The fuel enriched with $20 \%$ of $\mathrm{Pu}$;

- The dimensions of the core $-5.3 \mathrm{~m}$ in diameter and $10.6 \mathrm{~m}$ in height;

- The reactor thermal power - up to 4,590 MWt, the electric output - approx. 1,650 MWe;

- The thermal efficiency - up to $37 \%$;

- The length of the operating cycle - up to 24 months, the length of maintenance shutdown for refuelling only $<11$ days.

Other projects, such as the American AP 1000, the Russian VVER 1000 and V-392, the Japanese boiling ABWR / ESBWR or the German boiling SWR-1000 are also available for the European nuclear power plant operators. All have in common the philosophy of a passive (i.e. automatic) security system.

\subsubsection{Nuclear reactors in the Czech Republic-PWR and VVER}

\section{Pressurized Light-Water Moderated and Cooled Reactor (PWR) and Vodo-Vodjanoj Energetičeskij Reaktor (VVER)}

Nowadays, the Pressurized Water Reactor (PWR) or the Russian reactor (VVER) is the most common type of a nuclear reactor in the world (about $57 \%$ of all nuclear reactors). This reactor type works at both the Dukovany nuclear power plant and the Temelin nuclear power plant (see Tab. 35). It was originally developed in the USA; later, the concept was adopted by Russia. The same reactors, for their high safety, are used not only for nuclear power plants, but also for nuclear-powered submarines.

The fuel is enriched uranium in the form of uranium dioxide $\left(\mathrm{UO}_{2}\right)$, the moderator as well as the coolant is plain water. Natural uranium is composed of two isotopes with mass numbers 238 and 235. Only isotope 235 is suitable for fission; its amount in natural uranium is $0.7 \%$ and, therefore, the nuclear fuel must be enriched with this isotope artificially.

In a nuclear reactor, a controlled fission reaction takes place in the fuel. The nuclei of isotope ${ }^{235} \mathrm{U}_{92}$ affected by slow neutrons disintegrate into the nuclei of lighter elements (fragments) and simultaneously 2 to 3 fast neutrons liberate at each fission. The fragments repel one another and scatter at high speed. 
They are retarded due to collisions with other atoms of the fuel and the kinetic energy is converted to heat and the material is strongly heated. The liberated neutrons cause fission of other uranium nuclei and the nuclear reaction can continue to proceed as a controlled chain reaction.

The slower the bombarding neutrons, the greater the probability of uranium nucleus fission. During the fission, fast neutrons with a kinetic energy of up to $2 \mathrm{MeV}$ are produced. If they are to induce fission, their energy has to be reduced to 0.025 up to $0.5 \mathrm{eV}$. The degradation of neutrons happens due to their collisions with nuclei of the moderator, which sur-

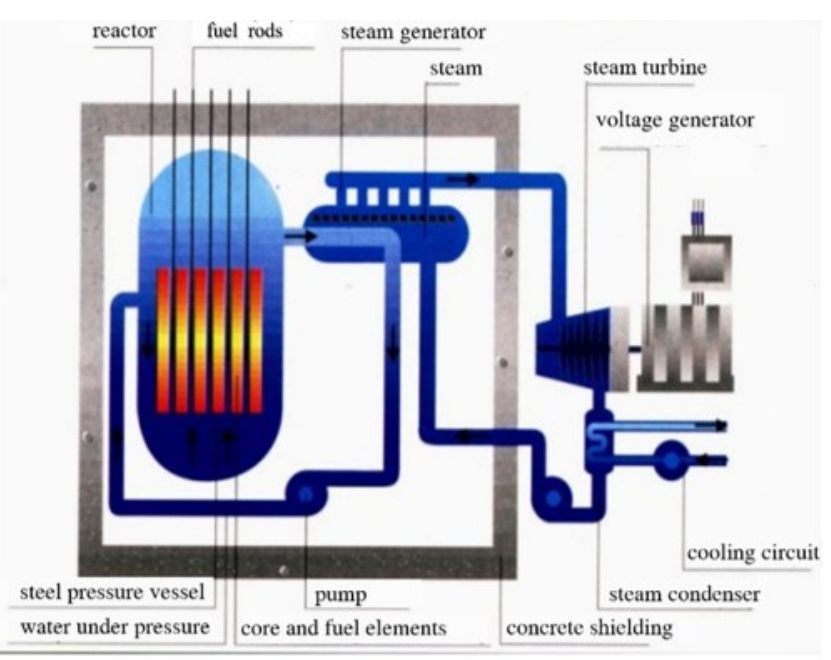

Figure 62: The Pressurized Water Reactor (PWR) and Vodo-Vodjanoj Energetičeskij Reaktor (VVER). [Source: Fig-62] rounds the fuel. Moderated neutrons either disintegrate uranium nuclei or are absorbed by the shielding of the reactor or by the material (absorber) of regulation rods.

Table 35: Parameters of nuclear reactors in our power plants. [Source: Tab-35]

\begin{tabular}{|c|c|c|}
\hline Reactor parameters & Dukovany nuclear power plant & Temelín nuclear power plant \\
\hline type of reactor & VVER 440 & VVER 1000 \\
\hline thermal power & $1,375 \mathrm{MW}$ & $3,000 \mathrm{MW}$ \\
\hline diameter of pressure vessel & $3.56 \mathrm{~m}$ & $4.5 \mathrm{~m}$ \\
\hline height of pressure vessel & $11.8 \mathrm{~m}$ & $10.9 \mathrm{~m}$ \\
\hline fuel assemblies & $312 \mathrm{pcs}$. & $163 \mathrm{pcs}$. \\
\hline fuel mass & $42 \mathrm{t}$ & $92 \mathrm{t}$ \\
\hline moderator and coolant & plain (light) water & plain (light) water \\
\hline pressure in a reactor & $12.25 \mathrm{MPa}$ & $15.7 \mathrm{MPa}$ \\
\hline coolant temperature & $267^{\circ} \mathrm{C}$ to $297^{\circ} \mathrm{C}$ & $290^{\circ} \mathrm{C}$ to $320^{\circ} \mathrm{C}$ \\
\hline
\end{tabular}

Using regulation rods, a number of free neutrons in the reactor, and thus also the fission process and the reactor output are regulated. The immediate stoppage of the reaction is provided by the emergency shut-off rods, which contain much higher concentrations of the absorber. Gradual changes in regulating the power are achieved by the change in the concentration of boric acid in the coolant. The part of the reactor, in which the fuel is stored and in which the fission reaction takes place, is called a core. The heat generated from the core is led away by the coolant and is used in the steam generator to produce steam for driving the plant turbogenerator.

Off-load refuelling (when the reactor is stopped) takes place once every 1 to 1.5 years. In doing so, 1/4 up to 1/3 of fuel assemblies are replaced with new fuel assemblies. The used (incorrectly referred to as spent) fuel is not outwardly different from the new fuel. Only its internal structure changes, i.e. instead of the part of uranium-235 nuclei the fragments of nuclei are present in it and the fuel becomes radioactive. The refuelling takes place under water; the assemblies with the used fuel have to be cooled in the pool next to the reactor for several years and only then they are transferred to the intermediate store of the fuel used. The radioactive fission products produce heat during their decay; therefore, it is necessary to cool the used fuel until the most active radionuclides decay and the temperature and the radioactivity drop to a certain level when they can be handled. 


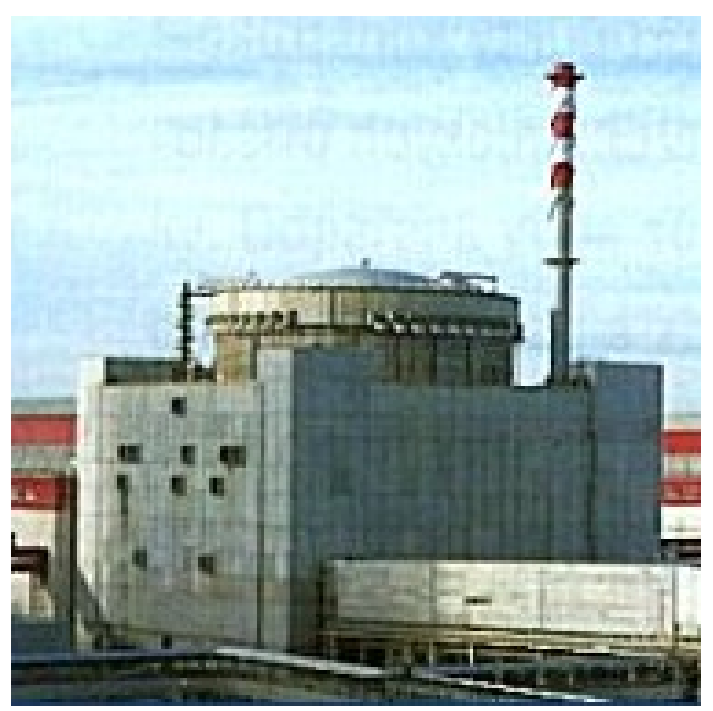

Figure 63: The containment with the reactor in the Temelin nuclear power plant. [Source: Fig-63]

At low levels, no harmful effects of ionizing radiation on the human body can be detected. These are manifested only at dose equivalents exceeding $500 \mathrm{mSv}$. In the Czech Republic, the law sets the highest permissible limit for the exposure of the general population during one year in the amount of $5 \mathrm{mSv}$.

The dose equivalent of radiation from natural sources is about 2.5 to $3 \mathrm{mSv}$ per year; annually, artificial sources (including nuclear facilities) contribute only minimally, about $0.01 \mathrm{mSv}$.

In each nuclear power plant, two types of radioactive materials arise during operation as follows:

- Radioactive waste is produced during the reactor operation, especially due to irradiation of its previously inactive components, materials and equipment. The waste is treated by pressing, bitumenation and vitrification. It is sealed in secure packing and stored in safe repositories. Most of the wastes are medium- and low-activity wastes.

- Used nuclear fuel is a highly active material that is usually isolated from the environment on a long-term basis.

A series of physical barriers protect the workers and the vicinity of the nuclear power plant against the consequences of accidents, which form:

- The nuclear fuel structure - almost all fission products are captured in the material of pellets;

- The cladding of fuel rods - hermetic sealing prevents leakage of fission products;

- Construction of the primary circuit - the pressure vessel and piping in the reinforced concrete shaft withstand a thermal as well as radiation load;

- The containment - a reinforced concrete hermetic cover around the nuclear section of the

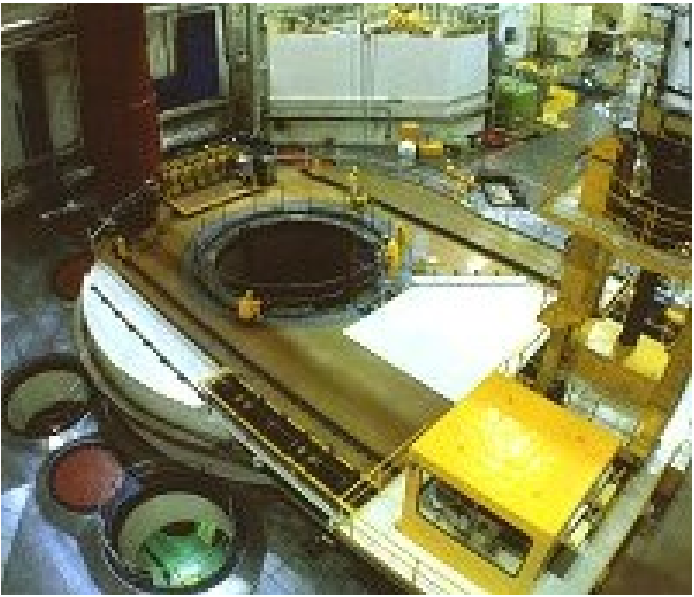

Figure 64: The reactor hall of the Dukovany nuclear power plant. [Source: Fig-64] plant prevents the leakage of radioactivity into the environment during an accident and is equipped with an emergency system.

The used fuel disposal procedure has three stages: first, the fuel assemblies are cooled for several years in the used fuel pool next to the reactor; then, they are stored in the intermediate stores of used fuel at the Dukovany power plant for a few decades and after that, in the permanent repository. With regard to the fact that the used fuel contains elements capable of releasing even a more significant amount of power, it may become a valuable energy resource in the future. In recent years, work has been done on the ADTT method, in which a lead target is bombarded with accelerated protons. The target becomes a source of neutrons, which cause the fission of additional nuclei of the used fuel. Thanks to this method the amount of nuclear waste would be reduced radically and a further, so far unused energy would be gained. 


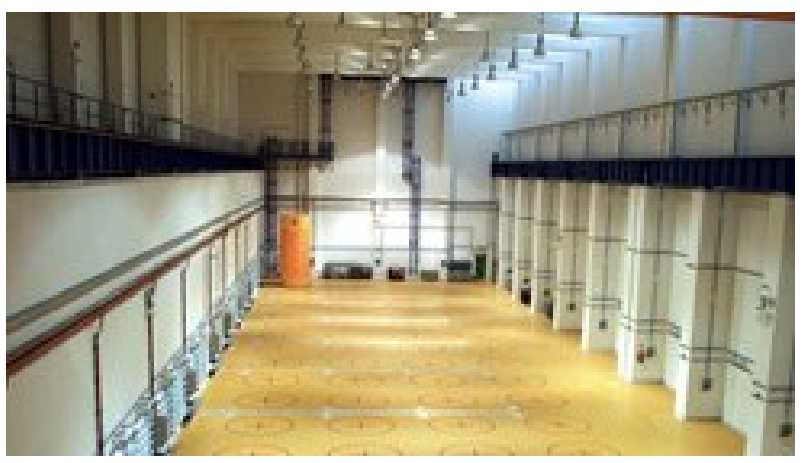

Figure 65: The storage of used fuel in the Temelin nuclear power plant. [Source: Fig-65]

An intermediate storage warehouse is a hall, in which containers filled with used fuel assemblies are placed. The containers are airtight; there is no leak of radionuclides. In the Dukovany power plant, the Castor container, which has several functions, is used (see Figure 67). First of all, it must safely separate the spent nuclear fuel from the environment and shield the radioactive radiation generated by the natural decay of fission products. Another function is to remove the heat released during the radioactive decay. The container also provides protection against external influences, which could cause damage to the fuel. The containers are cooled by the natural air circulation in the hall.

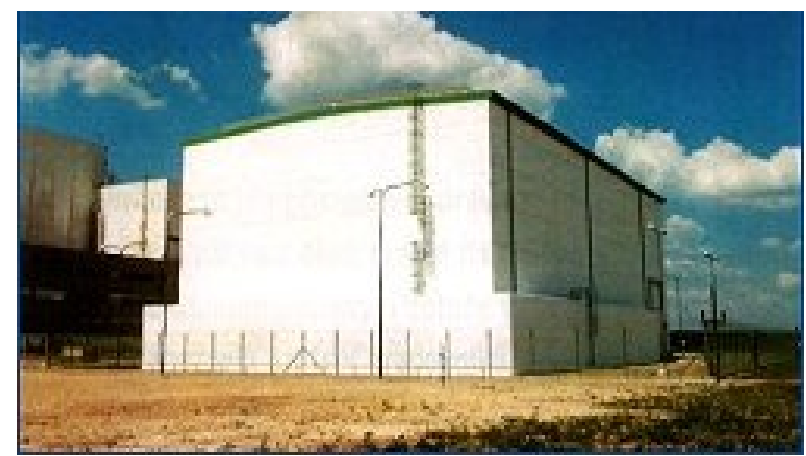

Figure 66: The storage of used fuel in the Dukovany nuclear power plant. [Source: Fig-66]

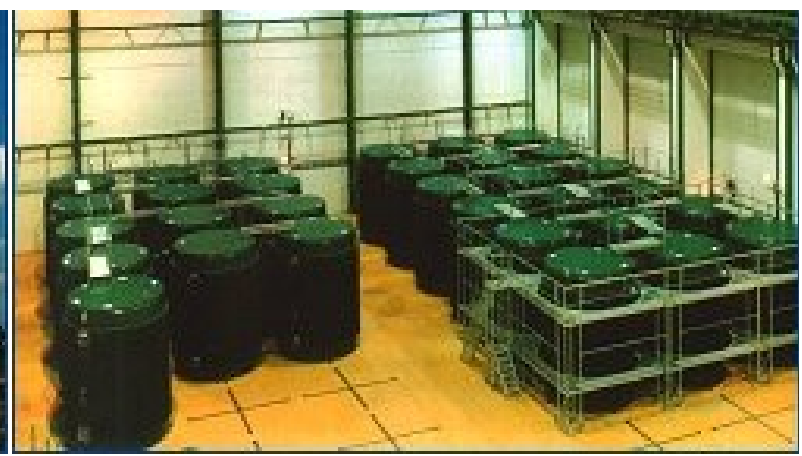

Figure 67: The Castor containers. [Source: Fig-67]

\subsubsection{Deep repository of nuclear waste and its anatomy}

With regard to the requirement for the perfect isolation of high-level radioactive wastes (including the used fuel) from the biosphere, all the projects of future long-term repositories are situated in deep geological formations at the depths of up to several hundreds of metres. In relation to the geological conditions of the Czech Republic, the deep repository will most likely be built in the granite massif in a seismically stable area. Scientists explore similar granite formations in the underground laboratories in Switzerland and Canada. The storage containers, their lining with bentonite and the solution of a deep geological repository correspond to the solution adopted in most countries. A deep nuclear waste repository is an artificially excavated or modified underground space situated in deep stable geological layers. Preference is given to the construction of a new repository, in an intact geological environment, in an area where there is no risk of volcanic activity, earthquakes, flooding by the sea or glaciation. A long-term deposition refers to the time period comparable to the geological time periods in a time scale longer than 10,000 years, but rather 40,000 up to 100,000 years. The purpose of all this work is to prevent any contact of future generations with the material deposited. The building of a deep geological repository of nuclear wastes is, therefore, preceded by costly, time consuming, development activities and exploration work.

The first barrier that ensures a repository safety is the immobilization of radionuclides in a resistant and insoluble chemical form (the so-called matrix). This may be borosilicate glass or ceramic materials for high-level nuclear wastes, and cement or bitumen (asphalt bitumen) for intermediate-level wastes. The methods called Synroc (synthetic rocks) have also been tried, which is the incorporation of waste into artificial, chemically created, very durable rock. 
The second barrier is a container, in which nuclear waste is placed. It is a thick-walled steel container or a copper vessel for high-level nuclear wastes; even containers made of titanium are taken into account. This container should isolate its contents from the surroundings for at least a thousand years. Drums or concrete containers are used for low-level and intermediate-level nuclear wastes. They should provide radiation shielding for a period of 300 up to 600 years.

Another barrier can be formed by concrete packages or covers, in which drums or concrete containers are deposited. Building structures on the surface, below the ground level or in geological formations (special concrete, impervious coatings, asphalt or clay insulations and drainage systems) also serve as a technical barrier.

A geological formation itself, in which a deep repository is located, is a natural barrier. The geological formation must be seismically stable. Mostly a rock is selected that has not changed demonstrably over a few millions of years and is expected to be steady even in the following years. In particular, its strength, insolubility and thermal stability are assessed. Salt deposits, clay sediments, tuffs, granites and gneissic rocks are considered to be suitable geological formations. The lifespan of engineered barriers is estimated to be 300 years old; the lifespan of a matter, in which radionuclides are immobilized, is up to 1 million years. The stability of geological formations, in which repositories are located, is at least 70 million years.

In 1990, a project was set up in Russia to put nuclear waste (used fuel and high-level nuclear waste) into boreholes up to five kilometres deep filled with low-melting and water-insoluble material, preferably sulphur. The waste is lowered into a borehole in hermetic cases where it melts sulphur using its own heat and raises the temperature at the borehole bottom to approximately $500{ }^{\circ} \mathrm{C}$. As a result of the thermal expansion of the rock and the chemical action of sulphur, the borehole diameter expands and the entire column of accumulated waste will slide down. A drop of up to $1,800{ }^{\circ} \mathrm{C}$ is formed, sulphur forms pyrite with iron oxides from the surrounding rocks. When the waste slides down slowly, it loses its temperature and radioactivity and the process slows down. Spontaneous descent may proceed up to 10 kilometres (one borehole can be used up to three times). Insoluble pyrite forms a matrix that will prevent the release of radionuclides at least for three million years.

\subsubsection{Foreign approaches to deep storage}

In the countries where used nuclear fuel and highlevel nuclear waste have accumulated, deep repositories are being developed in various ways. One of the differences is in a different geological environment, which is, to a great extent, predetermined by the geological situation of the territory of a particular country. Several types of rocks are being examined around the world, which in specific geological conditions can be assumed to have the desired properties. Selecting the geological environment (the site) represents a long-term and, from a technical and economic point of view, very demanding work. Predominantly, the geoscience disciplines, such as geophysics, geochemistry, engineering geology, hydrogeology and others are involved in the performance of this operation. Crystalline rocks (mainly granite) and depos-

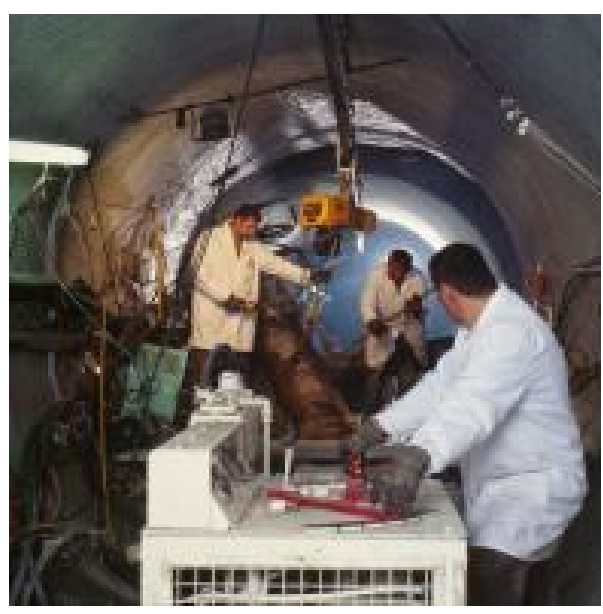

Figure 68: Tests in the underground laboratory at the Grimsel Test Site in Switzerland. [Source: Fig-68] its (mostly clays and salt deposits) have been investigated in the world as a host environment of a deep geological repository. In all these rock environments, the possibility for the construction of a deep geological repository has been verified and its safety has been proven. 
In Finland, Sweden, but also in Japan, they decided for granite as a host rock. In the United States, tuff in the area of Yucca Mountain serves as a host rock, while the Waste Isolation Pilot Plant (WIPP) repository near Carlsbad is located in the salt formation. The salt as a suitable rock for locating a deep geological repository is being discussed in Germany, where salt formations are researched very well. The clay formations are possible in France, Belgium or Switzerland. Nowadays, the construction of a deep granite repository in the Czech Republic is assumed. The countries that produce used nuclear fuel and high-level wastes can be divided into three groups.

The first group includes the countries that have developed their concept of deep geological disposal to such an extent that launching the repository can be expected in the next 20 up to 25 years, i.e. by 2035 . These countries have already found a site for deep geological disposal or are at an advanced stage of selecting a suitable site.

Thanks to the experience acquired during the operation of underground laboratories (see Fig. 68) they have mastered the issues of geology, mining work, a structural design and associated security issues. They have obtained the consent of the relevant country representatives and local residents with the construction of the repository. This group includes e.g. Sweden, Finland, the USA, France, Germany, Switzerland and Japan.

This is followed by the group of countries where the development of deep geological disposal proceeded more slowly. In these countries, a suitable location has not yet been selected, as it is very difficult to obtain the consent of the population with the location. Therefore, a survey is performed at the studied localities only to a limited extent and the storage system is solved only at the level of the preliminary (reference) project of the repository at the fictional locality. This group includes e.g. the Czech Republic, Slovakia, Hungary, Belgium and Spain.

The third group of countries have decided to defer the final solution till later time, mostly after 100 years or more. They have adequate storage capacities or they are planning to build them. In most of them the concept of the future disposal of used nuclear fuel and high-level nuclear wastes has not been established yet. Among the European countries that have chosen this approach is Great Britain, the Netherlands and other Eastern European countries that operate nuclear power facilities.

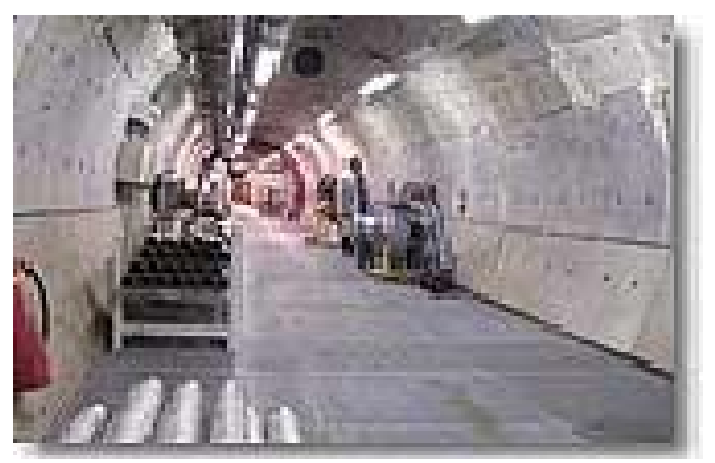

Figure 69: The preparation of the deep geological repository in Forsmark, Sweden. [Source: Fig-69]

\section{Sweden}

There are 10 nuclear reactors in operation in Sweden; in 2008, they generated 61 TWh of electricity, which represents approximately $42 \%$ of the total quantity of $146 \mathrm{TWh}$. The used fuel is stored at the Central Interim Storage Facility (CLAB) near the Oskarshamn nuclear power plant. At the end of 2009, more than 5,000 tonnes of used fuel were stored there. The development of a deep geological repository in the country has been taking place for several decades. In the course of this time, the underground research laboratory in Äspö was used to perform the tests needed for proving the safety of the deep geological disposal in the granite environment. The site selection for the repository resulted in a detailed survey of two sites, namely Forsmark in the Östhammar area and Oskarshamn. In June 2009, Forsmark (see Fig. 69) was selected as a final locality. A building licence application was submitted in 2010, the building was commenced in 2012 with a detailed characterization of a selected rock and the construction of the repository itself was planned for 2015 . 
It is expected that the operating licence application will be issued in 2019. After the approval, the loading of the first batch of used nuclear fuel could take place in 2020 . Concurrently with the construction of the storage facilities, a device for storing fuel in storage containers should be designed. With regard to the removal of the fuel from the storage space, it may happen in the first ten years after the commencement of the operation; then the situation should be reviewed in detail and the following activities should have the character of depositing waste forever.

\section{Finland}

In Finland, electricity production from 4 nuclear reactors $(2.3 \mathrm{GW})$ represents a total of a quarter $(25.5 \mathrm{TWh})$ of the total energy produced. Used fuel is stored in wet storage facilities on the premises of the nuclear power plant before its deposition into the deep geological repository. In 2010, its amount was 1,750 tonnes, and it is expected that after the commissioning of the new power plant in 2020 this amount will increase to 2,500 up to 2,800 tonnes. In the period between 2010 and 2020 , Finnish work on the development of the deep geological repository located in the granite rock in Olkiluoto, will include the excavation of the

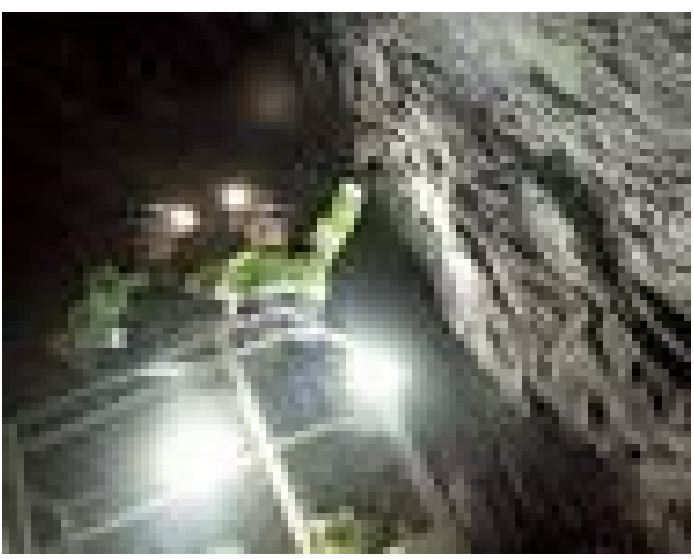

Figure 70: The excavation of the Finnish ONKALO underground laboratory. [Source: Fig-70] ONKALO underground research laboratory (from 2010 to 2011, see Fig. 70), the work in the underground laboratory (from 2010 to 2014), the preparation of the deep geological repository (from 2013 to 2014), the construction of the facilities for the placement of the fuel into the containers (from 2015 to 2018), the construction of the repository (from 2015 to 2018), the test operation (2019), and the commencement of the deep repository operation (the $2^{\text {nd }}$ half of 2020). The approval of documents will take place in parallel. The submission of applications for a permit for the construction of a repository and consent to the operation is expected at the end of 2012, or at the end of 2018.

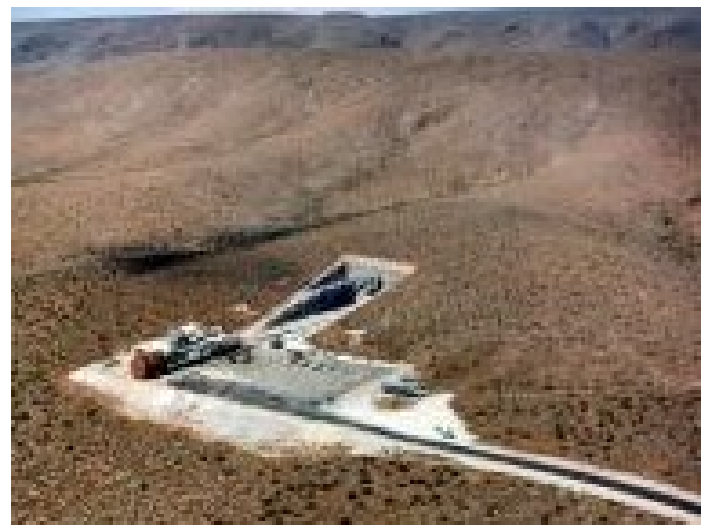

Figure 71: The entrance to the repository in

Yucca Mountain in the USA. [Source: Fig-71]

\section{The USA}

In the USA, there are currently 104 power reactors in operation that generate about $20 \%$ of electricity. Besides these reactors there are also research and military reactors, which produce used nuclear fuel. Until the deep geological repository is put into operation, the majority of the used fuel from commercial sources is stored on the nuclear power plant premises. By the end of 2009, the commercial nuclear industry had produced more than $60,000 \mathrm{tU}$ of used nuclear fuel, with an annual increase of 1,800 to $2,200 \mathrm{tU}$. It is expected that by 2055 approximately $130,000 \mathrm{tU}$ will be accumulated. The deep geological repository is being built in Yucca Mountain (Fig. 71), the State of Nevada. The host environment is a pyroclastic rock - tuff - with very favourable properties for the construction of storage spaces. The first part of the repository should serve for storing 63,000 tonnes of commercial fuel and 7,000 tonnes of fuel from military programs. Assuming that the life time of nuclear power plants in the USA will extend by twenty years, the additional 60,000 tonnes of fuel will be stored in the second stage. 
The deposition is expected to take 50 years, and over the next 50 years the inspection, maintenance and monitoring in and around the storage system will take place. In addition to the repository, there is a WIPP (Waste Isolation Pilot Plant) deep repository in the United States, near Carlsbad, New Mexico, built in a salt formation to store radioactive waste containing transuranic elements. By August 2008, 56,000 $\mathrm{m}^{3}$ of waste were deposited there.

\section{France}

In France, 58 power reactors are in operation, of which half of them use a mixture of uranium and plutonium oxides (MOX) as fuel. During the first decade of this century, around $420 \mathrm{TWh}$ of electricity per year were produced at nuclear power plants in France. The production of used nuclear fuel was around 1,150 tonnes per year. At the beginning of 2010, 41,000 tonnes of used fuel were stored in France. Three quarters of this fuel are reprocessed. The plants at La Hague and Marcoule process 850 tonnes of used fuel annually. The obtained plutonium in an amount of about 100 tonnes is then a source of the MOX fuel. The used nuclear fuel is stored in the same way as the used MOX fuel with a higher content of plutonium that could be used in the future in the advanced reactors of the $4^{\text {th }}$ generation. The fission products contained in the used fuel are sealed into a glass mass; medium-level wastes are also treated in the same way. The result is 110 up to $130 \mathrm{~m}^{3}$ of high-level nuclear wastes and $120 \mathrm{~m}^{3}$ of medium-level nuclear wastes per year.

The development of deep deposition in France continued in compliance with the conclusions published in the Dossier 2005 Argile, which describes the results of the operation of an underground laboratory in a clay formation located on the border of the Meuse and Haute-Marne districts at a depth of $445 \mathrm{~m}$ below the surface. Following this report, the expected concept in the area of development and construction of the deep repository was approved by the Parliament in 2006 . It was decided that the system would be designed so that it could be changed and adapted and the materials already

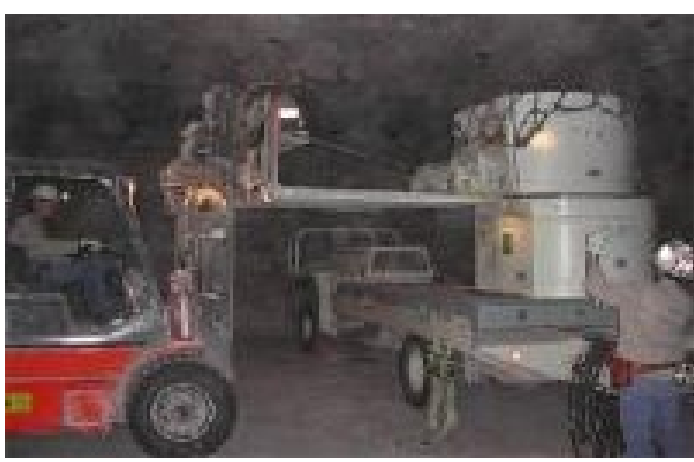

Figure 72: Handling drums at the WIPP, USA. [Source: Fig-72] stored could be taken out. The French National Radioactive Waste Management Agency (ANDRA) was commissioned to terminate the research work by 2012, to apply for the building licence by 2015, to build the deep geological repository from 2015 to 2020 and to put it into operation from 2020 to 2025 .

\section{Germany}

The production of electricity in Germany reaches 650 TWh, out of which 170 TWh (26\%) fall on operating nuclear power plants with a total capacity of $21 \mathrm{GWe}$. These plants (including 9 decommissioned facilities) produced 13,600 tonnes of used nuclear fuel. Its part was sent to France (5,400 tonnes) and Great Britain (850 tonnes) for reprocessing. High-level radioactive wastes are returned back to the country. Although sending the fuel abroad to be reprocessed was suspended in the middle of 2005, the return of high-level radioactive wastes will continue until 2020. The storage of used fuel in Germany takes place in three centralized storage facilities (Ahaus, Gorleben and Greifswald) and in 12 storages located on the premises of operating nuclear power plants. Approximately 720 tonnes are located in the centralized storage facilities, while approximately 2,950 tonnes are stored on the premises of nuclear power plants. In Gorleben, in addition to the centralized storage facility, a fuel treatment plant is in operation before its final disposal. 
Deep deposition in Germany is the subject of debate at the national level. According to the amendment to the Atomic Energy Act from 2002, the deep geological repository is to be built by 2030 . It was also decided that not only used fuel and high-level nuclear wastes, but also other wastes from the operation and dismantling of nuclear facilities or wastes originating from the research, medical and industrial use would be stored in the deep geological repository. According to the Atomic Energy Act in Germany, there is an obligation that the approval of repositories has to pass the compulsory EIA (Environmental Impact Assessment) process and the public has to be involved in the approval. The repository in the former Konrad iron ore mine satisfied this condition, while the survey in the salt mine near Gorleben, selected from 140 locations and studied in detail from 1979 to 2000, was suspended for 10 years.

\section{Switzerland}

In Switzerland, 5 nuclear reactors generate about $40 \%$ (approximately $26 \mathrm{TWh}$ ) of electric energy. These are a source of spent nuclear fuel, which has currently reached approximately 2,000 tonnes. Until 2005, the used fuel was sent abroad for reprocessing (a total of about 1,000 tonnes). Since 2006, this practice has been stopped for a period of ten years. The radioactive waste treatment and storage plant (Zwilag) stores both used fuel and returned high-level nuclear waste after reprocessing. The process of selecting sites for a deep geological repository is divided into three stages. In the first stage, which is currently in progress, the survey of six areas is carried out, which could be used for the construction of a deep geological repository according to geological, technical and safety criteria. In the second stage, a more detailed exploration of these areas is expected, in the conclusion of which at least two sites should be selected. Besides the technical and safety aspects, the selected sites should be examined from the viewpoint of regional planning and socio-economic conditions in the given area. The general public and especially the municipalities in the regions concerned should be involved. The third stage is devoted to deepening the knowledge of geology, technology and safety related to the sites and the use of drilling operations. At the end of the third stage, i.e. approximately in 2020, the Swiss National Cooperative for the Disposal of Radioactive Waste (NAGRA) should submit the application for the construction of the facility. The estimated date of the startup should be 2030 for the storage of low- and medium-level radioactive wastes and 2040 for the storage of high-level radioactive wastes and used fuel.

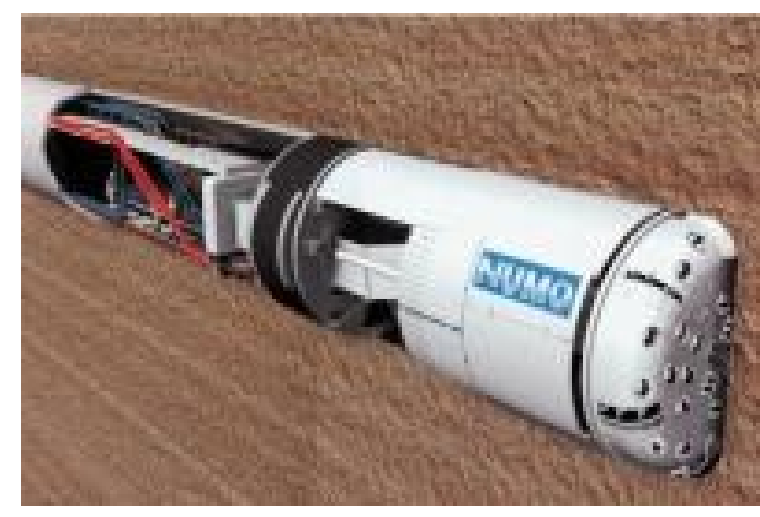

Figure 73: A Japanese tunnelling machine. [Source: Fig-73]

\section{Japan}

In Japan, there are 53 nuclear reactors in operation, which account for one quarter of electricity generation (1,040 $\mathrm{TWh} /$ year). The used nuclear fuel is stored in wet storages at 17 different sites. Before 2001, a part of fuel (a total of 7,100 tU) was sent for reprocessing to Le Hague in France and Sellafield in the UK. Now, the reprocessing is provided in its own reprocessing plant in Rokkasho. From France and Great Britain 1,670 tonnes of vitrified high-level radioactive wastes were returned back to the country. These (and oth-

ers from the reprocessing at Rokkasho) are to be stored for 30 to 50 years before their final disposal. On site, a storage facility receiving fuel for reprocessing is available. The total quantity of stored fuel is $29,000 \mathrm{tU}$. The site selection for a deep deposition in Japan is divided into three stages. The first stage (currently underway) is focused on the planning and studying of the existing information. 
In the second stage, geological exploration including drilling is carried out. In the third stage, the safety and technical aspects of the final site are verified and detailed exploration works are performed. The first stage was completed in 2012, the second stage will take place from 2012 to 2017, and the third stage is to be completed in 2030. The construction will take place in the period from 2030 to 2035; the operation including the approval will be commenced in 2035. The underground laboratories in Horonobe (clay formation) and Mizunami (granite formation) will play an important role in dealing with security issues.

\section{Belgium}

In Belgium, 7 nuclear reactors with a total capacity of $6.0 \mathrm{GWe}$ are in operation. They contribute to the overall power generation of almost $58 \%$ (78 TWh). Assuming the forty-year operation of reactors, the used nuclear fuel in Belgium in an amount of approximately 5,000 tonnes will be produced. Currently, this quantity is 3,400 tonnes and is stored temporarily on the premises of the operated nuclear power plants. A part of used fuel was reprocessed in France and high-level nuclear wastes were returned to Belgium. The development of deep deposition in Belgium entered the fourth decade. During this time, an underground laboratory was established on the site of the Nuclear Research Centre in Mol. It is located in the clay formation (the so-called Boom Clay) at a depth of $220 \mathrm{~m}$ below the surface. The construction of the laboratory already began in 1980 and later it was expanded. The access to it is provided by two shafts and a connecting tunnel. Although the final selection of the site has not yet been completed, the site is considered to be suitable for building a storage system, in which both used fuel and high-level radioactive wastes should be stored with the use of 5 to 6 engineering barriers. The national concept for the management of radioactive wastes is currently being prepared in Belgium; its approval is expected in 2010. Until 2015, a locality should be selected and verification tests performed. The work is expected to continue until 2025 when the project is to be approved. After the repository is constructed, the operation will be commenced in 2030 .

\section{Spain}

In Spain, 8 nuclear reactors with an output of $7.71 \mathrm{GWe}$ provide $18 \%$ of electric energy. The used nuclear fuel, the volume of which reached 3,800 tonnes in 2009, is first stored in power plants for about 10 years and then transported together with a small amount of highlevel radioactive waste to a central storage plant. In December 2009, the government offered the municipalities the placement of this central storage plant, which represents an investment of 700 million EUR, on their territory. The facility is expected to store about 6,700 tonnes of used fuel, 2,500 $\mathrm{m}^{3}$ of long-term medium-level radioactive wastes and approximately $12 \mathrm{~m}^{3}$ of high-level radioactive wastes produced by the reprocessing of fuel from the dismantled Vandellos -1 plant. The decision on the final storage in the deep geological repository is to be made after 2010. Suitable host rocks are granite, clay or salt formations.

\section{The Netherlands}

One nuclear power plant with an output of $482 \mathrm{MWe}$ operates in the Netherlands. Its production represents about $4 \%$ of the total quantity produced (100.5 TWh). Used nuclear fuel is sent to France for reprocessing under a contract that is due to expire in 2015. An exception was the remaining used fuel after the decommissioning of the Dodewaard nuclear power plant, which was sent to Sellafield, the UK, for reprocessing. Before sending the used fuel abroad, it is stored at the Borssele nuclear power plant (total of 561 tonnes). The other wastes including high-level nuclear wastes are stored in an industrial zone in Vlissingen-Oost, operated by the Dutch Agency for Radioactive Waste Management (COVRA). The research program focused on the deep deposition was launched in 1995. In 2001, the findings about the possibility to build a repository in salt or clay formations were published. 
As the government and parliament have established a strategy for dealing with used fuel to be stored for at least 100 years, it shows that, currently, the site selection is not urgent.

\subsubsection{Current near-surface repositories in the Czech Republic}

The radioactive waste disposal is a final step in the succession of the controlled activities, which include the collection and sorting of wastes, their storage, processing, treatment and transport. The purpose of these activities is to protect people and the environment. Therefore, it is necessary to isolate radioactive wastes from the environment for such a long time, until the radioactive agents disintegrate into other stable substances due to spontaneous processes. Just for this purpose, i.e. isolating radioactive wastes for a required time, radioactive waste repositories are intended.

In the Czech Republic, three repositories are in operation. These are the largest Dukovany repository on the premises of the Dukovany nuclear power plant, the Richard repository near Litomerrice at the foot of Bídnice, which is smaller, and the smallest Bratrství repository near Jáchymov at the foot of the Ore Mountains.

The Dukovany repository is comparable to similar constructions in the countries in Western Europe due to its structure and safety. The lowand medium-level radioactive wastes produced during the operation of the Dukovany and Temelín

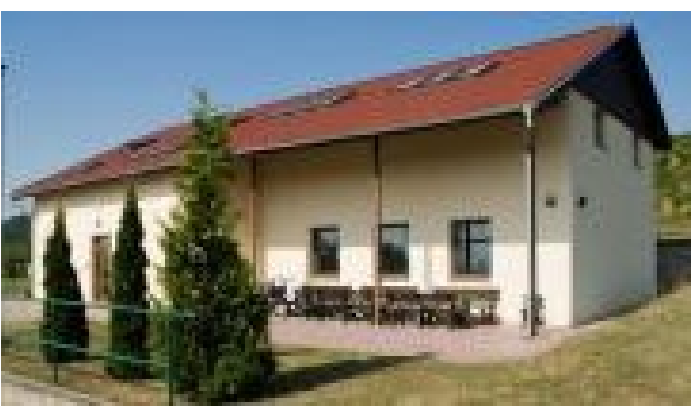

Figure 74: The administration building of the Richard radioactive waste repository. [Source: Fig-74] power plants are stored there. The institutional waste has been stored in the Richard radioactive waste repository since 1964 . More than 24,000 waste packages are stored here. The total volume of the used spaces exceeds $17,000 \mathrm{~m}^{3}$ and the capacity for the waste disposal itself is approximately half. The rest of the space is formed by tunnels, which are necessary for the operation and waste handling. The wastes containing natural radionuclides are deposited in the Bratrství repository; currently, the amount of waste stored here is small.

In accordance with the Atomic Act, the costs associated with the operation of all repositories within the Radioactive Waste Repository Authority (hereinafter referred to as RAWRA) are funded from the so-called Nuclear Account. All the originators of radioactive waste in the Czech Republic make contributions to the Nuclear Account. The funds deposited in the Nuclear Account are intended to cover the costs of dealing with radioactive waste. In accordance with the "Atomic Act" - Act No. 263/2016 Coll., the costs associated with the operation of all repositories within the Radioactive Waste Repository Authority (hereinafter RAWRA) are funded from the so-called Nuclear Account. All the originators of radioactive waste in the Czech Republic make contributions to the Nuclear Account. The funds deposited in the Nuclear Account are intended to cover the costs of dealing with radioactive waste - see "Government Order No. 35/2017 Coll., fixing the single fee relating to disposal of radioactive waste and the amount of contributions from the nuclear account to municipalities and laying down the rules for providing them."

The aim of the RAWRA is to make information on radioactive wastes easily available to all interested parties. Permanent exhibitions present the issues of radioactive wastes from their production up to their disposal in a repository especially in terms of safety and the environmental impact. For this, notice boards, three-dimensional models, photographs and a series of film clips are utilized; they are a part of the multimedia program. Visitors can also view the presentation CDs, DVDs, the RAWRA websites, etc. Thematically, the exhibition appears as a supplement to teaching ecology or physics at elementary and secondary schools. 


\section{The Richard - Litoměřice radioactive waste repository}

The Richard locality has an interesting history. Below Bídnice hill near Litoměřice, limestone has been quarried since the first half of the $19^{\text {th }}$ century. Limestone forms about $5 \mathrm{~m}$ thick layer in a depth of 70 to 80 metres below the surface. Between 1943 and 1944, Germany chose this site for an underground factory production of the Auto Union AG of Chemnitz (the production of components and parts for Maybach engines HL 230) and the OSRAM concern. The code name of the underground construction was Richard. Imprisoned miners, bricklayers, concrete workers, electricians, plumbers and other workers worked on this large building project. They were transported to the construction site from the labour camp in Litomerrice, some of them even from nearby Terezín. They managed to finish completely only a few factory buildings for the Auto Union Group.

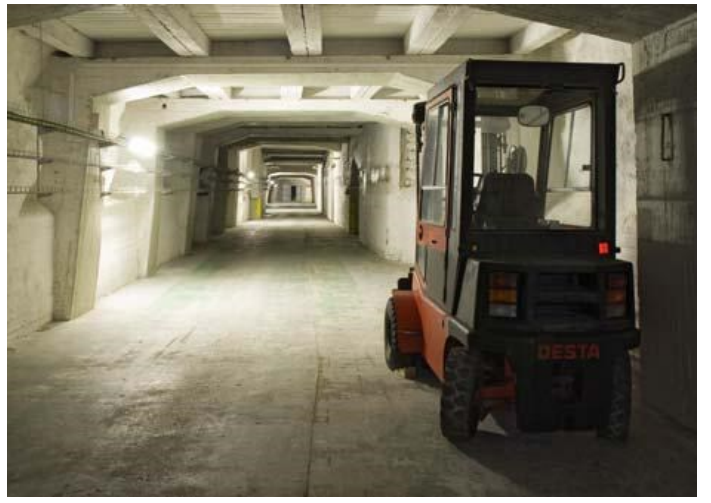

Figure 75: A tunnel in the Richard radioactive waste repository - Litomérice. [Source: Fig-75]

The end of the war caught the underground in various stages of construction work - from the completed production halls to the corridors, where only mining expansion work took place. At the end of 1945, all the equipment was removed and the Č́ižkovice cement works resumed the limestone mining operations. Over the next 15 years, a vast complex of connecting tunnels was built. However, the mining method employed in the underground was much more expensive than in a quarry and the mining was finished. In 1964, a part of the mine started to be used for storing radioactive wastes. Institutional waste, produced in the national health sector, industry, agriculture or research, has been stored in the Richard radioactive waste repository since 1964. The high-level wastes, i.e. the wastes that exceed a set limit for the content of radionuclides, are stored in the Richard radioactive waste repository until they can be stored in a deep geological repository.

Between 2005 and 2007, a project of the EC Phare Programme was implemented in the Richard repository, the aim of which was to verify the method of the final closure of storage chambers with radioactive wastes. For this purpose, the wastes from the period between 1965 and 1985 were transferred to modified spaces. Within the project, 15,000 units of the so-called historical wastes were modified, transferred and embedded in concrete. Each barrel was removed from its storage, inspected, provided with new packaging as needed, placed in a newly prepared chamber and embed in concrete to ensure safe isolation of

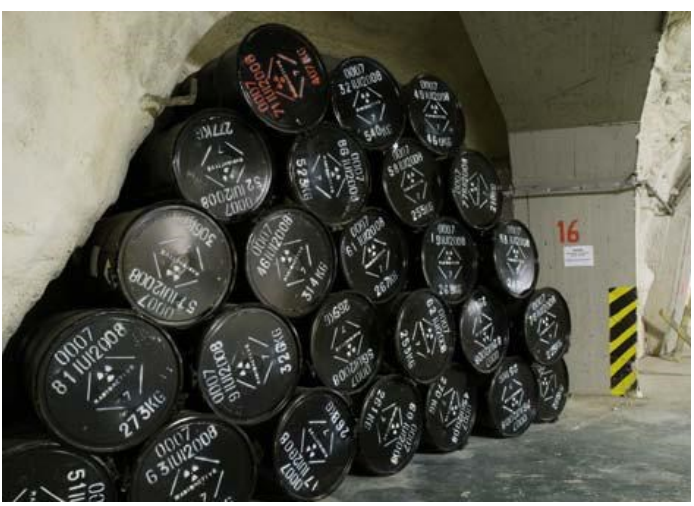

Figure 76: Disposal drums in the Richard radioactive waste repository. [Source: Fig-76] wastes. This project was financed by approximately EUR 1 million from the European Union, the contribution of the Czech Republic was approximately EUR 450 thousand. Thus, the sealed chambers and used technologies also serve for the demonstration and validation of the possibility for the safe closure of the repository. More than 25,000 waste packages with the current activity of limited radionuclides at the level of $6 \times 10^{14} \mathrm{~Bq}$ are stored there. The total volume of used space exceeds $17,000 \mathrm{~m}^{3}$, the capacity for self-storage of waste is about half, the rest of the space consists of corridors necessary for the operation and handling of waste. 
Assuming that the remaining storage space is filled at the current rate in the range of 100 to 200 barrels per year, we can estimate the operation time of the storage until 2070. The final closing date of the Richard repository is logically dependent on this speed. The premises of the repository cover an area of 16 hectares. The premises include a service building, information centre, laboratory and accredited testing room of waste packages and radioactive agents. Waste packages are used to transport and store radioactive agents as well as radioactive wastes. The Litoměřice testing laboratory performs tests of waste packages for radioactive consignments of the IP-2, IP-3, A and B type and tests of radioactive material of a special form, as required for the transport of dangerous agents. The testing room carries out tests required by the Atomic Act and "Decree of the State Office for Nuclear Safety No. 377/2016 Coll., on the requirements for the safe management of radioactive waste and on the decommissioning of nuclear installations or category III or IV workplaces", e.g. a water spray test, a free drop test, a pressure test, a penetration test, a drop test, a crushing test, a thermal test and an immersion test.

\section{The Bratrství repository in Jáchymov}

The Bratrství repository in Jáchymov is built in the abandoned underground premises of the former Bratrství uranium mine. The repository itself forms only a small part of the Bratrství mine field, the area of which is $9.8 \mathrm{~km}^{2}$ with more than $80 \mathrm{~km}$ of galleries and crosscuts. The repository is located in the area around the former Mining Tunnel, which was used in the 1950s to export material from the Zdař Bủh blind pit and the surrounding stopes. In 1974, this tunnel and adjacent chambers were converted into the radioactive waste repository.

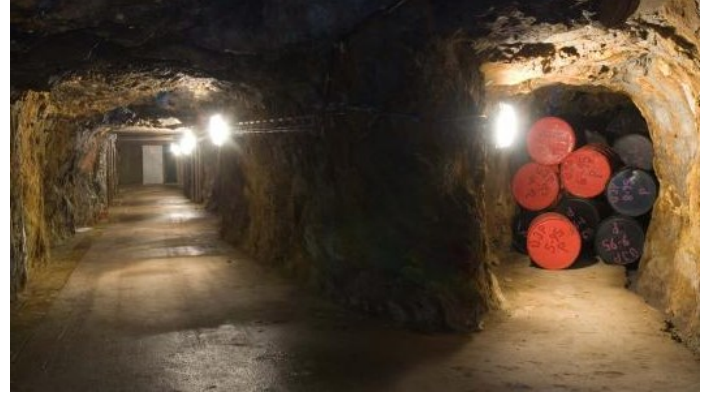

Figure 77: View of the storage chamber in the Bratrstvi radioactive waste repository Jáchymov. [Source: Fig-77]
The Mining Tunnel and adjacent chambers were modified for storage; the Mining Tunnel is $385 \mathrm{~m}$ long is a service road. The walls and ceilings of the chambers were also technically adapted for radioactive waste disposal. Certain parts of corridors and ceiling in the gallery are secured with concrete and reinforced with steel beams. Floors with a drainage system and a central retention sump are also concreted. The current ventilation system is artificial, with a fan at the mouth of the access gallery. Artificial ventilation is in operation only if workers are present in the repository.

Otherwise, the winds flow by natural draft, depending on the season, either outwards from the mine (breathable in summer) or towards the mine (retractable in winter).

The individual spaces are gradually being filled in the repository. Waste disposal is carried out in such a way that access to other galleries and technological facilities is not restricted. The waste packages are stored in layers. Only the wastes containing radionuclides are accepted and stored in this repository. The total volume of the storage space is approximately $1,200 \mathrm{~m}^{3}$. Currently, there are more than 2,100 waste packages with the current activity of $1.8 \mathrm{TBq}$. In 2008 , the Bratrství repository used more than $80 \%$ of its capacity. The final date and method of the repository closure is dependent on the volume of radioactive waste deposited in the future. Currently, there are already research projects dealing with this task.

\section{The Dukovany repository}

The Dukovany repository was built for the disposal of radioactive waste generated in the nuclear power industry. It falls under a category of low-level and intermediate-level waste. It is the largest modern radioactive waste repository in the Czech Republic and its structure and safety corresponds to the repositories in the countries of Western Europe. 
With the adoption of the Atomic Act (Act No. 18/1997 Coll., on Peaceful Utilization of Nuclear Energy and Ionizing Radiation - currently, new Act No. 263/2016 Coll., the Atomic Act is valid), the state assumed responsibility for the safe disposal of radioactive waste. In accordance with this Act, the Dukovany repository has been owned by the state since January 01, 2000 and is operated by the Radioactive Waste Repository Authority.

The repository is located in the area of the Dukovany nuclear power plant in the cadastral territory of the Rouchovany municipality in the Třebíc District and occupies an area of 1.3 hectares. In 1987, the construction of the Dukovany repository was started by the Power Company CEZ, a. s. (the former Czech Power Company, state-owned enterprise). The repository has been in permanent operation since 1995. Barrels with operational waste from the Dukovany and Temelín nuclear power plants are mainly deposited here. The total volume of storage space is $55,000 \mathrm{~m}^{3}$ (about 180,000 barrels). It is sufficient for storing all operational wastes from both plants, even in the case of their planned life extension to 40 years. The high-level radioactive wastes from the power engineering, industry and health services will not be stored in the Dukovany repository in any case. The used nuclear fuel, which is often discussed in connection with the nuclear energy industry, will not definitely be stored there as well.

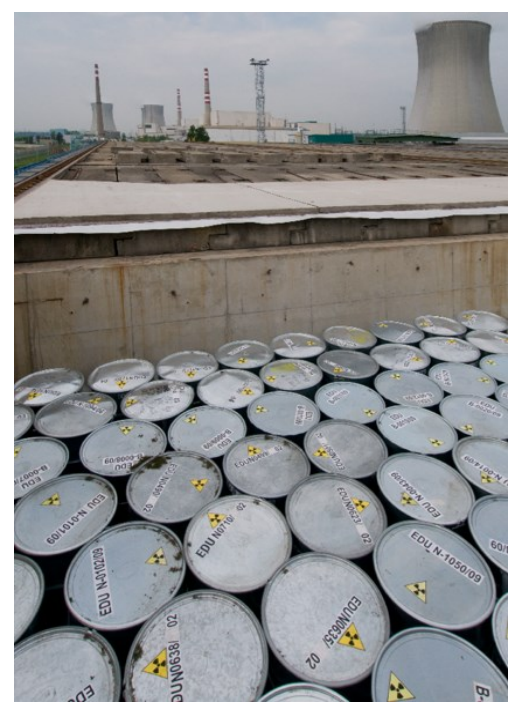

Figure 78: A vault with disposal drums at the Dukovany radioactive waste repository. [Source: Fig-78]

The nuclear power plant produces two types of low-level wastes, i.e. solid wastes (e.g. contaminated protective clothing, cleaning cloths, packing materials, paper, foils, wiring material, construction debris, etc.) and wastewater. The contaminated wastewater undergoes the multi-stage treatment. It consists mainly of evaporation, which leads to thickening. The resulting concentrate is then bituminized.

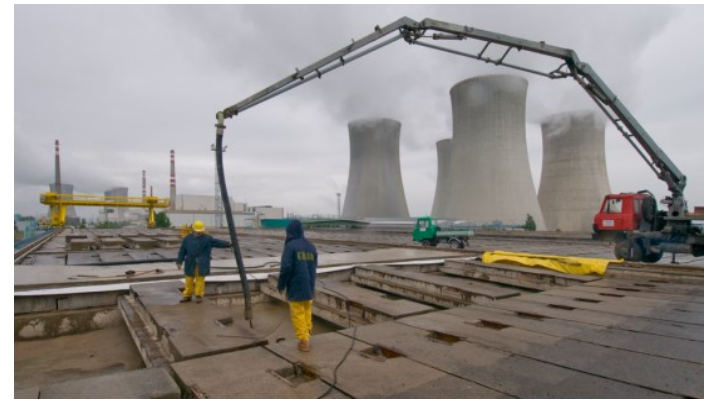

Figure 79: A vault with drums in the Dukovany radioactive waste repository. [Source: Fig-79]

Bituminization is a process, during which residual water on a bituminous (asphalt) film evaporates from a wastewater concentrate. This will result in a mixture of radioactive material with bitumen, in which the content of solids is about 30 to 40 percentage by weight. This mixture is stored directly in galvanized 200-litre drums and after it solidifies, the drums are closed. The sludge and ion exchangers also rank among liquid wastes. These wastes are processed using special technologies. Solid radioactive wastes are sorted and then treated according to their properties. The debris and wiring materials are collected in 200-litre drums and the packaging materials are pressed.

The size of each vault is $5.3 \times 5.4 \times 17.3 \mathrm{~m}$; if its available capacity is exploited to an optimal level, each vault can accommodate about 1,600 individual 200-litre drums. A gantry crane, operated from a cabin shielded against the effects of radioactive radiation, travels along the crane track located on the upper edges of the vaults. This makes it possible to handle the drums intended for storage as well as the concrete panels, with which the vaults are closed. After the RAWRA takes over the waste drums, they are unloaded on a mobile ramp, from where the crane takes them above the storage vault and stores them in a designated place in it. When storing, the position of each drum is recorded. 
Thanks to that, it is possible to accurately monitor, at which point of the repository a specific drum is located and how radioactive material is distributed in the repository. Once the vault is full of drums, the space among the drums is filled with fresh concrete and the vault is covered with a thick sheet of polyethylene, which prevents rain water from infiltrating the vault.

When the repository is completely filled, the vaults are covered from above by insulating and drainage layers. The repository will then be closed and guarded and its impact on the surrounding environment will be constantly monitored. The period of inspection of the repository before the site is released for other purposes is about 300 years, when the radioactivity of the deposited waste decreases to such an extent that it will not endanger the environment.

\section{The Hostim radioactive waste repository near Beroun}

The Hostim radioactive waste repository (hereinafter RAW) was established on the basis of the Czechoslovak Government Decree No. 231/1959 and subsequent decisions of the Ministry of Chemical Industry and was in operation from 1959 to 1964 . Now, this repository is closed and its effects on the environment are monitored.

The Hostim repository is located in the abandoned limestone quarry Hostim I (also called Alkazar), about $3 \mathrm{~km}$ east of Beroun. The quarry is situated in the Berounka River valley above the mouth of the Loděnice stream (also called Kačák) and is sunk into a rocky promontory with the Kozel u Hostimi prehistoric fortified place. The whole area is part of the Protected Landscape Area of the Bohemian Karst.

The limestone mining in the Alkazar quarry took place in the $1^{\text {st }}$ half of the $20^{\text {th }}$ century. Limestone was transported from

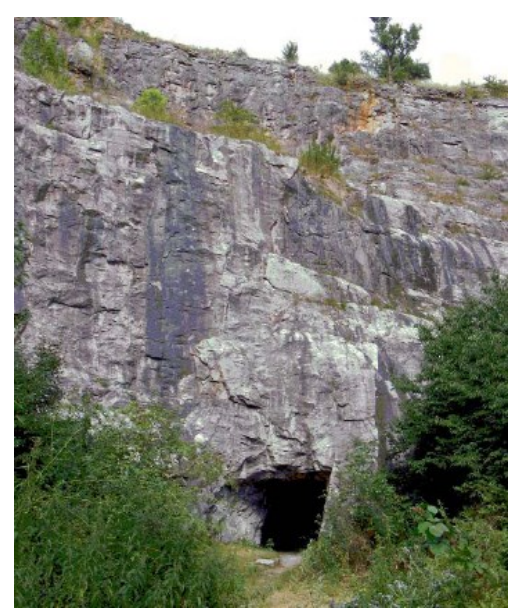

Figure 80: The closed access route to the Hostim repository near Beroun. [Source: Fig-80] the Hostim I and II quarries to Beroun along a narrow-gauge railway, the remnants of which have been preserved along the road to Beroun to the present day. The subject of mining was high-percentage Koněprusy and Slivenec limestone, used mainly for metallurgical purposes. The system of underground spaces, in which the Hostim repository is located, dates from the end of World War II.

The operation of the Hostim repository was finished on August 9, 1965. This happened in accordance with the then valid regulations and further care for the safety of the repository was taken over by the state. The repository has been closed since 1997 and is regularly monitored by the RAWRA.

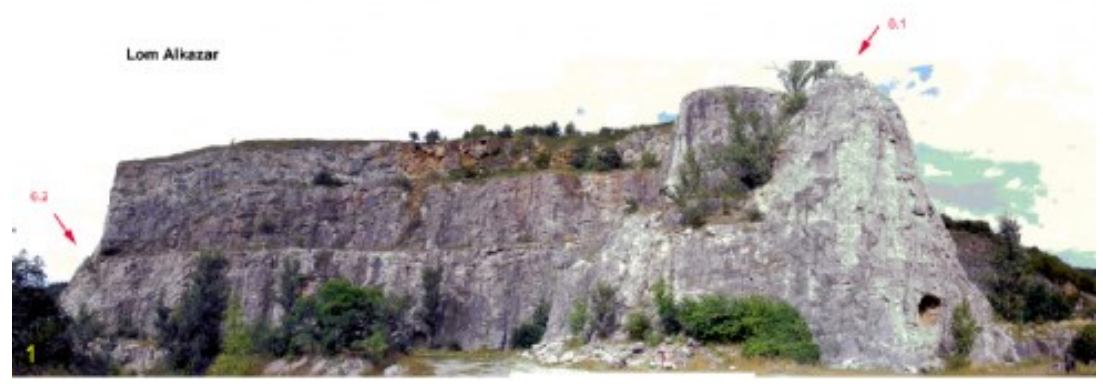

Figure 81: The rock formation of the Alkazar quarry. [Source: Fig-81]

The Hostim radioactive waste repository was built in 1959 in the Alkazar limestone quarry near the village of Hostim by the adaptation of two galleries excavated between 1942 and 1944. The total volume of both tunnels was about $1,690 \mathrm{~m}^{3}$. The repository stores low- and intermediate-level waste. The operation was terminated in 1965. Between 1991 and 1994, the inventory of the stored wastes, and the radiological and mining survey inside the both galleries were carried out. 
It was verified that the radiators and packaging containing waste with higher activity were transported in 1964 from gallery B to the Richard repository. The inspections showed that the risks associated with the reprocessing and transport of waste to another site would be significantly higher than the risks associated with the existence of the repository. And therefore, it was decided to fill the repository with a concrete mixture and to close it. Radionuclides tritium ${ }^{3} \mathrm{H}$ and carbon ${ }^{14} \mathrm{C}$ are dominant nuclides of radioactive wastes in the repository. In the course of time (approximately since 2030) the radionuclide ${ }^{14} \mathrm{C}$ will be prevalent due to the radioactive transformation.

\subsubsection{The concept of a deep geological repository in the Czech Republic}

Both Czech nuclear power plants - Dukovany and Temelín - will produce a total of about 4,000 tonnes of used fuel during their 40-year design life. Just for comparison, every Czech will produce about $400 \mathrm{~kg}$ of municipal wastes per year, which is more than 4 million tonnes nationwide. If the planned two new units are built at the Temelín power plant and one at the Dukovany power plant, then the amount of waste to be stored will rise to 9,000 tonnes of used nuclear fuel and $5,000 \mathrm{~m}^{3}$ of high-level waste. To get an idea - this amount of the used nuclear fuel will fill roughly 6,000 storage drums and 3,000 concrete containers.

Currently, used nuclear fuel is stored safely in the so-called interim storages (the interim storage of the used nuclear fuel in the Dukovany power plant has been operating since 1995 and the new interim storage in the Temelín power plant was put into operation in 2010). Since the used fuel contains elements capable of releasing even the more significant amount of power, it may become a valuable raw material in the future.

However, the future use of used nuclear fuel, if it does occur, does not mean that the need to build a deep repository is eliminated. The volume of future waste or its risk is likely to be reduced, so that the use of the planned repository will be more efficient. In any case, even in the future a certain amount of used fuel and other high-level wastes will be produced and it will be necessary to dispose of them safely.

A deep geological repository for high-level wastes and used nuclear fuel will consist of three parts:

- Underground spaces for the storage and handling of drums with used fuel and high-level wastes;

- Access shafts and tunnels; and

- Above-ground - surface area.

The storage chambers will be built at a depth of about $500 \mathrm{~m}$ (depending on the characteristics of the bedrock) in a stable geological formation and the waste will be placed in special drums with a long-term life of service. According to the quantity of the waste deposited, the underground tunnels may be extended over an area of several $\mathrm{km}^{2}$ based on the concept of a repository design (e.g. single-storeyed or multi-storeyed, horizontal or vertical storage of containers). However, the underground spaces and the storage activities taking place in them will not affect or limit what is happening on the surface in any way.

The storage areas will be connected to the surface area by vertical access shafts and a helical tunnel. The above-ground area of the repository will provide a necessary technical background and its size may be only a few hectares. It will include operations and facilities providing the electricity supply, the repository ventilation, workshops for the servicing of mining equipment, administrative buildings, social background, warehouses and the Information Centre. The building system of the entire repository must make provision for both the protection of nature and landscape in a given area and the legitimate demands of municipalities. 
The key role of the storage container is very important for ensuring long-term safety of a deep geological repository. The storage container must meet a number of requirements for e.g. the long-term tightness, the resistance to the chemical environment in the repository or the resistance to the ambient pressure.

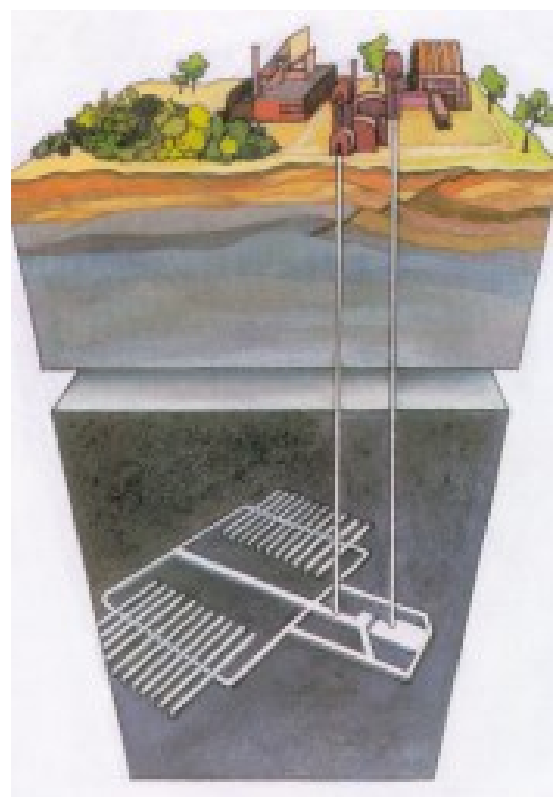

Scheme 2: A deep geological repository. [Source: Sche-2]

In the so-called Reference Project, the total costs for the preparation of a deep geological repository including its construction were estimated at 47 billion CZK according to the prices in 1999. These costs are related primarily to the exploration of suitable sites and the research of the rock environment on a selected site. The money for the construction of a deep geological repository is gradually deposited in a special account managed by the Ministry of Finance of the Czech Republic, where annually millions of CZK come from the CEZ Group, the nuclear power plant operator and other companies producing radioactive waste. In 2009, a sum of 13 billion CZK was deposited in the Nuclear Account and this sum increases by 1.4 billion CZK every year.

The Czech conceptual design of a deep geological repository does not differ from the similar ones abroad. The design of the surface area is presented in Scheme 3, i.e. the area at the time of operation when radioactive wastes and the used nuclear fuel are simultaneously received and reloaded into waste packages, transported to the underground and deposited. At the same time, the building of additional storage spaces underground will take place. In addition to the structures shown, the area includes technical facilities and the buildings for the stay of workers, an administrative building, information services, communications, etc. The object is located in an inactive part of the premises; the active operation is concentrated in the detached section, which is provided with the independent safeguarding.

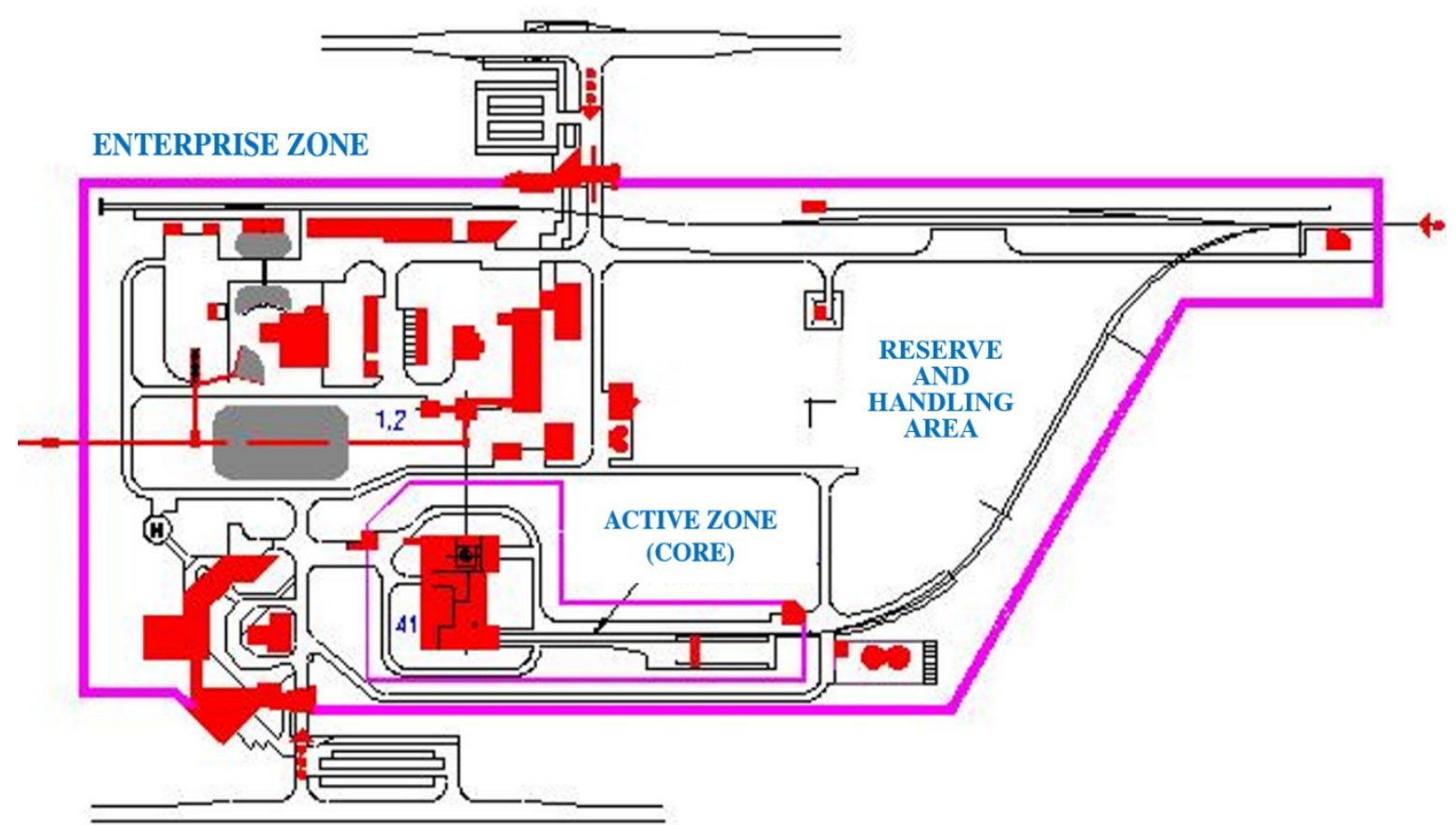

Scheme 3: The surface area of a deep geological repository. [Source: Sche-3] 
The total area of the surface area is 29.5 hectares, of which the part, where the used fuel and high-level wastes are handled, occupies 3 hectares. The remaining reserve and handling area will be used as a construction site; a part will be occupied by a railroad spur. For reasons of easier delimitation and its closure after the arrival of a train to transport used fuel, this area is part of the surface area, although no significant operations will take place here.

The underground part of the repository consists of access and ventilation shafts, tunnels and storage spaces. The largest part of the underground spaces represents an extensive network of tunnels, in which the drums (containers) of used nuclear fuel will be stored. Both the vertical location under a storage tunnel and the lateral horizontal location inside the walls of the tunnel are used. All access routes should be sealed gradually so that the underground spaces with the stored waste cannot communicate with the biosphere. Several barriers that support and complement one another are designed for the repository. The safety of the repository must also be maintained even in the case when one of the barriers loses its insulating capacity. Containers filled with used fuel or high-level wastes are surrounded by damping materials (bentonite) and deposited at a depth of about $500 \mathrm{~m}$ to the spaces excavated in the host rock.

First, Swedes tried to deposit canisters in the Äspö underground laboratory (Fig. 82). The damping material should keep the container in place (in a storage tank) and prevent corrosion of the containers. After the end of the container life span when a damage may occur, the damping material will prevent the transport of radionuclides from the repository to the surface of the Earth. This applies especially to the elements with high radioactivity and long radioactive half-lives, i.e. plutonium or americium. Rocks also contribute to the insulation as they provide a stable chemical and mechanical environment both for a container and a damping material. Chemical conditions in a host rock may influence the future transport

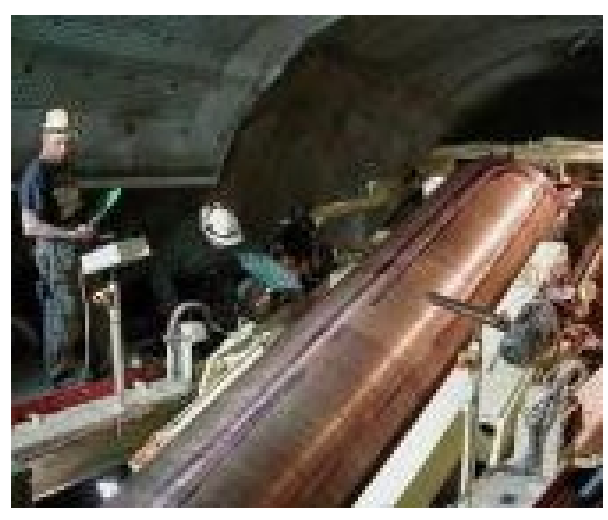

Figure 82: Locating canisters in Aspö. [Source: Fig-82] of radionuclides, i.e. its acceleration, deceleration or even stopping. Therefore, their knowledge is very important for proving the safety of the future repository. The goal is to find such an environment that will slow down the transport of radionuclides and will provide a guarantee of the sufficient stability for thousands of years.

If the insulating function of the repository is somehow impaired or a canister is damaged, the repository still has a secondary, decelerating function. This means that the radionuclide movement from the repository into the biosphere will be sufficiently long and slow, so that, in the meantime, the radioactivity level can drop to very low and acceptable values.

All the barriers contribute to the deceleration function of the repository. Even partially damaged canisters can effectively contribute to the slowing-down by preventing the access of water into them and the release of radionuclides out of them. If the fuel comes into contact with groundwater, a slow dissolving process begins since many radionuclides are slightly soluble in water. This reduces their possible movement through both a damping material and the rock fracture system. The clay damping material is able to retain a majority of radionuclides through the entrapment on the surface of clay particles. The rock will contribute to the deceleration by capturing radionuclides on the surfaces of cracks or by their penetration into the micropores among individual minerals. To verify these processes, a lot of research has taken place in underground laboratories in the world and these investigations must also be carried out within the development of the Czech deep geological repository. 
The selection of a suitable locality is one of the fundamental objectives of the deep geological repository development. The locality has to meet not only the requirements for the rock properties, especially for its ability to insulate and capture radioactive materials, but also a number of non-geological requirements, including the conflicts of interests, the acceptability of the locality by the public, the technical possibility of building a surface area of the repository and the locality accessibility.

As for the rock environment itself, it is required to select such an environment that occurs widely on the state territory and the geological development and position of which makes it possible to assume that it will have the required properties, which, in addition, will be stable for the necessary period of time.

Table 36. The localities considered for the construction of a deep geological repository in the Czech Republic. [Source: Tab-36]

\begin{tabular}{|c|c|c|}
\hline $\begin{array}{c}\text { Name of the } \\
\text { locality }\end{array}$ & \multicolumn{1}{|c|}{ Description of the locality } & $\begin{array}{c}\text { Number } \\
\text { of residents } \\
\text { in the locality }\end{array}$ \\
\hline Kraví Hora & $\begin{array}{c}\text { The locality is situated in the territory of the municipalities of Bukov, } \\
\text { Věžná, Stř́tež, Moravecké Pavlovice, Drahonín, Olší and Sejřek, } \\
\text { which fall under the Vysočina and South Moravian Regions. }\end{array}$ & 1,121 \\
\hline Čihadlo & $\begin{array}{c}\text { The locality is situated in the territory of the town of Deštná and the } \\
\text { municipalities of Světce, Lodhéřov and Pluhưv Žd'ár in the South } \\
\text { Bohemian Region. }\end{array}$ & 2,128 \\
\hline Březový potok & $\begin{array}{c}\text { The locality is situated in the territory of the municipalities of } \\
\text { Pačejov, Kvášñovice, Olšany, Maňovice, Chanovice and Velký Bor } \\
\text { in the Pilsen Region. }\end{array}$ & 2,507 \\
\hline Hrádek & $\begin{array}{c}\text { The locality is situated in the territory of the municipalities of } \\
\text { Rohozná, Dolní Cerekev, Cejle, Hojkov, Milíčov and the township of } \\
\text { Nový Rychnov in the Vysočina Region. }\end{array}$ & 3,602 \\
\hline Magdaléna & $\begin{array}{c}\text { The locality is situated in the territory of the municipalities of Jiste- } \\
\text { bnice, Nadějkov and Božetice in the South Bohemian Region. }\end{array}$ & 3,132 \\
\hline Čertovka & $\begin{array}{l}\text { The locality is situated in the territory of the municipalities of Blatno, } \\
\text { Lubenec in the Ústí Region and in the territory of the municipalities } \\
\text { of Tis u Blatna and Žihle in the Pilsen Region. }\end{array}$ & 3,482 \\
\hline Horka & $\begin{array}{c}\text { The locality is situated in the territory of the municipalities of Hodov, } \\
\text { Rohy, Oslavička, Budišov, Nárameč, Vlčatín, Osové, Rudíkov and } \\
\text { Osslavice in the Vysočina Region. }\end{array}$ & 3,602 \\
\hline
\end{tabular}

At the beginning of the century, the first stage of the preparation of the deep geological repository (i.e. the research stage) ended. It consisted of two phases, i.e. regional mapping and the selection of promising localities. After that, the second stage should have followed, during which the exploration work at selected localities should have been carried out. The work was suspended by a government decree for 5 years and should now be resumed. During the interruption, the geological work at the Melechov test site was carried out. Some techniques and procedures that would be used later in exploring the selected sites were verified. Moreover, the number of selected localities was increased; the Boletice and Hradiště military domains were included. The resumption of work so that, in accordance with the concept of the Czech Republic in the field of radioactive waste and spent nuclear fuel management, two sites could be selected for detailed research requires the fulfilment of one condition, which is the consent of municipalities to exploration work. 
The geological survey of the localities is scheduled as follows: after finding a suitable locality, it will be necessary to determine a space at a depth of $500 \mathrm{~m}$ below the surface for a future repository (the area of 3 to $5 \mathrm{~km}^{2}$ ). The exploration work will be performed in the $100 \times 100 \mathrm{~m}$ network within the time range of 3 months and will consist of the sampling to a depth of 1 to $2 \mathrm{~m}$ or, if need be, 3 to $5 \mathrm{~m}$. The geophysical survey will be carried out through the measurements from the surface only. The result should be a proposition of the places for several boreholes to a depth of approximately $500 \mathrm{~m}$ and one borehole to a depth of $1,000 \mathrm{~m}$. These drilling operations should take place with the consent of land owners within a few months.

The prerequisites for the solution include especially the following:

- Emplacement in a hypothetical locality with a deposition depth of around $500 \mathrm{~m}$;

- The host environment includes granite rocks with a mean temperature of $10^{\circ} \mathrm{C}$ and an assumed pressure of $20 \mathrm{MPa}$ on a waste package;

- For the transport of waste packages into the disposal site the rail transport or alternative road transport are considered; and

- The deposition of waste packages with a surface temperature of about $100{ }^{\circ} \mathrm{C}$ and their sealing in the borehole using bentonite is assumed.

According to the Reference Project of the deep geological repository, the final goal should be the construction of the underground area in excavated cavities that should be connected by a vertical shaft to transport people and material. Favourable terrain and geological conditions confirmed by the preliminary safety analyses are a prerequisite. Searching for a suitable site for a deep geological repository is formally divided into two stages: a research stage (searching for the potentially suitable areas and properties of the rock environment) and a survey stage (obtaining and verifying the data on geological structures and underground spaces before starting the construction work as well as in its course).

A geological survey has three sub-stages: search, exploration and detailed exploration. Selecting a suitable locality for a deep geological repository was started shortly after the activation of the first nuclear power units, i.e. in the 1980s. In the 1990s, the first studies assessing the potential of the rock environment in the Czech Republic were developed.

A geological research is the analysis of archival maps, aerial and satellite photographs, small geophysical measurements in the field and the feasibility studies of the surface premises. With regard to the nature of works, the agreement of the municipalities concerned is not required for its implementation. The basic framework for the future selection of a deep geological repository locality is the Radioactive Waste and Spent Nuclear Fuel Management Concept from 2002, approved by the government, which requires finding two localities (main and backup) with the best geological conditions, consistent with preserving the expected development of the area of interest. The second important document approved by the government in 2008, the Spatial Development Policy of the Czech Republic, requires making a selection of the two most suitable localities for the implementation of a deep geological repository by 2015 with the participation of municipalities.

The fundamental principles of the position of municipalities in selecting a site are as follows:

- The survey and the potential construction of a deep geological repository must be a benefit for municipalities;

- The municipalities voluntarily participate in selecting a suitable locality;

- The municipalities must have adequate tools as well as powers to defend their interests;

- The process must be transparent and democratic; and

- Territory with features suitable for the construction of a deep geological repository. 
On the basis of geological surveys done, the future exploration areas with potentially suitable properties for the construction of a deep geological repository are defined at particular localities. Within these areas, the surface area of premises is defined (in some cases in variants), where suitable conditions for the connection of all necessary technical infrastructure for a potential deep repository were found.

Table 37: The concept of a deep geological repository in the Czech Republic.

[Source: Tab-37]

\begin{tabular}{|c|c|c|}
\hline \multicolumn{2}{|r|}{ Period } & Activities - sequence of trades \\
\hline \multirow{5}{*}{ 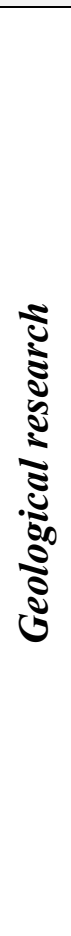 } & $1990-1993$ & $\begin{array}{l}\text { Based on several geological criteria, the Czech Geological Institute suggested } \\
27 \text { sites recommended for further research. }\end{array}$ \\
\hline & 1990-1998 & $\begin{array}{l}\text { The Nuclear Research Institute in Řež selected the } 13 \text { most promising areas and per- } \\
\text { formed the gathering and analysis of archived geological information. Based on this } \\
\text { analysis, the selection was narrowed to } 5 \text { areas, in which } 8 \text { sites were forecasted. }\end{array}$ \\
\hline & $2002-2003$ & $\begin{array}{l}\text { The RAWRA was involved in the work and added a regional research recommended } \\
\text { by the International Atomic Energy Agency; based on new criteria, } 11 \text { localities were } \\
\text { recommended. }\end{array}$ \\
\hline & 2003-2005 & $\begin{array}{l}\text { The RAWRA concluded the initial stage of regional research and selected the } 6 \text { most } \\
\text { suitable sites, which it recommended for the second stage of research using the aerial } \\
\text { geophysical survey and satellite images. The areas of a potentially homogeneous ge- } \\
\text { ological environment were identified and the polygons of the future exploration areas } \\
\text { in each locality were designed. The feasibility studies dealing with the surface areas } \\
\text { of the future deep geological repository, its connection to the underground and the } \\
\text { connection to the technical and transport infrastructure were also developed. }\end{array}$ \\
\hline & 2005-2009 & $\begin{array}{l}\text { On the basis of negative opinions of the municipalities concerned, the work in } \\
6 \text { surveyed localities were interrupted by the end of } 2009 \text { by the government deci- } \\
\text { sion. In } 2008 \text {, the geological research was assigned with the aim to prepare an anal- } \\
\text { ysis of archived geological information in } 5 \text { military domains in the Czech Republic. } \\
\text { The purpose of the research was to expand the list of suitable sites for geological } \\
\text { exploration and to include less conflict areas in terms of the public attitudes. }\end{array}$ \\
\hline \multirow{3}{*}{ 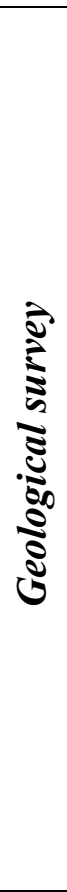 } & 2010-2015 & $\begin{array}{l}\text { The search stage of the geological survey included detailed geophysical and geo- } \\
\text { chemical mapping. A detailed geological map of the site was made. Its goal was to } \\
\text { propose a place for a borehole (to a depth of } 800 \text { to } 1,000 \mathrm{~m} \text { ) and, in particular, to } \\
\text { identify areas at a depth of } 500 \text { to } 600 \mathrm{~m} \text { of a relatively homogeneous geological } \\
\text { environment with an area of approximately } 3 \text { to } 5 \mathrm{~km}^{2} \text { for the future deposition itself. } \\
\text { In parallel, the technical solution of the surface area, the underground area and their } \\
\text { connection (including the transport system for future wastes to the underground and } \\
\text { their deposition) was elaborated. The suitability of the site was confirmed through } \\
\text { the technical solution and the preliminary safety assessment. The result of the search } \\
\text { stage was a proposal for the future main locality for the deep geological repository } \\
\text { and the backup locality. }\end{array}$ \\
\hline & 2015-2025 & $\begin{array}{l}\text { In the exploratory stage, the character and suitability of the selected main locality } \\
\text { will be confirmed on the basis of detailed drilling operations, the research of rocks } \\
\text { and other ongoing research work. The backup locality will be considered only if, } \\
\text { for some reasons, the main locality does not meet the original expectations. }\end{array}$ \\
\hline & 2025-2050 & $\begin{array}{l}\text { The work in the final locality will move to the stage of a systematically exploration } \\
\text { via the mine work for the construction of an underground laboratory. The character- } \\
\text { istic and suitability of the geological environment will be examined directly on the } \\
\text { site in the rock complex. The aim will be a credible set of data to prove the safety } \\
\text { of the site to apply for the building licence for the construction of the deep repository. }\end{array}$ \\
\hline \multicolumn{2}{|c|}{$2050-2065$} & $\begin{array}{l}\text { The construction of the underground complex and surface premises of the reposi- } \\
\text { tory and the commencement of operation. }\end{array}$ \\
\hline
\end{tabular}




\subsubsection{Radiation incidents and radiation accidents}

The use of ionizing radiation sources (hereinafter IRSs) in the branches of medicine, industry, agriculture and research continues to grow and is inevitably associated with the possibility of incidents and accidents. However, there are few areas of human activity where, in parallel with the development of applications, such attention has been paid to ensuring their safety in terms of health protection as the use of IRSs. Nevertheless, it is impossible to absolutely rule out that an unplanned exposure of humans will occur. The elimination of radiation incidents and accidents requires a very fast operational decision-making leading to the implementation of measures to protect the health of workers and residents, and the measures to protect the assets. The unintentional exposure or dispersion of radioactive agents is an emergency arising through the surprising and unforeseen mechanisms and ending with very diverse consequences. The basic division of emergencies is the division into radiation incidents and radiation accidents.

Radiation incident is an event that results in an inadmissible leakage of radioactive agents or ionizing radiation, or an inadmissible exposure of individuals.

Radiation accident is then a radiation incident, which requires the measures to protect the population and the environment. The consequences of radiation incidents are generally limited to the premises of the workplace with ionizing radiation sources; radiation accidents then affect its surroundings, especially through the escape of radioactive agents into the environment. In workplaces, there may be sources causing high dose rates and high-volume activities leading to significant intakes of radioactive agents can be released into the environment when there is a breach of the barrier system tightness. The loss of control over the source may thus lead most often to the exposure of one or a few employees who can be at risk of acute local or wholebody damage.

The corrective measures in radiation incidents are aimed at preventing the occurrence of deterministic damage to workers. Individual citizens are at risk only in rare cases when a strong IRS is lost or stolen and gets into a public place where it is found by ignorant people who mishandle it. In radiation accidents of nuclear facilities associated with the scattering/leakage of radioactive agents into the environment, larger groups of people may be irradiated or the contamination of air, water, land surface or food chains can occur. In these cases, we encounter the possibility of deterministic damage only exceptionally outside the area of the crashed facility; however, releases of radioactive agents, especially into the air, pose a risk in terms of exposure of the population (usually higher than for releases into the hydrosphere) - releases to the air cause higher doses and reach humans in a shorter time.

Unlike the regulation of exposure during activities, the regulation of exposure during interventions is not based on limits - the use of predetermined limits as a basis for making decisions on interventions could lead to measures disproportionate to their benefits, thus contrary to the principle of justification - but internationally accepted intervention measures, which our legal rules have also adopted are stated in:

- "Decree No. 21/2017 Coll." - Decree of the State Office for Nuclear Safety on ensuring nuclear safety of a nuclear installation.

- "Decree No. 422/2016 Coll." - Decree of the State Office for Nuclear Safety on radiation protection and security of a radionuclide source.

- "Decree No. 409/2016 Coll." - Decree of the State Office for Nuclear Safety on activities especially important from the viewpoint of nuclear safety and radiation protection, special professional qualification and training of the person ensuring radiation protection of the registrant. 
However, the optimization of the intervention is always limited by the need to prevent deterministic effects by any means. The basic principles of contingency planning and response are the same for all types of incidents and accidents. The choice of individual measures and the timing of their implementation will vary. The choice of protective measures depends on the nature of an incident or accident, its duration and an affected area. Besides the less probable radiation accidents of power plants, the radiation incidents or, if need be, accidents, related to the IRS during their manufacture, transport and use or misuse, loss or theft, damage to a source or its shield, etc. are frequent.

For the holders of the authorization to perform radiation activities establishes the requirements for the contents of the on-site emergency plan, the contents of emergency regulations for transport and movement of nuclear materials and determined radioactive agents, for which the authorization is required - "Decree No. 359/2016 Coll." - Decree of the State Office for Nuclear Safety on details of ensuring radiation extraordinary event management.

The consequences of a radiation incident or accident may differ depending on the type and nature of the event, the total quantity and composition of the mixture of leaked radionuclides and their properties, the nature of the environment, in which radionuclides are released and on the mechanism of the propagation of radionuclides. Then, important exposure channels are external irradiation caused by a damaged equipment or a source out of control, external irradiation caused by the cloud of released radioactive material, inhalation of radioactive agents from the cloud, external irradiation from the deposit of radioactive agents on the surface of the ground, contamination of the body surface and clothing, ingestion of food or water contaminated by radioactive agents.

On-site and off-site emergency plans of nuclear power plants must be based on a specific type of equipment and the potential for the leakage of different radionuclides. The environmental consequences calculated for a number of expected emergency sequences then form another source for the creation of off-site emergency plans.

We distinguish two basic areas for emergency planning - the workplace area with sources of ionizing radiation and its surroundings. In the vicinity of the plant the emergency planning zone (EPZ) is usually determined on the basis of safety analyses. The EPZ is divided into the zone of automatic adoption of emergency protective measures after warnings (PMZ - preliminary measure zone), the zone where the urgent protective measures are planned (EMZ-emergency measure zone) and the zone where long-term protective measures are planned (LMZ long-term measure zone), see Scheme 4.

The operator of the plant with the IRSs is responsible for planning and introducing urgent measures to mitigate the effects of an accident, i.e. the protection of people in the workplace, informing the relevant authorities and providing all necessary information, recommendations and technical assistance, warning the population in the vicinity of the workplace. The state administration at the local level and the government at the national level are responsible for the population protection in the vicinity of the nuclear power plant. The responsibility of the central authorities and the government includes especially organizing the follow-up actions that do not require immediate implementation and exceed the competencies or possibilities of lower territorial administrative units.

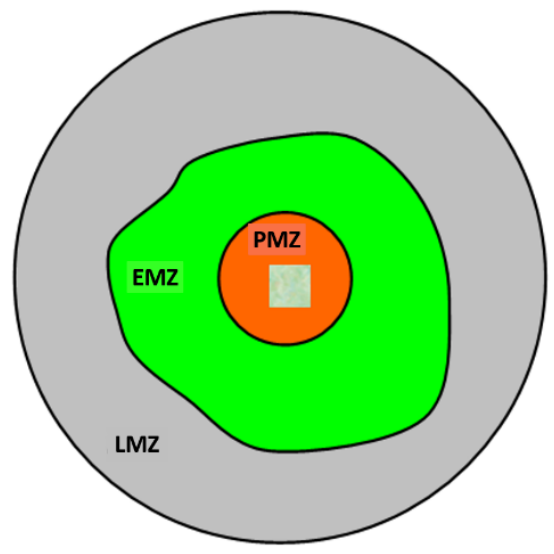

Scheme 4: Emergency planning zone (EPZ). [Source: Sche-4] 
In terms of the time course of a radiation accident, two phases are distinguished in principle: the early phase (before the leak and at the time of leak) and the corporate phase (long-term, subsequent).

If, in the early phase of an accident, most of the available information about the possible radionuclide composition of the leak and its size (source member), about the probable development of the accident and its consequences is burdened with considerable uncertainty and the information is based on the assessment of the technology status in a given plant, the decisionmaking on the protective measures will be based on condition of the facility and the forecast of its changes, on the available information about the radiation situation in the area and on the meteorological data; the results of monitoring in the ventilation stack, on the plant premises, the results acquired from the teledosimetric system and gradually also from the vicinity of the nuclear power plant (measuring by mobile groups, etc.) will be known. In the early phase, higher dose rates can be expected (both from external irradiation and due to internal contamination - inhalation and deposition on the Earth's surface) than in the corporate (long-term, subsequent) stage.

The radiation situation awareness in affected areas can already be expected in the corporate phase; the dominant part of the continuing irradiation is caused by the external irradiation from the deposit and by the internal contamination after the ingestion of food contaminated with radionuclides. The decisions on the nature and extent of protective measures will be based on the results of the environment monitoring and the content of radionuclides in food chains. The Czech Republic, just as other states, also operates the National Radiation Monitoring Network (NRMN) as one of the means of adequate response to a radiation accident, which is managed by the State Office for Nuclear Safety (SONS) in cooperation with the National Radiation Protection Institute for (NRPI).

Monitoring is performed by several subsystems - the Early Warning Network (EWN), which consists of about 60 measuring points with an automatic transmission of measured values, territorial and local networks of thermoluminescent dosimeters (TLDs) (around both nuclear power plants), the network of measuring points of air contamination and laboratories (equipped for gamma spectrometric or radiochemical analyses of radionuclide content in the samples of the environment and food chains); the mobile ground and air groups are prepared and trained. "Decree No. 360/2016 Coll." - Decree of the State Office for Nuclear Safety on radiation situation monitoring sets the requirements for the function and organization of the national radiation monitoring network and the method of data transmission.

Emergency protective measures are planned and, if need be, implemented for the early phase of an accident. These are notifying the responsible institutions, warning the population, sheltering, evacuation, iodine prophylaxis, limiting the stay of persons, decontamination of personnel and provision of special health care to irradiated and contaminated individuals. After the early phase, the consequent and long-term measures are applied, such as the decontamination of determined contaminated areas, buildings and facilities, the control of food chains, veterinary and agricultural measures and, if need be, the evacuation of people from the most contaminated areas.

The follow-up actions are implemented after the acquisition of reliable data (the results of monitoring) with regard to social, psychological and economic aspects; the social and economic losses associated with unsubstantiated decisions may be considerable due to the duration of follow-up actions. It is, therefore, important to decide on performing the follow-up actions on the basis of the most comprehensive information possible with the use of the best estimates of the impacts of individual variants. 
When implementing protective measures, the internationally recommended and by our legal standards adopted intervention and basic values of expected and averted doses are a guide. These values, which relate to the given measure and the given time after the leak of radionuclides, are set out by "Decree No. 422/2016 Coll." - Decree of the State Office for Nuclear Safety on radiation protection and security of a radionuclide source.

\subsubsection{The A-1 nuclear power plant accident at Jaslovské Bohunice (Czechoslovakia 1976 and 1977)}

The A-1 Jaslovské Bohunice nuclear power plant (designation: EBO A-1) was built between 1958 and 1972. The nuclear reactor indicated as KS-150 was designed in the USSR and Czechoslovakia. Besides the fuel elements, the reactor vessel and the internal components of the core were made in ŠKODA in Pilsen. The concept of the reactor should have verified the possibility of using unenriched (natural) uranium as a fuel. The fuel in the reactor was placed in 148 channels. The reactor design allowed refuelling during the operation using a refuelling machine.

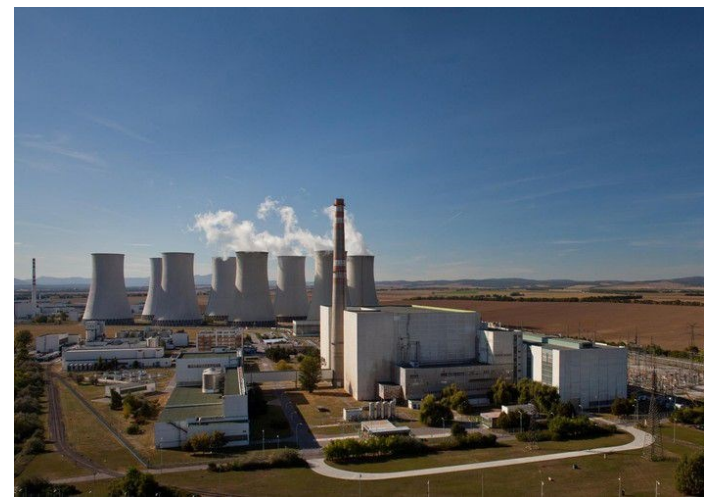

Figure 83: The A-1 nuclear power plant at Jaslovské Bohunice. [Source: Fig-83]

A total of 40 control rods were located in the reactor. The fuel elements were made of uranium metal and provided with the compound sintered metals of magnesium and beryllium. The active zone had a diameter of 3.56 metres and a height of $4.0 \mathrm{~m}$. The amount of 24.6 tonnes of natural uranium was placed in the core. The whole reactor was $20.1 \mathrm{~m}$ high and its diameter was $5.1 \mathrm{~m}$. The wall thickness was from $150 \mathrm{~mm}$ to $600 \mathrm{~mm}$.

The moderator was heavy water, which was 57.2 tonnes in the reactor, and the reactor was cooled with carbon dioxide. The coolant entered the reactor under a pressure of $6.5 \mathrm{MPa}$ and at a temperature of $112{ }^{\circ} \mathrm{C}$; at the reactor outlet, the pressure was $5.5 \mathrm{MPa}$ and the temperature was $426^{\circ} \mathrm{C}$. The coolant in a quantity of $1,576 \mathrm{~kg} . \mathrm{s}^{-1}$ flowed through the reactor. The designed thermal power of the plant was $560 \mathrm{MW}$, the gross electrical output $144 \mathrm{MW}$, the net electrical output $110 \mathrm{MW}$ (other sources also mention $104 \mathrm{MW}$ or $127 \mathrm{MW}$ ). Three electric generators served for generating electric power, each with an output of $50 \mathrm{MWe}$. At Jaslovské Bohunice, other two nuclear plants known as V-1 and V-2 are located on the premises.

The A-1 nuclear power plant accident at Jaslovské Bohunice was the most serious nuclear power plant accident in the former Czechoslovakia. On February 22, 1977, a major nuclear accident occurred at the A-1 nuclear power plant at Jaslovské Bohunice. This accident happened when the fresh fuel was loaded during the operation of the reactor and was classified as accident of level 4 of the INES scale. During the accident the damage to the nuclear fuel, its corrosion and leakage of $\mathrm{CO}_{2}$ into the area of the power plant occurred.

\section{Accidents}

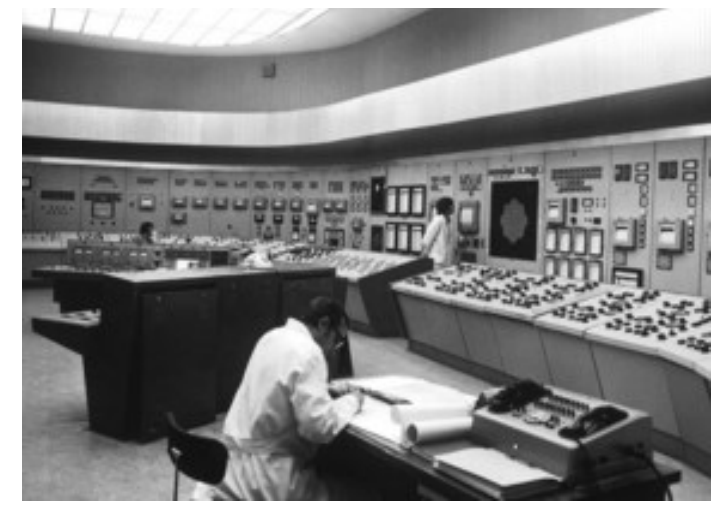

Figure 84: The main control room of the A-1 nuclear power plant. [Source: Fig-84]

With regard to the exacting concept of the A-1 power plant and dealing with many difficult problems, numerous break-downs occurred during its start-up and operation. 
The first serious event was an accident dated on January 05, 1976. During the replacement of the fuel assembly, the sealing plug of the fuel assembly was incompletely locked, which was ejected from the reactor into the hall space, where $\mathrm{CO}_{2}$ began to leak after the loading machine was removed from the reactor by coolant pressure. Later, it turned out that due to the error of mounting the sealing plug in the fuel assembly workshop in the power plant, a complete movement of the inter-connecting mechanism of the sealing plug was not possible and the locking stones in the reactor channel did not extend completely. At the request of the engineer managing the liquidation of the accident, Viliam Pačes, a worker in the transport-technology part of the reactor, secured by Milan Antolík (an expert in dosimetry), returned to the reactor hall with a breathing apparatus and protective clothing and drove the loading machine back to the open fuel channel and closed it. As the ejected fuel assembly was fresh, there was no significant leakage of radioactive fission products or irradiation of people. However, the leaked carbon dioxide (heavier than air) got into the lower area of the reactor, where two workers of the power plant were asphyxiated. In 1987, Lubomír Štrougal bestowed state decorations on Milan Antolík and Viliam Pačes and on January 1, 2008, President Ivan Gašparovič bestowed the Slovak state awards on them (the Cross of Milan Rastislav Stefánik, $3^{\text {rd }}$ class). The improper storage of used nuclear fuel was also one of the serious problems of the power plant. During the plant operation, the stored fuel assemblies and steam generator tubes were covered with corrosion.

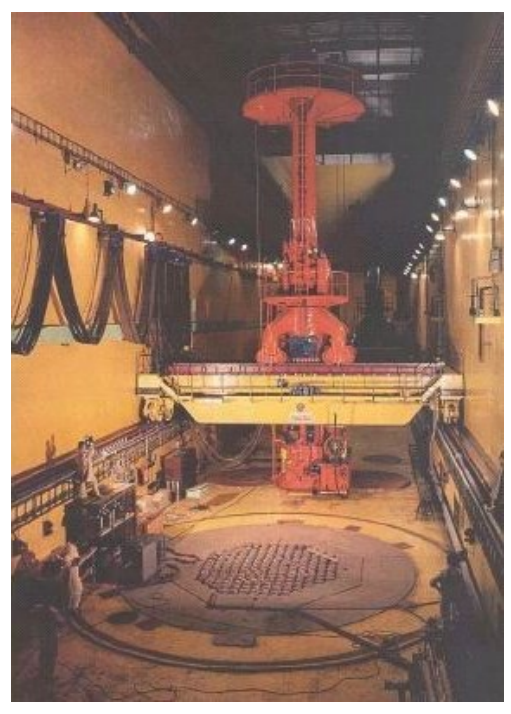

Figure 85: The reactor hall of the A-1 power plant. [Source: Fig-85]
The second accident of the A-1 reactor happened on February 22, 1977, during the replacement of a fuel assembly. When preparing a fresh fuel assembly, the personnel of the fuel assembly workshop noticed that a silica gel bag that had been inserted into the assemblies as a moisture absorber at the time of storage was torn and the silica gel beads got spilled into the fuel assembly. They vacuumed the silica gel, but they didn't notice that some of beads had been stuck inside the assembly in the spacer grids. After introducing the fuel assembly into the reactor, the coolant could not flow freely and local overheating caused the fuel rods to melt. It also caused the caisson pipe of the heavy-water moderator vessel to burn. This led to the penetration of the moderator (heavy water) to the primary circuit and consequently a rapid increase in the moisture, which led to the rapid damage of the fuel cladding located in the reactor.

The primary circuit was heavily contaminated with fission products and the secondary circuit was also partially contaminated due to leaks in the steam generators. As a result of this accident, the A-1 nuclear power plant was shut down and, currently, its dismantling is carried out. The accident was rated level 4 on the seven-point International Nuclear and Radiological Event Scale (INES). Since 1979, the gradual dismantling of the EBO A-1 plant has been under way. On the basis of the interstate agreement, all the nuclear fuel has been transported to the Russian Federation. At present, tanks with radioactive sludge and solid radioactive waste pose the greatest risk. The majority of the population in the former Czechoslovakia did not learn about the accident or, more precisely, most people have no idea about the very existence of the EBO A-1 nuclear power plant. The actual extent of the accident has not been published and even today there is practically no publicly available detailed information on the causes, course and consequences of this accident. 


\subsubsection{The Three Mile Island nuclear power plant accident (USA 1979)}

The Three Mile Island accident was an accident of the nuclear power plant situated on the island of the same name on the Susquehanna River near Harrisburg, Pennsylvania, the USA. It happened on March 28, 1979 when the second nuclear reactor melted partially. The service building was contaminated and there was a massive release of radioactivity into the environment. It led to the stricter regulations of the nuclear energy industry in the USA and the considerable restrictions of its development. It also negatively affected the perception of risks associated with nuclear energy, not only by the American public.

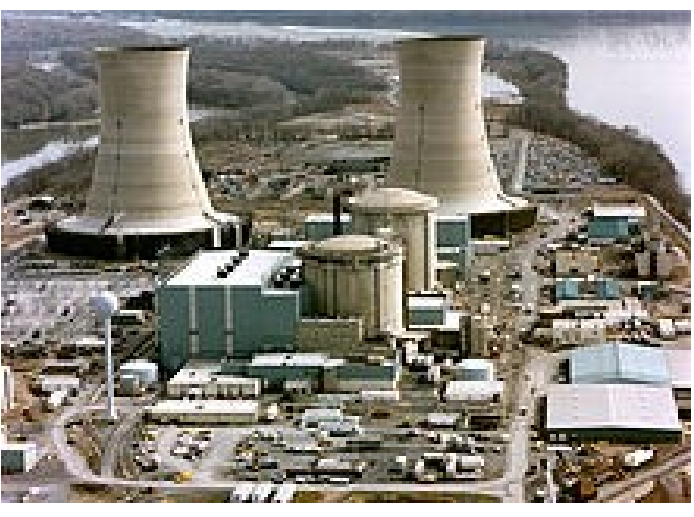

Photo 87: The Three Mile Island nuclear power plant. [Source: Pho-87]

\section{Event description:}

The main water feed pumps of the secondary circuit cooling system broke down around 4:00 a.m. on March 28, 1979. This mechanical or electrical failure caused the steam generator to stop cooling the primary circuit.

- $\mathbf{2} \mathbf{s}$ - The turbine was shut down automatically and the control rods were dropped into the reactor to stop the fission process.

- $5 \mathbf{s}-$ However, the pressure and temperature in the primary circuit continued to grow. To reduce the pressure, the valve on the pressurizer opened. The reactor was shut down by complete lowering the control rods.

- $12 \mathrm{~s}$ - When the pressure in the pressurizer dropped to a prescribed value, the safety valve was to close. But it did not. The plant was experiencing a loss-of-coolant accident (LOCA). The lights on the control panel did not indicate that the valve remained open. As a result, the pressure in the circuit dropped. (The blocking valve was closed, which would correct the situation, after 2 hours and 22 minutes. The LOCA lasted over $2 \mathrm{~h} 21$ minutes and in the first 8 minutes the heat dissipation from the reactor was impaired. There was a local boiling of water in the core.).

- $\mathbf{2}$ min - The high-pressure emergency core cooling system was turned on automatically to compensate the leakage of water from the primary circuit (it worked correctly).

- $4 \mathrm{~min}$ - Due to the boiling of water, its level rose to the safety valve in the core. The operators thought that it had been caused by the emergency cooling system and turned off the pump manually (they assumed that there was too much water, but in fact there was not enough water).

- $10 \mathrm{~min}$ - Due to the continued outflow of water, the membrane on the bubbling tank burst. Water flowed into the containment area. Resumption of heat removal from the primary circuit occurred up to 8 minutes after the accident. The water leak continued, the pressure dropped and the water in the core continued to boil. The boil raised the level and the operators thought there was enough water and everything was fine.

- 90 min - Bubbles from the primary circuit reached the pump and, after the shocks in the pump, it was necessary to shut it down. Cooling deteriorated and water and steam separated. As a result, the upper part of the reactor remained only in steam, and after overheating, the upper part of the core was damaged (due to the steam, the natural circulation of water was no longer possible).

- $\mathbf{2} \mathbf{h}$ - The radioactivity of water in the primary circuit as well as in the containment increased. The Information State Supervision of Nuclear Safety in Washington announced the radiation alert at the power plant. 
- $2 \mathbf{~ h ~} \mathbf{1 5}$ min - The containment was not isolated from the environment in a proper time. Weak radioactivity was detected outside the plant. The radiation alert was declared in the vicinity of the plant and the Governor of Pennsylvania was informed.

- 2 h 22 min - The operators closed the blocking valve and the discharge of water from the primary circuit stopped. The water in the primary circuit did not flow and the cooling of the core got worse.

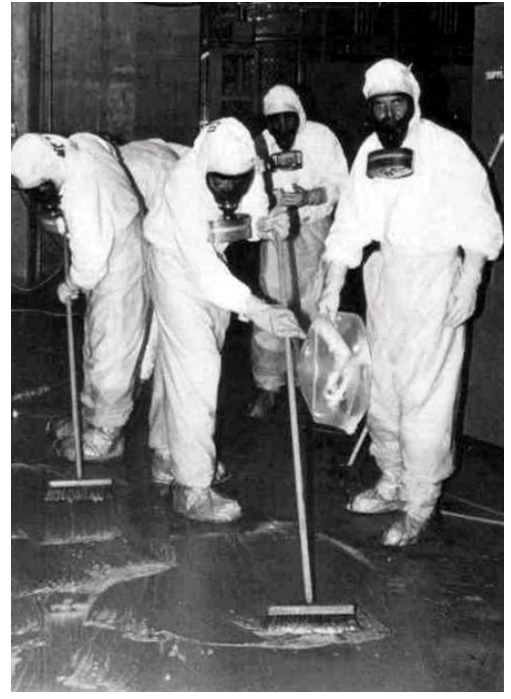

Photo 88: Workers of the TMI nuclear power plant in the auxiliary building during decontamination1979. [Source: Pho-88]
- $3 \mathbf{h ~} 20 \mathrm{~min}$ - The operation of the high-pressure emergency cooling system was restored. The temperature was lowered by injected water and further heating was eliminated. The operators made several erroneous operations when they drained water from time to time and switched on or switched off the pump. But they only followed the water level.

- $4 \mathrm{~h} 30 \mathrm{~min}$ - Weak explosions in the containment were registered. They were caused by hydrogen, which got into the containment during the discharge of water from the primary circuit. Due to fears of an explosion, the Governor ordered the evacuation of the surrounding area and the preparation of a general evacuation.

- $\quad \mathbf{5} \mathbf{h}$ - Specialists from the state supervision arrived and took over the management of the operation. The high-pressure emergency cooling system was put into permanent operation and the gradual degassing of the primary circuit began.

- $\quad 12 \mathbf{h}$ - The operation of main circulation pumps was resumed. The reactor was under control.

\section{The consequences of the accident}

In the atmosphere of growing uncertainty about the condition of the plant, the Governor of Pennsylvania decided on the evacuation of about 3,500 children and pregnant women from the vicinity of the power plant. However, in the ensuing panic, thousands of people decided to leave the area in their cars. In order to stop the mass escape of residents, American President, James Carter and the Governor of Pennsylvania, Richard L. Thornburgh visited the power plant on April 01, 1979. Subsequently, a commission was appointed to investigate the accident. The commission identified a failure on the safety valve as the cause of the accident. At the same time, it advised of the error of the staff and their lack of training in emergency management. It is assumed that about 2.5 million curies of radioactive gas escaped into the atmosphere.

\subsubsection{The Chernobyl nuclear power plant accident (the Soviet Union, Ukraine 1986)}

The Chernobyl accident happened on April 26, 1986 at a nuclear power plant in Ukraine (then the part of the Soviet Union). It is the worst nuclear accident in the history of nuclear energy and one of the two accidents of level 7, i.e. the highest level according to the International Nuclear Event Scale (INES). (Only the Fukushima Daiichi power plant accident in Japan in March 2011 is comparable.)

\section{Reactor destruction}

During a risky experiment in Chernobyl, one of the reactors overheated and subsequently exploded. The core of the reactor, the safety systems and the majority of the reactor structures bearing the reactor core were destroyed or severely damaged. The reactor environment was contaminated with active core fragments and pieces of fuel rods. The measured doses of gamma radiation were deterrent; in the reactor they exceeded the value of 5,000 $\mathrm{R}$ per hour, in the vicinity of Unit No. 4 they reached the values of 2,000 R per hour. 
The radioactive cloud spread in the air and advanced over the western part of the Soviet Union, Eastern Europe and Scandinavia over the entire northern hemisphere. Vast areas of Ukraine, Belarus and Russia were heavily contaminated, which demanded the evacuation and resettlement of more than 350,000 people. Approximately $60 \%$ of the radioactive fallout ended up in Belarus. The accident raised concerns about the safety of the Soviet nuclear industry, slowed its expansion for many years and, at the same time, forced the Soviet government to reconsider the degree of secrecy). After the collapse of the Soviet Union, the successor states, i.e. Russia, Ukraine and Belarus, still have been bearing the burden of ongoing costs of decontamination and the treatment of diseases caused by the Chernobyl accident up to the present day. It is difficult to accurately determine the number of deaths caused by the events at Chernobyl. The estimates range from 100 to 150 people up to nearly $1,000,000$. The accident and its consequences are still under investigation.

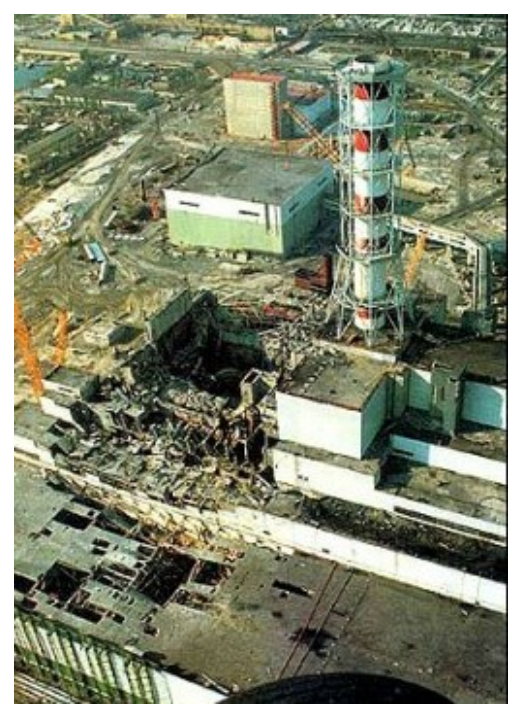

Photo 89: Reactor No. 4 after the explosion at the Chernobyl power plant. [Source: Pho-89]

The Chernobyl power plant is located $2 \mathrm{~km}$ far from the city of Pripyat, $18 \mathrm{~km}$ from the city of Chernobyl, $16 \mathrm{~km}$ from the border with Belarus, $110 \mathrm{~km}$ north of Kiev. It consists of four reactors, each with an output of $950 \mathrm{MW}(3.2 \mathrm{GW}$ of thermal energy), which at the time of the accident together produced $10 \%$ of Ukraine's electricity. The construction of the power plant began in the 1970s; reactor No. 1 was completed in 1977, followed by reactor No. 2 in 1978, reactor No. 3 in 1981 and reactor No. 4 in 1983. Reactors No. 5 and No. 6, each with a capacity of $950 \mathrm{MW}$, were under construction at the time of the accident. All four reactors were of the RBMK-1000 type, i.e. cooled with plain water and moderated with graphite. The fuel was uranium enriched to $2 \%$.

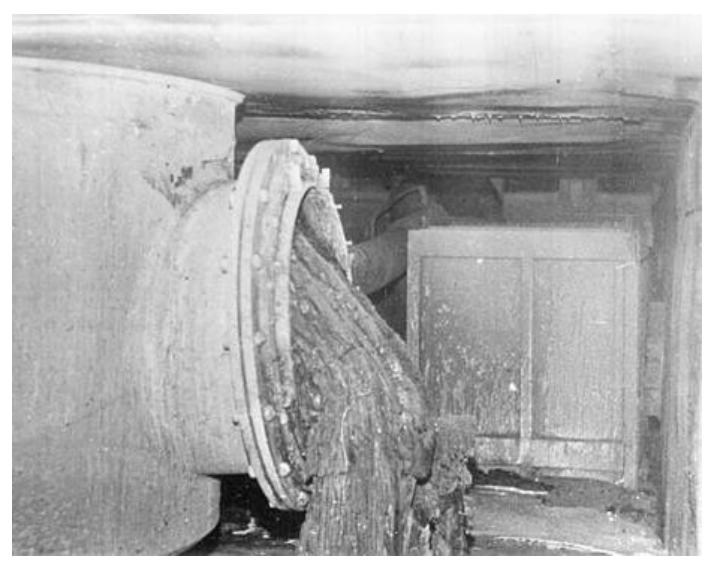

Photo 90: The melted nuclear fuel of reactor No. 4 at the nuclear power plant at Chernobyl. [Source: Pho-90]

\section{Causes of the accident}

On Saturday, April 26, 1986, at 1:23:58 a.m. local time, a catastrophic explosion occurred in the reactor No. 4 of the Chernobyl power plant (known as Chernobyl-4), that tore off the lid of the reactor occurred. It resulted in a fire, a series of explosions and melting of the reactor. The disaster is attributed to the poor reactor construction, its counterintuitive characteristics, non-compliance with the conditions, for which the planned experiment was prepared and a general lack of safety culture. As at the Three Mile Island nuclear power plant, the secondary factor contributing to the accident was the fact that the operators were not trained adequately and familiar with many of the characteristics of the reactor. One of the problems was poor communication between safety managers and operators concerning the command to perform an experiment. Additionally, due to the lack of sufficient training, the operators did not understand sufficiently how the reactor operates under a low degree of reactivity. In accordance with the experimental conditions, a few safety systems were taken out of service. The experiment was to verify whether the electric generator (driven by a steam turbine) would be able to feed emergency cooling pumps during inertia runout for about 40 seconds after the rapid closure of the steam supply to the turbine. 
Many technical characteristics of the reactor were considered to be a military secret and operators had no idea of them. The reactor had mainly a dangerously high positive void coefficient of reactivity (see below). The construction of its control rods was also a very significant defect of the reactor. The control rods were not completely filled; when they were inserted into the reactor, the coolant was replaced by the hollow parts of the control rods for the first few seconds. As the coolant (water) is an absorber of neutrons, the output of the reactor increased at that time. The operators had no notion of this counterintuitive behaviour of the reactor during the insertion of the control rods.

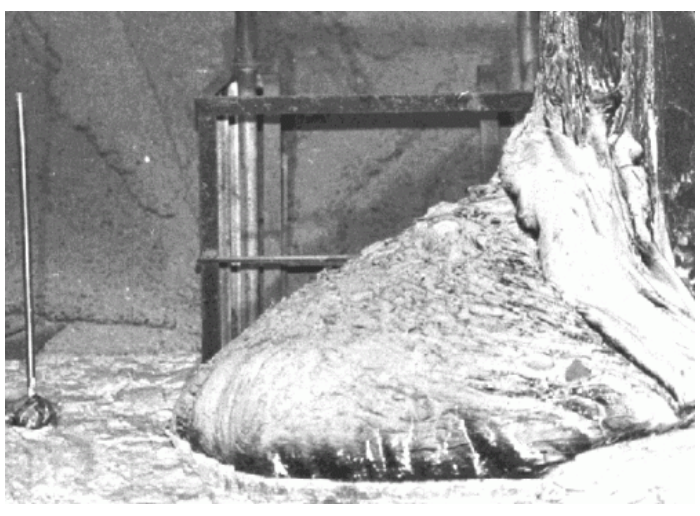

Photo 91: The melted nuclear fuel of reactor No. 4 at the nuclear power plant at Chernobyl. [Source: Pho-91]

\section{Accident progression}

On April 25, 1986, reactor No. 4 was scheduled to be shut down for regular maintenance. It was decided to use this opportunity for testing the ability of the reactor turbine generator to produce adequate amounts of electricity for the reactor safety systems (water pumps) in the event of a power outage of the reactor as well as external sources of electricity.

The power plant designer anticipated that in such a case, the spinning turbine would provide enough energy to shut down the reactor safely. It should have been tested to see if this was the case before the reactor started, but political pressure to get the plant up and running quickly caused a number of operational tests to be postponed.

According to the plan of the experiment, the reactor should have been used to spin the turbine, after that, the turbine should have been disconnected from the reactor and should have continued to revolve only by its own inertia. The output power of the reactor was reduced from the normal output of $3.2 \mathrm{GW}$ to $700 \mathrm{MW}$ of heat so that the experiment could take place at a safer, low output. However, during the delay at the beginning of the experiment, the actual power output fell to $30 \mathrm{MW}$ for unknown reasons.

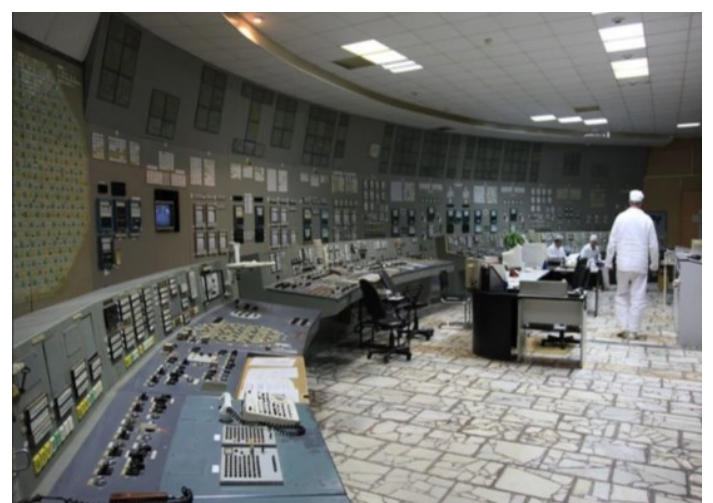

Photo 92: The control room of the Chernobyl nuclear power plant. [Source: Pho-92]

As a result of that, the concentration of a neutron-absorbing fission product, xenon $135\left({ }^{135} \mathrm{Xe}\right)$, increased. This product would normally continue to transform immediately at higher power values in the reactor. This phenomenon associated with a transient decrease in reactivity is called xenon poisoning of the reactor. Another phenomenon, which threatened the operating crew, is the fall of the reactor into the state of so-called iodine pit.

Due to a sharp decrease in power or a sudden shutdown, parasitic radionuclides will be produced, particularly iodine isotope generated by a fission reaction in fuel elements. It has significant absorption similar to xenon. It will not allow the reactor to resume operation for many hours until the spontaneous decay of the isotope with a subsequent possibility of restarting the fission reaction and increasing the reactivity take place. The experiment could not continue and the reactor would have to be out of operation for some time. The operators tried to improve the performance and to keep the reactor running by extending the control rods. 
However, the operators should have maintained the so-called operational stock of reactivity, but they did not comply with this regulation. They were not informed why this was important, and technically were not able to track current stock during the experiment. Although it failed to sufficiently improve the performance, the crew decided not to shut down the reactor and to continue in the experiment at $200 \mathrm{MW}$ instead of the planned $700 \mathrm{MW}$.

Due to the excess of neutron-absorbing ${ }^{135} \mathrm{Xe}$, the control rods were extended from the reactor slightly further than it was normally permissible for safe handling. As part of the experiment, on April 26, at 1:05 a.m., water pumps powered by a turbine generator were run and the generated water flow exceeded the limits prescribed by safety regulations. The water flow rose even higher at 1:19 a.m. Because water also absorbs neutrons, this further increase in water flow necessitated the removal of even manually operated control rods, which created unstable and hazardous operating conditions. Nevertheless, no regulation forbade all

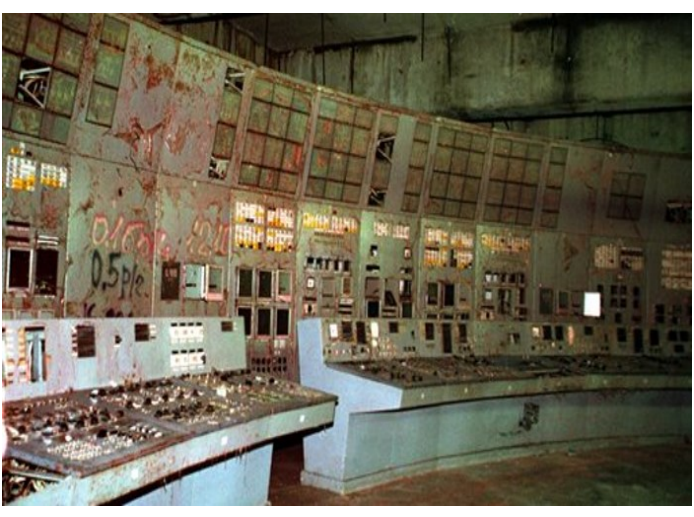

Photo 93: The control room of the Chernobyl nuclear power plant today. [Source: Pho-93] pumps to operate at full capacity.

The experiment began at 1:23:04 a.m. The extremely unstable condition of the reactor was not known to the reactor crew and no one of the crew seemed to be afraid of any danger. The electric power supply to water pumps was turned off, and because they were driven by a turbine generator by inertia only, the water flow decreased. The turbine was disconnected from the reactor and the steam pressure in the reactor core was increasing. As the coolant heated, pockets of steam began to form in its pipes. The RBMK type, the graphite moderated reactor, at Chernobyl is characterized by a large positive void coefficient, which means that in the absence of the neutron absorbing effect of water, the reactor power increases abruptly and the reactor becomes gradually unstable.

At 1:23:40, the operators pressed the "AZ" button (аварийная защита - emergency protection), which means quick shutdown of the reactor - complete insertion of all control rods, including manually operated rods, which were pulled earlier. It is not clear whether it was an emergency measure, or whether it was a routine step to shut down the reactor at the end of the experiment (the reactor was scheduled to stop for a planned maintenance). It is usually assumed that the emergency shutdown of the nuclear reactor was launched in response to the unexpected rapid power increase.

In contrast, Anatoly Stepanovich Dyatlov, the deputy chief engineer of the Chernobyl nuclear power plant, who was indirectly responsible for the accident, wrote in his book: "Before 1:23:40 a.m., the central control system did not register any parameter changes that could justify the emergency shutdown of the nuclear reactor. The Commission gathered and analysed a large amount of materials and, as stated in its report, it failed to determine the reason why the emergency shutdown of the nuclear reactor was launched. There is no need to look for a reason. After the experiment, the reactor was simply shut down."

Due to the slow mechanism of lowering the control rods (18 to 20 seconds until the end of the operation), their hollow ends and the temporary disconnection of the cooling circuit, the reaction rate was increased due to the rapid shutdown of the reactor. Increased heat production caused deformation of the control rod guiding. The rods became stuck after being inserted only one-third of the way, and were, therefore, unable to stop the reaction. 


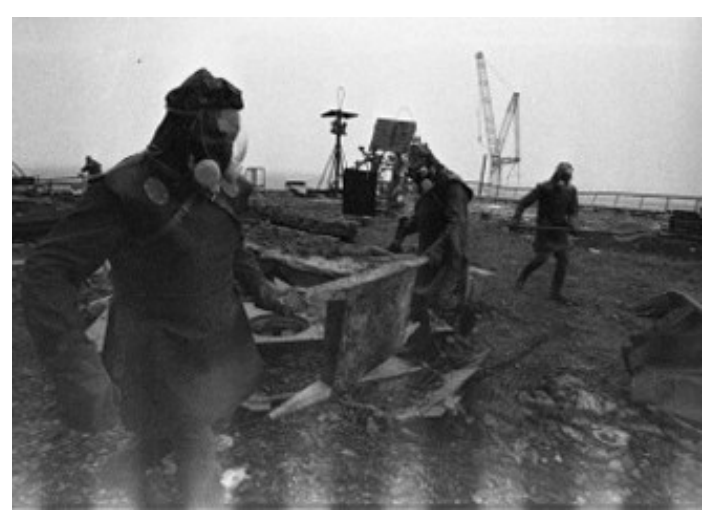

Photo 94: Biorobots - soldiers removing radioactive material from the roof. At the bottom of the photo radiation can be seen. [Source: Pho-94]
At 1:23:47 a.m., the reactor output increased to around $30 \mathrm{GW}$, i.e. ten times more than a normal operational output. The fuel rods began to melt and the sharply increased steam pressure caused a large steam expansion, which ejected and destroyed the reactor cover weighing 1,000 tonnes and tore the cooling pipes. The asphalt roof, which was supposed to protect the environment from the radioactive release, ignited due to hot debris flying from the exploding reactor and the roof collapsed. As a result of reducing the construction costs, the structure of the containment was not adequately dimensioned (in proportion to the reactor size). These austerity measures allowed contaminants to escape into the atmosphere after steam expansion disrupted the integrity of the primary pressure tank. As soon as the part of the roof was thrown off, an influx of oxygen combined with the extremely high temperature of the reactor fuel and a graphite moderator caused the graphite burning. This fire greatly contributed to the spread of radioactive material and the contamination of outlying areas.

There are disputes about the exact sequence of events after 1:22:30 a.m. local time due to the discrepancies between the reports of witnesses and the records of the plant. One version has already been described above. According to this theory, the first explosion occurred at about 1:23:47 a.m., seven seconds after the operators launched the emergency shutdown of the nuclear reactor. It is sometimes stated that the explosion happened before or immediately after the activation of the emergency control (this was a working version of the Soviet Committee studying the accident). The distinction is important because if the reactor reached a critical condition several seconds after the emergency shutdown of the nuclear reactor, its failure must be attributed to the poor construction of control rods. On the contrary, the explosion at the moment of the emergency shutdown of the nuclear reactor would rather point to the error of operators. A weak seismic event similar to an earthquake of a magnitude of 2.5 was actually recorded in the Chernobyl area at the time of 1:23:39 a.m. This event could be caused by an explosion or could be only a coincidence. The situation is complicated by the fact that the AZ-5 button (starting the quick reactor shutdown mechanism) was pressed more than once. Alexander Akimov, the shift leader who pressed the AZ-5 button (died two weeks later), said just before he died: "I don't know how it could have happened. I did everything as I should have."

\section{Immediate crisis management}

The tragedy was aggravated by the incompetence of the local management and the lack of equipment. The dosimeters, except two, had a limit of $1 \mathrm{mR} \cdot \mathrm{sec}^{-1}$ (milliroentgen per second) $=$ 3.6 R.h. ${ }^{-1}$. They had a limit of $1,000 \mathrm{R} \cdot \mathrm{sec}^{-1}$, but the access to one of them was blocked by the explosion and the second one failed immediately after switching-on. Therefore, the shift workers in the reactor could be sure only that the radiation levels in the majority of reactor buildings exceeded the values of 4 R.h ${ }^{-1}$ (in some areas, the actual level was more than 20,000 R.h. ${ }^{-1}$, the lethal dose is around 500 roentgens over more than 5 hours).

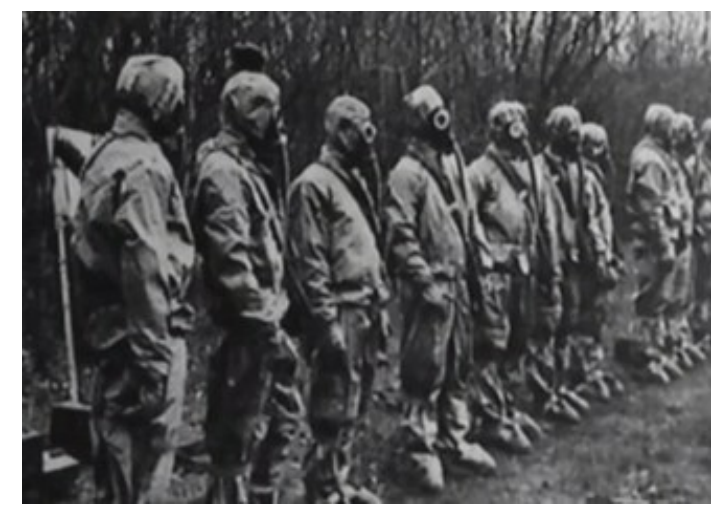

Photo 95: Special teams clean up contaminated animals. [Source: Pho-95] 
The shift supervisor Alexander Akimov assumed that the reactor remained intact. Evidence to the contrary, such as pieces of graphite and reactor fuel lying around the buildings, was ignored and data from another dosimeter brought at 4:30 was rejected, stating that the instrument must be defective. Akimov stayed with the shift workers in the building until morning, trying to pump water into the reactor. Nobody wore any protective clothing. Most of them died of radiation within three weeks of the crash.

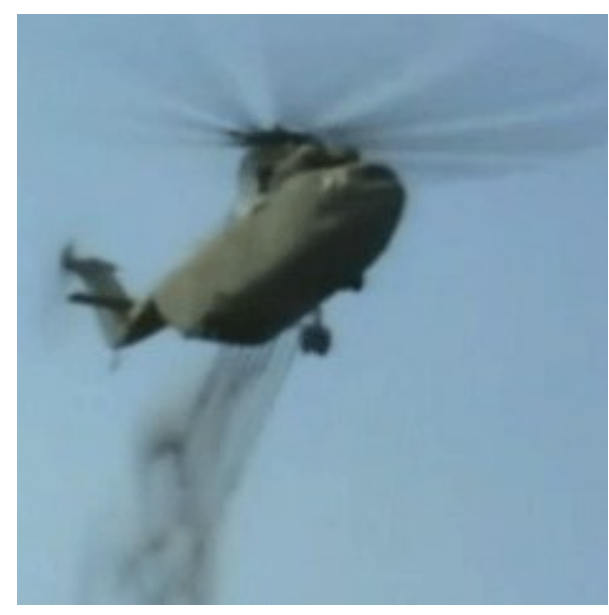

Photo 96: The helicopter is discharging a special liquid called Burba to bind radioactive dust to the ground. [Source: Pho-96]

Soon after the accident, firefighters arrived to extinguish the fires. No one told them that the debris and smoke were dangerously radioactive. They did not know the cause of the fire and, therefore, they used water to extinguish the reactor itself, where the temperature was about $2,000{ }^{\circ} \mathrm{C}$. At this temperature, water decomposed into hydrogen and oxygen; their recombination was accompanied by explosions, which further contributed to the release of radioactivity. Open fires were extinguished at 5 p.m.; many firefighters were exposed to high doses of radiation.

A government commissioner designated to investigate the accident arrived at Chernobyl in the morning on April 26. At that time, two people were dead and 52 were hospitalized. During the night from April 26 to April 27 (more than 24 hours after the explosion), the commissioner, confronted with the evidence of high levels of radiation and many cases of irradiation, had to admit the destruction of the reactor and to order the evacuation of the nearby city of Pripyat.

To limit the scope of the disaster, the Soviet government sent personnel to the site to clean it up. Many liquidators (members of the military and other workers) were sent there. Most of them did not know about the danger. They did not even have protective clothing. The radioactive debris ejected from the reactor were collected and placed in buildings. The reactor itself was covered with sandbags dropped from helicopters (about 5,000 tonnes during the week after the accident), and the damaged roof did not withstand such a load and part of it collapsed.

This caused more radiation to be released and

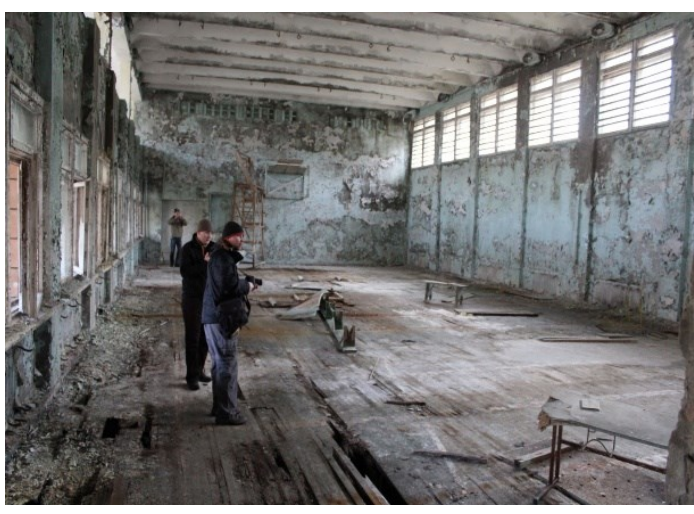

Photo 97: A basic school, Pripyat. [Source: Pho-97] many soldiers were seriously irradiated. Nine days after the accident, the leakage of radioactive material into the atmosphere was stopped. A concrete sarcophagus was built hastily over the site of the stricken reactor to seal the reactor and its content.

\section{Immediate consequences}

A total of 203 people was hospitalized immediately, 31 of them died ( 28 of them due to the acute radiation syndrome). Many of them were firefighters and rescuers trying to get the accident under control, but were not informed about how dangerous radiation exposure (from smoke) is. About 135,000 people, including 50,000 from the city of Pripyat, were evacuated from the area. 


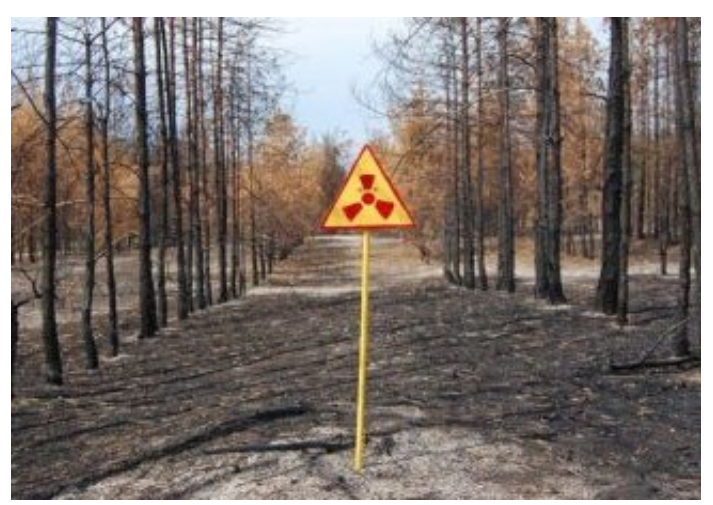

Photo 98: Exclusion zones around Chernobyl. [Source: Pho-98]
The Ministry of Health predicts that over the next 70 years there will be a $2 \%$ increase in cancer rate in the majority of the population, which was exposed to the 5-12 (depending on source) EBq $\left(5-12 \times 10^{18} \mathrm{~Bq}\right)$ of radioactive contamination released from the reactor. The analysis of the International Atomic Energy Agency (IAEA) from 1986 identified the errors of the power plant operators as the cause of the accident. In January 1993, however, the IAEA issued a revised analysis, in which it attributed the accident to flaws in the reactor design. The Chernobyl reactor contained about 190 tonnes of uranium dioxide and fission products. The estimates of the amount of escaped material range between 13 and 30 percent. The contaminated material from the accident was not simply scattered over the surrounding land, but it interspersed irregularly depending on the weather. According to the reports from Soviet and Western scientists, $60 \%$ of the contamination that affected the territory of the former Soviet Union fell on Belarus. The region of the Russian Federation south of Bryansk and parts of north-western Ukraine were contaminated.

The Chernobyl disaster was kept under wraps. The initial evidence that the nuclear accident had occurred came not from the Soviet sources, but from Sweden, where, on April 27, the workers at the Forsmark Nuclear Power Plant (approximately $1,100 \mathrm{~km}$ from the Chernobyl site) found radioactive particles on their clothes. The search for the source of radioactivity proved there was no leak at the Swedish plants; however, it was a serious nuclear problem in the west part of the Soviet Union. On May 1, the usual May Day demonstrations took

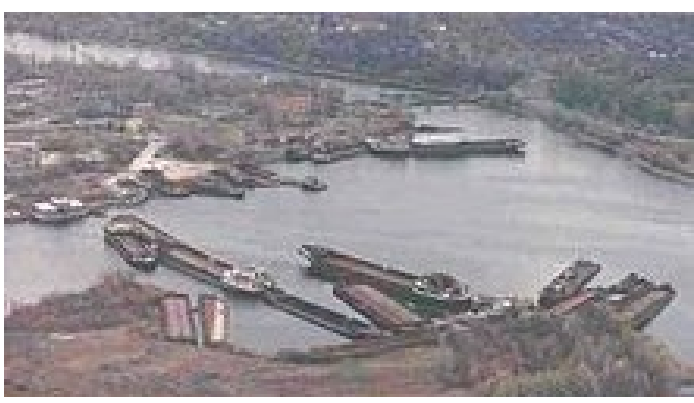

Photo 99: Abandoned vessels on the river of Pripyat. [Source: Pho-99] place in Kiev as the population was not informed of the disaster.

\section{Short-term impacts on the workers and liquidators of the accident.}

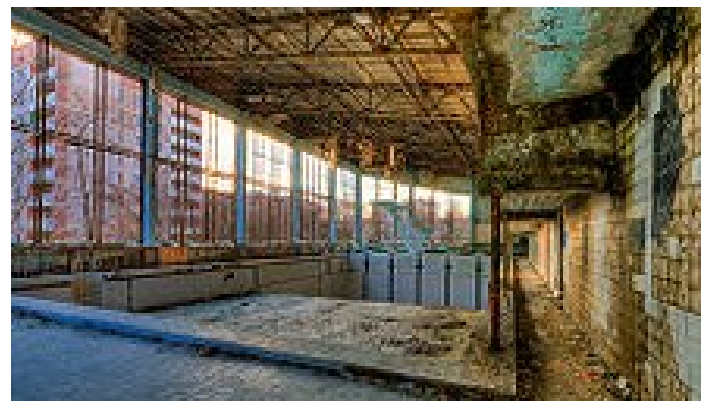

Photo 100: A swimming pool in the abandoned city of Pripyat. [Source: Pho-100]

The workers involved in disaster recovery and clean-up were hit by high doses of radiation. In most cases, they were not equipped with personal dosimeters measuring the amount of radiation received, so the magnitude of these doses could only be estimated by experts. Even where dosimeters were used, dosimetry procedures differed. It is assumed that the radiation dose estimates in some workers were more accurate than in others. Based on the Soviet estimates, 300,000 to 600,000 people participated in the cleaning of the $30 \mathrm{~km}$ evacuation zone around the reactor, but many of them entered the zone even 2 years after the accident. Estimates of the number of liquidators - workers brought in to manage the crisis and reconstruction work - differ. The World Health Organization (WHO) lists 800,000 people, and Russia also counts among the liquidators some people who did not work in contaminated areas. In the first year after the accident, the number of workers to clean up the zone was estimated at 211,000; these workers received an average dose of $165 \mathrm{mSv}(16.5 \mathrm{Rem})$. 


\section{Short-term impacts on civilians}

Some children in the contaminated areas were exposed to high doses of up to $50 \mathrm{~Gy}$, which increased the incidence of thyroid cancer. They were drinking the local milk contaminated with radioactive iodine, an isotope with a short half-life. Several studies confirm that the incidence of thyroid cancer among children in Belarus, Ukraine and Russia has risen sharply.

The IAEA states that in 1,800 documented cases of thyroid cancer in children who were 14 years old or younger at the time of the accident, the value is much higher, but it does not specify the accepted level expected. The occurring types of thyroid cancer in children are aggressive, but if they are recognized in time, they can be cured. The treatment consists of a surgery followed by applying radioactive iodine-131 to suppress metastases. This treatment seems to be successful in all diagnosed cases.

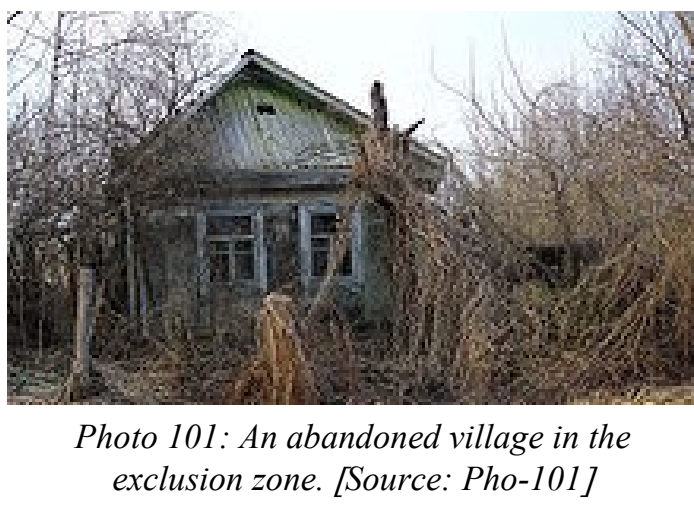

At the end of 1995, the World Health Organization attributed nearly 700 cases of thyroid cancer in children and adolescents to the Chernobyl accident and among these about 10 deaths were attributed to radiation. On the other hand, it results from the recorded significant increase in thyroid cancer that it is at least partly caused by X-rays. A typical latency of radiation-induced thyroid cancer is about 10 years, but an increase in thyroid cancer in children in some regions has been observed since 1987. Probably this increase is either not related to the accident or we have not yet properly understood the mechanism behind it. It has not been possible to detect the increase in leukaemia yet, but it is expected to be recorded in successive years, together with an increase in the incidence of other types of cancer, although perhaps statistically unrecognizable. No increase attributed to Chernobyl has been proven in birth defects, adverse outcomes of pregnancy or other diseases caused by radiation in the general population in contaminated areas.

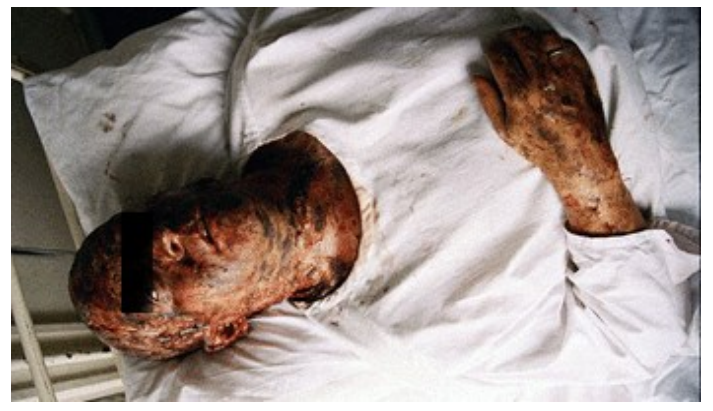

Photo 102: One of the pilots of General Antoshkin who received high radiation doses. [Source: Pho-102]
Soon after the accident, the greatest health risk was radioactive iodine $\left({ }^{131} \mathrm{I}\right)$ with a half-life of 8 days. Today, the soil contamination by isotopes of strontium $\left({ }^{90} \mathrm{Sr}\right)$ and caesium $\left({ }^{137} \mathrm{Cs}\right)$, the halflives of which are about 30 years, raises the worst fears. The highest concentrations of ${ }^{137} \mathrm{Cs}$ were found in the surface layers of the soil where they are absorbed by plants, insects and mushrooms and get into the local food chain. Previous tests (around 1997) have shown that in contaminated areas, the amount of ${ }^{137} \mathrm{Cs}$ in trees is still increasing. There is evidence that contamination moves into subterranean waters and confined water reservoirs such as lakes and ponds. It is believed that the main way to remove contamination will be the natural decay of ${ }^{137} \mathrm{Cs}$ to the stable isotope of barium $\left({ }^{137} \mathrm{Ba}\right)$ because rain and surface water leaching has been proved to be negligible.

\section{Long-term and global impacts}

As the IAEA notes, although the accident released as much radioactive contamination as 400 bombs dropped on Hiroshima, its overall size was about 100 to 1,000 times smaller than the contamination caused by the atmospheric tests of nuclear weapons in the middle of the $20^{\text {th }}$ century. 
It can, therefore, be argued that although the accident was a local disaster, it did not grow into a global catastrophe.

According to the reports of Soviet scientists at the $1^{\text {st }}$ International Conference on Biological and Radiological Aspects of the Chernobyl Accident (September 1990), the level of fallout in the $10 \mathrm{~km}$ zone around the power plant reached up to 4.81 GBq. $\mathrm{m}^{-2}$. The so-called Red Forest of pine trees destroyed by a strong radioactive fallout lies in this zone $\left(10 \mathrm{~km}^{2}\right)$ and begins right behind the reactor complex. The forest name comes from the days after the accident, when the trees showed the ginger-brown colour, after they died due to radia-

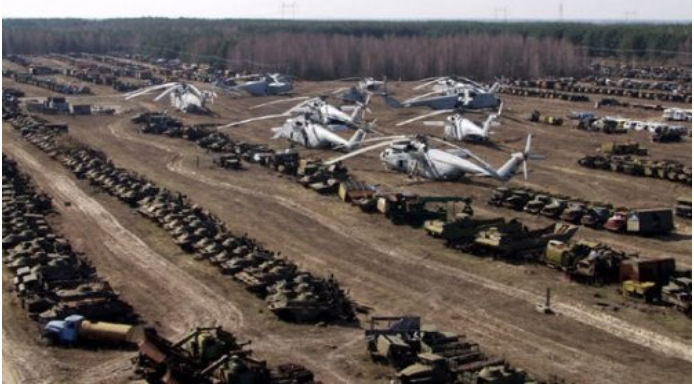

Photo 103: Contaminated equipment near Chernobyl. [Source: Pho-103] tion. During the clean-up operations after the accident, most of the forest $\left(4 \mathrm{~km}^{2}\right)$ was razed to the ground and burned. The territory of the Red Forest remained one of the most contaminated areas in the world. On the other hand, it turns out that it is a site rich in the occurrence of many endangered species.

The Soviet representatives began evacuating the residents from the Chernobyl area 36 hours after the accident. In May 1986, a month later, those who lived within a radius of $30 \mathrm{~km}$ around the plant were relocated (about 116,000 people). According to Soviet scientists, $28,000 \mathrm{~km}^{2}$ were contaminated with ${ }^{137} \mathrm{Cs}$ (the contamination level was higher than $185 \mathrm{kBq} \cdot \mathrm{m}^{-2}$ ). About 830,000 people lived in this area. About $10,500 \mathrm{~km}^{2}$ were contaminated with ${ }^{137} \mathrm{Cs}$ (the contamination level was higher than $555 \mathrm{kBq} \cdot \mathrm{m}^{-2}$ ). Around $7,000 \mathrm{~m}^{2}$ of this area is located in Belarus, $2,000 \mathrm{~km}^{2}$ in the Russian Federation and $1,500 \mathrm{~km}^{2}$ in Ukraine. About 250,000 people live in this area. The reports have been confirmed by the International Chernobyl Project of the IAEA. Today, the previously evacuated region around the power plant is divided into two zones. About 600 elderly people live in the first one. They have returned voluntarily to the area and receive a monetary contribution from the state, which also delivers food and water from uncontaminated areas. The second zone, also called the dead zone, is accessible only to scientists and excursions.

\section{Comparison with other disasters}

The Chernobyl accident was a rare event. For the first time in the history of the commercial production of electricity in a nuclear power plant, there were deaths caused directly by radiation. A later accident at the Japanese fuel reprocessing plant in Tokaimura, on September 30, 1999, resulted in the death of one worker due to radiation exposure on December 22 of the same year. The A-1 nuclear power plant accident at Jaslovské Bohunice in 1976 had two victims; however, they died of asphyxiation caused by carbon dioxide and not due to radiation.

This accident is comparable to dam failures by the number of deaths. In Europe, the largest accident of the dam killed around 2,000 people by a wave caused by a landslide in the Vaiont dam in Italy (October 9, 1966). The biggest disaster took place in China in 1975 on the Yangtze River, where 80,000 up to 200,000 people died in one day after the dam burst (exact numbers were kept secret by the Chinese authorities). The Chinese dams can serve for the comparison of the number of evacuees (it was necessary to resettle about 700,000 people because of the construction of the Three Gorges Dam). The comparison can be also carried out in generating electricity from coal; each year tens to hundreds of miners die in mining accidents in the world. Before the introduction of the technologies for purifying smoke, acid rains and the fallout of slightly radioactive ash, thousands of square kilometers of forests were destroyed and hundreds of thousands of people were struck with diseases and early deaths only in our country. 


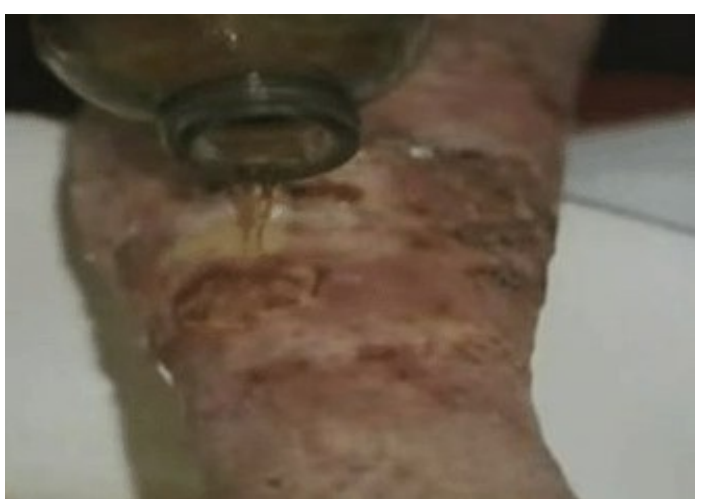

Photo 104: The treatment of burns after the body exposure to 900 roentgens for the time of 2 minutes. The man died on the second day. [Source: Pho-104]

\section{Long-term effects on civilians}

The findings of studies vary depending on the organization, which developed them. This is followed by WHO and UNSCEAR (the United Nations Scientific Committee on the Effects of Atomic Radiation), which report larger numbers of victims, but remain of the same order. Even much higher numbers are reported in the studies of post-Soviet researchers, the studies of the German International Physicians for the Prevention of Nuclear War (IPPNW) and the German Society for Radiation Protection (GfS), and the studies elaborated by the Green Party or Greenpeace. A report of the USSR drawn up for the Vienna International Conference in August 1986 estimates the number of people who will die of cancer caused by caesium isotopes at 30,000 up to 40,000 . The IAEA designated the prediction to be overvalued and specified the maximum number to be 25,000, then 10,000 and finally 5,100. On April 27, 1988, the author of the study, Professor Valery Legasov was found hanged in his office.

In 1996, the Chairman of the IAEA Health Commission submitted a report on the psychological impact of the accident. In his report, he writes that many adolescents and young adults from the affected areas suffer from stress symptoms, depression, fear, the feeling of helplessness, weakness and the loss of life prospects. Since they are called victims and not survivors, it causes either exaggerated fear for their health and the introspection, or a completely inconsiderate behaviour towards them themselves. The examples are as follows: eating wild berries from highly contaminated areas, the alcohol and tobacco abuse and unprotected promiscuous sexual activity.

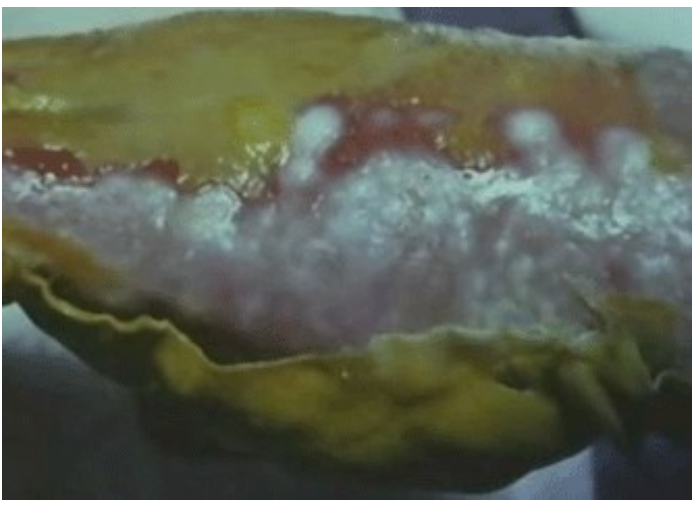

Photo 105: The yellow mass is cracked skin, through which burnt flesh with pieces of bone has penetrated. A photo of an elbow joint. [Source: Pho-105]

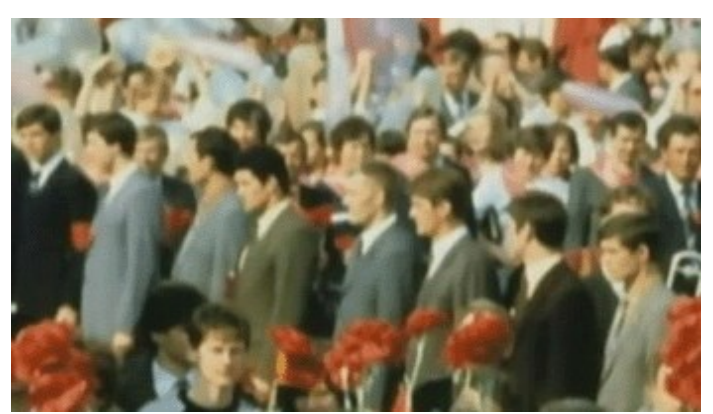

Photo 106: During May Day celebrations at least 300,000 citizens were contaminated in the area surrounding Chernobyl. [Source: Pho-106]

In 1997, the team of Professor Yury Bandazhevsky, the pathologist and the Director of the Health Centre in the Belarusian Gomel Region, studied the activity of radioactive caesium in dead people and their food from this agricultural region. The study claims that earlier the children were sent to a monthly curative stay out of the affected area once a year and received free uncontaminated food in the school dining-room. For economic reasons, the stay in the sanatorium was shortened and some contaminated areas were declared clean, which ended the deliveries of the decontaminated school

meals. The study called for the continuation since the contaminated agricultural land began to be cultivated and thus radioactive caesium entered the food chain. The study was published in 2003, at the time, when Professor Bandazhevsky was serving his 8-year sentence for alleged taking bribes. After 4 years of international protests, he was discharged. 
Main findings of the study:

- The concentration of radioactive caesium in local vegetables, milk, and especially wild berries is growing and their consumers are heavily contaminated;

- The babies less than six months old are the most affected, the ${ }^{137} \mathrm{Cs}$ activity is up to $11,000 \mathrm{~Bq} \cdot \mathrm{kg}^{-1}$ in the pancreas, $6,250 \mathrm{~Bq} \cdot \mathrm{kg}^{-1}$ in the thyroid gland and $5,333 \mathrm{~Bq} \cdot \mathrm{kg}^{-1}$ in the heart. Breast milk is an effective means for transmitting radioactive caesium. The babies died of sepsis, brain degeneration, bleeding disorders and heart disease, i.e. not of cancer; and

- In the bodies of 51 children less than 10 years old, 2 up to 3 times higher concentration of radioactive caesium levels than in adults was found. The highest levels were found in the thyroid gland $\left(2,054 \mathrm{~Bq} \cdot \mathrm{kg}^{-1}\right)$, in the adrenal glands $\left(1,576 \mathrm{~Bq} \cdot \mathrm{kg}^{-1}\right)$ and in the pancreas $\left(1,359\right.$ Bq. $\left.\mathrm{kg}^{-1}\right)$. The samples were measured by Ukrainian and German devices and then verified twice in France.

In 2005, an IAEA study estimated the number of people who would die of cancer caused by a disaster at 9,000 to 10,000. Another report on Chernobyl indicates errors and omissions of important data in the reports of the IAEA/WHO. According to this report, the IAEA deals only with the population of the three countries (Belarus, Ukraine and Russia), while more than half of the fallout ended on the non-Soviet territories in Europe. Therefore, there are much more people who have died or will die as a result of radioactivity depending on the radiation risk estimation model used; it is 18,000 up to 60,000 people.

In 2009, the Academy of Sciences in New

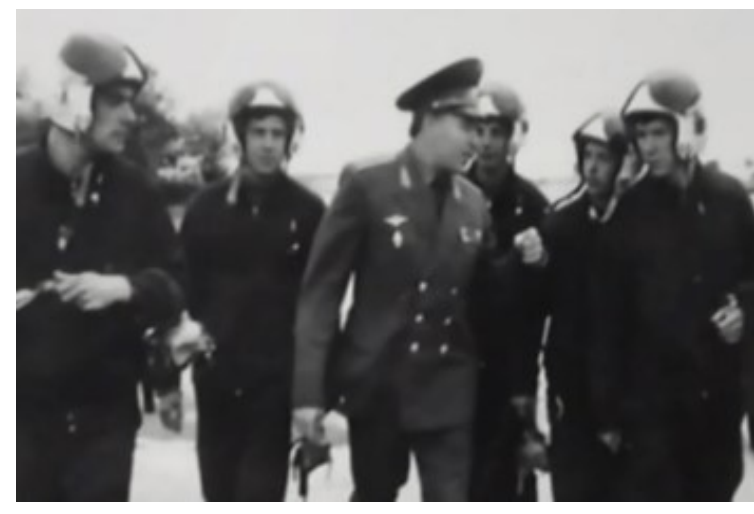

Photo 107: The pilots of military helicopters were between 18-25 years of age. Not a single one survived the cross-country flights over the Chernobyl reactor. [Source: Pho-107]

York issued an English translation of a very comprehensive study published in 2007, the crucial statement, of which is that by 2004 , already 985,000 people including 170,000 people in North America died due to the consequences of the accident. Only in Belarus, the overall mortality increased by $43 \%$ between 1990 and 2004.

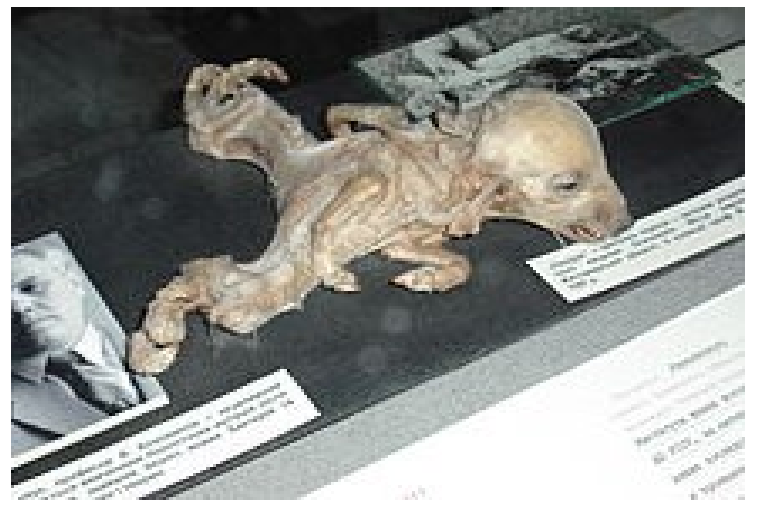

Photo 108: A mutated piglet. [Source: Pho-108]

However, the increase in mortality is also caused due to a sharp deterioration of the living standards and living conditions in Belarus after the collapse of the Soviet Union. The same is true for Ukraine and Russia. However, no study distinguishes these two things, i.e. radiation effects and the decline in living standards. Today as well as previously, rather exceptional symptoms of malnutrition are quite common.

The authors, V. Jablokov (the Russian Academy of Sciences), A. Nesterenko (the Belarus Institute of Radiation Safety) and Prof. V. Nesterenko (the former director of the Belarusian Nuclear Centre), used as a source the materials of over 1,000 scientific publications, and 5,000 other publications related to the accident, and medical records. The authors notified that these sources had been ignored or downplayed by the IAEA and UNSCEAR. 
An increase in the incidence in humans due to radioactive fallout was found in the analysed materials, as follows:

a) Cancer of:

- thyroid gland;

- leukaemia;

- other cancer types;

b) Non-cancerous disorders:

- diseases of

- respiratory system;

- digestive tract;

- blood circulation;

- muscles, bones and skin;

- reproductive organs;

- neurological and psychological disorders;

- hormonal disorders causing atherosclerosis, diabetes, obesity;

- immune system abnormalities - allergies, infections, changes in lymphocytes;

- genetic and chromosomal abnormalities;

- premature aging; and

- sensory organ disorders.

It should be noted that the increased incidence of malignant and non-malignant forms of cancer is partly the result of their targeted search in the affected population. Before the accident, a significant percentage of patients without health problems remained undetected.

In contrast to the effects on the human population, it can be said that the evacuation of the area around the power plant has allowed the creation of a rich and unique wildlife reserve. It is not known whether, due to the fallout, the contamination will have a long-term negative impact on the flora and fauna in the area because plants and animals differ significantly and their radiation tolerance is different in comparison with humans. It seems, however, that the species diversity in the contaminated zone has increased due to the removing the human influence. There are reports on mutations in some plants in the area called the Red Forest, containing strangely mutated plants and crops. It is characterized by the markedly rusty red colour of needles of living conifers. According to the reports, this area is silent, which indicates that birds have not colonized it yet again. Mice and other rodents do not also occur there. Conversely, there were wild boars living in dilapidated prefab buildings of the city of Pripyat.

Nearly half of wild boars caught in 2017 on the Czech side of the Bohemian Forest, showed an excessive level of radioactivity. The hunters on the German side of the Bohemian Forest also know the problems with radioactivity in the meat of wild boars. Wild boars show higher radiation due to the fact that they eat underground mushrooms called Deer Truffle. It is able to absorb radioactivity from the soil that has been there since the Chernobyl accident. According to scientists, the radioactive cloud was transmitted over Europe three times. "The values fluctuate significantly during the year as wild boars migrate. In long-term averages the level of about 40 to 50 percent of above-limit values of radionuclides is stable. The half-life of caesium is 30 years, that is, it takes 30 years for the radioactivity of the isotope to fall to half its original value", Jiři Drápal, the Head of Food Safety Division of the State Veterinary Administration said.

Radioactive food can pose a risk of cancer to humans. However, according to experts, it is possible to speak about the risk only if someone eats about 40 kilograms of contaminated meat per year. 
The quantity of radioactive agents in meat can also be reduced by means of its treatment. When cooked in a pressure cooker, they are halved, and when repeatedly brined, they will be reduced by up to 70 percent.

\section{The power plant after the accident}

The problems of the power plant did not end with the disaster in reactor No. 4. Due to the lack of electricity, the Ukrainian government decided to operate three reactors. In 1991, a fire damaged the cable line of reactor No. 2. The officials said it was irreparably damaged and disconnected the reactor.

Reactor No. 1 was shut down in November 1996 as part of an agreement between the Ukrainian government and international organizations such as the IAEA to decommission the plant. In November 2000, Ukrainian President Leonid

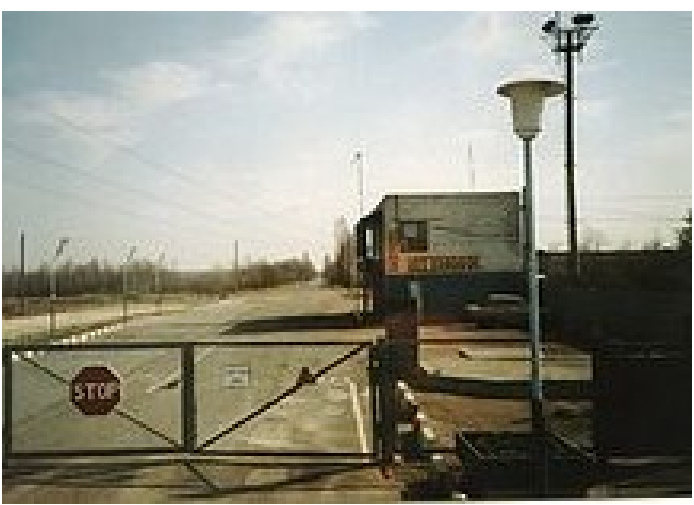

Photo 110: The entry into the abandoned Chernobyl zone. [Source: Pho-110] Kuchma personally pressed the switch of reactor No. 3 during the closing ceremony and thus definitively shut down the entire power plant.

The sarcophagus cannot enclose a destroyed reactor permanently. Its hasty construction, in many cases performed remotely by robots, results in its rapid aging, and if it collapsed, it could release another cloud of radioactive dust. Many plans for the construction of a permanent New Shelter have been discussed; however, their realization has still been hampered by corruption. Most of the money from foreign countries to help Ukraine was wasted by inefficient construction contracts and the overall management or it was simply stolen.

Under the sarcophagus, about $95 \%$ of the reactor fuel remained after the accident, which represents the radioactivity of about $18 \mathrm{MCi}=0.67 \mathrm{EBq}\left(0.67 \times 10^{18} \mathrm{~Bq}\right)$. The radioactive material consists of the remnants of the reactor core, dust, and lava-like fuel-containing materials (FCM) that flowed through the wreckage of the reactor building until it solidified. According to conservative estimates, at least 4 tonnes of radioactive dust can be found under the reinforced concrete sarcophagus. Water seeps into the concrete covering the reactor and leaches radioactive materials into the surrounding underground waters. High humidity inside the sarcophagus contributes to the further erosion of its steel structure and the subsequent release of radioactivity. A new mineral, called chernobylite (Elephant's Foot), appeared in the reactor.

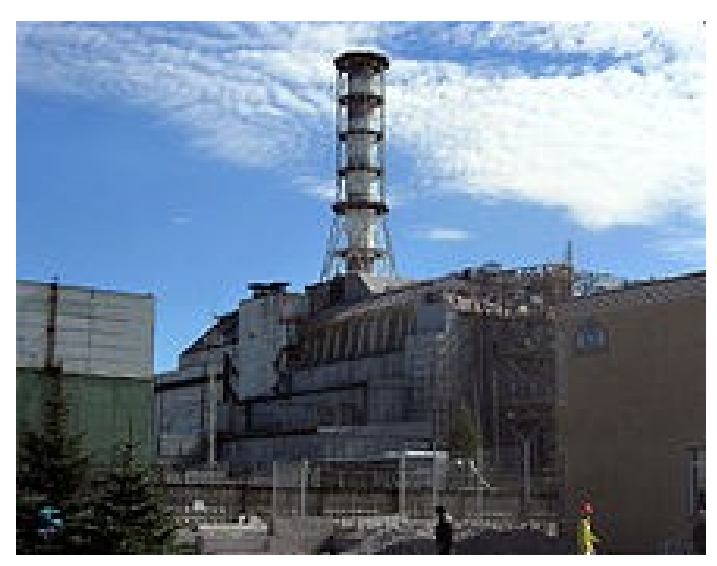

Photo 111: The sarcophagus of reactor No.4. [Source: Pho-111]
In 2001, however, experts concluded that a more permanent solution was needed. Thus, under the auspices of the European Bank for Reconstruction and Development launched a unique project called Shelter, i.e. the construction of a new sarcophagus. A total of 45 countries, including the Czech Republic, participated in the construction of the sarcophagus weighing 36,000 tonnes for 1.5 billion euros, or more than 40 billion crowns. Initially, the contribution of Ukraine was paradoxically so small that it did not even have any voting right among the other countries. However, Ukraine has increased its contribution and has become a full member. 
On November 29, 2016, the largest protective device of its kind in the world was completed. The process of sliding the arched structure into place to shield the damaged Unit 4 of the Chernobyl nuclear power plant took 15 days. The new sarcophagus should completely insulate the damaged Unit 4 of the Chernobyl nuclear power plant for the whole century; it should withstand temperatures ranging from -43 degrees to +42 degrees Celsius. Up to 1,200 employees from 27 countries participated in its construction at one time.

"Let the whole world see today what Ukraine and the world can do when they unite, how we are able to protect the world from nuclear contamination and nuclear threats, "President Petro O. Poroshenko of Ukraine proclaimed at a ceremony according to the Reuters News Agency. This followed after completing the sarcophagus transfer over Unit 4.

The contract for the construction of the new Shelter was given to the Novarka consortium, which consists of the French construction companies Vinci and Bouygues. According to the Czech News Agency, the foundations started to be built in September 2010, the construction was officially launched in April 2012. To prevent human contamination, thousands of tonnes of radioactive soil were removed from the area before the construction and replaced.

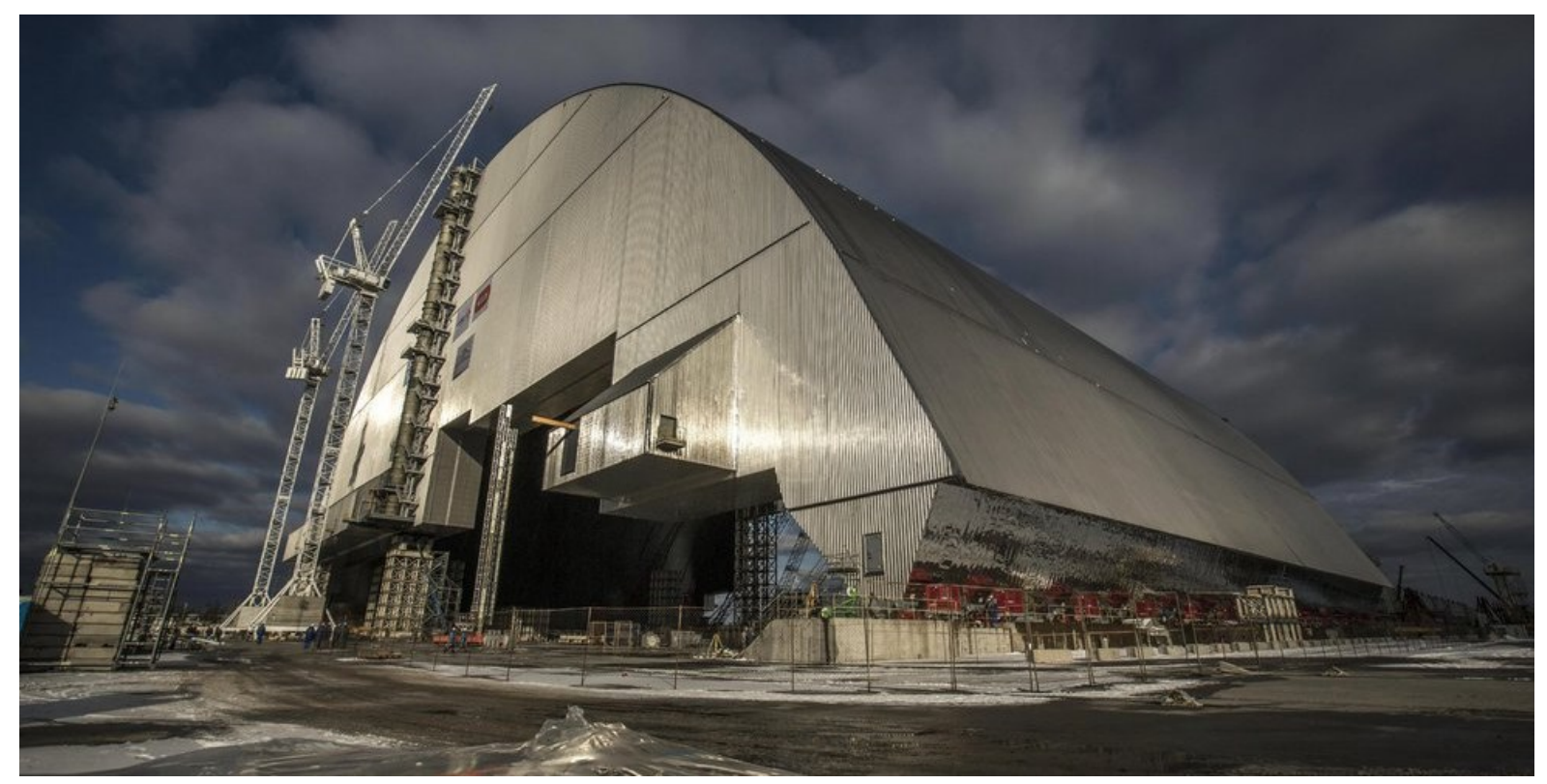

Photo 112: The new safe confinement to cover the stricken reactor. [Source: Pho-112]

The construction is 162 metres long, 260 metres wide and 108 metres high. This is the height comparable to the Prague skyscraper called City Tower. The new safe confinement is in its place, but work still continues. In November 2017, it became airtight. This has ensured perfect insulation. Part of the work is the dismantling of the old sarcophagus.

\subsubsection{The accident of the Fukushima I nuclear power plant (Japan 2011)}

On March 11, 2011, the accident at the Fukushima I Nuclear Power Plant happened, when Japan was hit by an earthquake and tsunami. It was rated 7 on the International Nuclear and Radiological Event Scale (the same level as the Chernobyl nuclear power plant accident) and is considered one of the most complicated in history.

The information on the scope of the accident published by the plant operator and the Japanese government was incomplete or false in some respects. They did not succeed in getting the accident under control even after one month. More than 200,000 people were evacuated from the protection zone, 30 kilometres in diameter, and the event was an impetus for political debates on nuclear energy worldwide. 


\section{The accident progression}

At the moment of the accident, reactors No. 1, 2 and 3 were in operation, while reactors No. 4, 5 and 6 were not operating due to a regular maintenance. Immediately after the disaster, the three running reactors were stopped automatically.

After the tsunami hit the coast about an hour after the earthquake, the generators used for emergency cooling stopped. This caused a rise in the temperature and pressure in reactors. Although the backup sources managed to cool reactors No. 2 and

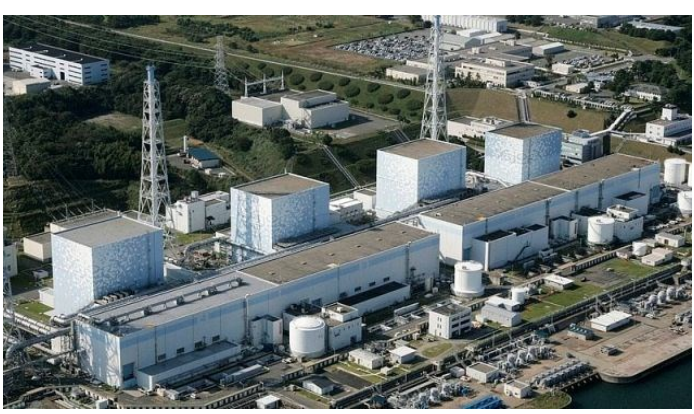

Photo 113: The Fukushima nuclear power plant before the accident. [Source: Pho-113]

No. 3 , in reactor No. 1, the water level was decreasing and the pressure was rising. To reduce it, radioactive steam was blown off from the containment; the increased radiation was measured inside and outside the premises. The later hydrogen explosion in the auxiliary building destroyed the concrete part that protected the reactor against the weather, but the steel pressure vessel, in which the reactor is placed, was not damaged. After that, seawater was also used to cool the reactor.

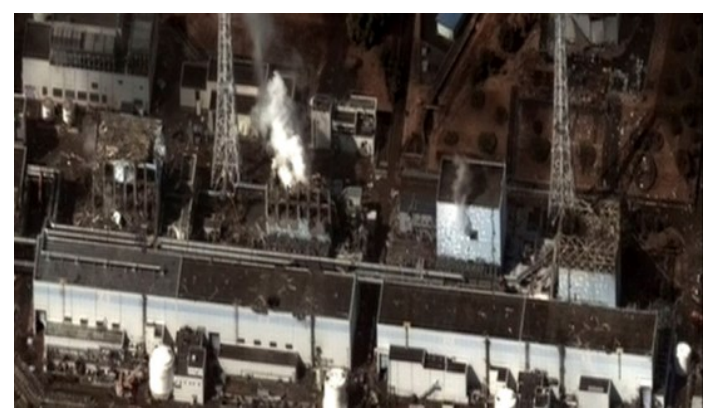

Photo 114: The Fukushima nuclear power plant after the accident. [Source: Pho-114]

On March 13, the cooling of reactor No. 3 was not sufficient. The slightly radioactive steam was blown off and the seawater cooling was also used here. The next day, however, hydrogen exploded here again, but did not damage the reactor vessel.

On March 15, the situation worsened - another explosion damaged reactor No. 2 vessel. In addition, a tank with used fuel ignited at reactor 4, but the fire was extinguished soon. On Wednesday night, March 16, between 20:45 and 21:15 UTC, reactor No. 4 was burning again, the cause was not

clear. The accident on March 12, 2011 was officially determined by the Japanese Nuclear and Industrial Safety Agency as level 4 according to the INES relating, however, only to the accident of Unit 1 of the nuclear power plant.

Later, the accident at Unit 1 worsened and spread to other Units as well. Therefore, on March 18, 2011, the Nuclear and Industrial Safety Agency reclassified the level of accident at level 5 for Units 1 to 3 . With regard to the finding that the amount of radiation leaking from the Fukushima reactors during the accident could be up to $630,000 \mathrm{TBq}$, on April 12, this accident was reclassified to the INES highest level 7. On March 18, the fire on Unit 4 was classified as level 3 .

\section{Consequences}

After the accident of the reactors, the exclusion

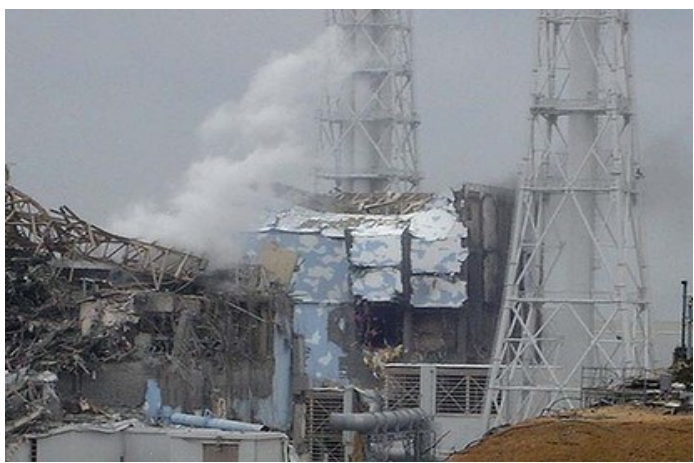

Photo 115: The unit of the Fukushima nuclear power plant after the accident. [Source: Pho-115] zone was established. Within a radius of $20 \mathrm{~km}$ around the plant, 200,000 people were evacuated. On March 31, the IAEA proposed to extend the evacuation and exclusion zones in Miyagi Prefecture to $40 \mathrm{~km}$ from the power plant. On April 11, it was decided to extend the zone over a distance of $30 \mathrm{~km}$. 


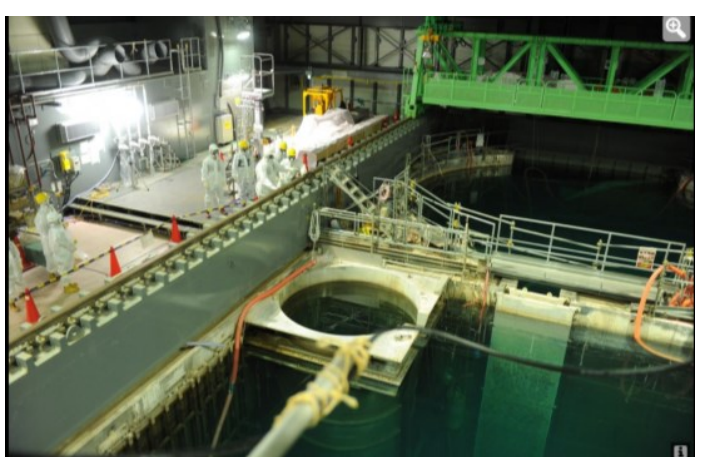

Photo 116: The water pool for storing used fuel in the Fukushima I power plant units.

[Source: Pho-116]

In the first week, the elevated levels of radioactive caesium and iodine were measured at measuring stations; the values dangerous to health were identified only in the immediate vicinity of the power plant. Russian meteorological stations did not notice any change from the normal state.

After a few days, measurements showed that the food in the vicinity of the power plant contained an excessive amount of radioactivity and export and consumption were prohibited These were, for example, milk, spinach, broccoli, etc. In the following days, an extreme concentration of radioactive iodine $\left({ }^{131} \mathrm{I}\right)$ was measured in the vicinity of the power plant. According to the original measurements, the normal value was exceeded ten million times, but in the end, it turned out that an error had occurred. Thus, in the vicinity of the power plant, the iodine concentration was only one hundred thousand times above the average.

In this context, the Ministry of Foreign Affairs of Japan recommended treatment plants not to use rainwater. In the soil around the power plant, increased values of plutonium concentration were measured. On April 2, a crack appeared in the tank, which captures the radioactive water escaping from reactor No. 2. The attempts to plug the crack by concrete and polymers followed. Finally, liquid glass was used. This helped to stop the radioactive water leaking into the Pacific Ocean.

Approximately at the same time, the amount of 11,500 tonnes of slightly radioactive water was discharged into the ocean in a controlled manner to

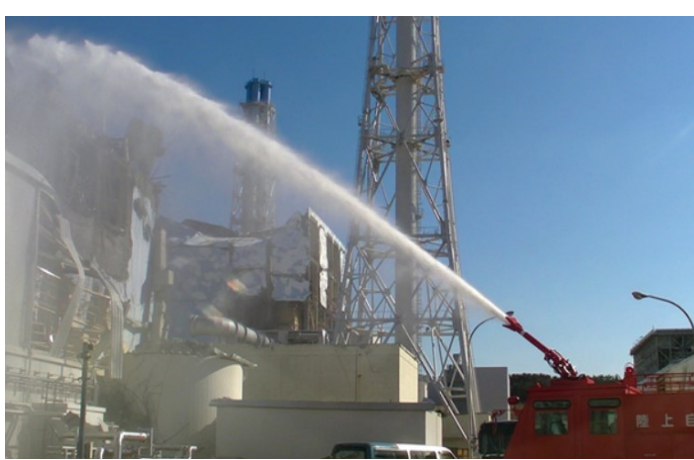

Photo 117: Adding water to the pool of Unit 3 of the Fukushima Daiichi nuclear power plant.

[Source: Pho-117] make space for the storage of the highly radioactive water leaking from the reactor into the surrounding buildings. Pumping out this highly radioactive water was a condition for enabling the movement of employees who worked on the restoration of the cooling systems of reactors.

\section{Complete dismantling of the nuclear power plant}

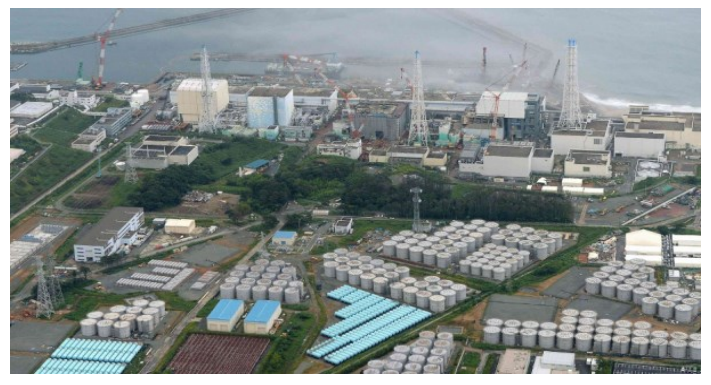

Photo 118: In the aerial photography of the Fukushima nuclear power plant from August 2013, the tanks with contaminated water can be seen. [Source: Pho-118]

Since the sea water was used for cooling the overheated reactors, the cooling systems were damaged. Moreover, the fuel rods in some reactors started to melt. Japanese Prime Minister Naoto Kan said it would be necessary to dismantle the plant. Japan has already requested assistance with eliminating the consequences of the accident from the Areva and EDF French nuclear corporation and it is possible that experts from other countries will be involved in the work. On April 13, Kenichi Matsumoto, adviser to the Prime Minister, told the media that the vicinity of the plant would be unin-

habitable for 20 years based on estimates. The Japanese government, however, denied the statement soon. 
The accident at the Fukushima I nuclear power plant in Japan sparked an international political debate on using nuclear energy. After the top-level security clearance, the federal government decided to shut down, at least temporarily, 7 nuclear power plants, which caused a rise in electricity prices on the market by $18 \%$. The Bavarian opposition also renewed the efforts to achieve the shutdown of the Temelín nuclear power plant.

In Japan itself, some projects of new nuclear power plant units were cancelled and it is likely that the Japanese project of the Monju prototype fast-breeder nuclear reactor in Tsuruga, Fukui Prefecture, will be cancelled. This project has been ac-

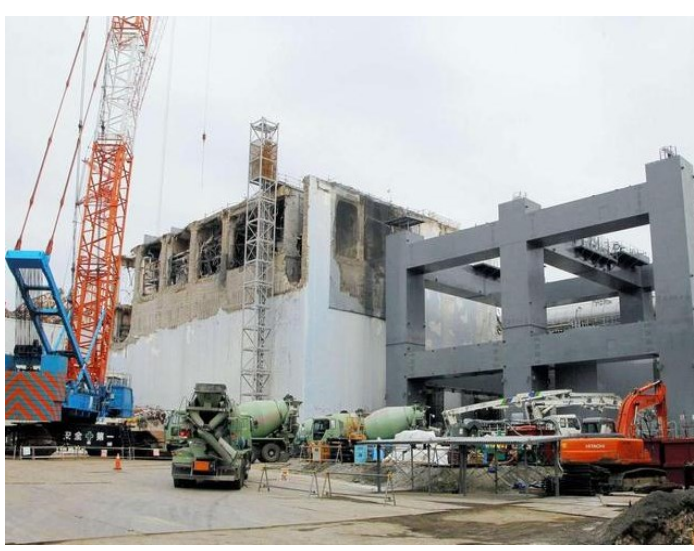

Photo 119: The construction of a new building where melted fuel rods will be stored.

[Source: Pho-119] companied by problems for a long time. The reactor was in operation for about one year altogether, although it was launched in 1995. However, the cancellation of the project will be a big problem for the Japanese energy concept since Japan counted on the transition to fast systems. According to a report by the Japanese parliamentary commission of inquiry, the disaster was not caused by a tsunami, but by a man. The commission stated: "It was a man-made accident. It was predictable and should have been foreseen. It could have been prevented and should have been prevented." The report criticizes the bad laws regulating nuclear energy, the inadequacy of safety measures, the errors in the plant management and the state supervision as well as the bad reactions after the accident. The report recommended strengthening government oversight in the field of nuclear energy.

\subsubsection{Radiation incidents caused by ionizing radiation sources}

Serious radiation incidents still occur even outside the workplaces with ionizing radiation sources (hereinafter IRSs) and it is not a question of the IRSs misuse. The cause of these incidents has been and often is the decline in the level of security of IRSs in some countries. The inconsiderable group of radiation incidents also includes those that were a result of certain human greed (the attempts to get metal articles with the aim to sell them in the scrap yards). The concern that an incident with a source of ionizing radiation, even outside the workplaces where it is handled, could have extensive consequences. This has been already confirmed in the following events.

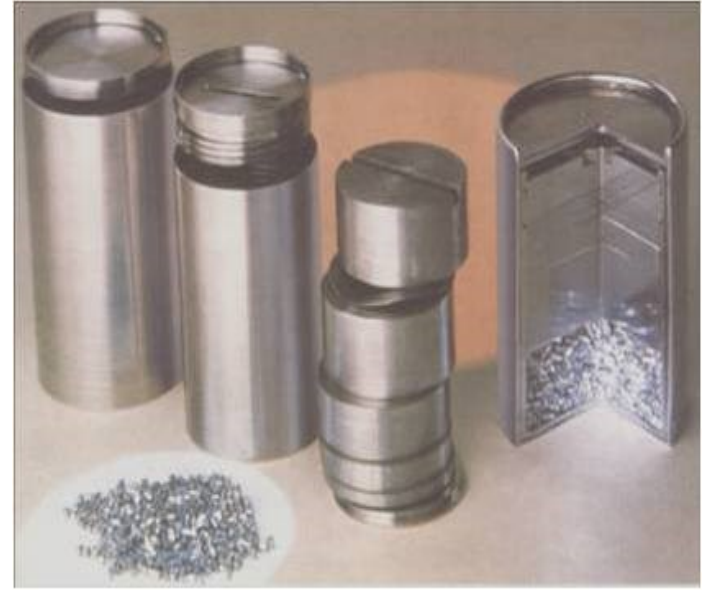

Photo 120: The emitter with thousands of ${ }^{60} \mathrm{Co}$ metal pellets. [Source: Pho-120]

\section{Ciudad Juarez (Mexico 1983)}

In this case, it was the IRS intended for radiotherapy $\left({ }^{60} \mathrm{Co}\right.$ activity $\left.-30 \mathrm{TBq}\right)$. The emitter consisted of 6,000 metal pellets with a size of $1 \times 1 \mathrm{~mm}^{2}$ (see Photo 120). It has never been used and was stored in the in the irradiation head for 6 years with virtually no control. The price of scrap caused that the warehouse technicians dismantled the device and transported it to a scrap yard. During the disassembly (it was not excluded that knowingly), the radiator that was inside was broken. In the car, which transported the disassembled device, many pellets were left (due to a failure of the car, it then parked close to houses for several days and their inhabitants were irradiated). 
The pellets were also scattered throughout the yard and many of them ended up in scrap metal converted into steel products. These were then transported to steelworks to be processed. Thus, metal products (building metal fittings, base plates, etc.) were contaminated and spread to a number of places.

The incident was revealed a month later when a truck carrying contaminated products was passing the nuclear laboratories in Los Alamos in New Mexico (the USA) and their automatic radiation sensors rang the alarm. During investigations and monitoring $\left(470 \mathrm{~km}^{2}\right.$ were measured by plane), it was found out that as a result of the incident, 4,000 people could have been irradiated, of which about 80 could have received a dose higher than $250 \mathrm{mSv}$ and about 5 people could have received doses between 3 and $7 \mathrm{~Sv}$ within two months. A total of 30,000 contaminated plates, 6,600 tonnes of fittings were produced and 17,636 buildings where the contaminated material was used were inspected ( 814 buildings were demolished partially or completely).

This incident revealed a number of factors that accompany this type of incidents - the insufficient control of sources, human errors, a difficult process of monitoring, i.e. both irradiated persons and the contaminated environment, buildings, and costly elimination of the consequences of the incident.

\section{Goiania (Brazil 1987)}

In 1985, the Goiania Institute of Radiotherapy moved to a new location and left behind an obsolete ${ }^{137} \mathrm{Cs}$ (caesium chloride powder with the activity of $51 \mathrm{TBq}$ ) teletherapy unit in its abandoned headquarters. Two men stole it and illegally carried it home. During unprofessional disassembly of the container, they got to the emitter, which they inadvertently destroyed. The people standing near and watching the disassembly were contaminated. They did not know that it was a powerful radionuclide IRS. Although several of them began to show

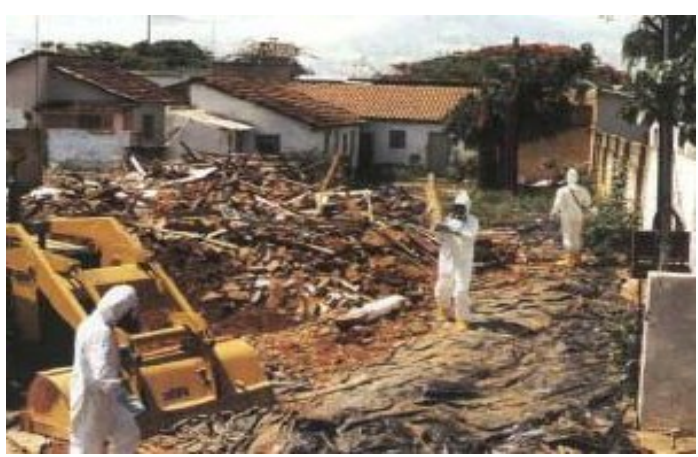

Photo 121: The disposal of houses contaminated by ${ }^{137}$ Cs in Brazilian Goiania. [Source: Pho-121] signs of radiation sickness, the doctor whom the patients visited did not diagnose these symptoms as a result of the radiation.

Late diagnoses and thus the late initiation of rescue and liquidation work resulted in extraordinary losses; 4 people died (they received doses of 4.5 up to $6 \mathrm{~Gy}$ ), 249 people were contaminated, 112,000 were monitored, which required the deployment of considerable medical capabilities, the area of $67 \mathrm{~km}^{2}$ was monitored by airplanes, 159 houses in the vicinity of the incident were measured, of which 42 had to be decontaminated. Some of them were demolished (see Photo 121). The disposal of contaminated waste (up to $35,000 \mathrm{~m}^{3}$ of material were contaminated) necessitated the construction of a special long-term storage where about $3,000 \mathrm{~m}^{3}$ of waste will be stored up to 300 years. The total costs of the disposal are estimated at tens of millions of US dollars.

\section{Istanbul (Turkey 1998) and Samut Prakarn (Thailand 2000)}

In both cases, these were again discarded ${ }^{60} \mathrm{Co}$ emitters that were stored for a long time (in screening boxes) and were not secured sufficiently (the activities of the unit up to tens of TBq). They fell into the hands of people who disassembled screening boxes as metal scrap and did not know that they contained emitters. During these manipulations some of the participants already felt the symptoms of the radiation sickness, which, analogous to the case of an incident in Goiania, was not diagnosed in time. 
However, the investigation and the demanding monitoring concluded in both cases that, fortunately, the emitters had not been damaged, when handled, and thus environmental contamination had been avoided.

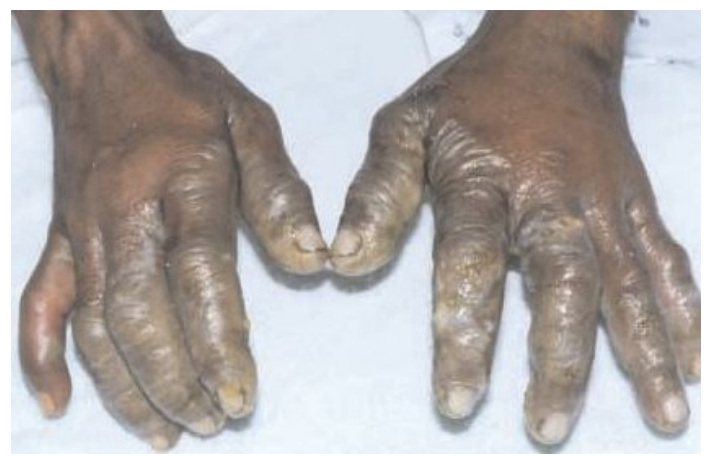

Photo 122: Radiation burns of hands caused by ${ }^{60}$ Co in Thai Samut Prakarn. [Source: Pho-122]

In the incident in Istanbul, 10 people who participated in the scrap handling (doses in a range of 1 up to 4 Gy were estimated based on clinical symptoms and haematology examinations) were seriously irradiated and treated, 404 people were subjected to clinical and haematology tests.

In Samut Prakarn, 10 people were also treated, 4 of them received doses greater than $6 \mathrm{~Gy}$ (an estimate based on clinical symptoms), 3 of them died within two months (the first one already on the $23^{\text {rd }}$ day after irradiation). The other participants received doses of about 2 Gy (see Photo 122). A total of 1,872 people was examined.

In these two accidents, the contamination of buildings and the environment was avoided and thus they did not result in such extensive clean-up operations as in Goiania. However, they did provide a number of findings in the field of treatment of lethally irradiated humans.

\section{Tammik (Estonia 1994)}

A few men broke into the inadequately protected Tammik repository of radioactive wastes (at the time of the accident, there were emitters of the total activity of $76 \mathrm{TBq}$, mainly ${ }^{137} \mathrm{Cs}$ and ${ }^{90} \mathrm{Sr}$ ) and took away a container, which contained a ${ }^{137} \mathrm{Cs}$ source. When handling the container, an emitter fell out of the metal box. It was a small metal cylinder and one of the men placed it into the pocket of his trousers. After returning home, he put it into the drawer in the kitchen, where it was left for about a month. Then the source was identified. Already during the first hours after visiting the repository, the man felt sick and vomited. After 4 days, he was hospitalized for a seriously injured leg (he did not admit he had broken into the repository) and the doctor did not recognize that it was a radiation burn. After a week, he died due to the acute radiation syndrome. The accident was identified after a few weeks when the stepson of the dead man was hospitalized for radiation burns on his hand (it was found out that he had held the source in his hand for a certain time). It was proved that 5 people had received doses between 0.3 and $2.7 \mathrm{~Gy}$.

\section{Lilo (Georgia 1997)}

Between April and August 1997, a strange skin damage appeared on soldiers' bodies during their training at the military training camp in Lilo, Georgia. At first, they were diagnosed as burns or allergy. Later, (in the first case after more than 9 months of treatment) irradiation was identified as the cause. The extensive investigation was started. It focused both on the origin of irradiation and the diagnosis and therapy of affected people. Gradually, 12 sources of ${ }^{137} \mathrm{Cs}$ and one source of ${ }^{60} \mathrm{Co}$ were found in different places; one source in the

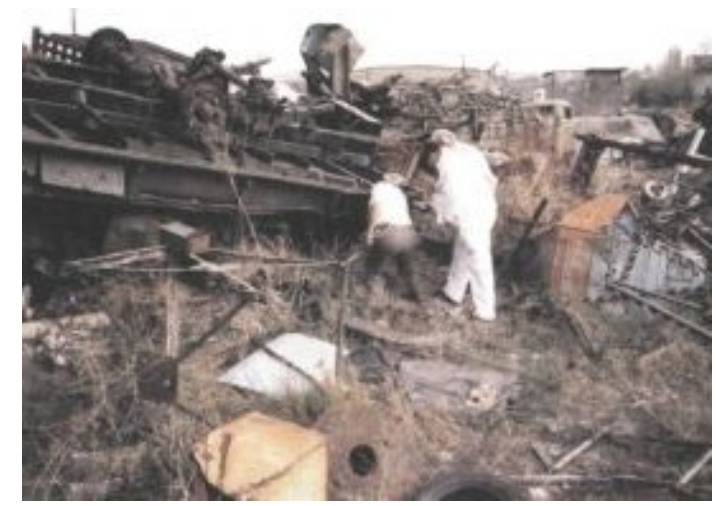

Photo 123: Radiological survey at Lilo, Georgia. [Source: Pho-123]

pocket of a winter field jacket, others in a building, in a shelter in a former military junkyard (see Photo 123) near the fence and in the surrounding area (the estimated activities ranged from 0.02 to $164 \mathrm{GBq})$. 
The contamination of the terrain or people was not found out. According to subsequent investigations and analyses, irradiation lasted from 60 to 300 days intermittently in 11 people (the beginning was not detected) and was highly heterogeneous. In the affected people chronic local radiation sickness (it gradually developed into radiation burns of up to $4^{\text {th }}$ degree) was diagnosed. The estimates of whole-body doses ranged in the interval from 0.2 to $5.9 \mathrm{~Gy}$. Two years after irradiation, it was stated that out of 11 patients, 3 patients would continue to require a subsequent treatment (surgeries, reconstruction of removed muscles and skin, plastic surgeries, etc.), due to which lasting depressive states were diagnosed in them. In addition to the events mentioned, other findings and manipulations of abandoned IRSs have been and continue to be reported, leading to serious exposures or even deaths of people (between 2001 and 2003, such cases were dealt with in several places in Russia, again in Georgia, in Egypt and other countries). This indicates that the security systems of IRSs from their production, or import into a given country, despite the various methods of disposal up to their final security/disposal/storage, are still insufficient and need constant attention at national and international levels.

\section{The Czech Republic}

Even in our country in recent years, there have been thefts of covers of drains, parts of railway security systems and wires of the distribution network in order to sell them in scrap metal yards. Only a strict system of control over the used IRSs can minimize the risk of similar incidents in the country. In 1996, the State Office for Nuclear Safety dealt with a case when a wagon of ferrous scrap exported from the Czech Republic was detained in Italy and returned because it included the IRS. Upon its arrival at the border, the wagon was detained and dissembled under the supervision of the specialists from the State Office for Nuclear Safety. The emitter of ${ }^{137} \mathrm{Cs}$ with a total activity of $1.79 \mathrm{TBq}$ was isolated and identified (its loss was reported by a Czech company a few days ago). It was found out that the emitter was intact, i.e. the environment was not contaminated. The investigation did not prove irradiation of humans. But what was missing to make it happen?

\subsubsection{Recommendations and conclusions when dealing with radiation incidents}

In the case of a radiation accident, it is assumed that radioactive agents escape into the environment, usually over a longer period. Large leaks can occur over a few minutes up to hours after the beginning of a radiation accident and the leak may take 30 minutes up to several days. In terms of a progression of explosive effect in a nuclear power facility and threats to the population, we distinguish three phases of a radiation accident (it also applies for a radiation accident due to other causes).

\section{Phases of a radiation accident:}

In the case of a radiation accident, it is assumed that radioactive agents escape into the environment, usually over a longer period. Large leaks can occur over a few minutes up to hours after the beginning of a radiation accident and the leak may take 30 minutes up to several days. From the standpoint of a time course of the accident at a nuclear power facility and threats to the population, we distinguish three phases of a radiation accident (it generally applies to a radiation accident caused by other causes as well).

Phases of a radiation accident:

\section{Early phase}

- Poses a radiation threat to the population by direct irradiation from a nuclear facility, external irradiation caused by radionuclides from the passing cloud and deposited on the Earth's surface, internal contamination by inhalation and surface contamination of the skin and clothing; it lasts several hours after the accident; and 
- The following urgent measures are crucial for the population protection in this phase:

- Warning of the population (via sirens, radio and other systems that warn with the General Warning signal - a fluctuating tone 140 seconds long or when using electronic sirens supplemented by voice information on the radiation accident or other information to the population). This signal requires the people occurring in the emergency planning zone to take shelter in buildings immediately and to turn on the TV or radio, from which they will receive more information;

- Hiding (is implemented immediately after the warning of the population using improvised shelters, e.g. private apartments, cinemas, gyms, etc.); residents will remain sheltered for a time announced to them in the media;

- Iodine prophylaxis (after the warning, the citizens living in the emergency planning zone must ingest potassium iodide tablets in the amount indicated in the media). When the thyroid gland is saturated with normal iodine, the deposition of radioactive iodine in the thyroid gland will be prevented;

- Individual protection (equipment/use of individual protective equipment);

- Population evacuation (organized relocation of people from threatened areas to pre-selected areas outside the emergency planning zone, it is carried out from the territory to 5 up to 10 (20) $\mathrm{km}$ from the radiation accident in the case of Dukovany nuclear power plant and 5 to $13 \mathrm{~km}$ in the case of Temelín).

These measures will also be carried out in the areas outside the emergency planning zone based on the assessment of the radiation accident development and its anticipated impact on the environment.

\section{Intermediate phase}

- Represents a radiation threat to the population by external irradiation caused by radionuclides from the contaminated terrain and their inhalation (when they are swirled on contaminated surfaces) and by the consumption of contaminated food and drinking water or contaminated agricultural products, e.g. milk and vegetable;

- May take several days up to months; and

- The following additional measures are crucial for the population protection:

- Decontamination of individuals (using individual protective equipment or improvised equipment);

- Healthcare (preventive, hygienic and epidemiological measures);

- Control of using contaminated food, water and feed;

- Prohibition of activities endangering the public health;

- Regulation of the movement of people (prohibition of people's entry into the endangered area, ensuring the passage of roads for monitoring groups, for the evacuation and movement of forces and equipment carrying out rescue and liquidation works);

- Resettlement of people (the purpose is to prevent the population from staying in inaccessibly contaminated areas);

- Monitoring (measurement, analysis and assessment of radioactive fallout).

\section{Late phase}

- Does not represent an immediate danger to the population;

- A period of gradual revocation of existing protective measures;

- Transition to a normal way of life;

- May take several years. 


\section{Outside the emergency planning zone:}

Dosimetric control (measurement) of water, soil, air, food and feed, etc.) is mainly performed. In the event that inadmissible limits of the dose equivalent of ionizing radiation or the content of radionuclides are found, effective measures are taken, similar in their content to the measures implemented in the emergency planning zone. To avoid endangering the population, and the contamination of the surroundings outside the emergency planning zone, control points are planned, secured and possibly implemented at the exits from the emergency planning zone, where, among other things, the dosimetric control of people, vehicles and materials, exported from the emergency planning zone. Near the control points, sites for decontamination are established. They are usually public or company washrooms or shower rooms and decontamination stations built in the field by the units of the Army of the Czech Republic (NBC companies or rescue units of the Chemical Corps).

\section{Nuclear safety}

Nuclear safety is the status and the ability of a nuclear facility and its operating personnel to prevent the uncontrolled development of the fission chain reaction and the unauthorized release of radioactive agents and ionizing radiation into the environment. In the area of the nuclear energy industry, it is necessary to automatically understand the obligation to ensure all processes associated with the release of energy so as to prevent a failure or an accident of technological systems. This is a wish, but a technological problem can never be excluded.

The adopted nuclear safety philosophy does not end with the requirements for quality and safe equipment only, but it also includes the measures to reduce the consequences of a failure or accident. This philosophy is embodied in a power plant project. Besides the fact, that a nuclear power plant must withstand any adverse external effects (earthquakes, a plane crash, a terrorist attack, etc.), it itself must be able to manage all conceivable failures and accidents. It is primarily considered what wrong (i.e. what failure) can happen. For each problem thus defined a solution for avoiding either the problem or subsequent effects has to be invented. The philosophy of nuclear safety aims at a maximalist outcome, i.e. a status, which experts call the maximum conceivable accident is defined.

With a bit of imagination, we can think of a discussion about the worst thing that can happen. It makes no sense to point out that it is precisely because the power plant must be designed to eliminate this accident. The greatest danger for workers of nuclear power plants and workplaces with ionizing radiation and for the population in their vicinity is the leakage of radionuclides and ionizing radiation from fuel, reactor and power plant. There are many obstacles to prevent the leakage of radionuclides and ionizing radiation.

It is always necessary to overcome increasingly more complex and more resilient obstacles and barriers:

- The $1^{\text {st }}$ barrier - the fuel is hermetically sealed in metal fuel rods, coated with a special alloy, assembled into fuel elements;

- The $2^{\text {nd }}$ barrier - a primary circuit is constructed to be extremely tight to prevent the leakage of cooling water out of this circle;

- The $3^{\text {rd }}$ barrier - a special hermetic enclosure of the primary circuit and a containment. The Dukovany reactors are located in the bubble hall and the Temelín reactors are protected by a more modern containment.

The design and technical solution of power plants, compliance with the specified operating conditions and the professional, medical and psychological competence of the staff of these power plants essentially excludes the possibility of an accident and their occurrence is very unlikely. 
Both plants operate different types of reactors (VVER) than those used at Chernobyl. In the case of an unlikely failure of the operator or control systems of the reactors, despite the increase in the thermal output of the reactor, the fission reaction would be spontaneously suppressed and thus the reactor would be gradually shut down (inherent system). Therefore, there can be no radiation accident as in Chernobyl, where the used reactors of the RBMK type are characterized by the so-called positive reactivity and instability at lower thermal outputs of the reactor.

\section{Ensuring emergency preparedness}

Despite of all safety measures, both our nuclear power plants (NPPs) have a system of protective measures for their employees and the population in the case that an emergency event occurs, which would result in the breach of protective barriers. This system is worked out within emergency preparedness, which is an important factor to ensure the protection of people during a radiation accident and is described in contingency plans.

The measures to protect the population stated in these contingency plans must be provided by qualified and professionally skilled personnel, material and equipment.

The method of ensuring emergency preparedness is established by "Decree of the State Office for Nuclear Safety No. 359/2016 Coll." - Decree of the State Office for Nuclear Safety on details of ensuring radiation extraordinary event management. The procedures for dealing with emergency sit-

Figure 86: The cross-section of a fuel element for a nuclear reactor. [Source: Fig-86]

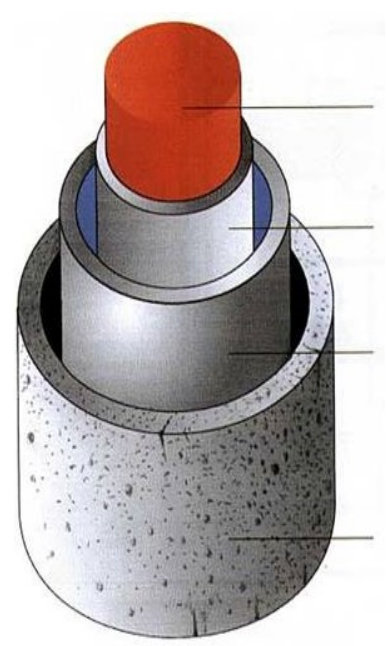

Fuel pellet

The $1^{\text {st }}$ barrier - fuel cover - coating of a fuel rod made of a special alloy called Zircaloy

The $2^{\text {nd }}$ barrier - construction of a primary circuit made of stainless steel that is resistant to an extraordinary pressure, dynamic, thermal and radiation stress

The $3^{\text {rd }}$ barrier - reinforced concrete enclosure of the primary circuit and a protective envelope $1.2 \mathrm{~m}$ thick with a steel lining - the so-called containment uations must be regularly rehearsed, practiced and reviewed.

In the case of the Dukovany nuclear power plant, the emergency planning zone extends to a distance of $20 \mathrm{~km}$ around the plant, and as for the Temelín nuclear power plant, it extends to a distance of $13 \mathrm{~km}$, including the town of Týn nad Vltavou. All residents living in these zones regularly receive the "Manual for the population protection in the event of a radiation accident."

It turns out that the destruction of a radionuclide source causes not only the irradiation and contamination of people, but also contamination of a considerable area and houses in the vicinity of the accident. Then the elimination of the accident represents big costs for decontamination and the disposal of radioactive waste and, moreover, also significant healthcare costs, etc.

It turns out (if we do not consider radiation accidents of nuclear facilities) that the radiation accidents outside the workplaces with the IRSs may be more severe than the accidents in the workplaces with IRSs. The initial diagnosis of the health effects caused by irradiation, usually made by general practitioners, sometimes specialists in other fields, e.g. dermatologists and specialists in infectious diseases, is not often correct. Especially in accidents outside the workplace with IRSs, this has been confirmed several times. Health symptoms were assessed as common burns, infections (insect bites), dietary errors, viral diseases and sometimes treated in this way for a long time. 
Basic documentation of emergency preparedness is formed by the following:

1. On-site emergency plan:

- Is developed for the operators of nuclear power plants for the case of a radiation accident;

- Describes the on-site emergency preparedness of the nuclear power plant operator and describes the protection of the staff on the premises of the nuclear power plant in the case of severe emergency events and the occurrence of a radiation accident.

2. Off-site emergency plan:

- Is developed for the vicinity of the nuclear power plant lying in the emergency planning zone;

- Describes protective measures for the population (informing and warning, radiation situation monitoring, sheltering, iodine prophylaxis, evacuation, the control of movement of people, dosimetric control and decontamination, the control of consuming food and drinking water and its sources, and healthcare);

- Describes ensuring emergency preparedness in the vicinity of the nuclear power plant;

- Includes the procedures to ensure and control the activities related to the population protection, the environment and assets in the case of the occurrence of a radiation accident (informing, warning, radiation situation monitoring, sheltering, etc.).

In 2000, the IAEA published a document entitled "How to recognize and initially respond to an accidental radiation injury", in which it summarizes the principles of how to detect a radiation accident and what activities to perform in the first phase after its detection to reduce the risk of misdiagnosis. Another finding is a low level of knowledge among ordinary residents about the risk of exposure when handling IRSs. This fact calls for an effective and sustained public education in this area.

It is a large problem that the greed for money in some people causes that there is a growing number of accidents. People try to obtain scrap metal (in the form of containers, irradiation sources, etc.) by all legal or illegal means, when these discarded or stored, inadequately secured containers contain abandoned IRSs with considerable activities in many cases. Conversely, the significant benefit of previous accidents is the development, improvement and validation of new methods and techniques for detection, dosimetry, investigation and finally the treatment of patients.

In therapy, for example, it has been recommended not to perform the bone marrow transplants for the doses lower than 2 up to $4 \mathrm{~Gy}$. The impact of psychological factors in the treatment of irradiated people (recurrence, long-term treatment) is emphasized. It has been stated that in some accidents, despite of all the efforts of treatment, the cause of the death of irradiated people was the secondary infection in an organism debilitated by irradiation (open wounds, radiation burns. Therefore, there is a requirement in international recommendations (fulfilled in developed countries for years) to treat irradiated patients in special isolated/sterile boxes (life islands).

Methods used to estimate the doses in irradiated people:

- Biological dosimetry methods (a dose estimate based on the evaluation of clinical status, morphological changes, the use of complex biochemical, microbiological, haematology and cytogenetic examinations);

- A combination of physical and biological methods (the local dose reconstruction was performed using the Monte Carlo method, when the photon transport simulations in the affected tissue was compared with the degree of damage to the tissue on the basis of biological dosimetry); and 
- Physical methods (phantom measurements, dosimetry reconstruction; for example, the method of electron paramagnetic resonance was used to estimate doses of the external exposure in the tooth enamel of the affected).

If a radiation accident occurs, each citizen who may be endangered by its effects, is obliged to act according to these guidelines:

- To react to warning signals properly (the unified system of warning and notification);

- To follow information in the mass media, instructions communicated by local radio, radio cars and behave according to the instructions of rescue units and public administration bodies that you trust (they want to help you);

- If a person is in the open air, he/she is obliged to immediately seek the nearest house (preferably cellars or basements in the house), to close the door and windows, to turn off ventilation, to seal the vents, to store food in plastic or at least paper bags and put them into refrigerators, freezers or enclosed spaces;

- To stay in the central room of the house on the ground floor, basement or basement, the room should have a minimum of windows (in prefabricated houses it can be halls or corridors);

- To prepare improvised individual protective equipment;

- To put out an open fire in the stove, turn off gas appliances, etc.;

- To provide pets with feed, water and to close them;

- To leave the apartment and the house based on the instructions of the Integrated Rescue System components or an official request;

- To prepare your evacuation baggage and hide or evacuate only on the basis of instructions from the components of the Integrated Rescue System or an official request;

- Iodine preparations (tablets of potassium iodide) will be issued to people in case of need together with the instructions on how to use them.

If a radiation accident occurs at the Dukovany or Temelín nuclear power plants, the residents living in the emergency planning zone will follow the instructions of the nuclear power plant operators and the state administration and self-administration bodies.

In the event of a road accident associated with the transport of radioactive agents (the vehicles transporting these materials are marked with warning symbols):

- It is necessary to leave the place of the accident immediately (to consider the possibility of providing the first aid to injured people);

- If nobody is informed about the accident, to report on this accident.

In case of detection of suspicious objects marked with the symbol radioactive agents:

- Not to manipulate this object and to leave the place of its discovery quickly;

- To prevent people from entering and notify the Police of the Czech Republic or the Fire Rescue Service on the finding immediately.

Although radiation accidents, as well as other ones, cannot be completely prevented, efforts must be made to reduce their risk. This consists in increasing the quality of the security of IRSs that are handled, increasing the level of knowledge of how to treat these resources, not only among radiation workers, but also among the population and finally, using and implementing the knowledge on the course and elimination of the consequences of such incidents in the system of radiation protection and emergency preparedness. 


\section{Chemical weapons}

\subsection{Historical and Current Situation}

Chemical weapons, together with nuclear and biological weapons, constitute a category of weapons of mass destruction. Their historical origin might date back to World War I, but that is not the case. The roots of the use of toxic substances are significantly older. It was already a prehistoric man who tried to drive animals out of hiding places using the irritating smoke from raw wood and who later began to use this hunting experience against the enemy.

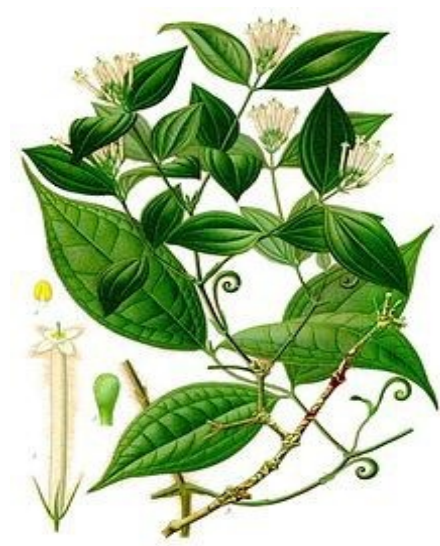

Figure 87: Strychnos toxifera is a liana from South America, from the Orinoco and Amazon River basins. It is used for curare. [Source: Fig-87]

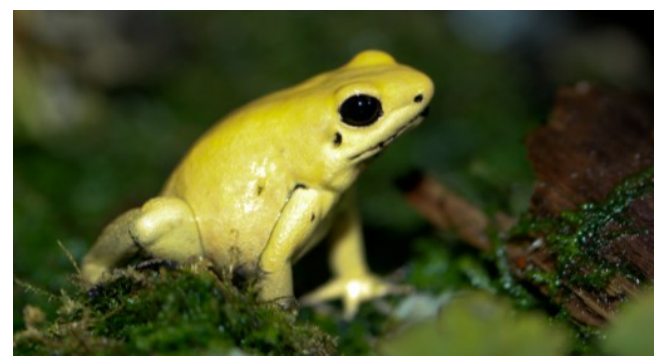

Photo 125: A golden poison frog (Phyllobates terribilis). One of the most poisonous frogs of the family Dendrobatidae. [Source: Pho-125]
However, the initial use of chemical substances against humans is still more associated with fire, which was used to protect against the attacks of animals and humans, later to defend or to capture cities and fortifications. Easily incendiary and available substances, e.g. oil, resins, etc., were used as components. Preserved sources say that about $2000 \mathrm{BC}$, toxic fumes containing even leached plant extracts that induced mass sleep were used. These fumes are often described in the Chinese sources from the time of the Song Dynasty. There are reports that around $600 \mathrm{BC}$, the Greeks and the Assyrians contaminated water sources with hellebore causing severe diarrhoeas and by ergot. The first evidence of the use of smoke from sulphur and pitch comes from $428 \mathrm{BC}$ from the Peloponnesian War (431 to 404 BC) during the Spartan siege of Plataea, as the ancient Greek historian Thucydides mentions.

Chemical weapons were not first used during World War I, but already in the $3^{\text {rd }}$ century as archaeologist Simon James (University of Leicester) says. This battle took place in the ancient city of Dura-Europos, which was located in eastern Syria. It was founded around 300 BC and in the $3^{\text {rd }}$ century AD it belonged to the Romans. The history of the town fortress was completed in 256, when it was occupied by the Persians (Sasanians), forgotten and covered with sand. The battle of the city was cruel. In addition to bringing a large rampart to attack the walls, the Persians also dug an underground passage. Roman soldiers also dug a tunnel. Therefore, the struggle also took place underground. As a result, many bodies of the Romans remained in the labyrinth beneath the city walls. About 20 remains of bodies, discovered under the walls, as well as a number of other finds, which he analysed, allowed Simon James to compile an interesting version of events. 
It is known that the Persians carried out excavation work to break the walls and towers (but they did not succeed, the walls only settled down a little), in addition, they tried to break into the city from the underground (but in the explanation of how Dura-Europos really fell, there is a lot of information missing so far). The Romans dug corridors in the opposite direction in an effort to complicate the attackers' situation. And, as the Leicester archaeologist thinks, the Persians used a new weapon - they set fire to asphalt and sulphur crystals to make dense toxic gases, which then reached the Romans (which was helped by the method of excavation) - see Figure 88. According to Simon James, the Romans who were just in the tunnel lost consciousness within a few seconds and died in a few minutes.

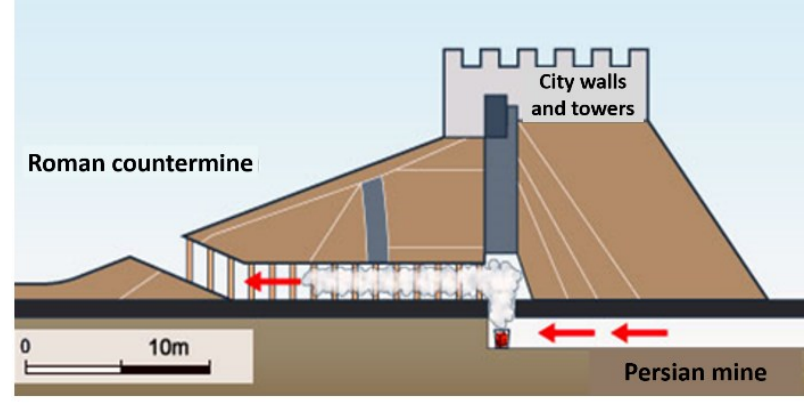

Figure 88: The use of poisonous gas by the Persians in the $3^{\text {rd }}$ century AD. [Source: Fig-88]

Greek fire was an ancient incendiary weapon, the invention of which is attributed to Kallinikos of Syria. It was a mixture of saltpetre, sulphur, antimony, the sap of an Egyptian fig tree, tar and quicklime. Greek fire was popular not only as a combustible mixture, but also because it generated suffocating gases and burned even on the water surface. The mixture was used by the Battle Fleet, where special mortars were used as flamethrowers. The combination of natural toxins and arrows can be considered the first chemical weapon. These so-called arrow poisons were used by warriors of all continents. The effect of arrow poisons was focused on the paralysis of the nervous system, the paralysis of the heart muscle and the respiratory system.

Leonardo da Vinci also dealt with toxic substances. He designed incendiary rockets with arsenical smokes that were used in the conquest of fortresses. During the conquest of castles, fortresses and cities the sources of water were very often contaminated by decomposing bodies of animals and killed warriors. Information from the New World is also interesting when the Indians used irritating substances arising by throwing pepper on hot coals against the Spanish inhabitants.

In our history, we also encounter the use of chemicals. According to Czech annals from the Hussite Wars, during the siege of Karlstejn in 1422, the people of Prague (using catapults), led by Sigismund Korybut, threw among the defenders of the castle1,822 barrels (about 25 litres each) with faeces and burning materials. Faecal hydrogen sulphide caused poisoning of the defenders. Their hair fell out, they suffered from intestinal troubles, which were typical symptoms of poisoning; nevertheless, the siege was not successful.

The importance of chemical agents in military use

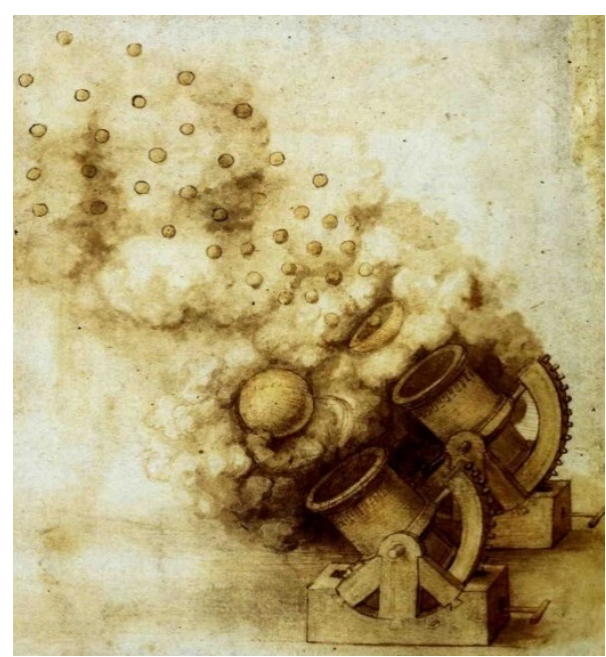

Photo 126: Leonardo da Vinci designed the cannon, which was movable to allow the angle and the height of the shot to be adjusted. From the cannon, it was also possible to fire cluster ammunition, which was split into a series of bomblets during the flight. [Source: Pho-126] increased when new knowledge about their possibilities was acquired. At the end of the $18^{\text {th }}$ century, France used chemical agents several times in wars to increase the effectiveness of artillery ammunition and introduced phosphorus as a new incendiary agent. During the Napoleonic Wars, English chemists suggested using grenades with hydrogen cyanide. In 1855, Admiral Thomas Cochran proposed the use of sulphur dioxide when capturing Sevastopol. 
From the viewpoint of existential impacts on human society, this historical period can be understood as nothingness in comparison with the true hell that occurred after the chemical weapons were deployed massively. Therefore, the military massive deployment of chemical weapons in World War I is historically considered to be the actual use of chemical weapons. The period from 1915 to 1918 is practically the only one when chemical weapons were used as weapons of mass destruction (more in Chapter 7 - Industrial chemicals - a secondary chemical weapon).

\subsubsection{The origin of chemical warfare}

Although there is a belief that in World War I the chemical warfare gas was used by Germans for the first time, it is not the case. Chemical warfare gases were used by all major belligerent powers. At that time, a relatively large range of chemical warfare agents (formerly called toxic agents or combat chemical agents) were used. In the period from August 1914 to spring 1915, irritating agents were sporadically used without a larger effect. In August 1914, the French Army on the Western Front used the 26-mm rifle cartridges filled with $19 \mathrm{ml}$ of ethyl bromoacetate and xylyl bromide. On October 2, 1914, the German artillery, in return, used o-dianisidine at Neuve-Chapelle when 3,000 pieces of 105-mm shells (Ni-schrapnell) were fired at the French. The French response came in November 1914 when they used chloroacetone in hand grenades and rifle grenades.

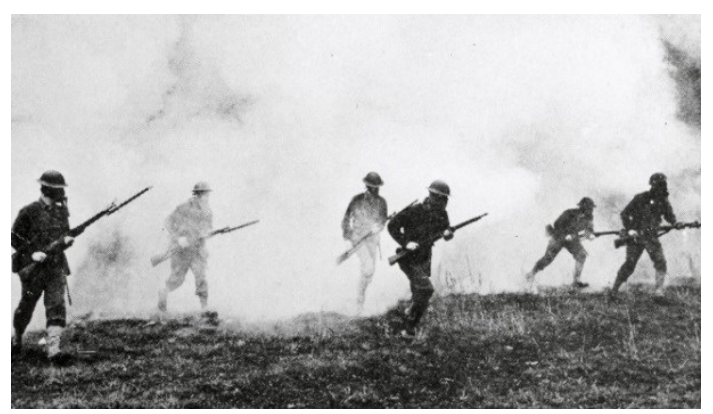

Figure 89: Soldiers wearing gas masks during a gas attack. World War I. [Source: Fig-89]

On the Eastern Front, the tear gas in the new German 150-mm shells, marked 12T, was used on January 31, 1915, at the Battle of Bolimov, $50 \mathrm{~km}$ west of Warsaw. Even though 18,000 pieces of cartridges containing xylyl-and xylylene-bromide were fired by the Germans, the use of gas was unsuccessful due to the low temperature (at $-20^{\circ} \mathrm{C}$ ). In March 1915, the effect was greater at Nieuport in Flanders due to the higher temperature when Germans used shells again. In summer, chlorinated methyl formate was used in grenades with a higher explosive charge to maintain the fragmentation effect.

These examples showed military experts that in order to achieve high combat concentrations and thus a sufficient poisonous effect, it was necessary to use a much larger amount of a chemical agent. Therefore, the German General Staff welcomed the proposal of Professor Fritz Haber, the German chemist (at that time the Governor). He recommended using chlorine for a human wave attack, which then meant a similar turning point in the history of wars as dropping the atomic bomb on Hiroshima.

The beginning of the chemical warfare is generally considered to be the war event of April 22, 1915, when the German troops released chlorine gas from the prepared cylinders onto French military units. This highly toxic gas hit a total of about 15,000 French soldiers, of whom 5,000 died within 3 days. It is understandable that this caused great dismay on the French side. On the contrary, this military success was not used and developed on the German side because the German Command did not trust this kind of warfare and, therefore, did not have sufficient military reserves ready to deploy them. On this day of World War I, chemical weapons were deployed massively on the battlefield for the first time. 


\subsubsection{What preceded the first massive chemical attack?}

The theoretical background papers for a gas attack were developed by the chemist Walther Nernst and his scientific and technical staff (R. Wilstätter, J. Franck, W. Westphal) at the Kaiser Wilhelm Institute for Physical Chemistry and Electrochemistry in Berlin-Dahlem. The proposal itself was presented by the above-mentioned Professor. F. Haber. Kaiser Wilhelm II hesitated to consent to the use of chemical agents with regard to fear of violating the international obligations of Germany. However, he was convinced by Professor Haber that there would be no violation of the Hague Convention (1907) and the objections were swept under the carpet. The Convention bound the contracting parties not to use chemical ammunition, however, no one counted on the release of gas from cylinders and the wind that brings a chemical agent to the enemy.

After major tests on flocks of sheep under the codename Desinfektion in January 1915 at the KölnWahnzim training ground, chemical weapons were to be deployed on the Eastern Front. However, on January 25, 1915, a section of the Western Front was selected at the Belgian town of Ypres in the area of the $4^{\text {th }}$ Army between Bixschoote and Poelkapelle, north of the town of Ypres. A total of 24,000 steel cylinders for the use of chlorine were produced in Germany, and other 6,000 steel cylinders were seized by the Army.

The chemical engineer Colonel Otto Peterson was charged with the preparation of the first operation with the combat use of chlorine and with the training and organization. The first unit of 500 reservists under the

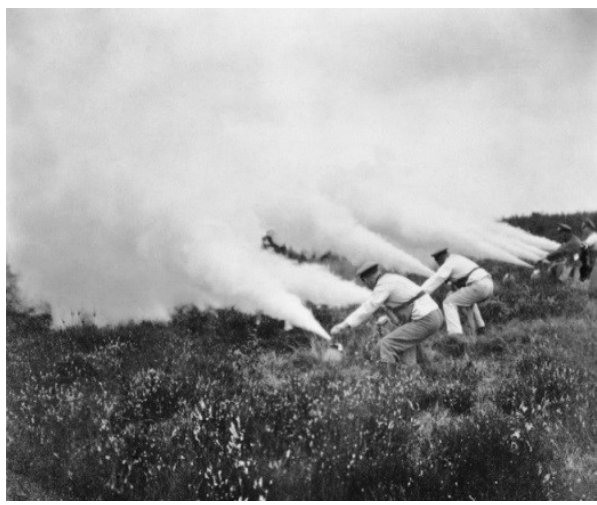

Figure 90: German soldiers discharging poisonous gas during a military test.

[Source: Fig-90] official name Pioneer Kommando or Desinfektion gruppe Peterson, unofficially Gasregiment Peterson or Stinkpioniere (Stunk Pioneers), grew to 1,600 men and was called Pioneer Regiment No. 35 (from September 1917 Pioneer Battalion 35 - deployed on the Western Front), which consisted of two gas battalions (gasbataillons), each with three companies and support units (Park Company, Weather Company and Telephone Section). It was equipped with DrägerTübben, Model 1914 oxygen apparatuses. Major von Zingler from the cavalry was appointed the commander. As early as May 1915, a second gas regiment was formed as Pioneer Regiment No. 36 (deployed on the Eastern Front). In February 1915, Colonel Peterson arrived in Flanders with a task to check and install chemical cylinders. On March 30, 1915, the XV Army Corps near Zillebeke (near Ypres) began to install pressure bombs into the trench line. The main depot and filling station were established in Kortemark and the filled cylinders were then moved by rail to particular places. The transport to the trenches was provided by the infantry. The first discharge line was being prepared in the area of the Canadian division. In order to protect the friendly units, protective gas masks were issued to soldiers. The first mask issued to German soldiers in April 1915 was known as a respirator or mouthguard or AOK Gent mask.

\subsubsection{D-Day - the day of the birth of chemical warfare}

It was not possible to launch a gas attack due to the adverse wind, which blew mostly from the west and northwest. Therefore, the Commander of the $4^{\text {th }}$ Army decided to build another gas discharge line in the northern part of the Front above the city of Ypres, in the area of the XXVI Army Corps and the XXVI Reserve Army Corps. In the period from April 5 to 10, 1915, Pioneer Rgt. No 35, under the leadership of professor Haber, laid down 1,600 large (40 kg chlorine) and 4,130 small ( $20 \mathrm{~kg}$ chlorine) cylinders with 146.6 tonnes of liquid chlorine on the Langemark-Poelkapelle discharge line north of Ypres. 
The preparation for the attack, a few hundred metres from the enemy, could not be kept secret, but met with disinterest and scepticism of both the enemy and the German Command.

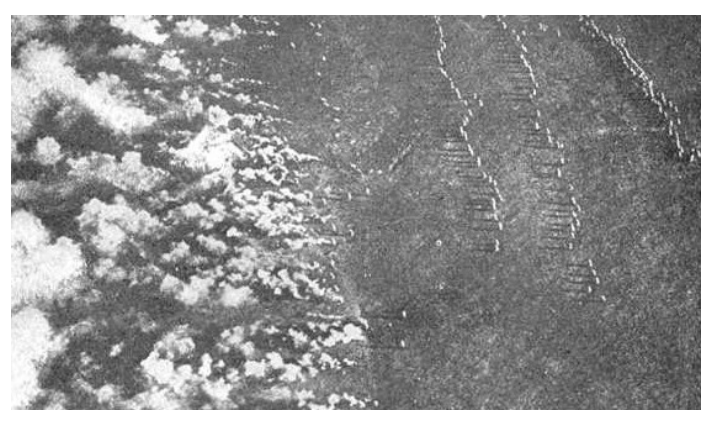

Figure 91: The German chlorine gas attack on the Eastern Front. It was photographed from the air by a Russian pilot. The photo was called Terror from the Air. [Source: Fig-91]

Already on April 14, a German prisoner August Jäger predicated of the planned gas attack, but nobody paid attention to that. Even the Canadian troops put out a poster from their trenches towards the position of the gasbataillon saying: You can wait a long while before the right wind blows.

Originally, the attack was scheduled to take place in the morning of April 14, then on April 19 and 21, 1915. All of them were cancelled due to the unfavourable wind. The required wind at the rate of 2-3 $\mathrm{m} \cdot \mathrm{s}^{-1}$ began to blow in the evening in the section of Bikschote-Langemark north of Ypres. The order was issued on April 22, 1915 at 05:24 p.m. with an attack time of 06:00 p.m. The news of the opening of the cylinders came at 06:05 p.m., along with a report that the gas cloud was moving well.

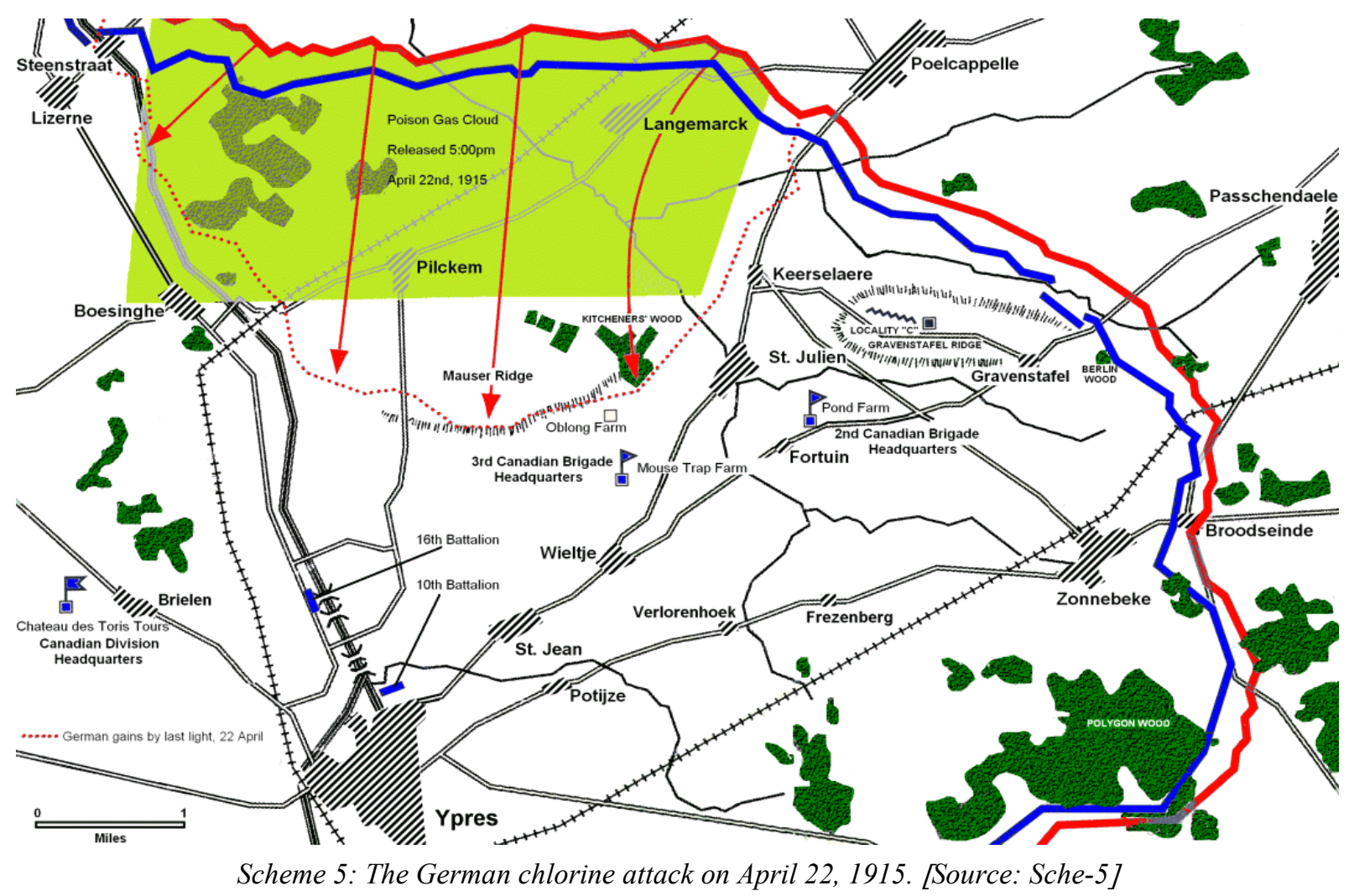

The troops of the Agreement did not expect anything like that. They considered a rolling green-yellow cloud to be a means, by which the German troops tried to camouflage their advance and so they were ordered to take the shooting positions. Chlorine resulted in severe damage to the eyes and respiratory organs. The attack disrupted the lines of the $45^{\text {th }}$ Algerian Division, the $87^{\text {th }}$ Territorial Division, and the $90^{\text {th }}$ Brigade. A total of 7,000 to 15,000 soldiers were affected; most of them were not able to fight and the rest of them escaped from the line. In the course of two days, the number of deaths was 350 to a maximum of 2,500 soldiers according to the British statistics (the French reported 15,000 affected and 5,000 dead soldiers). Those who survived suffered the damage to their health for the rest of their lives. 
The perfect success was surprising both for the attacked and for the German Command. Already 10 minutes after the chlorine release, the German troops launched an assault and advanced on the front $6 \mathrm{~km}$ wide to a depth of $4.5 \mathrm{~km}$ without a single shot. According to the German press, 2,740 French and English soldiers were captured and 34 cannons, of which 4 English heavy cannons, were seized. However, the German Command was not prepared for such a success. The operational reserves were not ready, so the attack stopped and the breakthrough of the first line was not used for a larger offensive.

\subsubsection{The use of chemical weapons in World War I}

An overview of using all kinds of chemical agents on the battlefields of World War I is considerably extensive. About 45 types of chemical agents were used on battlefields, of which 18 were lethal and 27 irritating in varying degrees. Some chemical agents failed with regard to their military use and others proved to be very effective. The most dangerous agents were especially chlorine, phosgene, diphosgene, hydrogen cyanide and mustard gas.

The amounts of chemical agents used by both parties reached 110,000 to 120,000 tonnes. In the war, about 8,540,000 soldiers died, about $21,220,000$ soldiers were wounded, not to mention the wounded and dead civilians. The chemical weapons affected 1,297,000 people (within 6 weeks, $70 \%$ of soldiers returned to the trenches), 91,200 of which died. These numerical statistical data are based on the book by American Colonel Augustin M. Prentiss (Chemicals in War, 1937.

All major belligerents, i.e. Germany, Austria-

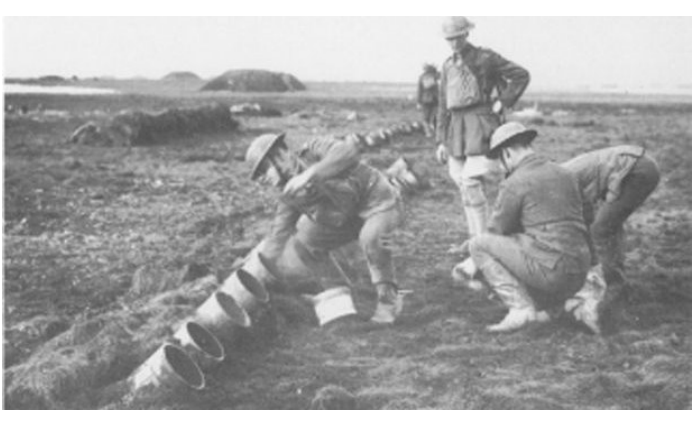

Figure 92: The British chemical unit is preparing gas cylinders at Loos. [Source: Fig-92] Hungary, Russia, France, England, Italy and the United States of America gradually began to use chemical weapons during World War I. Nevertheless, it was Germany, which had the greatest potential for the deployment of chemical weapons. Here, one important fact can be mentioned, i.e. in the period before World War I (1914), Germany produced as much as $85 \%$ of the world's chemical production, at that time focused mainly on industrial dyes.

Table 38: The use of chemical warfare agents in World War I in tonnes. [Source: Tab-38]

\begin{tabular}{|c|c|c|c|c|c|}
\hline State /year & 1915 & 1916 & 1917 & 1918 & Total \\
\hline Germany & 2,900 & 700 & 15,000 & 28,000 & 52,900 \\
\hline France & 300 & 3,500 & 7,500 & 15,000 & 26,300 \\
\hline England & 200 & 1,600 & 4,900 & 7,700 & 14,400 \\
\hline Austria-Hungary & - & 800 & 2,700 & 4,400 & 7,900 \\
\hline Italy & - & 400 & 2,500 & 3,400 & 6,300 \\
\hline Russia & 200 & 1,800 & 2,700 & - & 4,700 \\
\hline The USA & - & - & - & 1,000 & 1,000 \\
\hline TOTAL & 3,600 & 15,100 & 35,300 & 59,500 & 113,500 \\
\hline
\end{tabular}

The effectiveness of chemical weapons as compared with conventional ammunition was obvious - if 1 tonne of conventional explosives caused 4.9 health losses, then 1 tonne of chemical agents caused more than double (11.5). Thus, chemical agents were at least twice as effective, and when we take as an example only the blister agents that have remained in the arsenals of the army until the present time, then 1 tonne of these agents caused 36.4 losses, i.e. they were sevenfold more effective. And these were the agents, the effect of which is many times lower as compared with the current types of agents. To eliminate one soldier from combat, $250 \mathrm{~kg}$ of explosives were needed, but only $96 \mathrm{~kg}$ of chemical warfare agents. 
Toxic agents were introduced into the military equipment gradually, just as states produced chemical ammunition:

- 1914 - ethyl bromoacetate, xylyl bromide, o-dianisidine, chloroacetone;

- 1915 - benzyl bromide, xylyl bromide, chlorine, phosgene;

- 1916 - diphosgene, dibromomethyl ethylene ketone, chloropicrin, hydrogen cyanide, hydrogen sulphide, tin chloride, acrolein, bromoacetone;

- 1917 - diphenylchloroarsine (DA, Clark I), bis(2-chloroethyl)sulphide (mustard gas);

- 1918 - diphenylchloroarsine (DA, Clark II), ethyldichloroarsine, dichloromethyl ether, 2-chlorovinyldichloroarsine (lewisite).

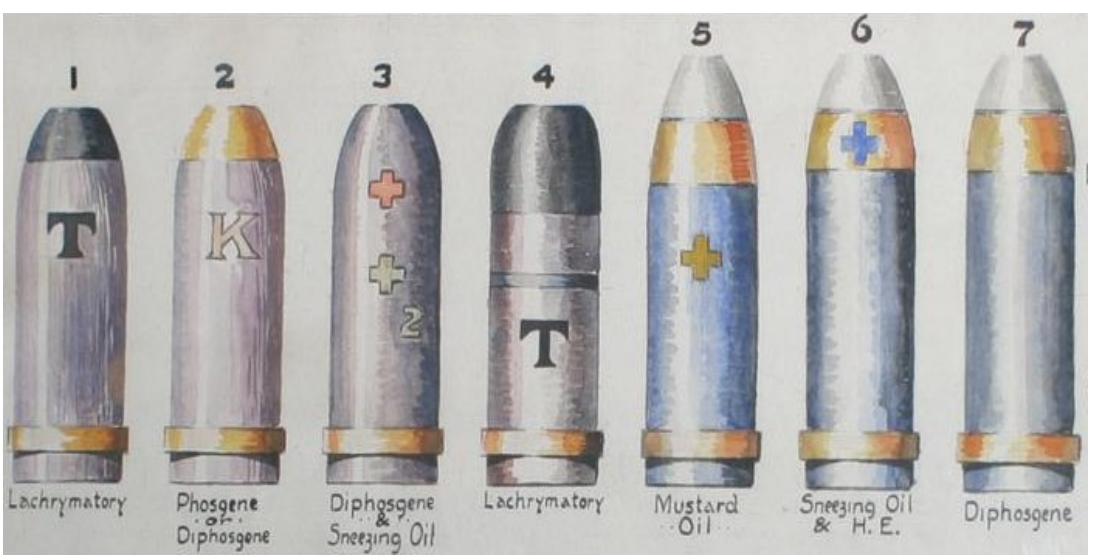

Figure 93: German chemical artillery shells. Different symbols were used for different chemicals. The grenade marked 1 was the first chemical grenade used during World War I. [Source: Fig-93]
World War I was the only period and hopefully the last one when chemical agents were used on a strategic scale and caused a large number of deaths (irretrievable medical losses) and injuries of the so-called poisonings (medical losses). The fact remains that a desperate opponent can use chemical agents to gain predominance regardless of international treaties. The point

is that chemical agents are commonly manufactured in the world for economic purposes and many of them can be quickly adapted to kill people (e.g. binary systems). It is known that many disasters have been caused by toxic chemicals during production, transport or poor storage.

\subsubsection{Use of chemical weapons after World War I}

After the end of World War I, local armed conflicts were taking place in the world. Chemical weapons were still used, although to a lesser extent. For instance, in 1918, chemical weapons were used by the British troops, which landed at Murmansk and Arkhangelsk.

On May 23, 1919, chemical weapons were used by the naval artillery to shell Kerch. In the period from August to September 1919, the White Guard members together with the armies of intervention used the shells with adamsite on the North Front. In August 1920, chemical shells containing phosgene were used by the White Guard members against a part of the $16^{\text {th }}$ Army in the Baranovich area, which they received from the English.

The Workers' and Peasants' Red Army

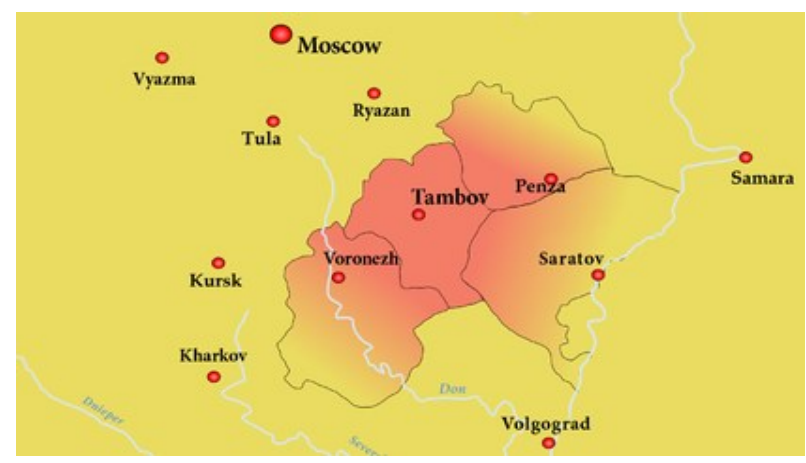

Scheme 6: The rebellion in the Tambov Gubernia in 1920-1921. [Source: Sche-6] used chemical shells charged with phosgene to suppress the peasant revolt in Yaroslavl in 1918; on March 18, 1919, the artillery of the Zaamur Regiment suppressed the uprising in the Upper Don region and on July 13, 1921, the Red Army suppressed the Rebel Army of Antonov in the Tambov Gubernia where the artillery of the Volga Military District used phosgene shells and chlorine cylinders. 
The students of the Moscow military training courses also took part in the action. It is reported that in the 1930s the Red Army Air Force used mustard gas in the form of aerial spraying against the Basmachi (the Central Asian armed robbers conducting armed raids into the territory of the Soviet Union).

In the 1920s, Spain used chemical weapons against the natives in Morocco. In 1930, Italy used mustard gas in Libya and, in 1936, against the Abyssinians (Ethiopia) - of 700 tonnes there were $60 \%$ of blister agents and $40 \%$ of choking agents. The estimated losses were 10,000 soldiers and 5,000 civilians out of 250,000 people affected.

\subsubsection{Use of chemical weapons in World War II}

Table 39: The stocks of German chemical ammunition on June 1, 1941. [Source: Tab-39]

\begin{tabular}{|c|c|}
\hline Chemical ammunition & Quantity in pieces \\
\hline $\begin{array}{c}\text { Shells for heavy field } \\
\text { artillery }\end{array}$ & 401,000 \\
\hline $\begin{array}{c}\text { Shells for light howitzers } \\
\text { and infantry grenades }\end{array}$ & $1,293,500$ \\
\hline $\begin{array}{c}\text { Ammunition for throwers } \\
\text { (Werfergeschosse) }\end{array}$ & 248,600 \\
\hline Chemical mines & 822,500 \\
\hline
\end{tabular}

Note: Chemical ammunition created $18 \%$ of the total quantity of ammunition.
During World War II, chemical weapons were not virtually used on an exposed European battlefield; nevertheless, a large number of chemical weapons were maintained in a high state of readiness in the arsenals of the belligerents. At the end of the war, the stocks of chemical warfare agents consisted of about 400,000 tonnes, which is twice the total amount produced in World War I. Blister agents, mustard gas and lewisite represented the largest part. Germany also planned to include an airborne chemical arsenal in the implementation of plans

to conquer Great Britain. The Luftwaffe counted on 76,000 KC-250 bombs charged with mustard gas, 5,000 bombs charged with phosgene and diphosgene and 8,000 bombs charged with irritating agents. In addition to chemical bombs, the use of aerial spraying equipment was also considered. Fortunately, chemical warfare agents were not used in the Battle of Britain. The available materials confirm that 13,052 tonnes of chemical warfare agents $(6,212$ tonnes of mustard gas, 2,230 tonnes of diphosgene and 1,985 tonnes of chloroacetophenone) were manufactured by German factories from May 1940 to April 1941.

All indications were that the German army was preparing to wage war using chemical weapons. Four special chemical regiments (Werfer regiments) took part in the attack on the Soviet Union. Each of them had 324 pieces of chemical weapons and was capable of firing up to 6 tonnes of chemical warfare agents by one salvo.

The reason, why chemical weapons were not used in World War II, is only speculated in the technical literature. For example, this is stated in the military technical journal entitled Historie a vojenstvi from 1993, No. 6, which gives specific reasons for

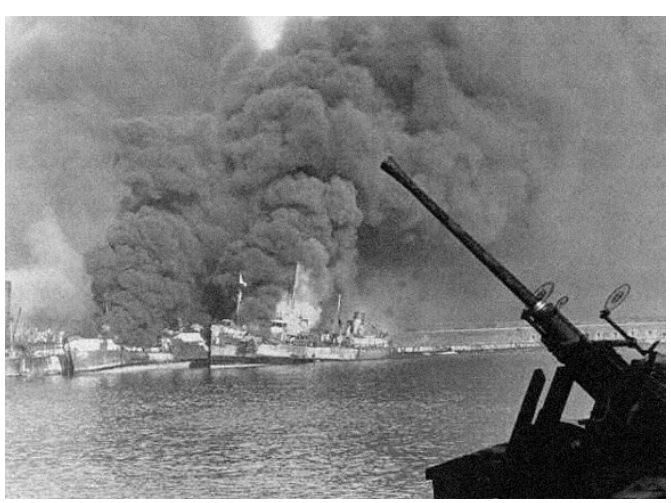

Figure 94: The burning American Liberty Ship (Liberty SS John Harvey type) with mustard gas, the non-use of chemical weapons in the period of December 2, 1943, Bari, Italy. [Source: Fig-94]
World War II. Fortunately, despite of the fact that there was no regular chemical war in World War II, chemical weapons were killing as a result of a series of incidents, and were used against Russian partisans. On September 08, 1939, a decision by a Polish Army officer to shell a bridge across the Nähe River near Yaslo resulted in the use of artillery shells charged with mustard gas. Two German soldiers were killed and twelve soldiers were wounded. 

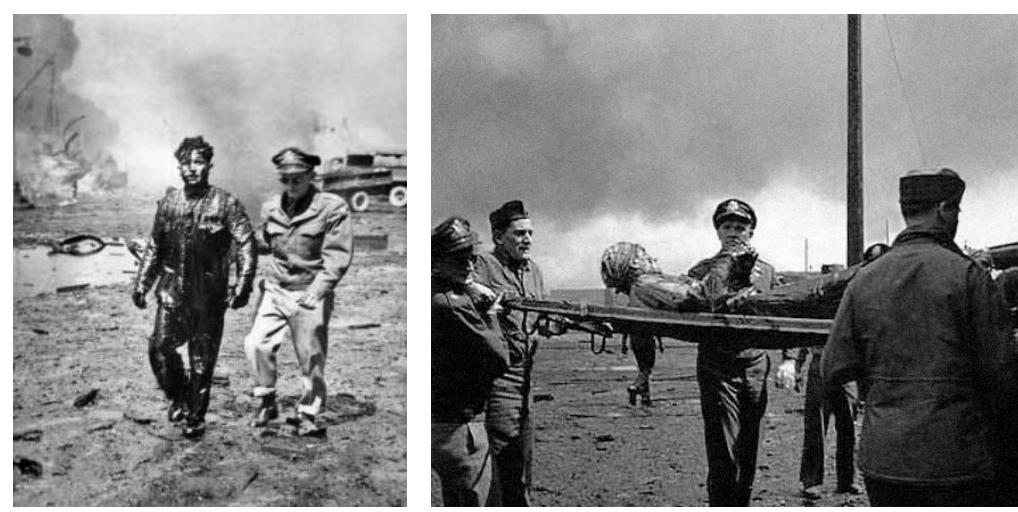

Figures 95 and 96: The sailors contaminated with engine oil with yperite after the bombing of Bari on December 2, 1943, Italy.

[Source Fig-95 and Fig-96]
After entering the war, the Americans secretly moved chemical weapons to many locations in the world. After the surrender in 1943, the Germans threatened Italy with the use of chemical weapons. The Allies took the threat seriously, therefore, they also moved their chemical weapons to Italy. On November 28, 1943, the Liberty Ship (Liberty SS John Harvey type) with displacement of 10,000 tonnes, carry-

ing 2,000 pieces of M47A1 aerial bombs containing a total of 55 tonnes of mustard gas from Baltimore arrived at the Italian port of Bari, overcrowded with the Allies, and waited for the material to be unloaded. The German air attack, carried out on December 02, 1943 at 19:30 by the number of one hundred and five JU-88 aircraft, was a surprise. After 20 minutes, 17 ships were sunk and 8 other ships were damaged. The ship with mustard gas was burning after the hit. When the ship crew tried to quench the fire, an explosion of ammunition took place and some mustard gas got into the air and into the water. The sailors from the ship swam in this deadly bath. A total of 2,000 soldiers, sailors and civilians were killed and the port was closed down for a month, which had a direct impact on the European theatre of war. At first, the Allies believed that the Germans had used chemical weapons; however, in the end everything was explained. To this day, due to secrecy, the public does not know how many people have been affected.

A similar situation occurred on the other side of the Front, when on April 08, 1945 US bombers attacked the Lossa railway station (between Sömmerda and Naumburg). At that time, there was a train transporting aerial bombs charged with tabun (180 tonnes) into the Luftwaffe depot. A number of bombs were damaged, but it is not known how many people died.

On May 20, 1942, after the second occupation of the Kerch Peninsula (Crimea) by Germans, 15,000 defenders, women, old men and children were hiding in the labyrinths of the Adzhimushkai quarries. The German troops carried out a massive gas attack on these defenders, who had been resisting for 170 days; during this attack about 5,000 people were killed.

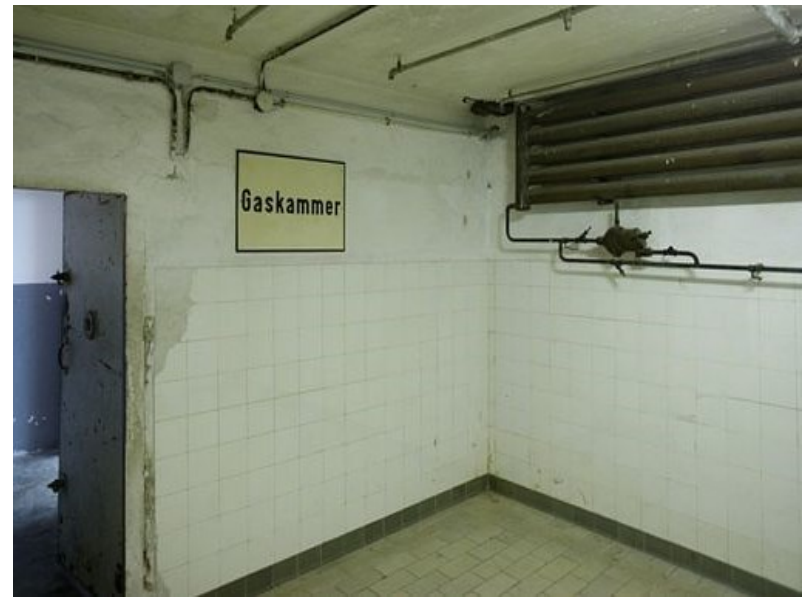

Photo 127: A gas chamber in the Mauthausen concentration camp. [Source: Pho-127]

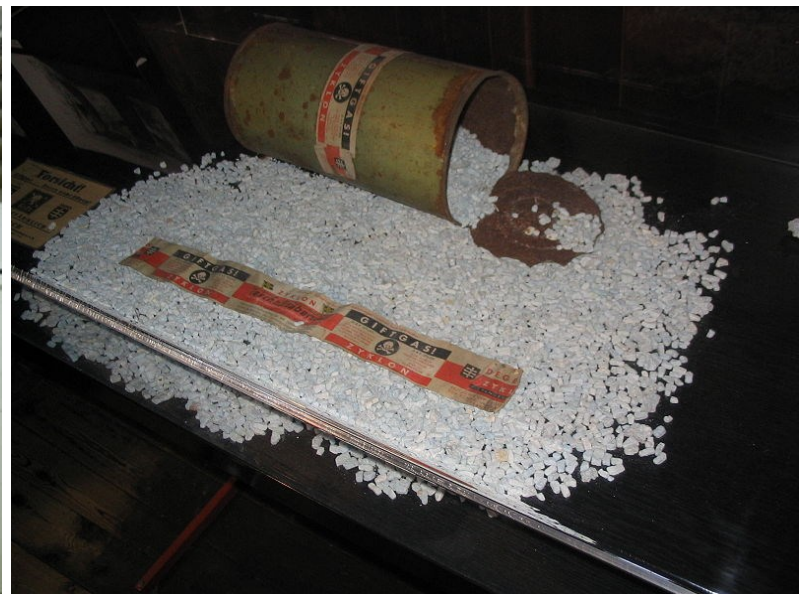

Photo 128: A can and Zyklon B (Cyclone B) substrate. [Source: Pho-128] 
Even though chemical warfare agents were not used on the Fronts of World War II, the deadly gas killed hundreds of thousands of people in death cars due to exhaust gases (carbon monoxide) and in the gas chambers of concentration camps due to Zyklon B (Cyclone B). Under the trademark Zyklon $B$ was the insecticide produced by the IG Farben German company. It was granulated diatomaceous earth saturated with hydrogen cyanide and used to kill lice in the seams of prison uniforms. Since August 1941, Zyklon B (Cyclone B) was used in concentration camps (first it was used in Auschwitz-Brzezinka). Between 1942 and 1943, 195 tonnes of deadly Zyklon B (produced in German Dessau, and at Czech Kolín nad Labem) was delivered to the SS units. Zyklon A (Cyclone A) was also produced there as a mixture of methyl cyanoformate and methyl chloroformate (90:10).

\subsubsection{Use of chemical weapons after World War II}

However, chemical weapons were also used several times in local conflicts. During the conflict in Southeast Asia between 1961 and 1973, the United States tested 15 different chemical agents, defoliants and herbicides to destroy vegetation, forests and fields. A total of 90,000 tonnes of chemical agents were used, of which 10,000 tonnes of toxic agents (BZ and CS type) and around 80,000 tonnes of defoliants and herbicides (di-and tri-chlorophenoxyacetic acids). During the war, about 18,000 human deaths, 200,000 people with the symptoms of poisoning and about 300,000 head of cattle poisoned were reported. Symptoms of poisoning (severe skin damage, indigestion, liver cancer, and hereditary consequences in children) have been reported in approximately 40,000 former U.S., Australian, and New Zealand soldiers. A part of herbicides was also Dioxin that was contained in up to $60 \%$ of them. The group of dioxins refers to a group of chlorinated organic compounds with similar properties and effects on living organisms. The most toxic dioxin is 2,3,7,8-tetrachlorodibenzo-p-dioxin (TCDD). According to the calculations, 170 up to $200 \mathrm{~kg}$ of dioxin were sprayed together with herbicides in Vietnam. $12 \%$ of forests and $5 \%$ of agricultural land were affected, most

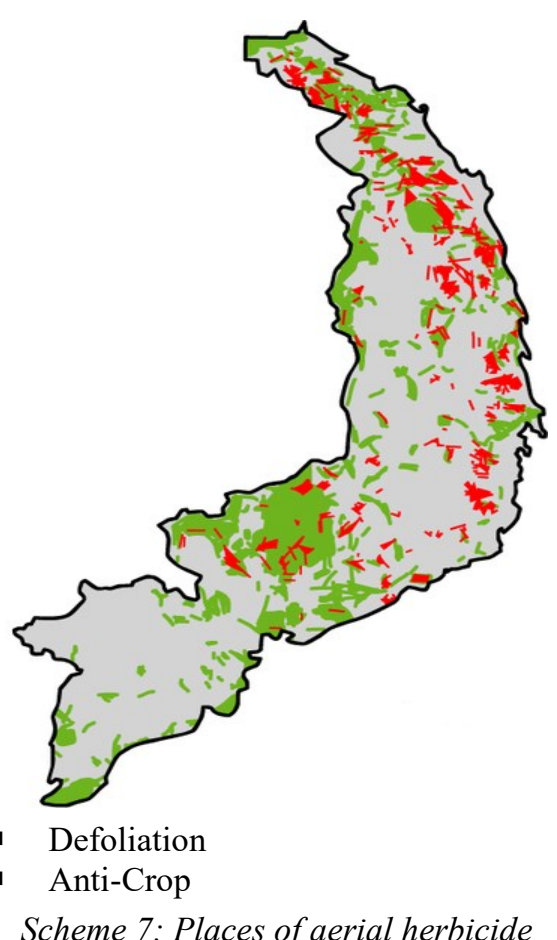

Scheme 7: Places of aerial herbicide spraying carried out by the US Army in South Vietnam between 1961 and 1971. [Source: Sche-7] of the mammals and $3 / 4$ birds disappeared from the affected forests, and the coastal mangroves were destroyed (the return to the standard conditions will take 100 years).

Table 40: The US Army order in the Vietnam War (CS gas in tonnes). [Source: Tab-40]

\begin{tabular}{|c|c|c|c|c|c|c|c|}
\hline \multirow{2}{*}{ Gas } & \multicolumn{7}{|c|}{ Year } \\
\cline { 2 - 9 } & 1964 & 1965 & 1966 & 1967 & 1968 & 1969 & Total \\
\hline CS & 112 & 46 & 188 & 220 & 362 & 1,009 & 1,929 \\
\hline CS-1 & 71 & 80 & 605 & 480 & 1,625 & 80 & 2,941 \\
\hline CS-2 & 0 & 0 & 0 & 0 & 145 & 1,950 & 2,095 \\
\hline Total & 183 & 126 & 783 & 700 & 2,132 & 3,039 & 6,965 \\
\hline
\end{tabular}

Between 1964 and 1972, the Americans used 7,000 tonnes of CS gas (o-chlorobenzylidene malononitrile) in Indochina that the generators were blowing into the underground bunkers and tunnels, which, at a high concentration, resulted in the death of the Vietcong warriors. Chemical weapons were used in the conflict between Iraq and Iran on a larger scale. Between 1983 and 1988, the Iraqis used 11,000 pieces of ammunition and 16,000 aerial bombs containing mustard gas, tabun and sarin, which resulted in the deaths of about 20,000 people and the injuries of 80,000 other people. 


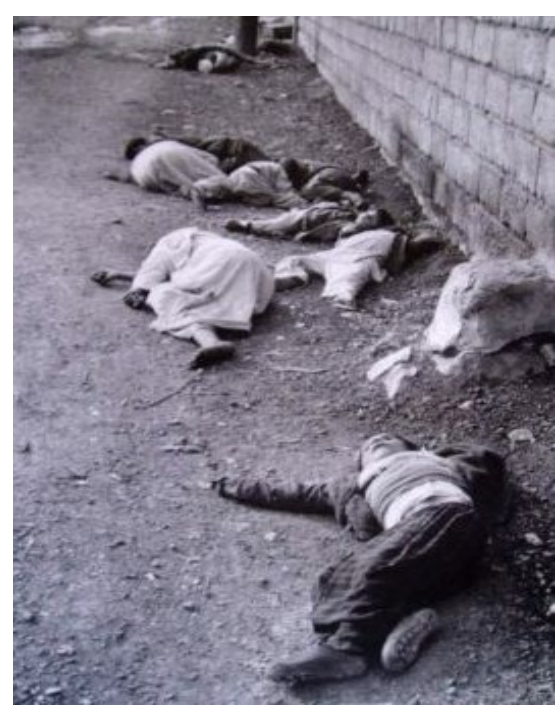

Photo 129: The consequences of the use of Iraqi chemical weapons, Halabja, 1988. [Source: Pho-129]

In 1988, Saddam Hussein also used the same chemical weapons against the Iraqi Kurds in the north of the country. It was in the attack on Halabja with 80,000 inhabitants. The attack was carried out by the Iraqi Air Force in two waves from March 16 to March 17, 1988. A total of 5,000 people was killed; 16,000 people were injured and they still continue to suffer the consequences of damage to the lungs, eyes and skin. The event can be viewed as the first historical case of using weapons of mass destruction on one's own territory and against their one's own population. Even the fact that it was an opposition action against the government does not change the barbarity of this act.

There are unconfirmed reports on the use of toxic agents in the conflict between the USSR and China in 1972, then in Cambodia where the Vietnamese also used a new type of a toxic agent designated as CR (dibenzo(b,f)-1,4-oxazepine) and nerve gases designated as blue gas and yellow-red gas, in addition to the known chemical agents for the temporary elimination of personnel (BZ and CS). In Afghanistan, the Soviet Union used a new type of nerve agents and the insurgents used chemical agents of the US and Chinese production.

In the Gulf Conflict in 1991, there were a few cases when the Iraqis used chemical weapons; they used sarin and mustard gas against the anti-Iraq coalition troops, even though it was concealed officially. Between January 19 and January 23, 1991, the Czechoslovak independent NBC defence unit found low concentrations of mustard gas and sarin in the Hafar Al-Batin and King Khalid Military City (KKMC) districts 40 to $80 \mathrm{~km}$ far from the Iraq-Kuwait border. Officials claimed it was a cloud of toxic agents from bombed-out Iraqi chemical weapons depots.

Officials claimed it was a cloud of chemical agents from destroyed Iraqi chemical weapon depots. US soldiers confirmed they had experienced health troubles, which could indicate poisoning when the Iraqi SCUD missiles were shot down by the US PATRIOT air defence missile system. Sometime after

Table 41: Range of application of phytotoxic substances in Vietnam.

[Source: Tab-41]

\begin{tabular}{|c|c|c|c|}
\hline \multirow{2}{*}{ Year } & \multirow{2}{*}{$\begin{array}{c}\text { Affected } \\
\text { area }\left(\mathrm{km}^{2}\right)\end{array}$} & \multicolumn{2}{|c|}{ Number of people } \\
\cline { 3 - 4 } & & poisoned & dead \\
\hline 1961 & 6 & 180 & - \\
\hline 1962 & 110 & 1,120 & 38 \\
\hline 1963 & 3,200 & 9,000 & 80 \\
\hline 1964 & 5,002 & 11,000 & 120 \\
\hline 1965 & 7,000 & 14,640 & 351 \\
\hline 1966 & 8,765 & 258,000 & - \\
\hline 1967 & 9,033 & 279,700 & 233 \\
\hline 1968 & 9,893 & 302,890 & - \\
\hline 1969 & 10,870 & 342,886 & 500 \\
\hline 1970 & 4,150 & 185,000 & 300 \\
\hline Total & 58,029 & $1,536,016$ & 1,620 \\
\hline
\end{tabular}
the reconnaissance of the Iraqi artillery firing position in the desert near the Iraq-Kuwait-Saudi Arabia border on March 01, 1991, the American Sergeant Fischer noticed the symptoms of the injury caused by mustard gas. An American medical doctor confirmed the suspicion. Let's ask a question: Where did the mustard gas come from? Up to the present, the use of chemical weapons in the Gulf War is unclear.

The shift in the importance of chemical weapons for the activities of non-governmental organizations was signalled by the actions of the Aum Shinrikyo religious cult, which carried out attacks using chemical (sarin, VX, hydrogen cyanide) and biological (botulinum toxin, anthrax) weapons from 1990 to 1995 in Japan. The attacks of June 1994 are best known, when a terrorist action in the city of Matsumoto took place; 7 people were killed and 500 people were injured. 


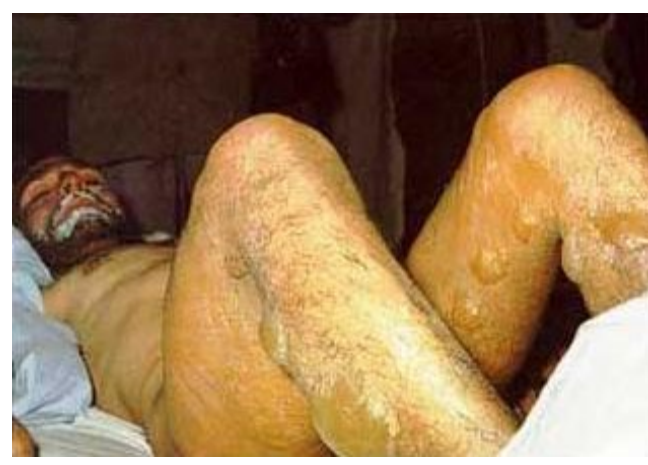

Photo 130: The consequences of the use of Iraqi chemical weapons. [Source: Pho-130]

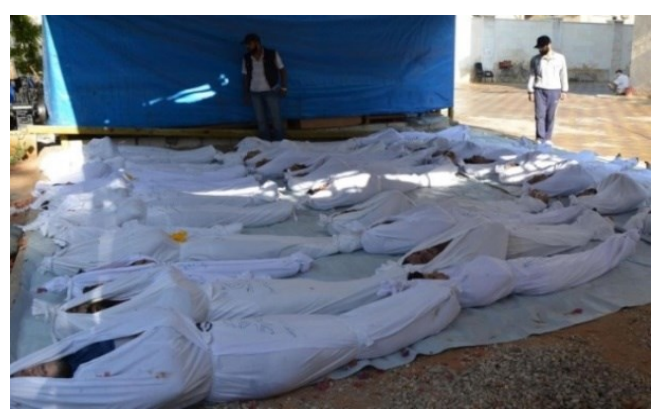

Photo 132: A chemical attack in Syrian Ghuta. [Source: Pho-132]

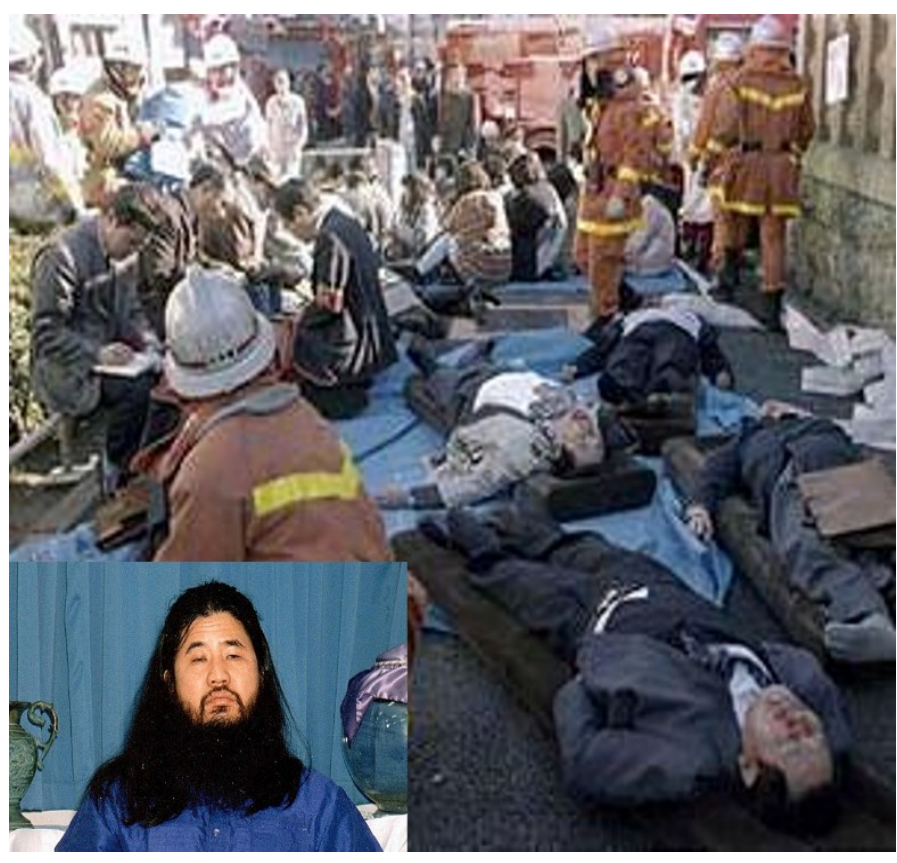

Photo 131: The sarin gas attack on the Tokyo subway on March 20, 1995, Japan, and Shoko Asahara the founder of the Aum Shinrikyo religious cult.

[Source: Pho-131]

The following action was much more serious; it was carried out in the Tokyo subway in March 1995; 12 people were killed and 5,500 were injured. In both cases, cult members used bags filled with sarin, which they punctured with sharpened umbrellas.

Table 42: Use of chemical agents by the Aum Shinrikyo religious cult in Japan.

[Source: Tab-42]

\begin{tabular}{|c|c|c|c|c|c|}
\hline Date & Place & Agent & Result & Target & Motive \\
\hline Nov 1993 & \multirow{2}{*}{ Tokyo } & \multirow{4}{*}{ Sarin } & - & & Elimination \\
\hline Dec 1993 & & & 1 injured & Keligious group & of competitors \\
\hline 1993/94 & Yamanashi & & 1 injured & $\begin{array}{c}\text { Judge } \\
\text { (prosecutor) }\end{array}$ & $\begin{array}{l}\text { Elimination } \\
\text { of enemies }\end{array}$ \\
\hline Jun 1994 & Matsumoto & & $\begin{array}{l}7 \text { dead, } \\
144 \text { injured }\end{array}$ & Judges & Abatement \\
\hline Dec 1994 & Tokyo & \multirow{3}{*}{ VX } & 1 injured & (City elders) & \multirow{3}{*}{$\begin{array}{l}\text { Elimination } \\
\text { of enemies }\end{array}$} \\
\hline Dec 1994 & Osaka & & 1 dead & Official & \\
\hline Jan 1995 & Tokyo & & 1 injured & $\begin{array}{l}\text { Anti-sectarian } \\
\text { activists }\end{array}$ & \\
\hline Mar 1995 & \multirow{3}{*}{$\begin{array}{l}\text { The Tokyo } \\
\text { subway }\end{array}$} & Sarin & $\begin{array}{c}12 \text { dead, } \\
3,938 \text { injured }\end{array}$ & $\begin{array}{l}\text { The Police, } \\
\text { citizenry }\end{array}$ & \multirow{3}{*}{$\begin{array}{l}\text { Stoping police } \\
\text { investigation, } \\
\text { causing confusion }\end{array}$} \\
\hline May 1995 & & Hydrogen & 4 injured & Citizenry & \\
\hline Jul 1995 & & cyanide & - & & \\
\hline
\end{tabular}

At present, the use of chemical weapons in the attack in Syria on August 21, 2013 seems to be the most probable. The Doctors Without Borders organization has confirmed 355 dead who, according to the Syrian opposition, died in a chemical attack (sarin). The insurgents say that up to 1,700 people were killed. According to the Doctors Without Borders, around 3,600 patients with the symptoms of poisoning were treated in hospitals. The Organization did not explicitly confirm the use of chemical weapons. 
According to reports on the violation of human rights in Syria, chemical weapons were used on March 19, 2013 in Khan al-Assal in the northern Syrian province of Halab, on the same day in Otaiba near Damascus, on April 13, in the Sheikh Maqsood neighbourhood in Halab and on April 29, in Saraqib. According to the US intelligence services, 100 to 150 Syrians died in the same year when these weapons were used.

\subsubsection{Prohibition of chemical weapons}

A globally valid legal document entitled Protocol for the Prohibition of the Use of Asphyxiating, Poisonous or Other Gases, and of Bacteriological Methods of Warfare from June 17, 1925 has been in existence for ninety years. In the Czech Republic, it was promulgated under No. 173/1938 Coll. All experts were aware of its low efficiency and a number of relatively easy circumvention possibilities. The main weakness was a small possibility of international control. The states with advanced chemical industry and products usable for the production of chemical weapons began to realize the real danger of the proliferation of chemical weapons.

In 1985, an Australian Group was formed at the

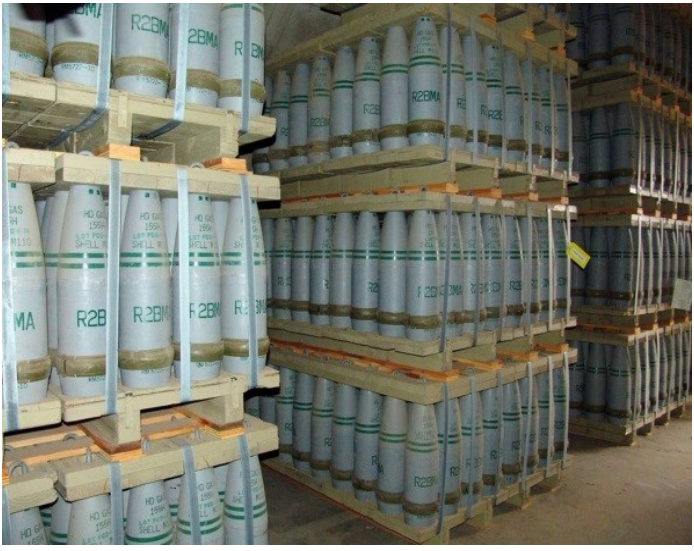

Photo 133: Store of weapons with 780,000 shells stored with a total of 2,600 tonnes of mustard gas in Colorado. [Source: Pho-133] initiative of Australia in reaction to a violation of the Geneva Protocol (from 1925) due to the use of chemical weapons in the Iran-Iraq conflict. The Australian Group determined the export control regime for chemicals that could be misused for the production of chemical weapons. In 1990, this regime was extended to biological weapons and key items of chemical and biological equipment and technology.

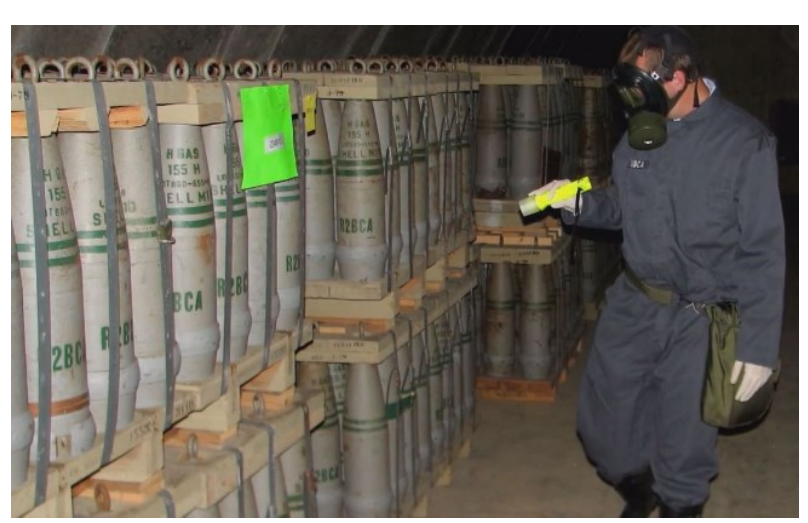

Photo 134: Store of weapons with 780,000 shells stored with a total of 2,600 tonnes of mustard gas in Colorado. [Source: Pho-134]

The Convention on the Prohibition of the Development, Production, Stockpiling and Use of Chemical Weapons and on their Destruction became a basic document of this Group (the Czech Republic signed the Convention on January 14, 1993 and ratified it on March 06, 1996.) The Convention became binding on April 29, 1997. It is the first valid document that explicitly and universally prohibits one clearly defined category of weapons of mass destruction, and also has a corresponding system of control and motivation measures, including coercive measures.

In connection with the entry into force of this document, the Organization for the Prohibition of Chemical Weapons (OPCW), seated in The Hague, was established. It has relatively extensive inspection powers and serves as a consultation forum of the Contracting States. In 2013, it was awarded the Nobel Peace Prize. Still, the existence of considerable reserves of the US and Russian chemical weapons, the real threat of chemical terrorism, and the authentic cases of chemical accidents are a clear reason for the existence and development of antichemical measures to protect the population as well as troops. 
Despite a strict international ban on chemical weapons and chemical warfare agents, a number of advanced states and their armies are counting on the possibility of chemical warfare. This is proved by the field regulations of these armies, which contain the basic principles as well as CBRN defence measures for the protection of the field troops and, if need be, the civilian population.

Table 43: Significant events in the $20^{\text {th }}$ century related to chemical weapons. [Source: Tab-43]

\begin{tabular}{|c|c|c|c|c|c|c|c|c|c|c|c|}
\hline & Decade & the $1^{\text {st }}$ decade & the & the & the & the & the & the & the & the & the \\
\hline & Event & and earlier & $1910 \mathrm{~s}$ & $1920 \mathrm{~s}$ & $1930 \mathrm{~s}$ & $1940 \mathrm{~s}$ & $1950 \mathrm{~s}$ & $1960 \mathrm{~s}$ & $1970 \mathrm{~s}$ & $1980 \mathrm{~s}$ & $1990 \mathrm{~s}$ \\
\hline & Choking & Chlorine & $\begin{array}{c}\text { Phosgene, } \\
\text { Diphosgene, } \\
\text { Chloropicrin }\end{array}$ & & & & & & & PFIB & \\
\hline 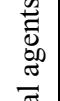 & Irritating & $\begin{array}{c}\text { Chloro- } \\
\text { acetophenone }\end{array}$ & $\begin{array}{l}\text { Arsines } \\
\text { (Adamsite, } \\
\text { Clark, etc.) }\end{array}$ & & & & & CS & CR & & Capsaicin \\
\hline 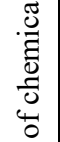 & Blood & $\begin{array}{l}\text { Hydrogen } \\
\text { cyanide } \\
\text { Cyanogen } \\
\text { chloride }\end{array}$ & & & & & $\begin{array}{l}\text { Natural } \\
\text { toxins }\end{array}$ & & & & \\
\hline 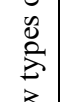 & Blister & & $\begin{array}{l}\text { Sulphur } \\
\text { mustard }\end{array}$ & Lewisite & $\begin{array}{l}\text { Nitrogen } \\
\text { mustard }\end{array}$ & & & & & $\begin{array}{c}\text { Relapse } \\
\text { mustard } \\
\text { gases }\end{array}$ & \\
\hline Z & Nerve & & & & & $\begin{array}{l}\text { Tabun, } \\
\text { sarin }\end{array}$ & \begin{tabular}{|c|} 
Soman \\
DFP, GF, \\
VX \\
\end{tabular} & & $\operatorname{IVA}(\mathrm{GV})$ & \begin{tabular}{|c|} 
Relapse - \\
tabun, \\
sarin, GF
\end{tabular} & Novichok \\
\hline & Psychoactive & & & & & & & $\mathrm{BZ}$ & & & \\
\hline met & $\begin{array}{l}\text { Means and } \\
\text { thods of attack }\end{array}$ & & $\begin{array}{l}\text { Gas cloud } \\
\text { attacks, } \\
\text { Artillery }\end{array}$ & & Air Force & $\begin{array}{c}\text { Artillery } \\
\text { rockets }\end{array}$ & $\begin{array}{l}\text { Guided } \\
\text { missiles }\end{array}$ & & $\begin{array}{c}\text { Binary } \\
\text { ammuni- } \\
\text { tion }\end{array}$ & & \\
\hline Us & e of chemical & & & & & & & Ind & ochina & & Iraq, \\
\hline weap & $\begin{array}{l}\text { conflict } \\
\text { ons in an armed } \\
\text { con }\end{array}$ & & $\begin{array}{l}\text { World War I- } \\
\text { most fronts }\end{array}$ & & $\begin{array}{c}\text { Italo- } \\
\text { Ethiopian } \\
\text { war }\end{array}$ & War II & & \begin{tabular}{|c|} 
South \\
east \\
Asia
\end{tabular} & $\begin{array}{c}\text { Afghani- } \\
\text { stan }\end{array}$ & $\begin{array}{l}\text { against } \\
\text { Iran }\end{array}$ & $\begin{array}{l}\text { the } \\
\text { Persian } \\
\text { Gulf }\end{array}$ \\
\hline $\begin{array}{r}\text { An } \\
\text { of ch }\end{array}$ & $\begin{array}{l}\text { other method } \\
\text { hemical weapon } \\
\text { use }\end{array}$ & & & & & $\begin{array}{c}\text { Nazi } \\
\text { genocide }\end{array}$ & & & & & $\begin{array}{l}\text { Terrorism } \\
\text { Japan }\end{array}$ \\
\hline lega & $\begin{array}{l}\text { nternational } \\
1 \text { restrictions on } \\
\text { chemical } \\
\text { weapons }\end{array}$ & $\begin{array}{l}\text { The Haag } \\
\text { Conventions }\end{array}$ & & $\begin{array}{l}\text { Geneva } \\
\text { Conven- } \\
\text { tion }\end{array}$ & & $\begin{array}{l}\text { Geneva } \\
1949 \\
\text { civil } \\
\text { defence }\end{array}$ & & & $\begin{array}{c}\text { Geneva } \\
\text { Appen- } \\
\text { dices } \\
\text { I, II }\end{array}$ & $\begin{array}{c}\text { Australian } \\
\text { Group }\end{array}$ & $\begin{array}{c}\text { Convention } \\
\text { on the } \\
\text { Prohibition } \\
\text { of } \\
\text { Chemical } \\
\text { Weapons }\end{array}$ \\
\hline
\end{tabular}

Authors' note:

A summary of the text and the time data must be taken roughly, it is not important when an agent was discovered. It is more important when at least the professional public became familiar with it.

\subsection{Basic concepts}

Chemical warfare agents (CWAs) are all toxic substances (solid, liquid, or gaseous) that can be used in a possible armed conflict and that direct their effects against living organisms or against their normal functions. The living organism is a human being, livestock and cultivated plants as well as wild plants.

Chemical warfare agents can be defined as toxic substances of all states of matter, which are usable in war conflicts and the effects of which are focused on living organisms or their normal function. The living organism is a human being, livestock and cultivated plants as well as wild plants.

An attack against the normal function of a living organism is perceived as any intervention by chemical agents, which will subsequently disrupt the normal function of an organism so that the attacker can reach his combat success without a greater resistance. 
Chemical warfare agents can also be used to deteriorate food and water, to reduce or prevent movement in contaminated areas, to reduce the usability of various materials and objects and to reduce the combat capability of personnel due to a long-term use of individual and collective protective equipment.

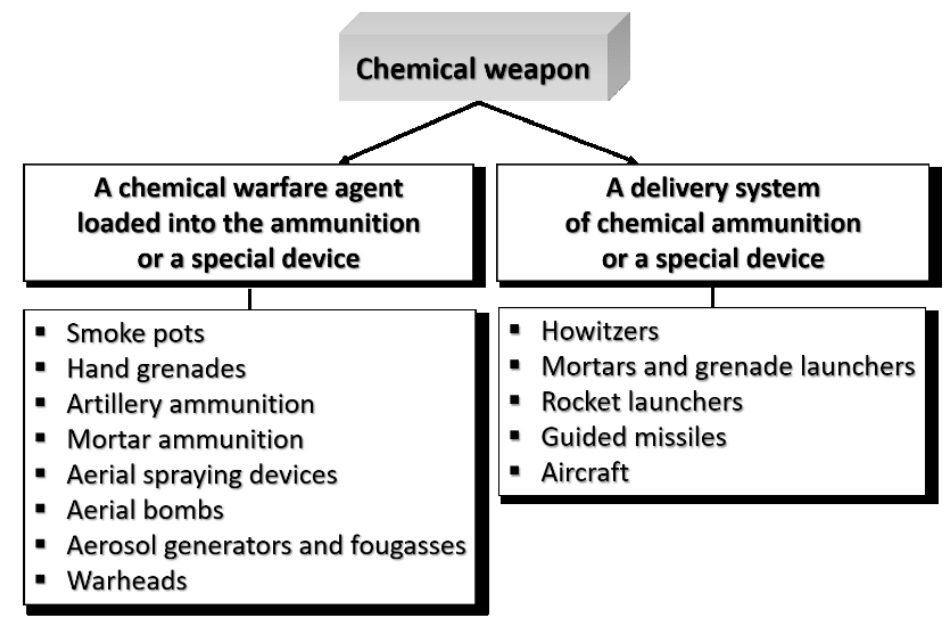

Scheme 8: Classification of a chemical weapon. [Source: Sche-8]

The Chemical Weapons Convention does not use the concept chemical warfare agent, but a toxic chemical. According to the definition of the Convention, the concept toxic chemical means that its effects on life processes can cause death, temporary paralysis or permanent harm to human and animal health. This includes all chemicals, regardless of their origin or method of production and regardless of whether they are generated in buildings, ammunition or elsewhere. If the device is somehow filled with a chemical warfare agent, used to convert it to a combat state in the target area, we speak of chemical ammunition. This conversion of a chemical warfare agent to a state suitable for combat can happen using explosive means (aerial, cluster bombs, artillery ammunition, warheads, hand grenades, mines, etc.) or special non-explosive devices (aerial spraying devices, aerosol generators, fougasses and smoke pots).

Chemical ammunition or a special device must be delivered to a target. The delivery system to transport chemical ammunition to a target is an inherent part of the use of chemical warfare agents and this system is called chemical weapon - see Scheme 8.

\subsection{Classification of chemical warfare agents}

Of a large number of known toxic substances, only a tiny number is used as militarily significant chemical warfare agents. Each chemical warfare agent must meet the requirements, including:

- High toxicity;

- Sufficient storage stability;

- Raw-material and technological availability of production;

- Realizable transfer of a substance to a state suitable for combat with the benefit of its toxic effects;

- The possibility of introducing a substance into a stockpile of chemical weapons without great expenses;

- Difficult detection of its presence (if possible, at least until the symptoms appear);

- Difficult to detect their presence (if possible, at least until symptoms appear);

- Difficult possibility of protection of enemy units and at the same time known method of protection (mechanism of action) for own troops.

Fortunately, there are not many substances that meet at least the abovementioned requirements. Of a wide range of known toxic agents, there are only a few dozens of agents that have either been used on the world battlefields or have been or are produced and stored for such purposes. The physical, chemical and toxicological properties of most of these agents have been investigated very closely. 
Chemical warfare agents are classified according to various aspects as follows:

1) According to the relation to the industrial and economic basis:

- Tabular chemical warfare agents - they are purposefully manufactured for military purposes in special facilities and loaded into chemical ammunition;

- Backup chemical warfare agents - they are not listed as tabular (are gradually withdrawn from the armament because they no longer meet some of the crucial requirements, but they are still stored (mostly in smaller volumes) and, if necessary, they may be used;

- Substitute chemical warfare agents - substances commonly manufactured industrially for commercial purposes, which can be used as toxic agents (insecticides, etc.) if necessary.

2) Physical classification:

- In terms of state:

- Solid agents (CS, BZ, chloroacetophenone, etc.);

- Liquid agents (tabun, sarin, soman, VX, mustards, etc.);

- Gaseous agents (chlorine).

- In terms of stability in the field:

- Persistent chemical agents (mustards, lewisite, VX, etc.);

- Semi-persistent agents (soman, IVA, etc.);

- Non-persistent agents (sarin, hydrogen cyanide, etc.).

3) Chemical classification is more perfect than physical classification; however, it does not allow the assessment of toxic properties of a particular agent. Agents are divided into individual groups according to their characteristic properties as follows:

- Derivatives of $\mathrm{H}_{2} \mathrm{CO}_{3}$ (phosgene, diphosgene);

- Cyanide compounds and nitriles (hydrogen cyanide, cyanogen chloride, bromobenzyl cyanide, CS);

- Halonitro compounds (chloropicrin);

- Haloketones (chloroacetophenone, bromoacetophenone);

- Cyclic ethers (agent CR, dioxin, etc.);

- Halo sulphides (sulphur mustard);

- Amines:

- Aliphatic (nitrogen mustard);

- Heterocyclic (adamsite, alkaloids);

- Organophosphate compounds:

- Derivatives of $\mathrm{H}_{3} \mathrm{PO}_{4}$ (tabun, IVA);

- Methylphosphonic acid derivatives (sarin, soman, VX);

- Arsenic compounds:

- Primary

○ Alkylated (lewisite, DICK);

○ Arylated (phenyldichloroarsine);

- Secondary

- Aromatic (diphenylchloroarsine);

- Heterocyclic (adamsite);

- Organometallic compounds of arsenic (arsines);

- Others. 
4) Tactical and operational (military) classification:

- Lethal agents are those which, after use in combat concentrations, cause severe damage to the organism or death;

- Temporarily incapacitating agents, when used in combat concentrations, cause a temporary disorder of some important physiological functions (i.e. most often, a nervous or mental disorder);

- Special purpose chemical agents, in addition to the agents irritating mucous membranes, also include diversion and sabotage toxins, training and substitute substances, herbicides and police gases.

5) Toxicological classification is currently the most widely used one. According to physiological effects on organisms it divides chemical warfare agents into 6 classes as follows:

- Choking agents (phosgene, diphosgene, chloropicrin);

- Blood agents (hydrogen cyanide, cyanogen chloride, hydrogen arsenide);

- Blister agents (sulphur mustard, nitrogen mustards, oxy-mustard, sesqui-mustard, lewisite);

- Nerve agents (tabun, sarin, soman, VX, IVA);

- Irritating agents (bromobenzyl cyanide, chloroacetophenone, adamsite, CS and CR, CLARK I, CLARK II);

- Psychoactive agents (BZ, LSD-25).

When assessing chemical warfare agents from a chemical point of view, their resistance to chemical agents, the natural environment itself, is usually evaluated first.

In other words, the ability of chemical warfare agents to participate in chemical reactions is assessed, especially those that affect their stability in the field, the ability to react with detoxifying agents used in their decontamination, or other chemicals in terms of detection, storage, etc.

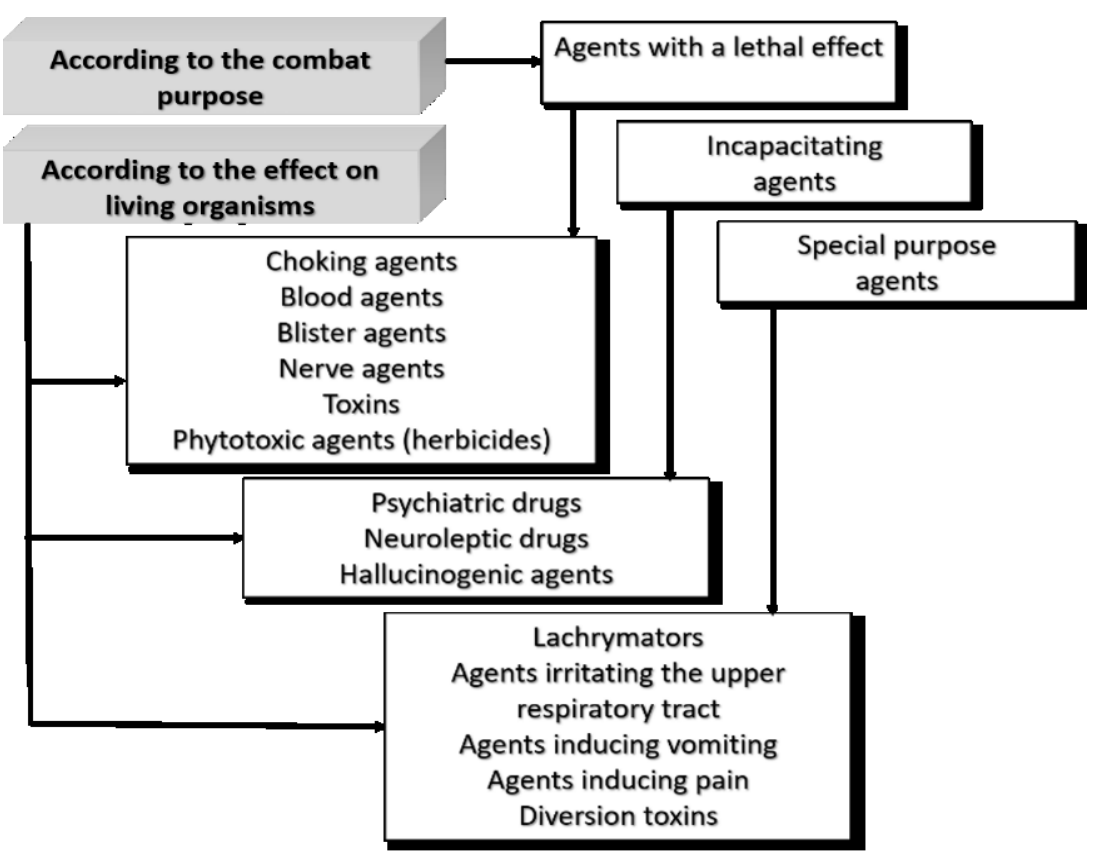

Scheme 9: Classification of chemical warfare agents. [Source: Sche-9]

\subsection{Properties of chemical warfare agents}

\subsubsection{Physical properties}

Physical properties characterize a given agent, but, in particular, they quantitatively illustrate the suitability for using a particular agent as a chemical warfare agent:

Relative molecular mass $\left(M_{r}\right)$ is the sum of the relative atomic masses of all the atomic elements that make up a molecule of a chemical warfare agent. 
Melting point - freezing point and boiling point (transition points) are characteristic physical quantities that are relevant to the informed guess (computation) of stability of chemical warfare agents in the field (persistence). They are important for decisions on the use of a chemical agent as a chemical warfare agent. The freezing point is important for loading ammunition and its use in field conditions.

The temperature of the thermal destruction is a temperature, at which chemical warfare agents decompose (it illustrates thermal stability). The thermal stability is a determining factor for the method of spreading chemical warfare agents in the target area, and thus for the construction of ammunition and the efficiency of heat decontamination.

Flash point is a temperature, at which vapours of chemical warfare agents ignite, when in contact with flame; it is important for the construction of ammunition.

(Relative) vapour density is the ratio of the vapour density of chemical warfare agents to the air density. For use in the form of a steam-air mixture, it is preferred that the vapour density of chemical warfare agents be higher when compared to the air density, to create an effective incapacitating concentration in the ground-level layer of the atmosphere.

Density is the mass to volume ratio. It is an important value for handling chemical warfare agents, especially for decontamination and for assessing the stability of aero-dispersed systems (e.g. particle sedimentation rate).

Solubility of chemical warfare agents is important for detecting and determining chemical warfare agents, their use and storage; it is particularly important for the effectiveness of detoxification and decontamination processes.

Surface tension - the value of the surface tension of liquid recipes of chemical warfare agents plays a significant role in decontamination as well as in the conversion of chemical warfare agents into a combat state, aerosol or drops.

Viscosity - the viscosity of liquid chemical warfare agents influences the conversion to a state suitable for combat, persistence and decontamination.

Evaporating power - maximum concentration or volatility. The vapour concentration of chemical warfare agents at a given temperature and pressure reaches an equilibrium maximum value in a closed system after a certain period of time. In an interval of $0{ }^{\circ} \mathrm{C}$ up to $30{ }^{\circ} \mathrm{C}$, the temperature increases by $10{ }^{\circ} \mathrm{C}$ and the evaporating power of chemical warfare agents is approximately doubled. This applies to a closed system where it is possible to achieve the equilibrium state with time and, therefore, a particular concentration. In real field conditions, depending on the stability of the atmosphere in the ground layers, the evaporation value will reach one hundredth to one tenth of the theoretical value. For the use of a particular chemical warfare agent to contaminate the atmosphere with vapours it is essential that its evaporating power, depending on the circumstances, exceeds 1 to 2 orders, under particularly unfavourable conditions 3 orders of physiologically effective concentration. The evaporating power affects the persistence of chemical warfare agents significantly.

Saturated vapour pressure - there is always a certain proportion of the substance in the gaseous state (the vapour pressure of a given substance) above the solid or liquid phase. Vapour pressure is a measure of the ability to release substance molecules into the gas phase and increases with the temperature. The evaporation rate (the surface contamination time or the life time of aerosol particles) depends on the vapour pressure.

Thermal expansion - when ammunition is filled with liquid chemical warfare agents, the ammunition casing can be damaged due to the thermal expansion. Therefore, a criterion called the minimum theoretical expansion space has been introduced, i.e. the minimum volume that must be left in the ammunition to prevent the ammunition from bursting. 
Table 44: Persistence of nerve agents and mustard gas. [Source: Tab-44]

\begin{tabular}{|c|c|c|c|}
\hline Chemical agent & $\begin{array}{c}\text { Sunny weather, light breeze } \\
+15^{\circ} \mathrm{C}\end{array}$ & $\begin{array}{c}\text { Wind, rain } \\
+15^{\circ} \mathrm{C}\end{array}$ & $\begin{array}{c}\text { Sunny weather, snow } \\
-10{ }^{\circ} \mathrm{C}\end{array}$ \\
\hline Sarin & $1 / 4-4$ hours & $1 / 4-1$ hour & $1-2$ days \\
\hline Tabun & $1-4$ days & $1 / 2-6$ hours & 1 day -2 weeks \\
\hline Soman & $2.5-5$ days & $3-12$ hours & $1-6$ weeks \\
\hline Mustard gas & $2-7$ days & $1 / 2-2$ days & $2-8$ weeks \\
\hline VX & $3-21$ days & $1-12$ hours & $1-16$ weeks \\
\hline
\end{tabular}

\subsubsection{Chemical properties}

Hydrolysis of chemical warfare agents - a basic chemical reaction that illustrates the storage stability and the ability of chemical warfare agents to contaminate water resources. It is an important decontamination reaction. According to the environment, in which hydrolysis of chemical warfare agents occurs, we distinguish acid hydrolysis, neutral hydrolysis and alkaline hydrolysis. Alkaline hydrolysis is the most important for the decontamination of chemical warfare agents.

Oxidation is a process that results in an increase in the positive valence; in the narrow sense, we understand it as introducing oxygen into the molecule of a chemical agent. The ability of chemical warfare agents to undergo oxidation processes is characterized by the stability of chemical warfare agents during storage and in the field.

Halogenation - the chlorination reaction is one of the most important decontamination reactions of chemical warfare agents.

Polymerization is rather an exception in chemical warfare agents and plays an important role in their storage. Additives stabilize chemical warfare agents and also prevent polymerization.

Cyclization is not a very common reaction for all chemical warfare agents, but is characteristic of mustard gases.

Dealkylation - the reaction is used for decontamination and analysis of chemical warfare agents.

Elimination - elimination reactions occur in some decontamination processes.

Creation of onium salts - onium salts, derived mainly from amine nitrogen, a series of sulphur compounds and exceptionally oxygen compounds, have a dominant position.

\subsubsection{Toxic properties}

The extent and degree of damage to the organism caused by a certain chemical warfare agent and the rate, at which these functional and morphological disorders occur are dependent on many factors. The physical and chemical properties of chemical warfare agents are of essential importance for the development of a pathological process in an exposed organism. The amount of a chemical warfare agent, the dose affecting the organism, the concentration of the chemical warfare agent in the external environment and the exposure time are no less important factors of the toxic effect.

The portals of entry (pathways, through which chemical warfare agents penetrate the organism) are an important factor influencing the ultimate toxic effect of chemical warfare agents. Chemical warfare agents get into the organism from the external environment from the contaminated air, terrain, water, food, equipment and military technology. The toxic effect of chemical warfare agents will depend on the so-called portal of entry and the amount of an agent penetrated. 
The most common portals of entry, through which chemical warfare agents penetrate, include the skin, airways, conjunctivae, digestive tract and injuries; an exceptional entry is using injection.

According to the degree of damage to the organism, a chemical warfare agent may penetrate the organism in particular:

- Through the skin by contacting the unprotected intact skin, often after the contact with contaminated equipment and material;

- Through inhalation - the penetration through the respiratory organs in unprotected humans when chemical warfare agents penetrate the body in the form of vapours and fine aerosols; it is usually associated with affecting the conjunctiva;

- Parenterally - intoxication due to the fragments of chemical ammunition, or more often by the penetration through the damaged skin due to scratches, injuries, burns, etc.;

- Orally by affecting especially the digestive organs after the ingestion of contaminated food or drinking contaminated water.

The portal of entry is an important factor that affects the distribution and metabolism of chemical warfare agents in the organism. It affects the rate of their absorption and impact on vital organs, the manner and rate of detoxification of chemical warfare agents in the body.

According to the rate of developing the clinical picture of poisoning (syndrome), the effect on the organism due to chemical warfare agents is manifested either immediately after contact of the organism with a contaminated environment or after a longer period (latency).

Slow-acting chemical warfare agents do not cause immediate damage to the organism, when it is affected; the development of clinical symptoms is slow and is characterized by a period, during which the injury does not show an apparent damage. The latency period, after which the symptoms of poisoning develop, usually lasts for several minutes to hours, only exceptionally for a longer time, depending on the type of a chemical warfare
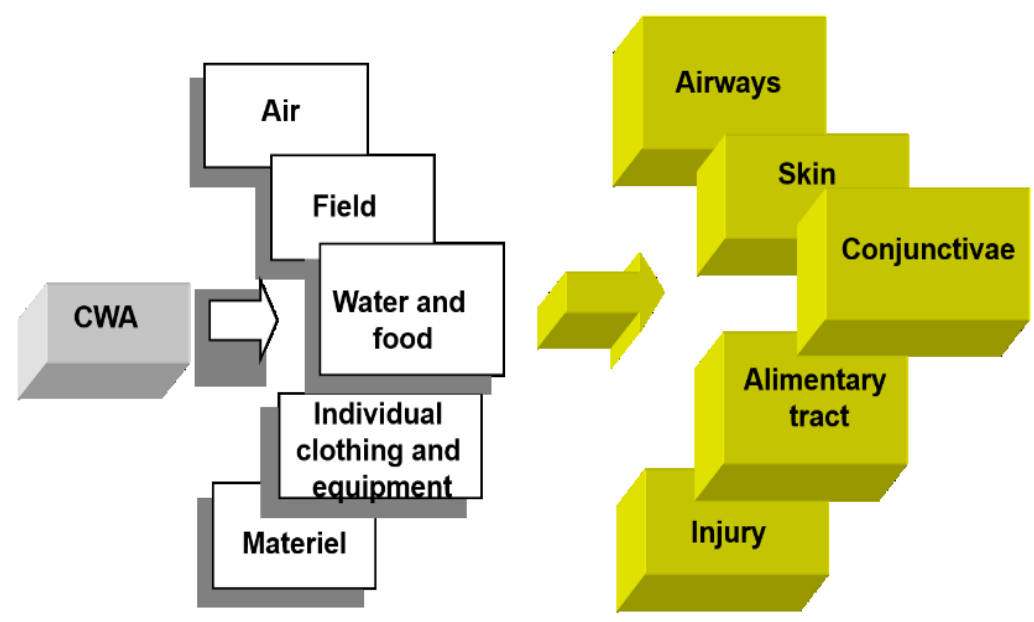

Scheme 10: Pathways of chemical warfare agents to enter the body. [Source: Sche-10] agent.

Fast-acting chemical warfare agents affect the living organism almost immediately after contact or in a very short time. The rapid development of clinical symptoms of poisoning requires effective emergency and protective measures to reduce the effect and to prevent lethal poisoning. In these cases, the irreversible health effects can be reduced by the early administration of antidotes within a short time after the injury.

\subsubsection{Properties of chemical warfare agents used in combat}

The term combat properties of chemical warfare agents is understood as their toxicity, which is characterized by combat concentrations, toxic doses, density and stability of contamination and downwind hazard. 


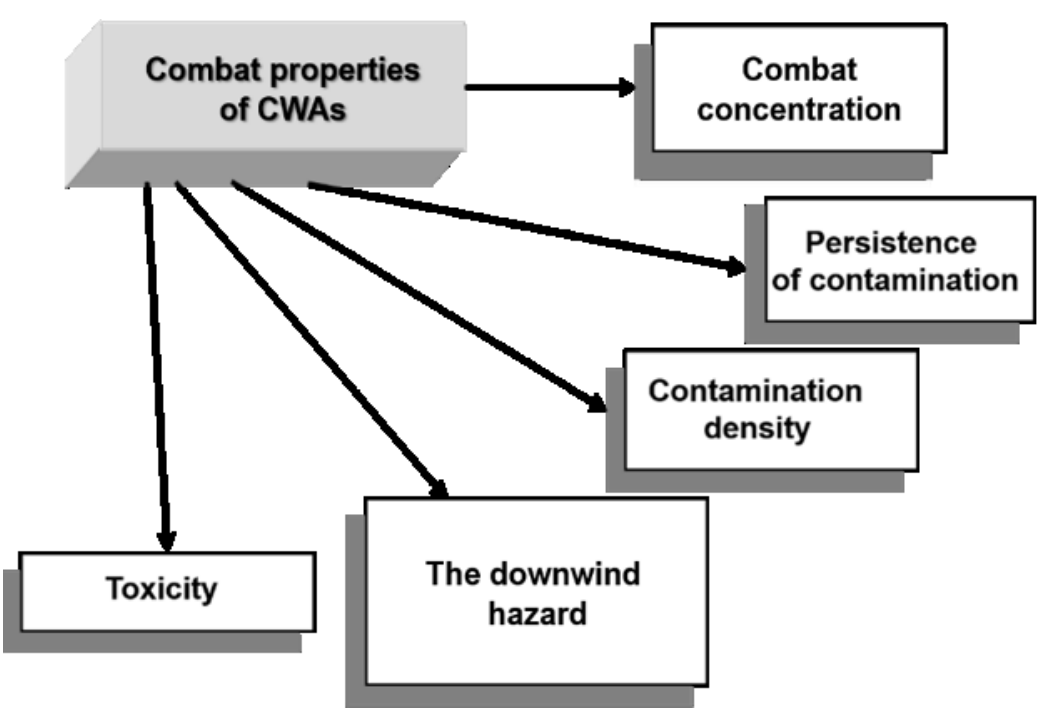

Scheme 11: Properties of chemical warfare agents used in combat. [Source: Sche-11]
Chemical warfare agents are usually subject to changes in the organism that lead to the development of new, relatively low-risk agents for the organism. The rate of detoxification, expressed by the amount of a chemical warfare agent that the organism is able to convert to less harmful products in a time unit, is important with respect to the risk of a repeated attack on humans by a chemical warfare agent. Some chemical warfare agents have the

so-called cumulative effect, i.e. the effects of a chemical warfare agent are added up after repeated impacts. Thus, they correspond to one-off exposure to effects with a total concentration of a chemical warfare agent.

\section{Combat concentration (Concentration of CWA used in combat)}

The amount of a chemical warfare agent in a unit volume of air required to achieve a certain effect, e.g. the elimination of personnel or a reduction in their combat capability. It is expressed in units of $\mathrm{mg}_{\mathrm{l}} \mathrm{l}^{-1}$ or $\mathrm{g} . \mathrm{m}^{-3}$. Combat concentration means the concentration of a chemical warfare agent in the air, which is necessary to eliminate personnel or to reduce their combat capability for a certain period of time. Combat concentration is an amount of a chemical warfare agent in a given air volume; therefore, it is most often expressed in units of mg. $l^{-1}$ or g.m $^{-3}$. For example, sarin at a concentration of $0.0002 \mathrm{mg} . \mathrm{l}^{-1}$ causes the first symptoms of injury within two minutes and death after a 24-hour stay. A sarin concentration of $0.1 \mathrm{mg} . \mathrm{l}^{-1}$ would cause death within a few minutes after a 1-minute stay in the contaminated atmosphere.

\section{Contamination density}

Contamination density indicates the weight of a chemical warfare agent found on the surface. Most commonly, it is expressed in units of $\mathrm{mg}_{\mathrm{cm}} \mathrm{cm}^{-2}, \mathrm{~g} \cdot \mathrm{m}^{-2}, \mathrm{t} . \mathrm{km}^{-2}$. Contamination density indicates a mass amount of a chemical warfare agent per unit area of an object of interest. For example, the contamination density caused by a V-type nerve agent, which is intended to annihilate the personnel protected by full-face masks, is 0.02 up to $0.1 \mathrm{~g} . \mathrm{m}^{-3}$.

\section{Persistence of contamination}

The persistence of contamination can be viewed in two ways:

- The time, during which a chemical retains its destructive effect - in this case it is the time, during which the chemical is in the unaltered state in the field and also the time, during which it contaminates the atmosphere by evaporation from soil and surfaces or in consequence of swirling dust;

- The time of existence of a chemical warfare agent in the field or in the atmosphere in the first case, this term can be understood as the time of existence of a chemical warfare agent in the field, on the surface or in the atmosphere in a certain point. Alternatively, the persistence of the contamination may be expressed as the sum of the time it remains in the field or on the surface in the unaltered state and the time when it contaminates the air by evaporation from the soil and surface or by swirling dust. 


\section{Toxicity}

The data on toxic properties are of great importance for the comparison of the effectiveness of individual chemical warfare agents in field conditions. The toxic effect of a chemical warfare agent depends mainly on the dose, the portal of entry into the body, the speed of action, the condition of the organism and other factors.

The toxic properties of chemical warfare agents used in the form of vapours or aerosol are most often characterized by:

- The median threshold concentration $\left(P C t_{50}\right)$ - the concentration of a chemical warfare agent that, after time $t$, evokes the development of the first negligible threshold symptoms of damage in $50 \%$ of the affected individuals;

- The median incapacitating concentration $\left(I C t_{50}\right)$ - the concentration of a chemical warfare agent that, after time $t$, evokes a temporary disablement in $50 \%$ of the affected individuals;

- The median effective concentration (ECt $t_{50}$ ) - the concentration of a chemical warfare agent that, after time $t$, evokes a full toxic effect in $50 \%$ of the affected individuals and will disable them;

- The median lethal concentration ( $\left.L C t_{50}\right)$ - the concentration of a chemical warfare agent that, after time $t$, will kill $50 \%$ of exposed individuals.

[The median $\mathrm{PCt}_{50}, \mathrm{ICt}_{50}, \mathrm{ECt}_{50}$ and $\mathrm{LCt}_{50}$ values represent a formal conversion per 1 minute (the so-called toxic product), usually the respective inhalation load of the organism, expressed as the product of chemical warfare agent concentration and the exposure time of the dimensions of $\left(\mathrm{mg} \cdot \mathrm{min} . \mathrm{l}^{-1}\right)$ or $\left(\mathrm{g} \cdot \mathrm{min} \cdot \mathrm{m}^{-3}\right)$. Due to the average breathing frequency, no formal conversion per second is performed.]

When using a chemical warfare agent, it is possible to determine the amount of the agent that has resorbed into the organism. It is a toxic effect, which expresses:

- Median threshold/protective dose ( $\left.P D_{50}\right)$, which is a dose of a chemical warfare agent that evokes the development of threshold symptoms of damage in $50 \%$ of affected individuals;

- Median incapacitating dose $\left(I D_{50}\right)$, which is a dose of a chemical warfare agent that temporarily incapacitates $50 \%$ of affected individuals;

- Median effective dose ( $\left.E D_{50}\right)$, which is a dose of a chemical warfare agent that evokes a full toxic effect in $50 \%$ affected individuals and thus disables the affected individuals;

- Median lethal dose $\left(L D_{50}\right)$, which is a dose of a chemical warfare agent that will kill $50 \%$ of the affected individuals.

[The $\mathrm{PD}_{50}, \mathrm{ID}_{50}, \mathrm{ED}_{50}$ and $\mathrm{LD}_{50}$ values are usually expressed in weight units per a body weight unit (e.g. in mg. $\mathrm{kg}^{-1}$ ) or per person $(70 \mathrm{~kg}$ ). For obvious reasons, the threshold criterion is misinterpreted for incapacitating and, on the contrary, effective for different chemical warfare agents with lethal and non-lethal (incapacitating) effects. The pathophysiological effects of chemical warfare agents that are detoxified in the body are lower in response to repeated attacks and do not correspond to the single-dose effect.]

\section{Downwind hazard}

The total downwind hazard depends on:

- The initial concentration of a chemical warfare agent;

- The type of vertical stability of the ground layer of the atmosphere (convection, isothermia, inversion);

- The speed and steadiness of the wind;

- The terrain ruggedness and terrain coverage. 
The downwind hazard is an important characteristic from the viewpoint of tactical warning. Depending on the use of a chemical weapon and on the properties of a chemical warfare agent, the atmosphere or terrain may be contaminated, or the simultaneous contamination of both may occur.

The cloud, which is created immediately as soon as a chemical weapon is used, is called primary cloud, and is the cause of immediate effect on humans or animals.

The cloud created due to the evaporation of a chemical warfare agent from different surfaces and the terrain is called secondary cloud. Both clouds spread depending on the strength and direction of the wind to different distances from the point of use. The total downwind hazard depends on the initial concentration of a chemical warfare agent, the type of vertical stability of the ground layer of the atmosphere, the wind speed and the terrain ruggedness and coverage.

\subsection{Symptoms of exposure and the first aid after the exposure to chemical warfare agents}

\subsubsection{Choking agents}

The agents of this group cause a general disease of the organism with the most significant changes in the respiratory organs. The most serious symptom of poisoning is pulmonary oedema. Choking agents enter the body through the respiratory tract in the form of gas or aerosol. The representatives of these agents are phosgene, diphosgene and chloropicrin; the last one is classified, not quite rightly, as an irritating agent in many countries. Chloropicrin was previously widely used for its lachrymatory effects in training and testing of protective equipment. Phosgene and diphosgene currently belong to the category of backup warfare chemicals. Of the other agents that can

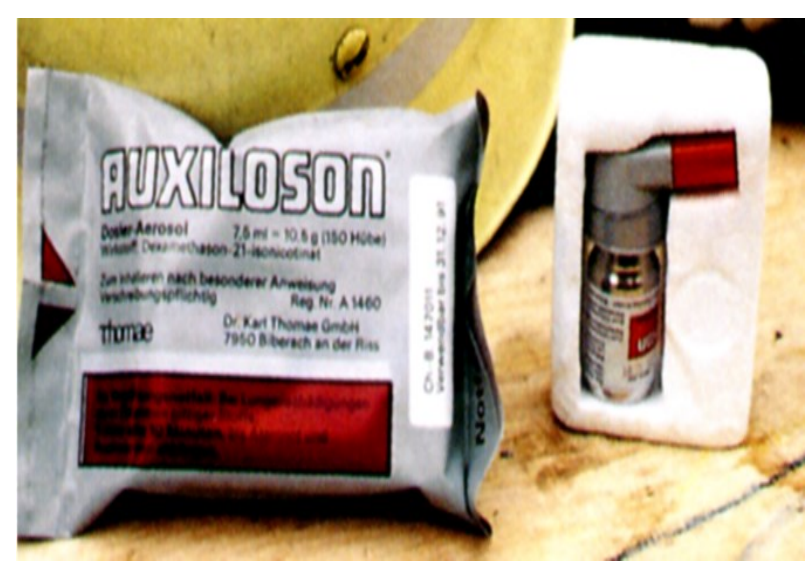

Figure 97: Auxilon ${ }^{\circledR}$ Dosier Spray for the treatment of acute smoke poisoning caused by fires and chlorine gas, ammonia, oxides of nitrogen, phosgene and heavy metal vapours. [Source: Fig-97] create dangerous concentrations under certain circumstances and cause toxic pulmonary oedema is perfluoroisobutene, which is a toxic product of pyrolysis of Teflon-based plastics.

\section{Symptoms of acute poisoning by choking agents}

Reflex period - immediately after intoxication, a slight irritation of the respiratory passages, pressure on the chest, possible vomiting and skin irritation occur. Along with headaches and weakness, these symptoms abate after one hour of the exposure to intoxication.

Latency period -3 to 6 hours. The affected person feels seemingly healthy and without symptoms. Mild cyanosis of the lips is possible and in case of a higher physical activity, dyspnoea and the acceleration of blood flow occur.

Period of increasing clinical symptoms - dyspnoea, cough and cyanosis begin to increase gradually. Accelerated breathing is typical.

Period of full development of symptoms occurs after 6 to 12 hours and takes 2 to 3 days. It is a critical phase, in which the highest number of deaths occurs. 
It can take place in two ways as follows:

- Blue type of hypoxia - the affected person suffers from severe dyspnoea; the skin acquires a visible blue tint and the visible veins clearly develop. The affected person breathes with difficulty, superficially and coughs up a large amount of fluid (more than one litre in the first 24 hours). The heart rate is fast, the blood pressure is normal and the prognosis of this type is relatively good. It is the better option.

- Gray type of hypoxia - the skin of an affected person takes on gray tones and is covered with sticky cold sweat. The heart rate is critically fast (130 to 160 beats per minute), it is filamentous and highly irregular. On the contrary, blood pressure drops significantly and the level of oxygen in the blood practically disappears. The peripheral blood circulation fails, pulmonary oedema occurs with increasingly shallow breathing. In the case of gray hypoxia, death almost usually occurs within one to two days.

Table 45: Properties of choking agents. [Source: Tab-45]

\begin{tabular}{|c|c|c|c|c|c|c|}
\hline Name & $\begin{array}{l}\text { Code } \\
\text { designa- } \\
\text { tion }\end{array}$ & $\begin{array}{l}\text { Physical } \\
\text { properties }\end{array}$ & $\begin{array}{c}\text { Basic chemical } \\
\text { properties }\end{array}$ & $\begin{array}{l}\text { Field } \\
\text { stability }\end{array}$ & $\begin{array}{c}\text { Decontamina- } \\
\text { tion }\end{array}$ & Protection \\
\hline Phosgene & $\begin{array}{c}\text { CG, } \\
\text { D-stoff, } \\
\text { Palite, } \\
\text { P-Ю }\end{array}$ & $\begin{array}{l}\text { Colourless } \\
\text { gas, scent } \\
\text { of mown hay }\end{array}$ & $\begin{array}{l}\text { Decomposes } \\
\text { rapidly with water, } \\
\text { dissolves poorly } \\
\text { in water, well in } \\
\text { organic solvents }\end{array}$ & $\begin{array}{l}\text { In summer } \\
5-10 \text { min., } \\
\text { in winter } \\
\text { up to } \\
20 \mathrm{~min} .\end{array}$ & $\begin{array}{c}\text { Sufficient } \\
\text { ventilation } \\
\text { of rooms } \\
\text { and clothes }\end{array}$ & $\begin{array}{c}\text { Full-face } \\
\text { mask } \\
\text { is sufficient }\end{array}$ \\
\hline Diphosgene & $\begin{array}{c}\text { DP, } \\
\text { Superpalite, } \\
\text { Perstoff or } \\
\text { Green } \\
\text { Cross }\end{array}$ & $\begin{array}{l}\text { Colourless, } \\
\text { clear, slightly } \\
\text { volatile oily } \\
\text { liquid, odour } \\
\text { of fruit }\end{array}$ & $\begin{array}{l}\text { Poorly soluble } \\
\text { in water, soluble in } \\
\text { organic solvents, } \\
\text { it decomposes } \\
\text { in boiling water }\end{array}$ & $\begin{array}{l}1 \text { up to } \\
3 \text { hours }\end{array}$ & $\begin{array}{c}\text { To use } \\
\text { ammonia } \\
\text { water, amine } \\
\text { or lye solutions }\end{array}$ & $\begin{array}{c}\text { Full-face } \\
\text { mask } \\
\text { is sufficient }\end{array}$ \\
\hline Chloropicrin & PS & $\begin{array}{c}\text { Colourless or } \\
\text { yellowish oily } \\
\text { liquid, } \\
\text { mousy smell }\end{array}$ & $\begin{array}{c}\text { Hydrolysis is } \\
\text { immeasurable, } \\
\text { it hardly dissolves } \\
\text { in water, } \\
\text { it dissolves well } \\
\text { in organic solvents } \\
\text { and mustard gases }\end{array}$ & $\begin{array}{l}\text { In summer } \\
1 \text { up to } \\
4 \text { hours, } \\
\text { in winter } \\
\text { up to } \\
1 \text { week }\end{array}$ & $\begin{array}{c}\text { To use } \\
\text { surface-active } \\
\text { substances, } \\
\text { water-alcohol } \\
\text { solution } \\
\text { of sodium } \\
\text { sulphide }\end{array}$ & $\begin{array}{c}\text { Full-face } \\
\text { mask } \\
\text { is sufficient }\end{array}$ \\
\hline $\begin{array}{l}\text { Perfluoro } \\
\text { isobutene }\end{array}$ & Unknown & $\begin{array}{l}\text { Colourless gas } \\
\text { without a } \\
\text { marked odour }\end{array}$ & $\begin{array}{l}\text { Hydrolysis is very } \\
\text { slow }\end{array}$ & $\begin{array}{l}\text { A few } \\
\text { minutes }\end{array}$ & $\begin{array}{l}\text { Sufficient } \\
\text { aeration } \\
\text { of rooms } \\
\text { and clothes }\end{array}$ & $\begin{array}{c}\text { Full-face } \\
\text { mask with } \\
\text { filters for } \\
\text { low-boiling } \\
\text { liquids }\end{array}$ \\
\hline
\end{tabular}

Period of regression of pathological changes - in the case of survival of the critical first 3 days, the absorption of fluid in the lungs begins to occur. The symptoms, such as dyspnoea and bluishness, disappear, the appetite returns, and the overall condition generally improves. A possible complication may be a secondary infection. When providing the first aid, it is necessary to isolate and protect the affected person from the further entrance of a noxious agent by applying a full-face mask and by taking him/her out of the contaminated atmosphere. When transporting, the affected person must not be subjected to any physical burden, he/she must not speak and must be moved in a lying position. The affected person must be undressed to prevent desorption of the vapours from the clothing and should be covered with a warm blanket. The affected person is allowed to get warm tea and coffee. When apneusis occurs, it is possible to carry out mouth-to-mouth resuscitation. The basic therapeutic measure is the rich supply of oxygen to the lungs, preferably under pressure. Therefore, it is necessary for an ambulance to be equipped with an oxygen breathing apparatus. Other treatments are prescribed by the medical doctor. 


\subsubsection{Blood agents}

The term blood agent is a misnomer and is conventionally used in military toxicology for substances that act as inhibitors of the respiratory chain. The toxic effect is mediated primarily by abnormal haemoglobin, which is typical of carbon monoxide, nitriles, nitrates, aniline derivatives and other agents. Another possibility then represents the direct inhibition of the respiratory chain enzymes. In particular, cyanides and sulphides act in this way. They are important especially in the industrial sphere, or in clinical toxicology and environmental toxicology.

\section{Symptoms of poisoning by blood agents}

There are three forms of inhalation poisoning caused by hydrogen cyanide and cyanides: superacute, acute and light. Two to three breaths of high concentrations of a noxious agent are sufficient for superacute poisoning with blood agents. The feeling of tightening the neck and irregular convulsive breathing occur and the affected person falls to the ground in convulsions, often with a loud scream, and loses consciousness rapidly. Death occurs within three minutes.
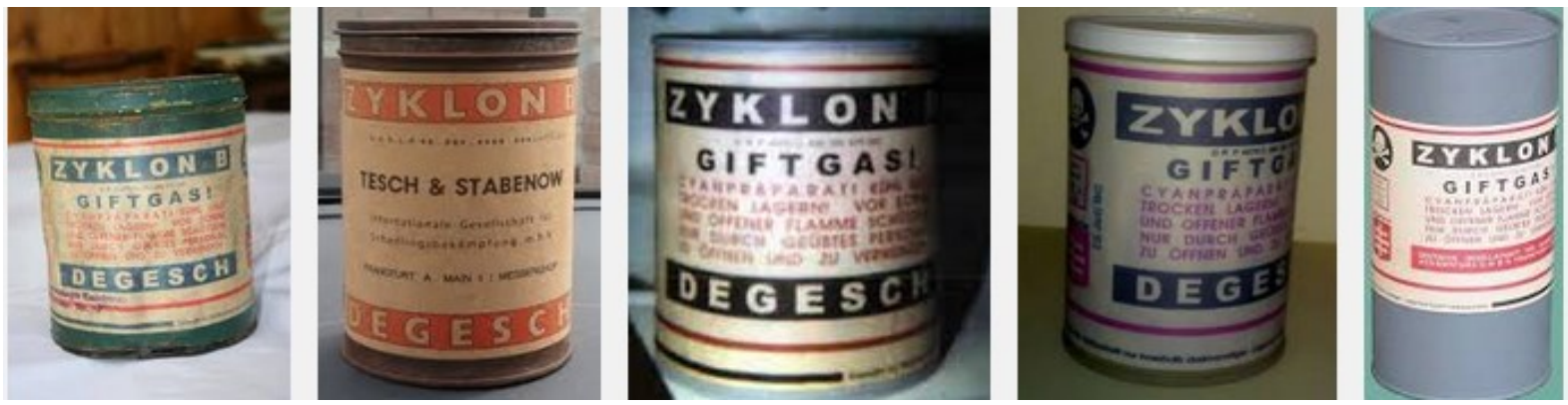

Photo 135: Zyklon B (cyanide compounds) from different manufacturers, used for gasification in concentration camps. [Source: Pho-135]

Acute poisoning is characterized by initial acceleration of the respiratory rate, which is so intense that the affected person is incapable of regulating the frequency and depth of breathing. The pupils of the eyes dilate and there is a strong sense of anxiety. In the case of loss of consciousness, muscle cramps develop, breathing gradually weakens until it stops completely, the irregular heart function continues for three to four minutes after the last exhalation. Slight poisoning occurs without the loss of consciousness; strong headache and sore throat are present; dizziness and transient visual disturbances occur. Breathing is difficult and sometimes accompanied by paroxysmal dyspnoea, but after a certain amount of time it is adjusted.

Generally, clinical symptoms of poisoning have their origin in the tissues with the highest demands on oxygen supply, therefore, headaches, feelings of anxiety, confusion and convulsions occur. Respiratory disorders can also cause pulmonary oedema. The function of the heart, especially in the case of oral poisoning, is irregular and slow, and the skin is dry and hot. The main cause
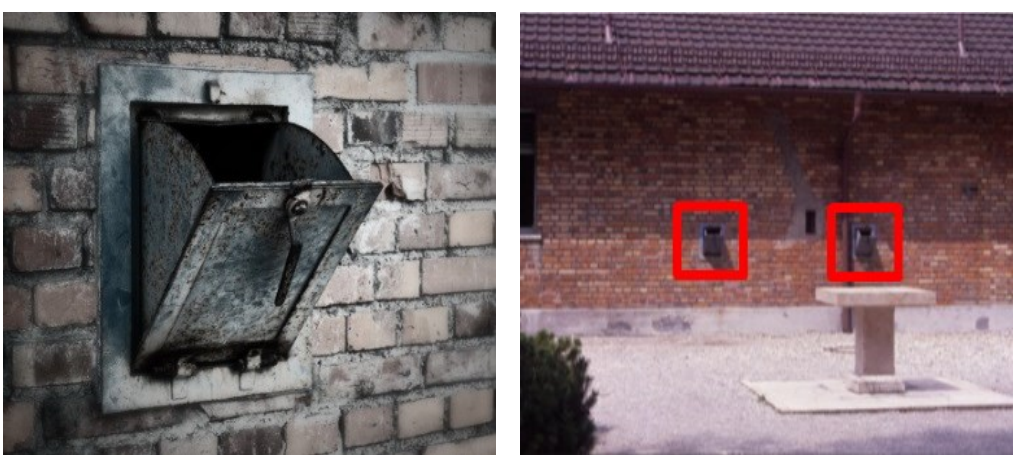

Photo 136-1 and 136-2: Zyklon B (Cyclone B) was poured into gas chambers through this opening. Dachau.

[Source: Pho-136-1 and Pho-136-2] of death is the attack on the important centres in the medulla oblongata, especially the areas conducting the respiratory activity. 
In the case of poisoning at high concentrations of cyanogen chloride, the poisoning is similar to that of superacute poisoning with hydrogen cyanide. At low concentrations, however, it irritates eye conjunctivae and the upper respiratory tract. If protection is not implemented, the pulmonary oedema may occur just as in phosgene poisoning, the fluid in the lungs will be produced much faster.

Table 46: Properties of blood agents. [Source: Tab-46]

\begin{tabular}{|c|c|c|c|c|c|c|}
\hline Name & $\begin{array}{c}\text { Code } \\
\text { designation }\end{array}$ & $\begin{array}{l}\text { Physical } \\
\text { properties }\end{array}$ & $\begin{array}{l}\text { Basic chemical } \\
\text { properties }\end{array}$ & Field stability & Decontamination & Protection \\
\hline $\begin{array}{l}\text { Hydrogen } \\
\text { cyanide }\end{array}$ & $\begin{array}{l}\mathrm{AC}, \mathrm{VN}, \\
\text { Forestite }\end{array}$ & $\begin{array}{c}\text { Colourless, } \\
\text { highly volatile } \\
\text { liquid, bitter } \\
\text { almond odour, } \\
\text { due to aging it } \\
\text { turns brown, } \\
\text { polymerizes } \\
\text { and hardens, } \\
\text { explosive with } \\
\text { the air }\end{array}$ & $\begin{array}{l}\text { Mixes well with } \\
\text { water, solvents } \\
\text { and some } \\
\text { CWAs, } \\
\text { hydrolysis } \\
\text { proceeds slowly } \\
\text { and is acceler- } \\
\text { ated in alkaline } \\
\text { medium }\end{array}$ & $\begin{array}{l}\text { In the open } \\
\text { area max. } \\
5 \text { min., } \\
\text { in woodlands } \\
\text { about } \\
15 \text { min., } \\
\text { in winter up } \\
\text { to } 60 \text { min. }\end{array}$ & $\begin{array}{l}\text { Due to high } \\
\text { volatility, } \\
\text { ventilation } \\
\text { is sufficient }\end{array}$ & $\begin{array}{l}\text { A full-face } \\
\text { mask is } \\
\text { sufficient; } \\
\text { at high con- } \\
\text { centrations } \\
\text { a filtration } \\
\text { protection } \\
\text { suit or } \\
\text { gas-tight suit } \\
\text { are suitable }\end{array}$ \\
\hline $\begin{array}{c}\text { Cyanogen } \\
\text { chloride }\end{array}$ & $\mathrm{CK}$ & $\begin{array}{l}\text { Colourless gas } \\
\text { with chlorine } \\
\text { odour, } \\
\text { at } 13^{\circ} \mathrm{C} \\
\text { it condenses } \\
\text { to form a } \\
\text { smelly brown } \\
\text { liquid }\end{array}$ & $\begin{array}{c}\text { Poorly } \\
\text { water-soluble, } \\
\text { dissolves well in } \\
\text { organic solvents, } \\
\text { mustard gas and } \\
\text { chloropicrin, } \\
\text { decomposition } \\
\text { in water } \\
\text { is gradual }\end{array}$ & $\begin{array}{l}\text { In summer in } \\
\text { the open area } \\
10 \text { min., } \\
\text { in winter } \\
20 \text { min., } \\
\text { in woodlands } \\
\text { in summer } \\
30 \text { min. and } \\
\text { in winter } \\
2 \text { hours }\end{array}$ & $\begin{array}{l}\text { Ventilation } \\
\text { is usually } \\
\text { sufficient; } \\
\text { ammonia can } \\
\text { be used in } \\
\text { rooms }\end{array}$ & $\begin{array}{l}\text { A full-face } \\
\text { mask with a } \\
\text { regular filter } \\
\text { is sufficient }\end{array}$ \\
\hline $\begin{array}{c}\text { Carbon } \\
\text { monoxide } \\
\text { (CO) }\end{array}$ & & $\begin{array}{c}\text { Colourless, } \\
\text { explosive gas, } \\
\text { tasteless and } \\
\text { odourless }\end{array}$ & Irrelevant & $\begin{array}{l}\text { In the open } \\
\text { area minimal, } \\
\text { in the closed } \\
\text { space } \\
\text { dangerous }\end{array}$ & $\begin{array}{l}\text { Ventilation } \\
\text { is sufficient }\end{array}$ & $\begin{array}{l}\text { A full-face } \\
\text { mask with } \\
\text { a filter, prin- } \\
\text { ciple of cata- } \\
\text { lytic oxida- } \\
\text { tion of CO } \\
\end{array}$ \\
\hline
\end{tabular}

\section{Symptoms of poisoning:}

- Symptoms of carbon monoxide poisoning come from the organs and tissues sensitive to a disruption in oxygen supply, when oxygen is not transported by haemoglobin, that has about 220 times higher chemical affinity for carbon monoxide;

- The first symptoms of light poisoning are headaches and a feeling of tension around the forehead. At a higher concentration the headaches intensify, qualm and vomiting occur. Other symptoms are muscle fatigue, dizziness and night-blindness, the skin redness may be a warning;

- The acceleration of cardiac function, a subsequent loss of consciousness and muscular spasms usually indicate a transition to a severe degree of poisoning;

- Death occurs as a result of cerebral oedema and its total damage.

The first aid for carbon monoxide poisoning lies in taking the affected person out of the contaminated environment. The most effective method is to breathe pure oxygen through a mask placed over the nose and mouth. It should be borne in mind that full-face mask active carbon filters do not protect against carbon monoxide. 
The speed of providing the aid in the case of hydrogen cyanide poisoning is of great importance. If, after an attack, a bitter almond odour is present in the air, it is necessary to prevent further penetration of a poison into the organism using a full-face mask and to deport the affected people from the contaminated environment.

The affected person must be undressed because of desorption of vapours from his/her clothes and underwear linen. For poisoning with severe breathing disorders, it is necessary to provide artificial respiration, but not from mouth to mouth, until spontaneous breathing or definitive clinical death is confirmed. Initially, cyanogen chloride has strong irritating effects; therefore, it is necessary to apply the full-face mask immediately when the first irritation of the nose, nasopharynx and eyes occur. The other treatments are identical to those of hydrogen cyanide poisoning. The respiratory disturbances are treated as if they were caused by phosgene.

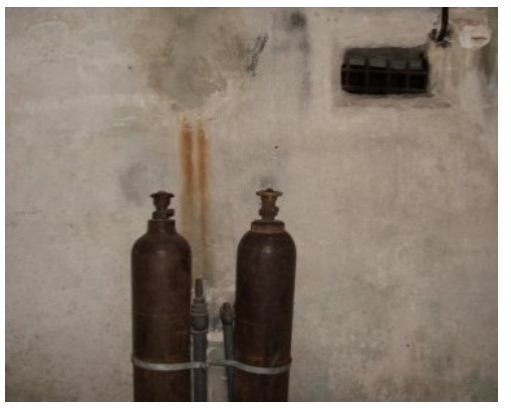

Photo 137: An SS small room, from which a gas chamber could be observed through a small window, and carbon monoxide bottles. The Majdanek Concentration Camp. [Source: Pho-137]
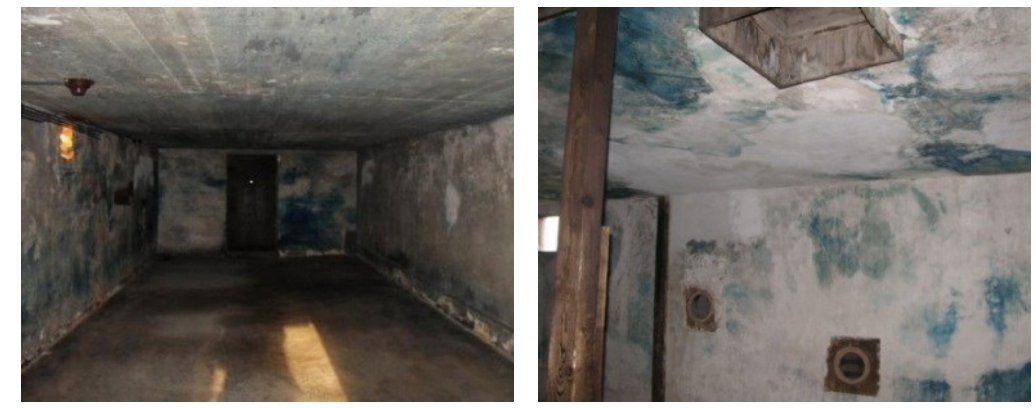

Photo 138-1 and 138-2: One of the five gas chambers. The clear Prussian blue stains (cyanide compounds) can be seen on the walls, the Prussian blue was used for fumigation. The ceiling opening to pour Zyklon B can be seen. The Majdanek Concentration Camp. [Source: Pho-138-1 and Pho-138-2]

\subsubsection{Blister agents}

This group of agents has been known since World War I. For the first time, they were used on July 13, 1917 by the German Army to attack the British $15^{\text {th }}$ Infantry Division at the Belgian city of Ypres, according to which it bears its slang name yperites (mustard gases). The need to incorporate these agents into the war arsenal resulted in the development of increasingly improved means of protecting the upper respiratory tract; therefore, other possibilities for the entry of toxicants into the body were sought.

Although, currently, we cannot consider blister chemical warfare agents to be long-term prospective chemical warfare agents, we need to put them in the second place behind nerve agents according to their toxicity and variability of entry into the body. The primary toxic effect is the action on the skin when the formation of erythema and blisters with subsequent necrotic changes occurs. Blister agents affect unprotected eyes severely and cause inflammation of the mucous membranes, which are difficult to treat. The pulmonary oedema develops when the respiratory tract is attacked by mustard gases.

The protection against blister agents is very difficult because they penetrate all kinds of materials including rubbers. Therefore, mustard gas is also used for the research of the porosity of these protective materials. Currently, blister agents are stored in large quantities. They also include the stocks intended for disposal in the spirit of the Chemical Weapons Convention as well as the insufficiently destroyed German and Japanese chemical weapons after World War II, which were sunk in the seas. The tactical use of blister agents is versatile. They can be used as a charge in artillery shells, rocket warheads, aerial bombs, chemical mines, aerial spraying equipment and aerosol generators. 
Mustard T-mixture (HT-gas) - a mixture of sulphur mustard and oxy-mustard - it is also known as the so-called winter mustard gas for its low freezing point.

Thickened sulphur mustard - designed for aerial spraying devices used at high altitudes and at high flying speeds. The mixture of mustard and a thickener used makes decontamination work very difficult.

The aim of the use of blister agents will be as follows:

- A permanent elimination of personnel - especially by percutaneous injury;

- Exhaustion of personnel due to the long-term use of individual protection equipment;

- The limitation of the opponent's manoeuvre by creating enclosed sections of contaminated areas for great length of time;

- Enforcing the time-consuming and material-intensive measures to eliminate contamination; and

- The most important agent of this chemical warfare agent class appears to be sulphur mustard, beside which other representatives can be found, e.g. nitrogen mustard, lewisite, sesqui-mustard, oxy-mustard and phosgene oxime.

\section{Symptoms of injuries caused by blister agents}

In addition to inhalation poisoning, the skin injury in war would most often occur because the perfect protection of the entire body surface is very difficult. Blister agents do not irritate the skin, with the exception of sweaty skin where a slight burn may occur. Blister agents are absorbed through the skin, which is accelerated by the presence of a larger number of sebaceous glands and, on the contrary, is slower in the places with a strong callous layer. Within 4 to 6 hours after the injury, the affected person feels skin tension, itching and burning.

The first objective symptom is a redness of the skin in the affected place. After about 24 hours small blisters begin to form, which gradually coalesce into larger blisters until a large blister is created over the entire affected surface. The blisters contain a clear, colourless, nontoxic liquid and its development takes 4 to 6 days. Bullous dermatitis is formed, which in mild cases is superficial, i.e. after removing the blister, only dark red erosion remains on the surface of the skin. In heavier cases, a deep, painful ulcer extending down to the subcutis occurs after the rupture of the blister. The ulcer crater is filled with a necrotic mass that is gradually replaced by granulation tissue sensitive to physical and chemical damage. Healing takes between 4 and 6 weeks, and if the secondary infection occurs, it takes up to 3 months. If the eyes are affected by vapours, the latency is 4 to 8 hours, and if they are affected by a liquid, it is between 2 and 4 hours.

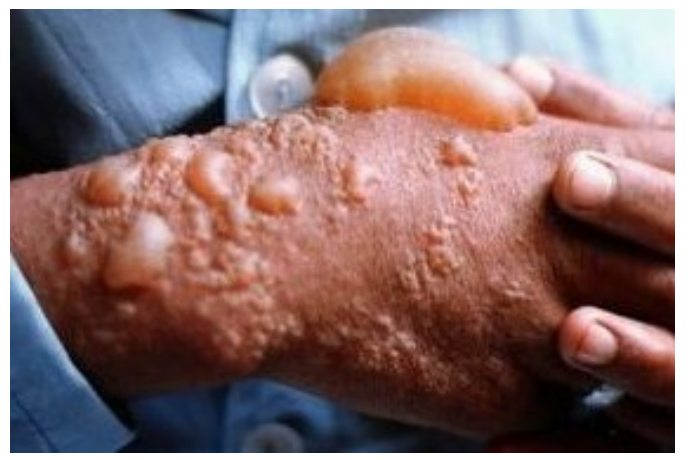

Figure 98: Blisters after the effects of mustard gas. [Source: Fig-98]

The injury is manifested by strong subjective difficulties characterized by a burning sensation and feeling of a foreign body in the eye. Photophobia, swelling and eyelid redness occur. In the event of severe eye contact with a blister agent, an inflammation of the cornea may occur; this may result in a corneal ulcer and an inflammation of the iris. In the most severe cases, the vision loss occurs.

Inhalation poisoning develops as a slight catarrh of the upper respiratory tract in the case of mild poisoning or as a catarrhal necrotic bronchopneumonia in the case of severe poisoning after several hours of latency, depending on the received dose of a noxious agent. First, the affected person feels chest pressure, accompanied by an irritating cough that turns into a productive cough producing bloody sputum. 
Fatigue, high temperatures and pulmonary manifestations similar to pneumonia can be observed in the affected person. In more complicated cases, death may occur after 3 to 4 days of poisoning. In some affected patients, clinical improvement occurs after the $4^{\text {th }}$ day of poisoning and the findings of the lungs gradually subside. However, on the $9^{\text {th }}$ and the $10^{\text {th }}$ day after poisoning, the affected person is at risk of suffocation due to the blockage of alveoli by the membranes released at the sites of the damaged airway mucosa or due to the secondary infection.

Table 47: Properties of blister agents. [Source: Tab-47]

\begin{tabular}{|c|c|c|c|c|c|}
\hline Name & $\begin{array}{c}\text { Code } \\
\text { designation }\end{array}$ & Physical properties & $\begin{array}{l}\text { Hydrolysis } \\
\text { and solubility }\end{array}$ & Field stability & Protection \\
\hline $\begin{array}{l}\text { Sulphur } \\
\text { mustard }\end{array}$ & \begin{tabular}{|} 
H, HD, R 74, \\
Yc, Yt, \\
Senfgas, \\
Mustard gas, \\
Sulphur \\
mustard, \\
Iprit, Lost \\
VM-soft
\end{tabular} & $\begin{array}{l}\text { Oily liquid with } \\
\text { garlic smell, } \\
\text { a technical product } \\
\text { is yellow to brown } \\
\text { with smell of burnt } \\
\text { rubber, the freezing } \\
\text { point is } 14.5^{\circ} \mathrm{C}\end{array}$ & $\begin{array}{c}\text { Dissolves very } \\
\text { reluctantly in water } \\
\text { with a tendency to } \\
\text { float on the surface, } \\
\text { the decomposition in } \\
\text { water is very gradual } \\
\text { and the products are } \\
\text { toxic }\end{array}$ & $\begin{array}{l}\text { In summer } \\
3 \text { to } 7 \text { days, } \\
\text { in winter } \\
\text { several weeks }\end{array}$ & $\begin{array}{l}\text { Full-face mask } \\
\text { and body } \\
\text { surface } \\
\text { protection } \\
\text { items, gloves, } \\
\text { overshoes }\end{array}$ \\
\hline $\begin{array}{c}\text { Nitrogen } \\
\text { mustard }\end{array}$ & \begin{tabular}{|c|} 
HN-3, \\
N-mustard, \\
ypérite à \\
l'azote, \\
nitrogen mus- \\
tard, \\
azotistij iprit \\
\end{tabular} & $\begin{array}{l}\text { Colourless to } \\
\text { yellowish liquid, } \\
\text { brown with aging, } \\
\text { a technical product } \\
\text { with fishy odour }\end{array}$ & See HD & $\begin{array}{c}\text { Considerably } \\
\text { longer than in } \\
\text { HD }\end{array}$ & See HD \\
\hline Lewisite & $\begin{array}{c}\text { L, R-43A, } \\
\alpha(\beta, \gamma)- \\
\text { Lewisite, } \\
\text { Lewisite A, } \\
\text { M-1, } \\
\text { Luizit }\end{array}$ & $\begin{array}{l}\text { Colourless, slightly } \\
\text { volatile liquid, be- } \\
\text { comes red to brown } \\
\text { with aging, faint } \\
\text { odour of geranium }\end{array}$ & \begin{tabular}{|c|} 
Almost insoluble \\
in water, hydrolysis \\
is very rapid, products \\
of decomposition \\
in water are toxic, \\
dissolves and mixes \\
well with yperites \\
\end{tabular} & \begin{tabular}{|l} 
In summer \\
about 1 day, \\
in winter up \\
to a week \\
(depending on \\
the terrain and \\
air humidity) \\
\end{tabular} & See HD \\
\hline $\begin{array}{c}\text { Oxy- } \\
\text { mustard }\end{array}$ & T, O-lost & $\begin{array}{l}\text { Dark oily liquid with } \\
\text { a non-specific odour, } \\
\text { freezes at } 10^{\circ} \mathrm{C}\end{array}$ & $\begin{array}{c}\text { Does not dissolve in } \\
\text { water, well soluble in } \\
\text { acetone and benzene }\end{array}$ & Similar to HD & See HD \\
\hline $\begin{array}{l}\text { Sesqui- } \\
\text { mustard }\end{array}$ & Q & $\begin{array}{c}\text { Crystalline } \\
\text { substance of amber } \\
\text { colour without } \\
\text { significant odour } \\
\end{array}$ & $\begin{array}{c}\text { Slightly soluble } \\
\text { in water, well soluble } \\
\text { in organic solvents }\end{array}$ & Not assessed & See HD \\
\hline $\begin{array}{c}\text { Phosgene- } \\
\text { oxime }\end{array}$ & $\mathrm{CX}$ & $\begin{array}{l}\text { A solid substance, a } \\
\text { technical product is } \\
\text { liquid, non-specific } \\
\text { and penetrating } \\
\text { odour, strongly } \\
\text { volatile substance } \\
\text { known as nettle gas }\end{array}$ & Not assessed & Not assessed & See HD \\
\hline $\begin{array}{l}\text { Mustard- } \\
\text { lewisite } \\
\text { mixture }\end{array}$ & HL, RK-7 & $\begin{array}{l}\text { A liquid with garlic } \\
\text { odour, lewisite } \\
\text { decreases the } \\
\text { freezing point } \\
\text { of mustard to }-25^{\circ} \mathrm{C}\end{array}$ & See HD and $L$ & $\begin{array}{l}\text { Lower than } \\
\text { in HD }\end{array}$ & See HD \\
\hline
\end{tabular}


Oral poisoning would be a rarer case than the previous cases. The symptoms of this type of poisoning occur almost immediately after the ingestion of contaminated water or food. The symptoms of poisoning are nausea, an upper abdominal pain, persistent vomiting and diarrhoea with blood. The loss of fluids, together with the direct toxic effect of blister agents, leads to the conditions that resemble diarrheal bacterial diseases, such as cholera. The shock caused by the fluid loss or serious infectious complications in the case of the digestive tract perforation may worsen health conditions.

When an injury caused by blister agents occurs, the primary principle of the first aid is to put on a full-face mask quickly, to move away from the area and to carry out decontamination using the individual decontamination kit. It is important to remove the main source of contamination, which is clothing. If the digestive tract is affected, it is necessary to induce vomiting mechanically immediately and then to use animal charcoal. Next, it is required to perform eye irrigation with $2 \%$ soda solution or $0.5 \%$ monochloroamine-B solution. The flush can also be done with a large amount of water.

There is no specific antidote and the treatment is intended to prevent secondary infection. The skin can be washed or compresses can be applied, e.g. 1 to $2 \%$ monochloroamine-B solution or $1 \%$ potassium permanganate solution (potash). Blisters should not be pricked and a bandage with ointment for skin defects should be used. There is an antidote for lewisite called Dicaptol. It is required to carry out complete decontamination.

\subsubsection{Nerve agents}

Nerve agents rank among organophosphorus compounds characterized by extraordinary toxicity in mammals. They are the most important and the most dangerous group of chemical warfare agents. In addition to their toxicity, they are characterized by a rapid action. They enter the body through all portals of entry. Their synthesis is relatively easy and inexpensive and they are easy to use for military and terrorist purposes. They are divided into two subclasses, which are generally referred to as G-series agents and V-series agents.

G-series nerve agents are most often the fluorides of alkylphosphonic acid or phosphoric acid esters. The most significant representatives are sarin, soman and tabun. The formula of tabun has already been obsolete and tabun belongs to the tertiary list of chemical warfare agents. All of these agents are intended to eliminate or kill personnel by the inhalation of vapours and aerosols as well as by the effect of the liquid phase of the agent on the skin.

$\mathrm{V}$-series nerve agents are most often esters of alkylphosphonic or phosphoric acid and aminothioalcohol. The most important representative of this series is a VX nerve agent. This compound is intended to eliminate and kill personnel; it acts primarily as a liquid on the unprotected skin and through inhaling its aerosol.

It should be noted that the compounds of the same basic structure are used in the industry as softeners, hydraulic fluids or for fireproofing. They are also used as pharmaceuticals in veterinary and human medicine or as compounds for the research of nerve functions. The broadest possible use of these agents as insecticides intended for an insect control has been made in agriculture

\section{Symptoms of injuries caused by nerve agents}

Nerve agents are highly toxic and enter the body through all pathways. This fact, along with the possibility of using these agents by any means, has put them first in their possible use in war. Therefore, the symptoms of this group of chemical warfare agents will be described in more detail than in the other groups. 

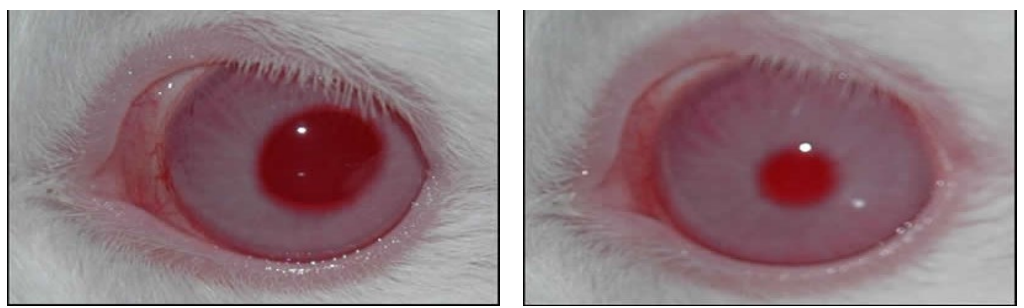

Photo 139-1 and 139-2: The effect of a drop of sarin on the left eye of a rabbit; (1) a normal eye, (2) the constriction of the pupilmiosis after 5 minutes at a concentration of $5 \mu \mathrm{g} . \mathrm{kg}^{-1}$.

[Source: Pho-139-1 and Pho-139-2]
The symptoms of sarin and soman poisoning share the same basic features regardless of the state, in which the agents enter the body. Small differences are evident depending on the portal of entry, i.e. in the early stages of poisoning only. In fully developed sarin poisoning, individual differences are wiped out. Depending on the severity and especially for the easier sorting of the affected people, three levels of poisoning can be distinguished in the clinical course of poisoning.

Mild poisoning begins 15 to 20 minutes, exceptionally within 2 hours, after contact. In poisoning due to inhalation, first of all, miosis develops, which is the constriction of the pupils. Other symptoms are a feeling of chest tightness and slight dyspnoea, thin nasal discharge, muscle fatigue, headache and problems with eye focusing. Sickness, exceptionally vomiting, the loss of appetite, abdominal pain, cough and excessive sweating occur. The affected person is restless, feels anxious, suffers from insomnia, has troubles to concentrate and remember the freshest events.

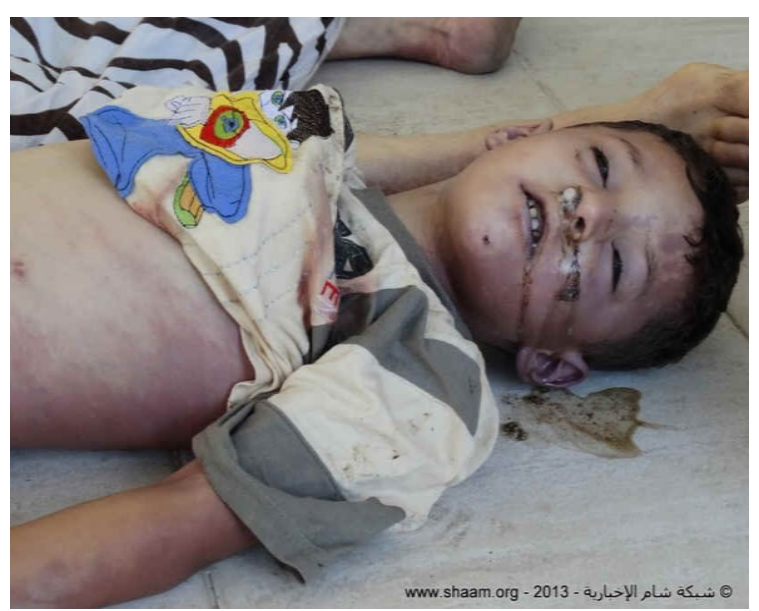

Photo 140: Sarin poisoning, Syria 2013.

[Source: Pho-140]

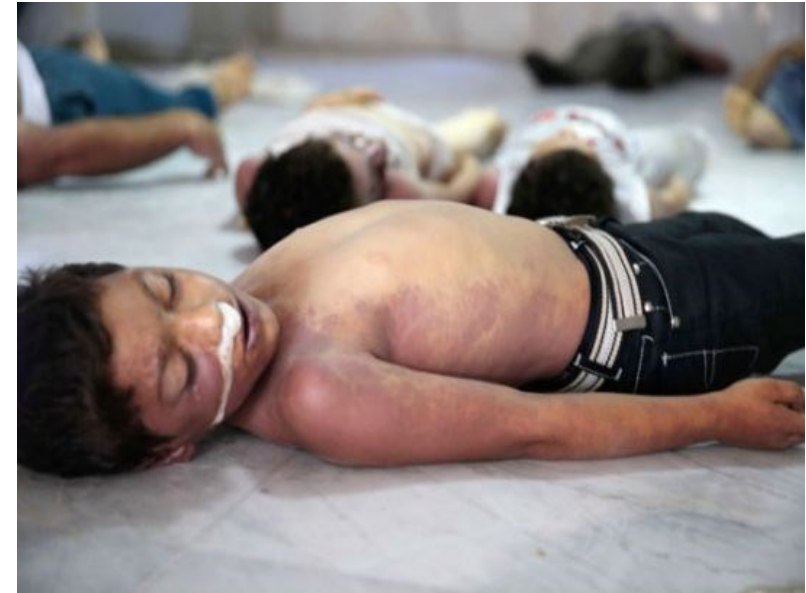

Photo 141: Sarin poisoning, Syria 2013.

[Source: Pho-141]

The convulsive status of the eyelids leads to a feeling of pressure or the pain behind the eyes; conjunctival sacs become congested and may also be swollen. Breathing problems are a result of the convulsive status of the bronchial smooth muscles and increased expectoration. Dyspnoea and irritating cough may occur. The heart rate is slowed-down (about 60 per minute); the blood pressure increases and later normalizes with a tendency to decrease. Outpatient treatment is sufficient. If there is miosis, the affected person cannot fulfil tasks.

In the case of moderate poisoning, the latency ranges between 5 and 10 minutes, exceptionally within 1 hour after contact. After this time, the same symptoms as in mild poisoning occur; however, they develop faster and more intensely. Miosis can cause complete disappearance of the pupils. Asthma problems are escalating, which are exacerbated by periodic laryngeal spasms accompanied by wheezing and rapid breathing. The oxygen supply is impaired, which causes bluish discolouration of the skin and mucous membranes. Salivation and nasal discharge increase, a cough with expectoration of frothy phlegm gets worse. The cardiac function fluctuates, the heart rate slows to 50 up to 60 per minute and the blood pressure decreases. 
The muscle tone increases in the range from the increased tension to the tics and the convulsions (around the mouth, neck, and calves). The convulsions last for a short while and are replaced by longer rest periods, in which the muscle tension persists. The loss of appetite leads to vomiting and diarrhoea sometimes occurs. The affected person suffers from severe headaches, dizziness, his/her mood is labile. The concentration is disturbed, he/she does not remember the freshest events and his/her speech is inarticulate.

The symptoms persist for about 24 hours, but then they disappear slowly and the recovery takes place. However, miosis sometimes persists for more than

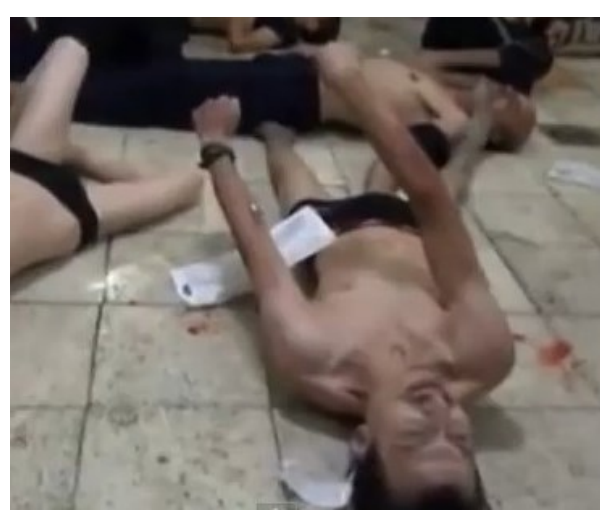

Photo 142: Sarin poisoning, Syria 2013. [Source: Pho-142] a week, dyspnoea and nausea disappear after two days. Muscle twitches persist for several days after the cramps disappear. However, exhaustion remains for a relatively long time, even with a minimal workload. In the case of moderate poisoning hospitalization is required and the treatment can take about two weeks. Nevertheless, the decreased immunity of the organism persists for about three months.

Severe poisoning occurs due to the exposure to aerosol, a high vapour concentration around exploded bombs, grenades and mines, or when the wound is contaminated by a liquid nerve agent or by spraying the surface of the body when the agent has a time to enter the body. According to the portal of entry, the latency is minimal or even absent. The first symptoms are similar; however, their development is fast and dramatic. Pain in the eyes and eyelid cramps are multiplied by attempts to focus eyesight and vision and orientation are severely impaired. Severe headaches are accompanied by reflexive vomiting. The affected person suffers from strong dyspnoea and a cough with expectoration of frothy phlegm.

The spasms of the vocal cords lead to speech disturbances, heavy breathing is accompanied by noisy breaths; pulmonary oedema may occur. Supplying the blood with oxygen is getting worse, the skin and mucous membranes are noticeably pale and start to become bluish. The upper abdominal pains can be accompanied by a colic or diarrhoea and spontaneous defecation and wetting due to the bladder spasms.

The increased muscle tension changes to very rapid and irregular contractions of various muscle groups that spread to other muscles and pass into the seizures of very painful cramps resembling epilepsy. During seizures, a break usually occurs accompanied by breathing problems and a total oxygen deficiency worsens. The pauses, depending on the degree of impact, may take several minutes to 2 hours. If the period between the cramps is longer, the consciousness may return; however, the affected person is exhausted, restless and hallucinates. The seizures may last for several days, and with gradual exhaustion of the body, the cramps may pass into a slight paralysis with the disappearance of reflexes. If breathing stops, the prognosis is very serious, and this condition can occur even after a longer period of time when seemingly the affected person is already in good condition. Death occurs within 6 to 12 hours, in the most difficult cases within a few minutes.

When a person is affected by nerve agents, the first aid rests in the fast use of a full-face mask and the administration of a substance specifically preventing the toxic effect of organophosphates using an auto-injector. Then, it is necessary to leave the contaminated area to prevent further penetration of the agent. If the clothing is contaminated, it is required to get undressed and to decontaminate the skin using an individual decontamination kit. 
Table 48: Properties of nerve agents. [Source: Tab-48]

\begin{tabular}{|c|c|c|c|c|c|}
\hline Name & Code marking & Physical properties & $\begin{array}{l}\text { Hydrolysis } \\
\text { and solubility }\end{array}$ & Field stability & Protection \\
\hline Sarin & $\begin{array}{c}\text { GB, } \\
\text { Trilon } 46, \\
\text { Trilon } 144, \\
\text { T144, T46, } \\
\text { EA1208, } \\
\text { zarin, R35 } \\
\end{array}$ & $\begin{array}{l}\text { Clear, colourless and } \\
\text { odourless liquid similar } \\
\text { to water, a technical } \\
\text { product is yellowish } \\
\text { with a fruit odour }\end{array}$ & \begin{tabular}{|c|} 
Mixes easily with \\
water and organic \\
solvents, hydrolysis \\
is very slow and \\
accelerates with \\
alkalis \\
\end{tabular} & $\begin{array}{c}\text { In summer vapours } \\
\text { are stable for } 0.5 \\
\text { up to } 6 \text { hours, in } \\
\text { winter } 6 \text { up to } \\
12 \text { hours }\end{array}$ & $\begin{array}{l}\text { Full-face } \\
\text { mask and } \\
\text { filtration } \\
\text { protection } \\
\text { suit }\end{array}$ \\
\hline Soman & \begin{tabular}{|c|} 
GD, R55 \\
(Russia) \\
Trilon, \\
EA1210, \\
thickened \\
form of VR55 \\
\end{tabular} & $\begin{array}{l}\text { Clear, colourless liquid } \\
\text { with a slight odour } \\
\text { similar to camphor, } \\
\text { turns brown with time }\end{array}$ & \begin{tabular}{|c|} 
Poorly soluble in \\
water, well soluble \\
in organic solvents, \\
oils and fats, \\
hydrolysis - \\
see sarin \\
\end{tabular} & $\begin{array}{l}\text { In summer max. } \\
1 \text { day, in winter } \\
\text { several days } \\
\text { according to the } \\
\text { conditions }\end{array}$ & $\begin{array}{l}\text { Full-face } \\
\text { mask and } \\
\text { filtration } \\
\text { protection } \\
\text { suit }\end{array}$ \\
\hline $\begin{array}{l}\text { Cyclo } \\
\text { sarin }\end{array}$ & GF & $\begin{array}{l}\text { Colourless liquid with } \\
\text { a slight fruit odour, } \\
\text { properties similar } \\
\text { to sarin }\end{array}$ & Similar to sarin & Similar to soman & $\begin{array}{l}\text { Full-face } \\
\text { mask and } \\
\text { filtration } \\
\text { protection } \\
\text { suit }\end{array}$ \\
\hline $\begin{array}{c}\mathrm{V} \text {-series } \\
\text { agent }\end{array}$ & \begin{tabular}{|} 
VX, VR, \\
EA5365, \\
A-group \\
agent, \\
F-group \\
agent, \\
R33 (Russia)
\end{tabular} & $\begin{array}{l}\text { Clean, colourless oily } \\
\text { liquid, nearly odourless, } \\
\text { a technical product is } \\
\text { yellow to dark brown }\end{array}$ & $\begin{array}{c}\text { Poorly soluble in } \\
\text { water and well } \\
\text { soluble in organic } \\
\text { solvents and fats, } \\
\text { decomposition in } \\
\text { water is slow, } \\
\text { accelerates in a } \\
\text { strong alkaline } \\
\text { medium }\end{array}$ & \begin{tabular}{|} 
During the sunny \\
weather and \\
temperatures above \\
$15^{\circ} \mathrm{C} 3$ up to \\
21 days, in a strong \\
wind and rain and \\
at a temperature \\
of $10^{\circ} \mathrm{C}$ about \\
10 hours, in frost \\
and snow up to \\
16 weeks
\end{tabular} & $\begin{array}{l}\text { Full-face } \\
\text { mask, } \\
\text { filtration } \\
\text { protection } \\
\text { suit, gas } \\
\text { protection } \\
\text { suit }\end{array}$ \\
\hline Amiton & $\begin{array}{c}\text { VG, amiton, } \\
\text { tetram, } \\
\text { inferno, } \\
\text { netramak } \\
\end{array}$ & $\begin{array}{c}\text { Colourless liquid, slight } \\
\text { fruit odour, well soluble } \\
\text { in water and organic } \\
\text { solvents }\end{array}$ & See VX & $\begin{array}{c}\text { Several days up to } \\
\text { a week }\end{array}$ & See VX \\
\hline Tabun & $\begin{array}{l}\text { GA, tabun, } \\
\text { Trilon 83, } \\
\text { T83, Gelan }\end{array}$ & $\begin{array}{c}\text { Colourless liquid with } \\
\text { a slight fruit odour, } \\
\text { a technical product } \\
\text { is green and yellow } \\
\text { to brown with an odour } \\
\text { of bitter almonds and } \\
\text { at large concentrations } \\
\text { it has a fishy odour } \\
\end{array}$ & \begin{tabular}{|c|} 
Poorly soluble in \\
water, mixes with \\
organic solvents, \\
mustard, lewisite \\
and hydrogen \\
cyanide, hydrolyses \\
slowly with the CN \\
group splitting off \\
\end{tabular} & \begin{tabular}{|c|} 
The surfaces \\
affected by liquid \\
tabun are contami- \\
nated for up to \\
2 days depending \\
on the wind, \\
temperature and \\
precipitation \\
\end{tabular} & $\begin{array}{l}\text { Full-face } \\
\text { mask, } \\
\text { filtration } \\
\text { protection } \\
\quad \text { suit }\end{array}$ \\
\hline $\begin{array}{l}\text { Medium } \\
\text { volatility } \\
\text { agent }\end{array}$ & $\begin{array}{c}\text { IVA, GP, GV, } \\
\text { Novichok }\end{array}$ & $\begin{array}{c}\text { Colourless, little stable } \\
\text { liquid that turns into a } \\
\text { white solid depending } \\
\text { on the temperature }\end{array}$ & Not mentioned & $\begin{array}{c}\text { Several days } \\
\text { depending on the } \\
\text { weather }\end{array}$ & See VX \\
\hline
\end{tabular}

If nerve agents enter the eye, it is necessary to flush it with a large amount of water and, if organophosphates are ingested, it is necessary to induce vomiting with the administration of animal charcoal. Basic life functions should be ensured, i.e. when apneusis occurs, the mouth-to-mouth resuscitation should be provided after decontaminating the face or the resuscitation apparatuses should be used. 


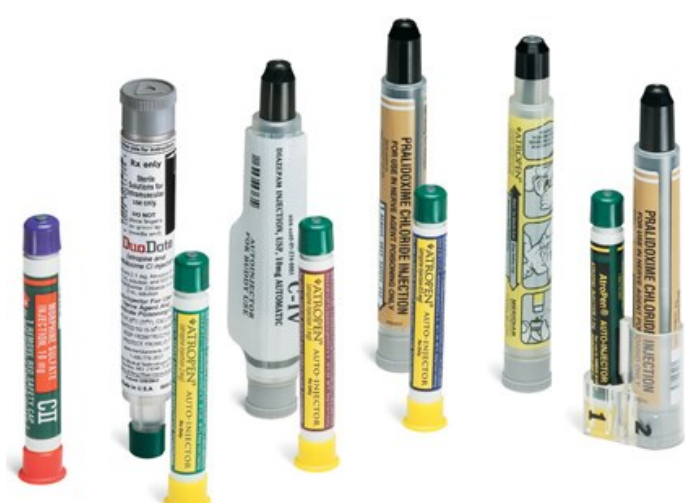

Figure 99: DuoDote, Mark I and ComboPen auto-injectors filled with morphine, diazepam, atropine and 2-PAM against nerve agents. [Source: Fig-99]

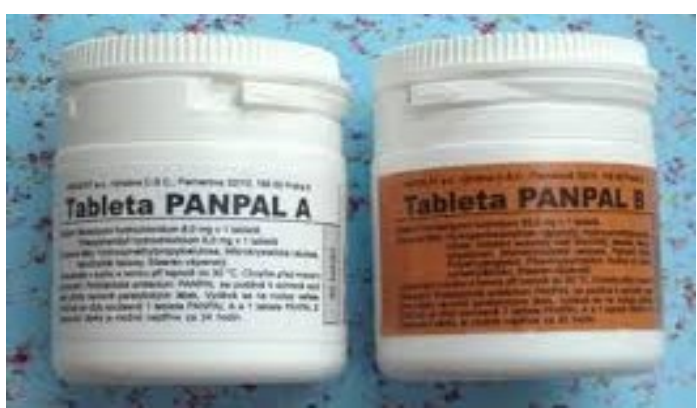

Figure 100: Prophylactic antidote called PANPAL. [Source: Fig-100]

When cardiac arrest occurs, an indirect heart massage is required. If the person is unconscious, he/she should be maintained in a stabilized position. The basis is an antidote therapy with the administration of atropine and obidoxime (ComboPen auto-injector) in 10 to 30-minute intervals up to the first symptoms of pupil dilation and skin redness. In the military, there is also a prophylactic antidote in the form of tablets called PANPAL.

\subsubsection{The FOLIANT Program - Novichoks and their properties, structure, reactivity}

According to a US Army secret intelligence report of the National Ground Intelligence Center in the Military Intelligence Digest of January 24, 1997 "the substances developed in the FOLIANT program are as toxic as VX, resistant to treatment as soman, more difficult to be detected and easier to be manufactured". Allegedly, the binary versions of the substances use acetonitrile and organic phosphate "which can be disguised as a precursor to pesticides".

In the case of data on the ownership of chemical weapons and their destruction, we may proceed from the official declarations of states possessing these weapons and subsequently from the data of the Organization for the Prohibition of Chemical Weapons (hereinafter referred to as OPCW). In the case of the Novichok group of agents, we do not dispose any official data and we must start from not always objective and truthful information. Let us assume that in the 1970s and 1980s, intensive innovation efforts were under way both in the United States and in the Soviet Union with the view to find new chemical warfare agents with generally more advantageous properties applicable essentially in the binary system.

The essence of binary recipes is the formation of a relevant chemical warfare agent by the rapid synthesis from relatively non-toxic compounds (precursors) when firing or transporting chemical ammunition to the target. In particular, some of the disadvantages of the two most important nerve agents have been eliminated - namely the high volatility of sarin and, on the contrary, the very low volatility of VX, which depreciates its percutaneous effectiveness when affecting through any textile barriers. The name Novichok used for a number of compounds without specifying any chemical formulas was widely used in a publication issued by The Henry L. Stimson Center in 1995. Table 50 presents these agents according to Mirzayanov.

The structural data on the group of organophosphorus compounds categorized by D. Hank Ellison according to a common name "Novichoks" was first provided in the second edition of the Handbook of Chemical and Biological Warfare Agents in 2008. The handbook presents the structure of 58 compounds which, according to the author, fall into the Novichok family of nerve agents; they are organophosphates with various combinations of heteroatom substituents, including oxygen, carbon, nitrogen, fluorine and bromine atoms. The index names were assigned to all of these compounds in the American Society Chemical Abstract System, which indicates that they were synthesized. 
Table 49: Nerve agents. [Source: Tab-49]<smiles>CC(C)OP(C)(=O)F</smiles>

$$
\begin{gathered}
\mathrm{C}_{4} \mathrm{H}_{10} \mathrm{FO}_{2} \mathrm{P} \\
\mathrm{M}_{\mathrm{r}}=140.09
\end{gathered}
$$

Sarin (GB) O-isopropylmethylphosphonofluoridate)<smiles>CCOP(C)(=O)SCCN(C(C)C)C(C)C</smiles>

$$
\begin{gathered}
\mathrm{C}_{11} \mathrm{H}_{26} \mathrm{NO}_{2} \mathrm{PS} \\
\mathrm{M}_{\mathrm{r}}=267.36
\end{gathered}
$$

O-ethyl-S-[2-N,N(diisopropylamino)ethyl]methylphosphonothioate (American VX)<smiles>CC(OP(C)(=O)F)C(C)(C)C</smiles>

$\mathrm{C}_{7} \mathrm{H}_{16} \mathrm{FO}_{2} \mathrm{P}$

$\mathrm{M}_{\mathrm{r}}=182.17$

Soman (GD)

O-(3,3-dimethylbutan-2-yl)methylphosphonofluoridate<smiles>CCN(CC)CCSP(C)(=O)OCC(C)C</smiles>

$$
\mathrm{C}_{11} \mathrm{H}_{26} \mathrm{NO}_{2} \mathrm{PS}
$$$$
\mathrm{M}_{\mathrm{r}}=267.36
$$

O-isobutyl-S-[2-N,N(diethylamino)ethyl]methylphosphonothioate (Russian Vx)

$$
\begin{gathered}
\mathrm{H}_{3} \mathrm{C}-\mathrm{CH}_{2}-\mathrm{CH}_{2}-\mathrm{CH}_{2}-\mathrm{O}^{\prime} \mathrm{S}-\mathrm{CH}_{2}-\mathrm{CH}_{2}-\mathrm{N}^{\prime} \mathrm{CH}_{2} \mathrm{CH}_{3} \\
\mathrm{C}_{11} \mathrm{H}_{26} \mathrm{NO}_{2} \mathrm{PS} \\
\mathrm{M}_{\mathrm{r}}=267,36
\end{gathered}
$$

O-butyl-S-[2-N,N(diethylamino)ethyl]- methylphosphonothioate (Chinese $V x$ )

In 2009, Vil S. Mirzayanov's book entitled "State Secrets: An Insider's Chronicle of the Russian Chemical Weapons Program" was published in the USA. This book provided the structural formulas of five compounds and their codes (A-230, A-232, A-234, A-242, A-262), which Mirzayanov also assigned to the Novichok group. These formulas do not correspond to the structures mentioned in the Ellison's book a year earlier. Mirzayanov in his book only deals with A-230 (referred to as substance 84) and A-232 to a very limited extent, however, in the other agents he only gives their formulas without any further specification.

However, other Russian specialists do not confirm these Mirzayanov's claims. According to Fedorov, the chemical formulas of these agents are not openly available. Another chemist, Vladimir Uglev, the assistant of Pyotr Kirpichev, actively participated in the development of Novichoks. He mentioned four agents developed in different years, which, however, were not called Novichoks; they were only denominated by codes. He designated them as A-1972, B-1976, C-1976 and D-1980 according to their dates of origin. The first three are liquid substances, the fourth is a powdered substance. They are organophosphorus compounds with an effect causing the injury to the nervous system; these compounds differ in their manufacturing method as well as combat using. Several hundreds of modifications of agents of this type were created in the group led by Kirpichev. "No newly developed agents can outperform them by their toxic properties."

According to him, the nerve agents known as Novichoks were developed in the laboratories in the region bordering the Volga River, in the city of Volsk; they were experimentally produced in volumes from 20 grams to several kilograms. According to him, they were working on the group of the Novichok nerve agents from 1972 to 1988. It is not possible to mistake the VX nerve agent for Novichok; the confusion with other agents of this type as sarin and soman is possible. No antidote exists. It is, therefore, not clear whether the name Novichok was officially mentioned in the program for the development of these agents. On the other hand, Fedorov himself questions it in his extensive book publication. In these documents we do not encounter the expression "Novichok program" or just "Novichok" anywhere, but only the A-232 nerve agent. It would, therefore, be correct to use the designation of the A-series nerve agents for these new chemical agents. 
Table 50: Mirzayanov's description of the Novichok program. [Source: Tab-50]

\begin{tabular}{|c|c|c|c|c|c|}
\hline $\begin{array}{l}\text { Name of the } \\
\text { compound }\end{array}$ & $\begin{array}{l}\text { Type of the } \\
\text { compound }\end{array}$ & $\begin{array}{l}\text { Research } \\
\text { program }\end{array}$ & Test Site & $\begin{array}{c}\text { Place of } \\
\text { production }\end{array}$ & Status \\
\hline R-33 agent & $\begin{array}{l}\text { Unitary agent similar } \\
\text { to VX nerve agent, } \\
\text { precursor to } \\
\text { Novichok }\end{array}$ & $\begin{array}{l}\text { GosNIIOKhT } \\
\text { Moscow }\end{array}$ & Shikhany & $\begin{array}{l}\text { Novoche- } \\
\text { boksarsk }\end{array}$ & $\begin{array}{l}15,000 \text { tonnes pro- } \\
\text { duced, declared } \\
\text { as VX under the } \\
\text { Wyoming } \\
\text { Memorandum }\end{array}$ \\
\hline $\begin{array}{l}\text { A-230 nerve } \\
\text { agent }\end{array}$ & $\begin{array}{l}\text { Unitary agent, } \\
\text { precursor to No- } \\
\text { vichok }\end{array}$ & $\begin{array}{l}\text { GosNIIOKhT } \\
\text { Shikhany } \\
\text { scientist Pyotr } \\
\text { Kirpichev }\end{array}$ & Nukus & $\begin{array}{l}\text { Shikhany } \\
\text { and } \\
\text { Volgograd }\end{array}$ & $\begin{array}{l}\text { Tested 1988-1989, } \\
\text { approved as a } \\
\text { chemical weapon } \\
\text { 1990, experimental } \\
\text { quantity (tens of } \\
\text { tonnes) produced. }\end{array}$ \\
\hline $\begin{array}{l}\text { A-232 nerve } \\
\text { agent }\end{array}$ & $\begin{array}{c}\text { Unitary agent similar } \\
\text { to A-230, } \\
\text { precursor to } \\
\text { Novichok }\end{array}$ & $\begin{array}{l}\text { GosNIIOKhT } \\
\text { Shikhany } \\
\text { scientist Pyotr } \\
\text { Kirpichev }\end{array}$ & $\begin{array}{l}\text { Nukus } \\
\text { and } \\
\text { Shikhany }\end{array}$ & $\begin{array}{l}\text { Shikhany } \\
\text { and } \\
\text { Volgograd }\end{array}$ & \begin{tabular}{|} 
Experimental quantity \\
(a few tonnes) \\
produced, not \\
approved by the \\
Army. \\
\end{tabular} \\
\hline Novichok-5 & $\begin{array}{l}\text { Binary agent based } \\
\text { on A-230, } \\
5-8 \text { times more } \\
\text { potent than VX. }\end{array}$ & $\begin{array}{l}\text { GosNIIOKhT } \\
\text { Moscow } \\
\text { chief Igor Va- } \\
\text { siliev and } \\
\text { Andrej } \\
\text { Zheleznyakov } \\
\end{array}$ & Nukus & $\begin{array}{l}\text { Shikhany } \\
\text { and } \\
\text { Volgograd }\end{array}$ & $\begin{array}{c}\text { Tested 1989-1990, } \\
\text { approved as } \\
\text { a chemical weapon } \\
\text { 1989, experimental } \\
\text { quantity (a few } \\
\text { tonnes) produced. } \\
\end{array}$ \\
\hline $\begin{array}{l}\text { Novichok-\#? } \\
\text { Name not cre- } \\
\text { ated }\end{array}$ & $\begin{array}{l}\text { Binary agent based } \\
\text { on R-33 }\end{array}$ & $\begin{array}{c}\text { GosNIIOKhT } \\
\text { Moscow and } \\
\text { Shikhany }\end{array}$ & $\begin{array}{l}\text { Nukus } \\
\text { and } \\
\text { Shikhany }\end{array}$ & $\begin{array}{l}\text { Novoche- } \\
\text { boksarsk } \\
\text { and } \\
\text { Shikhany }\end{array}$ & $\begin{array}{l}\text { Tested 1988-1989, } \\
\text { approved as } \\
\text { a chemical weapon } \\
\text { 1990, experimental } \\
\text { quantity (tens of } \\
\text { tonnes) produced. }\end{array}$ \\
\hline Novichok-7 & $\begin{array}{l}\text { Binary agent based } \\
\text { on soman nerve } \\
\text { agent, 5-8 times } \\
\text { more potent. }\end{array}$ & $\begin{array}{l}\text { GosNIIOKhT } \\
\text { Moscow } \\
\text { chief } \\
\text { George Drozd }\end{array}$ & Shikhany & Shikhany & \begin{tabular}{|c|} 
Tested in 1993. \\
Experimental quantity \\
(tens of tonnes) \\
produced.
\end{tabular} \\
\hline
\end{tabular}

Note:

GosNIIOKhT Государственный научно исследовательский институт органической химии и технологии (The State Scientific Research Institute of Organic Chemistry and Technology RF)

Properties - we do not have basically any authorized data on the properties of Novichoks at our disposal, only a few pieces of information from the Mirzayanov's book. Agents A-230 and A-232 should be liquids.

The disadvantage of agent A-230 was that it crystallized in containers at temperatures below $-10^{\circ} \mathrm{C}$. To relieve this shortage, N, N-dimethylformamide as a solvent was added. Even in this case, the toxicity of A-230 remained high. According to Mirzayanov it exceeded the toxicity of the Russian Vx agent 5-8 times depending on the route of administration, (percutaneous or intravenous). A-232 is as toxic as Vx, and is much more volatile than Vx and A-230. It is less stable to moisture than both of these agents. A-242 and A-262 should be highly toxic solids. Novichoks should easily overcome the standard chemical protection, penetrate rubber seals and otherwise efficient activated carbon filters.

No data on the nerve agent A-234 is available. Mirzayanov mentioned only its formula in his book. In the media, the nerve agent A-234 is repeatedly reported as a binary one only. 
However, such a chemical may exist as a unitary substance and, at the same time, can be prepared as a binary one, if necessary. During the investigation into the Skripals' poisoning incident, unconfirmed information about the significant instability of this agent (decomposition in the English fog) and exceptional toxicity appeared; its high purity of 97-98\% found during the analysis in the laboratories at Porton Down and subsequently in the OPCW laboratories was confirmed. However, the fact that samples should contain decomposition products is questioned by the former Russian workers involved in the research into the agents of this group. The views of the stability of this agent differ considerably as well. Nerve agents of the Novichok group should be organic phosphorus compounds, organophosphates, specifically phosphonofluoridates, or more precisely phosphorofluoridates. The toxic effect of a chemical is dependent primarily on the dose of the chemical, its physical and chemical properties, the route of entry into the organism, the speed of effect, the acting time and the state of the organism.

Non-traditional methods of producing nerve agents were used in preparing the agents of the Novichok family. For the first time, an acetamide radical (forming a P-N bond) was inserted into the sarin or soman molecule instead of the O-alkyl radical. Nevertheless, experts agree that the preparation of gram amounts under laboratory conditions should not be complicated. According to some of them, a chemist, a graduate from the master's study in the organic chemistry specialization, should be able to undertake this preparation using the laboratory equipment of a common organic laboratory. However, the condition is to equip the laboratory for work in hazardous conditions, especially with functional air conditioning with appropriate filters. With regard to the small-scale production or even the industrial-scale production, the conditions would be more complex and would require a specialized manufacturing equipment.

Structure of $\boldsymbol{A - 2 3 0 ,} \boldsymbol{A - 2 3 4}$ - the structural data on the group of organophosphorus compounds categorized by D. Hank Ellison under the generic title "Novichoks" was first provided in the second edition of the Handbook of Chemical and Biological Warfare Agents in 2008. The handbook presents the structure of 58 compounds, which, according to the author, fall into the Novichok family of nerve agents and are organophosphates with various combinations of heteroatom substituents, including oxygen, carbon, nitrogen, fluorine and bromine atoms. The index names were assigned to all of these compounds in the American Society Chemical Abstract System, which indicates that they were synthesized. In 2009, Vil S. Mirzayanov's "State Secrets: An Insider's Chronicle of the Russian Chemical Weapons Program" was published in the USA. This book provided the structural formulas of the five compounds and their codes (A-230, A-232, A-234, A-242, A-262), which Mirzayanov also assigned to the Novichok group. These formulas do not correspond to the structures that were introduced a year earlier in the Ellison's book. In his book, Mirzayanov deals only with A-230 (or 84 agent) and A-232 to a very limited extent, but in the other agents he only indicates their formulas without any further specification. The main advantage of A-232 when compared to R-33 (Russian VX) is its substantially higher volatility. The two-component synthesis of R-33 has also been studied in parallel within the project. In addition to the required 2-(diethylamino)ethane-1-thiol, isobutyl methyl-phosphonocyanidate analogous to Novichoks has been chosen as a basic precursor.

Structurally, A-230 and A-234 are similar. The difference lies in the fact that A-230 is a derivative of methylphosphonic acid and A-234 is a derivative of phosphoric acid. In the case of A-230, a methyl group is bound to the phosphorus atom and in the case of A-234 to an ethyloxy group. Four strongly electronegative atoms (fluorine, nitrogen, two oxygen atoms) and groups in case of A-234 and three electronegative groups (fluorine, nitrogen, oxygen) in case of A-230 are bound to the central phosphorus atom. In chemistry, electronegativity is a property of an atom, expressing its ability to attract bonding electrons. 
Table 51: Structural formulas of five Foliant compounds and their codes. [Source: Tab-51]<smiles>CCN(C)C=NP(C)(=O)F</smiles>

A-230 (nerve agent)

methyl-\{N-[1-(diethylamino)ethylidene]amido\} phosphonofluoridate<smiles>CCN(C)CC</smiles>

A-234 (nerve agent)

$\mathrm{N}$-[1-(diethylamino)ethylidene] amido-

O-ethyl-phosphorofluoridate<smiles>CP(=O)(F)N=C(N([N+](=O)[O-])[N+](=O)[O-])[N+](=O)[O-]</smiles>

A-242 agent

wherein $\mathrm{R}$ is

a diethyl radical<smiles>CCN(C)C=NP(=O)(F)F</smiles>

A-232 (nerve agent)

$\mathrm{N}$-[1-(diethylamino)ethylidene]amidoO-methyl-phosphorofluoridate

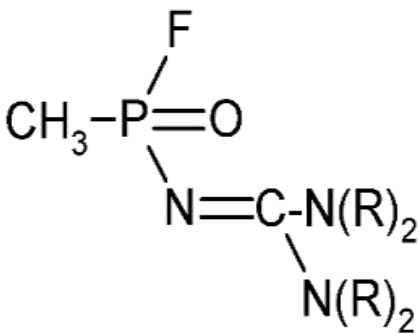

A-262 agent

The Novichok agents should be organophosphorus compounds, organophosphates, specifically phosphonofluoridates or phosphorofluoridates. The toxic effect of a chemical is dependent primarily on the dose of the chemical, its physical and chemical properties, the portal of entry into the organism, the rate of action, the acting time (exposure) and the state of the organism. Organophosphates are nerve agents; they inhibit the enzyme called acetylcholinesterase when they enter the body. This enzyme is necessary for the correct termination of nerve impulse transmission in the body. Thus, the concentration of acetylcholine, the transmitter of nerve impulses, rises, its hydrolysis is blocked in the synapse. An endogenous acetylcholine intoxication happens in the body, which is the main cause of toxic effect of nerve agents.

The dealkylation of inhibited acetylcholinesterase is essential for the treatment of nerve agent intoxication since dealkylated acetylcholinesterase is resistant to cholinesterase reactivators. The rate of dealkylation is dependent on the contact time of the enzyme with the nerve agent and on the chemical structure of the nerve agent.

From this viewpoint, the nerve agents, in which dealkylation proceeds rapidly, are very dangerous as the administration of the reactivator becomes ineffective after a suitable time is missed. The half-life of the dealkylation of acetylcholinesterase inhibited by soman is very fast, in the order of minutes (about 10 minutes), as for sarin the dealkylation is slower (half-life around 10 hours) and as for VX, the dealkylation has virtually not been observed within 24 hours. Some other sources report the values as follows: tabun 14 hours, sarin 5 hours, soman 2-6 minutes and VX 48 hours. Although no data related to Novichok is available, fast dealkylation, hours, and thus complicated treatment can be expected in this case. 
Table 52: Toxicity of nerve agents. [Source: Tab-52]

\begin{tabular}{|c|c|c|}
\hline \multirow{2}{*}{ NAs } & \multicolumn{2}{|c|}{ Mean lethal dose $\mathrm{LD}_{50}\left(\mathrm{mg} \cdot \mathrm{kg}^{-1}\right)$ for rats } \\
\cline { 2 - 3 } & intramuscularly & percutaneously \\
\hline GB & 0.096 & 84.00 \\
\hline GD & 0.069 & 11.25 \\
\hline GF & 0.080 & 3.94 \\
\hline VX & 0.015 & 0.077 \\
\hline GP & 0.017 & 1.37 \\
\hline
\end{tabular}

Note: according to MATOUSEK, J., MASEK, I. On the New Potential Supertoxic Lethal Organophosphorus Chemical Warfare Agents with Intermediary Volatility. The ASA Newsletter, 94-5, No 44, October 7, 1994.

GB sarin: O-isopropyl-methyl-phosphonofluoridate)

GD soman: O-(3,3-dimethylbutan-2-yl)-methyl-phosphonofluoridate

VX agent VX: O-ethyl-S-[2-N,N(diisopropylamino)ethyl]-methyl-phosphonothioate

GF cyklosin: O-cyklohexyl-methyl-phosphonofluoridate

GP agent GP: $N, N$-dimethyl-amido-O-[(2-dimethylamino)ethyl]phosphorofluoridate

Table 53 lists some of the physicochemical properties of nerve agents (NAs). In different sources, the data on the properties of these agents is variant, but here it serves to the mutual comparison.

Table 53: Physicochemical properties of some nerve agents. [Source: Tab-53]

\begin{tabular}{|c|c|c|c|c|c|}
\hline NAs & $\begin{array}{c}\text { Molecular } \\
\text { mass }\end{array}$ & $\begin{array}{c}\text { Specific weight } \\
\left(\mathrm{g} . \mathrm{ml}^{-1}\right)\end{array}$ & $\begin{array}{c}\text { Melting point } \\
\left({ }^{\circ} \mathrm{C}\right)\end{array}$ & $\begin{array}{c}\text { Boiling point } \\
\left({ }^{\circ} \mathrm{C}\right)\end{array}$ & $\begin{array}{c}\text { Maximum concentration } \\
\left(\mathrm{g} . \mathrm{m}^{-3}\right)\end{array}$ \\
\hline GA & 162.3 & 1.073 & -49 & 246 & 611 \\
\hline GB & 140.1 & 1.009 & -56 & 147 & 21,862 \\
\hline GD & 182.18 & 1.022 & -80 & 167 & 3,921 \\
\hline VX & 267.36 & 1.008 & -20 & 300 & 10.7 \\
\hline GP & 198.18 & 1.11 & 0 & $207-240$ & 700 \\
\hline GF & 180.14 & 1.133 & -12 & 239 & $659(581)$ \\
\hline
\end{tabular}

Note:

GA tabun: O-ethyl-N,N-dimethyl-phosphoramidocyanide

GB sarin: O-isopropyl-methyl-phosphonofluoridate

GD soman: O-(3,3-dimethylbutan-2-yl)-methyl-phosphonofluoridate

VX agent VX: O-ethyl-S-[2-N,N(diisopropylamino)ethyl]-methyl-phosphonothioate

GF cyklosin: O-cyklohexyl-methyl-phosphonofluoridate

GP agent GP: N,N-dimethylamido-O-[(2-dimethylamino)ethyl]phosphorofluoridate

Reactivity of $\boldsymbol{A - 2 3 0}$ and $\boldsymbol{A - 2 3 4}$ - the reactivity of organophosphorus compounds depends on the distribution of partial charges on the central phosphorus atom and on the surrounding substituents. The covalent bond between two atoms with different electronegativities is polarized.

The degree of polarization is directly proportional to the absolute value of the difference in the electronegativity of both atoms. The more electronegative atom thus acquires a small negative charge. Electron-attracting substituents show a negative inductive effect (-I), electronrepelling substituents have a positive inductive effect $(+\mathrm{I})$. The attraction of electrons by the inductive effect is indicated by an arrow on the respective bond. The electron shift $\pi$ of the multiple bond associated with conjugation (mesomeric effect) is represented by an arcuate arrow. 
In both agents, A-230 and A-234, these effects can be illustrated as follows:

Scheme 12: Mesomeric effect-electron shift $\pi$ of multiple bond. [Source: Sche-12]

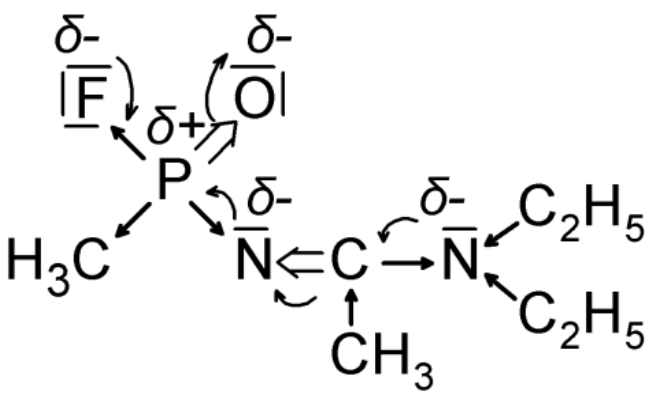

A-230 (nerve agent)

methyl-\{N-[1-(diethylamino)ethylidene]amido\} phosphonofluoridate

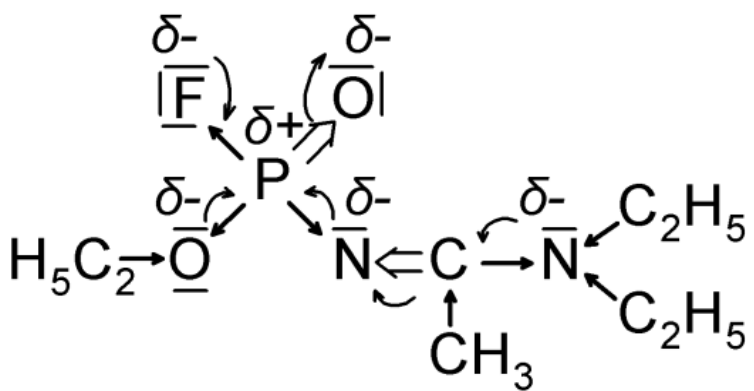

A-234 (nerve agent)

$\mathrm{N}$-[1-(diethylamino)ethylidene]amido-

O-ethyl-phosphorofluoridate

The result of the formation of a polarized bond is its easier heterolytic splitting and thus the higher reactivity of a given compound to electrophilic or nucleophilic reagents. In the reaction, nucleophilic reagents transfer or provide electrons for sharing with a chemical; electrophilic reagents in the reaction acquire or share electrons of a chemical.

The presence of four relatively strongly electronegative substituents in A-234 may lead to the assumption of the formation of a relatively large electron gap on the central phosphorus atom. However, due to the practically identical electronegativity of the substituents (the attracted electrons create an almost symmetrical arrangement of partial charges), which make further polarization of the molecule difficult, therefore, the nucleophilic substitutions on the phosphorus atom will proceed slowly.

Due to the conjugation between a free electron pair on the amide nitrogen and a multiple bond on the phosphoryl oxygen, the partial positive charge on the central phosphorus atom can also be reduced by the positive conjugation effect of this free electron pair. In addition, as Knunjanc states, with a suitable steric arrangement of the molecules, it is possible to assume the filling of an electron gap (reduction of the partial positive charge) on the central phosphorus atom by the action of a free electron nitrogen pair. The atoms that can be electron donors near the central phosphorus atom have the dispositions to react with electrophilic reagents. They are amide nitrogen, phosphoryl oxygen and fluorine. Fluorine, as the most electronegative element, attracts free electron pairs most strongly, and thus the electrophilic attack is out of the question. Upon the electrophilic attack of the phosphoryl oxygen, the introduced positive charge localizes on the oxygen or phosphorus atom, thereby increasing the dispositions for subsequent nucleophilic substitution, which results in the splitting of the P-F bond. The addition of the electrophilic reagent to the amide nitrogen will produce ammonium compounds.

The positive conjugation effect of a free electron pair disappears and a strong negative inductive effect of the ammonium nitrogen is created. This deepens the electron gap on the phosphorus atom and creates a disposition for the subsequent nucleophilic substitution. Therefore, the P-F bond will have a decisive influence on the reactivity of A-230 and A-234 owing to the strong electronegativity of fluorine. With regard to both the inductive effect and the mesomeric effect, there is a significant dilution of electrons on phosphorus, which allows reactions with nucleophiles. Fluorine completely attracts the electrons of the P-F bond and splits off as an anion. The rate of this elimination may differ in both agents, however, without taking necessary kinetic measurements it is not possible to estimate to what extent. Nevertheless, it can be assumed that slight differences in the structure of both of these agents will not result in a significant difference in their chemical properties. 
The chemical properties affect the use of the agent and its behaviour in the environment, which is used primarily for decontamination (detoxification). Hydrolysis, the most important chemical reaction of chemical warfare agents, oxidation, stability to packaging materials and thermal stability fall into chemical properties. Of course, this does not exclude the difference in other properties, physical and toxicological, when comparing these properties in other nerve agents (NAs) - sarin, soman, VX and Vx agents.

The latest published contribution to this issue is the Iranian scientists' work on the synthesis of the Novicok group. They synthetized five Novichok agents, along with four deuterated analogues. They were all $O$-alkyl $N$-[bis(dimethylamino)methylidene]- $P$-methylphosphonamidate compounds. Methoxy, ethoxy, isopropoxy, phenoxy and 2,6-dimethylphenoxy groups were used as O-alkyls. The measured spectral data were transmitted to the Technical Secretariat as a contribution to the OPCW Central Analytical Database.

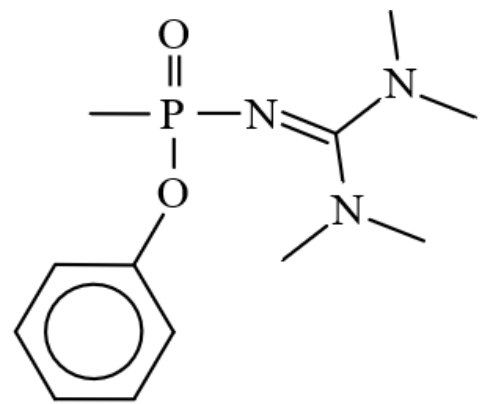

Figure 101: Example of Novichok derivatives from the research of Iranian scientists in 2016. [Source Fig-101]

According to unauthorized sources, chemical warfare agents on the basis of Novichok are to reach at least the VX toxicity (A 230) and others (A 232, A 234) are to reach the toxicity up to 5 to 8 times higher. If this information is confirmed, then the present parameter (detection limit) of the chemical reconnaissance means no longer proves satisfactory. This also applies to modern armies. The only exception is the means based on the biochemical cholinesterase reaction since its sensitivity correlates with the inhibiting effect and thus the toxicity of nerve agents. Due to the long-term focus on the research of the biochemical cholinesterase reaction, the Czech Republic has sufficient chemical reconnaissance means and sufficient control based on this reaction as well as toxicological knowledge necessary for effective prophylaxis.

\subsubsection{Novichoks and control measures under the Convention on the Prohibition of Chemi- cal Weapons}

The Convention on the Prohibition of Chemical Weapons (hereinafter referred to as the Convention) defines namely three schedules of chemicals (the so-called scheduled chemicals) for control purposes and, at the same time, it lays down the rules for the control of the other organic chemicals not included in the schedules (unscheduled discrete organic chemicals).

\section{It sets out the following principles for including the chemicals in these schedules:}

\section{Schedule 1:}

a) The chemical has been developed, produced, stockpiled or used as a chemical weapon as defined in Article II;

b) The chemical poses otherwise a high risk to the object and purpose of this Convention by virtue of its high potential for use in activities prohibited under this Convention because one or more of the following conditions are met:

- It possesses a chemical structure closely related to that of other toxic chemicals listed in Schedule 1, and has or can be expected to have, comparable properties;

- It possesses such lethal or incapacitating toxicity as well as other properties that would enable it to be used as a chemical weapon;

- It may be used as a precursor in the final single technological stage of production of a toxic chemical listed in Schedule 1, regardless of whether this stage takes place in facilities, in munitions or elsewhere;

c) The chemical has little or no use for purposes not prohibited under this Convention. 


\section{Schedule 2:}

a) The chemical poses a significant risk to the object and purpose of this Convention because it possesses such lethal or incapacitating toxicity as well as other properties that could enable it to be used as a chemical weapon;

b) The chemical may be used as a precursor in one of the chemical reactions at the final stage of formation of a chemical listed in Schedule 1 or Schedule 2, part A;

c) The chemical poses a significant risk to the object and purpose of this Convention significantly by virtue of its importance in the production of a chemical listed in Schedule 1 or Schedule 2, part A;

d) The chemical is not produced in large commercial quantities for purposes not prohibited under this Convention.

\section{Schedule 3:}

a) The chemical has been produced, stockpiled or used as a chemical weapon;

b) The chemical poses otherwise a risk to the object and purpose of this Convention because it possesses such lethal or incapacitating toxicity as well as other properties that might enable it to be used as a chemical weapon;

c) The chemical poses a risk to the object and purpose of this Convention by virtue of its importance in the production of one or more chemicals listed in Schedule 1 or Schedule 2, part B;

d) The chemical may be produced in large commercial quantities for purposes not prohibited under this Convention.

The Convention also specifies a clear control regime for the production of chemicals unregistered in schedules. This applies to certain organic chemicals, i.e. any chemicals belonging to the class of chemicals consisting of all carbon compounds except its metal oxides, metal sulphides and carbonates identifiable by a chemical name, structural formula, if known, and Chemical Abstracts Service registration number, if it is assigned.

Particular emphasis is placed on the so-called PSF chemicals, which are certain non-scheduled organic chemicals containing the elements phosphorus, sulphur or fluorine. Production sites that have produced exclusively explosives or hydrocarbons are not subject to control. What does this mean for agents A-230 and A-234 we are monitoring? None of these agents (let's note that neither the GP agent) was specifically included in Schedule 1 of chemicals of the Convention (highly dangerous agents according to Act No. 19/1997 Coll.) and, therefore, they are not subject to the strictest declarative and control measures.

From the viewpoint of its structure, the A-230 agent falls into Schedule 2 of part B, precursors, point 4) of chemicals according to the Convention. These are chemicals with the exception of the agents listed in Schedule 1 containing a phosphorus atom, to which one methyl, ethyl, n-propyl or i-propyl group is bonded, but not further carbon atoms. Initial and annual declarations are required for all production sites that contain one or more plants, in which more than 1 tonne of this chemical has been produced, processed or consumed during any of three preceding calendar years, or is expected to be produced, processed or consumed in the next calendar year. At the same time, national data on imported and exported quantities of these substances is submitted within the declaration of aggregate national data. The control is carried out through an on-the-spot inspection at those declared production sites, which contain one or more plants, in which more than 10 tonnes of this chemical has been produced, processed or consumed during any of three preceding calendar years, or is expected to be produced, processed or consumed in the next calendar year. The national reporting limit according to Act No. 19/1997 Coll. was set at $0.1 \mathrm{~kg}$ of list 2-part A substance with the symbol "*"; $10 \mathrm{~kg}$ of list 2-part A substance outside the symbol "*" or $100 \mathrm{~kg}$ of list 2-part B substance.per year. 


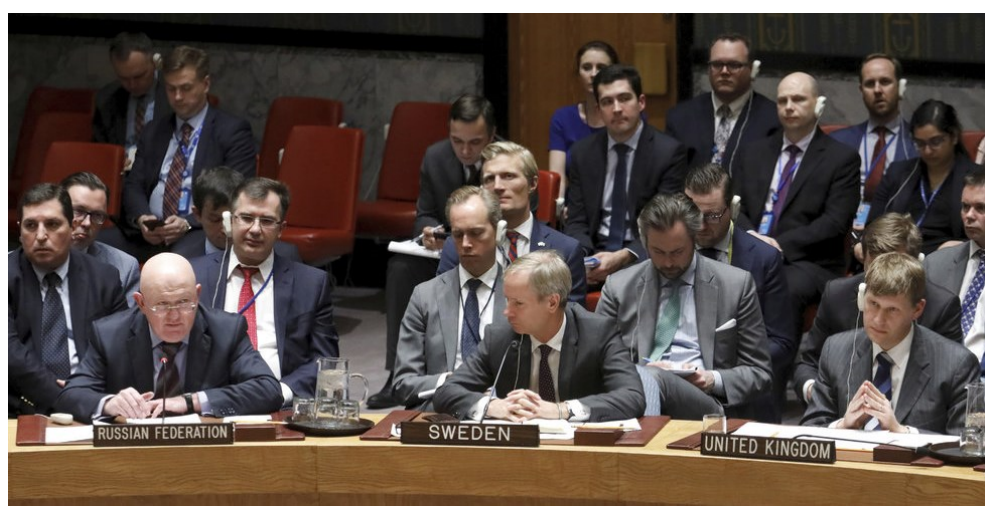

Figure 102: The UN Security Council talks on the case of Sergei Skripal. PHOTO: Reuters. [Source: Fig-102]

A-234 would fall under the Convention regime for other chemical production facilities ("PSF plants" and "PSF chemicals"). The declaration includes one or more plants, which have produced through synthesis more than 30 tonnes of unscheduled discrete organic chemicals containing the elements phosphorus, sulphur or fluorine during the previous calendar year. The control is carried out through an on-the-spot inspection at the production sites comprising one or more PSF plants, which have produced more than 200 tonnes of PSF during the previous calendar year.

The often-repeated claim of the media that these chemicals are not controlled by the Convention is not true. There is a question why they are not included in Schedule 1 of the Convention, where, of course, they would be subject to the most demanding control regime. The Schedules of controlled chemicals were rigorously assessed in the 1980s when the draft text of the Convention was being discussed. And it had to be approved by consensus, which was not easy with regard to the differences of opinions of all participating states. It should also be taken into account that at that time no information on the American GP agent, let alone on the newly developed A-series nerve agents in the Soviet Union was publicly available. Although, in the Convention, a mechanism of amendments to its text is carefully elaborated, to this very day only two amendments have been adopted, in particular in the Verification Annex. There, the procedure of amendments is not as strict as in the amendments to the text itself and also to the Schedule of controlled chemicals.

On April 18, 2018, at the OPCW 59 ${ }^{\text {th }}$ Meeting of the Executive Council, the Russian Federation recommended the Director-General to prepare and submit to the Executive Council a draft decision providing the possibility to begin practical work on amending the Annex on chemicals, in accordance with paragraph 5 of Article XV of the CWC ("Amendments" to the Convention) in order to enhance the Convention regime.

In May 2018, the Russian Federation sent a 400-page document to the OPCW Technical Secretariat that contained its proposals for the inclusion of nearly 1,000 new nerve agents in the Schedules of controlled chemicals.

In his address to the $23^{\text {rd }}$ Session of the Conference of States Parties to the CWC, the Director-General declared that on October 16, 2018 he had received a proposal from Canada, the Netherlands and the United States for the technical amendment to Schedule 1 of the Convention containing two groups of chemicals, including the chemical used in the incident in the UK. Now the Technical Secretariat evaluates this proposal in accordance with Article XV "Amendments" to the Convention.

\subsubsection{Cases of using the agents of the Novichok group, developed under a Soviet pro- gramme codenamed FOLIANT}

\subsection{Poisoning of banker Kivelidi}

The agent from the Novichok group was allegedly used to assassinate banker Kivelidi in August 1995 in Moscow. Ivan Kivelidi, the head of Rosbusinessbank, and his secretary Zara Ismailova died. 
Other people were also affected - a cleaning lady, eight police officers and visitors to Kivelidi's office that day. The poison was placed beneath the rubber cap that covered a tubular screw in his telephone receiver. The cap was just over five millimetres in diameter, so only a very small amount of toxicant was sufficient. The composition of this toxicant was studied independently by three different institutions as follows: The Ministry of the Interior's Expert Centre for Criminology, the Institute for the Environment and Evolution and the Russian Academy of Sciences. All three arrived at the same chemical composition. The Academy of Sciences stated that it was a substance that falls into the class of highly toxic organic phosphorus compounds used in the manufacture of chemical weapons. The Expert Centre for Criminology drew a similar conclusion and stated that the substance also contained fluorine.

The banker then died of hepatic failure, as did his secretary and later a forensic expert who worked on the case. A long-time acquaintance of the murdered banker and former board member of Rosbusinessbank was convicted of murder for nine years; allegedly, he liquidated the banker out of envy. However, the trial took place in private. Leonid Rink, a former research worker at the Saratov Institute of GNIIOKhT in Shikhany, appeared as a witness. Rink admitted that he had taken out 9 vials of Novichok hidden in ballpoint pens from the Institute. "We used only one gram of the agent. We divided the gram into quarters and put them into vials, which I took home and hid them in the garage."

Rink sold the poison to a few people connected to criminal structures and Chechen guerrillas. Rink no longer remembered how much money he had made for poison that could have killed hundreds of people - supposedly either $\$ 1,500$ or $\$ 1,800$. According to the newspaper, he stated in court that people had needed the agent to settle an old score in criminal circles. He said he himself had been the target of blackmail and persecution on the part of criminals.

Table 54: The Novichok nerve agent formula for the forensic analysis in the case of Kivelidi. [Source: Tab-54 A, B, C]

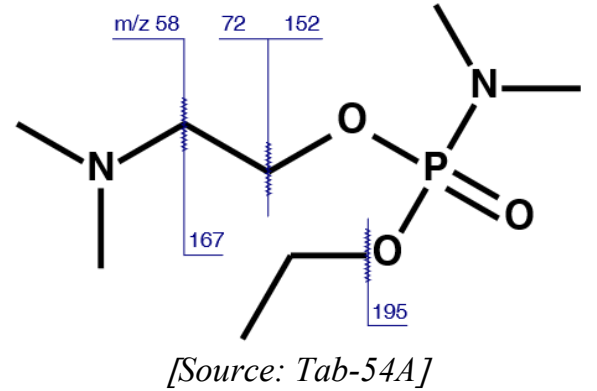

[Source: Tab-54A]

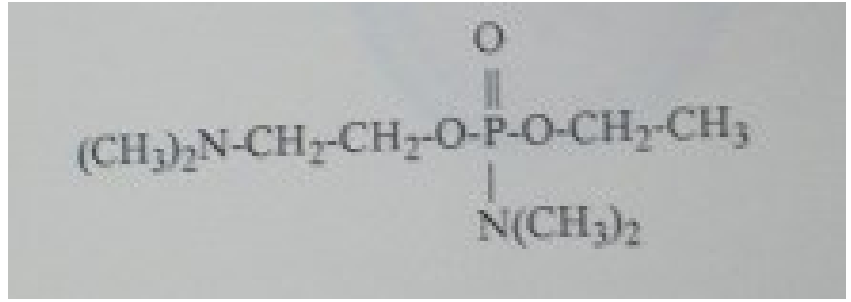

[Source: Tab-54B]

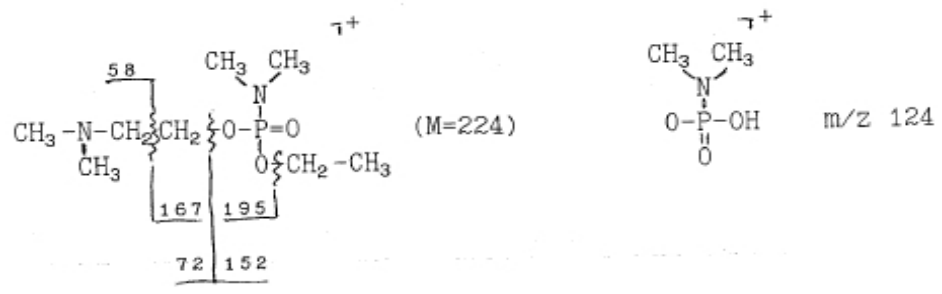

[Source: Tab-54C]

Note-sources:

[Tab-54A] https://en.wikipedia.org/wiki/File:Novichok agent formula from_Kivelidi_case.svg

[Tab-54B] https://www.facebook.com/photo.php?fbid=10216168878285530\&set =pcb.10216168879565562\&type $=3$ \& theater

[Tab-54C] https://static.novayagazeta.ru/storage/content/pictures/14022/content_001_doc7.jpg

First, they allegedly claimed that they needed the poison for poisoning a dog, but later demanded the poison for humans. "At first, I gave them something simple, I thought I would get rid of them; however, later I gave them something stronger. I kept one vial as a sample." 
Allegedly, Rink also admitted that he had persuaded a former colleague from the Institute to produce the poison based on his instructions; then, allegedly, he sold it for $\$ 1,500$. He was investigated for abuse of power in the 1990s, however, due to lack of evidence, the justice stopped the entire proceedings in 1999. On March 24, the findings of Novaya Gazeta journalists were described as a mystification by the scientist's daughter, Olga Rinkova. "We will apply to the court," she communicated her father's decision.

\subsection{Poisoning of Muslim leaders}

Two cases of the liquidation of two North Caucasian terrorist leaders are publicly known. The feared Black Arab, Field Commander Khattab, as well as the leader of the so-called Caucasus Emirate, Doku Umarov, succumbed to the poisoning caused by the Russian Federal Security Service.

It was not easy to find the feared terrorist Khattab for the Security Service. Khattab was accompanied by devoted warriors. He never used modern means of communication to communicate with the other field commanders and the Middle Eastern patrons; he used a network of couriers. The death of the Chechen President Dzhokhar Dudayev was a warning for him; the President was hit by a rocket guided to the signal of his satellite phone.

The Federal Security Service (FSS) of the Russian Federation managed to recruit Ibragim Magomedov, a courier who was conveying cash and letters from Saudi Arabia to the Black Arab. According to Rosbalt, the Russian website, in March 2002, the members of the FSS inserted a nerve agent in a letter addressed to Khattab. The poison was to begin to take effect after some time so that the field commander's death might look like food poisoning. The operation was successful. Khattab opened the letter and, after reading it, he burned the letter and envelope. After a few days, his health condition deteriorated. He started foaming at the mouth and the feared terrorist died suddenly. His bodyguards initially thought their commander had been poisoned by mushrooms. When other people holding the letter began to die, it was clear that Moscow was behind Khattab's death. The suspicion of the terrorists fell on the messenger who brought the letter. Under pretence of traveling to Saudi Arabia, the unsuspecting Magomedov was lured out to Azerbaijan. His dead body was found on the outskirts of Baku.

Doku Umarov organized several bloody assassinations. In addition to the explosions in the Moscow Metro, he claimed responsibility for the bombing of an express train travelling from Moscow to St. Petersburg in November 2009 or a bomb attack at Moscow's Domodedovo airport in January 2011. At a certain time, he was in the top ten of the FBI's most wanted.

The pursuit of Umarov by the Russian Security Service lasted 10 years. It managed to get close to the country's most feared terrorist in the summer of 2013. The versions of how Umarov was liquidated differ. According to one of them, the North Caucasian emir was poisoned during the appointment of a new commander of the Ingush militia unit. According to the second of them, Umarov took a potent poison during an inspection of a secret terrorist base in the mountains. The Islamists admitted the death of their leader in March 2014. Three years later, the tomb of Doku Umarov was discovered in the forests of Ingushetia. The Russian Interfax News Agency, referring to its source, added succinctly that the found body of the North Caucasus terrorists' leader had been still very toxic.

\subsubsection{Case study dealing with the poisoning of Sergei Skripal and his daughter Yulia Skripalova}

The contradictory information about the double agent Skripal's case has been spread from the UK since the very beginning. Gradually, we learned from official sources that the Russian agent and his daughter had been poisoned in different places, often far from each other. 
Experts provided us with diametrically different data on the amount of the toxicant used. We were informed that the victims' health conditions were hopeless, then we learned that the consequences would be permanent to be finally sure that both victims were OK. Of course, they must not talk to anyone. At the same manner, the data on the total number of people at risk, the number of people affected and those who had to be treated differed. At first, we were assured that Novichok (or more precisely its various types) was handled in Russia only. Gradually, the number of countries increased, so it is not easy to determine, which countries do not know this absolutely deadly nerve agent, the consequences of which, are not fortunately fatal.

According to the report of the OPCW Technical Secretariat from April 12, 2018, the substance, which was identified at the Salisbury incident site as well as its structure and mass spectrum, was registered in the spectral database of the American National Institute of Standards and Technology (NIST), version 1998 (NIST 98). The database contained a connection indicating that the spectrum of this compound had been provided by the Edgewood Chemical Biological Center of the US Army Research, Development and Engineering Center. This fact clearly indicates that this substance was synthesized and subjected to the spectral and possibly other research.

\subsection{Sequence of events from March 4, 2018 to February 14, 2019}

March 04, 2018 - Sergei Skripal and his daughter Yulia were found unconscious on a bench in Downtown Salisbury and hospitalized in a critical condition with suspected poisoning by a highly toxic substance. The testimonies of witnesses present on the scene about the symptoms of poisoning varied considerably. One of the witnesses testified that they both had looked like they had been getting something really strong. A couple, an elderly man and a younger woman, were sitting on the bench. She was leaning against him and seemed to be unconscious.

He was waving his hands strangely and was looking up to the sky. According to another witness, her eyes were wide open, but completely white, she had foam at the mouth. The man was motionless. The symptoms of poisoning were also described by the police who arrived at the crime scene. The woman was lying on the ground on her side. A doctor, who happened to be going past, provided assistance to her and cleared her airways. The man was sitting motionless on the bench in a catatonic stupor (stiffness with the inability to move and talk), staring into space. He was breathing, but he didn't react to anything. Sergei Skripal remained in this stance even when the doctors tried to place him on a stretcher. He was sitting and could not move or change his position. Yulia came around for a moment during the transfer to the hospital, however, she lost consciousness quickly.

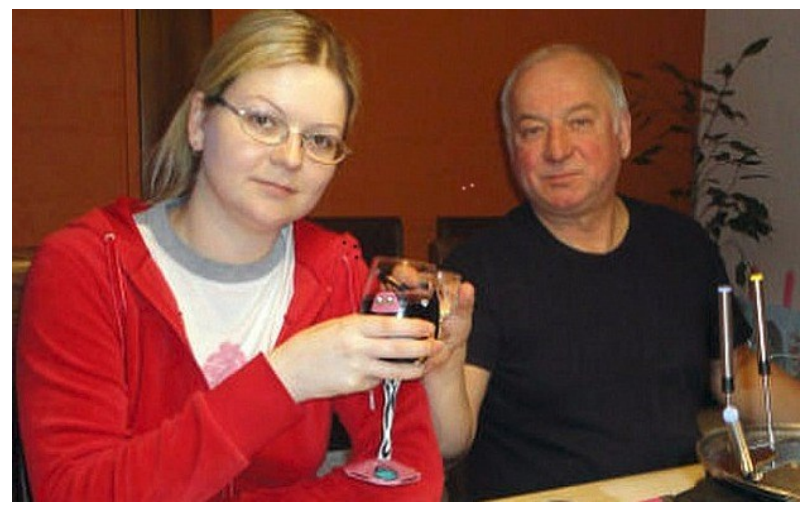

Figure 103: Yulia (33) with her father Sergei Skripal. PHOTO: Dailymail. [Source: Fig-103]

On the same day, the police closed the places where the two victims were staying, including the residence of Skripal, and had preventive decontamination carried out by workers in chemical protective suits. The restaurant and part of the shopping centre they passed through were closed, and the nearby inn as well.

March 05, 2018 - Laboratory tests of the chemical used to poison the Skripals took place in the Defence Science and Technology Laboratory at Porton Down. A media report states that this substance could be fentanyl, a synthetic opioid, which is up to a hundred times more effective than morphine. 
March 06, 2018 - Detective Sergeant Nick Bailey that was sent to Skripal's house together with his two colleagues on Sunday, March 04, was hospitalized. Although everyone was wearing a chemical protective suit, the Detective Sergeant stopped feeling well when he returned home. His pupils were like pinheads, he was sweaty and hot. He attributed it to stress, but when he did not feel well even on Tuesday (March 06), he went to the hospital. Doctors gave him medicaments, even though they didn't know what substance he had come in contact with. When they found out that it was Novichok, they started intensive treatment. All the time he was conscious and he received many injections. He had five or six infusions in his arm at once and was physically paralyzed. The Detective Sergeant still doesn't know how the poison sprayed on the door handle got through the protective gloves. Maybe he was adjusting his mask and goggles in the house. He lost his house, his car, all his household equipment, including children's toys. A small amount of poison adhered to his hands, contaminating his property.

March 07, 2018 - The British Police announced that a nerve agent had been used to poison the Skripals. The data was obtained through medical and chemical analyses and the symptoms of poisoning.

March 08, 2018 - UK Home Secretary Amber Rudd declared that a nerve agent had been used. However, it is not sarin or VX, an extremely rare agent was used. Police Officer Bailey is conscious and able to communicate.

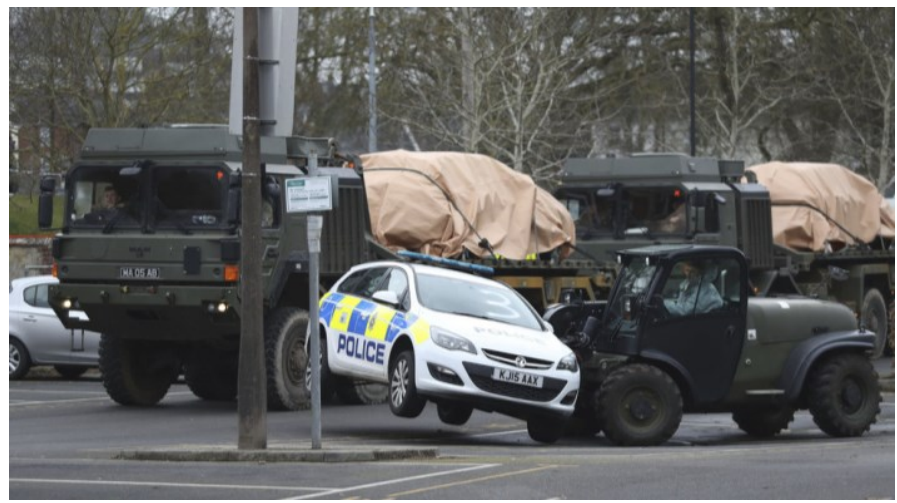

Figure 104: Cars around the crime scene may have been hit by nerve gas. PHOTO: Reuters. [Source: Fig-104] $\mathrm{He}$ is no longer in the Intensive Care Unit, but his condition remains serious.

March 09, 2018 - Police Officer Bailey has already been sitting and communicating. He is terribly pale.

March 10, 2018 - The investigation revealed the traces of a nerve agent at the Zizzi restaurant and The Mill pub. The police in chemical protective suits were also collecting evidence from Sergei Skripal's house and on the graves of his wife and son. Toxicologists mapped the terrain where the toxicant could occur. They also pointed out that it took several hours for its effects to show.

March 12, 2018 - According to British Prime Minister Theresa May, the poisoning was caused by a Novichok agent developed in the former Soviet Union. Experts from the Porton Down laboratory reportedly know with $100 \%$ certainty that the nerve agent originates from Russia and that A-230 was used. But its exact name is still concealed by Scotland Yard.

March 13, 2018 - The possibilities of how the toxicant could get into the bodies of the victims are stated as follows: from Skripal's car door handle, from the car air conditioning or it was sprayed directly in its interior. According to experts, Novichoks are very stable and persist in powder form for hours. Vil Mirzayanov described Novichok as an aerosol ten times more effective than any other nerve agent. It is practically impossible to recover from the consequences. Even if the victims survived, they would never recover. The perpetrators brought two separate harmless components to Salisbury, which were mixed before the attack. Ten grams is too much; in summer, only two grams are enough to kill 500 people. According to experts, A-230 is a much more dangerous and sophisticated nerve agent than VX and is more difficult to be detected. There are several similar compounds such as A-230, some are liquid, others are solid and can be used in powder form. A-232 (Novichok-5) is stable and effective at temperatures from -30 to $+50{ }^{\circ} \mathrm{C}$. 
March 15, 2018 - Novichok could be concealed in Yulia's luggage, hidden in a piece of clothing or in a cosmetic bag, or contained in a gift that Skripal opened in his house.

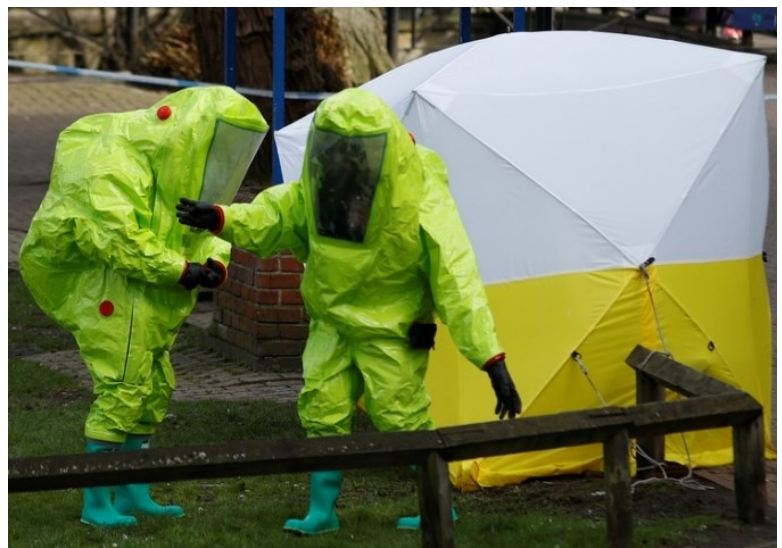

Figure 105: Experts in chemical protective suits near the tent at the site where Sergei Skripal was poisoned. [Source: Fig-105]

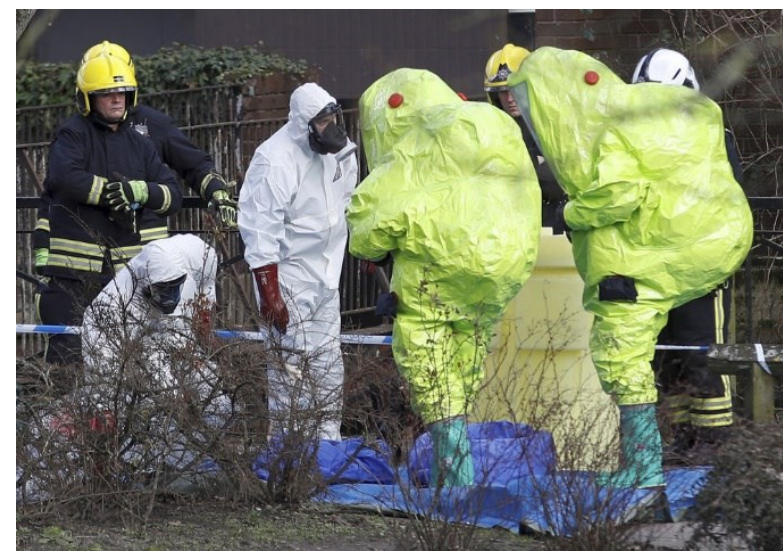

Figure 106: An investigation into the poisoning of Russian ex-spy Sergei Skripal in Salisbury, UK, continues. PHOTO: Reuters. [Source: Fig-106]

March 18, 2018 - According to British investigators, the substance was used in powder form and spread from the air conditioning of Skripal's car. It is neurotoxin of Russian military origin.

March 20, 2018 - According to Leonid Rink, the poisoning was not caused by Novichok at all; the substance was either poorly mixed or carelessly applied. Otherwise, the Skripals would not survive. The English used the antidote because they knew exactly what the substance was.

March 22, 2018 - In the evening, the Porton Down laboratories confirmed that Novichok or a similar nerve agent had actually been found in the blood of the Skripals. Doctors claim that the Skripals may never come out of a catatonic state. According to American experts, the poisoning occurred in Skripal's car via air conditioning; the British assume that the substance was unknowingly imported by Yulia. Novichok cannot be identified using modern expressive methods. To determine the presence of a toxicant, smears must be taken from objects and analysed in the laboratory. Police Officer Bailey was discharged from the hospital, his house was also inspected and his car was decontaminated.

March 24, 2018 - According to official statements of the British party, A-234 was used in the poisoning of the Skripals and Police Officer Bailey ("the date of the official statement may not be exact").

March 26, 2018 - Britain disposes of information that, for the past 10 years, Russia has been researching the ways of how to transport nerve agents, presumably for the purpose of murdering. According to Prime Minister May, more than 130 people could potentially be exposed to this nerve agent in Salisbury.

March 27, 2018 - The Skripals have been in a medically induced coma for more than 20 days. The official statement of the hospital says that they are both still alive, but their condition is consistently severe and even critical. If they survive, there is a high risk of permanent disability. According to Russian chemists and doctors who were involved in the development of Novichok, this nerve agent causes severe cramps, which may lead to bone fractures, followed by rapid death.

March 28, 2018 - The British Police believe that the Skripals were exposed to a nerve agent for the first time at the front door of Sergei Skripal's house. 
March 29, 2018 - Yulia's health condition has improved, she is no longer in direct danger of life. She is conscious and can talk, she eats and drinks on her own. Sergei Skripal's condition is still critical, but stable.

April 01, 2018 - The British Secret Intelligence Service revealed that Russian spies had practised various forms of liquidation of people in the last ten years. They were developing all sorts of methods for the new application of poisons, including their placement on the door handle.

April 02, 2018 - The Skripals could be poisoned by buckwheat containing the A-234 nerve agent, which was brought by Yulia's friend. At the same time, however, experts believe that a toxicant cannot be sneaked inconspicuously on a plane. The version of the transport of poison in a suitcase is improbable because the poison has a sharp smell and acts immediately.

April 03, 2018 - Gary Aitkenhead, Chief Executive Officer at the Defence Science and Technology Laboratory at Porton Down, announced that they had been able to identify the substance as Novichok, an army nerve agent. However, they did not determine the exact source. The agent is of military quality, requires extremely complex production methods, and some of the agents are only available to the state.

April 04, 2018 - According to German chemist and toxicologist Ralf Trapp, the nerve agent came from a laboratory that is part of the state program. It contained a minimum of impurities and was cleaned to a pure state. The actual return of the Skripals from the hospital may not mean anything. The agent didn't have to affect them that much, mainly because they probably absorbed it through the skin on the door handle, but didn't inhale it. In both of them, there may be a delayed effect of poisoning with lasting consequences.

April 05, 2018 - Through the police Yulia commented on her health condition in her first statement that her strength was growing daily. Investigators agreed that she had probably been poisoned at home since the highest contamination of the Novichok nerve agent was found there. The traces of Novichok were found on the handle of the front door as well as on the door handle of Skripal's car.

April 06, 2018 - According to the statement of the Salisbury Hospital representatives, Sergei Skripal responds well to treatment, improves rapidly and is no longer in critical condition. He is conscious and communicates with the hospital personnel.

April 07, 2018 - Alastair Hay, Professor of Toxicology at the University of Leeds, said that the Skripals had survived since they received extraordinary health care. If the emergency service workers did not arrive so soon and did not provide breathing, the Skripals would not survive. According to him, there is no antibody in the Novichok poisoning. Therefore, the doctors who treated the Skripals acted instinctively. The Skripals were put into a medically induced coma and doctors used sedatives to mitigate the effects of the Novichok nerve agent on the brain, and the body had time to eliminate the poison. As soon as it became clear that there had been no poison in their bodies, they began to come out of a coma. Subsequently, their bodies began to produce enzymes that were previously blocked by the Novichok nerve agent. As soon as doctors concluded that the toxicant had been excreted from their bodies, they could begin to reduce the effects of sedatives.

April 11, 2018 - Yulia was discharged from the hospital and was taken to a secure location. According to the media, the agent used to attack was in form of slow-release gel. The front door handle of Sergei Skripal's house was probably smeared with the gel and so Sergei spread the poison to other places. 
April 12, 2018 - The OPCW investigators confirmed the findings of the United Kingdom regarding the identity of the poison used in Salisbury. The inspection team stated that the toxicant had been of high purity and the samples taken had contained almost no other additives. The exact name of the toxicant and its composition is subject to secrecy. The OPCW team had the opportunity to take samples in the places where the Skripals were moving; it also had medical reports and blood samples of the Skripals and Police Officer Bailey. The chief physician at Salisbury hospital said in her statement that both patients had responded to treatment extremely well. She did not publish details about their treatment, she only stated that the doctors had used special methods to detoxify the bodies of both patients.

April 14, 2018 - Vil Mirzayanov, in his comment on the OPCW report, explained why the Skripals had not perished and the people around them had not been particularly affected. Someone smeared the door handle with a mixture of A-234 in the gel form. Upon the day, there was fog in the city, so the reaction of the agent with water began immediately. Its concentration thus decreased several times. Thus, the Skripals received a non-lethal dose. Upon the reaction with water, the Novichok nerve agent decomposes completely in a few

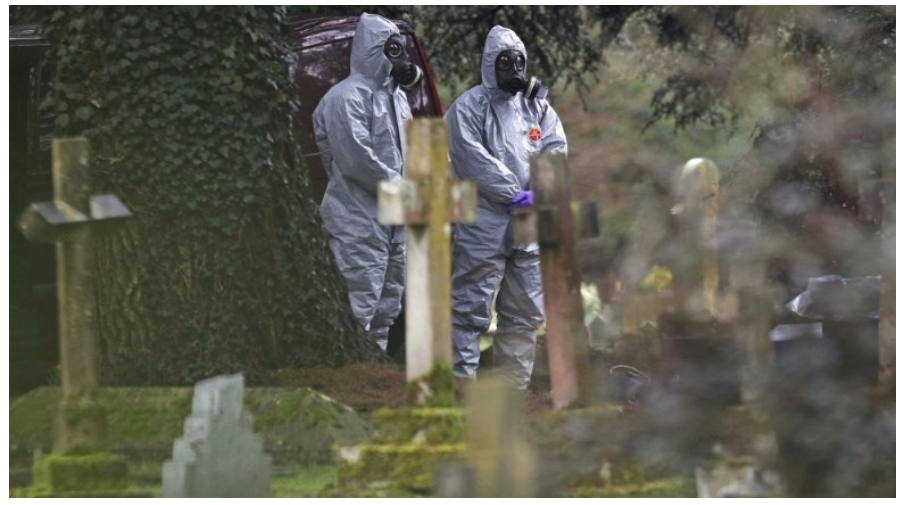

Figure 107: The investigation into the poisoning of ex-spy Sergei Skripal continues, the police are now testing the graves of his son and wife for the presence of the toxin. PHOTO: the Czech News Agency. [Source: Fig-107] hours. Thanks to the moisture, the Police Officer who entered Skripal's house contaminated with poison also survived. In a closed state, Novichok is very stable. Its weakness is moisture, then it decomposes. Decomposition is prevented by gel or oil.

April 15, 2018 - Leonid Rink questioned the OPCW data that high-purity A-234 had been used. If this nerve agent were used, the Skripals would not be able to walk away even 50 metres from the door and would die on the spot. A-234 is a complex nerve agent consisting of a mixture of a large number of different components and additives that decompose in different ways. It is very unstable, it is affected by water, lye, etc. Experts should find hydrolysis products and not a pure substance. According to Rink, the Skripals may have been poisoned by fentanyl and another symptom also indicates fraud. A-234 affects the victim's eyes, but the British party did not mention a similar symptom in any statement. The Skripals' health conditions are improving fast, but no one can see them.

April 16, 2018 - Sergei Skripal is no longer in a critical state. The hospital does not speak about the details of his health or the method of treatment.

April 17, 2018 - The British Department of the Environment, Food and Rural Affairs (DEFRA) stated that a very small amount of Novichok in liquid form had been used in the attack. In the following days, decontamination using lye will be carried out in a total of 9 places - the Zizzi restaurant, The Mill pub, the ambulance transporting the Skripals, the police station where Bailey served, the garage where Skripal's car was parked, Bailey's house and Skripal's house. The procedure is to include soil and paving sampling, testing for the presence of the substance, cleaning and retesting.

April 18, 2018 - According to the Russian party, the Swiss laboratory in Spiez found out the presence of the psychoactive agent called BZ during the analysis of a sample from Salisbury. 
April 23, 2018 - British investigators are convinced that the Skripals were poisoned by the Novichok nerve agent in liquid form applied to the door handle of Skripal's house.

April 24, 2018 - Vladimir Uglev questions the use of A-234. It is as liquid as water and would not stick to the door handle. However, he does not rule out a gel form. He is not certain of this poison for another reason - the inability to retain urine and stool is typical for the Novichok poisoning. Uglev was poisoned slightly by Novichok when a small amount of A-242 got on his skin. He had a lesion on the upper side of his hand for five or six years. It was A-242, which crystallizes immediately and this saved him, so that he had no other symptoms. He washed his hands in the hydrochloric acid solution immediately after being affected and then he rinsed it with hydrogen peroxide. The British Army began to decontaminate the places where the Skripals were moving and removed the bench, on which they were found.

May 04, 2018 - According to Mr. Ahmet Üzümcü, Director-General of the OPCW Technical Secretariat, 50 to 100 grams of Novichok could be used in Salisbury, either in aerosol or liquid form. The nerve agent A-234 is very stable and is not affected by weather conditions. The OPCW spokesman corrected this claim in the evening - the amount of poison used against the Skripals cannot be estimated, it would probably be milligrams. Leonid Rink stated that 50 to 100 grams was an amount used in combat and he did not even know how many people could be killed with such a dose. The Police found slight traces of Novichok at the CityStay Hotel in London, where the alleged Russian perpetrators of the attack on the Skripals were housed at the beginning of March.

May 18, 2018 - Sergei Skripal was discharged from the hospital.

May 23, 2018 - Yulia appeared in public for the first time since the March incident. She said that the recovery had been slow, extremely painful and depressing. The red scar on Yulia's throat corresponds to the scar of a patient who had to undergo tracheotomy, i.e. an operation, during which an opening in the patient's trachea is created to ensure breathing.

May 26, 2018 - In April, Mirzayanov stated that the Achilles heel of the poison was sensitivity to water and the poison could have lost its effectiveness in the fog. Rink admits that the water base would immediately decompose the toxicant. Uglev strongly disagrees with this; he says that the types of the so-called Novichok are very resistant to hydrolysis. It is a resistant agent which, when used in combat, surpasses VX in its toxic effects ten times. Uglev previously claimed that if the Skripals had been exposed to the lethal substance, they could not survive. They would die when disconnected from the devices ensuring vital functions. However, he claimed later that banal hand washing could have saved them. A-234 is essentially the same as dirt. What was left could not kill them. The main symptom he recognized in himself is a sweaty place on the body that came in contact with a chemical. Other symptoms are spontaneous urination and defecation.

May 29, 2018 - At first, doctors thought that the Skripals were overdosed on opiates. The turning point came when Police Officer Bailey was admitted to hospital for the treatment with the same symptoms. He reportedly had similar symptoms. The medical personnel (it is unknown when) ruled out that the Skripals were under the influence of opiates. According to the results of special tests, doctors found out that both of them had symptoms typical of poisoning by a nerve agent. Accelerated transport to the Intensive Care Unit, administration of strong sedatives that reduced the possibility of brain damage, and the advice and treatment proposed by the experts from the Porton Down laboratory were key to recovery. They performed several tests and came up with a proposal for the best possible treatment. Among other things, strong sedatives allowed the Skripals to tolerate all the medical appliances, to which they were connected. Later, the sedatives were limited and both patients underwent tracheotomy. 
When they were stable and able to speak, the main problem for the medical personnel was how to encourage the production of the important enzyme acetylcholinesterase, which is needed to restore normal bodily functions. The body itself produces the enzyme after being affected by a toxicant, but the process can take several months.

June 30, 2018 - Ms. Dawn Sturgess and, a few hours later, Charlie Rowley were transported from their house in Amesbury to Salisbury Hospital with the symptoms of poisoning. Rowley's friend Sam Hobson testified that after Ms. Sturgess had been taken to the hospital, he and Rowley had gone to the pharmacy to pick up prescription drugs. When they returned, they began planning a visit to the hospital. However, Rowley suddenly began to behave strangely, he was very hot, he was sweating, his eyes went red, and saliva was dripping from his mouth. So, Sam Hobson called an ambulance for him.

July 04, 2018 - The Police confirmed that Rowley and Sturgess had been poisoned by Novichok while handling a contaminated object.

July 06, 2018 - According to an unnamed government scientist, the British couple affected by Novichok could not be poisoned in the open space. The substance would gradually decompose on an object exposed to rain and sunlight. A sudden rain storm probably saved the Skripals from their deaths. A lethal dose of the nerve agent was applied to the front door handle. A few minutes before they opened the door, however, a downpour started in the city, which washed away a large part of A-234 and thus weakened its effect.

July 08, 2018 - Ms. Dawn Sturgess died. According to Dawn's mother, her daughter suffered from heart failure and her body was not strong enough to bear it after the years of alcoholism and drug use. A Scotland Yard press agent said in the evening that both of them had had their hands literally smeared with Novichok; the chemical was on their fingers, palms, between their fingers, and the contamination was high. Charles Rowley's condition remains critical.

July 09, 2018 - According to Rowley's friend, Ms. Sturgess was the first to be poisoned. She had convulsions, foaming at the mouth. Charlie tried to help her using cardiopulmonary resuscitation, but finally he himself got poisoned. Both of them were foaming at their mouths, their pupils were narrowing so that they were almost invisible. They spoke incoherently.

July 11, 2018 - The British Police discovered the source of Novichok that poisoned the couple in Amesbury. It was Nina Ricci perfume, which was found at Charlie Rowley's house.

July 12, 2018 - Charlie Rowley regained consciousness in the evening. According to the Medical Director, Public Health England, Professor Paul Cosford, Novichok was used in liquid form; it can be effective in the air even after three, but perhaps even after twelve hours.

July 01, 2018 - Based on tests at Porton Down, it was confirmed that there was Novichok in the bottle.

July 16, 2018 - Charlie Rowley's brother Matthew said after visiting the hospital that his brother was half awake half asleep, but was bone and skin, even though he already ate solid foods.

July 20, 2018 - Charlie Rowley was released from the hospital.

July 21, 2018 - Charlie Rowley could testify. He had the bottle in question at home for a few days before he gave it to his partner. He remembers she sprayed the substance on her wrist and then rubbed it. After about fifteen minutes, she felt sick, had a headache, and wanted some pills to relieve a headache. She said that she felt very strange and that she had to lie down in the bath. Rowley found her in the bath fully dressed and in a pitiful state. Apparently, he himself got poisoned when he handled the bottle. A little substance got on his hands. It was an oily substance, he sniffed at it and it didn't smell of perfume (it allegedly smelled of ammonia). Then he washed his hands. 
August 21, 2018 - Charlie Rowley was re-admitted to the hospital in Salisbury because he lost his sight for a short time. Doctors do not associate his current health problems with the effects of Novichok.

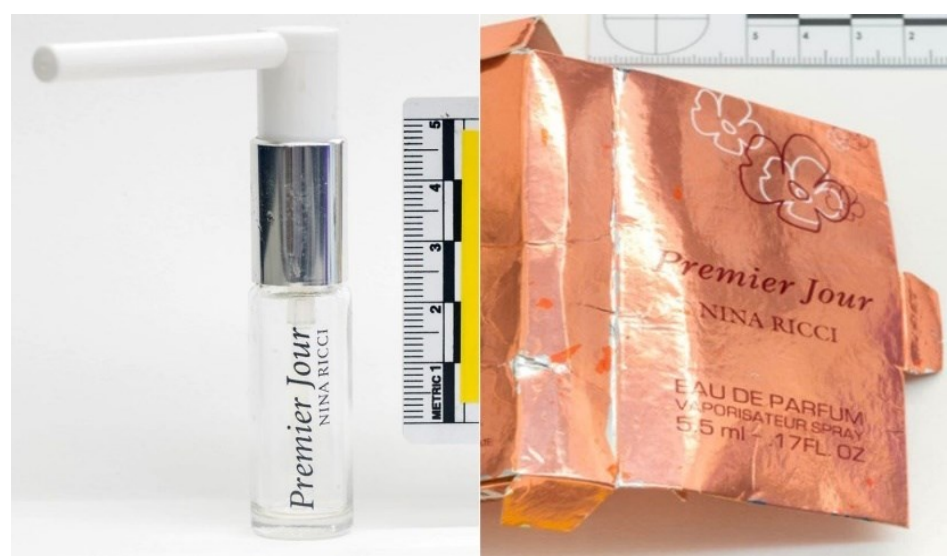

Figure 108: Novichok was in this perfume bottle, MI5 says. [Source: Fig-108]

September 04, 2018 - According to the OPCW, the toxic compound has the same composition as a nerve agent. It is the same toxicant that was found in biomedical and environmental samples relating to the poisoning of the Skripals and Bailey on March 04, 2018 in Salisbury. The analyte is very pure, its concentration is $97-98 \%$.

September 06, 2018 - According to British forensic scientists, the fake Nina Ricci perfume spray was created in a top-secret laboratory of

the Russian Special Services, and its development could cost millions of crowns. The $5.5 \mathrm{ml}$ bottle with a nozzle and the Nina Ricci Premier Jour logo is not different from ordinary perfumes of this type and it is equipped with a special closure. Reputedly, its production could take up to 3 months, followed by tests. Unlike ordinary bottles, it is made out of special toughened glass, ceramics or plastics, so it cannot break under any circumstances. The type of perfume was chosen according to the long applicator, which ensured that the agent had not been endangered when spraying the potent poison.

September 07, 2018 - According to a safety officer, the amount of the Novichok nerve agent in the perfume bottle could, in extreme cases, kill up to 4,000 people. The agent was not diluted, but in a concentrated form. DEFRA confirmed that it had begun decontamination of Skripal's house.

January 10, 2019 - Special units of the British Army began replacing the roof of Sergei Skripal's house under extraordinary security measures.

The case of Sergei and Yulia Skripal raised a number of questions - "Who?", "Why?", "How?" - and we do not know the answer to any of them. But this case also raised a number of doubts, to which no one responded either. This case is completely clear for someone:

"We, the leaders of France, Germany, the United States, Canada and the United Kingdom, reiterate our outrage at the use of a chemical nerve agent, known as Novichok, in Salisbury on March 4. We have full confidence in the British assessment that the two suspects were officers from the Russian Military Intelligence Service, also known as the $G R U$, and that this operation was almost certainly approved at a senior government level,"

was said in the statement of these states of September 06, 2018.

The Russian Federation categorically rejected this accusation. Moscow had no reason to poison the Skripals on the eve of the presidential elections and shortly before the FIFA World Cup. China took a sober assessment of the situation and called on Britain to respect international law and the basic norms in international relations, and also to try to avoid a growing confrontation. However, a number of rumours and conspiracy theories also appeared as to who and why could cause this case of Novichok. 


\subsection{Symptoms after affecting the organism}

The symptoms after affecting the organism by nerve agents are practically the same for all portals of entry into the organism and depend on the dose received.

Clinically, the extent of poisoning is divided into three degrees according to their symptoms. Let's compare these symptoms with those that occurred in people affected by the A-234 nerve agent. The symptoms of poisoning in people in the incidents in Salisbury and Amesbury and the duration of their treatment are listed in Table 55. The problem is that witnesses or the affected people themselves describe them in this way, there is no professional medical examination available, not even an examination performed by the doctor who provided the first aid to the Skripals.

\section{Mild poisonings}

- Latency time: 10 to 15 minutes, very light poisoning up to 120 minutes;

- Concentration: about $1 / 10$ of incapacitating concentration;

- Efficiency: up to 24 hours;

- Symptoms: contraction of the pupils, secretion from the nose, increased salivation, headache, mild breathing difficulties with a feeling of pressure in the chest. Anorexia, feelings of anxiety and fear, sweating, insomnia, lack of concentration. Pupil constriction can occur at much lower concentrations and persists for several days and even weeks depending on the circumstances. This leads to the inability of an affected person to act. The pupil is often contracted to the size of a pinhead, which greatly reduces the amount of light entering the eye and the ability to see decreases with decreasing light. The victim complains of declining visual acuity, the ability of the eye to accommodate is greatly reduced. Photophobia, eye pain and headaches are typical side effects.

\section{Moderate-to-severe poisonings}

- Latency time: 5 minutes, maximally up to 2 hours;

- Concentration: about 1/5 of incapacitating concentration;

- Efficiency: 1-2 weeks, full recovery of acetylcholinesterase activity after 4-6 weeks;

- Symptoms: as with mild poisonings, but only more intense. Short-term muscle cramps, pupil constriction (pinhead size), vomiting, very strong salivation, asthma attacks, periodic cramps in the larynx. Accelerated, irregular breathing, intensified cough, secretion of viscous foamy mucus, muscle cramps (especially in the lower limbs), etc. Moderate poisoning is fatal in case of later treatment. Complete reactivation of acetylcholinesterase takes 3-6 months. During this time, the affected person is significantly hypersensitive to the same or similar poisons.

\section{Severe poisonings}

- Latency time: no or only very short time;

- Concentration: about $1 / 3$ to $1 / 2$ of incapacitating concentration;

- Efficiency: after 6 to 12 hours;

- Symptoms: as with mild and moderate-to-severe poisonings, but in more rapid succession. Pupils without reactions, painful pressure in the eyes, severe headaches and reflexive retching and vomiting. Severe difficulty in breathing, severe seizures up to generalized tonic-clonic seizures progressing to opisthotonos. Disturbance of consciousness with increasing exhaustion of the organism, convulsions leading to gradual paralysis, death. 
Table 55: Symptoms of poisoning and the duration of treatment of individuals affected by A-234. [Source: Tab-55]

\begin{tabular}{|c|c|c|}
\hline $\begin{array}{l}\text { The people } \\
\text { affected }\end{array}$ & Symptoms & Duration of treatment \\
\hline $\begin{array}{l}\text { Yulia } \\
\text { Skripal }\end{array}$ & $\begin{array}{l}\text { Unconsciousness, eyes "wide open, but completely } \\
\text { white," foaming at the mouth }\end{array}$ & $\begin{array}{l}\text { After } 25 \text { days in a coma, } \\
\text { she is conscious, she eats and } \\
\text { drinks herself; released from } \\
\text { the hospital after } 36 \text { days. }\end{array}$ \\
\hline $\begin{array}{l}\text { Sergei } \\
\text { Skripal }\end{array}$ & $\begin{array}{l}\text { He was waving his hands strangely and looking up to } \\
\text { the sky; later, he was sitting motionless on the bench } \\
\text { in a catatonic stupor, looking somewhere into space; } \\
\text { he was breathing, but he didn't react to anything; } \\
\text { he remained in this stance even when the doctors tried } \\
\text { to place him on a stretcher; he was sitting and could } \\
\text { not move or change his position. }\end{array}$ & $\begin{array}{l}\text { Conscious after } 33 \text { days, } \\
\text { he is not in a critical } \\
\text { condition after } 43 \text { days, } \\
\text { released from the hospital } \\
\text { after } 75 \text { days. }\end{array}$ \\
\hline $\begin{array}{l}\text { Nick } \\
\text { Bailey }\end{array}$ & $\begin{array}{l}\text { Nausea, pupils like pinheads, sweating and heat, } \\
\text { feeling of anxiety and fear }\end{array}$ & $\begin{array}{l}\text { He arrived at the hospital } \\
\text { after } 2 \text { days; he communi- } \\
\text { cates after the next } 2 \text { days of } \\
\text { treatment; released } 17 \text { days } \\
\text { after starting treatment. }\end{array}$ \\
\hline $\begin{array}{l}\text { Charlie } \\
\text { Rowley }\end{array}$ & $\begin{array}{c}\text { After contact with the toxic substance, the symptoms } \\
\text { manifested themselves after several hours by a strange } \\
\text { behaviour, feeling of great warmth, sweating, redness } \\
\text { of the eyes, leakage of saliva from the mouth, pupil } \\
\text { constrictions, incoherent speech. }\end{array}$ & $\begin{array}{l}\text { Conscious after } 10 \text { days, } \\
\text { released after } 20 \text { days. }\end{array}$ \\
\hline $\begin{array}{c}\text { Dawn } \\
\text { Sturgess }\end{array}$ & $\begin{array}{c}\text { Nausea after } 15 \text { minutes from contact with a toxicant, } \\
\text { headache, pupil constrictions, incoherent speech and } \\
\text { muscular insufficiency }\end{array}$ & She dies after 8 days. \\
\hline $\begin{array}{c}\text { Andrei } \\
\text { Zheleznyakov }\end{array}$ & $\begin{array}{l}\text { Visual disturbances, red and orange circles, ringing } \\
\text { in the ears, feeling of fear, vomiting, muscular } \\
\text { insufficiency. He was unconscious for } 10 \text { days. } \\
\text { He was then treated for } 3 \text { months in a secret clinic } \\
\text { in Leningrad. The contact with a toxicant caused } \\
\text { permanent damage to the organism, effects included } \\
\text { chronic weakness of the hands, toxic hepatitis, which } \\
\text { progressed to cirrhosis of the liver, epilepsy, periods } \\
\text { of major depression and inability to read or concen- } \\
\text { trate, leading to his dismissal from work. He never } \\
\text { recovered and died in } 1992 \text {. However, the first reported } \\
\text { symptoms of Zheleznyakov's poisoning correspond } \\
\text { more to a panic attack in the event of a work error with } \\
\text { a nerve agent. He was probably poisoned by A-232. }\end{array}$ & He died after 5 years. \\
\hline
\end{tabular}

\subsection{Decontamination}

And now let's look at the issues of decontamination of this supposedly most toxic chemical. The term decontamination is used today as a general term for liquidating the consequences of the use/misuse of weapons of mass destruction and the release of toxic industrial chemicals after industrial accidents. Previously, the process of removing chemical warfare agents was called detoxification, removing radioactive material was called deactivation, and removing biological agents was called disinfection, which, according to the authors of this book, better described the given issues. 
How did decontamination proceed in this case?

- Immediately towards the evening on March 04, 2018, i.e. after finding the Skripals, the Police had preventive decontamination carried out by the workers wearing special chemical protective coveralls (decontamination of what, by which decontaminants and for what reasons?).

- On March 22, 2018, chemical experts also checked Nick Bailey's house for the presence of Novichok and decontaminated his car.

- On April 17, 2018 the British Department of the Environment, Food and

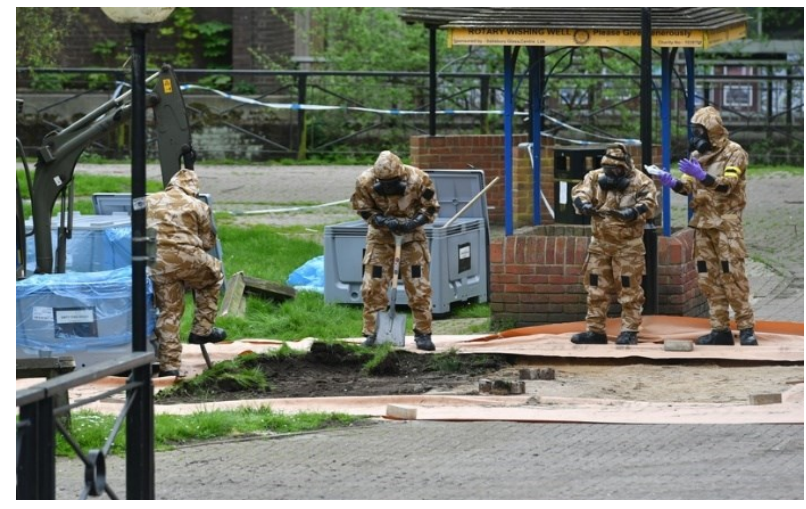

Figure 109: Soldiers are taking samples of contaminated soil near the bench, where the Skripals were found. [Source: Fig-109]

Rural Affairs (DEFRA) stated that a very small amount of the Novichok poison in liquid form had been used in the attack. It announced that in the following days, decontamination using lye would be carried out in a total of nine places - the Zizzi restaurant, The Mill pub, the ambulance transporting the Skripals, Bailey's police station, the garage where Skripal's car parked, Bailey's house and Skripal's house. The procedure included soil and paving sampling, testing for the presence of the poison, cleansing and re-testing.

- On April 24, 2018, the planned decontamination began. The bench, on which the Skripals were found, was removed.

- On September 07, 2018, DEFRA confirmed that it had started decontamination of Skripal's house (why just now?).

- On January 10, 2019, special units of the British Army began replacing the roof (after $3 / 4$ a year?) of Sergei Skripal's house under extraordinary security measures.

Table 56: Assumed contamination densities and droplet sizes. [Source: Tab-56]

\begin{tabular}{|c|c|c|c|}
\hline \multirow{2}{*}{$\begin{array}{c}\text { Chemical warfare } \\
\text { agent }\end{array}$} & \multicolumn{2}{|c|}{ Average contamination density $\left(\mathrm{g} . \mathrm{m}^{-2}\right)$} & \multirow{2}{*}{ Average droplet size (mg) } \\
\cline { 2 - 3 } & According to ,a, & According to „, $\mathrm{b}^{\prime}$ & \\
\hline Sarin & $6-8$ & 1 & $0.5-5.0$ \\
\hline Soman & 7 & 0.5 & $0.5-5.0$ \\
\hline VX & $0.5-1.0$ & 0.3 & $0.02-0.1$ \\
\hline Sulphur mustard & $8-10$ & 15 & $0.5-5.0$ \\
\hline
\end{tabular}

Note: The higher droplet size values apply to winter conditions.

a) VONDRÁČEK, V. Vybrané kapitoly z toxikologie OL a zdravotnické ochrany. (Učebnice VLVDÚ). Hradec Kralove, 1972.

b) Chemical Weapons: Destruction and Conversion. SIPRI. London, 1980.

It needs to be reminded repeatedly that we do not have any authorized data on the properties of Novichoks. It will certainly be useful to mention for comparison what assumed values of the density of contamination by chemical warfare agents and the nature of contamination were considered by military specialists (see Table 56). In his book "Chemical Weapons of a Probable Enemy" Professor A. N. Kalitayev states the following contamination densities: VX minimally $0.2-0.3 \mathrm{~g} \cdot \mathrm{m}^{-2}$, yperite $20 \mathrm{~g} \cdot \mathrm{m}^{-2}$, when the terrain is contaminated with droplets, and sarin about $1 \mathrm{~g} . \mathrm{m}^{-2}$. The aim of detoxification is, therefore, to remove the toxic effects of chemical warfare agents from contaminated objects up to a physiologically ineffective extent. For this purpose, the standards of permissible contamination of equipment were set for purposes of ground troops, which are listed in Table 57. 
Table 57: Permissible residual contamination of the surfaces of weapons and combat equipment. [Source: Tab-57]

\begin{tabular}{|c|c|c|c|}
\hline \multirow{2}{*}{$\begin{array}{c}\text { Character of the contact of the chemical } \\
\text { warfare agent with the contaminated } \\
\text { surface }\end{array}$} & \multicolumn{3}{|c|}{ Surface contamination density (mg.m-2 } \\
\cline { 2 - 4 } & Yperite & Soman & VX \\
\hline Uncovered skin & 4 & - & 2 \\
\hline Through summer wear & 40 & 19 & 7 \\
\hline Through winter wear & 60 & 30 & 10 \\
\hline
\end{tabular}

Note: According to KASSA, J., KRS, O., CABAL, J. Základy vojenské toxikologie a ochrany proti BCHL pro posluchače VLA JEP farmaceutického směru. Jan Evangelista Purkyně Military Medical Academy in Hradec Kralove, 1992.

For comparison, Table 58 shows the values of toxic doses of chemical warfare agents when acting percutaneously.

Table 58: Values of toxic doses of skin resorption effect in mg on humans.

[Source: Tab-58]

\begin{tabular}{|c|c|c|c|c|}
\hline \multirow{2}{*}{$\begin{array}{c}\text { Chemical } \\
\text { warfare } \\
\text { agent }\end{array}$} & \multicolumn{3}{|c|}{$\begin{array}{c}\text { When a chemical warfare agent acts through } \\
\text { the uncovered skin (mg/person) }\end{array}$} & $\begin{array}{c}\text { When a chemical warfare agent } \\
\text { acts through a summer army } \\
\text { uniform (mg/person) }\end{array}$ \\
\cline { 2 - 5 } & $\mathrm{LD}_{50}$ & $\mathrm{ID}_{50}$ & $\mathrm{PD}_{50}$ & $\mathrm{ID}_{50}$ \\
\hline VX & $6-10$ & $3-5$ & 0.1 & 100 \\
\hline Soman & $49-98$ & 28 & 1.4 & 50 \\
\hline Yperite & $4.9 \times 10^{3}-7 \times 10^{3}$ & 350 & 2.1 & 1.400 \\
\hline
\end{tabular}

Note: According to КАЛИТАЕФ А.Н. Химическое оружие вероятного противника. ВАХЗ, S/chem-3-84, Москва 1977.

$L D_{50}$ is a median lethal dose;

$I D_{50}$ is a median incapacitating dose;

$P D_{50}$ is a median threshold dose.

Based on these data, standards were set for the use of combat equipment that was contaminated with chemical warfare agents (spontaneous decontamination). Armament and combat equipment contaminated with sarin at temperatures of $20^{\circ} \mathrm{C}$ is safe 10 to 15 minutes after its use without skin protection means, but with a protective mask. In case of VX contamination, armament and combat equipment can be used without the means of protection after 3 days in summer, 5 to 15 days in spring and autumn, and 30 to 50 days in winter. As for yperite, spontaneous decontamination (detoxification) occurs after 2 to 3 days in summer, after up to 6 days in spring and autumn, and after 1 to 2 months in winter.

And for supplementation according to the Czech Defence Standard 681001, residual contamination for chemical warfare agents by contact with unprotected skin is considered $1 \mathrm{mg} \cdot \mathrm{m}^{-2}$ for VX and $10 \mathrm{mg} \cdot \mathrm{m}^{-2}$ for yperite.

If we are to comment on the decontamination performed, in our case, on liquidating the consequences of the use of milligram quantities of A-234, we can declare that all these bombastic measures had no value at all. The information we have at our disposal always shows the traces of the agent only. It is not specified anywhere what the numerical value of these traces is. What will the toxicity of A-234 actually be? The toxicity repeatedly appears 5-7 times higher than VX in the statements of politicians and the media; however, Mirzayanov states this for the agent A-230 only. A-232 should be as toxic as VX; he does not talk about A-234 at all. According to some other sources, its toxicity will be the same as in case of VX. Let's compare the toxicity and residual contamination values given in the tables above. 
Of course, these values apply to purposes of ground troops and as for the civilian population, their value would probably be much lower. But, on the other hand, did Novichok in Salisbury really spill on the pavement, in the park, on the roads or in the buildings? Let's recall an interesting photograph, where soldiers in chemical protective suits are removing the "contaminated soil" around the bench in question; they are digging the soil to a depth of several tens of centimetres and are loading it into containers, they are also tearing out the paving and are loading it into containers. However, even a liquid substance certainly could not reach such a depth. And it is surprising that where the highest contamination was supposed, i.e. at Sergei Skripal's house, DEFRA did not start decontamination until September 07, 2018 (after half a year). The removal of the roof by the Army under special security measures (after $3 / 4$ year) needs no comment.

\subsubsection{Irritating agents}

Irritating agents rank among debilitating agents and the purpose of their use is to reduce the enemy's combat capability by their effects and the long-term use of individual protective equipment. They are characterized by a characteristic irritating effect on the eyes, skin and mucous membranes of the respiratory and digestive tracts. The body defends against these effects through reflexes, e.g. by watering of the eyes, cramps of eyelids due to the increased light sensitivity, salivating, coughing, sneezing and vomiting. The effects of irritating agents are characterized by the immediate onset and predominance of subjective disorders over objective symptoms of effects and relatively rapid disappearance of symptoms after the interruption of contact of the affected person with a noxious agent.

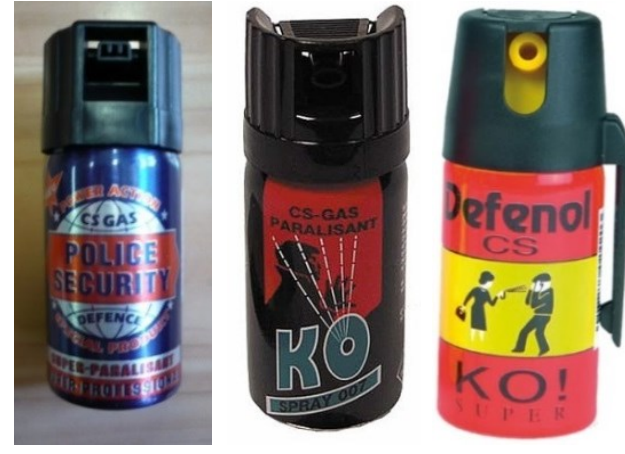

Figure 110-1 up to 110-3: Different types of defence sprays filled with highly effective CS irritating agent. [Source: Fig-110-1 up to Fig-110-3]

For the first time, irritating agents were used massively in the early years of World War I. With regard to the possibilities of simple defence and low toxicity, their deployment was not accompanied by the expected success; therefore, the use of irritating agents was gradually replaced by the use of choking and blister agents. However, the use of irritating agents was not abandoned completely. This is evidenced, for example, by the use of irritating agents by the US Army in the India-China War in the 1960s. The tactical use of irritating agents has also changed - the use can be a coverup only followed by the use of more toxic agents, or a goal to induce unbearable respiratory tract irritation that will make the use of a face mask impossible. Some irritating agents are used for police and training purposes due to rapid, effective and shortlasting effects and a relative safety.

\section{Symptoms of injuries caused by irritating agents}

The agents that irritate eyes are called lacrimators. The effect of irritating agents on humans is varied. The effect of a tear gas will instantly be felt by burning eyes, watering of the eyes and photophobia. There is often a sharp pain in the eyes, which leads to cramps of the eyelids. Subjective disorders are, therefore, very strong, but the objective finding of the affected eyes is minimal. It is mostly light conjunctivitis. The prolonged exposure to higher concentrations of tear gases may have an irritating effect on the upper respiratory tract. This is manifested by a burning sensation in the nose and nasopharynx, increased secretion and cough. Chloroacetophenone, bromobenzyl cyanide, CS, CR and capsaicin are considered to be militarily significant tear gases. 

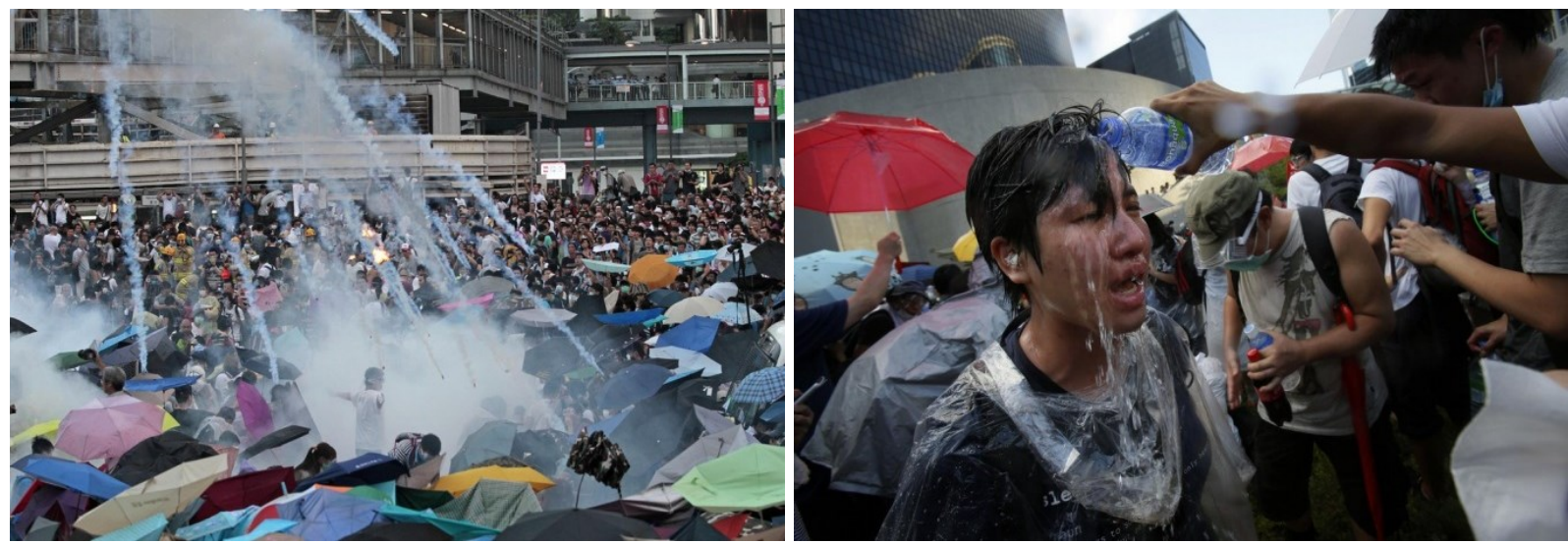

Photo 143-1 and 143-2: The Police used tear gas during the protests in Hong Kong. September 29, 2014.

[Source: Pho-143-1 and Pho-143-2]

The agents that irritate air passages are called sternites. They always irritate the mucous membranes of the upper respiratory tract and cause a chest pain. The latency usually takes only several seconds; then, the irritation of the mucous membranes of the nose, pharynx and larynx appears. The affected person suffers from nausea. The pain of jaws, gums and teeth occurs. The pain and pressure in the ears can often occur due to the Eustachian tube swelling.

The redness of the skin accompanied by a feeling of tension, pain, swelling and the formation of blisters can be seen on the unprotected skin. Sternites are most often used as fumes, which can also significantly affect the eyes in a similar way as tear gases. If they enter the digestive tract through water or food, a cholera-like disease arises soon. It is associated by a colic, vomiting and thin stool, which may be bloody. The militarily most significant agents irritating the upper respiratory tract are CLARK I, CLARK II and adamsite.

The first aid to people affected by tear gases is using the face masks immediately, fast leaving the contaminated environment and protecting the eyes against the blazing light. The symptoms of the eye irritation disappear spontaneously due to the stay in the fresh air as the tear gases are washed out by watering of the eyes.

After leaving the contaminated environment, the first aid is usually supplemented by the eye, nasal, oral and throat irrigation using 1 to $2 \%$ sodium bicarbonate, boric acid, saline solution or isotonic solution containing $0.25 \%$ sodium sulphite. It is not recommended to wash the eyes using clean water only since this increases the effect of certain tear gases, especially CS. In any case, the affected person must not rub his/her eyes because the cornea could be damaged. When the upper respiratory tract is irritated, it is possible to proceed in a similar way as in case of the first aid when the upper respiratory tract is affected by choking agents.

When a person is affected by sternites, the first aid lies in the immediate use of the face mask and in leaving the contaminated area. However, it must be borne in mind that, even after the contact with a chemical warfare agent is interrupted, the intensity of symptoms persists for a few minutes or increases.

If possible, the affected clothing must be thoroughly dusted to remove sternite particles because they could become a source of further irritation. Further professional treatment is already a matter of the health service. The contaminated parts of the skin can be treated with $2 \%$ sodium bicarbonate solution, $1 \%$ aqueous-alcoholic sodium sulphide solution or menthol alcohol. Decontamination using water and soap is mostly insufficient as it does not prevent the development of symptoms. 
Table 59: Properties of irritating agents. [Source: Tab-59]

\begin{tabular}{|c|c|c|c|c|c|}
\hline Name & $\begin{array}{c}\text { Code } \\
\text { marking }\end{array}$ & $\begin{array}{l}\text { Physical } \\
\text { properties }\end{array}$ & Hydrolysis and solubility & Field stability & Protection \\
\hline $\begin{array}{c}\text { Chloroaceto- } \\
\text { phenone }\end{array}$ & $\begin{array}{l}\text { CN (USA, } \\
\text { CZ), } \\
\text { CAP (GB) } \\
\text { O-salz (D) }\end{array}$ & $\begin{array}{l}\text { Yellow to brown } \\
\text { crystals with an } \\
\text { odour of rowan } \\
\text { and violet flowers }\end{array}$ & $\begin{array}{l}\text { Water insoluble, well } \\
\text { soluble in organic } \\
\text { solvents, hydrolysis } \\
\text { is very slow }\end{array}$ & \begin{tabular}{|c|} 
Highly stable \\
substance, in \\
the solid state \\
in summer lasts \\
days, in winter \\
weeks, as a \\
smoke a few \\
min.
\end{tabular} & $\begin{array}{l}\text { Full-face } \\
\text { masks with } \\
\text { filters with a } \\
\text { smoke insert }\end{array}$ \\
\hline $\begin{array}{c}\text { Bromobenzyl } \\
\text { cyanide }\end{array}$ & $\begin{array}{c}\text { CA (USA, } \\
\text { CZ) } \\
\text { BBC }\end{array}$ & $\begin{array}{l}\text { Pinkish crystalline } \\
\text { agent with an } \\
\text { odour of rotten } \\
\text { fruit and bitter } \\
\text { almonds, strongly } \\
\text { corrosive to met- } \\
\text { als, stored in glass }\end{array}$ & $\begin{array}{l}\text { Low solubility in water, } \\
\text { dissolves well in organic } \\
\text { solvents, hydrolysis } \\
\text { is very slow }\end{array}$ & $\begin{array}{c}\text { In summer up } \\
\text { to } 2 \text { days, } \\
\text { in winter up to } \\
14 \text { days }\end{array}$ & See CN \\
\hline Agent CR & CR & $\begin{array}{c}\text { White to yellow } \\
\text { crystalline agent } \\
\text { without any taste } \\
\text { and odour }\end{array}$ & $\begin{array}{c}\text { Dissolves slightly } \\
\text { in water, does not undergo } \\
\text { hydrolysis }\end{array}$ & See CS & See CN \\
\hline Adamsite & DM, Azin & $\begin{array}{c}\text { Yellow crystalline } \\
\text { agent, } \\
\text { no significant } \\
\text { odour }\end{array}$ & $\begin{array}{l}\text { Does not dissolve } \\
\text { in water, does not } \\
\text { decompose in water }\end{array}$ & $\begin{array}{c}\text { Contaminates } \\
\text { the terrain for } \\
\text { maximally } \\
1 \text { hour }\end{array}$ & See CN \\
\hline CLARK I & DA & $\begin{array}{l}\text { White crystalline } \\
\text { agent with a slight } \\
\text { fruit odour }\end{array}$ & $\begin{array}{l}\text { Does not almost dissolve } \\
\text { in water, dissolves well } \\
\text { in organic solvents, } \\
\text { hydrolysis is very slow, } \\
\text { accelerates with chlorine- } \\
\text { containing compounds } \\
\end{array}$ & $\begin{array}{l}\text { Contaminates } \\
\text { the terrain for } \\
\text { maximally } \\
15 \text { minutes }\end{array}$ & See CN \\
\hline CLARK II & $\mathrm{DC}$ & $\begin{array}{l}\text { White crystalline } \\
\text { agent with an } \\
\text { odour of bitter } \\
\text { almonds, } \\
\text { sometimes of } \\
\text { garlic } \\
\end{array}$ & $\begin{array}{c}\text { Dissolves slightly in } \\
\text { water, well in organic } \\
\text { solvents, hydrolysis is } \\
\text { very slow, accelerates } \\
\text { with chlorine-containing } \\
\text { compounds }\end{array}$ & $\begin{array}{l}\text { Contaminates } \\
\text { the terrain for } \\
\text { maximally } \\
30 \text { minutes }\end{array}$ & See CN \\
\hline Agent CS & $\begin{array}{c}\text { CS (USA, } \\
\text { CZ) } \\
\text { CB (F) }\end{array}$ & $\begin{array}{l}\text { Thermally stable } \\
\text { white crystalline } \\
\text { agent with an } \\
\text { odour of pepper }\end{array}$ & $\begin{array}{l}\text { Low solubility in water, } \\
\text { hydrolysis is slow, } \\
\text { accelerates with alkalis }\end{array}$ & \begin{tabular}{|c|} 
Highly stable \\
agent (namely \\
CS-2), \\
in summer it \\
lasts for a few \\
days in the \\
field, in winter \\
a few weeks \\
\end{tabular} & See CN \\
\hline Capsaicin & $\begin{array}{l}\text { Zacin, } \\
\text { Mioton, } \\
\text { Capsacutin, } \\
\text { Capsaicine }\end{array}$ & $\begin{array}{l}\text { Yellowish powder } \\
\text { isolated from } \\
\text { chilli peppers }\end{array}$ & $\begin{array}{c}\text { Does not dissolve in water } \\
\text { and does not hydrolyse, } \\
\text { dissolves well in carbon } \\
\text { disulphide, organic } \\
\text { solvents }\end{array}$ & Not mentioned & See CN \\
\hline
\end{tabular}




\subsubsection{Psychoactive agents}

Psychoactive agents are synthetic compounds as well as substances of natural origin. They can induce psychic anomalies or physical inability to perform assigned tasks in healthy individuals. Psychoactive agents at very low concentrations cause not only mental defects but also physical disorders, which are difficult to be detected by conventional detection methods.

The effect of psychoactive agents on humans is very diverse and very often even individual. Many psychoactive agents cause sudden changes in the behaviour of affected individuals, which can be compared to schizophrenia. They also cause disorders of movement coordination, temporary blindness and deafness, vomiting, and may suddenly change the blood pressure.

Conversely, other agents cause apathy, malaise, lethargy, indifference and have a negative influence on concentration and other abilities related to thinking. Although there is a very wide range of agents that can be classified as psychoactive, only two agents (d-lysergic acid derivatives and agent BZ) are used for military needs.

- D-lysergic acid derivatives

- Code designation: LSD, LSD-25, Delysid, Lysergamide;

- Physical properties: under normal conditions, a white to yellowish crystalline agent with no significant odour, the melting point is $83{ }^{\circ} \mathrm{C}$. It dissolves well in water and hydrolysis is very slow, it is accelerated by alkalis and by the increase in the temperature, producing inactive products.

\section{- Agent BZ}

- Code marking: BZ, QB, Ro 2-3308;

- Physical properties: an odourless, environmentally stable, white crystalline agent. It does not dissolve in water, but dissolves very well in the form of hydrochloride. The decomposition in water is gradual and can be accelerated by the addition of alkalis.

\section{Symptoms of injuries caused by psychoactive agents}

LSD enters the body through all portals of entry and the first symptoms of poisoning occur within 30 minutes. It can cause an apparent flight of ideas with a tendency to play with words, which is usually accompanied by frequent unmotivated laughter in an affected person.

Frequent hallucinations are created by grotesque figures of people and animals, and visions of geometric patterns; a characteristic feature is the distinctive colour diversity of these hallucinatory scenes. These images are accompanied by spatial and temporal deformations. Emotional reactions include euphoria or depression. Movement disorders are represented by uncoordinated movements, the twitches of calf muscles, mimic and eyelid muscles. The symptoms may take up to two days. Repeated poisonings may also trigger acute paranoid psychoses with hallucinations.

Agent BZ enters the body through inhalation, ingestion or injury, and the symptoms of poisoning occur within 30 minutes. The symptoms are the dilatation of pupils, dry mouth, rapid heart rate, dizziness, muscle weakness and the reddening of the skin. Dilated pupils respond to the light very slowly, the problems with focusing the eyes from more distant to closer objects occur. After 30 to 60 minutes, perception and reactions to external irritation begin to diminish and the psychomotor restlessness alternated with hallucinations occurs. The affected person tends to hold urine and his/her fingers tremble. The affected person loses contact with the environment and does not distinguish the illusion from the reality; he/she tries to do exactly the opposite of what is demanded, which is often accompanied by the explosions of anger and the loss of consciousness can often occur. Such symptoms may take several days. 
The timely use of prescribed individual protective equipment, namely a protective mask respirator, provides a reliable protection against the effects of psychoactive agents. The greatest percentage of casualties would probably be caused due to its delayed use or due to the lack of discipline (e.g. ingestion of contaminated water or food from unknown sources). The people who are in constant contact with a noxious agent must also use scalp surface protection items, which is fully provided by the hood of the filtration protection suit so that the possibility of agent penetrating through external auditory canals and the eardrum could be excluded.

The first aid is to immediately prevent further contact of the affected person with a noxious agent by applying a protective mask respirator, by leaving the contaminated environment, by isolating the affected person and by transporting him/her to the originating medical facility to be provided with professional medical assistance.

A specific antidote against the effects of LSD-25 has not been known yet. For practical needs, the most reliable substance removing the psychological and somatic symptoms of poisoning is professionally administered chloropromazine (Plegomazine, Aminazine, Megaphen, etc.) at a dose of 25-100 $\mathrm{mg}$ intramuscularly.

With respect to the characteristic damage to the cholinergic system when affected by BZ, physostigmine is administered as an antidote at a dose of 2 to $4 \mathrm{mg}$. The dose can be repeated as needed at intervals lasting 1 to 2 hours, but for at least 24 hours. In addition to physostigmine, there is also another antidote called tacrine (1,2,3,4-tetrahydro-9-acridinamine) administered at doses of $30 \mathrm{mg}$ intravenously or at doses of $60 \mathrm{mg}$ intramuscularly. 


\section{Industrial chemicals - a secondary chemical weapon}

The development of modern industry that began in the $19^{\text {th }}$ century forms a basis, upon which the whole presence and future of our consumer-oriented civilization is built. As any phenomenon, this one contains a number of contradictions. One of them is an adverse impact of products, which arise in the process of industrial activities and escape into the ambient environment uncontrollably, even if they are registered. In connection with this, we talk about toxic industrial chemicals or industrial toxicants, more generally and less precisely, about pollutants. The effect of these agents is multifaceted and can be divided into several basic categories, e.g. the direct threat to human health, the indirect threat to human health, the threat to the nutrition base, the damage to the landscape with a consequent psychological impact on the society, the threat to biodiversity and the disturbance of natural balance.

This text deals especially with a special case of the effects of toxic industrial chemicals, which manifests itself in emergency situations, such as chemical accidents, wars or terrorism. In view of this, a relatively small number of these agents with the potentially highest risk have also been selected. These are a total of 14 toxic industrial chemicals: ammonia, hydrogen fluoride, formaldehyde, phosgene, chlorine, phosphorus trichloride, hydrogen chloride, cyanogen chloride, hydrogen cyanide, nitrogen dioxide, sulphur dioxide, carbon monoxide, carbon disulphide and sulphane.

All these agents are at the lowest Table 60: Selected industrial chemicals. level of the imaginary inverted pyramid, from which a huge number of chemical compounds emerge in the production process. With the exception of formaldehyde, these are inorganic substances; in one case it is chlorine gas, in nine cases the compounds of two elements and in four cases the compounds of three elements - formaldehyde, phosgene, cyanogen chloride and hydrogen cyanide.

There are eight elements in the set, namely hydrogen, carbon, oxygen, nitrogen, sulphur, phosphorus, chlorine and fluorine. The lowest molecular mass of the described toxic industrial chemical is $\mathbf{1 7 . 0}$ for ammo-

\begin{tabular}{|c|c|c|}
\hline Agent & $\begin{array}{c}\text { Stored quantity } \\
\text { (tonnes) }\end{array}$ & Note \\
\hline Sulphur & 25,000 & $\begin{array}{c}\text { Formation of } \mathrm{SO}_{2}, \\
\mathrm{H}_{2} \mathrm{~S}\end{array}$ \\
\hline Ammonia & 16,159 & \\
\hline Chlorine & 3,878 & \\
\hline Carbon disulphide & 2,460 & \\
\hline Formaldehyde & 1,269 & \\
\hline Hydrogen fluoride & 277 & \\
\hline Hydrogen chloride & 143 & \\
\hline $\begin{array}{c}\text { Phosphorus } \\
\text { trichloride }\end{array}$ & 130 & Mníšek, Spolchemie \\
\hline Inorganic cyanides & 117 & $\begin{array}{c}\text { They release } \\
\text { hydrogen cyanide }\end{array}$ \\
\hline Phosgene & 26 & Everything in Semtín \\
\hline Sulphur dioxide & 26 & \\
\hline Sulphane & 16 & \\
\hline
\end{tabular}
nia and the highest molecular mass of the described toxic industrial chemical is 137.3 for phosphorus trichloride. The average molecular mass is 53.4. They are, therefore, very volatile low-molecular agents.

\section{Characteristics (term definition)}

The content of the term of a toxic industrial chemical is practically identical with the term of an industrial pollutant. However, the interpretation of these terms is not stable and countless formulations can be found in the literature. There are several reasons for this - on the one hand, the technical basis for producing chemical agents is being developed and, on the other hand, understanding the relationship between a human being and chemistry is improving. 
"Toxic industrial chemicals are chemical individuals that are characterized by toxic effects on the human organism and individual objects of living nature. They are produced, stored and used in such quantities that their leakage (e.g. due to a chemical accident) may result in a serious threat to the health and life of the population and the environmental disturbance or damage."

It is necessary to understand the term hazardous chemical substance, i.e. a substance, which, through its physicochemical and toxic properties, is capable of affecting people, living organisms, the environment and property. In accordance with Act No. 350/2011 Coll., on chemical substances and chemical mixtures, these substances exhibit hazardous properties, such as explosiveness, inflammability, oxygenation capacity, toxicity, causticity, mutagenicity and carcinogenicity (in accordance with Regulation No 1272/2008 of the European Parliament).

\subsection{Classification of toxic industrial chemicals}

To ensure a systematic approach to the study of toxic industrial chemicals, it is appropriate to include them in certain classes according to purposefully selected aspects, the scope of which is not predetermined by anything. Minimally, physical, chemical, toxicological or potentially military aspects must be taken into account. We just mention the examples of a possible approach to classification.

- Physical classification - according to the state of aggregation:

- Gases (phosgene, chlorine, hydrogen fluoride, formaldehyde, cyanogen chloride, hydrogen chloride, sulphur dioxide, carbon monoxide, sulphane);

- Liquids (hydrogen cyanide, phosphorus trichloride, nitrogen dioxide, carbon disulphide); and

- Solids (sulphur - combustion to sulphur dioxide, cyanides - release of hydrogen cyanide).

- Chemical classification (related to a selected set of agents only):

- Sulphur compounds (sulphur dioxide, sulphane, carbon disulphide);

- Nitrogen compounds (nitrogen dioxide, ammonia, hydrogen cyanide, cyanogen chloride);

- Carbon compounds (carbon monoxide, formaldehyde); and

- Halogenated substances (chlorine, hydrogen chloride, phosphorus trichloride, hydrogen fluoride and phosgene).

- Toxicological classification:

- Choking agents or asphyxiants (chlorine, phosgene);

- Blood agents (hydrogen cyanide, cyanogen chloride, sulphane, carbon monoxide);

- Neurotoxic agents (carbon disulphide);

- Irritants (nitrogen dioxide, sulphur dioxide); and

- Corrosive agents (ammonia, hydrogen chloride, hydrogen fluoride, phosphorus trichloride, formaldehyde).

- Military classification - according to military significance:

- Currently-used military agents (phosgene, hydrogen cyanide, cyanogen chloride, carbon monoxide);

- Militarily significant agents from the historical point of view (chlorine, sulphane, sulphur dioxide);

- Chemical warfare agent precursors (chlorine, hydrogen chloride, hydrogen fluoride, phosphorus trichloride, sulphane, ammonia);

- Relatively insignificant agents from the military point of view (formaldehyde, carbon disulphide). 


\subsection{Occurrence, production, storage and distribution}

When studying industrial substances, we cannot manage without knowledge of their origin, sources, production technology and storage and distribution conditions, including transport along all types of roads. These characteristics, as opposed to physical, chemical and toxicological properties, temporally and geographically variable and, therefore, they require constant attention. Even in the Czech Republic, industrial chemicals are produced, processed and used. In many locations and industrial agglomerations, there are several types of these agents together, by which means potential risks are increasing.

\subsubsection{Ammonia $\left(\mathrm{NH}_{3}\right)$}

Under normal conditions, ammonia in pure form is a colourless gas (under normal conditions, the boiling point is $-33.5^{\circ} \mathrm{C}$ ) with a typical distinct, pungent odour. It is alkaline, irritating and corrosive. It is lighter than air and its density is $0.77 \mathrm{~kg} . \mathrm{m}^{-3}$. It can be stored at elevated pressure in a liquid state. Its solubility in water is excellent $\left(540 \mathrm{~g} . \mathrm{l}^{-1}\right)$. It reacts with acids to form ammonium salts. It has strong corrosive effects on metals, especially copper alloys.

In 1786, the French chemist Claude Louis Berthollet (1748-1822) determined the structure of ammonia; the Italian physicist and chemist Amadeo Avogadro (1776-1856) also dealt with the study of ammonia. Ammonia in nature is formed by the microbial decomposition of organic residues in the excrements and urine of animals. It mostly binds in the form of ammonium salts and in the reduction of nitrites or nitrates (nitrification). Some animals, e.g. fish, excrete most of the waste nitrogen in the form of ammonia. In this way, a sizeable amount of ammonia is released into the environment than from anthropogenic sources, especially from the production of commercial fertilizers and urea. Industrial wastes are also a source of ammonia. The ammonia concentration in the clean atmosphere is $0.007 \mathrm{mg} \cdot \mathrm{m}^{-3}$, the polluted atmosphere contains over $0.014 \mathrm{mg} . \mathrm{m}^{-3}$ (the concentration may even be hundredfold). Ammonia remains in the atmosphere for about 7 days. The self-cleaning processes in the atmosphere are based on the reactions with sulphuric acid or nitric acid to form sulphates or nitrates, on the sedimentation and washout by raindrops. Ammonia in trace amount is, therefore, included even in the Earth's atmosphere. In the form of ammonium chloride, salmiac occurs as a mineral, especially in the vicinity of solphatars and other volcanic phenomena. It is contained in large quantities in the atmospheres of large planets in the Solar System (Jupiter, Saturn, Uranus and Neptune) and also in the atmosphere of Saturn's largest moon, Titan. It has also been found in comets. It is also one of the molecules found in the interstellar space.

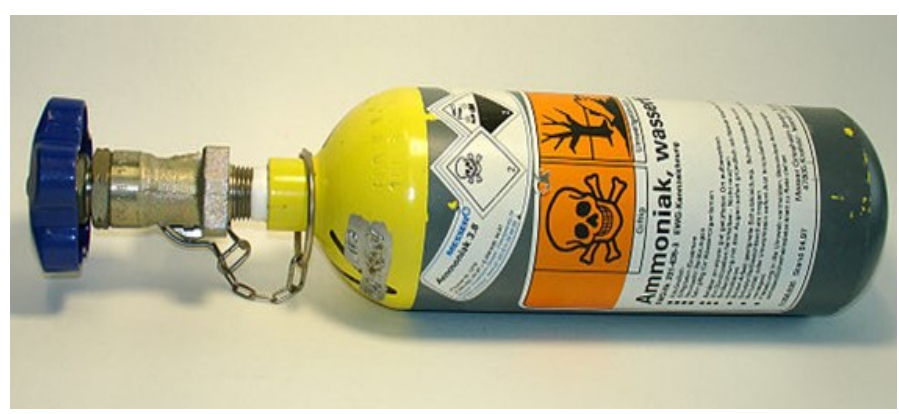

Figure 111: A small compressed gas cylinder with pure ammonia. [Source: Fig-111]

Ammonia is an important product and base material of the chemical industry. The boom in industrial ammonia production dates back to the early $20^{\text {th }}$ century. First in 1901, the French chemist Henry Louis Le Chatelier (1850-1936) discovered the possibility of the ammonia synthesis from nitrogen and hydrogen (the so-called synthesis gas). Later, the German chemists Fritz Haber (1868-1934) and

Carl Bosch (1874-1940) developed an industrially applicable method for the ammonia synthesis under high pressure (10 up to $100 \mathrm{MPa}$ ) and temperatures of around 400 to $600{ }^{\circ} \mathrm{C}$. Iron oxides $\left(\mathrm{Fe}_{2} \mathrm{O}_{3}\right.$ and $\left.\mathrm{Fe}_{3} \mathrm{O}_{4}\right)$ proved to be suitable catalysts. 
During World War I, this direct production method, launched in 1913 at the BASF Company, enabled Germany to cope with the loss of access to natural nitrate sources in Chile blocked by the British Navy; natural nitrates were a strategic raw material in the production of explosive substances. Fritz Haber became a Nobel Laureate in 1918 thanks to the development of this method, which is crucial for the production of nitrogen fertilizers and the multiplication of agricultural food production for the explosively growing population.

A huge increase in the ammonia production was observed at the turn of the 1970s and the 1980s. In 1970, a total of 61 million tonnes of ammonia and nine years later 105 million tonnes of ammonia were produced in the world, mostly in Asia and Central and South America. The main use of ammonia lies in the production of nitric acid, industrial fertilizers, explosives, polymers, pharmaceutical products, rubbers, surfactants and some pesticides. It is also used in the petrochemical industry and electroplating, where it is added to some baths.

It can also be used directly as a fertilizer in the form of an aqueous solution for irrigation. It has fungicidal properties and is, therefore, used in fruit farming to limit the growth of fungi on fruit. In large industrial plants, ammonia is used as a refrigerant charge for refrigeration equipment (ice production, food processing). To a lesser extent, it is also used in the form of chloramine to disinfect and treat drinking water.

Nitric acid, an important product and raw material in the production of explosives, industrial fertilizers and dyes, is produced by the catalytic oxidation of ammonia to $\mathrm{NO}$, which is oxidized to $\mathrm{NO}_{2}$ in an absorption-oxidation device. This method was discovered in 1902 by the German chemist Wilhelm Ostwald (1853-1932) and was put into practice in 1914. More than 30 million tonnes of $100 \%$ nitric acid are produced annually in the world. In addition to nitrogen fertilizers (ammonium phosphate, ammonium nitrate, ammonium sulphate), the direct or indirect (after

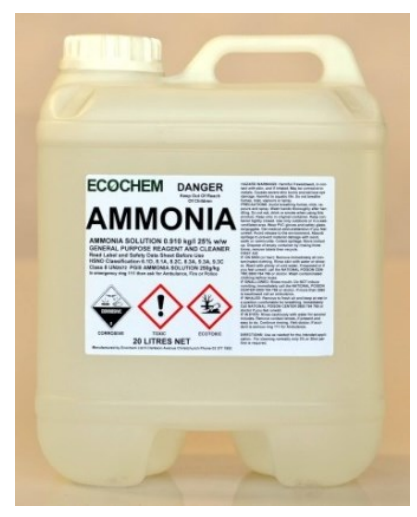

Figure 112: Ammonium hydroxide - 20 litres $(910 \mathrm{~g} / \mathrm{l})$. [Source: Fig-112]

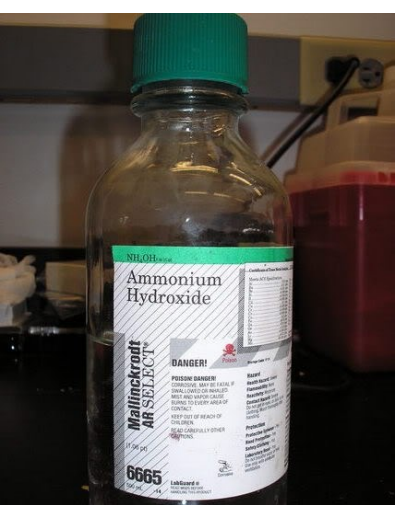

Figure 113: Ammonium hydroxide $-30 \%$ solution.

[Source: Fig-113] further processing) use of urea is relatively widespread in the agricultural practice; urea is produced by the synthesis from ammonia and carbon dioxide with an intermediate to ammonium carbamate.

It dissolves very well in water. At $0{ }^{\circ} \mathrm{C}$, up to $1,148 \mathrm{~cm}^{3}$ of ammonia is dissolved in $100 \mathrm{ml}$ of water to form an alkaline solution called ammoniac. The resulting solution is basic and is also called ammonium hydroxide. However, this designation is somewhat incorrect, as the $\mathrm{NH}_{4} \mathrm{OH}$ molecule does not exist. The absence of the $\mathrm{NH}_{4} \mathrm{OH}$ molecule is consistent with the fact that ammonia is a Brønsted-Lowry base, not an Arrhenius base. The basic nature of ammonia is, therefore, conditioned by its ability to bind the hydrogen ion $\left(\mathrm{H}^{+}\right)$, and not by forming hydroxide ions $\left(\mathrm{OH}^{-}\right)$during the $\mathrm{NH}_{3}+\mathrm{H}_{2} \mathrm{O} \rightarrow \mathrm{NH}_{4}{ }^{+}+\mathrm{OH}^{-}$reaction (only 4 out of 1,000 ammonia molecules react according to this reaction). The correct designation of an aqueous ammonia solution is, therefore, $\mathrm{NH}_{3}(\mathrm{aq})$ or $\mathrm{NH}_{3} \cdot \mathrm{H}_{2} \mathrm{O}$.

Note: In organic chemistry, the systematic name of ammonia is azane; its hydrazine derivative $\mathrm{NH}_{2}-\mathrm{NH}_{2}$ is called diazane.

It reacts with acids to form ammonium salts, e.g. it forms ammonium sulphate with sulphuric acid: $2 \mathrm{NH}_{3}+\mathrm{H}_{2} \mathrm{SO}_{4} \rightarrow\left(\mathrm{NH}_{4}\right)_{2} \mathrm{SO}_{4}$. 
Ammonia is very toxic to aquatic organisms (especially fish); therefore, its good solubility in water plays an important role. The toxic concentrations of ammonia can be released by the decomposition of manure, cattle slurry and wastes from large-scale breeding of poultry. Plants may also be adversely affected if they are exposed to higher ammonia concentrations in both the atmosphere and water. In waters with a sufficient content of oxygen, ammonia is oxidized by nitrifying bacteria to nitrates, which are significantly less toxic to aquatic organisms.

Ammonia occurs naturally in soils, especially in the form of an ammonium ion. The ammoniacal form of nitrogen is a key source of nitrogen for plants. For this reason, industrial nitrogen fertilizers are applied, from which, however, nitrates are released into underground waters. Underground waters can then be unsuitable for human use or, more precisely, the high cleaning costs and the nitrate removal are associated with their use. The presence of nitrates (originating directly from fertilizers or the bacterial oxidation of ammonia) also increases the acidity of soils with negative consequences. Soil acidity is also increased by the deposition originating in the atmosphere. Ammonia forms relatively stable salts with sulphates and nitrates (originating in acid gases $\mathrm{SO}_{2}, \mathrm{SO}_{3}$ and $\mathrm{NO}_{\mathrm{x}}$ ), which are present in the atmosphere.

In comparison with acid gases and ammonia itself such salts are then released much more rapidly from the atmosphere in the form of rains or a deposited matter and get into the soils. Thus, although ammonia itself is an alkaline substance, it participates in acid deposition. It is also one of the originators of the photochemical smog that occurs mainly in cities. Another effect of ammonia rests in its activity within the Total Nitrogen parameter where the main negative impact on the environment is the excessive introduction of nutrients into the environment and, for example, water eutrophication (the growth of algae and cyanobacteria).

A short-term exposure to ammonia may irritate and burn the skin and the eyes with the risk of persistent effects. It can irritate the nasal mucous membranes, mouth and pharynx; it can cause cough and breathing difficulties. The inhalation of ammonia may irritate the lungs and cause cough or dyspnoea. The exposure to higher concentrations of ammonia may cause pulmonary oedema and severe breathing difficulties. At a concentration higher than $0.5 \%$ vol. (about $3.5 \mathrm{~g} . \mathrm{m}^{-3}$ ), even a short-term exposure is fatal. In a normal environment, however, the concentration of ammonia is so low that it practically poses no risk. In this respect, its advantage is a very intense pungent odour, which will warn of its possible presence in the atmosphere before the concentration rises to a dangerous level.

Ammonium salts of strong acids (e.g. sulphuric acid) react in the solution in a slightly acid way because ammonia is only a very weak alkali. The US Occupational Safety and Health Administration (OSHA) has defined a 15-minute exposure limit to $35 \mathrm{ppm}$ (volume) and an 8-hour limit to $25 \mathrm{ppm}$ for gaseous ammonia. The National Institute for Occupational Safety and Health has reduced the concentration of IDLH (immediately dangerous to life and health) from 500 to $300 \mathrm{ppm}$ based on a recent more conservative interpretation of the original 1943 research. This is the concentration that a healthy worker may be exposed to for 30 minutes without suffering irreversible health effects. Other organizations or states have different exposure limits.

In the Czech Republic, the permissible exposure limits (PEL): $14 \mathrm{mg} \cdot \mathrm{m}^{-3}$ and a short-term exposure to the maximum permissible concentration (MPC): $36 \mathrm{mg} \cdot \mathrm{m}^{-3}$ apply; air emissions exceeding 10,000 kg per year are subject to reporting to the Integrated Pollution Register.

Ammonia has a sharp, irritating, pungent odour that warns against a potentially dangerous exposure. The average perception threshold is $5 \mathrm{ppm}$ (sufficiently lower than dangerous or harmful concentrations). The exposure to very high concentrations may lead to the lung damage and death. Ammonium compounds should not come into contact with alkalis (if this is not the goal) since the dangerous doses of ammonia may be released. 


\subsubsection{Hydrogen fluoride (HF)}

The research on fluorine and its compounds began relatively late. Around 1886, Henri Moissan (1852-1907) began to deal with this issue; he was awarded the Nobel Prize for his work in 1906.

Fluorine is a slightly yellowish gas with a pungent odour similar to chlorine. It is a very reactive element, which reacts very vigorously with many materials and substances to form fluorides or hydrogen fluoride. Its boiling point is $-188^{\circ} \mathrm{C}$, its melting point is $-223{ }^{\circ} \mathrm{C}$ and its density is $1.32 \mathrm{~kg} \cdot \mathrm{m}^{-3}$ (thus, its density is comparable that of the air, i.e. $1.26 \mathrm{~kg} . \mathrm{m}^{-3}$ ). In contact with water or air humidity, it reacts to form hydrogen fluoride. Under normal conditions, hydrogen fluoride is a colourless, non-flammable, highly toxic and irritating gas. Its boiling point is $19.5^{\circ} \mathrm{C}$ and its melting point is $-83^{\circ} \mathrm{C}$. However, it usually occurs as an aqueous solution (i.e. hydrofluoric acid). Hydrofluoric acid dissolves glass and attacks many metals (releasing inflammable hydrogen), minerals and organic compounds.

Hydrofluoric acid solutions are stored in plastic containers. Hydrogen fluoride is highly reactive; it does not persist very long in the environment and is rapidly converted to fluorides.

Fluorine compounds are emitted to the atmosphere from the volcanic activity and from a number of industrial productions, especially from aluminium works, the production of extractive phosphoric acid, the silicate industry, the steel manufacture and the fluoro compound production. A part of fluorine is consumed in the production and processing of uranium in nuclear power engineering, in the production of aluminium, stainless steel and in the organic synthesis, especially in the production of polymers (e.g. Teflon) and cooling mixtures of chlorofluorocarbons. Hydrogen fluoride is also used in many applications, i.e. glass cleaning and etching, the production of semiconductor devices, the production of ceramics, electroplating and complex chemical processes where it acts as an intermediate. Further, it is used, for example, in the manufacture of dentures. As for industrial applications, the production of aluminium fluoride and synthetic cryolite can be mentioned.

Hydrogen fluoride is also produced during coal combustion and in the oil industry. It is used as an alkylating catalyst in the production of high-octane petrol. The largest source of air pollutants (hydrogen fluoride and fluorine compounds) are chemical plants producing phosphate fertilizers - superphosphates. Their production is based on the reaction of ground mineral phosphates, e.g. apatite, phosphorite and fluorapatite with sulphuric acid. When decomposed, up to $90 \%$ of fluorine is released as hydrogen fluoride. At a normal temperature, hydrogen fluoride (fluorane) is a colourless, poisonous gas. It results from the direct combination of hydrogen and fluorine to generate heat (exothermic reaction):

$$
\mathrm{H}_{2}+\mathrm{F}_{2} \rightarrow 2 \mathrm{HF}
$$

Technically, hydrogen fluoride is produced industrially by the endothermic reaction of the fluorite mineral (fluorspar, calcium fluoride $\mathrm{CaF}_{2}$ ) with sulphuric acid at a high temperature (about $250{ }^{\circ} \mathrm{C}$ ), the so-called Bayer process. The reaction takes place in a rotary kiln with a capacity of more than 45 tonnes of hydrogen fluoride per day. The crude hydrogen fluoride is washed with sulphuric acid, cooled and, if need be, distilled. The annual world production of hydrogen fluoride exceeds one million tonnes.

$$
\mathrm{CaF}_{2}+\mathrm{H}_{2} \mathrm{SO}_{4} \rightarrow \mathrm{CaSO}_{4}+2 \mathrm{HF}
$$

It dissolves easily in water to form a colourless, highly corrosive solution of hydrofluoric acid. Hydrogen fluoride is highly corrosive and causes very painful and poorly healing wounds when in contact with the skin and mucous membranes. It etches glass. 
Hydrogen fluoride may be inhaled into the lungs and then it penetrates the whole body. The contact with it causes eye and skin burns with irreversible damage. The inhalation causes the irritation of the nose and the respiratory tract, the lung irritation, dyspnoea and pulmonary oedema. Repeated exposures result in bleeding nose, nausea, vomiting and the loss of appetite. There is also a risk of liver and kidney damage.

In the Czech Republic, the permissible exposure limits (PEL) over an 8-hour period: $1.5 \mathrm{mg} \cdot \mathrm{m}^{-3}$ and the short-term exposure to the maximum permissible concentration (MPC): $2.5 \mathrm{mg} . \mathrm{m}^{-3}$ apply; air emissions exceeding 5,000 kg per year are subject to reporting to the Integrated Pollution Register. In the above-mentioned text, it has already been stated that hydrogen fluoride and hydrofluoric acid cause very severe burns when in contact with the tissue. Figure 114 shows what these burns look like. The tissue damage is long-lasting and heals very slowly. Even a permanent damage to the appearance or structure of the skin cannot be ruled out.

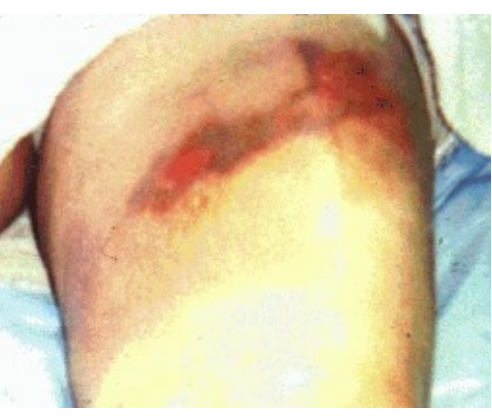

Figure 114: An acute burn caused by hydrogen fluoride. [Source: Fig-114]

\subsubsection{Formaldehyde (HCHO)}

The systematic name methanal, the common name formaldehyde is the simplest aldehyde. It is one of carbonyl (i.e. oxygenous) hydrocarbon derivatives. Its molecular formula is $\mathrm{CH}_{2} \mathrm{O}$ (HCHO). In the food industry, its code is E240; however, in the Czech Republic its use is forbidden.

With regard to its wide use, toxicity and volatility, the effect of formaldehyde is an important factor for human health. Formaldehyde has been classified as a carcinogen of Group 1 (Carcinogenic to Humans) by the International Agency for Research on Cancer.

Under normal conditions, pure formaldehyde is a colourless gas with a pungent odour. Its boiling point is $-19.2{ }^{\circ} \mathrm{C}$, its melting point is $-118{ }^{\circ} \mathrm{C}$ and its density is $1,400 \mathrm{~kg} \cdot \mathrm{m}^{-3}$. At higher temperatures $\left(>150{ }^{\circ} \mathrm{C}\right)$ it decomposes into formic acid and carbon monoxide. Its vapours are inflammable and explosive. Formaldehyde ranks among volatile organic compounds. It is freely soluble in water, alcohols and other polar solvents. Since a pure gas polymerizes easily, it is usually stored in the form of an aqueous solution ( $25 \%$ to $56 \%$ formaldehyde solution). The most frequent concentration is a $37 \%$ solution. The solution usually contains $0.5 \%$ to $15 \%$ of methanol, which serves as a stabilizer. It can also be stored in a solid form as trioxane, a cyclic trimer of formaldehyde or its polymer, i.e. paraformaldehyde. The pure gas is obtained from its aqueous solution or solid formaldehyde by heating.

In 1867, formaldehyde was discovered by the German chemist August Wilhelm von Hofmann (1818-1892); in 1892, another German chemist Friedrich August Kekulé von Stradonitz (1829-1896) isolated it in its pure state for the first time.

The production of formaldehyde is based on the oxidation of methanol using atmospheric oxygen at a temperature of 400 to $650{ }^{\circ} \mathrm{C}$ and the catalytic action of copper, silver or molybdenum. This process, based on Hofmann's observations, was introduced by the German chemist Hans Tropsch (1889-1935).

$\mathrm{CH}_{3} \mathrm{OH}+1 / 2 \mathrm{O}_{2} \rightarrow \mathrm{HCHO}+\mathrm{H}_{2} \mathrm{O}$

It may also be prepared from synthesis gas in the presence of catalysts:

$\mathrm{CO}+\mathrm{H}_{2} \rightarrow \mathrm{HCHO}$ 
The consumption of formaldehyde is enormous, in the United States it is 1.4 million tonnes per year. Formaldehyde is used in the leather, paper and wood-processing industry, in the production of synthetic fibres, urethane resins and phenolic plastics formed by the condensation of formaldehyde and phenol. Bakelite is the most famous phenoplast, which was patented in 1907 by the Belgian chemist Leo Hendrik Baekeland (1863-1944).

Formaldehyde polymers are used for the production of fertilizers, paper, plywood, chip boards and many consumer products. The largest part of total formaldehyde $(25 \%)$ is used for the production of urea-formaldehyde resins, which are used, for example, as adhesives for plywood and carpets. Formaldehyde polymers may also be used for moulded products or foam insulation. Other chemicals are also produced from formaldehyde, e.g. pentaerythritol (used in the manufacture of coatings and explosives), diphenyl diisocyanate (a component of polyurethane coatings and foams), hexamethylene-tetraamine (manufacture of phenol-formaldehyde resins and explosives), nitrilotriacetic acid, methylenedianiline and complexing agents (ethylenediaminetetraacetic acid /EDTA/). Further, it is also used in the textile and photographic industry, in electroplating, as an inhibitor of metal corrosion, a petrol stabilizer and a wood preservative. It is also used to produce dyes, surfactants, extracting agents, perfumes and fragrances.

Formaldehyde kills most bacteria and, therefore, it is also used as a preservative for some foodstuffs, cosmetics and pharmaceuticals and as a cleaning agent, a disinfecting agent and a sterilizer. In agriculture, it is used for the soil and seed disinfection and as an insecticide and fungicide. It is also of significant use in medicine and in the veterinary field. Its aqueous solution is commonly used for preserving biological material and for embalming human bodies. The disinfecting effect of formaldehyde is based on the reaction of the aldehyde group with free amino groups in proteins (resulting in $\mathrm{H}_{2} \mathrm{C}=\mathrm{N}-\mathrm{R}$ ).

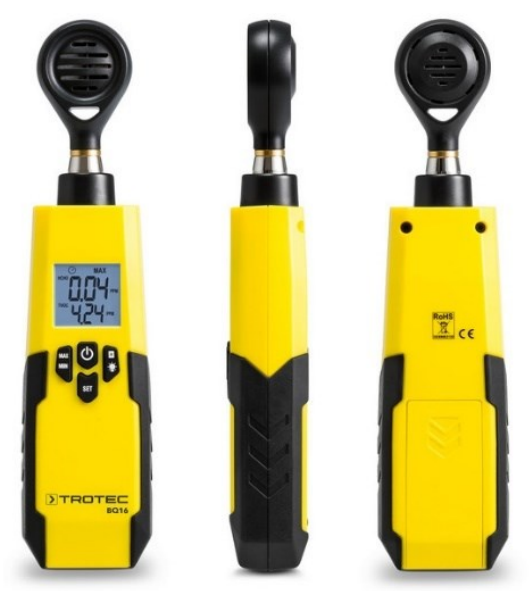

Photo 144: An apparatus for measuring formaldehyde in the atmosphere.

[Source: Pho-144]

Formaldehyde is a normal product of living cells, it occurs in small amounts in fruits, vegetables and meat. Forest fires and some decomposition processes are also a natural entry into the environment. A large amount of formaldehyde originates secondarily in the atmosphere by the oxidation of natural and anthropogenic organic compounds. It is estimated that natural and secondary emissions are higher than direct anthropogenic emissions. Formaldehyde is released into the environment during its production, processing and storage; it may leak out, when handling formaldehyde containing wastes. It is a product of imperfect combustion of organic materials. Automobile combustion engines are an important source. Formaldehyde is found in cigarette smoke and emissions from combustion plants, thermal power plants, heating plants and oil refineries. It gets into the atmosphere even when used as a disinfecting agent and a sterilizer. It is also released from the products containing formaldehyde, e.g. plywood, carpets, papers, cleaning agents, insulating materials, furniture, textiles and wood preservatives.

Most formaldehyde in the atmosphere decomposes during one day by the reaction with the hydroxyl radical and the resulting product is carbon dioxide. Only a very small amount of formaldehyde gets into water through the atmospheric deposition. Formaldehyde in water is decomposed with the help of microorganisms within a few days. Biodegradation reactions also occur in the soil. 
Thus, formaldehyde decomposes quickly in the environment and does not cumulate in food chains. Nevertheless, chronic exposures of organisms near formaldehyde sources may occur. Especially algae and other unicellular organisms are sensitive to formaldehyde. Formaldehyde, just as other volatile organic compounds, reacts with other pollutants in the atmosphere, by which it can contribute to the formation of ground-level ozone and photochemical smog.

Gaseous formaldehyde may enter the body through inhalation or through contact with the skin or eyes. The oral exposure is possible only through an aqueous solution of formaldehyde or contaminated food. Formaldehyde is absorbed easily in the lungs. The half-life of disintegration in the blood is about 90 seconds; the metabolite is formic acid, which is excreted in the urine, and carbon dioxide, which is exhaled.

The acute exposure to small doses of formaldehyde causes headaches and the inflammation of the nasal mucous membrane. A higher concentration causes serious mucosal irritation and respiratory problems, e.g. bronchitis, pulmonary oedema or pneumonia. In sensitive individuals, formaldehyde may cause asthma and skin inflammation. The chronic exposure causes bronchitis. Formaldehyde irritates the eyes and causes watering of the eyes. Higher concentrations may initiate corneal opacity or vision loss. Formaldehyde is absorbed through the skin rapidly and can cause irritation or allergic reactions. The damage may occur up to several hours after the exposure.

Ingestion may cause burns and the perforation of the gastrointestinal mucous membrane. The toxic effect increases the presence of methanol as a stabilizing agent. In the body, formaldehyde is converted to formic acid, which increases the acidity of the blood and leads to dyspnoea, to a decreased body temperature, coma and, in severe cases, to death. In addition to the increased acidity, formaldehyde damages the central nervous system (e.g. spasms), the liver and the kidneys. According to the US Environmental Protection Agency (US EPA) classification, formaldehyde ranks among probable human carcinogens. It also ranks among mutagenic agents and induces chromosomal changes in pneumocytes. Nevertheless, no significant carcinogenic potential has been proved. In connection with the exposure to formaldehyde, some studies have shown an increased incidence of tumours in the nasal and nasopharyngeal cavities. There was no evidence of teratogenicity or reproductive toxicity.

Formaldehyde is highly inflammable in both a gaseous and liquid form. Vapours can move over long distances, which may cause fire at a large distance from the source of the leak. It forms explosive mixtures with the air. The combustion generates poisonous gases. Formaldehyde containers can explode during the fire. Pure formaldehyde can polymerize spontaneously. In the Czech Republic, the permissible exposure limits (PEL) over an 8-hour period: $0.5 \mathrm{mg} \cdot \mathrm{m}^{-3}$ and a short-term exposure to the maximum permissible concentration (MPC): $1 \mathrm{mg} \cdot \mathrm{m}^{-3}$ apply; air emissions exceeding $50 \mathrm{~kg}$ per year or $10,000 \mathrm{~kg}$ per year in wastes are subject to reporting to the Integrated Pollution Register.

\subsubsection{Phosgene}

Phosgene, also called carbonyl dichloride, carbonyl chloride, carbon oxychloride or carbonic acid dichloride, is a highly poisonous, suffocating, colourless gas, which is much more dangerous than chlorine. When it is strongly diluted, it smells like rotten potatoes.

In 1812, phosgene gas was first synthesized by the English chemist Humphry Davy (17781829). The name of phosgene signifies light-born as it was prepared by combining chlorine and carbon monoxide at a temperature of $130{ }^{\circ} \mathrm{C}$ to $150{ }^{\circ} \mathrm{C}$ in the presence of a catalyst, which is activated carbon or platinum sponge in this reaction: $\mathrm{CO}+\mathrm{Cl}_{2} \rightarrow \mathrm{COCl}_{2}$, or if need be, more slowly by the action of light, especially ultraviolet, on the said gas mixture. 
It can also be produced by the photochemical decomposition of chlorinated hydrocarbons, e.g. dichloromethane or tetrachloromethane. It also arises as a result of the thermal decomposition of these compounds. Phosgene is produced using a traditional method, i.e. the reaction of carbon monoxide with chlorine under the catalytic action of activated carbon. This method was also used during World War I in Europe and in the United States. At that time, only a few Italian and French plants produced phosgene using the reaction of fuming sulphuric acid and tetrachloromethane $\left(\mathrm{CCl}_{4}+\mathrm{SO}_{3} \rightarrow \mathrm{COCl}_{2}+\mathrm{SO}_{2} \mathrm{Cl}_{2}\right)$. This method, described by Schüttzenberger in 1869 and by Grignard in 1919, can also be used in laboratory conditions, in a similar way as the thermal decomposition of chloropicrin to phosgene and nitrosyl chloride (Garden and Fox, 1919) or the oxidation of chloroform (Emmerling, 1869).

The high reactivity of phosgene, which releases active (atomic) chlorine easily, is used in the organic synthesis to prepare chlorinated derivatives or, if need be, to introduce the carbonyl group -CO- into organic compounds.

The world's largest phosgene producer is the French SNPE Group seated in Toulouse, the annual capacity of which is 100,000 tonnes of phosgene, i.e. about one-third of global production. The consumption of phosgene will continue to increase. Recently, this company, in cooperation with the American Dow Chemical Company (at the time of the Vietnam War it supplied the US Army with combat herbicides), has started the construction of a special plant, dealing with phosgene chemistry, at La Porte with an annual capacity of 10,000 tonnes.

One of the intermediates in the production of pesticides and insecticides is methyl isocyanate. It is a highly toxic organic compound $\mathrm{CH}_{3} \mathrm{NCO}$, also called methyl carbylamine or MIC. It is produced using the reaction of monomethylamine and phosgene in the gas phase at a high temperature. A mixture of methyl isocyanate and two moles of hydrogen chloride is formed; hydrogen chloride reacts with $\mathrm{N}$-methyl carbamoyl chloride (MCC), which condenses from the mixture. One mole of hydrogen chloride leaves as a gas.

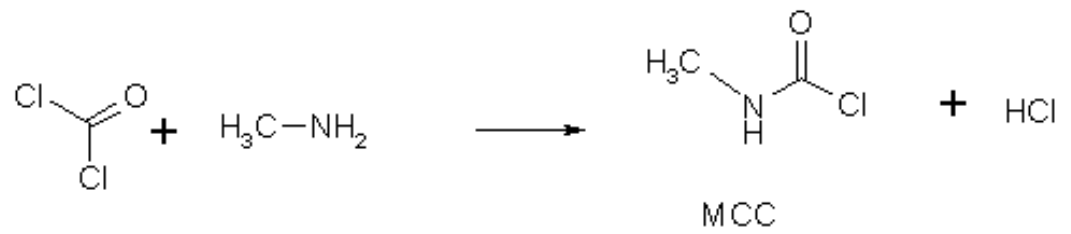

Methyl isocyanate is obtained by the treatment of MCC using the reaction with tertiary amine, e.g. N, N-dimethylaniline or pyridine, or is separated by distillation.

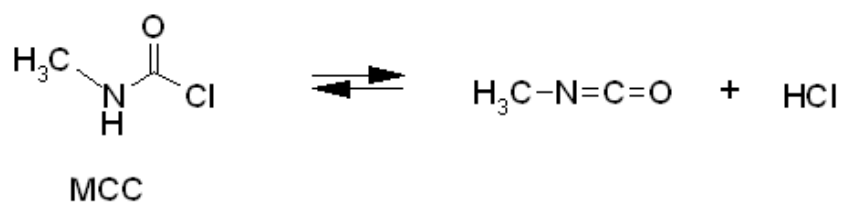

Methomyl $\mathrm{C}_{5} \mathrm{H}_{10} \mathrm{~N}_{2} \mathrm{O}_{2} \mathrm{~S}$ (intermediate) also arises due to the reaction of $\mathrm{N}$-methylformamide $\mathrm{C}_{2} \mathrm{H}_{5} \mathrm{NO}$ and air in the production of carbofuran. MIC is extremely toxic and irritating. When inhaled, ingested and when mucous membranes are exposed, irritation already at a low level $(0.4 \mathrm{ppm})$ appear. Cough, chest pain, dyspnoea, asthma, irritation of the eyes, nose and throat, itching and burning of the skin belong to the symptoms of poisoning. The higher exposure level (over $21 \mathrm{ppm}$ ) results in the permanent (partial) eye damage, pulmonary oedema, pulmonary emphysema, bleeding, bronchial pneumonia and death. Although methyl isocyanate is odourless, most people recognize its presence mainly because of copious lacrimation already at a level of $0.2 \mathrm{ppm}$. The limit (safe) values set by the American Conference of Governmental Industrial Hygienists are $0.02 \mathrm{ppm}$. Methyl isocyanate is a compound responsible for the poisoning and death of several thousands of people in Bhopal, India. 
Tetrachloromethane, also known as carbon tetrachloride, is a colourless liquid with a characteristic sweetish ether-like odour, insoluble in water, well soluble in organic solvents methanol, ethanol, benzene, petrol, etc. It is used as a solvent in a chemical laboratory. It is also used for preparing alkyl chlorides through the Appel reaction (converts alcohol into alkyl chloride in the presence of triphenylphosphine).

In the past, it was used as a cooling agent in refrigeration systems, for dry cleaning of fabrics and clothes, as an industrial degreaser of objects, as a paint thinner, as part of a propellant in aerosol cans (especially with paints) and also as a fire extinguisher charge (the so-called carbon tetrachloride extinguishers). It is little reactive chemically, it does not react with oxygen, therefore, it is non-flammable. At high temperatures, however, it reacts with oxygen to form phosgene and chlorine:

$$
2 \mathrm{CCl}_{4}+\mathrm{O}_{2} \rightarrow 2 \mathrm{COCl}_{2}+2 \mathrm{Cl}_{2}
$$

Currently, phosgene is manufactured by Synthesia a.s.

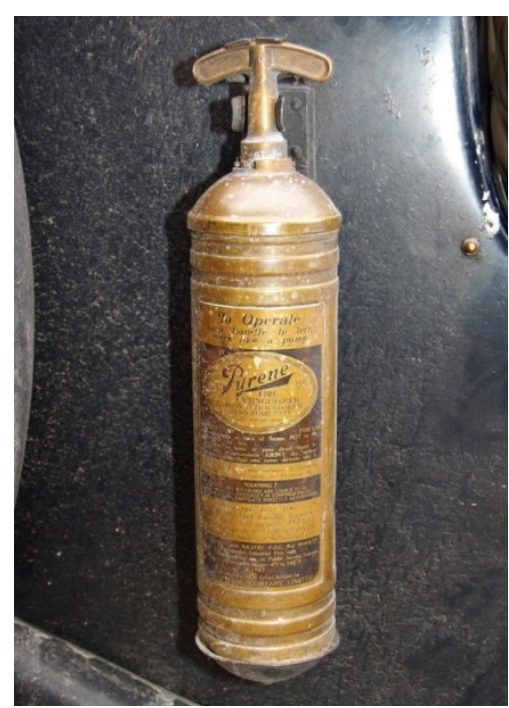

Photo 145: Carbon tetrachloride extinguisher from the 1930s.

[Source: Pho-145] Pardubice - Semtín in the Czech Republic. All phosgene produced in the manufacturing department, which is part of the SBU Organic Chemistry, is processed for the production of chloroformates (pesticide production), isocyanates (pesticide production), substituted urea (production of pesticides and explosives) and intermediates for the production of dyes and organic pigments. Synthesia manufactures its own carbon monoxide by the combustion of coke with a mixture of oxygen and carbon dioxide for the needs of phosgene production. The reaction of carbon monoxide with chlorine with the use of activated carbon (Supersorbon) takes place at a temperature of $140{ }^{\circ} \mathrm{C}$ and at an overpressure of $0.3 \mathrm{MPa}$. The optimum ratio for chlorine and carbon monoxide is $1: 1.25$. Resulting phosgene gas is liquefied in condensers cooled to $-20{ }^{\circ} \mathrm{C}$. Liquid phosgene (with a maximum residual chlorine content of $0.2 \%$ ) is stored in pressure tanks with a maximum content of 3.2 tonnes. Liquid phosgene is also transported in $500 \mathrm{~kg}$ barrels for the production of dyes. In 1998, the whole production of phosgene was modernized using the fully automated technology of the Swiss Buss ChemTech, which is not so risky since synthetized phosgene is not liquefied and stored; it is consumed directly, continuously in the gaseous state.

During World War I, it was used as a chemical warfare gas. The main target organ is the lungs. Phosgene irritates the skin and especially the eyes. It is not known that systemic absorption occurs; when in contact with the tissue, hydrolysis takes place immediately.

Due to the action of water, phosgene is hydrolysed (at a normal temperature slowly and at an elevated temperature faster) to produce hydrochloric acid and carbonic acid or, if need be, carbon dioxide:

$$
\begin{aligned}
& \mathrm{COCl}_{2}+2 \mathrm{H}_{2} \mathrm{O} \rightarrow \mathrm{H}_{2} \mathrm{CO}_{3}+2 \mathrm{HCl}, \\
& \mathrm{COCl}_{2}+\mathrm{H}_{2} \mathrm{O} \rightarrow \mathrm{CO}_{2}+2 \mathrm{HCl}
\end{aligned}
$$

The hydrolysis process is the main cause of the toxic effect on the human organism; in contact with the mucous membrane moisture, phosgene is decomposed according to the above-mentioned equations (as the case may be, chlorine may also be a decomposition product). The decomposition products react with free amino groups $-\mathrm{NH}_{2}$, hydroxyl groups $-\mathrm{OH}$ or sulphhydryl groups -SH in protein molecules in cellular membranes. Both effects lead to the disruption of the membranes separating air from blood in the lungs and ultimately to the development of pulmonary oedema, which is often the cause of death. 
A concentration of 500 to $800 \mathrm{ppm}$ is fatal $\left(\mathrm{LC}_{50}\right)$ during 1 minute of exposure. A concentration of $200 \mathrm{ppm}$ can pass through the air-blood barrier and cause blood clotting. Concentrations above $50 \mathrm{ppm}$ are considered to be almost certainly fatal. At concentrations of 2 to $5 \mathrm{ppm}$, symptoms of poisoning will occur; long exposures can be dangerous to life. A concentration of $0.5 \mathrm{ppm}$ for 2 hours produces distinct changes in the lung tissue in rats.

After exposure, there may be a symptom-free period lasting from 30 minutes to 24 hours. If a person survives poisoning for 2 to 3 days, the further prognosis is good. The recovery from poisoning takes usually a long time, the full pulmonary function usually restores for several weeks and the complete cure takes even several years. Some symptoms (cough, pulmonary insufficiency) may persist. Phosgene poisoning may worsen the course of later bout of flu.

\subsubsection{Chlorine}

Under normal conditions, chlorine is a toxic, corrosive, greenish yellow gas with an extremely pungent odour. Its boiling point is $-34{ }^{\circ} \mathrm{C}$, its melting point is $-101{ }^{\circ} \mathrm{C}$ and it has a density of $1.42 \mathrm{~kg} . \mathrm{m}^{-3}$, which means that it is slightly heavier than the air (air density is $1.29 \mathrm{~kg} . \mathrm{m}^{-3}$ ). It is a very reactive gas, which is able to oxidize many metals even at room temperature. As for the solubility in water, chlorine gas reacts with water to form chlorine water or, if need be, equilibrium mixtures of chlorine, hypochlorous acid and hydrochloric acid. At higher concentrations, hydrochloric acid is formed by dissolving hydrogen chloride in water.

Chlorine was discovered in 1774 by the Swedish chemist Carl Wilhelm Scheele (17421786). The name is derived from the Greek chloros (green). The natural source of chlorine is a volcanic activity. In volcanic gases, 7.6 million tonnes of chlorine are released annually into the atmosphere. Anthropogenic sources are even more significant. Chlorine plays a key role in the production of synthetic chemicals and plastics, especially PVC, polyurethanes and polycarbonates. It is used in the paper industry in large quantities. It is also used as a disinfectant for the drinking water treatment. Its importance is so great that it can be regarded as an indicator of the chemical industry performance in a given country.

It is produced using the electrolysis of an aqueous solution of sodium chloride - brine, when chlorine is precipitated at the anode and sodium at the cathode, which reacts with water to form sodium hydroxide and hydrogen. In principle, two types of electrolysers are used, i.e. with an iron cathode and a mercury cathode (the so-called amalgam method). Chlorine is liquefied and stored in tanks. Chlorine is intended for producing a PVC intermediate called ethylene dichloride, for producing organic and inorganic chemicals and for producing paper.

During World War I, the major powers produced 100,000 tonnes of chlorine. Nowadays, these powers produce about 100,000,000 tonnes, i.e. 1,000 times more, for the same time (about 4 years). This comparison is significant when assessing chlorine not only as a raw material for the production of chemical warfare agents, but it proves that chlorine can be used as a toxicant directly on the battlefield (e.g. information from the war in Bosnia in the mid-1990s).

Chlorine is a very important raw material in the chemical industry. It is widely used in the production of many common materials, e.g. polyvinyl chloride (PVC) and many other organic materials. Further, it is used for the production of chloroform, trichloro-benzenes, propylene oxide and, for example, phosgene and mustard (chemical weapons). It is also used for the production of inorganic compounds and disinfectants. Chlorine or some of its compounds are used for bleaching pulp, cellulose and paper. The bactericidal properties of chlorine are used for the disinfection of drinking water as well as water in reservoirs and swimming pools intended for recreation. Chlorine (and its compounds) is used for producing disinfectants, dyes, insecticides, varnishes, solvents, textiles or in medicine. 
If chlorine gets into the environment, e.g. as a result of an accident, it can immediately burn nearby plants, but then it quickly reacts with air humidity to produce hydrogen chloride.

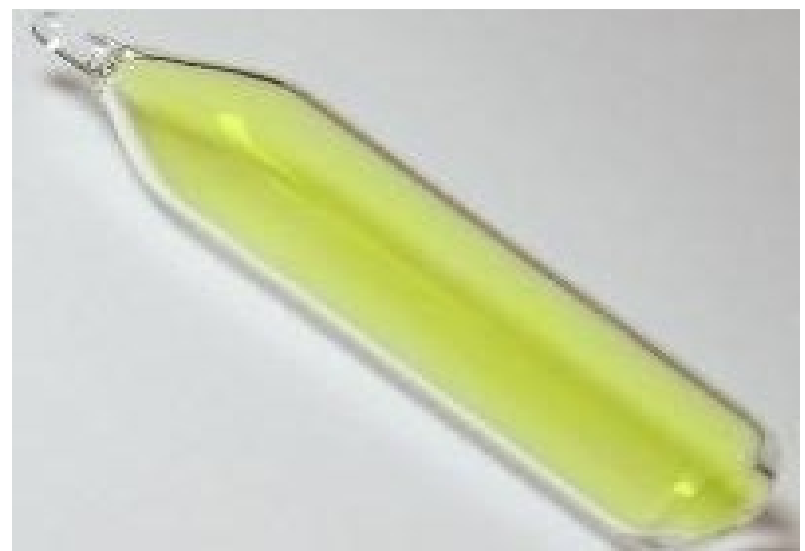

Photo 146: Liquid chlorine. [Source: Pho-146]

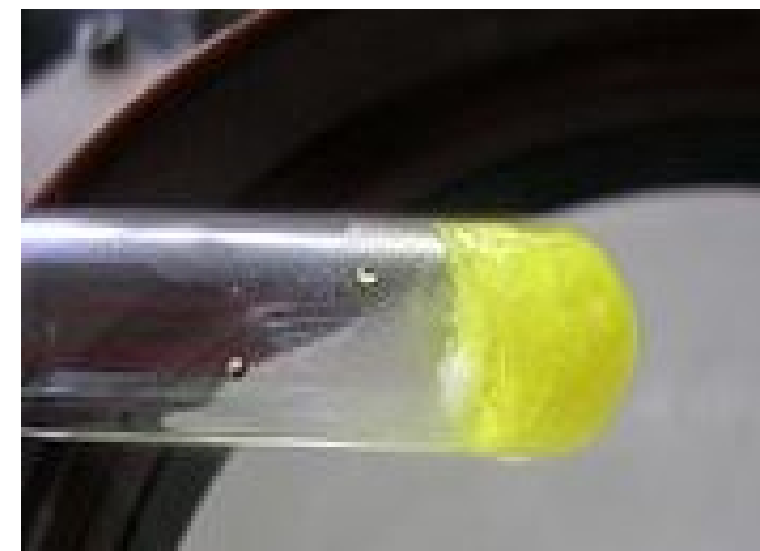

Photo 147: Solid chlorine at a temperature of $-150{ }^{\circ} \mathrm{C}$. [Source: Pho-147]

Chlorine is a very dangerous and aggressive gas. Its advantage is a very strong odour that a person notices even at low concentrations. This warns of the approaching danger and allows people to leave the affected area quickly. Chlorine may be inhaled into the body. It reacts with the humidity immediately to form aggressive hydrogen chloride (and hypochlorous acid). Therefore, the effects of exposure to chlorine or hydrogen chloride cannot be clearly distinguished. In a person exposed to chlorine (or hydrogen chloride) the following risks and difficulties may occur:

- Irritation of the nasal cavity and the respiratory tract, the formation of cracks in the airways, a heavy cough, bleeding nose and the chest pain;

- Lung irritation, dyspnoea, fluid production in the lungs (oedema) and the risk of suffocation; and

- Burns to the eyes and skin with irreversible damage.

Repeated exposures may damage the lungs and teeth irreversibly and cause rashes. In the Czech Republic, the permissible exposure limits (PEL) over an 8-hour period: $8 \mathrm{mg} . \mathrm{m}^{-3}$ and a short-term exposure to the maximum permissible concentration (MPC): $15 \mathrm{mg} . \mathrm{m}^{-3}$ apply; air emissions exceeding $10,000 \mathrm{~kg}$ per year are subject to reporting to the Integrated Pollution Register.

\subsubsection{Hydrogen chloride}

Hydrochloric acid (or dissolved hydrogen chloride) is a clear or slightly yellowish liquid. Its neutralization results in the formation of chlorides. Hydrogen chloride gas has a very pungent aggressive odour. Its density is $1.18 \mathrm{~kg} \cdot \mathrm{m}^{-3}$; thus, it is only slightly lighter than the air. It is a very aggressive and corrosive gas. Already in 1658, the German chemist and medical doctor Johann Rudolf Glauber (1604-1688) conducted salt decomposition experiments and developed a process for the production of hydrochloric acid. In 1772, the English chemist Joseph Priestley (1733-1804) prepared and described hydrogen chloride gas when he heated sodium chloride with sulphuric acid.

Hydrogen chloride is produced by the decomposition of sodium chloride using sulphuric acid (the so-called sulphate process) or by the direct synthesis of chlorine and hydrogen if a highly pure product is required. When using this process, which has become increasingly popular in recent years, a dried chlorine gas is burned in furnaces in a hydrogen flow. Produced hydrogen chloride is cooled and deprived of water (by freezing) and chlorine. 
A considerable portion of hydrogen chloride is also produced as a by-product of the chlorination of organic compounds, e.g. in the production of aliphatic and aromatic chlorinated hydrocarbons, in the production of isocyanates by the reaction of amines with phosgene or in the production of fluorocarbons by the conversion of chlorinated hydrocarbons using hydrogen fluoride (HF). Every year, several millions of tonnes of hydrogen chloride are produced worldwide. Excess hydrogen chloride is processed into chlorine and hydrogen. Generally, the amount of waste hydrogen chloride in organic chemistry exceeds its consumption. Hydrogen chloride is used for the hydrochlorination of rubber, in the production of vinyl chlorides and alkyl chlorides, in the separation of cotton from wool and in the cleaning of cotton. It is also used for etching semiconductor crystals and it is an intermediate in many industrial processes.

Hydrochloric acid is used to pickle steel surfaces. It can be used to remove rust (iron oxides) before further steel processing. Technical 18\% hydrochloric acid is most often used for this purpose. Hydrochloric acid is also used in the production of polyaluminium chloride. It is often used in the electrochemical industry for galvanizing and producing batteries. Its further use is in the organic chemical production of e.g. polycarbonates, activated carbon and ascorbic acid. It is also present in the production of food ingredients and additives, aspartame, fructose or citric acid. Hydrochloric acid is a substance naturally occurring in the digestive tract of many animals and humans, where it is a major contributor to the digestion of food intake.

Hydrogen chloride is a very corrosive substance that attacks numerous metals and limestone, which leads to the deterioration of buildings as well as protected national monuments. Hydrogen chloride gas dissolves very rapidly in water (even in air humidity) to form strong hydrochloric acid, which is toxic to aquatic organisms at higher concentrations and also damages plants. However, the acute threat to free-living animals and vegetation due to emissions from combustion processes is improbable, except for possible accidents. Hydrogen chloride arising in the atmosphere contributes to the acidity of rain by dissolving in the water particles of clouds and causes the increase in the acidity of the rainwater. Certain types of the soils and lakes can be particularly sensitive to the occurrence of acid rain. The main gases contributing to the formation of acid rains are sulphur dioxide and nitrogen oxides, but hydrogen chloride can also play a certain role. These substances can be transported over thousands of kilometres via atmospheric currents due to the use of tall chimneys dispersing pollutants high in the atmosphere.

In a person exposed to hydrogen chloride (or chlorine) the following difficulties may occur:

- Irritation of the nasal cavity and the respiratory tract, the formation of cracks in the airways, a heavy cough, bleeding nose and the chest pain;

- Lung irritation, dyspnoea, fluid in the lungs (oedema) and the risk of suffocation; and

- Burns to the eyes and skin with irreversible damage.

Repeated exposures may damage the lungs and the teeth irreversibly and cause rashes. In the Czech Republic, the permissible exposure limit (PEL) over an 8-hour period: 8 mg. $\mathrm{m}^{-3}$ and a short-term exposure to the maximum permissible concentration (MPC): $15 \mathrm{mg} \cdot \mathrm{m}^{-3}$ apply; air emissions exceeding $10,000 \mathrm{~kg}$ per year are subject to reporting to the Integrated Pollution Register.

\subsubsection{Phosphorus trichloride}

Phosphorus trichloride is a chemical compound of phosphorus and chlorine, having chemical formula $\mathrm{PCl}_{3}$. It is the most important of the three phosphorus chlorides. It is mainly important for the chemical industry and is used in the production of organic phosphorus compounds for a wide variety of applications. 
Phosphorus trichloride is used to produce phosphonic acid, di- and tri-esters of phosphonic acid, hydroxyethane diphosphonic acid, phosphorus pentachloride, phosphoryl trichloride, thiophosphoryl chloride, aliphatic acid chlorides, surfactants and stabilizers. It is used in the production of organophosphorus pesticides (also in the production of nerve agents), which is also of great importance from the military point of view. Its production is based on the direct synthesis of white phosphorus with chlorine gas $\left.\left(\mathrm{P}_{4}+6 \mathrm{Cl}_{2}\right) \rightarrow 4 \mathrm{PCl}_{3}\right)$.

It can also be prepared by the effect of hydrogen chloride gas on phosphorus trioxide $\left(\mathrm{P}_{4} \mathrm{O}_{6}\right)$. The purity of technical phosphorus trichloride is higher than $99.7 \%$ and does not contains elemental phosphorus. In 1979, its world consumption was 220,000 tonnes, of which the half of the consumption was in the United States. Phosphate ore reserves are estimated at 131 billion tonnes, the most in Morocco (42 billion tonnes). It is a precursor of other phosphorus compounds; it undergoes oxidation to phosphorus pentachloride $\left(\mathrm{PCl}_{5}\right)$, thiophosphoryl trichloride $\left(\mathrm{PSCl}_{3}\right)$ or phosphorus oxychloride $\left(\mathrm{POCl}_{3}\right)$. When an electric discharge is passed through a mixture of vapours of phosphorus trichloride $\left(\mathrm{PCl}_{3}\right)$ and hydrogen, rare phosphorus chloride, i.e. diphosphorus tetrachloride $\left(\mathrm{P}_{2} \mathrm{Cl}_{4}\right)$, is formed. Phosphorus trichloride $\left(\mathrm{PCl}_{3}\right)$ is toxic, at a concentration of $600 \mathrm{ppm}$ it kills in a few minutes. Directive 67/548/EEC identifies it as highly toxic and corrosive. Hydrochloric, phosphoric and phosphonic acids are formed by hydrolysis, even in contact with the skin and mucous membranes (including the respiratory tract and eyes). The result is severe irritation, with higher concentrations of burns of mucous membranes and the skin. Pulmonary oedema may develop, sometimes delayed by up to 36 hours. Poisoning also causes mild leukocytosis, neutrophilia and the increased erythrocyte sedimentation rate. Hyperphosphatasia, hypocalcaemia and metabolic acidosis (the result of absorption of phosphoric acid from the decomposition of phosphorus pentachloride) are systemic manifestations.

In the Czech Republic, the permissible exposure limit (PEL) over an 8-hour: $1 \mathrm{mg} \cdot \mathrm{m}^{-3}$ and a short-term exposure to the maximum permissible concentration (MPC): $3 \mathrm{mg} \cdot \mathrm{m}^{-3}$.

\subsubsection{Cyanogen chloride}

Cyanogen chloride (CK) is an inorganic compound with the formula $\mathrm{NCCl}$. Under normal conditions, this linear, triatomic pseudohalogen is an easily condensed colourless gas. It is soluble in water, alcohols and diethyl ether. Although the formula is referred to as $\mathrm{CNCl}$, the connectivity of the cyanogen chloride molecule is $\mathrm{ClCN}$. Carbon and chlorine are linked by a single bond; carbon and nitrogen by a triple bond. The molecule is linear, as in related cyanogen halides (NCF, NCBr, CNl). Cyanogen chloride is produced by the oxidation of sodium cyanide with chlorine. The compound trimerizes in the presence of acids to the heterocycle (2,4,6-trichloro-1,3,5-triazine).

Cyanogen chloride is slowly hydrolysed by water to release hydrogen cyanide:

$$
\mathrm{ClCN}+\mathrm{H}_{2} \mathrm{O} \rightarrow \mathrm{HCN}+\mathrm{HClO}
$$

In 1802, cyanogen chloride was discovered by the French chemist Claude Louis Berthollet. It is formed by the chlorination of hydrogen cyanide $\left(\mathrm{HCN}+\mathrm{Cl}_{2} \rightarrow \mathrm{ClCN}+\mathrm{HCl}\right)$. The reaction proceeds via the chemical intermediate - cyanogen $\left[(\mathrm{CN})_{2}\right]$. The laboratory and industrial production are based on the chlorination of sodium cyanide $\left(\mathrm{NaCN}+\mathrm{Cl}_{2} \rightarrow \mathrm{ClCN}+\mathrm{NaCl}\right)$. Cyanogen chloride is used for organic syntheses.

Cyanogen chloride is a highly toxic blood agent and was once proposed for use as a chemical warfare agent. When in contact with the eyes and respiratory organs, it causes immediate poisoning. The symptoms include drowsiness, rhinorrhoea (an excessive nasal discharge), sore throat, cough, nausea, vomiting, oedema, unconsciousness, convulsions, paralysis and death. 
Cyanogen chloride is particularly dangerous since it is, according to US analysts, able to pass through the filters of protective masks. It is also unstable due to its tendency to polymerize, which can sometimes proceed explosively. Cyanogen chloride is listed in Schedule 3 of the Chemical Weapons Convention. Its production must be reported to the Organization for the Prohibition of Chemical Weapons (OPCW).

\subsubsection{Hydrogen cyanide}

Under normal conditions, hydrogen cyanide is a very volatile colourless or pale-blue liquid (the boiling point is $26.5^{\circ} \mathrm{C}$ ) with a strong smell of bitter almonds. It is a weak acid; when dissolved in water, it is partly converted to the cyanide ion. Hydrogen cyanide vapours are inflammable and potentially explosive. Hydrogen cyanide salts, cyanides, are often used for various purposes. When the $\mathrm{pH}$ (acidification) is changed, hydrogen cyanide is released. Therefore, hydrogen cyanide and its salts cannot be separated unambiguously and strictly as two separate substances.

In the open air, hydrogen cyanide is contained in the so-called cyanogenic plants where it is bound to sugar in the form of glycosides, such as amygdaline. It is contained in bitter almonds, plum, cherry, apricot and peach stones. It is also produced by some mushrooms (Marasmius oreades) to prevent the occurrence of other types of mushrooms. An interesting source of hydrogen cyanide is the Apheloria corrugata millipede. It contains mandelic acid nitrile, which, in case of threat, can be split enzymatically into benzaldehyde and hydrogen cyanide. It is then fired at the attacker as a chemical weapon in defence.

The metallurgical industry is an important source of hydrogen cyanide. It is released during the activities involving the use of hydrogen cyanide or its salts. These are metal extraction (cyanide leaching), metallurgy, electroplating, metal hardening, coal gasification, coking and the use of cyanide compounds as smoke disinfectants.

Hydrogen cyanide is formed during the combustion of nitrogen-containing plastics - polyamide (silon, nylon), polyurethane (plastic foam), urea-formaldehyde resins (umakart, adhesives, varnishes), butylstyrene acrylate (car dashboards), peroxoacetyl nitrate, wool, feathers, natural silk, etc. Therefore, high concentrations of $\mathrm{HCN}$ are released in clothing and carpet fires, in car and aircraft interior fires, and in any residential fire. It may be also produced due to the incineration of municipal waste or in landfills by the conversion of cyanide wastes. It is also contained in tobacco smoke and car exhaust gases. It is released during the detonation of explosives, e.g. trinitrophenol. Hydrogen cyanide can also arise through natural processes. It can also get into the atmosphere due to the biomass burning, volcanic eruptions and natural biogenic processes of plants and bacteria.

In 1710, Johann Jacob Diesbach was working in the laboratory of the German chemist Johann Conrad Dippel (1673-1734) in Berlin and discovered a complex iron compound with cyanides (ferric ferrocyanide) known as Berlin blue (in Germany) or Prussian blue (in Englishspeaking countries). In 1782, Carl Wilhelm Scheele discovered hydrogen cyanide, when heating Berlin blue with sulphuric acid, and called it Berlin blue acid, the current German name Blausäure. In 1786, the French chemist Claude Louis Berthollet determined the chemical composition of this toxicant and, in 1811, the French chemist Joseph Louis Gay-Lussac (17781850) described its structure.

The main use of hydrogen cyanide is the production of organic chemicals (e.g. acrylonitrile, methyl methacrylate, adiponitrile), which are further used for the production of synthetic fibres and plastics (e.g. acrylic resins). Hydrogen cyanide is a rodent control and insecticide against pests and in organic syntheses. 
It is a starting agent for the production of sodium cyanide, nitrilotriacetic acid, chelating agents and other substances. Hydrogen cyanide is also used in various industrial processes (steel hardening, dyeing and in the production of explosives).

In the electroplating practice, metal finishing is carried out in cyanide baths (tanks containing up to 1,500 litres), where the concentration of cyanide ions reaches 45 to 90 g. $1^{-1}$. The concentration of cyanides in waste water is 40 to $60 \mathrm{mg} . \mathrm{l}^{-1}$ in the case of zinc plating or up to $200 \mathrm{mg} . \mathrm{l}^{-1}$ in the case of cadmium plating. Cyanides are used for extracting gold from ores and for silver, cobalt or nickel mining. The first company using this technology was founded in 1889 in New Zealand (the Crown Mines) and at the beginning of the next century the procedure was applied in South Africa, Australia, the United States, Mexico and France. In the world, including the Czech Republic, gold is extracted in this way.

The process to produce hydrogen cyanide is based on passing a mixture of ammonia and carbon monoxide over aluminium oxide or cerium oxide as a catalyst at a temperature of 500 to $700{ }^{\circ} \mathrm{C}$ :

$$
\mathrm{NH}_{3}+\mathrm{CO} \rightarrow \mathrm{HCN}+\mathrm{H}_{2} \mathrm{O}
$$

Another process (Andrussow) lies in the catalytic oxidation of a methane-ammonia mixture using atmospheric oxygen on platinum gauze at high temperatures:

$2 \mathrm{CH}_{4}+2 \mathrm{NH}_{3}+3 \mathrm{O}_{2} \rightarrow 2 \mathrm{HCN}+6 \mathrm{H}_{2} \mathrm{O}$

Hydrogen cyanide can also be prepared by the thermal decomposition of formamide by the acidification of cyanides, the reaction of acetylene with nitrogen, the heating of chloroform with ammonia or by the reaction of mercury cyanide with sulphane. The production of hydrogen cyanide and cyanides is quite considerable. For example, in 1994, a total of 36 companies in the USA, Western Europe and Japan operated a total of 44 plants producing hydrogen cyanide with a total production capacity of more than one million tonnes. A crucial part, about $80 \%$, is consumed for the production of organic substances, the rest falls on the production of sodium cyanide, of which $90 \%$ is used in the mining industry. The world's largest hydrogen cyanide producer is DuPont Company. Cyanide-based products are also produced by LZ Draslovka, a.s. Kolín, the Czech Republic, founded already in 1906. Its traditional products are sodium cyanide (for electroplating practice and gold extraction) and a rodenticide (URAGAN D2), which contains a solid carrier with adsorbed hydrogen cyanide similar to Zyklon B.

Hydrogen cyanide occurs freely in the air and in smaller quantities it can be bound to aerosol particles. The half-life of hydrogen cyanide removal from the atmosphere is 1 to 3 years. It gets into the water or the soil via the atmospheric deposition, where it can be converted into cyanides. With time, most of cyanides from the surface water volatilize in the form of hydrogen cyanide. Cyanides in the soil can volatilize into the atmosphere as hydrogen cyanide, can be washed away to deeper layers or may be transformed into other forms by the microbial activity. Cyanides are highly toxic for soil organisms at higher concentrations. To a varying extent, hydrogen cyanide is toxic to all organisms. It is highly toxic for aquatic organisms.

Hydrogen cyanide enters the organism very quickly through the mucous membranes, skin and lungs. Hydrogen cyanide can penetrate cell membranes easily as it occurs predominantly in the undissociated state at physiological $\mathrm{pH}$. The cyanide ion has a high ferric ion affinity. After penetrating the cell, it reacts readily with trivalent iron of the cytochrome oxidase enzyme of the mitochondrial respiratory chain. Thus, the transfer of electron to molecular oxygen, which cannot be used for oxidizing processes, is blocked. Since the tissues cannot process oxygen, the venous blood contains a lot of the oxyhaemoglobin and is, therefore, bright red. Thus, the skin colour is pink. 
Hydrogen cyanide ranks among the fastest acting poisons. After inhaling the vapours of hydrogen cyanide, the course of poisoning is the fastest; death occurs within seconds. When inorganic cyanides are ingested, hydrogen cyanide is released by the action of hydrochloric acid in the stomach and the first symptoms of poisoning appear in a few minutes. After the ingestion of nitrile or amygdaline from plants, poisoning begins to show after a certain latency - from a quarter of an hour to an hour. The lethal dose of hydrogen cyanide for a person is $50 \mathrm{mg}$, in the case of potassium cyanide $200 \mathrm{mg}$. The first symptoms of poisoning begin to occur in the tissues demanding most oxygen. The nerve tissue is the most sensitive; the first symptoms of cyanide poisoning are fatigue, headache, tinnitus and nausea. After the inhalation of hydrogen cyanide, dizziness, confusion, convulsions, vomiting, tachycardia and unconsciousness develop rapidly and death is instantaneous as a result of apneusis. Death occurs as a result of oxygen deficiency in vital centres in the medulla oblongata. Low concentrations of hydrogen cyanide (20 to $40 \mathrm{mg} . \mathrm{m}^{-3}$ ) irritate conjunctivae and respiratory passages.

In the Czech Republic, the permissible exposure limit (PEL) over an 8-hour period: $3 \mathrm{mg} \cdot \mathrm{m}^{-3}$ and a short-term exposure to the maximum permissible concentration (MPC): $10 \mathrm{mg} . \mathrm{m}^{-3}$ apply; air emissions exceeding $200 \mathrm{~kg}$ per year are subject to reporting to the Integrated Pollution Register. Hydrogen cyanide is highly inflammable and is explosive at concentrations above $5.5 \%$ volume.

The therapeutic response to hydrogen cyanide poisoning must be very fast so that the treatment can make sense. It is necessary to supply a sufficient quantity of ferric ions rapidly to break the bond of cyanides to cytochrome oxidase. The administration of nitrites is an effective measure. Nitrites oxidize the ferrous ion of the haemoglobin to the ferric ion and thus restore the function of cytochrome oxidase. Sulphur in the form of sodium thiosulphate administered therapeutically will allow further detoxification of cyanides. Cyanide ions, which are slowly released from cyanmethemoglobin, are then combined with sodium thiosulphate and excreted in the urine. In the therapy, the cyanide ion bond to hydroxocobalamin is also used to produce vitamin B12, a stable cyanocobalamin complex. It is a risk-free treatment; the problem is a rather high price of the drug.

Vitamin B17 from natural sources can release an indeterminable amount of free cyanide via hydrolysis. Vitamin B17 was first discovered in 1974 by the well-known physician and biochemist, doctor Ernst T. Krebs, Jr. Vitamin B17 is a water-soluble, substantially innocuous substance, referred to as a natural chemotherapeutic agent. It is contained in over 1,200 species of plants, most of which are edible. Vitamin B17 is also known under the name of laetrile or nitriloside. Each of these names, however, designates one and the same substance. Laetrile is a non-hydrolysed, purified form of amygdaline.

This vitamin is composed of four molecules that are mutually interconnected. The central molecule of this vitamin is a hydrogen cyanide molecule, just as in vitamin B12, by another name cyanocobalamin. Further, this vitamin is made up of two sugar molecules and a benzene chain or, if need be, acetone. As is well known, the highest concentration of vitamin B17 is contained in stone fruit kernels, such as apricots, peaches, plums, cherries, sour cherries,

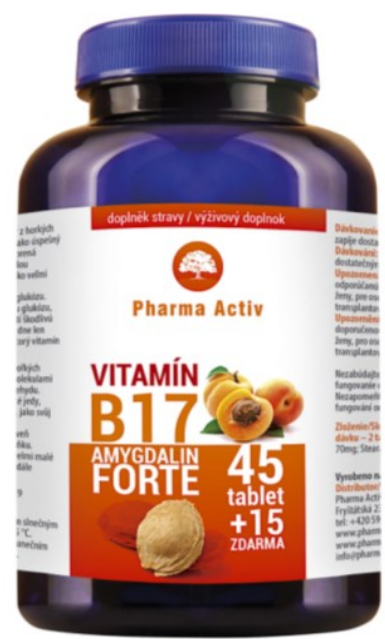

Figure 115: Vitamin B17 as an alternative cancer treatment. [Source: Fig-115] greengages, egg-plums and many others. Apricot and peach stone kernels contain almost $2 \%$ of vitamin B17 of their total weight. The only fruits in the northern hemisphere that do not contain any vitamin B17 are citrus fruits. 


\subsubsection{Nitrogen oxides}

The group of these substances includes a wide range of nitrogen oxides. The most common ones include: nitric oxide (NO, a colourless, odourless gas) and nitrogen dioxide $\left(\mathrm{NO}_{2}\right.$, a reddish-brown gas with a pungent acrid odour). With regard to their densities, the two most significant nitrogen oxides are comparable to air. Further, this group includes nitrous oxide $\left(\mathrm{N}_{2} \mathrm{O}\right)$ known as laughing gas, which is used as a general inhalation anaesthetic, dinitrogen trioxide $\left(\mathrm{N}_{2} \mathrm{O}_{3}\right)$, nitrogen tetroxide $\left(\mathrm{N}_{2} \mathrm{O}_{4}\right)$ and nitrogen dioxide $\left(\mathrm{N}_{2} \mathrm{O}_{5}\right)$. The other nitrogen oxides occur in smaller quantities and do not pose a significant risk. The sum of $\mathrm{NO}+\mathrm{NO}_{2}$ is commonly referred to as $\mathrm{NO}_{\mathrm{x}}$ or nitrous gases.

The natural sources of nitrogen oxides are the most important, e.g. the biological production of $\mathrm{NO}$ exceeds the emissions from industrial sources about 15 times and is 455 million tonnes per year. NO is oxidized by atmospheric oxygen or ozone in the atmosphere and is changed to $\mathrm{NO}_{2}$, which is also produced photochemically.

The content of oxides of nitrogen in the combustion products of domestic fireboxes is estimated at $0.002 \%$ volume, in the factory sidings at $0.5 \%$ volume and in the exhaust gases of cars at 0.005 to $0.3 \%$ volume. The so-called photochemical smog is formed by the photolysis of nitrogen dioxide, releasing ozone, which reacts with some other substances in the atmosphere to undesirable products. The product of this process is, e.g. peroxyacetyl nitrate (PAN), a highly toxic substance for the human organism, found in the smog, which occurs in Los Angeles.

Nitrogen oxides, namely nitrogen dioxide $\left(\mathrm{NO}_{2}\right)$, are used as an intermediate in the production of nitric acid $\left(\mathrm{HNO}_{3}\right)$. First, nitric oxide is formed by the oxidation of ammonia in the presence of catalysts (platinum, rhodium and palladium); then, it is oxidized to nitrogen dioxide in the absorption-oxidation unit. Nitrogen dioxide is introduced into diluted acid to produce concentrated nitric acid. Nitrogen dioxide is also used in many industrial processes as a strong oxidizing agent. Due to its oxidation properties, it can also be used in rocket fuels. Nitric oxide (NO) is used in the production of hydroxylamine, which arises due to the reaction of nitrogen dioxide with hydrogen in the presence of a catalyst.

Currently, the emissions of nitrogen oxides are a very serious problem because they are associated with the combustion of noble fuels (gas, diesel) and biomass. Moreover, the emissions of nitrogen oxides are growing today. The primary source (generating up to $55 \%$ of anthropogenic $\mathrm{NO}_{\mathrm{x}}$ ) is motor vehicles despite of the use of catalytic converters. The combustion of noble fuels in motor vehicles results in a high burning temperature and, therefore, the oxidation of atmospheric nitrogen $\left(\mathrm{N}_{2}\right)$ to the socalled high-temperature $\mathrm{NO}_{\mathrm{x}}$ takes place. Emissions of nitrogen oxides from combustion arise for three reasons and are called fuel, thermal and prompt.

Fuel $N O_{x}$ - the source of these nitrogen oxides is fuels containing nitrogen substances. During the

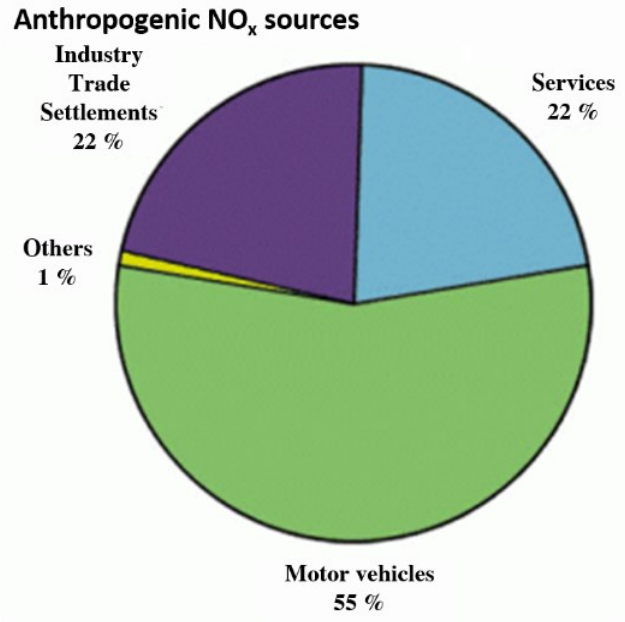

Graph 4: $N O_{x}$ emissions from anthropogenic sources. [Source: Grph-4] combustion, nitrogen is oxidized to nitrogen oxides and dissipates into the atmosphere with other combustion products. This type of nitrogen oxides can form up to $50 \%$ of the total production of nitrogen oxides, when burning light heating oil (LHO), and up to $80 \%$ when burning coal. Emissions can be reduced or eliminated using nitrogen-free fuels. 
Thermal $\mathrm{NO}_{x}$ - are formed by the $\mathrm{N}_{2}$ molecules contained in the air that is involved in the combustion. Due to the high temperature, this atmospheric nitrogen is cleaved and nitrogen oxides are formed with the oxygen atoms present. Their amount depends on the combustion temperature and the residence time in the combustion chamber. Emissions can, therefore, be reduced by a suitable combustion pattern.

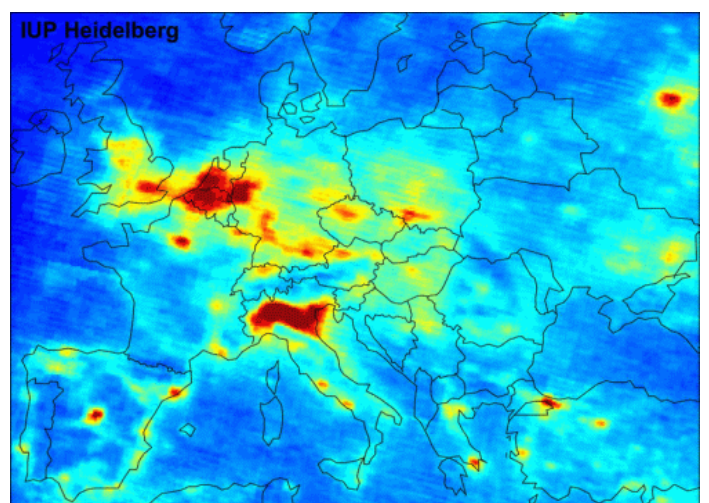

Figure 116: Distribution of $\mathrm{NO}_{2}$ concentration in the atmosphere over Europe (red = increased concentration). [Source: Fig-116]

Prompt $N O_{x}$ - are formed so that molecular nitrogen is converted to NO through intermediates at the flame boundary by radical reactions in the presence of hydrocarbons. Emissions can be reduced with difficulty; however, their share is usually small. The common concentration situation of nitrogen dioxide over Europe is shown in Figure 116. The picture shows the connection of nitrogen oxide emissions with road transport and the industrial activity, especially the energy industry. Therefore, the map shows the highest concentrations round large cities (Paris, London, Madrid, Prague and others) and in industrial areas (Rhineland, northern Italy, Belgium and the Netherlands).

All the chemical processes where these nitrogen oxides are present and where their leakage can take place (e.g. in the production of nitric acid) should be included in other possible anthropogenic sources of $\mathrm{NO}_{\mathrm{x}}$ leakage. However, such productions are now equipped with efficient devices to remove nitrogen oxides from waste gases. The situation of emissions from anthropogenic sources is shown in Graph 4. Further, natural sources, e.g. biological processes in soils, where microorganisms produce nitrous oxide $\left(\mathrm{N}_{2} \mathrm{O}\right)$ and nitrogen $\left(\mathrm{N}_{2}\right)$ within their life cycles, can be mentioned. Nitrogen oxides are also formed due to the oxidation of atmospheric nitrogen during atmospheric discharges (lightning discharges).

Nitrogen is a biogenic element, i.e. it is necessary for plant growth in an adequate quantity. It is a practice that it is supplied to the soil in the form of various fertilizers to promote plant growth. On the other hand, nitrogen oxides, e.g. $\mathrm{NO}$ and $\mathrm{NO}_{2}$, at higher concentrations are harmful to plants and can cause their greater susceptibility to adverse environmental influences such as frost or blight.

Nitrogen dioxide, along with sulphur oxides, is a part of the so-called acid rains, which have a negative influence on e.g. vegetation and structures. They acidify water surfaces and streams. The reason is that nitrogen oxides in the atmosphere are gradually converted to nitric acid, which reacts with dust particles and e.g. with magnesium and calcium oxides or with ammonia to form solid particles. These particles are removed from the atmosphere by sedimentation on the one hand and by washing-out due to rainfall on the other hand. It should be emphasized that the amount of nitrogen that gets into the soils by the atmospheric deposition is no longer negligible as compared with the amount of commercial fertilizers. Nitrate ions, which are then present in soils and waters, are beneficial for plant growth; however, at higher concentrations, fish mortality and the undesirable growth of aquatic plants (the so-called water eutrophication) may also happen.

Nitrogen dioxide $\left(\mathrm{NO}_{2}\right)$, together with oxygen and volatile organic compounds, contributes to the formation of ground-level ozone and the formation of the so-called photochemical smog. High concentrations of ground-level ozone damage live plants, including many agricultural products. Nitric oxide (NO) is also one of the greenhouse gases. 
It cumulates in the atmosphere and, together with other greenhouse gases, it absorbs the infrared radiation of the Earth's surface, which would otherwise escape into the space. It contributes to the so-called greenhouse effect and consequently to the global warming of the planet. Since the atmospheric deposition is also a source of nitrogen for surface waters, it is necessary to consider nitrogen oxides as substances, which can be reflected in the total nitrogen parameter, which has an impact mainly on the emergence of so-called eutrophication of water.

Nitrogen oxides can adversely affect human health, especially at higher concentrations, which are not normally present in the atmosphere. The inhalation of high concentrations or even pure gases, however, leads to serious health problems and can cause death. It is assumed that nitrogen oxides bind to haemoglobin and thus they deteriorate the transfer of oxygen from the lungs to the tissues. Some indications show that nitrogen oxides play a certain role even in the onset of cancer. The inhalation of higher concentrations of nitrogen oxides irritates air passages.

The main impact of nitrous oxide on the environment lies in its ability to absorb the infrared radiation of the Earth's surface, by which means it ranks among the so-called greenhouse gases, i.e. substances contributing to the greenhouse effect, which causes global warming of the Earth. Its potential to contribute to the intensification of the greenhouse effect (i.e. the ability of molecules to absorb the escaping infrared radiation of the Earth's surface) is roughly 270 to 310 times higher when compared with the most discussed carbon dioxide. At high altitudes $(30 \mathrm{~km})$, it is photochemically decomposed into nitrogen and oxygen. However, a small part $(\sim 10 \%)$ is decomposed into nitric oxide (NO). A part of nitrous oxide reactions also includes reactions with ozone; therefore, it also ranks among the substances damaging the Earth's ozone layer. In comparison with nitrogen oxides $\left(\mathrm{NO}_{\mathrm{x}}\right)$, however, it is a substance considered harmless. Its average concentrations in the atmosphere range between $0.24 \times 10^{-4} \%$ volume and $0.29 \times 10^{-4} \%$ volume. The exposure to higher concentrations of nitrous oxide may irritate the eyes, nose and pharynx with subsequent cough or dyspnoea. The exposed person may feel exhausted, tired and sleepy. High concentrations cause unconsciousness and very high concentrations can be fatal. There is a suspicion of teratogenicity (the damage to fetal development); however, this effect has been detected in animals only. In a normal environment, however, the concentration of nitrous oxide is very low and represents virtually no risk.

Although this may sound paradoxical at the time of the SARS-CoV-2 coronavirus outbreak, in many places the population is breathing better during the pandemic. The Fact that the coronavirus pandemic is having a positive impact on the environment was recently shown by the European Space Agency (ESA), which published satellite images of certain European countries, according to which the air in them visibly improved in March within a few days.

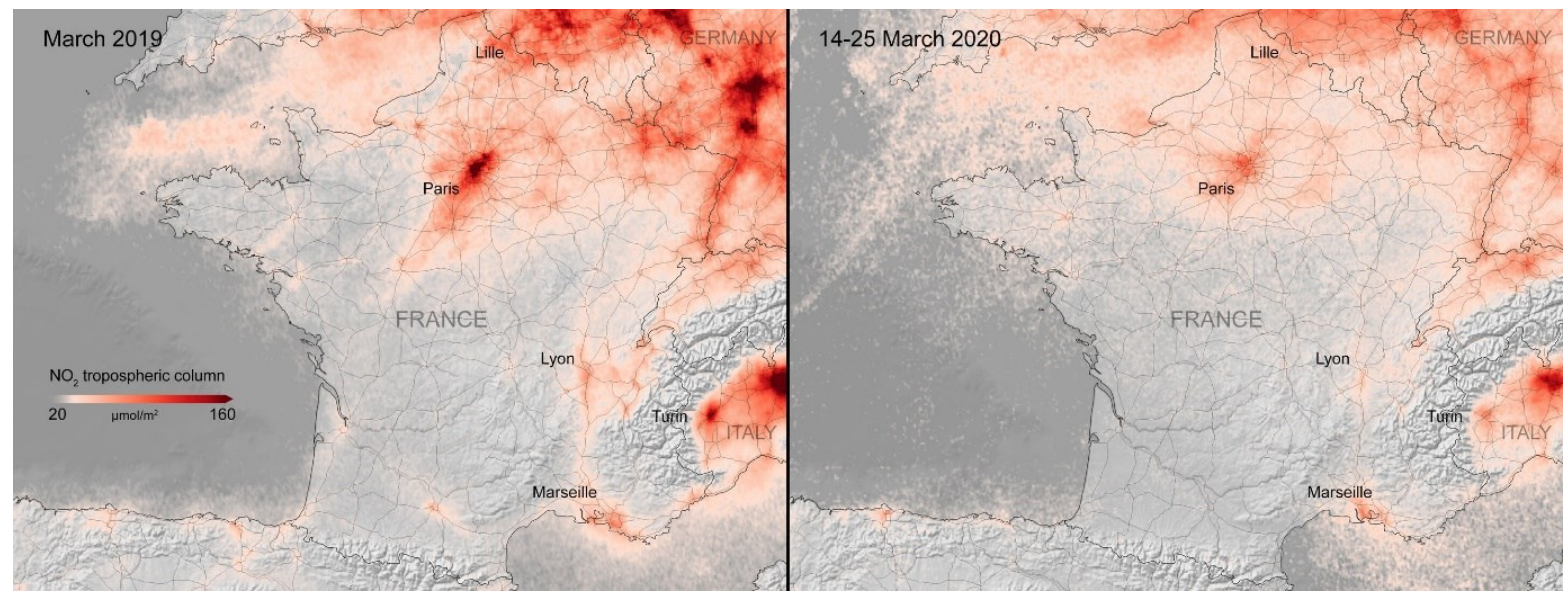

Figure 117: Development of nitrogen dioxide concentration over France. Photo: contains modified data from Copernicus Sentinel satellites (2019-20), processed by RNMI/ESA, Novinky.cz. [Source: Fig-117] 
Compared to a year ago, the values of nitrogen dioxide $\left(\mathrm{NO}_{2}\right)$, which is mainly produced by cars and heavy industry, have decreased significantly.

Copernicus data showed a significant reduction in nitrogen dioxide concentrations over France, Italy, Spain, Portugal, partly Germany, theBenelux countries and the countries on the Adriatic coast. The new images clearly illustrate the significant reduction in nitrogen dioxide concentrations in major cities - specifically Milan and Parisin particular. According to ESA, something like this can be observed over Madrid. The images capture the period from March 14 to 25, using the same type of images from last March.

According to some scientists, pollution may also be related to its impact on the human population. According to Italian experts, the new type of coronavirus can spread better in dusty environments, while according to a US study, infected people are at greater risk of death if they lived in an area with poorer air quality for a long time before the pandemic.

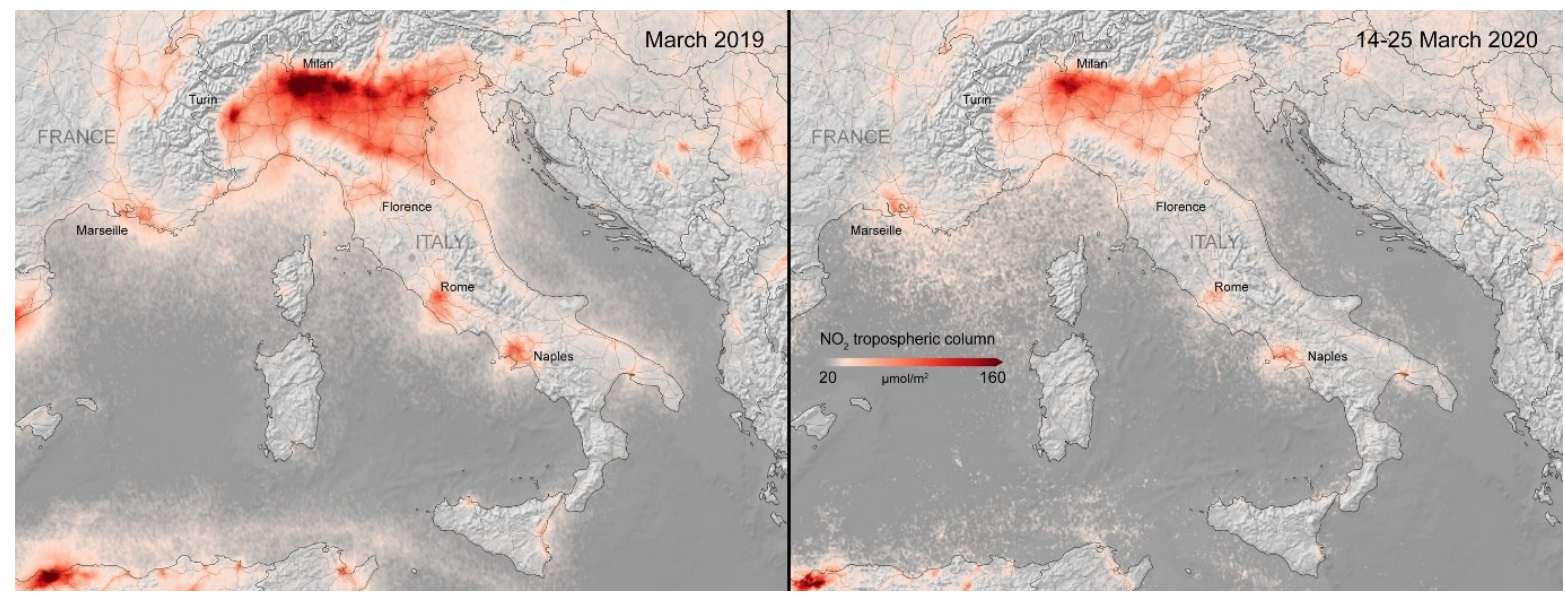

Figure 118: Development of nitrogen dioxide concentration over Italy. Foto: contains modified Copernicus Sentinel data (2019-20), processed by RNMI/ESA, Novinky.cz. [Source: Fig-118]

India's capital, Delhi, an integral part of which New Delhi has long had a reputation as the world's dustiest capital, is now reporting noticeably cleaner air. Mass shutdowns, factory closures and quarantine for residents have helped, causing a large number of cars to disappear from the streets. While usually sights such as the Gate of India or the Presidential Palace are shrouded in more or less dense smog, for example, on Monday, April 6, they unexpectedly shoved against the blue sky. Last year, the Indian metropolis was at the top of the list of the 50 dirtiest cities in the world, which was mainly influenced by industry, exhaust fumes and coal-fired power plants. In the last few days, the air quality index in New Delhi has hovered around 50 to 60, with air quality considered good when the number drops below 50. For comparison, at the end of last year, Indian values were in places as high as 500 .

According to research published in the journal Lancet Planetary Health, local toxic air in India cost the lives of about 1.24 million people in 2017. India has put the measures in place in response to the threat of the spread of the coronavirus. This is despite the fact that the statistics in a country of 1.3 billion people do not look as threatening as in other countries.

The satellite also took February images over China, where the air also improved - according to ESA, also due to anti-coronavirus measures, when production in factories was interrupted and all traffic was suppressed.

"The concentration of nitrogen dioxide changes from day to day due to weather changes. Conclusions cannot be drawn from one-day data alone," said Henk Eskes of the Royal Netherlands Meteorological Institute (RNMI), adding that in 10 days of monitoring it is already possible to clearly show the impact of changes due to human activity. 

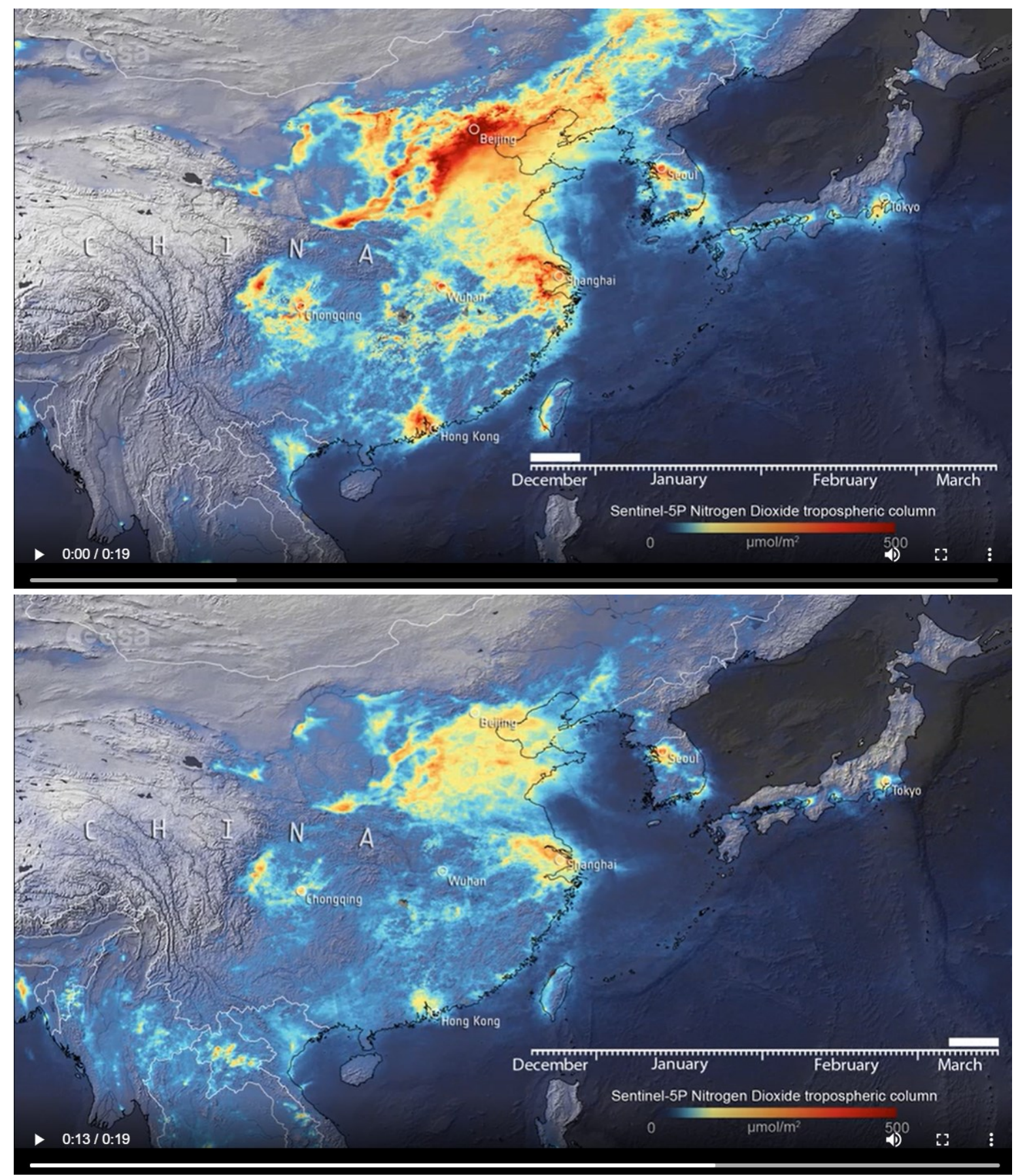

Figure 119-1 and 119-2: This animation, using data from the Copernicus Sentinel-5P satellite, shows the nitrogen dioxide concentrations from 20 December 2019 until 16 March 2020 - using a 10-day moving average. The drop-in concentrations in late-January is visible, coinciding with the nationwide quarantine, and from the beginning of March, the nitrogen dioxide levels have begun to increase. Foto: contains modified Copernicus Sentinel data (2019-20), processed by RNMI/ESA, Novinky.cz. [Source: Fig-119]

In the Czech Republic, for nitrogen oxides the permissible exposure limit (PEL) over an 8-hour period: $10 \mathrm{mg} \cdot \mathrm{m}^{-3}$, and a short-term exposure to the maximum permissible concentration (MPC): $20 \mathrm{mg} \cdot \mathrm{m}^{-3}$, for nitrous oxide, the PEL: $180 \mathrm{mg} \cdot \mathrm{m}^{-3}$, the MPC: $360 \mathrm{mg} \cdot \mathrm{m}^{-3}$ apply; air emissions exceeding 100,000 $\mathrm{kg}$ of nitrogen oxides per year or 10,000 $\mathrm{kg}$ of nitrous oxide per year are subject to reporting to the Integrated Pollution Register. 


\subsubsection{Sulphur oxides}

This group of substances includes sulphur dioxide $\left(\mathrm{SO}_{2}\right)$ and sulphur trioxide $\left(\mathrm{SO}_{3}\right)$. Sulphur dioxide is a colourless, pungent gas, the boiling point of which is $-10.2^{\circ} \mathrm{C}$. It is nonflammable and dissolves in water to form an acid solution. Its solubility is heavily dependent on the temperature: at $20^{\circ} \mathrm{C}$ it is $113 \mathrm{~g} \cdot 1^{-1}$ and at $0{ }^{\circ} \mathrm{C}$ it is $228 \mathrm{~g} .1^{-1}$. Sulphur trioxide is an intermediate in the production of sulphuric acid and it is a solid or liquid substance, which is freely soluble in water to form sulphuric acid.

One of the significant properties of sulphur dioxide is its ability to act as a reducing agent. Therefore, it is used in many applications, e.g. wood protection. In the food industry, sulphur dioxide is used as a preservative in alcoholic drinks and dried fruit. However, the primary site of sulphur dioxide is the sulfuric acid industry, where it is used in large quantities. In the past, liquid sulphur dioxide was used to refine petroleum products. Gaseous sulphur dioxide was used as a protective atmosphere to prevent oxidation when melting magnesium; however, it has been replaced by sulphur hexafluoride. Sulphur dioxide is used in the production of ultramarine, for bleaching wool, fabrics and paper, for disinfecting the vessels and as a fungicide agent in agriculture.

It is produced by burning pure sulphur, roasting sulphide ores (pyrite, chalcopyrite, galena and sphalerite), by burning sulphur trapped on a gas cleaning agent or from waste sulphuric acid. In our country, the most common method of elemental sulphur combustion is used. It is more expensive, but highly efficient.

The content of sulphur dioxide in the atmosphere is an important factor of the hygienic suitability of the environment and an indicator of its overall pollution. It gets into the atmosphere especially due to combustion processes in the production of heat and energy. When burning solid fuels, about $95 \%$ of sulphur converts to $\mathrm{SO}_{2}$, in liquid fuels it is practically $100 \%$. Sulphur dioxide is partially oxidized to $\mathrm{SO}_{3}$ in flue gases. The $\mathrm{SO}_{3} / \mathrm{SO}_{2}$ ratio reaches $1 / 40$ up to $1 / 80$ before the flue gas desulphurization from power plants. However, the effective desulphurization equipment or other technologies can be used. They can reduce or even virtually eliminate all sulphur oxide emissions in some sources. Sulphur dioxide emissions are of main importance since sulphur trioxide is normally found in flue gases in an amount of about $2 \%$ only (from the total sulphur compound content). Sulphur trioxide in the atmosphere is subsequently formed by the oxidation of sulphur dioxide. The thermal power plants (Tušimice, Prunéřov, Počerady, Tisová and the Vřesová IGCC Power Plant) that, in the 1980s, individually produced up to 100,000 tonnes of sulphur dioxide per year are the largest domestic sources of pollution. The high emission values of these sources resulted, among other things, in a continuous belt from Chomutov to Hřensko containing a sulphur dioxide $\left(\mathrm{SO}_{2}\right)$ concentration of about $100 \mu \mathrm{g} . \mathrm{m}^{-3}$ with all the consequences. Objectively, however, due to the large number of different sources, emissions in industrial and urbanized areas are widespread. Natural resources include a volcanic activity and natural forest fires.

Sulphur trioxide concentrations in the atmosphere are substantially lower than sulphur dioxide concentrations. Sulphur dioxide can cause a wide range of adverse effects on both the environment and human health. During a certain period of time, sulphur dioxide in the atmosphere (due to the photochemical or catalytic reaction) converts to sulphur trioxide, which is hydrated by the air humidity to sulphuric acid aerosol. The rate of oxidation depends on the weather conditions, temperature, sunshine, the presence of catalyzing particles, etc. Normally, 0.1 to $2 \%$ of sulphur dioxide present in the atmosphere is removed within one hour. Sulphuric acid can react with alkaline particles of dust aerosol to form sulphates. Sulphates are deposited on the Earth's surface or are washed out by precipitation. In the absence of alkaline particles in the atmosphere, the acidification of precipitated water takes place up to $\mathrm{pH}<4$. 
In this way, sulphur oxides together with nitrogen oxides form the so-called acid rains. These can then be transported by wind over long distances and cause considerable damages to forest stands as well as technical crops. They also release metal ions from the soil, damage microorganisms, degrade the water quality and cause fish kills. Sulphur oxides were a major cause of the so-called London-type smog. Acid rains deteriorate buildings by gradual dissolving some types of masonry at longer exposures.

At normal concentrations around $0.1 \mathrm{mg} \cdot \mathrm{m}^{-3}$, sulphur dioxide irritates the eyes and the upper respiratory tract. At a concentration of $0.25 \mathrm{mg} \cdot \mathrm{m}^{-3}$, respiratory morbidity is increased in sensitive adults and children. A concentration of $0.5 \mathrm{mg} . \mathrm{m}^{-3}$ leads to an increase in mortality in chronically ill old people. An especially vulnerable group of people are mainly asthmatics who are very sensitive to the effect of sulphur oxides. In contact with higher concentrations of sulphur dioxide $\left(\mathrm{SO}_{2}\right)$, an exposed person will experience the following specific manifestations:

- Eye damage;

- Damage to the respiratory organs (coughing, breathing difficulties);

- Formation of fluid in the lungs (oedema) at very high concentrations.

Repeated exposure causes a loss of smell, headaches, nausea and dizziness. The effects of sulphur trioxide, which is usually found in the atmosphere in a lower concentration, are virtually the effects of sulphuric acid aerosol, the irritant effects of which on the respiratory organs are even more unfavourable than those of sulphur dioxide.

In the Czech Republic, to sulphur trioxide the permissible exposure limit (PEL) over an 8-hour period: $1 \mathrm{mg} \cdot \mathrm{m}^{-3}$ and a short-term exposure to the maximum permissible concentration (MPC): 2 mg. $\mathrm{m}^{-3}$, and to sulphur dioxide the PEL: $5 \mathrm{mg} \cdot \mathrm{m}^{-3}$ and a short exposure to the MPC: $10 \mathrm{mg} \cdot \mathrm{m}^{-3}$ apply. Air emissions exceeding $150,000 \mathrm{~kg}$ per year are subject to reporting to the Integrated Pollution Register.

\subsubsection{Carbon monoxide}

Carbon monoxide is an inflammable, highly toxic, colourless and odourless gas (the boiling point is $-192{ }^{\circ} \mathrm{C}$ ). It is the main product of the incomplete combustion of carbon containing materials. As far as its weight is concerned, it is comparable to air (its density is $1.25 \mathrm{~kg} . \mathrm{m}^{-3}$ compared to $1.29 \mathrm{~kg} \cdot \mathrm{m}^{-3}$ of air at $101.325 \mathrm{kPa}$ and $20^{\circ} \mathrm{C}$ ).

Carbon monoxide, discovered by Joseph Priestley, is the most widespread poison, which is responsible for the highest number of poisonings, including the fatal ones. It is formed by burning carbon in an oxygen-deficient system (the essence of the reaction of its formation is the reduction of carbon dioxide). In the laboratory, it is prepared, e.g. by the decomposition of formic acid or oxalic acid by concentrated sulphuric acid. It is contained in numerous gases commonly used in the energy industry and in the mining industry: flue gases ( 1 to $36 \%$ of carbon monoxide according to the burning rate), a lighting gas (4 to $11 \%$ ), coke oven gases ( $7 \%$ ), a producer gas (27 to $29 \%$ ), a wood gas $(28 \%)$, a blue water gas (37 to $39 \%)$, blastfurnace gases ( 25 to $30 \%$ ), exhaust gases ( 4 to $8 \%$ ), gases produced by the dynamite explosion $(28 \%$ ), gases produced by the trinitrotoluene explosion (up to $60 \%$ ) or gases produced in the manufacture of calcium acetylide (60 to $70 \%$ ).

A producer gas is produced in shaft furnaces (generators), in which the air is blown from underneath through a few metres of a thick layer of coke $\left(2 \mathrm{C}+\mathrm{O}_{2} \rightarrow 2 \mathrm{CO}\right)$. If water vapour is fed to the coke-fired generator, a mixture of carbon monoxide and hydrogen is produced referred to as a blue water gas $\left(\mathrm{C}+\mathrm{H}_{2} \mathrm{O} \rightarrow \mathrm{CO}+\mathrm{H}_{2}\right)$. Carbon monoxide is also produced by the effect of water vapour on a natural gas or diesel or, if need be, by the partial oxidation of heavy fuel oil (the so-called steam reforming), when a synthesis gas (syngas) is formed. 
Carbon monoxide reactivity is used in the iron and steel industry when refining metallic nickel. Nickel and carbon monoxide form a volatile substance called nickel carbonyl, which is decomposed into nickel and carbon monoxide. The refining process is based exactly on this reaction. Carbon monoxide is also used in the production of some chemicals. The main method of the industrial production of acetic acid is based on the reaction of carbon monoxide and methanol.

Carbon monoxide in the atmosphere reacts with other substances due to photochemical reactions, especially with the hydroxyl radical, by which means it is decomposed, but on the other hand, these reactions increase the concentrations of methane and especially of harmful ground-level ozone in the atmosphere (photochemical smog). The final product of the carbon monoxide reactions is carbon dioxide. The residence time of carbon monoxide in the atmosphere is estimated at 36 up to 110 days. Carbon monoxide can also be designated as a greenhouse gas (a gas contributing to the intensification of the greenhouse effect and consequently to the warming of the planet) due to its conversion to carbon dioxide.

In the past, the so-called lighting gas, which, since the $19^{\text {th }}$ century, was used for lighting, heating and cooking, was a major source of carbon monoxide. It was also known as a town gas. It was produced by the reaction of hot coke with water vapour and was made up by a mixture of hydrogen and carbon monoxide. The lighting gas was toxic due to the presence of carbon monoxide. Currently, it is replaced by a natural gas. It is also known as a wood gas, which is produced by incomplete combustion of wood and it also contains carbon monoxide.

The concentration of carbon monoxide in the pure natural atmosphere is about 0.1 up to $0.2 \mathrm{mg} . \mathrm{m}^{-3}$ and shows a slight increase in the long-term perspective. In addition to the mentioned oxidation to carbon dioxide, carbon monoxide is naturally removed from the atmosphere by some species of soil bacteria and plants. Carbon monoxide is also slightly absorbed by the oceans; its solubility in water is approximately $26 \mathrm{mg} . \mathrm{l}^{-1}$. For the sake of interest, Figure 120 shows a satellite image of the Earth with carbon monoxide contents in the lower layers of the atmosphere; it was taken from the geostationary satellite within the EU atmosphere monitoring project called Copernicus.

Thursday 20 August 2015 00UTC MACC Forecast t+036 VT: Friday 21 August 2015 12UTC Surface Carbon Monoxide [ ppbv]

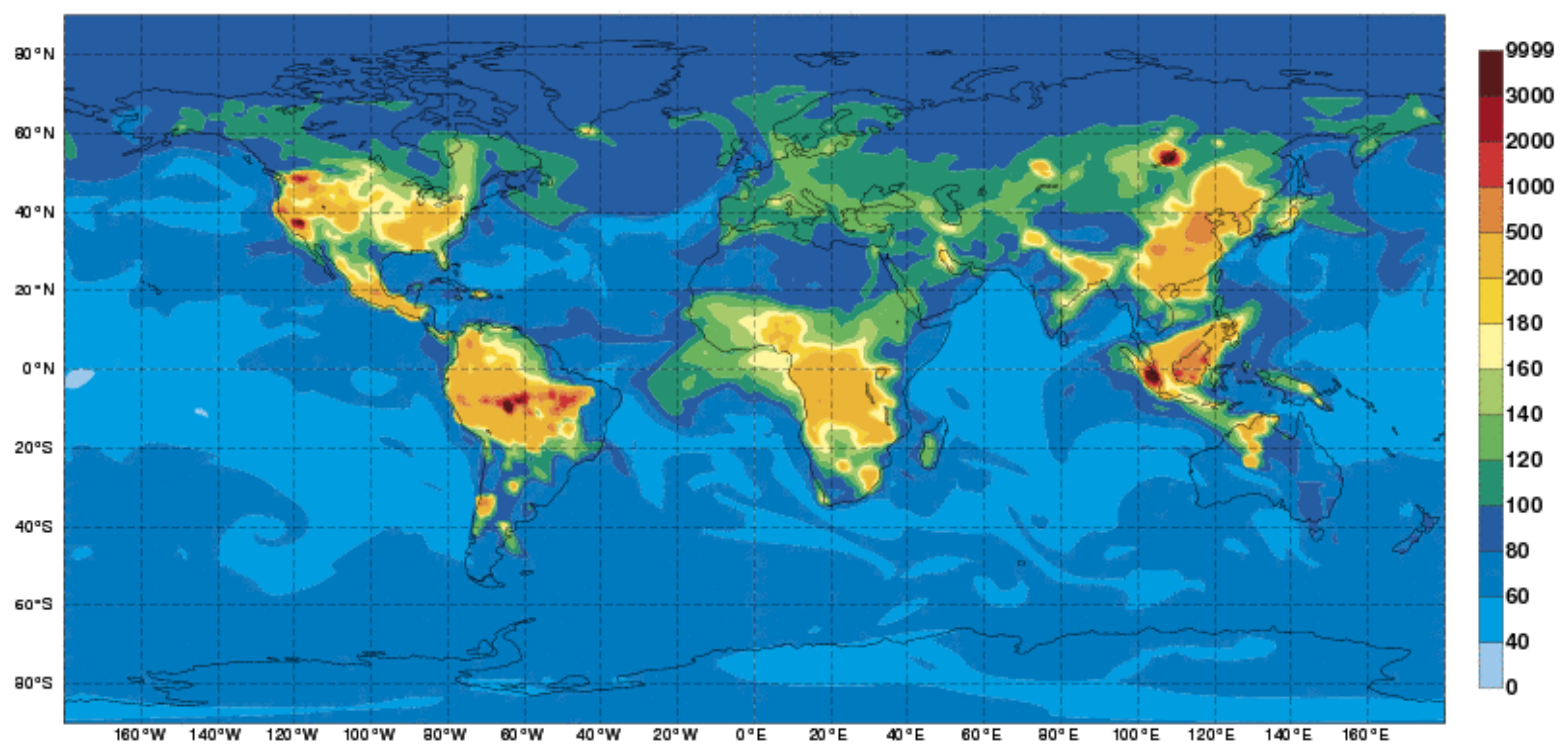

Figure 120: The content of carbon monoxide in the lower layers of the atmosphere. [Source: Fig-120] Note: 1 ppbv (1 ppb volume) denotes one volume fraction per a billion (10-9) 
Carbon monoxide enters the bloodstream via inhalation (pulmonary cells) where it binds to haemoglobin more strongly than oxygen, which is to be transported to the organs and tissues via haemoglobin. Small concentrations of carbon monoxide, which can also occur in the atmosphere (e.g. in the cities) can cause serious health problems, particularly in the people suffering from cardiovascular diseases (angina pectoris). A longer exposure to elevated concentrations of carbon monoxide $\left(>100 \mathrm{mg} \cdot \mathrm{m}^{-3}\right)$ in the atmosphere can cause a variety of problems in healthy people, i.e. the reduced work performance, reduced manual dexterity, impaired ability to study, and a difficulty in performing more complex tasks. During pregnancy, an exposure to small doses of carbon dioxide may cause a lower birth weight of a newborn baby. At higher concentrations carbon monoxide is directly toxic. The poisoning causes a reddish-brown colour of the skin followed by coma, convulsions and death.

In the Czech Republic, the permissible exposure limits (PEL) over an 8-hour period: $30 \mathrm{mg} \cdot \mathrm{m}^{-3}$ and a short-term exposure to the maximum permissible concentration (MPC): $150 \mathrm{mg} \cdot \mathrm{m}^{-3}$, and a short-term exposure to the MPC: $10 \mathrm{mg} \cdot \mathrm{m}^{-3}$ apply. The air emissions exceeding 500,000 $\mathrm{kg}$ per year are subject to reporting to the Integrated Pollution Register. Already in 2010, the production of industrial waste products achieved a level that dramatically overcame the worst-case scenario, against which scientists warned five years ago at the Intergovernmental Panel on Climate Change (IPCC). In 2013, the increase continued and the share of carbon dioxide increased by two particles from the previous 390.9 particles of $\mathrm{CO}_{2}$ in one million particles of the atmosphere. According to the World Meteorological Organization (WMO), the values of carbon dioxide in the atmosphere reach 140 percent of the level from the pre-industrial stage of the first half of the $18^{\text {th }}$ century. Over the last 260 years, 375 milliard tonnes of gas have been released into the atmosphere. These milliards of tonnes of carbon dioxide will remain in the atmosphere for centuries and will cause the continuing warming of our planet and will have an impact on all aspects of life on the Earth. In addition to carbon dioxide, significant greenhouse gases are, e.g. methane or nitrous oxide; last year, according to the report, their values also exceeded the records.

\subsubsection{Carbon disulphide}

Carbon disulphide is a compound of carbon and sulphur. Its formula is $\mathrm{CS}_{2}$. Carbon disulphide is a base material of the chemical industry that is used in the production of carbon tetrachloride, viscous fibres, cellophane, rubber chemicals, pesticides, etc. It is not produced in the Czech Republic; it is imported from abroad. Its production is based on the direct synthesis of sulphur and carbon (by passing sulphur vapours over red-hot carbon):

$\mathrm{C}+2 \mathrm{~S} \rightarrow \mathrm{CS}_{2}$ further, on the reaction of methane and sulphur

$\mathrm{CH}_{4}+2 \mathrm{~S}_{2} \rightarrow \mathrm{CS}_{2}+2 \mathrm{H}_{2} \mathrm{~S}$ or on sulphur vapours and semi-coke in the fluidized bed. The modern production of carbon disulphide is based on a natural gas. It is purified by the distillation and the waste sulphane is treated to sulphur using the Claus process.

Carbon disulphide is a colourless liquid with a sweet ether-like odour. Commercially available carbon disulphide has a strong odour that is caused by impurities, most often by carbonyl sulphide and phosphane. It turns yellow in the light. It is a toxic combustible. It is an excellent solvent for sulphur, phosphorus and iodine. Since it is toxic, caution should be exercised in the course of work with it. It is used as a solvent of organic compounds.

Carbon disulphide reacts with water at an elevated temperature:

$\mathrm{CS}_{2}+2 \mathrm{H}_{2} \mathrm{O} \rightarrow \mathrm{CO}_{2}+2 \mathrm{H}_{2} \mathrm{~S}$

It reacts with sulphur trioxide to form carbonyl sulphide:

$\mathrm{CS}_{2}+3 \mathrm{SO}_{3} \rightarrow \mathrm{COS}+4 \mathrm{SO}_{2}$ 
Its vapours mixed with the air form a fulminating mixture within a wide range of concentrations (from 1 to $60 \%$ volume). It is a nerve poison (headaches, mental disorders, delusional states, visual hallucinations, unconsciousness and death). Chronic poisoning reduces appetite; the skin pallor, sleep disturbances, neurosis, and the central nervous system (CNS) disorders are typical symptoms. The impairment of memory is a typical syndrome. The inhalation of high concentrations of the substance causes narcosis.

Carbon disulphide is used in the production of viscose, cellophane, rubber, etc. The range of carbon disulphide production and consumption in the world is considerable. In 1979, it was (without China) more than 1.7 million tonnes. In 2002, a total of 94,000 tonnes of carbon disulphide was produced in the USA $(159,000$ tonnes of the annual capacity of the US companies, e.g. the AkzoNobel Chemicals, Atochem North America and PPG Industries). In the same year, the USA imported 1,800 tonnes and exported 14,500 tonnes of carbon disulphide. The produced quantity included $40 \%$ of man-made fibres, $18 \%$ of chemical preparations for the cultivation of agricultural crops, $16 \%$ of products in the rubber industry, $12 \%$ of cellophane and regenerated cellulose and $14 \%$ for other purposes. Over a period of one year, 42,200 tonnes of carbon disulphide were released into the US environment, of which $99.2 \%$ were released into the atmosphere. In the Czech Republic, the following limits apply: the permissible exposure limit (PEL) over an 8-hour period, i.e. $10 \mathrm{mg} \cdot \mathrm{m}^{-3}$ and a short-term exposure to the maximum permissible concentration (MPC), i.e. $20 \mathrm{mg} \cdot \mathrm{m}^{-3}$.

\subsubsection{Sulfane (hydrogen sulphide)}

Hydrogen sulphide $\left(\mathrm{H}_{2} \mathrm{~S}\right)$ is a colourless gas having a characteristic odour of rotten eggs. It is heavier than air and can be liquefied easily. It is also the most stable and the most important compound of sulphur and hydrogen. It is the first member of the homologous series of sulphanes. The general formula of these compounds is $\mathrm{H}_{2} \mathrm{~S}_{\mathrm{n}}$, i.e. the formula of disulphane is $\mathrm{H}_{2} \mathrm{~S}_{2}$, the formula of trisulphane is $\mathrm{H}_{2} \mathrm{~S}_{3}$, etc. The salts of the corresponding acids are called polysulphides.

Hydrogen sulphide, the structure of which was described in 1796 by Claude Louis Berthollet, is the main source of sulphur in the atmosphere that comes from the volcanic activity due to the biological processes of organic matter decay and the emissions in the processing of oil, coal and cellulose, and in the paper production or in the production of viscose fibres. The total annual estimate of hydrogen sulphide emissions is more than 100 million tonnes. In the atmosphere, hydrogen sulphide changes due to oxygen, humidity and solar radiation to sulphur dioxide, sulphur trioxide and sulphuric acid.

Hydrogen sulphide is most often produced industrially using the direct synthesis of sulphur with hydrogen at a temperature of $350{ }^{\circ} \mathrm{C}$ and in the presence of catalysts (cobalt oxides, molybdenum oxides on aluminium oxide): $\mathrm{H}_{2}+\mathrm{S} \rightarrow \mathrm{H}_{2} \mathrm{~S}$ or in the laboratory

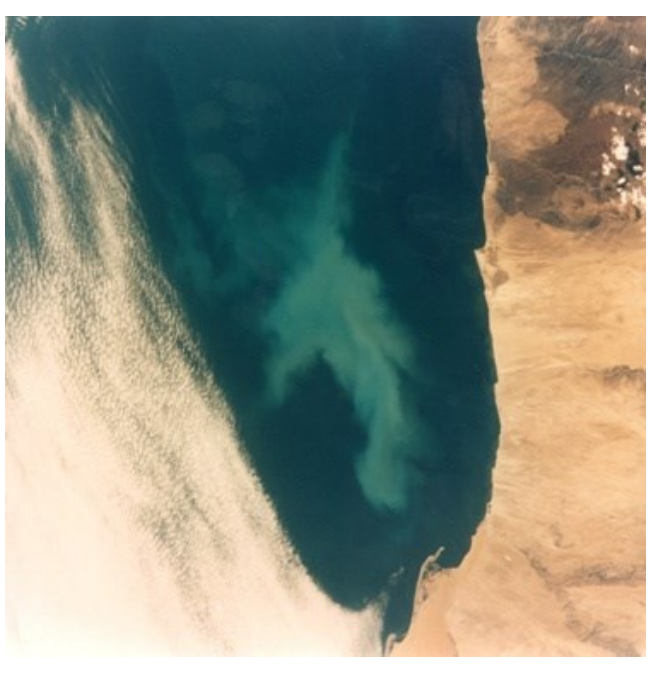

Photo 148: The massive eruption of hydrogen sulphide $\left(\mathrm{H}_{2} \mathrm{~S}\right)$ gases photographed from a shuttle in December 1985 near the coast of Namibia. [Source: Pho-148]

by reacting sulphides (e.g. FeS) with mineral acids. Hydrogen sulphide produced in this way is a starting substance for the production of hydrogen sulphide and sodium sulphide, and organic sulphur compounds such as thiophenes and thiols:

$\mathrm{FeS}+2 \mathrm{HCl} \rightarrow \mathrm{H}_{2} \mathrm{~S}+\mathrm{FeCl}_{2}$ 
It is freely soluble in various liquids including water and alcohol. When dissolving in water, hydrogen sulphide with the same formula as sulphane is produced. It is a weak acid, which forms salts of a double type - sulphides $\left(\mathrm{S}^{2-}\right)$ and hydrogen sulphides (HS $\left.{ }^{-}\right)$. In the bacteria that live in volcanoes it replaces water during photosynthesis to produce solid sulphur that is excreted by the bacteria. We distinguish two types of the combustion of hydrogen sulphide; there is the so-called complete combustion, i.e. with the sufficient air access and the incomplete combustion, i.e. with the insufficient air access. Complete combustion of sulphane produces sulphur dioxide and water:

$2 \mathrm{H}_{2} \mathrm{~S}+3 \mathrm{O}_{2} \rightarrow 2 \mathrm{H}_{2} \mathrm{O}+2 \mathrm{SO}_{2}$

In case of the incomplete combustion, sulphur and water are formed:

$2 \mathrm{H}_{2} \mathrm{~S}+\mathrm{O}_{2} \rightarrow 2 \mathrm{~S}+2 \mathrm{H}_{2} \mathrm{O}$

Hydrogen sulphide is used as a reagent in analytical chemistry. It can precipitate insoluble metal sulphides (e.g. lead sulphide) and prove the presence of given metal cations. Hydrogen sulphide is used in analytical chemistry to analyse metal ions. It is also used in metallurgy for the preparation of metal sulphides. It can also be used in the preparation of oil supplements and in organic synthesis. It is used in deuterium processing, which is one of three hydrogen isotopes.

Hydrogen sulphide is highly poisonous. It can cause fatal poisoning even in smaller doses (including immediate death without morphological changes). Its effects are similar to those of hydrogen cyanide. Both substances inhibit the enzyme cytochrome c oxidase and thus prevent the tissues from using oxygen. This is manifested primarily in the central nervous system (CNS) by the paralysis of the respiratory centre.

Hydrogen sulphide has an irritating and suffocating effect. It irritates the respiratory system and eyes (the irritation occurs in case of a longer exposure at concentrations of 10.5 to $21.0 \mathrm{ppm}$ ). It causes keratoconjunctivitis in the eyes. The respiratory tract irritation is the greatest in its lower part and can also lead to the lung oedema. At concentrations between 1,000 and 2,000 ppm, hydrogen sulphide is rapidly absorbed into the blood and initiates an accelerated respiration, which is later replaced by apneusis. Higher concentrations paralyze the respiratory centre immediately. Without resuscitation (or the spontaneous recovery of breathing) this leads to death by asphyxiation.

At concentrations of 100 up to $1,000 \mathrm{ppm}$, the cause of death is pulmonary oedema. The concentrations of 0.0005 up to $0.13 \mathrm{ppm}$ (depending on the individual sensitivity) are recognizable by the sense of smell. However, high concentrations paralyze olfactory cells rapidly and the smell of gas loses its warning function.

Hydrogen sulphide, along with nitric oxide and carbon monoxide, ranks among the so-called gasotransmitters. Hydrogen sulphide, therefore, acts (as nitric oxide) as a relaxant on smooth muscle cells in the walls of blood vessels (vasorelaxant effect). Its effect on the relaxation of smooth muscle tone in the digestive tract (myorelaxant effect) is also noticeable. Hydrogen sulphide improves penile blood flow, survival of heart attack and blood loss. It can treat erectile dysfunction, some types of migraine and various cardiovascular problems or help in preventing them. The problem for human use is relatively high gas toxicity for people as contrasted with some laboratory animals that tolerate it relatively better. 


\subsection{Toxic industrial chemicals as chemical warfare agents}

\subsubsection{World War I period}

\section{Chlorine, phosgene and hydrogen cyanide}

In principle, there is no sharp dividing line between toxic industrial chemicals and chemical warfare agents. Many toxic industrial chemicals have met and still meet the basic requirements imposed on chemical warfare agents and, in particular, the requirements for toxicity, mass production and ease of use at war.

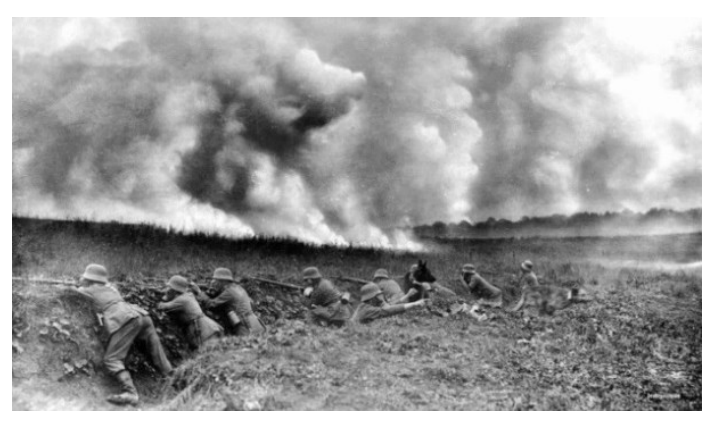

Photo 149: The gas attack on German units (the Western Front near Sedan, May 1917). [Source: Pho-149]

Although there is a general opinion that in World War I, chemical warfare gas was used for the first time by the Germans, this is not the case. Chemical warfare gases were used by all the major warring powers. Between August 1914 and spring 1915, irritants were used sporadically without a greater effect. In August 1914, the French Army on the Western Front used the 26-mm rifle cartridges containing $19 \mathrm{ml}$ of ethyl bromoacetate and xylyl bromide. On October 02, 1914, the German artillery, in return, used o-dianisidine and peppered the French position at Neuve-Chapelle with 3,000 artillery shells of 105-mm calibre (Ni-schrapnell). The French response came in November 1914 when they used chloroacetone in hand and rifle grenades.

On January 31, 1915, tear gas was used in newly constructed German shells of 150-mm calibre marked 12T on the Eastern Front in the Battle of Bolimov $50 \mathrm{~km}$ west of Warsaw. Even though 18,000 pieces of howitzer shells containing xylyl-and xylylene bromide were fired by the Germans, the use of gas was unsuccessful due to the low temperature $\left(-20^{\circ} \mathrm{C}\right)$. In March 1915, when the Germans used these shells at Nieuwpoort in Flanders, their effect was greater due to the higher air temperature. In summer, methyl chloroformate was used in similarly constructed shells with a higher-explosive charge to preserve the splinter effect.

These examples of the first use showed military experts that in order to achieve high combat concentrations and a sufficient poisonous effect, it was necessary to use a much larger amount of a poisonous substance. The German General Staff, therefore, welcomed the proposal of the German chemist Professor Fritz Haber (at that time a governor), who recommended the use of chlorine for the wave attack, which marked a similar divide in the history of war as the dropping of the atomic bomb on Hiroshima.

Chlorine, as one of the most important chemicals for the production of organic dyes, actually began the modern history of chemical warfare. It happened on the Western Front when, on April 22, 1915, the German Army carried out a gas attack with chlorine against the positions of the French troops at Belgian Ypres and killed up to 5,000 soldiers. The example of Germany was also followed by the other powers. The United Kingdom carried out its first gas attack with chlorine at Loos on September 25, 1915, France near Reims on February 15, 1916 and Russia at Smorgon on September 05, 1916. Another important compound in the organic dye industry, which underwent mass military use, was phosgene. On February 21, 1916, it was first used by the French Army in the Battle of Verdun. Four months later, on July 01, 1916, the French introduced another potentially lethal chemical warfare agent called Vincennite. The French began firing Vincennite shells containing hydrogen cyanide in the Battle of Somme. 
Of the total amount of 189,020 tonnes of chemical warfare agents produced during World War I in Germany, France, the United Kingdom and the USA, the amount of chlorine, phosgene and hydrogen cyanide produced was $73 \%$ (138,500 tonnes). In addition to chlorine, phosgene and hydrogen cyanide, other toxic industrial chemicals were used in smaller quantities during World War I. For example, on June 14, 1916, the United Kingdom carried out a gas attack with a mixture of hydrogen sulphide and carbon disulphide (90:10) at Monchy and one year later it introduced a mixture of hydrogen sulphide and chloropicrin (35:65).

Table 61: Production of chemical warfare agents in WW I (in tonnes). [Source: Tab-61]

\begin{tabular}{|c|c|c|c|c|c|}
\hline \multirow{2}{*}{ Agent } & \multicolumn{5}{|c|}{ Country } \\
\cline { 2 - 6 } & Germany & France & $\begin{array}{c}\text { The United } \\
\text { Kingdom }\end{array}$ & The USA & Total \\
\hline Chlorine & 58,100 & 12,500 & 20,800 & 2,400 & 93,800 \\
\hline Phosgene & $18,100^{\mathrm{a}}$ & 15,700 & 1,400 & 1,400 & 36,600 \\
\hline $\begin{array}{c}\text { Hydrogen } \\
\text { cyanide }\end{array}$ & - & $7,700^{\mathrm{b}}$ & 400 & - & 8,100 \\
\hline
\end{tabular}

Note:

${ }^{a}$-Moreover, Germany produced 11,600 tonnes of diphosgene.

${ }^{b}$ - The Vincennite mixture (3,850 tonnes of hydrogen cyanide).

In September 1916, the Austro-Hungarian Army used artillery ammunition filled with cyanogen bromide and the French Army used much more toxic cyanogen chloride. Interestingly, as early as the autumn of 1915, Count Dundonald (Admiral's grandson of the Crimean War) proposed the use of sulphur dioxide, but as in case of his grandfather, the proposal was rejected. In total, more than 50 chemical agents were tested on the battlefields of World War I.

Table 62: Code names of selected agents used in WW I. [Source: Tab-62]

\begin{tabular}{|c|c|c|c|}
\hline \multirow{2}{*}{ Agent } & \multicolumn{3}{|c|}{ Names } \\
\hline & France & The United Kingdom & Germany \\
\hline Chlorine & $\begin{array}{c}\text { Bertholite } \\
\text { Clairsite (thiophosgene) }\end{array}$ & $\begin{array}{c}\text { Blue Star } \\
\text { (+ sulphuric monochloride) } \\
\text { Red Star } \\
\text { White Star (+ phosgene) } \\
\text { Yellow Star (+ chloropicrin) }\end{array}$ & $\begin{array}{l}\text { Grünkreuz } \\
\text { Klop (chloropicrin) } \\
\text { Zusatz (phosgene) }\end{array}$ \\
\hline Phosgene & Collongite $\left(\mathrm{SnCl}_{4}\right)$ & $\begin{array}{l}\text { CBR (+ arsenic trichloride) } \\
\text { CG } \\
\text { PG-Mixture (+ chloropicrin) } \\
\text { White Star (+ chlorine) }\end{array}$ & $\begin{array}{c}\text { Grünkreuz } \\
\text { D-Stoff (diphosgene) } \\
\text { F-Öl }\end{array}$ \\
\hline $\begin{array}{l}\text { Hydrogen } \\
\text { cyanide }\end{array}$ & $\begin{array}{c}\text { Vincennite } \\
\left(\mathrm{AsCl}_{3}, \mathrm{SnCl}_{4}\right) \\
\text { Forestite } \\
\text { Manganite }\left(\mathrm{AsCl}_{3}\right)\end{array}$ & $\begin{array}{l}\text { IL (+ tetrachloromethane) } \\
\text { JBR (+ chloropicrin) } \\
\text { Jellite (+ chloroform) } \\
\text { VN (Vincennite) }\end{array}$ & \\
\hline $\begin{array}{l}\text { Cyanogen } \\
\text { chloride }\end{array}$ & $\begin{array}{c}\text { Mauguinite } \\
\text { Vitrite }\left(\mathrm{AsCl}_{3}\right)\end{array}$ & $\begin{array}{c}\mathrm{CC} \\
\mathrm{CK} \text { (USA) }\end{array}$ & \\
\hline $\begin{array}{l}\text { Hydrogen } \\
\text { sulphide }\end{array}$ & & $\begin{array}{l}\text { NG, NG-2 (carbon disulphide) } \\
\text { Red Star-2 } \\
\text { Vomiting Gas (chloropicrin) }\end{array}$ & \\
\hline
\end{tabular}




\subsubsection{Period after World War I}

After World War I, phosgene, hydrogen cyanide and cyanogen chloride as fast-acting lethal chemical warfare agents were included in the chemical equipment of advanced armies all over the world. When preparing for the German invasion after 1936, the Czechoslovak Army also planned to create a substantial supply of phosgene, but finally, it preferred the production of explosive stabilizers (phosgene served as a basic mix). Major world supplies of these chemicals were created especially during World War II.

Phosgene appeared on the battlefield in civil wars in Russia (1918-1922), in Spain (19361939), during the Italian Army invasion of Abyssinia (1935-1936), in the Sino-Japanese War (1937-1945) and when Egyptian troops were involved in operations in Yemen (between 1965 and 1967). The Chemical Weapons Convention considers phosgene, hydrogen cyanide and cyanogen chloride to be chemical warfare agents listed in Schedule $3 \mathrm{~A}$. Their declaration limit is 30 tonnes and the limit for inspections is 200 tonnes. The classic military use of hydrogen cyanide was observed during the Iraq-Iran War (1980-1988). Between 1985 and 1987, at least 26 cases of the use of blood poisons by aviation and artillery, mostly in combination with nerve agents or mustard, were reported. According to some data, hydrogen cyanide was used on March 18, 1988 in the Kurdish town of Halabja, when 5,000 people died due to the consequences of the chemical attack.

Table 63: Production of chemical warfare agents in selected countries until 1945.

[Source: Tab-63]

\begin{tabular}{|c|c|c|c|c|c|}
\hline Agent & The USA & The USSR & Germany & Japan & Total \\
\hline Phosgene & 18,200 & 8,300 & $5,900^{\mathrm{a}}$ & - & 32,400 \\
\hline $\begin{array}{c}\text { Hydrogen } \\
\text { cyanide }\end{array}$ & 500 & 11,100 & Zyklon B & 255 & $11,855+$ Zyklon B \\
\hline $\begin{array}{c}\text { Cyanogen } \\
\text { chloride }\end{array}$ & 11,400 & - & - & - & 11,400 \\
\hline
\end{tabular}

Note:

${ }^{a}$ - the figure applies to phosgene and diphosgene altogether

In addition to these industrial toxic substances (the so-called backup or substitute warfare chemicals), the possibility of using other simple chemicals, such as chlorine and ammonia, was not completely forgotten. These agents were also used during the wars in the Balkans, Chechnya, Afghanistan, Syria and Iraq (Islamic State). Russia even accused the Chechen armed men that, at the turn of 1999 and 2000, they had used improvised chemical ammunition filled with chlorine and ammonia against federal units and thus had forced them to sound a chemical alert.

An example of the misuse of toxic industrial chemicals is the mass extermination of inferior races (Jews, Slavs and Gypsies) in German concentration camps during World War II. At first, carbon monoxide was used; it was generated as diesel exhaust gas (the so-called Wirth's Heckenhold's exhaust fume) and blown into the load compartment of vehicles or, if need be, gas chambers full of prisoners.

It was later proposed to use an insecticide known as cyclone B (Zyklon B), which contained a solid porous support saturated with hydrogen cyanide (the older composition known as Zyklon A contained methyl cyanate). The Diagriess variant contained discs of ligneous fibre as a support, the Erco variant contained granules of gypsum material. The preparation was invented by the German chemist Walter Heerdt (patent 438818 from 1922) and its owner became DEGESCH (Deutsche Gesellschaft für Schädlingsbekämpfung) from Frankfurt-on-Main, the shareholder of which was IG Farben chemical concern; it introduced bromoethyl acetate (a warning substance), and chloromethyl formate (stabilizer) in the preparation. 
Zyklon $\mathrm{B}$ for DEGESCH was manufactured by Dessauer Werken für Zucker und Chemische Industrie (Dessau) and Kaliwerken (Cologne) and was sold by the Heerdt und Lingler Company (Frankfurt-on-Main) and the Tesch und Stabenow Corporation (Hamburg). Available literature from the Stockholm International Peace Research Institute (SIPRI) lists realized deliveries of Cyclone B to concentration camps: Auschwitz 19,653 kg, Sachsenhausen 4,352 kg, Lublin 1,628 kg (according to other authors up to about $7,000 \mathrm{~kg}$ ), Neuengamme $607 \mathrm{~kg}$, GrossRosen $430 \mathrm{~kg}$ and Ravensbrück $352 \mathrm{~kg}$, in total $27,022 \mathrm{~kg}$. Zyklon B had a deci-

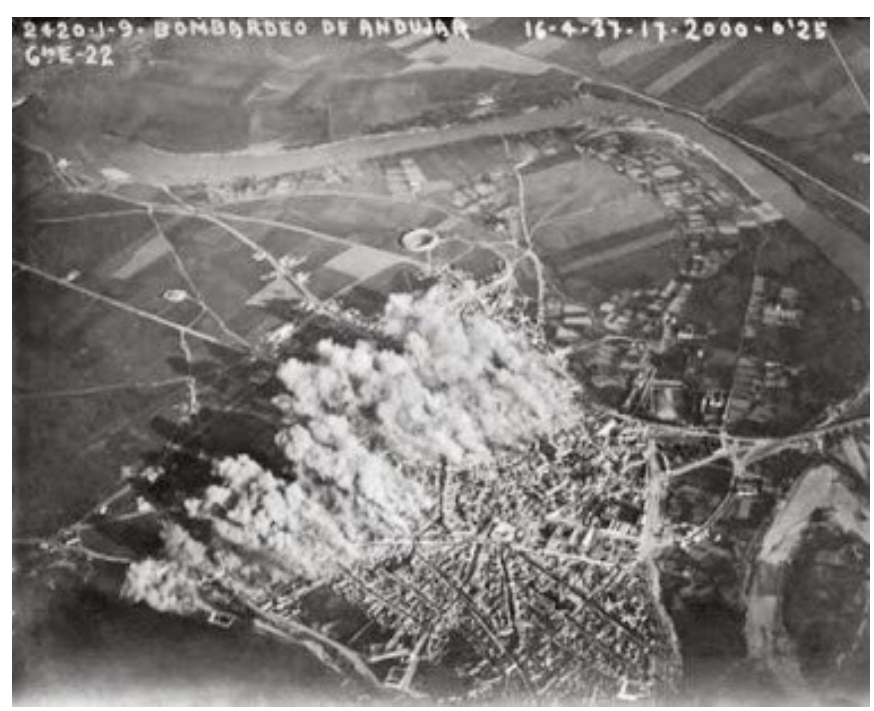

Figure 121: The Spanish Civil War. Bombing of the city of Andujar, 1938. [Source: Fig-121] sive share in the extermination of $6,000,000$ Jews and other nations.

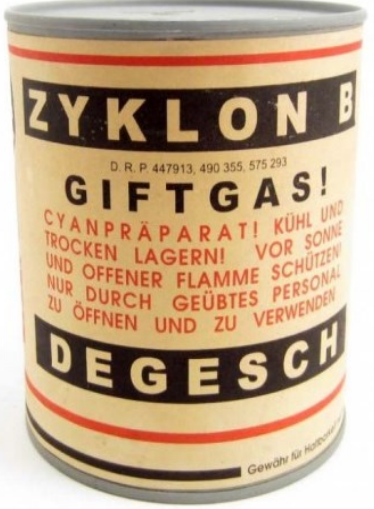

Figure 122: Hydrogen cyanide, ZYKLON B, (Cyclone B) used in German concentration camps.

[Source: Fig-122]

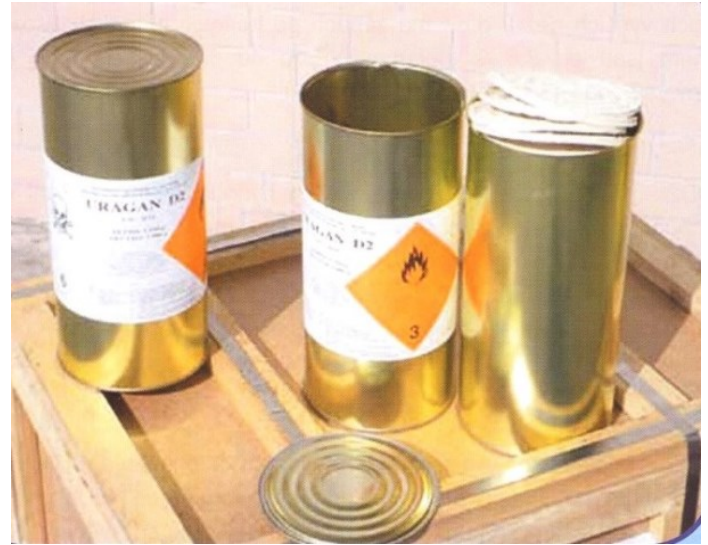

Figure 123: Hydrogen cyanide (stabilized), URAGAN D2, (HCN min. $96.7 \%$ ). Manufacturer: Lučebni závody Draslovka Kolín, joint-stock company. [Source: Fig-123]

\subsubsection{Toxic industrial chemicals as precursors}

Based on the Chemical Weapons Convention, it is necessary to take into account not only toxic chemicals, but also their precursors, when assessing a chemical weapon. Precursor means any reactant that is involved in the production of a toxic chemical in any way and at any stage. Of the substances relevant to the issues of toxic industrial chemicals, phosphorus trichloride as a precursor was included in Schedule $3 \mathrm{~B}$.

For example, during the Gulf War (1990-91), the Allied Forces were bombing the Iraqi Habbaniyah-2 factory (Fallujah-2) from January 17 to February 01, 1991, which stored a quantity of this agent as a precursor for the production of nerve agents (in addition to that, the supplies of chlorine, hydrochloric acid and a large number of organic compounds). Another may be the production of mustard (HD) according to Meyer (from ethylene chlorohydrin to thiodiglycol), in which sulphides and hydrogen chloride are used:

$$
\begin{aligned}
& 2 \mathrm{ClCH}_{2}-\mathrm{CH}_{2} \mathrm{OH}+\mathrm{Na}_{2} \mathrm{~S} \rightarrow \mathrm{S}\left(\mathrm{CH}_{2} \mathrm{CH}_{2} \mathrm{OH}\right)_{2}+2 \mathrm{NaCl} \\
& \mathrm{S}\left(\mathrm{CH}_{2} \mathrm{CH}_{2} \mathrm{OH}\right)_{2}+2 \mathrm{HCl} \rightarrow \mathrm{S}\left(\mathrm{CH}_{2} \mathrm{CH}_{2} \mathrm{Cl}\right)_{2}+2 \mathrm{H}_{2} \mathrm{O}
\end{aligned}
$$


Table 64: An overview of selected toxic industrial chemicals used in the production of chemical warfare agents. [Source: Tab-64]

\begin{tabular}{|c|c|c|}
\hline Agent & $\begin{array}{l}\text { The use in the production of chemical } \\
\text { warfare agents }\end{array}$ & Note \\
\hline Phosgene & Warfare chloroformates & $\begin{array}{c}\text { Chemical Weapons Convention, } \\
\text { Schedule } 3 \text { A }\end{array}$ \\
\hline $\begin{array}{c}\text { Hydrogen } \\
\text { cyanide (cyanides) }\end{array}$ & Bromobenzyl cyanide, Clark II, tabun & $\begin{array}{c}\text { Chemical Weapons Convention, } \\
\text { Schedule } 3 \mathrm{~A}\end{array}$ \\
\hline Chlorine & $\begin{array}{c}\text { Chemical warfare agent with a chlorine } \\
\text { content }\end{array}$ & \\
\hline Nitrites & Clark I & For diazotization \\
\hline $\begin{array}{l}\text { Sulphur dioxide, } \\
\text { sulphites }\end{array}$ & Methyldick, Dick, Clark I & Reduction agent \\
\hline $\begin{array}{c}\text { Sulphane } \\
\text { (sulphides) }\end{array}$ & $\begin{array}{c}\text { Sulphur mustard (gas), phosgene oxime, } \\
\text { thiophosgene }\end{array}$ & \\
\hline Hydrogen chloride & $\begin{array}{c}\text { Clark I, sulphur mustard (gas), } \\
\text { organophosphates, bis(chloromethyl)ether }\end{array}$ & \\
\hline $\begin{array}{l}\text { Carbon } \\
\text { disulphide }\end{array}$ & $\begin{array}{l}\text { Phenyl carbylamine chloride, } \\
\text { perchloromethyl mercaptan }\left(\mathrm{Cl}_{3} \mathrm{C}-\mathrm{SCl}\right)\end{array}$ & World War I \\
\hline Hydrogen fluoride & Organophosphates & \\
\hline $\begin{array}{l}\text { Phosphorus } \\
\text { trichloride }\end{array}$ & Sulphur mustard (gas), organophosphates & $\begin{array}{c}\text { Chemical Weapons Convention, } \\
\text { Schedule } 3 \text { B (precursors) }\end{array}$ \\
\hline Ammonia & Hydrogen cyanide & \\
\hline Carbon monoxide & Phosgene, hydrogen cyanide & \\
\hline Formaldehyde & Bis(chloromethyl)ether & \\
\hline
\end{tabular}

\subsubsection{Chemical accidents and fires}

A chemical accident is a special case of an industrial accident. When using the definition of toxic industrial chemicals, a chemical accident can be classified as the leakage of these chemicals during industrial activities (production, processing, use, transport, storage), which leads to immediate or delayed dangerous consequences for humans and the environment inside or outside a damaged building. In principle, we talk about a chemical type of accident, in which a toxic industrial chemical is released without burning or explosion, a type of fire accident when these chemicals are produced during a fire or an explosion, and finally a combined type of accident that most commonly occurs in practice.

Since 1900, more than 2,500 major industrial accidents have been systematically recorded and evaluated; many of them had all the hallmarks of chemical accidents. The history of industrial disasters included in particular the chemical accidents in Seveso and Bhopal, which (analogous to Chernobyl and Fukushima Daichi in the case of nuclear power) marked a major turning point in the issues of approach to the safety of chemical plants with an emphasis on prevention. Both accidents confirmed the well-known fact that the most sensitive factor of the technological process is its creator himself, i.e. a man.

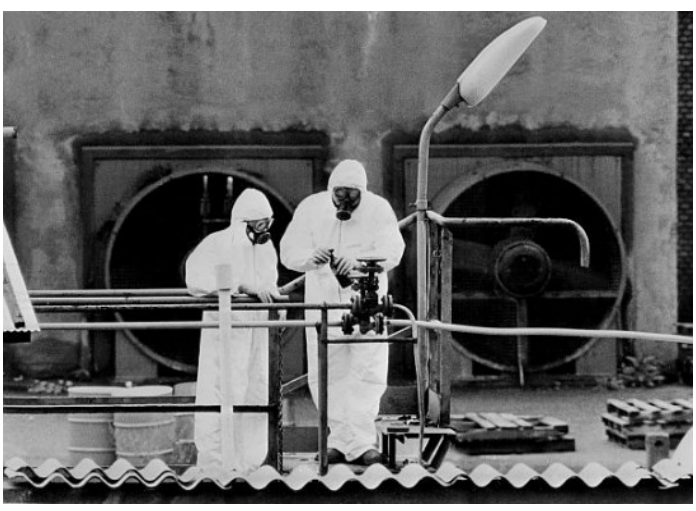

Figure 124: Chemists in Seveso, Italy, in 1976 after the accident. [Source: Fig-124] 


\section{Seveso}

On July 10, 1976, there was an explosion in a plant producing 2,4,5-trichlorophenol (serves as a raw material for making herbicides) near the town of Seveso, $20 \mathrm{~km}$ north of Milan, Italy. About $2.5 \mathrm{~kg}$ of highly toxic 2,3,7,8-tetrachlorodibenzo-p-dioxin (TCDD, dioxin), arising as a by-product, escaped from the reactor of the plant. The Industrie Chemiche Meda Societa, Anonima (ICMESA), an Italian firm owned by the Swiss company Givaudan (Hoffmann LaRoche concern), announced this leak seventeen days after the explosion (on July 27) when the effects of poison appeared not only on animals but also on humans. There was a chemical contamination of an area of at least 1,800 hectares. More than 3,100 small livestock died and 200 adults (chloracne) and a large number of children became ill. Approximately 220,000 people underwent preventive examinations.

However, this accident was certainly not the first of its kind. Already at the end of 1953, TCDD leaked from the BASF chemical plant in Ludwigshafen, Germany, where at least 21 people died due to poisoning. In 1954, another accident with the TCDD leak occurred at Boehringer Ingelheim, a Hamburg-based plant manufacturing 2,4,5-trichlorophenol. However, it was not the last one - in 1983, dioxin escaped from a chemical plant in Trenton, New Jersey, the USA. There is a serious link between these accidents and the wartime use of herbicides that contained impurities in the form of TCDD, as recorded in Vietnam.

\section{Bhopal}

A chemical accident with huge direct losses of human lives happened on the night from December 02 to December 03, 1984 in Bhopal, the capital city of the Indian state of Madhya Pradesh. The accident took place at the factory of the Union Carbide India Limited (UCIL) of the American Union Carbide Corporation of West Virginia producing a pesticide called Aldicarb. About 64 tonnes of methyl isocyanate and 12 tonnes of other substances escaped, not excluding hydrogen cyanide, phosgene and chlorine. A toxic cloud contaminated an area of $40 \mathrm{~km}^{2}$. The tragedy claimed the death toll of 3,800 people (according to other data up to $15,000)$. Around 150,000 people had to be evacuated and the total number of people affected was estimated at 500,000. It can be stated that the cause of the accident was serious structural and technological defects caused by the introduction of truncated technology (so-called ecological colonialism). The security system did not even include a major measure, i.e. the installation of automatic detectors that would caution against the methyl isocyanate leak, which prolonged the exposure time and thus led to high death toll.

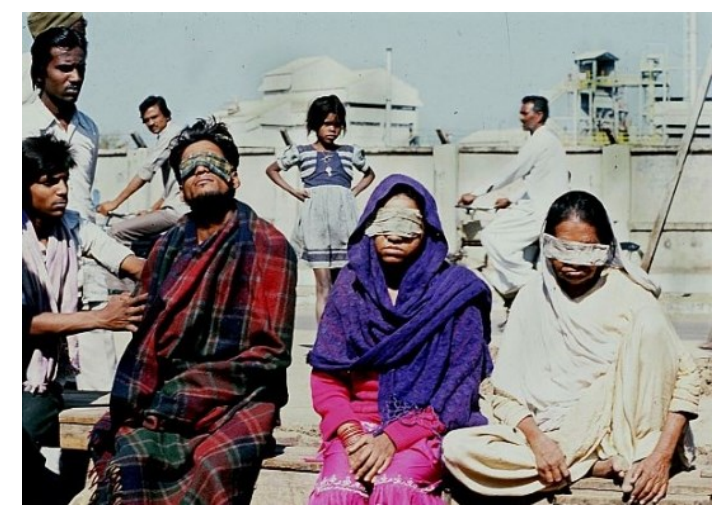

Figure 125: People lost their sigh during the chemical accident in the Indian city of Bhopal in 1984. [Source: Fig-125]

Approximately 64 tonnes of methyl isocyanate and 12 tonnes of other substances, not excepting hydrogen cyanide, phosgene and chlorine, escaped. A toxic cloud contaminated an area of $40 \mathrm{~km}^{2}$. The tragedy claimed the death toll of 3,800 people (according to other data up to 15,000). Around 150,000 people had to be evacuated and the total number of people affected was estimated at 500,000. It can be stated that the cause of the accident was serious structural and technological defects caused by the introduction of imperfect technology (the so-called ecological colonialism). The security system did not even include a major measure, i.e. the installation of automatic detectors that would caution against the methyl isocyanate leak, which prolonged the exposure time and thus led to high death toll. 


\section{Ammonia leak accidents}

Ammonia leak accidents belong to the most common ones. There is not a day when such an event does not occur somewhere in the world, even if it does not have the most serious consequences. The risk cannot be underestimated. In 1969, a road tanker with ammonia crashed in Crete (the Netherlands), killing 9 people. In 1989, a tank containing 7,000 tonnes of liquid ammonia exploded at the Azotas Fertilizer Plant about $12 \mathrm{~km}$ from the Lithuanian city of Jonova.

The toxic cloud reached a length of $35 \mathrm{~km}$ and the disaster area was $4,000 \mathrm{~km}^{2}$. A total of 32,000 people was evacuated (official statistics state 7 dead and 57 poisoned people). Recently, there has been an extremely serious accident at the French AZF fertilizer factory, located about 3 kilometres from the centre of Toulouse. On September 21, 2001, an explosion occurred in the complex, where 3,000 tonnes of ammonium nitrate were stored; a total of 2,400 people were injured, 29 people died and 34 people were seriously injured.

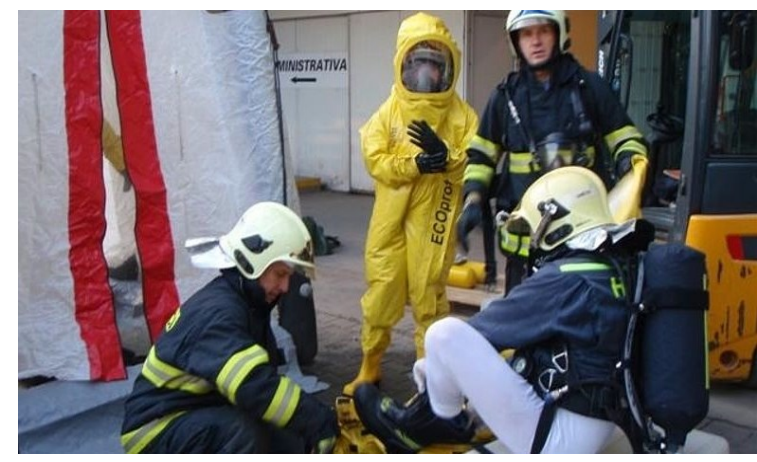

Photo 150: An ammonia leakage at Medlov and a decontamination tent. [Source: Pho-150]

On January 13, 2014, two firefighters suffered chemical burns of hands at Medlov in the Olomouc Region during the liquidation of an ammonia leak from a storage tank in the engine room of the company producing frozen pastries. Firefighters set up a decontamination station. An amount of 200 litres of ammonia escaped from a 1,000-litre storage tank. Ammonia remained inside the engine room. The firefighters sprayed it with a stream of water, and then collected it and poured it into spare vessels. The minimum amount got into the atmosphere and no evacuation was necessary.

\section{Phosgene leakage accidents}

After the end of World War I, on October 24, 1919, there was an explosion and a subsequent release of about 1,000 tonnes of phosgene and mustard in the facilities at Breloh (near Munster) in northern Germany. These were German chemical warfare agents, which were determined for disposal under the supervision of the commission of victorious powers.

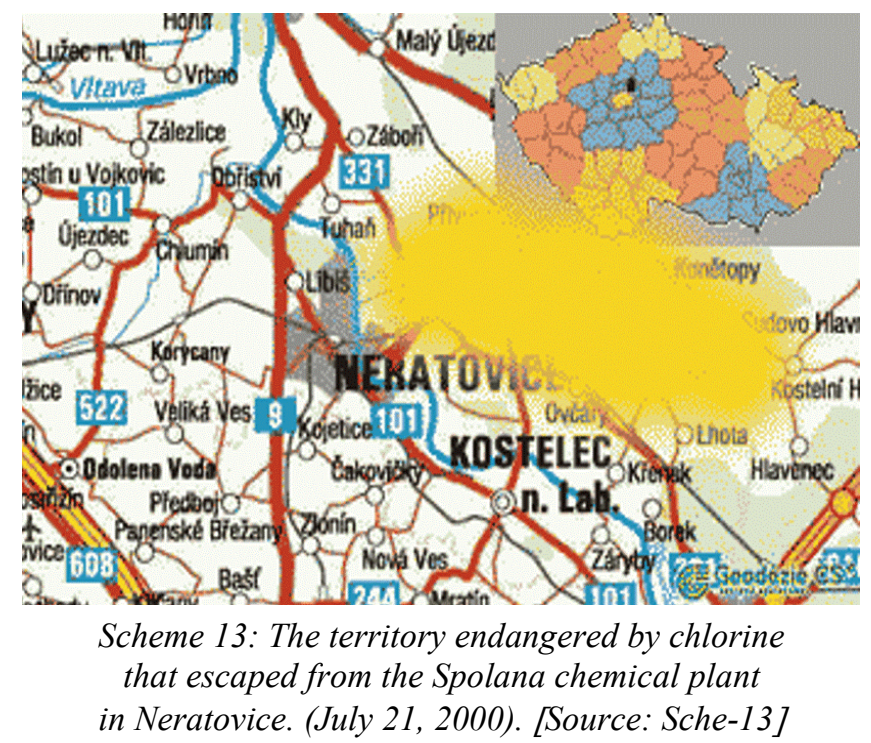

On May 28, 1928, at the time of the rearmament of Germany, storage tanks with 10 tonnes of phosgene exploded in the building of the Stoltzenberg Company in Hamburg. Several hundreds of people, mostly from the Hamburg district, were poisoned and 10 people died. In 1974, some phosgene escaped in the Pardubice plant and 80 people were injured.

\section{Chlorine leak accidents}

With regard to the huge production of chlorine and its high toxicity, the accidents with its escape rank among very dangerous ones. In April 1952,

an accidental emission of chlorine occurred in Walsum, Germany, due to which 5 people died. 
In 1962, a road tanker containing chlorine had an accident in Cornwall, Canada, and 89 people died. In 1988 and 1989, tankers transporting bromine/chlorine overturned in Israel. In both cases there were no accident victims. In the first case, the wind blew the gas out of the inhabited area and in the second case the population was hidden in their homes in time.

On April 11, 1996, an accident of tankers transporting chlorine took place in Alberton, Montana. About 59 tonnes of gas escaped into the environment. One person died of gas poisoning and many others were poisoned slightly. About 1,000 residents had to be evacuated for a few weeks.

A textbook case of the chlorine leak in the Czech Republic without fatal consequences took place on July 21, 2000 at the Spolana chemical plant in Neratovice. From one of the two warehouses, equipped with sensors set to a concentration of 6 or, if need be, $24 \mathrm{mg} \cdot \mathrm{m}^{-3}$, about $188 \mathrm{~kg}$ of chlorine escaped, which contaminated the premises of the company and its surroundings.

A substantial part of escaped chlorine was trapped using the sodium hydroxide solution to produce sodium hypochlorite (directly in the

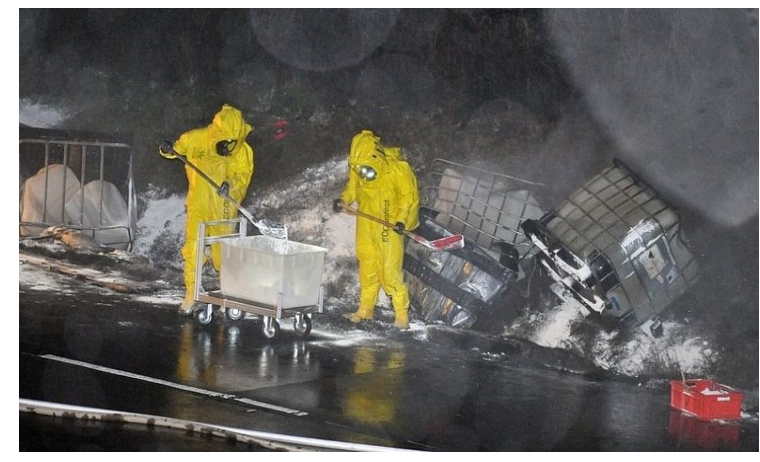

Photo 151: Firefighters work to neutralize hydrochloric acid. [Source: Pho-151] warehouse) and using the water curtains installed by the company fire protection unit. During the intervention, a total of 12 firefighters were provided with medical care. There was also a leak of a large amount of chlorine, perhaps several tonnes, at the Spolana chemical plant in Neratovice during the floods in August 2002 when the entire area of the chemical plant was flooded and the barrels containing gas were ruptured. The smell of chlorine was recognizable within a distance of $10 \mathrm{~km}$.

Table 65: The overview of accidents at the Spolana chemical plant since 1991.

[Source: Tab-65]

\begin{tabular}{|c|c|c|}
\hline Date & Quantity & Event description \\
\hline June 1991 & $\begin{array}{c}\text { About } 50 \mathrm{~kg} \\
\text { of chlorine }\end{array}$ & $\begin{array}{c}\text { An adjacent construction site, where more than } 200 \text { workers worked, } \\
\text { was hit by gas. There were no serious health consequences. }\end{array}$ \\
\hline $\begin{array}{c}\text { April 5, } \\
1993\end{array}$ & $\begin{array}{c}\text { An explosion and subsequent fire of toxic carcinogenic vinyl chloride } \\
\text { monomer (VCM). The atmosphere around Neratovice was not contami- } \\
\text { nated. Six people were heavily injured, five people were moderately } \\
\text { and three lightly injured. The damage was 18 million CZK. }\end{array}$ \\
\hline $\begin{array}{c}\text { August 20, } \\
1998\end{array}$ & $\begin{array}{c}\text { Several kg } \\
\text { of hydrogen } \\
\text { chloride }\end{array}$ & $\begin{array}{c}\text { The breakdown did not cause injuries and did not burden the } \\
\text { Neratovice environment. }\end{array}$ \\
\hline $\begin{array}{c}188 \mathrm{~kg} \text { of } \\
\text { chlorine in } 21, \\
\text { more than } \\
12 \text { hours. }\end{array}$ & $\begin{array}{c}\text { Liquid chlorine penetrated the inner part of the pump through a cracked } \\
\text { protective membrane. The explosion was then initiated by the connec- } \\
\text { tion of the electrical circuit. Chlorine damaged plants in the immediate } \\
\text { vicinity of the plant. The seedlings of decorative and forest-tree species, } \\
\text { leafy vegetable and potatoes were affected most. }\end{array}$ \\
\hline
\end{tabular}

On January 21, 2014, the accident of a truck carrying hydrochloric acid happened at kilometre 177 of the motorway D1 near Ríčany in the Brno region in the direction to Prague. A roughly 10-kilometre motorway segment had to be closed in both directions for 15 hours. 
In the accident, four barrels were damaged and 3,500 of 19,000 litres of transported acid escaped. The rescuers created a safety zone around the affected place. The chemical produced a thick fog.

\section{Cyanide leakage accidents and the contamination of water resources}

An example of the harmful effects of cyanides on aquatic ecosystems are the accidents recorded relatively recently in the work of companies mining gold and other heavy metals. In December 1992, the Alamosa River ( $27 \mathrm{~km}$ long) was contaminated by cyanides that leaked from the Summitville Gold Mine (the San Juan Mountains in south-western Colorado). In the same year, a similar event happened in South Carolina, where cyanides from the Brewer Gold Mine killed over 11,000 fish and contaminated $80 \mathrm{~km}$ of the Lynches River. In August 1996, more than 3.2 milliards litres of cyanide waste escaped from the Omai Gold Mine in Guyana to the Essequibo River. All life was destroyed in a length of $4 \mathrm{~km}$ of the river. Two years later, around 1,000,000 litres of this waste escaped from the Gold Quarry Mine into two rivers in Nevada.

On May 20, 1998, 1,762 $\mathrm{kg}$ of sodium cyanide $(\mathrm{NaCN})$ escaped into the local water sources from the Kumtor Gold Mine in Kyrgyzstan. Nine days later, about 7 tonnes of cyanide waste were discharged from the Homestake Mine in the Black Hills (South Dakota) into the Whitewood Creek. From the mid-1990s, the long struggle of the Assiniboine Indian tribe in the Fort Becknap Reservation in the Little Rocky Mountains in Montana against the Canadian Pegasus mining company is known.

On January 30, 2000, a major accident happened in the Baia Mare Region, Romania, in the Aurul mine where an Australian mining company was involved in mining. In the accident, about 100 million litres of waste cyanide water escaped, which was discharged into the Szamos River, flowing into the Tisza River, the largest tributary of the Danube River. On November 5, 2001, a similar accident occurred, to a lesser extent, in China, where approximately 11 tonnes of sodium cyanide solution flowed into the Luo River (the Yellow River tributary) in the He-

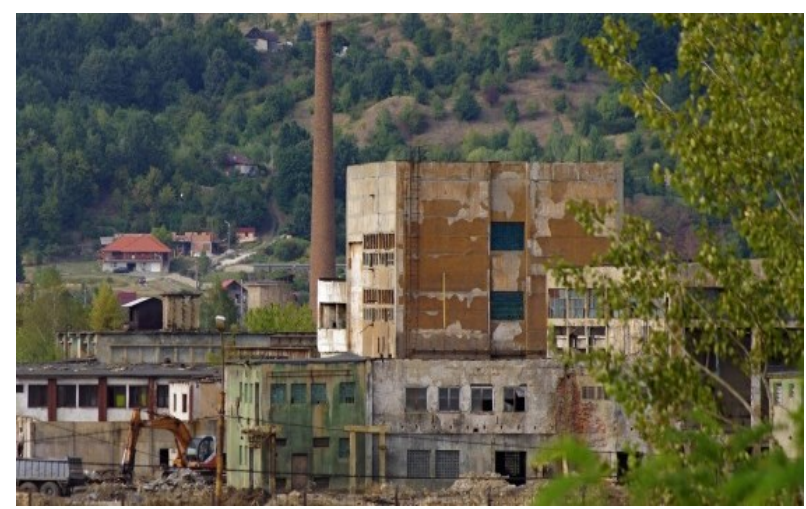

Figure 126: The Aurul Gold Mine in the Baia Mare Region, Romania. [Source: Fig-126] nan Province. The Army, which used 500 tonnes of decontaminants, was called up to eliminate the consequences.
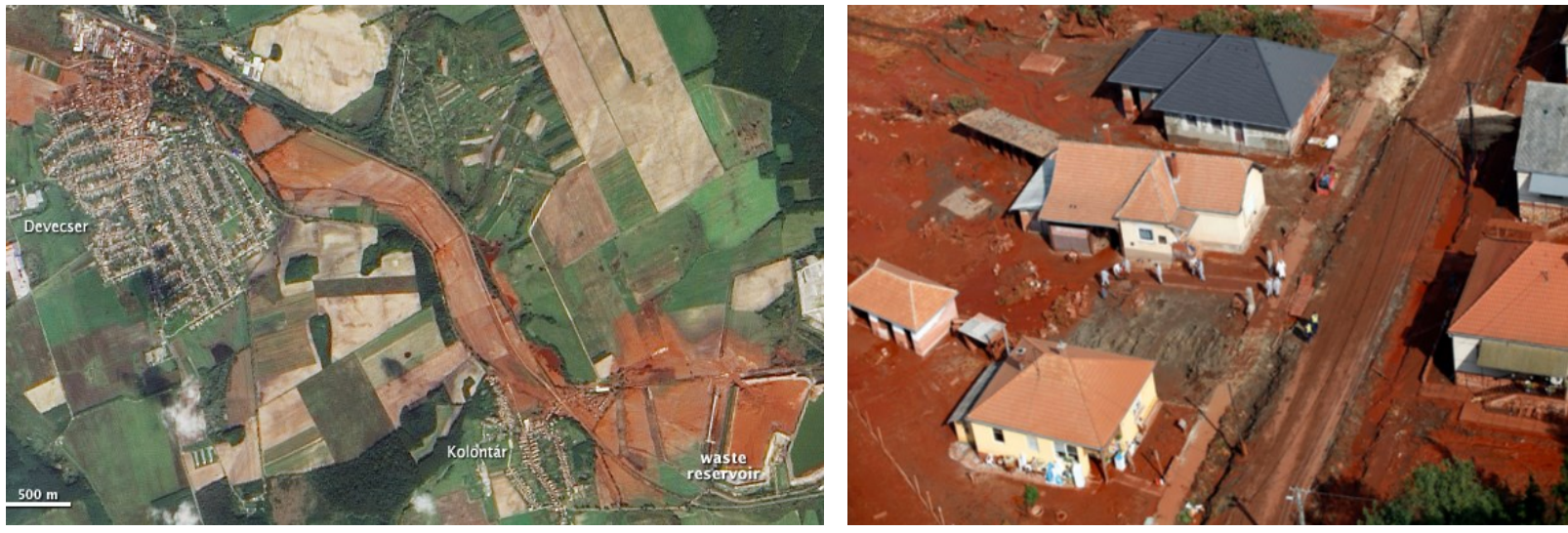

Photo 152 and 153: Chemical accident in the Hungarian town of Ajka in 2010. [Source: Pho-152 and Pho-153] 
In 2010, a containment reservoir at the Ajka alumina plant in western Hungary collapsed. The red mud accident contaminated a vast area of $40 \mathrm{~km}^{2}$. Up to a billion litres of red mud, which was corrosive, toxic and contained heavy metals, escaped. High concentrations of mercury, arsenic and chromium were subsequently measured in the soil. The mud also got into the waters in the surroundings and reached the Danube River. It killed all life in the nearest brook and caused water contamination. According to the authorities, it was necessary to remove a two-centimetre layer of soil in the affected area.

In our conditions, there are quite frequent accidents in plating plants. In the former Czechoslovakia, a total of 50 cyanide leak accidents were reported over the course of 10 years (1970 to 1980). For example:

- on October 13, 1976, about 3,000 litres of the cyanide bath (about $200 \mathrm{~kg}$ of cyanides) escaped from the Šroubárna Turnov Company and caused fish kills in the Jizera River;

- on April 24, 1979, more than 600 litres of the cyanide copper bath (about $60 \mathrm{~kg}$ of cyanides) escaped in the Tesla Rožnov pod Radhoštěm Company and contaminated the Bečva River;

- on September 18, 1980, a similar contamination of the Červený potok (Red Brook) occurred after the copper bath escape from the ALBA Hořovice Company.

It is worth mentioning the recent case of one of our biggest plating plants - Bižuterie Jablonec nad Nisou where the fire of 18 February 2001 did not just accidentally overheat and rupture the tank with a high content of cyanides.

\section{Leak of toxic industrial chemicals during fires}

The importance of the issues related to the accidental release of toxic industrial chemicals is emphasized by the fact that their considerable quantity and practically their complete range is deposited in the form of various, even if commonly non-toxic and low risk chemicals and industrial products. These can release toxic industrial chemicals, when burning.

Table 66: Examples of the formation of toxic industrial substances during combustion.

[Source: Tab-66]

\begin{tabular}{|c|c|}
\hline $\begin{array}{c}\text { Toxic } \\
\text { industrial } \\
\text { chemical }\end{array}$ & Organic compounds \\
\hline Phosgene & $\begin{array}{c}\text { Haloalkanes (chloroethane, dichloromethane, dichloroethane), haloalkenes } \\
\text { (dichloroethene, tetrachloroethene), (perchloromethyl)benzene, propionyl } \\
\text { chloride, 2-chloroethanol, chloroacetic acid, acetyl chloride, ethyl dichlorostearate }\end{array}$ \\
\hline $\begin{array}{c}\text { Hydrogen } \\
\text { cyanide }\end{array}$ & $\begin{array}{c}\text { Nitriles (acetonitrile, propionitrile, acrylonitrile, benzyl cyanide), } \\
\text { dimethyl cyanamide, 2-cyanoethyl acrylate, cyanoacetic acid derivatives }\end{array}$ \\
\hline $\begin{array}{c}\text { Nitrogen } \\
\text { oxides }\end{array}$ & Pyrrole, pyridine derivatives, urea derivatives, heteroatoms \\
\hline $\begin{array}{c}\text { Sulphur } \\
\text { dioxide }\end{array}$ & $\begin{array}{r}\text { Thiophene, ethanethiol, butane-1-thiol, perchloromethane thiol, } \\
\text { p-toluenesulphonamide, 2-sulphanyl-benzothiazole, thioglycolic acid, }\end{array}$ \\
\hline $\begin{array}{c}\text { Hydrogen } \\
\text { sulphide }\end{array}$ & Thiols (ethanethiol, butane-1-thiol, 2-hydroxyethane-1-thiol) \\
\hline $\begin{array}{c}\text { Hydrogen } \\
\text { chloride }\end{array}$ & Most of chlorinated organic compounds \\
\hline $\begin{array}{c}\text { Hydrogen } \\
\text { fluoride, PFIB }\end{array}$ & Most of fluorinated organic compounds \\
\hline Formaldehyde & Some aldehydes, e.g. 1,3,5-trioxane, paraformaldehyde \\
\hline
\end{tabular}


The danger is even increased by a low degree of certainty as to what chemicals and in what quantities (or in what proportions) can be released to the environment during fires. In practice, this means that in case of a fire, it is necessary to behave as if a chemical accident occurred.

On August 12, 2015, an explosion happened in the Chinese port of Tianjin. The Chinese authorities ordered the evacuation of the population living within a three-kilometre radius around the warehouse of hazardous materials. On August 13, 10,000 people were evacuated from the site of explosion. In the past, the Ruihai International Logistics Company, being in possession of the warehouse, where explosions took place, had problems with the infringement of safety regulations.

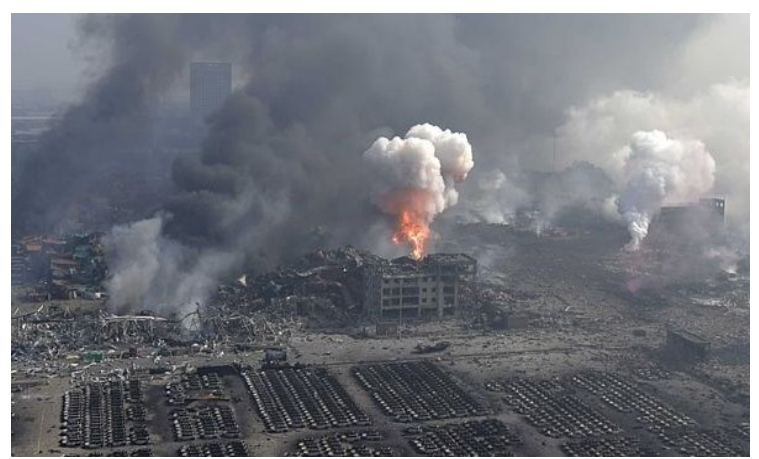

Photo 154: Hundreds of firefighters and CBRN defence troop soldiers are extinguishing the fire. [Source: Pho-154]

The Chinese rules concerning the occupational safety require similar facilities to be at least 1,000 metres away from residential buildings, offices and roads. However, an online map shows that the Ruihai International Logistics warehouse was at a distance of 500 metres from the highway and also from a housing estate with an area of $100,000 \mathrm{~m}^{2}$. In the flats, a pressure wave smashed the windows and the fireball scorched the walls. The company was handling dangerous chemicals for eight months without being authorized to do so. An unnamed member of the company management told the AP Agency: "The Company was dealing with hazardous chemicals even when it was not allowed to do so.".

On August 15, the Chinese authorities officially confessed that, in addition to sodium nitrate $\left(\mathrm{NaNO}_{3}\right)$, calcium carbide $\left(\mathrm{CaC}_{2}\right)$ and potassium nitrate $\left(\mathrm{KNO}_{3}\right)$, even 700 tonnes of fatally poisonous sodium cyanide $(\mathrm{NaCN})$, i.e. seventy times the amount allowed, had been located in the warehouse. The relatives of victims and missing people protested in front of the hotel where press conferences were held because they had not been informed about the dangerous chemicals stored in the warehouse. The authorities closed 50 websites that allegedly caused panic
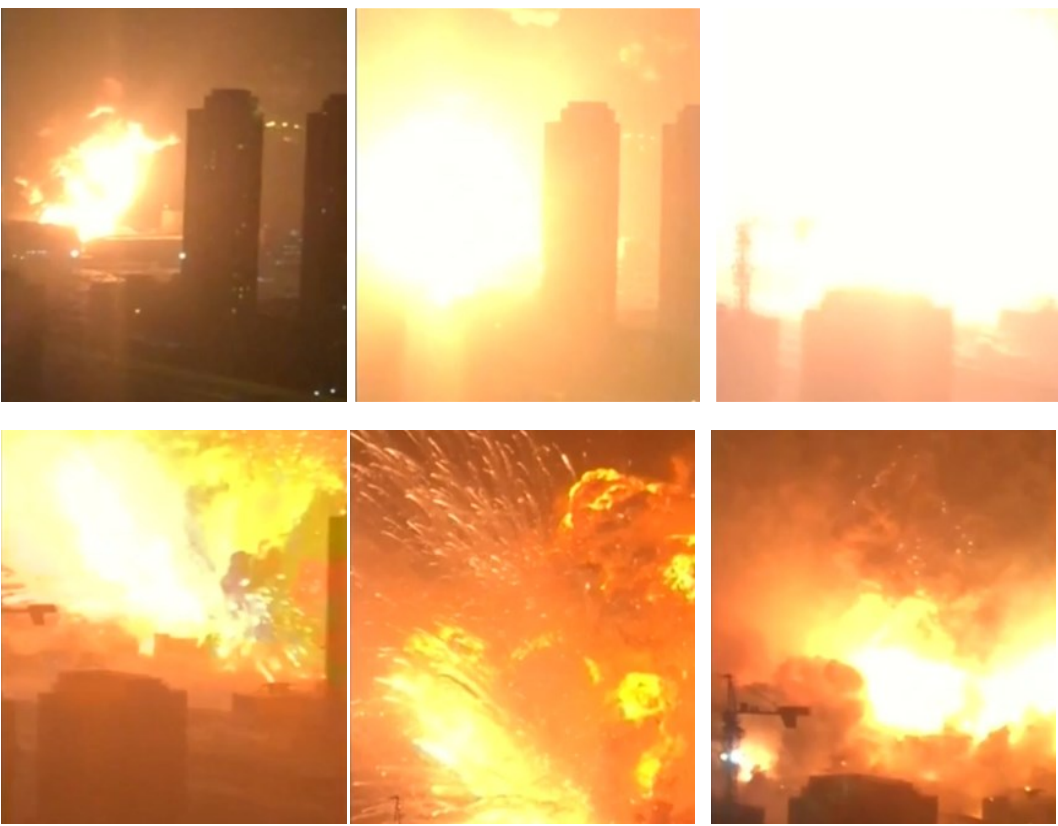

Photo 155-1 up to 155-6: The progression of the first explosion in the warehouse in the Chinese port of Tianjin on August 12, 2015. [Source: Pho-155-1 up to Pho-155-6]

in connection with explosions as they had released unverified information. For the same reason, several hundreds of social network accounts were deleted. Firefighters also faced criticism since they used water first. Calcium carbide, which reacts vigorously with water to form highly inflammable acetylene, was also stored in the warehouse. 
One thousand firefighters fought the blaze. A total of 214 soldiers from the CBRN defence troop were called. Half a kilometre from the site of an explosion, high concentrations of sulphur, carbon and nitrogen oxides were measured. The blaze at the site of an explosion was hundreds of metres high.

The explosion was also recorded by satellite imagery. According to experts, the first explosion had a power of 3 tonnes of trinitrotoluene (TNT); the second one was much larger and had a power of 21 tonnes of TNT. According to Chinese seismologists, the first explosion caused shaking, the strength of which was 2.3 degrees. The strength of the second explosion was 2.9 degrees. Explosions claimed 139 lives and 34 people were missing. At least 21 firefighters died in the blaze during the intervention. The police detained a total of 23 people. The explosion in the warehouse at the Tianjin port has become the most tragic event for more than sixty years of the fire department history. The explosions were so strong that only 24 bodies could be identified. The rest of the remains required DNA testing. The New China stated that about 721 people had suffered injuries, 25 of them still had remained in critical condition, and the health status of the other 33 people had been serious. Due to the explosions, 6,300 people lost the roofs over their heads.

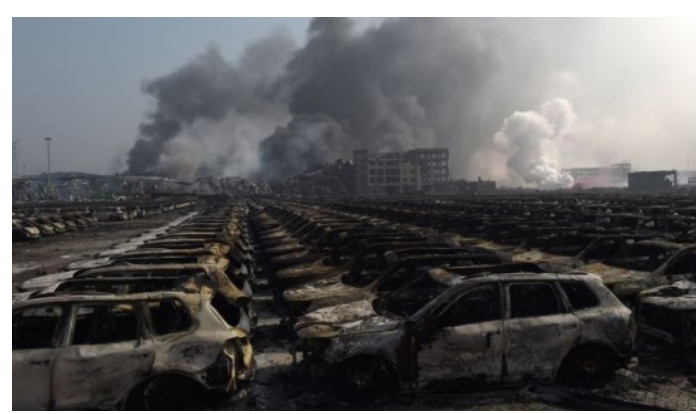

Photo156: Hundreds of firefighters and CBRN defence troop soldiers are extinguishing the fire. [Source: Pho-156]

Eyewitnesses stated that they had first glimpsed a giant fireball, after which a strong explosion had been heard. Residents of neighbouring municipalities considered it to be an earthquake. The surrounding area was without electricity and the pressure wave broke the windows.

"For the first time, I felt I was at the point of death. I thought things like that were happening in movies only," a woman who introduced herself as Chuo told The Guardian. "I was just going to bed when I heard a terrible noise from the outside. It broke all windows. I saw a huge fireball running toward the building opposite to us. The whole house trembled and we did not know what it was. The pressure wave knocked me down on the floor and my husband helped me regains my footing. We headed for the bedroom, but the second explosion came and so we were running out of the flat. We live on the $20^{\text {th }}$ floor. All fire exits and emergency staircases were full of people. Some people could not get out of the flat because the pressure wave damaged the door," she added.

"There were a lot of people downstairs. Many of them hurried down and did not have the time to get dressed; some of them were dressed in their underwear only. All cars had broken windows and damaged roofs. We jumped into the car and headed to the hospital. On the way, we took up a woman with a small child stained with blood and an injured man. There were lots of cars on the road and the road was congested. When we arrived at the hospital, they told us it was overcrowded and we had to go to another hospital," the woman said. Another witness described that he had seen a huge

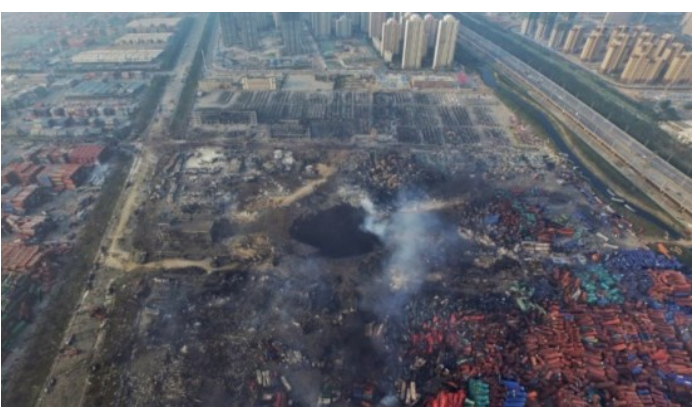

Photo 157: Hundreds of firefighters and CBRN defence troop soldiers are extinguishing the fire. [Source: Pho-157] glow in the sky, followed by a pressure wave. "It sounded as if someone tried to break the door open, as if someone shook the door," he described. 
After the second explosion, a young worker was thrown a few yards away by the pressure wave and was knocked to the ground. He was in a hostel a mile away from the industrial zone. "I did not understand what was going on," he said.

Table 67: The selection of fires in the Czech Republic that inflicted damage of 200 million CZK or more. [Source: Tab-67]

\begin{tabular}{|c|c|c|c|}
\hline Date & Place & Cause & Damage in CZK \\
\hline $\begin{array}{c}\text { November } \\
21,2002\end{array}$ & $\begin{array}{l}\text { The resin plant of the } \\
\text { Association for Chemical and } \\
\text { Metallurgical Production } \\
\text { (Spolchemie) in Ústí nad Labem }\end{array}$ & $\begin{array}{c}\text { The non-observance } \\
\text { of technological discipline } \\
\text { in the production was the cause } \\
\text { of an explosion and fire }\end{array}$ & 2.17 billion \\
\hline $\begin{array}{l}\text { October } \\
16,2008\end{array}$ & $\begin{array}{c}\text { Fire of the left wing of the Industrial } \\
\text { Palace on the Prague Exhibition } \\
\text { Ground }\end{array}$ & $\begin{array}{c}\text { The fire was caused by an act } \\
\text { of negligence; a particular guilty } \\
\text { person was not identified. }\end{array}$ & $\begin{array}{l}\text { According to } \\
\text { firefighters } \\
\text { a billion, } \\
\text { according to the } \\
\text { insurance office } \\
181 \text { million }\end{array}$ \\
\hline $\begin{array}{l}\text { May } 30, \\
2001\end{array}$ & $\begin{array}{c}\text { Woodworking company Haas } \\
\text { Fertigbau, Ltd. in Chanovice } \\
\text { near Klatovy }\end{array}$ & Wiring failure & 525 million \\
\hline $\begin{array}{c}\text { November } \\
23,1996\end{array}$ & $\begin{array}{l}\text { The petrol station and technological } \\
\text { equipment at the company } \\
\text { Česká rafinérská in Záluží u Mostu }\end{array}$ & - & 326 million \\
\hline $\begin{array}{l}\text { April 8, } \\
2011\end{array}$ & $\begin{array}{l}\text { The premises of the Remiva } \\
\text { Company for plastics recycling } \\
\text { in Chropyně near Kroměříž }\end{array}$ & $\begin{array}{c}\text { According to firefighter's } \\
\text { deliberate fire setting or an act of } \\
\text { negligence caused by smoking }\end{array}$ & 290 million \\
\hline \begin{tabular}{|c|} 
March 9, \\
1998
\end{tabular} & $\begin{array}{l}\text { The flax spinning mill of PAJA, Ltd. } \\
\text { in Trutnov }\end{array}$ & Flax dust explosion & 289 million \\
\hline $\begin{array}{c}\text { January } \\
9-10,1999\end{array}$ & $\begin{array}{c}\text { The warehouse of finished products } \\
\text { and packaging materials } \\
\text { of the STV Glass Company } \\
\text { Valašské Meziřičí near Vsetín } \\
\end{array}$ & - & 256 million \\
\hline $\begin{array}{c}\text { December } \\
24,2009\end{array}$ & $\begin{array}{l}\text { The glass-making shop in } \\
\text { Heřmanova Hut' north of Pilsen }\end{array}$ & $\begin{array}{l}\text { Melt leakage and explosion } \\
\text { of pressure cylinders stored } \\
\text { in the shop }\end{array}$ & 250 million \\
\hline $\begin{array}{l}\text { May } \\
29-30 \\
2001\end{array}$ & $\begin{array}{l}\text { The factory building of the VDO } \\
\text { Mannesmann Company in Brandýs } \\
\text { nad Labem with stored parts } \\
\text { for car factories }\end{array}$ & Deliberate fire setting & 226 million \\
\hline $\begin{array}{l}\text { October } \\
16,2007\end{array}$ & $\begin{array}{c}\text { The factory building of the Lohmann } \\
\text { \& Rauscher Company in Nová Paka } \\
\text { near Jičín, bandaging material }\end{array}$ & - & 210 million \\
\hline $\begin{array}{c}\text { December } \\
22,2012\end{array}$ & $\begin{array}{l}\text { The production shop of the Mileta } \\
\text { textile factory in Hořice near Jičín }\end{array}$ & - & $\begin{array}{l}\text { Preliminary } \\
\text { damage } \\
200 \text { million }\end{array}$ \\
\hline $\begin{array}{c}\text { August } \\
13-14 \\
2015\end{array}$ & $\begin{array}{c}\text { The factory building for ethylene } \\
\text { production of the Unipetrol chemical } \\
\text { plant in Záluží near Litvínov }\end{array}$ & $\begin{array}{l}\text { Cooling water was missing, the } \\
\text { explosion due to the } \\
\text { increase in the temperature }\end{array}$ & $\begin{array}{c}\text { Under } \\
\text { investigation }\end{array}$ \\
\hline
\end{tabular}

On May 14, 1998, a fire occurred in the warehouse of Linde Frigera, Ltd. in Beroun producing cooling and freezing devices; about 25 tonnes of wood, 10 tonnes of paper-, cardboardand plastic-based packing material, 2.5 tonnes of polyvinyl chloride and 2.5 tonnes of polyethylene, polystyrene and polyurethane burned away. 
Hydrogen chloride, chlorine and phosgene were released into the atmosphere. During the fire, 140 members of the Fire Rescue Service and 72 members of the Rakovník Civil Protection Regiment took part in the intervention. The measurement of toxic pollutant concentration in the atmosphere was performed by the specialists of the Civil Protection Training Centre in Kamenice. During the intervention, 36 people were affected, 12 people were hospitalized, of which some were poisoned partially.
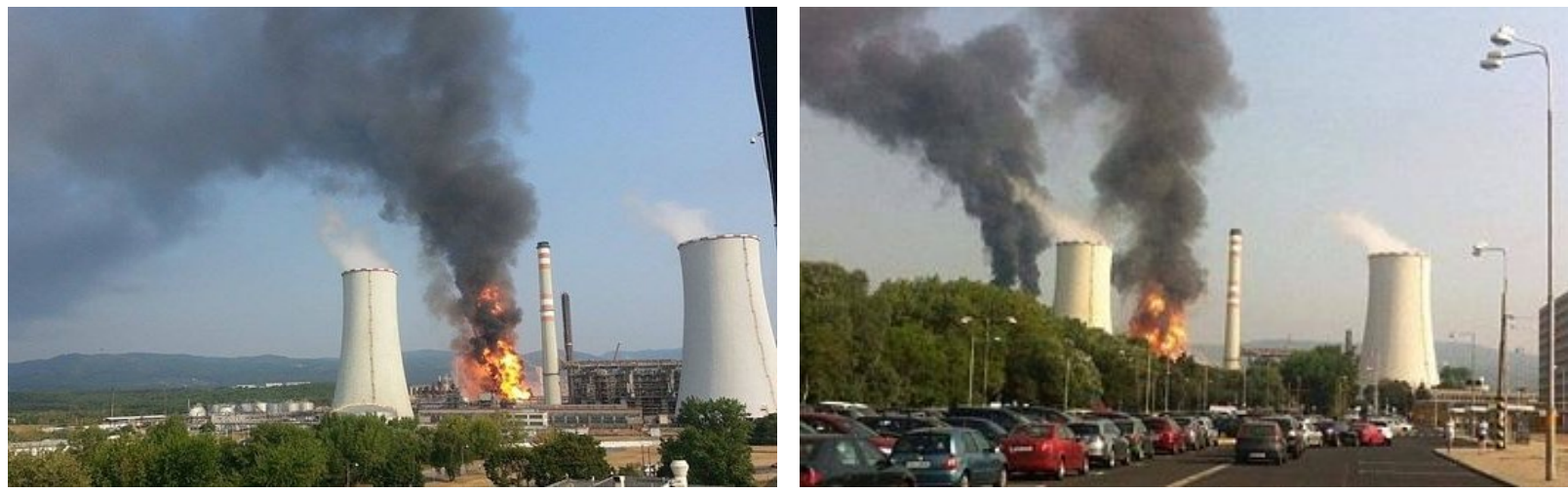

Photo 158 and 159: A photo of the Unipetrol fire taken by one of the readers. [Source: Pho-158 and Pho-159]

On May 24, 2000, a similar case occurred in Otovice near Karlovy Vary, where part of the inventory stocks of plastic clothes hangers burned (70 million pieces stored). When burning, these polystyrene products released styrene, hydrogen cyanide, carbon monoxide and aldehydes. Two firefighting trucks of the Fire Rescue Service and later the chemical laboratory unit of the Training Centre belonging to the Třemošná Fire Rescue Service were called to the scene. A total of 92 firefighters participated in the intervention, of which 50 wore breathing apparatuses. More than 1,000,000 litres of water and 1,600 litres of a foam compound were used.

\subsubsection{Industrial accident as a secondary chemical weapon}

The military power of the state is given by many factors, of which the economic power plays one of the decisive roles. An important prerequisite of the economic power is a certain level of the chemical and petrochemical industry providing warring armed forces with necessary fuels, explosives and raw materials for the production of necessary means for the conduct of war (including the means of chemical protection and decontamination). For this reason, the most important production complexes become an important target of aerial bombing and artillery bombarding or, if need be, a target of specially trained commandos.

This form of combat is absolutely legitimate in a regular war (compare e.g. allied air raids on the German industry during World War II); however, it also endangers a significant percentage of the population living in the adjacent area when each chemical plant or warehouse becomes a very dangerous secondary chemical weapon, when hit.

If the main objective of such an attack is to intimidate the civilian population and increase its hardships of war, then it is one of the manifestations of chemical terrorism. This naturally also applies to the activities of various terrorist groups, which use, in particular, methods of sabotage

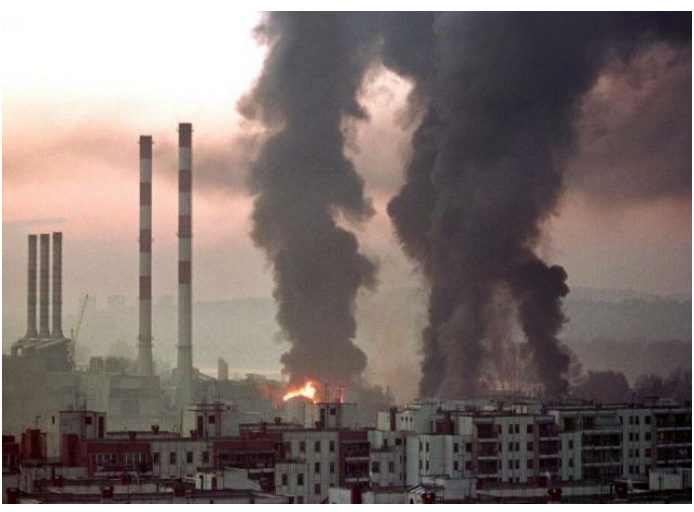

Figure 127: Bombing of the Novi Beograd complex. [Source: Fig-127]

to damage or liquidate chemical plants and transports with toxicants. 


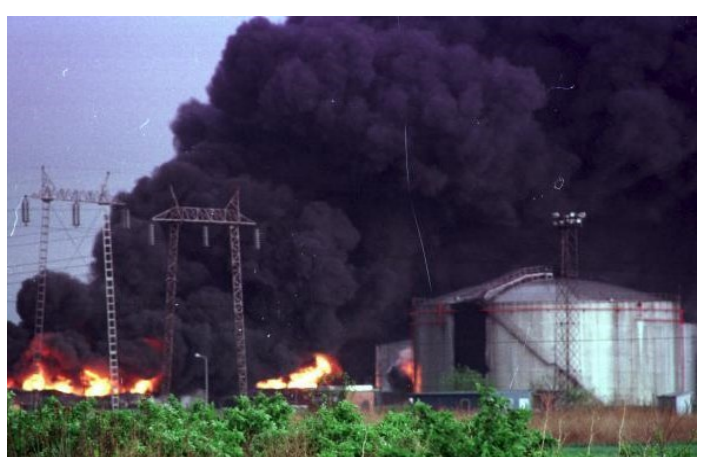

Figure 128: Bombing of the Pancevo complex. [Source: Fig-128]

At the time of the Civil War in Yugoslavia, on August 06, 1995, the Federal Air Force took a massive attack on the INA Petrokimija Plant near Kutina (Croatia). The type of Eagle aircraft fired 32 unguided missiles (the calibre of 57-mm) on the factory and destroyed a part of the plant.

Fortunately, there were no more serious consequences; however, the risk was considerable. At the time of the attack, the factory stored more than 200,000 tonnes of chemicals, which, in the event of container destruction and fire, could release large amounts of toxic vapours and gases into the atmosphere. These would spread to a distance of $100 \mathrm{~km}$ and would endanger the lives of several tens of thousands of people. The factory stored e.g. 13,705 tonnes of anhydrous ammonia, 3,639 tonnes of sulphuric acid, 8,000 tonnes of elemental sulphur, 1,971 tonnes of nitric acid, 20,500 tonnes of potassium chloride, 20,000 tonnes of crude phosphorus and 103,000 tonnes of artificial mineral fertilizers, mainly nitrogen-based ones. From March 24 to June 08, 1999, a total of 23 petrochemical plants, oil refineries, 121 important industrial plants containing different chemicals and hazardous substances, and fuel depots (Pancevo, Novi Sad, Prahovo, Lipovica, Bogutovac, Smederevo, Novi Beograd, Sombor, Pristina, Kragujevac, Baric and Bor) were attacked.

The case of the Pancevo industrial complex is the best-known. Pancevo with 150,000 inhabitants is situated $15 \mathrm{~km}$ northeast of Belgrade. On the night of April 18, 1999, two plants of the industrial complex were bombed (the plant producing nitrogen and the petrochemical plant). Huge amounts of chemicals leaked into the environment, including 1,000 tonnes of ethylene dichloride, 1,000 tonnes of vinyl chloride, but also 1,000 tonnes of 33\% hydrochloric acid and more chlorine, phosgene, ammonia and petroleum products (about

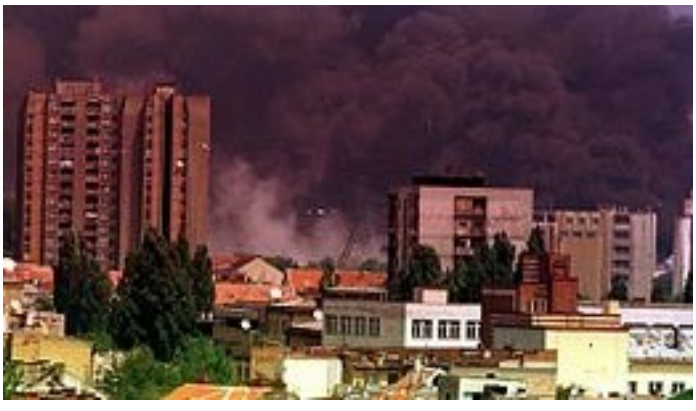

Figure 129: Bombing of the Novi Sad complex. [Source: Fig-129] 80,000 tonnes of crude oil burned). During the war, thousands of tonnes of highly dangerous agents (including dioxine) were released into the atmosphere, the soil and waters. They contaminated an area of more than $100,000 \mathrm{~km}^{2}$ (area of the Australian island of Tasmania).

During the bombing of Pristina, about 1,000 tonnes of ammonia, 330 tonnes of chloric acid, 1,400 tonnes of ethylene dichloride and hundreds of tonnes of petroleum, which could reach the Black Sea, escaped into the Danube River. Some sources disclosed the information about a potential environmental disaster throughout the Balkan Region. For example, the Romanian Government complained of acid rains as a result of the bombing of chemical plants and refineries in Yugoslavia; Bulgaria reported on yellow rain in the Danube Region of Vidin.

\subsection{Use of sarin in the Prague Metro - a case study}

Although this part is focused on the possibility of using only nerve agents (belonging to chemical warfare agents) and on the conditions of the Prague metro, to a large extent, it is possible to apply the conclusions to other large metropolises where the underground railway occurs. Since only the code designations of chemical warfare agents are used in the following text, these dangerous and highly toxic chemical compounds are clearly listed in Table 68. 
If we rank nerve poisons from the viewpoint of combat use (in the most common explosive manner) according to dangerousness, which is given by the simultaneous combination of inhalation and percutaneous exposure, then it will probably come out quite clearly:

- For colder climatic zones the sequence is: $\mathrm{VX} \rightarrow \mathrm{GD} \rightarrow \mathrm{GB} \rightarrow \mathrm{GA} \rightarrow \mathrm{GF}$; and

- For very warm climatic zones the sequence is: $\mathrm{VX} \rightarrow \mathrm{GF} \rightarrow \mathrm{GD} \rightarrow \mathrm{GA} \rightarrow \mathrm{GB}$.

The space of the Prague Metro can be assigned to a colder (mild) climatic zone. However, an explosive method of scattering probably does not seem appropriate, especially not in the case of the interior of the train carriage and probably not even when used in metro stops. It can be assumed that the most suitable scattering method is free, or more precisely, facilitated evaporation and the dominant mode of exposure is inhalation poisoning.

In this case, volatility must be taken into account in addition to toxicity. Under the conditions described and from the viewpoint of hazardousness, a considerably different sequence (from the most suitable agent to the least suitable one) appears, in the following order:

$\mathrm{GB} \rightarrow \mathrm{GF} \rightarrow \mathrm{GD} \rightarrow \mathrm{GA} \rightarrow \mathrm{VX}$

Based on the above-mentioned criteria, sarin (GB) appears to be the most dangerous and highly toxic agent and, at the same time, the most volatile one, to which exclusive attention is paid in the next section. It is probable that based on these properties, the religious sect of Aum Shinrikyo (Supreme Truth) selected sarin as "the most suitable agent" for a terrorist attack.

Table 68: Codes and chemical names of nerve agents. [Source: Tab-68]

\begin{tabular}{|c|c|c|}
\hline $\begin{array}{c}\text { Trivial names } \\
\text { for CWAs }\end{array}$ & CWA codes & Chemical names of CWAs \\
\hline Sarin & GB & O-isopropyl methylphosphonofluoridate \\
\hline Cyklosarin & GF & O-cyklohexyl methylphosphonofluoridate \\
\hline Soman & GD & O-pinacolyl methylphosphonofluoridate \\
\hline $\begin{array}{c}\text { VX nerve agent, } \\
\text { the USA }\end{array}$ & VX & O-ethyl S-[2-(diisopropylamino)ethyl] methylphosphonothioate \\
\hline $\begin{array}{c}\text { R-VX nerve } \\
\text { agent, Russia }\end{array}$ & R-33 & O-isobutyl S-[2-(diethylamino)ethyl] methylphosphonothioate \\
\hline Tabun & GA & O-ethyl N,N-dimethyl phosphoramidocyanidate \\
\hline
\end{tabular}

It is obvious or even very probable that with regard to the real possibilities of the scattering technique, but especially with regard to the set of toxic and physicochemical properties, the most probable way of intoxication is acute inhalation poisoning. Both for elimination of personnel by incapacitating owing to severe symptoms of acute inhalation poisoning (miosis, respiratory problems), and for death, sarin still ranks among the most important nerve poisons; despite of this fact, sarin is in third place (death - LCt 100 mg.min.m ${ }^{-3}$, incapacitating $\mathrm{ECt}_{50} 50$ up to $75 \mathrm{mg} \cdot \mathrm{min} . \mathrm{m}^{-3}$ ) behind three times more toxic soman and about three to ten times more toxic VX.

If we consider the potential possibilities of dispersion through simple evaporation, especially under given conditions, then its dramatically higher overall hazardousness results unequivocally from the comparison of volatility. The maximum concentration (volatility) $\mathrm{C}_{20 \mathrm{max}}$ is $11,500 \mathrm{mg} \cdot \mathrm{m}^{-3}$. Thus, it surpasses soman about fivefold and VX even thousandfold. The high toxicity of VX would only be assessed by the technique of aerosol dispersion, in order to exploit its extremely high toxicity as to the unprotected skin, preferably in an explosive manner that is difficult to imagine in a terrorist attack in inner spaces. 
Such use already corresponds to the conditions of military deployment of chemical weapons. It results from the above-mentioned information that in the target area it is necessary to achieve a value of dose rate in the range of 50 to $100 \mathrm{mg} \cdot \mathrm{min} . \mathrm{m}^{-3}$, in order to achieve a dangerous effect by inhalation poisoning caused by sarin, i.e. $50 \%$ incapacitating up to death. For further calculations, it is necessary to apply another input assumption, i.e. an estimate of real exposure to sarin vapours, resulting from the expected stay of people in the (contaminated) areas of the Metro.

With regard to the size of the stops and the frequency of train movements, which differ according to the lines and a daytime, it can be estimated that the practical stay of an individual, or, more precisely, groups of passengers from entering the escalator tunnel, waiting for the train and boarding a carriage or the analogous stay and movement after getting off the carriage in the opposite direction, will not probably exceed 5 minutes on average. It follows from this that, due to the above-mentioned values, the target concentration of sarin in vapours of 10 to $50 \mathrm{mg} . \mathrm{m}^{-3}$ will be required for a given exposure of 5 minutes in the interior of the Metro.

It will be a little different in carriages. With regard to the smaller area of the Prague Metro, the travelling times are disproportionately shorter in comparison with Paris, London, New York, Moscow, Tokyo and other megalopolises, where lines with more than one-hour travelling time are common. Due to the only three lines with a central triangle and the high frequency of interchange passengers in the central zones, it can be assumed that the average length of stay in a carriage for passengers between Prague's long-distance rail and bus stations, connections to the airport and for other passengers will (according to the experience of the author of this report) range on average from about 8 to 12 minutes. If we choose for simplicity a 10-minute exposure time for a metro carriage, then the target concentration of sarin in vapours of 5 to $25 \mathrm{mg} . \mathrm{m}^{-3}$ will be needed in the inner space of the carriage.

In both cases mentioned, these are the average target concentrations of a chemical warfare agent. It is obvious that, depending on the dispersion method, these concentrations will be reached gradually and especially in the cases of simple evaporation from zero initial values. The respective degree of danger to the Metro passengers includes, depending on the dispersion method, the integral value; this value is given by the dynamics of the gradual reach of effective concentrations, which must be included in further considerations of the possibilities of a chemical attack. In particular, it implies that the initial amounts required for a given volume of space will probably have to be substantially (i.e. several times) higher or it will be necessary to calculate with the use of the facilitated accelerated evaporation methods.

Such methods may use scattering techniques appropriate for the terrorist use in an enclosed space, without endangering the actors of the chemical terrorist attack themselves. In our conditions, the unpredictable consequences of attacks done by suicidal terrorists willing to sacrifice their lives within the framework of extreme religious, ethnic, national or political fanaticism do not seem possible. However, this situation can change dramatically, both in connection with tourism, but also from the viewpoint of large-scale population migration. As is well known, various Muslim community groups are also emerging in the Czech Republic today, including building basic religious symbols, such as mosques, houses of prayer and other buildings.

Conclusions, recommendations and summary - terrorism is a global threat that has grown since the terrorist attacks of September 11, 2001. It requires a global solution that is not only based on the defeat of terrorists, but must also include a reduction in the suffering of some nations, which terrorists exploit for their own purposes. Multilateral international and national solutions are also needed to prevent the further proliferation of weapons of mass destruction and the possibilities for their exploitation. 
Chemical terrorism represents a serious security threat in the Czech Republic in the current, near and long-term perspective. Its timeliness and dangerousness stem from many facts. Some of them have been detailed in this expert communication.

When it concerns the victims of terrorist attacks, they are not only direct victims, the people killed and injured, but also indirect victims such as surviving relatives, friends, acquaintances, but also the informed public. Terrorists rely primarily on the informed public and prepare their actions as cruel, brutal and very violent to shock the whole public and put it under stress. Chemical terrorism, which can cause unprecedented and even catastrophic consequences, falls into this category. Here, we can also count the category of participants who were not affected or harmed at all. Nevertheless, the trauma caused by the horrors experienced at the scene of the chemical attack will certainly leave deep and mostly negative memories of the dead and affected individuals in these people. At present, there is a need for intensive involvement of state intelligence and secret services, which must constantly deal with the detection of the preparation of terrorist attacks in order to prevent such violence or extortion in cooperation with the police and other state administration bodies.

From the above-mentioned facts, a number of different conclusions can be taken into account, or they can be further elaborated in such a way that a very specific and clear technical and organizational security measures for the protection of the population can be derived from them. In conclusion, it must be stated that:

- In order to illustrate the simplicity of carrying out a chemical terrorist attack and

- to prepare a whole complex and interconnected chain of preventive, repressive, rescue, protective, liquidating and recovery measures,

- it is necessary to create possible illustrative scenarios of chemical terrorism, as outlined in this expert communication. It should be emphasized that the modelling of a chemical terrorist attack and its devastating consequences is a prerequisite for thorough scientific research in the given field to increase the effectiveness of measures to protect the population. It is understandable that even in a highly-developed society of the Czech Republic, the citizen and his personal, family and other safety must come first.

\section{The overall conclusions can be summarized in the following recommendations:}

Regardless of the real or probable expectation of terrorist attacks in our conditions, it is reasonable to assume that the Prague Metro is one of the likeliest targets of a potential chemical attack (both a single carriage and the space of the stops with platforms). Therefore, it is necessary to study the possibilities and circumstances of such a possible chemical attack as an important and basic starting point for real preventive, repressive, protective, rescue, liquidating or corrective measures. From a practical viewpoint, it is expedient to consider extreme scenarios of a chemical attack, i.e. the worst-case scenario with murderous goals and the pursuit of stirring a panic. Both extreme scenarios may have a number of graduated feasible methods of execution, of which some are indicated.

- For the first and the most dangerous scenario, it is useful to assume the use of the most toxic super-toxic nerve agents (sarin, cyclosarin, soman and tabun).

- For the second scenario, the use of especially irritants (CS gas, CR gas, chloroacetophenone, bromobenzyl cyanide, Adamsite, Clark I, Clark II, chloropicrin) can be assumed.

- With regard to the likeliest manner of poisoning in the form of acute inhalation poisoning, O-2-propyl methylphosphonofluoridate, i.e. sarin, appears to be the most dangerous contaminant (due to the most appropriate set of physical and toxic properties). The safe production of sarin is not entirely simple, however, an organized group and a qualified chemist in conditions of a high degree of protection can produce a required amount; the question is the final purity of the product (or the smell of impurities). 
The places where a contaminant is dispersed correspond essentially to the target places of the attack. In the case of a carriage, a suitable place is on the floor or close to the floor; in the case of a Metro stop, it is either a central space (close to island stops) or, more precisely, a platform space at passenger halls with central rail yards (the type of the Main Station, Vyšehrad), or at all types of stops it is also the edge of the platform at the entrance from the line tunnel (with possible use of air flow compressed in front of the arriving train to disperse contaminants). Due to the toxicity of a selected contaminant, the average target contaminant concentrations are derived based on the parameters of its acute inhalation poisoning (i.e. the mean incapacitating effect $\mathrm{ECt}_{50}$ and the mean lethal effect $\mathrm{LCt}_{50}$ ) and estimated periods of the stay of the travelling public in the terminal area itself for two basic types of stops (tunnelled and excavated, differing in the volume) and in the carriage space. Based on such expertly estimated target concentrations, the minimum amounts of the contaminant for a given application are derived.

The authors do not know whether, from the viewpoint of the underground structure and its technical equipment, there are other possible risks of hidden external entering of a contaminant, e.g. through a Metro stop ventilation system or another similar entrance. However, it is definitely possible to generally consider other possibilities of introducing a contaminant through a traffic tunnel. The proposed amounts of a contaminant for the given cases are initial considerations for real model testing under authentic conditions, whereas the manner to quickly reach target average concentration (especially in a carriage) can be considered critical (from the viewpoint of the proposed minimum amount).

For the required target concentration (due to the desired effect), a much higher initial amount will be required for free evaporation (due to the dynamics of gradual reach of the target concentration in an enclosed space) than in the case of a possible real, facilitated evaporation using vaporizers of different designs or in an extreme case mechanical dispersion, which is able to reach a given concentration in a time of tens of seconds (but with a higher possibility of early detection). Only an authentic model experiment can give a completely real answer to this (such experiments have already been performed in the conditions of the Prague Metro, but they are secret for obvious reasons). The ideal solution is to prepare a professional safety analysis report or study, in which experts in many different fields should participate (i.e. civilian and military toxicologists, medical doctors, representatives of the Fire Rescue Service and the Police of the Czech Republic, representatives of the Prague Metro, etc.). Highly qualified and careful teamwork can bring fundamentally new theoretical knowledge and practical solutions in this case as well. Only such a comprehensive professional safety report or study can thoroughly analyse and evaluate the issues and thus basically prepare the conditions for both theoretical and practical training of the entire Integrated Rescue System, including the incorporation of preventive issues.

\subsection{Impacts of pesticides on human health and the environment - a case study}

\subsubsection{Adverse effects of pesticides on food and health}

Human health and food safety can be adversely affected by residues of pesticides contained in food and food raw materials, if they occur in amounts higher than the officially set so-called maximum residue limits (hereinafter MRLs). The maximum level of pesticide residues is the highest permissible, toxicologically acceptable amount of pesticides in food and food raw materials, which is expressed in the weight ratio $\left(\mathrm{mg}^{\mathrm{kg}} \mathrm{kg}^{-1}\right)$ of the entire defined product. 
Pursuant to Act No. 110/1997 Coll., on Foodstuffs and Tobacco Products and on the amendment and supplementation of some related acts, as amended by subsequent regulations, it applies that:

- Foodstuffs are substances intended for consumption in the unaltered or modified state, such as food or drink (from plant products such as fruit, vegetables, potatoes, etc.); and

- Food raw materials are agricultural, forestry, marine and other products intended for food production, or food intended for further processing (for cereals, hops, etc.).

In the process of verifying the properties of each plant protection preparation within the registration procedure (another authorization procedure), the course and rate of its disintegration after the treatment of a given crop is monitored. At the same time, a protection period is derived from the evaluation of the residue dynamics of the preparation as a period specified in days, which must be observed by the date of application and harvest or treatment of the stored plant product and its consumption, removal from storage, release for consumption or feeding. Therefore, the protection period is always stated in the List of Authorized Plant Protection Products, if applicable with regard to the relevant date of use.

According to the Food Act cited, it is forbidden to place food other than non-hazardous on the market. Foodstuffs containing pesticide residues higher than the maximum level for a given pesticide or containing pesticide residues, for which no MRLs are set, i.e. usually when an unregistered pesticide preparation is used, are "other than non-hazardous". As such, they do not meet the health conditions and the competent state supervisory authority (in the case of food of plant origin, the relevant Agriculture and Food Inspection Authority) prohibits the placing of this defective food on the market and orders appropriate measures for its use (use as raw materials, reprocessing).

A serious threat to the health and safety of food and food raw materials can occur when using pesticide preparations; it can happen especially in cases when the user of preparations uses an unregistered preparation, for which no MRL is set in the Czech Republic, or exceeds a set dose or does not observe the protection period. Most customers are primarily interested in how chemically treated fields affect our health. Just most foreign substances enter the human body through food. According to official tests, pesticide residues appear in a large part of fruits and vegetables, which can be bought in shops. The Czech Agriculture and Food Inspection Authority has found residues of 116 types of pesticides in them. However, in most samples the prescribed limits are observed. Approximately one percent of the tested foods exceeds them. These have included Czech apples, Spanish grapefruits or peppers from Morocco.

In recent decades, researchers have found out that certain chemicals, the so-called endocrine disruptors, can interfere with the effects of human hormones and the development of young children in the mother's body. They also include a number of pesticides. The Rainbow Movement mapped their use in detail in Czech agriculture. Farmers use hundreds of tonnes of them a year, e.g. linuron intended for protecting potatoes or maize, or thiram used for protecting cereals. The problem is that, according to some results, endocrine disruptors could act even in extremely low doses, which are considered to be completely safe as for common toxic effects. Doctors believe that they are the cause of some unfavourable health trends, mainly a long-term decline in sperm counts.

Moreover, inspectors monitor only the concentrations of individual pesticides. In real life, however, a mixture of many substances affects human health. Some medical research suggests that in a cocktail of different chemicals, the effects may support and multiply each other. It is not yet clear how serious this is. According to the state Scientific Committee for Food, these combinations are a "serious and as yet unresolved problem". 
Finally, statistics show that you rarely come across foods with excessive pesticide content in the shops. Nevertheless, this still does not change the fact that the few people who are unlucky are affected by their effect. Similar optimistic figures are based on tests in the United Kingdom. A few local toxicologists and environmental experts have subjected them to mathematical probability calculations. The calculations show that 10 to 220 children eat an apple or pear, where the concentration of pesticides exceeds the safe limit, every day.

There is definitely no danger of poisoning with fruits and vegetables from the supermarket. And it is certainly healthier to eat apples or carrots, even if treated with considerable doses of pesticides, than to combine sausages, cola full of sugar and salted chips. The main risk of toxic sprays lies undoubtedly in the damage they cause when in use. At least because of the recovery of the landscape and the return of nature to the fields and orchards, it is necessary to buy the goods that farmers have grown without the mass use of pesticides. The adverse effects of pesticides on human health are very complex. In recent years, scientific studies have been increasing. They show a link between certain pesticide exposure and the development of serious civilizational diseases, such as heart and vascular diseases (e.g. stroke, heart attack), hormonal system disorders (e.g. diabetes, thyroid disorders) or the nervous system disorders (e.g. Parkinson's disease).

In the European Union, pesticides were found in almost half of the food samples tested in 2007. These residual amounts of chemical sprays are referred to as pesticide residues. Laboratory analyses have identified almost 350 different chemicals, and among the 10 most commonly detected pesticides there were chemicals causing mutations and cancer, chemicals that disrupt the endocrine system or threaten reproduction. Approximately $5 \%$ of the food samples tested contained pesticides exceeding European limit values. About a quarter of the fruits, vegetables and cereals tested contained two or more pesticides. However, more than 10 pesticides were found in a lot of foods (!), most often in peppers and grapes.

The effects of long-term exposure to low doses of pesticide residues and their mixtures have not yet been sufficiently investigated. In particular, experts consider the co-occurrence of several types of pesticides with a similar effect (e.g. organophosphates and carbamates acting on the cholinesterase enzyme) to be a serious problem.

\section{Foodstuffs with the highest pesticide levels (sorted in descending order)}

- Celery root - the content of 64 residues of known pesticides. Of these, 13 known or possible carcinogens, 31 suspected endocrine disruptors, 12 neurotoxins, 14 toxins that are detrimental to the development and reproduction, and 20 bee venoms.

- Peaches - the content of 62 residues of known pesticides. Of these, 10 known or possible carcinogens, 29 suspected endocrine disruptors, 12 neurotoxins, 11 toxins that are detrimental to the development and reproduction, and 25 bee venoms. As they are extremely attractive for pests, a lot of pesticides are used, more pesticides will be in imported peaches.

- Savoy cabbage - the content of 55 residues of known pesticides. Of these, 9 known or possible carcinogens, 27 suspected endocrine disruptors, 10 neurotoxins, 10 toxins that are detrimental to the development and reproduction, and 23 bee venoms.

- Strawberries - the content of 54 residues of known pesticides. Of these, 9 known or possible carcinogens, 24 suspected endocrine disruptors, 11 neurotoxins, 12 toxins that are detrimental to the development and reproduction, and 19 bee venoms. Imported strawberries are often treated by spraying, it is better to prefer domestic strawberries with a proven origin.

- Blueberries - the content of 52 residues of known pesticides. Of these, 8 known or possible carcinogens, 24 suspected endocrine disruptors, 14 neurotoxins, 7 toxins that are detrimental to the development and reproduction, and 21 bee venoms. It is better to pick them in the woods. 
- Lettuce - the content of 51 residues of known pesticides. Of these, 12 known or possible carcinogens, 29 suspected endocrine disruptors, 9 neurotoxins, 10 toxins that are detrimental to the development and reproduction, and 21 bee venoms.

- Peppers - the content of 49 residues of known pesticides. Of these, 11 known or possible carcinogens, 26 suspected endocrine disruptors, 13 neurotoxins, 10 toxins that are detrimental to the development and reproduction, and 19 bee venoms. Especially Spanish and Turkish peppers contain more pesticides.

- Spinach - the content of 48 residues of known pesticides. Of these, 8 known or possible carcinogens, 25 suspected endocrine disruptors, 8 neurotoxins, 6 toxins that are detrimental to the development and reproduction, and 23 bee venoms. Using nitrogen fertilizers causes an increase in nitrates in spinach leaves.

- Cabbage - the content of 46 residues of known pesticides. Of these, 9 known or possible carcinogens, 25 suspected endocrine disruptors, 10 neurotoxins, 8 toxins that are detrimental to the development and reproduction, and 25 bee venoms. Heavy metals and the pesticides used can accumulate in cabbage leaves.

- Beans - the content of 44 residues of known pesticides. Of these, 8 known or possible carcinogens, 22 suspected endocrine disruptors, 11 neurotoxins, 8 toxins that are detrimental to the development and reproduction, and 18 bee venoms.

- Apples - the content of 42 residues of known pesticides. Of these, 7 known or possible carcinogens, 19 suspected endocrine disruptors, 10 neurotoxins, 6 toxins that are detrimental to the development and reproduction, and 17 bee venoms. Czech apples must not be waxed, but can be sprayed; thus, pesticides are on the apple skin, which will lose many good substances, if peeled. The "more ordinary apples" will probably be better, even with a little worm.

- Cherries - the content of 42 residues of known pesticides. Of these, 7 known or possible carcinogens, 22 suspected endocrine disruptors, 7 neurotoxins, 8 toxins that are detrimental to the development and reproduction, and 18 bee venoms. Imported cherries contain a considerable amount of "plant protection preparations", the best thing is to pick them.

- The following should be mentioned:

- Potatoes - the content of 37 residues of known pesticides;

- Cucumbers - the content of 35 residues of known pesticides;

- Tomatoes - the content of 35 residues of known pesticides;

- Grapes - the content of 34 residues of known pesticides; and

- Broccoli - the content of 33 residues of known pesticides.

\section{Foodstuffs containing the lowest amounts of pesticide residues}

- Bananas - the content of 12 known pesticide residues. Of these, 4 known or possible carcinogens, 7 suspected endocrine disruptors, 2 neurotoxins, 5 toxins that are detrimental to the development and reproduction, and 2 bee venoms. Banana peels may be automatically treated by spraying, as they are not expected to be consumed.

- Grapefruit - the content of 11 known pesticide residues. Of these, 4 known or possible carcinogens, 4 suspected endocrine disruptors, 4 neurotoxins, 4 toxins that are detrimental to the development and reproduction, and 2 bee venoms.

- Almonds - the content of 9 known pesticide residues. Of these, 1 known or possible carcinogen, 4 suspected endocrine disruptors, 3 neurotoxins, 0 toxins that are detrimental to the development and reproduction, and 4 bee venoms.

- Asparagus - the content of 9 known pesticide residues. Of these, 1 known or possible carcinogen, 7 suspected endocrine disruptors, 4 neurotoxins, 3 toxins that are detrimental to the development and reproduction, and 5 bee venoms.

- Onions - the content of 1 known pesticide residue. Of these, 0 known or possible carcinogens, 0 suspected endocrine disruptors, 0 neurotoxins, 0 toxins that are detrimental to the development and reproduction, and 0 bee venoms. 


\subsubsection{Adverse effects of pesticides on the health of farmers}

The farmers who come into contact with pesticides have an increased risk of developing brain cancer. The Reuters News Agency reported on that with reference to a new scientific study. The study involved almost 700 adults, some of them with brain tumours. French researchers have found out that the people working in agriculture who are most exposed to pesticides are twice as likely to develop brain cancer as those who do not work with pesticides. At the same time, researchers have found evidence that people who treat their house plants with pesticides are also more at risk for developing brain cancer. However, the researchers have pointed out that the new findings have not yet been observed in previous studies; the Reuters News Agency reports that further research is needed to confirm them.

Older studies linked exposure to pesticides with adverse effects influencing the brain, e.g. an increased risk of Parkinson's disease. A new study focused on the residents of the French Bordeaux region. This region with famous vineyards is one of the areas with the highest incidence of brain cancer in the world. Isabelle Baldi of the University of Bordeaux and her colleagues compared 221 adults in whom brain cancer developed between 1999 and 2001 with 442 healthy adults of the same age.

It has been found out that the average risk of brain cancer is generally $29 \%$ higher among people who are exposed to pesticides at work than among people who are not exposed. There has been no evidence that people exposed to lower concentrations are more at risk for brain cancer. However, among farmers, winegrowers and other people who are heavily exposed to pesticides, the risk of brain tumour is doubled. A survey of tumour types has shown that glioma was three times more frequent in the people working with pesticides.

\subsubsection{Adverse effects of pesticides on hymenoptera}

Bees belong to the most endangered species of insects when pesticides, especially insecticides are used. Pesticides used by farmers to protect crops or bee hives can "short-circuit" the bees' brains and affect their memory and navigational abilities. These are necessary for a bee to be able to find food and, at the same time, to pollinate crops, which is essential for human food production, the researchers stated in the study published by the Nature Communications journal. The team observed the brains of bees in the laboratory after exposing them to neonicotinoid insecticides used on crops, and organophosphates, the most widely used group of insecticides in the world, which are used to control mites infesting beehives. "After being exposed to concentrations similar to those that bees would encounter in the open air, their brain circuits for learning stopped working quickly", said the researchers. "These two classes of pesticides have shown a greater adverse effect on the bee brain and are predicted to inhibit bees from learning", added study co-author Christopher Connolly of the University of Dundee Medical Research Institute for the AFP News Agency.

"Pollinators perform sophisticated behaviours while searching for food, which requires them to learn and remember the floral signs associated with food", added Geraldine Wright of the Centre for Behaviour and Evolution at the Newcastle University.

If a beekeeper finds out that bees have died due to the use of preparations, he will promptly pass on the information to the competent authority of the State Veterinary Administration (SVA). This authority, in cooperation with the Central Institute for Supervising and Testing in Agriculture (Czech abbreviation - ÚKZUZ), will carry out a local investigation and, depending on the result, will ensure sampling and examination by a professional institute (the National Reference Laboratory/NRL/). 
Then it will inform the beekeeper about the result of this examination. The result of the examination of the samples will also be provided by the Central Institute for Supervising and Testing in Agriculture. To investigate the causes of bee mortality, a sample of dead bees must be taken in a number of at least 500 individuals and a sample of treated vegetation weighing at least 200 grams. The samples must be marked and packed in a breathable solid package and delivered to a professional institute for analysis no later than 72 hours after the treatment of vegetation.

\subsubsection{Adverse effects of military use of pesticides}

\subsubsection{Military use of pesticides in Vietnam - 1962 to 1971}

Herbicides are not included in any list of chemicals contained in the Convention, but their use as a means of combat operation is prohibited by the Convention.

The tactical and strategic intention of the use of herbicides in Vietnam within the framework of "Operation Ranch Hand" was, in addition to the anticrop operation, especially the defoliation of the natural cover of military bases. In combat, herbicides were most often used in the form of aqueous or oily solutions, emulsions and suspensions. However, phytotoxic substances in the form of aerosols were mostly used. These were dispersed into the air on the physicochemical or mechanical principle. Contamination of the ground layers of the atmosphere in Vietnam was performed as follows:

- By means of the dispersion of liquid or solid substances; and

- By means of the evaporation or sublimation of liquids or solids.

In both cases, the substance used passes into the air either only in the form of vapours or in the form of aerosols. Based on the conducted field tests and experience with the use of herbicides, especially in a conflict, it has been shown, which of these components predominates in a given situation. It has also been found out that the effective use of these types of substances depends on many factors as follows:

- On the type and method of dispersion;

- On the physicochemical properties of the substance;

- On the temperature and vertical stability of the atmosphere in the aerosol cloud propagation area;

- On the size of aerosol particles (their size and shape depend on the vapour pressure of these substances);

- On the type of a chemical compound; and

- On the design of ammunition or a launching device.

By converting the substance into an aerosol form, the dispersion of a larger amount of the substance into the air than corresponds to its evaporability was achieved. Liquid or solid substances, which are not able to reach the required vapour concentration under normal conditions, can also be dispersed.

By converting herbicides into an aerosol form with the same total volume of the substance, a several-fold increase in its surface area and thus an increase in the effective (contact) area was achieved. This fact played an important role in herbicides because direct contact is necessary to achieve a destructive effect on the vegetation. Dispersing herbicides from the air was the most feasible procedure to quickly cover the area regardless of size. The most important tactical mixtures of herbicides used by the US military in Vietnam were named after the coloured bands painted around the barrels, in which they were shipped, e.g. Agent Orange, Agent White, Agent Purple and Agent Blue. 
The following methods were most often practiced in Vietnam:

- Spraying or dusting with undiluted herbicides;

- Spraying with diluted herbicides, but in large quantities; and

- Repeated spraying of the same areas.

Table 69: Types of herbicides used by the US military in Vietnam. [Source: Tab-69]

\begin{tabular}{|c|c|c|c|}
\hline Herbicide & Composition & Use & Note \\
\hline Agent Orange & $\begin{array}{l}\text { 50:50 mixture of 2,4-D n-butyl } \\
\text { ester and 2,4,5-T n-butyl ester }\end{array}$ & $1 / 65-4 / 70$ & $\begin{array}{l}\text { Soluble in diesel fuel, water } \\
\text { insoluble, use - woodland, } \\
\text { agriculture }\end{array}$ \\
\hline $\begin{array}{l}\text { Agent Orange } \\
\text { II } \\
\text { Super Orange } \\
\end{array}$ & $\begin{array}{c}50: 50 \text { mixture of 2,4-D n-butyl ester } \\
\text { and 2,4,5 Trichlorophenoxy acetic } \\
\text { acid isooctyl ester }\end{array}$ & $1968-1969$ & $\begin{array}{l}\text { Soluble in diesel fuel, water } \\
\text { insoluble, use - woodland, } \\
\text { agriculture }\end{array}$ \\
\hline Agent Purple & $\begin{array}{c}\text { 50:30:20 mixture of 2,4-D n-butyl es- } \\
\text { ter, 2,4,5-T n-butyl ester and 2,4,5-T } \\
\text { iso-butyl ester }\end{array}$ & $1 / 62-1964$ & $\begin{array}{l}\text { Soluble in diesel fuel, water } \\
\text { insoluble, use - woodland, } \\
\text { agriculture }\end{array}$ \\
\hline Agent Pink & $\begin{array}{l}\text { 4:1 mixture of 2,4-D triisopropanol- } \\
\text { amine and 4-amino-3,5,6-trichloro-2- } \\
\text { pyridinecarboxylic acid (Picloram) }\end{array}$ & $1962-1964$ & $\begin{array}{l}\text { Water soluble, insoluble } \\
\text { in diesel fuel }\end{array}$ \\
\hline Agent Green & $2,4,5-\mathrm{T}$ & $1962-1964$ & \\
\hline Agent White & $\begin{array}{c}36 \% \text { of } 2,4-\mathrm{D} \text { triisopropanolammo- } \\
\text { nium } \\
8 \% \text { of triizopropanolamonium- } \\
\text { 4-amino-3,5,6-trichloropicolinate } \\
\text { (Picloram salt) } \\
\end{array}$ & --- & Use - mainly in agriculture \\
\hline Agent Blue & $\begin{array}{l}27.7 \% \text { of sodium dimethylarsinate } \\
\text { (sodium cacodylate) and } 4.8 \% \text { of } \\
\text { dimethylarsinic acid (cacodylic acid) }\end{array}$ & --- & $\begin{array}{l}\text { Aqueous solution, use - } \\
\text { woodland, agriculture and } \\
\text { around US military bases }\end{array}$ \\
\hline Dinoxol & 2,4-D and 2,4,5-T & 1962-1964 & \\
\hline Trinoxol & $2,4,5-\mathrm{T}$ & 1962-1964 & \\
\hline Diquat & $\begin{array}{l}\text { 1,1'-Ethylene-2,2'-bipyridylium } \\
\text { dibromide }\end{array}$ & $1962-1964$ & \\
\hline Bromacil & $\begin{array}{l}\text { 5-bromo-6-methyl-3-(1-methyl } \\
\text { propyl)uracil }\end{array}$ & $1962-1964$ & $\begin{array}{c}\text { Powder containing } 80 \% \text { of } \\
\text { active substance, name Hyvar-X, } \\
\text { water soluble powder containing } \\
50 \% \text { of active substance, name } \\
\text { Hyvar-X-WS, } \\
\text { liquid solution } 480 \text { g.litr-1, name } \\
\text { Urox B }\end{array}$ \\
\hline Monuron & 3-(4-chlorophenyl)-1,1-dimethylurea & $1962-1964$ & $\begin{array}{c}\text { Granulate with } 2 \% \text { of } \\
\text { monuron-TCA name Urox } 2\end{array}$ \\
\hline Diuron & $\begin{array}{l}\text { 3-(3,4-dichlorophenyl)-1,1-dimethyl- } \\
\text { carbonyldiamide }\end{array}$ & $1962-1964$ & \\
\hline Dalapon & $\begin{array}{c}\text { sodium salt of 2,2-dichloropropionic } \\
\text { acid }\end{array}$ & $1962-1964$ & \\
\hline
\end{tabular}


Defoliants affected $12 \%$ of forests and $5 \%$ of agricultural land in Vietnam. Most mammals and more than $3 / 4$ of bird species disappeared from the affected forests. The mangrove ecosystem on the coast was also destroyed. Here, the return to a normal state is estimated at about 100 years.

Vietnam had to bear the consequences of Operation Ranch Hand for next 45 years after the war and will have to bear them for a long time to come, although it was probably not the American intention to destroy the territory of its then ally in this way. Dioxins were not known at the time, so Operation Ranch Hand can serve as a warning that not every seemingly harmless idea will be appreciated by humans and nature.

\subsubsection{Military use of pesticides outside Vietnam}

Australia - in 2008, Australian researcher Jean Williams claimed that the incidence of cancer in Innisfail, Queensland, had been 10 times higher than the national average, namely due to the secret testing of Agent Orange by Australian military scientists during the Vietnam War. Jean Williams received the Order of Australia for research on the effects of chemicals on the American war veterans. However, the Queensland Government Department of Health concluded that the incidence of cancer in Innisfail had not been higher than in other parts of the Australian state.

Brazil - the Brazilian Government used herbicides to destroy a part of the Amazonian rainforest in order to build a dam near Tucuruí due to mining activities. Large areas of the rainforest were destroyed, along with the homes and land of thousands of rural peasants and indigenous peoples.

Cambodia - Agent Orange was used as a defoliant in eastern Cambodia during the Vietnam War, but its impact on the population and nature is difficult to assess due to the chaos that prevailed under the Khmer Rouge rule.

Canada (New Brunswick) - with the permission of the Government of Canada, the U.S. military tested herbicides including Agent Orange in forests near the Canadian Forces Base Gagetown, New Brunswick, for three days in 1966 and for four days in 1967. The soldiers working on the base were told that the chemicals would not have any harmful effects on them. Many years later, this inaccuracy led to claims for reimbursement of medical bills. On September 12, 2007, Greg Thompson (Canadian Veterans Affairs Minister) announced that the Government of Canada was offering one-time compensation in the amount of 20,000 dollars to those exposed to Agent Orange near the Canadian Forces Base Gagetown. On July 12, 2005, Merchant Law Group LLP filed a lawsuit for failure to act in Agent Orange and Agent Purple lawsuits on behalf of more than 1,100 Canadian veterans and civilians living in and around Gagetown. On August 04, 2009, the case was dismissed by the court for the lack of evidence. An appeal was lodged against the decision. In 2007, the Government of Canada announced that research and fact-finding programs launched in 2005 had shown that people working on the base had been safe.

Canada (Ontario) - on February 17, 2011, the Toronto Star reported that the same chemicals used in the jungles of Vietnam had been used on lands in northern Ontario. The Toronto Star stated that records from the 1950s, 1960s and 1970s indicated the presence of forest workers, often students and young Rangers. They were there for weeks while low-flying planes were spraying toxic herbicides, including a mixture known as Agent Orange. On the same day, in response to a Toronto Star article, the Ontario Government launched an investigation into the use of the herbicide Agent Orange. The next day, on February 18, 2011, the Ontario Ministry of Natural Resources extended the investigation into the use of Agent Orange to all areas of the province where the provincial government was in charge of forest management. 
Canada (British Columbia) - records show that in the late 1960s and early 1970s, tens of thousands of gallons of mixtures were used to destroy grass, shrubs, and trees near highways and along power line. In some cases, the mixture was sprayed near inhabited houses and farms. The mixture of 2,4-D and 2,4,5-T acids was referred to as "Type B Weed and Brush Killer" in the government invoices. When engineers ordered and used (pure) 2,4,5-T acid itself, they referred to it as "Type $C$ Weed and Brush Killer". In total, about 26,000 gallons of herbicides of "Type B Weed and Brush Killer" and about 10,000 gallons of herbicides of "Type C Weed and Brush Killer" were used for spraying between 1965 and 1972. The barrels of chemicals were sent by the Ministry of Transportation and Infrastructure to four areas: Kamloops, Nelson, Prince George and Vancouver.

Guam - the analyses of substances in the soil on the island of Guam show that Agent Orange was among the herbicides used on and around the military bases of Anderson Air Force Base, Naval Air Station Agana and Guam. Despite of the evidence, the US Department of Defense continues to deny that Agent Orange was stored or used on the island of Guam. The veterans serving on Guam obtained evidence in lawsuits, in which they called for claims for the disabled due to direct exposure to dioxins that contain herbicides, e.g. 2,4,5-T acid. The disabilities of people exposed to the effects of herbicides on Guam was the same as those of soldiers exposed to the same chemical (Agent Orange) used in Vietnam.

Korea - Agent Orange, a mixture of herbicides, was used in Korea in the late 1960s. The military units of the Republic of Korea were the only ones involved in spraying herbicides in the Korean Demilitarized Zone (DMZ). Declassified US Department of Defense documents show that Korean officials fear the legal actions of thousands of their soldiers who may have come into contact with herbicides in the late 1960s and early 1970s. According to a high-ranking South Korean government official, there may be as many as 30,000 Korean veterans suffering from diseases due to herbicide exposure. In 1999, about 20,000 South Koreans filed two separate lawsuits against U.S. companies and claimed damages at the amount of more than 5 milliard dollars. After losing the lawsuit, they filed an appeal against the decision in 2002. In January 2006, the South Korean Court of Appeal ordered the US chemical companies (Dow Chemical and Monsanto) to pay 62 million dollars in compensation for some 6,800 people. The court ruling stated that "the defendants (companies) had failed to ensure safety because their defoliants produced had higher levels of dioxins than the standard", which was a "causal link" between Agent Orange and 11 proven diseases, including cancer of lungs, larynx and prostate. The judge failed to confirm "the relationship between the effects of chemicals and peripheral neuropathy (damage to the nerves of the peripheral nervous system)", the most common disease among Agent Orange victims. The peripheral nervous system records stimuli such as heat, pain and touch, and sends the information about them to the spinal cord and further to the brain. The information is evaluated here and the body then responds accordingly. Common manifestations include weakness, decreased sensitivity and pain, which mainly affect arms and hands or legs and feet, but can also affect other parts of the body.

Japan (Okinawa) - dozens of reports on the use and/or storage of military herbicides on Okinawa Island have been published in the press. These reports came from the statements by the former US officials who were stationed on the island, based on the photographs, government records and stored barrels of herbicides discovered. In January 2013, the US Department of Defense denied the allegations in a statement by military officials through its spokesman.

Johnston Atoll - the US Air Force operation to remove Agent Orange supplies from Vietnam in 1972 was called Operation Pacer IVY, and the operation to destroy Agent Orange supplies deposited on Johnston Atoll in 1977 was called Operation Pacer HO. Operation Pacer IVY lay in collecting the Agent Orange herbicide in South Vietnam, then removing it in 1972 aboard the MV Transpacifik and depositing it on Johnston Atoll (see Figures 130-131). 
The Environmental Protection Agency (EPA) reports that $1,800,000$ gallons of Agent Orange were stored in the Pacific close to Johnston Island and 480,000 gallons in Gulfport, Mississippi. Research and the study were launched to find a safe method for disposing these agents; it was found out that they could have been safely incinerated under specific temperature and time conditions. Nevertheless, the purchase of herbicides was costly, so the Air Force decided to sell its surplus stocks of herbicides instead of storing them in the sea or incinerating them at sea.

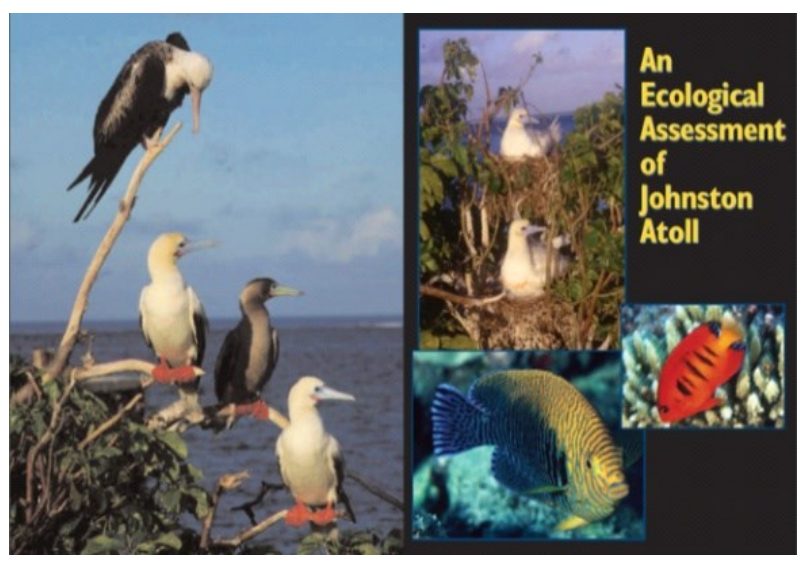

Figure 130: An Ecological Assessment of Johnston Atoll. [Source: Fig-130]

One of a number of methods tested was the method of herbicide processing; toxic 2,3,7,8-tetrachlorodibenzo-p-dioxin (TCDD) was removed using the carbonized coconut fibre. In 1976, this procedure was tested and a pilot plant was subsequently built in Gulfport, Mississippi.

During Operation Pacer HO (Agent Orange) from July to September 1977, all stocks of Agent Orange from both Gulfport, Mississippi, and Johnston Atoll storage sites were burned aboard the Dutch waste incinerator ship MT Vulcanus near Johnston Island (4 voyages).

Laos - some parts of Laos were sprayed with Agent Orange during the Vietnam War.

New Zealand - the exposure of the New Zealand Army troops in Vietnam to Agent Orange after its use was controversial due to their own production of Agent Orange for Vietnam and other users at the Ivon Watkins Dow chemical plant in Paritutu, New Plymouth, because the suburb of Paritutu was also contaminated. However, there are cases of cancer, especially bone cancer, in New Zealand soldiers, however, no scientific research has confirmed a link between the occurrence of this cancer and herbicide exposure.

Thailand - Agent Orange was tested by the United States in Thailand during the war in Southeast Asia. It was confirmed that the workers who had opened unknown barrels when working at the airport during the 1999 airport innovation near Hua Hin, $100 \mathrm{~km}$ south of Bangkok, had showed signs of Agent Orange poisoning. Many veterans of the Vietnam War (at any time between February 28, 1961 and May 07, 1975) who were assigned to airport customs or served (or worked) at/or near U.S. military bases in Thailand could be exposed to the toxic effects of herbicides and may be eligible for veteran benefits. The entitlement by reason of direct exposure is possible if the individual can prove that, at that time, he was working or living in close proximity to the affected areas of US bases in Thailand. According to a declassified US Department of Defense report from 1973, a significant use of herbicides around the fencing of US military bases in Thailand occurred due to removing grasses and shrubs, in which the enemy could hide. 
The Philippines - studies of soil contamination with Agent Orange and White Orange in the Philippines were performed. The Philippine Herbicide Test Program was conducted in cooperation with the University of the Philippines, the College of Forestry and Natural Resources, and was described in a 1969 issue of The Philippine Collegian.

The United States - The University of Hawaii confirmed extensive testing of Agent Orange by the US Department of Defense on Hawaiian Kauai island from 1967 to 1968 and on Hawaii Island in 1966. Testing and storage elsewhere in the United States were documented by the US Department of Veterans Affairs.

In 1971, C-123 aircraft, which was used to spray Agent Orange in Vietnam, was assigned to the US Air Force Reserve Squadron on the East Coast after returning to the United States. From 1972 to 1982, it was used in the traditional air transport of deployed forces in foreign missions. In 1994, within the testing of crop-dusting aircraft, the aircraft was found to be "heavily contaminated" with residual dioxin. When asked by veteran air crews in 2011, the US Department of Veterans Affairs replied that residual dioxin level was not high enough to include air crews in the Post-Vietnam Era Veterans' Program. On January 26, 2012, the Centers for Disease Control and Prevention (CDC) and the Agency for Toxic Substances and Disease Registry (ATSDR) challenged this finding, arguing that the former aircraft had been indeed contaminated and that crews had been exposed to harmful concentrations of dioxins.

In response to veterans' concerns, the Vietnam Veterans of America (VVA) submitted the affair of C-123 to the Institute of Medicine for study in February 2014. The report on defence from December 2006 dealt with testing Agent Orange and storing it in 32 repositories across the United States, as well as in Canada, Thailand, Puerto Rico, Korea and the Pacific Ocean. Eglin Air Force Base in Florida was one of the test sites in 1960.

\subsubsection{Chemical accident with mustard gas in the port of Bari-weapons in the sea-a case study}

The Italian city of Bari is located on the Adriatic coast. During World War II, the seaport in the city of Bari was under British administration. The total population was 200,000 people. It was the main supply base of General Montgomery's $8^{\text {th }}$ US Army, as well as the $15^{\text {th }}$ US Air Force Command. To the north, there was an airport in Foggia used by the Americans. Military hardware on ships was transported to the seaport of Bari, including large quantities of aviation fuel. The port of Bari was a critical point for supplying the Allies. By bombing the port and destroying it, the Germans expected a significant weakening of the Allies, including the paralysis of their air forces.

During World War II, there was a constant possibility that the Germans would use chemical weapons. Among other things, it must be emphasized that they had both tabun and sarin ready, and at the end of the war soman was developed; all of these nerve agents are still considered the "most dangerous chemical warfare agents". From the end of 1943, however, the strategic initiative passed from Germany to the Allies. Despite of the above-mentioned considerations about the renunciation of the use of chemical weapons in World War II in Europe, the Allies feared that Hitler might use his chemical weapons to reverse the strategic balance in his favour.

Based on the above-mentioned concerns, it was decided that the John Harvey, an American Liberty ship, would transport a cargo of mustard gas (in the form of aerial bombs) from the United States of America to Italy, as a strategic reserve just for the case of the outbreak of "chemical warfare". In November 1943, Lieutenant Howard D. Beckstrom of the $701^{\text {st }}$ Chemical Company was given an order to secure the transportation of 2,000 pieces of chemical ammunition for the Italian battlefield. 
Chemical ammunition was transported from the Eastern Chemical Warfare Depot in Maryland to Baltimore by train. In Baltimore, the above-mentioned ship was loaded with 2,000 pieces of M47-A1 chemical munitions, which were 100-pound mustard gas aerial bombs. In total, there were 100 tonnes of mustard gas aerial bombs. The commander of the ship was Captain Elwin Knowles (war veteran). He was accompanied by Lieutenant Thomas H. Richardson, the ship's cargo security officer, whose task was to ensure the secrecy of this sensitive cargo.

The American ship carried equipment, foodstuffs and large quantities of ammunition, including mustard gas bombs. The Liberty ship John Harvey arrived in the Italian port of Bari on November 28, 1943, after stopping for several times in other seaports. At the end of November, the seaport of Bari was overcrowded and very busy. The Liberty ship John Harvey waited for the discharge of cargo until December 02, 1943. Because the ship's cargo was top secret, the John Harvey was given no priority to be unloaded. Despite of working day and night in the seaport, Captain Knowles learned that the cargo would not be unloaded for several days. Therefore, the captain of the ship made several journeys to the headquarters of the port of Bari, but it was completely vain. Either he did not know what cargo he was carrying, or he did not want to divulge its contents. Lieutenant Thomas H. Richardson contacted all responsible officers in the seaport, but was limited in what he could reveal and was unable to negotiate any priority for unloading the ship. The British commander of the seaport in Bari allegedly knew the contents of the John Harvey's cargo, but he had strict instructions not to reveal anything to anyone. Therefore, he refused to give the ship any priority in the discharge of cargo - probably because of secrecy.

The Germans observed a high concentration of many ships in the seaport of Bari. They knew well how the port was important for Allied war operations and their logistic support in Italy. The German air raid on the seaport of Bari was a big surprise. The British radar warning system was expected to sound a warning, but at the crucial moment the important equipment was not in operation. Eyewitnesses stated that no air-raid sirens had been activated. The German air raid on the seaport of Bari was carried out by the German Luftwaffe (JU-88 bombers) and the attack began in the morning at 7:20 on December 02, 1943 on a clear day. At that time, there were a total of 30 sea ships in the seaport, both war and merchant ones. The German aircraft arrived from the east, the port was plainly visible and the entire air raid lasted about 20 minutes only. The threatened naval ships had no possibility to manoeuvre and escape from the bombed port, the quay was overcrowded with ships. The American Liberty ship John Harvey was not hit directly by a bomb; however, the surrounding ships were hit, which was often associated with several explosions and a subsequent large-scale fire. The situation was extremely serious. Although the Liberty ship John Harvey was not hit directly, it exploded owing to fires of the surrounding ships. Everyone on board was killed instantly and pieces of the ship and her cargo were hurled into the air. Mustard gas leaked from the broken bombs and mixed with the oil on the water surface and with billowing clouds of smoke from extensive fires. While mustard gas is poorly soluble in water, it dissolves well in organic solvents (including oils). Many soldiers and sailors swam in this "mustard gas sludge" to save their lives without knowing it.

The victims were gradually transported to hospitals. Hospital staff left the victims in the "oil" clothing, which was a mistake. The victims suffered from burns, blisters, temporary blindness, swollen genitals and irritation of the respiratory tract. The insidiousness of mustard gas lies also in the fact that the manifestations of mustard gas have a relatively long latency period (hidden course of poisoning), with a delay of about 4 to 6 hours and this shows only in skin or eye irritation. As soon as the victims began to die, doctors started speculating that the victims might have been affected by chemical warfare agents. Some literary sources state that Lt. Col. Stewart F. Alexander finally confirmed that the victims had been exposed to mustard gas. 
A total of 628 "mustard gas victims" were treated (90\% of the victims were Americans), of whom 69 died within the first 2 weeks. The first deaths occurred 18 hours after exposure to mustard gas. Most of the victims were saved and cured. However, the data on the civilians adversely affected by mustard gas are not available. Moreover, many people left the city after the air raid, some of them might have been victims of mustard gas and died later due to the lack of medical care.

On December 02, 1943, of the total number of 30 naval ships present in the port a total of 17 ships were destroyed (sunk) and other 7 ships were seriously damaged. The Americans sustained the highest losses in consequence of the German air raid, namely five ships; the British also lost five ships, the Norwegians three, the Italians two and the Poles two. Other seven naval ships were severely damaged. The German air raid on Bari closed the seaport for three weeks. The German air raid on the Italian seaport of Bari is sometimes dubbed "the second Pearl Harbour".

Up to the present it is not completely clear whether the Germans knew about the "mustard gas cargo" on the Liberty ship John Harvey. In particular, British Prime Minister Winston L. S. Churchill wanted to keep the whole unpleasant affair in secret, even after the fatal bombing of the seaport of Bari. Above all, he feared that after the revelation of the "special American cargo" the whole event would be interpreted as a German partial victory and would be used by Nazi propaganda. The case thus remained shrouded in mystery.

\section{Threats posed by chemical weapons sunk in the seas - a case study}

The above-mentioned serious chemical accident with mustard gas clearly demonstrates its high dangerousness. Although the international treaty "Chemical Weapons Convention" as well as the national law and implementing decree prohibit the development, production and use of mustard gas, there is no complete guarantee that this chemical warfare agent will not be misused in the future against humans or, if need be, against other targets (livestock poisoning, contamination of space, etc.). Moreover, the data on mustard gas production are very easily available, e.g. Viktor Ettel's old specialized publication entitled "Chemical Warfare" from 1932 (see Literature) lists several methods of preparing mustard gas. The book is commonly available in many public libraries and, in addition to that, the indicated mustard gas production processes are essentially a "cookery book", i.e. the literature not only mentions starting reactants and subsequent chemical reaction mechanisms, but also describes reaction conditions such as temperature, pressure, etc. Pages 98 to 103 describe three methods of producing mustard gas in detail: the German production method, the French production method and the English (American) production method. In this old literature, the physiological effects of mustard gas, its use, protection against it and the first aid on other pages of the book are described in detail.

Although mustard gas, also called yperite, has been considered an "obsolete chemical warfare agent" for many years in professional circles, its high toxicity is clear from the abovementioned facts. Therefore, mustard gas could become an interesting chemical warfare agent for terrorists. Not only for this reason, fast and correct protection against mustard gas, recognition of poisoning and treatment of mustard gas poisoning remain in the constant interest of both crisis managers and medical staff both in the Czech Republic and abroad.

Another problem is sunken unexploded ordnance, which corrodes, and mustard gas begins to leak. According to Italian journalist Gianluca di Feo from the weekly L'Espresso, the author of "Poisons of State", an unspecified number of mustard gas bombs lie at the bottom of the seaport of Bari, just as in several other places in the Adriatic Sea where they were moved and sunk by the Allied troops in camouflaging the incident. According to him, the bombs are in a deplorable state and it is a matter of time when the gas releases. Reportedly, it is a ticking chemical death... 
The Italian Central Institute for Applied Marine Research (ICRAM) warned against these "ticking time bombs" at the sea bottom as early as 1999. According to it, sonars discovered thousands of chemical charges in the southern part of the Adriatic. They are said to be in such a deplorable state that it is only a matter of time before the toxic agents are released from them. The giant chemical arsenal of Italy was built by Benito Mussolini, the fascist dictator of Italy. His reserves of toxic agents ranked among the largest ones in the world. During fascism from 1922 to 1945 , the Italians produced 12,500 up to 23,500 tonnes of chemical poisonous compounds. However, according to the British, there were many more such compounds allegedly, only two Italian factories produced 50 to 60 thousand tonnes of mustard gas.

After the end of World War II, 65,000 tonnes of chemical weapons were dropped into the Baltic Sea, according to Professor Jacek Beldowski of the Polish Institute of Oceanography. The Russian and British troops deposited at least 15,000 tonnes of German ammunition containing chemicals in the Gotland Deep. Most of these repositories are known: in the Baltic Sea, it is mainly around the islands of Gotland and Bornholm. These are dangerous agents, e.g. mustard gas, chlorine gas, adamsite, phosgene, tabun, sodium cyanide or arsines. These chemical warfare agents have been found in landfill sediments, which proves that they can escape through corroded containers.

A recent study has revealed alarming findings: fish caught near these underwater dumps show a high rate of genetic and cellular damage. EU part-funded research within the Chemsea project was carried out in the Bornholm Deep, an important area for spawning commercially valued fish species. The researchers studied the populations at 42 stations: flounder (Platichthys flesus), herring (Clupea harengus) and cod (Gadus morhua), which were caught using standard trawls.

Extremely high levels of genotoxicity have been recorded almost completely at all stations, in all fish species studied. Moreover, in comparison with research carried out in the past years, there has been a higher degree of damage to fish and more serious genetic mutations; higher fishing mortality has been recorded in the polluted areas. One of the reasons for this may be large undersea projects implemented in recent years, such as the laying of gas pipelines and cables and the mine clearance at the sea bottom, which may have disrupted chemical ammunition envelopes.

Chemical weapons were deposited in the oceans not only after World War II, but also after World War I. According to a US Department of Defense report, the U.S. military itself placed chemical weapons on the ocean floor between 1918 and 1970 in 74 cases. Ammunition containing chemicals (artillery and mortar shells) or stocks of chemicals stored in concrete or metal containers ended up in the sea. They were often stacked in the belly of a retired ship and sent to the bottom. At that time, not much attention was paid to possible environmental impacts.

These operations were mostly carefully recorded, but some of them took place at random without any recording. In particular, the former Soviet Union has never informed the international community of such activities. This was often done as follows: sailors stood on board the ship, dropping ammunition into the water as they sailed. The chemical weapons that corrode are thus stored in large underwater areas. Thus, up to 160,000 tonnes of chemical weapons can be stored in Russia's coastal waters, posing a potential threat to ecology and human health.

In 2009, Swedish viewers were shocked by a documentary broadcasted by the local public state television, which stated that the Soviet Union had stored chemical weapons at the bottom of the Baltic Sea as early as 1992. At that time, a candid camera, located in Swedish waters, captured one such operation. In the footage, the Soviet Army members were throwing containers of nerve gases and radioactive material directly into the sea. 
No one knows exactly how many discarded chemical weapons are hidden in European waters. But only one-sixth of the chemical ammunition from German ordnance depots, which was demonstrably stored in the Baltic Sea, could kill everything alive for a hundred years.

Chemical weapons on the ocean floor pose three types of threats:

- Many of them contain explosive material, which can cause an explosion.

- Fishing, dredging, laying pipes and cables in these areas can damage corroded packaging and release chemicals into the water, which may endanger people in the area.

- The third threat lies in the direct and indirect damage caused by chemicals and their degradation products, which can have an impact on the environment.

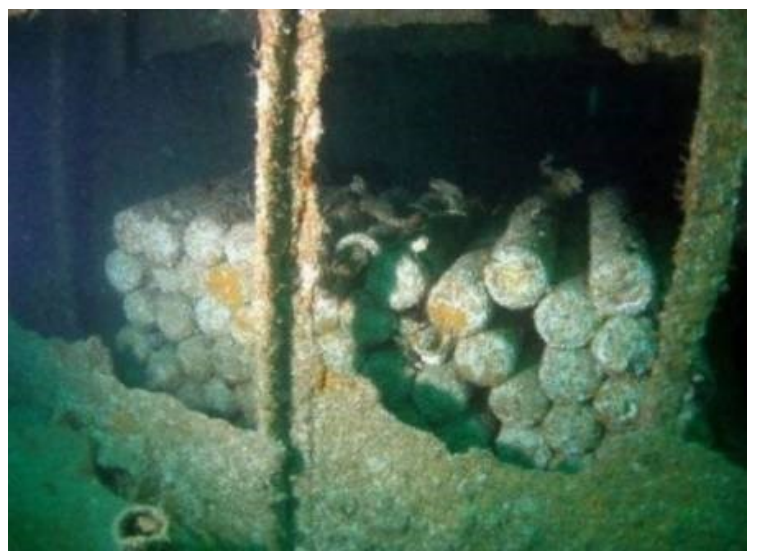

Figure 132: Chemical ammunition sunk in the sea. [Source: Fig-132]

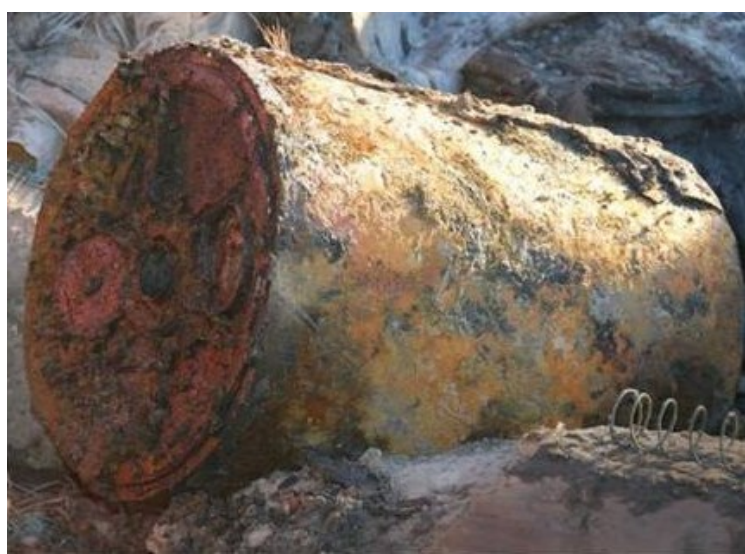

Figure 133: A rusty barrel containing chemicals at the bottom of the sea. [Source: Fig-133]

Since the mid-1990s, the incidence of lung and skin cancer has risen sharply among Swedish fishermen who fished round the islands of Bornholm and Gotland near the south coast of Sweden. These are typical consequences of contact with mustard gas. However, a layman cannot get to know that a dangerous chemical is leaking into the water - mustard gas is almost a colourless liquid that "smells of garlic or radish lightly". It outlasts in containers for decades and escapes into the surrounding environment slowly...

This danger exists not only in the Baltic Sea, but also, for example, near the Japanese islands or in the Adriatic Sea, where a large number of accidents have been reported as a result of exposure to chemical agents in accidental contact with warfare agents. This mostly happened when towing fishing nets or dredging. Since the end of World War II, Italian scientists have recorded more than two hundred cases of mustard gas injuries, including five deaths in the Adriatic Sea.

For example, in the Baltics, where the Allies, after World War II, dropped ammunition originating from German ordnance depots on the sea floor, it is at least 40,000 tonnes according to estimates. Of it, at least 13,000 tonnes of ammunition contain toxic agents. One-sixth of this amount could kill everything alive in the Baltic Sea for a hundred years. Ten years ago, Russian scientist Alexander Korotenko predicted that at some time between 2020 and 2060, corrosion would progress to such an extent that poisons would begin to leak into the environment. Just 16 percent of the total quantity would be sufficient for eradicating any form of life in the Baltic Sea.

"That is true, but it is very unlikely that all the ammunition would rust at once", says Jacek Beldowski, who puts the statement in a broader context. Beldowski works at the Institute of Oceanology in Sopot, a seaside town in Poland. He is also a coordinator of the Chemsea project (Chemical Munitions Search \& Assessment), which is a European-funded international research project dealing with the search and assessment of chemical weapons. 
"On the one hand, poisons will certainly escape, but, on the other hand, they become less dangerous after contact with water", says Beldowski. "Chemical weapons are placed over a large area, where they are exposed to very diverse conditions. They are also in places where there is a lack of oxygen, so they will hardly be subject to corrosion." So, the main problem is uncertainty. "What is certain is that a new form of pollution is guaranteed to appear in the Baltic over the upcoming years."

According to Katja Broeg of the Alfred Wegener Institute in Bremerhaven, an institution also involved in the Chemsea project, the results of research in the Baltic Sea will provide valuable information for the utilization in the North Sea: "This is especially true in the case of toxicological research. We fish in the given localities or drop cages with sea shells to find out if they can get cancer." Nevertheless, in relation to spreading the poisons, the conditions in the North Sea and the Baltic Sea are completely different. Broeg explains: "The North Sea is far saltier and has far more strong sea currents than the Baltic Sea."

The Chemsea project and the follow-up research must, among other things, also lead to elaborating a summary of guidelines for fishermen. What should you do if you find a $150 \mathrm{~mm}$ grenade together with cod in the net? And what steps will you take if you find a block of yperite among herring in the net? Yperite does not escape in gaseous form, but in water it turns into a sticky mass, which is carried by sea currents for many years.

Shortly after these agents began to be stored under the sea in the 1950s, the first cases of holidaymakers from the coastal areas of the GDR and Poland suffering from burns caused by mustard gas were reported. Twenty-four serious accidents occurred in Poland. The last of these happened in 1997, when fishermen pulled a huge piece of jelly-like lumps of yperite aboard.

However, the biggest risk is mechanical damage. For this reason, the authorities have decided virtually everywhere not to try to pick up ammunition aboard. Building activities can have catastrophic consequences, as it can damage large amounts of explosives at once.

The press wrote extensively about this danger thanks to the construction of the Nord Stream submarine gas pipeline, the route of which runs from Russia to Germany through the Baltic Sea. According to Jacek Beldowski, the pipeline is just one example. "The seafloor is increasingly being disrupted by construction projects: cables, wind power plants and pipelines. Procedures for excavation, construction and drilling in risk zones must, therefore, be developed as a matter of urgency."

According to OSPAR, a cooperation agreement among the countries bordering the North Sea, there are 31 places in the North Sea and adjacent parts of the Atlantic Ocean where chemical weapons are slowly rusting. Further, there are also 120 conventional weapon dumps here, which are known to contain heavy metals and other hazardous chemicals; 64 of them are located on the French coast. In the German Bight, close to the Wadden Islands, more than 1.5 million tonnes of ammunition were dumped in the North Sea after World War II, of which 90 tonnes were chemical weapons. In the Skagerrak between Denmark and Norway, the Allies sank at least 45 ships carrying chemical weapons. Between Ireland and Scotland, a million tonnes of ammunition were dumped into the sea in Beaufort's Dyke, some of which again consisted of chemical weapons.

There are two main toxic waste landfills in the Baltic Sea: near the island of Bornholm and in the Gotland Deep between the islands of Gotland and the Baltic Republics. In the Mediterranean area, there is the largest chemical ammunition dump near the Italian seaport of Bari. Since World War II, there have been a total of 232 accidents caused by chemical waste, especially mustard gas. 
One of the largest submarine chemical weapon dumps is located in the North Sea off the Belgian coast near the Dutch border. After World War I, the battlefields in Belgium were cleared of ammunition. However, people regularly died while trying to transport and store these weapons, so at the end of 1919, the Government of the Brussels decided to get rid of them by dropping them into the sea. Every day for six months, the entire shipload of ammunition disappeared in the sea off the coast near Knokke-Heist. "We don't know why they didn't decide to sail further out to the sea. They probably wanted to get rid of their cargo as quickly as possible because its transport was also very dangerous. ", says Tine Missiaen of the Renard Centre of Marine Geology in Ghent.

As a result, the Paardenmarkt shoal near the coast must be inspected annually. It is the last resting place of at least 35,000 tonnes of ammunition, of which at least one third are grenades filled with chemical warfare gas. Most of them have already disappeared under a thick layer of sediment. In 1972, however, some of them were pulled out of the water. They proved to be in remarkably good condition, thanks to a low oxygen environment. At that time, strong corrosion had not yet occurred. 


\section{Conclusion}

The right to life and its consistent and effective protection is one of the fundamental human rights, which is also clearly stated in the Constitution of the Czech Republic. The Czech state takes on a considerable part of its responsibility for protecting the population. Therefore, in accordance with the Charter of Fundamental Rights and Freedoms, it must constantly develop and monitor effective protection mechanisms and models for the protection of the population, including new threats of terrorism, i.e. the threat of chemical, biological, radiological and nuclear (CBRN) terrorism.

The first part of the publication details the effects of weapons of mass destruction and industrial accidents (radiation, chemical and other accidents) and analyses, evaluates and describes the threats mentioned. The aim is to create an appropriate system of prevention, protection and rescue of the population within the framework of the rescue systems created. Thus, the state is, to a certain extent, prepared to face this serious danger. It is believed in the expert public that new threats of terrorism will generally not only be further modified according to scientific knowledge, but the probability of the described attacks on the population will increase.

A detailed study of the political, economic, social or security background of current terrorism or, more precisely, the well-known search for the roots of terrorism is an activity that requires an intensive and long-term work of the international team of specialists in a number of disciplines. However, this has not been the aim of this publication.

Therefore, the readers of this publication must be satisfied with the statement that terrorism poses a major global security issue, which will not probably be suppressed completely in the foreseeable future, but which it is necessary to fight uncompromisingly.

Currently, the degree of civilian population preparedness is at a relatively low level. Public awareness of preventive measures, the nature of the potential threat to the population and the assumed scenarios of possible emergencies, the prepared salvage and liquidation operations and the protection of the population is not sufficient. It is often underestimated both by the competent administrative authorities and by most of the population. This is despite of the fact that both in the past and recently a number of literary background papers or even pocket handbooks and other useful reference books to inform the population have been prepared.

The more open and efficient cooperation of the intelligence and information services is one of the promising ways concerning the global suppression of terrorism and is particularly necessary for preventive measures. However, it is quite obvious that information is a force; therefore, it is bad to work with or, more precisely, its exchange is accompanied by considerable difficulties, not only at the international level, but often also within a national framework. Are intelligence services able to find effective ways of acceptable and efficient cooperation? The experts experienced in these issues are very sceptical in this respect. Already Napoleon knew that if three information services worked in his system, it would be virtually impossible to stick them together.

The current capabilities of the rescue units and resources of the entire system in the Czech Republic must be utilized effectively. New equipment required must be added and the practical training and exercise must be carried out. It is also necessary to perform a practical verification of existing emergency plans so that we can be prepared for chemical, biological, radiological and nuclear terrorism. 
Last but not least, it must be emphasized that, due to the threat of chemical, biological, radiological or nuclear terrorism, strong psychological effects may occur that will further complicate and escalate the situation. The origin and manifestations of these effects have not yet been investigated thoroughly; the responses from the military environment to the attack with the weapons of mass destruction are the most commonly known.

The expected and already progressive transition from the conventional instruments of terrorism, i.e. silent weapons, explosives, incendiary agents and firearms, to chemical, biological, radiological and nuclear terrorism requires a decisive joint action of the international community in the fight against terrorism. It is also necessary to deepen the ability to respond adequately at national level when preventive, repressive, protective, salvage and liquidation measures are applied in connection with terrorist attacks. The fundamental starting point for these activities and their success is a common political will and resoluteness embedded in the system of political starting points and legal standards. Based on these legal standards, it is possible to develop a set of specific measures of emergency management within the existing national security strategies and the institutional arrangement for population protection.

The changes that terrorism undergoes are large and significant. The countries having ethnic, cultural and religious contradictions, a low economic performance, a weak government, and an inadequate regime at the borders are potentially the main source of terrorism growth. However, that is just one side of the coin. The terrorist attacks on the Twin Towers of the World Trade Center in the United States, the events in Madrid, London as well as Sharm El Sheikh have confirmed that there is no place in the world today that would be safe from terrorism.

Uherské Hradiště on November 11, 2021 


\section{Appendices}

\subsection{List of Schemes (Sche-)}

Scheme 1: Illustration of gamma decay. [Source: Sche-1 - Author's archive]

Scheme 2: A deep geological repository. [Source: Sche-2 - State Institute of Radiation Protection of the Czech Republic, http://www.surao.cz]

Scheme 3: The surface area of a deep geological repository. [Source: Sche-3 - State Institute of Radiation Protection of the Czech Republic, http://www.surao.cz]

Scheme 4: Emergency planning zone (EPZ). [Source: Sche-4 - Author's archive]

Scheme 5: The German chlorine attack on April 22, 1915. [Source: Sche-5 - Authors: unknown on the website canadiansoldirs.com, (C) canadiansoldiers.com 1999-present, http://www.canadiansoldiers.com/history/battlehonours/westernfront/ypres1915.htm]

Scheme 6: The rebellion in the Tambov Gubernia in 1920-1921. [Source: Sche-6 - Author: P. S. Burton after Memnon335bc - English translation of File: Tambover Aufstand.png. Created: October 01, 2014. License: CC BY 3.0, https://en.wikipedia.org/wiki/Tambov Rebellion]

Scheme 7: Places of aerial herbicide spraying carried out by the US Army in South Vietnam between 1961 and 1971. [Source: Sche-7 - Author: 718 Bot - Transferred from en.wikipedia to Commons by SreeBot. Image made after HERBS file maps. Created: March 15, 2009. License: CC0 Public Domain, https://en.wikipedia.org/wiki/Operation_Ranch_Hand]

Scheme 8: Classification of a chemical weapon. [Source: Sche-8 - Author's archive]

Scheme 9: Classification of chemical warfare agents. [Source: Sche-9 - Author's archive]

Scheme 10: Pathways of chemical warfare agents to enter the body. [Source: Sche-10 - Author's archive]

Scheme 11: Properties of chemical warfare agents used in combat. [Source: Sche-11-Author's archive]

Scheme 12: Mesomeric effect - electron shift $\pi$ of multiple bond. [Source: Sche-12 - Author: Pplk. v. z. Ing. Ladislav STŘEDA, CSc. Novičok. Případ Sergeje a Julije Skripalových. Published: website SřípkyZeSvěta.cz@ Střípky ze světa, 2012, Created by CRS NETCOM, 2012. He publishes: INSPIRACE, o.s., 2019, 237 pages, without ISBN, http://www.stripkyzesveta.cz/public/img/novicok_streda_pdf.]

Scheme 13: The territory endangered by chlorine that escaped from the Spolana chemical plant in Neratovice. (July 21, 2000). [Source: Sche-13 - Author: čtk, ids. Únik chloru ze Spolany způsobil výbuch. Published: October 19, 2000 in the website idnes.cz, (C) 1999-2021 MAFRA, a. s., and content providers: Profimedia, Reuters, ČTK, AP, https://www.idnes.cz/zpravy/domaci/unik-chloru-ze-spolany-zpusobil-vybuch.A001019 160042 domaci nad]

\subsection{List of Graphs (Grph-)}

Graph 1: The distribution of nuclear explosion energy in a nuclear airburst $\mathrm{H}=$ up to $30 \mathrm{~km}$. [Source: Grph-1 - Author's archive]

Graph 2: The course of the pressure wave of a nuclear explosion depending on time and distance. [Source: Grph-2 - Author's archive]

Graph 3. Values of coefficients $\mathrm{K}_{\text {raw }}, \mathrm{K}_{\mathrm{ci}}$ and $\mathrm{K}_{\mathrm{cis}}$ and the area density of the floor construction. [Source: Grph-3 - Author's archive]

Graph 4: $\mathrm{NO}_{\mathrm{x}}$ emissions from anthropogenic sources. [Source: Grph-4 - Integrated Pollution Register of the Czech Republic - Nitrogen oxides, $\underline{\text { https://irz.cz/repository/latky/oxidy_dusiku.pdf] }}$

\subsection{List of Tables (Tab-)}

Table 1. List of English abbreviations. [Source: Tab-1 - Author's archive]

Table 2: The emergence of nuclear powers. [Source: Tab-2 - Author's archive]

Table 3: The year of the acquisition of thermonuclear weapons. [Source: Tab-3 - Author's archive]

Table 4: Experimental nuclear explosions. [Source: Tab-4 - Author's archive]

Table 5: Survey of the Korean War 1950-1953. [Source: Tab-5 - https://en.wikipedia.org/wiki/Korean War]

Table 6: Missile carriers of nuclear weapons in the Third World countries. [Source: Tab-6 - Author's archive]

Table 7: Modification and types of systems in the Czechoslovak People's Army (CPA). [Source: Tab-7 - Author's: plk. v. v. Ing. Vladimír Šufajzl a Vladimír Mohyla, Taktické jaderné prostředky ČSLA, bojové použití raketového vojska a dělostřelectva pozemního vojska v Československé lidové armádě, Praha: 2010, 171 pages, without ISBN, http://www.fortifikace.net/soubory/studie_takticke_jaderne_prostredky_csla.pdf]

Table 8. Nuclear submarine accidents (since 1960). [Source: Tab-8 - Author's: Michal Béza, Martin Faix: Nehody ruských ponorek, http://www.military.cz/russia/navy/submarin/nehody.htm and Author's archive]

Table 9: The present state of nuclear weapons in the world (January 2021). [Source: Tab-9 - Stockholm International Peace Research Institute, SIPRI YEARBOOK 2021, https://sipri.org/sites/default/files/2021-06/yb21 10 wnf 210613.pdf]

Table 10: Nuclear yields. [Source: Tab-10 - Author's archive - Author's archive] 
Table 11: The range of beta particles in different materials. [Source: Tab-11 - Author's archive]

Table 12: Division of neutrons depending on energy. [Source: Tab-12 - Author's archive]

Table 13: Characteristics of other thermonuclear reactions. [Source: Tab-13 - Author's archive]

Table 14: Conversion relationships between units and quantities. [Source: Tab-14 - Author's archive]

Table 15: Used units and quantities characterizing the source of radiation. [Source: Tab-15 - Author's archive]

Table 16: The values of coefficient "k". [Source: Tab-16 - Author's archive]

Table 17: Levels of personal injuries in dependence on overpressure at the shock front. [Source: Tab-17 - Author's archive]

Table 18: Distribution of ultraviolet radiation. [Source: Tab-18 - Author's archive]

Table 19: Distribution of infrared radiation (IR). [Source: Tab-19 - Author's archive]

Table 20: The magnitude of light pulse during a nuclear explosion (the light pulse is in $10^{-3} \mathrm{~J}_{\mathrm{m}}$ ). [Source: Tab-20 - Author's archive]

Table 21: Degrees of burn injuries. [Source: Tab-21 - Author's archive]

Table 22: Half value layers in $\mathrm{cm}$ for materials and the mean value of the energy of gamma rays and neutron radiation in a nuclear explosion. [Source: Tab-22 - Author's archive]

Table 23: Characteristic of radionuclides (radioactivity induced in the soil). [Source: Tab-23 - Author's archive]

Table 24: Characteristic of radionuclides (radioactivity induced in water). [Source: Tab-24 - Author's archive]

Table 25: Characteristic of radionuclides (radioactivity induced in objects and combat equipment). [Source: Tab-25 - Author's archive]

Table 26: Processes taking place in the cell after irradiation, biological effects of irradiation and health consequences. [Source: Tab-26 - Author's archive]

Table 27: Values of quality factor Q for different types of radiation. [Source: Tab-27 - Author's archive]

Table 28: Permissible standards for contamination of surfaces with radioactive agents. [Source: Tab-28 - Author's archive]

Table 29: Radionuclides. [Source: Tab-29 - Author: Vojtěch Ullman. Jaderná a radiační fyzika, nukleární medicína, Chapter 1. Jaderná a radiační fyzika, subchapter 1.4. Radionuklidy, https://www.astronuklfyzika.cz/strana2.htm]

Table 30: Comparison of properties of permanent and improvised shelters. [Source: Tab-30 - Author's archive]

Table 31: Comparison of the density of building materials and their availability in crises. [Source: Tab-31 - Author's archive]

Table 32: Values of coefficient Kepp for different widths of the entrance $2 \mathrm{~m}$ high. [Source: Tab-32 - Author's archive]

Table 33: Values of coefficient P. [Source: Tab-33 - Author's archive]

Table 34: Values of coefficient $V_{2}$. [Source: Tab-34 - Author's archive]

Table 35: Parameters of nuclear reactors in our power plants. [Source: Tab-35 - Author's archive]

Table 36. The localities considered for the construction of a deep geological repository in the Czech Republic. [Source: Tab-36 - State Institute of Radiation Protection of the Czech Republic, https://www.surao.cz/]

Table 37: The concept of a deep geological repository in the Czech Republic. [Source: Tab-37 - State Institute of Radiation Protection of the Czech Republic, https://www.surao.cz/]

Table 38: The use of chemical warfare agents in World War I in tonnes. [Source: Tab-38 - Author's archive]

Table 39: The stocks of German chemical ammunition on June 1, 1941. [Source: Tab-39 - Author's archive]

Table 40: The US Army order in the Vietnam War (CS gas in tonnes). [Source. Tab-40 - Author's archive]

Table 41: Range of application of phytotoxic substances in Vietnam. [Source: Tab-41 - H. Lindsey Arison III. Statistical Summary of Herbicidal Warfare in Vietnam, SIPRI, 1976 and Cecil, 1986 and Author's archive]

Table 42: Use of chemical agents by the Aum Shinrikyo religious cult in Japan. [Source: Tab-42 - Author's archive]

Table 43: Significant events in the $20^{\text {th }}$ century related to chemical weapons. [Source: Tab-43 - Author's archive]

Table 44: Persistence of nerve agents and mustard gas. [Source: Tab-44 - Author's archive]

Table 45: Properties of choking agents. [Source: Tab-45 - Author's archive]

Table 46: Properties of blood agents. [Source: Tab-46 - Author's archive]

Table 47: Properties of blister agents. [Source: Tab-47 - Author's archive]

Table 48: Properties of nerve agents. [Source: Tab-48 - Author's archive]

Table 49: Nerve agents. [Source: Tab-49 - Author: Pplk. v. z. Ing. Ladislav Středa, CSc. Novičok. Př́pad Sergeje a Julije Skripalových. [on-line]. Download at: http://www.stripkyzesveta.cz/public/img/novicok_streda_pdf. Střípky ze světa, Publishing: INSPIRACE, o.s., 2019, 237 pages, without ISBN ]

Table 50: Mirzayanov's description of the Novichok program. [Source: Tab-50 - Author: MIRZAJANOV, V. S. Dismantling the Soviet/Russian Chemical Weapons Complex: An Insider's View. In: SMITHSON, A. M., MIRZAJANOV, V. S., LAJOIE, R., KREPON, M. Chemical Weapons Disarmament in Russia: Problems and Prospects. The Henry L. Stimson Center. Report No. 17, October 1995]

Table 51: Structural formulas of five Foliant compounds and their codes. [Source: Tab-51 - Author: MIRZAJANOV, V. S. State Secrets. An Insider's Chronicle of the Russian Chemical Weapons Program. Outskirts Press, Inc. 2009. ISBN 978-1-4327-2566-2]

Table 52: Toxicity of nerve agents. [Source: Tab-52 - Author's: MATOUŠEK, J., MAŠEK, I. On The New Potential Supertoxic Lethal Organophosphorus Chemical Warfare Agents With Intermediary Volatility. The ASA Newsletter, 945, No 44, October 7, 1994]

Table 53: Physicochemical properties of some nerve agents. [Source: Tab-53 - Author's: KLEMENT, C., MEZENCEV, R., BAJGAR, J. Biologické a chemické zbrane: pripravenost' a odpoved'. 1. vyd. Banska Bystrica: PRO, 2013, 781 pgs. ISBN 978-80-89057-43-6.] 
Table 54. The Novichok nerve agent formula for the forensic analysis in the case of Kivelidi. [Source: Tab-54 A, B, C]:

- Tab 54A https://en.wikipedia.org/wiki/File:Novichok agent formula from_Kivelidi case.svg,

- Tab 54B https://www.facbook.com/photo.php?fbid=102161688782-85530\&set=pcb.1021616887956562\&ty-pe=3\&theater,

- Tab 54C https://static.novayagazeta.ru/storage/content/pictures/14022/content_001_doc7.jpg,

Table 55: Symptoms of poisoning and the duration of treatment of individuals affected by A-234. [Source: Tab-55 - Author: Pplk. v. z. Ing. Ladislav Středa, CSc. Novičok. Př́pad Sergeje a Julije Skripalových. [on-line]. Download at: http://www.stripkyzesveta.cz/public/img/novicok streda .pdf. Stř́ípky ze světa, Publishing: INSPIRACE, o.s., 2019, 237 pages, without ISBN]

Table 56: Assumed contamination densities and droplet sizes. [Source: Tab-56 - Author: VONDRÁČEK, V. Vybrané kapitoly z toxikologie OL a zdravotnické ochrany. (Učebnice VLVDÚ). Hradec Kralove, 1972 and Chemical Weapons: Destruction and Conversion. SIPRI. London, 1980]

Table 57: Permissible residual contamination of the surfaces of weapons and combat equipment. [Source: Tab-57 - Author's: KASSA, J., KRS, O., CABAL, J. Základy vojenské toxikologie a ochrany proti BCHL pro posluchače VLA JEP farmaceutického směru. Vojenská lékařská akademie Jana Evangelisty Purkyně in Hradec Kralove. 1992. Textbooks, volume 273, 185 pages, without ISBN]

Table 58: Values of toxic doses of skin resorption effect in mg on humans. [Source: Tab-58 - Author: КАЛИТАЕФ А. Н. Химическое оружие вероятного противника. ВАХ3, S/chem-3-84, Москва 1977, 218 c.]

Table 59: Properties of irritating agents. [Source: Tab-59 - Author's archive]

Table 60: Selected industrial chemicals. [Source: Tab-60 - Author's archive]

Table 61: Production of chemical warfare agents in WW I (in tonnes). [Source: Tab-61 - Author's archive]

Table 62: Code names of selected agents used in WW I. [Source: Tab-62 - Author's archive]

Table 63: Production of chemical warfare agents in selected countries until 1945. [Source: Tab-63 - Author's archive]

Table 64: An overview of selected toxic industrial chemicals used in the production of chemical warfare agents. [Source: Tab64 - Author's archive]

Table 65: The overview of accidents at the Spolana chemical plant since 1991. [Source: Tab-65 - Author: čtk, ids. Únik chloru ze Spolany způsobil výbuch. Published: October 19, 2000 in the website idnes.cz, C 1999-2021 MAFRA, a. s., and content providers: Profimedia, Reuters, ČTK, AP, https://www.idnes.cz/zpravy/domaci/unik-chloru-ze-spolanyzpusobil-vybuch.A001019_160042_domaci_nad]

Table 66: Examples of the formation of toxic industrial substances during combustion. [Source: Tab-66 - Author's archive]

Table 67: The selection of fires in the Czech Republic that inflicted damage of 200 million CZK or more. [Source: Tab-67 Author: Právo, lž. Požár zachvátil textilku Mileta, škoda je téměř čtvrt miliardy. Published: Dec 22, 2012 in the website Novinky.cz, Copyright (C) 2003-2021 Borgis a.s., Copyright (C) 2019-2021 Seznam.cz a.s., Copyright (C) ČTK, DPA, Reuters and photobank Profimedia, https://www.novin-ky.cz/krimi/clanek/pozar-zachvatil-textilku-miletaskoda-je-temer-ctvrt-miliardy-176701]

Table 68: Codes and chemical names of nerve agents. [Source: Tab-68 - Author's archive]

Table 69: Types of herbicides used by the US military in Vietnam. [Source: Tab-69 - Buckingham W. A. (1982): The Air Force and Herbicides in Southeast Asia 1961-1971. Office of Air Force History, United States Air Force, DS559.8.C5B82, 959.704'348, 81-11244, AACR2. For sale by the Superintendent of Documents, U.S. Government Printing Office Washington, D.C. 20402 - https://media.defense.gov/2010/Sep/28/2001329797/-1/-1/0/AFD100928-054.pdf]

\subsection{List of Figures (Fig-)}

Figure 1: Designs types of nuclear weapons. [Source: Fig-1 - Author's archive]

Figure 2: Scheme of nuclear fission ammunition of explosive (gun) type. [Source Fig-2 - Author's archive]

Figure 3: Scheme of nuclear fission ammunition of absorptive type. [Source: Fig-3 - Author's archive]

Figure 4: Scheme of the implosive type of nuclear ammunition. [Source: Fig-4 - Author's archive]

Figure 5: Diagrammatic section of one-stage thermonuclear ammunition. [Source: Fig-5 - Author's archive]

Figure 6: Diagrammatic section of two-stage thermonuclear ammunition. [Source: Fig-6 - Author's archive]

Figure 7: Diagrammatic section of three-stage thermonuclear ammunition. [Source: Fig-7- Author's archive]

Figure 8: A map illustrating the development in nuclear weapon possession. [Source: Fig-8 - Pražský model Spojených národů Background Report, Valné shromáždění (GA) - Proliferace jaderných zbraní. Model OSN - XVI. Ročník 2010/2011. Praha: Asociace pro mezinárodní otázky, (C) AMO 2010. https://www.amo.cz/wp-content/uploads/2016/01/PSS-Proliferace-jadern\%C3\%BDch-zbran\%C3\%AD-GA.pdf]

Figure 9: Nuclear ammunition depots in Europe. [Source: Fig-9 - Author: Patrik Jambor. Akce Javor, historické dokumenty. Published: to website FortifikaceCZ, vojenske-prostory.cz (C) 2021. http://vojenske-prostory.cz/akce-javor-historicke-dokumenty/]

Figure 10: Places in Kosovo and in the south of Central Serbia where depleted uranium ammunition was used by the NATO Air Forces in the bombardment in 1999. [Source: Fig-10 - Author: PANONIAN, Own work, Created: 2010, License: CC-0, https://en.wikipedia.org/wiki/Depleted uranium] 
Figure 11: The 30mm x 173 GAU-8 the most efficient ammunition used in Operation Desert Storm (1991) against all targets including tanks, armoured and light vehicles. The $30 \mathrm{~mm}$ ammunition was developed to optimize the air-surface missile on the US Army AH-64 Apache helicopters. [Source: Fig-11 - Maintained by Robert Sherman, originally created by John Pike Updated Friday, January 08, 1999, FAS - Federation of American Scientists (C) 2021 FAS.org, http://www.fas.org/man/dod-101/sys/land/30mm.htm]

Figure 12: The present state of declared nuclear-weapon-free zones (NWFZs) in the world. [Source: Fig-12 - Created by CNS for NTI, Copyright (C) 2007 by MIIS. https://web.archive.org/web/20081120154046/http://www.opanal.org/NWFZ/nwfz.htm]

Figure 13: Proposed nuclear- weapon- free zones (NWFZs) in the world. [Source: Fig-13 - official website Nuclear Threat Initiative (NTI), https://www.nti.org/]

Figure 14: Ionizing radiation hazard symbol. [Source: Fig-14 - Author's archive]

Figure 15: The decrease in the activity with time. [Source: Fig-15 - Author's archive]

Figure 16: The dependence of mean energy on mass number A. [Source: Fig-16 - Author's archive]

Figure 17: Division of nuclear bursts according to coefficient k (or k'). [Source: Fig-17 - Author's archive]

Figure 18: Surface nuclear explosion. [Source: Fig-18 - Author's archive]

Figure 19: Sub-surface nuclear explosion. [Source: Fig-19 - Author's archive]

Figure 20: Nuclear airburst. [Source: Fig-20 - Author's archive]

Figure 21: Nuclear burst above the water surface. [Source: Fig-21 - Author's archive]

Figure 22: Underwater nuclear burst. [Source: Fig-22 - Author's archive]

Figure 23: Radiation distribution. [Source: Fig-23 - Author's archive]

Figure 24: Description of the electromagnetic pulse bomb. [Source: Fig-24 - Author's archive]

Figure 25: Principle of operation of an electromagnetic pulse bomb. [Source: Fig-25 - Author's archive]

Figure 26: The Russian MMPS Ranets-E High Power Microwave (HPM) weapon system on the MZKT-7930 chassis. [Source: Fig-26 - Aus Air Power, Artwork, graphic design, layout and text (C) 2004-2014 Carlo Kopp; Text (C) 2004-2014 Peter Goon, http://www.ausairpower.net/APA-Rus-PLA-PD-SAM.html]

Figure 27: The Champ test EMP missile. [Source: Fig-27 - official website Boeing. Published: CHAMP - Lights Out, October 22, 2012 in Defense, Technology. Copyright (C) 1995-2020 Boeing. https://www.boeing.com/features/2012/10/bdschamp-10-22-12.page]

Figure 28: The explosion of the EMP bomb will disable technologies and will blind the enemy. [Source: Fig-28 - Author: Chalupa Tomáš. Totální blackout a návrat do středověku? Nové zbraně to umějí. Výsledkem je chaos a zhroucení společnosti. Publishing: extraStory.cz, September 18, 2014. (C) 2021 Extra Online Media s.r.o., https://www.extrastory.cz/totalni-blackout-a-navrat-do-stredoveku-nove-zbrane-to-umeji]

Figure 29: The EMP weapon will explode at a high altitude and will hit the region. [Source: Fig-29 - see source Fig-28]

Figure 30: EMP may be a bomb, a missile or a ballistic rocket. [Source: Fig-30 - see source Fig-28]

Figure 31: The CSSR was developing an EMP missile on the basis of the RPG rocket launcher. [Source: Fig-31 - see source Fig-28]

Figure 32: Basic notions of radioactive transformation. [Source: Fig-32 - official website CEZ Group, (C) 2021 ČEZ, a. s., http://www.cez.cz]

Figure 33: Photoelectric effect. [Source: Fig-33 - Author's archive]

Figure 34: Compton scattering. [Source: Fig-34 - Author's archive]

Figure 35: Pair production. [Source: Fig-35 - Author's archive]

Figure 36: Radiation scattering on an atom. [Source: Fig-36 - Author's archive]

Figure 37: The shielding effect of different types of material for particular types of radiation. [Source: Fig-37 - Author's archive]

Figure 38: The characteristic mushroom after a nuclear explosion - the source of radioactive particles. [Source: Fig-38 - Author's archive]

Figure 39: The direction of nuclear fallout after the detonation of a $5 \mathrm{kt}$ nuclear bomb in Prague - the west wind speed of 24 km/h. [Source: Fig-39 - Author: Grohmann Jan. Výbuch jaderné bomby: Vylepšete své šance na přežití. Publishing: Armádní noviny, March 17, 2014. (C) 2018-2021 Armadninoviny.cz, https://www.armadninoviny.cz/jaderna-valka-vylepsete-sve-sance-na-preziti.html]

Figure 40: The direction of nuclear fallout after the detonation of a $550 \mathrm{kt}$ nuclear bomb in Prague - the west wind speed of $24 \mathrm{~km} / \mathrm{h}$. [Source: Fig-40 - see source Fig-39]

Figure 41: The effect of ionizing radiation on organisms. [Source: Fig-41 - official website CEZ Group, (C) 2021 ČEZ, a. s., http://www.cez.cz]

Figure 42: Saddam's Dirty Bomb - Iraq manufactured and tested a radiological bomb in 1987. [Source: Fig-42 - Author: Pavel Čuda / Military Research Institute in Brno - to Author's archive]

Figure 43: Gammamat SE Type A - gamma ray projector using ${ }^{75}$ Se for defectoscopy. [Source: Fig-43 - Author's archive]

Figure 44: Industrial radiator using ${ }^{58} \mathrm{Co}$ for defectoscopy. [Source: Fig-44 - Author's archive]

Figure 45: Radioactive strontium in the form of chloride salt $\left({ }^{89} \mathrm{SrCl}_{2}\right)$ for chemotherapy. [Source: Fig-45 - Narodowe Centrum Badań Jądrowych Ośrodek Radioizotopów POLATOM. (C) 2005-2021, POLATOM, https://www.polatom.pl/produkty/newsletter-produkty-medycyna-15] 
Figure 46: North Korean missile - Taepodong-2. [Source: Fig-46 - Author's: stf, Reuters. Severní Korea ukázala video z odpálení rakety dlouhého doletu. Publishig: idnes.cz/zpravodajství, April 7, 2009. (C) 1999-2021 MAFRA, a. s., and content providers Profimedia, Reuters, ČTK, AP, https://www.idnes.cz/zpravy/zahranicni/severni-korea-ukazala-video-z-odpaleni-rakety-dlouheho-doletu.A090407 141959 zahranicni stf]

Figure 47: The construction of a chimney for an improvised shelter for up to 50 people (principle of gravity ventilation). [Source: Fig-47 - regulations of civil protection, issued by the Ministry of the Interior - General Directorate of the Fire and Rescue Service of the Czech Republic, author's archive]

Figure 48: Basic dimensions of a shelter. [Source: Fig-48 - regulations of civil protection, issued by the Ministry of the Interior - General Directorate of the Fire and Rescue Service of the Czech Republic, author's archive]

Figure 49: Example of an improvised shelter with air filtering equipment. [Source: Fig-49 - regulations of civil protection, issued by the Ministry of the Interior - General Directorate of the Fire and Rescue Service of the Czech Republic, author's archive]

Figure 50: Long-term contamination when using a dirty bomb (caesium ${ }^{137} \mathrm{Cs}$ ) in Washington, D. C. [Source: Fig-50 - Levi MA, Kelly HC. Weapons of mass disruption. Sci Am. 2002 Nov; 287(5):76-81. DOI: 10.1038/scientificamerican1102-76. PMID: 12395729.]

Figure 51: Long-term contamination when using a dirty bomb $\left(\right.$ cobalt $\left.{ }^{60} \mathrm{Co}\right)$ in Washington, D. C. [Source: Fig-51 - Levi MA, Kelly HC. Weapons of mass disruption. Sci Am. 2002 Nov; 287(5):76-81. DOI: 10.1038/scientificamerican110276. PMID: 12395729.]

Figure 52: Development of nuclear reactors. [Source: Fig-52 - official website CEZ Group, (C) 2021 ČEZ, a. s., https://www.cez.cz]

Figure 53: Development of nuclear reactors in Europe. [Source: Fig-53 - official website CEZ Group, C 2021 ČEZ, a. s., https://www.cez.cz]

Figure 54: Nuclear boiling water reactor. [Source: Fig-54 - official website CEZ Group. Základní typy jaderných reaktorů. (C) 2021 ČEZ, a. s. https://www.cez.cz/cs/o-cez/vyrobni-zdroje/jaderna-energetika/je-ve-svete/zakladni-typy-jadernych-reaktoru]

Figure 55: CANDU 6 nuclear reactor. [Source: Fig-55 - see source Fig-54]

Figure 56: Magnox nuclear reactor. [Source: Fig-56 - see source Fig-54]

Figure 57: Nuclear advanced gas cooled reactor (AGR). [Source: Fig-57 - see source Fig-54]

Figure 58: RBMK nuclear reactor. [Source: Fig-58 - see source Fig-54]

Figure 59: HTGR nuclear reactor. [Source: Fig-59 - see source Fig-54]

Figure 60: Nuclear reactor (FBR). [Source: Fig-60 - see source Fig-54]

Figure 61: A virtual model of the section view through the unit with the EPRTM reactor. [Source: Fig-61 - Areva supplying nuclear power plant simulator for research. Publishing: Power Engineering January 22, 2013, (C) 2019-2020 Clarion Events, official website POWERGEN International, Copyright (C) 2020 Clarion Events, Tulsa, OK. https://www.power-eng.com/nuclear/areva-supplying-nuclear-power-plant-simulator-for-research/\#gref]

Figure 62: The Pressurized Water Reactor (PWR) and Vodo-Vodjanoj Energetičeskij Reaktor (VVER). [Source: Fig-62 - see source Fig-54]

Figure 63: The containment with the reactor in the Temelín nuclear power plant. [Source: Fig-63 - Press Department of Temelín Nuclear Power Plant, official website CEZ Group, (C) 2021 ČEZ, a. s., https://www.cez.cz]

Figure 64: The reactor hall of the Dukovany nuclear power plant. [Source: Fig-64 - Press Department of Dukovany Nuclear Power Plant, official website CEZ Group, (C) 2021 ČEZ, a. s., https://www.cez.cz]

Figure 65: The storage of used fuel in the Temelín nuclear power plant. [Source: Fig-65 - Press Department of Temelín Nuclear Power Plant, official website CEZ Group, (C) 2021 ČEZ, a. s., https://www.cez.cz]

Figure 66: The storage of used fuel in the Dukovany nuclear power plant. [Source: Fig-66 - Press Department of Dukovany Nuclear Power Plant, official website CEZ Group, (C) 2021 ČEZ, a. s., https://www.cez.cz]

Figure 67: The Castor containers. [Source: Fig-67 - Press Department of Dukovany Nuclear Power Plant, official website CEZ Group, (C) 2021 ČEZ, a. s., https://www.cez.cz]

Figure 68: Tests in the underground laboratory at the Grimsel Test Site in Switzerland. [Source: Fig-68 - official website Radioactive Waste Repository Authority of the Czech Republic, http://www.surao.cz]

Figure 69: The preparation of the deep geological repository in Forsmark, Sweden. [Source: Fig-69 - official website Radioactive Waste Repository Authority of the Czech Republic, http://www.surao.cz]

Figure 70: The excavation of the Finnish ONKALO underground laboratory. [Source: Fig-70 - official website Radioactive Waste Repository Authority of the Czech Republic, http://www.surao.cz]

Figure 71: The entrance to the repository in Yucca Mountain in the USA. [Source: Fig-71 - official website Radioactive Waste Repository Authority of the Czech Republic, http://www.surao.cz]

Figure 72: Handling drums at the WIPP, USA. [Source: Fig-72 - official website Radioactive Waste Repository Authority of the Czech Republic, http://www.surao.cz]

Figure 73: A Japanese tunnelling machine. [Source: Fig-73 - official website Radioactive Waste Repository Authority of the Czech Republic, http://www.surao.cz]

Figure 74: The administration building of the Richard radioactive waste repository. [Source: Fig-74 - official website Radioactive Waste Repository Authority of the Czech Republic, http://www.surao.cz]

Figure 75: A tunnel in the Richard radioactive waste repository - Litoměřice. [Source: Fig-75 - official website Radioactive Waste Repository Authority of the Czech Republic, http://www.surao.cz] 
Figure 76: Disposal drums in the Richard radioactive waste repository. [Source: Fig-76 - official website Radioactive Waste Repository Authority of the Czech Republic, http://www.surao.cz]

Figure 77: View of the storage chamber in the Bratrství radioactive waste repository - Jáchymov. [Source: Fig-77 - official website Radioactive Waste Repository Authority of the Czech Republic, http://www.surao.cz]

Figure 78: A vault with disposal drums at the Dukovany radioactive waste repository. [Source: Fig-78 - official website Radioactive Waste Repository Authority of the Czech Republic, http://www.surao.cz]

Figure 79: A vault with drums in the Dukovany radioactive waste repository. [Source: Fig-79 - official website Radioactive Waste Repository Authority of the Czech Republic, http://www.surao.cz]

Figure 80: The closed access route to the Hostim repository near Beroun. [Source: Fig-80 - official website Radioactive Waste Repository Authority of the Czech Republic, http://www.surao.cz]

Figure 81: The rock formation of the Alkazar quarry. [Source: Fig-81 - official website Radioactive Waste Repository Authority of the Czech Republic, http://www.surao.cz]

Figure 82: Locating canisters in Aspö. [Source: Fig-82 - official website Radioactive Waste Repository Authority of the Czech Republic, http://www.surao.cz]

Figure 83: The A-1 nuclear power plant at Jaslovské Bohunice. [Source: Fig-83 - official website Jadrová energetická spoločnost' Slovenska, a. s., (JESS), Copyright Jadrová energetická spoločnost' Slovenska, a.s., 2011, http://www.jess.sk/en]

Figure 84: The main control room of the A-1 nuclear power plant. [Source: Fig-84 - Novákoviny, stránky publicisty Jana A. Nováka: Jaslovské Bohunice: Utajená jaderná havárie v srdci Evropy. Publishing: March 16, 2011. C 2021 Novakoviny. Licence: GNU General Public License. Jaslovské Bohunice: utajená jaderná havárie v srdci Evropy (novakoviny.eu)]

Figure 85: The reactor hall of the A-1 power plant. [Source: Fig-85 - see source Fig-84]

Figure 86: The cross-section of a fuel element for a nuclear reactor. [Source: Fig-86 - official website CEZ Group, (C) 2021 ČEZ, a. s.,https://www.cez.cz]

Figure 87: Strychnos toxifera is a liana from South America, from the Orinoco and Amazon River basins. It is used for curare. [Source: Fig-87 - Author: Franz Eugen Köhler, Köhler's Medizinal-Pflanzen - List of Koehler Images. Created: 1, January 1897. License: CC-0 Public Domain, https://cs.wikipedia.org/wiki/Kul\%C4\%8Diba jedod\%C3\%A1rn\%C $3 \% \mathrm{~A} 1]$

Figure 88: The use of poisonous gas by the Persians in the 3rd century AD. [Source: Fig- 88 - official website the University of Leicester, NEWS - PRESS RELEASES, University of Leicester archaeologist uncovers evidence of ancient chemical warfare (Image copyright Dr. Simon James), Managed by Press Office https://www.le.ac.uk/ebulletinarchive/ebulletin/news/press-releases/2000-2009/2009/01/nparticle.2009-01-14.html]

Figure 89: Soldiers wearing gas masks during a gas attack. World War I. [Source: Fig-89 - official website the University of Kansas Medical Center. Gas in The Great War. James Patton, BS Military Historian, U.S. Army Veteran, and WWI Feature Writer. (C) 2021 The University of Kansas Medical Center, http://www.kumc.edu/wwi/medicine/gas-inthe-great-war.html]

Figure 90: German soldiers discharging poisonous gas during a military test. [Source: Fig-90 - official website the 14-18 NOW the UK's arts programme for the First World War centenary. http://www.1418now.org.uk]

Figure 91: The German chlorine gas attack on the Eastern Front. It was photographed from the air by a Russian pilot. The photo was called Terror from the Air. Unknown author. It was photographed from the air by a Russian pilot. The photo was called Terror from the Air. [Source: Fig-91 - Bundesarchiv, Bild 183-F0313-0208-007. License: CC-BY-SA 3.0 de. Created: 1916 date QS:P571,+1916-00-00T00:00:00Z/9, https://en.wikipedia.org/wiki/Chemical weapons in World War_I]

Figure 92: The British chemical unit is preparing gas cylinders at Loos. [Source: Fig-92 - Author: not stated. Assumed British military - This is photograph Q 14945 from the collections of the Imperial War Museums. License: CC0 - PD, https://en.wikipedia.org/wiki/Chemical weapons in World War I]

Figure 93: German chemical artillery shells. Different symbols were used for different chemicals. The grenade marked 1 was the first chemical grenade used during World War I. [Source: Fig-93 - War Stories: John Thomas Bloor and the Battle of Hill 70. Published: November 11, 2013, (C) Mad Dogs and Englishmen 2004-2021. http://self-preservationsociety.blogspot.com/2013/11/war-stories-john-thomas-bloor-and.html]

Figure 94: The burning American Liberty Ship (Liberty SS John Harvey type) with mustard gas, December 02, 1943, Bari, Italy. [Source: Fig-94 - Author: Unknown photographer - https://audiovis.nac.gov.pl/obraz/2360/, Date: December 02. 1943. License: CC0 - Public Domain, https://en.wikipedia.org/wiki/Air raid_on_Bari]

Figures 95 and 96: The sailors contaminated with engine oil with yperite after the bombing of Bari on December 02, 1943, Italy. [Source Fig-95 and Fig-96 - Second World War II La storia. BOMBARDAMENTO A BARI NEL 1943. License: public domain, Blog at altervista and WORDPRESS.COM. https://italia1943.altervista.org/bombardamento-a-bari-nel-1943/\#gsc.tab=0]

Figure 97: Auxilon ${ }^{\circledR}$ Dosier Spray for the treatment of acute smoke poisoning caused by fires and chlorine gas, ammonia, oxides of nitrogen, phosgene and heavy metal vapours. [Source: Fig-97 - Author's archive]

Figure 98: Blisters after the effects of mustard gas. [Source: Fig-98 - Toxoplanet - Mustard Gas, Inspired by the work of Saul Bass, Art Goodman, and Dave Nagata. Hitchcock font by Matt Terich. BLOG AT WORDPRESS.COM. https://toxplanet.files.wordpress.com]

Figure 99: DuoDote, Mark I and ComboPen auto-injectors filled with morphine, diazepam, atropine and 2-PAM against nerve agents. [Source: Fig-99 - Author's archive] 
Figure 100: Prophylactic antidote called PANPAL. [Source: Fig-100 - Disaster Medicine Conference 2010, MEdicína KAtastrof - MEKA 2010: Bajgar, J., J. Kassa, K. Kuča, J. Fusek, R. Štětina. Antidota proti bojovým otravným látkám (BOL) v AČR a možnosti jejich vývoje. bajgar.pdf (zsa.cz)]

Figure 101: Example of Novichok derivatives from the research of Iranian scientists in 2016. [Source Fig-101 - DE VOOGHTJOHNSON, R. Iranian chemists identify Russian chemical warfare. Spectroscopy Now.com, January 01, 2017 and Seyed Esmaeil Hosseini, Hamid Saeidian, Ali Amozadeh, Mohammad Taghi Naseri, Mehran Babri. Fragmentation pathways and structural characterization of organophosphorus compounds related to the CW Convention by electron ionization and electrospray ionization tandem mass spektrometry. Published: October 05, 2016, Rapid Communications in Mass Spectrometry, https://doi.org/10.1002/rcm.7757. Online ISSN:1097-0231, (C) John Wiley \& Sons Ltd.]

Figure 102: The UN Security Council talks on the case of Sergei Skripal. PHOTO: Reuters. [Source: Fig-102 - Author's: ČTK, Mii. Proč to otrávený Skripal udělal? V den útoku si exagent vypnul GPS v mobilu. Published: Blesk.cz, March 26, 2018. (C) 2001-2021 Copyright CZECH NEWS CENTER a.s. and content providers. https://www.blesk.cz/clanek/zpravy-svet/532660/proc-to-otraveny-skripal-udelal-v-den-utoku-si-exagent-vypnul-gps-v-mobilu.html]

Figure 103: Yulia (33) with her father Sergei Skripal. PHOTO: Dailymail. [Source: Fig-103 - see source Fig-102]

Figure 104: Cars around the crime scene may have been hit by nerve gas. PHOTO: Reuters. [Source: Fig-104 - see source Fig102]

Figure 105: Experts in chemical protective suits near the tent at the site where Sergei Skripal was poisoned. [Source: Fig-105 - Novinkc.cz: Skripalovi byli otráveni novičokem v tekuté formě, ve městě proběhne dekontaminace. Published: April 17, 2018. Copyright (C) 2003-2021 Borgis a.s., Copyright (C) 2019-2021 Seznam.cz a.s., Copyright (C) ČTK, DPA, Reuters and photobank Profimedia, https:/www.novinky.cz/zahranicni/evropa/clanek/skripalovi-byliotraveni-novicokem-v-tekute-forme-ve-meste-probehne-dekontaminace-11862]

Figure 106: An investigation into the poisoning of Russian ex-spy Sergei Skripal in Salisbury, UK, continues. PHOTO: Reuters. [Source: Fig-106 - see source Fig-102]

Figure 107: The investigation into the poisoning of ex-spy Sergei Skripal continues, the police are now testing the graves of his son and wife for the presence of the toxin. PHOTO: the Czech News Agency. [Source: Fig-107 - see source Fig-102]

Figure 108: Novichok was in this perfume bottle, MI5 says. [Source: Fig-108 - Author: VK: Éto děbily? Britové zachytili na dvou snímcích dva agenty GRU samostatně ve stejný čas na sekundu přesně! Published in AE News, September 6, 2018. C Copyright 2021 American European News, LLC. https://aeronet.cz/news/eto-debily-britove-zachytilina-dvou-snimcich-dva-agenty-gru-samostatne-ve-stejny-cas-na-sekundu-presne-disponuje-rusko-zarizenim-naohybani-casoprostoru-theresa-may-tancovala-v-africe/]

Figure 109: Soldiers are taking samples of contaminated soil near the bench, where the Skripals were found. [Source: Fig-109 - Novinky.cz: Britové identifikovali podezřelé v př́ípadu otravy agenta Skripala. Published: April 24, 2018. Copyright (C) 2003-2021 Borgis a.s., Copyright (C) 2019-2021 Seznam.cz a.s., Copyright (C ČTK, DPA, Reuters and photobank Profimedia, https://www.novinky.cz/zahranicni/evropa/clanek/britove-identifikovali-podezrele-v-pripadu-otravy-agenta-skripala-12669]

Figure 110-1 up to 110-3: Different types of defence sprays filled with highly effective CS irritating agent. [Source: Fig-1101 up to Fig-110-3 - Author's archive]

Figure 111: A small compressed gas cylinder with pure ammonia. [Source: Fig-111 - Author's archive]

Figure 112: Ammonium hydroxide - 20 litres (910 g/l). [Source: Fig-112 - Author's archive]

Figure 113: Ammonium hydroxide - 30\% solution. [Source: Fig-113 - Author's archive]

Figure 14: An acute burn caused by hydrogen fluoride. [Source: Fig-114 - The Integrated Register of Environmental Pollution of the Czech Republic, https://irz.cz/irz/repository/latky/fluor a anorganicke slouceniny.pdf]

Figure 115: Vitamin B 17 as an alternative cancer treatment. [Source: Fig-115 - VIVANTIS a.s. - Prozdravi.cz, (C) 2021 vivantis, a.s., https://www.prozdravi.cz/zdravi/amygdalin-forte-vit-b17-45-tbl-15-tbl-zdarma.html]

Figure 116: Distribution of $\mathrm{NO}_{2}$ concentration in the atmosphere over Europe (red = increased concentration). [Source: Fig116 - The Integrated Register of Environmental Pollution of the Czech Republic, https://irz.cz/node/79 ]

Figure 117: Development of nitrogen dioxide concentration over France. [Source: Fig-117 - Photo: contains modified data from Copernicus Sentinel satellites (2019-20), (c) processed by KNMI/ESA, CC BY-SA 3.0 IGO, Novinky.cz. https://www.esa.int/ESA_Multimedia/Images/2020/03/Nitrogen_dioxide_concentrations_over_France]

Figure 118: Development of nitrogen dioxide concentration over Italy. [Source: Fig-118 - Photo: contains modified data from Copernicus Sentinel satellites (2019-20), (C) processed by KNMI/ESA, CC BY-SA 3.0 IGO, Novinky.cz., https://www.esa.int/ESA_Multimedia/Images/2020/03/Nitrogen_dioxide_concentrations_over_Italy]

Figure 119: This animation, using data from the Copernicus Sentinel-5P satellite, shows the nitrogen dioxide concentrations from 20 December 2019 until 16 March 2020 - using a 10-day moving average. The drop-in concentrations in late-January is visible, coinciding with the nationwide quarantine, and from the beginning of March, the nitrogen dioxide levels have begun to increase. [Source: Fig-119 - Photo: contains modified data from Copernicus Sentinel satellites (2019-20), (C) processed by KNMI/ESA, CC BY-SA 3.0 IGO, https://www.esa.int/ESA Multimedia/Videos/2020/03/Nitrogen dioxide emissions over_China]

Figure 120: The content of carbon monoxide in the lower layers of the atmosphere. [Source: Fig-120 - Satellite Monitoring of Atmospheric Compozition. Produced by The COMET® Program in collaboration with EUMETSAT, http://kejian1.cmatc.cn/vod/comet/EUMETSAT/atmos comp/index.htm] 
Figure 121: The Spanish Civil War. Bombing of the city of Andujar, 1938. [Source: Fig-121 - Author: Santiago Jaén Milla. Memoria soterrada: los refugios antiaéreos de la Guerra Civil en Jaén/ Underground Memory: air - raid shelters of the Civil War in Jaén. CLIO. History and History teaching (2016), 42. ISSN: 1139-6237. http://clio.rediris.es Recibido: 14/3/2016. Aceptado: 9/6/2016, http://clio.rediris.es/n42/articulos/jaen2016.pdf]

Figure 122: Hydrogen cyanide, ZYKLON B, (Cyclone B) used in German concentration camps. [Source: Fig-122 - Online Collectibles Auctions, Copyright 1996-2021 C iCollector.com Online Auctions https://www.icollector.com/GERMAN-NAZI-ZYKLON-B-POISON-GAS-CAN i16373013]

Figure 123: Hydrogen cyanide (stabilized), URAGAN D2, (HCN min. 96.7 \%). Manufacturer: Lučební závody Draslovka Kolín, joint-stock company. [Source: Fig-123 - D.D.D. SERVIS OPAVA v.o.s, https://www.infoopava.cz/dddservis-opava-vos/index.html]

Figure 124: Chemists in Seveso, Italy, in 1976 after the accident. [Source: Fig-124 - Author: KPA, OBRAZEM: Deset nejhorších ekologických katastrof. Published: May 28, 2010 in the TÝDEN.cz. (C) 2006 EMPRESA MEDIA, a.s., 2006-2021 C Created by Sabre s.r.o., https:/www.tyden.cz/rubriky/zahranici/den-d/obrazem-deset-nejhorsichekologickych-katastrof $170432 . \mathrm{html}]$

Figure 125: People lost their sigh during the chemical accident in the Indian city of Bhopal in 1984. [Source: Fig-125 - Author: KPA, OBRAZEM: Deset nejhorších ekologických katastrof. Published: May 28, 2010 in the TÝDEN.cz. C) 2006 EMPRESA MEDIA, a.s., 2006-2021 (C) Created by Sabre s.r.o., https://www.tyden.cz/rubriky/zahranici/dend/obrazem-deset-nejhorsich-ekologickych-katastrof 170432.html]

Figure 126: The Aurul Gold Mine in the Baia Mare Region, Romania. [Source: Fig-126 - From Chimney database http://koda.kominari.cz/, (C) M.i.X 2008-2021, Pilsen Division of the Association of Czech Chimney Sweeps (C) 2015 PlzDi. https://plzdi.cz/RO Baia/index.htm]

Figure 127: Bombing of the Novi Beograd complex. [Source: Fig-127 - Autor: TANJUG, Serbia marks anniversary of start of NATO bombing. Published: March 24, 2016 in blog B92. (C) 1995-2021, B92, https://www.b92.net/eng/news/society.php? yyyy $=2016 \& \mathrm{~mm}=03 \& \mathrm{dd}=24 \&$ nav id $=97466$ ]

Figure 128: Bombing of the Pancevo complex. [Source: Fig-128 - Autor: TANJUG, Serbia marks anniversary of start of NATO bombing. Published: March 24, 2016 in blog B92. (C) 1995-2021, B92, https://www.b92.net/eng/news/society.php?yyyy $=2016 \& \mathrm{~mm}=03 \& d d=24 \&$ nav $\mathrm{id}=97466$ ]

Figure 129: Bombing of the Novi Sad complex. [Source: Fig-129 - Autor: Darko Dozet - Own work. Нато бомбардовање СР Југославија 1999. године. Нато бомбе свакодневно су погађале Рафинерију нафте Нови Сад и изазивале еколошку катастрофу. Created: January 01 1999. License: CC BY-SA 3.0, https://en.wikipedia.org/wiki/NATO bombing of Novi Sad]

Figure 130: An Ecological Assessment of Johnston Atoll. [Source: Fig-130 - Autor: United States Army Chemical Materials Agency. Zdroj: Phillip Lobel, Elizabeth A. Schreiber, Gary McCloskey, Leo O’Shea, Robert Harris, Mindy Richlen. An Ecological Assessment of Johnston Atoll. Washington Group International. This magazine was produced through funding from the Chemical Materials Agency, United States Department of the Army, pgs. 49, https://apps.dtic.mil/dtic/tr/fulltext/u2/a571836.pdf]

Figure 131: Leaking Agent Orange from barrels on Johnston Atoll in 1973. [Source: Fig-131 - Source: Craig Bowman, US Begins Largest Ever Agent Orange Clean-up in Vietnam. Published: April 29, 2019 in the War History Online The Place for Military History News and Views. (C) Copyright 2012-2021 War History Online, https://www.warhistoryonline.com/news/us-begins-largest-agent-orange.html]

Figure 132: Chemical ammunition sunk in the sea. [Source: Fig-132 - Autor: Kasander. Chemické zbraně v mořích stále hrozí. Upraveno ze zdrojů: War History Online, VOXeurop.eu, Hlas Ruska, PolskoDnes, official website the Metal de$\begin{array}{llll}\text { tector shop, } & \text { C DETEKTORWEB.CZ 2003-2021, https://detektorweb.info/in- }\end{array}$ dex. $4 \mathrm{me} ? \mathrm{~s}=$ show $\& \mathrm{i}=60781 \& \mathrm{~mm}=1 \& \mathrm{vd}=1]$

Figure 133: A rusty barrel containing chemicals at the bottom of the sea. [Source: Fig-133 - Autor: Kasander. Chemické zbraně v mořích stále hrozí. Adjusted from sources: War History Online, VOXeurop.eu, Hlas Ruska, PolskoDnes, official website the Metal detector shop, C DETEKTORWEB.CZ 2003-2021, https://detektorweb.info/index. $4 \mathrm{me} ? \mathrm{~s}=$ show $\& \mathrm{i}=60781 \& \mathrm{~mm}=1 \& \mathrm{vd}=1]$

\subsection{List of Photos (Pho-)}

Photo 1: The course of the TRINITY nuclear test. [Source: Pho-1 - Author: Andrey Grushin, F-1 MPEG, photo from video, Author's archive]

Photo 2: Drop of the nuclear bomb on Hiroshima. [Source: Pho-2 - Author: Andrey Grushin, F-1 MPEG, photo from video, Author's archive]

Photo 3: Drop of the nuclear bomb on Nagasaki. [Source: Pho-3 - Author: Andrey Grushin, F-1 MPEG, photo from video, Author's archive]

Photo 4: The first Soviet atomic bomb test. [Source: Pho-4 - Author: Andrey Grushin, F-1 MPEG, photo from video, Author's archive]

Photo 5: The test of the first thermonuclear bomb IVY MIKE (USA), 10 Mt. [Source: Pho-5 - Author: Andrey Grushin, F-1 MPEG, photo from video, Author's archive] 
Photo 6: A Korean girl carrying her brother on her back in Haengju, Korea. M-26 tank in the background. [Source: Pho-6 Maj. R.V. Spencer, UAF (Navy). U.S. Army Korea - Installation Management Command. - This media is available in the holdings of the National Archives and Records Administration, cataloged under the National Archives Identifier (NAID) 520796. Created: June 9, 1951. License: CC0 - public domain, https://cs.wiki-pedia.org/wiki/Korejsk $\% \mathrm{C} 3 \% \mathrm{~A} 1 \mathrm{v} \% \mathrm{C} 3 \% \mathrm{~A} 1 \mathrm{ka}]$

Photo 7: Bombing of supply depots and facilities in the port of Wonsan by Air Force B-26 Invader North Korea, 1951. [Source: Pho-7 - USAF (photo 306-PS-51(10303)) - This media is available in the holdings of the National Archives and Records Administration, catalogued under the National Archives Identifier (NAID) 541959. Created: approx. 1951. License: CC0 - public domain, https://cs.wikipedia.org/wiki/Korejsk\%C3\%A1_v\%C3\%A1lka\#/media/Soubor:Korean_War_bombing_Wonsan.jpg]

Photo 8: Aerial bombing of the HWACHEON Dam in South Korea - a picture from F4U Corsair, May 1, 1951. [Source: Pho8 - Charles K. Armstrong. The Destruction and Reconstruction of North Korea, 1950-1960. The Asia-Pacific Journal /Japan Focus Volume 7, Issue 0, Article ID 3460. Published: March 16, 2009, https://apijf.org/-Charles-K.-Armstrong/3460/article.html]

Photo 9: The F4U-4B Corsair pilots of VF-114 fighter squadron known as Executioners taking off from the USS Philippine Sea (CV-47) aircraft carrier, October 1950. [Source: Pho-9 - USN - Official U.S. Navy photo 80-G-420967. Created: October 01, 1950. License: CC0 - public domain, https://commons.wikimedia.org/wiki/Korean War\#/media/File:F4U-4Bs_VF-114 CV-47 Oct1950.jpg]

Photo 10: Landing of US units at the port of Incheon one day after the Battle of Incheon in September 15, 1950. [Source: Pho10 - US Navy, Record Group 80: General Records of the Department of the Navy, 1804-1983 (National Archives Identifier: 409 ) NAIL Control Number: NWDNS-80-G-420027, https://commons.wikimedia.org/wiki/File:Battle of Inchon.png]

Photo 11: Smoke from the dock and the city during the Gangnam evacuation, October 1950. [Source: Pho-11 - USN - Official U.S. Navy photo. License: CC0 - public domain, https://commons.wikimedia.org/wiki/File:KoreanWar Hungnam.jpg]

Photo 12: F4U-4B Corsair fighter of VF-113 fighter squadron also known as the Stingers from USS Philippine Sea (CV-47) aircraft carrier is flying over vessels in Incheon, Korea, September 15, 1950. [Source: Pho-12 - U.S. Defence Imagery photo VIRIN: HD-SN-98-07598, Air and Space Museum No. 306-FS-237-2. The photo is part of the larger U.S. Navy photo NH 97076. License: CC0 - public domain, https://commons.wikimedia.org/wiki/File:F4U-4B VF113 CV-47 1950.JPEG]

Photo 13: Pyongyang in May 1951. [Source: Pho-13 - Author: Women's International Democratic Federation (Life time: N/A). Description: Pyongyang in May 1951, during the Korean War, this shows the effect of US bombing. In the foreground are office blocks in ruins; in the background churches, a shopping area, and a residential district. Photograph taken from the Women's International Democratic Federation report, "We Accuse". Original publication: "We Accuse", 1951, East Berlin Immediate source: Twitter. Created: December 31, 1950. License: CCA-SA-PD, https://en.wikipedia.org/wiki/File:Pyongyang_1951.jpg]

Photo14: Korean escapees on the deck of the SS Meredith Victory, December 1950. [Source: Pho-14 - Unknown author. Description: Hungnam Evacuation, December 1950: Some of the 14,000 Korean refugees crowded on board the SS Meredith Victory in December 1950, as she transported them from Hŭngnam to South Korea. Created: December 1950, U.S. Navy photo. This image is available from the Naval History and Heritage Command under the digital ID NH 95597. License: CC0-PD, https://commons.wikimedia.org/wiki/File:Korean_refugees aboard_SS_Meredith_Victory in_December_1950(NH 95597).jpg]

Photo 15: UN forces' transport vehicles re-crossing the $38^{\text {th }}$ Parallel as they withdraw from Pyongyang in 1950. [Source: Pho15 - Author: History.com Editors. Article Title: Korean War. URL: https://www.history.com/topics/korea/koreanwar. Access Date: January 25, 2021. Publisher: A\&E Television Networks. Last Updated: May 11, 2020. Original Published Date: November 9, 2009. (C) 2021 A\&E Television Networks, LLC.]

Photo 16: One of the prisoners of war on the eve of the execution near the city of Daejeon in South Korea. [Source: Pho-16 Major Abbott, U.S. Army - National Archives, Major Abbott/U.S. Army via Associated Press copy. Context articles: http://www.google.com/hostednews/. Created: July 01, 1950. License: CC0-PD, https://cs.wikipedia.org/wiki/Korejsk\%C3\%A1_v\%C3\%A1lka\#/media/Soubor:Prisoners_on_ground_before_execution,Taejon,_South_Korea.jpg]

Photo 17: The border in demilitarized zone. [Source: Pho-17 - Author: Fox News / By Katherine Lam. North Korean Soldier Is Shot While Defecting Across DMZ, South Says. Published: 13 Nov, 2017 in the Military.com Network, (C) Copyright 2021 Fox News, (C) 2021 Military Advantage, https://www.military.com/daily-news/2017/11/13/north-koreansoldier-shot-defecting-dmz-south-says.html]

Photo 18: Photographs of a missile base in Cuba. [Source: Pho-18 - Author: USAF - http://www.af.mil/photos, Cuba - An aerial view showing the medium range ballistic missile field launch site number two at Sagua la Grande. October 17, 1962. License: CC0-PD, https://commons.wikimedia.org/wiki/File:Cubacrisis 17 Oct 1962.jpg]

Photo 19: Cuban crisis - a map. [Source: Pho-19 - Photo from video at Youtube: THIS IS ABOUT THE CUBAN MISSILE CRISIS WHICH WAS THE HIGH POINT OF CONFLICT BETWEEN USA AND USSR DURING THE COLD WAR at the Class XII Political Science by Rakesh Rajput. Created: January 15, 2019, https://www.youtube.com/watch? $\left.\mathrm{v}=\mathrm{mlXQ} 2 \mathrm{t} \_\mathrm{Cr} 4 \mathrm{w}\right]$ 
Photo 20: Spy plane images. [Source: Pho-20 - Autor: http://warandgame.com, and Joseph S. Nye. Byl, či nebyl svět před půlstoletím krůček od jaderné války? Published: October 11, 2012 in the iDNES.cz, Copyright: Project Syndicate, 2012. Translated from English: Jiří Kobělka, (C) 1999-2021 MAFRA, a. s., a dodavatelé Profimedia, Reuters, ČTK, AP. $\quad$ https://www.idnes.cz/zpravy/archiv/byl-ci-nebyl-svet-pred-pulstoletim-krucek-od-jadernevalky.A121010 115333 kavarna chu]

Photo 21: The Soviet submarine B-59. [Source: Pho-21 - U.S. Navy photographer - http://www.gwu.edu/ ns archiv/NSAEBB/NSAEBB75/\#IV. Created: October 28-29, 1962. License: CC0-PD, https://en.wikipedia.org/wiki/Soviet submarine B-59\#/media/File:Soviet b-59 submarine.jpg]

Photo 22: The naval blockade of Cuba. [Source: Pho-22 - WRITTEN BY The Editors of Encyclopaedia Britannica: Blockade (warfare) - Cuban missile crisis; blockade. The destroyer USS Barry intercepting a missile-carrying Soviet freighter during the Cuban missile crisis, November 1962. (C) Everett Collection/Shutterstock.com, https://www.britannica.com/topic/blockade-warfare]

Photo 23: Napalm used by the French Army in the Indochina War, 1953. [Source: Pho-23 - Author: Warner Pathé News - Public Domain https://archive.org/details/NewsMaga 4. News Magazine of the Screen. The (Vol. 4, Issue 4) (1953/12): "The war in Indo-China goes on." Created: December 01, 1953. License: CC0-PD, https://cs.wikipedia.org/wiki/Indo $\% \mathrm{C} 4 \% 8 \mathrm{D} \% \mathrm{C} 3 \% \mathrm{ADnsk} \% \mathrm{C} 3 \% \mathrm{~A} 1$ v $\% \mathrm{C} 3 \% \mathrm{~A} 11 \mathrm{ka}]$

Photo 24: Units of the French Foreign Legion and M24 Chafee tank. [Source: Pho-24 - Author: PIX - http://www.dodmedia.osd.mil/DVIC View/Still Details.cfm?SDAN=HDSN9902041\&JPGPath=/Assets/Still/1999/DoD/HD-SN-9902041.JPG Public Domain (Defence Visual Information Centre): http://www.dodmedia.osd.mil/ Created: 1 January, 1954. License: CC0-PD, https://cs.wikipedia.org/wiki/Indo\%C4\%8D\%C3\%ADnsk\%C3\%A1 v\%C3\%A1lka\#/media/Soubor:HD-SN-99-02041.JPEG]

Photo 25: USS Maddox (DD-731). [Source: Pho-25 - Unknown author - U.S. Navy photo NH 97900. The U.S. Navy destroyer USS Maddox (DD-731) underway at sea, circa the early 1960s. Created: between 1960-1964. License: CC0-PD, https://en.wikipedia.org/wiki/USS Maddox (DD-731)\#/media/File:USS Maddox (DD-731) underway_at_sea,_circa_the early_1960s_(NH_97900).jpg]

Photo 26: Aircraft Carrier USS Ticonderoga (CVS-14) Essex class in 1972. [Source: Pho-26 - U.S. Navy - U.S. Navy National Museum of Naval Aviation photo No. 1996.488.039.075. The U.S. Navy aircraft carrier USS Ticonderoga (CVS-14) underway off the coast of California (USA) bound for the Western Pacific in 1972. Ticonderoga, with assigned Carrier Anti-Submarine Air Group 53 (CVSG-53), was deployed to the Western Pacific from 17 May to 29 July 1972. License: CC0-PD, https://cs.wikipedia.org/wiki/USS_Ticonderoga_(CV-14)\#/media/Soubor:USS_Ticonderoga (CVS-14) underway off California 1972.jpeg]

Photo 27: American units when searching for guerrillas. [Source: Pho-27 - James K. F. Dung, SFC, Photographer - This media is available in the holdings of the National Archives and Records Administration, catalogued under the National Archives Identifier (NAID) 530610. U.S. Army Bell UH-1D helicopters airlift members of the 2nd Battalion, $14^{\text {th }}$ Infantry Regiment from the Filhol Rubber Plantation area to a new staging area, during Operation "Wahiawa", a search and destroy mission conducted by the $25^{\text {th }}$ Infantry Division, northeast of $\mathrm{Cu}$ Chi, South Vietnam, 1966. Created: May 16, 1966. License: CC0-PD, https://en.wikipedia.org/wiki/Vietnam War\#/media/File:UH-1D helicopters in Vietnam 1966.jpg]

Photo 28: USAF aircraft - the spraying of Agent Orange. [Source: Pho-28 - Author: Charles P. Pierce, photo: DICK SWANSON / GETTY IMAGES. Agent Orange Won't Go Away - in Vietnam, or the Courts. Published: January 25, 2021 in the Esquire, C2021 Hearst Magazine Media, Inc., https://www.esquire.com/news-politics/politics/a35307904/agent-orange-manufacturers-lawsuit-monsanto/]

Photo 29: "Zippo" boat equipped with a flamethrower could fire compressed napalm up to 200 yards. [Source: Pho-29 - Author: Weaponry Used by U.S. and Communist Forces, http://www.riverinesailor.com/Weaponry.htm]

Photo 30: Devastated nature after pesticide-spraying. [Source: Pho-30 - Author: von Günther Hirsch. US-Soldaten in der "Horrorlandschaft" des vietnamesischen Dschungel-Krieges. Damals waren der politischen Öffentlichkeit der mörderische Krieg der USA als Fluchtursache noch bewusst genug, um gegen diesen Krieg massenhaft und quer durch alle Gesellschaftsschichten zu protestieren. Published: January 27, 2019 in the RT DE, RT DE (C) 2005-2021. https://de.rt.com/meinung/83025-fluechtlingskrise-damals-und-heute-kriege-politisch-mediale-umnachtung/]

Photo 31: Burning houses at Trang Bang in 1972. [Source: Pho-31 - Fotografia de autor desconhecido, Bettmann/CORBIS, Postado há $6^{\text {th }}$ October 2013 por Anonymous, http://thesnakegonnasmoke.blogspot.com/2013/10/napalm-girl.html]

Photo 32: Civilian victims of the Vietnam War. [Source: Pho-32 - Ronald L. Haeberle - Copied from Krysstal.com, "The Acts of the Democracies" http://www.krysstal.com/democracy_vietnam mylai.html. Photo taken by United States Army photographer Ronald L. Haeberle on March 16, 1968 in the aftermath of the My Lai massacre showing mostly women and children dead on a road. Created: March 16, 1968. License: CC0-PD, https://cs.wikipedia.org/wiki/V\%C3\%A1lka ve Vietnamu\#/media/Soubor:My Lai massacre.jpg]

Photo 33: Ex-serviceman Do Duc Diu spent more than twenty years trying for a baby. The children always died and their parents didn't know why. After the birth of the fifteenth child they found out it was caused by a chemical agent in the father's body. All their deceased children are in the coffins. [Source: Pho-33 - Author: Jakub Plíhal / Reuters, photo: Reuters. Foto: Agent Orange zabíjí i 40 let po konci vietnamské války. Published: April 30, 2015 in the Aktuálně.cz, Centrum.cz / Atlas.cz 1999-2021 (C) Economia, a.s. https://zpravy.aktualne.cz/zahranici/foto-agent-orange-zabiji-i-40-let-po-konci-vietnamske-valky/r 6718d14eecc411e485d7002590604f2e/] 
Photo 34: Three fighter-bombers McDonnell Douglas F-4B Phantom II of fighter squadron VF-161 Chargers from the aircraft carrier USS Midway (CVA-41) and three aircraft LTV-7C Corsair II in the attack of air squadron VA-86 Sidewinders from the ship USS America (CVA-66), March, 1973, Vietnam. [Source: Pho-34 - Unknown author or not provided. This media is available in the holdings of the National Archives and Records Administration, catalogued under the National Archives Identifier (NAID) 558517. Created: March 1973. License: CC0, CCA-SA, https://commons.wikimedia.org/wiki/File:Vietnam. Three Fighter Squadron 161 (VF-161) F-4D Phantom II fighter aircraft from the attack aircraft carrier USS... - NARA - 558517.tif]

Photo 35: Agent Orange continues to kill even 40 years after the war. About 5,000,000 people were exposed to its effects; more than 3,000,000 of them suffered or still have been suffering from killer diseases. [Source: Pho-35 - Author: Jakub Plíhal / Reuters, photo: Reuters. Foto: Agent Orange zabíjí i 40 let po konci vietnamské války. Published: April 30, 2015 in the Aktuálně.cz, Centrum.cz / Atlas.cz 1999-2021 (C) Economia, a.s. https://zpravy.aktualne.cz/zahranici/foto-agent-orange-zabiji-i-40-let-po-konci-vietnamske-valky/r 6718d14eecc411e485d7002590604f2e/]

Photo 36: The Geneva conference where the fate of Vietnam was negotiated. [Source: Pho-36 - US Army Photograph - http://en.wikipedia.org/wiki/File:Gen.jpg (George Esper, The Eyewitness History of the Vietnam War, A sociated Press 1983). Created: January 01, 1954. License: CC0-PD, https://cs.wikipedia.org/wiki/Indo\%C4\%8D\%C3\%ADnsk\%C3\%A1_v\%C3\%A1lka\#/media/Soubor:Gen-commons.jpg]

Photo 37: B-52 Stratofortress US strategic bomber is flying to bomb Iraq during Operation Desert Storm. [Source: Pho-37 Author: aš / Novinky.cz, photo: Profimedia.cz. Boeing B-52 Stratofortress. Published: September 17, 2010 in the Novinky.cz. Copyright (C) 2003-2021 Borgis a.s. Copyright (C) 2019-2021 Seznam.cz a.s. Copyright C ČTK, DPA, Reuters and photobank Profimedia, https://www.novinky.cz/tema/clanek/boineg-b-52-stratofortress-40096084]

Photo 38: The Tupolev Tu-16 (NATO codename: Badger) was a Soviet or Russian long-range bomber. [Source: Pho-38 Unknown author - DefenseImagery.mil ID DN-SC-86-00466. Created: January 01, 1985. License: CC0-PD, https://en.wikipedia.org/wiki/Tupolev Tu-16\#/media/File:Tu-16 Badger E.jpg]

Photo 39: The US Bomber Convair B-58 Hustler. [Source: Pho-39 - Author: USAF. United States Air Force Convair B-58A Hustler in flight (B-58A-15-CF, SN 60-1118). http://www.nationalmuseum.af.mil/shared/media/photodb/photos/061101-F-1234P-022.jpg. Uploaded: October 30, 2020. License: CC0-PD, https://en.wikipedia.org/wiki/Convair B-58 Hustler\#/media/File:B-58 Hustler.jpg]

Photo 40: The Soviet bomber Tu-22M. [Source: Pho-40 - Author: Tubenutdave. Image of believed Tu-22M, 30-01-2006 at Riga airport aircraft museum. Created: December 26, 2006. License: CC BY-SA 3.0, https://cs.wikipedia.org/wiki/Tupolev_Tu-22M\#/media/Soubor:Tu-22Mprobe.JPG]

Photo 41: The US Boeing B-47 Stratojet Bomber. [Source: Pho-41 - Author: TECH. SGT. MICHAE HAGGERTY - http://www.dodmedia.osd.mil/. ID: DF-ST-88-01015 Service Depicted: Air Force Command Shown: F3203 An air-to-air right side view of a restored B-47E-25-DT Stratojet $(52-0166,44020)$ aircraft in the markings of the $93 \mathrm{~d}$ Bombardment Wing. The aircraft is one of the last flyable B-47s in the world and will be flown to Merced, Calif., where it will be displayed with other preserved aircraft in the Castle AFB Museum, China Lake Weapons Center. Created: June 17, 1986. License: CC0-PD US Air Force, https://en.wikipedia.org/wiki/Boeing B47 Stratojet\#/media/File:B47 DF-ST-88-01015.jpg]

Photo 42: The US B-1B Lancer Bomber. [Source: Pho-42 - Author: DoD photo, USAF - http://www.b1b.wpafb.af.mil. USAF B-1 Bomber dropping 30 CBUs (Cluster bombs). Created: Unknown date. License: CC0-PD US Air Force, https://cs.wikipedia.org/wiki/Rockwell_B-1_Lancer\#/media/Soubor:CBUbombs.jpg]

Photo 43: The US B-2A Spirit bomber. [Source: Pho-43 - Author: Staff Sgt. Bennie J. Davis III. A B-2 Spirit soars after a refuelling mission over the Pacific Ocean on Tuesday, May 30, 2006. The B-2, from the 509th Bomb Wing at Whiteman Air Force Base, Mo., is part of a continuous bomber presence in the Asia-Pacific region. (U.S. Air Force photo/Staff Sgt. Bennie J. Davis III), Created: May 30, 2006. License: CC0-PD US Air Force, https://en.wikipedia.org/wiki/Northrop_Grumman_B-2_Spirit\#/media/File:B-2_Spirit_(cropped).jpg]

Photo 44: The Russian Tupolev Tu-95 Bear bomber. [Source: Pho-44 - Author and photo: RAF/MOD. A Russian Tu-95 Bear 'H' photographed from a RAF Typhoon Quick Reaction Alert aircraft (QRA) with 6 Squadron from RAF Leuchars in Scotland. RAF Typhoon Quick Reaction Alert aircraft were launched from RAF Leuchars to determine the identity of unknown aircraft that approached the NATO Air Policing Area north of Scotland and could not be identified by other means. The aircraft were subsequently identified as Russian military reconnaissance (Bears). The Russian Bears aircraft remained in international airspace as they are perfectly entitled to do. Organization: RAF Object Name: LEU-OFFICIAL-20140423-0326-0015 Category: MOD Supplemental Categories: Equipment, Aircraft, Foreign Aircraft Keywords: QRA, Russia, Russian, Bear, Aircraft, Quick Reaction Alert, Intercept Country: Scotland. Images are downloadable at high resolution, made available at http://www.defenceimagery.mod.uk for reuse under the OGL (Open Government License) Created: April 23, 2014. License: OGL v 1.0, https://en.wikipedia.org/wiki/Tupolev Tu-95\#/media/File:Russian Bear 'H' Aircraft MOD 45158140.jpg]

Photo 45: The Russian Tupolev Tu-160 Blackjack long-range strategic bomber. [Source: Pho-45 - Author: Kremlin.ru. Presidential Press and Information Office: http://www.kremlin.ru/eng/text/images/92633.shtml. Murmansk Region, Olenegorsk. The strategic bomber Tu-160. Created: August 16, 2005. License: CC-BY-4.0, https://en.wikipedia.org/wiki/Tupolev_Tu-160\#/media/File:Kremlin_Tupolev_Tu-160.jpg]

Photo 46: The Russian Tupolev Tu-22M3 Backfire bomber. [Source: Pho-46 - Author: Alex Beltyukov - http://russianplanes.net/EN/ID56447. Russian Air Force Tupolev Tu-22M3 at Ryazan Dyagilevo. Created: January 01, 2011. License: CC-BY-SA-3.0, https://cs.wikipedia.org/wiki/Tupolev_Tu-22M\#/media/Soubor:Russian_Air_Force_Tupolev Tu22M3 Beltyukov.jpg] 
Photo 47: Lockheed Martin's Long-Range Strike Bomber (LRSB) concept. [Source: Pho-47 - Author: ANAND DATLA. Boeing's Bomber Protest Is Fundamentally Flawed. Published: December 02, 2015 in the BREAKING DEFENSE, Copyright (C) 2021 Breaking Media, Inc., https://breakingdefense.com/2015/12/boeings-bomber-protest-is-fundamentally-flawed/]

Photo 48: One of possible PAK DA variations, which has appeared on the internet forums /www.anti-teror.ucoz.ua /. [Source: Pho-48 - Author: Michal Polák. Nejasnosti kolem ruského bombardéru další generace. Published: September 01, 2012 in the ARMÁDNÍ NOVINY, (C) 2018-2021 Armadninoviny.cz, https://www.armadninoviny.cz/nejasnosti-kolem-ruskeho-bombarderu-dalsi-generace.html]

Photo 49: The French Rafale aircraft. [Source: Pho-49 - Indian Air Force, https://indianairforce.nic.in/content/induction-rafaleindian-air-force-0. IAF Rafale aircraft touching down at Air Force Station Ambala on its arrival after covering a distance of nearly $8500 \mathrm{~km}$ from France to India on July 29, 2020. Created: July 29, 2020. License: GODL-India, https://en.wikipedia.org/wiki/Dassault_Rafale\#/media/File:IAF_Rafale_aircraft_touching down at Air Force Station Ambala on its arrival on 29 July 2020 (cropped).jpg]

Photo 50: The Chinese Xian H-6 bomber. [Source: Pho-50 - Author and photographs by Kevin McGil from Den Bosch, Netherlands. PLAAF Xian H-6M makes a turn over central Changzhou. Created: November 09, 2010. License: CC-BYSA-2.0, https://commons.wikimedia.org/wiki/File:PLAAF Xian H-6M Over Changzhou.jpg]

Photo 51: The MGR-1A Honest John artillery rocket. [Source: Pho-51 - Author: U.S. Army - Redstone Arsenal Historical Information http://www.redstone.army.mil/history/archives/missiles/honest_john_06.jpg. MGR-1 Honest John. Created: July 10, 2007. License: CC0-PD U. S. Army, https://commons.wikimedia.org/wiki/File:MGR-1_Honest John 05.jpg]

Photo 52: FILIN - 3R2 (Frog-1). [Source: Pho-52 - Author: One half 3544 - Eigenes Werk. 2P4 Transporter-Erector-Launcher with 3R2 missile of 2K4 missile complex «Filin» in Saint-Petersburg Artillery museum. Created: October 24, 2010. License: CC0-PD, https://de.wikipedia.org/wiki/FROG (Rakete)\#/media/Datei:2P4 Filin.JPG]

Photo 53: The MGM-52 LANCE (SS-21) tactical guided missile. [Source: Pho-53 - Author: U.S. Army - Redstone Arsenal Historical Information http://www.redstone.army.mil/history/archives/lance/lance_1965_001.jpg. MGM-52 Lance on M667. Created: January 01, 1965. License: CC0-PD U. S. Army, https://commons.wikimedia.org/wiki/File:MGM-52 Lance 12.jpg]

Photo 54: The 9M79K TOCHKA-U (SS-21 Scarab) tactical guided missile. [Source: Pho-54 - Аuthor: Владислав Фальшивомонетчик - Own work. Ракетные комплексы Точка-У на репетиции парада в Екатеринбурге. Uploaded: October 25, 2009. License: CC-BY-SA-3.0, https://en.wikipedia.org/wiki/OTR-21_Tochka\#/media/File:Tochka-U rep parad Yekat.jpg]

Photo 55: Le Redoutable S611 ballistic missile submarine. [Source: Pho-55 - Galerie Vojsko.net. Powered by Coppermine Photo Gallery, Coppermine Photo Gallery Copyright 2003-2010. Coppermine Photo Gallery (CPG) is an open source project released under the GNU/GPL terms, https://galerie.vojsko.net/displayimage.php?pid=23066]

Photo 56: RT-2UTTKh Topol-M. [Source: Pho-56 - Author: Vitaly V. Kuzmin - http://vitaly-kuzmin.net/?q=node/446. RT2PM2 Topol-M TEL with presumably Yars system transport-launch container during the first rehearsal for the Victory Day Parade at the training ground in Alabino. Created: March 19, 2012. License: CC-BY-SA-4.0, https://en.wikipedia.org/wiki/RT-2PM2 Topol-M\#/media/File:19-03-2012-Parade-rehearsal - Topol-M.jpg]

Photo 57: Special ammunition depot - the Boží Dar u Milovic airport. [Source: Pho-57 - Author: Miroslav Němec. Milovice - letiště Boží Dar (2/4) - sklad speciální munice Na Vinici. Uploated: November 01, 2016, http://vojenske-prostory.cz/milovice-municni-sklad-na-vinici/]

Photo 58: The JAVOR 51 nuclear ammunition depot in Míšov (Borovno). [Source: Pho-58 - Author: Miroslav Němec. Akce JAVOR - Sklady jaderných zbraní JAVOR 51. Uploated: July 22, 2015, http://vojenske-prostory.cz/skladyjadernych-zbrani-javor-51/]

Photo 59: The 3R10-3N14-901A4 nuclear warhead. [Source: Pho-59 - Author: ŠUFAJZL Vladimír a Vladimír MOHYLA. Taktické jaderné prostředky ČSLA, bojové použití raketového vojska a dělostřelectva pozemního vojska v Československé lidové armádě, výzbrojní služba v poli - bojové použití dopravní baterie a pohyblivé raketové technické základny. Praha: 2010, e-book, C vlado - vlas, pgs 171, https://doczz.cz/doc/74974/taktick\%C3\%A9jadern $\% \mathrm{C} 3 \%$ A9-prost $\% \mathrm{C} 5 \% 99$ edky- $\% \mathrm{C} 4 \% 8 \mathrm{Dsla}]$

Photo 60: 2K6 LUNA (Frog-3). [Source: Pho-60 - One half 3544 - Own work. 2P16 Transporter-Erector-Launcher with 3R9 rocket of 2K6 missile complex «Luna» in Saint-Petersburg Artillery museum. Created: May 06, 2007, License: CC0PD, https://commons.wikimedia.org/wiki/File:2P16 Luna.jpg]

Photo 61: RK 9K52 Luna-M (Frog-7). [Source: Pho-61 - Author: Balcer commonswiki - Own work. Soviet FROG-7B (LunaM) missile system, displayed in Hämeenlinna Artillery Museum. This was a tactical weapon, with a range from 10 to $65 \mathrm{~km}$ and a $450 \mathrm{~kg}$ warhead, conventional, chemical or nuclear. Photo taken on June 18, 2006. Source: Photo by me, User: Balcer. Created: June 17, 2006, License: CC-BY-SA-3.0, https://commons.wikimedia.org/wiki/File:Luna_m_frog_7_hameenlinna_1.jpg]

Photo 62: Nuclear warhead 9N32 AA-22. [Source: Pho-62 - Author: ŠUFAJZL Vladimír a Vladimír MOHYLA. Taktické jaderné prostředky ČSLA, bojové použití raketového vojska a dělostřelectva pozemního vojska v Československé lidové armádě, výzbrojní služba v poli - bojové použití dopravní baterie a pohyblivé raketové technické základny. Praha: 2010, e-book, C) vlado - vlas, pgs 171, https://doczz.cz/doc/74974/taktick\%C3\%A9-jadern\%C3\%A9prost $\% \mathrm{C} 5 \% 99 \mathrm{edky-} \% \mathrm{C} 4 \% 8 \mathrm{Dsla}]$ 
Photo 63: The 9M79 TOCHKA missile on the 9P129 missile launcher. [Source: Pho-63 - Author: Author: DIMMI. Пуск ракеты 9М79 комплекса 9К79-1 "Точка-У", полигон Капустин Яр, 22.09 .2011 г. (автор фото - Вадим Савицкий, http://twower.livejournal.com) (C) 2009-2015 militaryrussia.ru. Uploated: March 9, 2017, http://militaryrussia.ru/blog/topic-191.html]

Photo 64: The 8K11 system on the 8U218 missile launcher (SCUD-A). [Source: Pho-64 - Author: DIMМI. Пусковая установка 2У218 ракетного комплекса 8K11 SS-1B SCUD-A в музеe Militar Naţional "Regele Ferdinand I", Бухарест, Румыния (https://rocketumbl.tumblr.com). (C) 2009-2015 militaryrussia.ru. Uploated: July 30, 2020, http://militaryrussia.ru/blog/topic-176.html]

Photo 65: The 8K14 system (SCUD-B). [Source: Pho-65 - Wo st 01 / Wikimedia Commons, Scud-Launcher, picture taken on the RAF Airforce base Spadeadam, England. ПУ 9П117 с ракетой 8К14 на авиабазе Спадеадам (англ.) русск. Королевских ВВC, Англия. Created: June 9, 2005, License: CC-BY-SA-3.0 de, https://commons.wikimedia.org/wiki/File:Scud-launcher-England1.jpg]

Photo 66: The 9K714 OKA system (SS-23 SPIDER). [Source: Pho-66 - self-made - Own work. An SS-23 Spider ballistic missile complex in the National Museum of Military History in Sofia. Created: June 14, 2008, License: CC-BY3.0, https://en.wikipedia.org/wiki/OTR-23 Oka\#/media/File:SS-23 Sofia Military History Museum.JPG]

Photo 67: The belts of Mark 149 Mod 2 with 20mm DU ammunition on the battleship (USS Missouri). [Source: Pho-67 Author: PANONIAN, Own work, Created: 2010, License: CC-0, https://en.wikipedia.org/wiki/Depleted uranium]

Photo 68: Radiation burns - the consequence of the radiation accident in the Chernobyl atomic power plant. [Source: Pho- 68 - The battle of Chernobyl [videorecording]. Play Film presents; a film by Thomas Johnson; produced by Hind Saïh; a coproduction Corbis/Sygma, Guillaume Valabrègue; with the participation of France 3; for Discovery Networks International; Discovery Communications, Inc. Imprint: Brooklyn, N.Y.: First Run/Icarus Films, [2006]. Physical description: 1 videodisc (94 min.): sd., col.; 4 3/4 in., from Author's archive]

Photo 69: Fetal genetic disorders - consequence of a radiation accident at the Chernobyl nuclear power plant on April 26, 1986. [Source: Pho-69 - The battle of Chernobyl [videorecording]. Play Film presents; a film by Thomas Johnson; produced by Hind Saïh; a coproduction Corbis/Sygma, Guillaume Valabrègue; with the participation of France 3; for Discovery Networks International; Discovery Communications, Inc. Imprint: Brooklyn, N.Y.: First Run/Icarus Films, [2006]. Physical description: 1 videodisc (94 min.): sd., col.; 4 3/4 in., from Author's archive]

Photo 70: Radiation burns of a girl after the nuclear explosion in Hiroshima on August 06, 1945. [Source: Pho-70 - Author: Yamahata, the photographer of Nagasaki. Article: Hiroshima, the pictures they didn't want us to see. Published: September 28, 2007 at Blog at WordPress.com, https://infidelkafirwatch.wordpress.com/2007/09/28/hiroshima-thepictures-they-didnt-want-us-to-see/]

Photo 71: Keloid scars (hypertrophic scars) - the consequence of the nuclear explosion in Hiroshima on August, 06, 1945. [Source: Pho-71 - Photo by US Army Signal Corps/FPG/Getty Images World War Two: A Japanese casualty from World War Two, now part of the Atomic Bomb Casualty Commission; Akira Yamaguchi has arms covered in keloid scars from the flash burn at Hiroshima, Japan, 1947. (C) 2021 Getty Images, https://www.gettyimages.com/detail/news-photo/japanese-casualty-from-world-war-two-now-part-of-the-atomic-news-photo/467145109]

Photo 72: Genetic disorders of the fetus - the result of a nuclear explosion in Hiroshima. [Source: Pho-72 - Authors: Prof. Dr. Ahmet Saltık - Özgeçmiş (CV). HİROŞIMA ve NAGASAKİ VAHŞETİNIN 70. YILI. Published: August 7, 2015 at www.ahmetsaltik.net, http://ahmetsaltik.net/tag/hirosima-ve-nagasaki-vahsetinin-67-yili/]

Photo 73: The fire on the SSN-755 nuclear submarine caused \$ 440 million in damage. [Source: Pho-73 - Author: Admin. Photo: Rt.com. Spojené státy odepsaly jadernou ponorku USS Miami (SSN-755), kterou zapálil žháŕ. Published: April 03, 2014, (C) 2016-2021 Atominfo.Cz, https://atominfo.cz/2014/04/spojene-staty-odepsaly-jadernou-ponorkuuss-miami-ssn-755-kterou-zapalil-zhar/]

Photo 74: The Soviet K-278 Komsomolets nuclear submarine, which sank in the Norwegian Sea on April 07, 1989, 42 dead. [Source: Pho-74 - Author: not stated - DoD ID: DN-SN-87-07042. K-278 underway in 1986. An aerial port quarter view of a Soviet Mike class nuclear-powered attack submarine underway. Created: January 01, 1986, License: CC0-PD US Navy, https://en.wikipedia.org/wiki/Soviet submarine K-278 Komsomolets\#/media/File:DN-SN-8707042-Mike class submarine-1 Jan 1986.JPEG]

Photo 75: Nuclear explosion effects, Hiroshima 1945. The ruin was later named the Hiroshima Peace Memorial. [Source: Pho75 - Author: dpa/picture alliance/UPPA/Photoshot. Das zerstörte Hiroshima nach dem Abwurf der Atombombe durch die US-Amerikaner am August 06, 1945. Atombombe über Hiroshima: "Japaner waren eine Art Versuchskaninchen". Published: August 02, 2015 in the Deutschlandfunk, Deutschlandradio (c) 2009-2021, https://www.deutschlandfunk.de/atombombe-ueber-hiroshima-japaner-waren-eine-art.694.de.html?dram:article id $=327149]$

Photo 76: Nuclear explosion effects, Nagasaki 1945. [Source: Pho-76 - Photo: AP Photo/U.S. Army. This area of Nagasaki, seen in 1945, was crowded with industrial buildings and small residences. In the background are the remains of the Mitsubishi arms factory and a reinforced concrete school building at the foot of the hills. Published: Published 10/11/2010 at $\times$ in the death of the japanese city/gojira/jack burton » NAGASAKI DESTRUCTION 1945 at Blog at WordPress.com, https://pianonecktie.wordpress.com/2010/11/10/the-death-of-the-japanese-citygojiraharry-s-morgan/nagasaki-destruction-1945-4/]

Photo 77: Victims of the nuclear explosion, Nagasaki 1945. [Source: Pho-77 - Author: Georgia NeSmith / AP wire photo. The Legacy of Nagasaki: Contradictions from my father's past. Published: March 29, 2018 in the Medium.com, https://medium.com/@matrixeditorial/the-legacy-of-nagasaki-3a91a025fc75] 
Photo 78: The effect of light (thermal) radiation and the pressure wave of a nuclear explosion. A test in the USA. [Source: Pho78 - Autor's archive]

Photo 79: Victims. Hiroshima 1945. [Source: Pho-79 - Author: di MATTEO RUBBOLI. Il Bombardamento di Tokyo fu il Raid Aereo più Mortale della Storia. Una madre portava il bambino sulla schiena, che risulta l'unica parte non carbonizzata (A mother carried the baby on her back, which is the only non-charred part). Published: VANILLA MAGAZINE - PI IT02579490398, https://www.vanillamagazine.it/il-bombardamento-di-tokyo-fu-il-raid-aereopiu-mortale-della-storia/]

Photo 80: One of the victims. Hiroshima. [Source: Pho-80 - Author: Yamahata, the photographer of Nagasaki. Article: Hiroshima, the pictures they didn't want us to see. Published: September 28, 2007 at Blog at WordPress.com, https://infidelkafirwatch.wordpress.com/2007/09/28/hiroshima-the-pictures-they-didnt-want-us-to-see/]

Photo 81: Acute radiation syndrome, Hiroshima. [Source: Pho-81 - Hiroshima Peace Memorial Museum. Perilous Memories - (5) Victims of the Bombing. Published: Blog at WordPress.com, https://perilousmemories.wordpress.com/5-thevictims-of-the-bombing/]

Photo 82: The damage to fetus after irradiation, Hiroshima. [Source: Pho-82 - Author: Hiroshima Peace Media Center. EXPOSURE $\rightarrow$ 5. A High Incidence of Deformities. Photo: A partial lifting of restrictions on research involving the effects of radiation has finally enabled Gricia Gadikbyeva and other physicians to begin accessing information on genetic defects and radiation-related illnesses. These pictures of deformed children were provided by Dr. Gadikbyeva. Published: January 18, 2013, http://www.hiroshimapeacemedia.jp/?expo$\underline{\text { sure }=20130115160444538 \text { en] }}$

Photo 83: Presidents of the USA and Russia (Obama a Medvedev) signing the major Nuclear Arms Control Agreement on April 08, 2010 in Prague. [Source: Pho-83 - Author: Lisbeth Gronlund. US Should Extend the New START Nuclear Weapons Treaty to Make Us All Safer. Published: Union of Concerned Scientists - Science for a healthy planet and safer world, April 22, 2020, https://allthingsnuclear.org/lgronlund/newstart]

Photo 84: The civil protection shelters below the Spilberk Castle in Brno. [Source: Pho-84 - Author: Adam KAFELANKA Brno $\rightarrow$ Špilberk $\rightarrow$ Kryt CO, (C) adam@kafelanka.cz 2004-2021, https://www.kafelanka.cz/mista/krytco5.php]

Photo 85: The civil protection shelters below the Spilberk Castle in Brno. [Source: Pho-85 - Author: Adam KAFELANKA Brno $\rightarrow$ Špilberk $\rightarrow$ Kryt CO, (C) adam@kafelanka.cz 2004-2021, https://www.kafelanka.cz/mista/krytco5.php]

Photo 86-1 to 86-4: The civil protection shelters under the Strahov tunnel. [Source: Pho-86 - Author's: ap, sfo /iDNES.cz. Podívejte se do protiatomového krytu ve Strahovském tunelu. Published: May 03, 2013 in the iDNES.cz / MAGAZÍNY, (C) 1999-2021 MAFRA, a. s., a dodavatelé Profimedia, Reuters, ČTK, AP, https://www.idnes.cz/technet/reportaze/video-frekventovany-strahovsky-tunel-slouzi-i-jako-protiatomovy-kryt.A110503_135145_prahazpravy sfo]

Photo 87: The Three Mile Island nuclear power plant. [Source: Pho-87 - Author: United States Department of Energy - http://ma.mbe.doe.gov/me70/history/photos.htm Copyright status: Identified on DOE page as "DOE photo", i.e. not copyrighted. Color photograph of the Three Mile Island nuclear generating station, which suffered a partial meltdown in 1979. The reactors are in the smaller domes with rounded tops (the large smokestacks are just cooling towers). Created: October 01, 1979, License: CC0-PD US Government, https://cs.wikipedia.org/wiki/Hav\%C3\%A1rie elektr\%C3\%A1rny Three Mile Island\#/media/Soubor:Three Mile Island (color)-2.jpg]

Photo 88: Workers of the TMI nuclear power plant in the auxiliary building during decontamination - 1979. [Source: Pho-88 - Author: John G. Kemeny et al - Report of The President's Commission on the Accident at Three Mile Island: The Need for Change: The Legacy of TMI, p. 140 TMI personnel cleaning up radioactive contamination in the auxiliary building — 1979 Three Mile Island nuclear accident. Created: October 01, 1979, License: CC0-PD US Government, https://en.wikipedia.org/wi-ki/Three_Mile_Island_accident\#/media/File:TMI_cleanup-2.jpg]

Photo 89: Reactor No. 4 after the explosion at the Chernobyl power plant. [Source: Pho-89 - Author: Soviet Authorities. This image is a faithful digitalization of Chernobyl disaster, a historically significant photograph. Uploaded: March 09, 2014, License: CCA-SA, https://en.wikipedia.org/wiki/Chernobyl_disaster\#/media/File:Chernobyl_Disaster.jpg]

Photo 90: The melted nuclear fuel of reactor No. 4 at the nuclear power plant at Chernobyl. [Source: Pho-90 - Author: David Bressan / INSP. How the Chernobyl Nuclear Plant Meltdown Formed World's Most Dangerous Lava. Published: Jun 14, 2019 at Forbes.com, https://www.forbes.com/sites/davidbressan/2019/06/14/how-the-chernobyl-nuclearplant-meltdown-formed-worlds-most-dangerous-lava-flow/?sh=731842d81691]

Photo 91: The melted nuclear fuel of reactor No. 4 at the nuclear power plant at Chernobyl. [Source: Pho-91 - Author: Barbara LORENZOVÁ. Zajímavosti k seriálu Černobyl: Znáte tamní sloní nohu, nejnebezpečnější látku světa? Published: May 30, 2019 in the Extralife.cz, Copyright (C) Extra Online Media s.r.o., https://www.extralife.cz/sloni-noha-jenejnebezpecnejsi-latka-na-svete-dve-minuty-u-ni-a-je-po-vas_1009]

Photo 92: The control room of the Chernobyl nuclear power plant. [Source: Pho-92 - Author: marianomariano / DailyMail, Photo: EPA / Wikimedia. The famous control room for reactor 4 at the Chernobyl power plant is open to all tourists. Published at whaleshares.io, https://whaleshares.io/@marianomariano/the-famous-control-room-for-reactor-4-atthe-chernobyl-power-plant-is-open-to-all-tourists]

Photo 93: The control room of the Chernobyl nuclear power plant today. [Source: Pho-93 - Author: AP Photo / Efrem LUKATSKY, File. Photos: 30 Years of Chernobyl. Published: Apr 21st, 2016 in the IEN - Industrial Equipment News, (C) 2021 Industrial Media, LLC., https://www.ien.com/safety/news/20553952/photos-30-years-of-chernobyl] 
Photo 94: Biorobots - soldiers removing radioactive material from the roof. At the bottom of the photo radiation can be seen. [Source: Pho-94 - Photo: Igor KOSTIN. A photograph of "liquidators" on the roof of Reactor three taken by Igor KOSTIN. The white streaks at the bottom of the photo were due to the high levels of radiation emanating from below. Published: The Chernobyl Gallery. License: CC BY-NC-ND 3.0, http://www.chernobylgallery.com/chernobyl-disaster/liquidators/]

Photo 95: Special teams clean up contaminated animals. [Source: Pho-95 - Author: Mii. Zázračné dítě Černobylu: Marijka (19) se jako jediná narodila v zamořené zóně. Published: June 10, 2019 in the Blesk.cz, (C) 2001-2021 Copyright CZECH NEWS CENTER a.s. and content providers, https://www.blesk.cz/cla-nek/zpravy-svet/609392/zazracnedite-cernobylu-marijka-19-se-jako-jedina-narodila-v-zamorene-zone.html]

Photo 96: The helicopter is discharging a special liquid called Burba to bind radioactive dust to the ground. [Source: Pho-96 Authorship of photographs: Youtube.com / Přesný čas online. License: CC BY-NC-ND 3.0, https://www.presnycas-online.cz/obsah/technologie-likvidace-havarie-elektrarny-cernobyl-1986 ]

Photo 97: A basic school, Pripyat. [Source: Pho-97 - Author and Photo: Tomáš ZELENKA. Černobyl očima turisty. Místo vyjmuté $\mathrm{z}$ běhu času máme možnost sledovat v př́mém přenosu. Published: March 07, 2017 in the Český rozhlas, (C) 1997-2021 Český rozhlas, https://hradec.rozhlas.cz/cernobyl-ocima-turisty-misto-vyjmute-z-behu-casu-mamemoznost-sledovat-v-primem-6126096]

Photo 98: Exclusion zones around Chernobyl. [Source: Pho-98 - Author: Timm Suess - Flickr: Red Forest Hill. Radioactivity warning sign on a hill at the east end of Red Forest For the story behind the picture: Chernobyl Journal on www.iaea.org. May 14, 2014. Created: March 26, 2009, License: CC BY-SA 2.0, https://en.wikipedia.org/wiki/Chernobyl disaster\#/media/File:Red Forest Hill.jpg]

Photo 99: Abandoned vessels on the river of Pripyat. [Source: Pho-99 - Author: Elena Filatova - Elena Filatova, www.elenafilatova.com, accessible through http://www.angelfire.com/extreme4/kiddofspeed/chapter5.html. Abandoned vessels on Pripyat River. Uploaded: October 29, 2006, License: CC0, https://cs.wikipedia.org/wiki/\%C4\%8Cernobylsk\%C3\%A1 hav\%C3\%A1rie\#/media/Soubor:Pripyat-river-container-vessels.jpg]

Photo 100: A swimming pool in the abandoned city of Pripyat. [Source: Pho-100 - Author: Timm Suess from Basel, Switzerland-Swimming Pool Hall 4 (Flickr). The public swimming pool in the ghost town of Pripyat near Chernobyl. Modified by Hiob with Gimp (resized, coloured, light). Created: March 26, 2009, License: CC BY-SA 2.0, https://cs.wikipedia.org/wiki/\%C4\%8Cernobylsk\%C3\%A1_hav\%C3\%A1rie\#/media/Soubor:Swimming Pool Hall 4 Pripyat.jpg]

Photo 101: An abandoned village in the exclusion zone. [Source: Pho-101 - Author: Elena Filatova - www.elenafilatova.com. Some abandoned house in the inner closed zone around the Chernobyl power plant. Uploaded: October 29, 2006, License: CC0, https://cs.wikipedia.org/wiki/\%C4\%8Cernobylsk\%C3\%A1 hav\%C3\%A1rie\#/media/Soubor:Deadzone.jpg]

Photo 102: One of the pilots of General Antoshkin who received high radiation doses. [Source: Pho-102 - Authorship of photographs: Youtube.com / Přesný čas online. License: CC BY-NC-ND 3.0, https://www.presny-cas-online.cz/obsah/nasledky-havarie-jaderne-elektrarny-cernobyl-1986]

Photo 103: Contaminated equipment near Chernobyl. [Source: Pho-103 - Artificial Owl. Irradiated giant helicopters and vehicles at Rassorva, Chernobyl (Chornobyl, Чорнобиль ) region, Kyiv Oblast, Ukraine. Published at the web: http://www.artificialowl.net/2008/10/radiation-contaminated-vehicles_07.html]

Photo 104: The treatment of burns after the body exposure to 900 roentgens for the time of 2 minutes. The man died on the second day. [Source: Pho-104 - Authorship of photographs: Youtube.com / Přesný čas online. License: CC BYNC-ND 3.0, https://www.presny-cas-online.cz/obsah/nebezpeci-druheho-vybuchu-elektrarny-cernobyl-1986]

Photo 105: The yellow mass is cracked skin, through which burnt flesh with pieces of bone has penetrated. A photo of an elbow joint. [Source: Pho-105 - Authorship of photographs: Youtube.com / Přesný čas online. License: CC BY-NC-ND 3.0, https://www.presny-cas-online.cz/obsah/nasledky-havarie-jaderne-elektrarny-cernobyl-1986]

Photo 106: During May Day celebrations at least 300,000 citizens were contaminated in the area surrounding Chernobyl. [Source: Pho-106 - Author: Igor Kostin, / Přesný čas online. License: CC BY-NC-ND 3.0, https://www.presny-casonline.cz/obsah/nebezpeci-druheho-vybuchu-elektrarny-cernobyl-1986]

Photo 107: The pilots of military helicopters were between 18-25 years of age. Not a single one survived the cross-country flights over the Chernobyl reactor. [Source: Pho-107 - Authorship of photographs: Youtube.com / Přesný čas online. License: CC BY-NC-ND 3.0, https://www.presny-cas-online.cz/obsah/technologie-likvidace-havarie-elektrarnycernobyl-1986]

Photo 108: A mutated piglet. [Source: Pho-108 - Autor: Vincent de Groot - http://www.videgro.net - Own work. Piglet with dipygus - Kiev - Ukrainian National Chernobyl Museum. "Коліцво порося" visible in the display's caption translates as "mutated piglet". Created: November 16, 2009, License: CC BY-SA 4.0, https://en.wikipedia.org/wiki/Chernobyl_disaster\#/media/File:Kiev-UkrainianNationalChernobylMuseum_15.jpg]

Photo 109: Genetic mutations in children after the accident at Chernobyl. [Source: Pho-109- Author: kaw. Nehody a katastrofy jaderných elektráren - III. díl - Černobylská katastrofa. Published: June 27, 2009 at Požáry.cz, https://www.pozary.cz/clanek/18239-nehody-a-katastrofy-jadernych-elektraren-iii-dil-cernobylska-katastrofa/]

Photo 110: The entry into the abandoned Chernobyl zone. [Source: Pho-110 - Author: Slawojar - own work. Entrance to the zone of alienation around Chernobyl. Created: April 23, 2006, License: CC BY-SA 3.0, https://cs.wikipedia.org/wiki/\%C4\%8Cernobylsk\%C3\%A1 hav\%C3\%A1rie\#/media/Soubor:Entrance to zone_of_alienation_around_Chernobyl.jpg] 
Photo 111: The sarcophagus of reactor No.4. [Source: Pho-111 - Author: Carl Montgomery - Flickr. The Chernobyl reactor \#4 building as of 2006, including the later-built sarcophagus and elements of the maximum-security perimeter. reactor 4. Created: September 18, 2006, License: CC-BY 4.0, https://en.wikipedia.org/wiki/Chernobyl disaster\#/media/File:Chernobylreactor 1.jpg]

Photo 112: The new safe confinement to cover the stricken reactor. [Source: Pho-112 - Authors: Alexandr Božilov / Czech News Agency, Photo: EPA, REUTERS. Černobyl má po 30 letech nový sarkofág. Konstrukce je vyšší než socha Svobody. Published: November 19, 2016 in the Blesk.cz, (C) 2001-2021 Copyright CZECH NEWS CENTER a.s. and content providers, https://www.blesk.cz/clanek/zpravy-svet/431847/cernobyl-ma-po-30-letech-novy-sarkofagkonstrukce-je-vyssi-nez-socha-svobody.html]

Photo 113: The Fukushima nuclear power plant before the accident. [Source: Pho-113 - Autor's: Kyodo / X01481, Published: Updated March 11, 2011; 40 Photos, Massive earthquake hits Japan in NBC News, (C) 2021 NBC UNIVERSAL, https://www.nbcnews.com/slideshow/news/massive-earthquake-hits-japan-42024158]

Photo 114: The Fukushima nuclear power plant after the accident. [Source: Pho-114 - Authors: Digital Globe - Earthquake and Tsunami damage-Dai Ichi Power Plant, Japan. Created: March 16, 2011. License: CC BY-SA 3.0, https://en.wikipedia.org/wiki/Fukushima Daiichi nuclear disaster]

Photo 115: The unit of the Fukushima nuclear power plant after the accident. [Source: Pho-115 - Imagine: Tokyo Electric Power Co. - Kyodo News/AP. Published: Britannica, T. Editors of Encyclopaedia (May 27, 2020). Fukushima accident. Encyclopedia Britannica. https://www.britannica.com/event/Fukushima-accident]

Photo 116: The water pool for storing used fuel in the Fukushima I power plant units. [Source: Pho-116 - Photo: Reuters. Autor: Ladislav Kryzánek, Osm let po atomové havárii láká japonská Fukušima na „nukleární“ turistiku, Published: November 19, 2018 in iDNES.cz, (C) 1999-2021 MAFRA, a. s., and content providers Profimedia, Reuters, ČTK, AP. https://www.idnes.cz/zpravy/zahranicni/japonska-fukusima-laka-na-nuklearni-turistiku.A181119 145946 zahranicni jumi]

Photo 117: Adding water to the pool of Unit 3 of the Fukushima Daiichi nuclear power plant. [Source: Pho-117 - Author: 出 典：防衛 省ホームページ Ministry of Defense. Source: Ministry of Defense website https://www.mod.go.jp/e/jdf/no22/photo/photo10.html. Created: August 01, 2011. License: CC-BY 4.0. https://commons.wikimedia.org/wiki/Category:Fukushima_I_accidents?uselang=de\#/media/Fi-le:Injecting_water_into_Unit 3 of the_Fukushima_Daiichi_Nuclear_Power_Station,_Japan.jpg]

Photo 118: In the aerial photography of the Fukushima nuclear power plant from August 2013, the tanks with contaminated water can be seen. [Source: Pho-118 - Photo: Reuters. Autor: Ladislav Kryzánek, Osm let po atomové havárii láká japonská Fukušima na "nukleární" turistiku, Published: November 19, 2018 in iDNES.cz, C 1999-2021 MAFRA, a. s., and content providers Profimedia, Reuters, ČTK, AP. https://www.idnes.cz/zpravy/zahranicni/japonska-fukusima-laka-na-nuklearni-turistiku.A181119_145946_zahranicni jumi]

Photo 119: The construction of a new building where melted fuel rods will be stored. [Source: Pho-119 - Autor's: rc/dr (AFP, AP, dpa). Photo: Reuters. Published: March 21, 2013, Rat linked to power outage at Fukushima nuclear plant in Deutsche Welle, (C) 2021 Deutsche Welle. https://www.dw.com/en/rat-linked-to-power-outage-at-fukushima-nuclear-plant/a-16687127]

Photo 120: The emitter with thousands of ${ }^{60} \mathrm{Co}$ metal pellets. [Source: Pho-120 - Published: IAEA - Radiation Protection of Patients (RPOP) - the training material. https://www.iaea.org/ and Author's archive]

Photo 121: The disposal of houses contaminated by ${ }^{137} \mathrm{Cs}$ in Brazilian Goiania. [Source: Pho-121 - Published: INTERNATIONAL ATOMIC ENERGY AGENCY, The Radiological Accident in Goiania, IAEA, Vienna (1988), STI/PUB/815, ISBN 92-0-129088-8, 157 pages, https://www.iaea.org/publica-tions/3684/the-radiological-accident-in-goiania and Author's archive]

Photo 122: Radiation burns of hands caused by ${ }^{60} \mathrm{Co}$ in Thai Samut Prakarn. [Source: Pho-122 - Published: INTERNATIONAL ATOMIC ENERGY AGENCY, The Radiological Accident in Samut Prakarn, IAEA, Vienna (2002) STI/PUB/1024, ISBN 92-0-110902-4, 60 pages, https://www-pub.iaea.org/MTCD/Publications/PDF/Pub1124 scr.pdf and Author's archive]

Photo 123: Radiological survey at Lilo, Georgia. [Source: Pho-123 - Published: INTERNATIONAL ATOMIC ENERGY AGENCY, The Radiological Accident in Lilo, IAEA, Vienna (2000), STI/PUB/1097, ISBN 92-0-101300-0, 103 pages, 39 figures, https://www.iaea.org/publications/5968/the-radiological-accident-in-lilo and Author's archive]

Photo 124: The Huaorani tribe lives in the rainforest in eastern Ecuador. [Source: Pho-124 - Author: Im / Photo: Profimedia.cz / Pete Oxford / mediadrumworld.com. Published: January 22, 2017, Tajemství Amazonského pralesa: Odlehlý kmen se živí opicemi, na nohou mají 6 prstů in BLESK.cz, (C) 2001-2021 Copyright CZECH NEWS CENTER a.s. and content providers, https://www.blesk.cz/cla-nek/cestovani/444875/tajemstvi-amazonskeho-pralesa-odlehly-kmense-zivi-opicemi-na-nohou-maji-6-prstu.html]

Photo 125: A golden poison frog (Phyllobates terribilis). One of the most poisonous frogs of the family Dendrobatidae. [Source: Pho-125 - Author: Brian Gratwicke - https://www.flickr.com/photos/brian-gratwicke/3624354133/si-zes/o/in/photostream/. Created: 14 June 2009. License: CC BY 2.0, https://en.wikipedia.org/wiki/Phyllobates]

Photo 126: Leonardo da Vinci designed the cannon, which was movable to allow the angle and the height of the shot to be adjusted. From the cannon, it was also possible to fire cluster ammunition, which was split into a series of bomblets during the flight. [Source: Pho-126 - Author: Vincent Finnan, Leonardo Da Vinci: Weapons of war, C Copyright, 2008-2020, by Vincent Finnan, Italian-Renaissance-Art.com, https://www.italian-renaissance-art.com/Da-Vinciweapons.html\#gallery[pageGallery]/4/] 
Photo 127: A gas chamber in the Mauthausen concentration camp. [Source: Pho-127 - Author: Kasa Fue - Own work. File: KZ Mauthausen Gaskammer Sep 2020 1.jpg. Created: September 6, 2020. License: CC BY-SA 4.0. https://commons.wikimedia.org/wiki/Category:KZ Mauthausen concentration camp complex\#/media/File:KZ Mauthausen Gaskammer Sep 2020 1.jpg]

Photo 128: A can and Zyklon B (Cyclone B) substrate. [Source: Pho-128 - Author: Goku122. File: Cyklonb.JPG. Uploaded: December 17, 2007. License: CC BY-SA 3.0. https://commons.wikimedia.org/wiki/Zyklon_B\#/media/File:Cyklonb.JPG]

Photo 129: The consequences of the use of Iraqi chemical weapons, Halabja, 1988. [Source: Pho-129 - Authors: Minhaj Akreyi / Ekurd.net. Published: M arch 16,2013, Halabja 1988 - Poem in Ekurd Daily, Copyright (C) 1998-2020 Kurd Net巴. https://ekurd.net/mismas/articles/misc2013/3/state6929.htm\#Readmore]

Photo 130: The consequences of the use of Iraqi chemical weapons. [Source: Pho-130 - J R Army Med Corps: first published as 10.1136/jramc-148-04-05 on December 01, 2002. Downloaded from http://militaryhealth.bmj.com/ on February 20, 2021 by guest. Vesicants (Blister Agents), J R Army Med Corps 2002; 149: 358-370, Copyright @ 2021 BMJ Publishing Group Ltd., online ISSN: 2633-3775, https://militaryhealth.bmj.com/content/jramc/148/4/358.full.pdf]

Photo 131: The sarin gas attack on the Tokyo subway on March 20, 1995, Japan, and Shoko Asahara - the founder of the Aum Shinrikyo religious cult. [Source: Pho-131 - Author: reports by Staff Writers, Japan police turned away surrendering Aum fugitive: Tokyo (AFP) Januuary 03, 2012, Copyright 1995-2012 - Space Media Network, Agence FrancePresse and United Press International, https://www.spacewar.com/reports/Japan_police turned away_surrendering_Aum fugitive reports 999.html and Photo: Shoko Asahara, (C) EPA PHOTO JIJI PRESS - Author: (C) TASS, Russian news agency, Japan executes founder of Aum Shinrikyo doomsday cult, July 06, 2018, https://tass.com/world/1012147]

Photo 132: A chemical attack in Syrian Ghuta. [Source: Pho-132 - Author: Ashley Collman, Intelligence report says U.S. officials knew about nerve-gas attack in Syria three days before it killed over 1,400 people - including more than 400 children. Published: September 01, 2013 by Associated Newspapers Ltd, Part of the Daily Mail, The Mail on Sunday \& Metro Media Group, https://www.dailymail.co.uk/news/article-2408404/Intelligence-report-says-U-Sofficials-knew-nerve-gas-attack-Syria-days-killed-1-400-people-including-400-children.html]

Photo 133: Store of weapons with 780,000 shells stored with a total of 2,600 tonnes of mustard gas in Colorado. [Source: Pho-133 - Authors: US Government - http://www.cma.army.mil/pueblo.aspx. This image originally uploaded to EN Wikipedia as en: File: $155 \mathrm{mmMustardGasShells.jpg} \mathrm{by} \mathrm{en:} \mathrm{User:} \mathrm{Nabokov} \mathrm{September} \mathrm{25,} \mathrm{2009.} \mathrm{Created:}$ December 31, 2008. License: CC 0 Public domain, https://en.wikipedia.org/wiki/Chemical_weapon]

Photo 134: Store of weapons with 780,000 shells stored with a total of 2,600 tonnes of mustard gas in Colorado. [Source: Pho134 - Author: Emilie Arroyo. Deconstruction of aging chemical weapons set to begin at Madison Co. plant in 2019. Published: June 14, 2018 in A Gray Media Group, Inc. Station - C 2002-2021 Gray Television, Inc., https://www.wkyt.com/content/news/Deconstruction-of-aging-chemical-weapons-to-set-to-begin-at-Madison-Coplant-in-2019-485441611.html]

Photo 135: Zyklon B (cyanide compounds) from different manufacturers, used for gasification in concentration camps. [Source: Pho-135 - Author's archive]

Photo 136-1 and 136-2: Zyklon B (Cyclone B) was poured into gas chambers through this opening. Dachau. [Source: Pho-1361 and Pho-136-2 - Author's archive ]

Photo 137: An SS small room, from which a gas chamber could be observed through a small window, and carbon monoxide bottles. The Majdanek Concentration Camp. [Source: Pho-137 - Author's archive]

Photo 138-1 and 138-2: One of the five gas chambers. The clear Prussian blue stains (cyanide compounds) can be seen on the walls; the Prussian blue was used for fumigation. The ceiling opening to pour Zyklon B can be seen. The Majdanek Concentration Camp [Source: Pho-138-1 and Pho-138-2 - Author's archive]

Photo 139-1 and 139-2: The effect of a drop of sarin on the left eye of a rabbit; (1) a normal eye, (2) the constriction of the pupil - miosis after 5 minutes at a concentration of $5 \mu \mathrm{g} \cdot \mathrm{kg}^{-1}$. [Source: Pho-139-1 and Pho-139-2 - Author's archive]

Photo 140: Sarin poisoning, Syria 2013. [Source: Pho-140 - Author: Dominic Evans and Khaled Yacoub Oweis, Photo: Mohamed Abdullah / Reuters. Syrian forces kill 1300 in gas attack. Published: August 22, 2013 in Stuff, newstips@stuff.co.nz, https://www.stuff.co.nz/world/middle-east/9071902/Syrian-forces-kill-1300-in-gas-attack]

Photo 141: Sarin poisoning, Syria 2013. [Source: Pho-141 - Photo from videos: YouTube, opposition videos show Syria 'chemical attack victims' , Author's archive]

Photo 142: Sarin poisoning, Syria 2013. [Source: Pho-142 - Photo from videos: YouTube, opposition videos show Syria "chemical attack victims", Author's archive]

Photo 143-1 and 143-2: The Police used tear gas during the protests in Hong Kong. September 29, 2014. [Source: Pho-143-1 and Pho-143-2 - Author: Wally Santana, ČTK / AP, Hongkong zažil největší nepokoje za posledních 17 let. Published: September 29, 2014 in ČT24, C) Česká televize 1996-2021, https://ct24.ceska-televize.cz/svet/1015918hongkong-zazil-nejvetsi-nepokoje-za-poslednich-17-let]

Photo 144: An apparatus for measuring formaldehyde in the atmosphere. [Source: Pho-144 - Source: BQ16 instrument for measuring the content of formaldehyde (HCHO) and total volatile organic compounds (TVOC), (C) Trotec GmbH, 2021, https://cz.trotec.com/produkty-a-sluzby/merici-pristroje/emise/plynove-de-tektory/merici-pristroj-hchotvoc-bq16/]

Photo 145: Carbon tetrachloride extinguisher from the 1930s. [Source: Pho-145 Author: WolfgangS, Feuerlöscher aus den 1930er-Jahren. Created: July 11, 2007. License CC BY-SA 3.0, https://cs.wikipedia.org/wiki/Tetrachlormethan] 
Photo 146: Liquid chlorine. [Source: Pho-146 - Premium Metals India Pvt. Ltd., Mumbai, Maharashtra, India, ExportersIndia.com, Copyright (C) 1997 Weblink.In Pvt. Ltd., https://www.exportersindia.com/premium-metals-india-pvt3998641/liquid-chlorine-gas-2766763.htm]

Photo 147: Solid chlorine at a temperature of $-150{ }^{\circ} \mathrm{C}$. [Source: Pho-147 - Author: Alexander C. Wimmer, Festes Chlor bei $150^{\circ} \mathrm{C}$. Created: December 08, 2011. License CC BY-SA 3.0, https://de.wikipedia.org/wi-ki/Chlor]

Photo 148: The massive eruption of hydrogen sulphide $\left(\mathrm{H}_{2} \mathrm{~S}\right)$ gases photographed from a shuttle in December 1985 near the coast of Namibia. [Source: Pho-148 - Author: unknown - Highly reflective feature photographed from the Space Shuttle in December 1985 off the coast of Namibia, showing massive gas eruptions of hydrogen sulphide $\left(\mathrm{H}_{2} \mathrm{~S}\right)$. Walvis Bay is on the coast at lower right. License CC0 PD NASA, https://commons.wikimedia.org/wiki/File:Namibia notbloom.jpg\#mw-jump-to-license]

Photo 149: The gas attack on German units (the Western Front near Sedan, May 1917). [Source: Pho-149 - Photos: THE GERMAN ARMY ON THE WESTERN FRONT, 1914-1918 - German stormtroopers manning a trench behind a smoke screen. Note they all wear gas masks. Near Sedan, May 1917. Imperial War Museums, C IWM 2021 Q 45340, https://www.iwm.org.uk/collections/item/object/205222944]

Photo 150: An ammonia leakage at Medlov and a decontamination tent. [Source: Pho-150 - Author: Ltc. Vladimíra Hacsiková, spokesperson of the Olomouc Region Fire and Rescue Service. V Medlově unikl čpavek. Published: January 2014 in the website of the Olomouc Region Fire and Rescue Service, (C) 2020 General Directorate of the Fire and Rescue Service of the Czech Republic, https://www.hzscr.cz/clanek/v-medlove-unikl-cpavek.aspx]

Photo 151: Firefighters work to neutralize hydrochloric acid. [Source: Pho-151 - Author: ČTK, Ijš. Na D1 se převrátila cisterna s kyselinou, dálnice je uzavřena. Published: January 21, 2014 in the Blesk.cz, (C) 2001-2021 Copyright CZECH NEWS CENTER a.s. and content providers, https://www.blesk.cz/cla-nek/zpravy-udalosti/229540/na-d1-se-prevratila-cisterna-s-kyselinou-dalnice-je-uzavrena.html]

Photo 152: Chemical accident in the Hungarian town of Ajka in 2010. [Source: Pho-152 - Author: Jesse Allen - NASA Earth Observatory. Natural-colour image of the area surrounding the toxic sludge spill in Hungary. The alumina plant appears along the right edge of the image and incorporates both bright blue and brick red reservoirs. The sludge forms a red-orange streak running west from the plant. This view shows the spill thinning but remaining discernible for several kilometres to the west. Created: October 09, 2010. License: CC0 - Public domain, https://en.wikipedia.org/wiki/Ajka alumina plant accident]

Photo 153: Chemical accident in the Hungarian town of Ajka in 2010. [Source: Pho-153 - Author: Ministry of Public Administration and Justice, Ministry for Government Communication - Ministry of Public Administration and Justice, Ministry for Government Communication "Red sludge" alumina plant accident, Devecser, Hungary. Created: October 13, 2010. License: CC0 - Copyrighted free use, https://en.wikipedia.org/wiki/Ajka alumina plant accident]

Photo 154: Hundreds of firefighters and CBRN defence troop soldiers are extinguishing the fire. [Source: Pho-154 - Author: admin. Самые мощные неядерные взрывы, от которых пострадали целые города. Published: June 24, 2020 in the BillionNews.ru, (C) COPYRIGHT (C) 2020. ИНЕTЕСНЫЕ ФАКТЫ, https://billionnews.ru/9688-samyemoschnye-neyadernye-vzryvy-ot-kotoryh-postradali-celye-goroda.html]

Photo 155-1 up to 155-6: The progression of the first explosion in the warehouse in the Chinese port of Tianjin on August 12 , 2015. [Source: Pho-155-1 to Pho-155-6 - Author of the paper: Vít Hofman. Masivní exploze v př́stavu Tchien-t’in 2015. Published: December 08, 2019 in the BOZPForum.cz. Author video: Youtoobe / MrPyroCZ. The explosion in China - all in one video, https://www.bozpforum.cz/2019/12/08/masivni-exploze-v-pristavu-tchien-tin-2015/]

Photo 156: Hundreds of firefighters and CBRN defence troop soldiers are extinguishing the fire. [Source: Pho-156 - Author: admin. Самые мощные неядерные взрывы, от которых пострадали целые города. Published: June 24, 2020 in the BillionNews.ru, (C) COPYRIGHT (C) 2020. ИНЕTЕСНЫЕ ФАКТЫ, https://billionnews.ru/9688-samyemoschnye-neyadernye-vzryvy-ot-kotoryh-postradali-celye-goroda.html]

Photo 157: Hundreds of firefighters and CBRN defence troop soldiers are extinguishing the fire. [Source: Pho-157- Author: admin. Самые мощные неядерные взрывы, от которых пострадали целые города. Published: June 24, 2020 in the BillionNews.ru, (C) COPYRIGHT (C) 2020. ИНЕTECHЫЕ ФАКТЫ, https://billionnews.ru/9688-samyemoschnye-neyadernye-vzryvy-ot-kotoryh-postradali-celye-goroda.html]

Photo 158: A photo of the Unipetrol fire taken by one of the readers. [Source: Pho-158 - Author of the paper: David Klempír. Lékař z okolí Unipetrolu: Na krizovou situaci v chemičce nejsme připravení. Published: August 15, 2015 in the BLESK.cz, (C) 2001-2021 Copyright CZECH NEWS CENTER a.s. and content providers, Author video: Twitter, Instagram, Požár chemičky v Litvínově. https://www.blesk.cz/clanek/zpravy-udalosti/336986/lekar-z-okoliunipetrolu-na-krizovou-situaci-v-chemicce-nejsme-pripraveni.html]

Photo 159: A photo of the Unipetrol fire taken by one of the readers. [Source: Pho-159 - Author: ok, Novinky, ČTK. Plameny šlehaly nad komíny. Kamera zachytila litvínovskou chemičku krátce po výbuchu. Photo published from video: August 15, 2015 in the Novinky.cz, Copyright (C) 2003-2021 Borgis a.s., Copyright (C) 2019-2021 Seznam.cz a.s., Copyright (C) ČTK, DPA, Reuters and photobank Profimedia, https://www.novinky.cz/krimi/clanek/plamenyslehaly-nad-kominy-kamera-zachytila-litvinovskou-chemicku-kratce-po-vybuchu-40258378] 


\section{Literature}

\subsection{Selection of Publications}

[1] BULÍKOVÁ, Táňa. Medicína katastrof. Liberec: Ing. Martin Farkaš, KD Osvěta, 2011, 408 s. ISBN: 978-80-8063-361-5.

[2] ČESKÁ REPUBLIKA. Ministerstvo obrany ČR. Katalog materiálu k ochraně proti ZHN. Praha: Vláda ČR, 2001.

[3] ČESKÁ REPUBLIKA. Ministerstvo obrany ČR. Zásady ochrany proti zbraním hromadného ničení. Předpis: Vševojsk-2-1. Praha: Vláda ČR, 2006.

[4] ČESKÁ REPUBLIKA. Ministerstvo obrany ČR - Úřad pro obrannou standardizaci, katalogizaci a státní ověřování jakosti. Český obranný standard - ČOS 999935: , Vliv okolního prostředi na vojenskou techniku. Podmínky elektrického a elektromagnetického prostředi “". Praha: Vláda ČR, 2013, 2. vydání, 104 s.

[5] ČESKÁ REPUBLIKA. Ministerstvo obrany ČR - Úřad pro obrannou standardizaci, katalogizaci a státní ověřování jakosti. Český obranný standard - ČOS 999935: „Požadavky na konstrukci bojových vozidel ke zlepšeni ochrany před účinky ionizujícího zárení ". Praha: Vláda ČR, 2009, 1. vydání, 24 s.

[6] ČESKÁ REPUBLIKA. Ministerstvo vnitra - Hlavní úřad civilní ochrany. Civilní ochrana v České republice. Praha: Vláda ČR, 1995, s. 56.

[7] ČESKÁ REPUBLIKA. Ministerstvo vnitra - Generální ředitelství HZS. Civilní ochrana. Lázně Bohdaneč: Institut civilní ochrany České republiky, 1998, s. 79.

[8] ČESKÁ REPUBLIKA. Ministerstvo vnitra - generální ředitelství HZS České republiky. Pro př́pad ohroženi (přiručka pro obyvatele). Praha: Vláda ČR, 2001, s. 16.

[9] ČESKÁ REPUBLIKA. Ministerstvo vnitra - Generální ředitelství Hasičského záchranného sboru ČR. Katalog typových činností IZS ,,Uskutečněné a ověrené použití radiologické zbraně STČ - 01/IZS“. Praha: Vláda ČR, 2005. 196 s., ISBN 80-86640-55-8.

[10] ČESKÁ REPUBLIKA. Ministerstvo vnitra - generální ředitelství HZS České republiky. Sebeochrana obyvatelstva. Praha: Vláda ČR, 2001, s. 40.

[11] ČESKÁ REPUBLIKA. Ministerstvo zahraničních věcí ČR: Bezpečnostní strategie ČR 2015. Praha: Vláda ČR, únor 2015. 24 s. ISBN 978-80-7441-005-5.

[12] ČESKÁ REPUBLIKA. Státní úřad pro jadernou bezpečnost. Radiační ochrana, doporučení. Postup při záchytu radioaktivních materiálì. Principy a praxe radiační ochrany. Praha: 2002 (modrá řada).

[13] ČESKÁ REPUBLIKA. Vláda ČR. Zákon č. 18/1997 Sb., „Zákon o mírovém využívání jaderné energie a ionizujícího záření (atomový zákon) a o změně a doplnění některých zákonů“.

[14] ČESKÁ REPUBLIKA. Vláda ČR. Zákon č. 263/2016 Sb., „Zákon atomový zákon a o změně a doplnění některých zákonů“.

[15] DUŠEK, J. a J. PÍŠALA. Jaderné zbraně. Praha: Computer press, 2006. 88 str. ISBN 80251-0817-1.

[16] FLORUS, S. Charakteristika zbrani hromadného ničení, nebezpečných škodlivin a zápalných látek I, (Charakteristika ZHN). Skripta. Vyškov: VVŠ PV, 2002. 266 s.

[17] FLORUS, S. Charakteristika zbrani hromadného ničení, nebezpečných škodlivin a zápalných látek II, (Charakteristika škodlivin). Skripta. Vyškov: VVŠ PV, 2003. 112 s. 
[18] GILCOV, L., L. OSIPENKO a N. MORMUL. Podmořská atomová dramata: Úspěchy, nezdary a katastrofy utajované po třicet let. [Z franc. org. přel. Miroslav Brož, Spolupr. Jean-Charles Deniau]. Vimperk: 1994, PAPYRUS, 283 s. ISBN 80-85776-22-7.

[19] HÁLA, J. Radioaktivita, ionizující záření, jaderná energie. Brno: Nakladatelství Konvoj, spol. s.r.o., 1998. 311 s. ISBN 80-85615-56-8.

[20] JANEČEK, F., J. MARUŠÁK, a J. BALÁŠEK. CO-6-1/č př́prava, projektování a výstavba protiradiačních úkrytů (Předpis). Praha: Ministerstvo národní obrany, 1978. 50s.

[21] KLENER, V. a kol. Hygiena záření. Praha: Nakladatelství Avicenum, 1988.

[22] KMENTA. J., J. VALO a P. ŽELINSKÝ. Pouštní horečka. Praha: Želinský 1492, 1999. ISBN 80-238-3453-3.

[23] KOHOUTEK, J. Prostředky pro ochranu proti zbraním hromadného ničení a chemickému nebezpeči. Praha: Ministerstvo obrany, 2005.

[24] Kolektiv: Jaderné zbraně a ochrana obyvatelstva a národního hospodářství proti jejich ničivým účinkưm, pomůcka pro př́pravu lektorů, instruktorů a cvičitelü CO a príslušníků nevojenských sil CO ČSSR. Praha: 1988, Naše vojsko, 384 stran.

[25] KRATOCHVÍLOVÁ, D. Ochrana obyvatelstva. Ostrava: SPBI, 2005. 140 s., ISBN 8086634-70-1.

[26] KUNA, P. Chemická radioprotekce. Praha: Avicenum, 1985. 148 s., ISBN 08-078-85.

[27] LINHART, P. a B. ŠILHÁNEK. Ochrana obyvatelstva v Evropě. Praha: Ministerstvo vnitra - Generální ředitelství Hasičského záchranného sboru ČR, 2005. 196 str. ISBN 8086640-55-8.

[28] MAJER, V. a kol. Základy jaderné chemie. Praha: SNTL, 1981.

[29] MALINOVSKÝ, K. a P. ŠIMÁČEK. Jak dále v ochraně obyvatelstva? Zlín: 2002, Krajský úřad Zlínského kraje a Hasičský záchranný sbor Zlínského kraje, s. 23.

[30] MARTÍNEK, B. a kol. Ochrana člověka za mimořádných událostí. Praha: Ministerstvo vnitra - Generální ředitelství Hasičského záchranného sboru ČR, 2003. 119 s., ISBN 8086640-08-6.

[31] MATOUŠEK, J., J. ÖSTERREICHER a P. LINHART. CBRN-jaderné zbraně a radiologické materiály. Ostrava: SPBI Spektrum, 2007. 216 s. ISBN 978-80-7385-029-6.

[32] McCRACKEN, G. M. a P. E. STOTT. Fúze: energie vesmíru. Vyd. 1. Praha: Mladá fronta, 2006, 324 s., [16] s. barev. obr. př́l. ISBN 80-204-1453-3.

[33] MIKA O. J., I. MAŠEK, I. a M. ZEMAN. Prevence závažných průmyslových havárií. Prevence závažných průmyslových havárií. 01. Brno: 2006, Vysoké učení technické, Chemická fakulta. s. 108. ISBN: 80-214-3336-1.

[34] MIKA O., L. POLÍVKA a J. SABOL. Zbraně hromadného ničení a ochrana proti jejich účinkům. Praha: 2009, Policejní akademie ČR. ISBN: 978-80-7251-302-4.

[35] MIKA O. J., M. ZEMAN a L. POLÍVKA. Základy ochrany před zbraněmi hromadného ničení. Brno: 2011, Vysoké učení technické v Brně, Fakulta chemická, ISBN: 978-80214-4263-4.

[36] MOHYLA V., ŠUFAJZL V. a kolektiv. Taktické jaderné prostředky ČSLA. Praha: Československý spisovatel s.r.o., 2012, 272 s. ISBN: 978-80-7459-111-2.

[37] MOHYLA V. SCUD a OKA ve službách ČSLA, když na nás mírily jaderné zbraně Západu. Praha: Levné knihy KMa, 2012, 290 s. ISBN: 978-80-87391-48-8.

[38] PIJÁK, A. Dozimetrie ionizujícího záření - veličiny a jednotky (Skriptum). Vyškov: Vysoká vojenská škola, 1987. Pčt.2811/1. 
[39] PITSCHMAN, V. Jaderné zbraně: Nejvyšši forma zabijení. Praha: Naše vojsko, 2005, ISBN 80-206-0784-6.

[40] PRINC, I. Ochrana proti zbraním hromadného ničení. Projekt OPVK „Inovace a rozvoj výuky bezpečnosti se zaměřením na krizové rrízení“ Studijní texty, CZ.1.07/2.2.00128.0185, Uherské Hradiště, 2014, 332 s.

[41] PRINC Ivan. Desert Shield and Desert Storm 1990-1991 Memories of Participant Gulf War. Brno: Univerzita obrany. OBRANA A STRATEGIE-DEFENCE \& STRATEGY. Volume: 17, Issue: 2, Pages: 5-25. DOI: https://doi.org/10.3849/18027199.17.2017.02.005-026.

[42] PROUZA, Z. a J. ŠVEC. Zásahy při radiační mimořádné události. Ostrava: SPBI, 2008. 125 s., ISBN 978-80-7385-046-3.

[43] RAK Jakub, Petr SVOBODA, Dušan VIČAR, Ivan PRINC a Markéta HABROVÁ. Design of the Data Model for Information Support in the Field of Civil Protection of Municipalities. WSEAS Transactions on Environment and Development, ISSN / E-ISSN: 1790-5079 / 2224-3496, Volume 15, 2019, Art. \#34, pp. 311-318. Available at: https://www.wseas.org/multimedia/journals/environment/2019/a665115-428.pdf

[44] RICHTER, V. Výkladový slovník krizového ř́zení. Praha: Ministerstvo vnitra - Generální ředitelství Hasičského záchranného sboru ČR, 2010. ISBN 978-80-86640-54-9.

[45] ŘÍPA, M. a kol., Řizená termojaderná fúze pro každého - 4U. 4., rozš. a čísl. vyd. Praha [i.e. Ostrava]: Vítkovice - výzkum a vývoj - technické aplikace, 2013. ISBN 80-2041453-3.

[46] SIČÁK, P. Obrana, bezpečnost a krizový management. Vyškov: 2000, VVŠ PV, skripta, 98 stran.

[47] SOUKUP, V. a kolektiv. Zbraně hromadného ničení a ochrana proti nim. Brno: Vojenská akademie, 1985, učebnice VOI oborů, I. díl, 242 stran.

[48] SOUKUP, V. a kolektiv. Zbraně hromadného ničení a ochrana proti nim. Brno: Vojenská akademie, 1985, učebnice VOI oborů, II. díl, 160 stran.

[49] STŘEDA, L. Kontrola šíření zbrani hromadného ničení. Vyškov: Vysoká vojenská škola pozemního vojska, 2001, Habilitační práce, 162 stran.

[50] ŠENOVSKÝ, M., P. ŠENOVSKÝ a V. ADAMEC. Ochrana kritické infrastruktury. Ostrava: SPBI, 2007. 141 s., ISBN 978-80-7385-025-8.

[51] ŠPIČÁK, F., V. ČABLA, M. PAŘÍZEK a L. DOBROVOLSKÝ. Technické základy OPZHN a chemického zabezpečeni III. Vyškov: 1989, VVŠ PV, skripta, 95 stran.

[52] ŠTĚPÁNEK K. a P. MINAŘIIK. Československá lidová armáda na Rýnu. Praha: Naše vojsko, 2007, s348 s. ISBN: 80-206-0832-X.

[53] ŠTĚTINA, J. a kol. Medicina katastrof a hromadných neštěstí. Praha: Grada 2001. 436 s., ISBN 80-7169-688-9.

[54] TRTÍLEK, L. NN 30 0101: Chemické vojsko, názvoslovná norma. Praha: 2002, Ministerstvo obrany ČR, 202 stran.

[55] TƯMA, M. a kol. Nešiřrení zbraní hromadného ničení v kontextu aktuálních otázek mezinárodní bezpečnosti a boje proti terorismu. Brno: Ústav strategických studií Univerzity obrany, 2004-233 s. ISBN: 80-85960-90-7.

[56] TŮMA M. Jaderné odzbrojení. Utopie, nebo projev politického realismu? Praha: Ústav mezinárodních vztahů, v. v. i., Tisk: Petr Dvořák - Tiskárna, Dobř́̌šs, 2011. 224 s. ISBN 978-80-86506-96-8. 
[57] VIČAR Dušan, Jan STROHMANDL, Ivan PRINC, Jakub RAK, Ivan MAŠEK a Danuše ULČÍKOVÁ. Vzdělávání v oblasti bezpečnosti a ochrany obyvatelstva. Institut ochrany obyvatelstva Lázně Bohdaneč: The Science for Population Protection 1/2016, Volume 8, 2016, str. 77-88. ISSN 1803-568X. Available at: http://www.population-protection.eu/prilohy/casopis/31/235.pdf.

[58] VIČAR, D., J. DVOŘÁK a S. FLORUS. Chemické vojsko a ochrana životního prostředí. Praha: 1994, Ministerstvo obrany ČR, 116 stran.

[59] VIČAR, Dušan a Stanislav FLORUS. Dlouhodobějši trendy vývoje a rozvoje v oblasti zbrani hromadného ničení, jejich detekce, identifikace a ochrana proti jejich následküm. (Výzkumná zpráva VGA ÚSS VA v Brně). Vyškov: Vysoká vojenská škola, 2003. $98 \mathrm{~s}$.

[60] VIČAR, Dušan, Stanislav FLORUS a Petr ŽUJA. Trendy vývoje v oblasti zbrani hromadného ničení a ochrany proti jejich následkưm s důrazem na uplatnění v oblasti CBRN zvolněných mobilnich prvki̊ pro krizové situace. (Studie). Vyškov: Ústav ochrany proti ZHN, 2008. $122 \mathrm{~s}$.

[61] ZAHRADNÍČEK, P. a M. RAUS. Technické základy OPZHN a chemického zabezpečení, část jaderné zbraně. Vyškov: 1986, VVŠ PV, skripta, 114 stran.

[62] ZAHRADNÍČEK, P. Havárie (destrukce) jaderných energetických zařizení. Vyškov: 1993, VVŠ PV, skripta, 90 stran.

[63] ZEMAN, M. a O. J. MIKA. Ochrana obyvatelstva. Brno. Vysoké učení technické v Brně, Fakulta chemická, 2007, ISBN 978-80-214-3449-3.

\subsection{Selection of Articles}

[1] DVOŘÁK, I. Pražská iniciativa v oblasti obrany proti zbraním hromadného ničení. Armáda České republiky dnes, 2002, č. 4, 10.

[2] FREEDMAN, L. War in Iraq: Selling the Threat. Survival, Vol. 46, No. 2, Summer 2004, S 30.

[3] LEWIS, M., S. Zbraně hromadného ničení, V knize neblahého odkazu dvacátého století se otevírá nová a hrozivá kapitola. Praha: 2002, National Geographic, Česká republika, listopad, 108-141.

[4] MIKA O. J. Aktuální hrozba jaderné apokalypsy. In Sborník mezinárodní konference Bezpečnostní management a společnost. Brno: 2013, Universita obrany, s. 337-343. ISBN: 97880-7231-928-2.

[5] PROCHÁZKA, J. Specializace Armády České republiky pokračuje. Armáda České republiky dnes, 2002, č. 4, 12-13.

[6] PROUZA, Z. Radiační nehody na pracovištích se zdroji ionizujícího záření. Bezpečnost a ochrana zdraví při práci v praxi. 9/2009.

[7] REVUE POLITIKA. Špinavá bomba-perspektivní zbran̆ teroristů. Analýza Centra strategických studií. Brno: Centrum pro studium demokracie a kultury /CDK). ISSN 1803-8468.

[8] VIČAR, D. a O. MIKA. Zranitelná mista kritické infrastruktury společnosti. In Sborník z konference Zásah 2011 na téma: „Aktuální problémy řešení mimořádných událostí na teritoriu územně samosprávných celkư “. Jihlava: Vysoká škola polytechnická, 1. červen 2011, s. 209-216. ISBN 978-80-87035-38-2.

\subsection{Domestic and Foreign Periodicals}

[1] Acta Medica

[2] Armáda České republiky dnes 
[3] A-Report

[4] Bezpečnost a ochrana zdraví při práci v praxi

[5] Civilní obrana

[6] Časopis 112

[7] Historie a vojenství

[8] Jane's Defence Weekly

[9] Jane's Intelligence Review

[10] Mezinárodní politika

[11] National Geographic

[12] Nature

[13] NBC Defence and Technology

[14] New Scientist

[15] Obrana a strategie

[16] Revue Politika

[17] Science

[18] Soudní lékařství

[19] Survival

[20] Vojenské rozhledy

[21] Vojenské zdravotnické listy

[22] Zpravodaj Civilní ochrany

\subsection{Electronic Sources}

[1] Federal Emergency Management Agency (USA): www.fema.gov.

[2] Federal Bureau for Investigation (USA): www.fbi.gov.

[3] Central Intelligence Agency (USA): www.cia.gov.

[4] State Department (USA): www.state.gov.

[5] The Applied Science and Analysis, Inc. (USA): www.asanltr.com.

[6] Stockholm International Peace Research Institute (Švédsko): www.sipri.se.

[7] Wilton Park, Winston House (Velká Británie): www.wiltonpark.org.uk.

[8] ISI: http://isinet.com.

[9] Australská skupina: http://www.australiagroup.net/.

[10] Portál veřejné správy ČR: http://portal.gov.cz.

[11] Evropská komise: http://ec.europa.eu/.

[12] Předpisy EU: http://eur-lex.europa.eu/cs/index.htm.

[13] Státní úřad pro jadernou bezpečnost: http://www.sujb.cz/.

[14] Severoatlantická aliance (NATO): http://www.nato.int/.

[15] Organizace spojených národů (OSN): http://www.un.org/.

[16] Státní úložiště radioaktivního odpadu: http://www.surao.cz.

[17] MAAE: http://www.iaea.orghttps://cs.wikipedia.org.

[18] http://www.nti.org. 
[19] http://www.cez.cz.

[20] https://catalog.archives.gov.

[21] http://collections.naval.aviation.museum.

[22] http://military.tomsk.ru.

[23] http://www.cernobyl-1986.eu.

[24] http://files.cernobyl-fukusima.webnode.cz.

[25] http://www.novinky.cz.

[26] https://www.wikimedia.org.

[27] http://www.wikimedia.cz.

\subsection{Foreign sources}

[1] ANDERSON, K. G. Radioactive contamination in urban areas. J. Environ. Radioactivity, vol. 85, s. 151-153, 2006.

[2] DALTON, R. Dirty bomb scare prompts clampdown on lab security. Nature, vol. 417, p. $776,2002$.

[3] EDWARDS, R. Dirty bomb. New Scientist, vol. 174, pg. 42- 45, 2002.

[4] INTERNATIONAL ATOMIC ENERGY AGENCY. IAEA-TECDOC-1242: Inventory of accidents and losses at sea involving radioactive material. Vienna: IAEA, 2001. ISSN $1011-4289,76 \mathrm{pg}$.

[5] INTERNATIONAL ATOMIC ENERGY AGENCY. IAEA - TECDOC 953: Methods for the development of emergency response preparedness for nuclear or radiological accidents. Vienna 1997, $128 \mathrm{pg}$.

[6] INTERNATIONAL ATOMIC ENERGY AGENCY. International Basic Safety Standards for Protection against Ionizing Radiation and for the Safety of Radiation Sources. Vienna: 1996, International Atomic Energy Agency, p. 354.

[7] INTERNATIONAL ATOMIC ENERGY AGENCY. Source not under control in Mexico. Available at: http://rpop.iaea.org/RPoP/RPoP/Content/Documents/Trai-ningAccidentPrevention/Lectures/AccPr 6.02 Source not under_control Mexico_WEB.ppt.

[8] INTERNATIONAL ATOMIC ENERGY AGENCY. The Radiological Accident in Goiania Vienna: IAEA, 1988. STI/PUB/815.

[9] INTERNATIONAL ATOMIC ENERGY AGENCY. The Radiological Accident in Istanbul. Vienna: IAEA, 2000. STI/PUB/1102.

[10] INTERNATIONAL ATOMIC ENERGY AGENCY. The Radiological Accident in Samut Prakarn. Vienna: IAEA, 2002. STI/PUB/1024.

[11] INTERNATIONAL ATOMIC ENERGY AGENCY. The Radiological Accident in Tammiku. Vienna: IAEA, 1998. STI/PUB/1053.

[12] INTERNATIONAL ATOMIC ENERGY AGENCY. The Radiological Accident in Lilo. Vienna: IAEA, 2000. STI/PUB/1097.

[13] INTERNATIONAL ATOMIC ENERGY AGENCY. How to recognize and initially respond to an accidental radiation Indry. IAEA, Vienna, 2000. Available at: http://wwwpub.iaea.org/MTCD/publications/PDF/IAEA-WHO-L-Eng.pdf.

[14] INTERNATIONAL ATOMIC ENERGY AGENCY. Lessons Learned from Accidental Exposures in Radiotherapy. Safety Reports Series, No. 17, Vienna: IAEA, 2000. 
[15] JOHNSTON, R.: Database of Radiological Incidents and Related Events, modified 17 Feb. 2008. Vienna: IAEA, 2008. Available at: http://www.johnstons-archive.net/nuclear/radevents/index/.

[16] NATO Handbook. NATO Office of Information and Press. Brussels, 1995, p. 277 - 282.

[17] NATO Handbook. NATO Office of Information and Press. Brussels, 2001, p. 144.

[18] NUCLEAR ENERGY INSTITUTE. Medicine \& Scientific Research. Available at: http://www.nei.org/howitworks/medicineandscientificresearch/.

[19] Uses of Nuclear Energy: http://www.buzzle.com/articles/uses-of-nuclear-energy.html.

[20] Utajené nehody nukleárních zbraní - dokument. Available at: http://do-kumenty.tv/category/technika/?orderby $=$ comments.

[21] Testimony of Dr. Henry Kelly, President Federation of American Scientists before the Senate Committee on Foreign Relations. March 6, 2002, 1-14 pg.

[22] Unclassified Report to Congress on the Acquisition of Technology Relating to WMD and Advanced Conventional Munitions. Available at website: www.cia.gov/cia/publications/bian/bian_jan_2003.htm.

[23] Unclassified Report to Congress on the Acquisition of Technology Relating to WMD and Advanced Conventional Munitions. Available atwebsite: www.cia.gov/cia/publications/bian/bian jan 2003.htm.

\subsection{Primary information about the authors}

\section{Doc. Ing. Ivan Mašek, CSc. (1949)}

He is an academic at the Tomas Bata University in Zlín, the Faculty of Logistics and Crisis Management in Uherské Hradiště, the Department of Population Protection. From 1992 to 2008, he was an academic at the Brno University of Technology, the Faculty of Chemistry, the Institute of Chemistry and Environmental Protection.

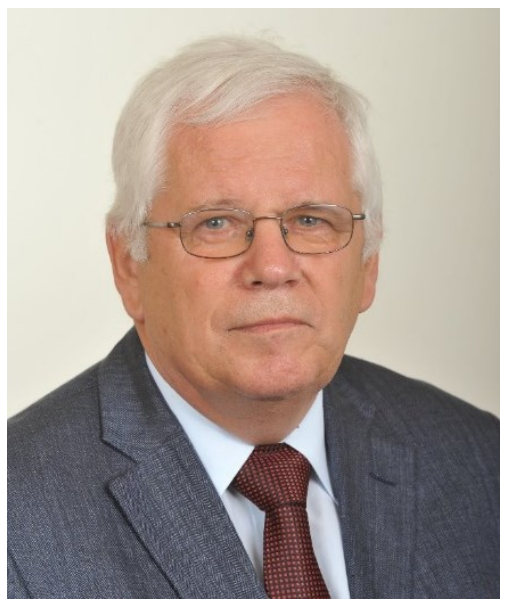

In 1976, he graduated from the Antonin Zapotocky Military Academy in Brno, chemical engineering branch of study; from 1990 to 1992, he studied English language at the Military Academy in Brno; from 1989 to 1992, he completed part-time postgraduate studies "Modern Instrumental Methods" at the Slovak Technical University in Bratislava; from 1985 to 1992, he became involved in the external research training at the Antonin Zapotocky Military Academy in Brno, he became a candidate of technical sciences in the "Weapons of Mass Destruction and Protection against Them" branch of study, in 2000, he earned his higher doctorate at the Military Academy in Brno in the „State Defence Theory” branch of study. He is an author and co-author of dozens of publications for international conferences and technical journals in the field of highly toxic chemicals and environmental protection, population protection, toxic waste dumps, electronic waste recycling; he is an author and co-author of 5 patents; currently, he deals with the issues of security and population protection, highly toxic chemicals, weapons of mass destruction and protection against them, individual and collective protection of personnel, crisis management and contingency planning. $\mathrm{He}$ is a founder of bachelor's study programme entitled "Population Protection". 


\section{Doc. Ing. Otakar Jiří Mika, CSc. (1953)}

Since September 1, 2014, he has been working at the Tomas Bata University in Zlín, the Faculty of Logistics and Crisis Management in Uherské Hradiště, the Department of Population Protection. Here, he works as a lecturer - associate professor and teaches the issues of population protection in the bachelor's study programme. He is a supervisor and an external examiner of bachelor's final projects of students. He works on various security projects. He has been teaching at universities for 20 years.

In 1977, he graduated from the Antonin Zapotocky Military Academy in Brno in the branch of chemical engineering. Then, he held military-professional positions in the 19th Motorized Rifle Division in Plzeň, he worked there for nine years. On completion of the internal research assistantship (from 1986 to1989) led by Professor Ing. Jiřr Matoušek, DrSc. at the Antonin Zapotocky Military Academy in Brno, he earned a title of candidate of technical sciences (CSc.) in the branch of "Protection against Weapons of Mass Destruction" on December 12, 1990.

In 2013, he earned his higher doctorate in the branch of "Crisis Management and Criminal Science" at the Police Academy of the Czech Republic. Population protection, chem-

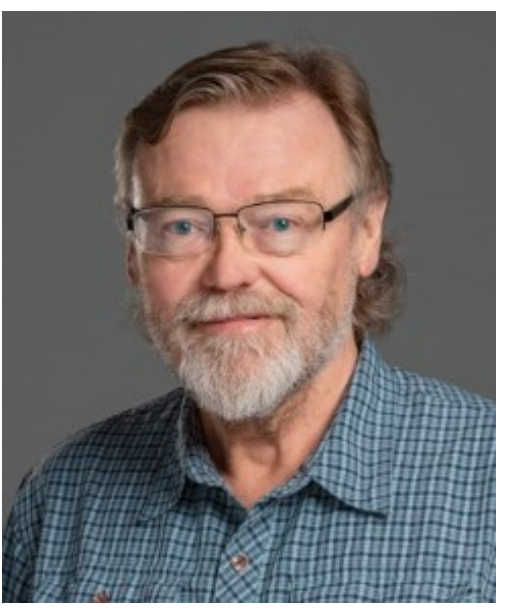
ical security, protection against weapons of mass destruction, CBRN terrorism and protection against it and other related branches fall into his specialization.

Since 2008 to the present, he has been a forensic expert in the issues of impacts of major chemical accidents. Since 2013, he has been a professionally qualified person for the field of radiation protection.

He has published more than 350 technical articles and reports, of which 26 titles are university textbooks in the Czech Republic and Slovakia. He has also published technical articles in 11 foreign countries. As a leader or a member of a team of authors he has worked on some projects aimed at security issues with different focus.

Since 1998, he has been a member of the Czech Chemical Society and since 2011 he is a member of the Civil Protection Association of the Czech Republic.

\section{Ing. Ivan Princ (1968)}

He graduated from the Military University of the Ground Forces in Vyškov (1986-1990), where he acquired a university qualification in the "Command-Engineering - Military Chemistry" branch of study and subsequently worked in the army for more than 20 years. He served in professional positions in the ground forces, especially in the 7th Mechanized Brigade in Hranice na Moravě for 19 years with the tasks aimed at the following: "The management of individual subsystems within the brigade with the responsibility for brigade tasks, the support of combat and mobilization readiness and the training of subordinate chemical units, the organization and management of the brigade chemical support and special training of brigade members."

He worked as a lecturer of the Military Strategy and Operational Art Group at the Department of Martial Art Studies at the Institute for Strategic and Defence Studies (chemical expertise) at the University of Defence in Brno (2009-2010). 


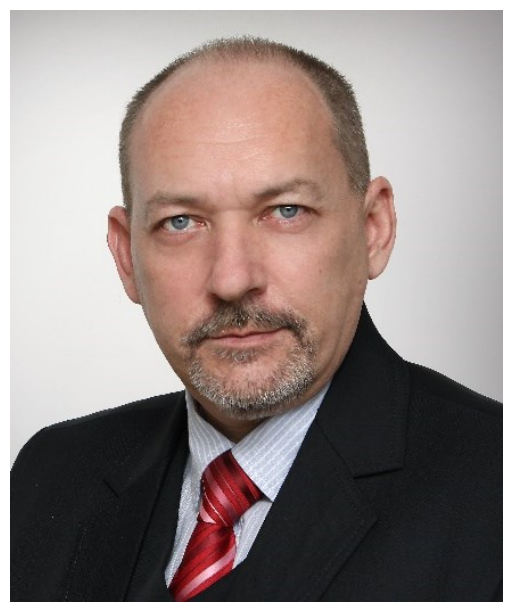

Between 1990 and 1991, he took part in the Desert Storm and Desert Shield combat missions in Saudi Arabia and Kuwait as a member of the 1st special Czechoslovak NBC Defence Battalion where chemical weapons were detected. In 2002, he took part in the ISAF 2 foreign security mission in Kabul, Afghanistan, in the professional position (expert adviser to the commander of the contingent in the area of Protection against Weapons of Mass Destruction and the Protection of Troops) in the 11th Field Hospital Headquarters.

Since September 1, 2012, he has been working as an assistant lecturer at the Tomas Bata University in Zlín, the Faculty of Logistics and Crisis Management (the Department of Population Protection). He teaches the issues of population protection in the bachelor's study program. He is a supervisor and an external examiner of bachelor's final projects of students. His research and pedagogical practice at universities lasts 10 years.

He has published technical articles and expert reports. He has developed a number of internal military regulations, aids and publications. He has worked as a leader or a member of the team of authors on a few technical military and civilian projects focused on security issues with different aspects.

\section{Prof. Ing. Dušan Vičar, CSc. (1953)}

He is a researcher and educationalist, with many years of experience in performing academic positions and managing research teams, when working on research projects and research intents. Currently, he holds the position of the Director of the Department of Population Protection at the Faculty of Logistics and Crisis Management at the Tomas Bata University in Zlín.

$\mathrm{He}$ is a graduate from the Antonin Zapotocky Military Academy in Brno, branch of chemical engineering (1977); from 1983 to 1988, he was involved in external research training at the Antonin Zapotocky Military Academy in Brno in the branch of „Operational and Combat Employment of Army Branches, Special Technical and Logistic Support"; in 1992, he earned his higher doctorate in the "Weapons and Protection against Them" branch of study at the Military University of the Ground Forces in Vyškov; in 2004, he became a professor in the procedure for the appointment to a professorship in the branch of "Protection of Troops and Population" at the Military University of the Ground Forces, Vyškov.

$\mathrm{He}$ is a member of many Branch and Academic Councils

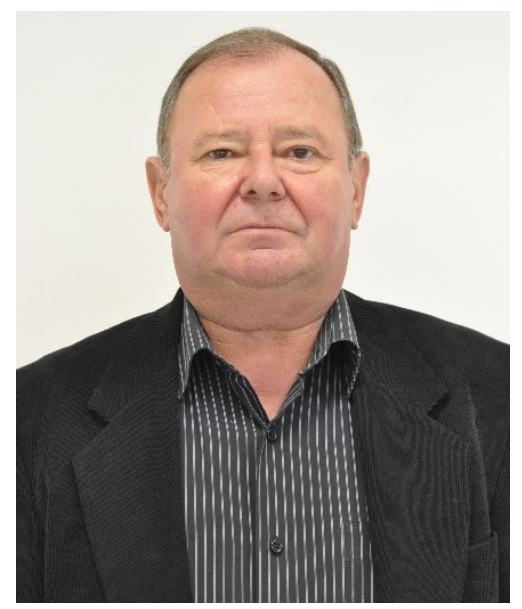
and Editorial Boards, a member of a Work Group in the field of education in "Security Branches" and a member of the Assessment Commission of the National Accreditation Agency for the field of "Security". He is a main research worker and co-research worker of more than two dozen of defence research projects and research intents for developing the organization, an author of more than two hundred of publications in technical journals, contributions for national and international conferences in the field of chemical monitoring of compounds of military interest, decontamination and elimination of ecological disaster consequences. Over the last few years, he deals with the issues of population protection and crisis management. 
Title: Nuclear, radiological and chemical weapons, radiation and chemical accidents Authors: VIČAR Dušan, PRINC Ivan, MAŠEK Ivan, MIKA Otakar Jiří

Publisher: Tomas Bata University in Zlín

Year of publication: 2021

Order of issue: First

Issued electronically

ISBN 978-80-7678-053-8

DOI: https://doi.org/10.7441/978-80-7678-053-8 